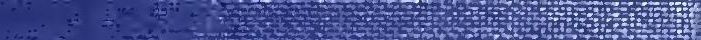

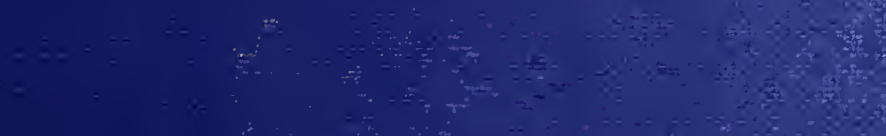

4

$$
\therefore \cdots
$$

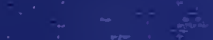
ats.

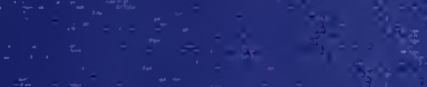
*3.

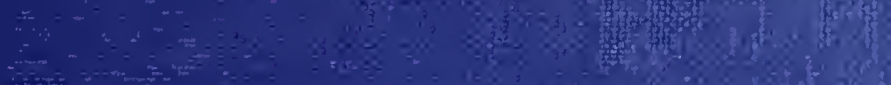

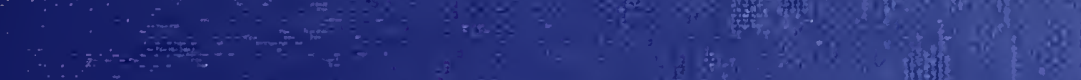

$\because$
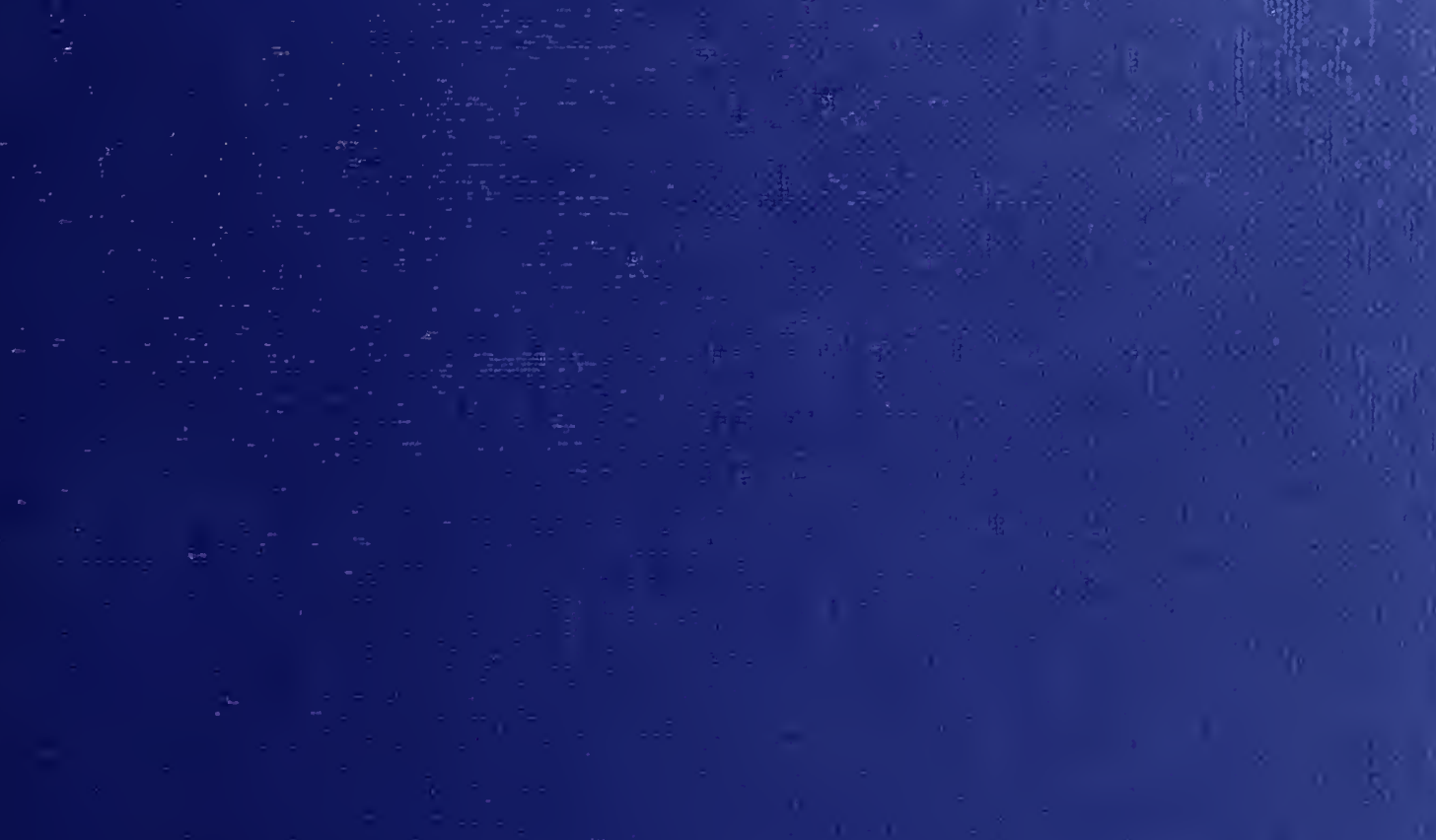



\title{
Catalogue of the \\ Type Specimens of Microlepidoptera in the British Museum (Natural History) described by Edward Meyrick
}

\author{
$B T^{\circ}$ \\ J. F. Gates Clarke \\ Smitbsonian Institution \\ formerly with \\ Entomology Research Branch \\ U.S. Department of Agriculture \\ IOLUMEIII \\ TORTRICIDAE \\ OLETHREUTIDAE \\ NOCTUIDAE
}

LONDON

PRINTED BY ORDER OF THE TRUSTEES

OF THE BRITISH MUSEUM 
Sold at The Britsh Museum (Natural History), Cromwell Road, S.W.7 and by

B. Quaritch, Ltd.

and H.M. Stationery Office

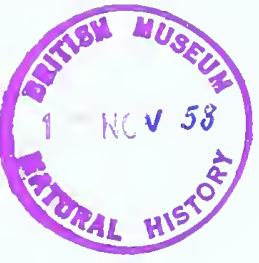

MADE AND PRINTED IN GREAT BRITAIN

BY JARROLD AND SONS LTD, NORWICH 


\section{FAMILY TORTRICIDAE}

\section{NOTE}

In this volume several old names of longstanding use have been dropped. Peronea Curtis (1 824) is preoccupied by Peronea Rafinesque (I 8 I5) and the name Acleris Hübner (I 825) is substituted. All species referred to Peronea by Meyrick, and others obviously conspecific with them, are placed in Acleris. Some species referred to Peronea by Meyrick do not belong in Acleris but are retained here until revisionary works make proper disposition of them.

$$
\begin{aligned}
& \text { FAMILY OLETHREUTIDAE . } \\
& \text { FAMILY NOCTUIDAE } \\
& \text {. . . . }
\end{aligned}
$$



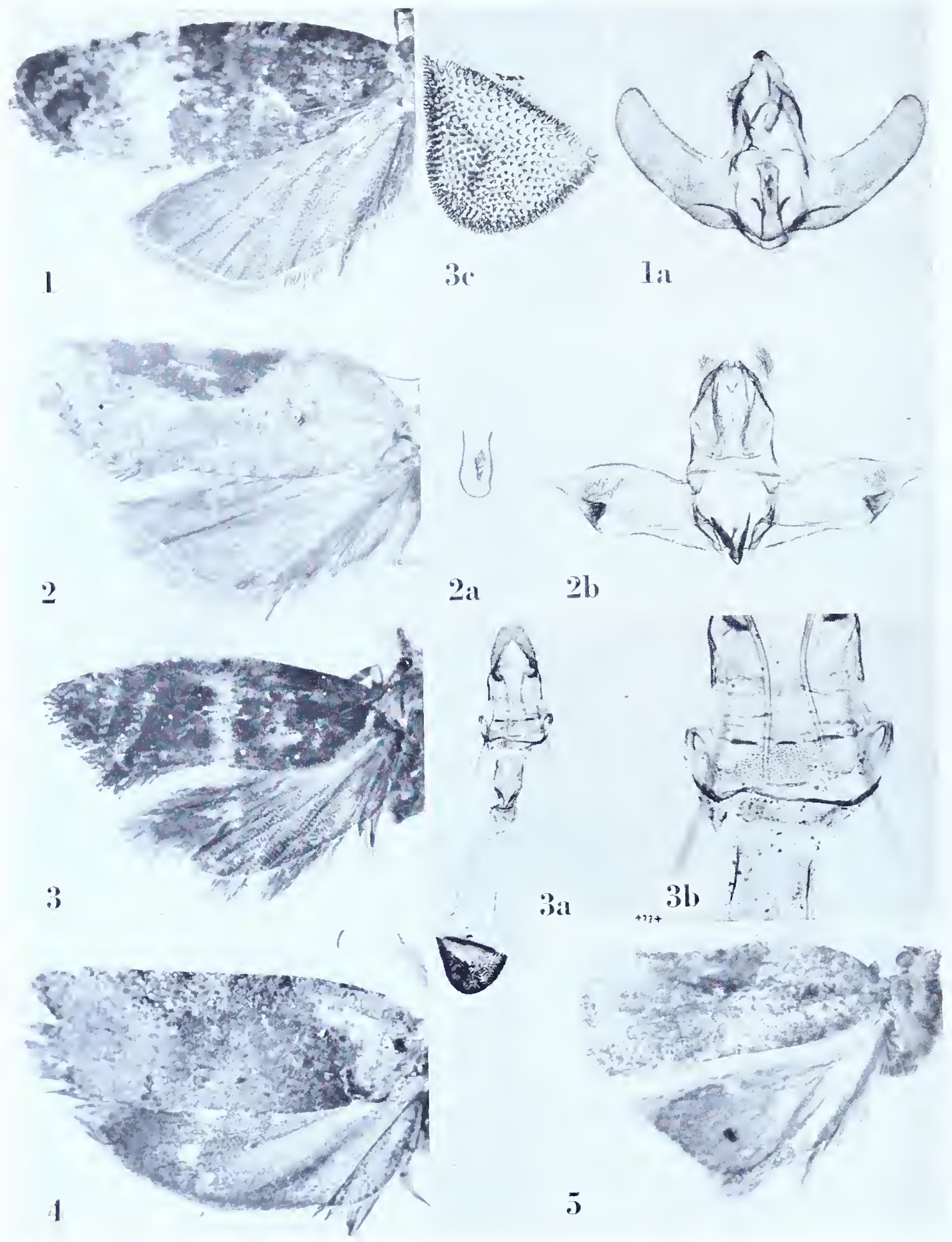

ACLERIS 


\title{
ACLERIS Hübner
}

\section{Acleris acmanthes (Meyrick), new combination}

\author{
Plate I, Figures 1-1a
}

Peronea acmanthes Meyrick, I93I, Ann. Mus. Nacional de Hist. Nat., Buenos Aires, $36: 382$. " ${ }^{\circ}$. 15 mm. ... S. Chile, Llanquihue Province, Puerto Montt, December; 1 ex. Superficially strongly resembling an Argyroploce; probably an early form of the genus, reminiscent of its origin."

Type: The above indicated specimen marked "type" in the British Museum. It is dated "24.xii. I926". Slide No. 6456.

Figure $\mathrm{I}$, left wings; ra, ventral view of male genitalia with aedeagus in situ.

\section{Acleris agrioma (Meyrick), new combination}

Plate I, Figures 2-2b

Peronea agrioma Meyrick, I920, Exotic Microlepidoptera, 2: 342.

" స. I 5-16 mm., o i $8 \mathrm{~mm}$.... Assam, Shillong, 5, ooo feet, June, 3 ex., I bred from a larva on apple (Fletcher)."

Lectotype: ô, I6 mm., dated ".6.18”. Slide No. 9415.

Figure 2 , left wings; $2 \mathrm{a}$, lateral aspect of aedeagus; $2 \mathrm{~b}$, ventral view of male genitalia with aedeagus removed.

\section{Acleris amethystas (Meyrick), new combination}

Plate I, Figures $3^{-} 3^{\mathrm{c}}$

Peronea amethystas Meyrick, I912, Exotic Microlepidoptera, I : i6.

"q. I4 mm. . . Assam, Khasis, in January; one specimen."

Type: 'The above indicated female, "Khasi Hills, Assam. .6.1906." Slide No. 6875.

Figure 3 , left wings; 3 , ventral view of female genitalia; 3 b, detail of genital plate and ostium; 3 c, signa.

\section{Acleris aphorista (Meyrick), new combination}

Plate I, Figure 4

Peronea aphorista Meyrick, 1923, Entomologist, 56: 278 .

"ㅇ․ I4 mm. . . Platres, 5,00o-6,ooo feet, in September; one example."

Type: 'The female, without abdomen, as marked in the British Museun, "Platres, Cyprus. KJH.5-6,00o'. 9.2 г."

Figure + , left wings. 


\section{Acleris chalcophanes (Meyrick), new combination}

Plate 2, Figures I-IC

Percnea chalcophanes Meyrick, I 93 I, Exotic Microlepidoptera, 4: I 56.

“ڤł. 9-10 mm. . . India, New Forest, Dehra Dun, July (G. D. Bhasin); 2 ex.”

Lectotype: The female dated “.7.29". Slide No. 6897. The male is missing.

Figure I, left wings; Ia, ventral view of female genitalia; Ib, signum; Ic, detail of genital plate and ostium.

\section{Acleris chionocentra (Meyrick), new combination}

Plate 2, Figures 2-2b

Argyrotova chicnocentra Meyrick, igo8, Journ. Bombay Nat. Hist. Soc., i 8: 623.

" $\hat{o}$. I $5 \mathrm{~mm}$. ... Khasis, in July; one specimen."

Type: The above indicated male, "Khasi Hills, Assam. .7.1906." Slide No. 6870.

Figure 2, left wings; 2 a, lateral aspect of aedeagus; 2 b, ventral view of male genitalia with aedeagus removed.

\section{Acleris compsoptila (Meyrick), new combination}

Plate 2, Figures $3-3 \mathrm{c}$

Peronea compsoptila Meyrick, I923, Exotic Microlepidoptera, 3: 56.

“. I 9 mm. . . A Assam, Shillong, November (Fletcher); I ex."

Type: The female indicated above dated “. I1.I 8". Slide No. 6906.

Figure 3 , left wings; $3 \mathrm{a}$, ventral view of female genitalia; $3 \mathrm{~b}$, detail of genital plate and ostium; $3 \mathrm{c}$, signum.

\section{Acleris crocoptycha (Meyrick), new combination}

\section{Plate 2, Figures $4-4 \mathrm{~b}$}

Peronea crocó łycha Meyrick, 1931, Ann. Mus. Nacional de Hist. Nat., Buenos Aires, $36: 3^{8}$.

" o. I 7 mm. ... Argentina, 'Territory Rio Negro, Lake Gutierrez, November; I ex. Allied to preceding [acmanthes], and also resembling an Argyroploce."

Type: The male indicated above and dated "3-I 4.xi.I 926". Slide No.6457. 'This species is obviously misplaced in Acleris.

Figure 4 , left wings; 4 a, lateral aspect of aedeagus; 4 b, ventral view of male genitalia with aedeagus removed. 

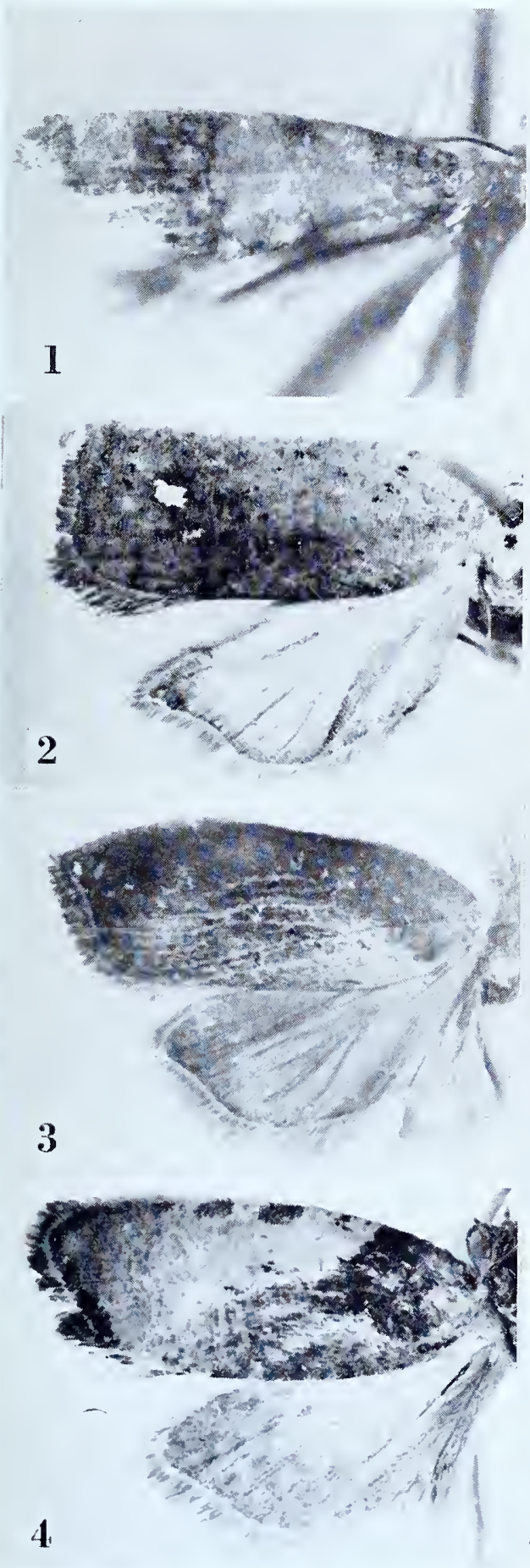

n
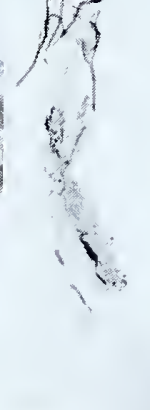

la

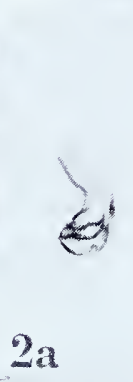

$2 \mathrm{a}$

?

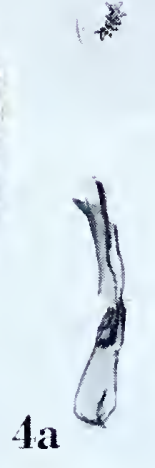

ACLERIS
(1)

1b

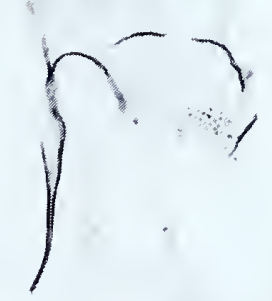

lc

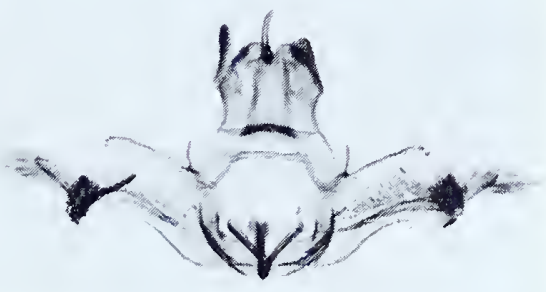

2b

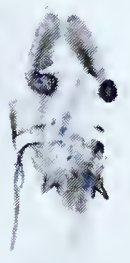

$3 b$
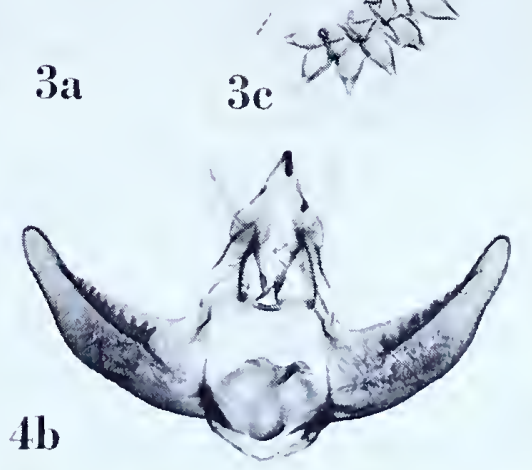


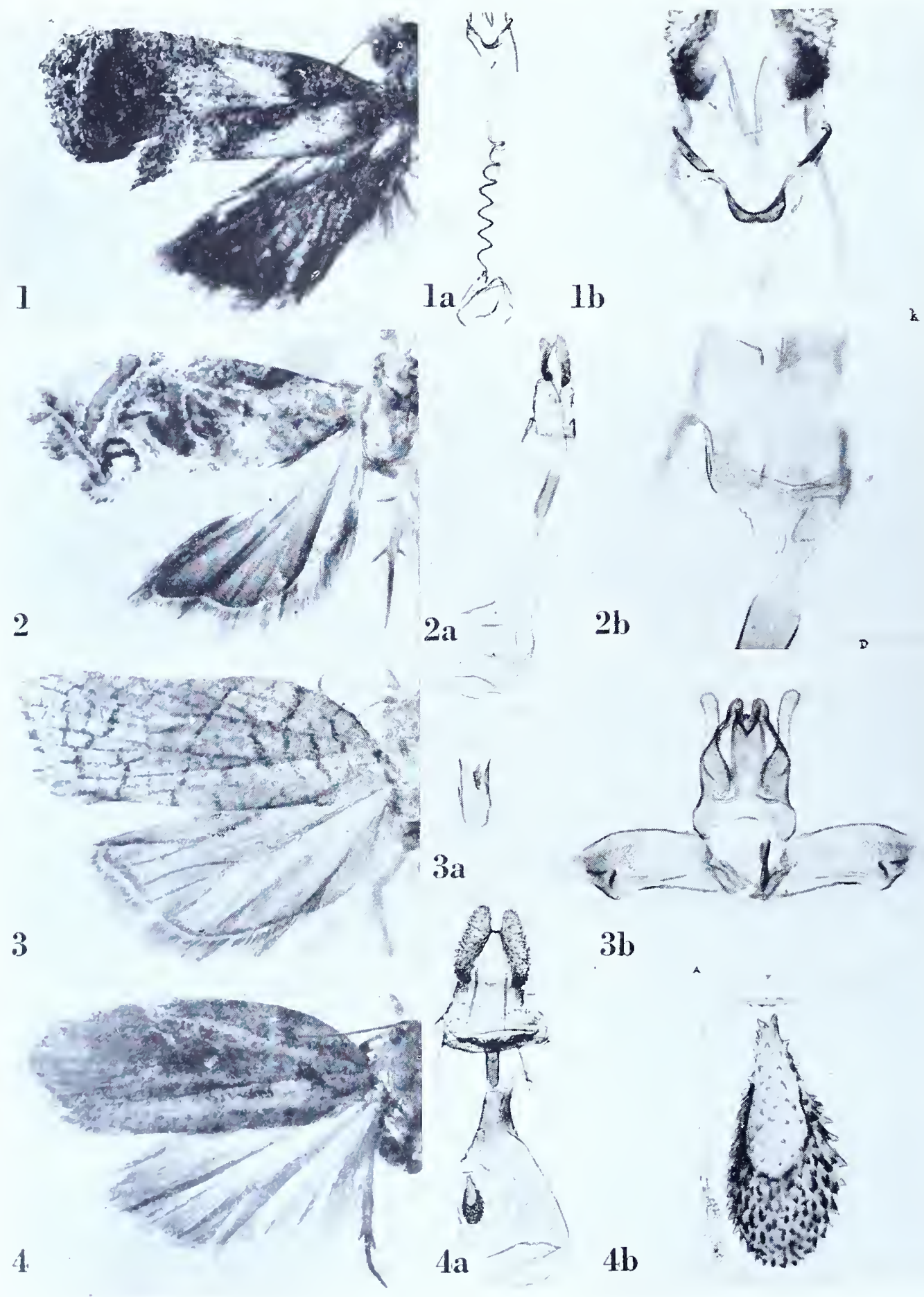




\section{Acleris cuprata (Meyrick), new combination}

Plate 3, Figures $\mathbf{I}-\mathbf{I}$ b

Peronea cuprata Meyrick, I917, Trans. Ent. Soc. London, 1917: I4.

"․ I3 mm. . . British Guiana, Bartica, in January (Parish); one specimen."

Type: The specimen indicated above dated “.I.I3”. Slide No. 6258 .

Figure I, left wings; Ia, ventral view of female genitalia, except ovipositor; $\mathrm{I} b$, detail of genital plate and ostium.

\section{Acleris curiosa (Meyrick), new combination}

Plate 3, Figures 2-2b

Oxygrapha curiosa Meyrick, Iço8, Journ. Bombay Nat. Hist. Soc., I8: 625.

"․ $17 \mathrm{~mm}$.... Khasis, in October; one specimen."

Tyfe: The above indicated female, "Khasi Hills, Assam. .ro.r 1906." Slide No. 6896.

Figure 2, left wings; $2 \mathrm{a}$, ventral view of female genitalia; $2 \mathrm{~b}$, detail of genital plate and ostium.

\section{Acleris dictyodes (Meyrick), new combination}

$$
\text { Plate } 3 \text {, Figures } 3-3 \mathrm{~b}
$$

Oxygrapha dictyodes Meyrick, I907, Journ. Bombay Nat. Hist. Soc., I7: 734.

" specimens (Pole, de Mowbray, Alston)."

Lectotype: A male measuring 17 mm., "Maskeliya, Ceylon, Pole. .8.05." Slide No. 6900 .

Figure 3 , left wings; $3 \mathrm{a}$, lateral aspect of aedeagus; $3 \mathrm{~b}$, ventral view of male genitalia with aedeagus removed.

\section{Acleris dryadarcha (Meyrick), new combination}

\section{Plate 3, Figures 4-4b}

Peronea dryadarcha Meyrick, I912, Exotic Microlepidoptera, I : I 7 .

"․ 28-30 mm. ... Assam, Khasis, in July; Sikkim, Darjiling, 7, ,oo feet, in March; two specimens."

Lectotype: The female, "Khasi Hills, Assam. .7.I906." Slide No. 688o.

Figure 4 , left wings; 4 a, ventral view of female genitalia; 4 b, signum. 


\section{Acleris elaearcha (Meyrick), new combination}

Plate 4, Figures I-I b

Argyrotoxa elaearcha Meyrick, I908, Journ. Bombay Nat. Hist. Soc., I 8: 623.

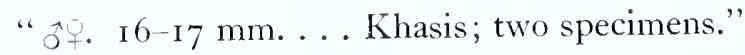

Lectotype: The male, "Khasi Hills, Assam. D. .1906." Slide No. 6873.

Figure I, left wings; ra, lateral aspect of aedeagus; $\mathrm{r} b$, ventral view of male genitalia with aedeagus removed.

\section{Acleris enitescens (Meyrick), new combination}

Plate 4 , Figures 2-2b

Peronea enitescens Meyrick, I9I 2, Exotic Microlepidoptera, I: I6.

" $\hat{f}^{\circ}$ I $4^{-1} 5 \mathrm{~mm}$. . . Assam, Khasis, in September and October; three specimens."

Lectotype: The male, "Khasi Hills, Assam. .9.1906." Slide No. 6901.

Figure 2 , left wings; $2 \mathrm{a}$, lateral aspect of aedeagus; $2 \mathrm{~b}$, ventral view of male genitalia with aedeagus removed.

\section{Acleris erioptila (Meyrick), new combination}

Plate 4 , Figures $3-3 b$

Peronea erioptila Meyrick, I912, Exotic Microlepidoptera, I : I6.

" + . I f $^{-1} 5 \mathrm{~mm}$. . . Ceylon, Maskeliya, in June (Pole); two specimens. Allied to rapax and halidora; ..."

Lectotype: The female measuring i $5 \mathrm{~mm}$., dated ".6.06". Slide No. 6876.

Figure 3 , left wings; 3 a, ventral view of female genitalia, except bursa copulatrix; $3^{\mathrm{b}}$, detail of genital plate and ostium.

\section{Acleris erythrites (Meyrick), new combination}

Plate 4 , Figures $4-4 \mathrm{c}$

Argyrotoxa erythrites Meyrick, I928, Exotic Microlepidoptera, $3: 46 \mathrm{I}$.

" $+20 \mathrm{~mm}$. . . Java, Tjibodas, Mt. Gede, August (Bryant and Palmer); i ex."

Type: The above indicated female dated "8.25". Slide No. 6871.

Figure 4 , left wings; $4^{\mathrm{a}}$, ventral view of female genitalia; $4^{\mathrm{b}}$, signum; $4 \mathrm{c}$, detail of genital plate and ostium. 

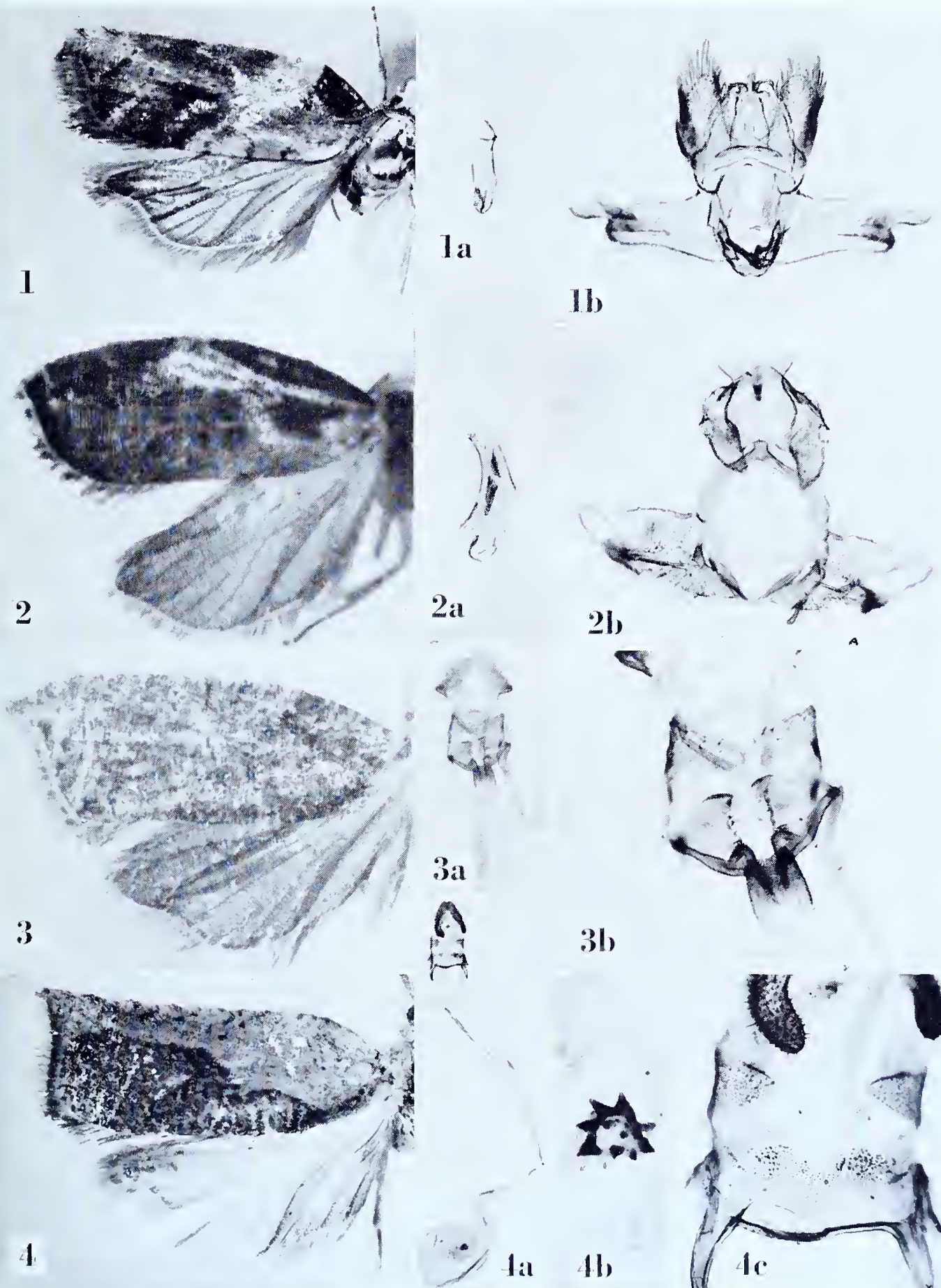

$3 a$

A

$1+7$

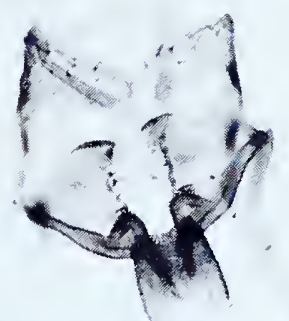

$31)$

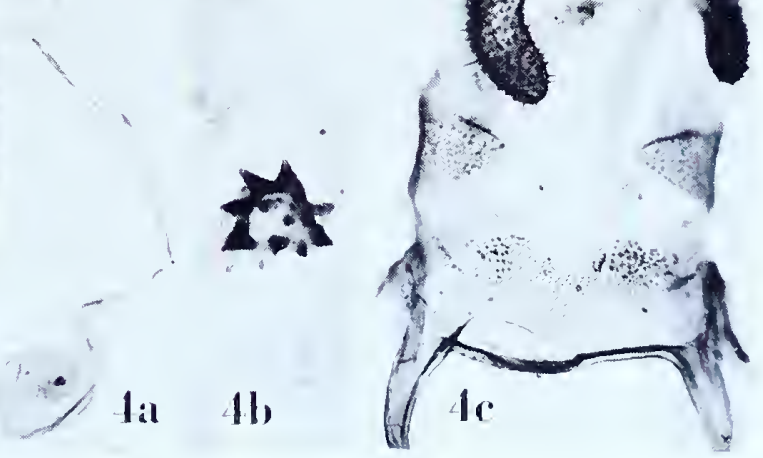



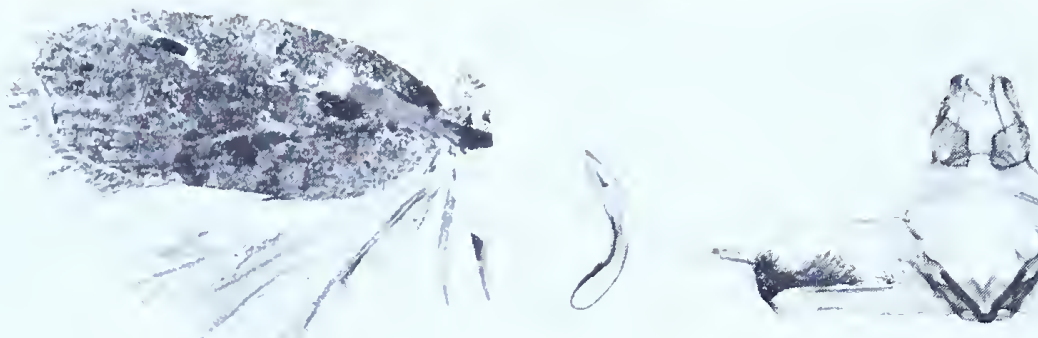

1

$1 a$

1b)

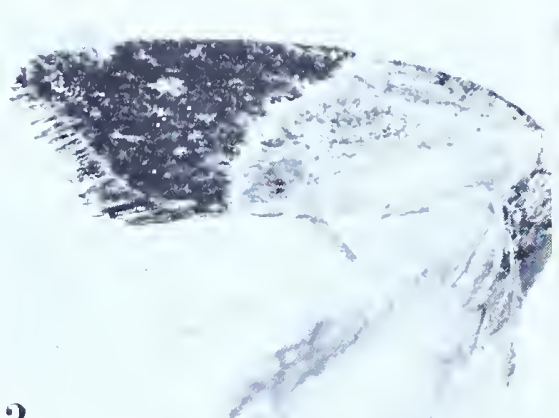

2
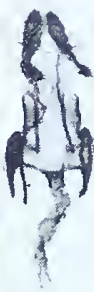

$2 a$
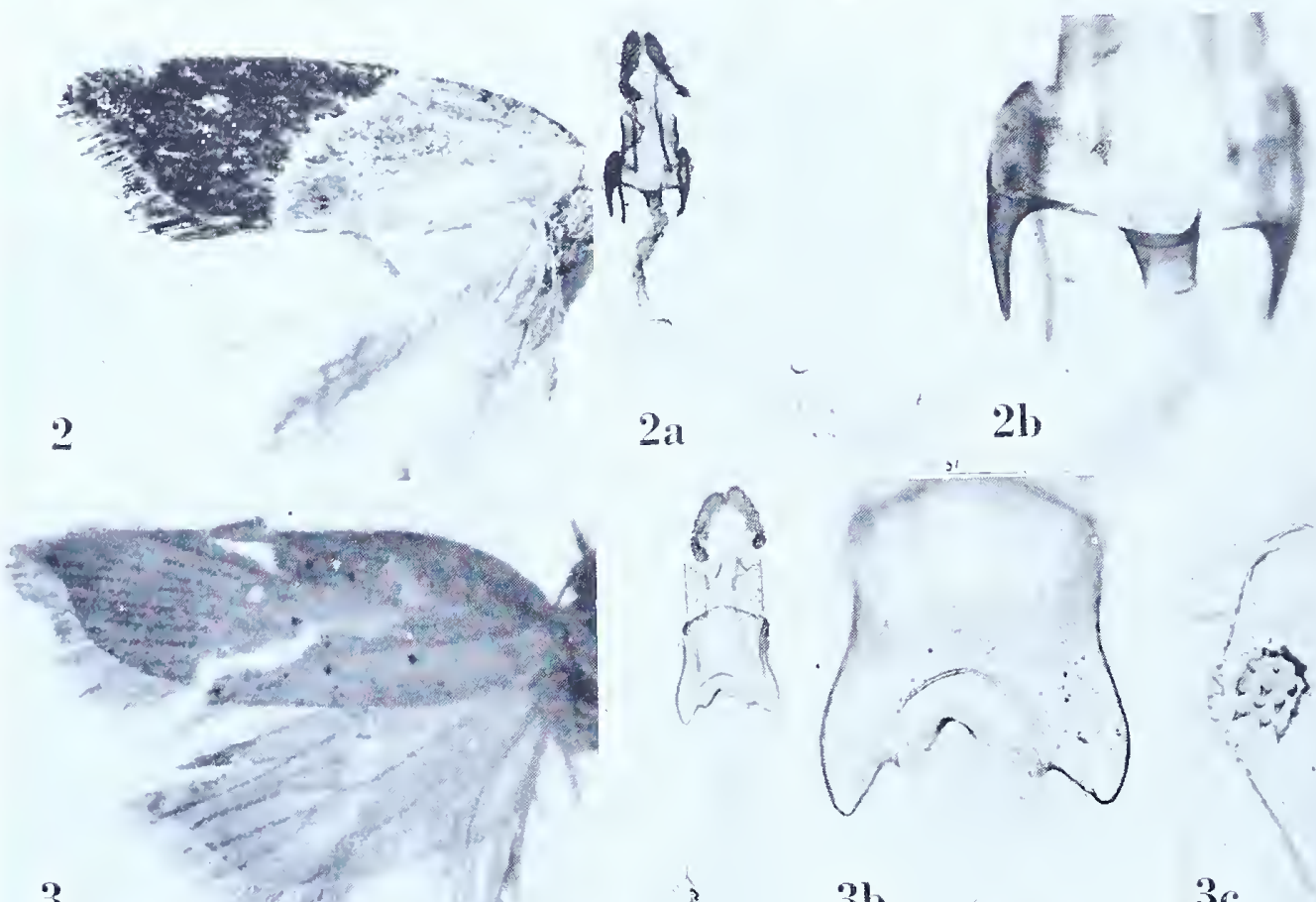

3
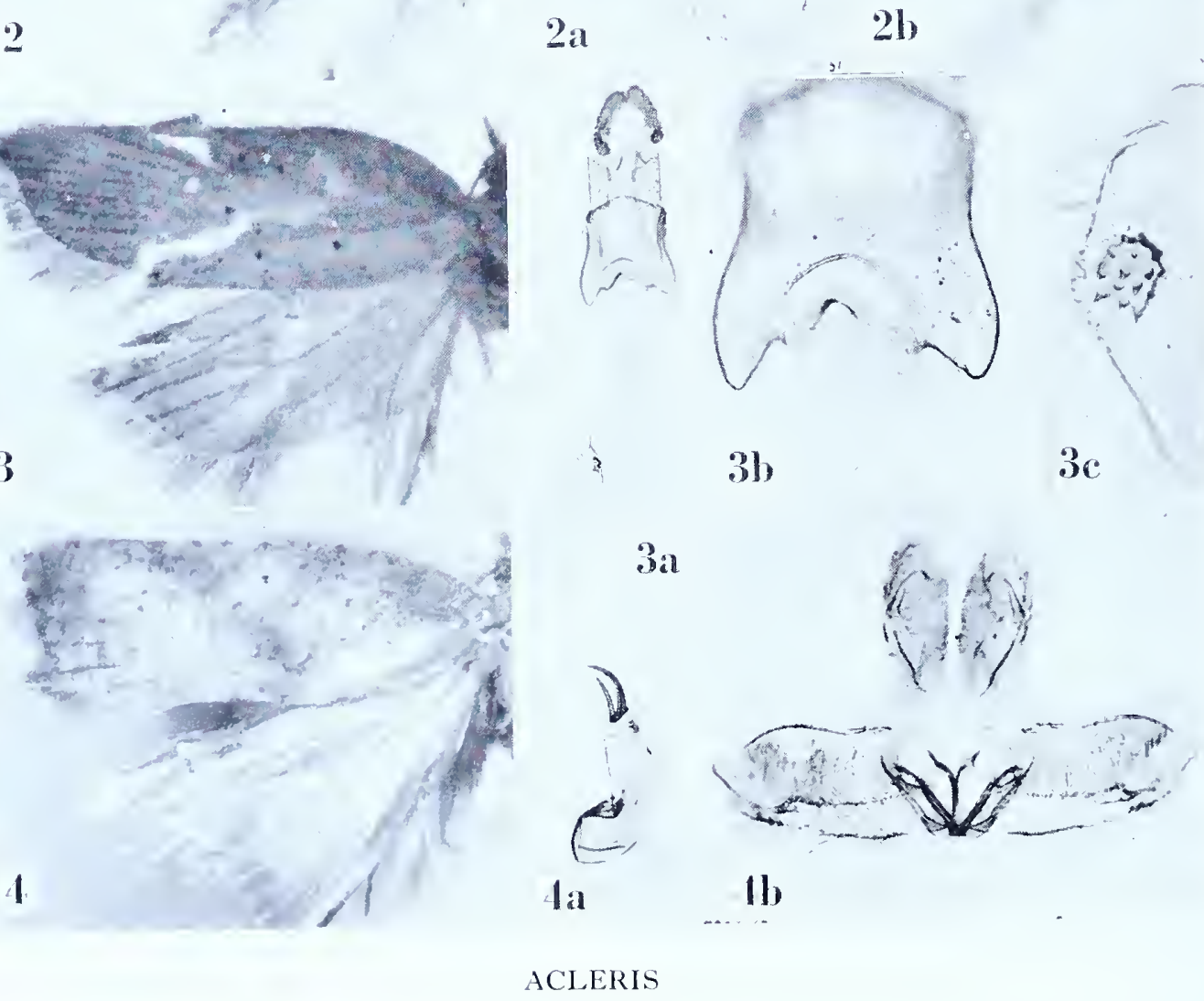

3b)

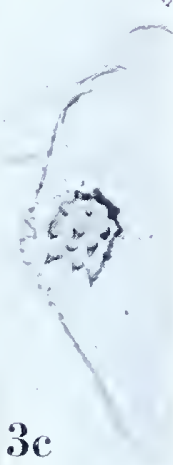




\section{Acleris glaucomis (Meyrick), new combination}

\section{Plate 5, Figures $\mathrm{I}-\mathrm{I} \mathrm{b}$}

Argyrotoxa glaucomis Meyrick, I908, Journ. Bombay Nat. Hist. Soc., I8: 623.

" $\$$ ㅇ․ I $6-18 \mathrm{~mm}$. . . . Khasis, in June and July; twenty-five specimens."

Lectotype: ô, I6 mm., "Khasi Hills, Assam. D. .ı go6." Slide No. 6874.

Figure I, left wings; $\mathrm{s}$, lateral aspect of aedeagus; $\mathrm{s}$, ventral view of male genitalia with aedeagus removed.

\section{Acleris halidora (Meyrick), new combination}

See Hyponomeutidae.

\section{Acleris hapalactis (Meyrick), new combination}

Flate 5 , Figures $3-3 \mathrm{c}$

Peronea hapalactis Meyrick, I912, Exotic Microlepidoptera, I : 18.

"․ I 15-16 mm. . . A Assam, Khasis, in July; two specimens."

Lectotype: The smaller of the two females, "Khasi Hills, Assam. -7.1 9o6." Slide No. 6904.

Figure 3 , left wings; $3 \mathrm{a}$, ventral view of female genitalia; $3^{\mathrm{b}}$, detail of genital plate and ostium; $3 \mathrm{c}$, signum.

\section{Acleris leucophracta (Meyrick), new combination \\ Plate 5, Figures 2-2b}

Argyrotoxa leucophracta Meyrick, 1937, Deuts. Ent. Zeit. Iris, 51 : I75.

" స. $17 \mathrm{~mm}$. . . . Yül., 4,000-5,000 m., June; I ex. A distinct form, nearest distinctana Wals."

Type: 'The specimen referred to above, “Likiang, China. H. I3,000' .6.35." Slide No. 6872 . The specimen was erroneously recorded as a male.

Figure 2, left wings; 2a, ventral view of female genitalia; $2 \mathrm{~b}$, detail of genital plate and ostium.

\section{Acleris loxoscia (Meyrick), new combination}

Plate 5, Figures $4-4 \mathrm{~b}$

Oxygrapha loxoscia Meyrick, 1907, Journ. Bombay Nat. Hist. Soc., I7: 735.

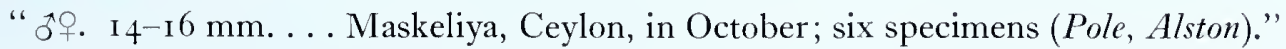

Lectotype: A male measuring I 4 mm., with "JP. .04" at the bottom of the pin-label. Slide No. 6899. Two specimens are missing.

Figure 4 , left wings; 4 a, lateral aspect of aedeagus; 4 b, ventral view of male genitalia with aedeagus removed. 
ACLERIS

\section{Acleris napaea (Meyrick), new combination}

Plate 6, Figures $\mathrm{I}-\mathrm{Ib}$

Peronea napaea Meyrick, I912, Exotic Microlepidoptera, I : 18.

"ڤ. $27 \mathrm{~mm}$. . . Baluchistan, Quetta, 5,000 feet; one specimen."

Type: 'The male indicated above, "Quetta, India. R. .07." Slide No. 6903.

Figure 1 , left wings; 1 a, lateral aspect of aedeagus; 1 b, ventral view of male genitalia with aedeagus removed.

\section{Acleris nectaritis (Meyrick), new combination}

Plate 6, Figures 2-2b

Peronea nectaritis Meyrick, I912, Exotic Microlepidoptera, I: is.

"o. $17 \mathrm{~mm}$. . . Madras, Nilgiris, at 6,000 feet, in May (Andrezes); one specimen."

Type: The male indicated above, "Nilgiri Hills, S. India. HLA. 6,000' .5.07." Slide No. 6905.

Figure 2, left wings; $2 \mathrm{a}$, lateral aspect of aedeagus; $2 \mathrm{~b}$, ventral view of male genitalia with aedeagus removed.

\section{Acleris orphnocycla (Meyrick), new combination \\ Plate 6, Figures $3-3 \mathrm{~b}$}

Peronea orplnocycla Meyrick, 1937, Deuts. Ent. Zeit. Iris, 5 I : 175.

"o. $19 \mathrm{~mm}$.... Yüil., 3,200-4,000 m., VI, 2 ex. Doubtless allied to the European lorquimiana ..."

Lectotype: One of the above-mentioned males labelled, "Likiang, China. H. .6.34." Slide No. 6908 .

Figure 3 , left wings; 3 a, lateral aspect of aedeagus; 3 b, ventral view of male genitalia with aedeagus removed.

\section{Acleris placata (Meyrick), new combination}

Plate 6 , Figures $4-4 \mathrm{c}$

Peronea placata Meyrick, 1912, Exotic Microlepidoptera, I : I7.

" "ै. 1 15-18 mm. . . Assam, Khasis, from July to October; five specimens."

Lectotype: A female measuring 16 mm., "Khasi Hills, Assam. .ı.igo8." Slide No. 6go2.

Figure 4 , left wings; 4 a, ventral view of female genitalia; 4 b, detail of genital plate and ostium; $4 \mathrm{c}$, signum. 

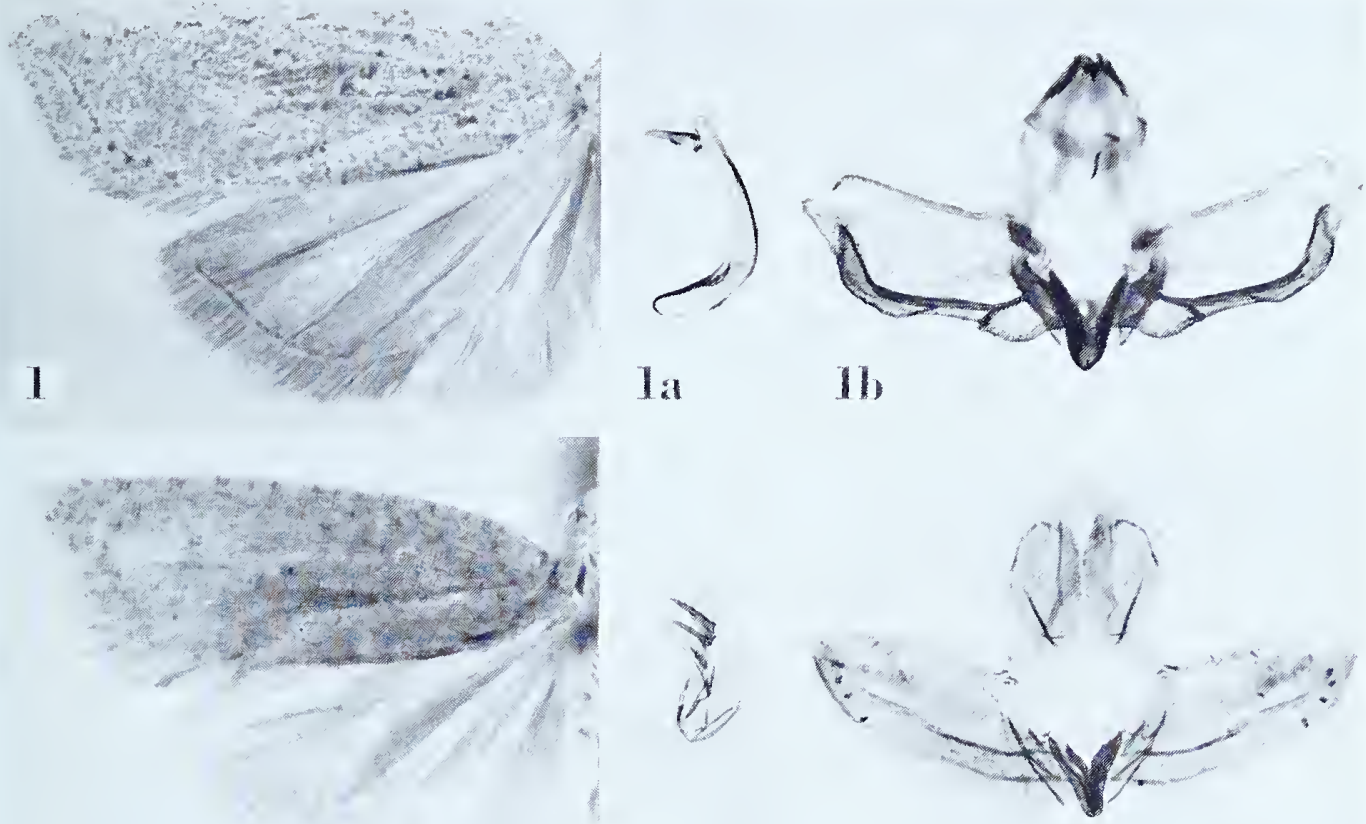

2
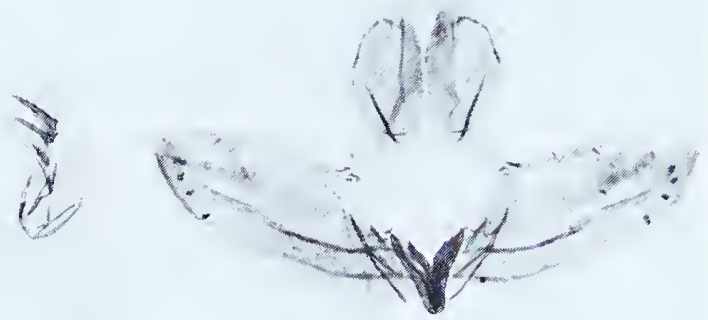

211

21
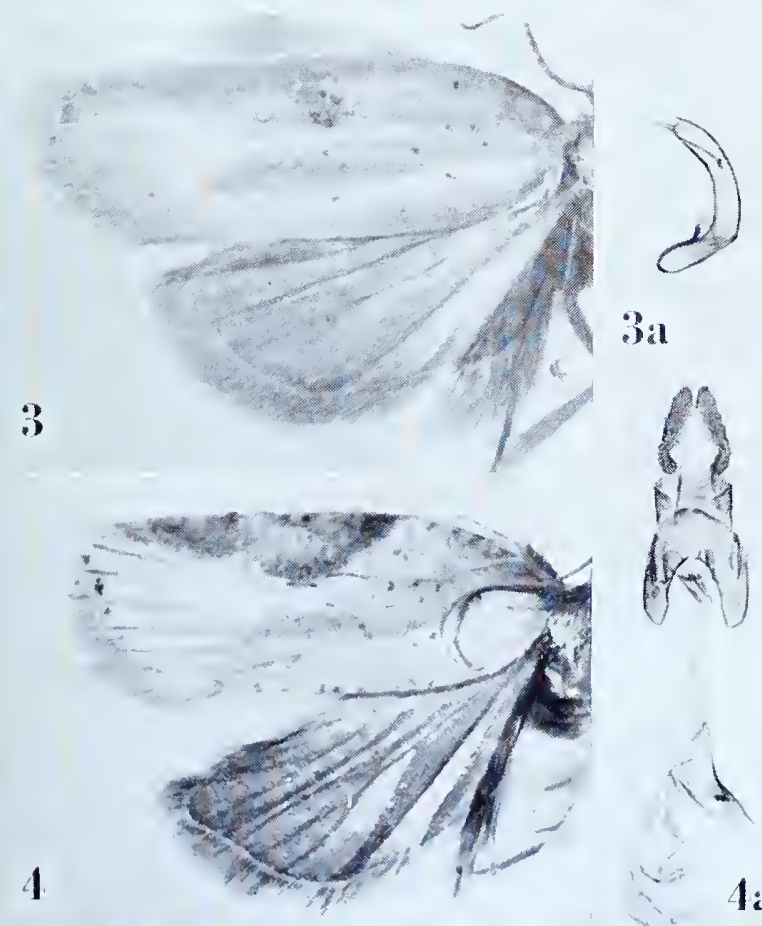

$1-1$

$(y+1)$
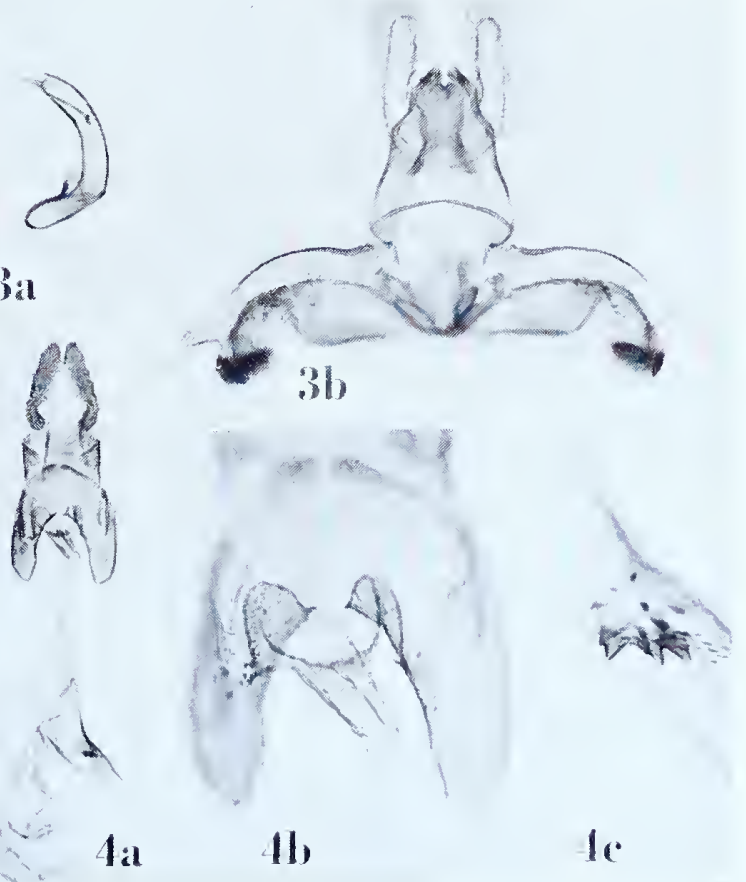

ACLERIS 

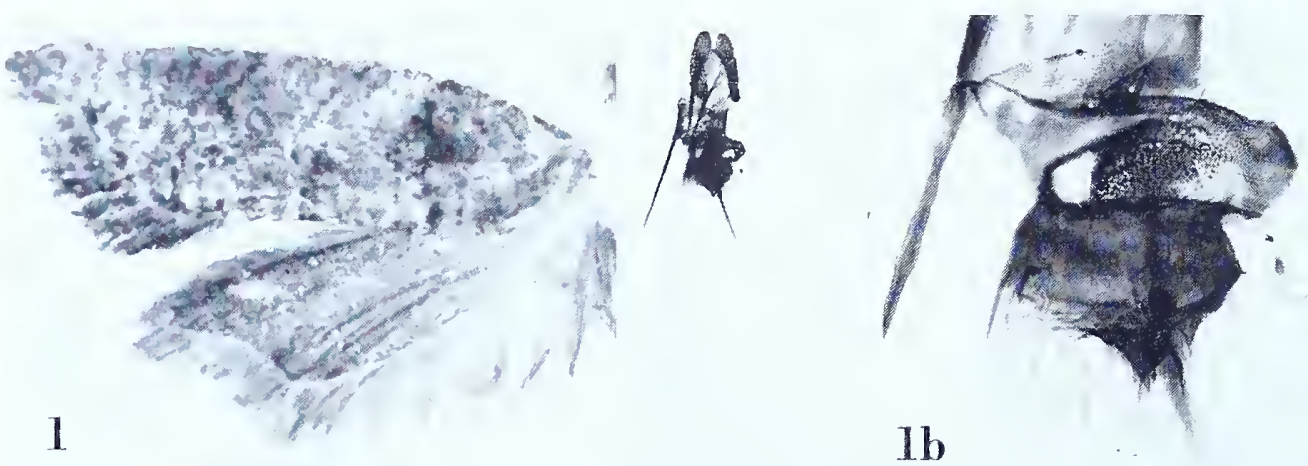

2

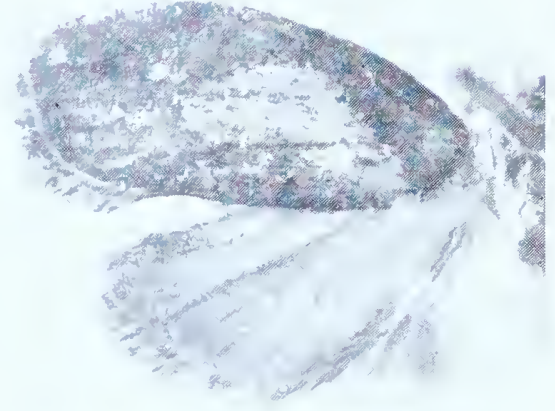

la

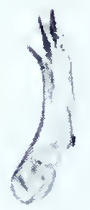

2a

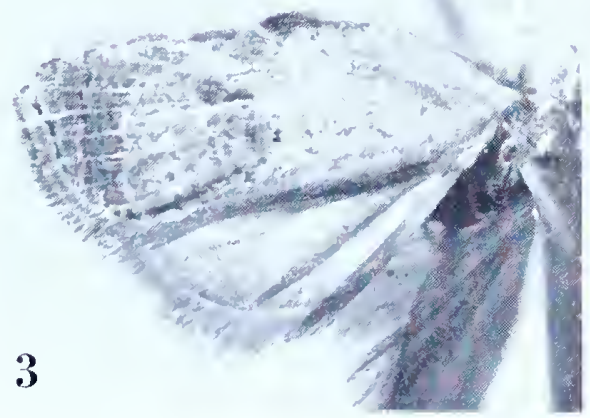

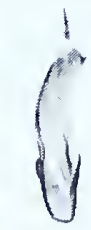

$3 a$

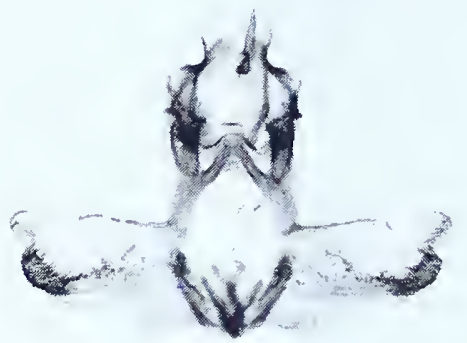

$2 \mathrm{~b}$

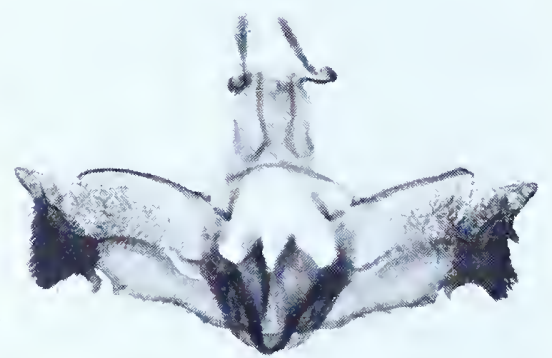

$3 \mathrm{~b}$

ACLERIS 


\section{Acleris rapax (Meyrick), new combination}

Plate 7 , Figures $\mathbf{I - I b}$

Oxygrapha rapax Meyrick, i 908, Journ. Bombay Nat. Hist. Soc., i 8: 624.

“ for $^{\circ}$ I 7-19 mm. ... Maskeliya and Maturatta, Ceylon, in June, September, and October (Pole, de Mowbray); three specimens. The narrowest-winged species of the genus known to me."

Lectotype: A female measuring i 8 mm., "Maskeliya, Ceylon. de Mowbray. .ro.o4." The three original specimens are females. Slide No. 6894 .

Figure $\mathrm{I}$, left wings; $\mathbf{a}$, ventral view of female genitalia; $\mathrm{rb}$, detail of genital plate and ostium.

\section{Acleris sagmatias (Meyrick), new combination}

Plate 7 , Figures 2-2b

Oxygrapha sagmatias Meyrick, I905, Journ. Bombay Nat. Hist. Soc., i6: 588.

" ${ }^{\circ}$. $17^{-20} \mathrm{~mm}$. . . Five specimens, Maskeliya and Horton Plains, Ceylon, in February and March (Pole, Green)."

Lectotype: A male measuring 17 mm., "Maskeliya, Ceylon. Pole. .3.04." Slide No. 6898 .

Figure 2 , left wings; $2 \mathrm{a}$, lateral aspect of aedeagus; $2 \mathrm{~b}$, ventral view of male genitalia with aedeagus removed.

\section{Acleris semitexta (Meyrick), new combination}

Plate 7 , Figures $3-3 \mathrm{~b}$

Peronea semitexta Meyrick, I9ı2, Exotic Microlepidoptera, I: 17.

“ڤ. $16 \mathrm{~mm}$. . . . Sikkim, at 4,500 feet, in November (Dudgeon); one specimen."

Type: The above indicated male, dated “. I r.99”. Slide No. 6879 .

Figure 3 , left wings; 3 a, lateral aspect of aedeagus; 3 b, ventral view of male genitalia with aedeagus removed. 


\section{Acleris siderota (Meyrick), new combination}

Plate 8, Figure I

Peronea siderota Meyrick, i9 8, Exotic Microlepidoptera, 2: I7 I.

" . Io mm. . . Ceylon, Peradeniya, December, bred from larva mining in twigs of Cinnanomult camphora (Rutherford); one specimen."

Type: The female, without hind wings or abdomen, so marked in the British Museum, dated "I5.xii.1914". Apparently not an Acleris but too little remaining to place properly.

Figure 1 , left forewing.

\section{Acleris tephromorpha (Meyrick), new combination}

Plate 8 , Figures $2-2 b$

Peronea teplıromorpha Meyrick, 1930, Exotic Microlepidoptera, 3: 6r 3 .

"

Type: The above indicated male, "Manchuria, AB. bred. .28." Slide No. 6907.

Figure 2, left wings; $2 \mathrm{a}$, lateral aspect of aedeagus; $2 \mathrm{~b}$, ventral view of male genitalia with aedeagus removed.

\section{Acleris ulmicola (Meyrick), new combination}

See Acleris boscana (Fabricius).

\section{Acleris xylodryas (Meyrick), new combination \\ Plate 8, Figures $3-3 \mathrm{c}$}

Peronea xylodryas Meyrick, I927, Insects of Samoa, Part III, Lepidoptera, fasc. 2: 69.

"ㅇ. $\quad 17 \mathrm{~mm}$. ... U Upolu, Malololelei, 2,000 feet, April; I ex. Allied to the Indian and Australian P. epidesma..."

Type: The female so marked in the British Museum, "Samoan Is. Upolu Is. Malololelei, 2i.iv. 1925. 2,000 ft. P. A. Buxton and G. H. Hopkins." Slide No. 9427.

Figure 3 , left wings; $3 \mathrm{a}$, ventral view of female genitalia; $3 \mathrm{~b}$, signum; $3 \mathrm{c}$, detail of genital plate and ostium. 

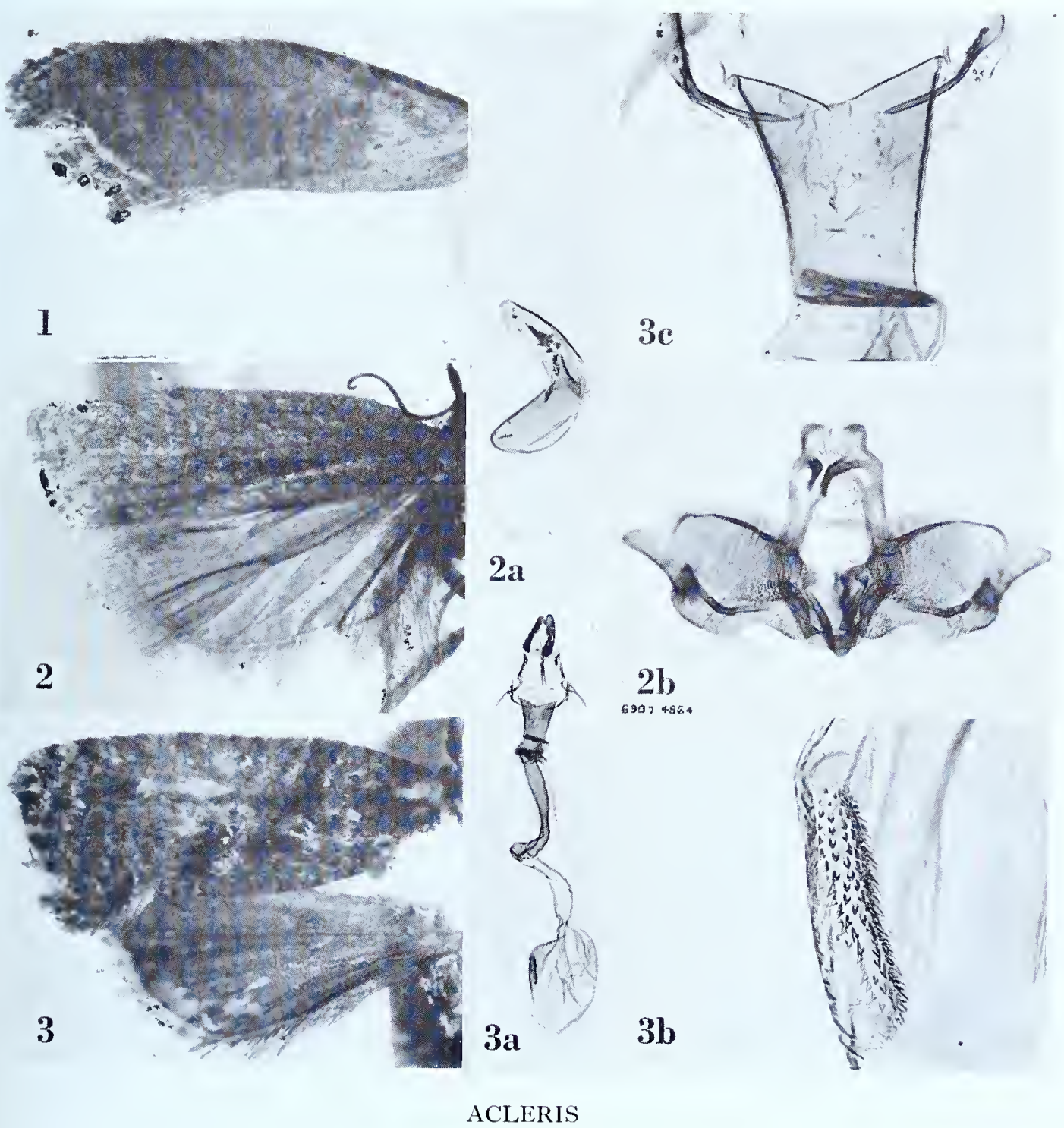

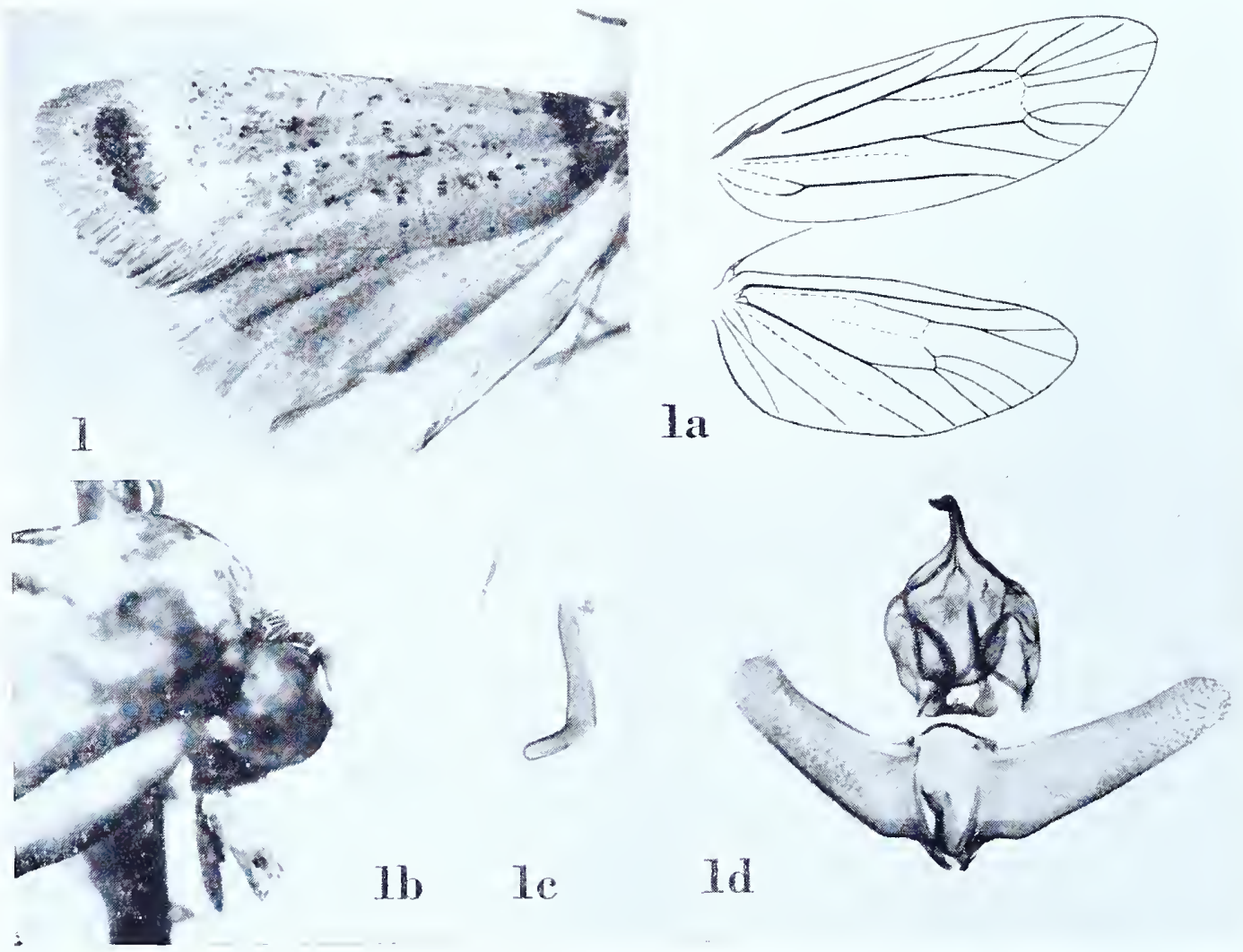

ACROPLECTIS 


\section{ACROPLECTIS Meyrick}

Acroplectis Meyrick, I927, Exotic Microlepidoptera, 3: 370.

(Typus generis: Acroplectis haemanthes Meyrick, ibid. [monotypy].)

\section{Acroplectis haemanthes Meyrick}

Plate 9, Figures I-Id

Acroplectis haemanthes Meyrick, I92.7, Exotic Microlepidoptera, 3:370.

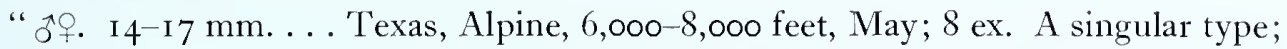
I had no suspicion that it belonged to the Tortricidae until I examined it."

Lectotype: A male measuring I4 mm., labelled "Brenster Co., Texas. 8,00o ft., 5-26." Slide No. 634I.

Figure I, left wings; Ia, venation of right wings; $\mathrm{Ib}$, lateral aspect of head to show palpus; ic, lateral view of aedeagus; id, ventral view of male genitalia with aedeagus removed.

Continued from $p \cdot 3$.

\section{Acleris boscana (Fabricius) \\ Plate I, Figure 5}

Pyralis boscana Fabricius, I794, Entomologia Systematica, III (2), 269.

Peronea ulmicola Meyrick, I930, Exotic Microlepidoptera, 3: 6I 2 (new synonymy).

[ulmicola]

“․ $\quad$ i $6 \mathrm{~mm}$. . . . Manchuria, bred October from larva rolling leaf of Ulmus; i ex. Easily distinguished from boscana by sinuate termen of forewings."

Type: The female indicated above, without abdomen. 'The "sinuate" termen of the forewing, by which Meyrick distinguished his species from boscana, only occurs on one side, which is dcformed. Since boscana is circumpolar, and the foodplants are the same, I do not hesitate to suppress Meyrick's ulmicola.

Figure 5, left wings. 


\title{
ADOXOPHYES Meyrick
}

\author{
Adoxophyes cyrtosema Meyrick \\ Plate 10 , Figures $\mathrm{i}-\mathrm{I} b$
}

Adoxophyes cyrtosema Meyrick, i 886, Trans. Ent. Soc. London, i 886: 276.

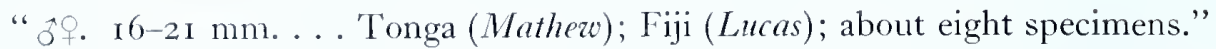

Type: J, 17 mm., "Tonga. Mathew 1004, No. I513." Slide No. 9430. There are two males and a female in the British Museum marked "TYPE". I have selected the one indicated above.

Figure 1 , left wings; 1 a, lateral aspect of aedeagus; 1 b, ventral view of male genitalia with aedeagus removed.

\section{Adoxophyes ergatica Meyrick \\ Plate 10, Figure 2}

Adoxophyes ergatica Meyrick, 191 I, Trans. Linnean Soc. London, 14: 267.

"F. 20-2x mm. . . Silhouette, Mare aux Cochons plateau and edge of forest, about 1,000 feet, in September; two specimens."

Type: The female, without abdomen, so marked in the British Museum, "Seychelles: Silhouette, Mare-aux-Cochons. i,ooo ft. ix. Igo8. H. Scott."

Figure 2, left wings.

\section{Adoxophyes euryomis Meyrick}

See Adoxophyes prizatana (Walker).

\section{Adoxophyes faeculosa Meyrick \\ Plate 10 , Figures $3^{-} 3^{a}$}

Adoxophyes faeculosa Meyrick, 1928, Exotic Microlepidoptera, 3:453.

" 5.2 I-22 mm. . . India, United Provinces, Ramgarh, June (Maxwell); 2 ex."

Lectotype: The male measuring $22 \mathrm{~mm}$. Slide No. 6799. Both specimens are dated "17.6.25".

Figure 3 , left wings; 3 a, ventral view of male genitalia with aedeagus in situ.

\section{Adoxophyes flagrans Meyrick \\ Plate io, Figures $4^{-4} \mathrm{c}$}

Adoxophyes flagrans Meyrick, 1912, Exotic Microlepidoptera, 1: 3 .

" + . 2 1 mm. .. U Upper Burma, Maymyo, in May (H. L. Andrewes); one specimen."

Type: The above indicated female dated ".5.10". Slide No. 6795 .

Figure 4 , left wings; $4 \mathrm{a}$, ventral view of female genitalia; $4 \mathrm{~b}$, detail of genital plate and ostium; $4 \mathrm{c}$, detail of part of bursa copulatrix and signum.

[continued on p. 24. 


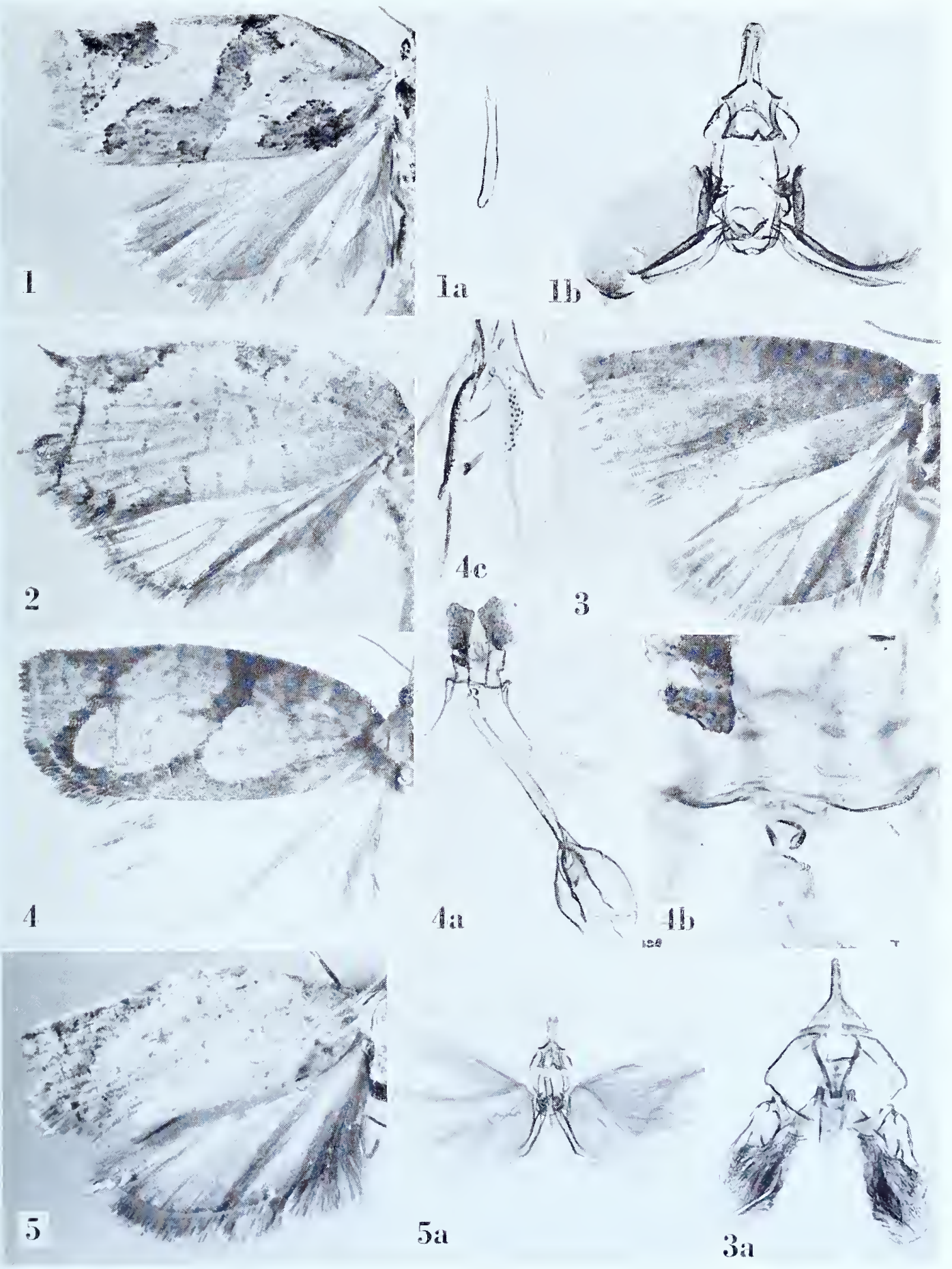



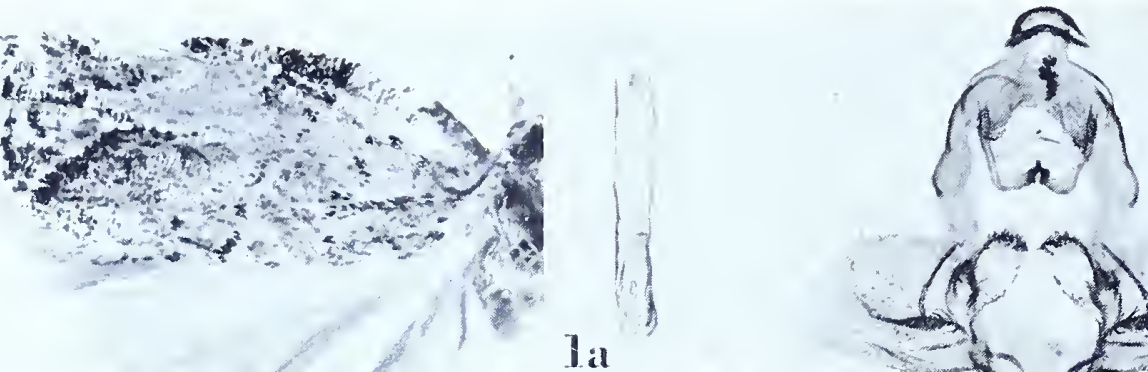

I
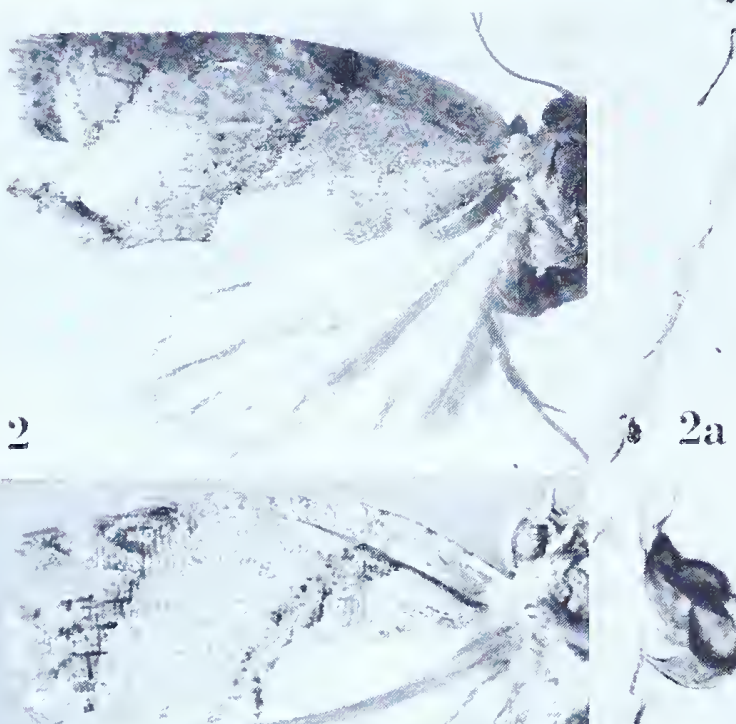

;)

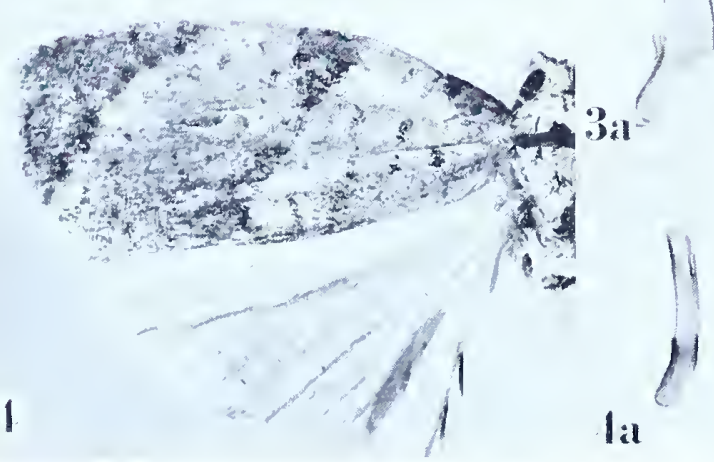

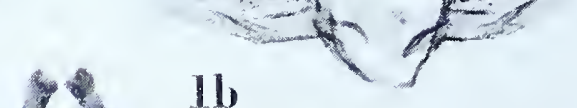

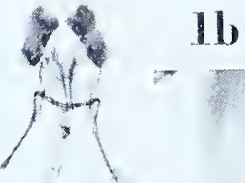

6

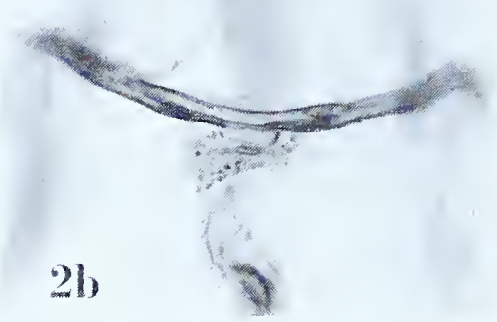

$3 b$
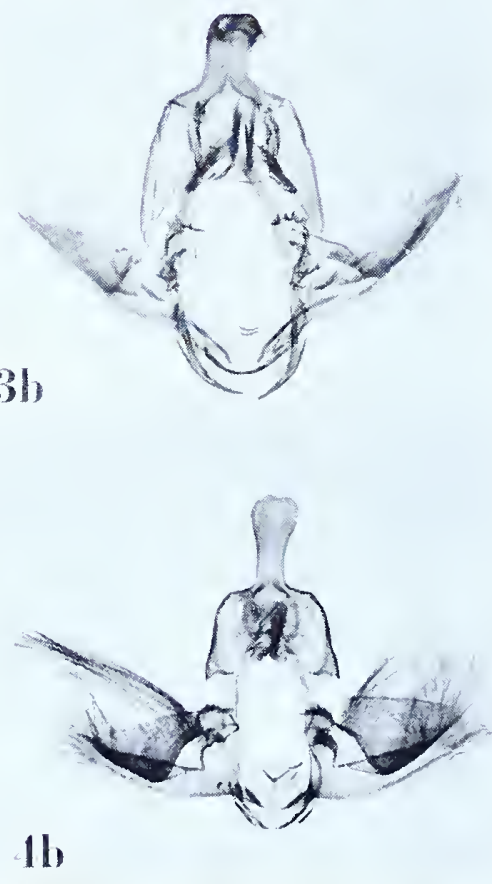


\title{
Adoxophyes peritoma Meyrick
}

\author{
Plate I I, Figures I-Ib
}

Adoxophyes peritoma Meyrick, I9 8 , Exotic Microlepidoptera, 2: i67.

" ô. I 4 mm. . . Madagascar, Antananarivo, April ; one specimen."

Type: The male denoted above, "Antananarivo, Madagascar. LeM. .4.I 5." Slide No. 9343 .

Figure I, left wings; ıa, lateral aspect of aedeagus; $\mathrm{s} b$, ventral view of male genitalia with aedeagus removed.

\section{Adoxophyes perstricta Meyrick}

Plate 1 I, Figures 2-2c

Adoxophyes perstricta Meyrick, I928, Exotic Microlepidodera, 3: 453.

“ $\hat{o}$. I 5 mm., 우 I $8-20$ mm. . . Java; Philippines, Los Baños (Baker); 3 ex. Very like melichroa Low., ...."

Lectotype: The female measuring $20 \mathrm{~mm}$., "Java, LM. .2 г." Slide No. 6796.

Figure 2, left wings; $2 \mathrm{a}$, ventral view of female genitalia; $2 \mathrm{~b}$, detail of genital plate and ostium; $2 \mathrm{c}$, signum.

\section{Adoxophyes privatana (Walker)}

Dichelia privatana Walker, I 863 , List of the specimens of lepidopterous insects in the collection of the British Museum, 28: 320 .

Adoxophyes euryouis Meyrick, I902, in Gardiner, The Fauna and Geography of the Maldive and Laccadive Archipelagoes, i : I 26.

In volume I, p. I 36 , of this same work I listed the type of euryomis as possibly lost. Since the first volume was written Mr. D. S. Fletcher, of the British Museum, has located the type in the collection of Cambridge University, Cambridge, England.

\section{Adoxophyes prosiliens Meyrick}

Plate i I, Figures $3^{-} 3^{b}$

Adoxophyes prosiliens Meyrick, I928, Exotic Microlepidoptera, 3: 454 .

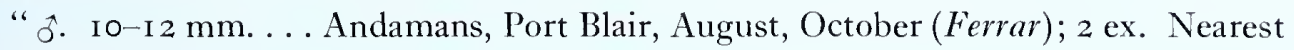
moderatana. ..."

Lectotype: 'The male dated ". го.27". Slide No. 6798. One specimen is missing.

Figure 3 , left wings; 3 a, lateral aspect of aedeagus; 3 , ventral view of male genitalia with aedeagus removed.

[continued on p. 27. 


\section{AESIOCOPA Zeller \\ Aesiocopa concavata (Meyrick), new combination \\ Plate 26, Figure 3}

Cacocia concazata Meyrick, 1930, Exotic Microlepidoptera, 3:614.

“ 今. 29 mm. ... Peru, Agualani, Carabaya, 9,000 feet, April (Ockenden); I ex. (Coll. Paravicini)."

Type: 'The specimen indicated above, in the British Museum. A small white label bears the inscription "M6I". The type lacks the abdomen.

Figure 3, left wings.

\section{AMNIODES Meyrick}

Amniodes Meyrick, 1938, in Caradja and Meyrick, Deuts. Ent. Zeit. Iris, 52 : 13.

Typus generis: Anniodes xanthocycla Meyrick, ibid. [monotypy]).

\section{Amniodes xanthocycla Meyrick}

Plate I 2, Figures $\mathrm{I}-\mathrm{Id}$

Anniodes xanthocycla Meyrick, I938, in Caradja and Meyrick, Deuts. Ent. Zeit. Iris, 52: 13. "... o. $20 \mathrm{~mm}$. ... Yül., 2,\$oo m., VI, I ex."

Type: The male indicated above labelled, "Likiang, China. H. .6.34". Slide No. 7645. This genus is a synonym of Terthreutis Meyrick.

Figure $\mathrm{s}$, left wings; 1 a, venation of right wings; $\mathrm{ib}$, lateral aspect of head to show palpus; 1 c, lateral aspect of aedeagus; Id, ventral view of male genitalia with aedeagus removed.

Continued from p. 20.

\section{Adoxophyes parastropha Meyrick \\ Plate 10, Figures $5^{-5}$ a}

Adoxophyes parastropha Meyrick, I9 I2, Exotic Microlepidoptera, I: 3 .

" 5 . I7-I $8 \mathrm{~mm}$. ... Assam, Khasis, in April and July; three specimens."

Lectotype: A male measuring 17 mm., "Khasi Hills, Assam. 4.1907." Slide No. 6797 .

Figure 5, left wings; 5 a, ventral view of male genitalia with aedeagus in situ. 

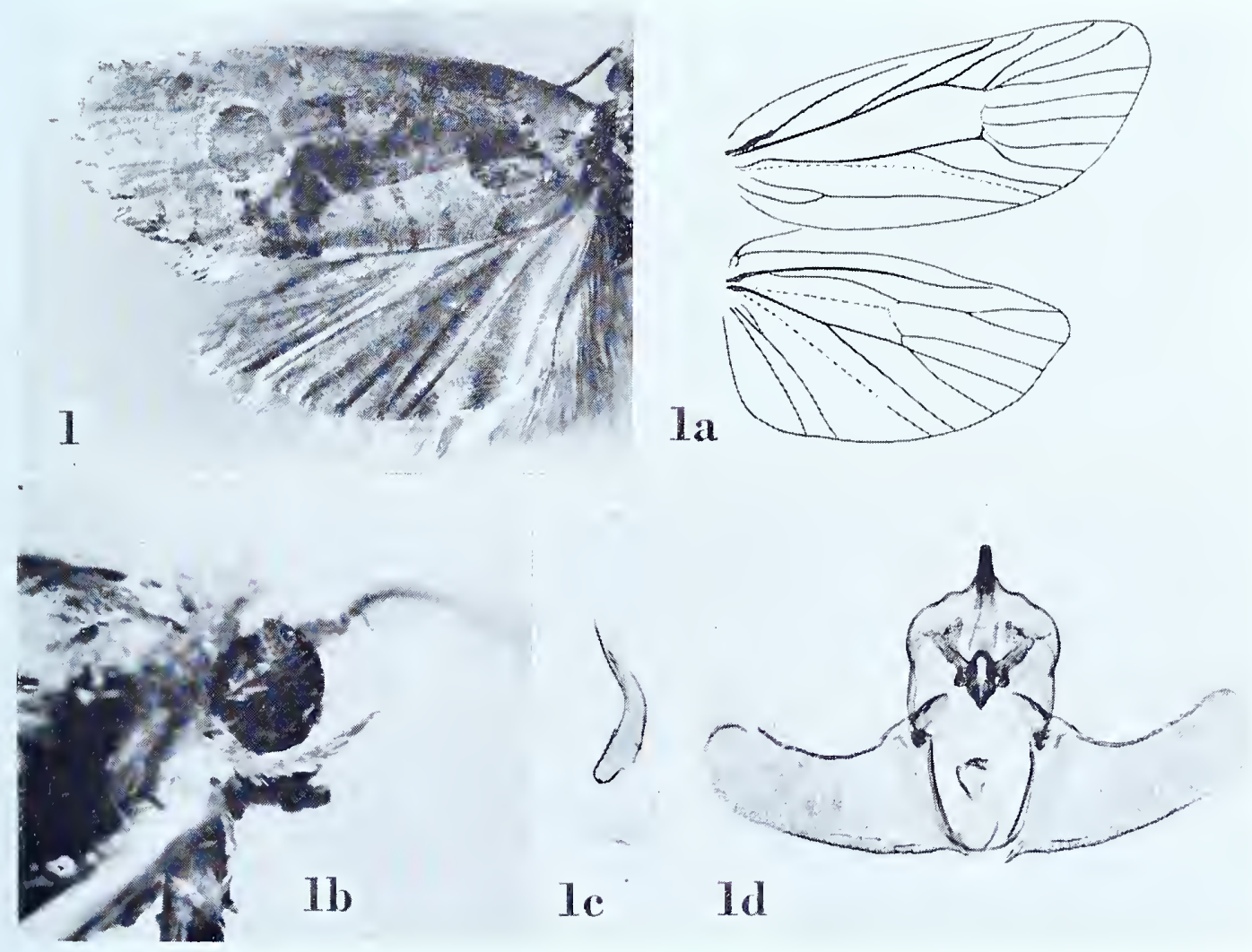

AMNIODES 
Meyrick Catalogue

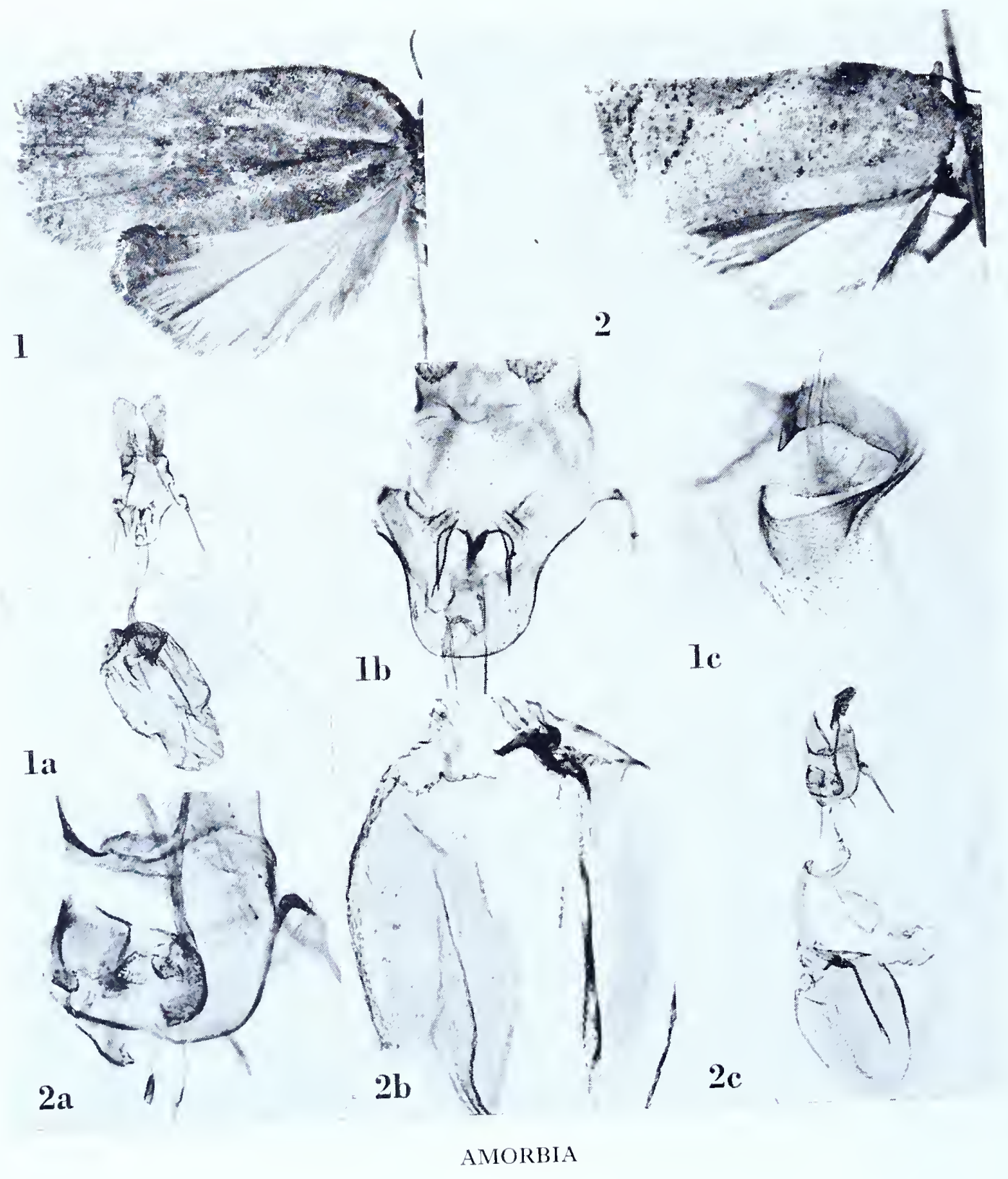




\section{AMORBIA Clemens}

\section{Amorbia helioxantha Meyrick}

Plate I3 $_{3}$, Figures $\mathrm{I}-\mathrm{xc}$

Amorbia helioxantha Meyrick, I917, Trans. Ent. Soc. London, I9I7: 12.

“q. 24-26 mm. . . . French Guiana, R. Maroni; eleven specimens. . ."

Lectotype: A female measuring $24 \mathrm{~mm}$. Slide No. $6_{3} 67$. Three of the original specimens are missing.

Figure $\mathrm{r}$, left wings; $\mathrm{ra}$, ventral view of female genitalia; $\mathrm{rb}$, detail of genital plate and ostium; Ic, signum.

\section{Amorbia zymogramma Meyrick}

Plate I $_{3}$, Figures $2-2 \mathrm{C}$

Amorbia zymogramma Meyrick, 1926, Exotic Microlepidoptera, 3: 260.

"ㅇ. I9 mm. . . Peru, Cocapata, 12,00o feet; x ex."

Type: The specimen indicated above with ".20" in the lower right corner of the pin-label. Slide No. 6368 .

Figure 2, left wings; $2 \mathrm{a}$, detail of genital plate and ostium; $2 \mathrm{~b}$, bursa copulatrix to show signum; $2 \mathrm{c}$, ventral view of female genitalia.

Continued from p. 23.

\section{Adoxophyes tetraphracta Meyrick}

Plate I I, Figures $4-4 \mathrm{~b}$

Adoxophyes tetraphracta Meyrick, I938, Trans. R. Ent. Soc. London, 87: 505 .

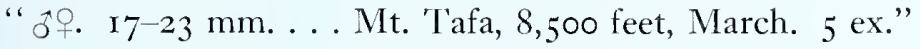

Type: The male so marked in the British Museum, "Mt. Tafa, Papua, 8,500 ft. iii. 1934. L. E. Cheesman." Slide No. 7032.

Figure 4 , left wings; 4 a, lateral aspect of aedeagus; 4 b, ventral view of male genitalia with aedeagus removed. 


\section{ANACRUSIS Zeller}

\section{Anacrusis aerobatica (Meyrick), new combination}

Plate I4, Figures I-I b

Cacoecia aerobatica Meyrick, 1917, Trans. Ent. Soc. London, i917: 7.

"3. $30 \mathrm{~mm}$. . . Colombia, San Antonio, 5,800 feet, in November; one specimen."

Type: The specimen indicated above dated “.11.07”. Slide No. 6333 .

Figure I, left wings; $\mathrm{ia}$, lateral aspect of aedeagus; $\mathrm{ib}$, ventral view of male genitalia with aedeagus removed.

\section{Anacrusis aulaeodes (Meyrick), new combination}

Plate if, Figures 2-2b

Eulia aulaeodes Meyrick, 1926, Exotic Microlepidoptera, 3:254.

“ స. 22-26 mm. ... Colombia, Minero, Cacagualito ( $\mathrm{I}, 500$ feet), Mt. Tolima [sic!] $(5,600$ feet $) ; 3$ ex."

Lectotype: The male, "Tolima Cañon, Colombia, 5,600' i r.20." Slide No. 6309. One specimen is missing.

Figure 2, left wings; $2 \mathrm{a}$, lateral aspect of aedeagus; $2 \mathrm{~b}$, ventral view of male genitalia with aedeagus removed.

\section{Anacrusis piriferana (Zeller), new combination}

\section{Plate 14 , Figures $3^{-} 3^{\mathrm{b}}$}

Grapholitha piriferana Zeller, i 877, Hor. Soc. Ent. Ross., I3: 156.

Cacoecia geographica Meyrick, i912, Trans. Ent. Soc. London, I9I I : 678 (new synonymy). [geographica]

“ô. $25 \mathrm{~mm}$. .. . Venezuela, Palma Sola; one specimen."

Type: The specimen referred to above, without abdomen. Male genitalia figured from a male, an exact match for the type, "R. Maroni, Fr. Guiana. LeM. .i5." Slide No. 6334 .

Figure 3 , left wings; $3 a$, lateral aspect of aedeagus; 3 b, ventral view of male genitalia with aedeagus removed. 

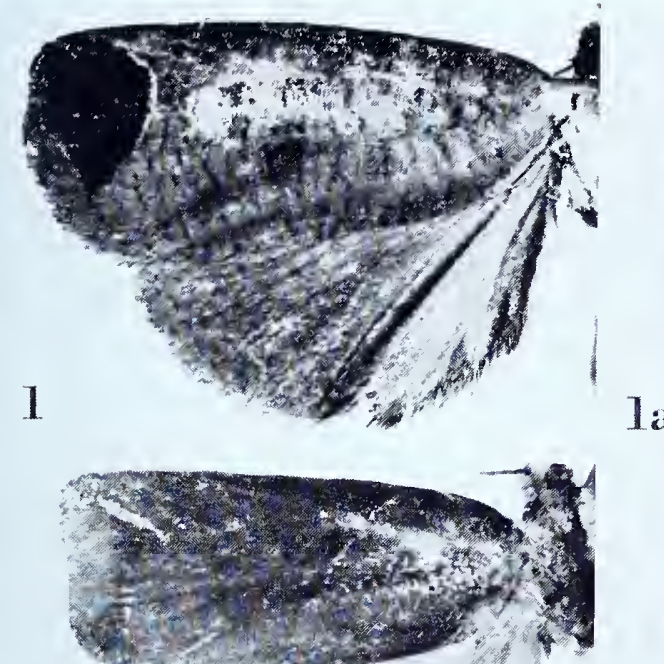

2
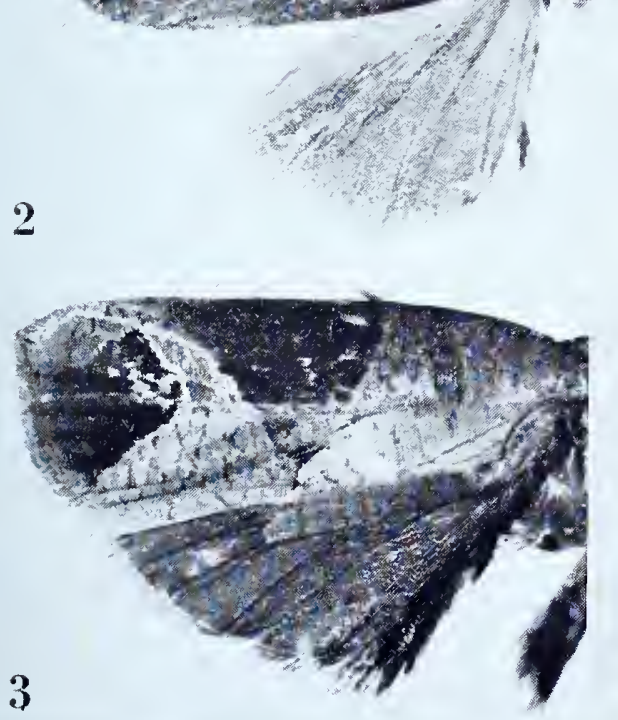

$1 a$

$2 \mathrm{a}$

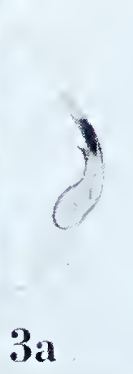

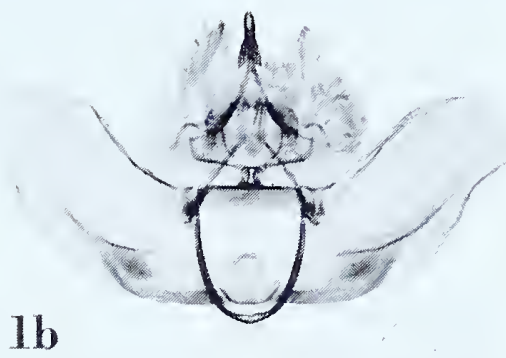

$2 b$

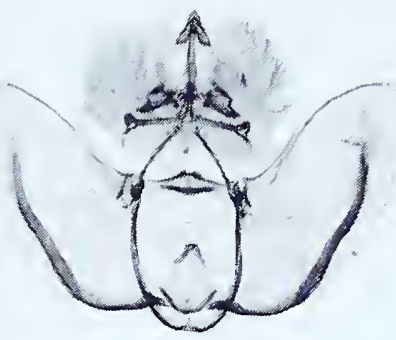



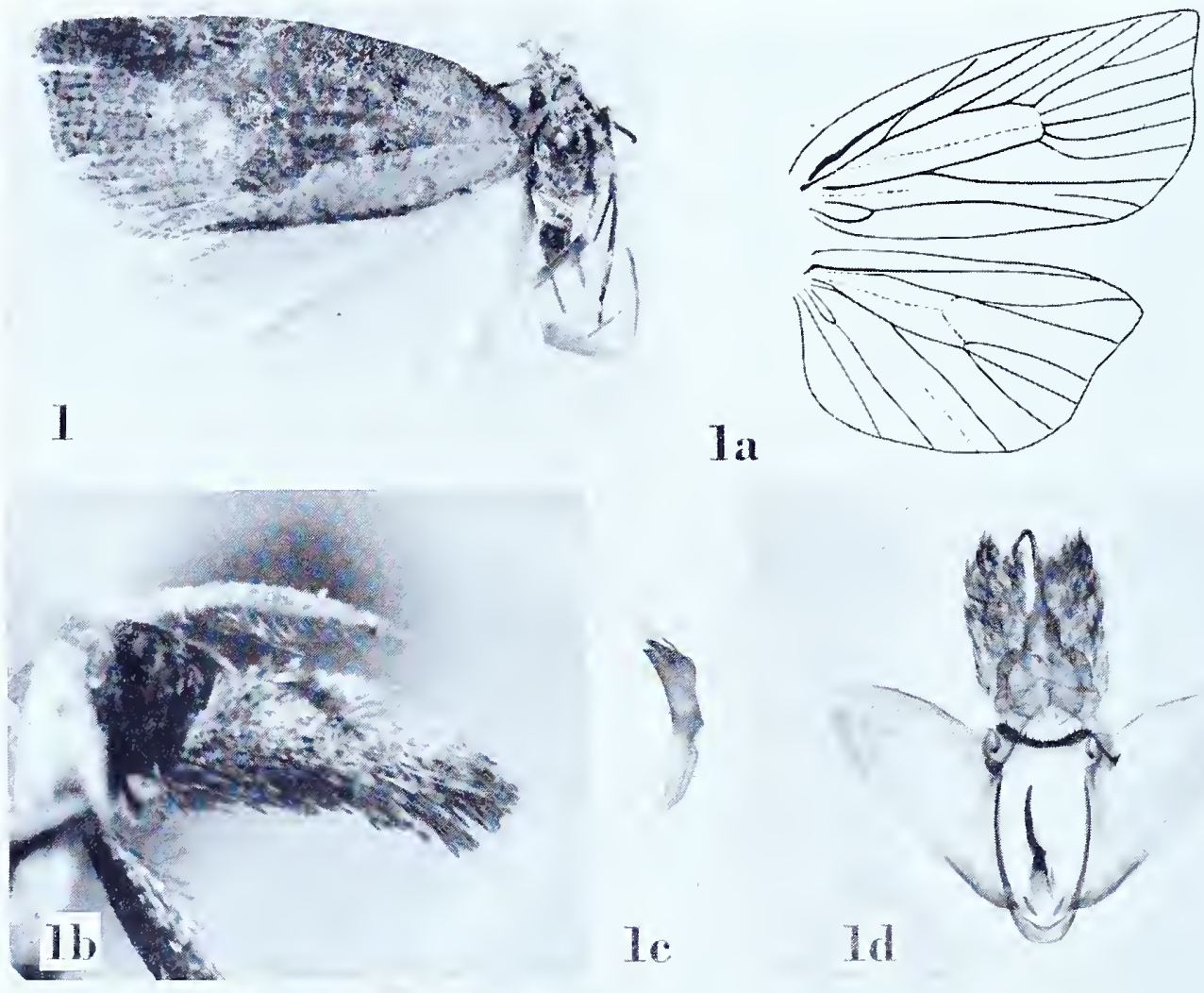

Ic
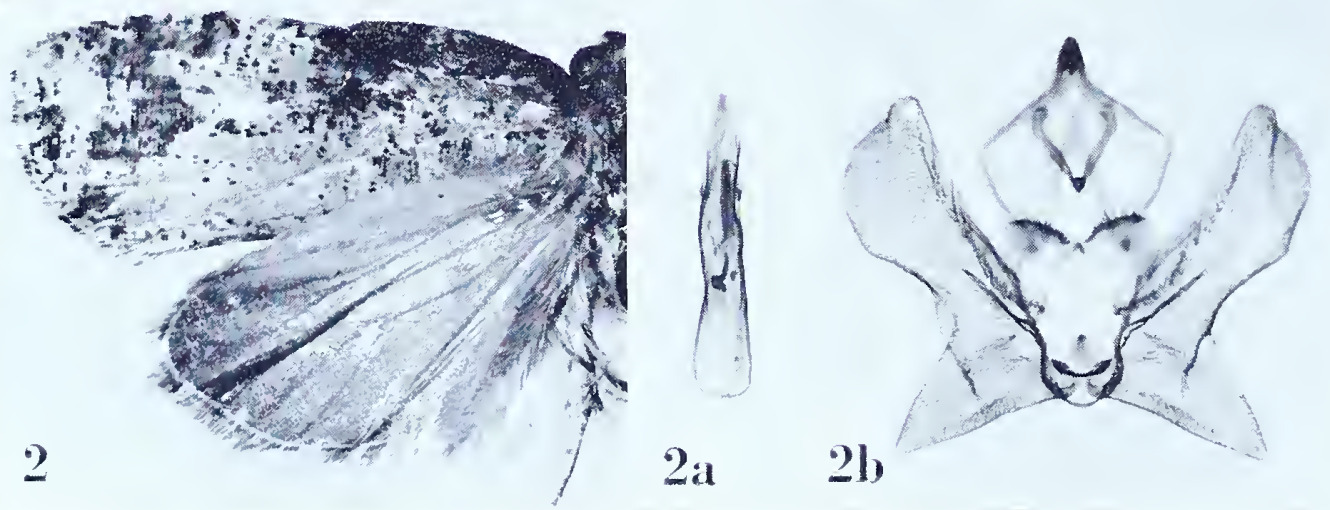

ANCIICREMNA and ANISOCHORISTA 


\section{ANCHICREMNA Meyrick}

Anchicremna Meyrick, 1926, Exotic Microlepidoptera, 3:246. (Typus generis: Anchicremna enlidias Meyrick, ibid. [monotypy].)

\section{Anchicremna eulidias Meyrick}

Plate I 5, Figures I-Id

Anchicremna enlidias Meyrick, 1926, Exotic Microlepidoptera, 3: 246.

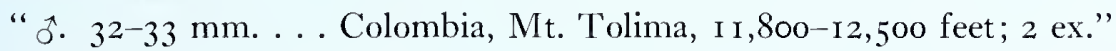

Lectotype: The male dated ". 10.20 " from 12,500 feet. The second specimen is missing. Slide No. 6292.

Figure $\mathrm{r}$, left wings; $\mathrm{ra}$, venation of right wings; $\mathrm{rb}$, lateral aspect of head to show palpus; rc, lateral aspect of aedeagus; $\mathrm{Id}$, ventral view of male genitalia with aedeagus removed.

\section{ANISOCHORIS'TA Turner \\ Anisochorista ostracopis Meyrick \\ Plate I $_{5}$, Figures 2-2b}

Anisochorista ostracopis Meyrick, 1938, Trans. R. Ent. Soc. London, 87: 505.

"o. $23 \mathrm{~mm}$. . . . Mafulu, 4, ooo feet, December. I ex."

Type: The above indicated male, so marked in the British Museum. "Mafulu, Papua, 4,oooft. xii.r 923. L. E. Cheesman." Slide No. 703 o.

Figure 2, left wings; 2a, dorsal aspect of aedeagus; $2 \mathrm{~b}$, ventral view of male genitalia with aedeagus removed. 


\section{ANISOGONA Meyrick}

Anisogona Meyrick, I88I, Proc. Linnean Soc. New South Wales, 6:464. (Typus generis: Teras similana Walker, $186_{3}$, List of the specimens of lepidopterous insects in the collection of the British Museum, 28: 300 [subsequent designation by Meyrick, I9I3, in Wytsman, Genera Insectorum, fasc. I 49: 19].)

Meyrick suppressed this genus as a synonym of Homona Walker (1863), but it is distinct and is hereby removed from synonymy.

\section{Anisogona similana (Walker)}

Plate I6, Figures I-Id

Teras similana Walker, $\mathbf{1} 86_{3}$, List of the specimens of lepidopterous insects in the collection of the British Museum, 28: 300 .

Figure I, left wings; ra, venation of right wings. Hindwing with freak venation; I b, lateral aspect of head to show palpus; Ic, lateral aspect of aedeagus; Id, ventral view of male genitalia with aedeagus removed. 

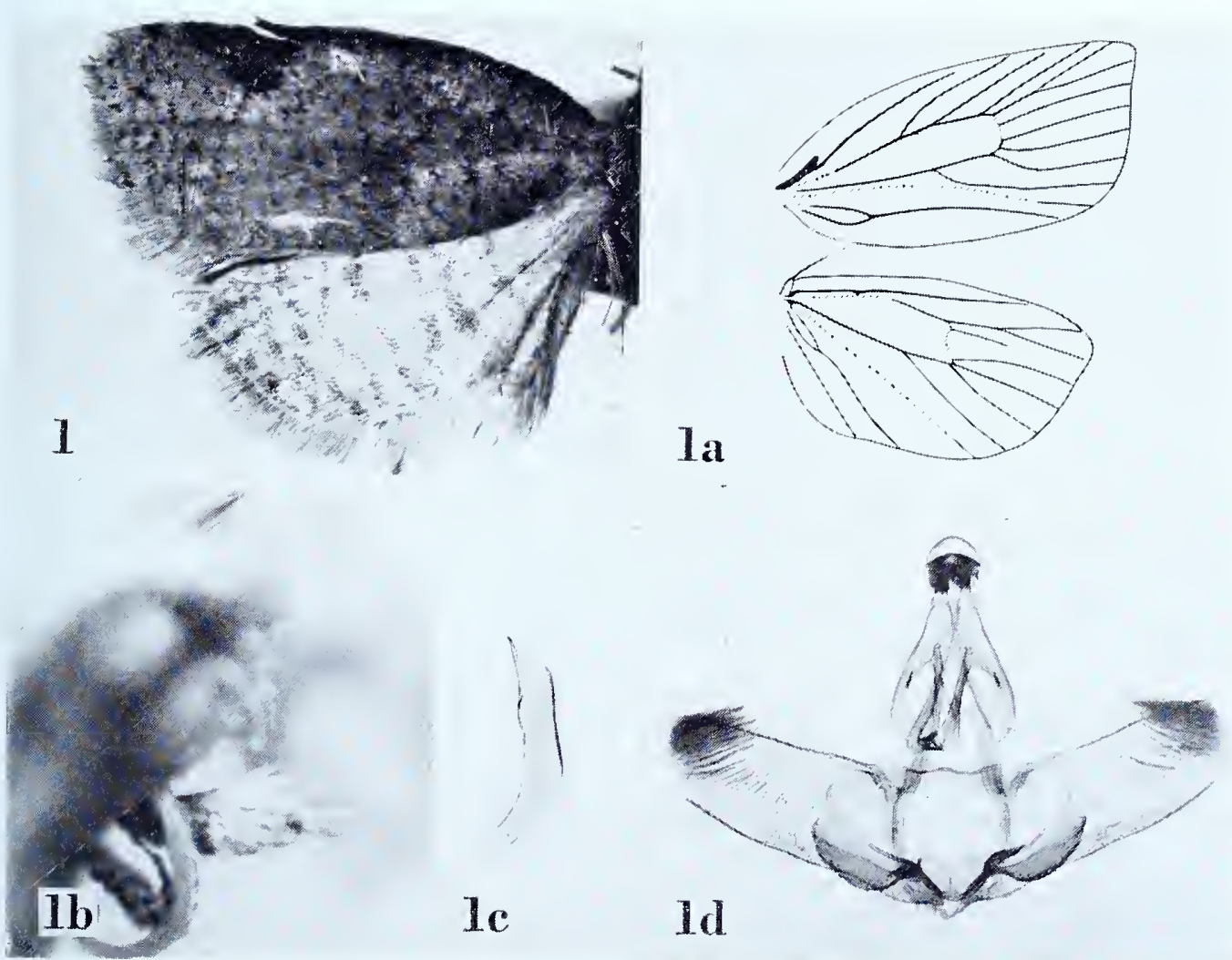

ANISOGONA 


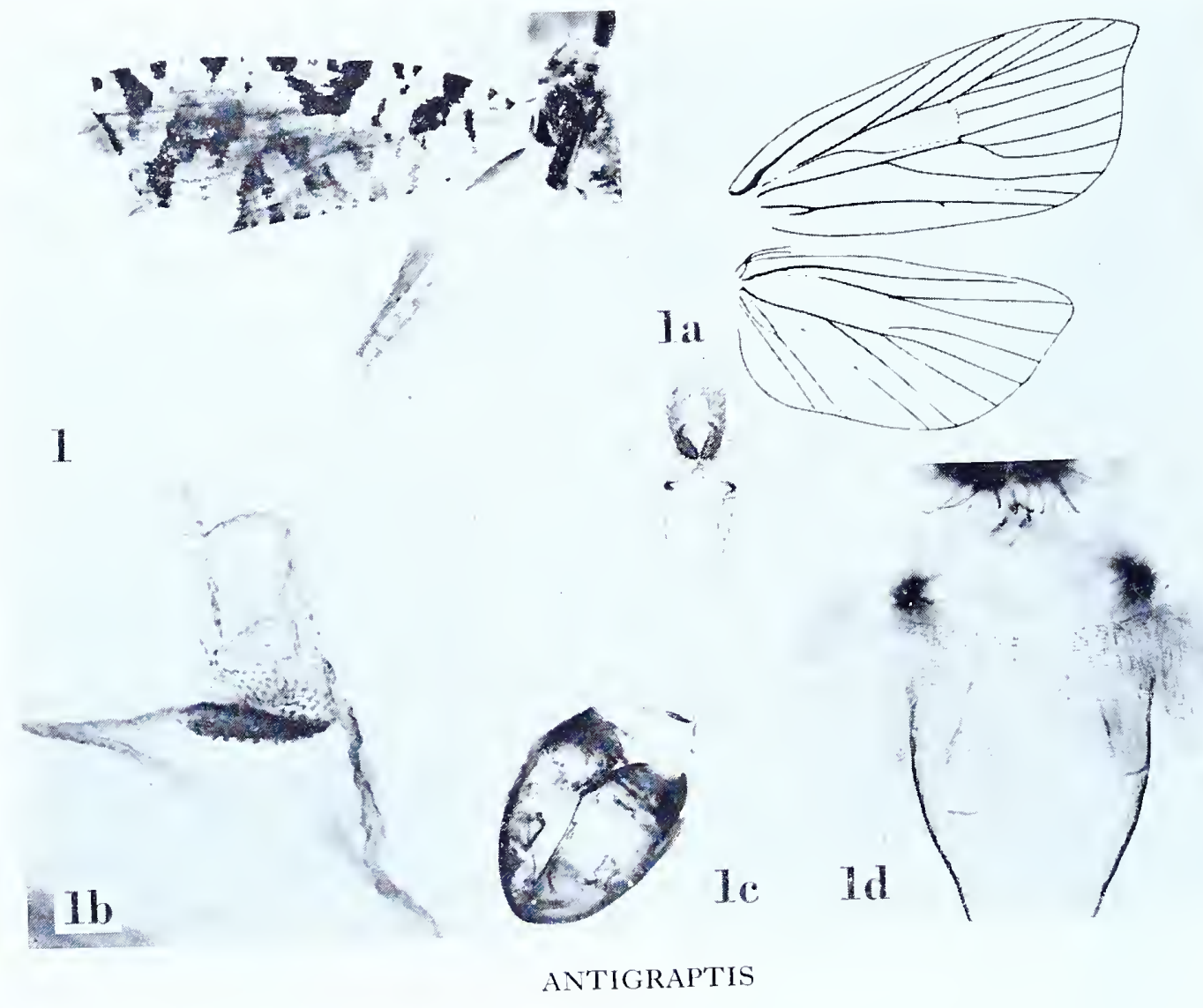




\title{
AN'TIGRAPTIS Meyrick
}

Antigraptis Meyrick, I930, Exotic Microlepidoptera, 3: 6r3. (Typus generis: Antigraptis henicrates Meyrick, ibid. [monotypy].)

\section{Antigraptis hemicrates Meyrick}

\author{
Plate 17 , Figures I-Id
}

Antigraptis henicrates Meyrick, I930, Exotic Microlepidoptera, 3:6r 3 .

"q. $22 \mathrm{~mm}$. . . . Dutch New Guinea, Mt. Goliath, 5-7,00o feet (Meek); I ex. (Coll. Paravicini)."

Type: The female so marked in the British Museum, without date. Slide No. AD I 56 . The head of the type is missing.

Figure I, left wings; Ia, venation of right wings; $\mathrm{rb}$, signum; Ic, ventral view of female genitalia (spermatophore in bursa copulatrix); Id, detail of genital plate and ostium. 


\section{APHROZESTIS Meyrick}

Aphrozestis Meyrick, I93 I, Exotic Microlepidoptera, 4: 156. (Typus generis: Aphrozestis scoriopa Meyrick, ibid. [monotypy].)

\section{Aphrozestis scoriopa Meyrick}

Plate I 8, Figures I-Id

Aphrozestis scoriopa Meyrick, I93 I, Exotic Microlepidoptera, 4: 156.

" o. I 5 mm. . . Fiji, Lautoka, November (H. Phillips); i ex. (Brit. Mus.)."

Type: The male so marked in the British Museum, dated "8.xi.1930". Slide No. 9389 .

Figure I, left wings; $\mathrm{a}$, venation of right wings; $\mathrm{ib}$, lateral aspect of head to show palpus; ic, lateral aspect of aedeagus; Id, ventral view of male genitalia with aedeagus removed (both harpes damaged). 

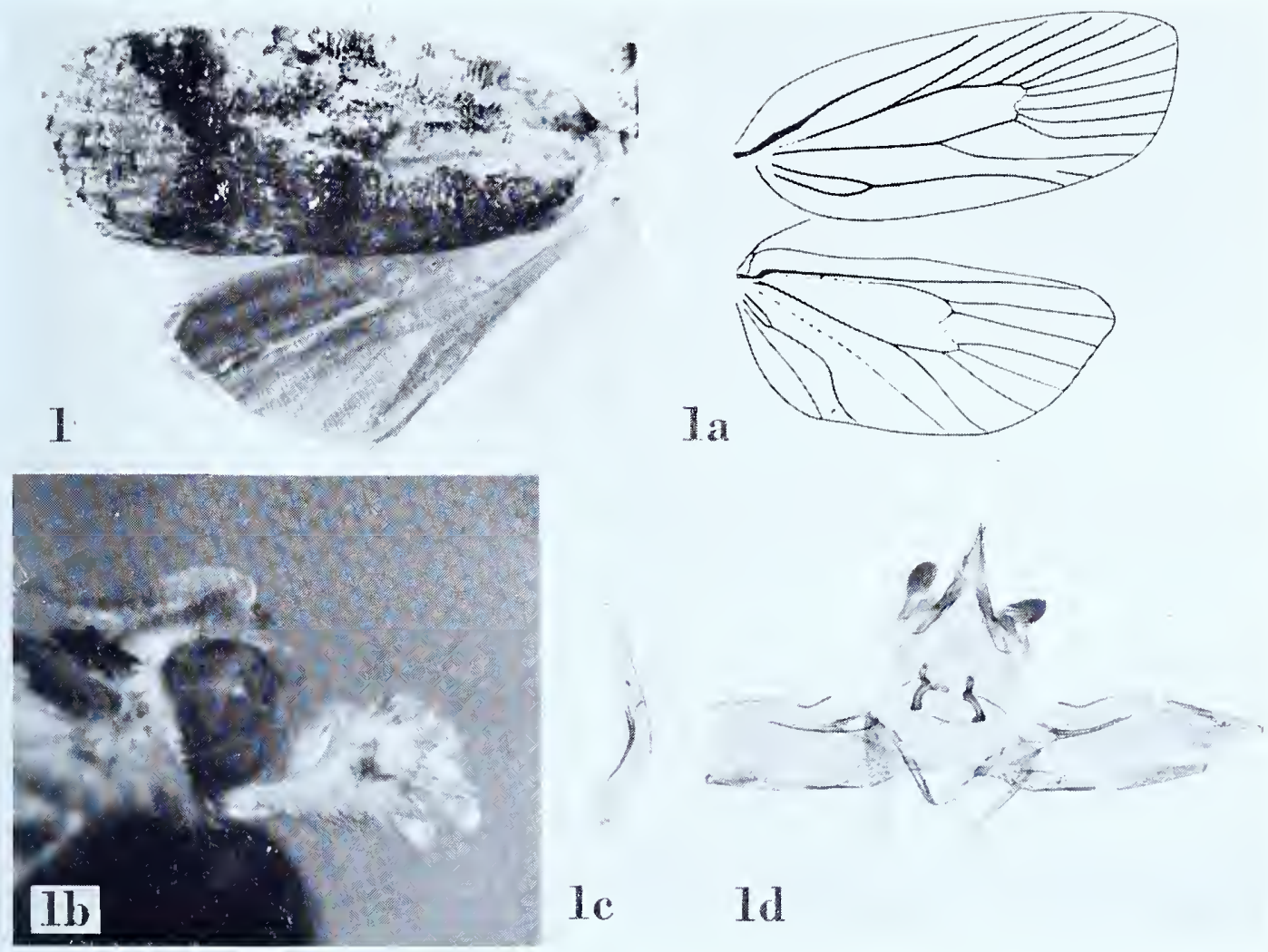

APHROZESTIS 

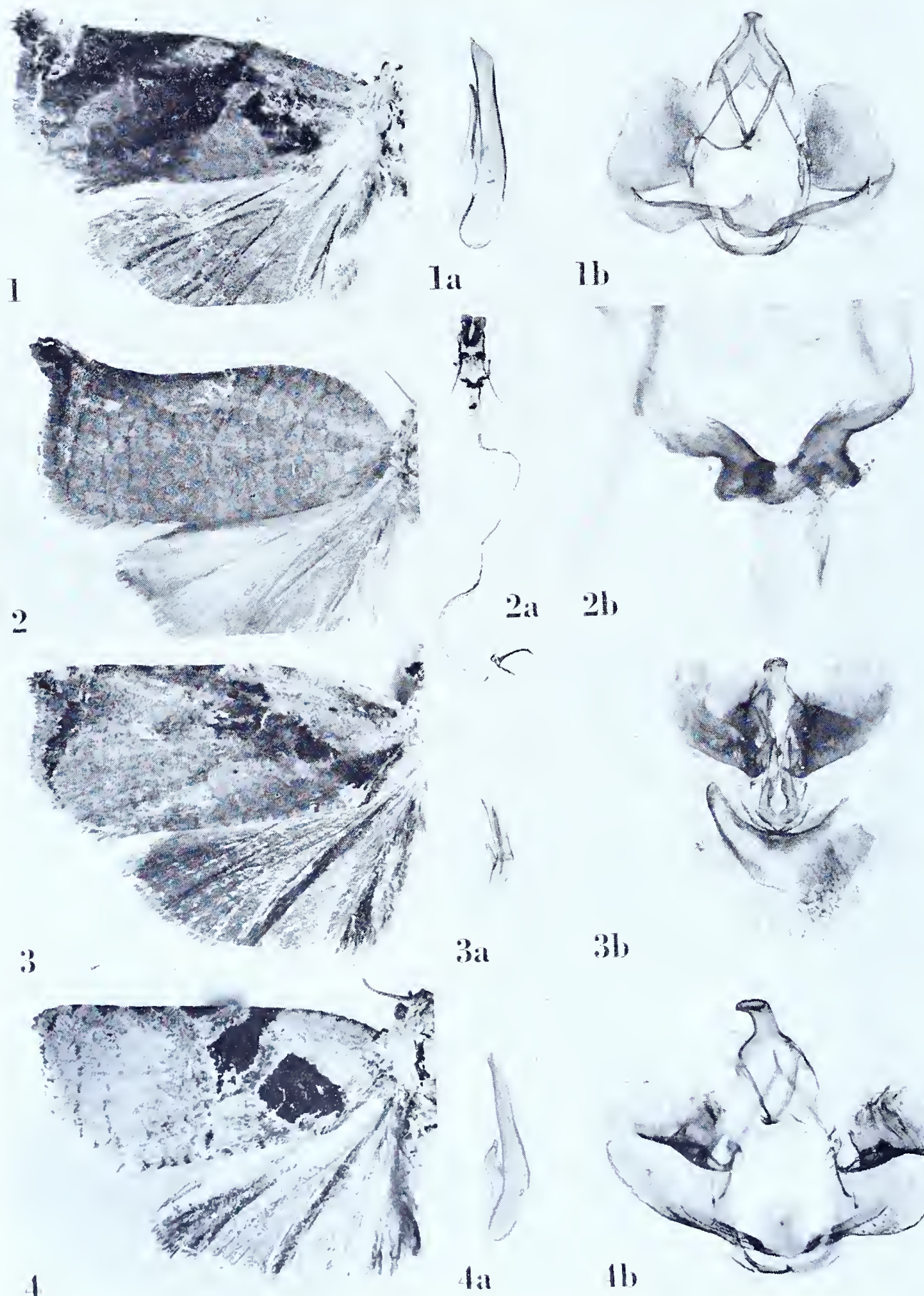

36
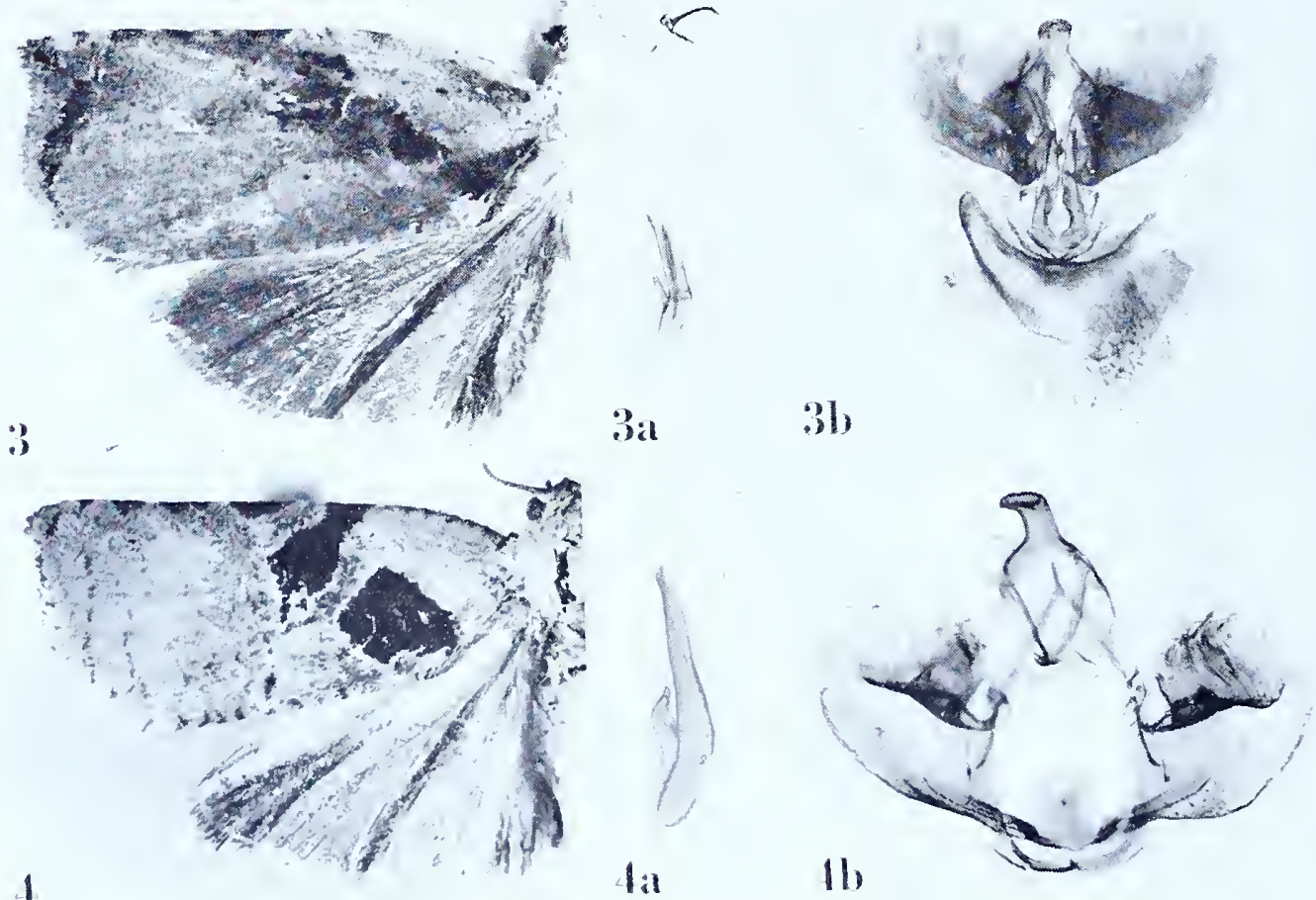


\section{ARCHIPS Hübner}

\section{Archips binigrata (Meyrick), new combination}

Plate I 9, Figures I-Ib

Cacoecia binigrata Meyrick, I928, Exotic Microlepidoptera, 3:456.

" స. 20-2 I mm. ... Assam, Shillong, 5,00o feet, August, October (Fletcher); 2 ex. Near solida. ...'

Lectotype: The male dated “.ı.I6”. Slide No. 68I4.

Figure I, left wings; 1 a, lateral aspect of aedeagus; 1 b, ventral view of male genitalia with aedeagus removed.

\section{Archips brachytoma (Meyrick), new combination}

See Archips seditiosa (Meyrick).

\section{Archips compacta (Meyrick), new combination}

See p. 43

\section{Archips contemptrix (Meyrick), new combination}

Plate 19 , Figures 2-2b

Cacoecia contemptrix Meyrick, I925, in Caradja, Bull. Sec. sci. Acad. roum., 3: 378.

Cacoecia alcmaeonis Meyrick, 1928, Exotic Microlepidoptera, 3:455.

[alcmaeonis]

"o. 30-3 I mm. ... Assam, Shillong, 5,000 feet, September (Fletcher); 2 ex."

Lectotype: The female measuring $3 \mathrm{I}$ mm., dated " 19.9 .27 ”. Slide No. 68 ${ }_{5}$. The second specimen is missing.

Figure 2, left wings; 2a, ventral view of female genitalia; $2 \mathrm{~b}$, detail of genital plate and ostium.

\section{Archips difficilis (Meyrick), new combination}

Plate 19, Figures $3-3 \mathrm{~b}$

Cacoecia difficilis Meyrick, 1928, Exotic Microlepidoptera, 3: $45^{6}$.

" o. $2 \mathrm{I}-22 \mathrm{~mm}$. ... ㅇ. $24 \mathrm{~mm}$. . . Borneo, Sarawak, Kuching, Labuan; 4 ex. Nearest tabescens from Java."

Lectotype: A male measuring 22 mm., "Kuching, Borneo, R. .o7." Slide No. 6803.

Figure 3 , left wings; $3 \mathrm{a}$, lateral aspect of aedeagus; 3 b, ventral view of male genitalia with aedeagus removed.

[contimued on $p .59$. 
ARCHIPS

\title{
Archips eupatris (Meyrick), new combination
}

\author{
Plate 20, Figure I
}

Cacoecia eupatris Meyrick, igo8, Journ. Bombay Nat. Hist. Soc., i8: 6r 4.

" $0.20 \mathrm{~mm}$. . . . Wellawaya, Ceylon, in November (Greeil); one specimen. Allied to $C$. epicyrta....'

Type: The male indicated above dated ". I I.05". The abdomen of the type is missing.

Figure $\mathrm{I}$, left wings.

\section{Archips euryplintha (Meyrick), new combination}

Plate 20, Figures 2-2c

Cacoecia euryplintha Meyrick, 1923, Exotic Microlepidoptera, 3: 53.

“ +. 20 mm. . . Bengal, Darjiling, Mangpu, 4,000 feet, September (Fletcher); I ex."

Type: The female indicated above dated ".9.20". Slide No.68 I8.

Figure 2 , left wings; $2 a$, ventral view of female genitalia; $2 b$, detail of genital plate and ostium; 2c, signum.

\section{Archips expleta (Meyrick), new combination}

See Archips hemixantha (Meyrick).

\section{Archips hemixantha (Meyrick), new combination}

\section{Plate 2o, Figures $3-3 \mathrm{~b} ; 4-4 \mathrm{~b}$}

Cacoecia hemixantha Meyrick, i 9 8, Exotic Microlepidoptera, 2: I65.

Cacoecia expleta Meyrick, I923, Exotic Microlepidoptera, 3: 54 (new synonymy).

[hemixantha]

" o. $24 \mathrm{~mm}$. $+.28 \mathrm{~mm}$. . . . Sikkim, Darjiling (Fletcher); three examples."

Lectotype: A male, "Darjiling, India. 'TBF. .I 7." Slide No. 6820. One specimen is missing.

Figure 3 , left wings; $3 \mathrm{a}$, dorsal aspect of aedeagus; $3 \mathrm{~b}$, ventral view of male genitalia with aedeagus removed.

[expleta]

"ふ. 2 I-22 mm. +. 27-28 mm. . . Assam, Shillong, May, October (Fletcher); 4 ex."

Lectotype: A male measuring 2 I mm., dated ".5.I 8". Slide No. 68I9. Two specimens are missing.

Figure 4 , left wings; 4 a, lateral aspect of aedeagus; 4 b, ventral view of male genitalia with aedeagus removed.

\section{Archips isocyrta (Meyrick), new combination}

See Archips micaceana (Walker).

$$
\text { Archips machlopis (Meyrick), new combination }
$$

See Archips micaceana (Walker). 

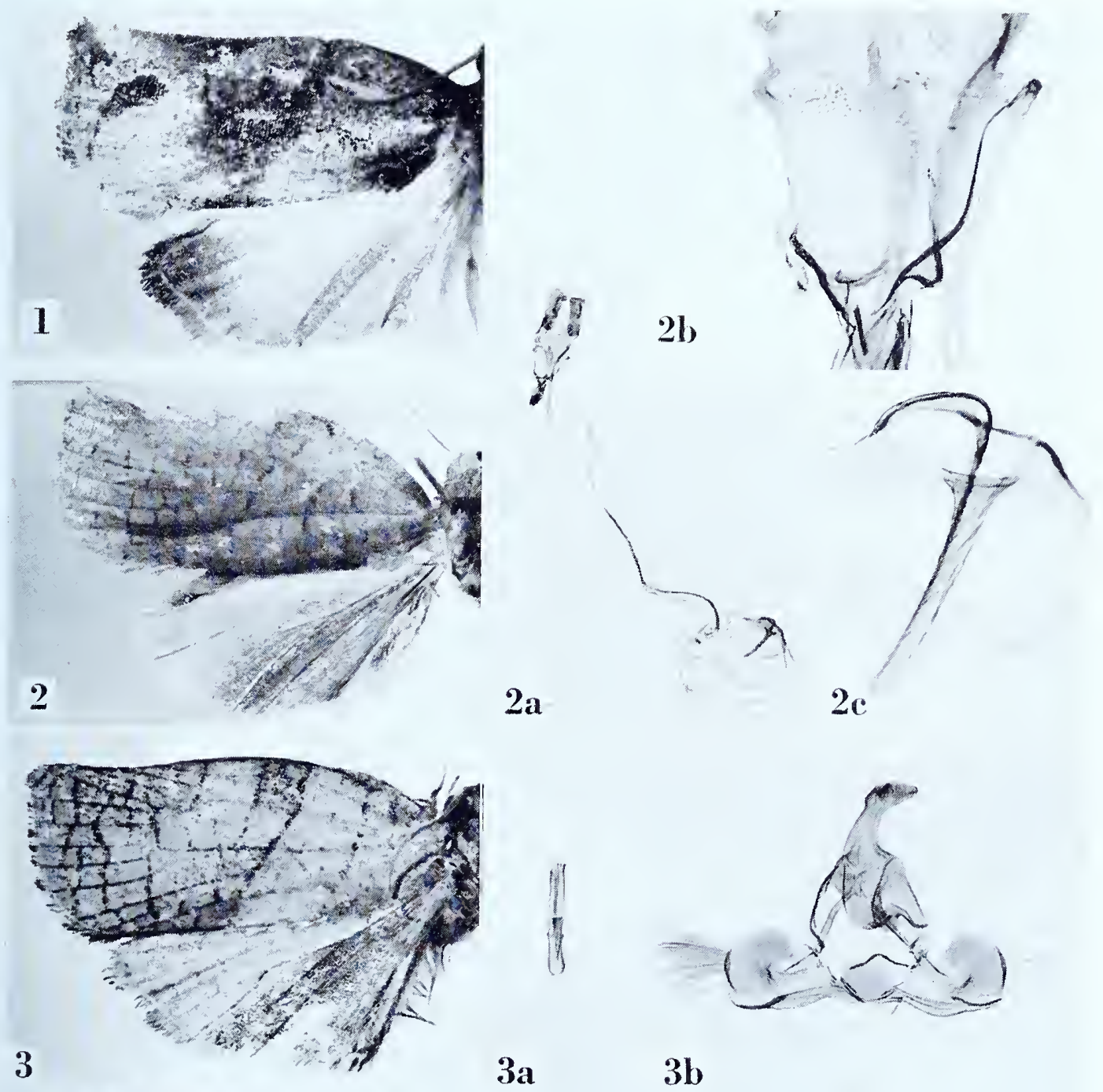

3a
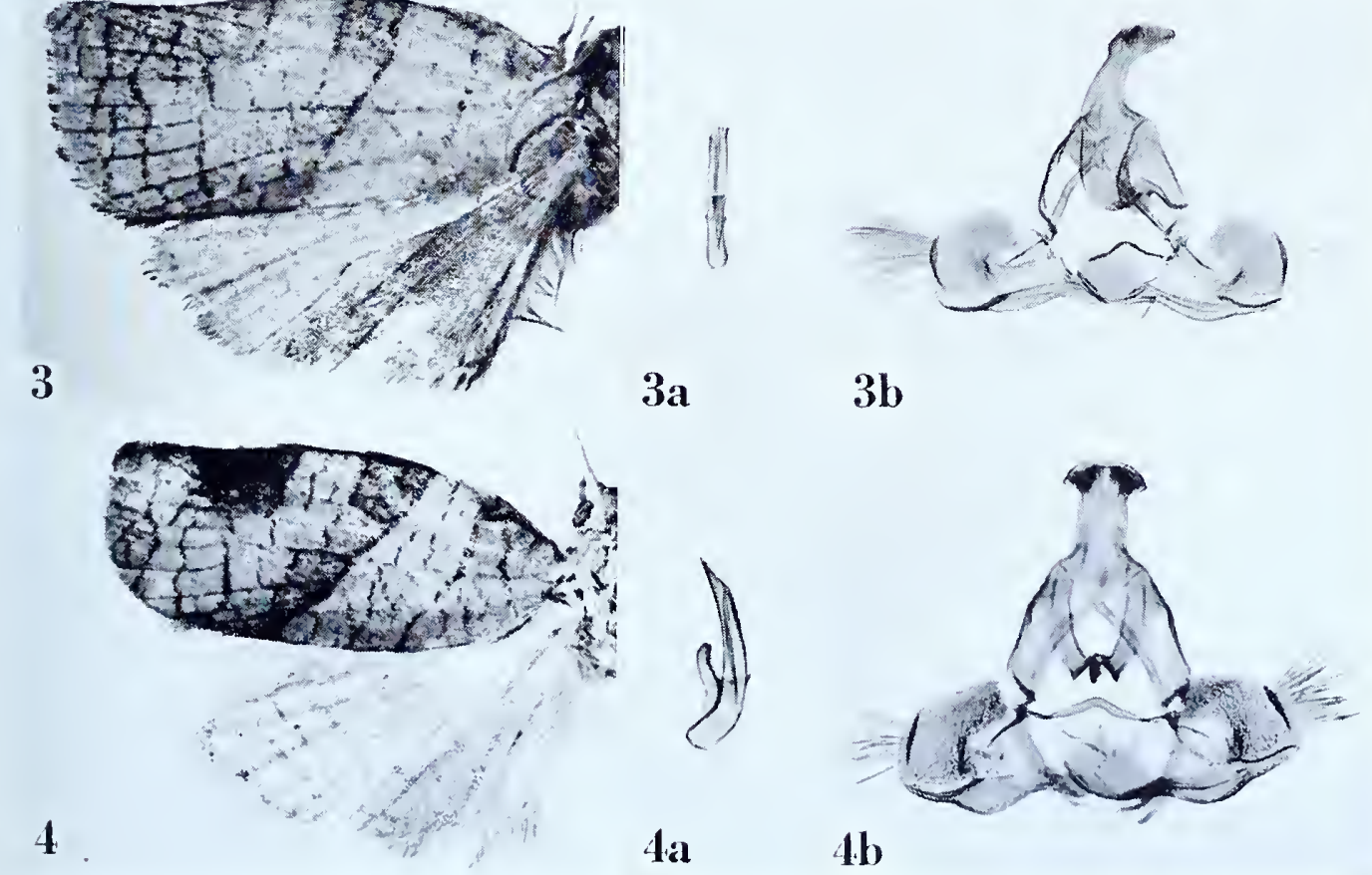


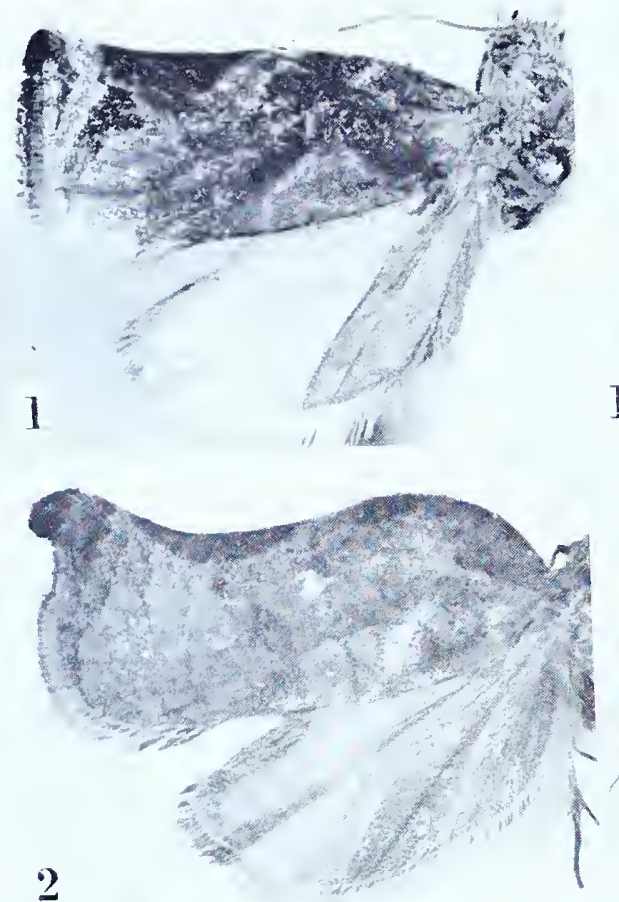

2

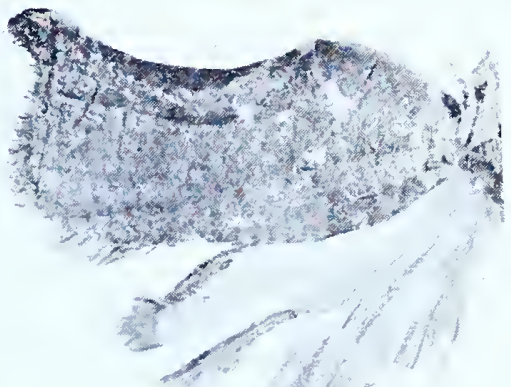

3

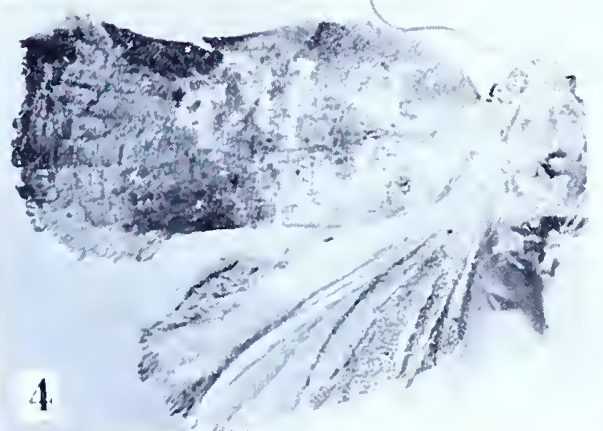

$3 a$

i)

ref
Ib

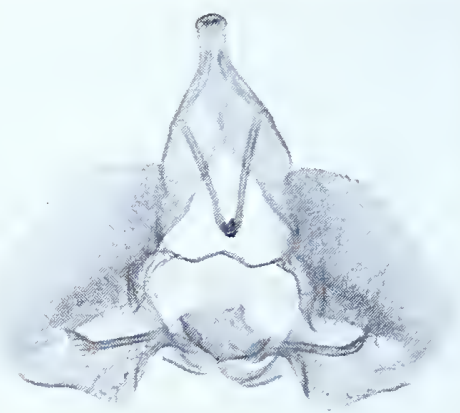

$3 b$
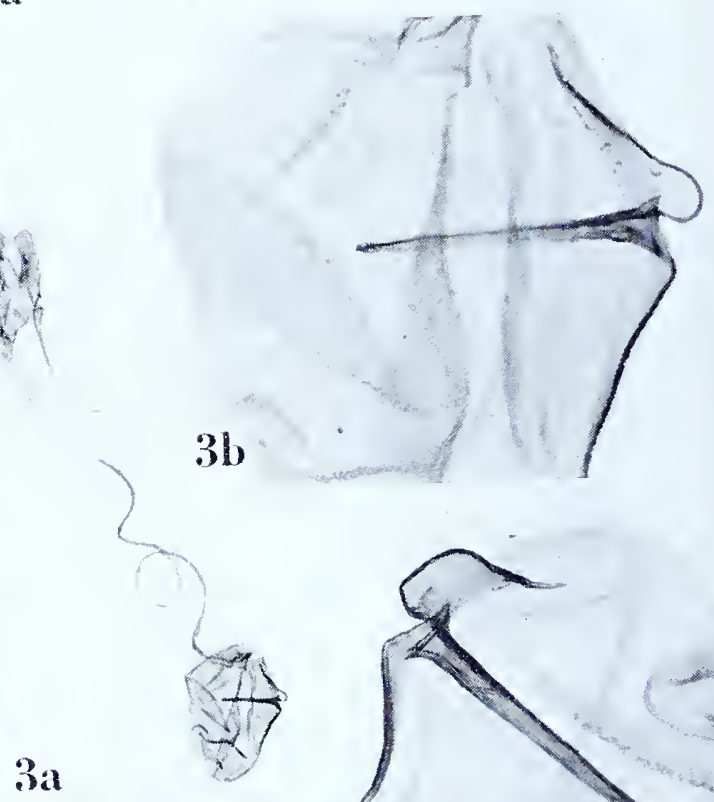

4b
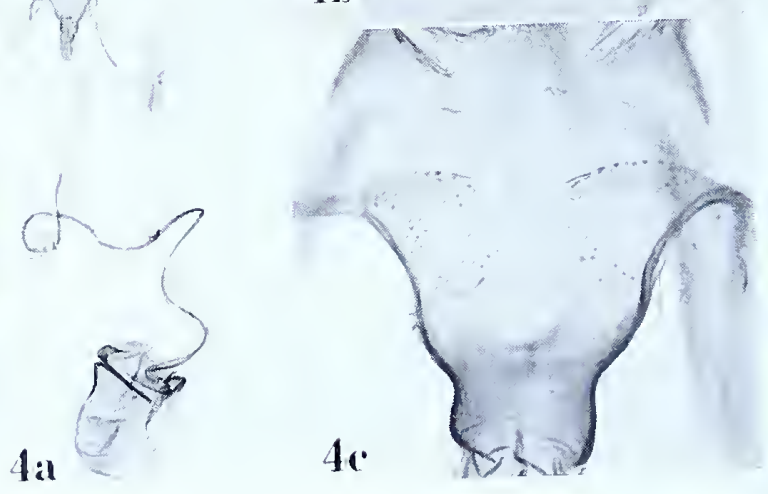

ARCIIIPS 


\title{
Archips micaceana (Walker)
}

\author{
Plate 2I, Figures $\mathrm{I}-\mathrm{I} \mathrm{b} ; 2,3-3 \mathrm{~b}$
}

Cacoecia micaceana Walker, 1863 , List of the specimens of lepidopterous insects in the collection of the British Museum, 28: 3 I 4.

Cacoecia epicyrta Meyrick, I905, Journ. Bombay Nat. Hist. Soc., I6: 589 .

Cacoecia isocyrta Meyrick, 1920, Exotic Microlepidoptera, 2: 340.

Cacoecia machlopis Meyrick, I912, Exotic Microlepidoptera, I : 4.

[epicyrta]

“․ I 8-2 I mm. 우 $23 \mathrm{~mm}$. . . . Seven specimens, Maskeliya, Puttalam, and Newera Eliya, Ceylon, from July to September. Bred from larvae feeding in fruit of plum...."

Lectotype: A male measuring $20 \mathrm{~mm}$., "Maskeliya, Ceylon. EEG. /7/02." Slide No. 6807. Only two of the original seven remain in the Meyrick collection.

Figure $\mathrm{I}$, left wings; $\mathrm{s}$, lateral aspect of aedeagus; $\mathrm{ib}$, ventral view of male genitalia with aedeagus removed.

[isocyrta]

"ㅇ․ $20 \mathrm{~mm}$. . . . Bengal, Pusa, bred in February from larva in shoot of lucerne (Medicago) (Fletcher)."

Type: The above indicated female dated ".2.17". The abdomen of the type is missing.

Figure 2, left wings.

[machlopis]

"ㅇ. 20-25 mm. . . . Assam, Khasis; Java, Bandong; from October to December, four specimens. Allied to epicyrta, but with all curves of forewings exaggerated."

Lectotype: A female measuring 22 mm., "Khasi Hills, Assam. .ro.r 906." Slide No. 6808 .

Figure 3 , left wings; 3 a, ventral view of female genitalia; 3 b, signum.

\section{Archips compacta (Meyrick), new combination}

Plate 2I, Figures $4-4 \mathrm{c}$

Cacoecia compacta Meyrick, I918, Exotic Microlepidoptera, 2: I64.

" o. $19 \mathrm{~mm}$. ... . . I $9 \mathrm{~mm}$. . . . Bengal, Pusa, bred from larvae on Salix, April (Fletcher); two specimens. ..."

Lectotype: The female. Slide No. 68II. 'The male lacks the abdomen. Both specimens bear identical data and are dated ".4.16".

Figure 4 , left wings; 4 a, ventral view of female genitalia; 4 b, signum; 4 c, detail of genital plate and ostium. 
ARCHIPS

\section{Archips ochrostoma (Meyrick), new combination}

Plate 22, Figures $I-I b$

Cacoecia ochrostoma Meyrick, i9 18, Exotic Microlepidoptera, 2: i66.

" $+34 \mathrm{~mm}$. ... French Congo, Fort Crampel; one specimen."

Type: The above indicated female, "Fort Crampel, French Congo. LeM. .15". Slide No. 9340.

Figure I, left wings; 1 a, ventral view of female genitalia; $\mathrm{Ib}$, detail of genital plate and ostium.

\section{Archips paredraea (Meyrick), new combination}

Plate 22, Figures 2-2b

Cacoecia paredraea Meyrick, I93 I, Exotic Microlepidoptera, 4: I49.

" o. I9 mm. . . Formosa, Taihoku, October (S. Issiki); 2 ex. Nearest binigrata."

Lectotype: One of the above indicated males, both of which are dated ".10.25". Slide No. 68I7.

Figure 2, left wings; $2 \mathrm{a}$, lateral aspect of aedeagus; $2 \mathrm{~b}$, ventral view of male genitalia with aedeagus removed.

\section{Archips pensilis (Meyrick), new combination}

Plate 22, Figures $3^{-} 3^{\mathrm{c}}$

Cacoecia pensilis Meyrick, I920, Exotic Microlepidoptera, 2: 339.

"f. $17 \mathrm{~mm}$. ... S. India, Madras, bred from larva boring in fruits of orange at base of stalk (Fletcher)."

Type: The female indicated above with ".I5" in the lower right corner of the pin-label.

Figure 3 , left wings; $3 \mathrm{a}$, ventral view of female genitalia (slightly turned); $3 \mathrm{~b}$, detail of genital plate and ostium; $3 \mathrm{c}$, signum.

\section{Archips permutata (Meyrick), new combination \\ Plate 22, Figures $4-4 b$}

Cacoecia permutata Meyrick, I928, Exotic Microlepidoptera, 3:457.

" o. $24^{-27}$ mm. ... S. Andamans, I,200 feet, May, June (Ferrar); 4 ex. Near difficilis and spilotoma."

Lectotype: A male dated “.5.27”. Slide No. 6804. Two specimens are missing.

Figure 4 , left wings; $4 \mathrm{a}$, lateral aspect of aedeagus; $4 \mathrm{~b}$, ventral view of male genitalia with aedeagus removed. 

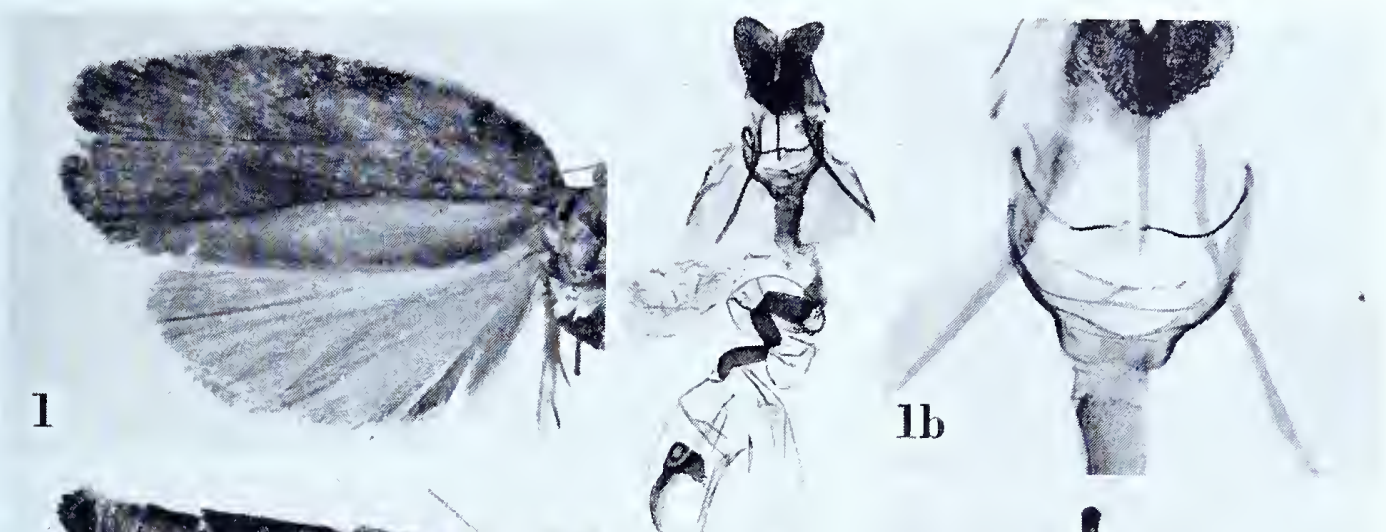

2
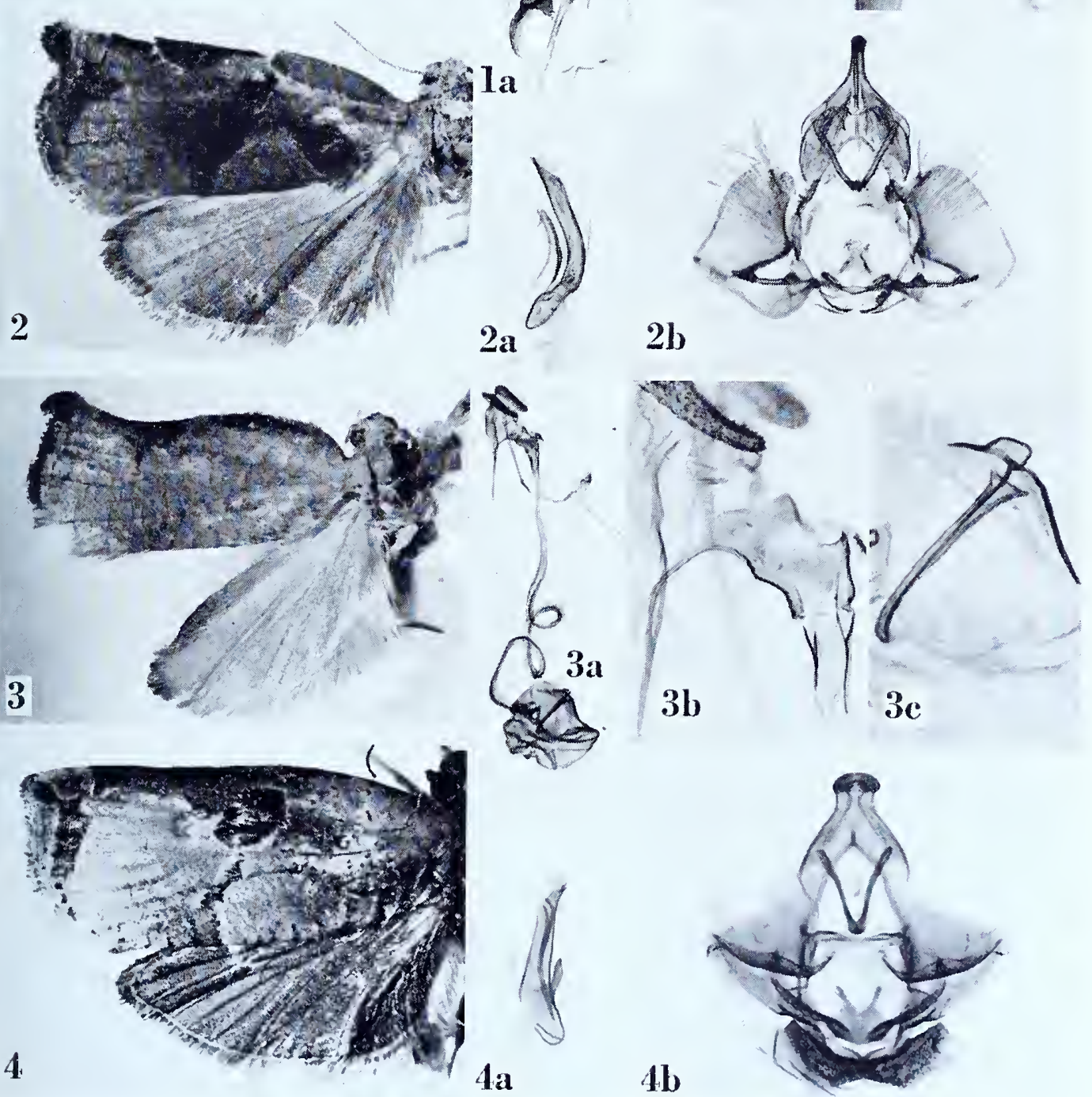

ARCHIPS 

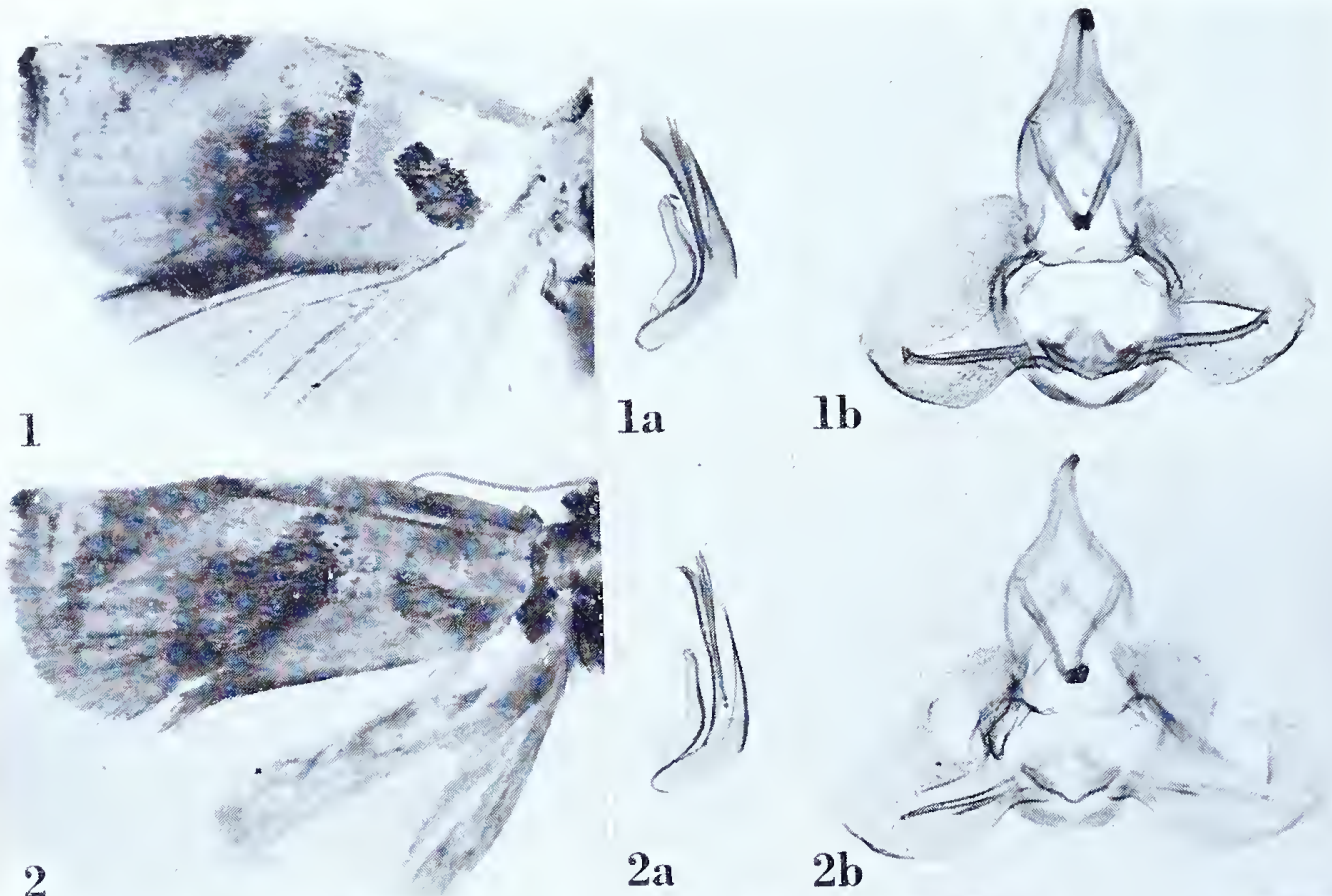

2
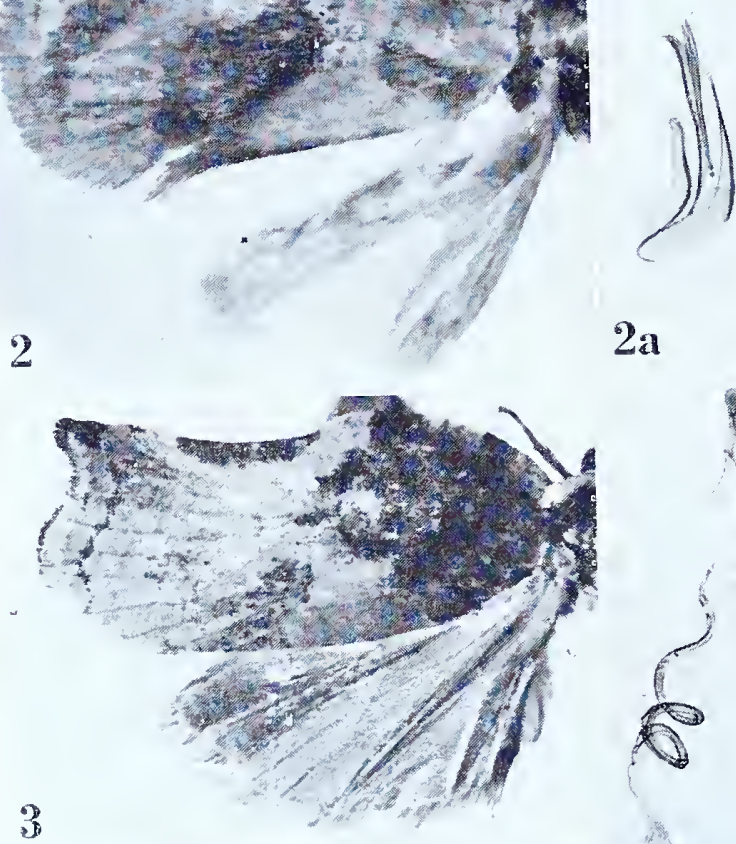

$2 a$
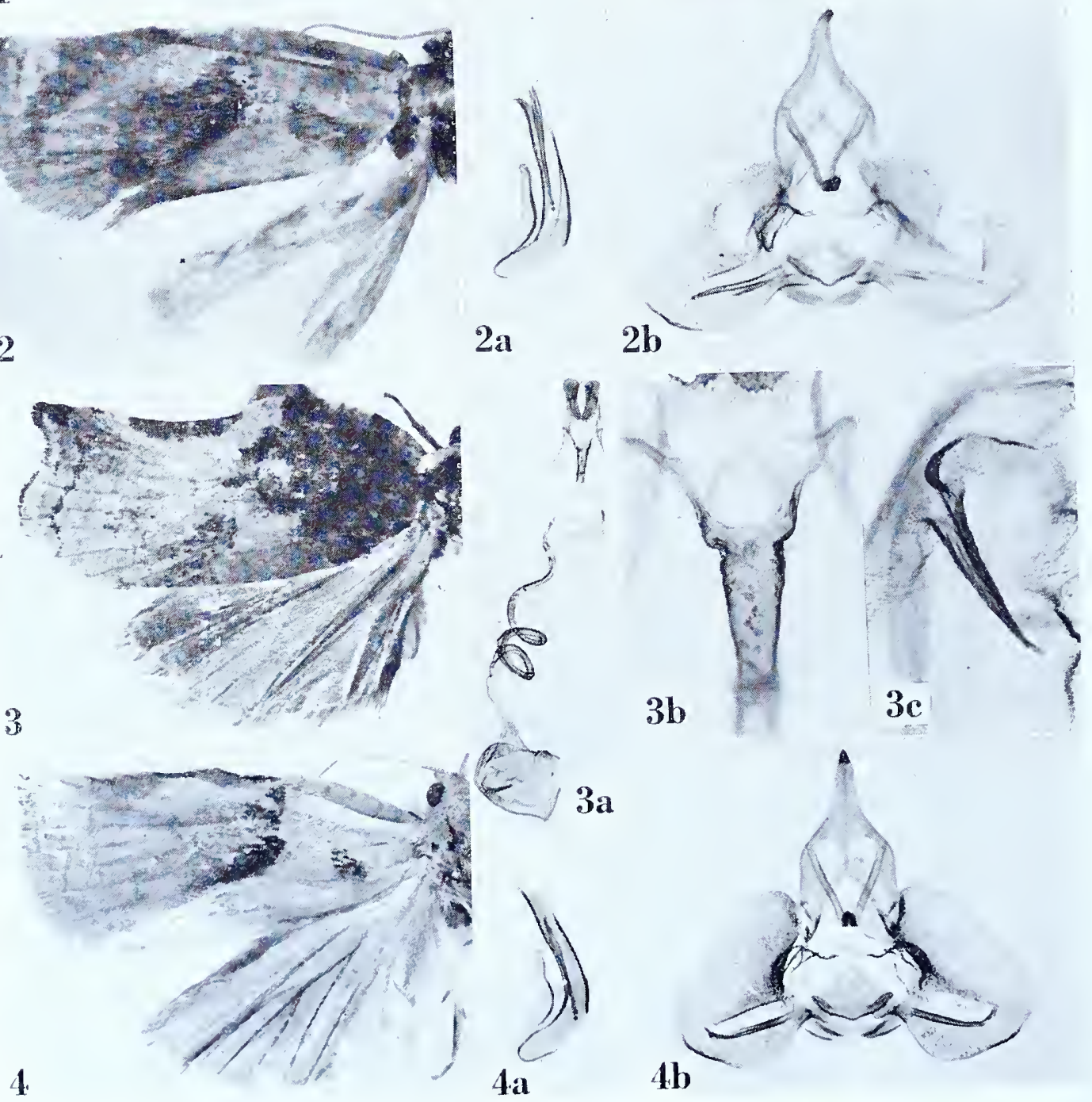

ARCHIPS 


\section{Archips philippa (Meyrick), new combination}

Plate 23, Figures $I-I b$

Cacoecia philippa Meyrick, 1918, Exotic Microlepidoptera, 2: 165.

"o. $20 \mathrm{~mm}$. . . . N.W. India, Abbottabad, bred from larva on Hedera, June (Fletcher); one specimen."

Type: The male indicated above dated “6.16”. Slide No. 681 3.

Figure I, left wings; $\mathrm{I}$ a, lateral aspect of aedeagus; $\mathrm{Ib}$, ventral view of male genitalia with aedeagus removed.

\section{Archips pomivora (Meyrick), new combination}

\section{Plate 23, Figures 2-2b}

Cacoecia pomivora Meyrick, I920, Exotic Microlepidoptera, 2:340.

" đ. I6-I $8 \mathrm{~mm}$. ... +. 2 21-23 mm. ... Himalaya, Kumaon, Ramgarh, bred in September from larvae boring into fruits of apple. ..."

Lectotype: The male measuring 16 mm., dated ".9.19". Slide No. 68ı.

Figure 2 , left wings; $2 \mathrm{a}$, lateral aspect of aedeagus; $2 \mathrm{~b}$, ventral view of male genitalia with aedeagus removed.

\section{Archips salaconis (Meyrick), new combination}

Plate 23, Figures $3-3 \mathrm{c}$

Cacoecia salaconis Meyrick, I912, Exotic Microlepidoptera, I: 5 .

“+. $26 \mathrm{~mm}$. . . Philippines, Mindoro, Laguna de Naujan, near sea-level, in March (Mounsey); one specimen."

Type: The female indicated above dated ".3.10". Slide No. 6802.

Figure 3 , left wings; 3 a, ventral view of female genitalia; 3 b, detail of genital plate and ostium; $3 \mathrm{c}$, signum.

\section{Archips sarcostega (Meyrick), new combination}

Plate 23 , Figures $4-4 \mathrm{~b}$

Cacoecia sarcostega Meyrick, 1924, Exotic Microlepidoptera, 3: 107.

“ڤ. 23-24 mm. ... ㅇ. 27-30 mm. ... Kumaon, Muktesar, 7,300 feet, April, May (Fletcher); 14 ex. (10 ô, 4 ㅇ)."

Lectotype: A male measuring $24 \mathrm{~mm}$., dated “.4.23”. Slide $682 \mathrm{I}$. Six ơ $^{\star}$ and 2 \% are missing.

Figure 4 , left wings; 4 a, lateral aspect of aedeagus; 4 b, ventral view of male genitalia with aedeagus removed. 


\title{
Archips secura (Meyrick), new combination
}

\author{
Plate 24, Figures I-IC
}

Cacoecia secura Meyrick, i910, 'Trans. Ent. Soc. London, 1910: 432.

"q. $32 \mathrm{~mm}$. . . . Flores; one specimen."

Type: The above indicated specimen labelled, "Flores. CS. .o6". Slide No. 6823.

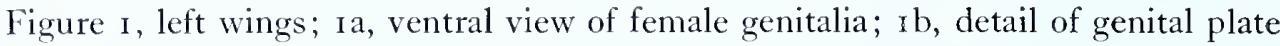
and ostium; ic, signum.

\section{Archips seditiosa (Meyrick), new combination}

Plate 24, Figures 2-2b

Cacoecia seditiosa Meyrick, I 92 I, Zool. Meded., 6: 147.

Cacoecia brachytoma Meyrick, 1932, Exotic Microlepidoptera, 4: 34I.

\section{[brachytoma]}

" ڤ. I 5-I6 mm. . . Malaya, Kuala Lumpur, bred March, April from larvae feeding on leaves of Cinnamomm zeylanicum; 2 ex. (type Brit. Mus.). Nearest epicyrta...."

Type: The male so marked in the British Museum, "Kuala Lumpur, Malay Peninsula, 25.4.32." A second label bears the name "Cinnamomum zeylanicum, B." Slide Stringer No. 273. The left wings of the type are missing.

Figure 2, right wings (image reversed); $2 a$, lateral aspect of aedeagus; $2 b$, ventral view of male genitalia with aedeagus removed.

\section{Archips solida (Meyrick), new combination}

Plate 24, Figures $3-3 \mathrm{~b}$

Cacoecia solida Meyrick, igo8, Journ. Bombay Nat. Hist. Soc., i 8: 6 I 4.

" oै. I9-20 mm. . . Darjiling; two specimens."

Lectotype: The male measuring $20 \mathrm{~mm}$., "Darjiling, Bengal. D. .8.04." Slide No. 68 I 6.

Figure 3 , left wings; 3 a, lateral aspect of aedeagus; $3 \mathrm{~b}$, ventral view of male genitalia with aedeagus removed.

\section{Archips stenochorda (Meyrick), new combination}

Plate 24, Figures $4-4 \mathrm{~b}$

Cacoecia stenochorda Meyrick, 1928, Exotic Microlepidoptera, 3:456.

“ڤ. I $8 \mathrm{~mm}$. ... Philippines, Luzon, Mt. Makiling (Baker); i ex. A very distinct form."

Type: The above indicated male with "B. .27" on the bottom of the pin-label. Slide No. 680 I.

Figure 4 , left wings; $4 \mathrm{a}$, lateral aspect of aedeagus; $4 \mathrm{~b}$, ventral view of male genitalia with aedeagus removed. 

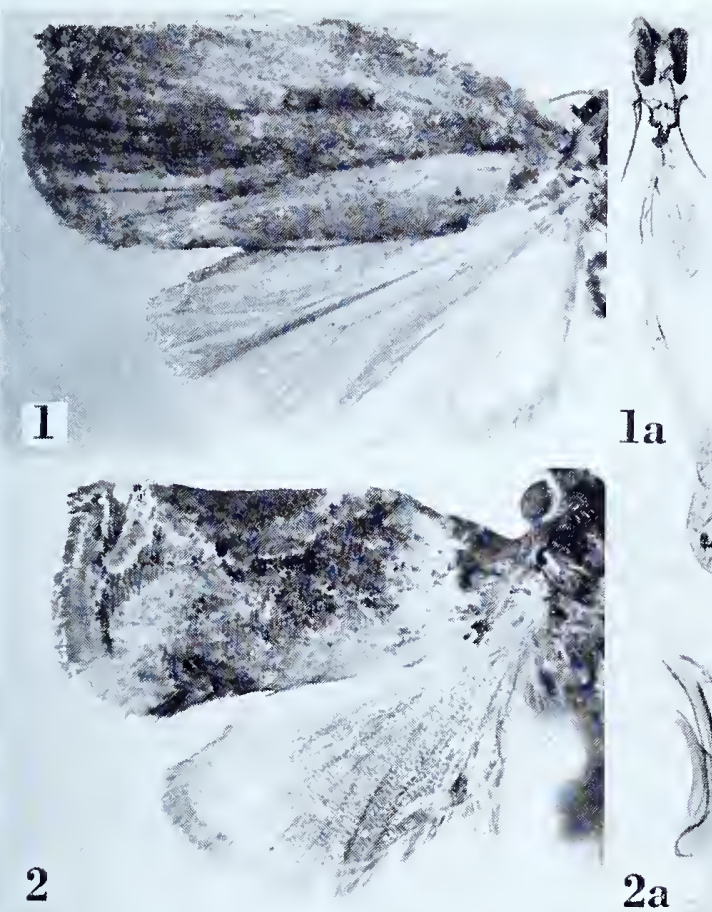

1b
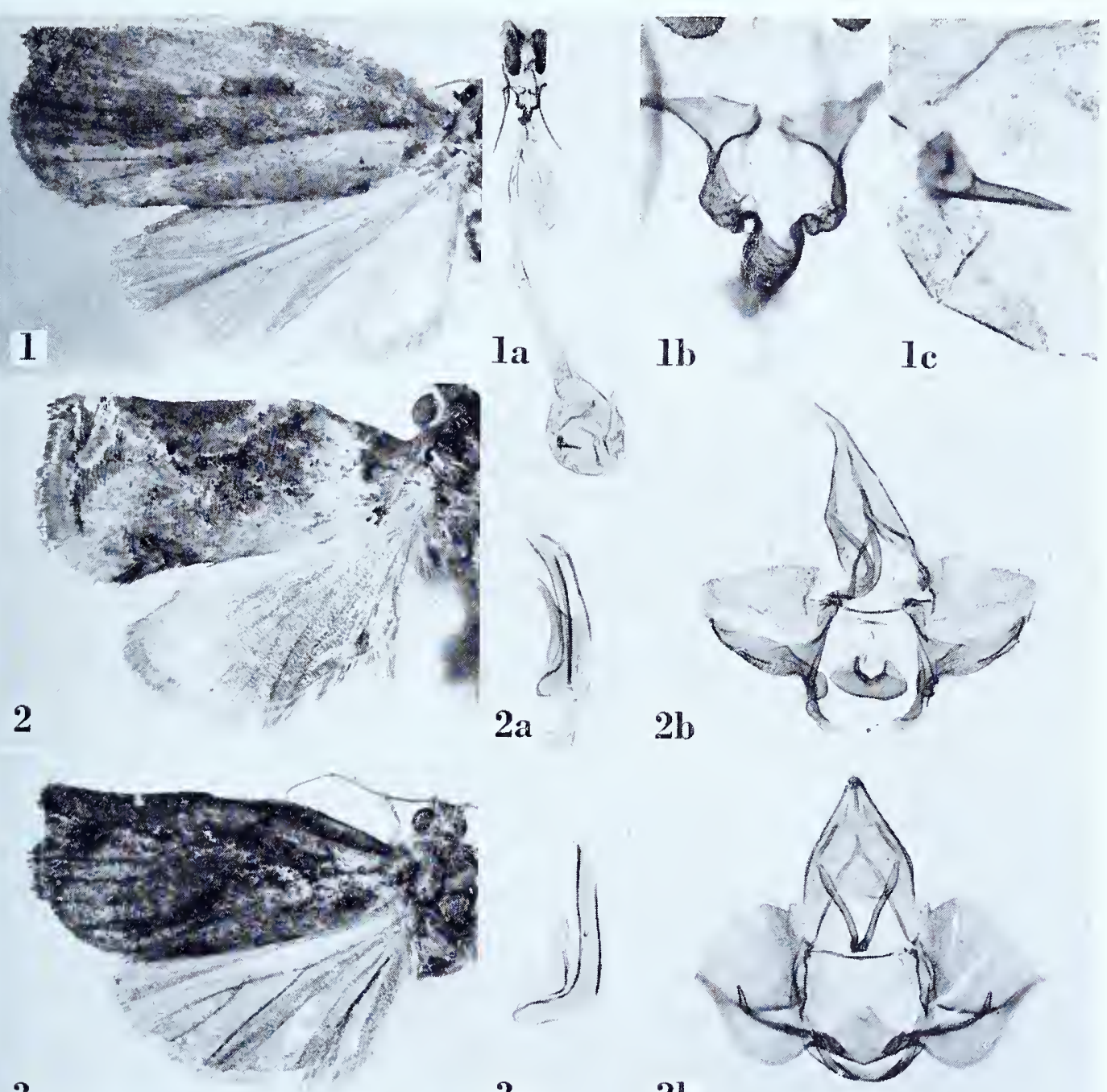

3
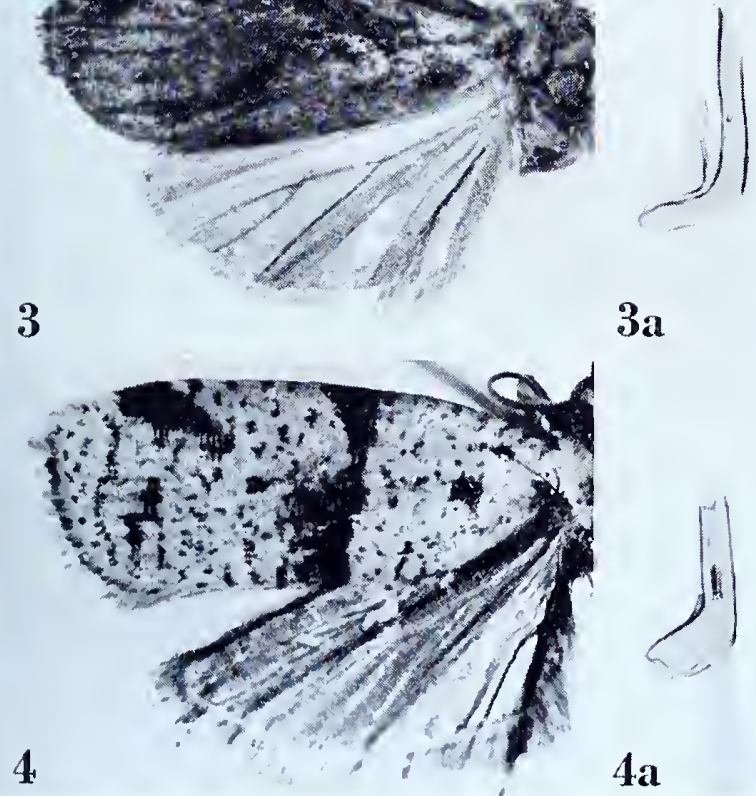

$3 a$

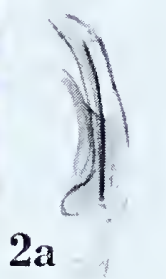

$2 b$
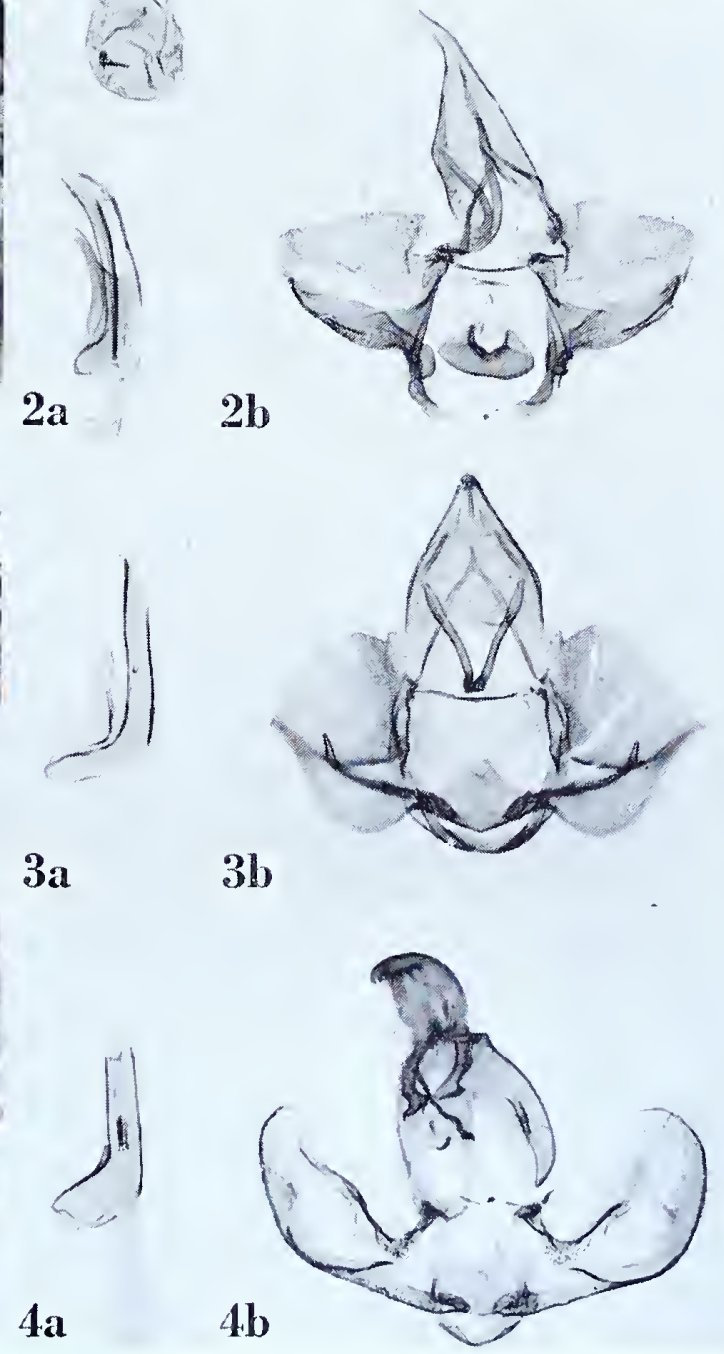

ARCHIPS 

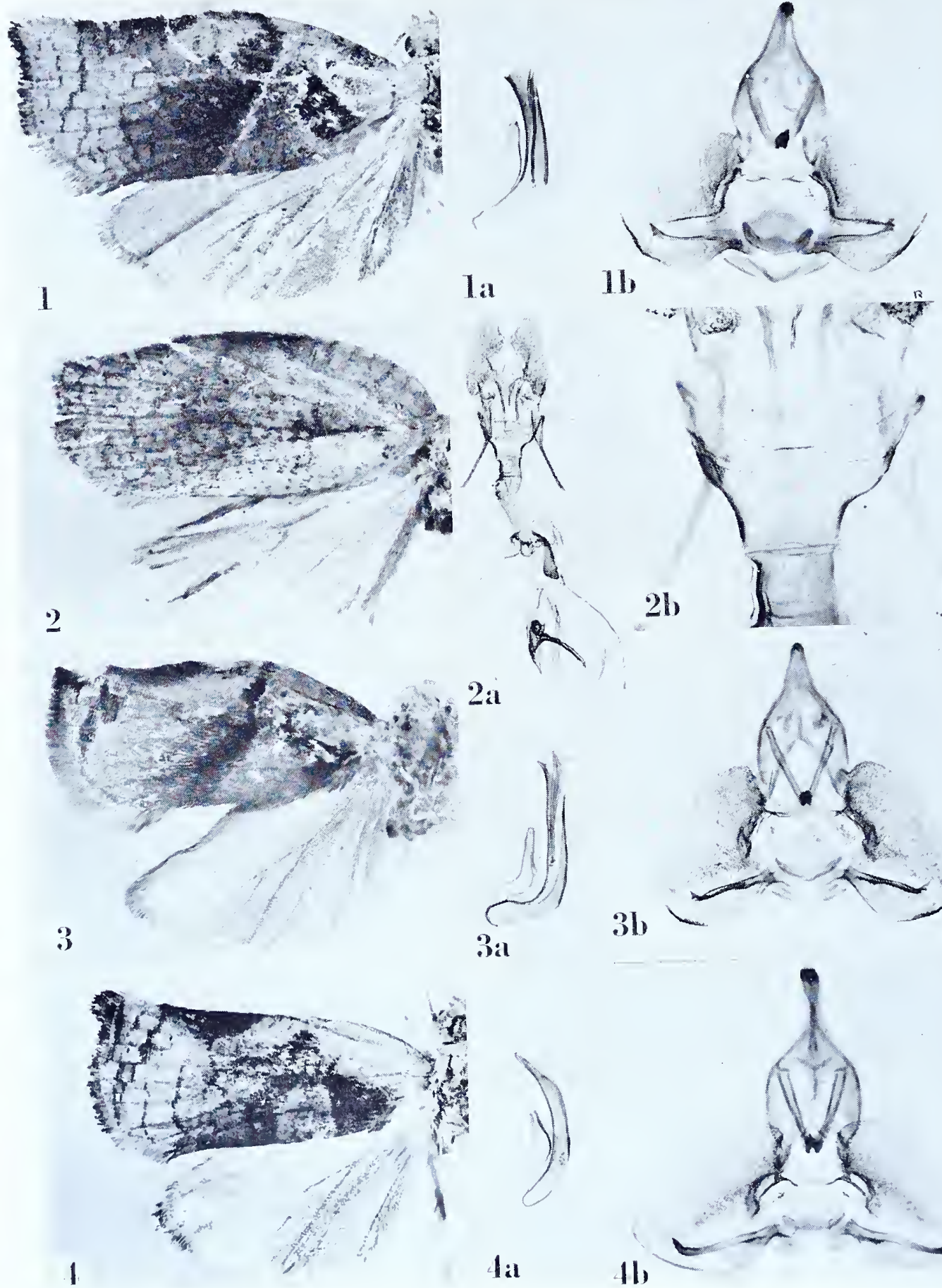

36
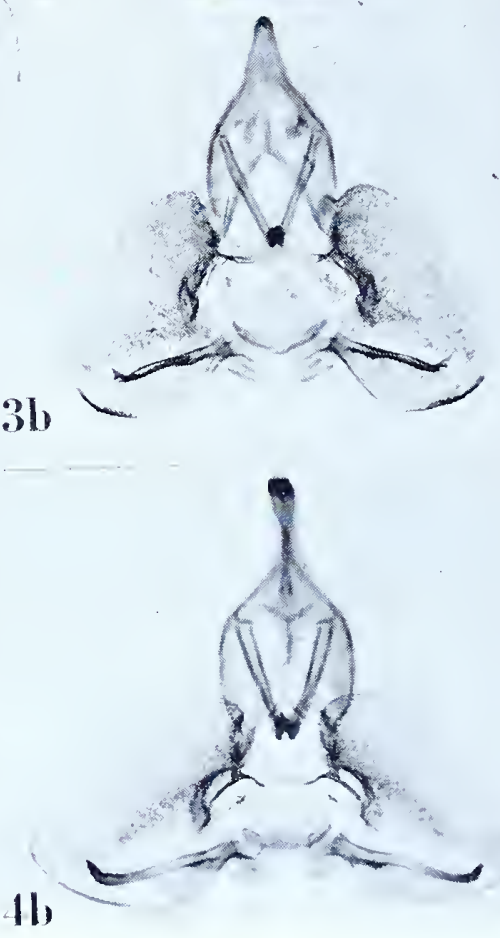

ARCHIPS 
ARCHIPS

\section{Archips subsidiaria (Meyrick), new combination}

Plate 25, Figures I-Ib

Cacoecia subsidiaria Meyrick, 1924, Exotic Microlepidoptera, 3:107.

“ f. 21-22 mm. ... ․ $25 \mathrm{~mm}$. . . Kashmir, Srinagar, 5,200 feet, May, June (Fletcher); 9 ex. (8 ô, I 우)."

Lectotype: A male measuring $22 \mathrm{~mm}$., dated ".5.23". Slide No. 6822 . Only two of the original specimens remain in the Meyrick collection.

Figure I, left wings; $\mathrm{I}$, lateral aspect of aedeagus; $\mathrm{r} b$, ventral view of male genitalia with aedeagus removed.

\section{Archips symmetra (Meyrick), new combination}

Plate 25, Figures 2-2b

Cacoecia symmetra Meyrick, i9 18, Exotic Microlepidoptera, 2: І 66.

"․ 26-27 mm. . . . French Congo, Ubangi; two specimens."

Lectotype: +27 mm., "Bangi, French Congo. LeM. .r6." Slide No. 934r.

Figure 2, left wings; $2 \mathrm{a}$, ventral view of female genitalia; $2 \mathrm{~b}$, detail of genital plate and ostium.

\section{Archips termias (Meyrick), new combination}

Plate 25, Figures $3-3 \mathrm{~b}$

Cacoecia termias Meyrick, I918, Exotic Microlepidoptera, 2: I64.

" o. $17 \mathrm{~mm}$. . . Assam, Shillong, 5,000 feet, September, October (Fletcher); two specimens. Very closely allied to epicyrta...."

Lectotype: The male dated ".ro.16". Slide No. 6812. The second specimen is missing.

Figure 3 , left wings; 3 a, lateral aspect of aedeagus; $3 \mathrm{~b}$, ventral view of male genitalia with aedeagus removed.

\section{Archips tharsaleopa (Meyrick), new combination}

\section{Plate 25, Figures $4-4 \mathrm{~b}$}

Cacoecia tharsaleopa Meyrick, 1935, in Caradja, Materialien zu einer Microlepidopteren Fauna der Chinesischen Provinzen Kiangsu, Chekiang und Hunan. Berlin, 50.

" J. 2 I mm. ... I ex., Tienmushan, V, VI. Allied to capsigerana."

Type: The male indicated above labelled "'Tien-Mu-Shan, China. H. 5,300' .5.32". Slide No. 6806.

Figure 4 , left wings; 4 a, lateral aspect of aedeagus; 4 b, ventral view of male genitalia with aedeagus removed. 


\section{ARDEUTICA Meyrick}

Ardeutica Meyrick, 1913, Trans. Ent. Soc. London, 1913: 172. (Typus generis: Ardeutica spumosa Meyrick, l.c., I73 [by original designation].)

\section{Ardeutica spumosa Meyrick}

Plate 26, Figures I-Id

Ardentica spumosa Meyrick, I913, Trans. Ent. Soc. London, I913: I73.

" $\hat{\sigma}^{2} 26 \mathrm{~mm}$. . . Peru, Huancabamba; one specimen."

Type: The male indicated above with "R. .I " at the bottom of the pin-label. Slide No. 6373 .

Figure I, left wings; Ia, venation of right wings; $\mathrm{s} b$, lateral aspect of head to show palpus; Ic, posterior abdominal tuft; Id, ventral view of male genitalia with aedeagus in sitn.

\section{Ardeutica semipicta Meyrick}

Plate 26, Figures 2-2c

Ardeutica semipicta Meyrick, I913, Trans. Ent. Soc. London, 1913: 173.

"亏. $23 \mathrm{~mm}$. . . Brazil, Petropolis; one specimen."

Type: The specimen referred to above with "R. .o6" at the bottom of the pin-label. Slide No. 6374. Meyrick suppressed this species as a synonym of spumosa, but it is distinct and I hereby remove it from synonymy.

Figure 2, left wings; $2 a$, lateral aspect of aedeagus; $2 \mathrm{~b}$, ventral view of male genitalia with aedeagus removed; $2 \mathrm{c}$, denuded abdomen to show posterior tufts and specialised scales on 6 th and 7 th segments. 

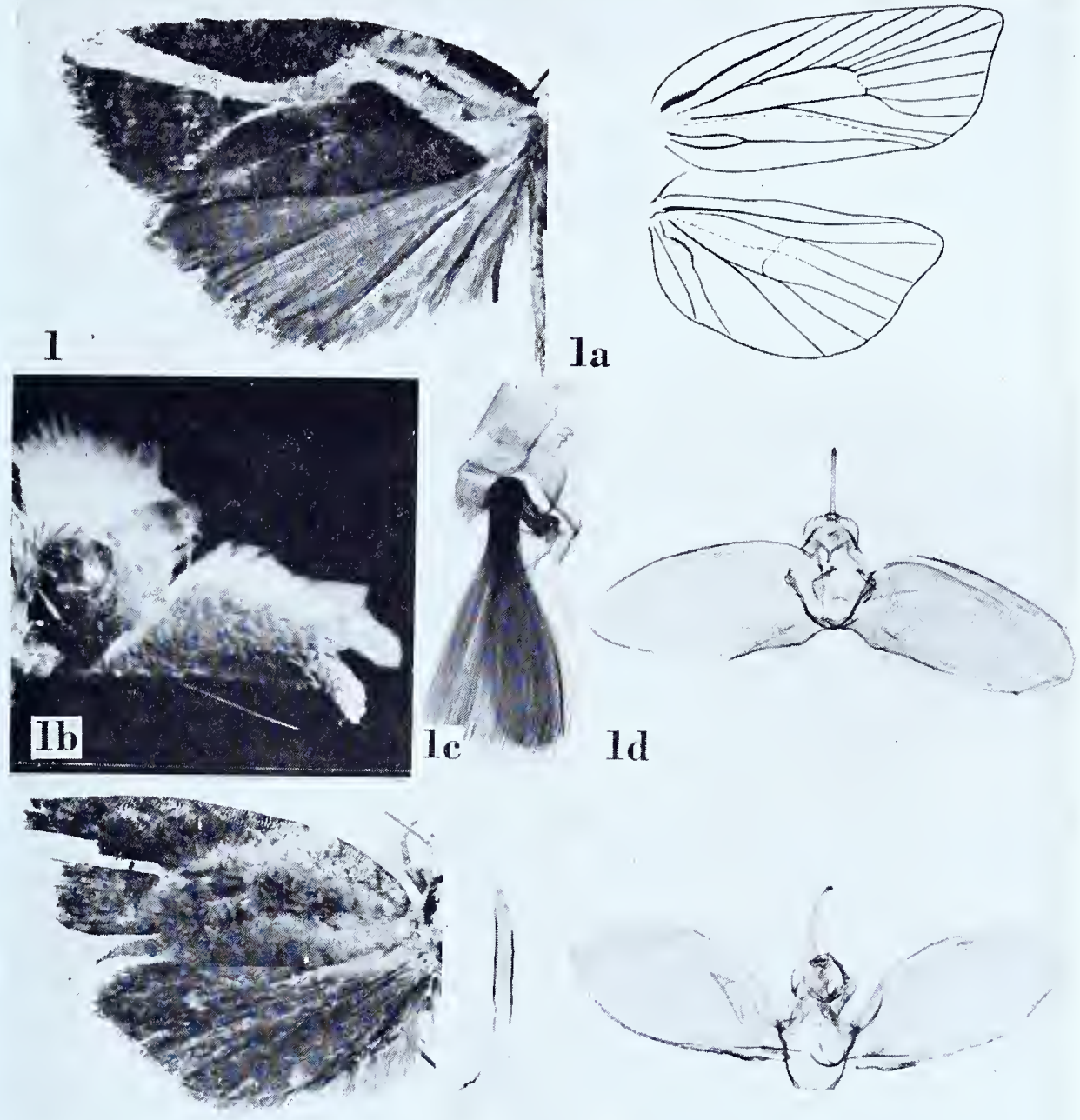

2

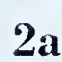

$2 \mathrm{~b}$
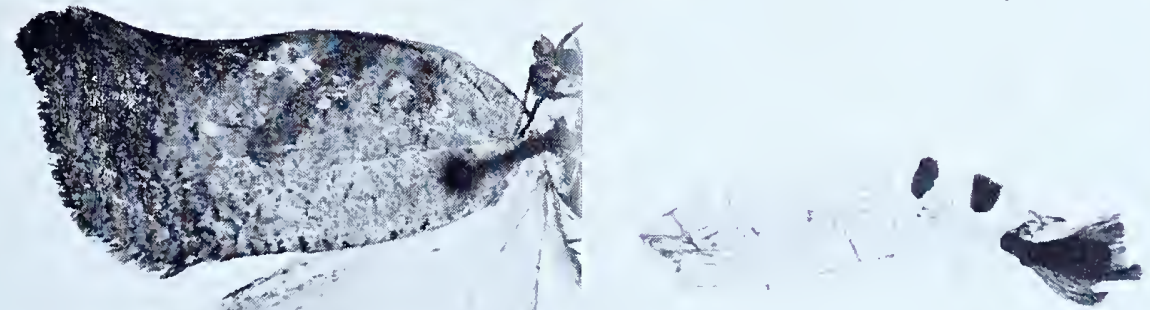

3

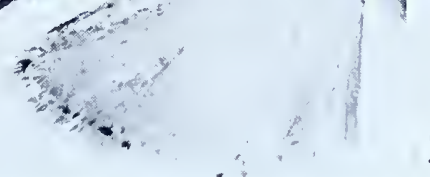

$2 \mathbf{c}$ 


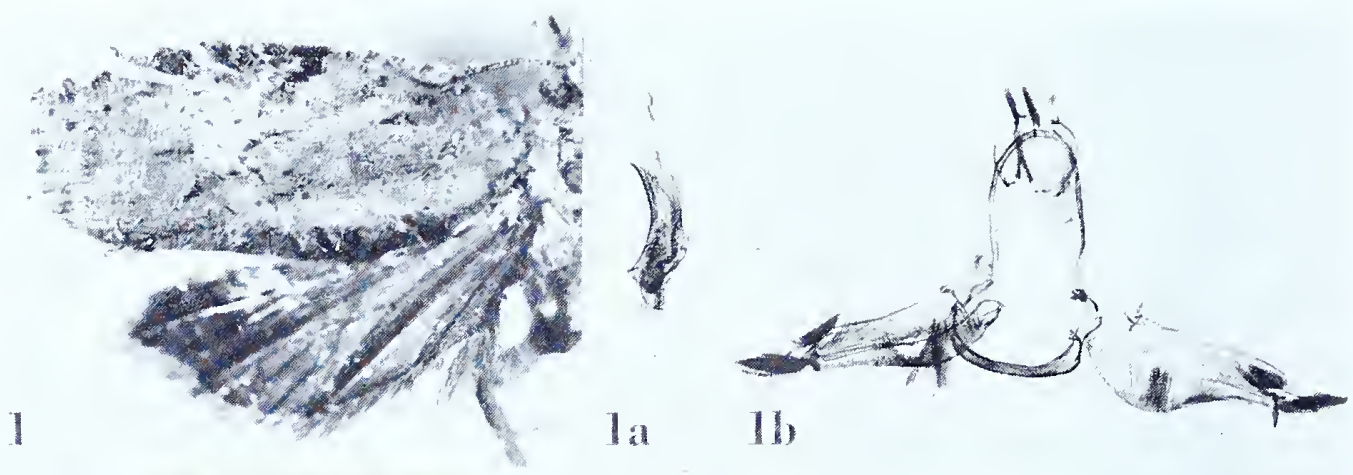

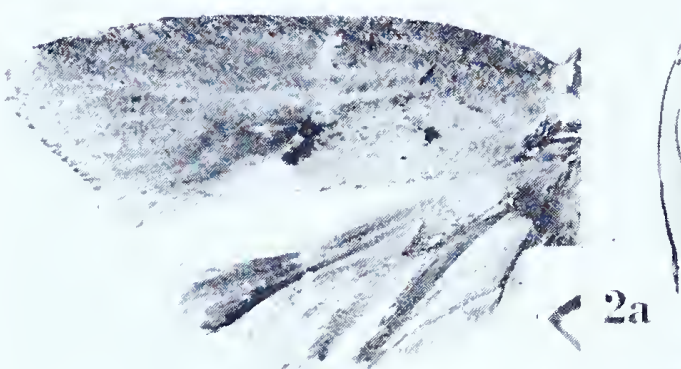

2

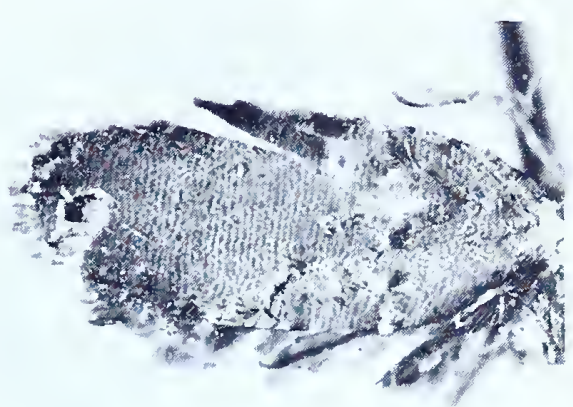

3

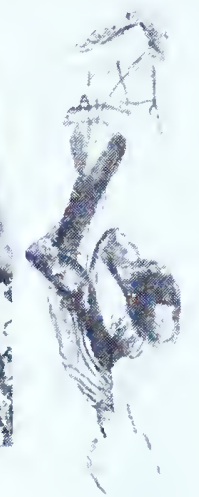

$3 a$

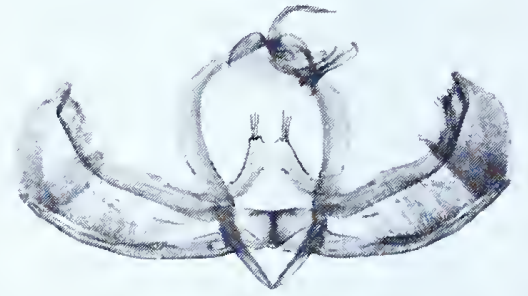

2b

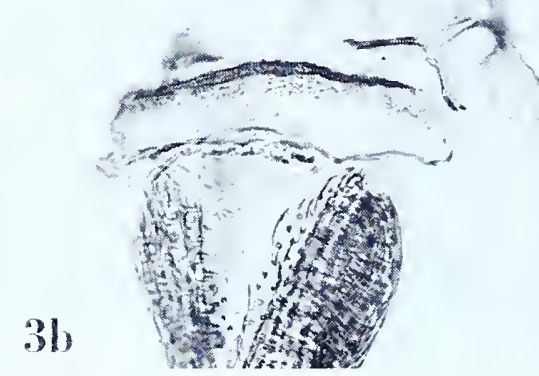

ARGYRO'TOXA 


\section{ARGYROTOXA Stephens}

\section{Argyrotoxa erythrocyma Meyrick \\ Plate 27, Figures $\mathrm{I}-\mathrm{Ib}$}

Argyrotoxa erythrocyma Meyrick, 1930, Exotic Microlepidoptera, 3: 612.

“ㅇ. I 5 mm. . . . Cameroons, Lolodorf (Conradt); i ex. (Coll. Paravicini)."

Type: The specimen so marked in the British Museum, "Kamerun, Lolodorf. L. Conradt. I $894^{-1} 895$," erroneously recorded as a female. A white label bears the inscription "M978". A small yellow label bears the date "2.3.95". Slide No. 9366.

Figure I, left wings. (Red spotting does not show in photograph); Ia, lateral aspect of aedeagus; $\mathrm{ib}$, ventral view of male genitalia with aedeagus removed.

\section{Argyrotoxa melanophyta Meyrick}

Plate 27, Figures 2-2b

Argyrotoxa melanophyta Meyrick, 1913, Trans. Ent. Soc. London, 1913: i72.

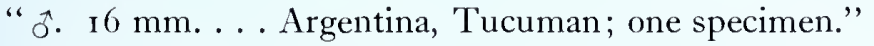

Type: The above indicated specimen with "R. .08" at the bottom of the pin-label. Slide No. 6364.

Figure 2 , left wings; $2 \mathrm{a}$, lateral aspect of aedeagus; $2 \mathrm{~b}$, ventral view of male genitalia with aedeagus removed.

\section{Argyrotoxa venatrix Meyrick}

Plate 27 , Figures $3-3$ b

Argyrotoxa venatrix Meyrick, 1930, Exotic Microlepidoptera, 3: 612.

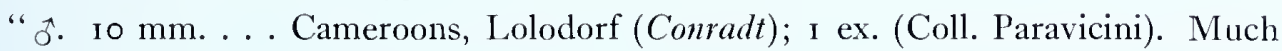
like albardana Snell. ..."

Type: The specimen so marked in the British Museum, erroneously recorded as a male, "Kamerun, Lolodorf. Conradt. i $894-1895 . "$ A small yellow label bears the date "1.3.95". A third label bears the inscription "M977". Slide No. 9367.

Figure 3 , left wings; 3 a, ventral view of female genitalia; 3 b, ostium. 


\section{ARGYROTAENIA Stephens \\ Argyrotaenia sphaleropa (Meyrick), new combination \\ Plate 28, Figures I-I b}

Tortrix sphaleropa Meyrick, I909, Trans. Ent. Soc. London, I909: I 5.

" ${ }^{3}$. I $4^{-1} 6 \mathrm{~mm} . .$. Bolivia, Songo; three specimens."

Lectotype: The male measuring $16 \mathrm{~mm}$. Slide No. 6360. The three specimens bear identical data with "S. .o " at the bottom of the pin-label.

Figure I, left wings; ra, lateral aspect of aedeagus; $\mathrm{rb}$, ventral view of male genitalia with aedeagus removed.

\section{AROTROPHORA Meyrick \\ Arotrophora crustata Meyrick \\ Plate 28, Figures 2-2b}

Arotrophora crustata Meyrick, i912, Exotic Microlepidoptera, I: 9.

" $3 \nmid+$. I $3^{-1} 4 \mathrm{~mm} . .$. Assam, Khasis, from June to August; two specimens."

Lectotype: The male dated ".6.1906". Slide No. 6882.

Figure 2 , left wings; $2 \mathrm{a}$, lateral aspect of aedeagus; $2 \mathrm{~b}$, ventral view of male genitalia with aedeagus removed.

\section{ATTERIA Walker}

\section{Atteria pavimentata Meyrick}

Plate 28 , Figures $3-3 b$

Atteria pavimeniata Meyrick, i9i3, Trans. Ent. Soc. London, г9г3: г7г.

" . $39 \mathrm{~mm}$. . . Peru, Huancabamba; one specimen."

Type: 'The specimen indicated above, but erroneously recorded as a male. Slide No. 4416.

Figure 3 , left wings; 3 a, ventral view of female genitalia $; 3$ b, detail of genital plate and ostium. 

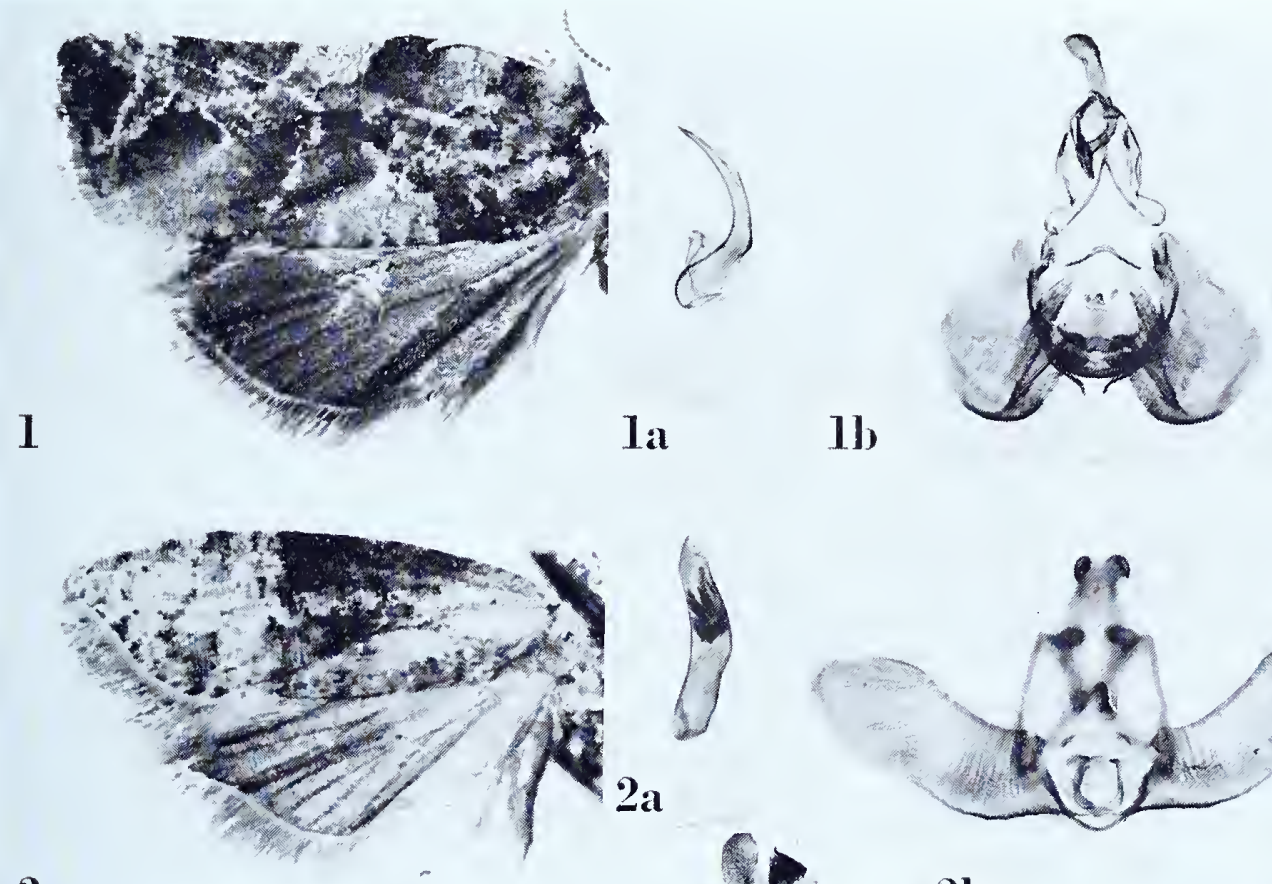

2
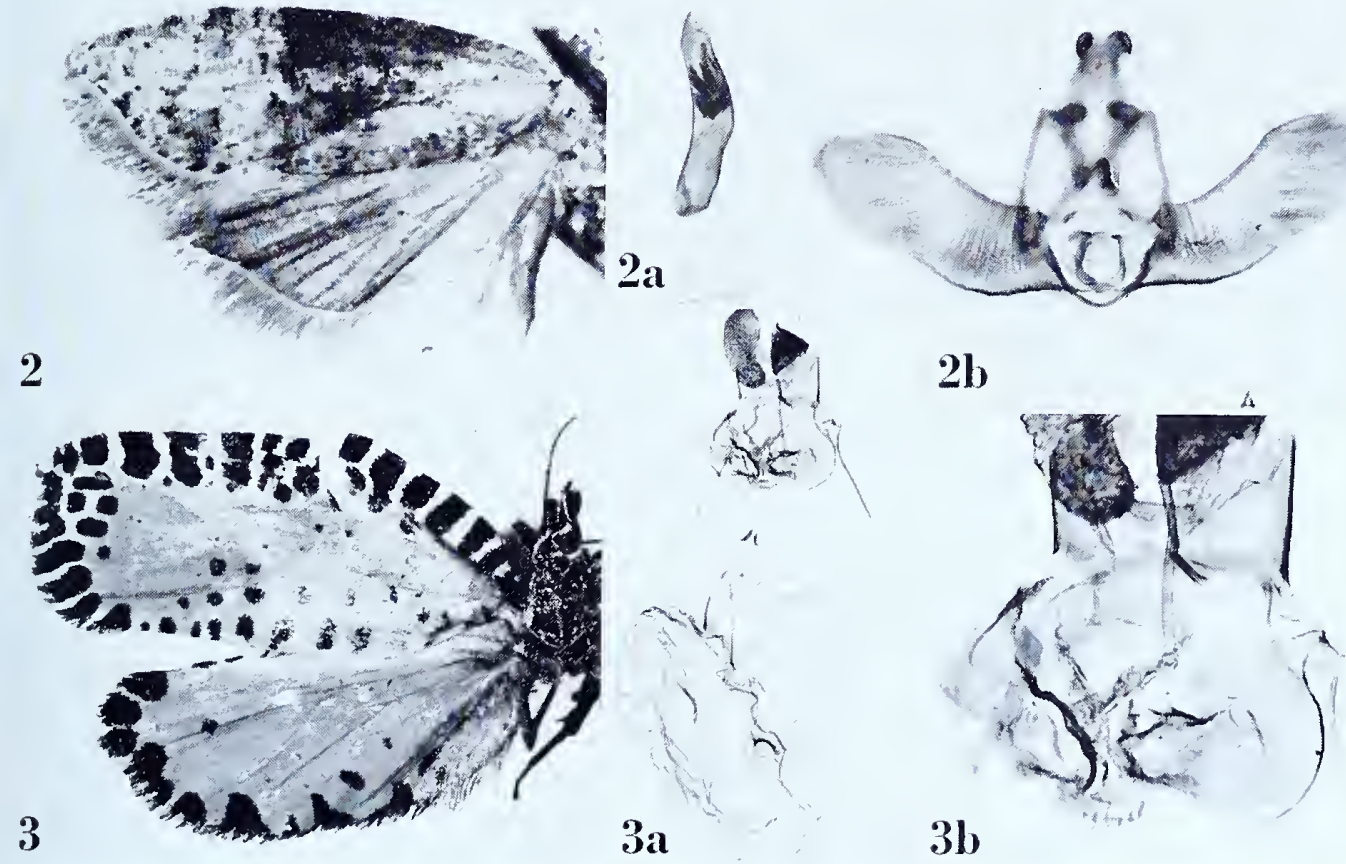

ARGYROTAENIA, AROTROPHORA and ATTERIA 

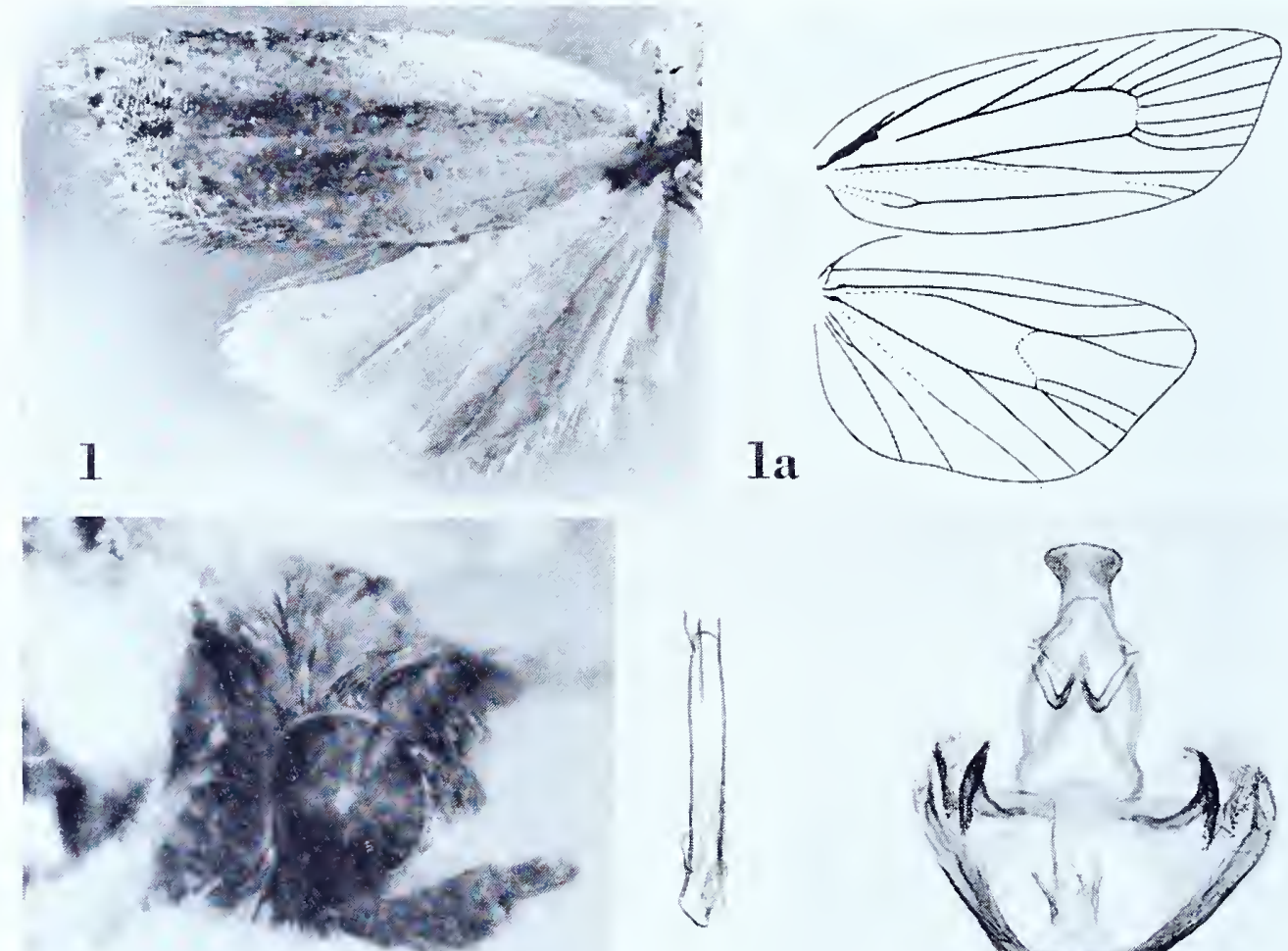

1b
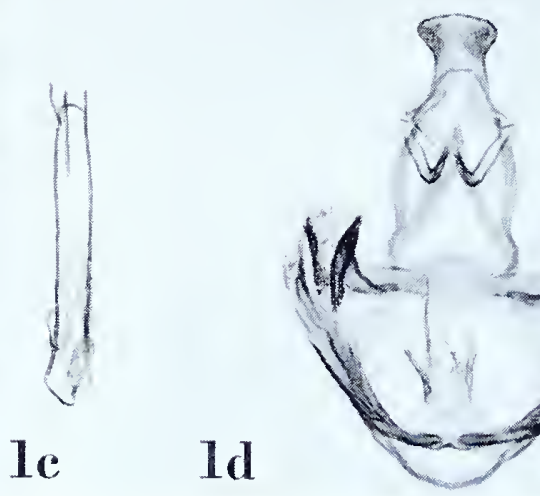

BALIOXENA 


\section{BALIOXENA Meyrick}

Balioxena Meyrick, I912, Exotic Microlepidoptera, I : 12. (Typus generis: Balioxena iospila Meyrick, l.c., p. I 3 [monotypy].)

\section{Balioxena iospila Meyrick}

Plate 29, Figures I-Id

Balioxena iospila Meyrick, 1912, Exotic Microlepidoptera, I : 13.

" o. $18 \mathrm{~mm}$. . . . Madagascar, Antananarivo; one specimen."

Type: The male denoted above, "Antananarivo, Madagascar, R. .i I." Slide No. 9384 .

Figure I, left wings; Ia, venation of right wings; $\mathrm{I}$ b, lateral aspect of head to show palpus; ic, lateral aspect of aedeagus; id, ventral view of male genitalia with aedeagus removed.

Continued from $p \cdot 39$.

\section{Archips encausta (Meyrick), new combination}

Plate 19 , Figures $4-4 \mathrm{~b}$

Tortrix encausta Meyrick, I907, Journ. Bombay Nat. Hist. Soc., I7: 735.

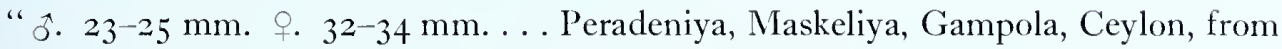
May to January; fourteen specimens (Pole, Green, Alston)."

Lectotype: A male measuring 24 mm., "Gampola, Ceylon, JP. .5.97." Slide No. 6800 .

Figure 4 , left wings; 4 a, lateral aspect of aedeagus; 4 b, ventral view of male genitalia with aedeagus removed.

\section{Archips epicyrta (Meyrick), new combination}

See Archips micaceana (Walker). 


\section{BERYLLOPHANTIS Meyrick}

Beryllophantis Meyrick, I938, Trans. R. Ent. Soc. London, 87: 509. (Typus generis: Beryllophantis cochlias Meyrick, ibid. [monotypy].)

\section{Beryllophantis cochlias Meyrick}

Plate 30, Figures I-Id

Beryllophantis cochlias Meyrick, I938, Trans. R. Ent. Soc. London, 87: 500.

"ㅇ. I 7 mm. ... Mt. Tafa, 8,500 feet, March; i ex."

Type: The female indicated above so marked in the British Museum, "Mt. Tafa, Papua, 8,500 ft. iii.r934. L. E. Cheesman.” Slide No. Diakonoff i r6o.

Figure I, left wings; Ia, venation of right wings; $\mathrm{Ib}$, signum; Ic, ventral view of female genitalia; Id, detail of genital plate and ostium. 


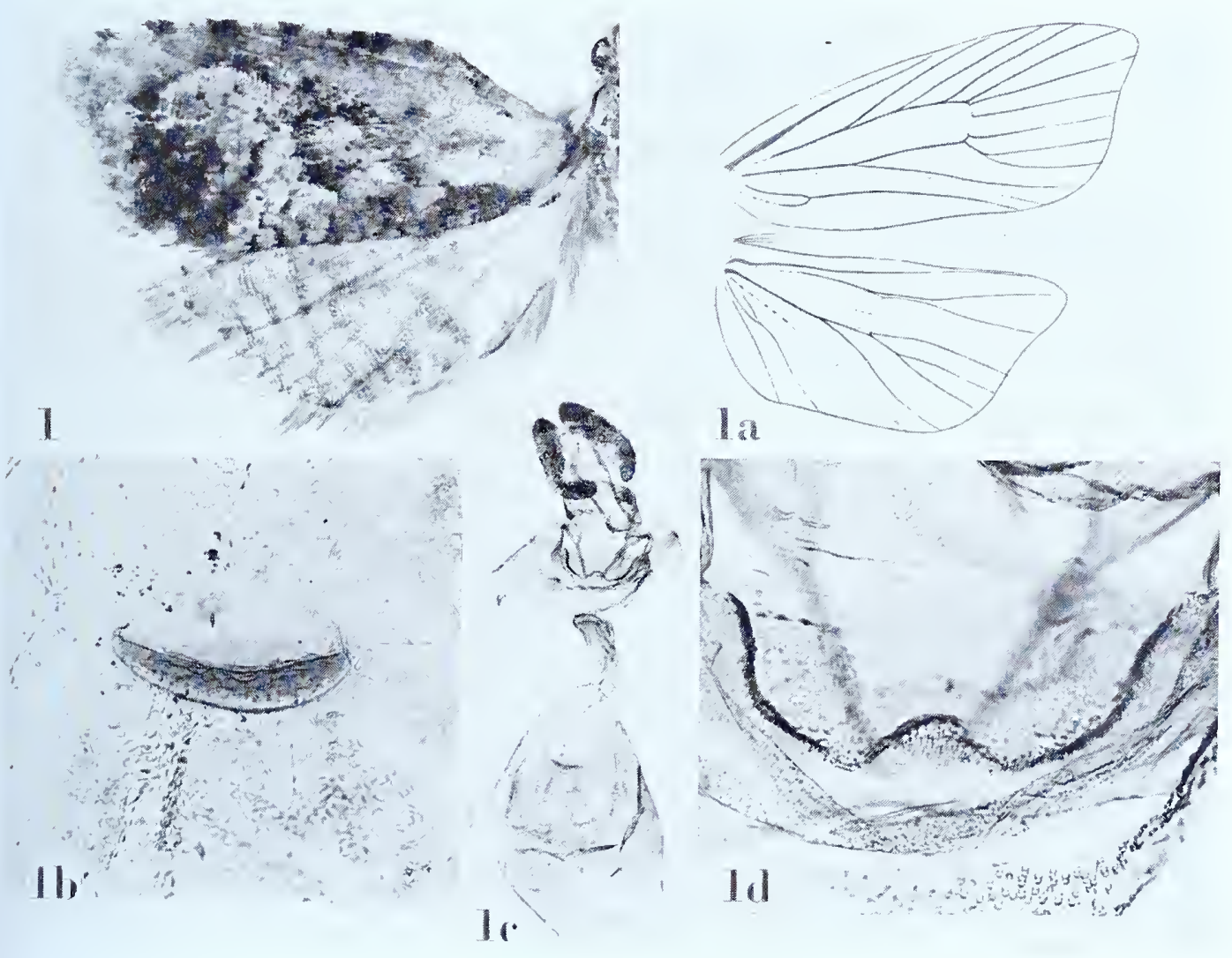

BERYLLOPHAN'TIS 


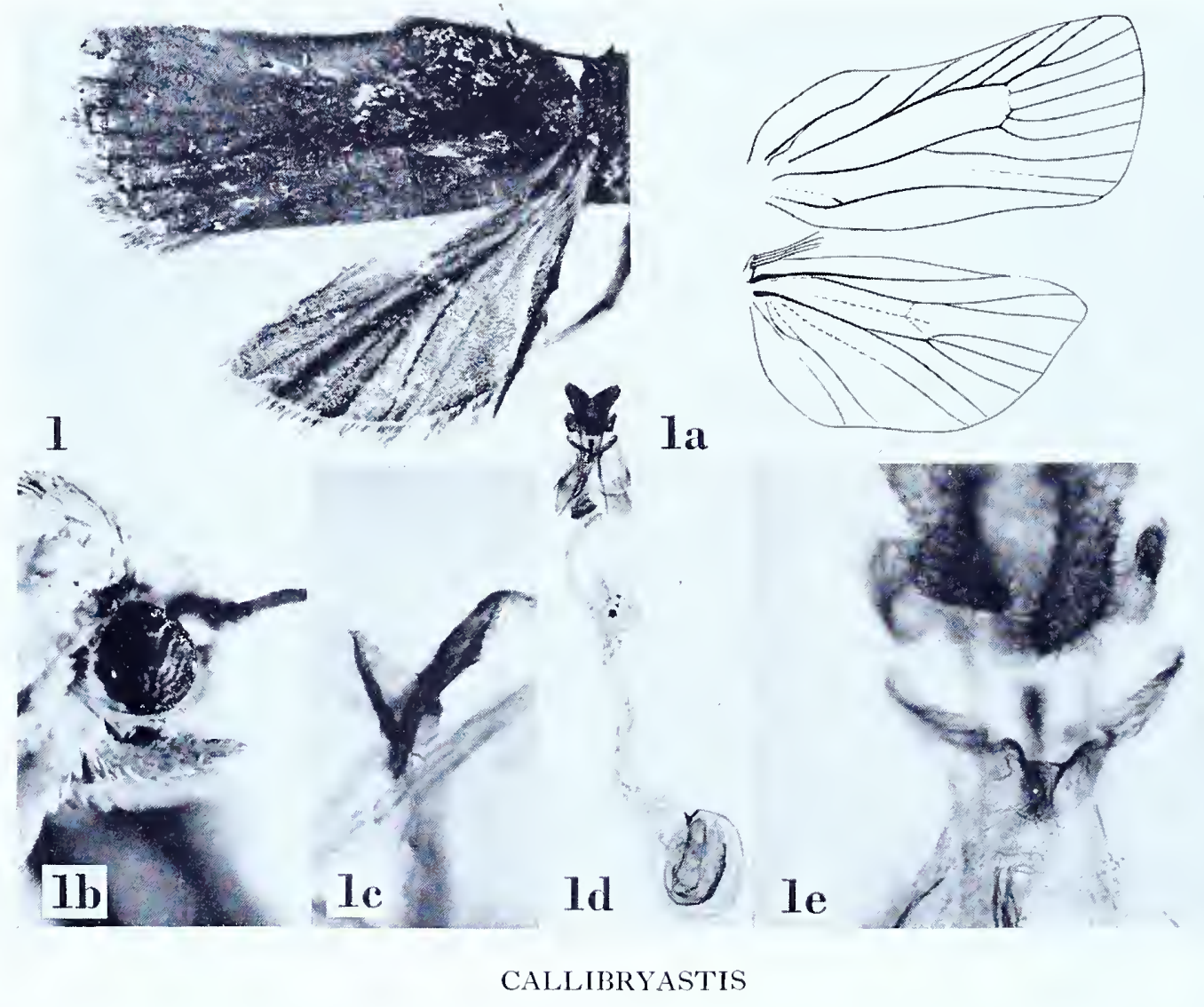




\section{CALLIBRYASTIS Meyrick}

Callibryasiis Meyrick, I912, Exotic Microlepidoptera, I: I3. (Typus generis: Callibryastis pachnota Meyrick, 1.c., I4 [monotypy].)

\section{Callibryastis pachnota Meyrick}

Flate 3I, Figures I-I e

Callibryastis pachnota Meyrick, I9I2, Exotic Microlepidoptera, I： I4.

"․ 2 I mm. ... Assam, Khasis; one specimen."

Type: The above indicated specimen, "Khasi Hills, Assam. D. .r go6." Slide No. Diakonoff I 158 .

Figure $\mathrm{I}$, left wings; $\mathrm{ra}$, venation of right wings; $\mathrm{rb}$, lateral aspect of head to show palpus; rc, signum; Id, ventral view of female genitalia; re, detail of genital plate and ostium. 


\section{CANCANODES Meyrick}

Cancanodes Meyrick, 1922, Exotic Microlepidoptera, 2: 498. (Typus generis: Cancanodes orthometalla Meyrick, l.c., p. 499 [monotypy].)

\section{Cancanodes orthometalla Meyrick \\ Plate 32, Figures I-Ia}

Cancanodes orthometalla Meyrick, I922, Exotic Microlepidoptera, 2: 499.

“ô. 9 mm. . . Fiji, Cuvu, October (Greenwood); i ex. (Brit. Mus.). Example not in good order but curious."

Type: The specimen so marked in the British Museum, erroneously recorded as a male, "Cuvu, Fiji Is. ro.x.r 919. W. Greenwood." Slide No. 9433.

Figure I, left wings; Ia, venation of right wings. The specimen is in such poor condition that no figures of the palpus or genitalia are possible. 


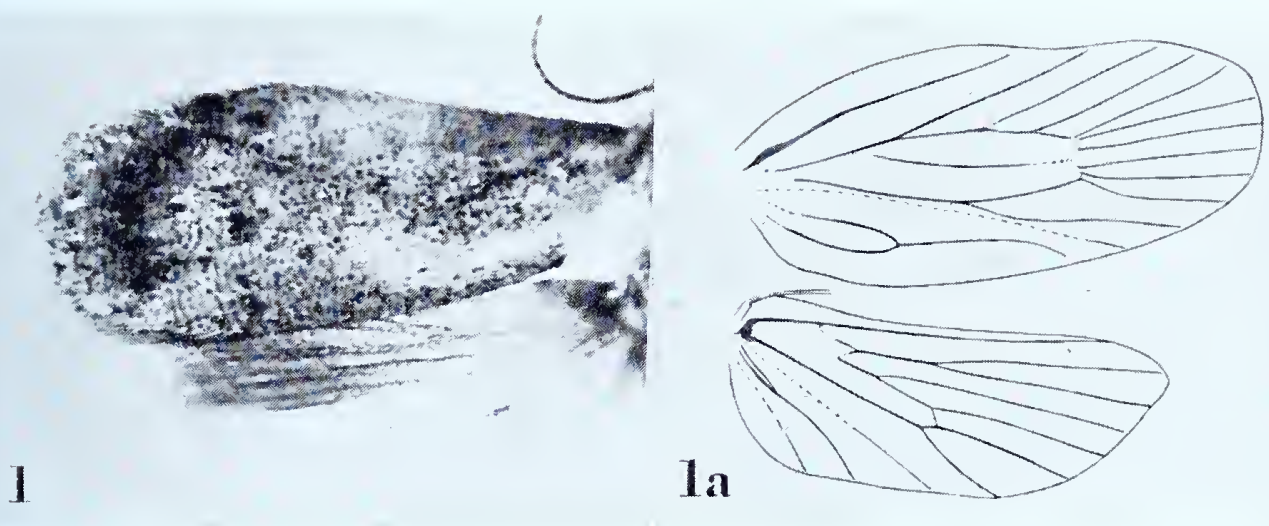

CANCANODES 


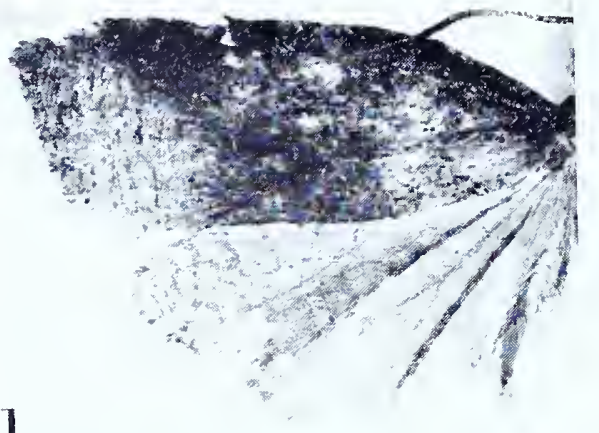

la
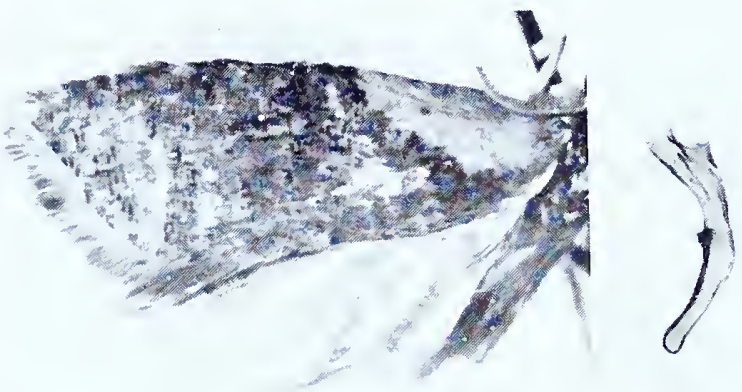

2

$2 a$

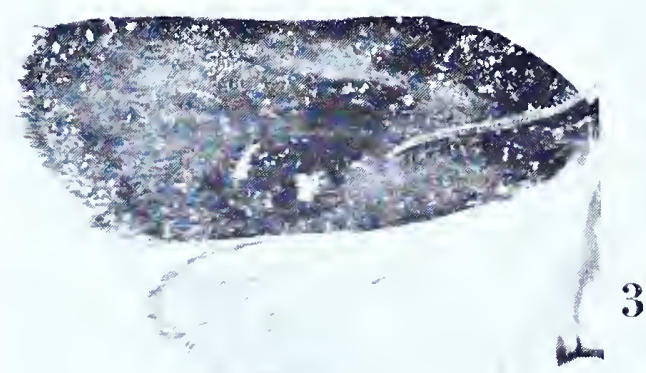

3

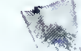

3a

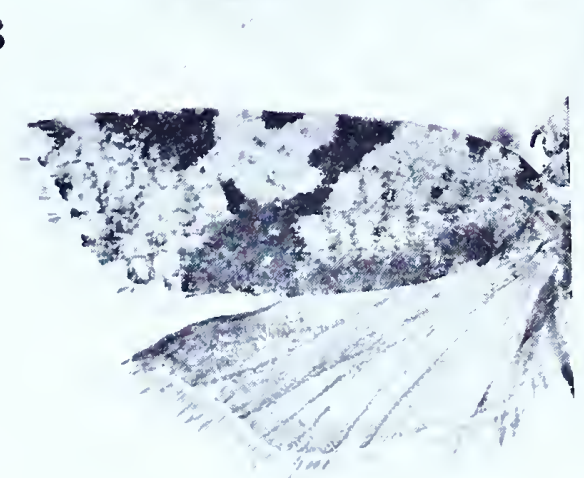

4

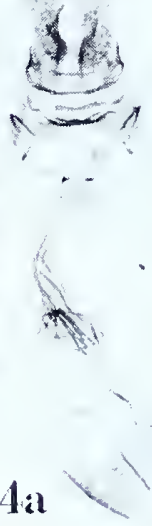

Ib
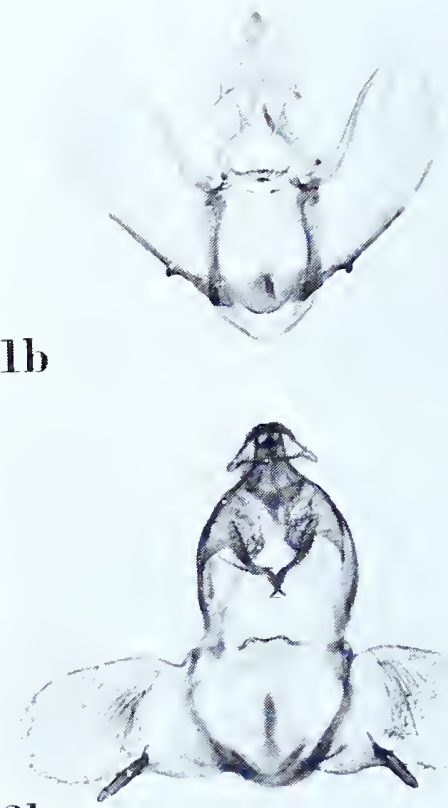

2b

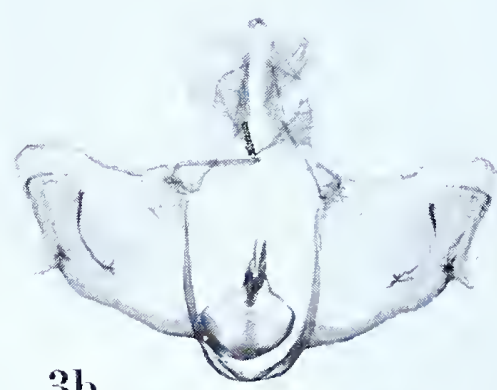

CAPUA 


\section{CAPUA Stephens \\ Capua arrecta Meyrick}

Plate 33, Figures $\mathbf{x}-\mathbf{x} b$

Capua arrecta Meyrick, I9I7, Trans. Ent. Soc. London, I9I7: 5.

“ڤ. 17 mm. . . Peru, Lima, in August (Parish); two specimens."

Lectotype: One of the above, both of which bear the same data and are dated "8-I 4 ". Slide No. 6287 .

Figure I, left wings; 1 a, lateral aspect of aedeagus; $\mathrm{rb}$, ventral view of male genitalia with aedeagus removed.

\section{Capua chloraspis Meyrick}

Plate 33, Figures 2-2b

Capua chloraspis Meyrick, 1924, Exotic Microlepidoptera, 3: 106.

" J. $13 \mathrm{~mm}$. . . Bengal (Bihar and Orissa), Saran (Mackenzie); I ex. Nearly allied to the common Australian retractana."

Type: The male indicated above labelled "Saran, India. M. .23". Slide No. 6787 .

Figure 2, left wings; $2 \mathrm{a}$, lateral aspect of aedeagus; $2 \mathrm{~b}$, ventral view of male genitalia with aedeagus removed.

\section{Capua chrysostoma Meyrick}

Plate 33, Figures $3-3 \mathrm{~b}$

Capua chrysostoma Meyrick, I9ı2, Trans. Ent. Soc. London, 19г I : 675.

“ o. 22-25 mm. . . . Colombia, San Antonio, 5,80o feet, in November and December; nine specimens."

Lectotype: A male measuring 24 mm., dated ".r2.07”. Slide No. 6288.

Figure 3 , left wings; 3 a, lateral aspect of aedeagus; 3 b, ventral view of male genitalia with aedeagus removed.

\section{Capua cornigera Meyrick}

Plate 33, Figures $4-4 \mathrm{~b}$

Capua cornigera Meyrick, 1912, Exotic Microlepidoptera, I: 2.

"ㅇ․ $20 \mathrm{~mm}$. . . Madras, Nilgiris, at 3,500 feet, in August (H. L. Andrewes)."

Type: The female indicated above dated "VIII.o7". Slide No. 6776.

Figure 4 , left wings; 4 a, ventral view of female genitalia; $4 \mathrm{~b}$, detail of genital plate and ostium. 
CAPUA

\section{Capua endocypha Meyrick}

Plate 34, Figures $I-I b$

Capua endocypha Meyrick, I93I, Exotic Microlepidoptera, 4: 148.

" §. I 7 mm. . . Fiji, Lautoka, June (H. Phillips); I ex. (Brit. Mus). In damaged condition. ..."

Type: The male so marked in the British Museum, "Lautoka, Fiji. 23.6.1930. H. Phillips." A small white label bears the inscription "M $\mathrm{M}_{3} 08_{3}$ ". Slide No. 9334.

Figure 1 , left wings; $r a$, lateral aspect of aedeagus; $r b$, ventral view of male genitalia with aedeagus removed.

\section{Capua epiclintes Meyrick}

Plate 34, Figures 2-2b

Capua epiclintes Meyrick, I928, Exotic Microlepidoptera, 3:452.

"ㅇ. 22 mm. . . Bengal, Calcutta (Atkinson); i ex."

Type: The female indicated above with "A. .I 5 " at the bottom of the pin-label. Slide No. 6772.

Figure 2, left wings; $2 \mathrm{a}$, ventral view of female genitalia; $2 \mathrm{~b}$, detail of genital plate and ostium.

\section{Capua fabrilis Meyrick}

Plate 34 , Figures $3-3 b$

Capua fabrilis Meyrick, I912, Exotic Microlepidoptera, I : I.

"ㅇ. $20 \mathrm{~mm}$. . . . Philippines, Luzon, at 5,000 feet; one specimen."

Type: 'The above indicated female labelled, "Luzon, Philippine Is. W. 5,000' .92." Slide No. 6777.

Figure 3 , left wings; $3^{\mathrm{a}}$, ventral view of female genitalia; $3 \mathrm{~b}$, detail of genital plate and ostium.

\section{Capua harmonia (Meyrick)}

Plate 34 , Figures $4-4 b$

Epagoge harmonia Meyrick, I908, Journ. Bombay Nat. Hist. Soc., i 8: 617.

" 3 f . 23-30 mm., Sik1kim, Darjiling, Khasis, from April to August; eleven specimens.”

Lectotype: A male measuring $23 \mathrm{~mm}$., "Darjiling, Bengal. D. .8.o4." Slide No. 6791 .

Figure 4 , left wings; $4 \mathrm{a}$, lateral aspect of aedeagus; $4 \mathrm{~b}$, ventral view of male genitalia with aedeagus removed. 

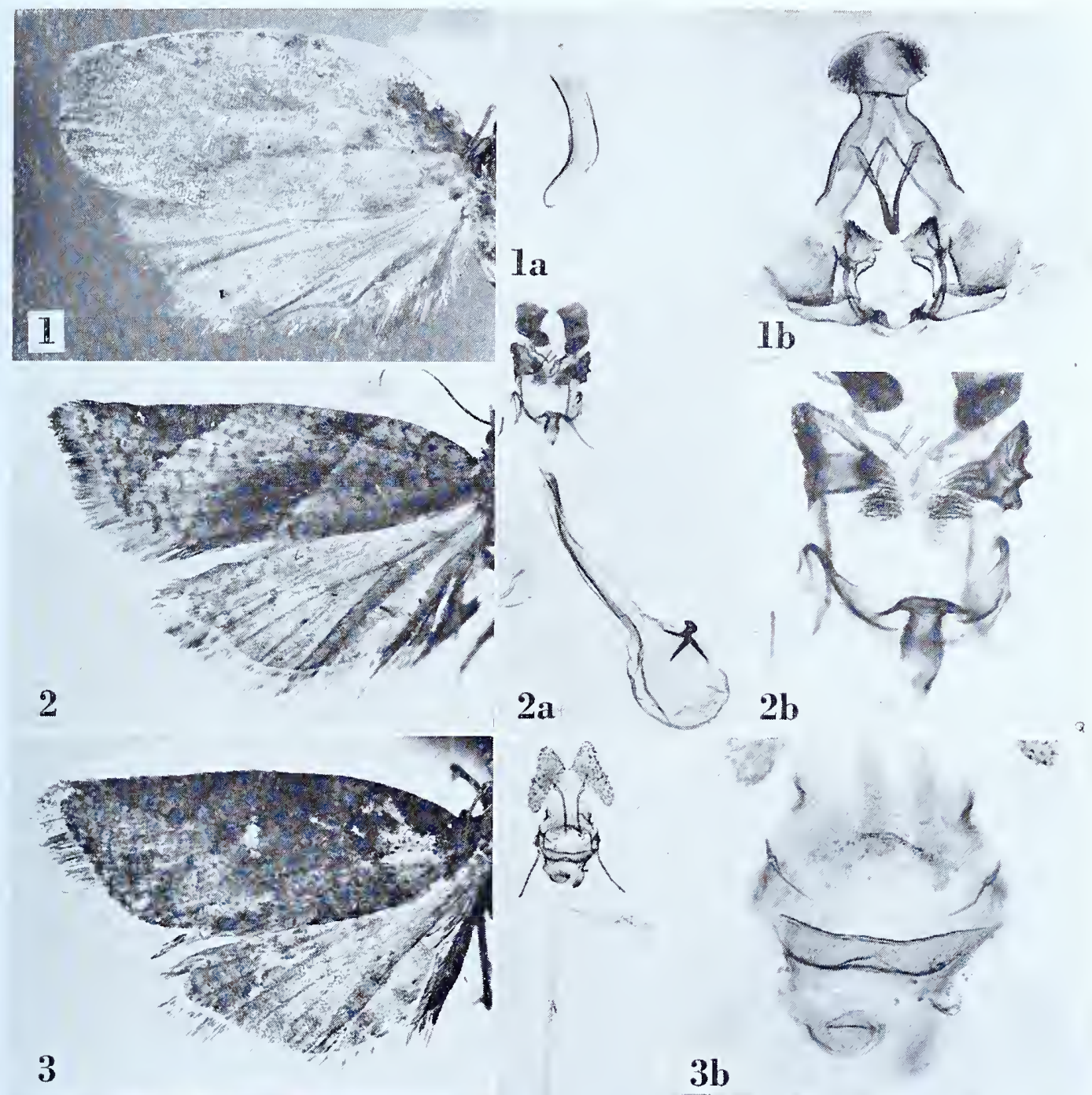

3

2
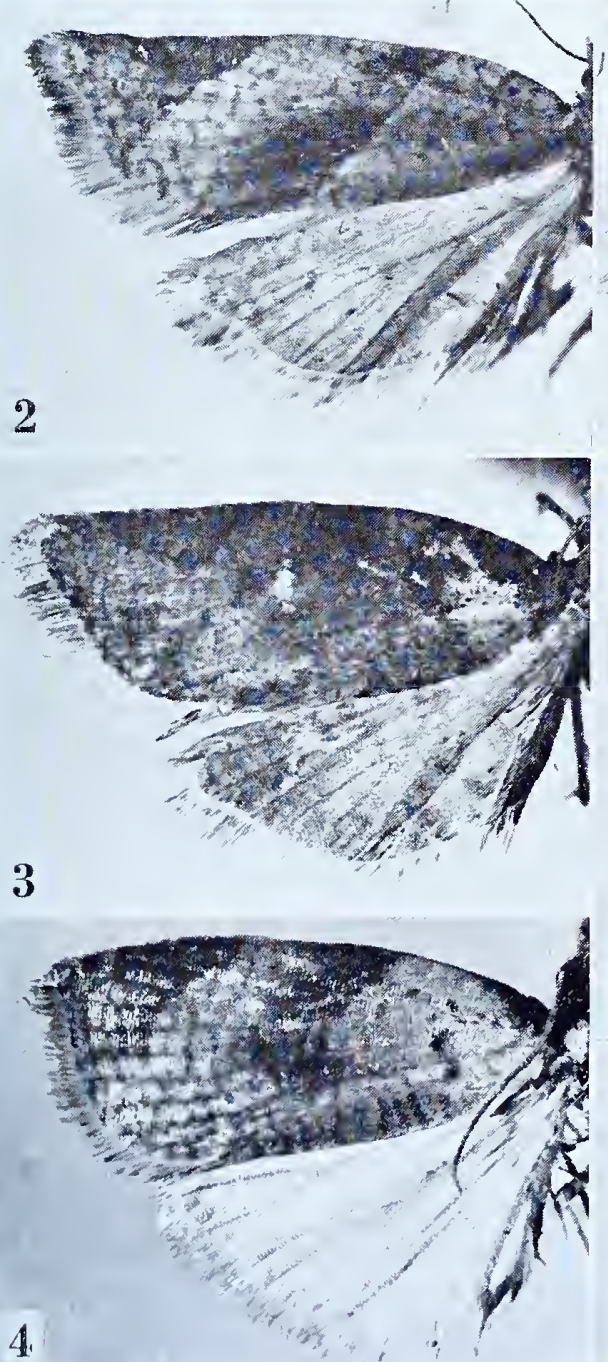

$3 a$

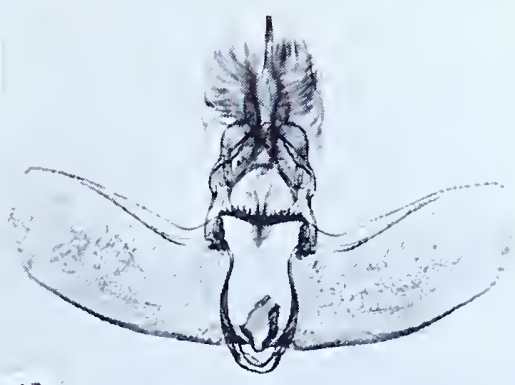

$4 \mathrm{~b}$

CAPUA 

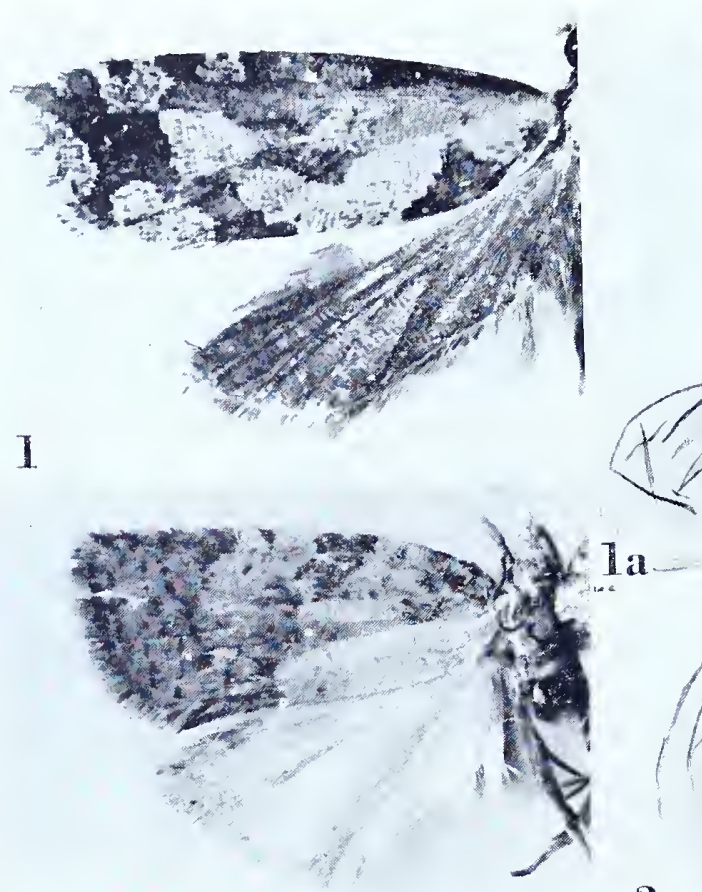

2

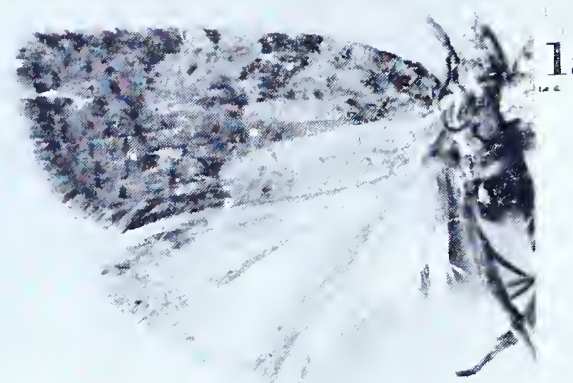

6

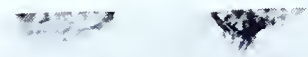

1
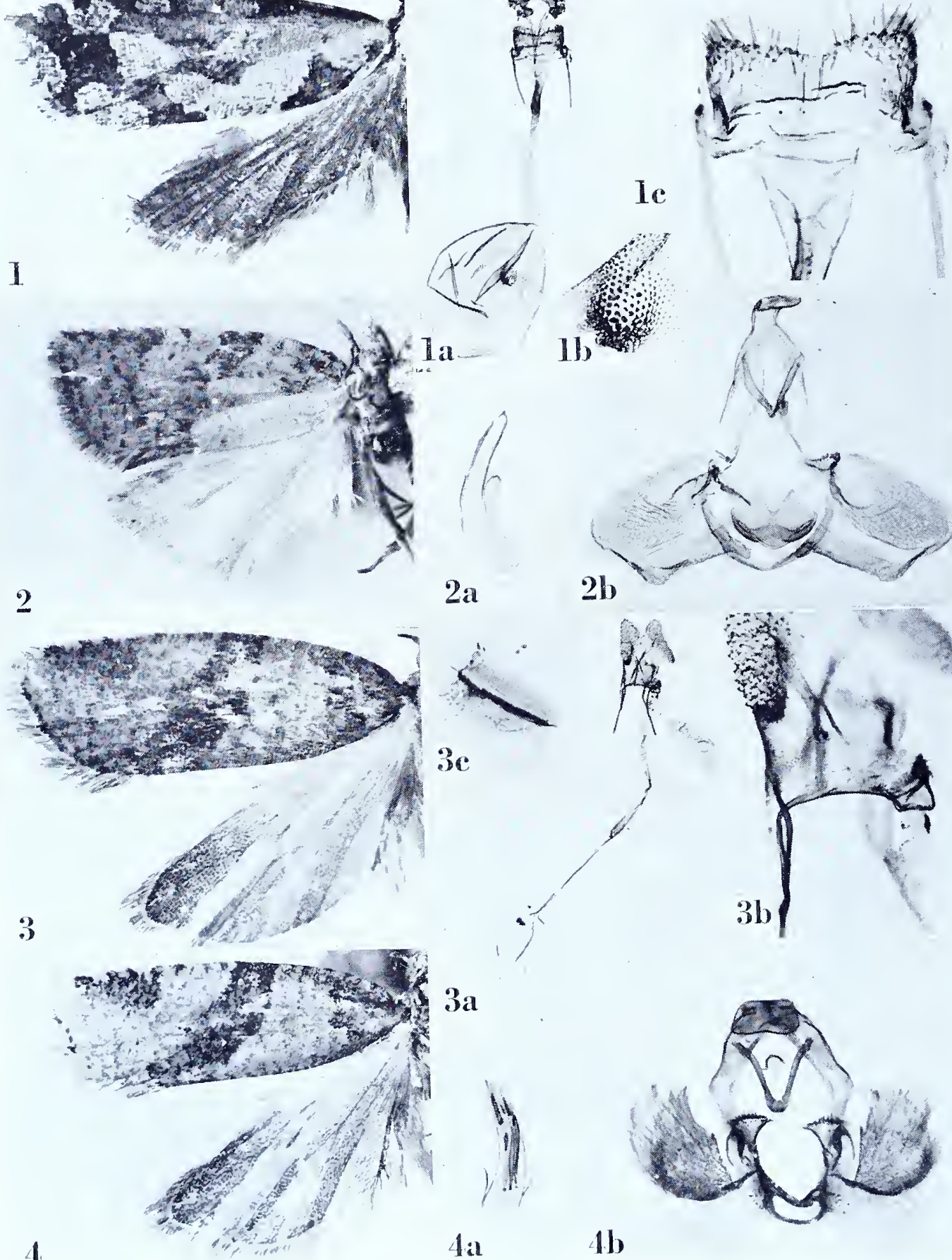

$3 a$
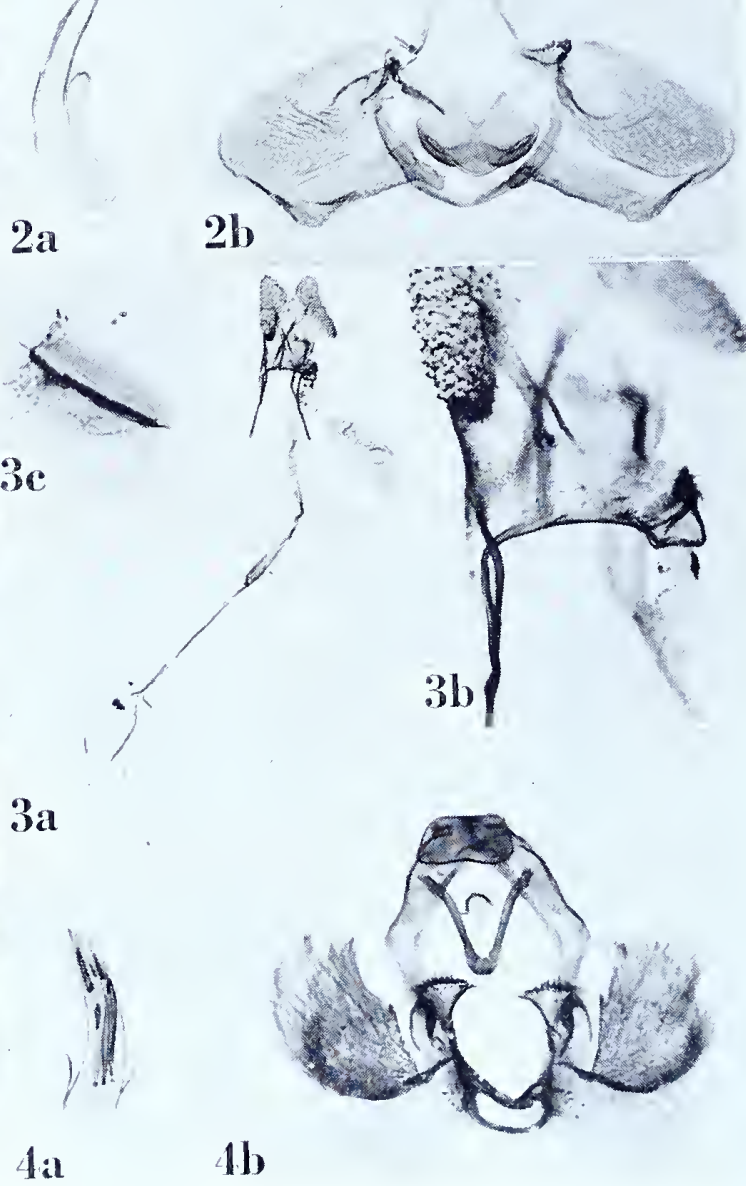

2b

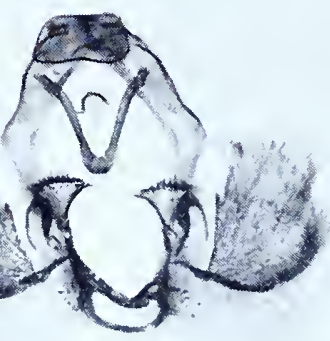

CAPUA 


\section{Capua illaquaeta Meyrick}

Plate 35, Figures I-IC

Capua illaquaeta Meyrick, I917, Trans. Ent. Soc. London, I917: 6.

"․ $14 \mathrm{~mm}$.... French Guiana, R. Maroni; one specimen. Allied to aluminias."

Type: The above indicated specimen with "LeM. .16" at the bottom of the pinlabel. Slide No. 6289 .

Figure I, left wings; ıa, ventral view of female genitalia; Ib, signum; Ic, detail of genital plate and ostium.

\section{Capua liparochra Meyrick}

Plate 35 , Figures $2-2 \mathrm{~b}$

Capua liparochra Meyrick, I928, Exotic Microlepidoptera, 3: $45^{2}$.

“ ${ }^{\circ}$. I 8 mm. . . Belgian Congo, Upper Oso R., N.W. Kivu, 4,, 00 feet, February (Barns)."

Type: The above indicated male dated “.2.24”. Slide No. 9337.

Figure 2, left wings; $2 \mathrm{a}$, lateral aspect of aedeagus; $2 \mathrm{~b}$, ventral view of male genitalia with aedeagus removed.

\section{Capua malacotorna Meyrick}

Plate 35, Figures $3-3 \mathrm{c}$

Capua malacotorna Meyrick, I93 I, Exotic Microlepidoptera, 4: I48.

“ф. I $7 \mathrm{~mm}$. . . . Formosa, Daizyurin, March (S. Issiki); I ex."

Type: The female indicated above dated "16.3.26". Slide No. 6786.

Figure 3 , left wings; 3 a, ventral view of female genitalia; $3^{b}$, detail of genital plate and ostium; 3 c, signum.

\section{Capua melanatma Meyrick}

\section{Plate 35 , Figures $4-4 \mathrm{~b}$}

Capua melanatma Meyrick, I908, Journ. Bombay Nat. Hist. Soc., i8: 614.

" of ${ }^{\circ}$. I2-1 $5 \mathrm{~mm}$. . . Khasis, in June and September; fourteen specimens."

Lectotype: A male measuring I4 mm., "Khasi Hills, Assam, .6.1906." Slide No. 6775. Four specimens are missing.

Figure 4 , left wings; 4 a, lateral aspect of aedeagus; 4 b, ventral view of male genitalia with aedeagus removed. 
CAPUA

\section{Capua melissa Meyrick}

Plate 36 , Figures $1-\mathrm{Ib}$

Capua melissa Meyrick, 1908, Journ. Bombay Nat. Hist. Soc., 18: 613.

" 30 . $14^{-17} \mathrm{~mm}$. ... Khasis, in March, June and September; five specimens."

Lectotype: A male measuring 16 mm., dated ".3.1906”. Slide No. 6774 .

Figure I, left wings; $\mathrm{ia}$, lateral aspect of aedeagus; $\mathrm{Ib}$, ventral view of male genitalia with aedeagus removed.

\section{Capua mesoloba Meyrick}

Plate 36, Figures 2-2a

Capua mesoloba Meyrick, 1937, im Caradja and Meyrick, Deuts. Ent. Zeit. Iris, 51 : 172.

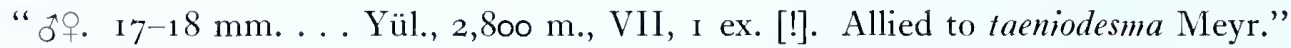

Lectotype: The male labelled "Likiang, China. H. .7.34". Slide No. 6770. There are three specimens in the Meyrick collection bearing the same data. Meyrick indicated he had only one specimen, therefore the selection of a lectotype is purely arbitrary.

Figure 2, left wings; 2a, ventral view of male genitalia with aedeagus in situ.

\section{Capua micronca Meyrick}

Plate $3^{6}$, Figures $3^{-} 3^{\mathrm{a}}$

Capua micronca Meyrick, 1937, im Caradja and Meyrick, Deuts. Ent. Zeit. Iris, 51 : 173.

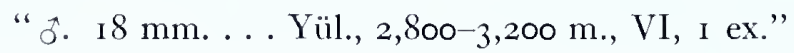

Type: The above indicated male labelled "Likiang, China. H. .6.34". Slide No. 677 I.

Figure 3 , left wings; 3 , ventral view of male genitalia with aedeagus in situ.

\section{Capua nematodes Meyrick}

Plate $3^{6}$, Figures $4^{-4} \mathrm{c}$

Сариа nematodes Meyrick, 1928, Exotic Microlepidoptera, 3:452.

"․ $\quad$ I $3 \mathrm{~mm}$.... Philippines, Los Baños (Baker); I ex. Allied to pusillana and melanatma."

Type: The above indicated female with "B. .27" at the bottom of the pin-label. Slide No. 6773. 'The type lacks the right forewing.

Figure 4, left wings; $4 \mathrm{a}$, ventral view of female genitalia; $4 \mathrm{~b}$, signum; $4 \mathrm{c}$, detail of genital plate and ostium. 


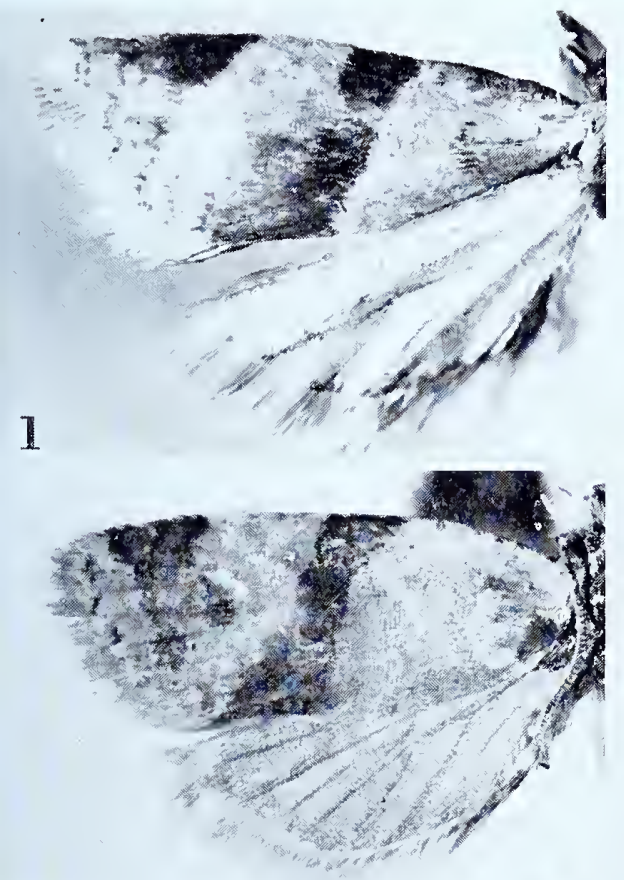

2

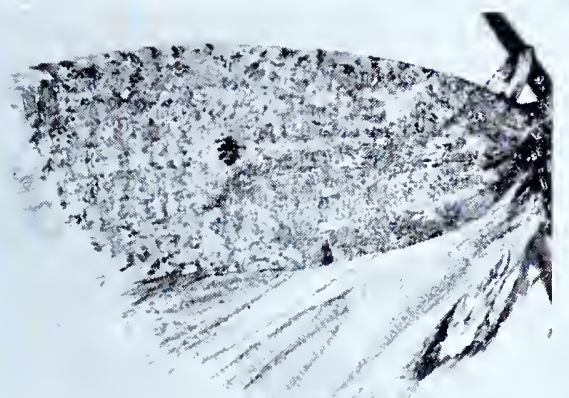

3

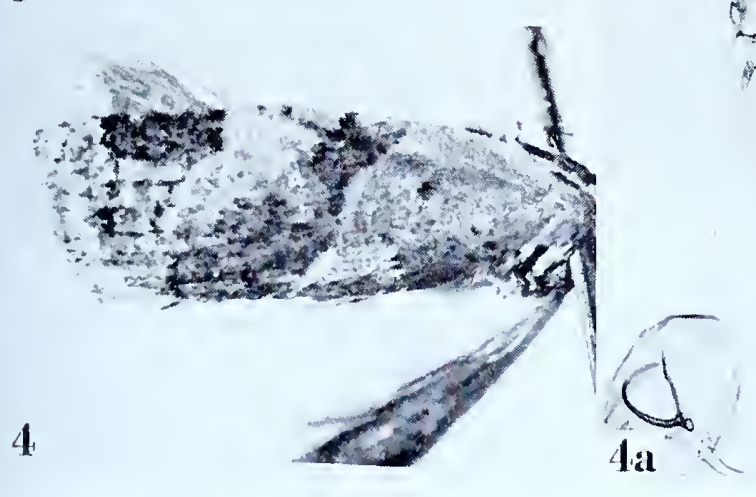

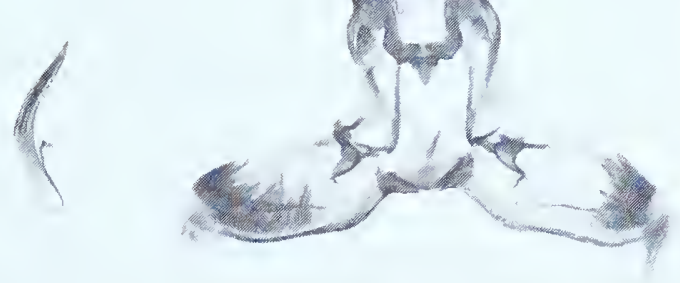

$1 a$

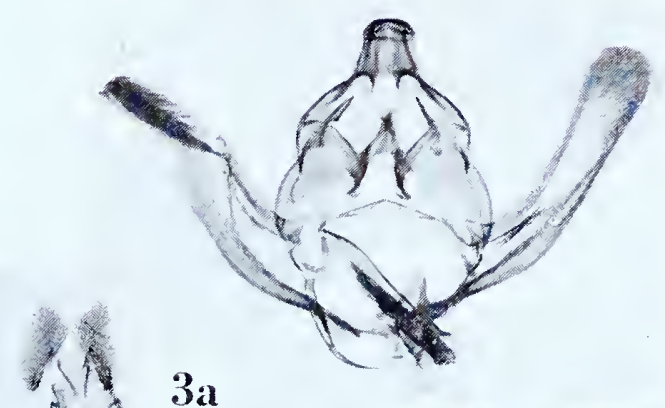

$3 a$

$1 b$

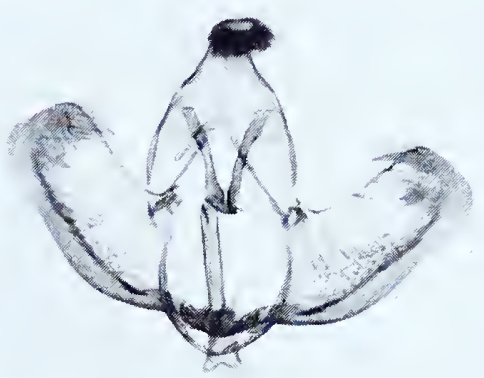

$2 a$
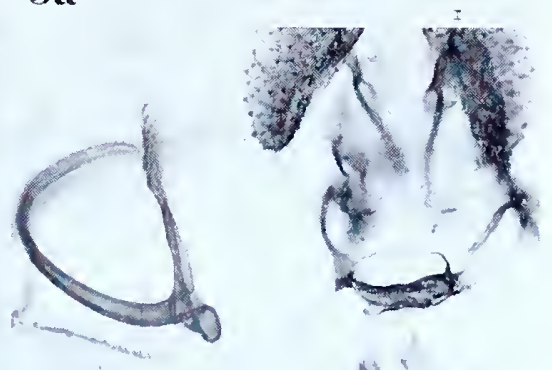

4b

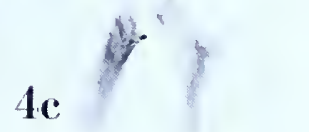

CAPUA 

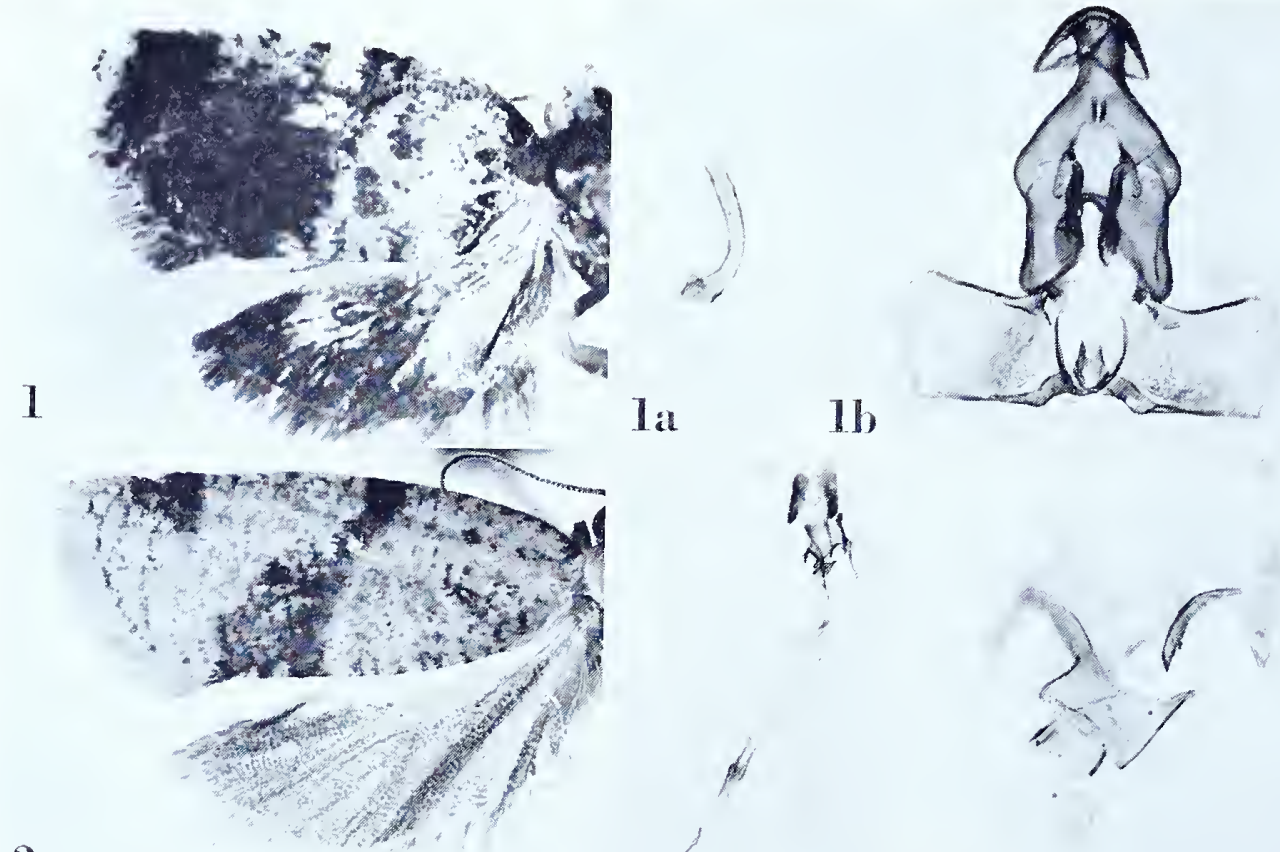

2

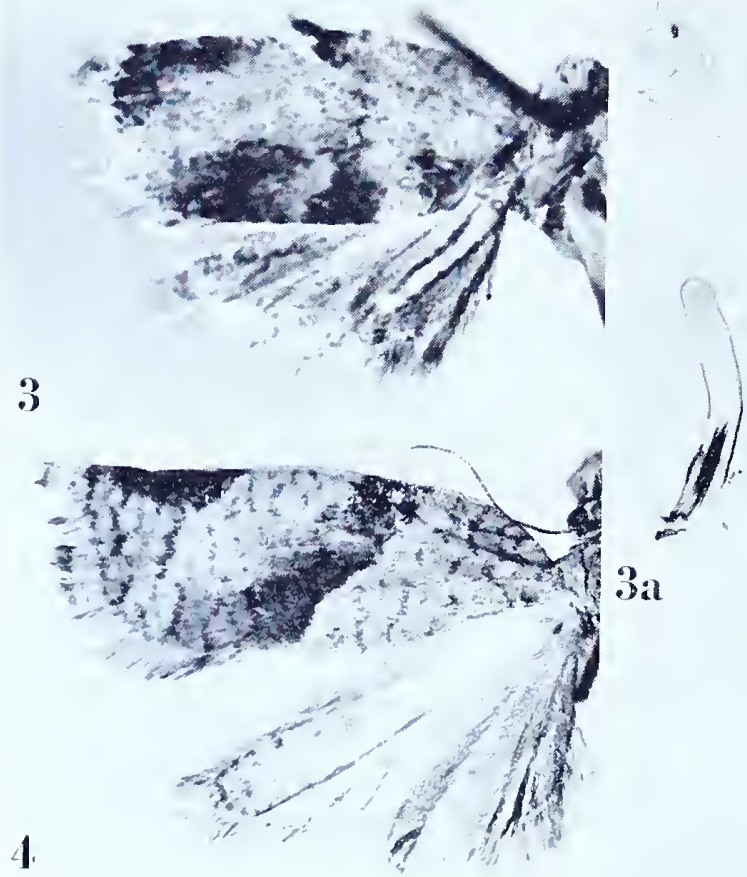

21,

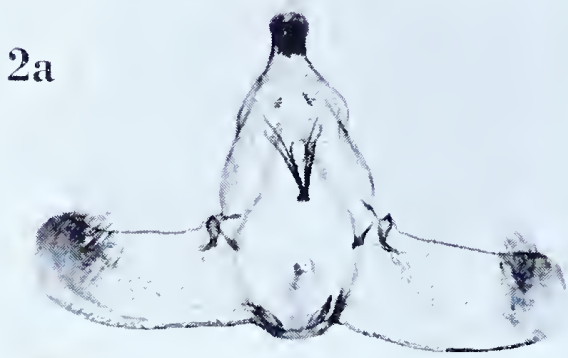

$3 b$

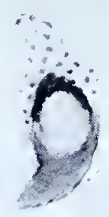

$2 c$ 


\section{Capua pantherina (Meyrick)}

Plate 37, Figures $\mathrm{I}-\mathrm{I} \mathrm{b}$

Epagoge pautherina Meyrick, I 908, Journ. Bombay Nat. Hist. Soc., i 8: 6 I8.

" f. 12 mm. ... N. Coorg, 3,500 feet, in August (Newcome); one specimen."

Type: The male indicated above labelled "Dibidi, N. Coorg. Newcome. Io.8.06". Slide No. 6792.

Figure $\mathrm{I}$, left wings; $\mathrm{I}$, lateral aspect of aedeagus; $\mathrm{I}$ b, ventral view of male genitalia with aedeagus removed.

\section{Capua pedaliota Meyrick}

Plate 37, Figures 2-2c

Capua pedaliota Meyrick, 1936, Exotic Microlepidoptera, 5: 58 .

"․ 16 mm. . . Formosa, Kappansan, May (Prof. S. Issiki); I ex. . . . nearest the Chinese taeniociesma Meyr."

Type: The above indicated female with ".35" in the lower right corner of the pin-label. Slide No. 6784 .

Figure 2, left wings; 2a, ventral view of female genitalia; 2 b, detail of genital plate and ostium; 2 c, signum.

\section{Capua prochyta (Meyrick)}

Plate 37 , Figures $3-3 b$

Epagoge prochyta Meyrick, igo8, Journ. Bombay Nat. Hist. Soc., i 8: 618.

" fot $^{\circ}$ I I-I 2 mm. . . Khasis, in June and September; six specimens."

Lectotype: A male measuring i mm., dated ".9.1906". Slide No. 6790. All specimens are labelled "Khasi Hills, Assam".

Figure 3 , left wings; $3 \mathrm{a}$, lateral aspect of aedeagus; $3 \mathrm{~b}$, ventral view of male genitalia with aedeagus removed.

\section{Capua provocata (Meyrick)}

Plate 37 , Figure 4

Catamacta provocata Meyrick, I912, Exotic Microlepidoptera, I: I.

"․ $23 \mathrm{~mm}$. . . Assam, Khasis, in April; one specimen."

Type: The female indicated above, without abdomen, dated ".4.1906".

Figure 4, left wings. 
CAPUA

\section{Capua psammocyma (Meyrick)}

Plate 38 , Figures I-Ib

Epagoge psammocyma Meyrick, igo8, Journ. Bombay Nat. Hist. Soc., i8: 6і 7 .

" ${ }^{\circ} .22 \mathrm{~mm}$. . . . Palni Hills, 6,000 feet (Campbell); two specimens."

Lectotype: One of the above two males, both of which bear identical data. Slide No. 6785 . In this preparation the harpes are curled towards the observer and are broader than they appear.

Figure I, left wings; $\mathrm{a}$, lateral aspect of aedeagus; $\mathrm{r} b$, ventral view of male genitalia with aedeagus removed.

\section{Capua ptilocrossa Meyrick}

Plate 38 , Figures $2-2 \mathrm{c}$

Capua ptilocrossa Meyrick, I9I4, Exotic Microlepidoptera, I: 274.

" o. I I-I $2 \mathrm{~mm}$., o + I $4-\mathrm{I} 5 \mathrm{~mm}$. . . Nyassaland [sic], Mt. Mlanje, in January and March (Neave); four specimens. . . Type in British Museum."

Type: The female so marked in the British Museum, "Mt. Mlanje, Nyassaland. I8.III.r9i3. S. A. Neave." Slide No. 9333.

Figure 2, left wings; $2 \mathrm{a}$, ventral view of female genitalia; $2 \mathrm{~b}$, detail of genital plate and ostium; 2c, signum.

\section{Capua revoluta (Meyrick)}

Plate 38 , Figure 3

Epagoge revoluta Meyrick, i9o8, Journ. Bombay Nat. Hist. Soc., i 8: 6i 8.

"o. $21 \mathrm{~mm}$.... Khasis, in March; one specimen."

Type: The female indicated above labelled "Khasi Hills, Assam. .3.1907". The abdomen of the type is missing.

Figure 3 , left wings.

\section{Capua rhabdomaga Meyrick}

Plate 38 , Figures $4-4 \mathrm{c}$

Сариа rhabdomaga Meyrick, i938, 'Trans. R. Ent. Soc. London, 87: 505.

"ㅇ. $16 \mathrm{~mm}$. . . . Kokoda, I,200 feet, July; i ex."

Type: 'The female indicated above so marked in the British Museum. It is labelled "Kokoda, Papua, i,200 Ft. VII.r933. L. E. Cheesman". Slide No. 703 I.

Figure 4 , left wings; 4 a, ventral view of female genitalia 4 b, signum; 4 c, detail of genital plate and ostium. 

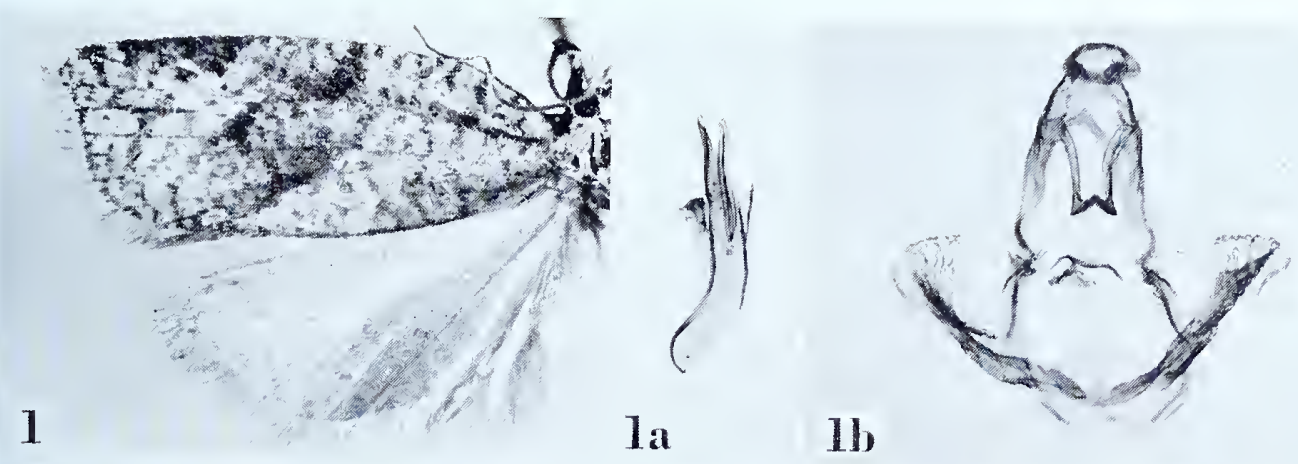

2

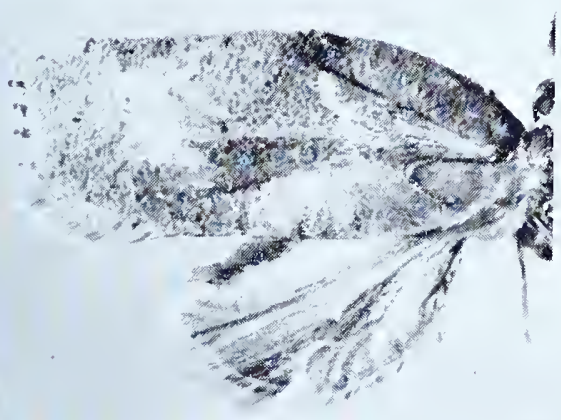

18

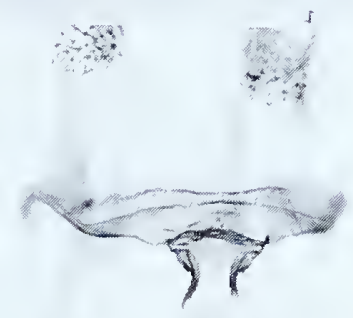

$2 b$

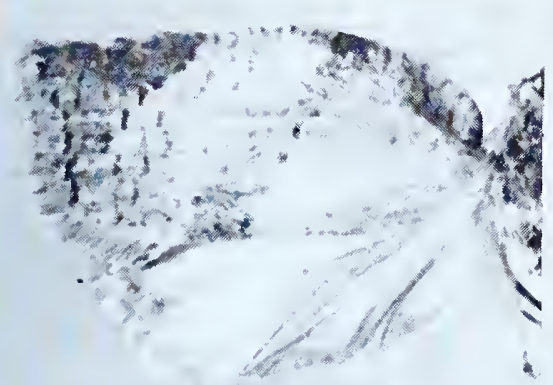

3

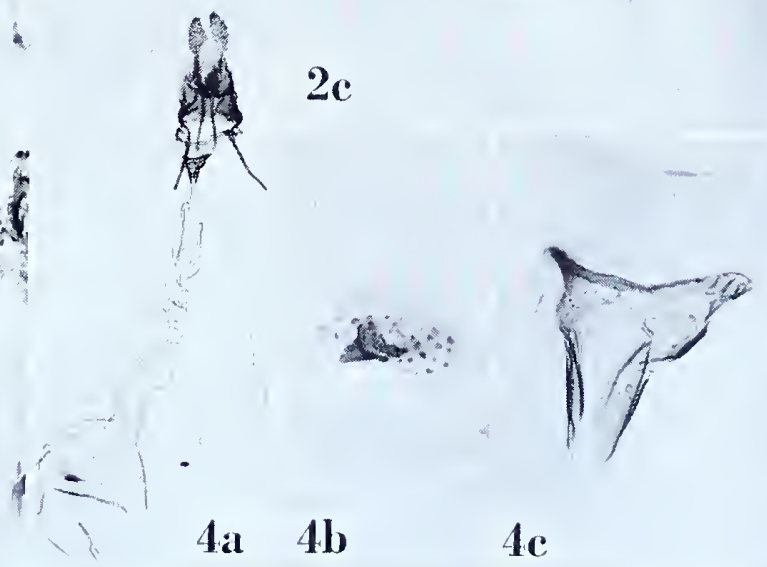

CAPUA 

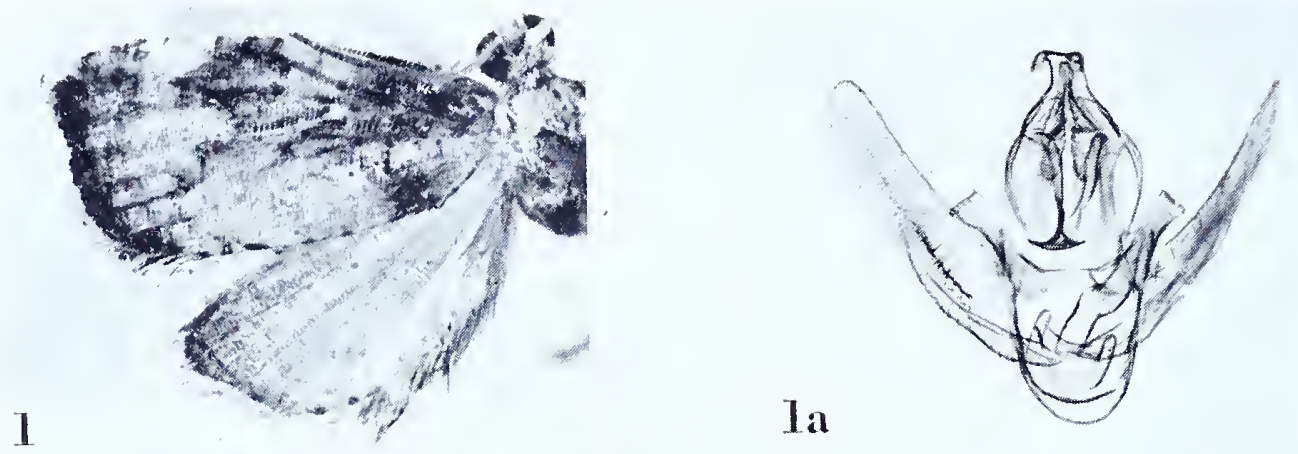

2

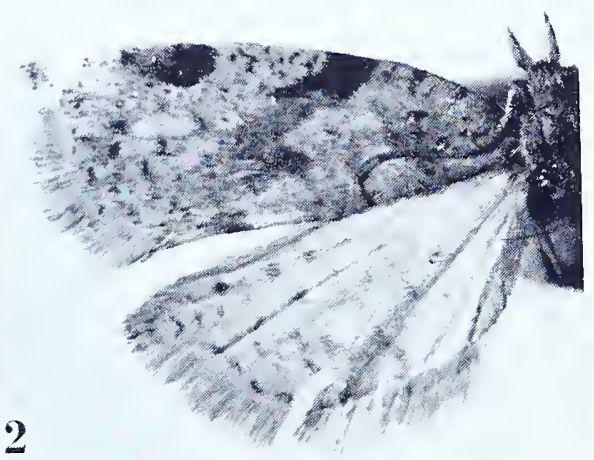

$2 a$
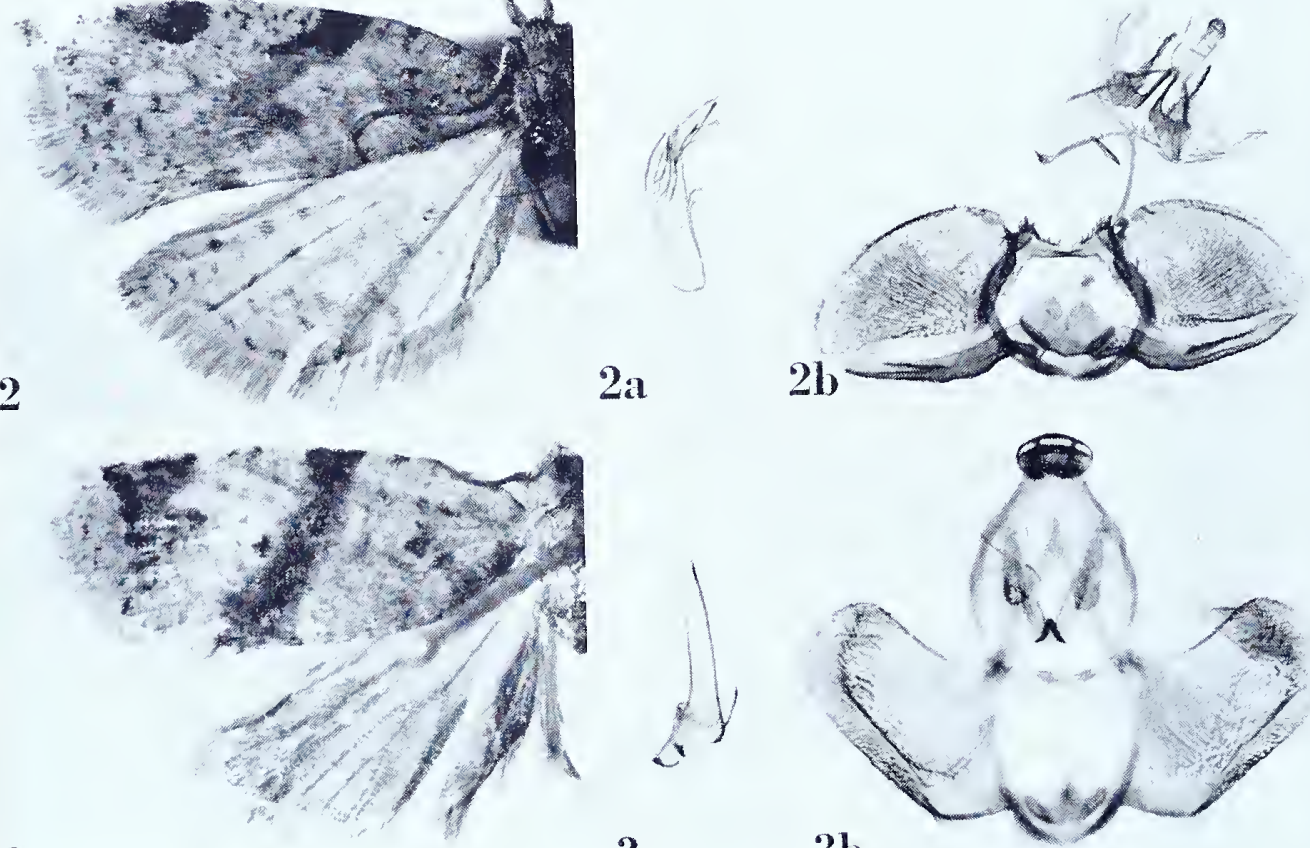

3

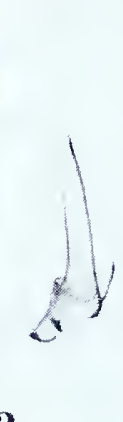

$3 a$
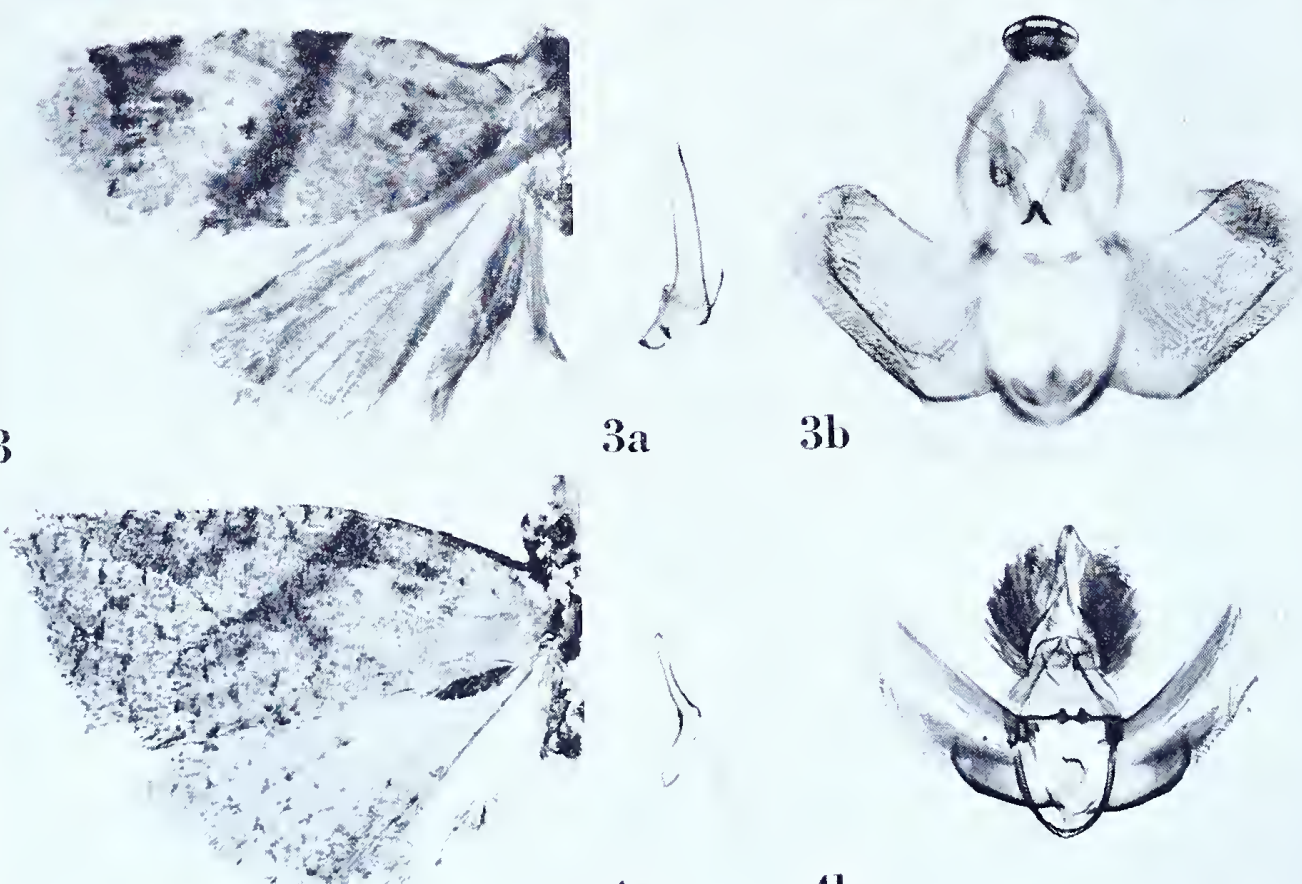

4

$4 a$

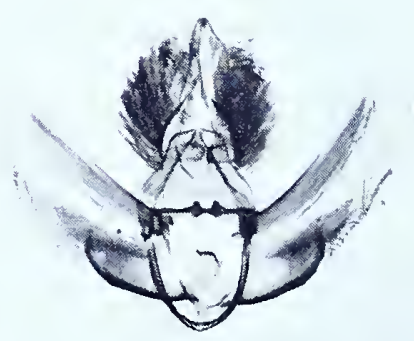

CAPUA 


\section{Capua siderantha (Meyrick)}

Plate 39, Figures I-ia

Epagoge siderantha Meyrick, 1905, Journ. Bombay Nat. Hist. Soc., I6: 588.

" $\delta$ o . I2-14 mm. . . Three specimens, Maskeliya, Ceylon, in February and March (Pole)."

Lectotype: A male measuring 12 mm., dated ".2.04". Slide No. 6805.

Figure I, left wings; ra, ventral view of male genitalia with aedeagus in situ.

\section{Capua spilonoma Meyrick}

Plate 39, Figures 2-2b

Capua spilonoma Meyrick, 1932, 'Trans. Ent. Soc. London, 80: i 10.

" o. $19 \mathrm{~mm}$. . . . Jem-Jem Forest, over 8,000 feet, October; i ex. Allied to liparochra...."

Type: The male so marked in the British Museum, "Abyssinia, Djem-Djem Forest, over 8,000 ft. Io.X. 1926. H. Scott." A second label, in Meyrick's hand, reads "Capna spilonoma n. sp." Slide No. 9332.

Figure 2, left wings; $2 \mathrm{a}$, lateral aspect of aedeagus; $2 \mathrm{~b}$, ventral view of male genitalia with aedeagus removed.

\section{Capua taeniodesma Meyrick}

Plate 39 , Figures $3 \div 3 \mathrm{~b}$

Capna taeniodesma Meyrick, 1934, Exotic Microlepidoptera, 4: 525 .

" ô. I 2-13 mm. ... W. China, Mt. Omei, 4 , ooo feet, July, August (Franck); 4 ex. Allied to melanatma."

Lectotype: A male measuring $13 \mathrm{~mm}$., dated "7.22". Slide No. 6789 .

Figure 3 , left wings; $3 \mathrm{a}$, lateral aspect of aedeagus; 3 b, ventral view of male genitalia with aedeagus removed.

\section{Capua tylonota Meyrick}

Plate 39, Figures $4-4 \mathrm{~b}$

Capna tylonota Meyrick, I926, Exotic Microlepidoptera, 3: 247 .

" o. $20 \mathrm{~mm}$. . . Colombia, Cañon del Callo, 5,200 feet, October."

Type: The specimen indicated above labelled "Cañon del Callo, Colombia, 5,250' .10.20',. Slide No. 6286 .

Figure 4 , left wings; 4 a, lateral aspect of aedeagus; 4 b, ventral view of male genitalia with aedeagus removed. 


\section{CA'TAMAC'TA Meyrick \\ Catamacta scrutatrix Meyrick \\ Plate 40, Figures $\mathbf{I}-\mathbf{I b}$}

Catamacta scrutatrix Meyrick, I912, Exotic Microlepidoptera, I : I.

" "q. $17 \mathrm{~mm}$. . . Natal, Pinetown, in June (Leigh); one specimen."

Type: The above indicated female, "Pinetown, Natal. L. . . o9." Slide No. 9335. This is another case in which a January date has been published as June.

Figure I, left wings; гa, signum; $\mathbf{b}$, detail of genital plate and ostium and showing sclerotised posterior portion of ductus bursae.

\section{CERACE Walker \\ Cerace sardias Meyrick \\ Plate 40, Figures 2-2b}

Cerace sardias Meyrick, I907, Journ. Bombay Nat. Hist. Soc., I7: 748.

"․ 33-40 mm. . . Khasi Hills; three specimens (Swinhoe)."

Lectotype: A female measuring $34 \mathrm{~mm}$., "Khasi Hills, Assam. CS. .05." Slide No. 6827 .

Figure 2, left wings; $2 \mathrm{a}$, ventral view of female genitalia; $2 \mathrm{~b}$, detail of genital plate and ostium. 


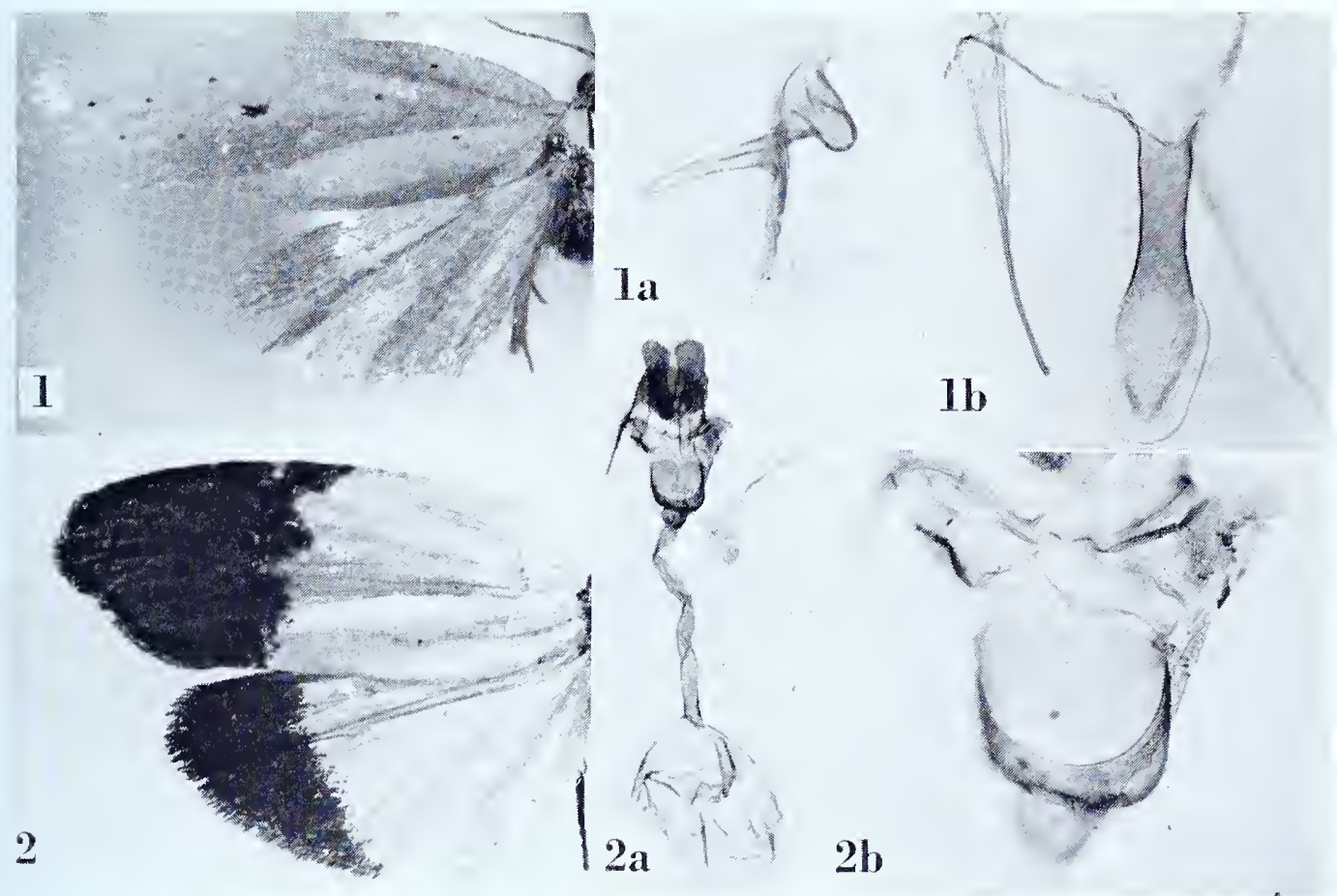

CATAMACTA and CERACE 

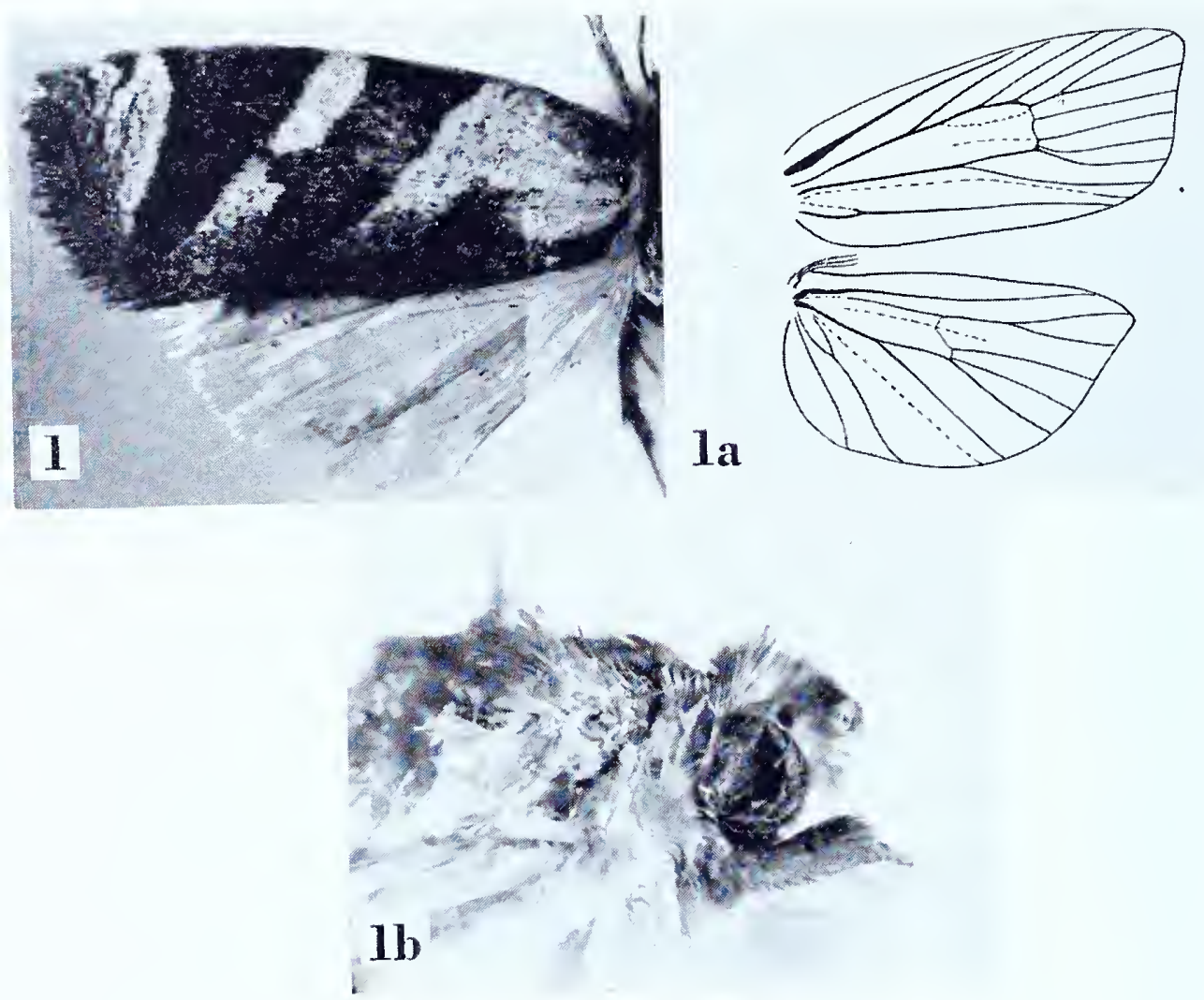

CHOANOGRAP'TIS 


\section{CHOANOGRAP'TIS Meyrick}

Choanograptis Meyrick, 1938, Trans. R. Ent. Soc. London, 87: 504. (Typus generis: Choonograptis didyma Meyrick, ibid. [monotypy].)

\section{Choanograptis didyma Meyrick}

Plate 4I, Figures $\mathrm{I}-\mathrm{I}$ b

Choanograptis didyma Meyrick, I938, Trans. R. Ent. Soc. London, 87: 504.

"․ $20 \mathrm{~mm}$. . . . Mt. Tafa, 8,500 feet, March. I ex."

Type: The above indicated female, so marked in the British Museum, "Mt. Tafa. Papua, 8,500 ft. III. 1934. L. E. Cheesman." The abdomen of the type is missing.

Figure I, left wings; Ia, venation of right wings; Ib, lateral aspect of head to show palpus. 


\section{CHRYSOXENA Meyrick}

Chrysoxena Meyrick, 1912, 'Trans. Ent. Soc. London, I91 I: 685. (Typns generis: Tortrix aıriferana Busck, 19ı1, Proc. U.S. Nat. Mus., 40: 227 [by original designation].)

\section{Chrysoxena auriferana (Busck)}

$$
\text { Plate } 42 \text {, Figures I-IC }
$$

Tortrix aniferana Busck, I9I I, Proc. U.S. Nat. Mus., 40: 227.

Figured from a co-type in the U.S. National Museum.

Figure $\mathrm{I}$, left wings; $\mathrm{ra}$, venation of right wings; $\mathrm{rb}$, lateral aspect of head to show palpus; Ic, ventral view of male genitalia with aedeagus in sitn. 

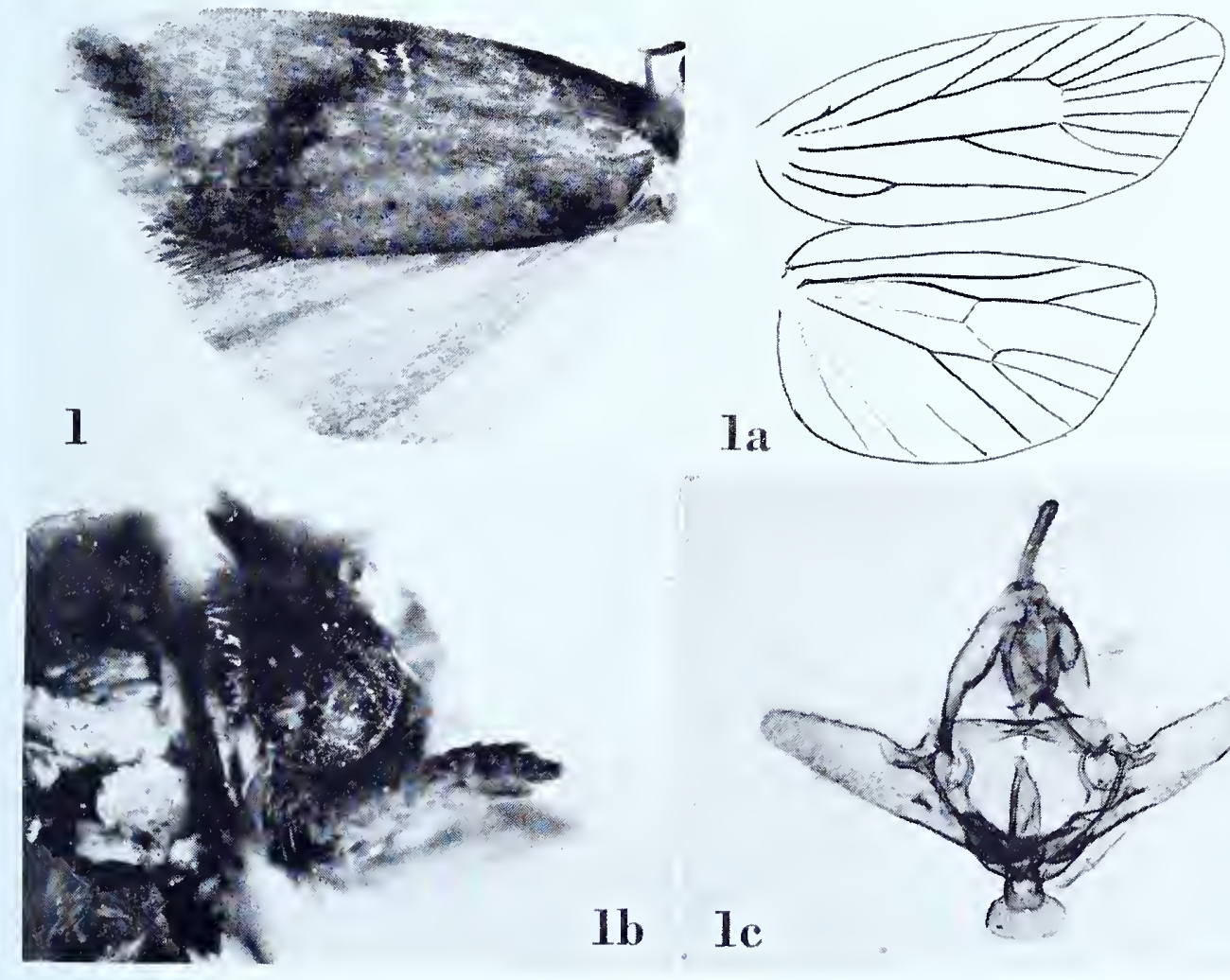

Ib Ic

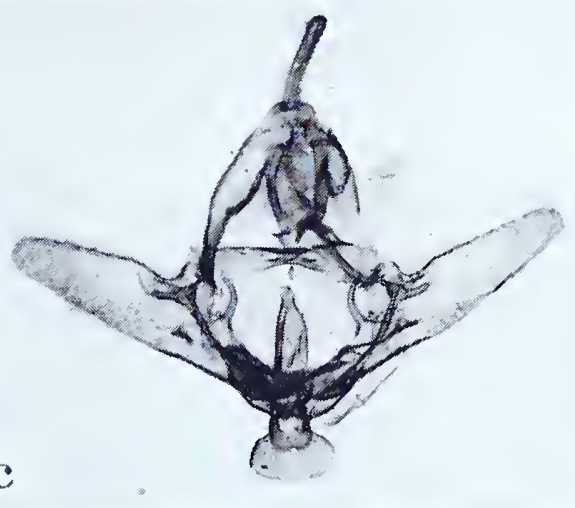

CHRYSOXENA 


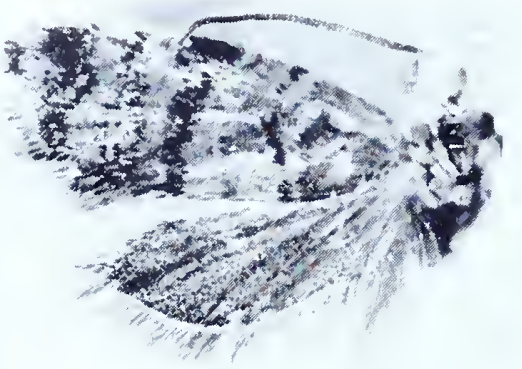

1

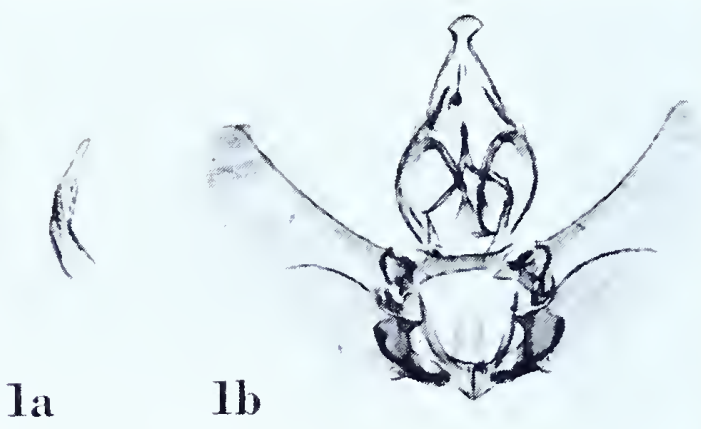

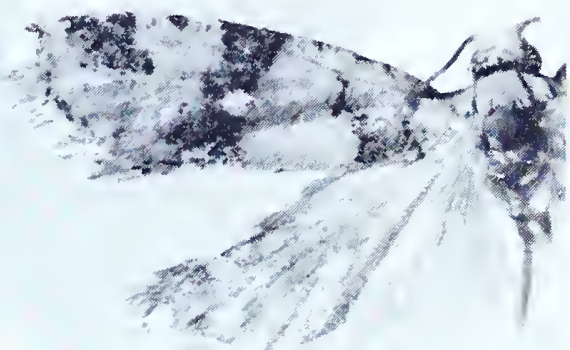

2

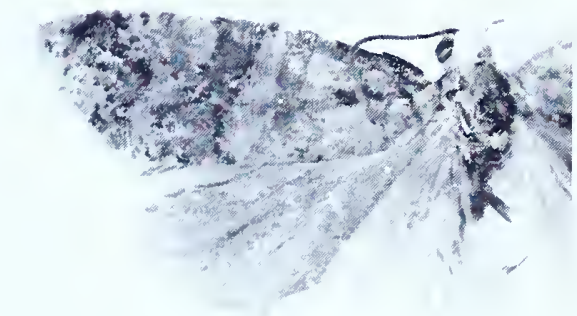

3

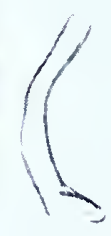

$3 a$

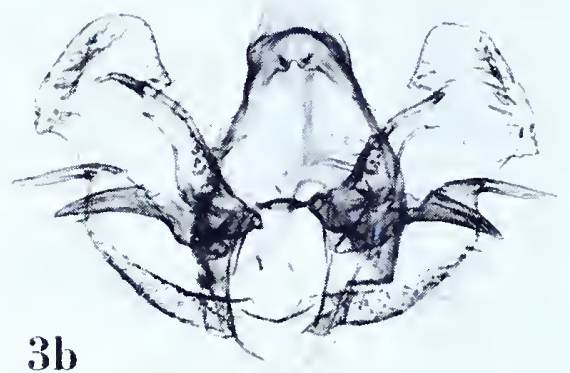

CNEPHASIA 


\section{CNEPHASIA Curtis \\ Cnephasia captiva Meyrick \\ Plate 43, Figures I-I b}

Cnephasia captiva Meyrick, I9I I, Ann. Transvaal Mus., 2: 224.

"Male, ro mm. . . . Haenertsburg, in December (Swierstra); one specimen."

Type: The male denoted above, "Haenertsburg, Transvaal. CJS. 8.r2.o9." Slide No. 9386.

Figure I, left wings; $\mathrm{a}$, lateral aspect of aedeagus; $\mathrm{ib}$, ventral view of male genitalia with aedeagus removed.

\section{Cnephasia cedrota (Meyrick)}

Plate 43 , Figures $2-2 b$

Tortrix cedrota Meyrick, 1908, Proc. Zool. Soc. London, 722.

“

Type: The above indicated male dated “І .3 .07 ”. Slide No. 9388.

Figure 2 , left wings; $2 \mathrm{a}$, lateral aspect of aedeagus; $2 \mathrm{~b}$, ventral view of male genitalia with aedeagus removed.

\section{Cnephasia ergastularis Meyrick}

Plate 43 , Figures $3-3 \mathrm{~b}$

Cnephasia ergastularis Meyrick, I9I I, Ann. Transvaal Mus., 2: 225.

"Male, I4 mm. . . . Haenertsburg, in December (Swierstra); one specimen."

Type: The above indicated specimen, "Haenertsburg, Transvaal. CJS. 6.I2.o9." Slide No. 9387 .

Figure 3 , left wings; 3 a, lateral aspect of aedeagus; 3 b, ventral view of male genitalia with aedeagus removed. 


\section{Cnephasia melliflua Meyrick \\ Plate 44, Figures I-Ib}

Cnephasia melliflna Meyrick, I914, Exotic Microlepidoptera, I: 195.

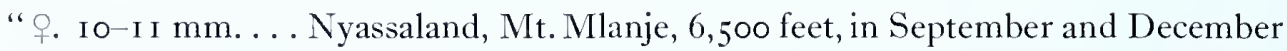
(Neaze); four specimens. Type in British Museum."

Type: The female so marked in the British Museum, "Mt. Mlanje, Nyasaland. 30.ix.1913. S. A. Neave." A small white label bears the inscription "M29". A third label, in Meyrick's hand, reads "Cneplaasia melliflna Meyr. type". Slide No. 9369.

Figure I, left wings; ıa, ventral view of female genitalia; $\mathrm{ib}$, detail of genital plate and ostium.

\section{Cnephasia oricasis Meyrick}

Plate 44, Figures 2-2b

Cnephasia oricasis Meyrick, I932, Exotic Microlepidoptera, 4: 342.

" $\hat{o}+$. I 7-2 I mm. . . Kashmir, Gulmarg (8,80o feet), Killanmarg (io, 500 feet), June, July (T. B. Fletcher); 39 ex. (only I ). Specimens from the higher elevation tend to be lighter, greyer. ..."

Lectotype: A male measuring $20 \mathrm{~mm}$., "Gulmarg, Kashmir. 'TBF. 8,800' .7.23." Slide No. 6858 . Only i s specimens remain in the Meyrick collection.

Figure 2 , left wings; $2 \mathrm{a}$, lateral aspect of aedeagus; $2 \mathrm{~b}$, ventral view of male genitalia with aedeagus removed.

\section{Cnephasia rastrata Meyrick \\ Plate 44 , Figures $3^{-} 3^{b}$}

Cuephasia rastrata Meyrick, 1910, Ent. Mon. Mag., 21 : 2 I I.

" สิำ. 26-3 I mm. . . Hab. Saas-Fée, 6,000-7,000 feet, in August."

Type: The male so marked in the British Museum, "Saas, Switzerland, 6,00o' 15/8/00." Slide No. 9432.

Figure 3 , left wings; $3 \mathrm{a}$, lateral aspect of aedeagus; $3 \mathrm{~b}$, ventral view of male genitalia with aedeagus removed.

\section{Cnephasia tofina Meyrick \\ Plate +4 , Figures $4^{-}+\mathrm{b}$}

Cuephasia tofuna Meyrick, 1922, Exotic Microlepidoptera, 2: 498.

"ơ. 19 mm. . . Palestine, Nazareth, April (Barrand); i ex. (Brit. Mus.)."

Type: The above indicated male so marked in the British Museum, "Nazareth. Palestine. 3.iv.1920. P. J. Barraud. I920-347." Slide No. 9368.

Figure 4 , left wings; 4 a, lateral aspect of aedeagus; 4 b, ventral view of male genitalia with aedeagus removed, 

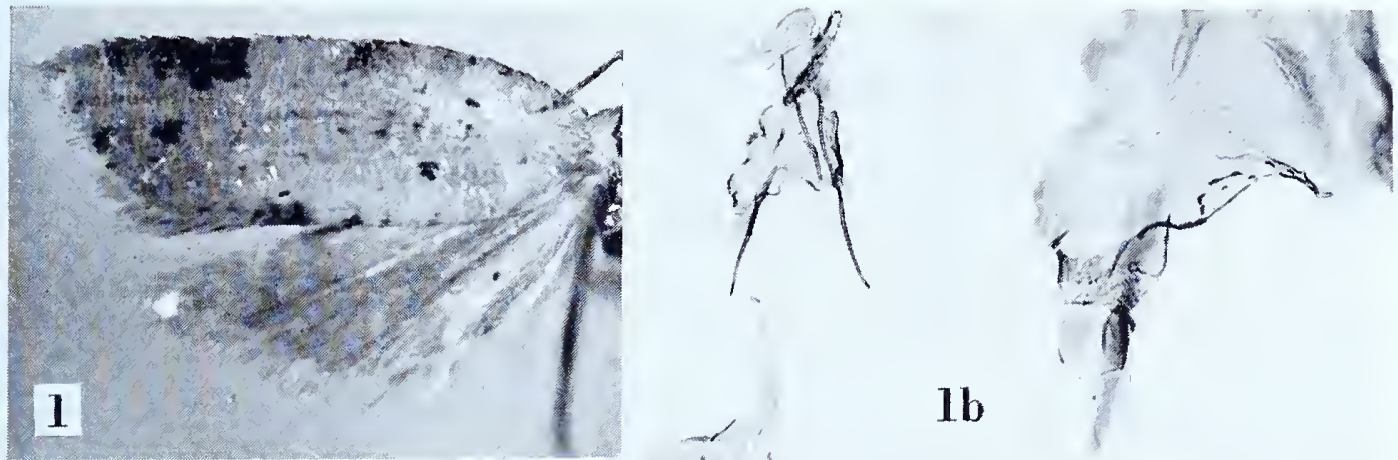

2
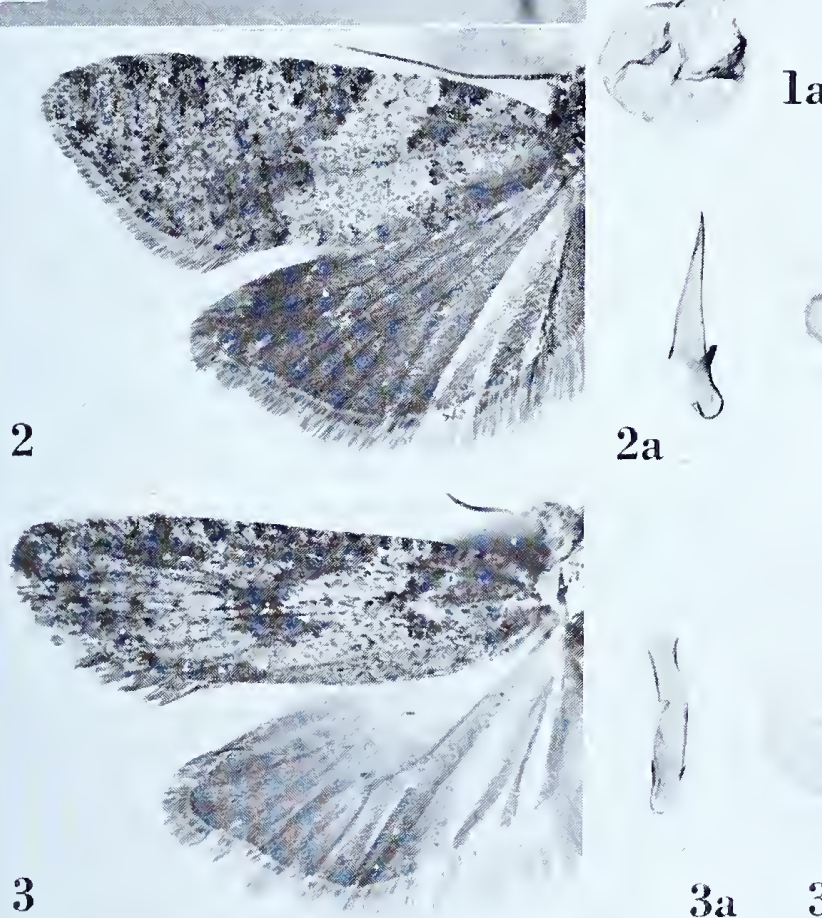

$2 \mathbf{a}$
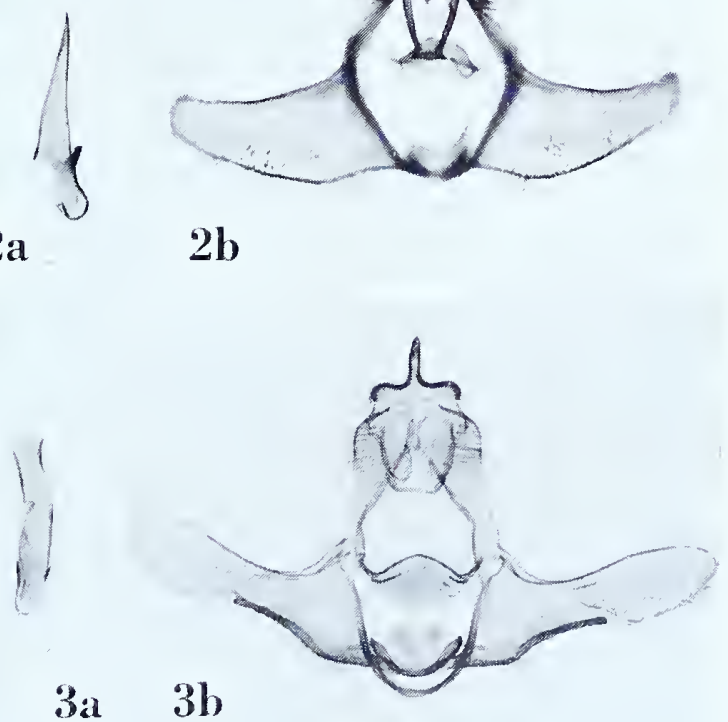

$2 b$

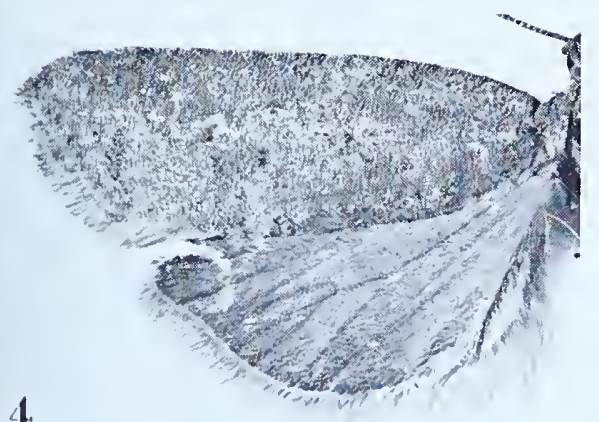

4
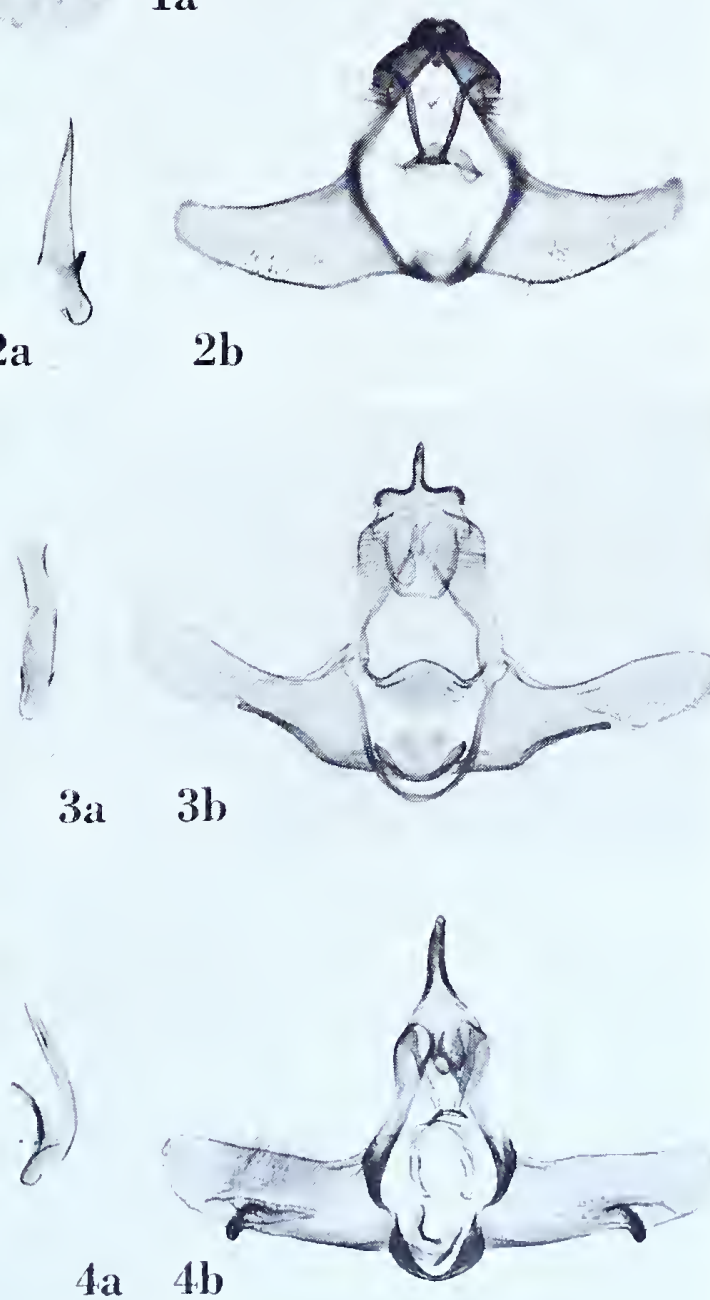

CNEPHASIA 

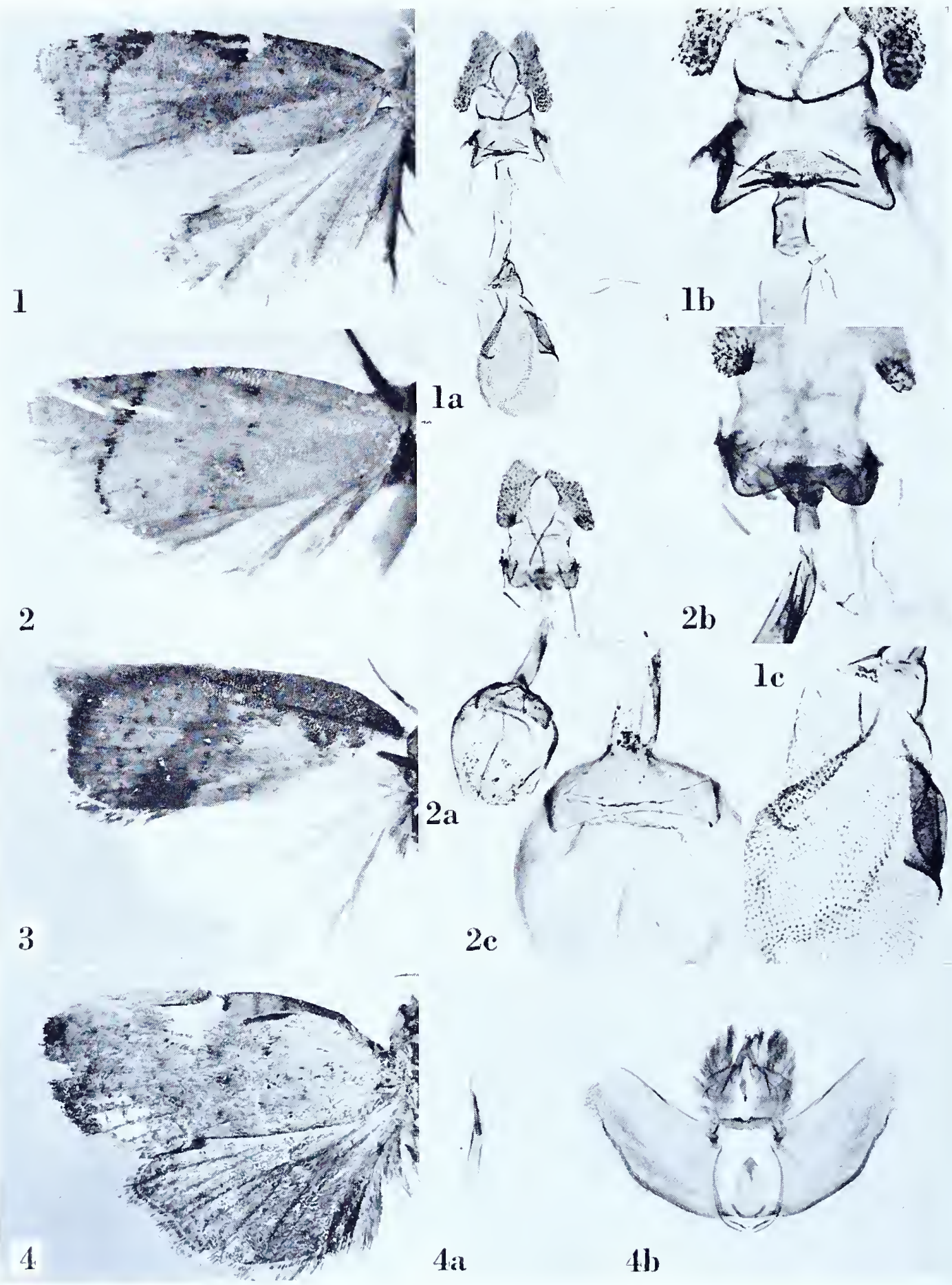

$4 a$

4b)

COELOSTATHMA and C'TENOPSEUSTIS 


\section{COELOSTA'THMA Clemens}

\section{Coelostathma contigua Meyrick}

Plate 45 , Figures I-IC

Coelostathma contigua Meyrick, 1926, Exotic Microlepidoptera, 3: 259.

“o. I $3^{-1} 4 \mathrm{~mm}$. . . . Brazil, Teffé, January; Peru, Rio Napo, May (Parish); 2 ex. Very near discopunctana."

Lectotype: The female, "Teffé, Brazil, Parish. 1.20." Slide No. 6365.

Figure I, left wings; Ia, ventral view of female genitalia; Ib, ostium; ic, signum.

\section{Coelostathma immutabilis Meyrick}

Plate 45, Figures 2-2c

Coelostathma immutabilis Meyrick, 1926, Exotic Microlepidoptera, 3: 259.

“ ふ̊ํ. 9-12 mm. . . Brazil, Pará, July (Parish); Bolivia, Prov. del Sara, Dept. Sta. Cruz, $1,500 \mathrm{ft} . ; 4$ ex. Exceptional in separation of vein 9 of forewings. . ."

Lectotype: 'The female, "Pará, Brazil, Parish. 7-r9." Slide No. 6366.

Figure 2, left wings; $2 \mathrm{a}$, ventral view of female genitalia; $2 \mathrm{~b}$, ostium; $2 \mathrm{c}$, signum.

\section{C'TENOPSEUSTIS Meyrick}

Ctenopseustis acrocharis Meyrick

Plate 45, Figure 3

Ctenopseustis acrocharis Meyrick, 1932, Exotic Microlepidoptera, 4:261.

" J. 25 mm. . . . Colombia, Mt. Tolima, I2,500 feet, December; i ex."

Type: The specimen indicated above, dated " 12.20 " and without abdomen.

Figure 3 , left wings.

\section{Ctenopseustis lurida Meyrick}

Plate 45 , Figures $4-4 b$

Ctenopseustis lurida Meyrick, г912, Trans. Ent. Soc. London, г19 г : 68г.

"亏. 27-28 mm. . . . Colombia, San Antonio, 5, 800 feet, in November; five specimens."

Lectotype: A male measuring $28 \mathrm{~mm}$. Slide No. 6362. 'Two specimens are missing, the three remaining ones are dated " I I.07".

Figure 4 , left wings; 4 a, lateral aspect of aedeagus; 4 b, ventral view of male genitalia with aedeagus removed. 


\section{DEL'TOBATHRA Meyrick}

Deltobathra Meyrick, 1923, Exotic Microlepidoptera, 3: 55. (Typus generis: Deltobathra platamodes Meyrick, ibid. [monotypy].)

\section{Deltobathra platamodes Meyrick}

Plate 46, Figures I-IC

Deltobathra platanodes Meyrick, 1923, Exotic Microlepidoptera, 3: 55 .

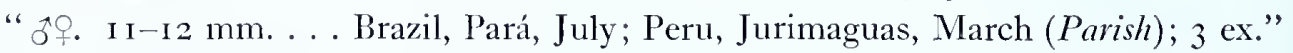

Lectotype: The male, "Jurimaguas, Peru. Parish. .3.20." Slide No. 6342.

Figure I, left wings; Ia, venation of right wings; $\mathrm{Ib}$, lateral aspect of head to show palpus; Ic, ventral view of male genitalia with aedeagus in situ. 


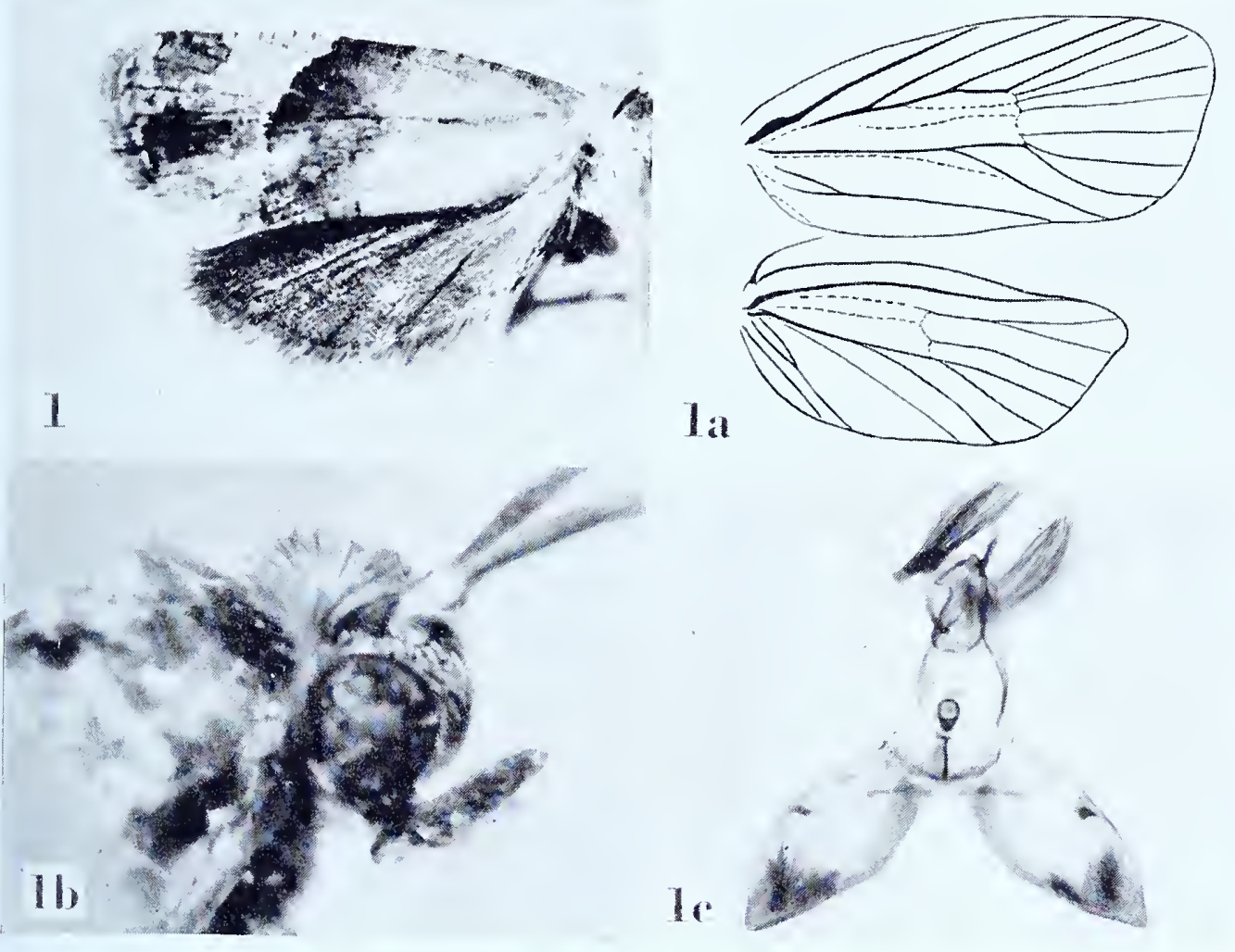

DELTOBATHRA 

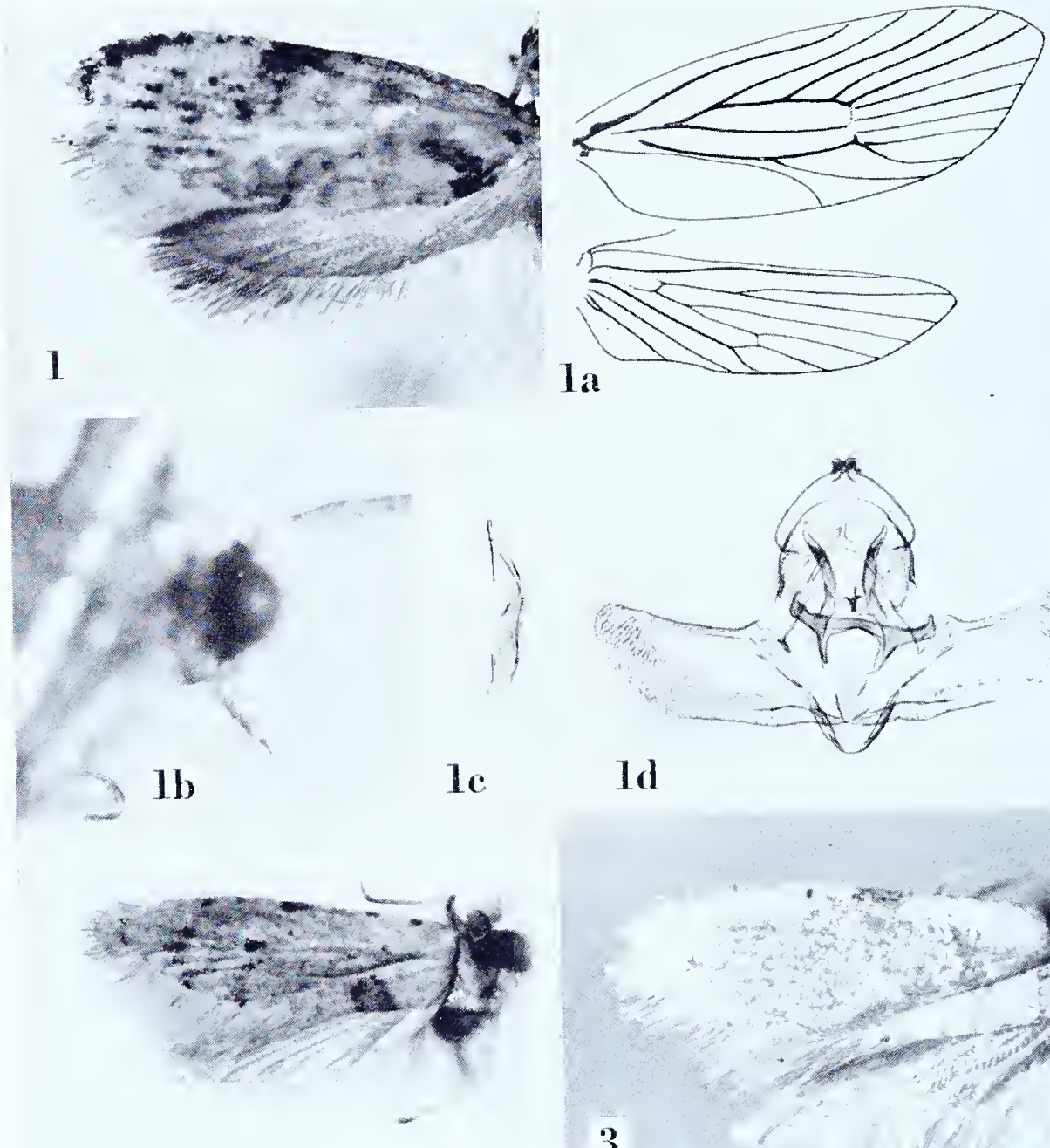

2
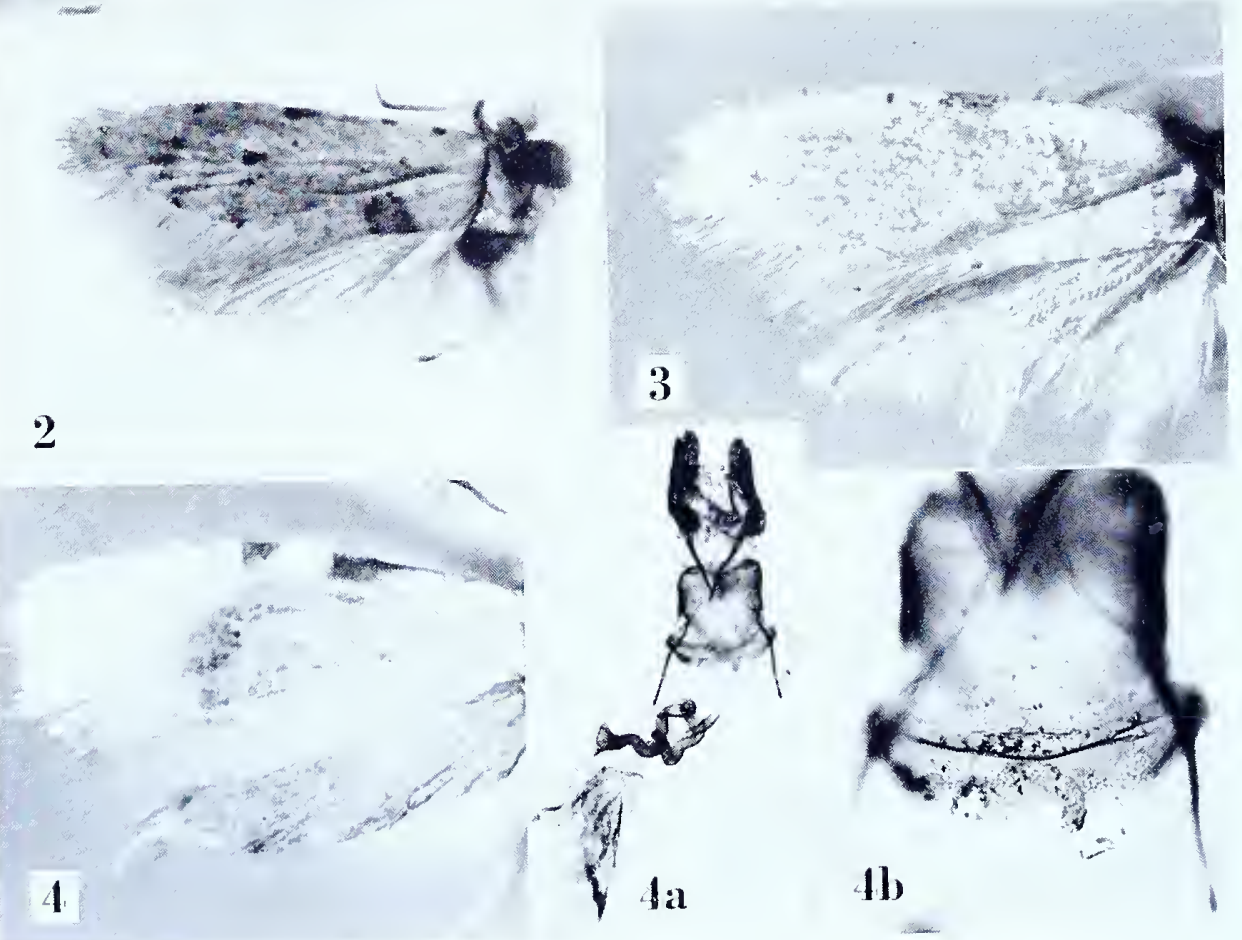

DIACTENIS 


\section{DIACTENIS Meyrick}

Diactenis Meyrick, ı907, Journ. Bombay Nat. Hist. Soc., 17: 979. (Typus generis: Diactenis pteroneura Meyrick, l.c. $9^{80}$ [monotypy].)

\section{Diactenis pteroneura Meyrick \\ Plate 47, Figures I-Id}

Diactenis ptercneura Meyrick, 1907, Journ. Bombay Nat. Hist. Soc., 17: $9^{80 .}$

“ 3 ㅇ. 8-1 о mm. ... Ten specimens, Maskeliya and Madulsima, Ceylon; Coorg (3,500 feet); from February to October (Pole, Vatghn, Newcome)."

Lectotype: A male measuring $8 \mathrm{~mm}$., "Maskeliya, Ceylon, Pole. .ı.05." Slide No. 6867 .

Figure I, left wings; $\mathrm{a}$, venation of right wings; $\mathrm{ib}$, lateral aspect of head to show palpus; Ic, aedeagus; Id, ventral view of malc genitalia with aedeagus removed.

\section{Diactenis bidentifera Meyrick}

\section{Plate 47 , Figure 2}

Diactenis bidentifera Meyrick, I928, Exotic Microlepidoptera, 3: 458 .

" c. $8 \mathrm{~mm}$. ... Assam, Khasis; I ex."

Type: The above indicated male, without abdomen, "Khasi Hills, Assam. 1925."

Figure 2, left wings.

\section{Diactenis deformata Meyrick}

Plate 47 , Figure 3

Diactenis deformata Meyrick, 1928, Exotic Microlepidoptera, 3: $45^{8}$.

" o. Io mm. . . . Assam, Khasis; I ex."

Type: The above indicated male, without abdomen, dated " 1925 ".

Figure 3 , left wings.

\section{Diactenis veligera Meyrick}

Plate 47 , Figures $4-4 \mathrm{~b}$

Diactenis zeligera Meyrick, 1928, Exotic Microlepidoptera, 3: $45^{8}$.

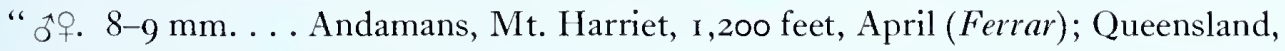
Cairns, October (Dodd); 2 ex."

Lectotype: The female, “Mt. Harriet, Andamans. F. I,200' .4.27." Slide No. 6868. The male is missing.

Figure 4 , left wings; 4 a, ventral view of female genitalia; 4 b, detail of genital platc and ostium. 
DICELLITIS

\section{DICELLITIS Meyrick}

Dicellitis Meyrick, ı 908, Journ. Bombay Nat. Hist. Soc., i 8: 6 I6. (Typus generis: Dicellitis nigritula Meyrick, ibid. [monotypy].)

\section{Dicellitis nigritula Meyrick}

Plate 48 , Figures $\mathrm{I}-\mathrm{Id}$

Dicellitis nigritula Meyrick, ı908, Journ. Bombay Nat. Hist. Soc., i 8: 6 I6.

“․ I 5-I7 mm. . . . N. Coorg, 3.500 feet, in August and October (Newcome); two specimens."

Lectotype: 'The larger of the two specimens. Both are labelled, "Dibidi, N. Coorg, Newcome". The lectotype is dated "I I-I0-o6". Slide No. 6857.

Figure I, left wings; $\mathrm{a}$, venation of right wings; $\mathrm{s}$ b, lateral aspect of head to show palpus; Ic, signum; Id, detail of genital plate and ostium. 

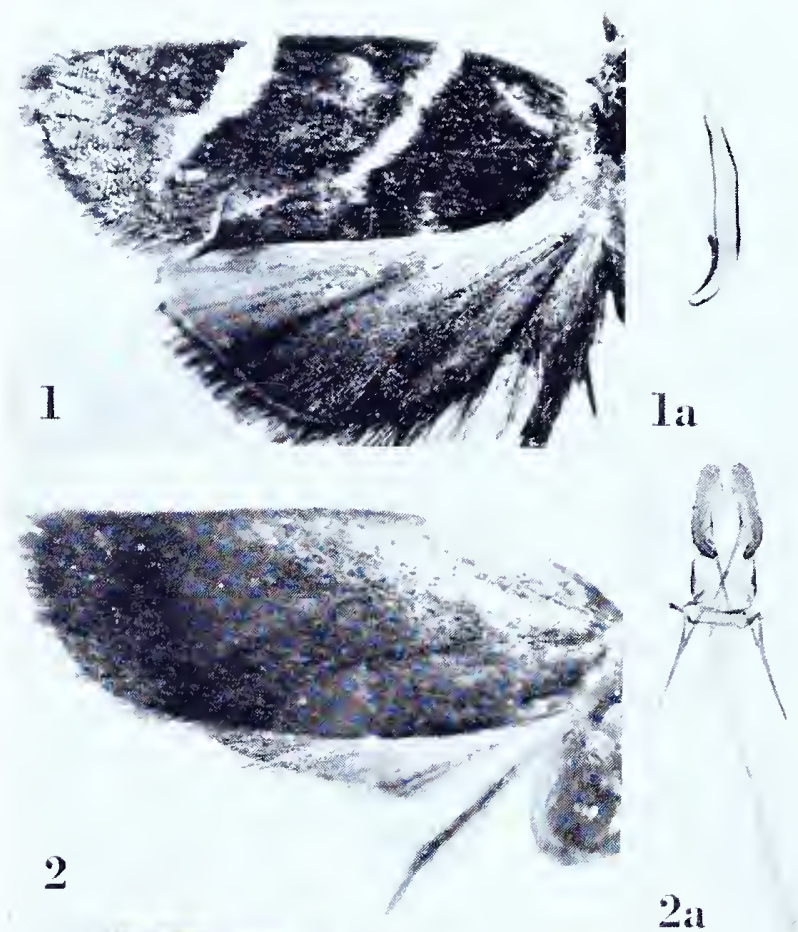
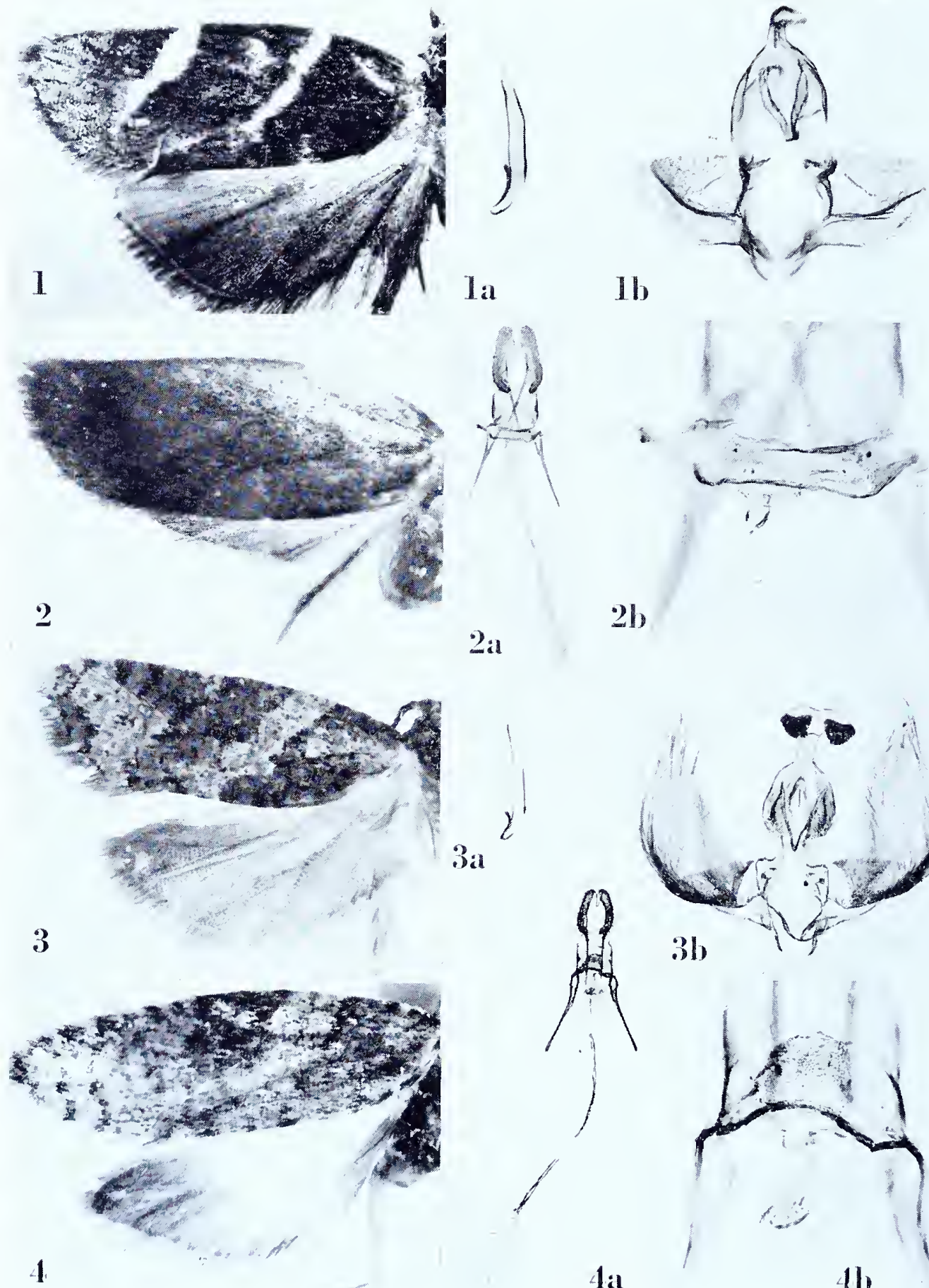

Ib

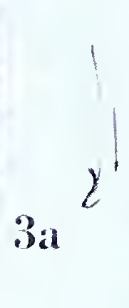

$2 b$
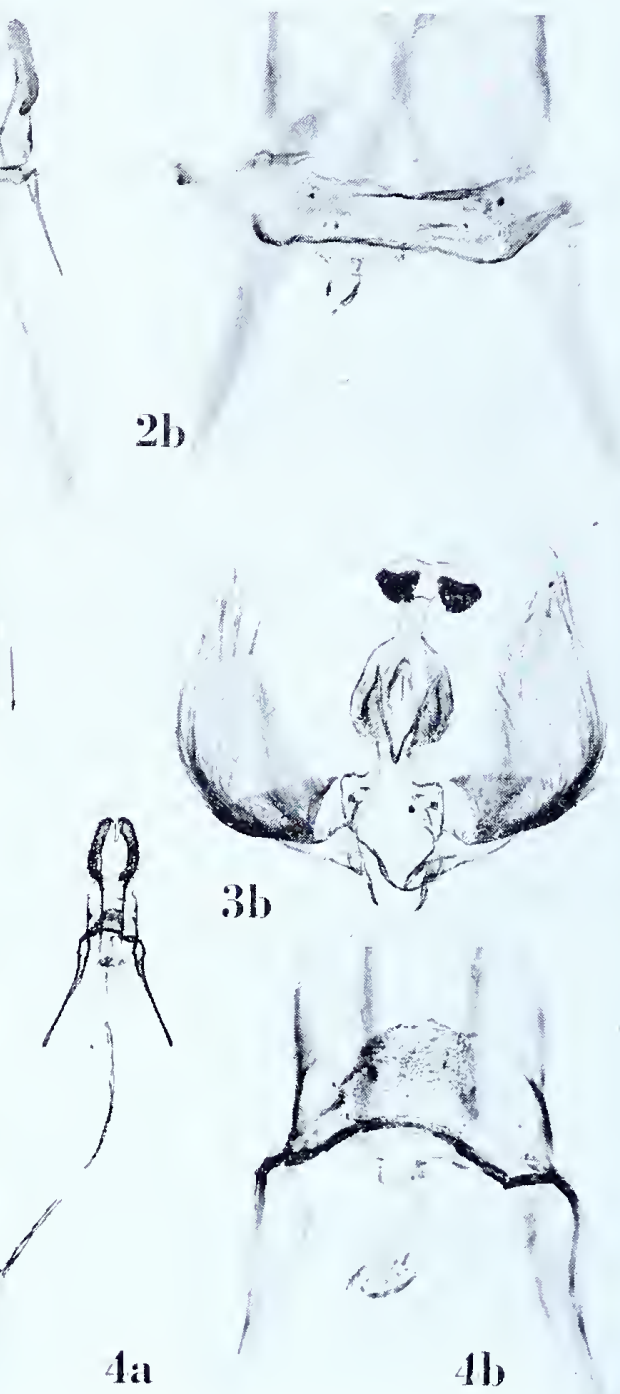
DICHELOPA

\section{DICHELOPA Lower \\ Dichelopa argoschista Meyrick}

Plate 49, Figures $\mathrm{I}-\mathrm{I}$ b

Dichelopa argoschista Meyrick, I928, Trans. Ent. Soc. London, 76: 492.

“ ${ }^{\star}$. I $5^{-1} 6 \mathrm{~mm}$. . . . Society Is., Tahiti, March, at light; 2 ex."

Type: The male so marked in the British Museum, "Papeete, Tahiti, at light, 300 ft. $4 \cdot 3 \cdot 25$. C. L. Collenette." Slide No. 6965.

Figure I, left wings; $\mathrm{ia}$, lateral aspect of aedeagus; $\mathrm{ib}$, ventral view of male genitalia with aedeagus removed.

\section{Dichelopa ceramocausta Meyrick}

Plate 49, Figures 2-2b

Dichelopa ceramocausta Meyrick, I926, Trans. Ent. Soc. London, 74: 272.

" ${ }^{\circ}$. I3-I $5 \mathrm{~mm} . .$. At low level; 3 ex."

Type: The female so marked in the British Museum, "Rapa Island. At light. 14.4.25. C. L. Collenette." Slide No. 7002.

Figure 2, left wings; $2 \mathrm{a}$, ventral view of female genitalia; $2 \mathrm{~b}$, detail of ostium.

\section{Dichelopa choleranthes Meyrick}

Plate 49 , Figures $3-3 \mathrm{~b}$

Dichelopa choleranthes Meyrick, I928, Trans. Ent. Soc. London, 76: 493.

" $0^{\text {*ㅇ․ }}$ I $3^{-1} 4 \mathrm{~mm} . .$. Marquesas, Hiva Oa, 3,500 feet, January, at light; 2 ex."

Type: The male so designated in the British Museum. Slide No. 6969. Both specimens bear identical data and are dated "28.1.25".

Figure 3 , left wings; 3 a, lateral aspect of aedeagus; $3 \mathrm{~b}$, ventral view of male genitalia with aedeagus removed.

\section{Dichelopa deltozancla Meyrick}

Plate 49 , Figures $4-4 \mathrm{~b}$

Dichelopa deltozancla Meyrick, 1926, Trans. Ent. Soc. London, 74: 272.

" ${ }^{*}$. I $3 \mathrm{~mm}$. .... o i I $5^{-1} 8 \mathrm{~mm}$. ... At 800 feet, 3 ex. The form of the uncus is unique, the broadest part (or base of the triangle) being at the apex. The $q$ is taken as the type, since it is possible that the single ot may belong to the preceding species;..."

Type: The female so marked in the British Museum, "Rapa Island. At light, Soo ft., I 5.4.25. C. L. Collenette." Slide No. 7005.

Figure 4 , right wings (image reversed); $4^{\mathrm{a}}$, ventral view of female genitalia; $4^{\mathrm{b}}$, detail of ostium. 
DICHELOPA

\section{Dichelopa dryomorpha Meyrick}

Plate 50, Figures I-Ia

Dichelopa dryomorpha Meyrick, I928, Exotic Microlepidoptera, 76: 492.

"s. IO-I I mm., ㅇ. I4 mm. ... Marquesas, Tahuata, January, beaten from herbage; i 6 ex."

Type: The male so marked in the British Museum, "Tahuata, Marquesas. Beaten from herbage. i i.r.25. C. L. Collenette." Slide No. 6967.

Figure I, left wings; Ia, ventral view of male genitalia with aedeagus in sitn.

\section{Dichelopa exulcerata Meyrick}

Plate 5o, Figures 2-2b

Dichelopa exulcerata Meyrick, 1926, Trans. Ent. Soc. London, 74: 273.

"o. 26-30 mm. ... At 800 feet; 2 ex."

Type: 'The male so marked in the British Museum, "Rapa Island. At light. $800 \mathrm{ft}$. 17.4.25. C. L. Collenette." Slide No. 7004.

Figure 2, left wings; 2a, lateral aspect of aedeagus; 2b, ventral view of male genitalia with aedeagus removed.

\section{Dichelopa fulvistrigata Meyrick}

Plate 50, Figures $3^{-} 3^{b}$

Dichelopa fulzisirigata Meyrick, I928, Trans. Ent. Soc. London, 76: 494.

" ${ }^{\circ}$. ${ }^{1} 3^{-1} 4 \mathrm{~mm}$. . . . Society Is., Tahiti, I, 500 feet, at light, March; 2 ex."

Type: The male so marked in the British Museum, "Fautaua, 'Tahiti, at light, I,5co ft., I6.3.25. C. L. Collenette." Slide No. 6972.

Figure 3 , left wings; 3 a, lateral aspect of aedeagus; 3 b, ventral view of male genitalia with aedeagus removed.

\section{Dichelopa harmodes Meyrick}

Plate 5o, Figures $4-4 \mathrm{~b}$

Dichelopa harmodes Meyrick, 1928, Trans. Ent. Soc. London, 76: 494.

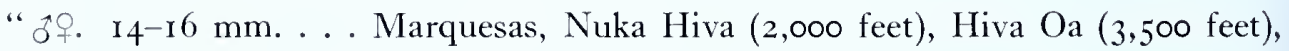
Fatu Hiva (2,000 feet), January, at light ; 4 ex."

Type: The male so labelled in the British Museum, "Fatu Hiva, Marquesas, at light, 2,000 ft., 31.r.25. C. L. Collenette." Slide No. 697r.

Figure 4 , left wings; 4 a, lateral aspect of aedeagus; 4 b, ventral view of male genitalia with aedeagus removed. 

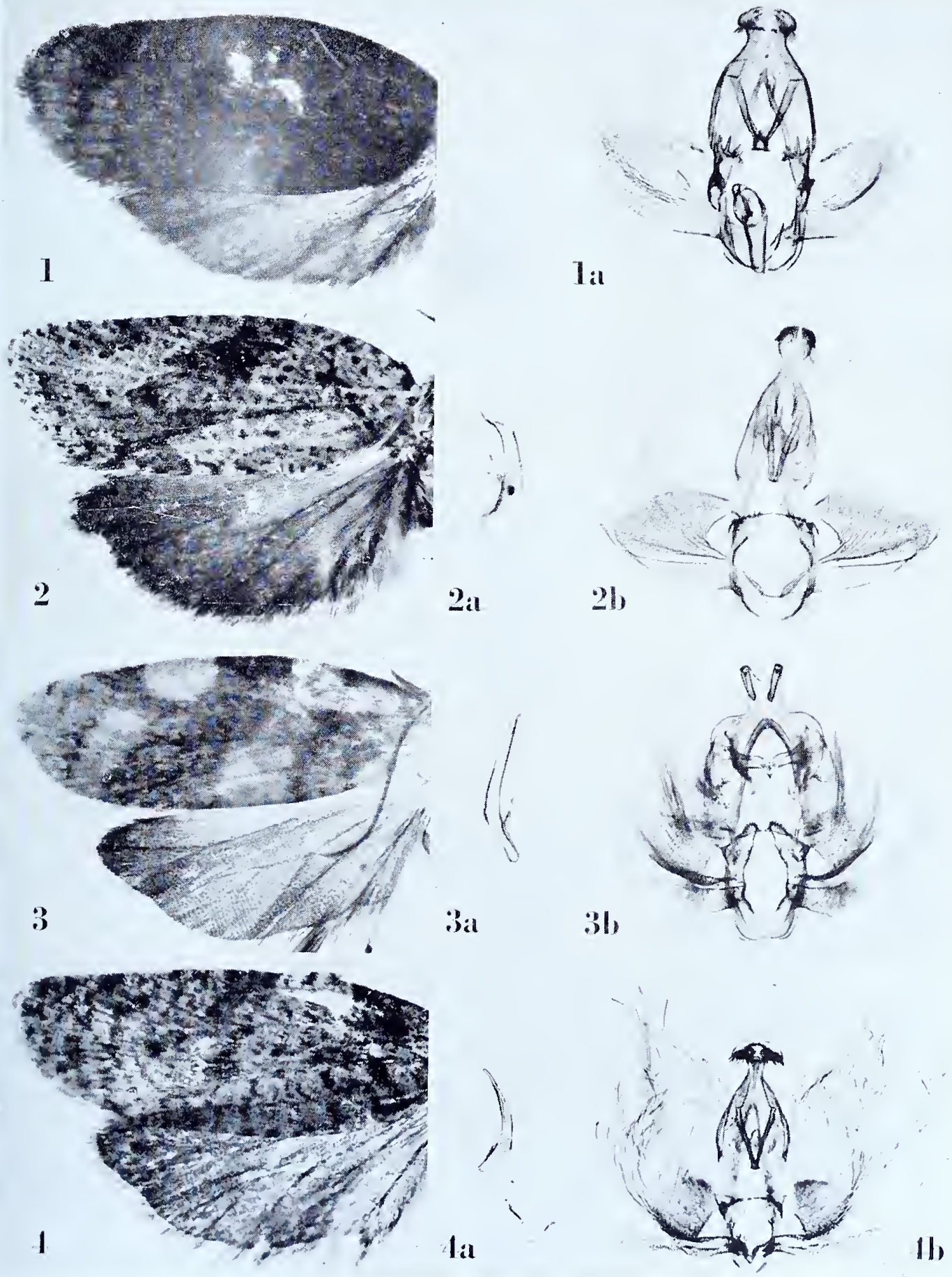

316

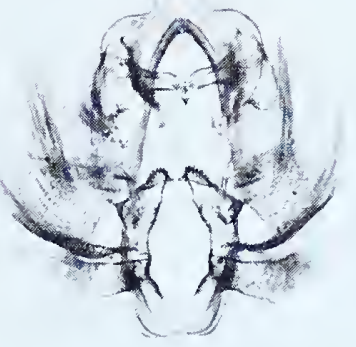



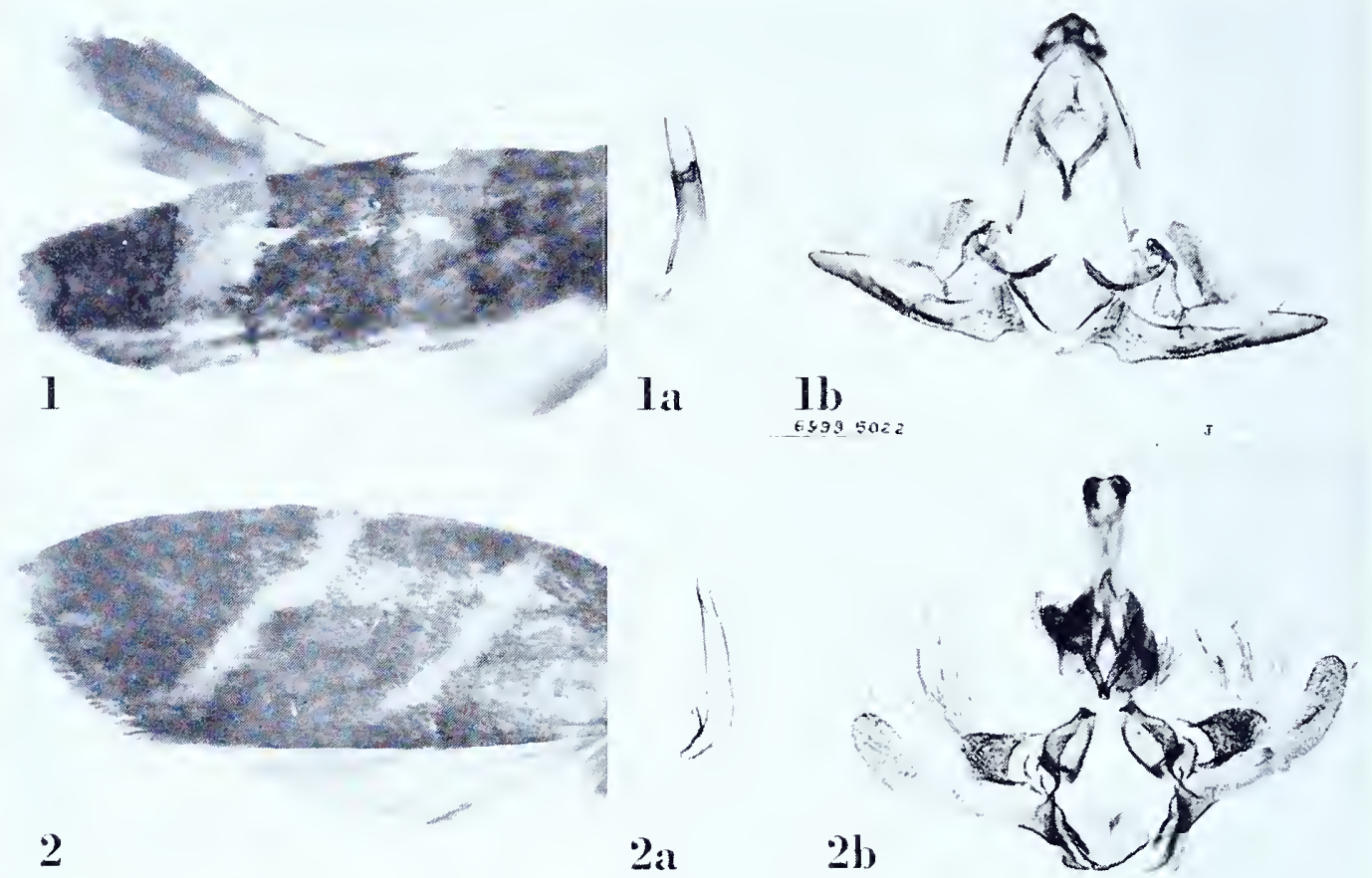

2
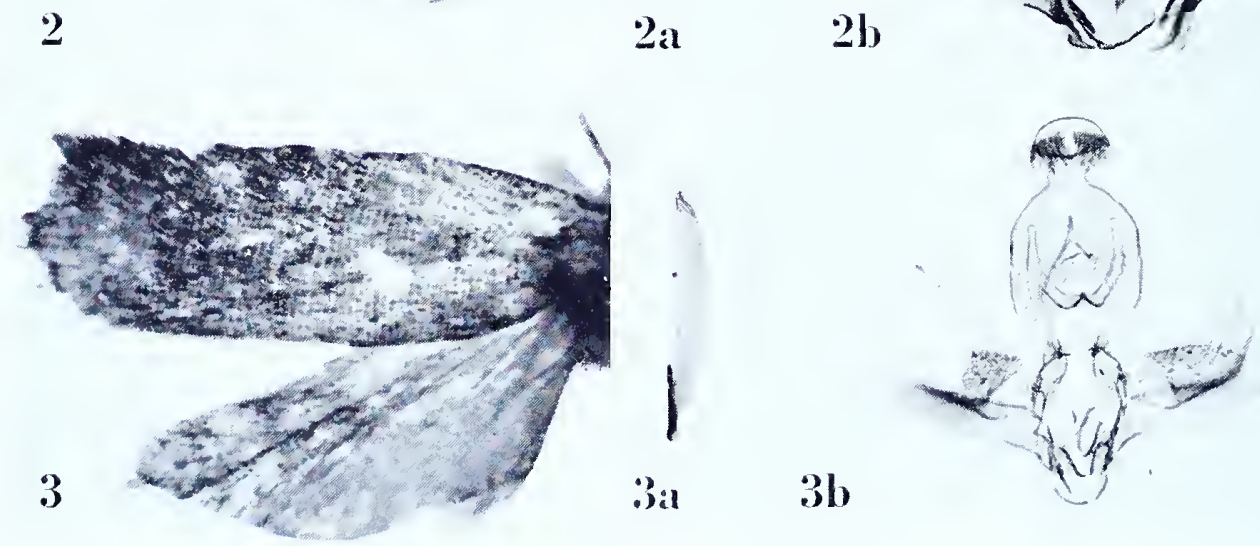

DICHELOPA 


\section{Dichelopa honoranda Meyrick}

Plate 5I, Figures I-I b

Dichelopa honoranda Meyrick, I926, Trans. Ent. Soc. London, 74: 272.

“o. $12 \mathrm{~mm}$. . . . At 800 feet; i ex."

Type: The specimen referred to above in the British Museum, "Rapa Island. At light, 800 ft., 17.4.25. C. L. Collenette." Slide No. 6999.

Figure I, left wings; ra, lateral view of aedeagus; $\mathrm{r} b$, ventral view of male genitalia with aedeagus removed.

\section{Dichelopa iochorda Meyrick}

Plate 5 I, Figures 2-2b

Dichelopa iochorda Meyrick, 1926, 'Trans. Ent. Soc. London, 74: 273.

"ふ. I $7 \mathrm{~mm}$.... At 800 feet; i ex."

Type: The above indicated specimen marked "type" in the British Museum, "Rapa Island. At light, 800 ft., I7.4.25. C. L. Collenette." Slide No. 7003.

Figure 2, left wings; $2 \mathrm{a}$, lateral aspect of aedeagus; $2 \mathrm{~b}$, ventral view of male genitalia with aedeagus removed.

\section{Dichelopa pachydmeta Meyrick}

Plate 5 I, Figures $3^{-3} \mathrm{~b}$

Dichclopa pachydmeta Meyrick, I928, Trans. Ent. Soc. London, 76: 493.

“ 3 우. IO-I I mm. . . . Marquesas, Hiva Oa, 3,500-4,000 feet, January, 우 at light, ot beaten from herbage; 2 ex."

Type: The specimen labelled "... beaten from herbage, 4,000 ft., 3I.I2.24." Both specimens are males, the second example without abdomen and lacking left forewing. Slide No. 6970.

Figure 3 , left wings; 3 a, ventral aspect of aedeagus; 3 b, ventral view of male genitalia with aedeagus removed. 


\section{Dichelopa peropaca Meyrick}

Plate 52, Figures $1-\mathbf{r}$

Dichelopa peropaca Meyrick, 1928, Trans. Ent. Soc. London, 76: 493.

" $3.22 \mathrm{~mm}$. . . Marquesas, Fatu Hiva, 2,000 feet, January, at light; i ex."

Type: The above indicated specimen so marked in the British Museum, dated "31.1.25". Slide No. 6968.

Figure I, left wings; ra, lateral aspect of aedeagus; r b, ventral view of male genitalia with aedeagus removed.

\section{Dichelopa praestrigata Meyrick}

Plate 52, Figures 2-2b

Dichelopa praestrigata Meyrick, I928, Trans. Ent. Soc. London, 76: 492.

" o. $^{1} 3^{-1} 5 \mathrm{~mm}$. ... ‥ 15-19 mm. . . Marquesas, Hiva Oa, 3,500-4,000 feet, January, mostly at light; 3 ex. Varies considerably."

Type: The male so marked in the British Museum, "Hiva Oa, Marquesas, at light, 3,500 ft., 28.1.25. C. L. Collenette." Slide No. 6966.

Figure 2, left wings; $2 \mathrm{a}$, lateral aspect of aedeagus; $2 \mathrm{~b}$, ventral view of male genitalia with aedeagus removed.

\section{Dichelopa sericopis Meyrick}

Plate 52 , Figures $3^{-} 3^{\mathrm{b}}$

Dichelopa sericopis Meyrick, 1926, Trans. Ent. Soc. London, 74: 272.

"․ I $3^{-1} 6 \mathrm{~mm}$. . . . At low level and 800 feet; i 2 ex. . .."

Type: The female labelled type in the British Museum, "Rapa Island. At light, I 1.4.25. C. L. Collenette." Slide No. 7000.

Figure 3 , left wings; $3 \mathrm{a}$, lateral view of female genitalia; $3 \mathrm{~b}$, lateral view to show detail of ostium and genital plate. 

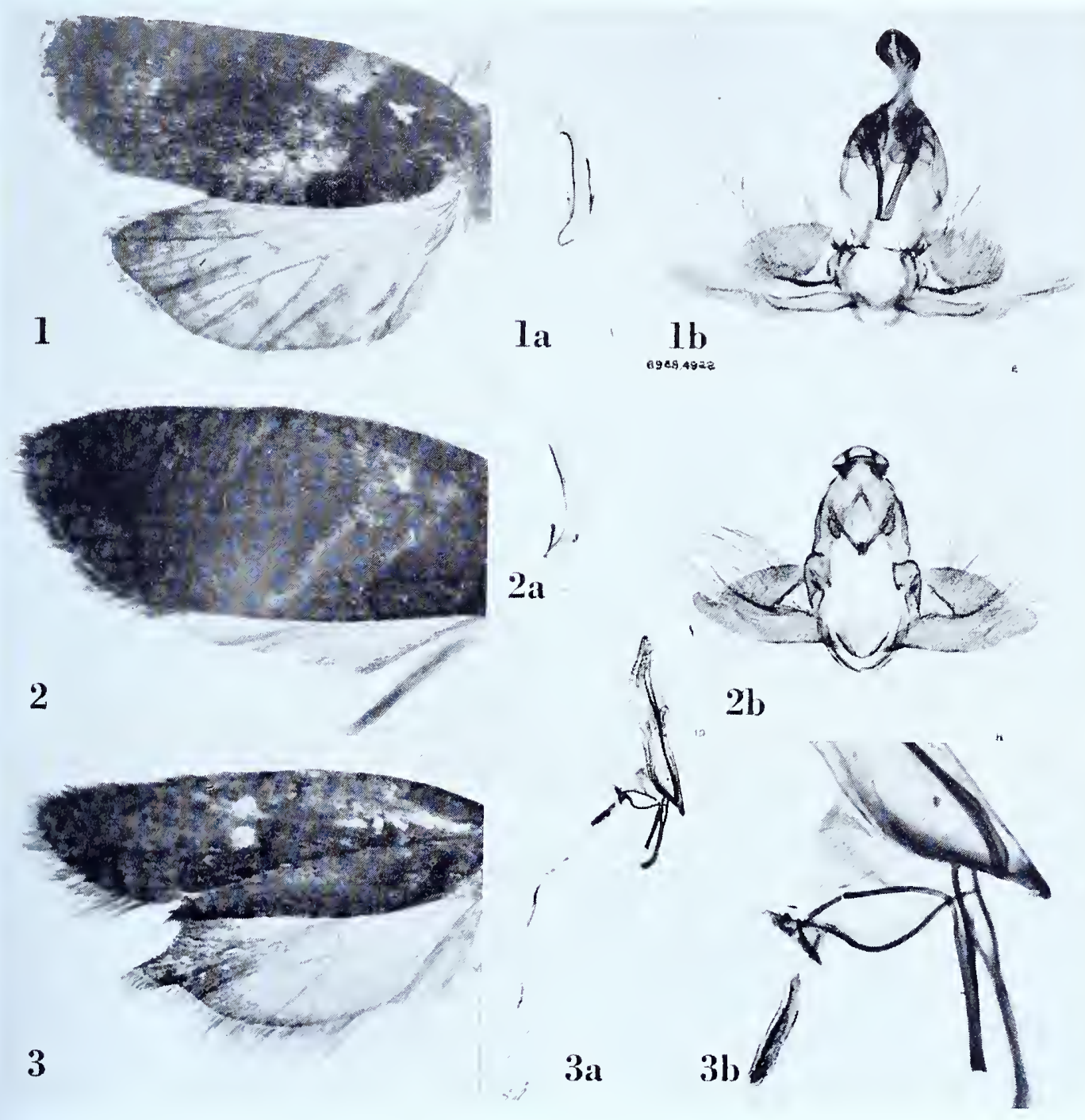

3

DICHELOPA 


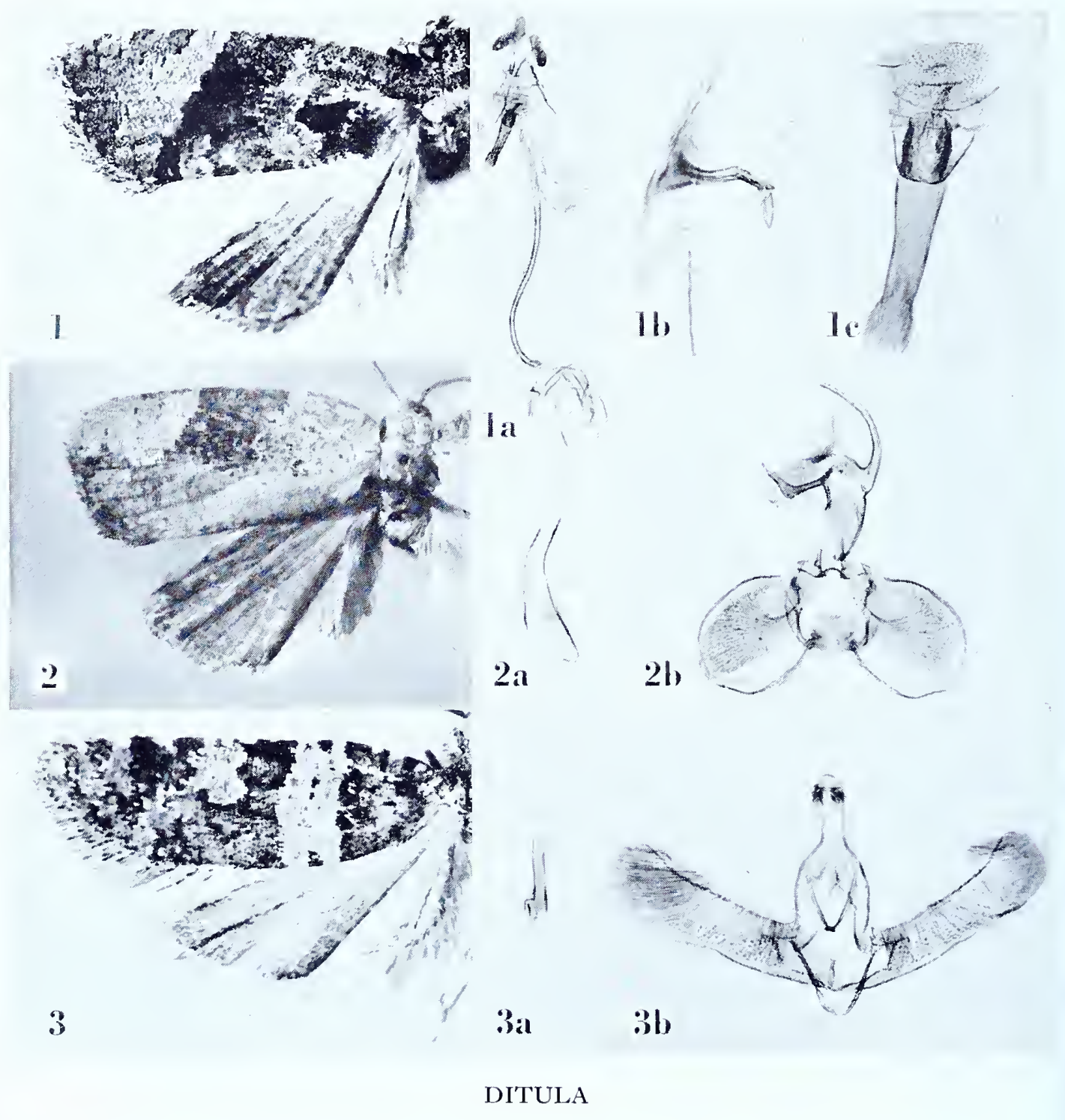




\section{DITULA Stephens}

\section{Ditula encratopis (Meyrick), new combination}

Plate 53, Figures I-Ic

Batodes encratopis Meyrick, I920, Exotic Microlepidoptera, 2: 322.

"ㅇ. $16 \mathrm{~mm}$. . . Q Queensland, Brisbane, February (Dodd); one specimen. Type in Wals. Coll. (19315)."

Type: The female so marked in the British Museum, "Toowong, Queensland. I6.ii. I 897. Dodd. I93 I5." Slide No. 9328.

Figure I, left wings; Ia, ventral view of female genitalia; rb, signum; Ic, detail of ostium and genital plate and the narrow, long, sclerotised "blind sac" anterior to ostium.

\section{Ditula euryplaca (Meyrick), new combination}

Plate 53, Figures $2-2 \mathrm{~b}$

Batodes euryplaca Meyrick, I933, Exotic Microlepidoptera, 4:422.

“ స. I 8-i 9 mm. ... Madagascar, Antananarivo; i ex., also one in Vienna Museum."

Type: The male in the Meyrick collection "Antananarivo, Madagascar. LeM. . 5 ". Slide No. $933^{6}$.

Figure 2, left wings; $2 \mathrm{a}$, lateral aspect of aedeagus; $2 \mathrm{~b}$, ventral view of male genitalia with aedeagus removed.

\section{Ditula portuosa (Meyrick), new combination}

Platc 53, Figures $3-3 b$

Batodes portuosa Meyrick, I922, Exotic Microlepidoptera, 2: 495.

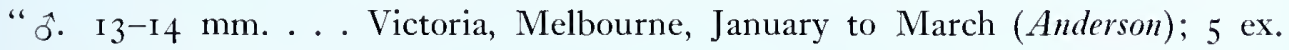
(Wals. Coll., type 2 г 726 )."

Type: The male so marked in the British Museum, dated "ז.iii. 890 ". Slide No. 9329 .

Figure 3 , left wings; 3 a, lateral aspect of aedeagus; $3 \mathrm{~b}$, ventral view of male genitalia with aedeagus removed. 


\section{DRACHMOBOLA Meyrick}

Drachmobola Meyrick, 1907, journ. Bombay Nat. Hist. Soc., 17: 978. (Typus generis: Draclimobola periastra Meyrick, ibid. [monotypy].)

\section{Drachmobola periastra Meyrick}

Plate 54, Figures I-Id

Drachmobola periastra Meyrick, I907, Journ. Bombay Nat. Hist. Soc., 17: 978 .

“우. $12-13 \mathrm{~mm}$. . . . Fifteen specimens, Khasi Hills, in June."

Lectotype: A male measuring $12 \mathrm{~mm}$. Slide No. 6859. The nine remaining specimens in the Meyrick collection bear identical data and are dated ".6.1906".

Figure I, left wings; Ia, venation of right wings; $\mathrm{s} b$, lateral aspect of head to show palpus; Ic, aedeagus; Id, ventral view of male genitalia with aedeagus removed. 

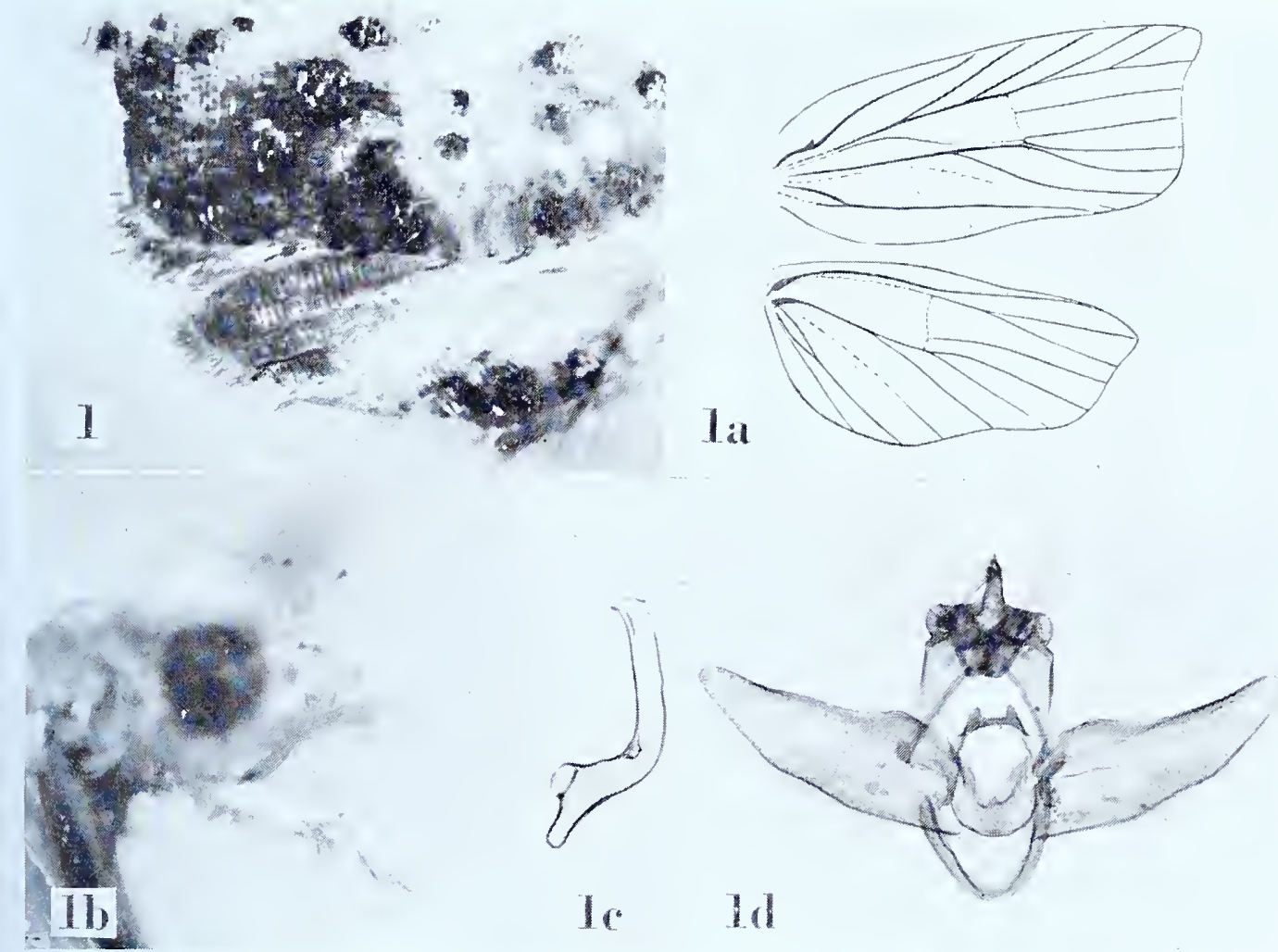

DRACHMOBOLA 

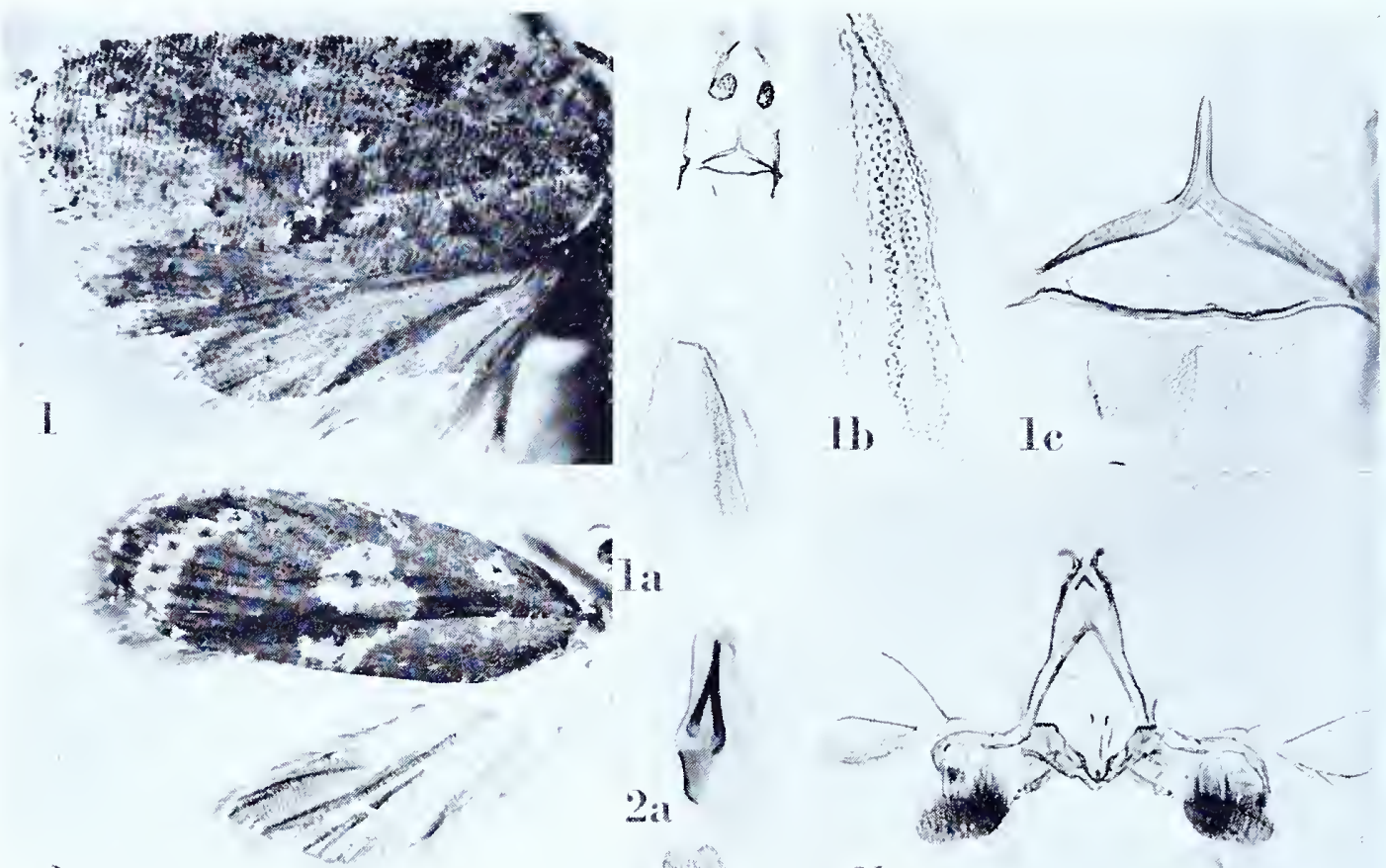

2

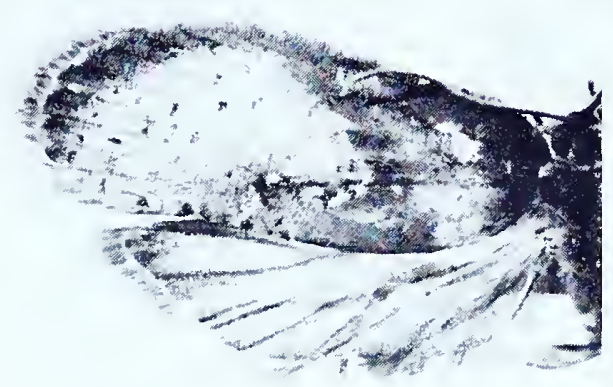

;
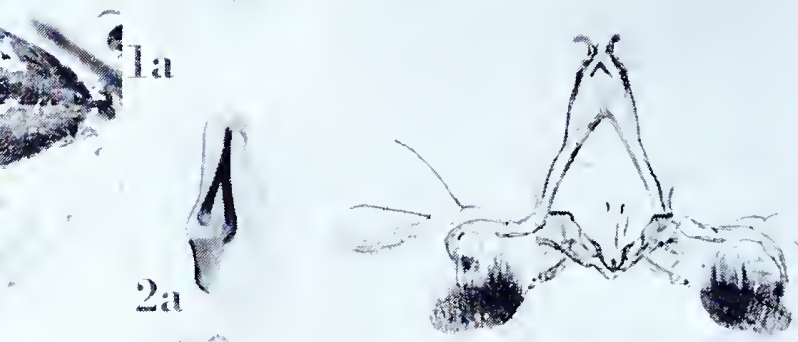

2b
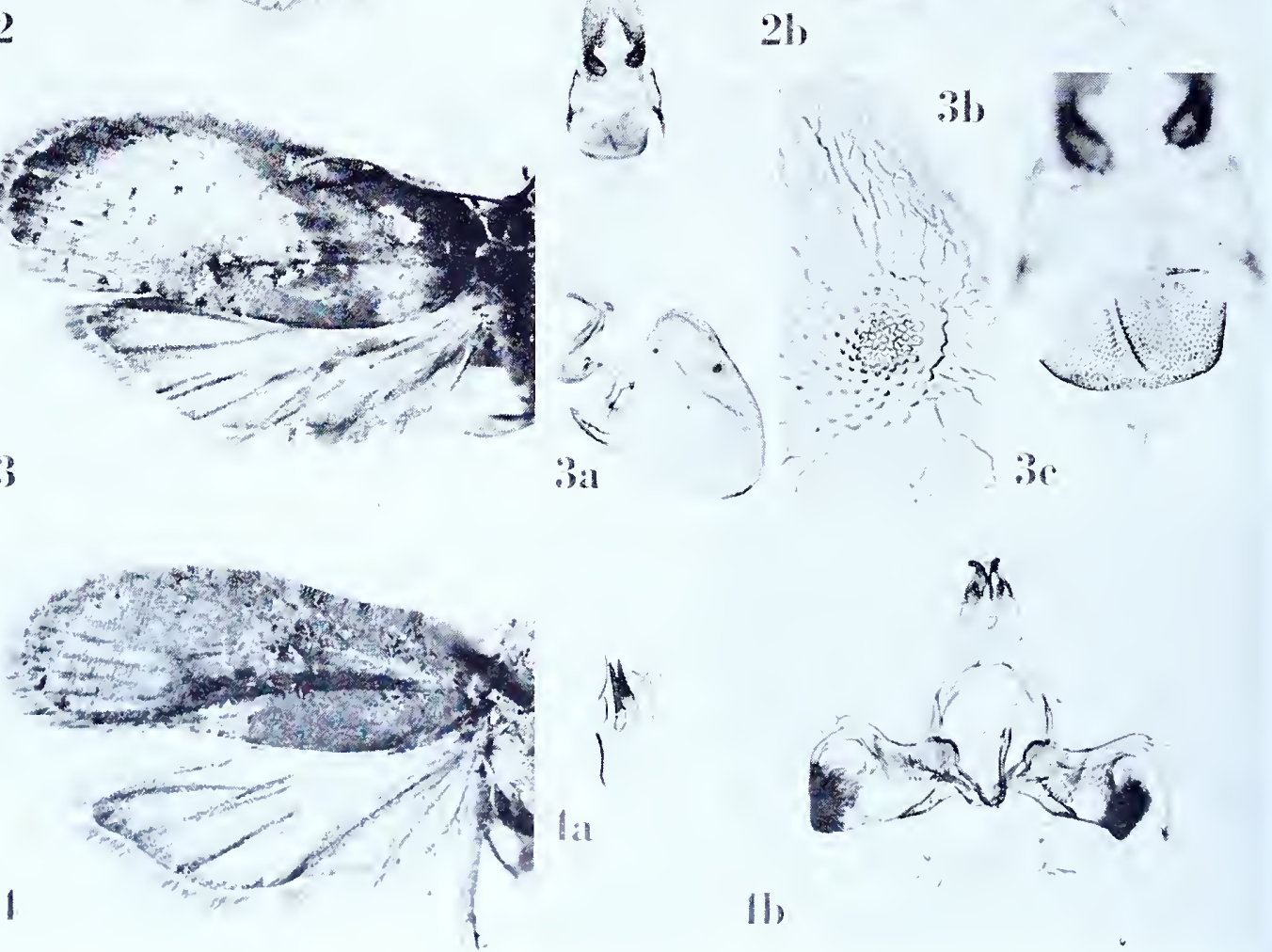

EBODA 


\section{EBODA Walker}

\section{Eboda amblopis Meyrick}

Plate 55, Figures I-IC

Eboda amblopis Meyrick, I911, Trans. Linnean Soc. London, I4:267.

"q. $13 \mathrm{~mm}$. . . Aldabra; one specimen."

Type: The female so marked in the British Museum, "Seychelles, Aldabra. I908. J. C. F. Fryer." Slide No. 9423 .

Figure I, left wings; ıa, ventral view of female genitalia; $\mathbf{b}$, signum; ıc, detail of genital plate and ostium.

\section{Eboda celligera Meyrick}

Plate 55, Figures 2-2b; $3-3 \mathrm{c}$

Eboda celligera Meyrick, I9ı, Exotic Microlepidoptera, 2: 170.

Paratorna glaucoprosopis Meyrick, I93 I, Exotic Microlepidoptera, 4: I55.

[celligera]

" đ. I 3 mm. . . Bengal, Pusa, March (Fletcher); one specimen."

Type: The above indicated male, "Pusa, Bengal. 'TBF. г8.3.ı." Slide No.6891.

Figure 2, left wings; $2 \mathrm{a}$, aedeagus; $2 \mathrm{~b}$, ventral view of male genitalia with aedeagus removed.

\section{[glaucoprosopis]}

"ㅇ. $15 \mathrm{~mm}$. ... Formosa, Kagi, March (S. Issiki); I ex. Differs from the type and resembles Eboda in the modification of vein 4 in both wings, but is nevertheless a true Paratorna."

Type: The female indicated above dated " 8.3 .28 ". Slide No. 6892.

Figure 3 , left wings; $3 \mathrm{a}$, ventral view of female genitalia; $3 \mathrm{~b}$, signum; $3 \mathrm{c}$, detail of genital plate and ostium.

\section{Eboda facilis Meyrick}

Plate 55, Figures 4-4b

Eboda facilis Meyrick, I9г 2, Exotic Microlepidoptera, I: I5.

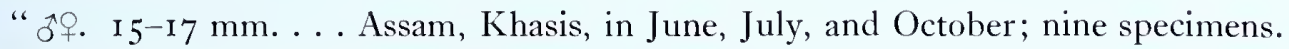
Very similar in colouring to haruspex, but easily distinguished by different form of apex and termen of forewings."

Lectotype: A male measuring 5 mm., "Khasi Hills. .6.1906." Slide No. 6878.

Figure 4 , left wings; 4 a, aedeagus; 4 b, ventral view of male genitalia with aedeagus removed. 


\section{Eboda haruspex Meyrick}

Plate 56 , Figures $1-\mathrm{Ib}$

Eboda haruspex Meyrick, I912, Exotic Microlepidoptera, I: I5.

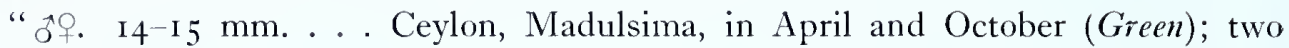
specimens."

Lectotype: The male dated “.4.07”. Slide No. 6877 .

Figure I, left wings; $ı$, lateral aspect of aedeagus; $\mathrm{rb}$, ventral view of male genitalia with aedeagus removed.

\section{Eboda obstinata Meyrick}

Plate 56 , Figures 2-2b

Eboda obstinata Meyrick, I908, Journ. Bombay Nat. Hist. Soc., I8: 624.

"․ I $3^{-14}$ mm. . . Puttalam, Ceylon, in November (Pole); two specimens."

Lectotype: The female, without abdomen, measuring $\mathrm{I} 3 \mathrm{~mm}$. 'The second specimen is missing. Genitalia figured from a male, "Pusa, Bengal. TBF. 20.8.07." Slide No. 6893 .

Figure 2, left wings; $2 \mathrm{a}$, lateral aspect of aedeagus; $2 \mathrm{~b}$, ventral view of male genitalia with aedeagus removed.

\section{EPICHORISTA Meyrick}

\section{Epichorista ingenua Meyrick}

Plate 56, Figures $3^{-3} \mathrm{c}$

Epichorista ingenua Meyrick, I912, Exotic Microlepidoptera, I: 9.

"․ I4 mm. . . Sikkim, Kangra Valley, at 4,500 feet, in July (Dudgeon); one specimen."

Type: 'The above indicated female dated “.7.99”. Slide No. 6852 .

Figure 3 , left wings; $3 \mathrm{a}$, ventral view of female genitalia; $3 \mathrm{~b}$, signum; $3 \mathrm{c}$, detail of genital plate and ostium. 

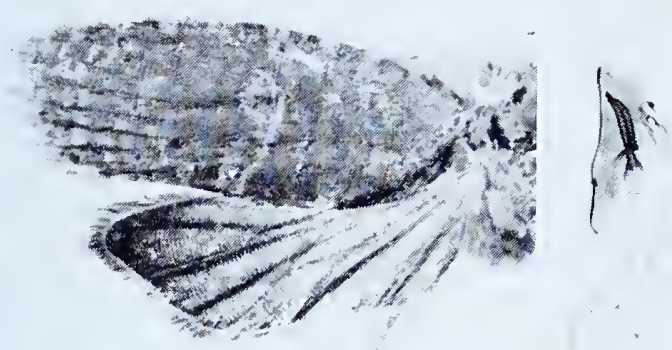

1

la

$11)$
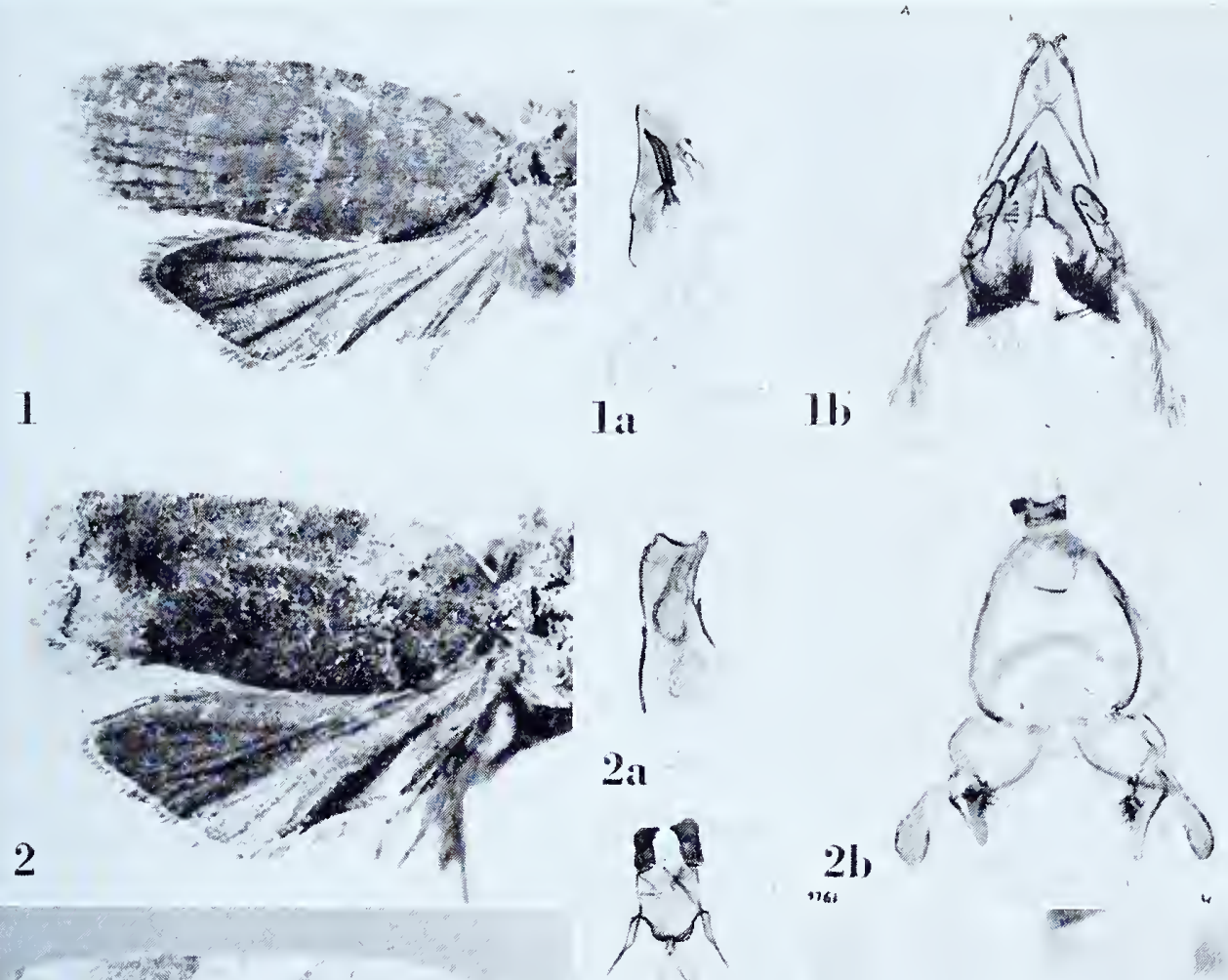

3
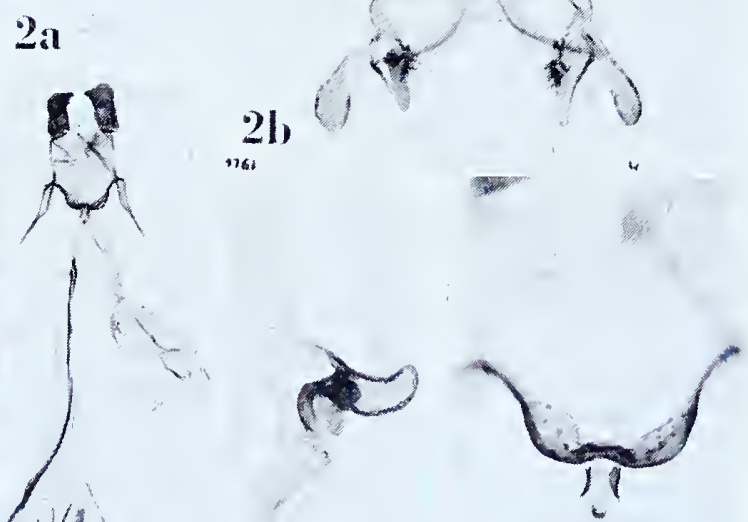

31,30

EBODA and EPICHORIS'TA 


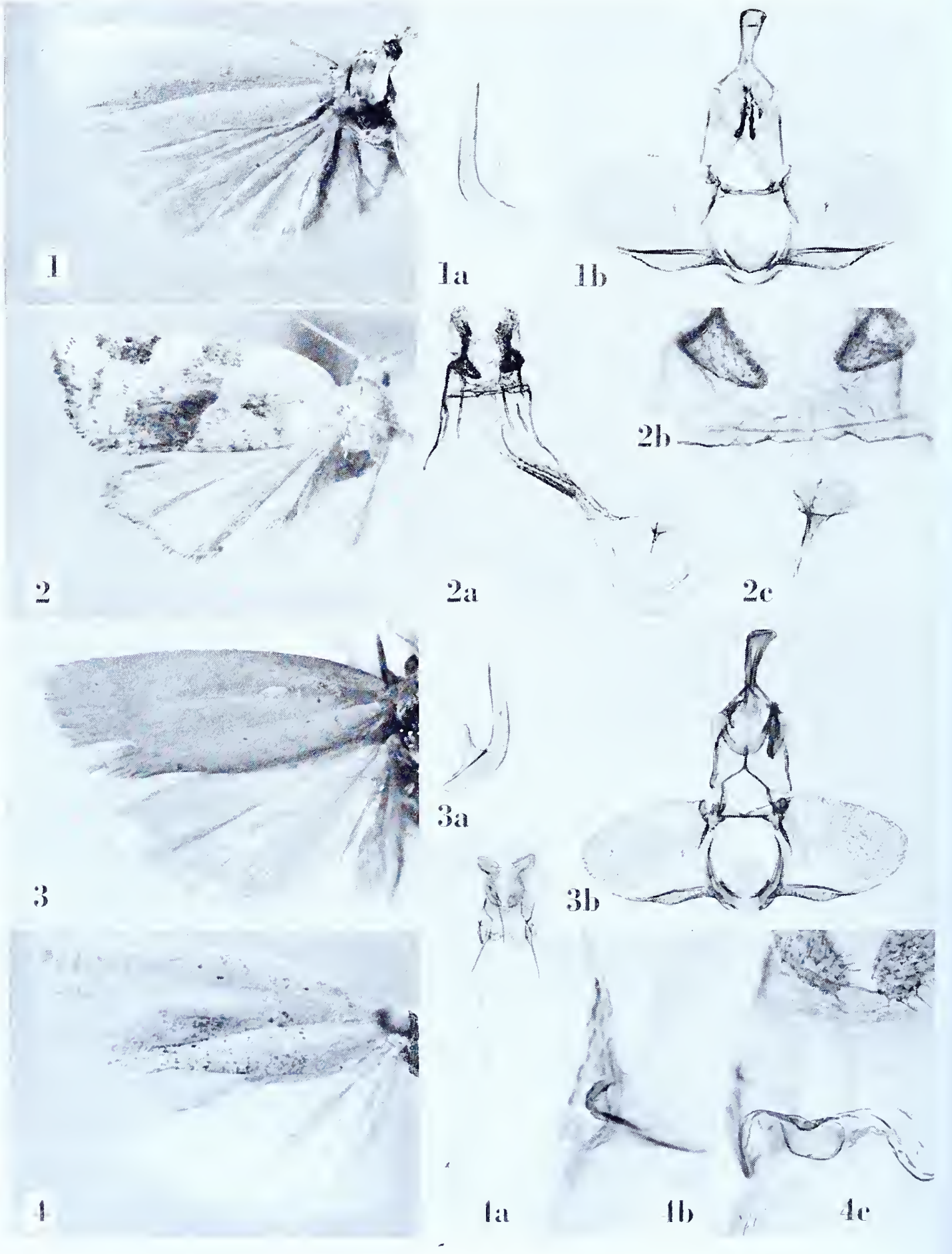




\section{Epichorista iocoma (Meyrick)}

Plate 57 , Figures I-Ib

Tortrix iocoma Meyrick, i 9o8, Proc. Zool. Soc. London, 723 .

" o. I 8-22 mm. . . Transvaal, N.E. Pretoria district, in December and January (Ganse); four specimens."

Lectotype: ô, I 8 mm., dated “.12.12.06”. Slide No. 9379.

Figure I, left wings; ra, lateral aspect of aedeagus; Ib, ventral view of male genitalia with aedeagus removed.

\section{Epichorista perversa Meyrick}

Plate 57 , Figures 2-2c

Epichorista perzersa Meyrick, I9I2, Exotic Microlepidoptera, I: 9.

“우 I $^{-1} 7 \mathrm{~mm}$. . . . Natal, Pinetown and Camperdown, from January to March (Leigh); three specimens."

Lectotype: + , I 5 mm., "Camperdown, Natal. L. .3.o8." Slide No. 9382.

Figure 2, left wings; $2 \mathrm{a}$, ventral view of female genitalia; $2 \mathrm{~b}$, detail of genital plate and ostium; $2 \mathrm{c}$, signum.

\section{Epichorista phaeocoma Meyrick \\ Plate 57 , Figures $3-3 \mathrm{~b}$}

Epichorista phaeocoma Meyrick, I914, Exotic Microlepidoptera, I : I95.

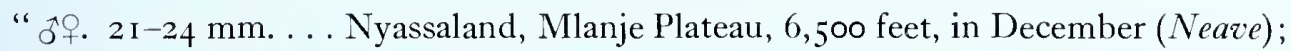
six specimens. Type in British Museum."

Type: The male so marked in the British Museum, dated "I 8.xii.r9I3". A small white label bears the inscription "M82". A third label, white, in Meyrick's hand reads "Efichorista phaeocoma Meyr. type". Slide No. 9365.

Figure 3 , left wings; 3 a, lateral aspect of aedeagus; 3 b, ventral view of male genitalia with aedeagus removed.

\section{Epichorista sicca Meyrick}

Plate 57, Figures $4-4 \mathrm{c}$

Epichorista sicca Meyrick, i 9 I 2, Exotic Microlepidoptera, I : 9 .

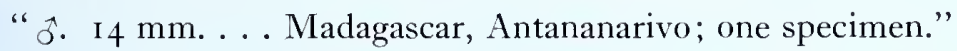

Type: The specimen referred to above, erroneously recorded as a male, "Antananarivo, Madagascar. R. . I I." Slide No. $93^{8}$ I.

Figure 4 , left wings; $4 \mathrm{a}$, ventral view of female genitalia; $4 \mathrm{~b}$, signum; $4 \mathrm{c}$, detail of genital plate and ostium. 
EULIA

\section{EULIA Hübner \\ Eulia achyritis Meyrick \\ Plate 58, Figures I-Ib}

Enlia achyritis Meyrick, 1926, Exotic Microlepidoptera, 3: 257.

"q. $22 \mathrm{~mm}$. . . Colombia, Mt. Tolima, ${ }_{3}, 850$ feet; i ex."

Type: The above indicated female with a ".20" in the lower right corner of the pin-label. Slide No. 6350.

Figure I, left wings; Ia, ventral view of female genitalia; rb, detail of genital plate and ostium.

\section{Eulia aenigmatica (Meyrick)}

Plate 58 , Figures 2-2b

Chephasia aenigmatica Meyrick, ig12, 'Trans. Ent. Soc. London, I9I I: 682.

" o. $19 \mathrm{~mm}$. . . Colombia, San Antonio, 5,800 feet, in November; one specimen."

Type: 'The specimen indicated above dated “.I I.07”. Slide No. 6303.

Figure 2, left wings; 2a, lateral aspect of aedeagus; 2 b, ventral view of male genitalia with aedeagus removed.

\section{Eulia aeolozona Meyrick \\ Plate 58 , Figure 3}

Eulia aeolozona Meyrick, 1926, Exotic Microlepidoptera, 3: 252.

" 0 . 20 mm. . . Colombia, Mt. Tolima, I 2,500 feet, December; I ex."

Type: The specimen indicated above and dated ".I2.20". The abdomen of the type is missing.

Figure 3 , left wings.

\section{Eulia agatharcha Meyrick}

Plate 58 , Figure 4

Enlia agatharcha Meyrick, 1926, Exotic Microlepidoptera, 3: 253.

"ㅇ. $38 \mathrm{~mm}$. . . Colombia, C. Cordilleras, 12,500 feet, November; i ex."

Type: The above indicated female dated ".I I.20". The type is without abdomen.

Figure 4, left wings.

\section{Eulia arachnogramma Meyrick}

Plate 58 , Figures $5^{-5} \mathrm{~b}$

Enlia arachnogramma Meyrick, 1926, Exotic Microlepidoptera, 3:252.

"s. $30 \mathrm{~mm}$.... Colombia, Mt. Socorro (I 2,500 feet), Mt. Tolima (I 0,500 feet); 2 ex."

Lectotype: The male labelled “Mt. Socorro, Colombia, I2,500' .7.20”. Slide No. 6305. The Mt. Tolima specimen is missing.

Figure 5 , left wings; 5 a, lateral aspect of aedeagus; 5 b, ventral view of male genitalia with aedeagus removed. 

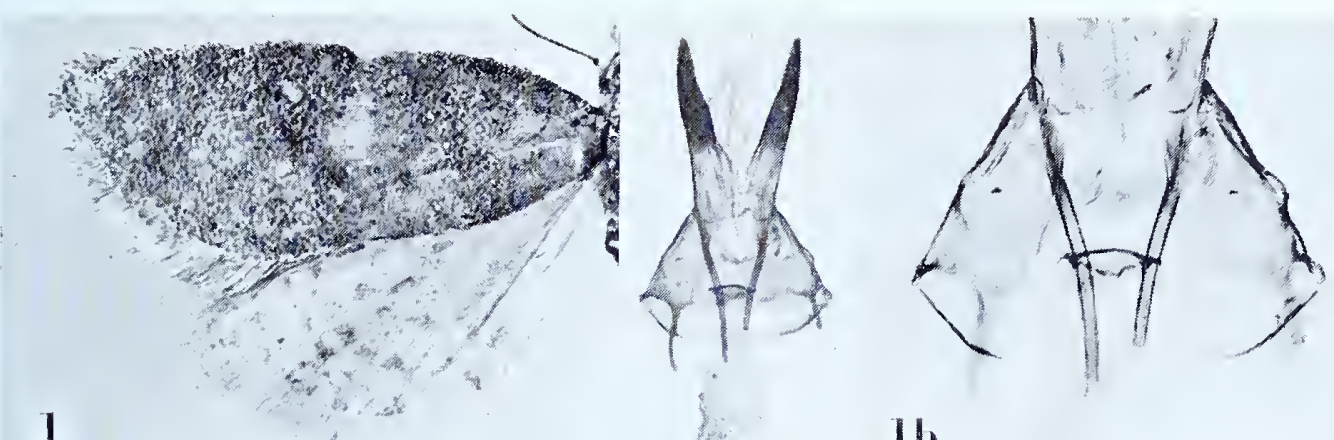

1

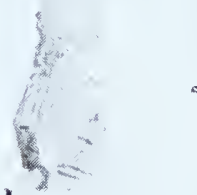

If

H.

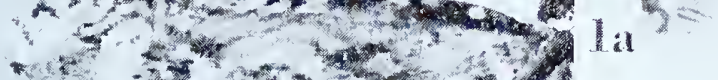

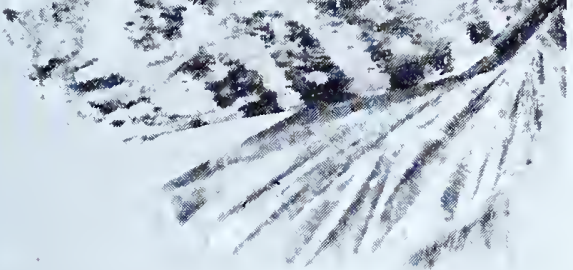

2

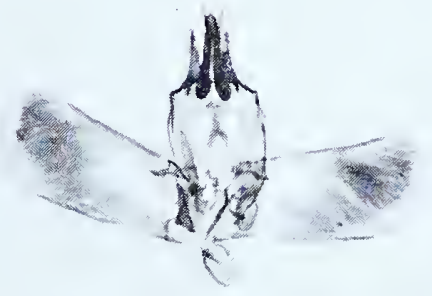

21

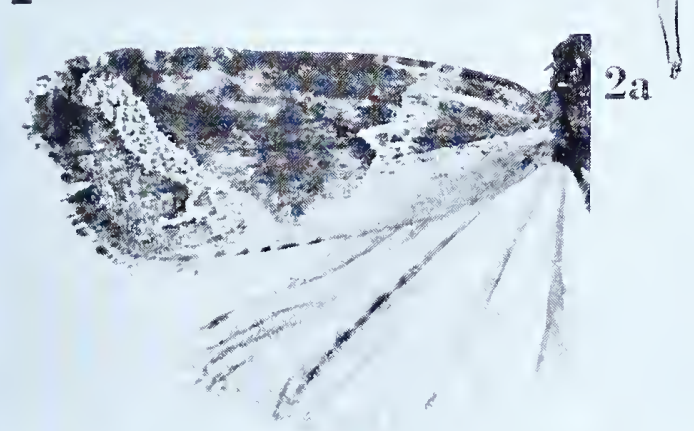

3

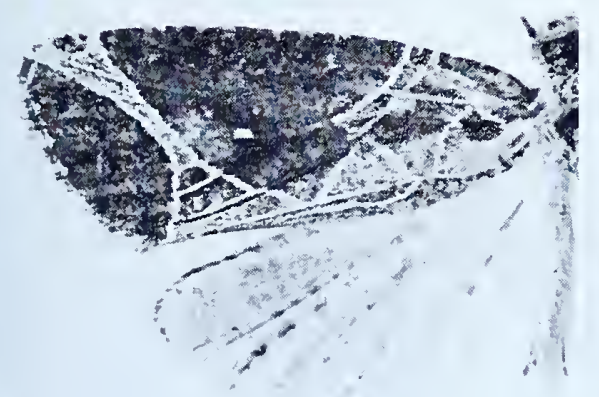

5

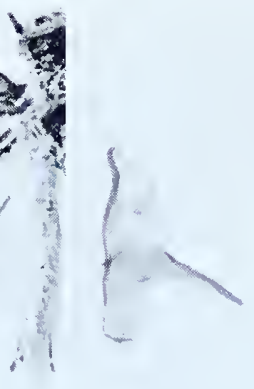

5

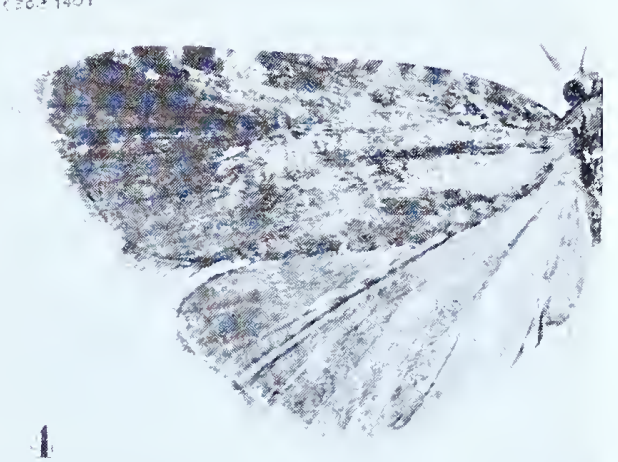

1

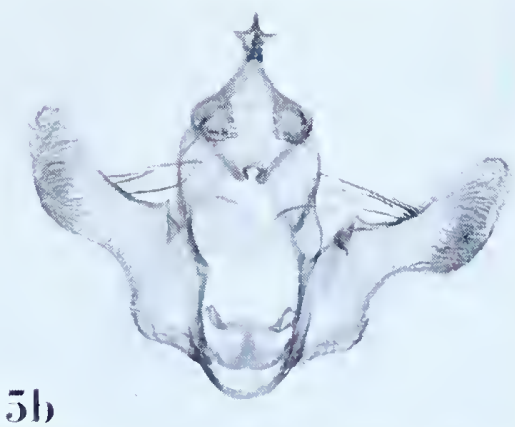

EULIA 

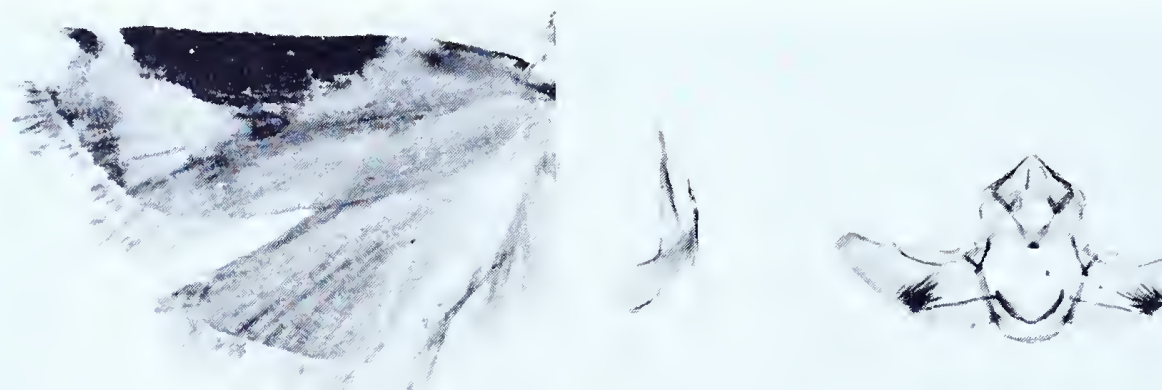

1

la

11.
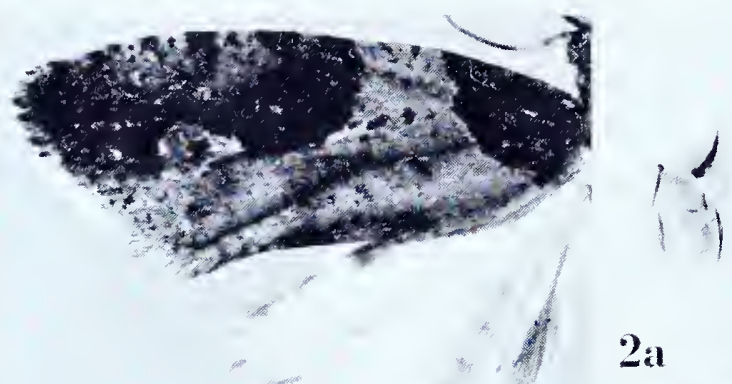

2

2a
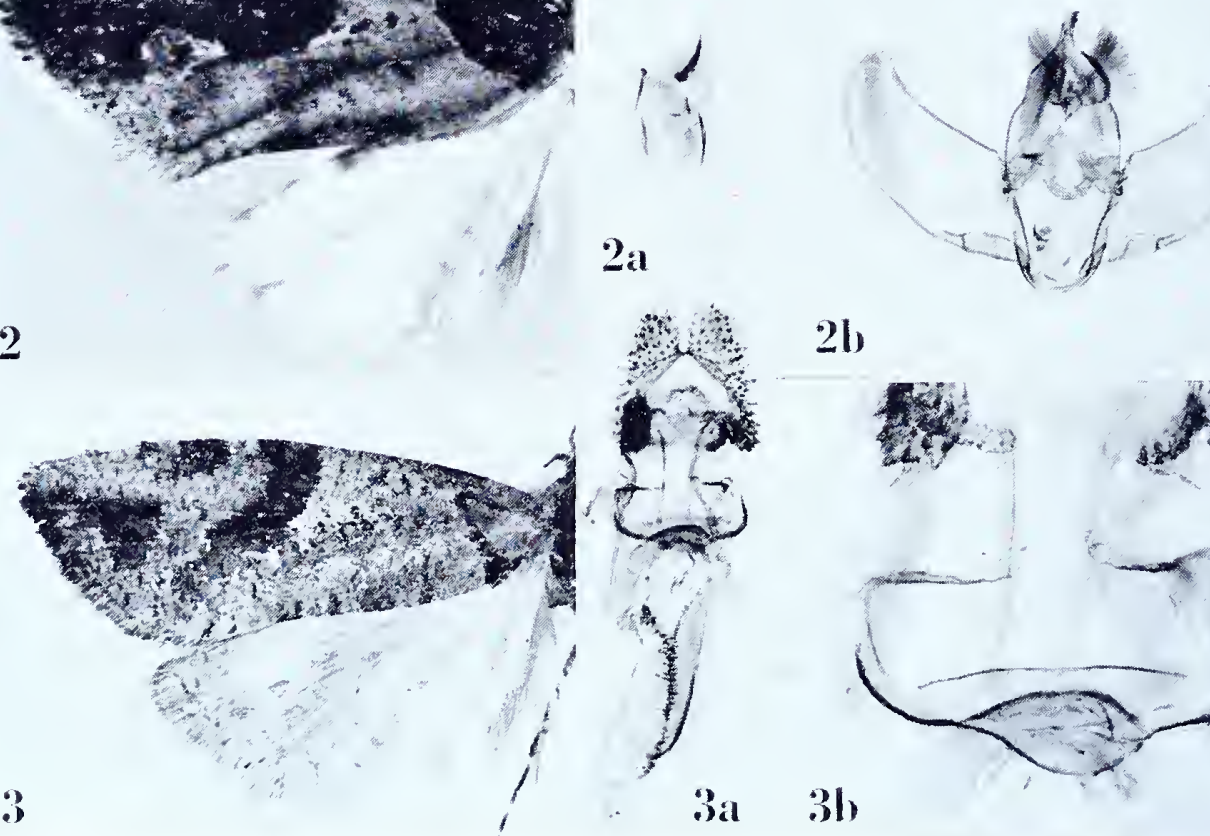

14. 2 b

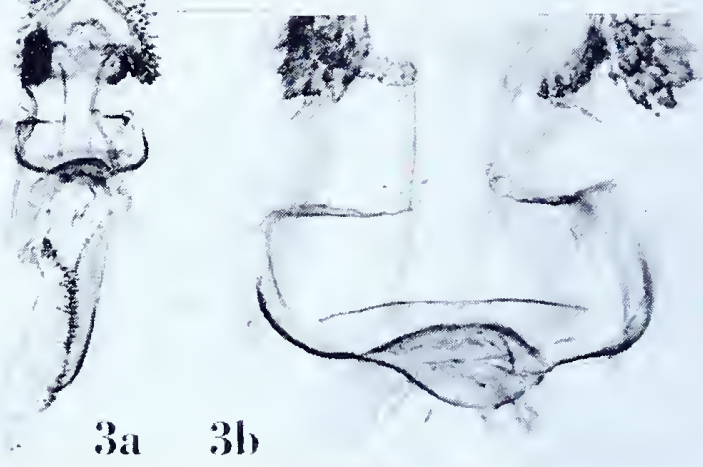

EULIA 


\section{Eulia atalodes Meyrick}

Plate 59, Figures I-Ib

Eulia atalodes Meyrick, 1917, Trans. Ent. Soc. London, 1917:9.

" ${ }^{\circ} .14 \mathrm{~mm}$. . . Colombia, San Antonio, 5,80o feet, in November; one specimen."

Type: The above indicated specimen dated “.I I.०7”. Slide No. 6324.

Figure $\mathbf{~}$, left wings; $\mathbf{a}$, lateral aspect of aedeagus; $\mathbf{r b}$, ventral view of male genitalia with aedeagus removed.

\section{Eulia auxoplaca Meyrick}

Plate 59, Figures 2-2b

Eulia auxoplaca Meyrick, 1926, Exotic Microlepidoptera, 3: 255.

“ ”. 23-25 mm. . . Colombia, Mt. Tolima ( 1 0,500 feet), Mt. Socorro (I 2,500 feet), Monte del Eden (9,50o feet); 7 ex. Varies considerably."

Lectotype: A male, “Mt. 'Tolima, Colombia, 10,500' . 10.20." Slide No.6328. Four specimens are missing.

Figure 2 , left wings; $2 \mathrm{a}$, lateral aspect of aedeagus; $2 \mathrm{~b}$, ventral view of male genitalia with aedeagus removed.

\section{Eulia biremis Meyrick}

Plate 59, Figures $3-3 \mathrm{~b}$

Eulia biremis Meyrick, 1926, Exotic Microlepidoptera, 3: 256 .

"ㅇ. $24 \mathrm{~mm}$. . . Colombia, Mt. Tolima, 10,500 feet, October; I ex."

Type: The female indicated above dated "ro.20". Slide No. 6348.

Figure 3 , left wings; 3 a, ventral view of female genitalia; 3 b, detail of genital plate and ostium. 


\section{Eulia carycodes Meyrick}

Flate 60 , Figures $\mathrm{I}-\mathrm{I} b$

Eulia carycodes Meyrick, I926, Exotic Microlepidoptera, 3: 256.

" 0 . 2 I mm. . . . Colombia, Mt. Tolima, i 2,500 feet; i ex."

Type: The specimen indicated above dated ".I2.20". Slide No. 6347.

Figure I, left wings; ra, lateral aspect of aedeagus; $\mathrm{Ib}$, ventral view of male genitalia with aedeagus removed.

\section{Eulia clisias (Meyrick)}

Plate 6o, Figures 2-_b

Cnephasia clisias Meyrick, I912, 'Trans. Ent. Soc. London, I91 I : 685.

" $\hat{\sigma}$. I $4^{-1} 5 \mathrm{~mm}$. . . Argentina, Parana; two specimens."

Lectotype: The smaller of the two specimens both of which are females, erroneously recorded as males by Meyrick. Slide No. 6345 .

Figure 2, left wings; $2 a$, ventral view of female genitalia; $2 b$, detail of genital plate and ostium.

\section{Eulia conchitis Meyrick}

Plate 6o, Figures $3-3 \mathrm{~b}$

Eulia conchitis Meyrick, I9I2, Trans. Ent. Soc. London, I91 г : 68 I.

" $+.19 \mathrm{~mm}$. . . Colombia, San Antonio, 5,800 feet, in November; one specimen."

Type: The specimen indicated above dated “. I I.o7". Slide No. 63i6.

Figure 3 , left wings; 3 a, ventral view of female genitalia; 3 , detail of genital plate and ostium.

\section{Eulia corusca (Meyrick)}

Plate 6o, Figures $4-4 \mathrm{~b}$

Cnephasia corusca Meyrick, I9 2, Exotic Microlepidoptera, I: I I.

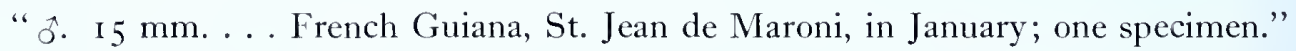

Type: The above indicated specimen with "M. .I.I I" at the bottom of the pinlabel. Slide No. 630r.

Figure 4 , left wings; $4^{\mathrm{a}}$, lateral aspect of aedeagus; 4 b, ventral view of male genitalia (damaged) with aedeagus removed. 


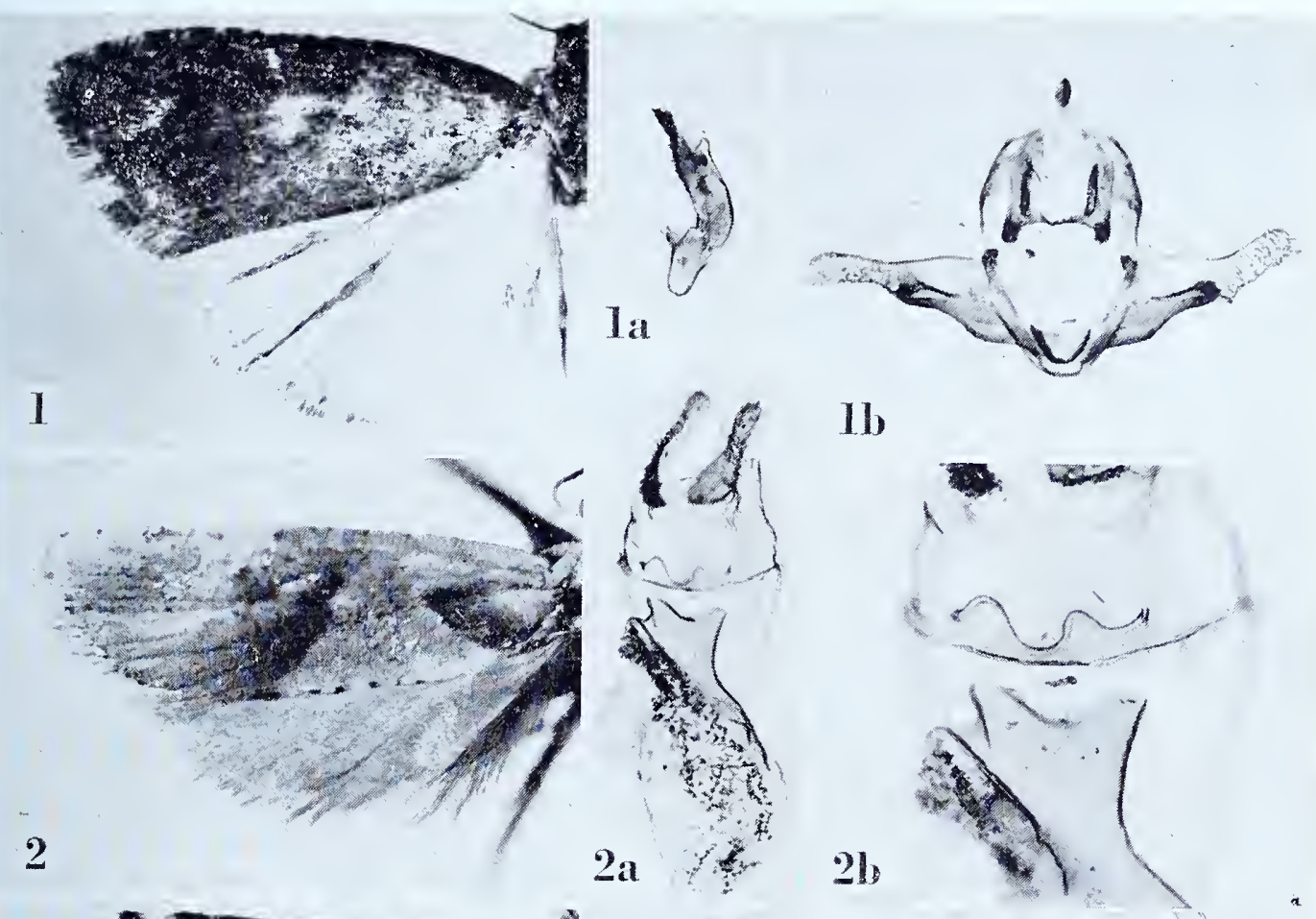

3
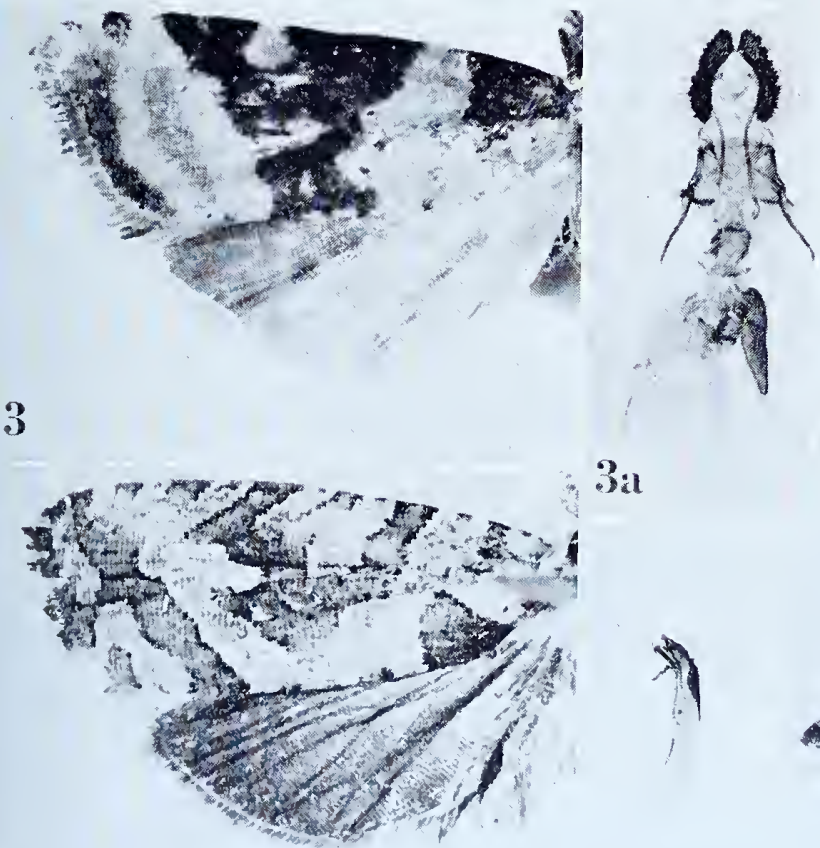

3)

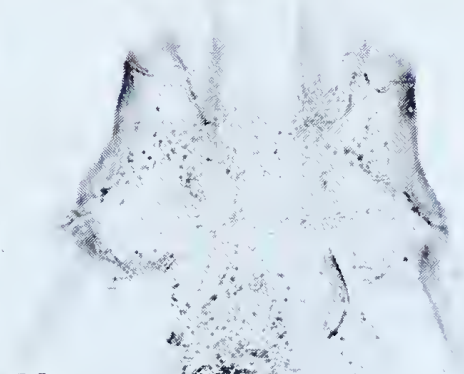

4

4a

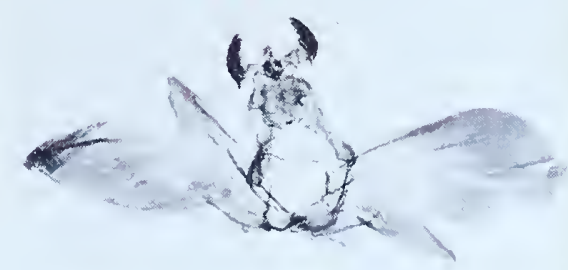

(1)

EULIA 


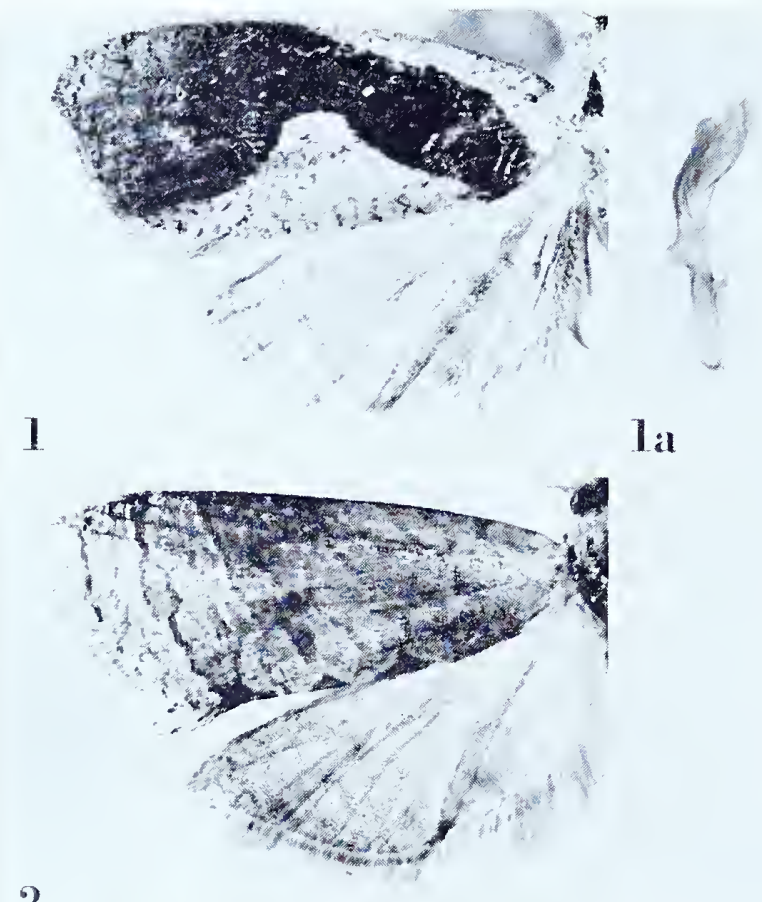

2

$2 \mathbf{a}$
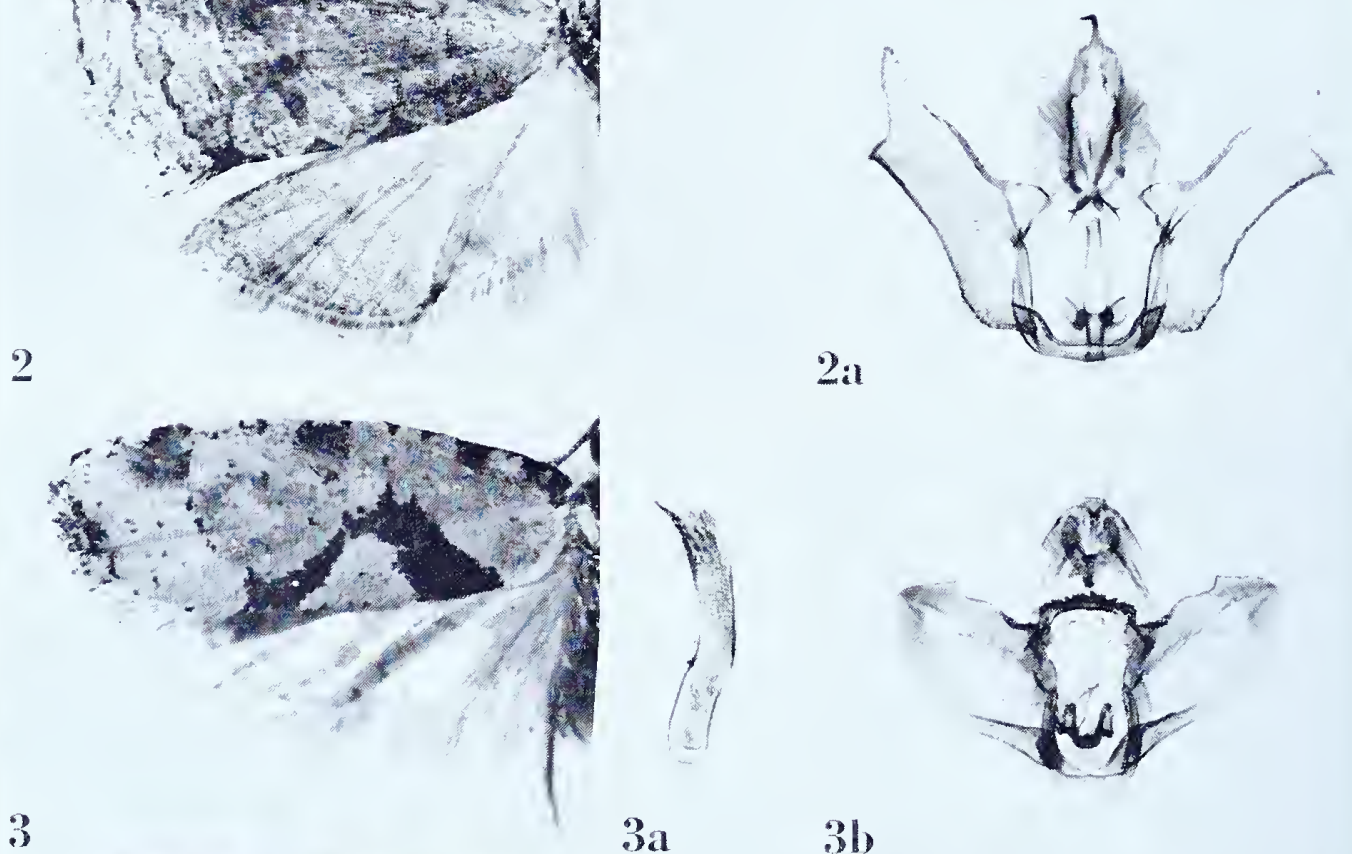

11)
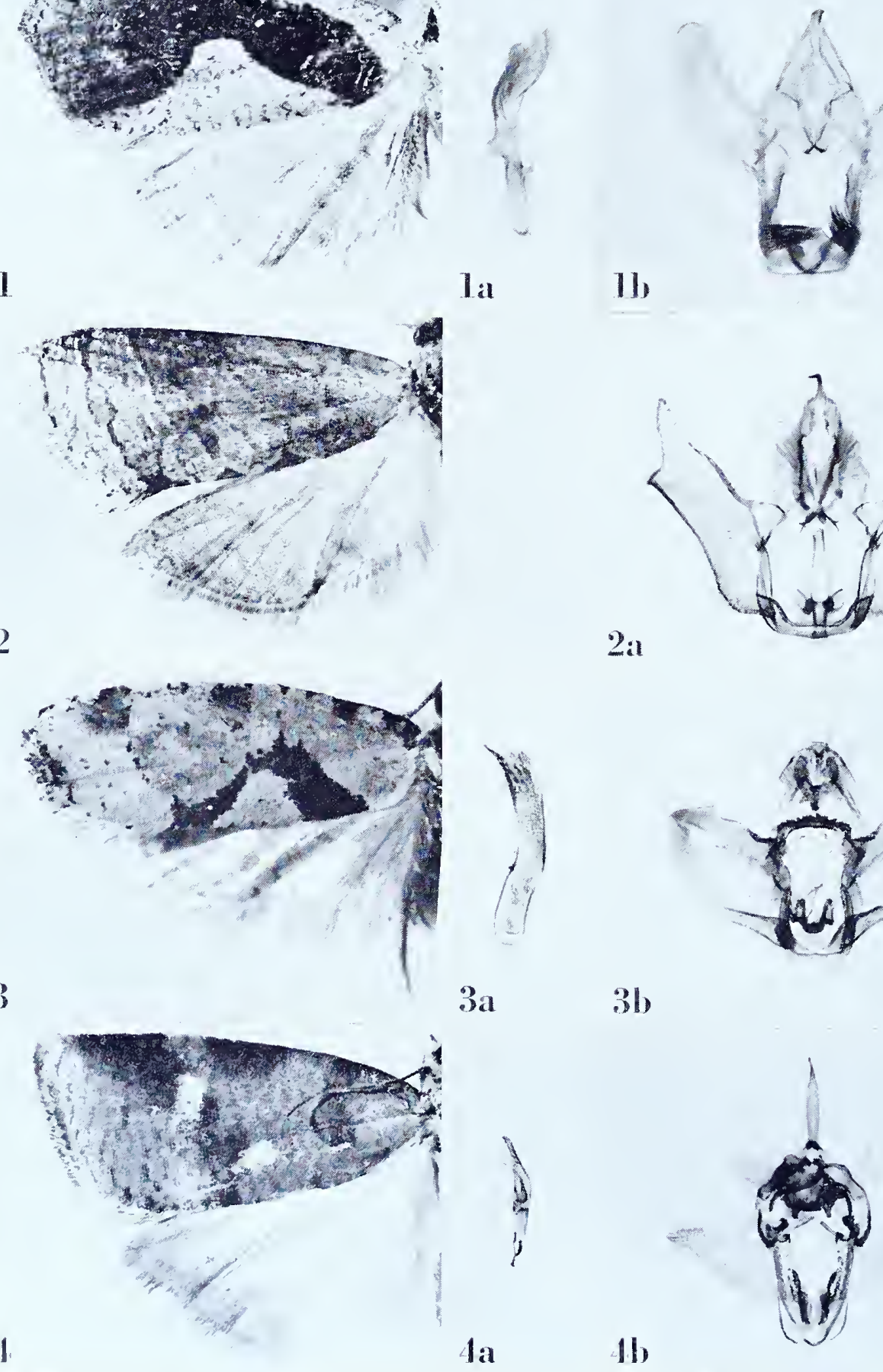

$3 a$

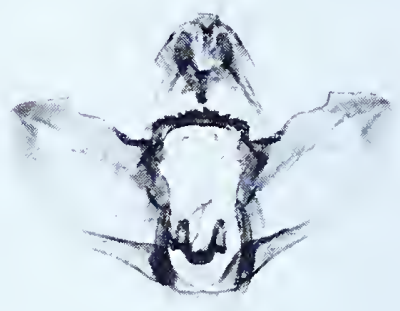

$31)$
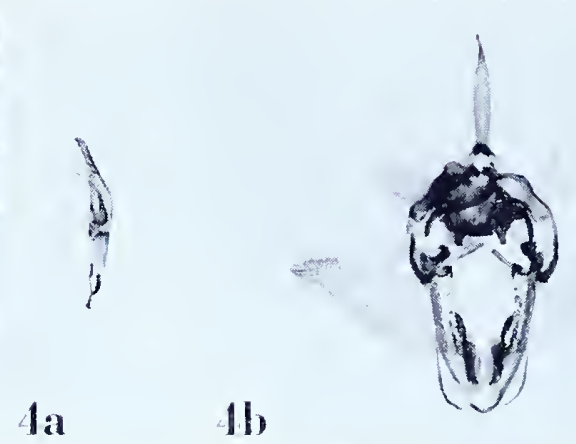

EULIA 


\section{Eulia craterosema Meyrick}

Plate 6I, Figures I-Ib

Enlia craterosema Meyrick, 1912, Trans. Ent. Soc. London, I9I I : 678.

" స. I 8 mm. . . Brazil, São Paulo; one specimen."

Type: The male indicated above with "R. .o6" at the bottom of the pin-label. Slide No. 6321 .

Figure I, left wings; $\mathrm{ra}$, lateral aspect of aedeagus; $\mathrm{ib}$, ventral view of male genitalia with aedeagus removed.

\section{Eulia defricata Meyrick}

Plate 6r, Figures 2-2a

Enlia defricata Meyrick, 1926, Exotic Microlepidoptera, 3: 253.

" oै. $22 \mathrm{~mm}$. . . Colombia, E. Cordilleras, I2,500 feet, November; i ex."

Type: The above indicated male dated “.1 I.20". Slide No. 6308.

Figure 2, left wings; 2a, ventral view of male genitalia with aedeagus in sitn.

\section{Eulia dentata (Meyrick)}

Plate 6I, Figures $3-3 \mathrm{~b}$

Cnephasia dentata Meyrick, I917, Trans. Ent. Soc. London, I917: I I.

" సิํ. 13-14 mm.... Ecuador, Huigra, 4,500 feet, in June (Parish); two specimens."

Lectotype: The male. Both specimens are dated "6.14". Slide No. 6354 .

Figure 3 , left wings; 3 a, lateral aspect of aedeagus; 3 b, ventral view of male genitalia with aedeagus removed.

\section{Eulia dictyophanes Meyrick}

Plate 6I, Figures 4-4b

Enlia dictyophanes Meyrick, I926, Exotic Microlepidoptera, 3:254.

" o. $25 \mathrm{~mm}$. . . Colombia, Mt. Socorro, I2,500 feet, July; i ex."

Type: The specimen indicated above dated ".7.20". Slide No. 6294.

Figure 4 , left wings; 4 a, lateral aspect of aedeagus; 4 b, ventral view of male genitalia with aedeagus removed. 


\section{Eulia dryoglypta (Meyrick)}

Plate 62, Figures $\mathrm{I}-\mathrm{Ib}$

Cnephasia dryoglypta Meyrick, I9I3, Trans. Ent. Soc. London, I9I3: I72.

"ㅇ․ 14 mm. . . Argentina, Parana; two specimens."

Lectotype: A female. Both are females; the opposite sex was erroneously recorded by Meyrick. Both specimens bear identical data with "R. .07" at the bottom of the pin-label. Slide No. 6359.

Figure $\mathrm{x}$, left wings; $\mathrm{ra}$, ventral view of female genitalia; $\mathrm{r} b$, detail of genital plate and ostium.

\section{Eulia epicremna Meyrick}

Plate 62, Figures 2-2a

Eulia epicremna Meyrick, 1926, Exotic Microlepidoptera, 3:25 I.

“

Type: The specimen indicated above labelled, "Mt. Tolima, Colombia, $\mathrm{I}_{4}, 800$ ' .20". Slide No. 6346.

Figure 2, left wings; $2 \mathrm{a}$, ventral view of male genitalia with aedeagus in situ.

\section{Eulia eurychlora Meyrick}

Plate 62, Figures $3-3$ a

Eulia eurychlora Meyrick, I926, Exotic Microlepidoptera, 3: 258.

" f. I9 mm. . . Colombia, Mt. 'Tolima, I2,500 feet, December; i ex."

Type: 'The male indicated above dated ".I 2.20 ”. Slide No. $635^{2}$.

Figure 3 , left wings; 3 a, ventral view of male genitalia with aedeagus in situ.

\section{Eulia fissiculata (Meyrick)}

Plate 62, Figures $4-4^{c}$

Tortrix fissiculata Meyrick, I917, Trans. Ent. Soc. London, I917: 9.

" fof $^{\circ}$ I $8-20 \mathrm{~mm}$. . . Peru, Aqualani [sic], in June; four specimens."

Lectotype: The male measuring i $8 \mathrm{~mm}$. Slide No. 6332 .

Figure 4 , left wings; 4 a, lateral aspect of aedeagus; 4 b, ventral view of male genitalia with aedeagus removed; $4 \mathrm{c}$, lateral view of gnathos and uncus. 

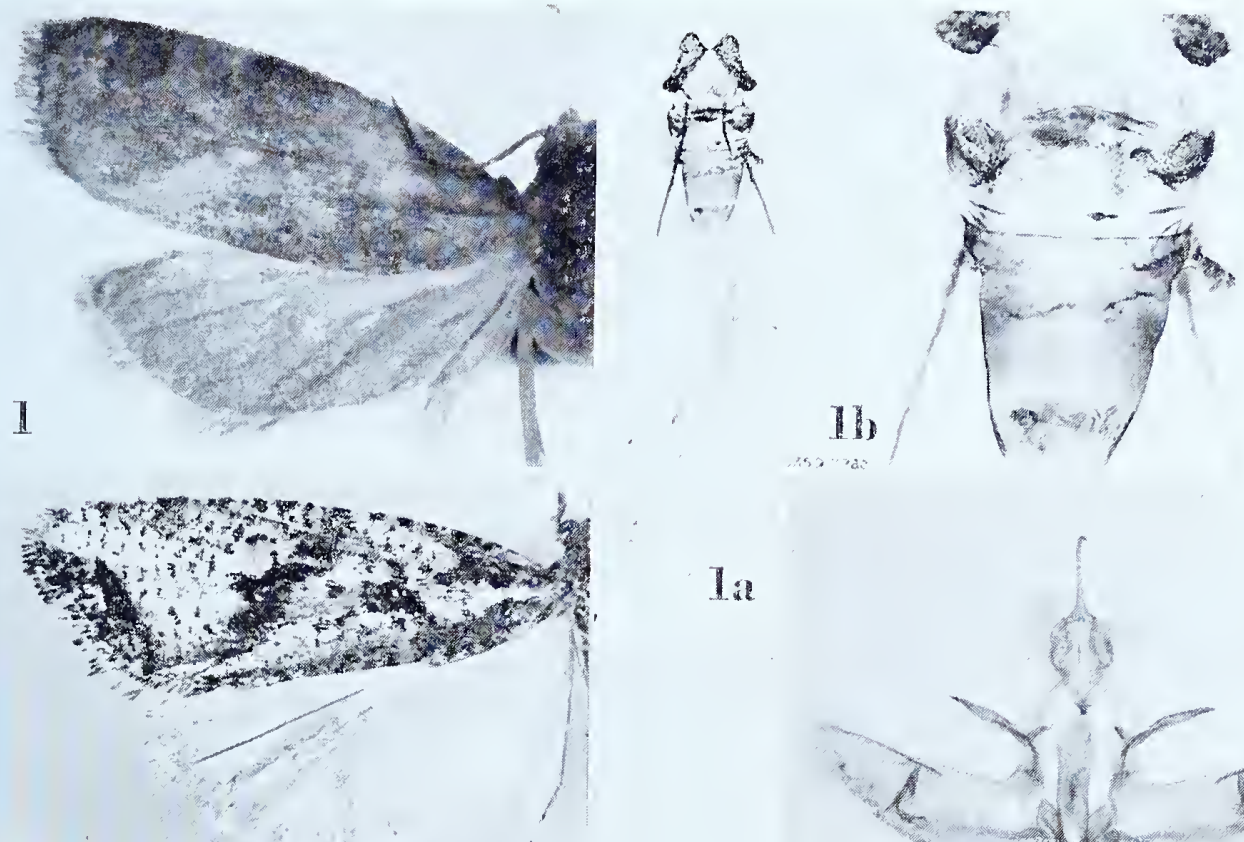

3
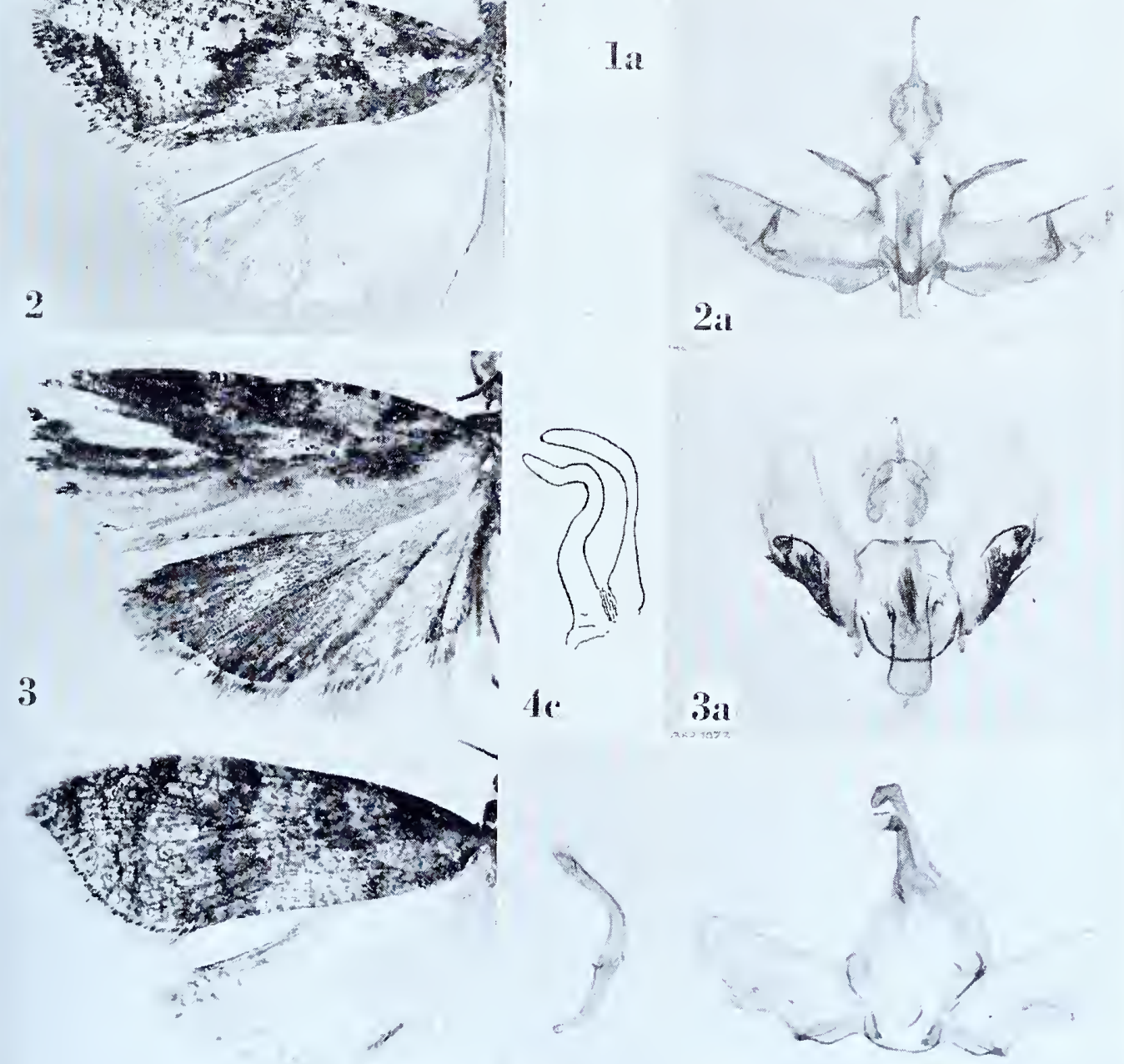

4

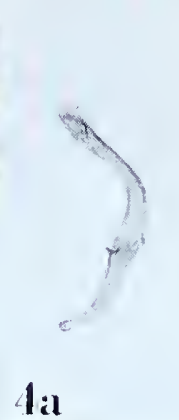

Ba
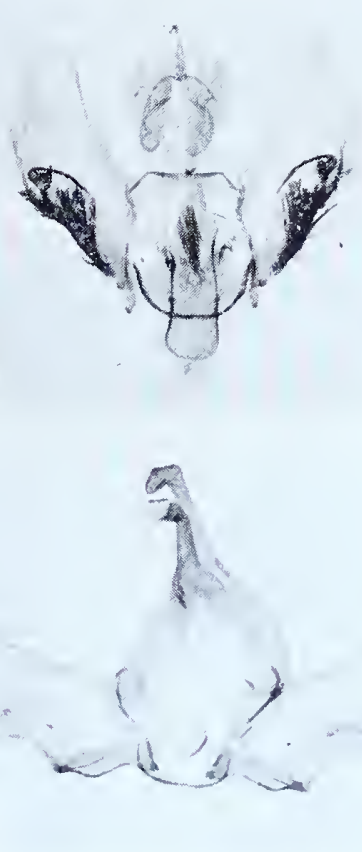

EULIA 


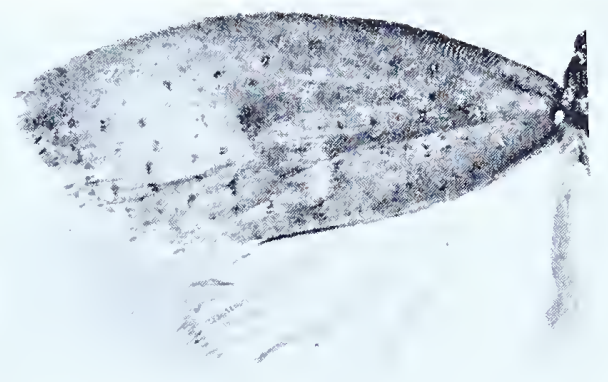

1
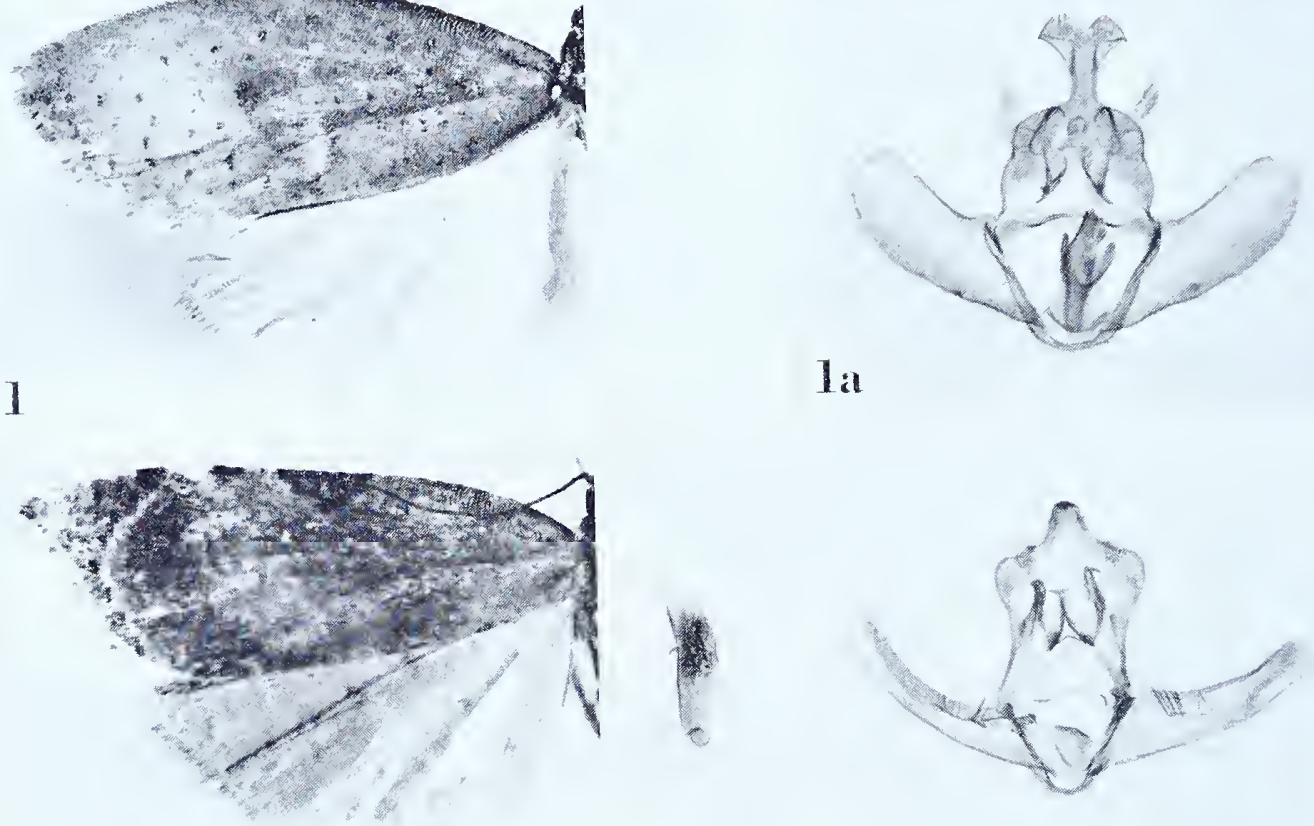

2

$2 a$
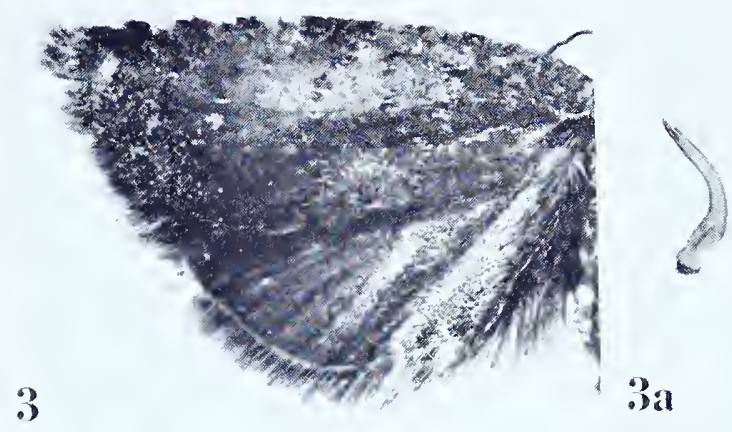

$2 b$
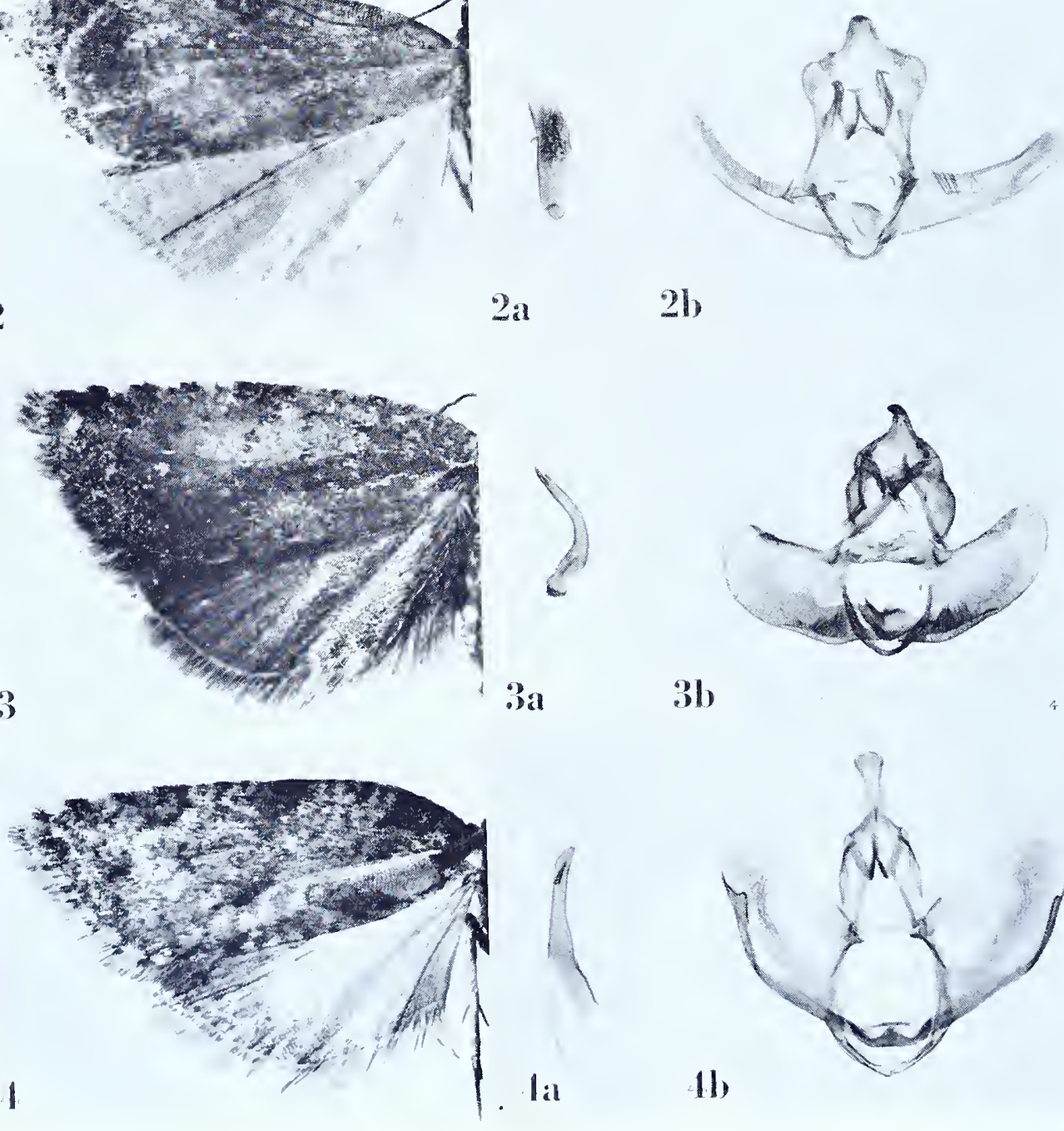

Ba

31

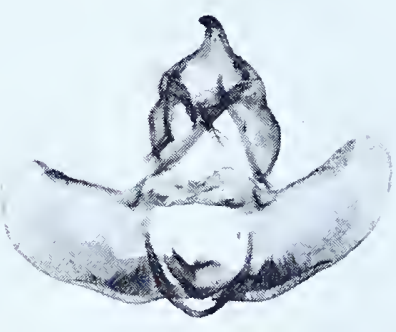

EULIA 


\section{Eulia flaminia Meyrick}

Plate $6_{3}$, Figures $1-1 \mathbf{a}$

Eulia flaminia Meyrick, 1926, Exotic Microlepidoptera, 3: 255.

" $\hat{~}$. $22 \mathrm{~mm}$. . . Colombia, Mt. Socorro, I2,500 feet, July; I ex."

Type: The specimen indicated above dated “.7.20". Slide No. 6327.

Figure I, left wings; Ia, ventral view of male genitalia with aedeagus in situ.

\section{Eulia grammotorna Meyrick}

Plate 63 , Figures 2-2b

Eulia graumotorua Meyrick, I926, Exotic Microlepidoptera, 3: 256.

" స. I 8-20 mm. . . Colombia, Mt. Tolima, I 0,500 feet, October; I ex."

Type: The unique male dated "I0.20". Meyrick indicated a single specimen, but gave the wing expanse for at least two. Slide No. 6330.

Figure 2, left wings; $2 \mathrm{a}$, lateral aspect of aedeagus; $2 \mathrm{~b}$, ventral view of male genitalia with aedeagus removed.

\section{Eulia haematitis Meyrick}

\section{Plate 63 , Figures $3-3$ b}

Eulia haenatitis Meyrick, I93 I, Ann. Mus. Nacional de Hist. Nat. Buenos Aires, 36: $3^{8}$ I.

" f. I 4 mm. ... ․ 15 mm. . . S. Chile, Llanquihue Province, Peuilla, December; 2 ex."

Type: The male, "Casa Pangue, 4-Io-xii-I 926, S. Chile, Llanquihue Prov., F. \& M. Edwards," marked type in the British Museum. Slide No. 6453 .

Figure 3 , left wings; 3 a, lateral aspect of aedeagus; $3 \mathrm{~b}$, ventral view of male genitalia with aedeagus removed.

\section{Eulia haemothicta Meyrick}

Plate $6_{3}$, Figures $4-4 \mathrm{~b}$

Eulia haemothicta Meyrick, 1926, Exotic Microlepidoptera, 3: 257.

“ $\hat{0}$. 20-23 mm. . . Colombia, Mt. Tolima (I 2,500 feet), Monte del Eden (9,600 feet); 6 ex."

Lectotype: A male labelled, "Monte del Eden, Colombia. 9,600' io.20." Slide No. 633I. Three specimens are missing.

Figure 4 , left wings; 4 a, lateral aspect of aedeagus; 4 b, ventral view of male genitalia with aedeagus removed. 


\section{Eulia homosacta Meyrick}

Plate 64, Figures $1-\mathrm{Ib}$

Eulia homosacta Meyrick, 1930, Exotic Microlepidoptera, 3: 610.

" స. $21 \mathrm{~mm}$. . . Ecuador, Hacienda Cayandeled, Prov. Rio Bamba, 4,200 feet, February; I ex. (Coll. Paravicini). Near sagmatica, with very similar markings. ..."

Type: The above indicated male, marked type in the British Museum. Slide No. 6454 .

Figure $\mathrm{I}$, left wings; $\mathrm{ra}$, lateral aspect of aedeagus; $\mathrm{rb}$, ventral view of male genitalia with aedeagus removed.

\section{Eulia hyacinthina (Meyrick)}

Plate 64 , Figures 2-2b

Cnephasia hyacinthina Meyrick, 1912, Trans. Ent. Soc. London, г91 г : 682.

" ${ }^{\circ}$. $18 \mathrm{~mm}$. . . Colombia, San Antonio, 5,80o feet, in November; one specimen."

Type: The above indicated specimen dated “. I I.07”. Slide No. 6302.

Figure 2, left wings; $2 a$, ventral view of aedeagus; $2 b$, ventral view of male genitalia with aedeagus removed.

\section{Eulia hydrogramma (Meyrick)}

Plate 64 , Figures $3-3 \mathrm{~b}$

Cnephasia hydrogramma Meyrick, I9I2, Trans. Ent. Soc. London, I9I I : 683.

" $\$ .24 \mathrm{~mm}$. . . Dutch Guiana, Paramaribo, in August; one specimen."

Type: The above indicated male dated ".8.92". Slide No. 6319.

Figure 3 , left wings; 3 a, ventro-lateral view of aedeagus; 3 b, ventral view of male genitalia with aedeagus removed.

\section{Eulia hypsithrona Meyrick}

Plate 64 , Figures $4-4 \mathrm{~b}$

Eulia hypsithrona Meyrick, 1926, Exotic Microlepidoptera, 3: 25I.

" of. 19 mm. . . . Colombia, Mt. Tolima, ${ }_{3} 3,850$ feet, October; I ex."

Type: The specimen indicated above with ".20" in the lower right corner of the pin-label. Slide No. 6304.

Figure 4 , left wings; 4 a, lateral aspect of aedeagus; 4 b, ventral view of male genitalia with aedeagus removed. 

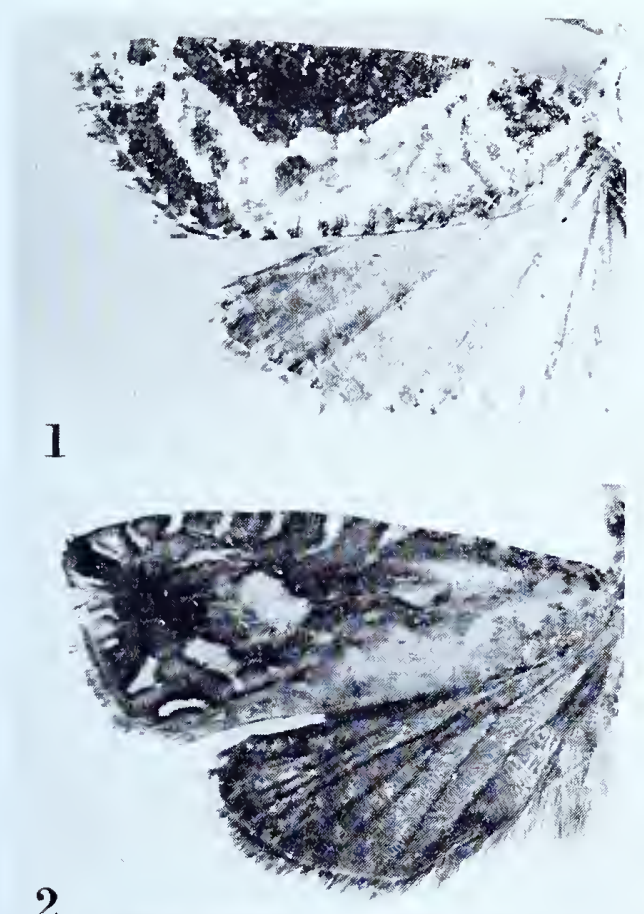

2

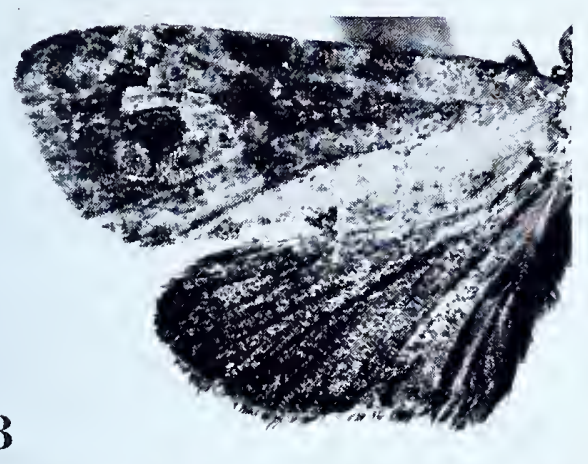

$2 a$

3a

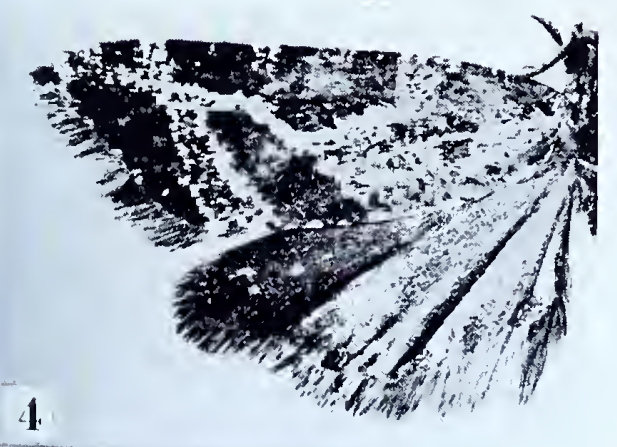

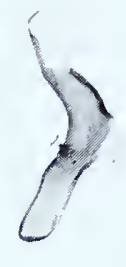

la

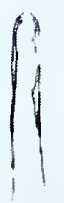

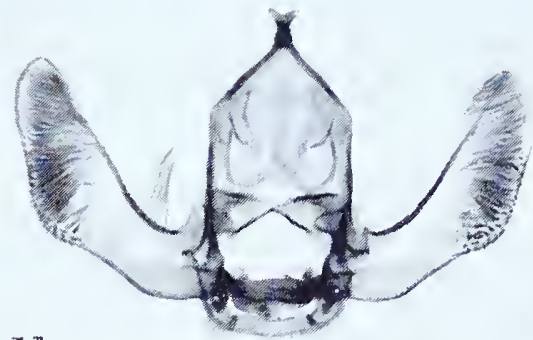

Ib

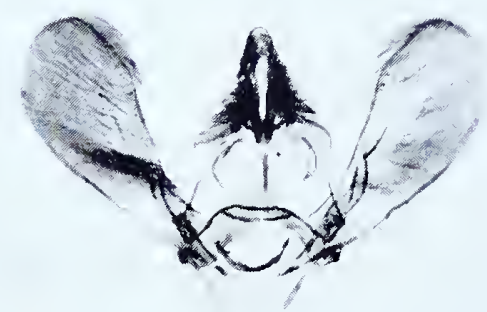

$2 \mathrm{~b}$

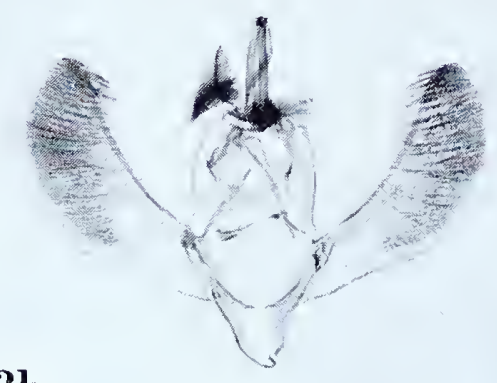

3b

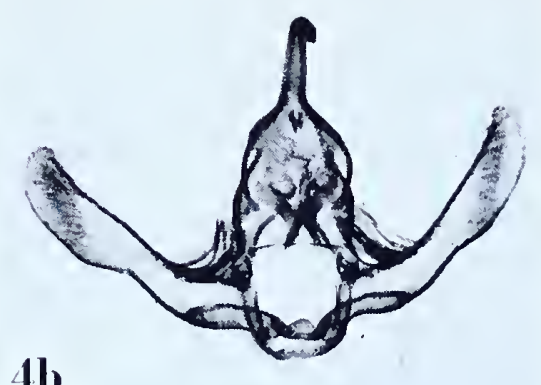



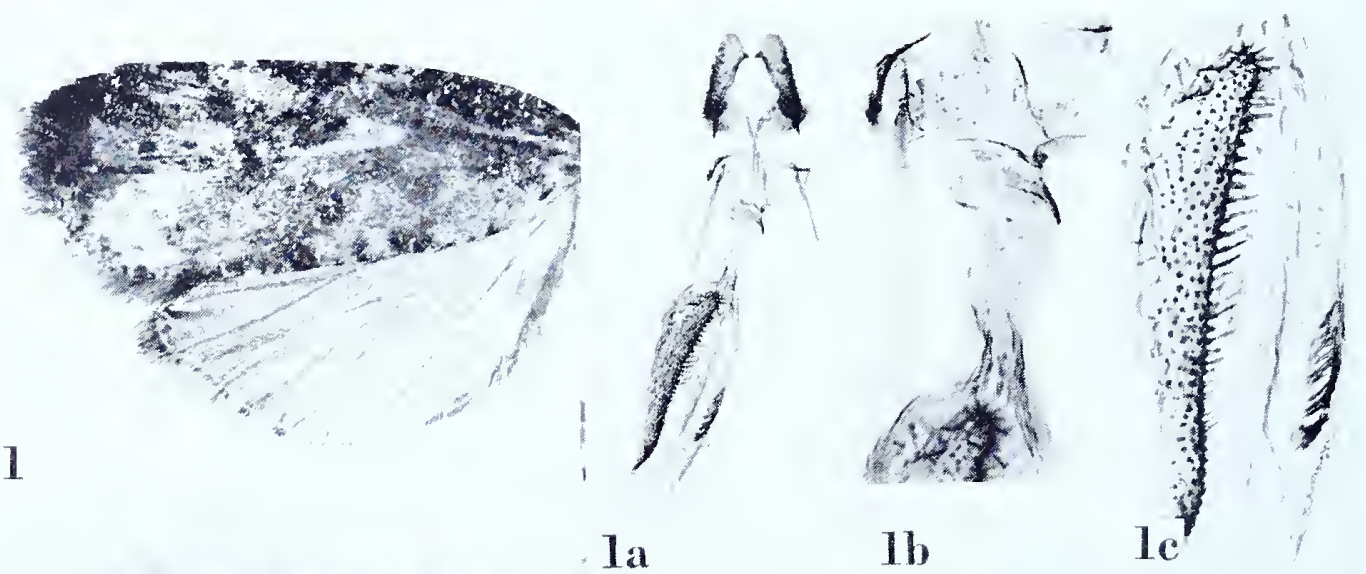

\section{2}
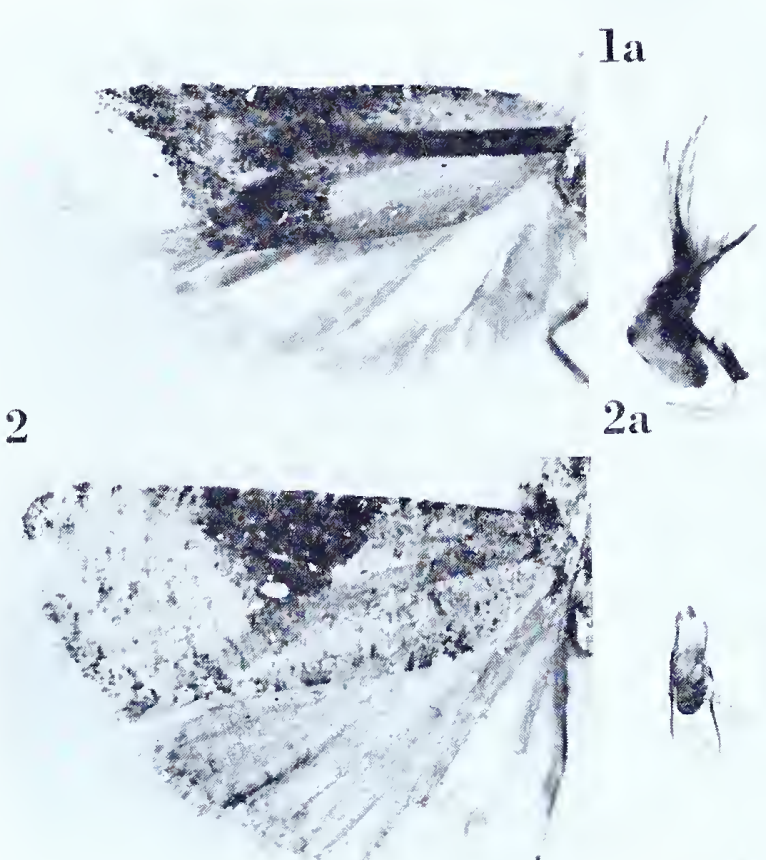

$2 \mathbf{a}$

$2 b$

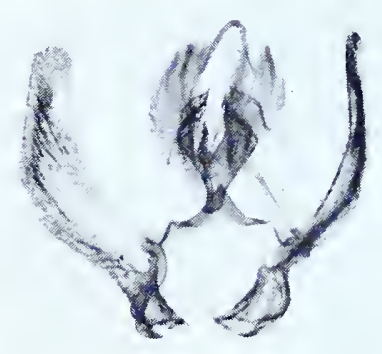

3
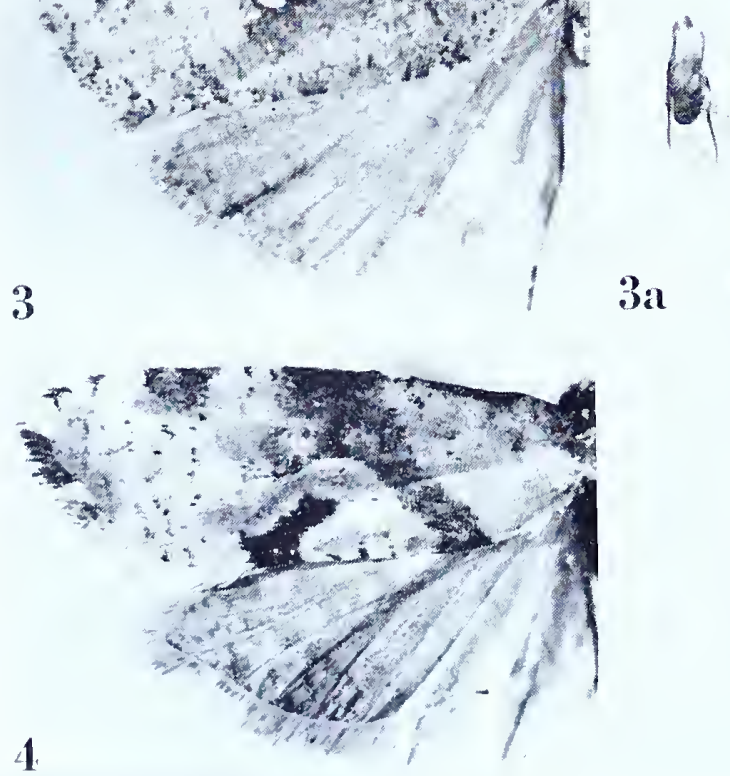

$3 a \quad 3 b$
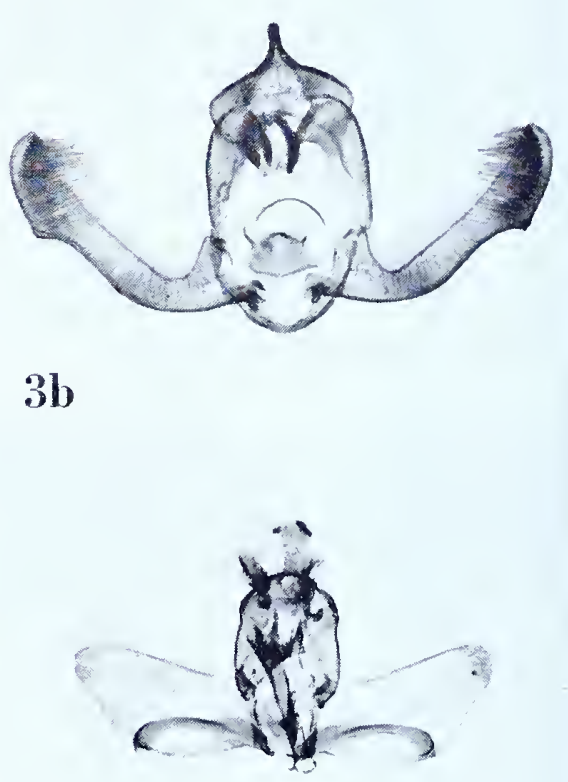

$4 a$

EULIA 


\section{Eulia iantha (Meyrick)}

Plate 65, Figures I-IC

Cnephasia iantha Meyrick, i912, Trans. Ent. Soc. Londion, I91 I: 684.

"․ $28 \mathrm{~mm}$. . . Colombia, San Antonio, 5,80o feet, in November; one specimen."

Type: The above indicated female dated ".ix.07". Slide No. 6320.

Figure I, left wings; Ia, ventral view of female genitalia; $\mathrm{Ib}$, detail of genital plate and ostium; ic, signa.

\section{Eulia incusa (Meyrick)}

Plate $6_{5}$, Figures $2-2 \mathrm{~b}$

Cnephasia incusa Meyrick, I917, Trans. Ent. Soc. London, 1917: I2.

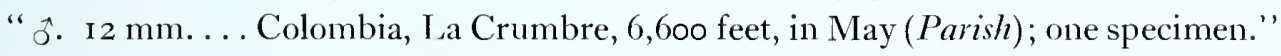

Type: The specimen indicated above dated "5-14". Slide No. 6353.

Figure 2, left wings; $2 \mathrm{a}$, lateral aspect of aedeagus; $2 \mathrm{~b}$, ventral view of male genitalia with aedeagus removed.

\section{Eulia isodelta Meyrick}

Plate 65 , Figures $3^{-3} \mathrm{~b}$

Enlia isodelta Meyrick, i912, Trans. Ent. Soc. London, I9г I: 68 I.

" fำ. I 8-19 mm. . . Colombia, San Antonio, 5,800 feet, in November; two specimens."

Lectotype: The male. Both specimens are dated ". I I.07". Slide No.63I 5 . Gnathos broadly expanded distally, the two terminal elements compressed and covered with spines.

Figure 3 , left wings; 3 , lateral aspect of aedeagus; 3 b, ventral view of male genitalia with aedeagus removed.

\section{Eulia juncta Meyrick}

Plate 65 , Figures $4-4 \mathrm{a}$

Eulia juncta Meyrick, I926, Exotic Microlepidoptera, 3: 258 .

" *우. I 8-22 mm. . . . Colombia, Mt. Tolima, 12,500 feet; 3 ex. Apparently very variable."

Lectotype: A male measuring $22 \mathrm{~mm}$., and dated “.10.20". Slide No. 6356. One specimen ( $(9)$ is missing and the two remaining males represent two species.

Figure 4, left wings; 4 a, ventral view of male genitalia with aedeagus in sitn. 


\section{Eulia leucobactra Meyrick}

Plate 66, Figures I-Ia

Eulia leucobactra Meyrick, 1926, Exotic Microlepidoptera, 3: 256.

"3. $23 \mathrm{~mm}$. . . Colombia, Mt. Tolima, ${ }_{3}, 850$ feet, October; i ex."

Type: The above indicated male dated ".10.20". Slide No. 6349.

Figure I, left wings; ra, ventral view of male genitalia with aedeagus in situ.

\section{Eulia melanecta Meyrick}

Plate 66, Figures 2-2b

Eulia melanecta Meyrick, 1917, Trans. Ent. Soc. London, 1917: 10.

"ㅇ. $19 \mathrm{~mm}$. . . E Ecuador, Alausi, 9,450 feet, in June (Parish); one specimen."

Type: The female referred to above dated ".6.I 4 ". Slide No. 6357.

Figure 2, left wings; $2 \mathrm{a}$, ventral view of female genitalia; $2 \mathrm{~b}$, detail of genital plate and ostium.

\section{Eulia melitocrossa Meyrick}

Plate 66, Figures $3^{-3} \mathrm{~b}$

Eulia melitocrossa Meyrick, 1926, Exotic Microlepidoptera, 3: 253. 2 ex."

" స. 24 mm. . . Colombia, San Antonio (5,800 feet); Alto de las Ances ( 7,250 feet);

Lectotype: The male labelled "San Antonio, W. Colombia. R. 5,800' .I I.07". Slide No. 6326. 'The second specimen is missing.

Figure 3 , left wings; 3 , lateral aspect of aedeagus; 3 b, ventral view of male genitalia with aedeagus removed.

\section{Eulia neolopha Meyrick}

See Laspeyresia neolopha (Meyrick).

\section{Eulia nivescens Meyrick}

Plate 66, Figures $4-4 \mathrm{~b}$

Eulia nivescens Meyrick, 1926, Exotic Microlepidoptera, 3: 250.

" J. 27 mm. . . Colombia, Mt. Tolima, I o, 500 feet, October; I ex."

Type: The above indicated specimen dated “.10.20”. Slide No. 6295.

Figure 4 , left wings; $4 \mathrm{a}$, lateral aspect of aedeagus; $4 \mathrm{~b}$, ventral view of male genitalia with aedeagus removed. 

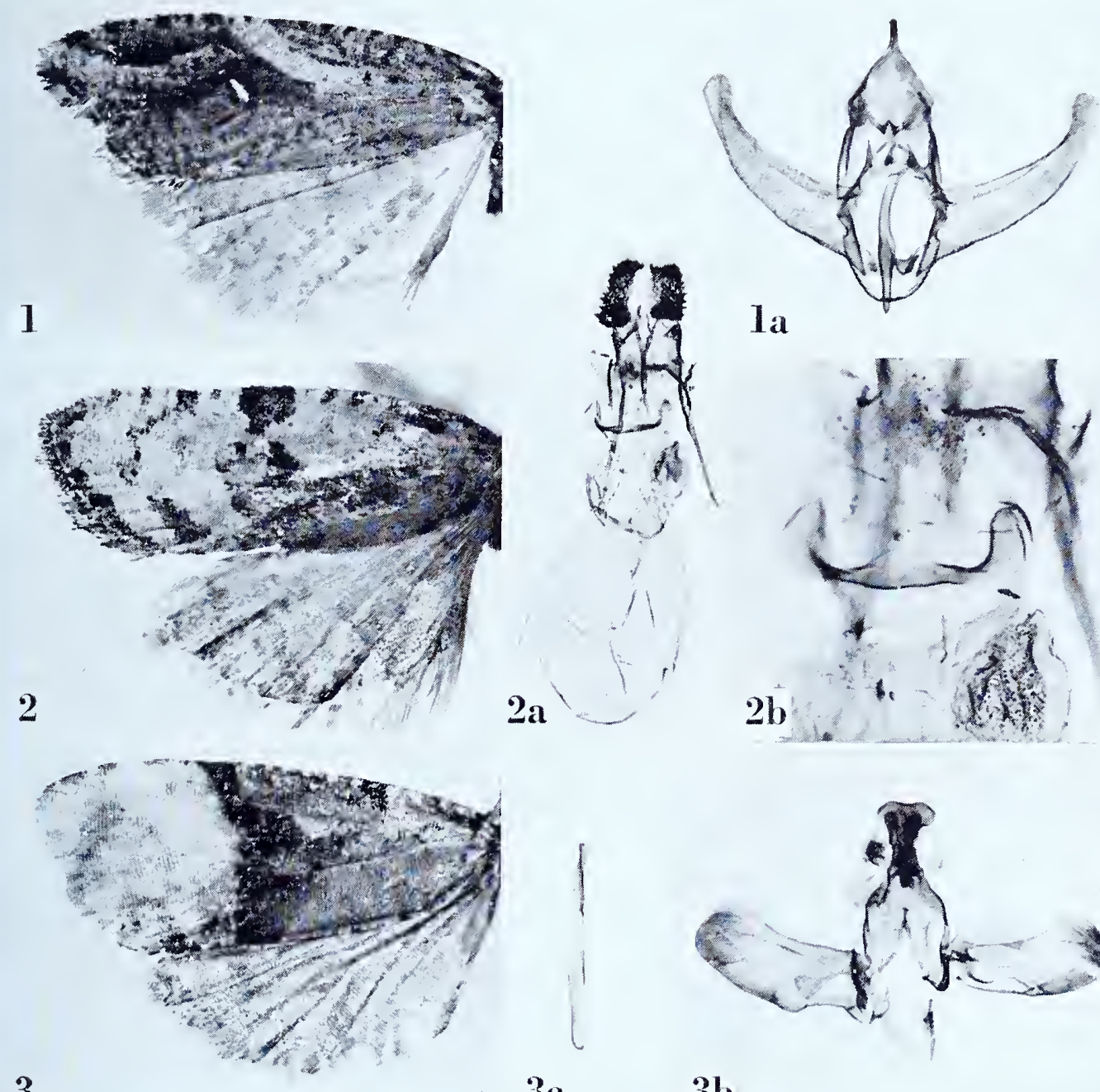

3
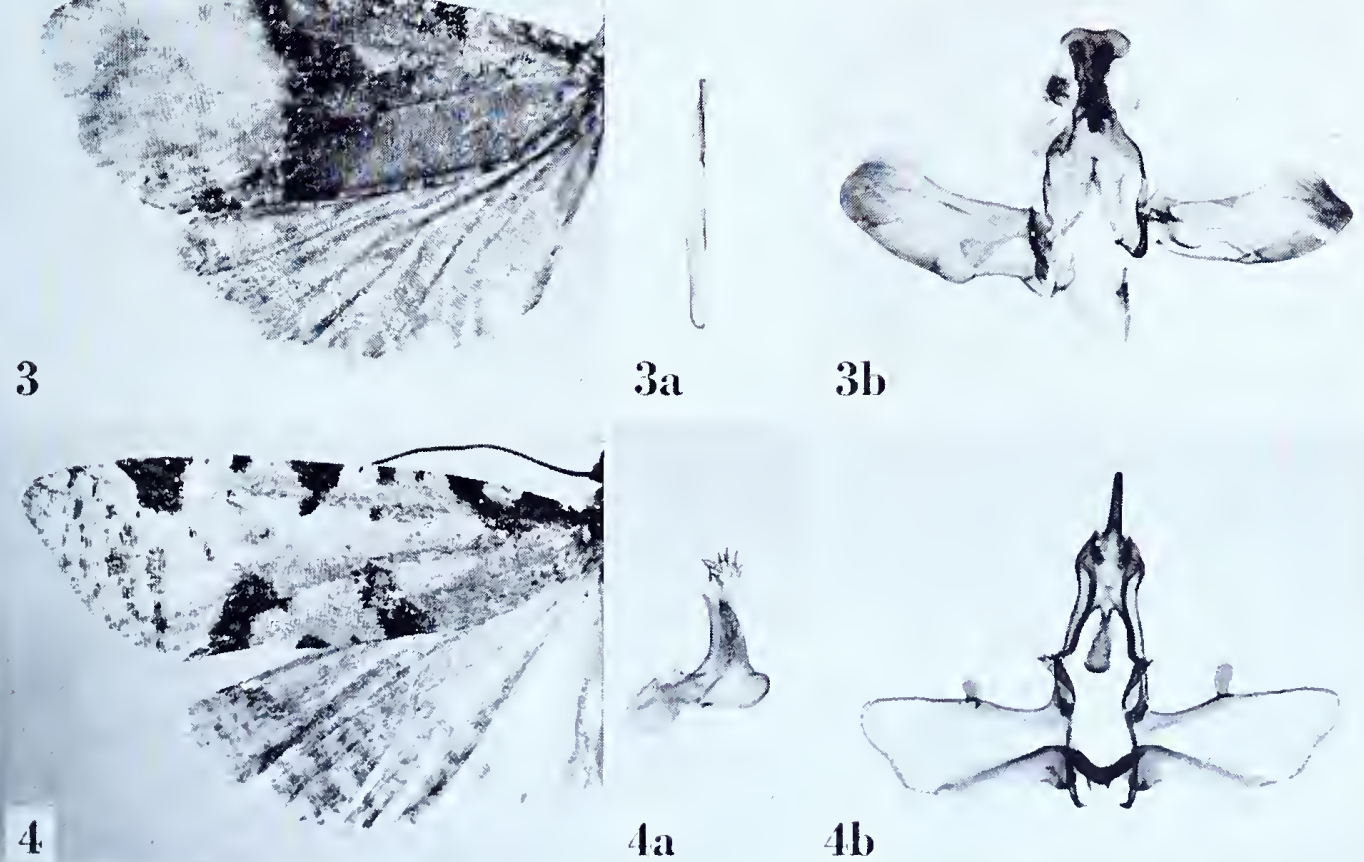

EULIA 


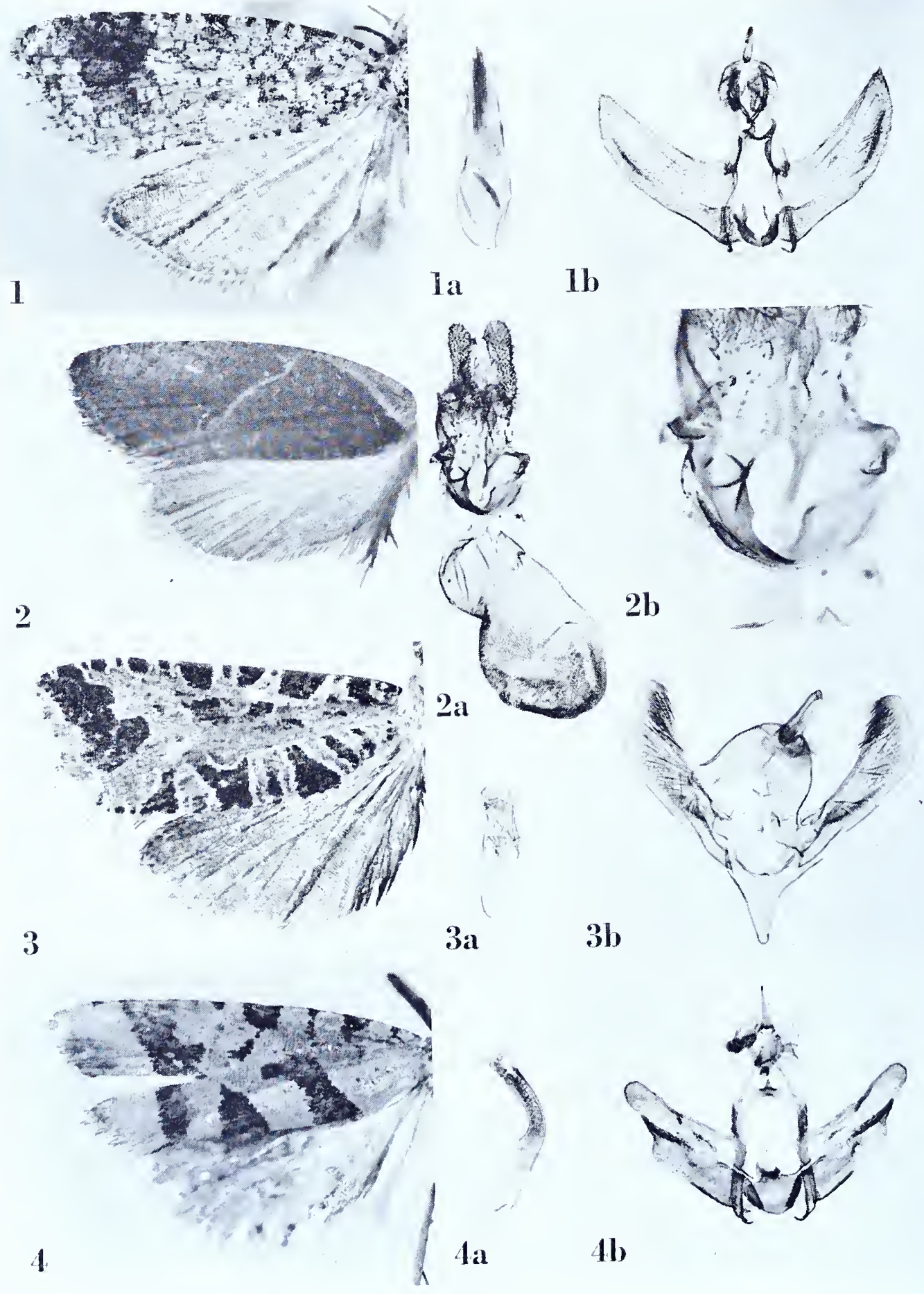

EULIA 


\section{Eulia oppressa Meyrick}

Plate 67, Figures $\mathrm{I}-\mathrm{Ib}$

Eulia oppressa Meyrick, 1926, Exotic Microlepidoptera, 3: 258.

" 今. $20 \mathrm{~mm}$. . . Colombia, Mt. Tolima (1 2,500 feet), Monte del Eden ( 9,600 feet); 2 ex."

Lectotype: The male labelled, "Mt. Tolima, Colombia, 12,500' .10.20." Slide No. 635 I. The "Monte del Eden" specimen is missing.

Figure I, left wings; $\mathrm{s}$, lateral aspect of aedeagus; $\mathrm{rb}$, ventral view of male genitalia with aedeagus removed.

\section{Eulia oreographa (Meyrick)}

Plate 67, Figures 2-2b

Tortrix oreographa Meyrick, i 909 , Trans. Ent. Soc. London, I909: i 6.

Eulia oreographa (Meyrick), Clarke, 1949, Acta Zool. Lilloana, 7: 580.

"ㅇ․ $20 \mathrm{~mm}$. . . Bolivia, Songo; one specimen."

Type: The above indicated specimen with "S. . 07 " at the bottom of the pin-label. Slide No. 4953 .

Figure 2, left wings; $2 \mathrm{a}$, ventral view of female genitalia; $2 \mathrm{~b}$, detail of genital plate and ostium.

\section{Eulia petalocrossa Meyrick}

Plate 67 , Figures $3-3 \mathrm{~b}$

Eulia petalocrossa Meyrick, 1926, Exotic Microlepidoptera, 3: 25 c.

" of. 25-28 mm., ㅇ $33 \mathrm{~mm}$. . . Colombia, R. Tamaua, 320 feet (Palmer); Costa Rica, Vulkan Irazu (4,000 feet); Palo Verde (5,000 feet); 3 ex."

Lectotype: The male labelled, "El Tigre, Rio Tamaua, Choco Colombia. $320 \mathrm{ft}$. G. M. Palmer, Feb. .og.” Slide No. 6297.

Figure 3 , left wings; 3 a, lateral aspect of aedeagus; 3 b, ventral view of male genitalia with aedeagus removed.

\section{Eulia praecipua (Meyrick)}

Plate 67 , Figures $4-4 b$

Cnephasia praecipua Meyrick, I917, Trans. Ent. Soc. London, I917: i I.

" o. I $8 \mathrm{~mm}$. . . Colombia, San Antonio, 5,8 co feet, in November; one specimen."

Type: The specimen indicated above dated “.1 1.07”. Slide No. 6355 .

Figure 4 , left wings; 4 a, lateral aspect of aedeagus; 4 b, ventral view of male genitalia with aedeagus removed. 


\section{Eulia pyrrhocolona Meyrick}

Plate 68, Figures $1-\mathrm{I} b$

Eulia pyrrhocolona Meyrick, I 926, Exotic Microlepidoptera, 3: 257.

“خ. 2 I mm. . . Colombia, Mt. Socorro, I 2,500 feet, July; i ex."

Type: The above indicated male dated ".7.20". Slide No. 6329.

Figure I, left wings; 1 a, lateral aspect of aedeagus; $\mathrm{r} b$, ventral view of male genitalia with aedeagus removed.

\section{Eulia ranunculata (Meyrick)}

Plate 68, Figures 2-2b

Cnephasia ranunculata Meyrick, i912, Trans. Ent. Soc. London, ig1 I : 684.

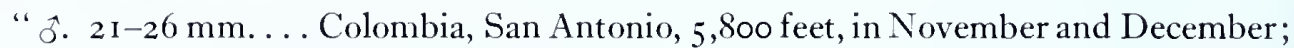
fifteen specimens."

Lectotype: A male dated “. I I.07" measuring 22 mm. Slide No. 6343. Six specimens are missing.

Figure 2, left wings; $2 \mathrm{a}$, lateral aspect of aedeagus; $2 \mathrm{~b}$, ventral view of male genitalia with aedeagus removed.

\section{Eulia sagmatica Meyrick}

Plate 68 , Figures $3-3 b$

Eulia sagmatica Meyrick, 1912, Trans. Ent. Soc. London, i91 I : 680.

" స. $23 \mathrm{~mm}$. . . Colombia, San Antonio, 5,800 feet, in November; one specimen."

Type: The male indicated above dated “.1 1.07”. Slide No. 6317.

Figure 3 , left wings; 3 a, lateral aspect of aedeagus; 3 b, ventral view of male genitalia with aedeagus removed.

\section{Eulia sciodryas Meyrick}

Plate 68, Figures $4-4 \mathrm{~b}$

Eulia sciodryas Meyrick, 1926, Exotic Microlepidoptera, 3: 255.

" of + 30-32 mm. . . . Colombia, Mt. Tolima, I 2,500 feet, December; 2 ex."

Lectotype: The female dated ".I 2.20", without abdomen. There are two specimens in the Meyrick collection, both females. The female dated ".I2.20" is undoubtedly one of the original types; the male, if Meyrick had one, is missing. The second female in the Meyrick collection is from "Mt. Tolima, Colombia, Z. I I,500' 30 ". The date (1930) excludes this specimen from the original pair unless the date is wrong. The genitalia are figured from this specimen. Slide No. 6335 .

Figure 4 , left wings; $4 \mathrm{a}$, ventral view of female genitalia; 4 b, detail of genital plate and ostium. 

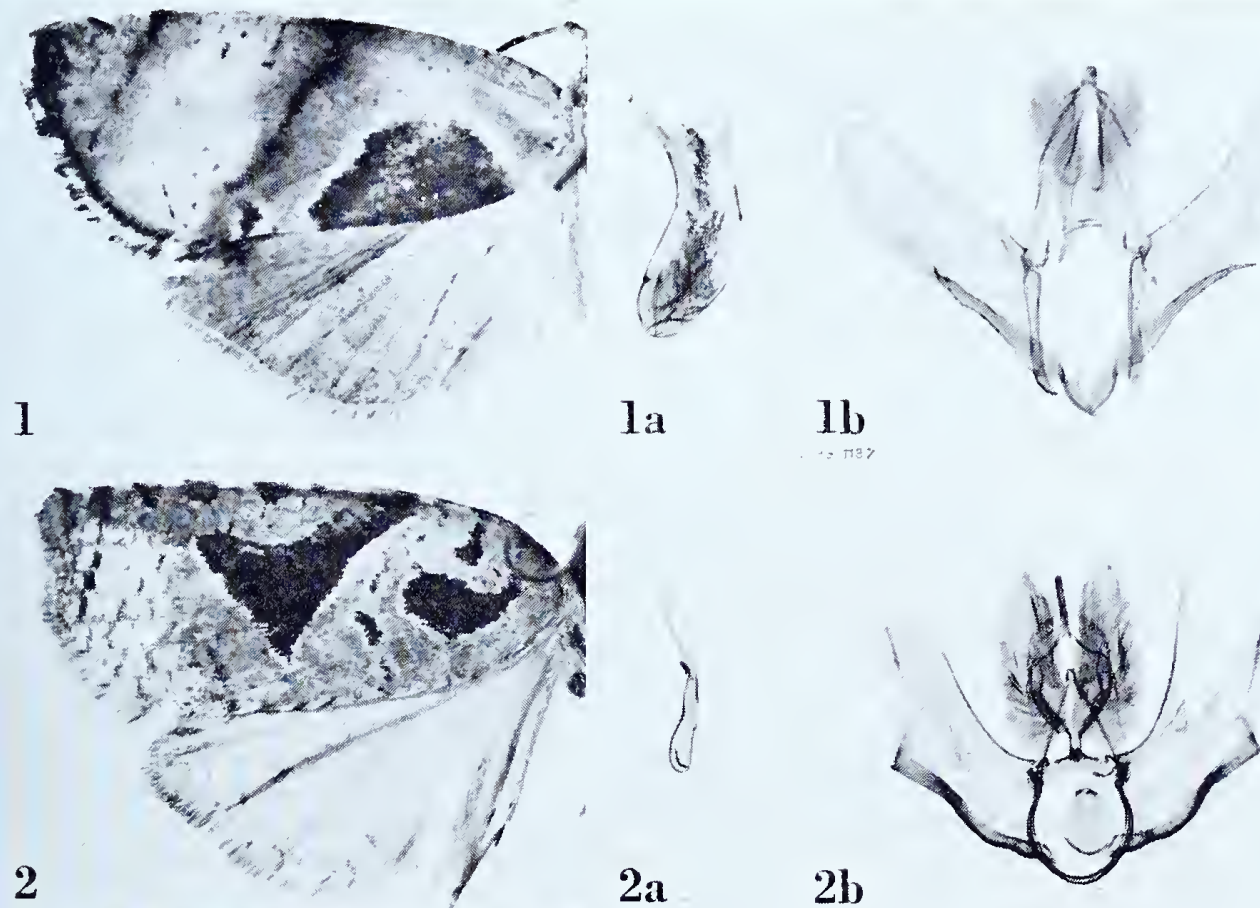

$2 a$
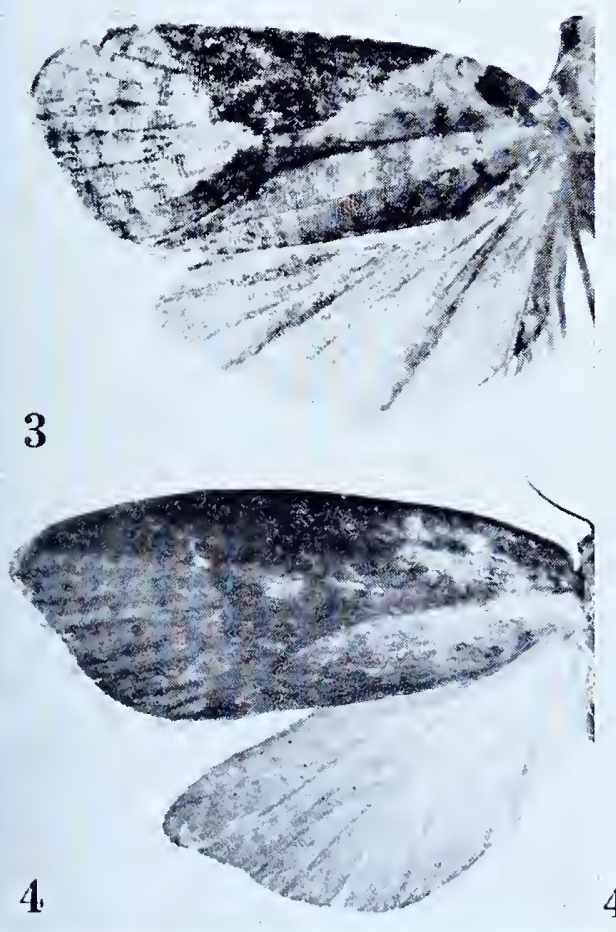

$3 a$

4
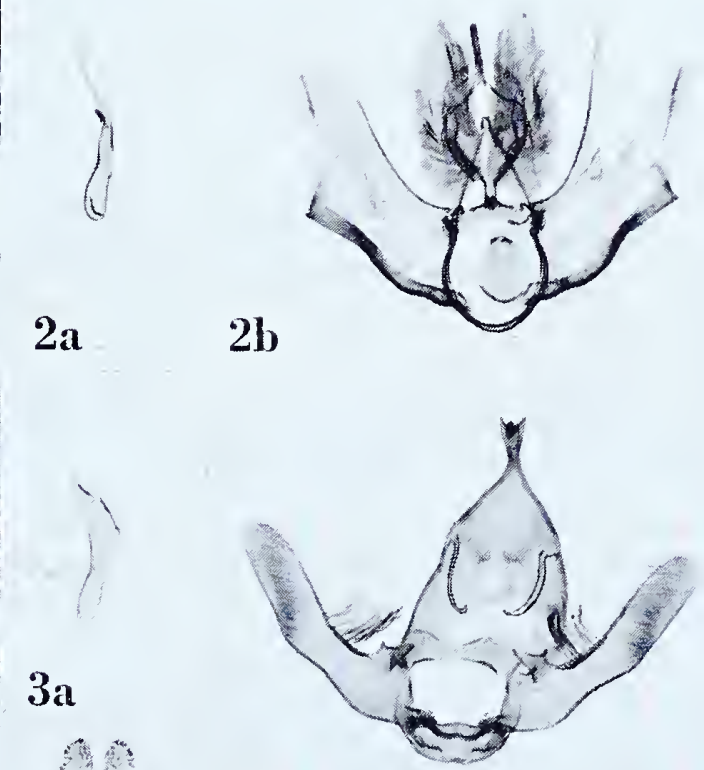

$4 a$

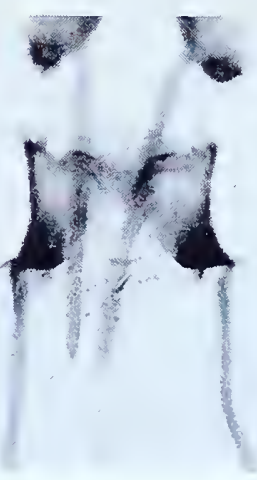

EULIA 

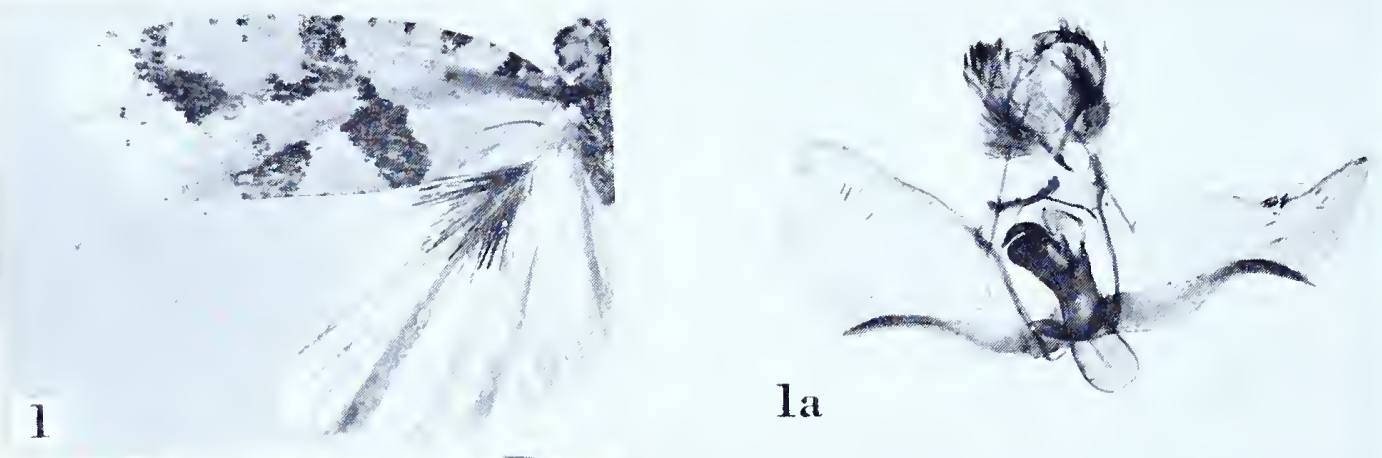

2
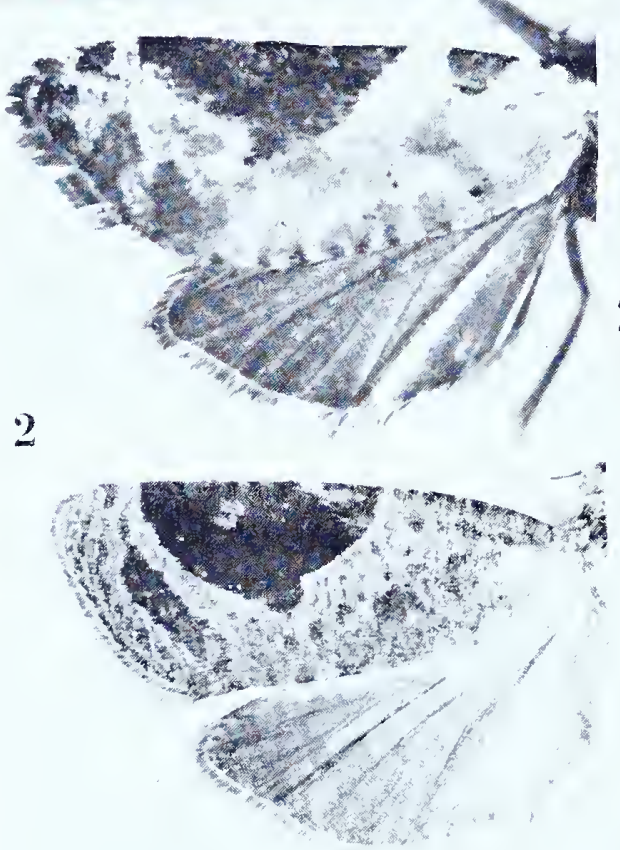

3

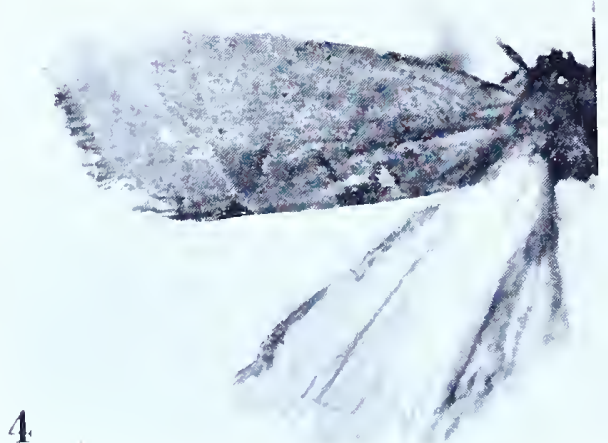

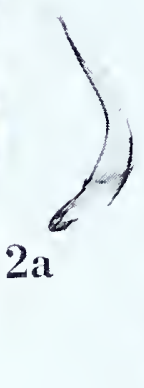

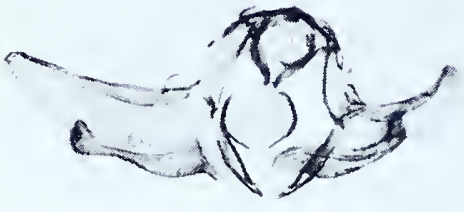

$2 \mathrm{~b}$

$3 a \quad 3 b$

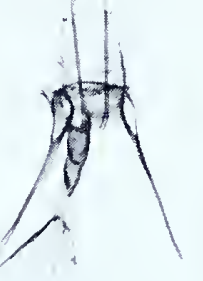

sa 9 b l :
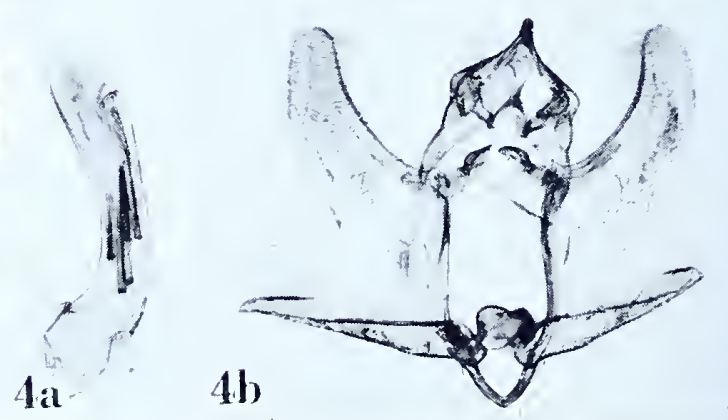

EULIA 


\section{Eulia setosa (Meyrick)}

Plate 69 , Figures I-Ia.

Cnephasia setosa Meyrick, 1917, 'Trans. Ent. Soc. London, 1917: 10.

“ f. I 8 mm. . . Colombia, San Antonio, 5,80o feet, in November; one specimen." Type: The male denoted above with "R. .r I.o7" at the bottom of the pin-label. Slide No. 4442. Right harpe apparently deformed. Vesica armed with two pointed, strong cornuti.

Figure I, left wings; ra, ventral view of male genitalia with aedeagus in situ.

\section{Eulia stalactitis Meyrick}

Plate 6o, Figures 2-2b

Eulia stalactitis Meyrick, I931, Ann. Mus. Nacional de Hist. Nat., Buenos Aires, $3^{6:} 3^{82}$.

“ส̊ํ. I7-19 mm. . . Argentina, Territory Rio Negro, Bariloche, November; S. Chile, Casa Pangue, December; 2 ex. Intermediate between conchitis Meyr. and atalodes Meyr."

Type: The male so marked in the British Museum and labelled, "Casa Pangue, 4-I0.xii.r926. Argentina, Terr. Rio Negro, F. \& M. Edwards.” Slide No. 6455.

Figure 2, left wings; $2 \mathrm{a}$, lateral aspect of aedeagus; $2 \mathrm{~b}$, ventral view of male genitalia with aedeagus removed.

\section{Eulia strophota Meyrick}

Plate 69 , Figures $3^{-} 3^{b}$

Eulia strophota Meyrick, I926, Exotic Microlepidoptera, 3: 252.

"ㅇ. 26-27 mm. . . Colombia, Mt. Tolima, 12,500 feet; 2 ex."

Lectotype: The specimen measuring 27 mm., and dated "I 0.20 ". Slide No. 6306. The second specimen is missing.

Figure 3 , left wings; $3 \mathrm{a}$, ventral view of female genitalia; $3 \mathrm{~b}$, detail of genital plate and ostium.

\section{Eulia tenontias (Meyrick)}

Plate 69, Figures $4-4 b$

Cnephasia tenontias Meyrick, I912, Trans. Ent. Soc. London, I9I I : 685.

“今. $22 \mathrm{~mm}$. . . Chili; one specimen."

Type: The above indicated specimen with "R. .05" at the bottom of the pin-label. Slide No. 6344 .

Figure 4 , left wings; 4 a, lateral aspect of aedeagus; 4 b, ventral view of male genitalia with aedeagus removed. 


\section{Eulia tholeraula Meyrick}

Plate 70 , Figures I-Ib

Eulia tholeraula Meyrick, I912, 'Trans. Ent. Soc. London, i91 I : 680.

" o. I 6 mm. . . A Argentina, Parana, one specimen."

Type: The male indicated above with "R. .06" at the bottom of the pin-label. Slide No. 6318.

Figure $\mathrm{I}$, left wings; $\mathrm{r}$ a, lateral aspect of aedeagus; $\mathrm{I}$ b, ventral view of male genitalia with aedeagus removed.

\section{Eulia torrens (Meyrick), new combination}

Plate 70 , Figure 2

Eucosma tortens Meyrick, 1927, Exotic Microlepidoptera, 3: 334 .

" o. 20-26 mm. ... Colombia, Mt. Tolima, I 3,850 feet, October; 2 ex."

Type: The male measuring $26 \mathrm{~mm}$., without abdomen, dated ". 10.20 ". The second specimen is missing. This is certainly not referable to Eucosula and is placed in Eulia until more material is available and its proper generic position can be established.

Figure 2, left wings.

\section{Eulia trapeziodes Meyrick}

Plate 70 , Figures $3-3 \mathrm{c}$

Eulia trape $i o d e s$ Meyrick, 1926, Exotic Microlepidoptera, 3: 253.

"ㅇ. I 7-1 $8 \mathrm{~mm}$. . . . Colombia, Monte del Eden (9,500 feet), Mt. Tolima (1 2,500 feet); 2 ex."

Lectotype: The female "Monte del Eden, Colombia, 9,500' .10.20". Slide No. 6307. The "Mt. Tolima" specimen is missing.

Figure 3 , left wings; $3 \mathrm{a}$, ventral view of female genitalia; $3 \mathrm{~b}$, detail of genital plate and ostium; $3 \mathrm{c}$, signum.

\section{Eulia triloba Meyrick}

Plate 70 , Figure 4

Eulia triloba Meyrick, 1926, Exotic Microlepidoptera, 3: 249.

" o. $26 \mathrm{~mm}$. . . Brazil, Rio Grande do Sul; i ex. Allied to lacertana."

Type: The specimen indicated above with ".20" in the lower right corner of the pin-label. The abdomen of the type is missing.

Figure 4, left wings. 

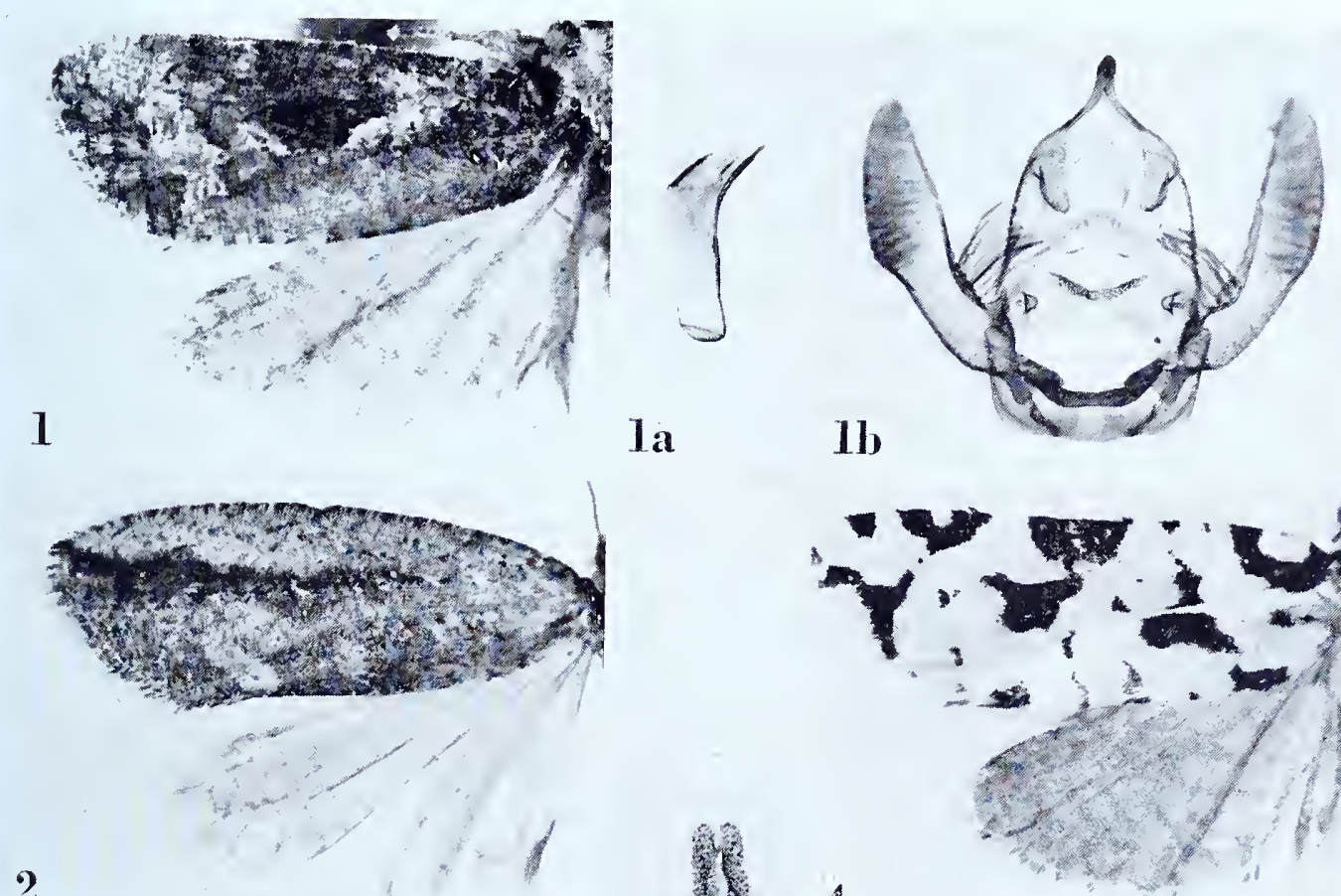

2
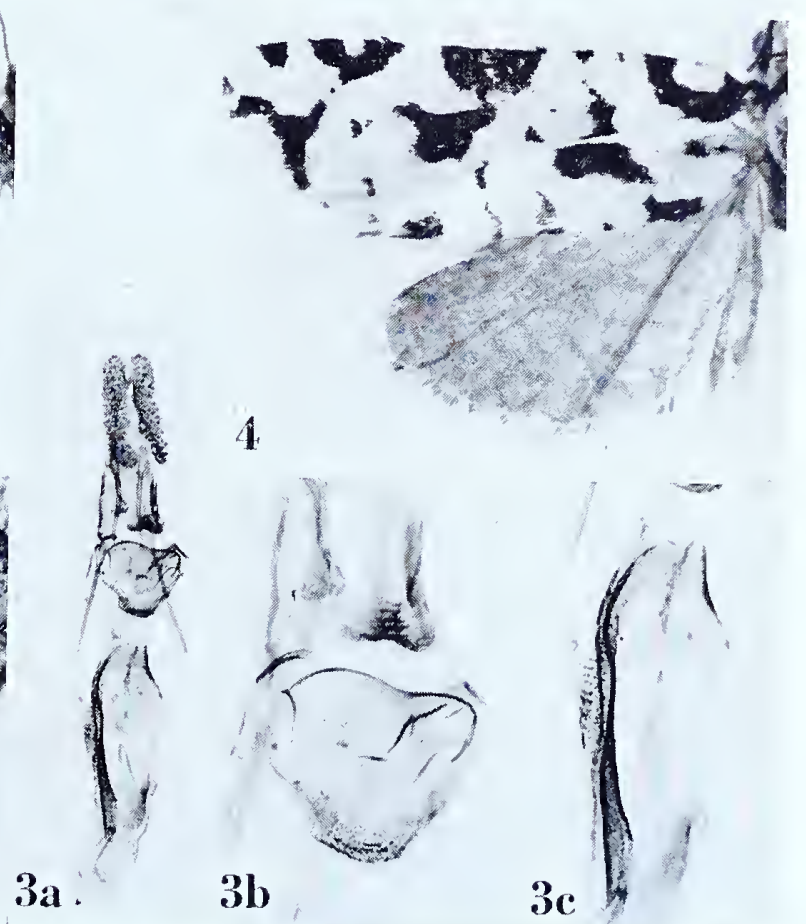

3
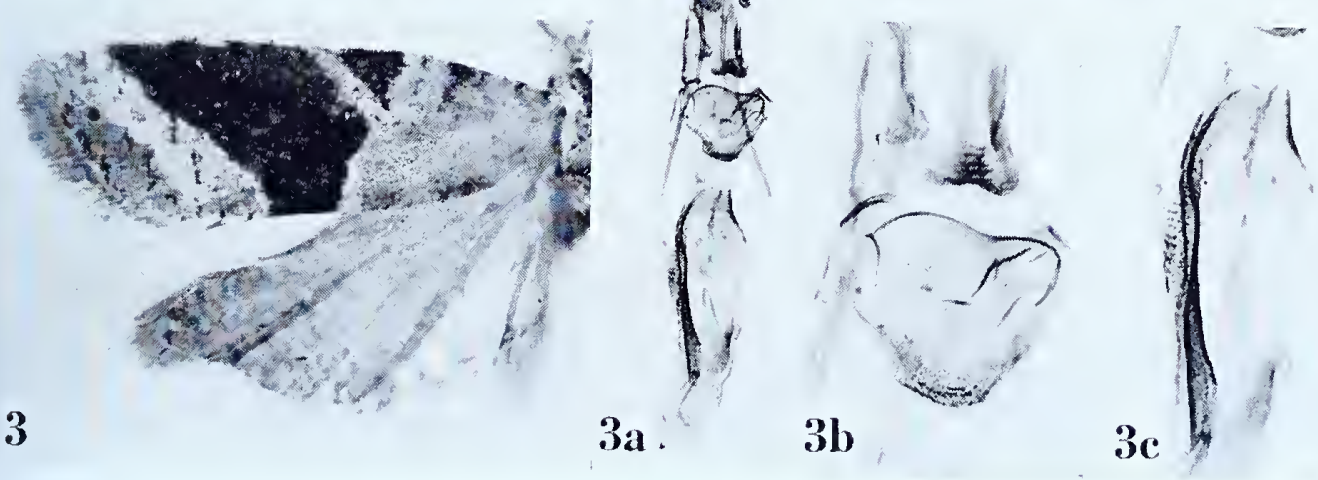

EULIA 

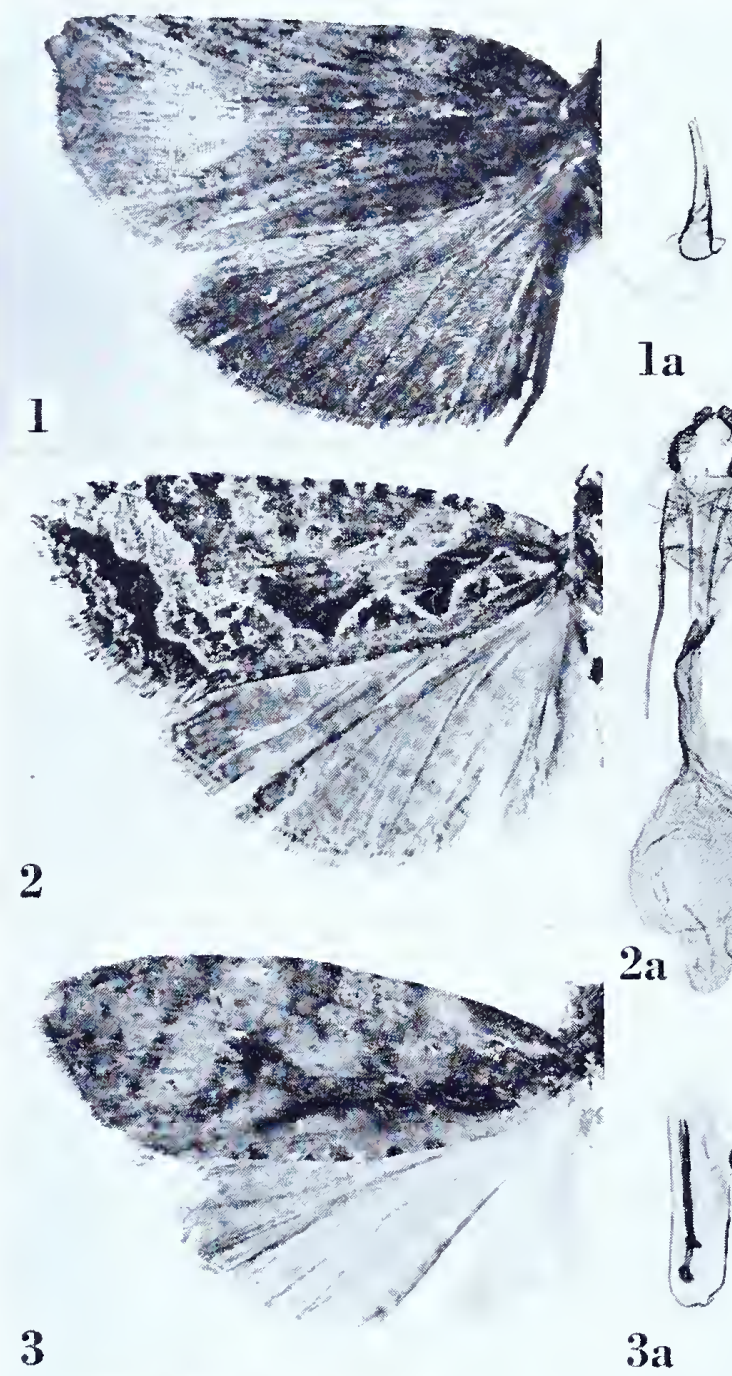

$2 a$
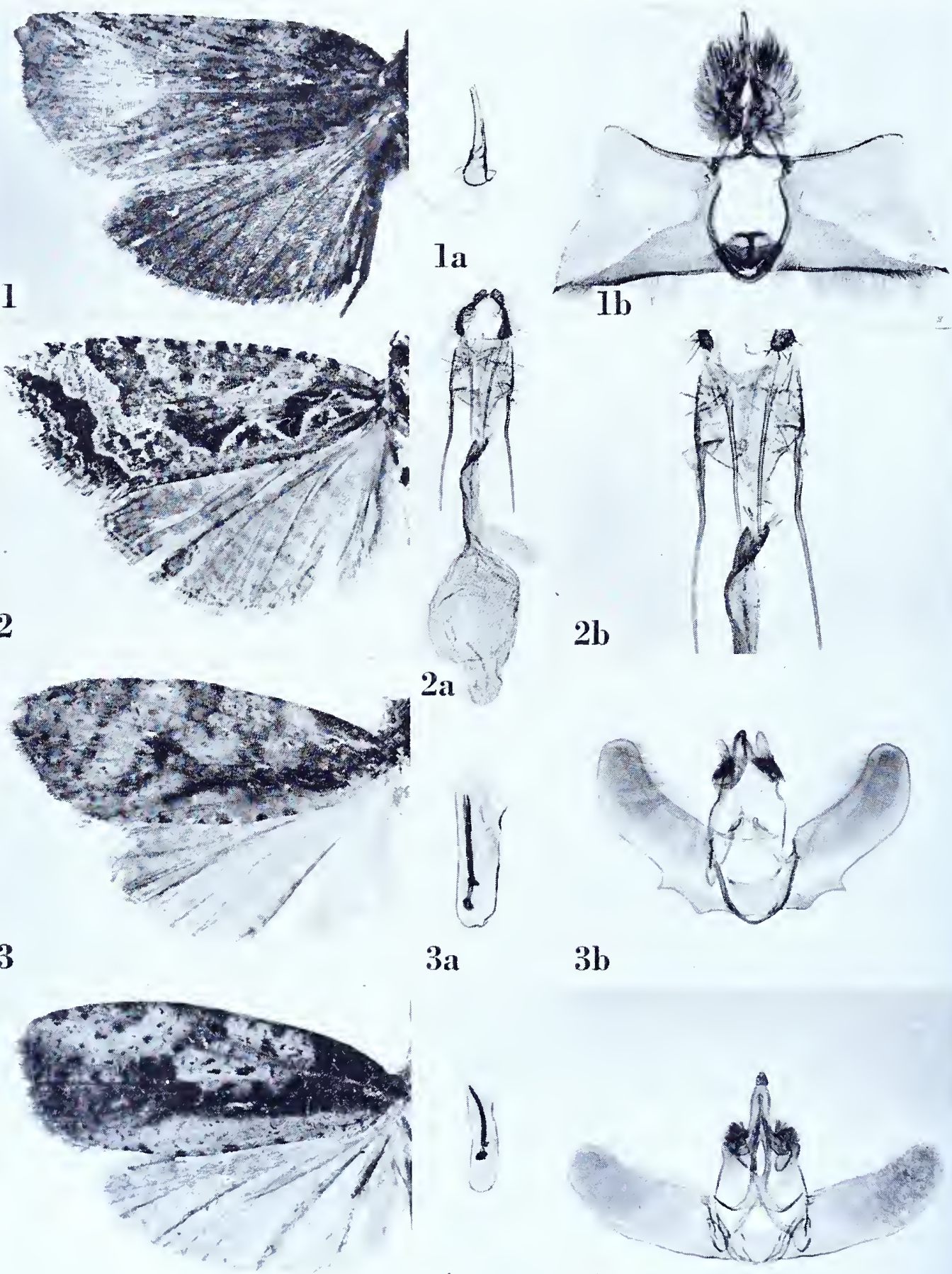

3a

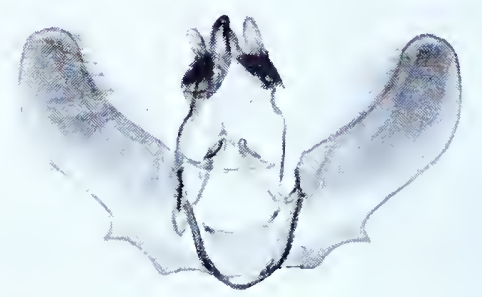

$3 b$

4
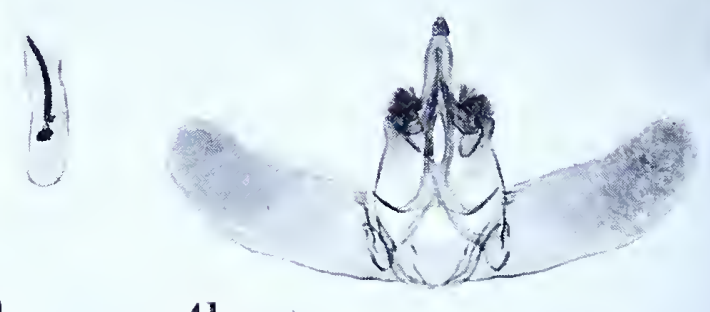

$4 a$

$4 b$

EULIA 


\section{Eulia umbellifera Meyrick}

Plate 7 I, Figures $\mathrm{I}-\mathrm{rb}$

Enlia umbellifera Meyrick, I 926, Exotic Microlepidoptera, 3: 254 .

“ f. $2 \mathrm{I}-35 \mathrm{~mm}$. . . Colombia, San Antonio (6,600 feet), Mt. Socorro ( 12,500 feet), Mt. Tolima (5,600-I2,500 feet); Io ex. Very variable; the largest forms from the higher levels."

Lectotype: A male measuring $34 \mathrm{~mm}$., "San Antonio, W. Colombia. R. 5,800" .r r.07." Slide No. 6325. Only four specimens remain in the Meyrick collection.

Figure I, left wings; Ia, ventral view of aedeagus; $\mathrm{s}$, ventral view of male genitalia with aedeagus removed.

\section{Eulia versabilis Meyrick}

Plate 7I, Figures 2-2b

Eulia versabilis Meyrick, I926, Exotic Microlepidoptera, 3:25I.

"†. $35 \mathrm{~mm}$. . . Bolivia, Andes, i o,000 feet; I ex."

Type: The specimen indicated above with ".20" in the lower right corner of the pin-label. Slide No. 6296.

Figure 2, left wings; 2 a, ventral view of female genitalia; $2 \mathrm{~b}$, enlarged view of genital plate, ostium and posterior portion of ductus bursae.

\section{Eulia xerophanes (Meyrick)}

Plate 7 I, Figures $3-3$ b

Tcrtrix xerophanes Meyrick, I909, 'Trans. Ent. Soc. London, 1909: I 5 .

" ô. $28 \mathrm{~mm}$. . . . Peru, Aqualani [sic]; one specimen."

Type: The specimen indicated above with "0. 9,000'.12.05" at the bottom of the pin-label. Slide No. 6323.

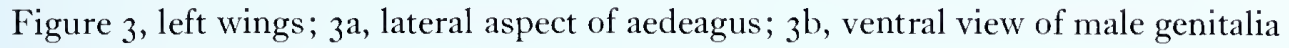
with aedeagus removed.

\section{Eulia zelotypa Meyrick}

Plate $7 \mathrm{r}$, Figures $4-4 \mathrm{~b}$

Eulia zelotypa Meyrick, г9г2, Trans. Ent. Soc. London, г9г г 679 .

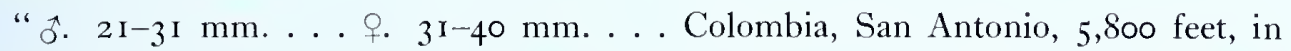
November and December; fifteen specimens ( $13 \hat{\delta}, 2$ P). Very similar to xerophanes, Meyr. (also referable to Eulia), but forewings broader . . . and xerophanes is without the hairpencil and black mark of hindwings."

Lectotype: A male measuring $3 \mathrm{r}$ mm., and dated ".r r.07". Slide No. 6322. Five of the males are missing.

Figure 4 , left wings; 4 a, lateral aspect of aedeagus; 4 b, ventral view of male genitalia with aedeagus removed. 


\section{GNORISMONEURA Issiki and Stringer \\ Gnorismoneura violascens Meyrick \\ Plate 72, Figures I-Ib}

Cimorismoneura violascens Meyrick, 1934, Exotic Microlepidoptera, 4: 525.

" zㅇ. 19-23 mm. ... W. China, Mt. Omei, 4,000-I I,000 feet, July (Franck); 4 ex." Lectotype: A male measuring $19 \mathrm{~mm}$., "Mt. Omei, W. China, $4,000^{\prime} \cdot 7 \cdot 32$." Slide No. 6765 .

Figure I, left wings; Ia, aedeagus; $\mathrm{Ib}$, ventral view of male genitalia with aedeagus removed.

\section{HARMOLOGA Meyrick \\ Harmologa athliopa Meyrick}

Plate 72 , Figures $2-2 \mathrm{c}$

Harmologa athliopa Meyrick, I938, 'T'rans. R. Ent. Soc. London, 87: 506.

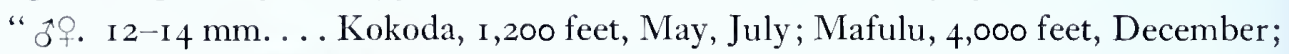
5 ex. Allied to H. miserana Walk., ..."

Type: A female so marked in the British Museum, "Mafulu, Papua, 4,000 ft. xii.1933. L. E. Cheesman." Slide No. 7028.

Figure 2, left wings; $2 \mathrm{a}$, ventral view of female genitalia; $2 \mathrm{~b}$, detail of ostium; $2 c$, signum.

See Xyloryctidae.

\section{LASIODICTIS Meyrick}




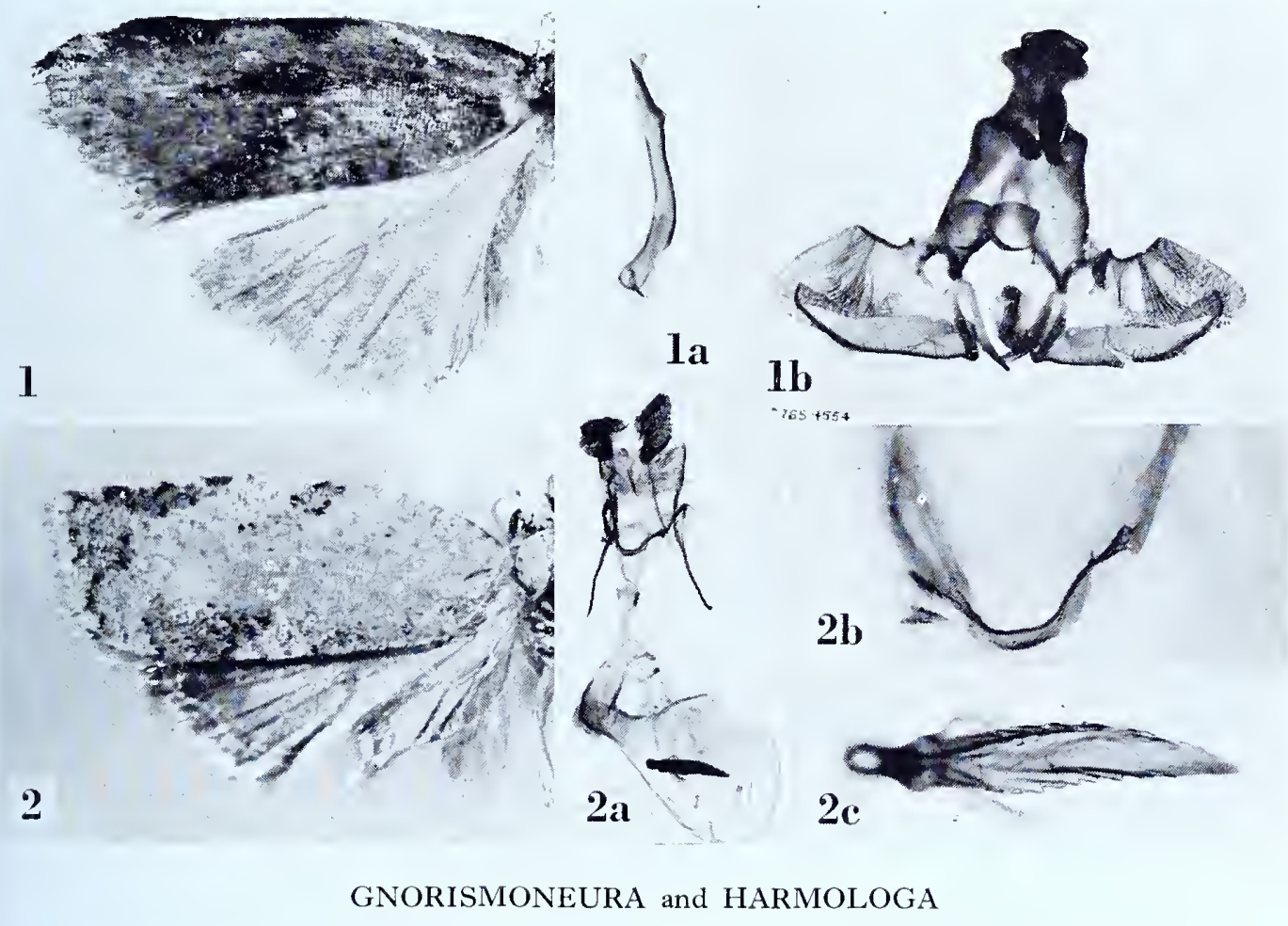




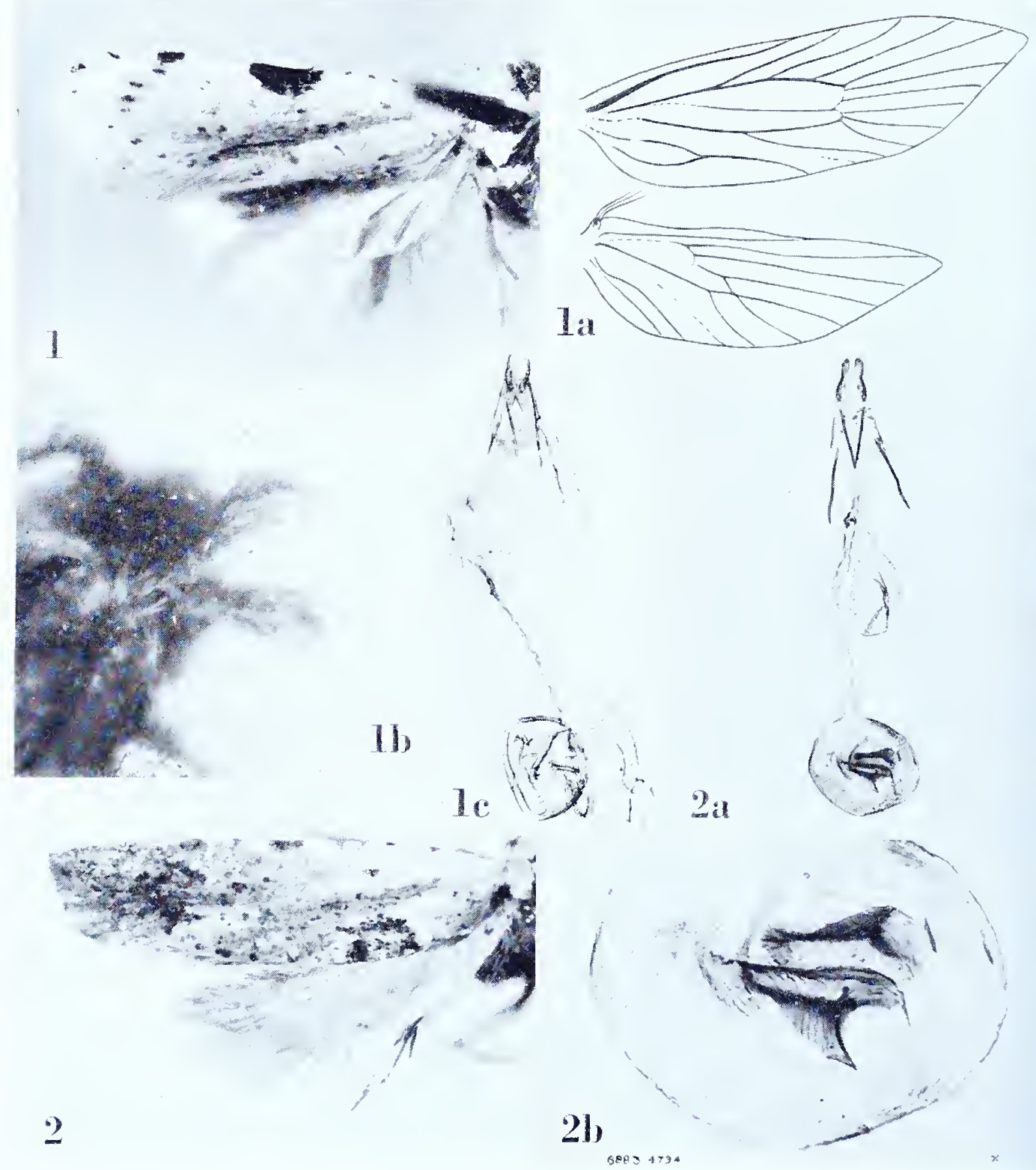

HOMALERNIS 


\section{HOMALERNIS Meyrick}

Homalernis Meyrick, 1908, Journ. Bombay Nat. Hist. Soc., 18: 620. (Typus generis: Homalernis semaphora Meyrick, ibid. [monotypy].)

\section{Homalernis semaphora Meyrick}

Plate 73, Figures I-IC

Homalernis semaphora Meyrick, 1908, Journ. Bombay Nat. Hist. Soc., i 8: 620.

" $‡$. $12 \mathrm{~mm}$. . . Khasis, in June; two specimens."

Lectotype: A female. Both specimens are females, "Khasi Hills, Assam. .6.rgo6." Slide No. Diakonoff 1148 .

Figure $\mathrm{I}$, left wings; $\mathrm{a}$, venation of right wings; $\mathrm{I} b$, lateral view of head to show palpus; Ic, ventral view of female genitalia (damaged and with spermatophore in bursa copulatrix).

\section{Homalernis arystis Meyrick}

Plate 73, Figures 2-2b

Homalernis arystis Meyrick, I918, Exotic Microlepidoptera, 2: I6g.

"१. $12 \mathrm{~mm}$. . . Assam, Khasis, June; one specimen."

Type: The above indicated female, "Khasis Hills, Assam, .6.r go6." Slide No. 6883.

Figure 2, left wings; $2 \mathrm{a}$, ventral view of female genitalia; $2 \mathrm{~b}$, signa. 
HOMONA

\section{HOMONA Walker \\ Homona biscutata Meyrick \\ Plate 74, Figures I-Ib}

Homona biscutata Meyrick, I93 I, Exotic Microlepidoptera, 4: I 49.

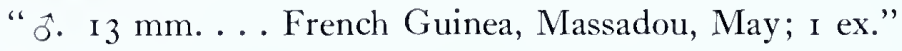

Type: The above indicated male, "Massadou, Fr. Guinea. CLC. .5.28." Slide No. 9338 .

Figure I, left wings; $\mathrm{Ia}$, lateral aspect of aedeagus; $\mathrm{Ib}$, ventral view of male genitalia with aedeagus removed.

\section{Homona capnobathra Meyrick}

Plate 74, Figures 2-2b

Homona capnobathra Meyrick, I930, Exotic Microlepidoptera, 3:605.

"§. $28 \mathrm{~mm}$. . . . Madagascar; I ex. (Coll. Paravicini)."

Type: The male so marked in the British Museum, without specific locality or date. A small white label bears the inscription "Mro34". Slide No. 9428.

Figure 2, left wings; $2 \mathrm{a}$, lateral aspect of aedeagus; $2 \mathrm{~b}$, ventral view of male genitalia with aedeagus removed.

\section{Homona cerioschema Meyrick \\ Plate 74, Figure 4}

Homona cerioschema Meyrick, I 934, Exotic Microlepidoptera, 4: $5^{26 .}$

"ๆ. 3 I mm. ... Uganda, Kampala, December (H. Hargreaves); 2 ex. (type Brit. Mus.)."

Type: The female, without abdomen, so marked in the British Museum dated "29.xii.1932". A long, pale blue label in Meyrick's hand reads "Homona cerioschema n. sp.".

Figure 4 , left wings.

\section{Homona fatalis Meyrick}

Plate 74, Figures 3-3a

Homona fatalis Meyrick, I936, Exotic Microlepidoptera, 5: 59 .

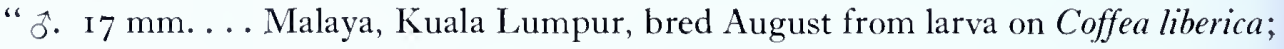
I ex. (Brit. Mus.)."

Type: 'The male so marked in the British Museum, "9669 Malaya, K Lumpur. 4.8.1934. Entom. Div. Agric. Dept. Coffea liberica." A white label bears the number "944". A long, pink label in Meyrick's hand reads "Homona fatalis n. sp." Slide No. Diakonoff 274 .

Figure 3, left wings; 3 a, ventral view of male genitalia (left harpe excluded) with aedeagus in situ.

[continued on $p . I_{5}$. 

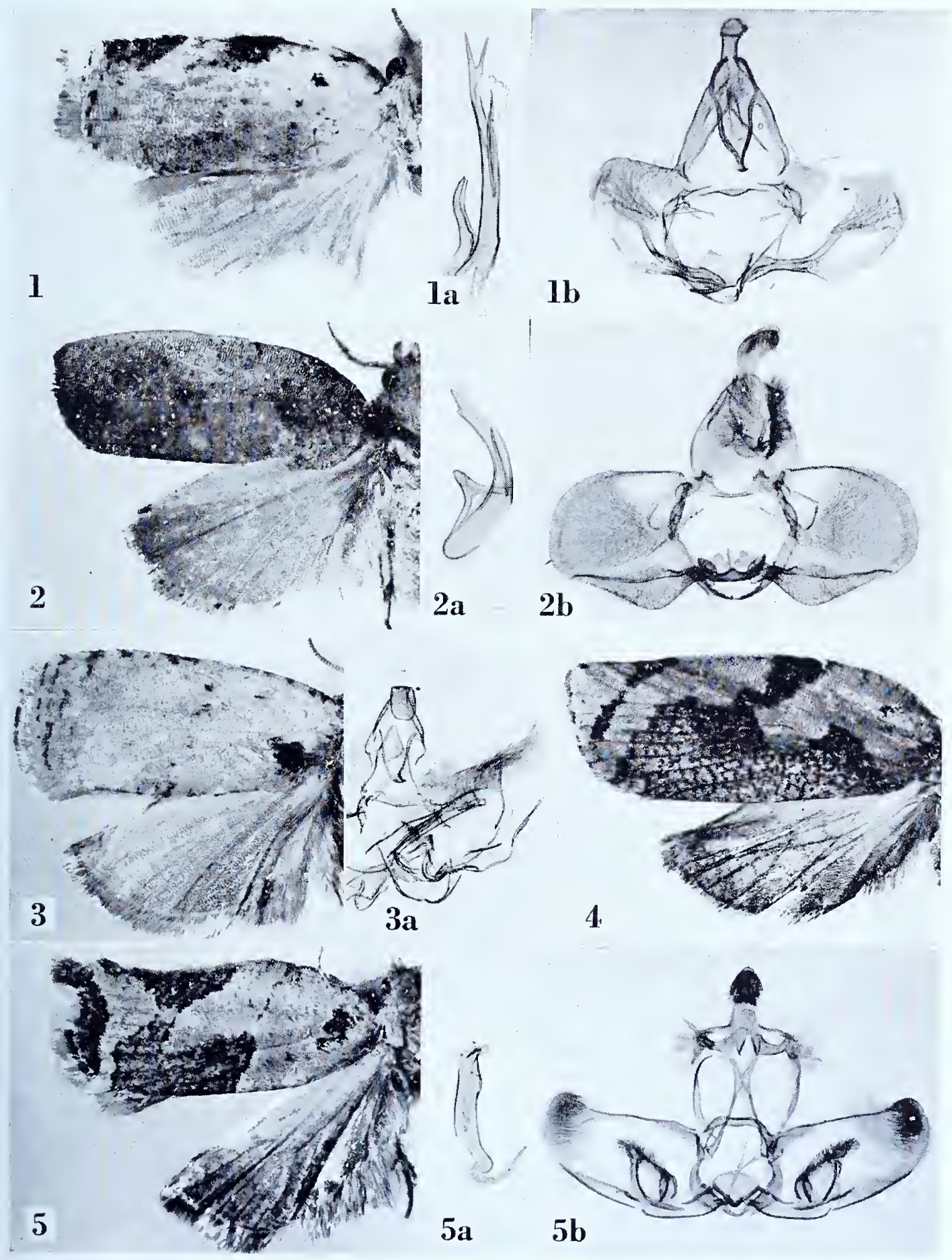

HOMONA 


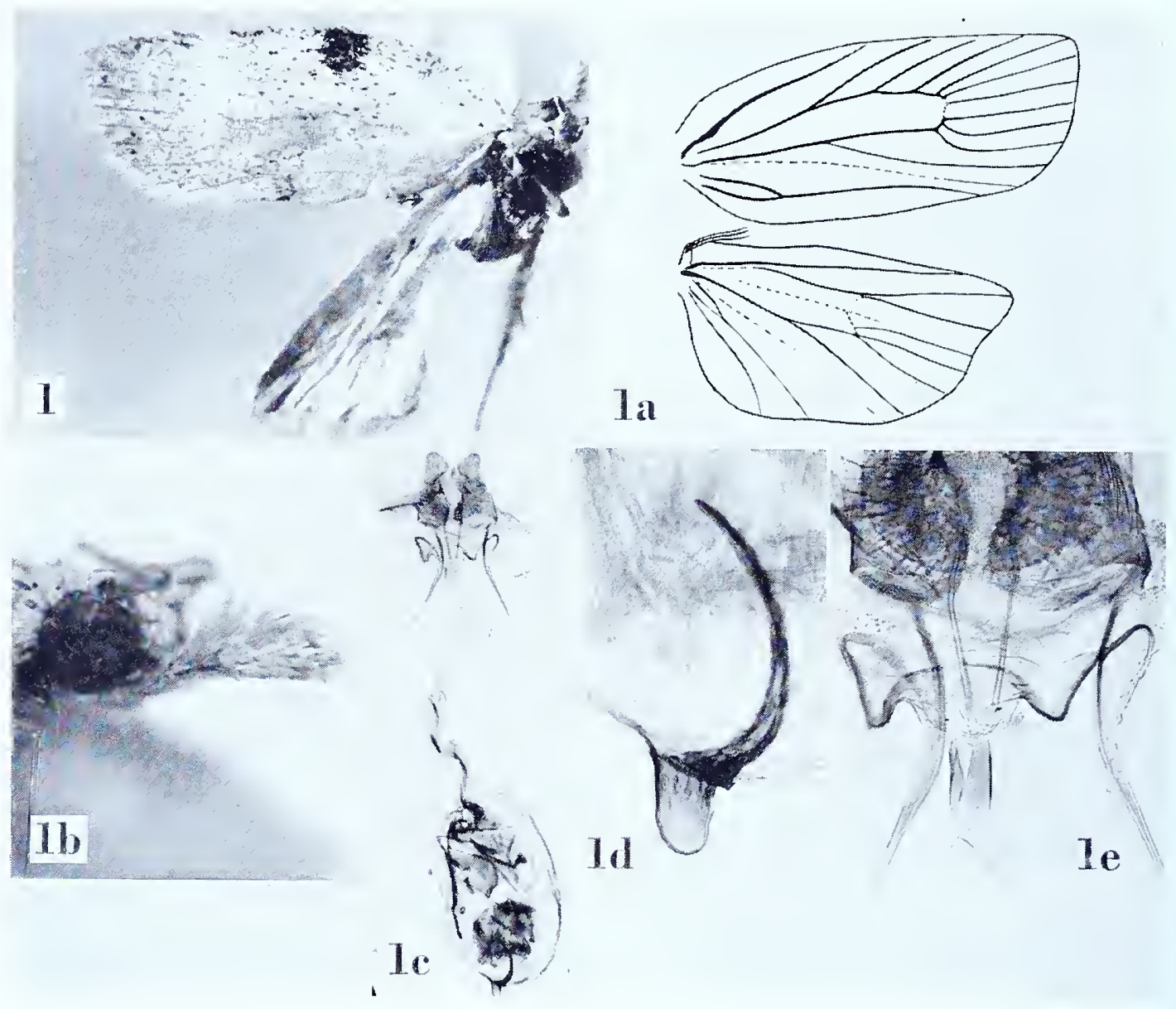

ISOTENES 


\section{ISOTENES Meyrick}

Isotenes Meyrick, 1938, Trans. R. Ent. Soc. London, 87: 507. (Typus generis: Isotenes melanoclera Meyrick, ibid. [monotypy].)

\section{Isotenes melanoclera Meyrick}

Plate 75 , Figures I $^{-}$Ie

Isotenes melanoclera Meyrick, I938, Trans. R. Ent. Soc. London, 87: 507.

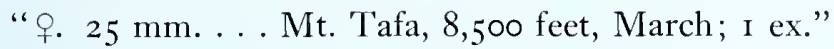

Type: The above indicated specimen so marked in the British Museum, "Mt. Tafa, Papua, 8,500 ft., III-r 934. L. E. Cheesman.” Slide No. Diakonoff I I 55 .

Figure I, left wings; Ia, venation of right wings; $\mathrm{Ib}$, lateral view of head to show palpus; ic, ventral view of female genitalia (spermatophore and extraneous matter in bursa copulatrix); Id, signum; Ie, detail of genital plate and ostium.

Continued from $p .1 \neq 8$.

\section{Homona simana (Meyrick)}

Plate 74 , Figures $5^{-} 5^{\mathrm{b}}$

Anisogona simana Meyrick, I88I, Proc. Linnean Soc. New South Wales, 6: 465.

" ${ }^{\pi} 7 \frac{1}{2}$ ", $q 88_{2}^{1}$ ". . . Mr. G. H. Raynor took three specimens . . at Waratah on the Hunter River, New South Wales, in September."

Type: The male so marked in the British Museum, "Waratah, N. S. Wales. 27.ix.1 878. Raynor iо 33." Slide No. 9429.

Figure 5 , left wings; 5 a, lateral aspect of aedeagus; 5 b, ventral view of male genitalia with aedeagus removed. 


\section{LOPHOPRORA Meyrick}

Lophoprora Meyrick, I930, Exotic Microlepidoptera, 3: 6I I. (Typus generis: Lophoprora cyanostacta Meyrick, ibid. [monotypy].)

\section{Lophoprora cyanostacta Meyrick \\ Plate 76 , Figures $\mathrm{I}-\mathrm{I} b$}

Lophoprora cyanostacta Meyrick, I930, Exotic Microlepidoptera, 3: 6I I.

"

Type: The male, without head, so marked in the British Museum "Kumusi, R., N.E. Brit. N. Guin., low elev., v.-ix. 1907 (A. S. Meek)." A small white label bears the inscription "M593". Slide No. Diakonoff 277.

Figure I, left wings; $\mathrm{I}$, venation of right wings; $\mathrm{Ib}$, ventral view of male genitalia with aedeagus in situ.

See Olethreutidae.

\section{MACRAESTHE'TICA Meyrick}



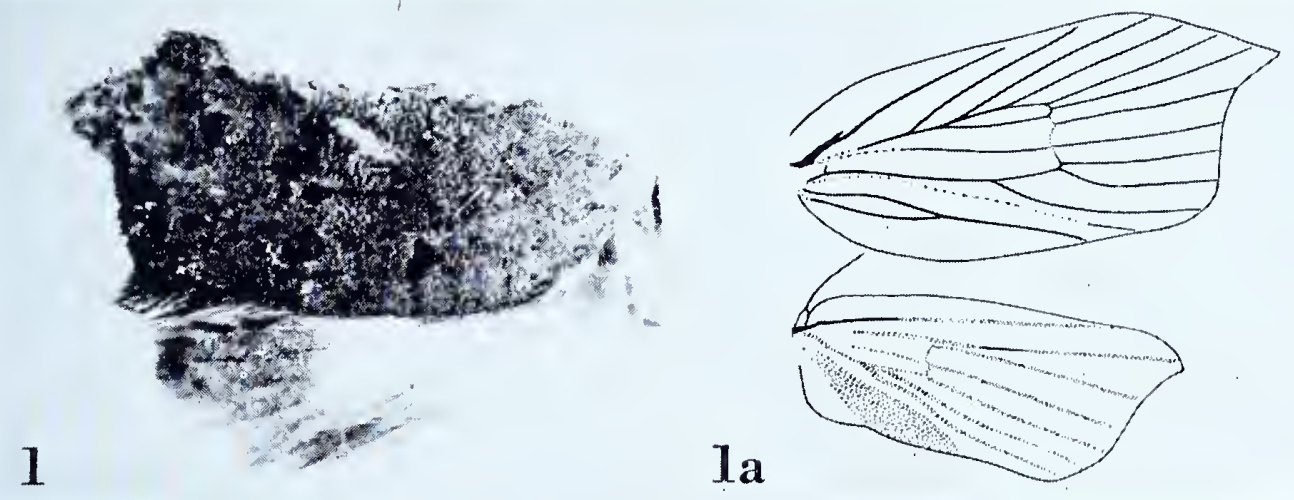

lb

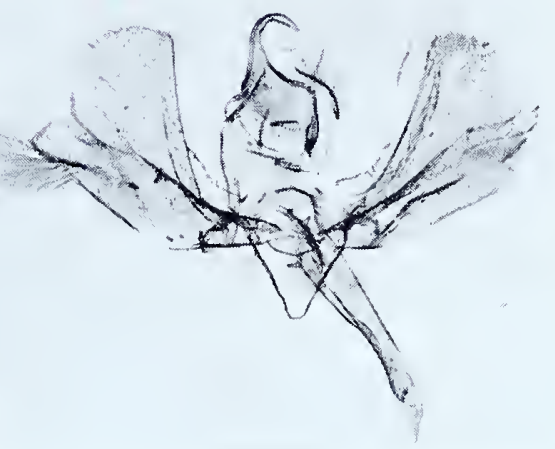

LOPHOPRORA 


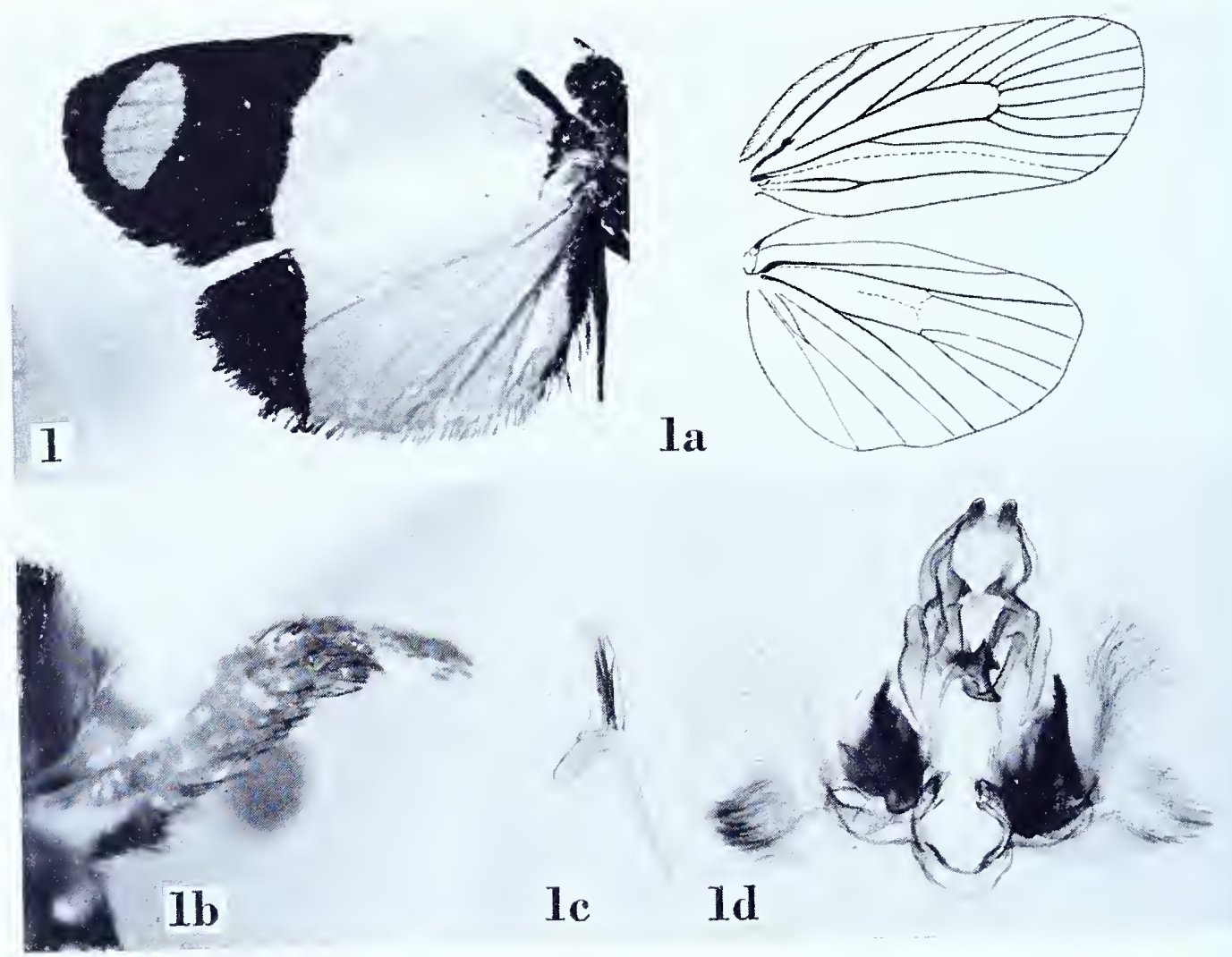

MEGALODORIS 


\section{MEGALODORIS Meyrick}

Megalodoris Meyrick, I912, Exotic Microlepidoptera, I: 5. (Typus generis: Atteria stephanitis Meyrick, I910, Trans. Ent. Soc. London, 1910: 433 [by original designation].) This genus is a synonym of Zacorisca Meyrick.

\section{Megalodoris stephanitis (Meyrick)}

Plate 77, Figures I-Id

Atteria stephanitis Meyrick, I910, 'Trans. Ent. Soc. London, I910: 433.

"

Lectotype: The male dated ". 11.96 ". Slide No. 6825.

Figure I, left wings; Ia, venation of right wings; Ib, lateral view of palpus; Ic, lateral aspect of aedeagus; $\mathrm{Id}$, ventral view of male genitalia with aedeagus removed. 


\section{MERI'TAS'TIS Meyrick}

Meritastis Meyrick, i9 10, Proc. Linnean Soc. New South Wales, 35:255. (Typus generis: Meritastis umbrosa Meyrick, ibid. [monotypy].)

\section{Meritastis umbrosa Meyrick}

Plate 78 , Figures I-Id

Meritastis umbrosa Meyrick, ı9ı, Proc. Linnean Soc. New South Wales, 35:255.

Figured from a specimen in the British Museum. Slide No. 9574.

Figure I, left wings; Ia, venation of right wings; $\mathrm{ib}$, lateral view of head to show palpus; ic, lateral aspect of aedeagus; Id, ventral view of male genitalia with aedeagus removed.

\section{Meritastis voluta Meyrick \\ Plate 78 , Figures 2-2b}

Meritastis voluta Meyrick, I9ı2, Trans. Ent. Soc. London, I9ı I: 677.

“ '. $23 \mathrm{~mm}$. . . Colombia, San Antonio, 5,000 [sic!] feet, in November; one specimen."

Type: The above indicated specimen labelled, "San Antonio, W. Colombia, 5,80o' .r I.07". Slide No. $66_{3} 6$.

Figure 2, left wings; $2 \mathrm{a}$, lateral aspect of aedeagus; $2 \mathrm{~b}$, ventral view of male genitalia with aedeagus removed.

\section{MNESIPYRGA \\ Mnesipyrga trichostrota Meyrick}

See Noctuidae, page 600. 

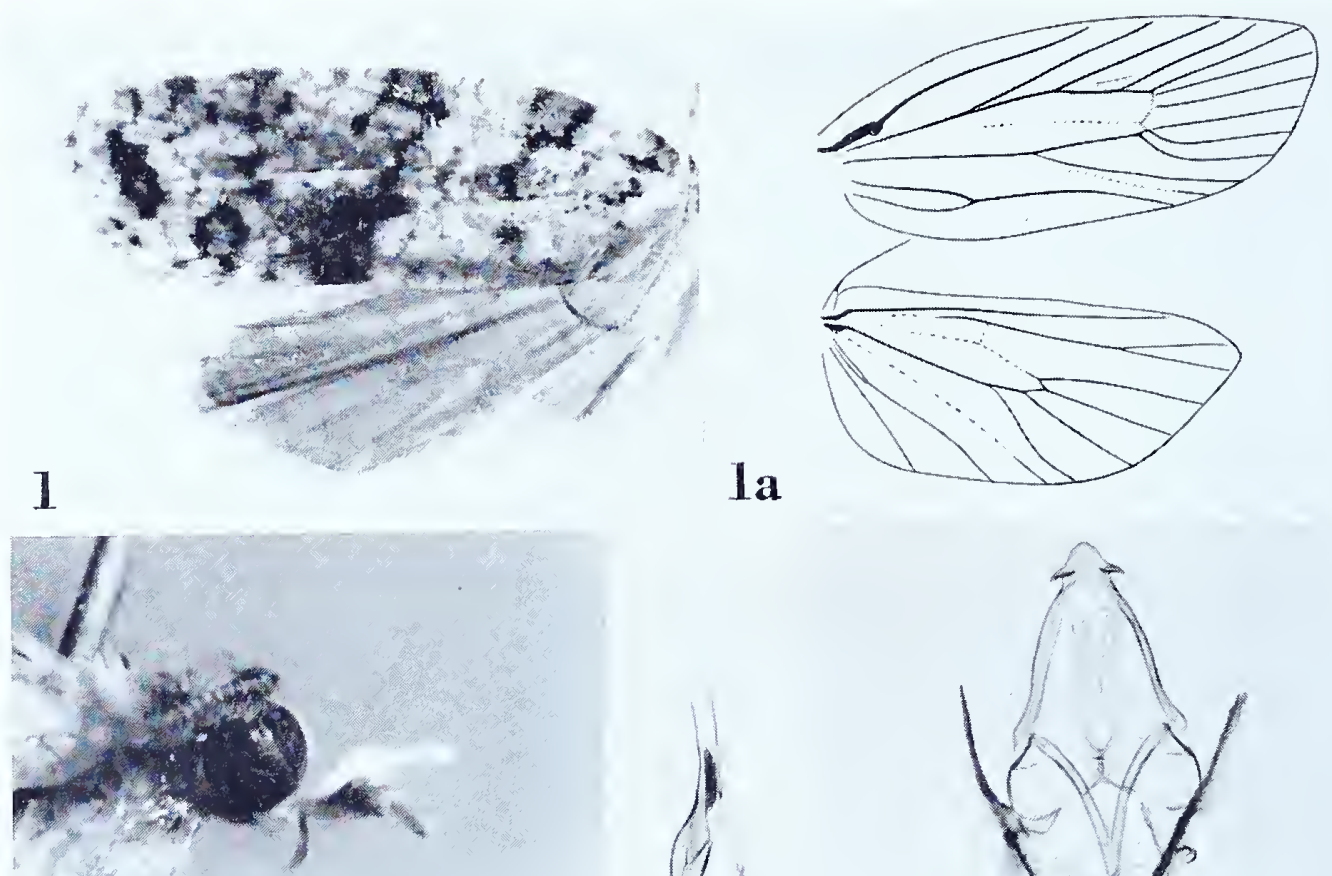

\section{1b}
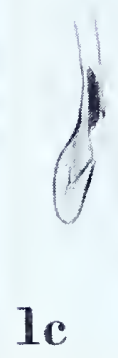

\section{Id}

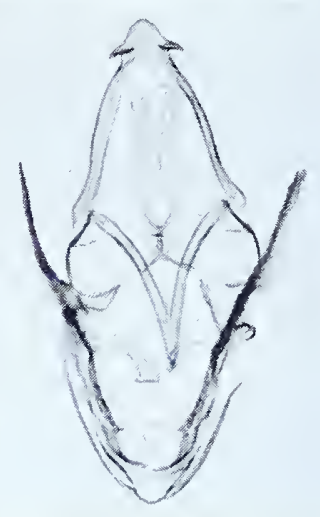

NESOSCOPA 


\section{NESOSCOPA Meyrick}

Nesoscopa Meyrick, 1926, Trans. Ent. Soc. London, 74: 271. (Typus generis: Nesoscopa exsors Meyrick, ibid. [monotypy].)

\section{Nesoscopa exsors Meyrick}

$$
\text { Plate 79, Figures I-Id }
$$

Nesoscopa exsors Meyrick, 1926, Trans. Ent. Soc. London, 74: 271.

"今. I 5-1 $6 \mathrm{~mm}$. . . . At 800 feet; 3 ex."

Type: The male, without abdomen, so marked in the British Museum, "Rapa Island. At light, 800 ft., I 5.4.25, St. George Expedn. C. L. Collenette." Male genitalia figured from a "cotype" with identical data. Slide No. 9426.

Figure I, left wings; Ia, venation of right wings; $\mathrm{rb}$, lateral view of head to show palpus; Ic, lateral aspect of aedeagus; id, ventral view of male genitalia with aedeagus removed. 


\section{OR'THOCOMOTIS Dognin}

\section{Orthocomotis citroleuca (Meyrick)}

Plate 8o, Figure I

Cnephasia citroleuca Meyrick, I912, Trans. Ent. Soc. London, I9 I : 683.

Orthoconotis citrolenca (Meyrick), Clarke, I955, Trans. R. Ent. Soc. London, ro7: i 55.

" $\hat{0}$. $23 \mathrm{~mm}$. . . . Colombia, San Antonio, 5,80o feet, in November; one specimen."

Type: The above indicated specimen dated “. I I.07". The abdomen of the type is missing.

Figure $\mathrm{I}$, left wings.

\section{Orthocomotis smaragditis (Meyrick)}

Plate 8o, Figures 2-2b

Eulia sunaragditis Meyrick, I9 2, Exotic Microlepidoptera, I : I I.

Orthocomotis smaragditis (Meyrick), Clarke, I955, Trans. R. Ent. Soc. London, I07: I 49.

" $\hat{o}$. $24 \mathrm{~mm}$. . . A Argentina, Parana, in October; one specimen."

Type: The specimen referred to above labelled, "Rio Parana, Argentina, LeM. . I6". Slide No. 6300.

Figure 2, left wings; $2 \mathrm{a}$, lateral aspect of aedeagus; $2 \mathrm{~b}$, ventral view of male genitalia with aedeagus removed. 

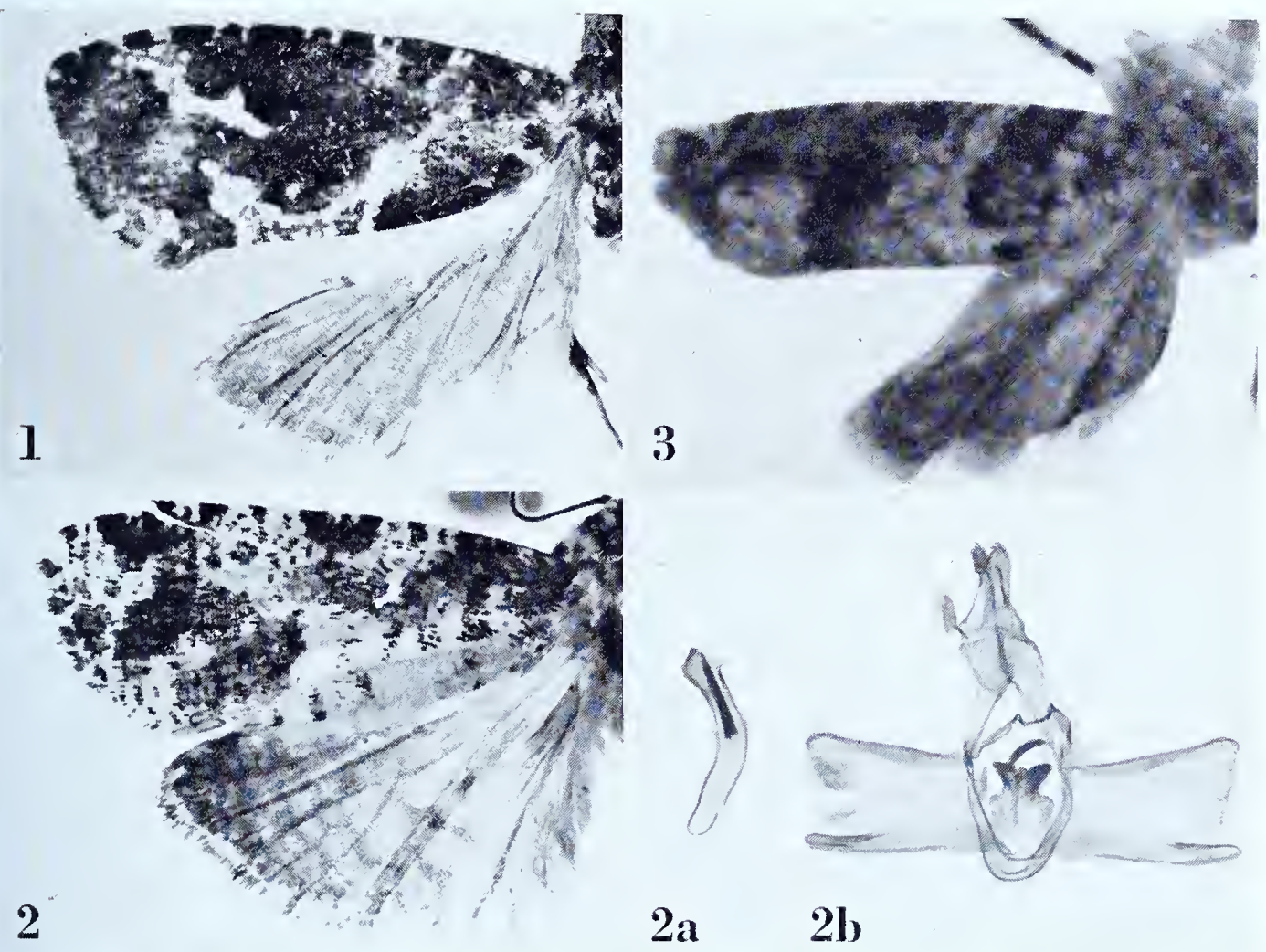

$2 a \quad 2 b$

OR'THOCOMOTIS and EUCOSMA 


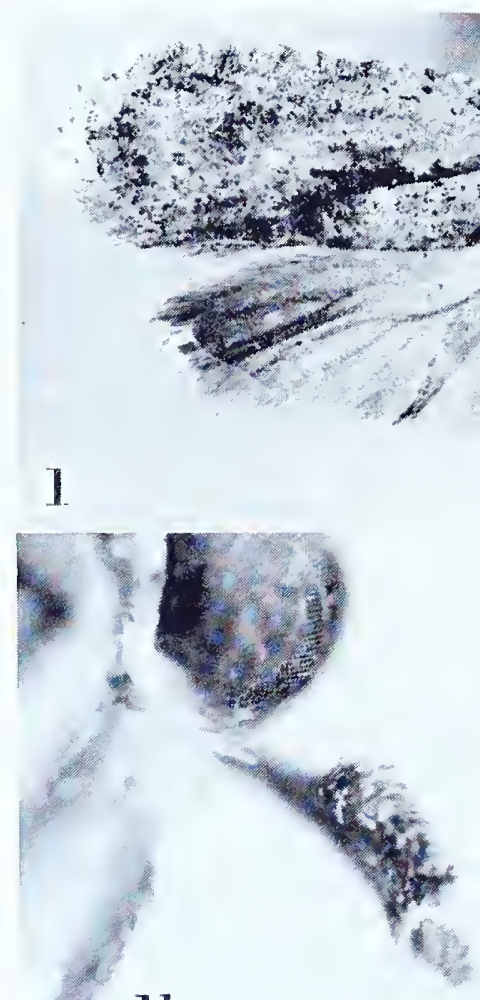

lb
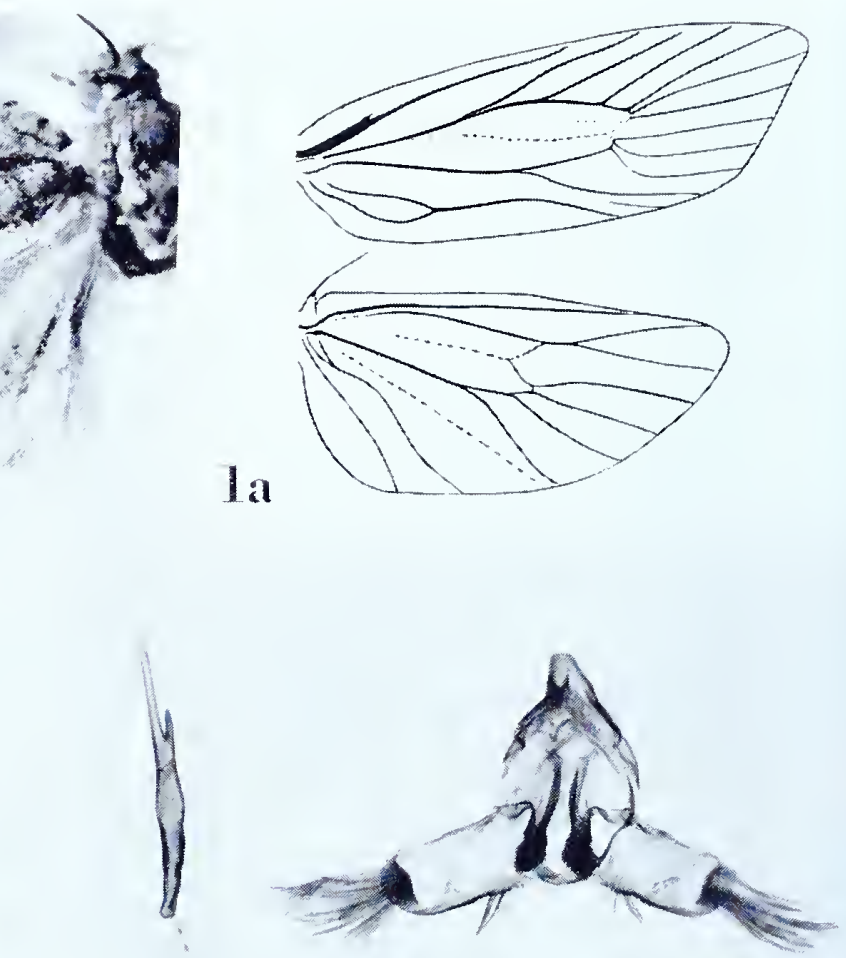

$1 c$

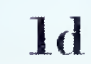

PALAEOTOMA 


\section{PALAEOTOMA Meyrick}

Palaeotoma Meyrick, I882, Proc. Linnean Soc. New South Wales, 6: 422. (Typus generis: Palaeotoma styphelana Meyrick, 1.c., p. 423 [monotypy].)

\section{Palaeotoma styphelana Meyrick}

Plate 8I, Figures I-Id

Palaeotomu styphelana Meyrick, i 882, Proc. Linnean Soc. New South Wales, 6: 423.

" 0 fo. $6 "-8$ " . . three specimens at rest near Sydney in September and January." Lectotype: A male, "Sydney, N. S. Wales. 6/9/79." Slide No. 6985.

Figure $\mathrm{I}$, left wings; $\mathrm{ra}$, venation of right wings; $\mathrm{rb}$, lateral view of labial palpus; Ic, lateral aspect of aedeagus; Id, ventral view of male genitalia with aedeagus removed. 


\section{PANDEMIS Hübner \\ Pandemis dryoxesta Meyrick \\ Plate 82, Figures $1-\mathrm{Ib}$}

Pandemis dryoxesta Meyrick, 1920, Exotic Microlepidoptera, 2:341.

" fof $^{\circ}$. 23-25 mm. . . Punjab, Murree, 7,500 feet, June (Dutt); I I ex. Nearest the Mongolian praefloratana...."

Lectotype: A male measuring $25 \mathrm{~mm}$. Slide No. $685^{6}$. The four specimens remaining in the Meyrick collection bear identical data and are dated ".6.18".

Figure $\mathrm{I}$, left wings; $\mathrm{ra}$, lateral aspect of aedeagus; $\mathrm{ib}$, ventral view of male genitalia with aedeagus removed.

\section{Pandemis emptycta Meyrick}

Plate 82, Figures 2-2b

Pandemis emptycta Meyrick, 19.37, Exotic Microlepidoptera, 5: ${ }_{5} 6$.

" o. $22 \mathrm{~mm}$. . . China, Pehlingting, 6,000 feet, July (Franck); I ex. The only species of the genus with a costal fold."

Type: The male indicated above dated “.7.32". Slide No. 6854 .

Figure 2, left wings; $2 \mathrm{a}$, lateral aspect of aedeagus; $2 \mathrm{~b}$, ventral view of male genitalia with aedeagus removed. 

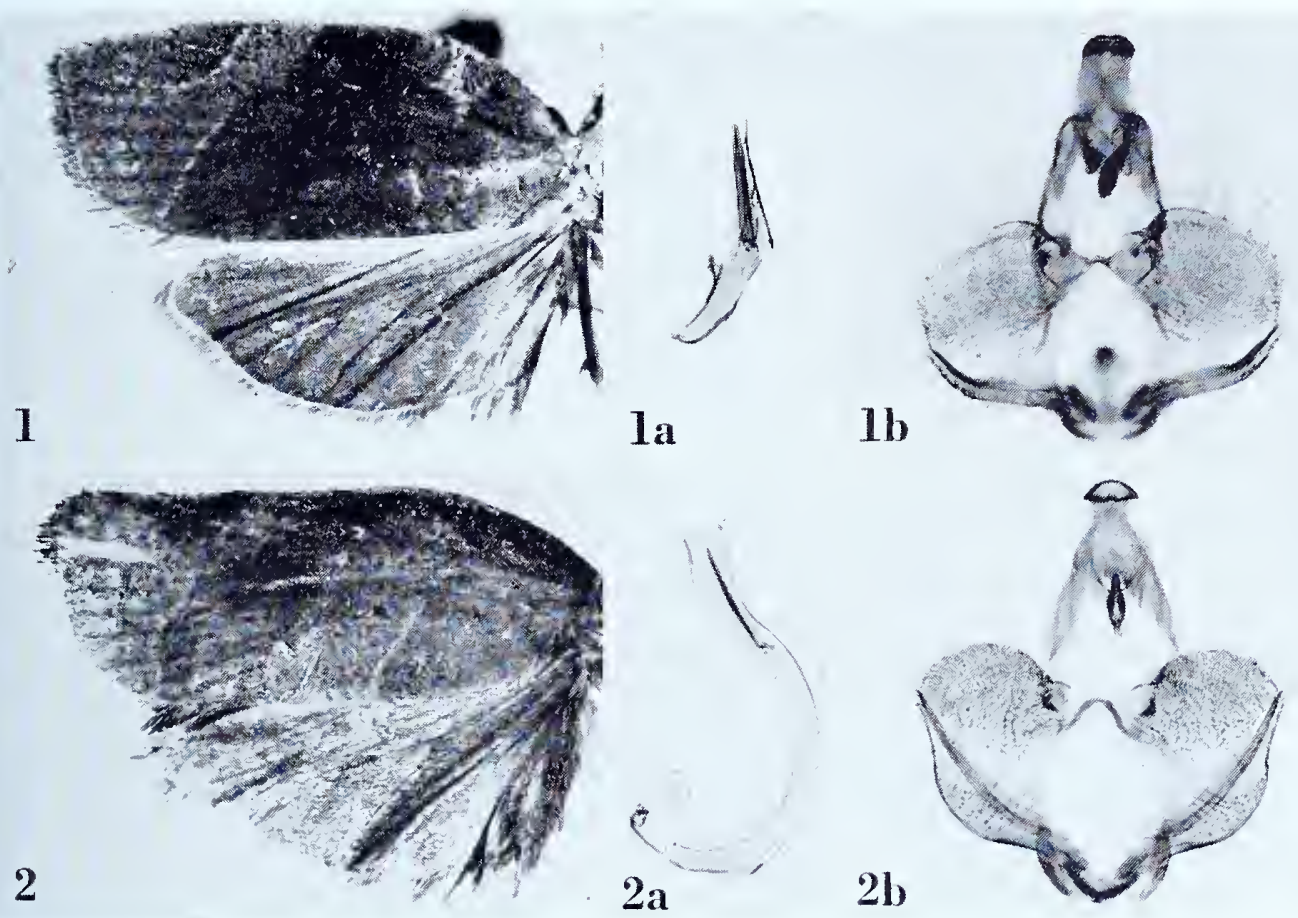

2
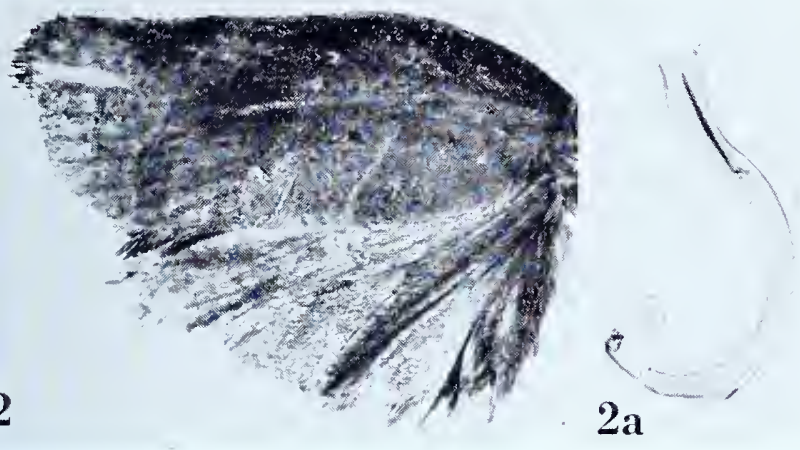

2b

PANDEMIS 


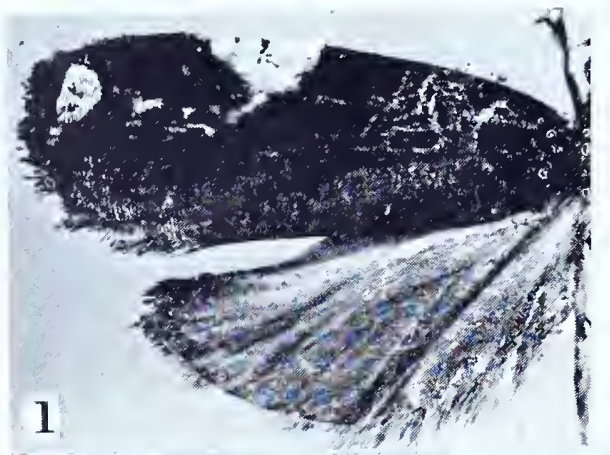

$1 a$
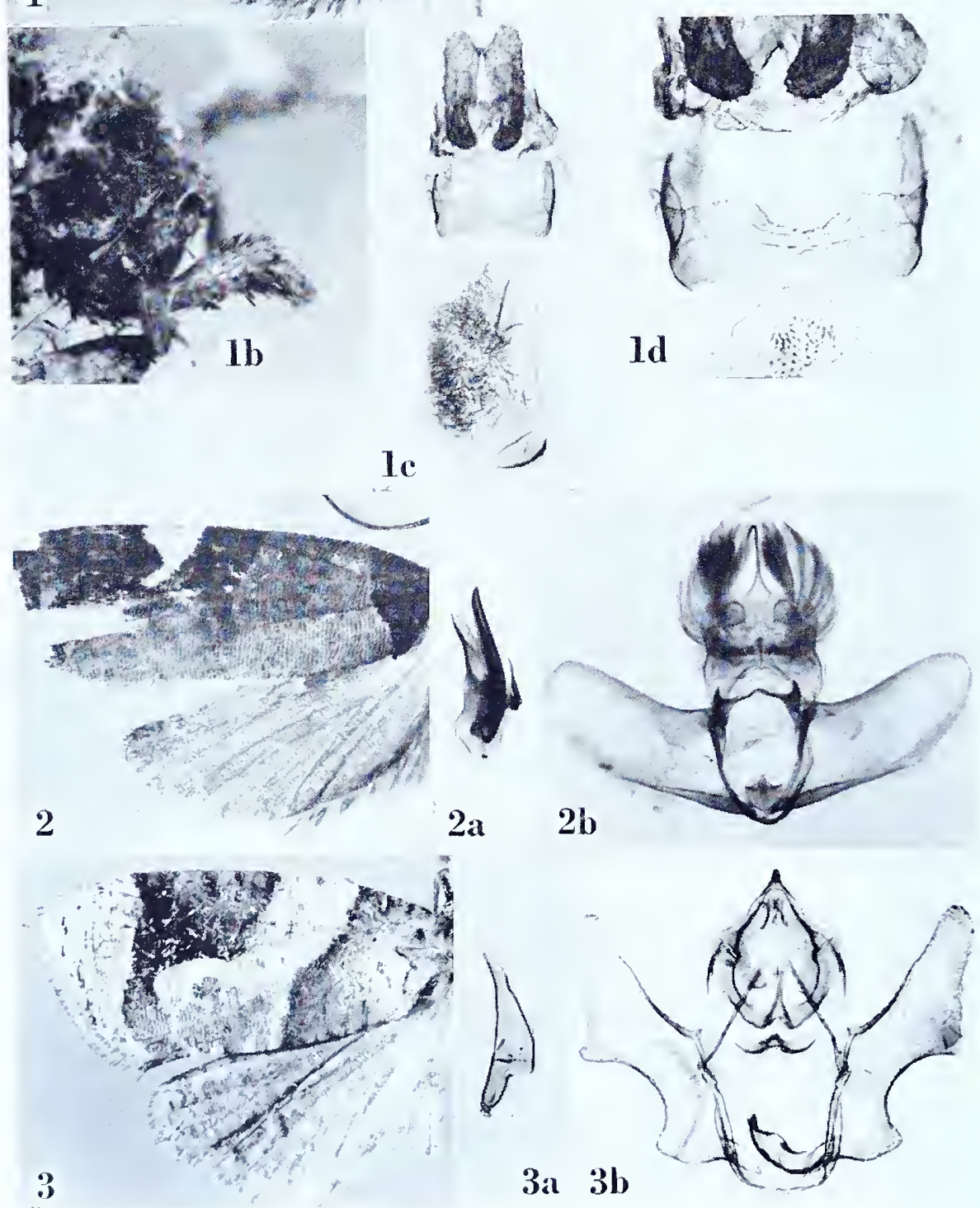

PARAP'TILA 


\section{PARAPTILA Meyrick}

Paraptila Meyrick, 1912, Trans. Ent. Soc. London, 191 1: 677. (Typus generis: Paraptila argocosma Meyrick, ibid. [monotypy].)

\section{Paraptila argocosma Meyrick \\ Plate 83 , Figures I-Id}

Paraptila argocosma Meyrick, i 912, Trans. Ent. Soc. London, i91 I: 677.

"․ $24^{-25} \mathrm{~mm}$. . . Colombia, San Antonio, 5,800 feet, in November; two specimens."

Lectotype: The larger of the two females both of which are dated ".11.07". Slide No. 636r.

Figure I, left wings; 1 a, venation of right wings; $\mathrm{i} b$, lateral aspect of head to show palpus; ic, ventral view of female genitalia; id, detail of genital plate and ostium.

\section{Paraptila infusoria Meyrick}

Plate $8_{3}$, Figures $2-2$ b

Paraptila infusoria Meyrick, 1926, Exotic Microlepidoptera, 3: 259 .

"đ̃, ૧. . . . Costa Rica, San José; 4 ex."

Lectotype: The male, with ".22" in the lower right corner of the pin-label. Slide No. 4444 .

Figure 2 , left wings; $2 \mathrm{a}$, lateral aspect of aedeagus; $2 \mathrm{~b}$, ventral view of male genitalia with aedeagus removed.

\section{Paraptila hydrochroa Meyrick}

Plate 83 , Figures $3-3$ b

Paraptila hydrochroa Meyrick, 1930, Exotic Microlepidoptera, 3: 61 о.

“ $\hat{0}$. $17 \mathrm{~mm}$. . . Ecuador, Hacienda Cayandeled, Prov. Rio Bamba, 4,200 feet, February; i ex. (Coll. Paravicini)."

Type: The male so marked in the British Museum, "Hacienda Cayandeled, Prov. Rio Bamba. (Versant Ouest Cordilleres) 4,200' Fevrier I 883. Stolzmann." A small white label bears the inscription "M43". Slide No. 943I.

Figure 3 , left wings; 3 a, lateral aspect of aedeagus; 3 b, ventral view of male genitalia with aedeagus removed. 


\section{PARASELENA Meyrick}

Paraselena Meyrick, 1910, Proc. Linnean Soc. New South Wales, 35: 164. (Typus generis: Paraselena thamnas Meyrick, l.c., I 65 [by original designation].)

\section{Paraselena thamnas Meyrick \\ Plate 84 , Figures $\mathrm{I}-\mathrm{Id}$}

Paraselena thamnas Meyrick, I910, Proc. Linnean Soc. New South Wales, 35: 165.

" ${ }^{\circ}$. I 2 mm. ... S. Aust., Adelaide, in October; two specimens."

Lectotype: A male, "Adelaide, S. Australia, 19/10/82." Slide No. 6742. One of the original specimens is missing.

Figure I, left wings; $\mathrm{xa}$, venation of right wings; $\mathrm{I} b$, lateral aspect of head to show palpus; Ic, lateral aspect of aedeagus; $\mathrm{rd}$, ventral view of male genitalia with aedeagus removed.

\section{Paraselena tenella Meyrick}

Plate 84 , Figures 2-2a

Paraselena tenella Meyrick, I9ro, Proc. Linnean Soc. New South Wales, 35: r64. "․ $8 \mathrm{~mm}$. . . N.S.W. Bathurst, 2,500 feet, in November; one specimen."

Type: The female indicated above labelled, "Bathurst, N.S. Wales. 7/1 I/84". Slide No. 674x.

Figure 2, left wings; 2a, ventral view of female genitalia. 


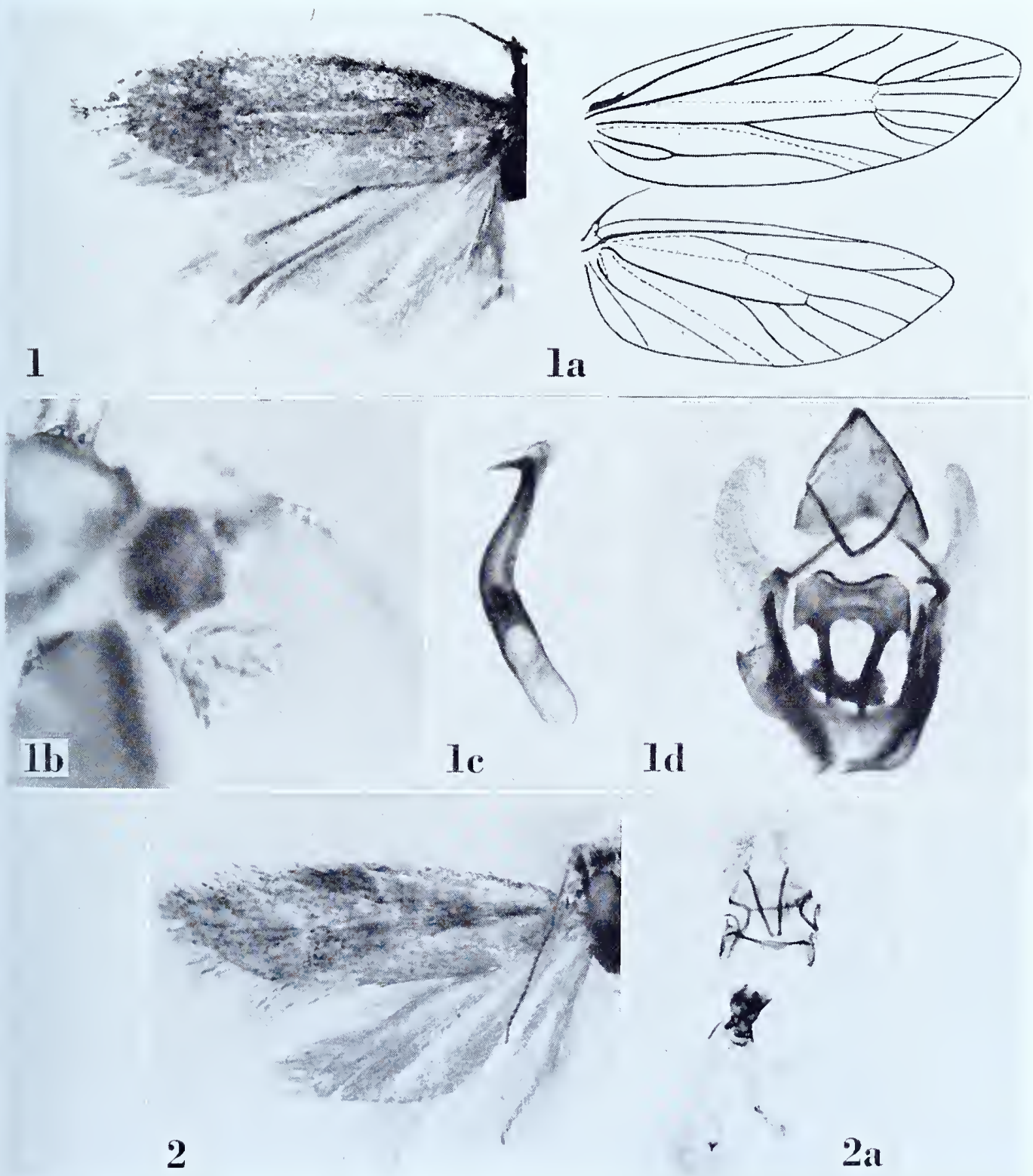

PARASELENA 

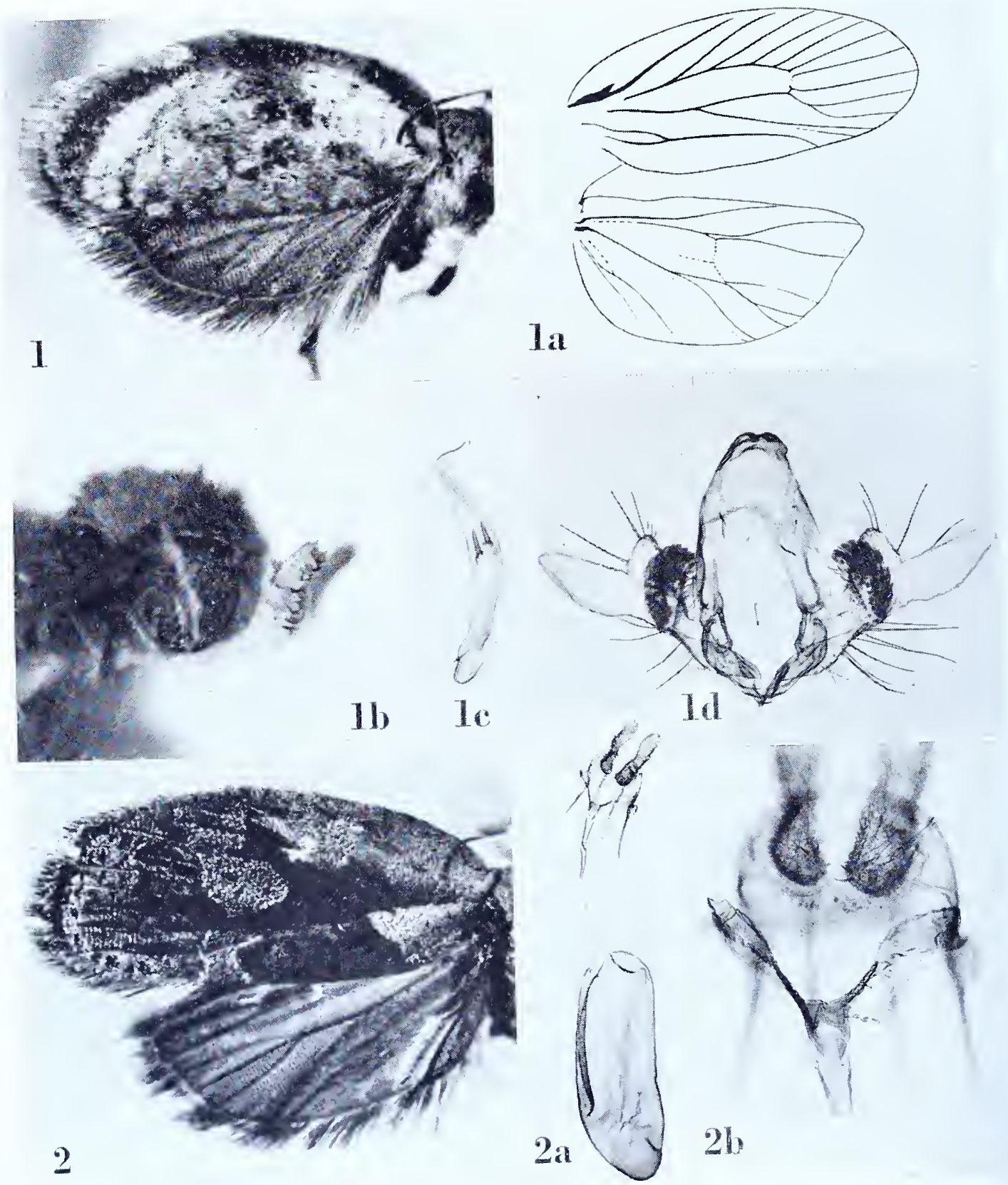

PARATORNA 


\section{PARATORNA Meyrick}

Paratorna Meyrick, 1907, Journ. Bombay Nat. Hist. Soc., 17: 980. (Typus generis: Paratorna dorcas Meyrick, ibid. [monotypy].)

\section{Paratorna dorcas Meyrick}

Plate 85 , Figures I-Id $^{-}$

Paratorna dorcas Meyrick, I907, Journ. Bombay Nat. Hist. Soc., I7: 980.

" ${ }^{1}$ 우. I $2-16 \mathrm{~mm}$. . . E Eighteen specimens, Khasi Hills, in June. This is a highly variable species but easily recognised."

Lectotype: A male measuring $14 \mathrm{~mm}$., "Khasi Hills, Assam. D. .1906." Slide No. 6890. Eight specimens are missing.

Figure I, left wings; $\mathrm{ia}$, venation of right wings; $\mathrm{Ib}$, lateral aspect of head to show palpus; Ic, lateral aspect of aedeagus; Id, ventral view of male genitalia with aedeagus removed.

\section{Paratorna elephantodes Meyrick}

Plate 85 , Figures $2-2 \mathrm{~b}$

Paratorna elephantodes Meyrick, 1938, in Caradja and Meyrick, Deuts. Ent. Zeit. Iris, $52: 84$. ". . . . . 16 mm. . . . Mt. Guntur; i ex."

Type: The female so marked in the British Museum, "Mt. Guntur, Garoet, Westjava. I350 m., Overbeck leg." A small label bears the inscription " $\mathrm{M}_{5} 6_{4}$ ". Slide No. 9390.

Figure 2, left wings; $2 \mathrm{a}$, ventral view of female genitalia; $2 \mathrm{~b}$, detail of genital plate and ostium. 


\section{PETELIACMA Meyrick}

Peteliacma Meyrick, 1912, Exotic Microlepidoptera, I: 12. (Typus generis: Peteliacma torrescens Meyrick, ibid. [monotypy].)

\section{Peteliacma torrescens Meyrick}

Plate 86, Figures I-Id

Peteliacma torrescens Meyrick, 1912, Exotic Microlepidoptera, I: i2.

“ $\hat{o}$. 15 mm. . . Madagascar, Antananarivo, in May; one specimen."

Type: The above indicated male, "Madagascar, Tananarive. Collection LeMoult." Slide No. 9383 .

Figure I, left wings; Ia, venation of right wings; $\mathrm{ib}$, lateral view of head to show palpus; Ic, lateral aspect of aedeagus; Id, ventral view of male genitalia with aedeagus removed. 

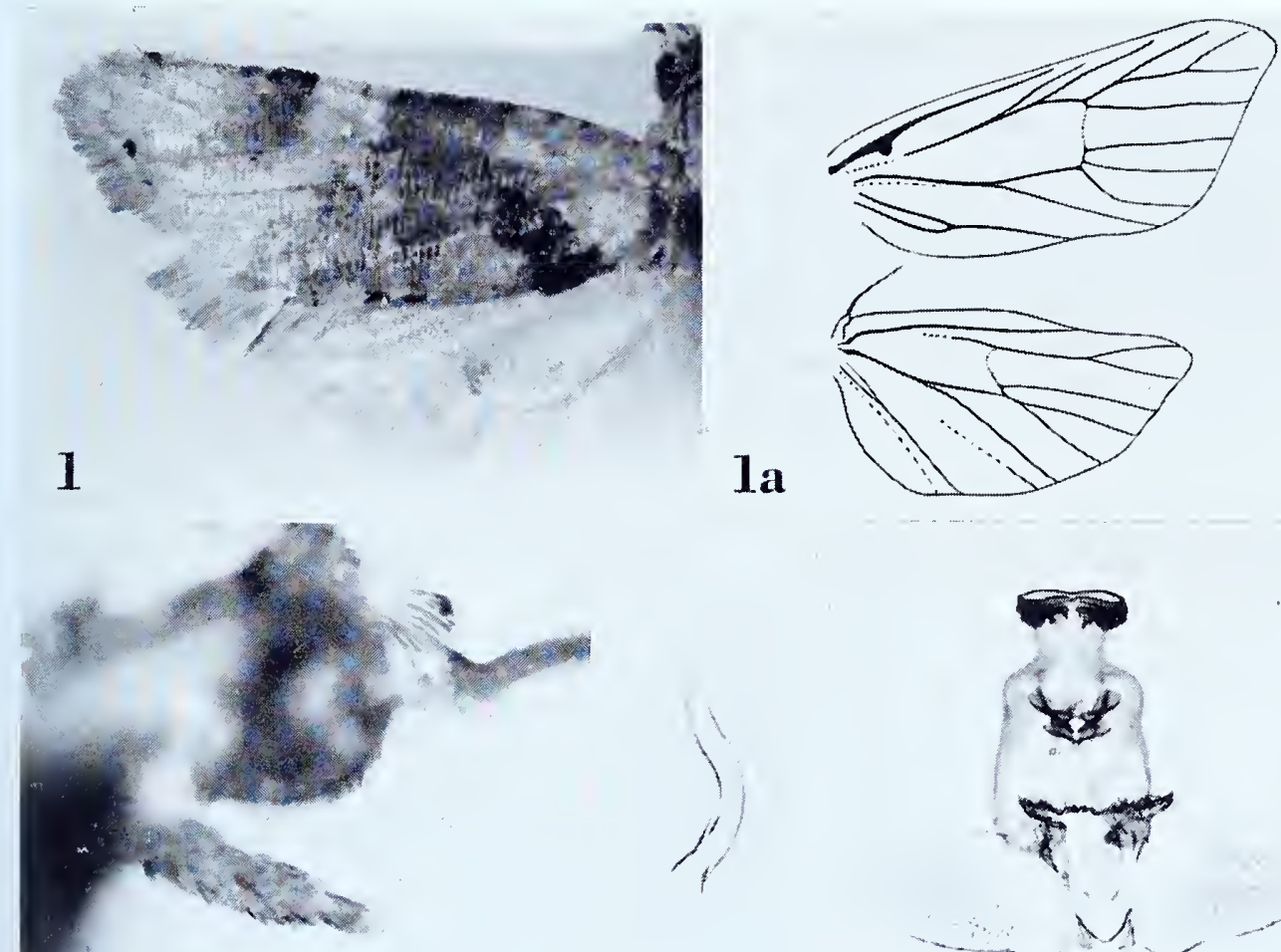

Ib

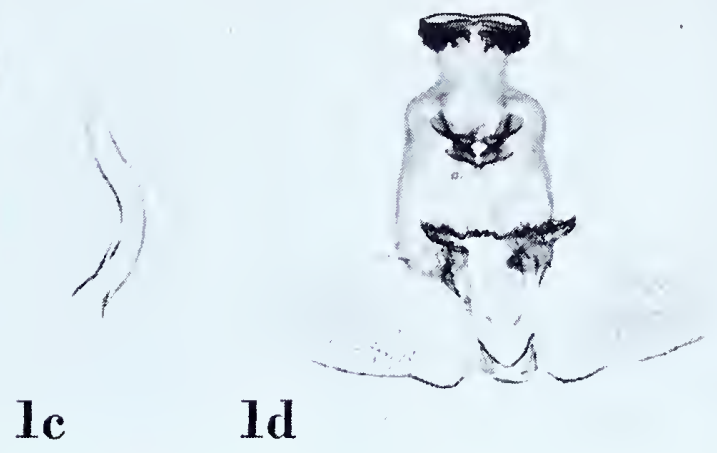

PE'TELIACMA 


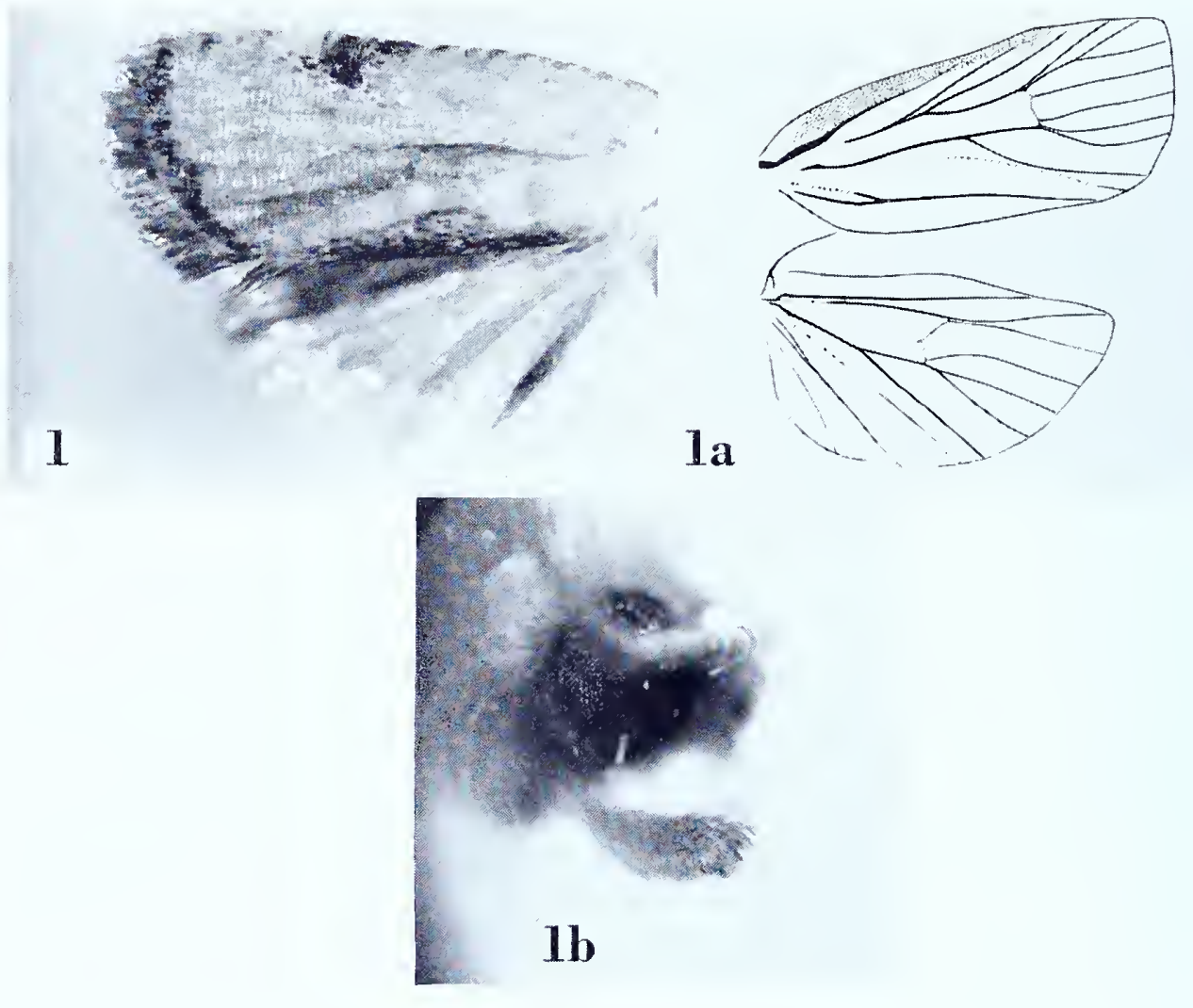

PHALAROCARPA 


\section{PHALAROCARPA Meyrick}

Phalarocarpa Meyrick, 1937, Exotic Microlepidoptera, 5: 129. (Typus generis: Phalarocarpa harmographa Meyrick, ibid. [monotypy].)

\section{Phalarocarpa harmographa Meyrick}

Plate 87 , Figures I-Ib

Phalarocarpa harmographa Meyrick, I937, Exotic Microlepidoptera, 5: 129.

" స. 13 mm. ... Uganda, Kampala, bred March from Acanthus (T. H. C. Taylor); I ex. (Brit. Mus.)."

Type: The male, without abdomen, so marked in the British Museum, dated "vi-1936". A narrow white label, in Meyrick's hand, reads "Phalarocarpa (n. g.) harmographa n. sp."

Figure $\mathrm{x}$, left wings; $\mathbf{a}$, venation of right wings; $\mathbf{r} b$, lateral aspect of head to show palpus. 


\section{PHILEDONE Hübner \\ Philedone aluminias (Meyrick) \\ Plate 88, Figures I-Ib}

Capua aluninias Meyrick, i912, Trans. Ent. Soc. London, г9 1 : 674 .

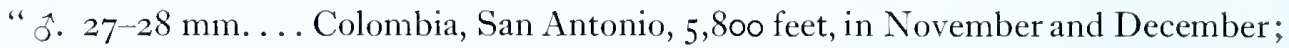
four specimens."

Lectotype: A male measuring 28 mm., dated ".I2.07”. Slide No. 6290.

Figure I, left wings; Ia, aedeagus; $\mathrm{I} b$, ventral view of male genitalia with aedeagus removed.

\section{Philedone citrochyta Meyrick \\ Plate 88, Figures 2-2b}

Philedone citrochyta Meyrick, I926, Exotic Microlepidoptera, 3:247.

“ 今. 2 I mm. . . Ecuador, El Topo, R. Pastaza, 4,200 feet (Paluer); Colombia, Sosomoko, 2,600 feet; 2 ex. Allied to almuinias Meyr., which should also be placed in Philedone."

Lectotype: The male labelled, "El. Topo, Rio Pastaza, E. Ecuador, 4,200 feet, M. G. Palmer." Slide No. 6291. The Sosomoko specimen is missing.

Figure 2 , left wings; $2 \mathrm{a}$, lateral aspect of aedeagus; $2 \mathrm{~b}$, ventral view of male genitalia with aedeagus removed.

\section{Philedone vermicularis Meyrick}

Plate 88 , Figures $3-3 \mathrm{~b}$

Philedone vermicularis Meyrick, I935, in Caradja, Materialien zu einer Microlepidopteren Fauna der Chinesischen Provinzen Kiangsu, Chekiang und Hunan, 48.

" ${ }^{\circ} .20 \mathrm{~mm}$. ... I ex. Tienmushan, IV. Allied to prodromana...."

Type: 'The above indicated male labelled, "Tien-Mu-Shan, China. C. 5,000'.4.22". Slide No. 6794 .

Figure 3 , left wings; $3 \mathrm{a}$, lateral aspect of aedeagus; $3 \mathrm{~b}$, ventral view of male genitalia with aedeagus removed.

\section{PHRICAN'THES Meyrick \\ Phricanthes petulans (Meyrick) \\ Plate 88 , Figures $4^{-}+\mathrm{c}$}

Peronea petulans Meyrick, I912, Exotic Microlepidoptera, I: I9.

"ㅇ․ I $7^{-1} 8 \mathrm{~mm} . .$. Assam, Khasis, in October; two specimens."

Lectotype: The female measuring $17 \mathrm{~mm}$. Slide No. 6909. Both specimens have identical data, "Khasi Hills, Assam. .Io.I906."

Figure 4, left wings; $4 \mathrm{a}$, ventral view of female genitalia; $4 \mathrm{~b}$, signum; $4 \mathrm{c}$, detail of genital plate and ostium. 


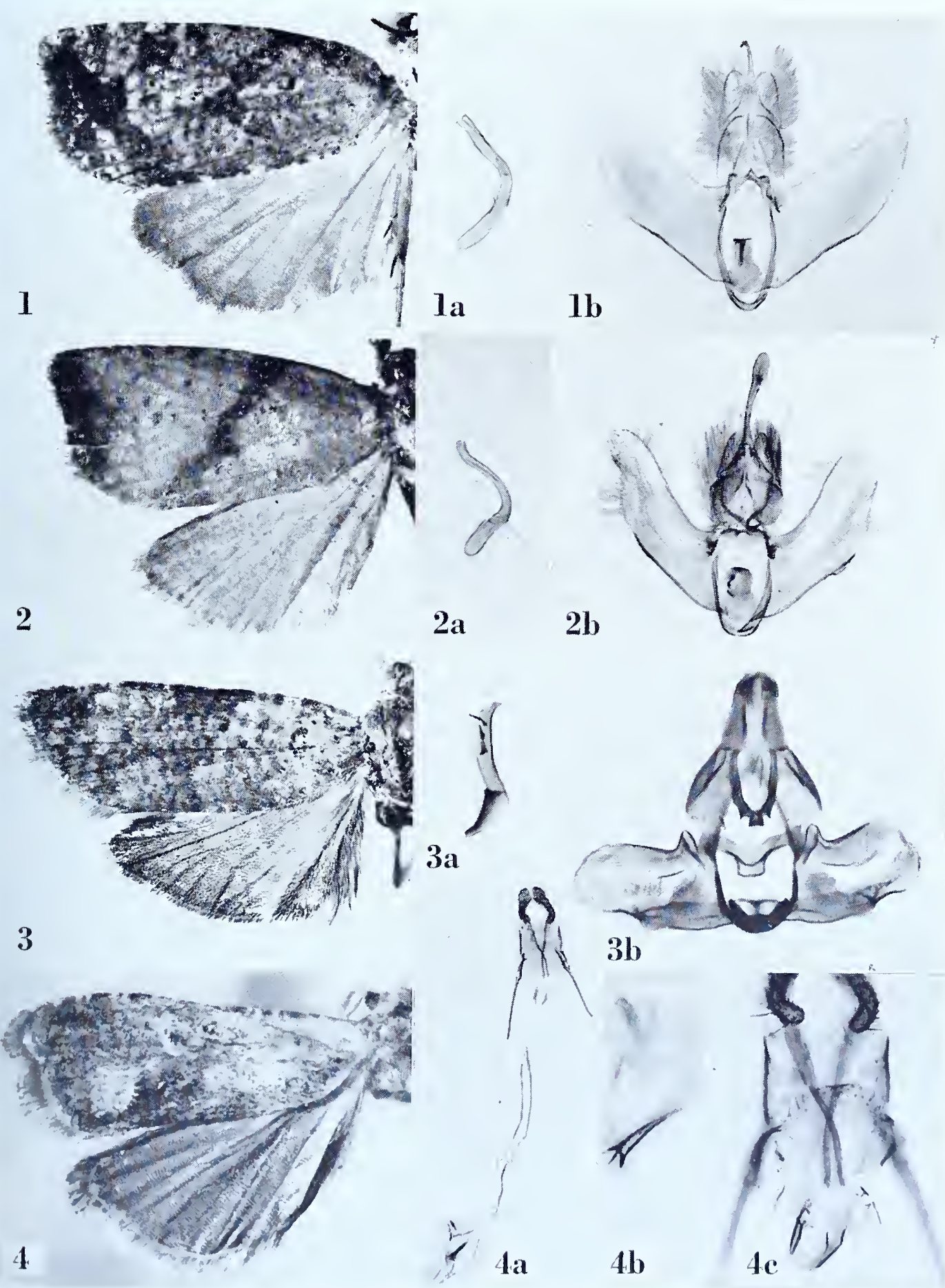

PHILEDONE and PHRICANTHES 

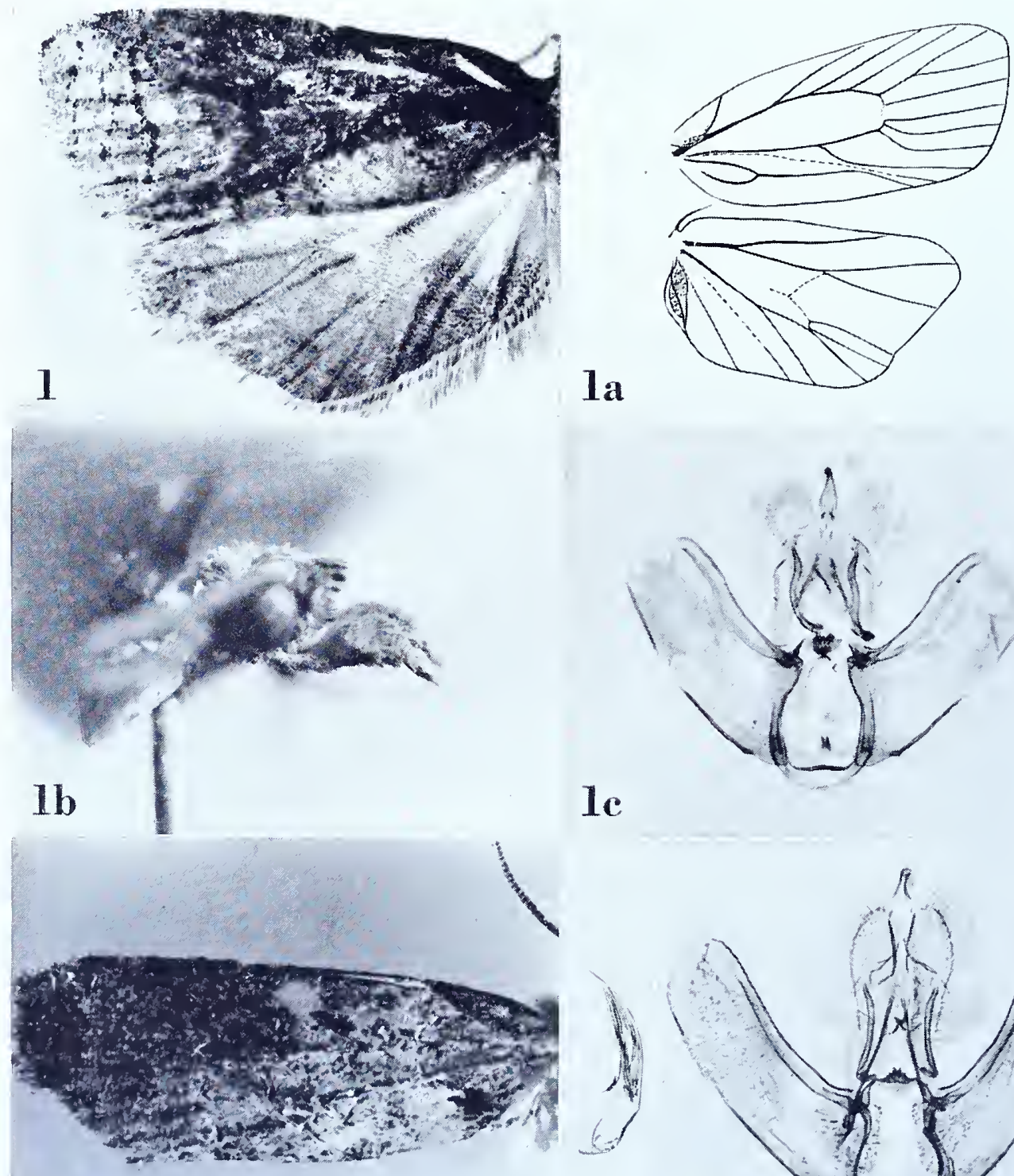

lc

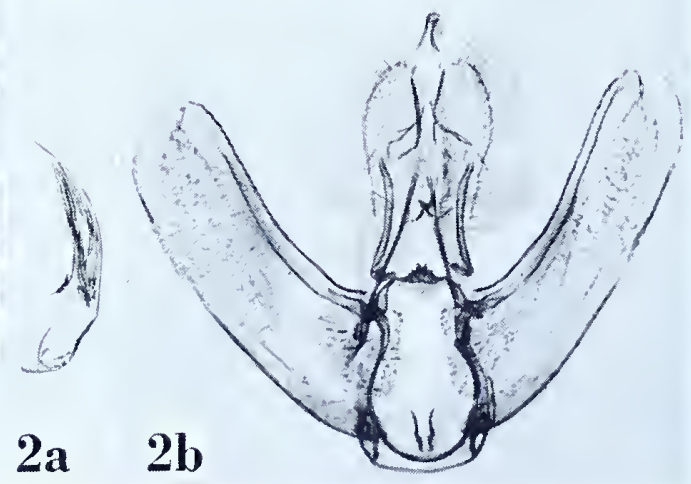

2

$2 a \quad 2 b$

PHYLACTERITIS and PLATYNOTA 


\section{PHYLACTERITIS Meyrick}

Phylacteritis Meyrick, I 922, Exotic Microlepidoptera, 2: 499. (Typus generis: Phylacteritis dioptrica Meyrick, ibid. [monotypy].)

\section{Phylacteritis dioptrica Meyrick}

Plate 89, Figures I-IC

Phylacteritis dioptrica Meyrick, 1922, Exotic Microlepidoptera, 2: 499.

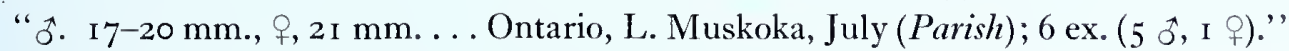

Lectotype: A male measuring $16 \mathrm{~mm}$., dated ".7.18". Slide No. 6617. One specimen is missing. Phylacteritis Meyrick is a synonym of Platynota Clemens, and dioptrica is a synonym of Platynota sentana Clemens.

Figure $\mathrm{I}$, left wings; $\mathrm{r}$, venation of right wings; $\mathrm{rb}$, lateral aspect of head to show palpus; ic, ventral view of male genitalia with aedeagus removed.

\section{PLATYNOTA Clemens}

\section{Platynota colobota Meyrick}

Plate 89 , Figures 2-2b

Platynota colobota Meyrick, I 926, Trans. Ent. Soc. London, 74:276.

"o. I $3 \mathrm{~mm}$. . . A Albemarle Island, July; i ex."

Type: The male so marked in the British Museum, "Albemarle, Galapagos, at light, 200 ft., 7.8.24. St. George Expedn. C. L. Collenette." A small white label bears the inscription "M4r". Slide No. 9424 .

Figure 2, left forewing; $2 \mathrm{a}$, lateral aspect of aedeagus; $2 \mathrm{~b}$, ventral view of male genitalia with aedeagus removed. 


\section{PLANOSTOCHA Meyrick}

Planostocha Meyrick, I9I2, Exotic Microlepidoptera, I: I3. (Typus generis: Cacoecia cumulata Meyrick, I907, Journ. Bombay Nat. Hist. Soc., I 7: 977 [by original designation].)

\section{Planostocha cumulata (Meyrick)}

Plate 90, Figures I-Id

Cacoecia cumulata Meyrick, I907, Journ. Bombay Nat. Hist. Soc., I 7: 977.

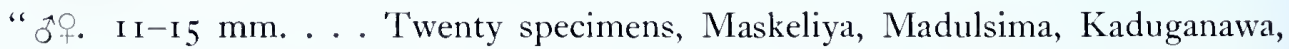
Ceylon; Coorg $(3,500$ feet $)$; from February to May, and in August and September (Pole, de Mowbray, Green, Vaughn, Newcome)."

Lectotype: A male measuring I 3 mm., "Dibidi, N. Coorg. Newcome. Io.8.o6." Slide No. 6869. Only eight of the original specimens remain in the Meyrick collection.

Figure I, left wings; $\mathrm{a}$, venation of right wings; $\mathrm{Ib}$, lateral view of palpus; $\mathrm{Ic}$, lateral aspect of aedeagus; Id, ventral view of male genitalia with aedeagus removed. 

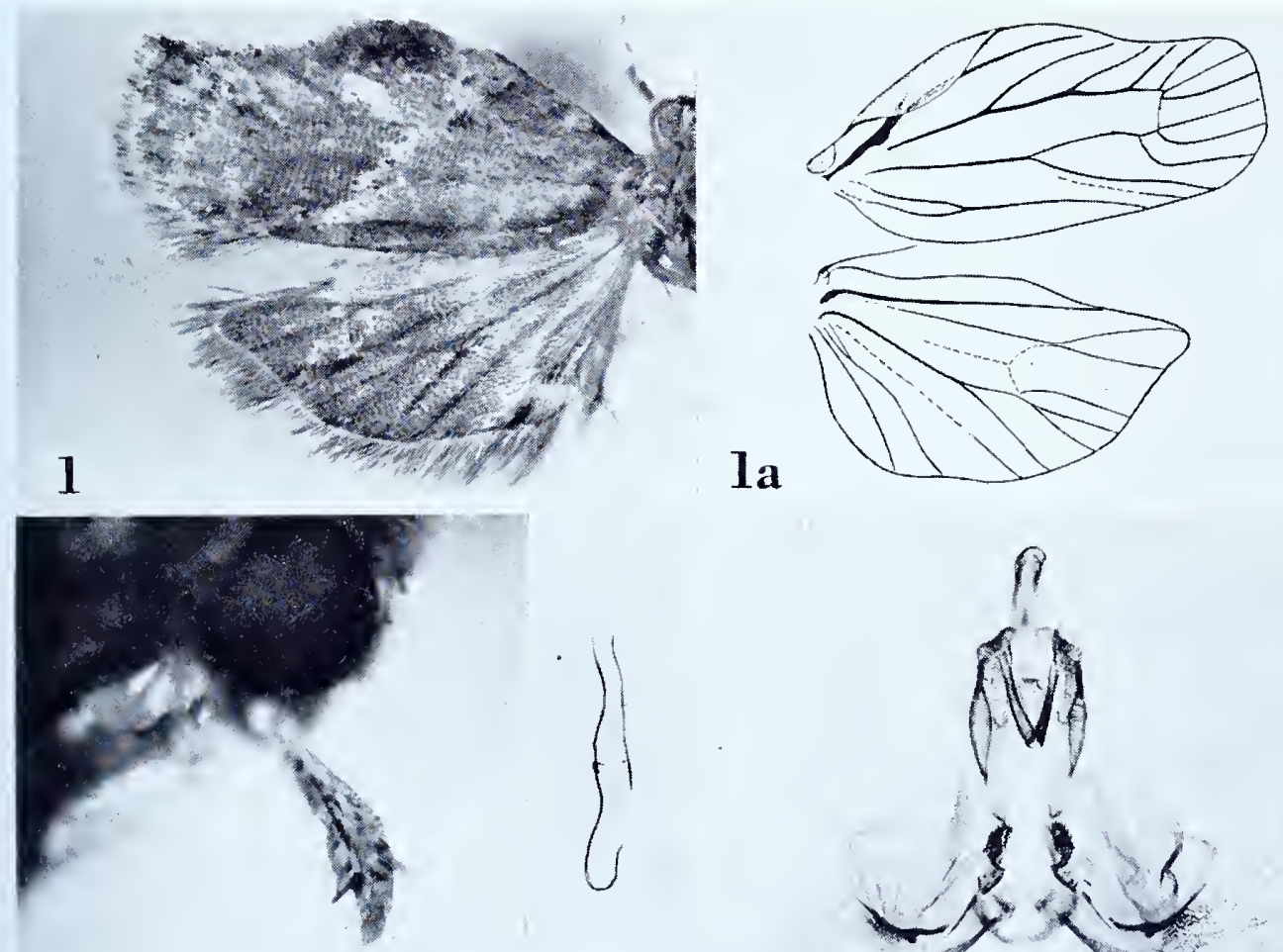

lb
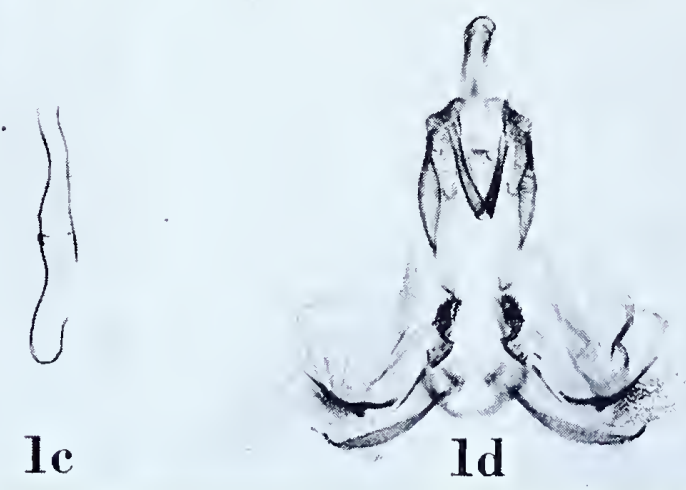

PLANOSTOCHA 


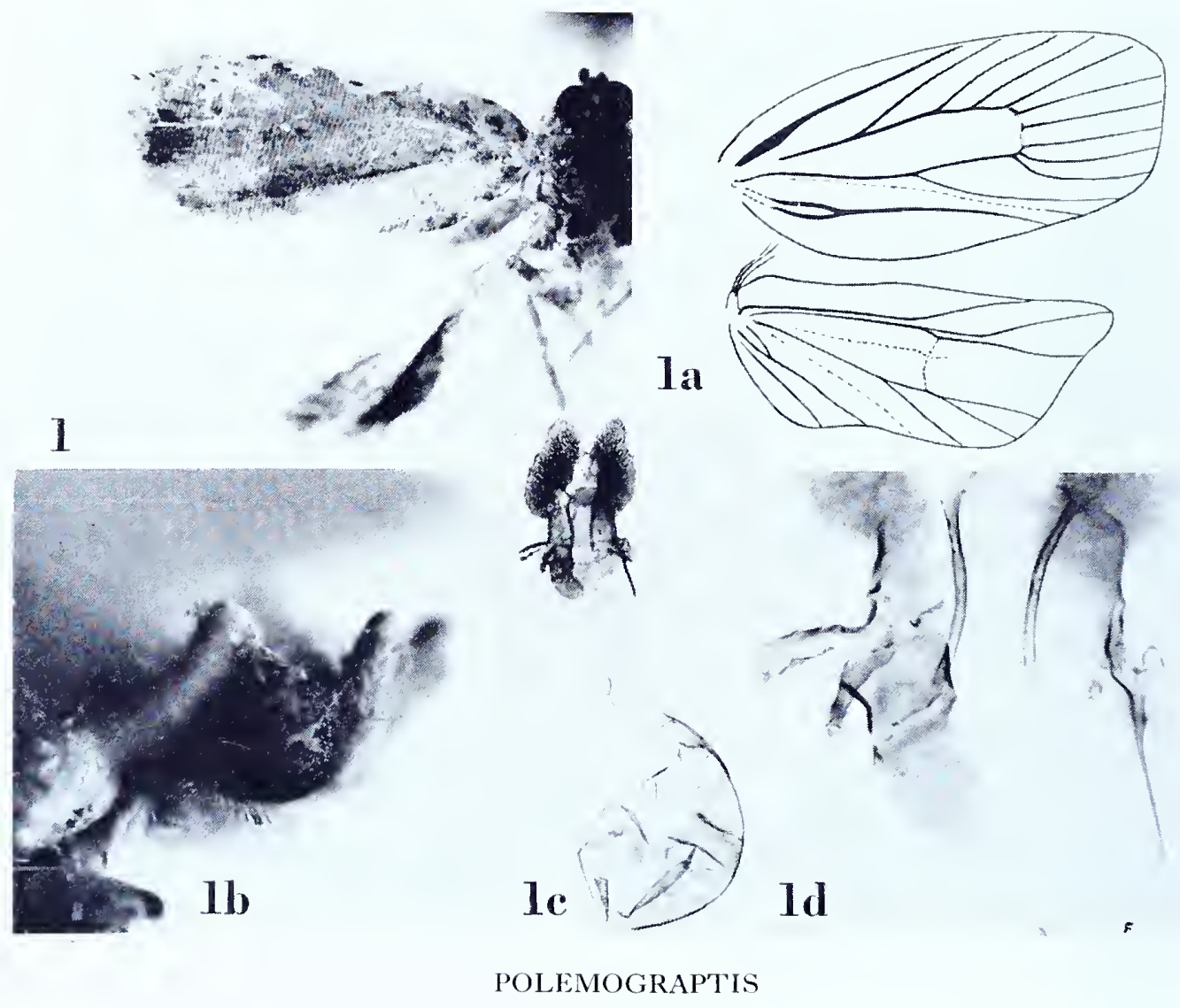




\section{POLEMOGRAP'TIS Meyrick}

Polemograptis Meyrick, I910, Trans. Ent. Soc. London, I910: 432. (Typus generis: Polemograptis miltocosma Meyrick, ibid. [monotypy].)

\section{Polemograptis miltocosma Meyrick}

\section{Plate 9I, Figures I-Id}

Polemograptis miltocosma Meyrick, ig10, 'Trans. Ent. Soc. London, ig1o: 432.

"․ $12 \mathrm{~mm}$. . . Borneo, Kuching (Hewitt); in February, one specimen."

Type: The above indicated specimen, in poor condition, dated ".2.07". Slide No. 688ז.

Figure I, left wings; 1 a, venation of right wings; $\mathrm{Ib}$, lateral aspect of head to show palpus; Ic, ventral view of female genitalia; Id, detail of ostium. 


\section{POLYORTHA Dognin \\ Polyortha bryographa (Meyrick), new combination}

Plate 92, Figures $\mathbf{I}-\mathrm{Ib}$

Peronea bryographa Meyrick, I909, Trans. Ent. Soc. London, I 909: I6.

" $\hat{j}$ ㅇ. 29-33 mm. . . . Peru, Aqualani $[$ sic]; ten specimens. This large and elegantly coloured species is very variable; ..."

Lectotype: A male. Slide No. 6250. One specimen is missing, the remainder are dated ".12.05".

Figure I, left wings; 1 a, lateral aspect of aedeagus; $\mathrm{s} b$, ventral view of male genitalia with aedeagus removed.

\section{Polyortha bryometalla Meyrick}

Plate 92, Figures 2-2b

Polyortha bryonetalla Meyrick, I932, Exotic Microlepidoptera, 4: 343 .

" ô. $27 \mathrm{~mm}$. . . Costa Rica, Orosi, 5,000 feet; i ex. Allied to trochilodes."

Type: The specimen indicated above with ".30" in the lower right corner of the pin-label. Slide No. 6256.

Figure 2, left wings; $2 a$, ventral view of aedeagus; $2 b$, ventral view of male genitalia with aedeagus removed.

[Note: With the description of this species Meyrick accepted the genus Polyortha as distinct from Peronea (synonym of Acleris Hübner).]

\section{Polyortha gradatulana (Zeller), new combination}

Plate 92 , Figures $3-3 \mathrm{c}$

Teras gradatulana Zeller, ı 866, Stett. Ent. Zeit., 27: $3^{8 .}$

Peronea purpurascens Meyrick, I9 12, Trans. Ent. Soc. London, I91 I : 686 (new synonymy).

[purpurascens]

“ 3 . 24-28 mm. . . Peru, Aqualani [sic], 9,000 feet, in December, I f, type; Colombia, San Antonio, 5,800 feet, in November, I $\hat{\jmath}$. . . ."

Type: The specimen indicated (but not marked) by Meyrick, with "0. .12.05" at the bottom of the pin-label. Slide No. 625 $\mathrm{I}$.

Figure 3 , left wings; 3 a, ventral view of female genitalia; $3 \mathrm{~b}$, signum; $3 \mathrm{c}$, detail of genital plate and ostium.

[contimued on p. Is8. 

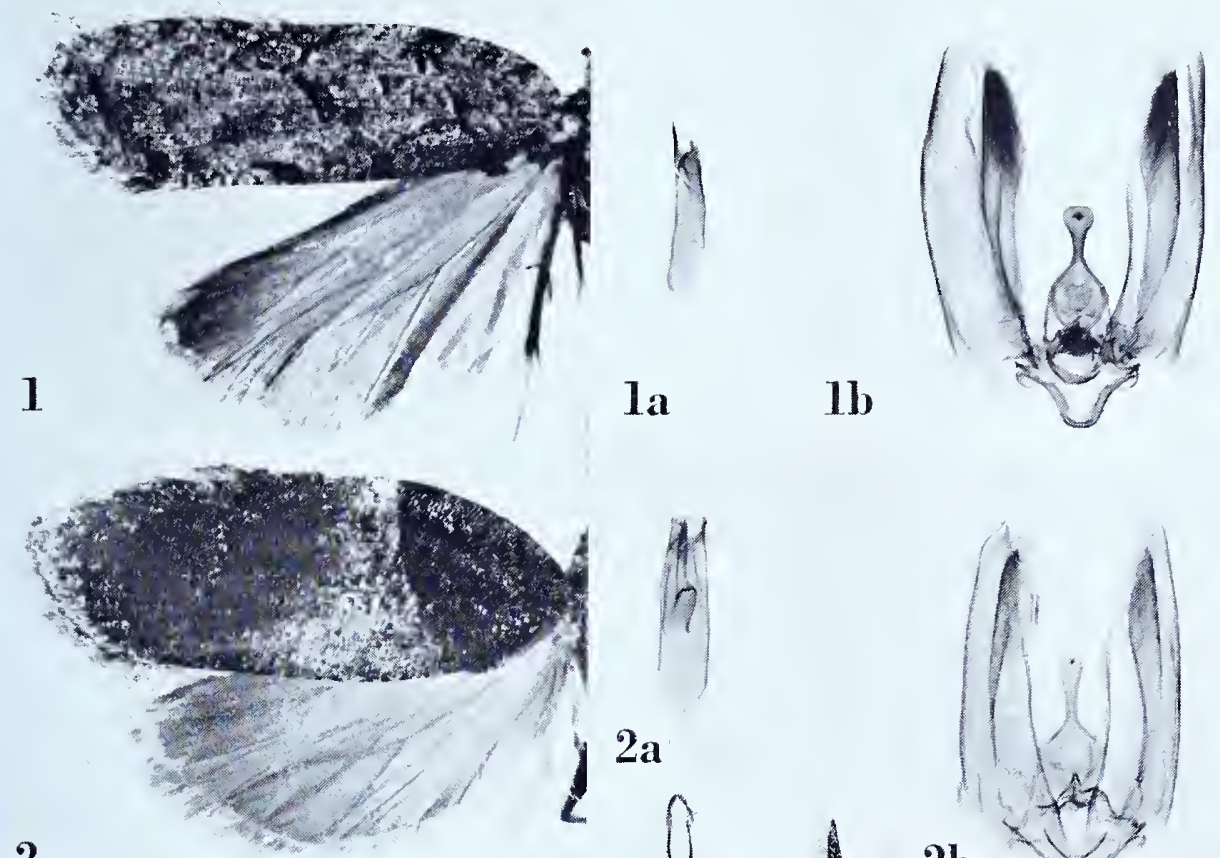

2
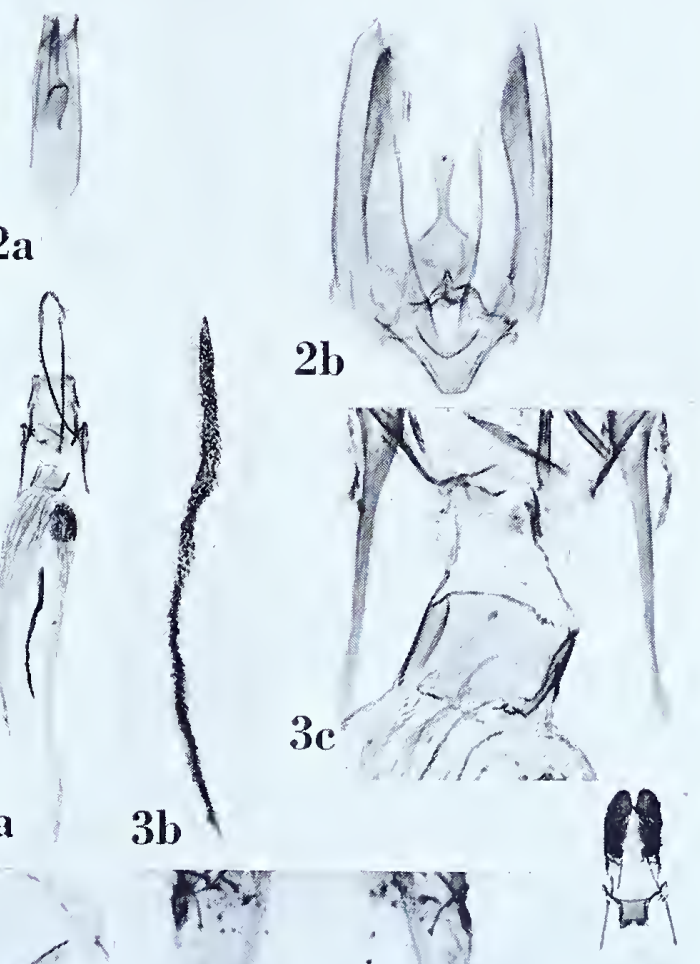

3
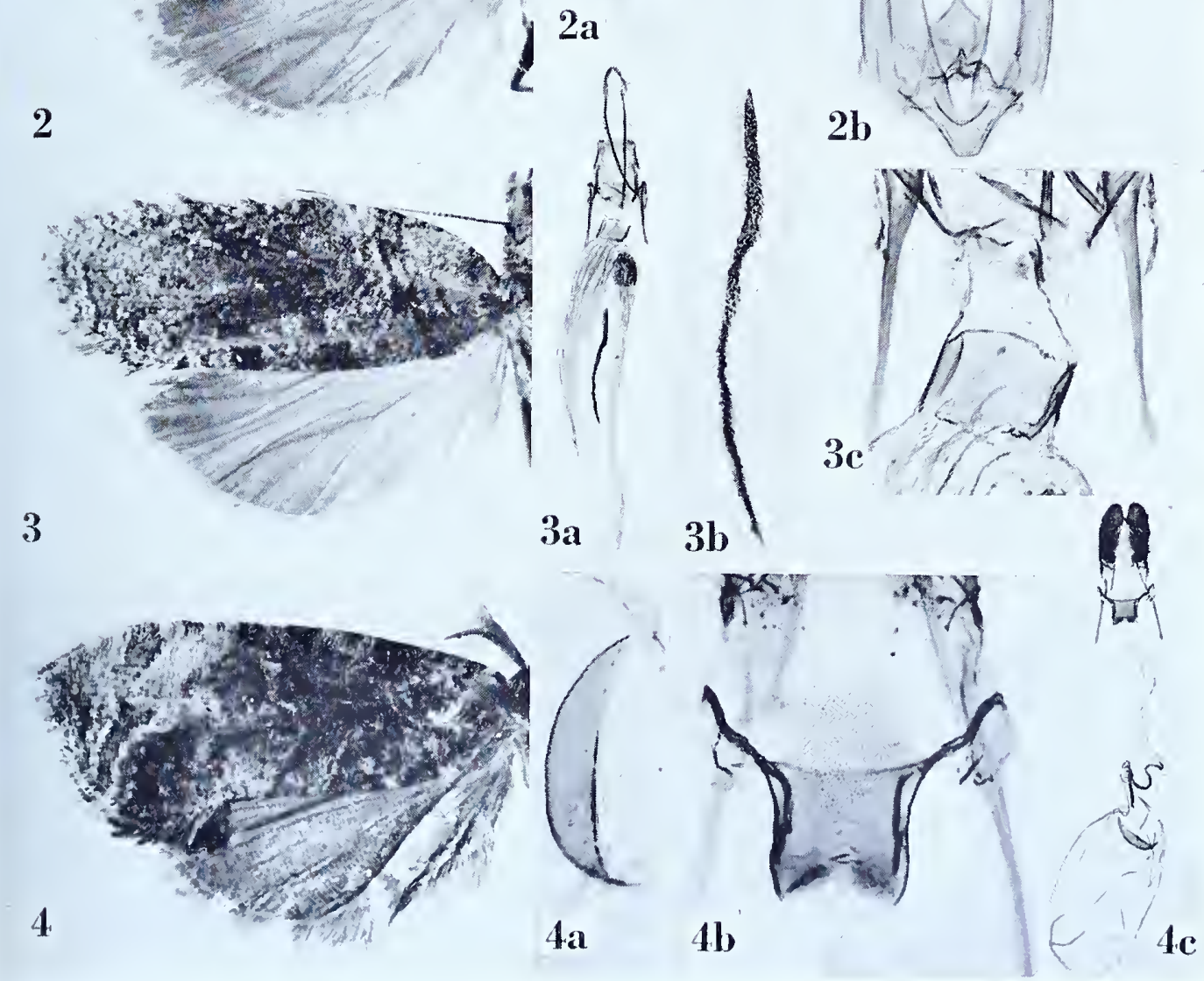

POLYOR'THA 


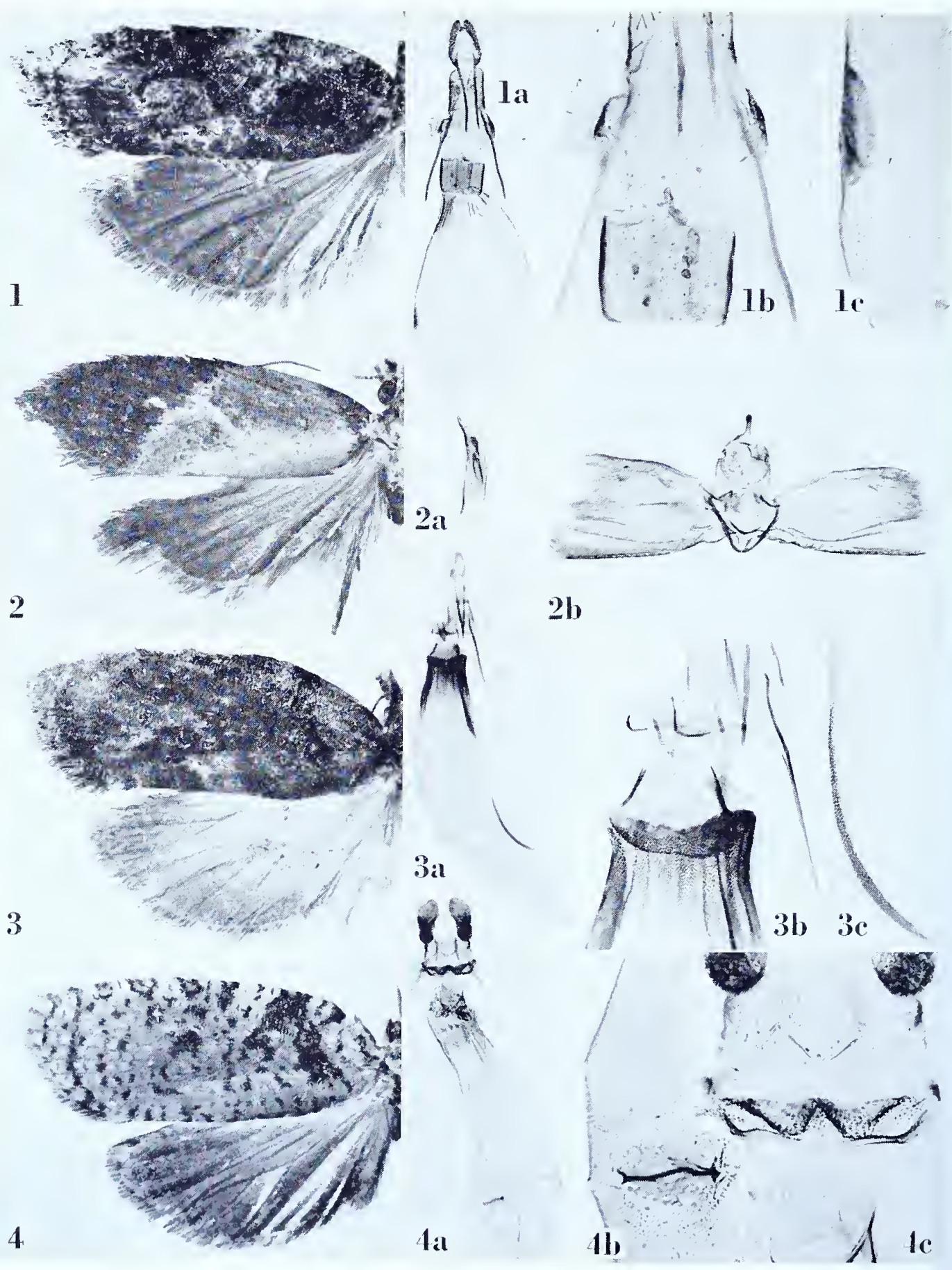

POLYORTHA 
Polyortha marmarodes (Meyrick), new combination

Plate 93, Figures I-I c

Peronea marmarodes Meyrick, i912, Trans. Ent. Soc. London, i9 I : 687.

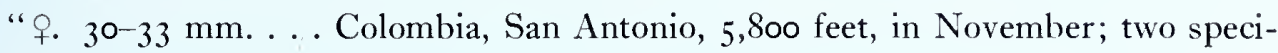
mens."

Lectotype: The larger of the two females, dated “i .07". Slide No. 6254 .

Figure I, left wings; $\mathrm{a}$, ventral view of female genitalia; $\mathrm{rb}$, detail of genital plate and ostium; Ic, signum.

\section{Polyortha purpurascens Meyrick}

See Polyortha gradatulana (Zeller).

\section{Polyortha sphenobathra (Meyrick), new combination}

Plate 93, Figures 2-2b

Peronea sphenobathra Meyrick, I9I7, 'Trans. Ent. Soc. London, I9I7: 13.

" ${ }^{\text {. }}$ I 5 mm. . . B British Guiana, Bartica, in February (Parish); one specimen."

Type: The above indicated specimen dated “.2.13". Slide No. 6257.

Figure 2, left wings; $2 \mathrm{a}$, lateral aspect of aedeagus; $2 \mathrm{~b}$, ventral view of male genitalia with aedeagus removed.

\section{Polyortha trochilodes (Meyrick), new combination}

Plate 93 , Figures $3-3 \mathrm{c}$

Peronea trochilodes Meyrick, i912, Trans. Ent. Soc. London, i9 I : 687.

"․ 34-36 mm. . . . Colombia, San Antonio, 5,80o feet, in November; two specimens."

Lectotype: The larger of the two specimens; the smaller one is a male, erroneously recorded as a female. Slide No. 6253. Both specimens are dated “. I I.07”.

Figure 3 , left wings; 3 a, ventral view of female genitalia; 3 b, detail of ostium; 3 c, signum.

\section{Polyortha viridescens (Meyrick)}

Plate 93 , Figures $4-4 \mathrm{c}$

Peronea viridescens Meyrick, i912, Trans. Ent. Soc. London, I9 I : 686.

"․ $27 \mathrm{~mm}$. . . . Brazil, Novo Friburgo; one specimen."

Type: The specimen indicated above with "R. .o6" at the bottom of the pin-label. Slide No. $625^{2}$.

Figure 4 , left wings; 4 a, ventral view of female genitalia $; 4^{b}$, signum $; 4$ c, detail of genital plate and ostium. 


\section{PROSELENA Meyrick}

Proselena Meyrick, i 88I, Proc. Linnean Soc. New South Wales, 6: 421. Typus generis: Proselena annosana Meyrick, ibid. [monotypy].)

\section{Proselena annosana Meyrick}

Plate 94, Figures I-Id

Proselena annosana Meyrick, I88I, Proc. Linnean Soc. New South Wales, 6: $42 \mathrm{I}$.

This species is figured from a specimen from "Sydney, New South Wales, i I/10/79." Slide No. BM 2 108. Wing venation from Slide No. 9585 .

Figure I, left wings; $\mathrm{ra}$, venation of right wings; $\mathrm{ib}$, lateral aspect of head to show palpus; Ic, aedeagus; Id, ventral view of male genitalia with aedeagus removed.

\section{PROCALYPTIS Meyrick \\ Procalyptis chelophora Meyrick}

Plate 94, Figures 2-2a

Procalyptis chelophora Meyrick, I910, Trans. Ent. Soc. London, I910: 431.

"o. 19-20 mm. ... Malay States, Loeboe Rajah; in May, three specimens."

Lectotype: A male measuring 2 I mm. Slide Diakonoff No. I I 43. "Two of the original three specimens remain in the Meyrick collection and are dated ".5.97".

Figure 2, left wings; 2a, ventral view of male genitalia with aedeagus in situ.

Continued from p. I8.

\section{Polyortha limosa (Meyrick), new combination}

Plate 92, Figures $4-4 \mathrm{c}$

Peronea limosa Meyrick, i 912, Trans. Ent. Soc. London, I9і г : 688.

"ㅇ. I $8 \mathrm{~mm}$. . . . Colombia, at 4,400 feet, in February; one specimen."

Type: The above indicated specimen labelled, " 4,400 ' W. Colombia. P. .2.08." Slide No. 6255 .

Figure 4 , left wings; $4 \mathrm{a}$, signum, $4 \mathrm{~b}$, detail of genital plate and ostium; $4 \mathrm{c}$, ventral view of female genitalia. 

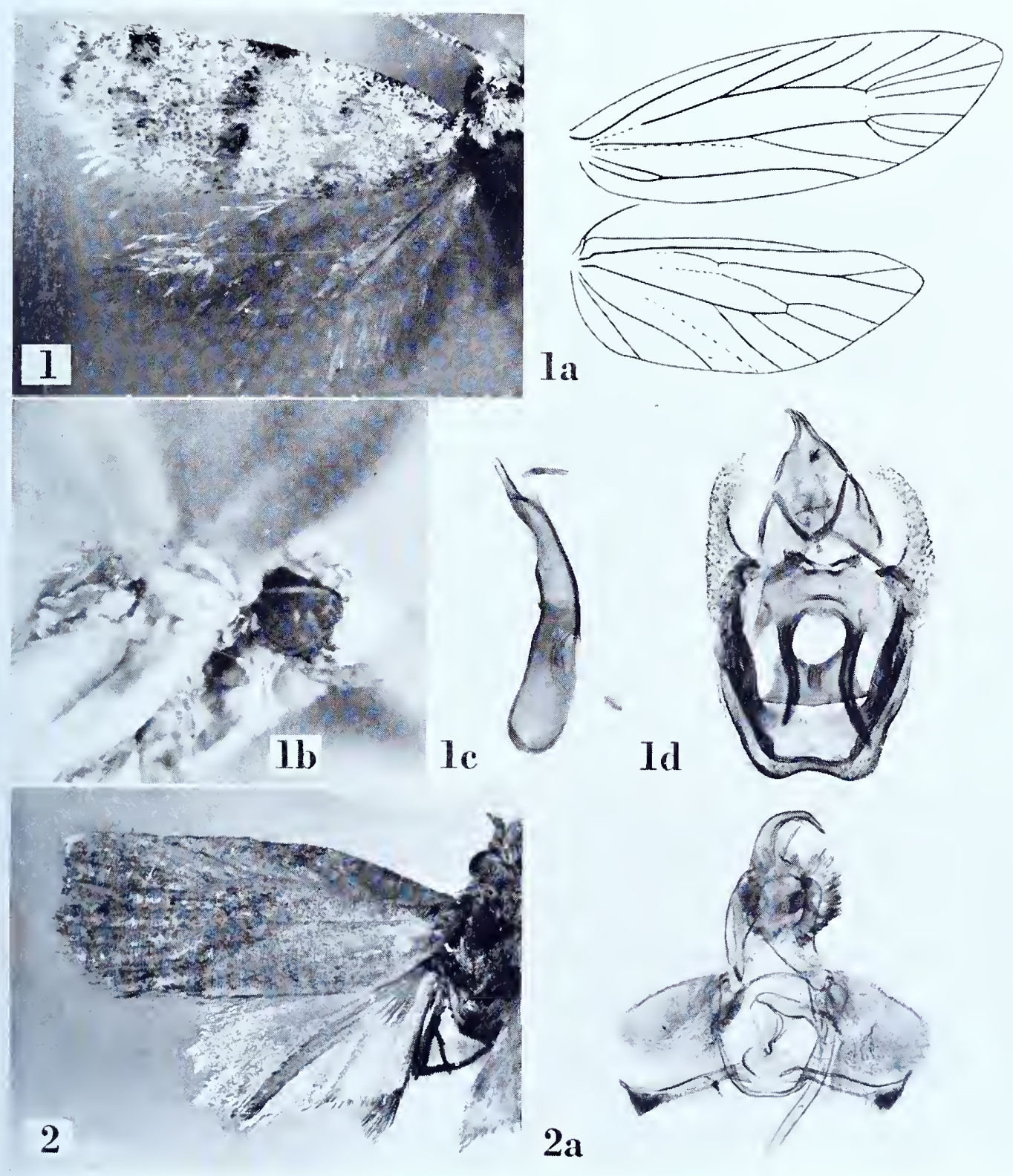

PROSELENA and PROCALYP'TIS 

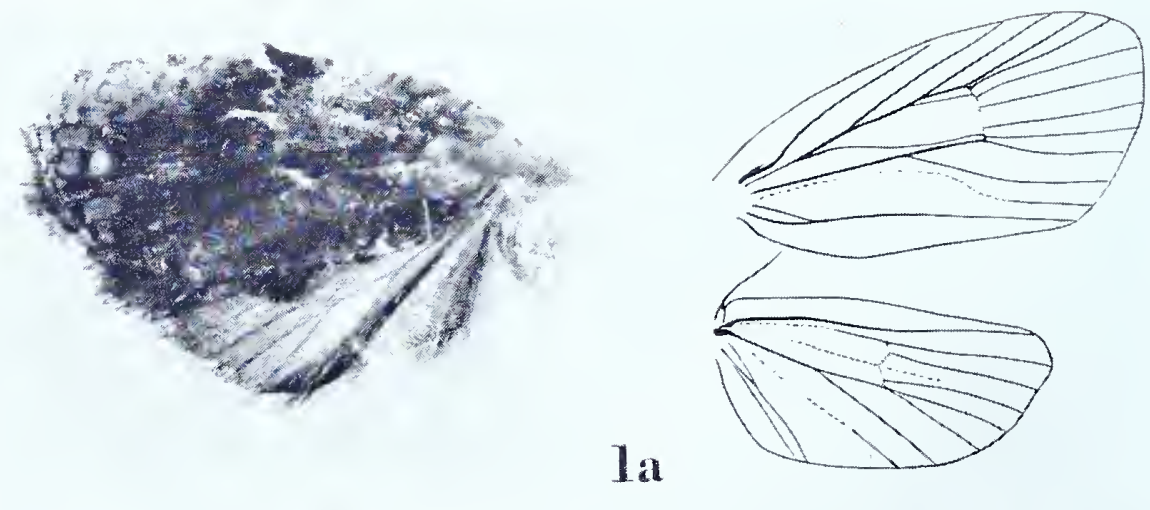

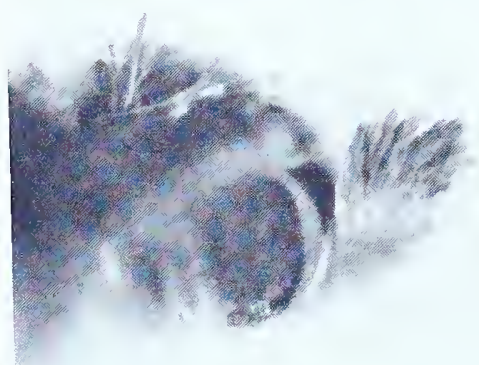

1b

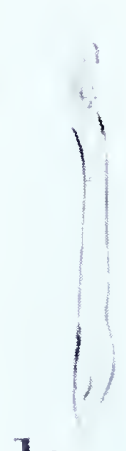

lc

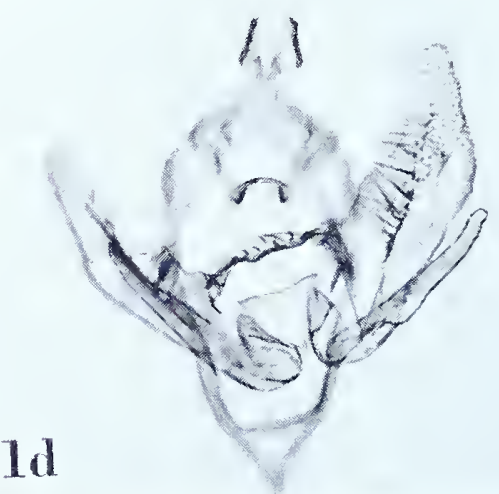

PRO'TOPTERNA 


\section{PROTOP'TERNA Meyrick}

Protopterna Meyrick, 1908, Journ. Bombay Nat. Hist. Soc., I8: 621. (Typus generis: Protopterna chalybias Meyrick, ibid. [monotypy].)

\section{Protopterna chalybias Meyrick}

Plate 95, Figures $\mathrm{I}-\mathrm{Id}$

Protopterna chalybias Meyrick, I908, Journ. Bombay Nat. Hist. Soc., I8: 62 I.

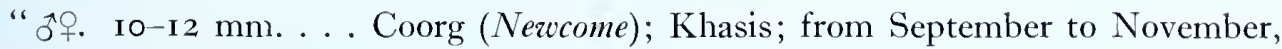
seven specimens."

Lectotype: A male measuring i I mnı., "Khasi Hills, Assam. .9.I906." Slide No. 6889 .

Figure I, left wings; Ia, venation of right wings; Ib, lateral view of head to show palpus; Ic, lateral aspect of aedeagus; $\mathrm{Id}$, ventral view of male genitalia with aedeagus removed. 


\title{
PROTYPANTHES Meyrick
}

Protypanthes Meyrick, 1933, Exotic Microlepidoptera, 4:424. (Typus generis: Protypanthes hybristis Meyrick, ibid. [monotypy].)

\section{Protypanthes hybristis Meyrick}

\author{
Plate 96, Figures I-1e
}

Protypanthes hybristis Meyrick, 1933, Exotic Microlepidoptera, 4:424.

" fo$^{\circ}$. $15 \mathrm{~mm}$. . . . Java, Seneng, bred February, March from larvae feeding on leaves of Dillenia (Dr. L. G. E. Kalshoven); 2 ex."

Lectotype: The female dated ".3.32" in the Meyrick collection, marked "holotype o". Slide Diakonoff No. i 153 . The second specimen (February) is missing.

Figure $\mathrm{I}$, left wings; $\mathrm{a}$, venation of right wings; $\mathrm{ib}$, lateral view of head to show palpus; Ic, ventral view of female genitalia; Id, detail of ostium; re, signum. 


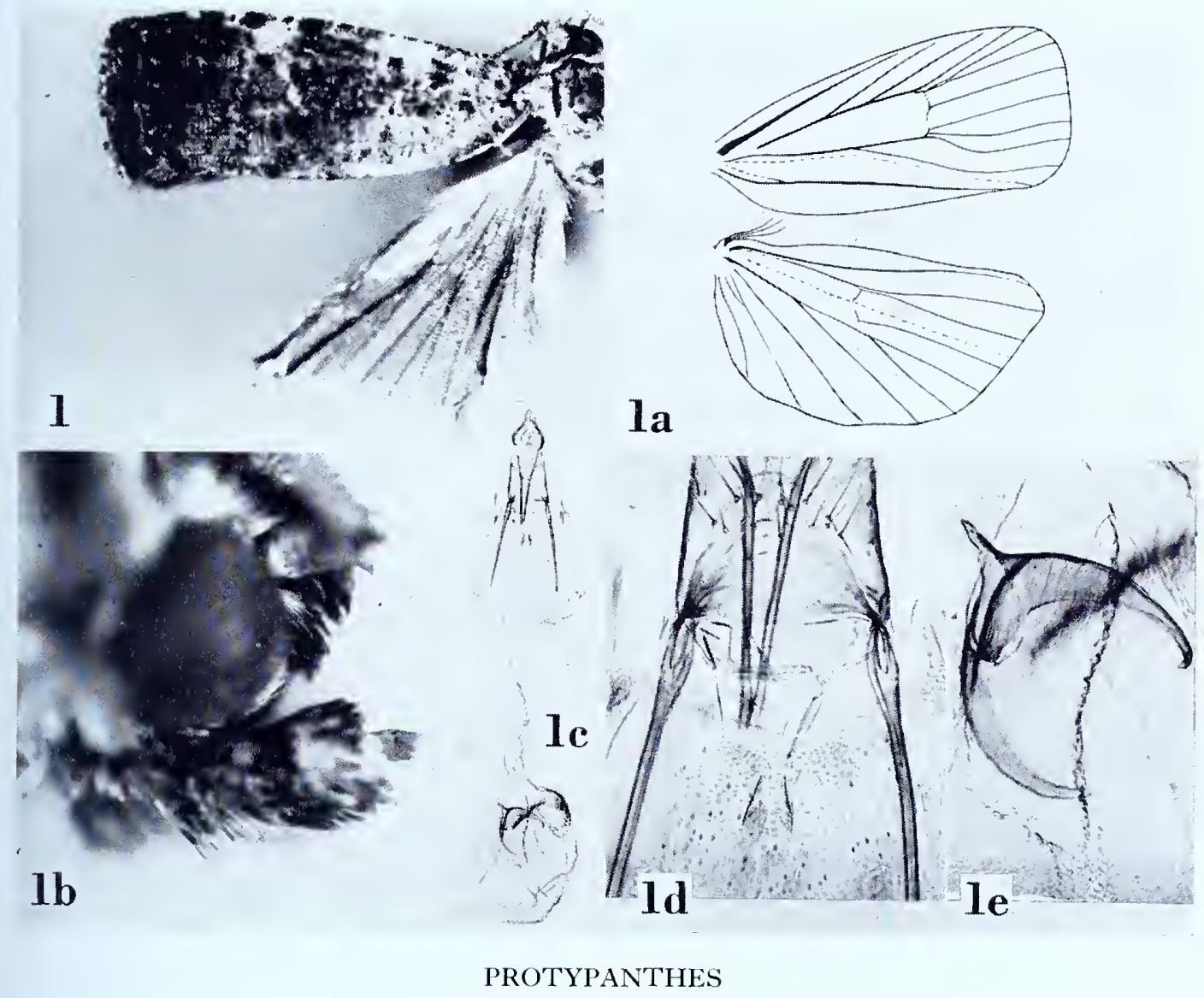



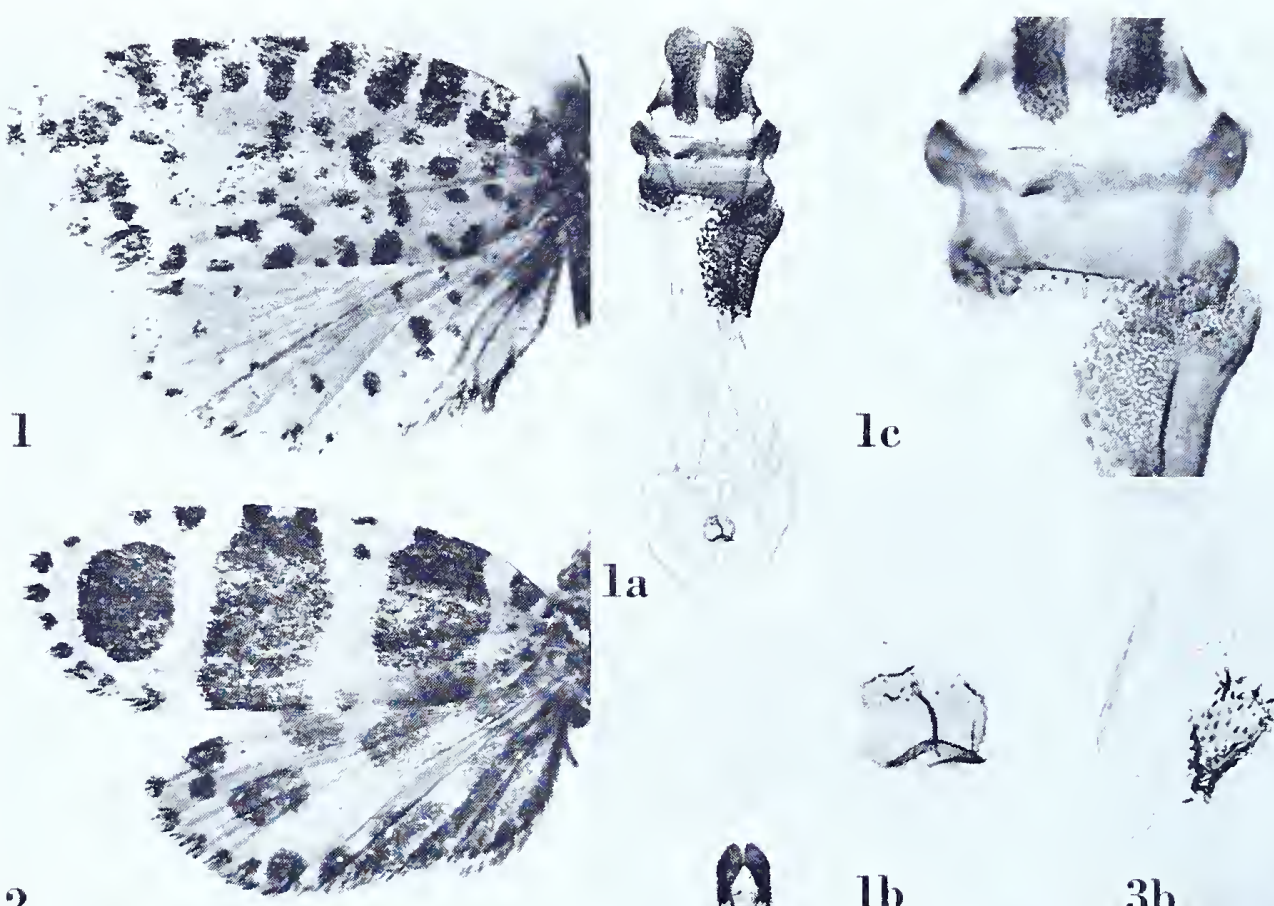

3

2

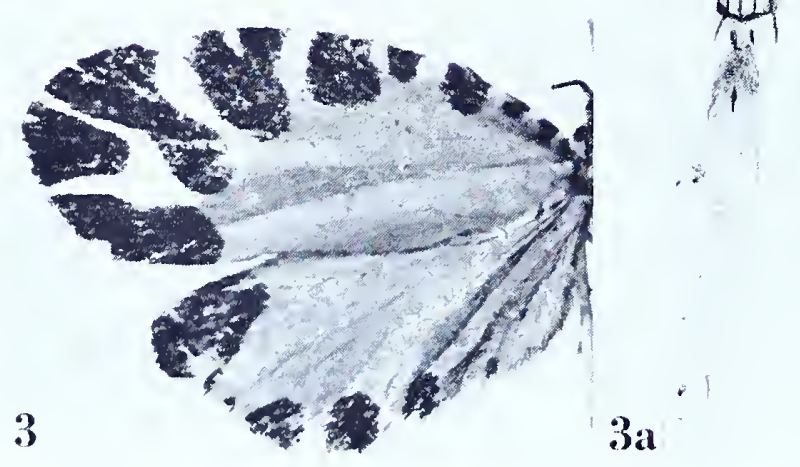

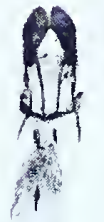

1b)
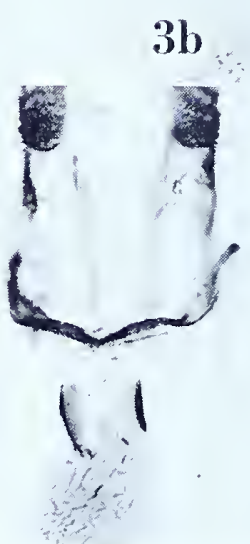

PSEUDATTERIA 


\section{PSEUDATTERIA Walsingham}

\section{Pseudatteria anemonantha Meyrick}

See Psendatteria symplacota Meyrick.

\section{Pseudatteria baccheutis Meyrick}

Plate 97, Figures I-IC

Psendatteria bacchentis Meyrick, I924, Exotic Microlepidoptera, 3: Io9.

"ぷ+. 3I mm. . . Costa Rica, Miravalles Volcano; 2 ex."

Lectotype: The female labelled, "Miravalles Volcano, Costa Rica, U. .95." Slide No. 4437. The male is missing.

Figure I, left wings; гa, ventral view of female genitalia; $\mathbf{b}$, signum; ıc, detail of genital plate and ostium.

\section{Pseudatteria cantharopa (Meyrick)}

Plate 97 , Figure 2

Atteria cantharopa Meyrick, I909, Trans. Ent. Soc. London, I909: I4.

"ㅇ. $29 \mathrm{~mm}$. . . Bolivia, Chulumani, in December; one specimen."

Type: The above indicated specimen, without abdomen, labelled, "Chulumani, Bolivia. S. 6,500' I 2.06".

Figure 2, left wings.

\section{Pseudatteria chrysanthema (Meyrick)}

Plate 97, Figures $3-3 \mathrm{c}$

Atteria chrysanthena Meyrick, I912, Trans. Ent. Soc. London, I9 I : 676.

"ㅇ. 23-25 mm. . . Colombia, San Augustin, 3,500 feet, in September; Peru, Yquitos; two specimens."

Lectotype: The female labelled, "San Augustin, Colombia. S. .9.95". Slide No. 4435 .

Figure 3 , left wings; 3 , ventral view of female genitalia; $3 \mathrm{~b}$, signum; $3 \mathrm{c}$, detail of genital plate and ostium.

\section{Pseudatteria flabellata (Meyrick)}

See Psendatteria splendens (Druce).

\section{Pseudatteria fornicata Meyrick}

See Pseudatteria heliocansta (Dognin). 
PSEUDATTERIA

\section{Pseudatteria heliocausta (Dognin)}

Plate 98, Figures I-IC; $2-2 \mathrm{C}$

? Atteria heliocansta Dognin, I912, Hétérocères Nouveaux de L'Amérique du Sud, 6: $5 \mathrm{I}$. Psendatteria fornicata Meyrick, 1917, Trans. Ent. Soc. London, 1917: 6 (new synonymy). Pseudatteria metacapna Meyrick, 1924, Exotic Microlepidoptera, 3: 108 (new synonymy). [fornicata]

"우. 30-38 mm. . . . Colombia, San Antonio, 5,80o feet, in November; two specimens."

Lectotype: The smaller of the two specimens. Both are labelled, "San Antonio, W. Colombia. R. .i r.07". Slide No. 4420.

Figure I, left wings; ra, ventral view of female genitalia; Ib, signum; rc, detail of genital plate and ostium.

[metacapna]

" $\hat{o}+$. 28-29 mm. . . . Colombia, San Antonio, 8,00o feet, a pair taken in cop."

Lectotype: The female. Slide No. $442 \mathrm{I}$.

Figure 2, left wings; $2 \mathrm{a}$, ventral view of female genitalia; $2 \mathrm{~b}$, signum; $2 \mathrm{c}$, detail of genital plate and ostium.

\section{Pseudatteria igniflora Meyrick}

Plate 98, Figures $3-3 \mathrm{c}$

Psendatteria igniflora Meyrick, 1930, Exotic Microlepidoptera, 3: 606.

"ㅇ. $28 \mathrm{~mm}$. . . . Bolivia; I ex. (Coll. Paravicini)."

Type: The above indicated specimen labelled, "Bolivia. Ex. Germain." Slide No. 4424 .

Figure 3 , left wings; $3 \mathrm{a}$, signum; $3 \mathrm{~b}$, ventral view of female genitalia; $3 \mathrm{c}$, detail of genital plate and ostium.

\section{Pseudatteria maenas Meyrick}

Plate 98 , Figures $4-4 b$

Pseudatteria maenas Meyrick, 1924, Exotic Microlepidoptera, 3: Io9.

"․ 28 mm. . . Panama, Chiriqui; I ex."

Type: The above indicated specimen labelled, "Chiriqui, Panama. R. .99". Slide No. 4531 .

Figure 4 , left wings; 4 a, ventral view of female genitalia; 4 b, detail of genital plate and ostium. 


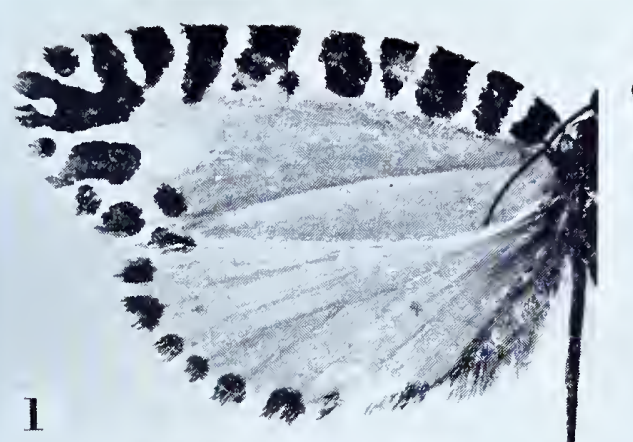

12

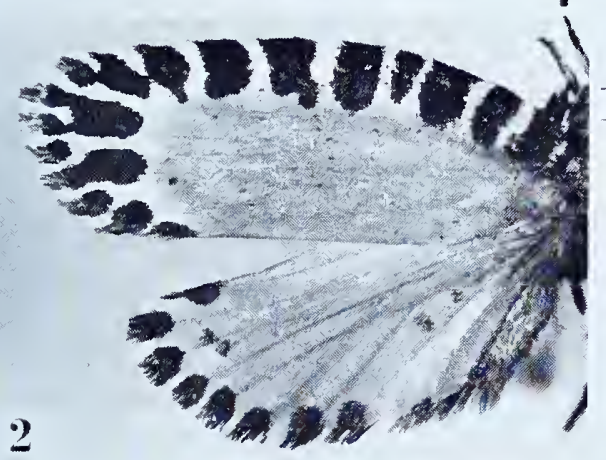

(18)
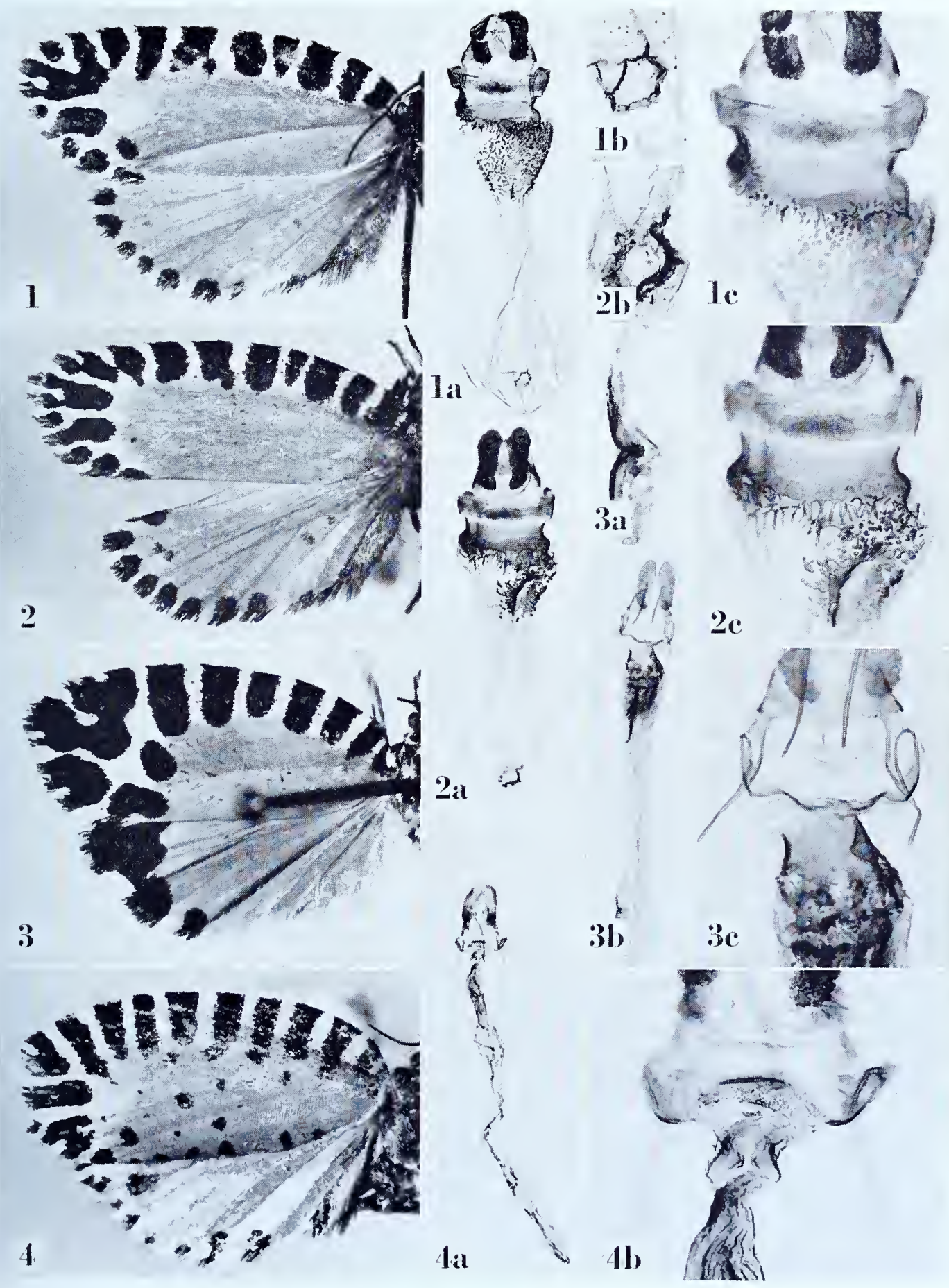

PSEUDATTERIA 

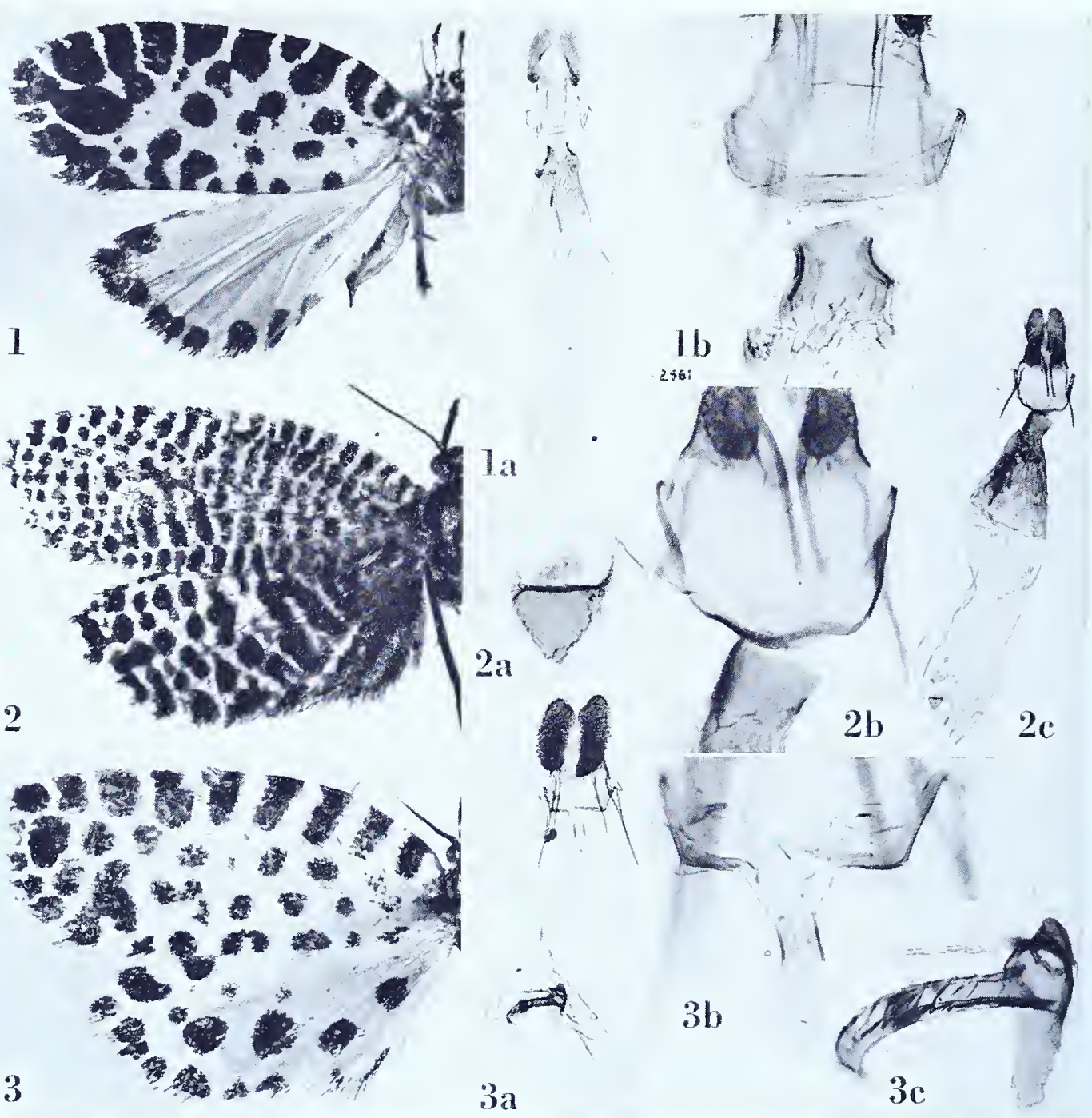

PSEUDA'T'TERIA 


\section{Pseudatteria marmarantha Meyrick}

Plate 99, Figures $\mathrm{I}-\mathrm{I}$ b

Pseudatteria marmarantha Meyrick, 1924, Exotic Microlepidoptera, 3: Io9.

"후우 30-34 mm. . . Colombia, R. Cauca; 7 ex."

Lectotype: . The original seven specimens are in the Meyrick collection, all bear the same data and all are females. Slide No. 44I 4 .

Figure I, left wings; гa, ventral view of female genitalia; $\mathrm{b}$, detail of genital plate and ostium.

\section{Pseudatteria metacapna Meyrick}

See Pseudatteria heliocausta (Dognin).

\section{Pseudatteria myriocosma Meyrick}

Plate 99, Figures 2-2c

Pseudatteria myriocosma Meyrick, i930, Exotic Microlepidoptera, 3: 608.

"․ $30 \mathrm{~mm}$. . . Bolivia, Cochabamba; i ex. (Coll. Paravicini)."

Type: The above indicated specimen in the British Museum. Slide No. 4426.

Figure 2, left wings; 2a, signum; $2 \mathrm{~b}$, detail of genital plate and ostium; $2 \mathrm{c}$, ventral view of female genitalia.

\section{Pseudatteria orgias Meyrick}

Plate 99, Figures $3^{-3} \mathrm{c}$

Pseudatteria orgias Meyrick, I930, Exotic Microlepidoptera, 3:607.

"ㅇ. $23 \mathrm{~mm}$. .. . Colombia, Pacho, E. Cordilleras, 7,250 feet; I ex. (Coll. Paravicini)."

Type: The specimen indicated above in the British Museum. Slide No. $444^{\circ}$.

Figure 3 , left wings; $3 \mathrm{a}$, ventral view of female genitalia; $3 \mathrm{~b}$, detail of genital plate and ostium; 3 c, signum. 


\section{Pseudatteria splendens (Druce)}

Plate I00, Figures I-IC

Atteria splendens Druce, I90 I, Ann. Mag. Nat. Hist., 7 (7): 440.

Atteria flabellata Meyrick, 19г2, Trans. Ent. Soc. London, г9г г 676 (new synonymy).

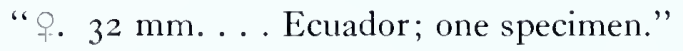

Type: The specimen indicated above, "Ecuador. B. o6." Slide No. 4423.

Figure I, left wings; Ia, ventral view of female genitalia; Ib, signum; Ic, detail of genital plate and ostium.

\section{Pseudatteria symplacota Meyrick}

Flate Ioo, Figures 2-2c; $3^{-3}$ c

Pseudatteria symplacota Meyrick, 1930, Exotic Microlepidoptera, 3: 606.

Pseudatteria anemonantha Meyrick, I932, Exotic Microlepidoptera, 4:254 (new synonymy). [symplacota]

"ㅇ. $38 \mathrm{~mm}$. . . . Ecuador, Balzapamba, Prov. Bolivar; i ex. (Coll. Paravicini)."

Type: The specimen indicated above, "Balzapamba, Prov. Bolivar, Ecuador. M. de Mathan, 9. 1893 a Fev. I894." Slide No. 4427.

Figure 2, left wings; $2 \mathrm{a}$, signum; $2 \mathrm{~b}$, ventral view of female genitalia; $2 \mathrm{c}$, detail of genital plate and ostium.

\section{[anemonantha]}

“ㅇ. $28 \mathrm{~mm}$. . . B Bolivia, Marcopata; I ex. (German Entom. Mus.)."

Type: The specimen indicated above, "Marcopata, Bolivia. H. .34." Slide No.4530. The type is in the Meyrick collection although one would expect it to be in the German Entomological Museum, the apparent source.

Figure 3 , left wings; 3 a, ventral view of female genitalia; 3 b, signum; $3 \mathrm{c}$, detail of genital plate and ostium.

\section{Pseudatteria xanthocapna Meyrick \\ Plate 100 , Figures $4^{-4} \mathrm{~b}$}

Pseudatteria xanthocapna Meyrick, I930, Exotic Microlepidoptera, 3:607.

“ ふ. 27 mm. . . Colombia, Manizales; I ex. (Coll. Paravicini)."

Type: The male indicated above, "Manizales, Colombia. A. M. Patino." Slide No. 4428.

Figure 4 , left wings; $4^{\mathrm{a}}$, lateral aspect of aedeagus; 4 b, ventral view of male genitalia with aedeagus removed. 


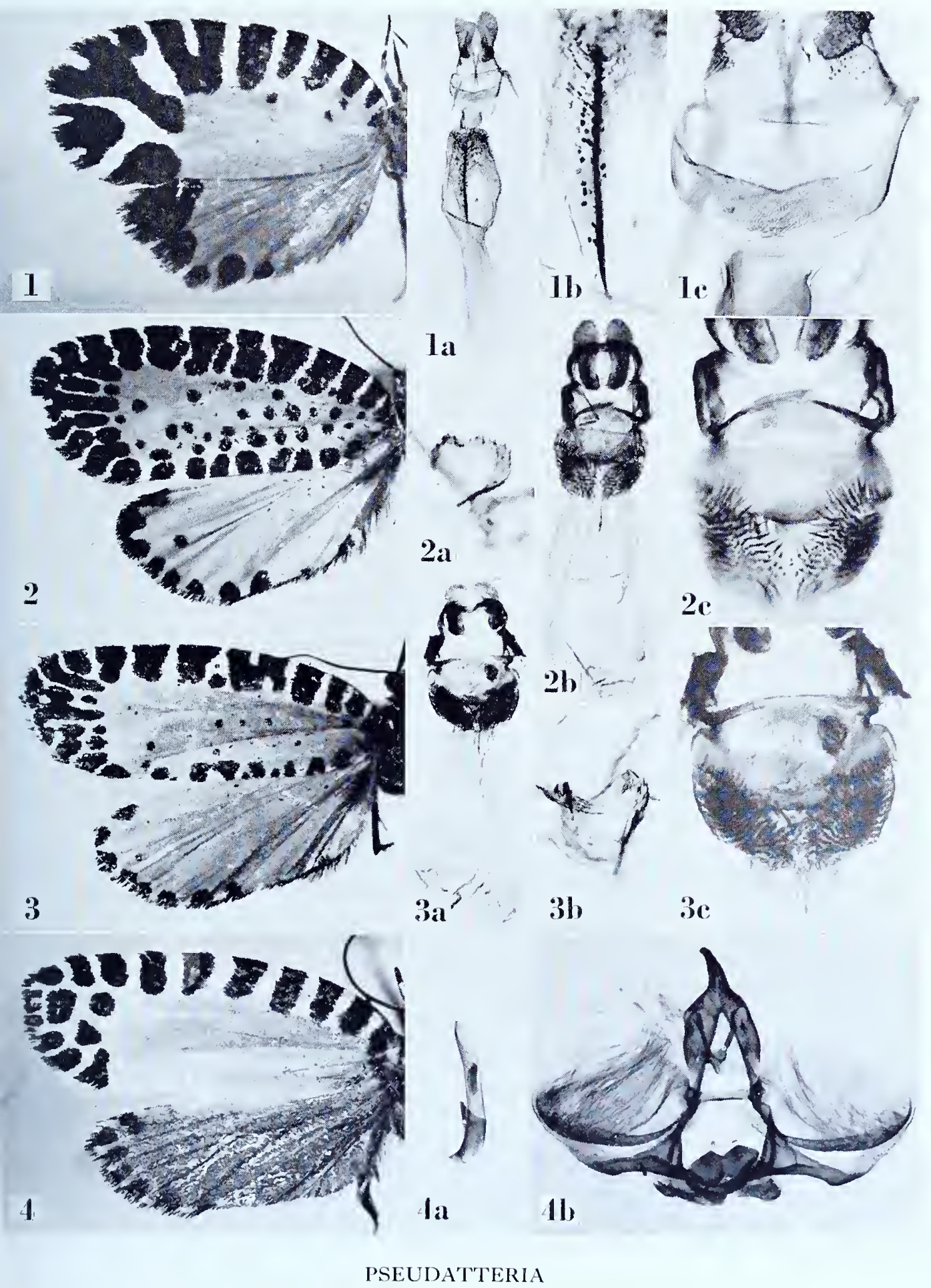




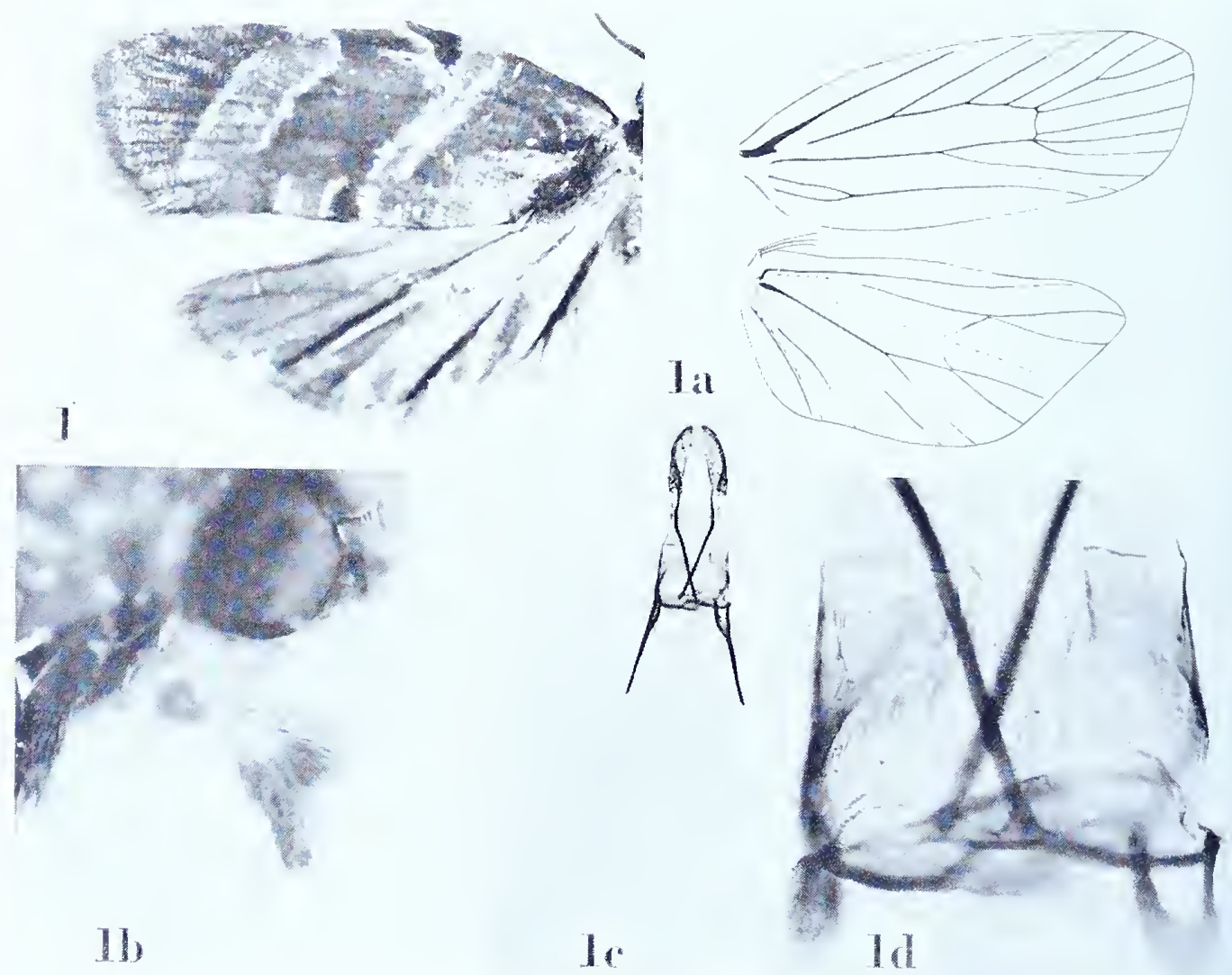

P'TERIDOPORTHIS 


\title{
PTERIDOPORTHIS Meyrick
}

Pteridoporthis Meyrick, I937, Exotic Microlepidoptera, 5: 156. (Typus generis: Pteridoportliis euryloxa Meyrick, ibid. [monotypy].)

\section{Pteridoporthis euryloxa Meyrick}

\author{
Plate IoI, Figures I-Id
}

Pteridoporthis euryloxa Meyrick, I937, Exotic Microlepidoptera, 5: I56.

“ Aㅇ. ro-12 mm. . . . Fiji, Vunidawa, May (H. Plillips); 3 ex. (type Brit. Mus.). Feeds on tree-fern (Alsophila) (R. Browul)."

Type: The female so marked in the British Museum, "Vunidawa, Fiji. I I.5.I933. H. Phillips. 84r." Slide No. 9344.

Figure 1 , left wings; Ia, venation of right wings; $\mathrm{rb}$, lateral view of labial palpus; Ic, ventral view of female genitalia; Id, detail of ostium. 


\section{PTERNOZYGA Meyrick}

Pternozyga Meyrick, 1908, Journ. Bombay Nat. Hist. Soc., 18: 621. (Typus generis: Pternozyga haeretica Meyrick, ibid. [monotypy].)

\section{Pternozyga haeretica Meyrick \\ Plate I02, Figures I-Id}

Ptemozyga haeretica Meyrick, I908, Journ. Bombay Nat. Hist. Soc., I 8: 62 I.

“ "s. I 6-I 7 mm.... Palni Hills, 6,000 feet (Campbell); Nilgiris, 6,ooo feet (Andrewes); in May two specimens."

Lectotype: The specimen labelled, "Nilgiri Hills, S. India. HLA 6,000' .5.07". Slide Diakonoff No. I I I. Both specimens are females erroneously recorded as males by Meyrick.

Figure I, left wings; Ia, venation of right wings; Ib, lateral aspect of head to show palpus; Ic, ventral view of female genitalia (spermatophore in bursa copulatrix); Id, detail of genital plate and ostium. 


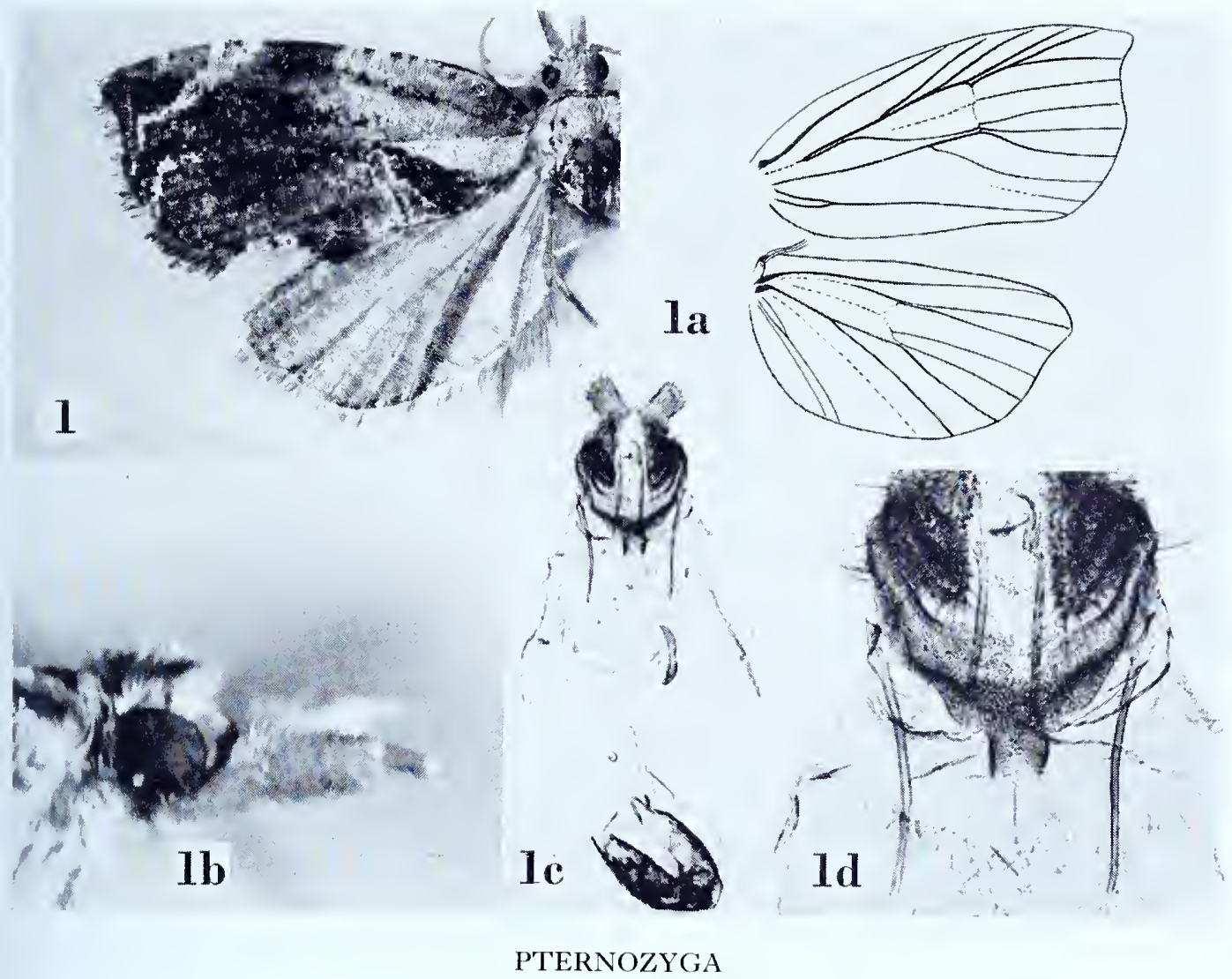




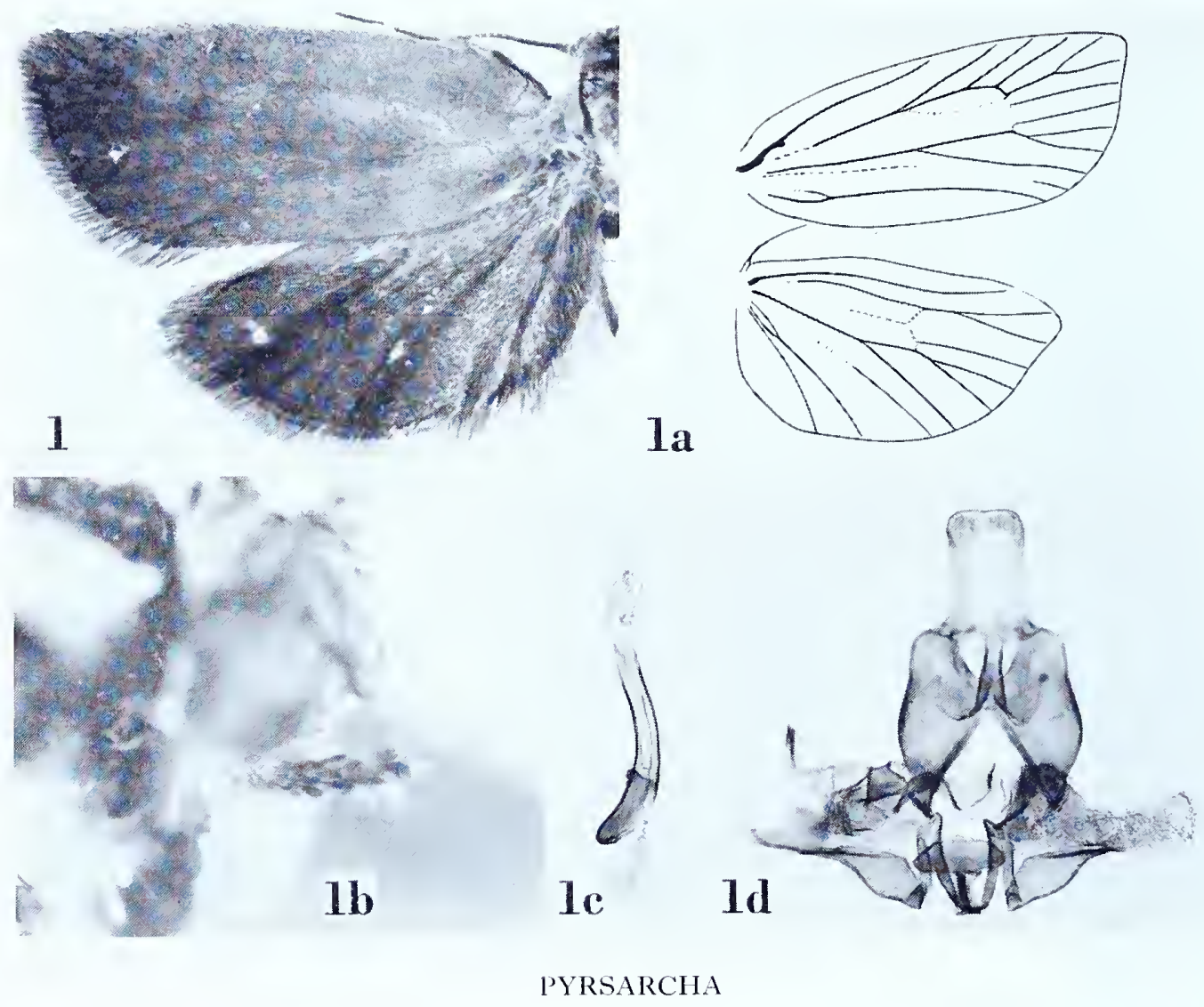




\section{PYRSARCHA Meyrick}

Pyrsarcha Meyrick, 1932, Exotic Microlepidoptera, 4: 340. (Typus generis: Pyrsarcha hypsicrates Meyrick, ibid. [monotypy].)

\section{Pyrsarcha hypsicrates Meyrick \\ Plate Io3, Figures I-Id}

Pyrsarcha hypsicrates Meyrick, I932, Exotic Microlepidoptera, 4: 340.

" J. I6-I 8 mm. . . . Kashmir, Gulmarg, 8,800 feet, June, July (T. B. Fletcher); 4 ex."

Type: The male so marked in the Meyrick collection and dated ".7.3I". Slide Stringer No. 1142.

Figure I, left wings; $\mathbf{a}$, venation of right wings; $\mathbf{I b}$, lateral aspect of head to show palpus (from a second specimen); Ic, lateral aspect of aedeagus; $I d$, ventral view of male genitalia (damaged) with aedeagus removed. 
RHAPSODICA

\section{RHAPSODICA Meyrick}

Rhapsodica Meyrick, 1927, Exotic Microlepidoptera, 3: 363. (Typus generis: Rhapsidoca [sic!] antitona, 1.c., 364 [monotypy].)

\section{Rhapsodica antitona Meyrick}

Plate 104, Figures I-Id

Rhapsidoca [sic!] antitona Meyrick, I927, Exotic Microlepidoptera, 3: 364 .

" o. 2 I mm. ... Sumatra (D. L. Fulmek); i ex."

Type: The above indicated male, "Sumatra. F. .24." Slide No. 7705.

Figure I, left wings; $\mathrm{ia}$, venation of right wings; $\mathrm{ib}$, lateral aspect of head to show palpus; Ic, lateral aspect of aedeagus; $\mathrm{rd}$, ventral view of male genitalia with aedeagus removed. 


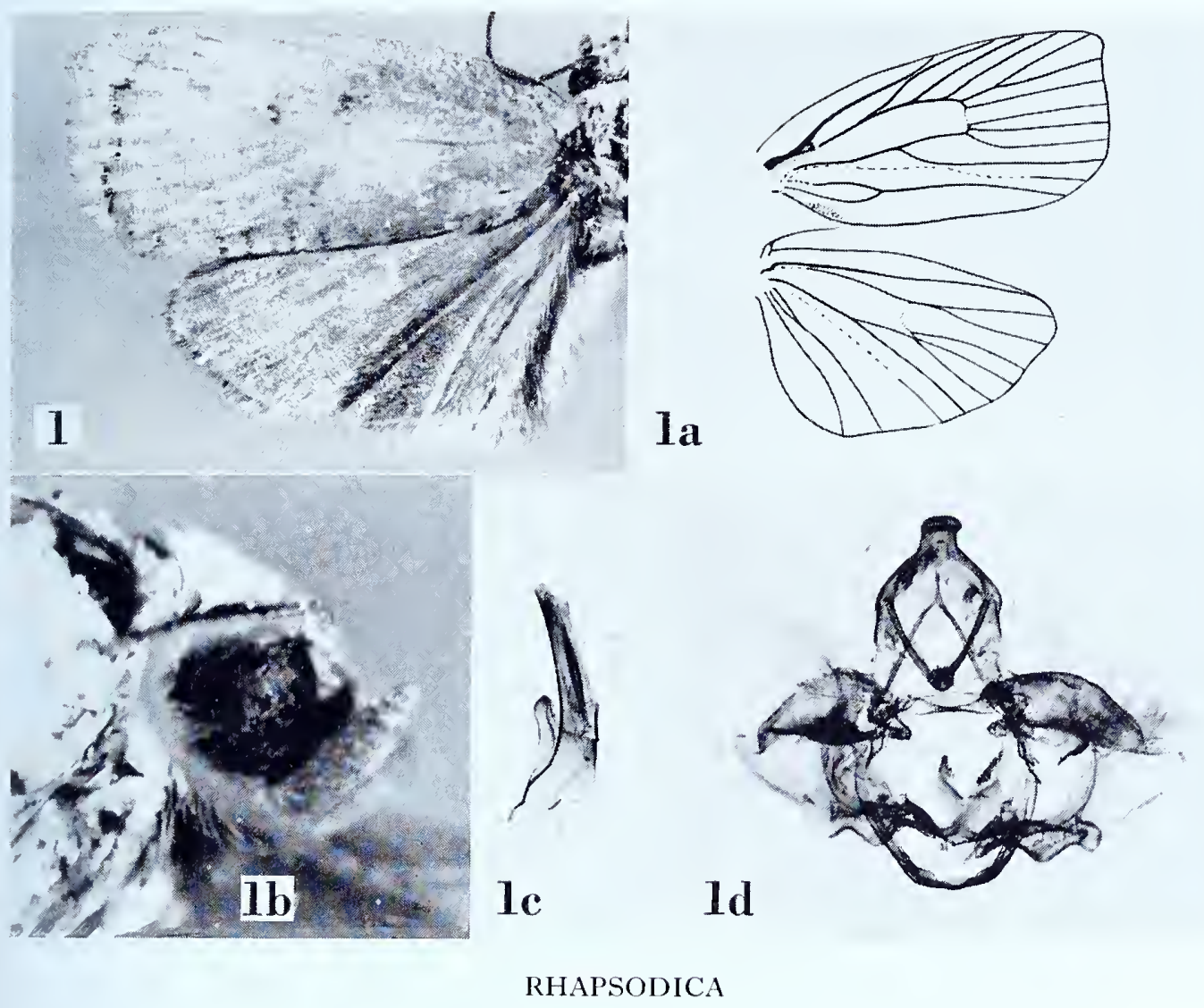




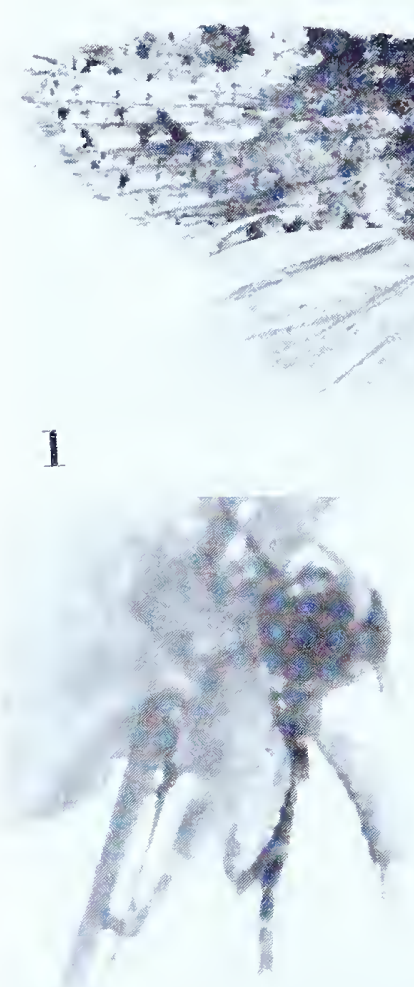

I1)
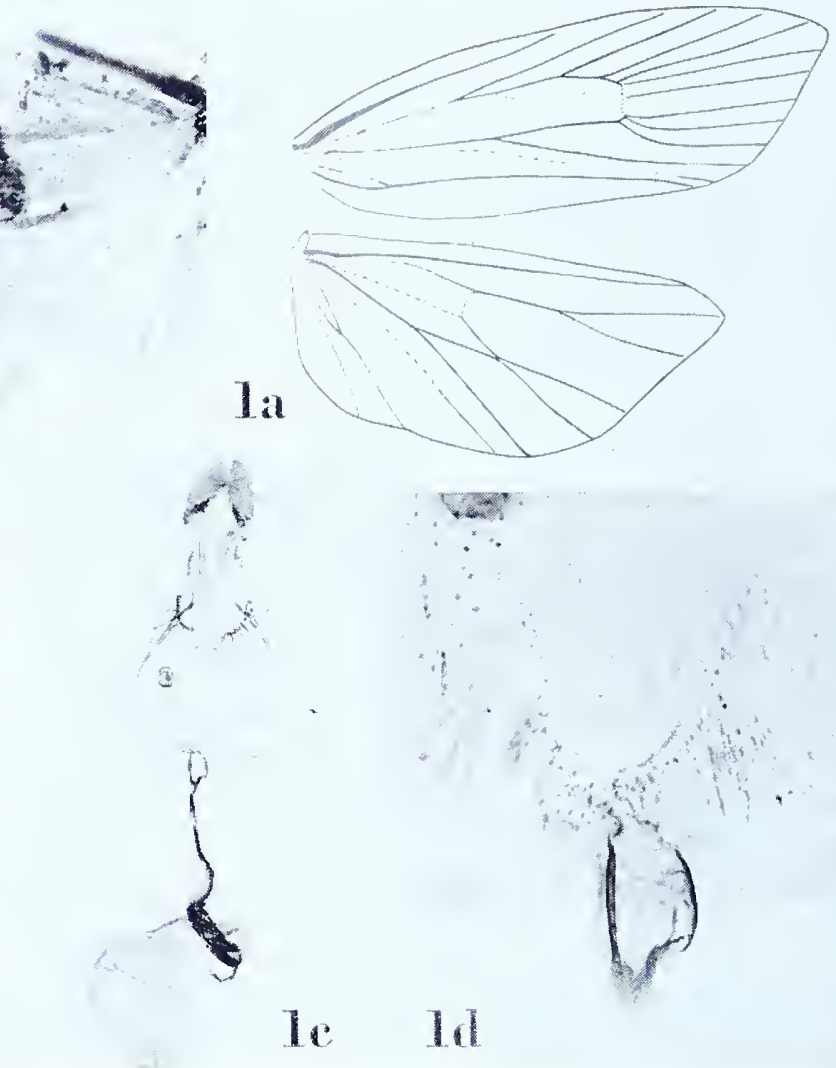

RHY'THMOLOGA 


\title{
RHYTHMOLOGA Meyrick
}

Rhythmologa Meyrick, 1926, Exotic Microlepidoptera, 3: 249. (Typus generis: Rhythmologa numerata Meyrick, ibid. [monotypy].)

\section{Rhythmologa numerata Meyrick}

\author{
Plate 105, Figures I-Id
}

Rhythmologa numerata Meyrick, I926, Exotic Microlepidoptera, 3: 249.

“"ㅇ. 24 mm. . . . Colombia, Mt. Tolima, I0,500-I 1,500 feet, October; 2 ex."

Lectotype: The female, "Mt. Tolima, Colombia. 10,500' . I0.20." The lectotype lacks both forewings, and one of the original specimens is missing. Wings and genitalia figured from a second specimen in the Meyrick collection labelled, "Mt. del Eden, Colombia. 9,500' . 10.20". Slide No. 7944.

Figure I, left wings; Ia, venation of right wings; $\mathrm{s}$, lateral view of head to show palpus; Ic, ventral view of female genitalia; id, detail of ostium. 


\section{SCHOENO'TENES Meyrick}

Schoenotenes Meyrick, 1908, Journ. Bombay Nat. Hist. Soc., i8: 619. (Typus generis:

Schoenotenes synchorda Meyrick, 1.c., 620 [by original designation].)

\section{Schoenotenes synchorda Meyrick \\ Plate Io6, Figures I-IC}

Schoenotenes synchorda Meyrick, i908, Journ. Bombay Nat. Hist. Soc., i8: 620.

" ${ }^{\circ} .16 \mathrm{~mm} . .$. Khasis, in July; one specimen."

Type: The above indicated male, "Khasi Hills, Assam. .7.1906." Slide Diakonoff No. II 50.

Figure I, left wings; Ia, venation of right wings; $\mathrm{Ib}$, lateral aspect of head to show palpus; Ic, ventral view of male genitalia with aedeagus in situ. 

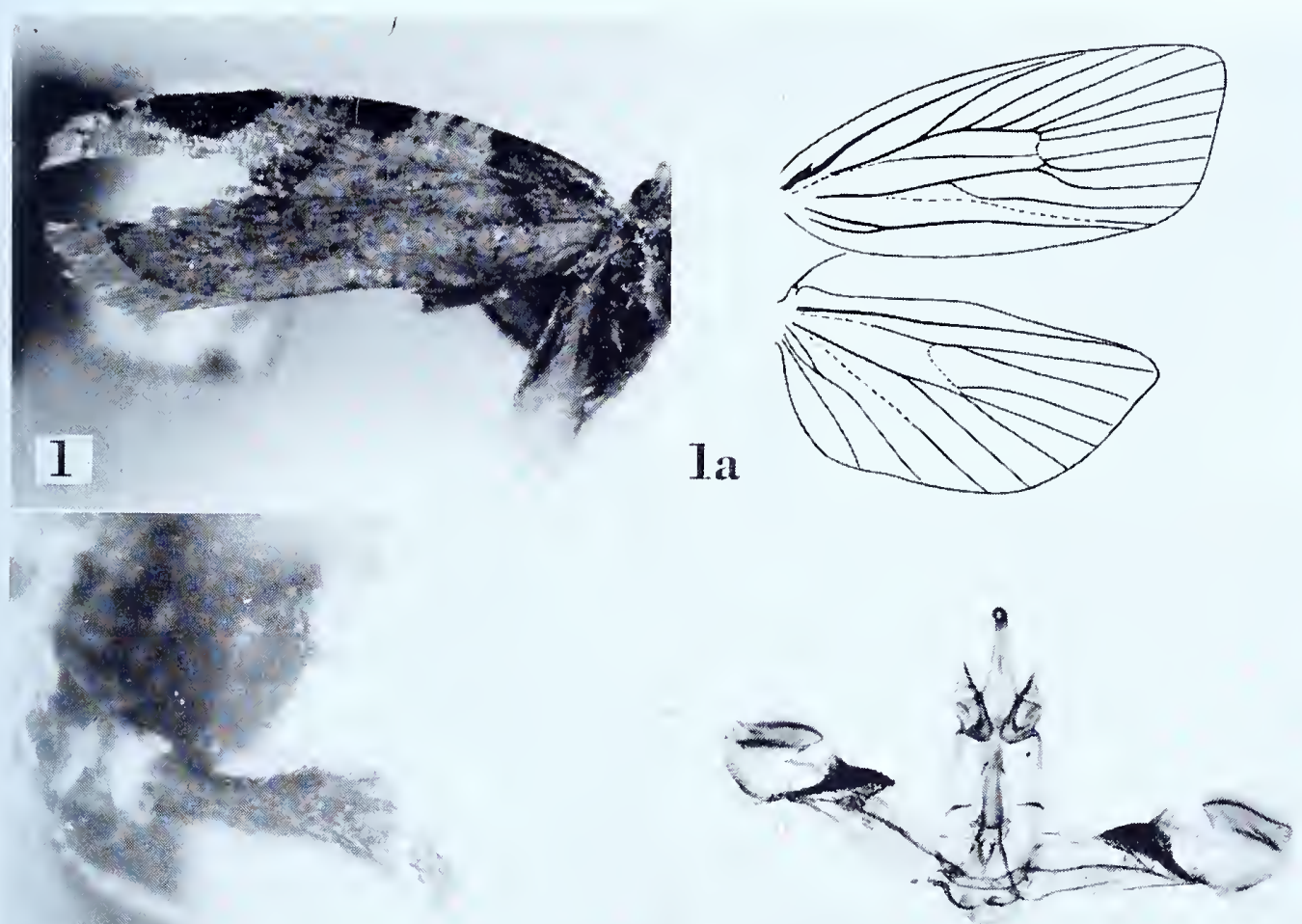

Ib

$1 c$

SCHOENOTENES 


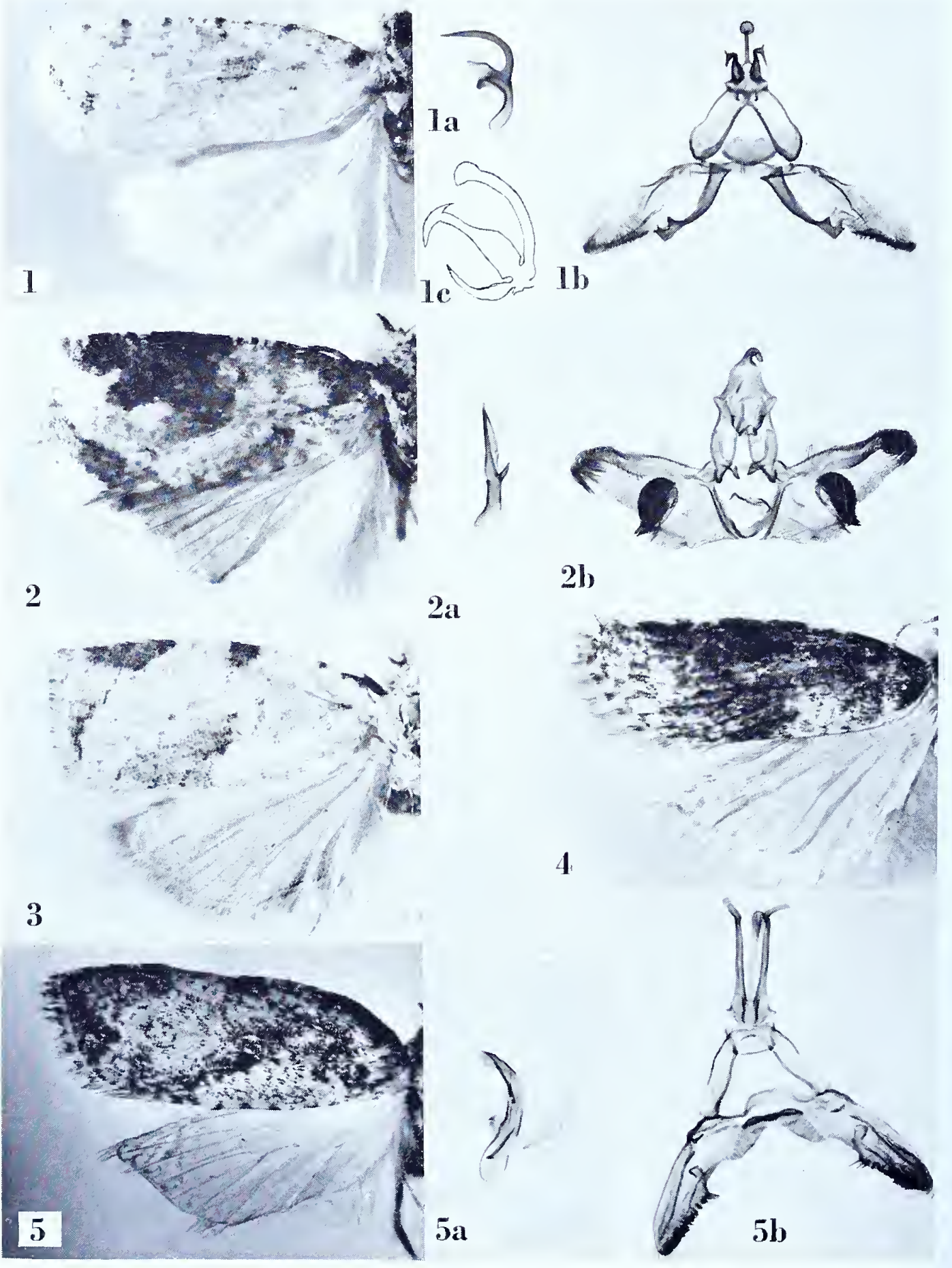




\section{Schoenotenes anthracobathra Meyrick}

Plate 107, Figures I-IC

Schoenotenes anthracobathra Meyrick, I938, Trans. R. Ent. Soc. London, 87: 508.

“ 3 ㅇ․ I 6-I7 mm. . . . Mt. 'Tafa, 8,500 feet, March; Kokoda, I, 200 feet, August, September. 5 ex.”

Type: The male so marked in the British Museum, "Mt. 'Tafa, Papua, 8,50o ft. iii-r 934. L. E. Cheesman." Slide No. 7015.

Figure I, left wings; $\mathbf{a}$, lateral aspect of aedeagus; $\mathrm{rb}$, ventral view of male genitalia with aedeagus removed; Ic, lateral aspect of uncus, gnathos and socii.

\section{Schoenotenes caryotrota Meyrick}

Plate 107, Figures 2-2b

Schoenotenes caryotrota Meyrick, I938, Trans. R. Ent. Soc. London, 87: 508.

" స̊ㅇ. I 1 -20 mm. . . Mt. Tafa, 8,500 feet, March; 4 ex."

Type: The male so marked in the British Museum, "Mt. Tafa, Papua, 8,500 ft. iii-r 934. L. E. Cheesman." Slide No. 7017.

Figure 2, left wings; $2 \mathrm{a}$, lateral aspect of aedeagus; $2 \mathrm{~b}$, ventral view of male genitalia with aedeagus removed.

\section{Schoenotenes cremnotoma Meyrick}

\section{Plate 107 , Figure 3}

Schoenotenes cremnotoma Meyrick, I936, Exotic Microlepidoptera, 5:62.

" o. I 4 mm. . . Java, Buitenzorg, bred October from tea-plant (Dr.v.d. Goot); I ex. (Brit. Mus.)."

Type: The male, without abdomen, so marked in the British Museum. Pin-label data are: "[undecipherable word] B. leg. Dr. v. d. Goot. Sindanglaja, 8.x.'35. I. v. Pl." A second label reads "On tea (leaves)" with the data of the first label repeated. A long white label bears the following inscription: "949. Schoenotenes cremnotoma n. sp."

Figure 3 , left wings.

\section{Schoenotenes halirrhothia (Meyrick), new combination}

\section{Plate 107 , Figures $5-5 \mathrm{~b}$}

Harmologa halirrhothia Meyrick, I938, Trans. R. Ent. Soc. London, 87: 507.

" 주우. I 5-20 nim. . . . Mt. Tafa, 8,500 feet, March; i2 ex."

Type: The male so marked in the British Museum, "Mt. Tafa, Papua, 8,50o ft. iii-1934. L. E. Cheesman." Slide No. 7027.

Figure 5 , left wings; 5 , lateral aspect of aedeagus $; 5^{b}$, ventral view of male genitalia with aedeagus removed.

[continued on p. 220. 


\section{Schoenotenes octosticta Meyrick}

Plate ı08, Figures I-Ia

Schoenotenes octosticta Meyrick, I 930, Exotic Microlepidoptera, 3: 6ro.

" $\hat{o}$. $18 \mathrm{~mm}$. ... British New Guinea, Owgara (Meek); I ex. (Coll. Paravicini)."

Type: The male so marked in the British Museum, "Owgara, B. N. Guinea. A. S. Meek." A small white label bears the inscription "M59I". Slide Diakonoff No. 278 .

Figure I, left wings; Ia, ventral view of male genitalia with aedeagus in situ.

\section{Schoenotenes paraptera Meyrick}

Plate io8, Figures 2-2b

Schoenotenes paraptera Meyrick, i 910, Trans. Ent. Soc. London, I 910: 433.

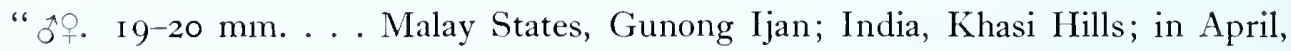
two specimens."

Lectotype: 'The male, "Khasi Hills, Assam. 4.igo6." Slide No. 6884.

Figure 2, left wings; $2 \mathrm{a}$, lateral aspect of aedeagus; $2 \mathrm{~b}$, ventral view of male genitalia with aedeagus removed.

\section{Schoenotenes sciocosma Meyrick}

Plate 108 , Figures $3^{-3} 3^{a}$

Schoenotenes sciocosma Meyrick, 1938, Trans. R. Ent. Soc. London, 87: 507.

"․ $26 \mathrm{~mm}$. ... Mt. Tafa, 8, 500 feet, March; I ex."

Type: The female indicated above, so marked in the British Museum, "Mt. Tafa, Papua, 8,500 ft., iii-1934. L. E. Cheesman." Slide No. 7014.

Figure 3 , left wings; 3 a, ventral view of female genitalia. Dorsally, opposite the ostium, there is a large, bulbous process.

\section{Schoenotenes spilonoma Meyrick \\ Plate ro8, Figure 4}

Schoenotenes spilonoma Meyrick, 1938, Trans. R. Ent. Soc. London, 87: 507.

"o. $19 \mathrm{~mm}$. .... Mt. Tafa, 8,500 feet, March; i ex."

Type: The female indicated above, so marked in the British Museum, "Mt. Tafa, Papua, 8,500 ft. iii-r 934, L. E. Cheesman." The abdomen of the type is missing.

Figure 4 , left wings.

[continued on p. 223 . 

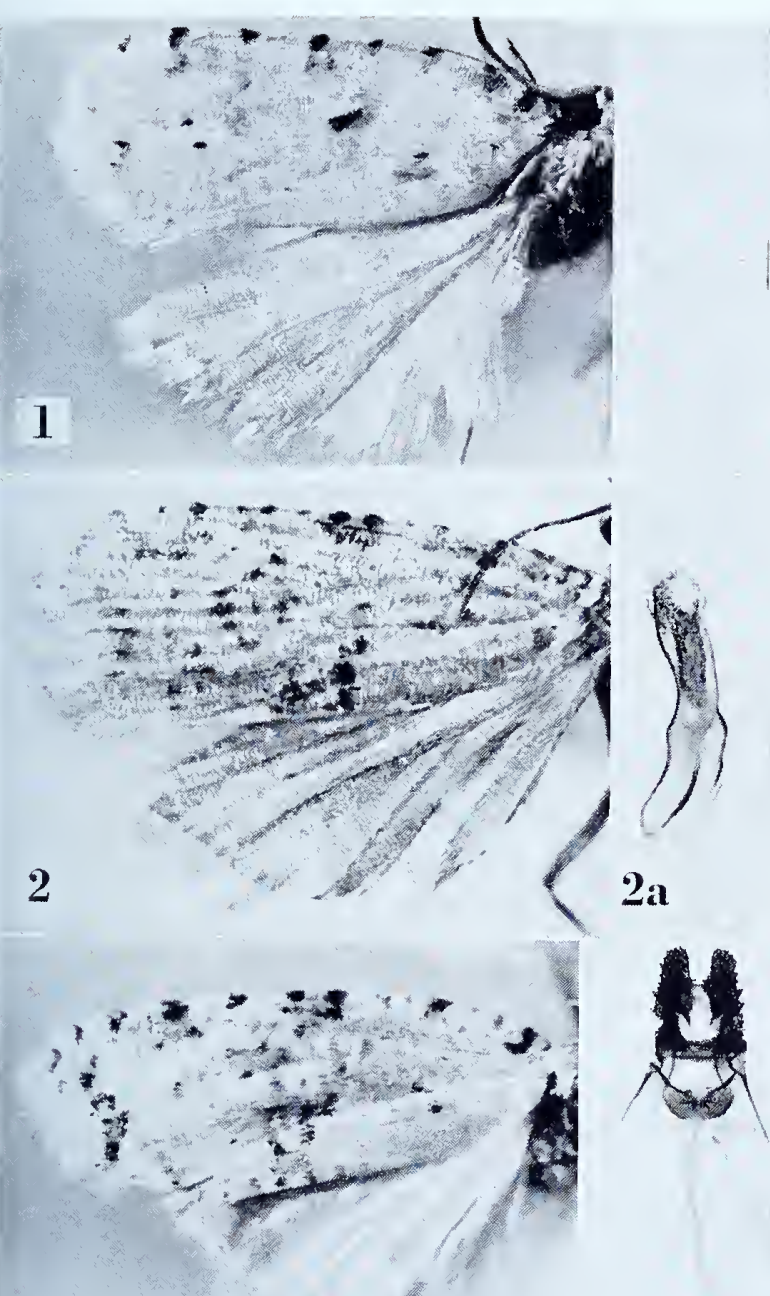

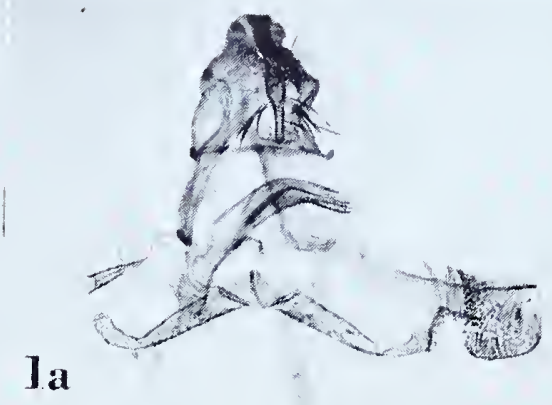

2b
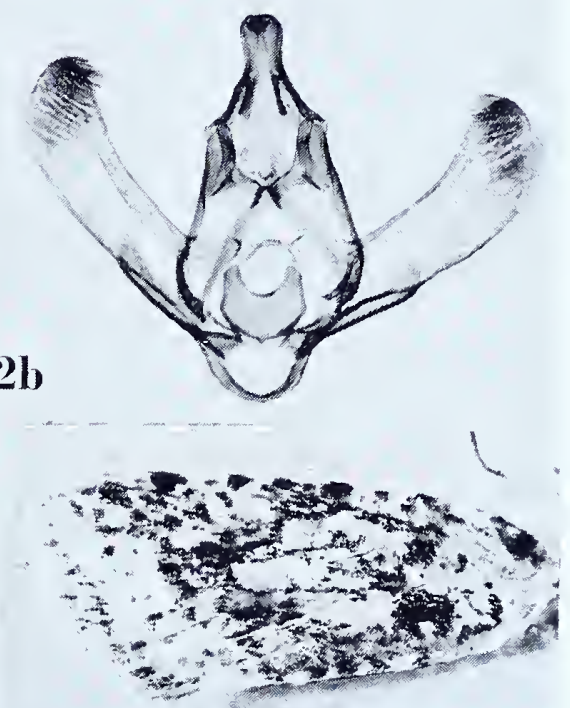

3

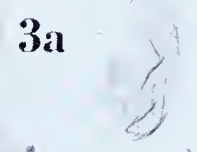

5
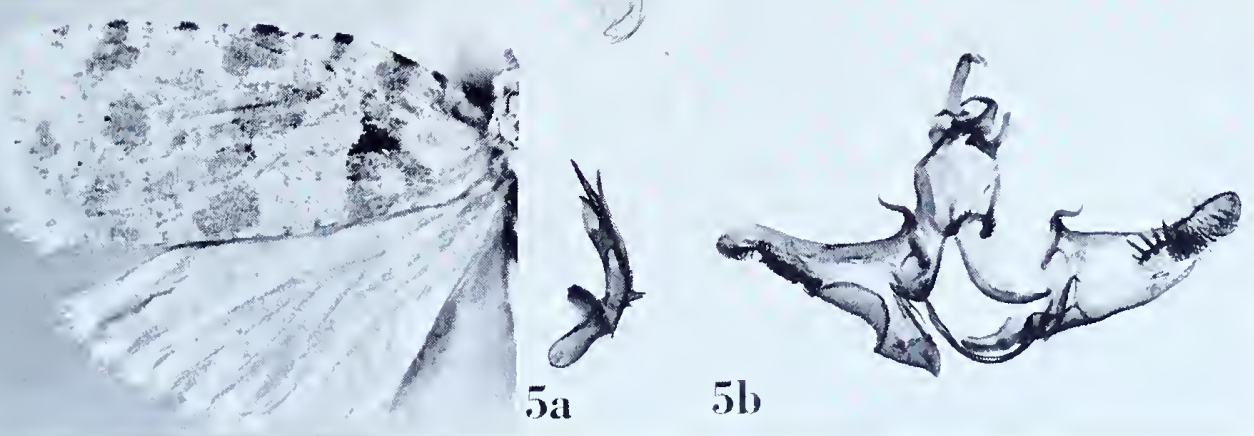

SCHOENOTENES 

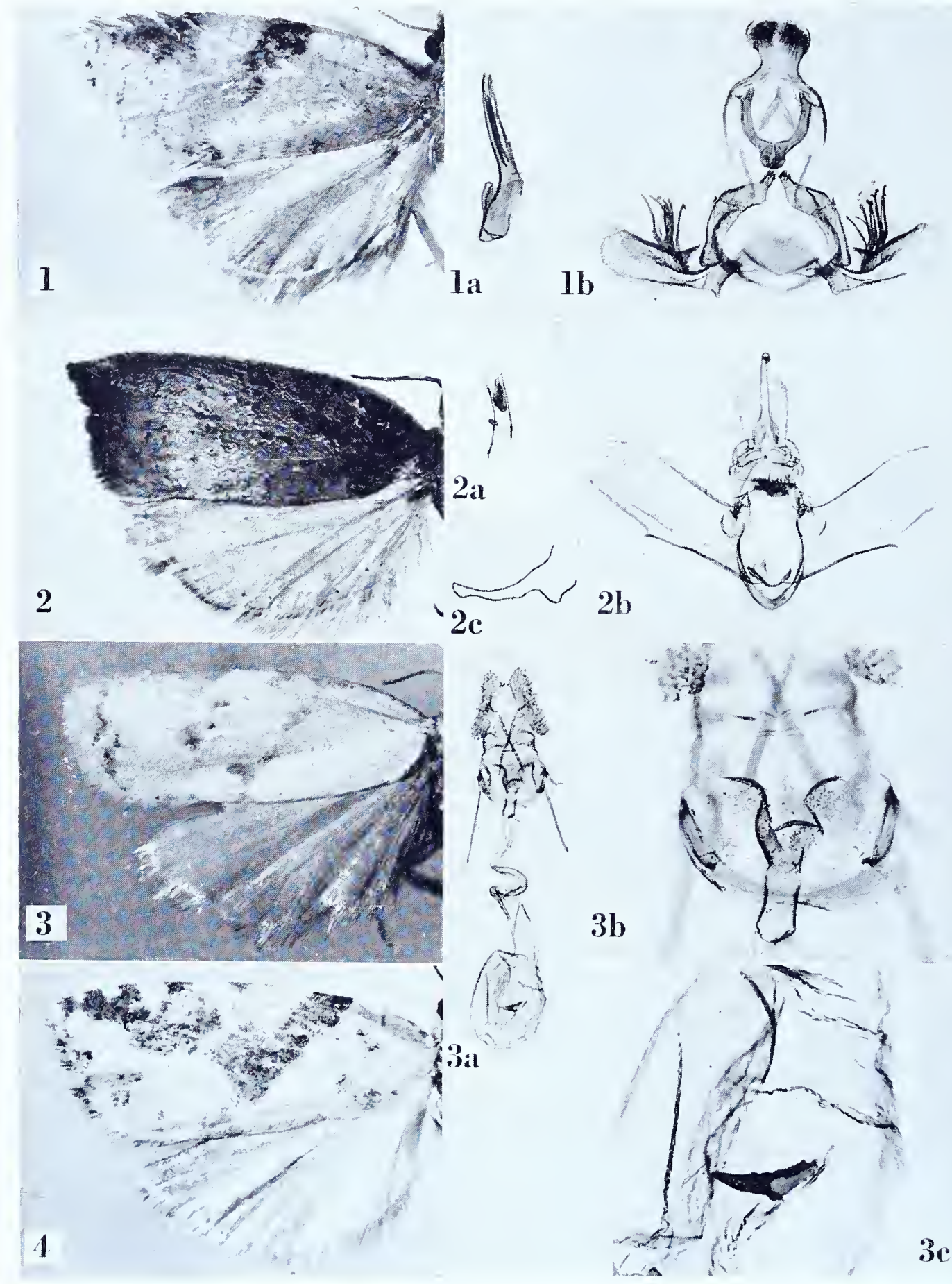

$3 c$

SICLOBOLA and SPARGANOTHIS 


\section{SICLOBOLA Diakonoff}

\section{Siclobola xylotoma (Meyrick), new combination}

Plate rog, Figures $\mathrm{I}-\mathrm{ib}$

Tortrix xylotoma Meyrick, 1891, Ent. Mon. Mag. 27: 13 .

"o. I $6 \mathrm{~mm}$. . . . Bougie; two specimens."

Type: The male so marked in the British Museum, "Bougie, Algeria. 25/4/90." Slide No. 9364 .

Figure $\mathrm{I}$, left wings; 1 a, lateral aspect of aedeagus; $\mathrm{rb}$, ventral view of male genitalia with aedeagus removed.

\section{SPARGANOTHIS Hübner \\ Sparganothis elimata Meyrick}

Plate I09, Figures 2-2c

Sparganothis elimata Meyrick, I930, Exotic Microlepidoptera, 3: 61 I.

" o. 2 I mm. ... Ecuador, Hacienda, Cayandeled, Rio Bamba, 4,200 feet, February; I ex."

Type: The above indicated male so marked in the British Museum. Slide No. $645^{8}$. A small white label bears the inscription "M64".

Figure 2 , left wings; $2 \mathrm{a}$, lateral aspect of aedeagus; $2 \mathrm{~b}$, ventral view of male genitalia with aedeagus removed; $2 \mathrm{c}$, lateral view of gnathos.

\section{Sparganothis euphronopa Meyrick}

Plate rog, Figures $3^{-} 3^{\mathrm{c}}$

Sparganothis euphronopa Meyrick, 1927, Exotic Microlepidoptera, 3:370.

"ㅇ. I 7-20 mm. . . . Texas, Alpine, 7,000-8,000 feet, May to July; 6 ex. Nearest procax and tempestiva."

Lectotype: A female measuring $20 \mathrm{~mm}$., dated ".7.26" from 7,000 feet. Slide No. 6370 .

Figure 3 , left wings; 3 a, ventral view of female genitalia; 3 b, detail of genital plate and ostium; $3 \mathrm{c}$, signum

\section{Sparganothis ithyclina Meyrick}

\section{Plate rog, Figure 4}

Sparganothis ithyclina Meyrick, 1926, Exotic Microlepidoptera, 3: 260.

" o. 24-25 mm. . . Colombia, Alto de las Ances, 7,250 feet, March, April; 2 ex."

Lectotype: The male dated ".4.20" which has no abdomen. The second specimen is missing.

Figure 4, left wings. 


\section{Sparganothis myrota Meyrick}

Plate i io, Figures $\mathrm{I}-\mathrm{Ib}$

Sparganothis myrota Meyrick, I9I2, Trans. Ent. Soc. London, i9I I : 686.

" o. 20-22 mm. . . . Colombia, San Antonio, 5,800 feet, in November; two specimens."

Lectotype: The male measuring $22 \mathrm{~mm}$. Slide No. 6369. Both specimens are dated ".i 1.07 ".

Figure I, left wings; $\mathrm{Ia}$, lateral aspect of aedeagus; $\mathrm{I} b$, ventral view of male genitalia with aedeagus removed.

\section{Sparganothis subacida Meyrick}

Plate i Io, Figures 2-2b

Sparganothis subacida Meyrick, 1917, Trans. Ent. Soc. London, I917: I3.

"o. I 5 mm.; +. $22 \mathrm{~mm}$. . . French Guiana, R. Maroni; two specimens."

Lectotype: The male, "St. Jean, R. Maroni, Fr. Guiana. LeM. .r 5." Slide No.6372.

Figure 2, right wings (image reversed); $2 \mathrm{a}$, lateral aspect of aedeagus; $2 \mathrm{~b}$, ventral view of male genitalia with aedeagus removed.

\section{Sparganothis xylophaea (Meyrick) \\ Plate i io, Figures $3-3 \mathrm{~b}$}

Capua xylophaea Meyrick, i912, Trans. Ent. Soc. London, I91 I: 675.

" $\$$. I $5 \mathrm{~mm}$. ... Argentina, Tucuman; one specimen."

Type: The specimen indicated above with "R. .08" at the bottom of the pin-label. Slide No. 637I.

Figure 3 , left wings; 3 a, lateral aspect of aedeagus; 3 b, ventral view of male genitalia with aedeagus removed.

Continued from p. 215 .

\section{Schoenotenes melitoptila Meyrick}

Plate 107 , Figure 4

Schoenotenes melitoptila Meyrick, I 938, 'Trans. R. Ent. Soc. London, 87: 508.

" o. I $5 \mathrm{~mm}$. . . . Mt. Tafa, 8,500 feet, March; i ex."

Type: The above indicated male so marked in the British Museum, "Mt. Tafa, Papua, 8,500 ft. iii-I 934. L. E. Cheesman." The abdomen of the type is missing.

Figure 4, left wings. 

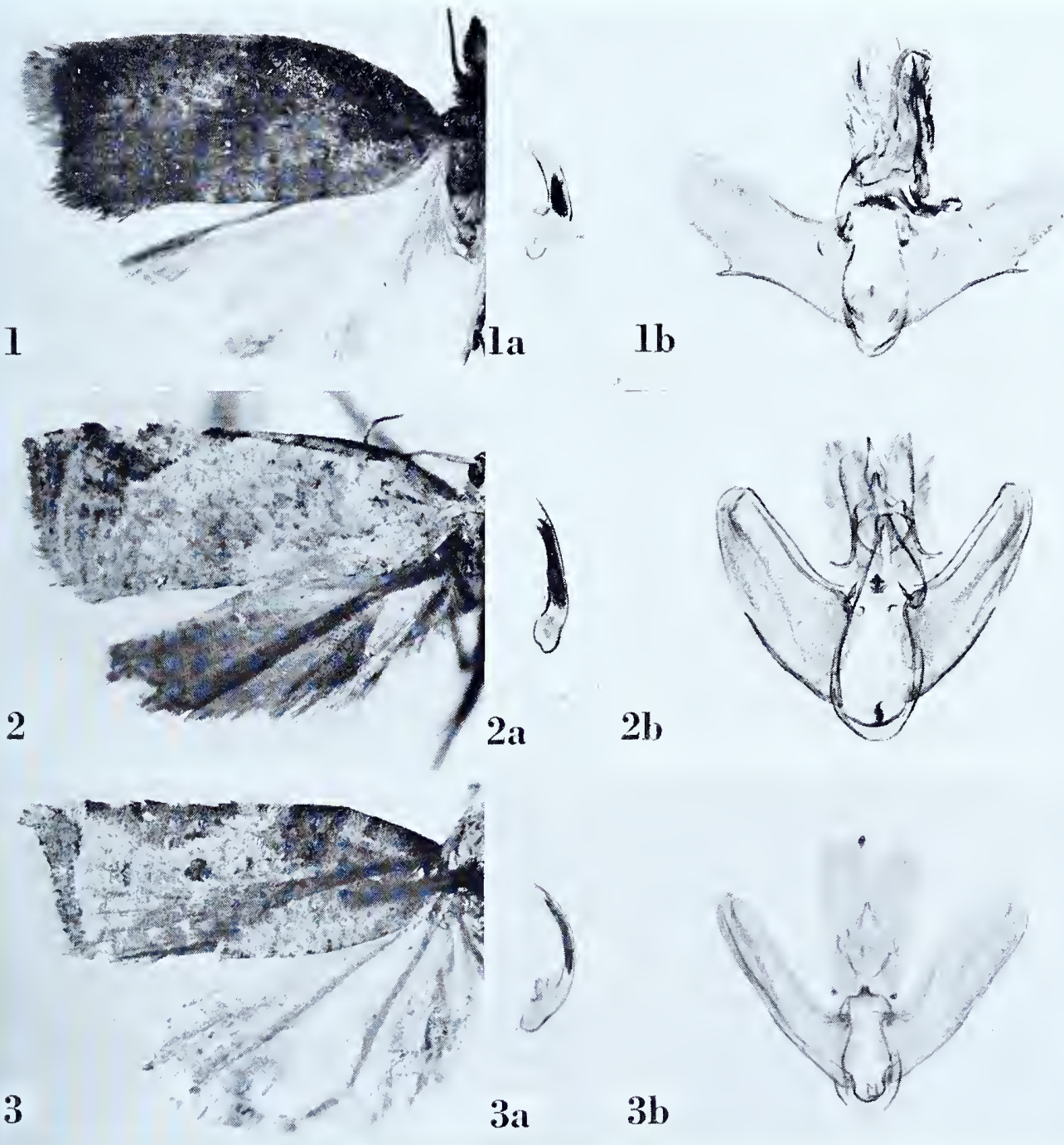

SPARGANOTHIS 


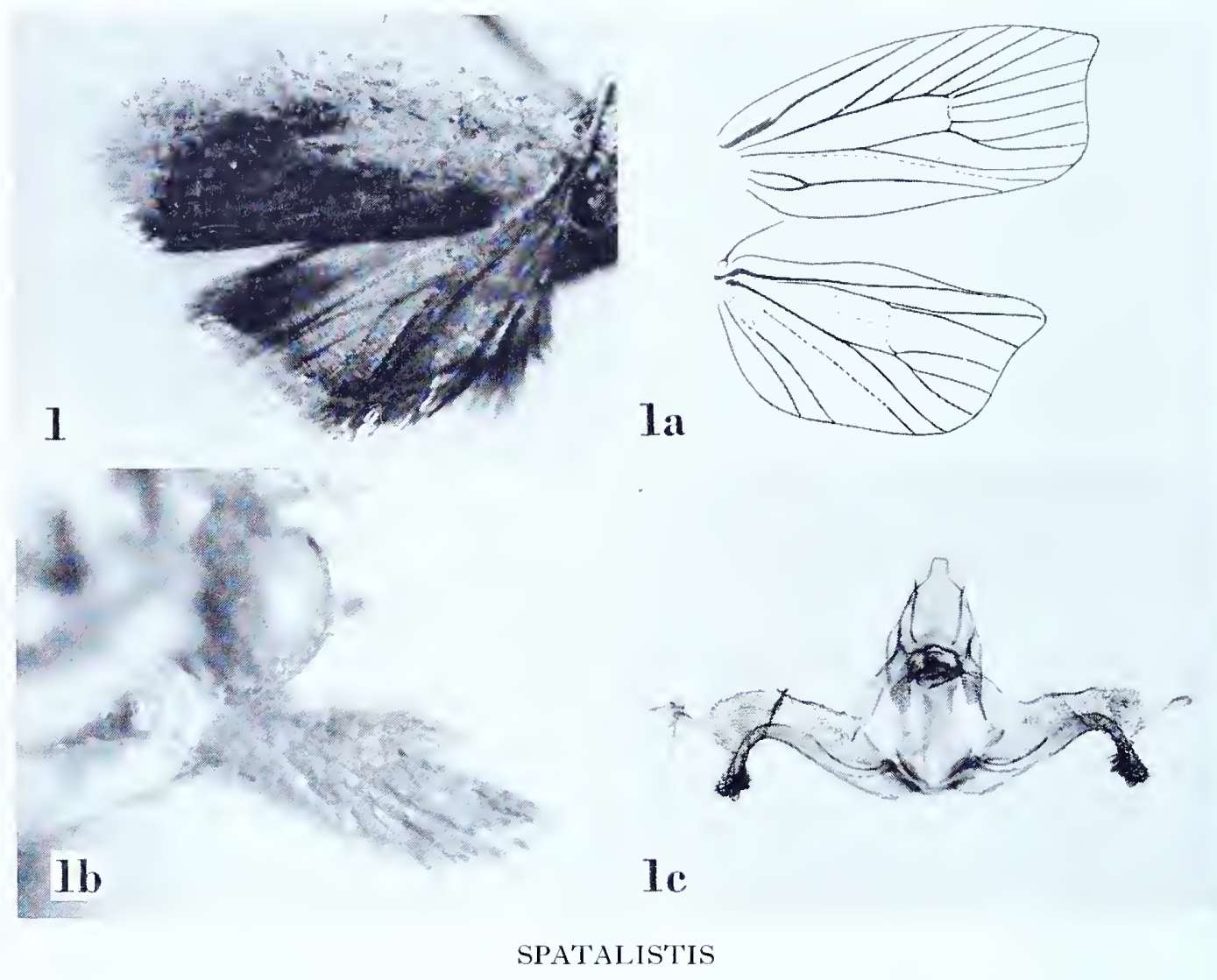




\section{SPATALISTIS Meyrick}

Spatalistis Meyrick, 1907, Journ. Bombay Nat. Hist. Soc., I7: 978. (Typns generis: Spatalistis rhopica Meyrick, 1.c., 979 [by original designation].)

\section{Spatalistis rhopica Meyrick}

Plate I I , Figures I-I c

Spatalistis rhopica Meyrick, I907, Journ. Bombay Nat. Hist. Soc., I 7: 979.

" ‘ㅇ․ I4-16 mm. . . . Fifteen specimens, Khasi Hills, in June."

Type: The male so designated in the British Museum. Slide No. 6860. Seven of the original specimens are missing. The remainder are dated ".6. igo6".

Figure I, left wings; Ia, venation of right wings; $\mathrm{rb}$, lateral aspect of head to show palpus; Ic, ventral view of male genitalia with aedeagus $i n$ sitn (cornuti similar to those of Acleris spp.).

Continued from p. 216 .

\section{Schoenotenes subcroceata Meyrick}

Plate 108 , Figures $5^{-5} \mathrm{~b}$

Schoenotenes snbcroceata Meyrick, i 938, Trans. R. Ent. Soc. London, 87: 508.

" స̊ํ. I 7-1 $8 \mathrm{~mm}$. . . . Mt. Tafa, 8,500 feet, March; Mafulu, 4,000 feet, January; 6 ex."

Type: The male so marked in the British Museum, "Mt. Tafa, Papua, 8, $500 \mathrm{ft}$. iii-r 934. L. E. Cheesman." Slide No. 70 or6.

Figure 5 , left wings; 5 a, lateral aspect of aedeagus; 5 b, ventral view of male genitalia with aedeagus removed. 


\section{Spatalistis aglaoxantha Meyrick \\ Plate I I 2, Figures I-Ib}

Spatalistis aglaoxantha Meyrick, 1924, Exotic Microlepidoptera, 3: 116.

"ㅇ. $16 \mathrm{~mm}$. . . China, Kwanhsien, July (Franck); I ex."

Type: The female indicated above dated “.2.7.20”. Slide No. 6864.

Figure I, left wings; Ia, ventral view of female genitalia (ovipositor destroyed); $\mathrm{Ib}$, detail of genital plate and ostium.

\section{Spatalistis cyanoxantha Meyrick}

Plate i 12, Figures $2-2 b$

Spatahistis cyanoxantha Meyrick, I907, Journ. Bombay Nat. Hist. Soc., I 7: 979.

" $\$$ ㅇ․ 8-10 mm. ... Three specimens, Maskeliya, Ceylon, from April to June (de Mowbray, Pole)."

Lectotype: A male measuring io mm., "Maskeliya, Ceylon. Pole. .6.o6." Slide No. 6862.

Figure 2, right wings (image reversed); $2 \mathrm{a}$, aedeagus; $2 \mathrm{~b}$, ventral view of male genitalia with aedeagus removed.

\section{Spatalistis droserantha Meyrick}

Plate I 2 , Figures $3^{-} 3^{\mathrm{c}}$

Spatalistis droserantha Meyrick, I930, Exotic Microlepidoptera, 3: 61 I.

"․ I $5 \mathrm{~mm}$. . . . Assam, Shillong, 5,000 feet, May (Fletcher); I ex. Allied to hormota."

Type: The above indicated female dated ".5.28”. Slide No. 6865.

Figure 3 , left wings; $3 \mathrm{a}$, ventro-lateral aspect of female genitalia; $3 \mathrm{~b}$, detail of genital plate and ostium; $3 \mathrm{c}$, signum.

\section{Spatalistis hormota Meyrick}

Plate i I2, Figures $4-4$ a

Spatahistis hormota Meyrick, I 907, Journ. Bombay Nat. Hist. Soc., I 7: 979.

" ㅇํ. I 5-17 mm. . . . Twenty specimens, Khasi Hills, in June and July."

Lectotype: A male measuring i6 mm., dated ".6.1906". Slide No. 6863.

Figure 4, left wings; 4 a, ventral view of male genitalia with aedeagus in situ (six cornuti). 


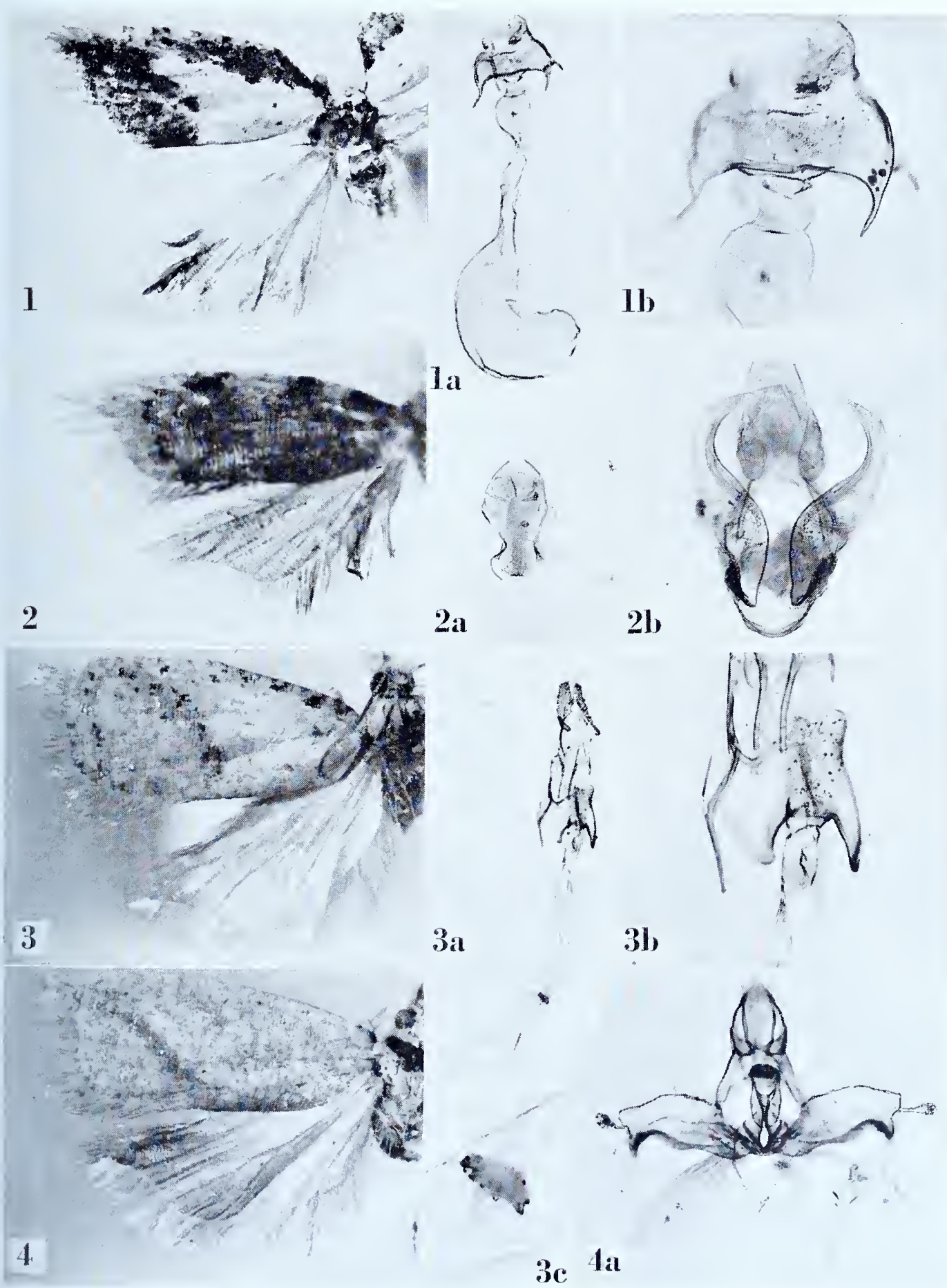




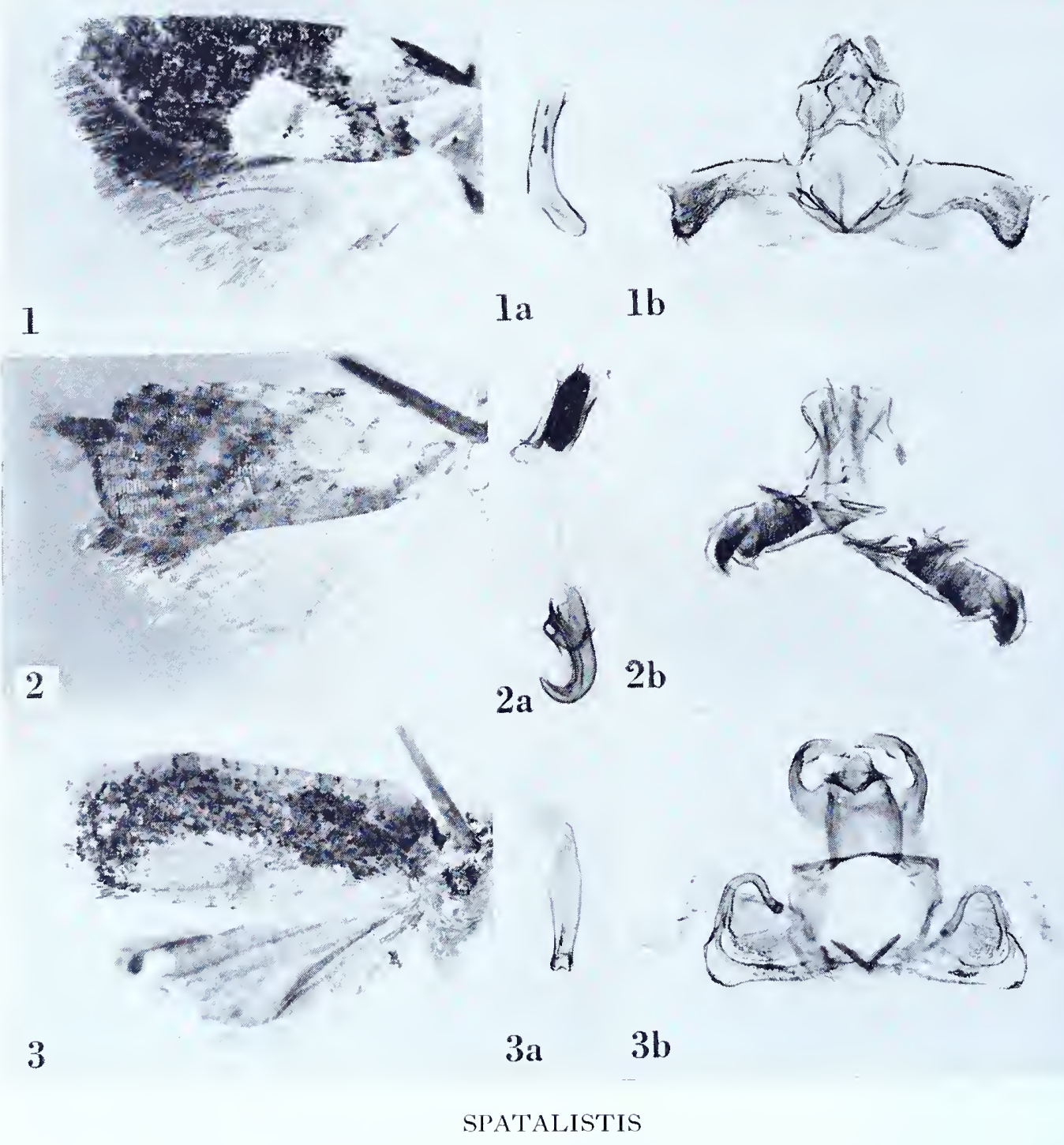




\section{Spatalistis orbigera Meyrick}

Plate I I3, Figures I-Ib

Spatalistis orbigera Meyrick, I912, Exotic Microlepidoptera, I : I4.

" o. $13 \mathrm{~mm}$. . . A Assam, Khasis, in April; one specimen."

Type: The above indicated male labelled, "Khasi Hills, Assam. .4.1907". Slide No. 6866.

Figure I, left wings; $\mathbf{a}$, lateral aspect of aedeagus; $\mathbf{r} b$, ventral view of male genitalia with aedeagus removed.

\section{Spatalistis paryphaea Meyrick}

Plate I 3 , Figures 2-2b

Spatalistis paryphaea Meyrick, I907, Journ. Bombay Nat. Hist. Soc., I7: 978.

" 후오. I4-17 mm. . . E Eight specimens, Khasi Hills, in June."

Lectotype: A male measuring $16 \mathrm{~mm}$. Slide No. 686I.

Figure 2 , left wings; $2 \mathrm{a}$, aedeagus; $2 \mathrm{~b}$, ventral view of male genitalia with aedeagus removed.

\section{Spatalistis tyrophthora Meyrick}

Plate I I 3 , Figures $3-3 b$

Spatalistis tyrophthora Meyrick, I9I2, Exotic Microlepidoptera, I : I5.

"수우 I2-I3 mm. . . Assam. Khasis, in November; two specimens."

Lectotype: The male. Slide No. 6888. Both specimens have identical data, "Khasi Hills, Assam. .I I.I906."

Figure 3 , left wings; $3^{\mathrm{a}}$, aedeagus; $3 \mathrm{~b}$, ventral view of male genitalia with aedeagus removed. 


\section{SPHE'TERISTA Meyrick}

Plate I I 4, Figures I-Id

Spheterista Meyrick, I912, Exotic Microlepidoptera, I : 2. (Typus generis : Capua variabilis Walsingham, I 907, Fauna Hawaïensis, I : 706, pl. I 2, fig. 4 [by original designation].)

The type of the genus is figured from a specimen in the British Museum. Slide No. $953^{6 .}$

Figure I, left wings; гa, venation of right wings; ib, labial palpus; ic, lateral aspect of aedeagus; Id, ventral view of male genitalia with aedeagus removed.

\section{TEMPLEMANIA Busck}

\section{Templemania rhythmogramma (Meyrick), new combination}

Plate I I 4, Figures 2-2a

Cacoecia rhythmogramma Meyrick, I924, Exotic Microlepidoptera, 3: io6.

" $\hat{o}+$. 3 I-34 mm. . . Mexico, Zacualpan, July; 3 ex. Allied to sarothrura. . .."

Lectotype: The male measuring $31 \mathrm{~mm}$., and dated “7.14". Slide No. 6293. One of the original specimens is missing.

Figure 2, left wings; 2a, ventral view of male genitalia with aedeagus in situ. 

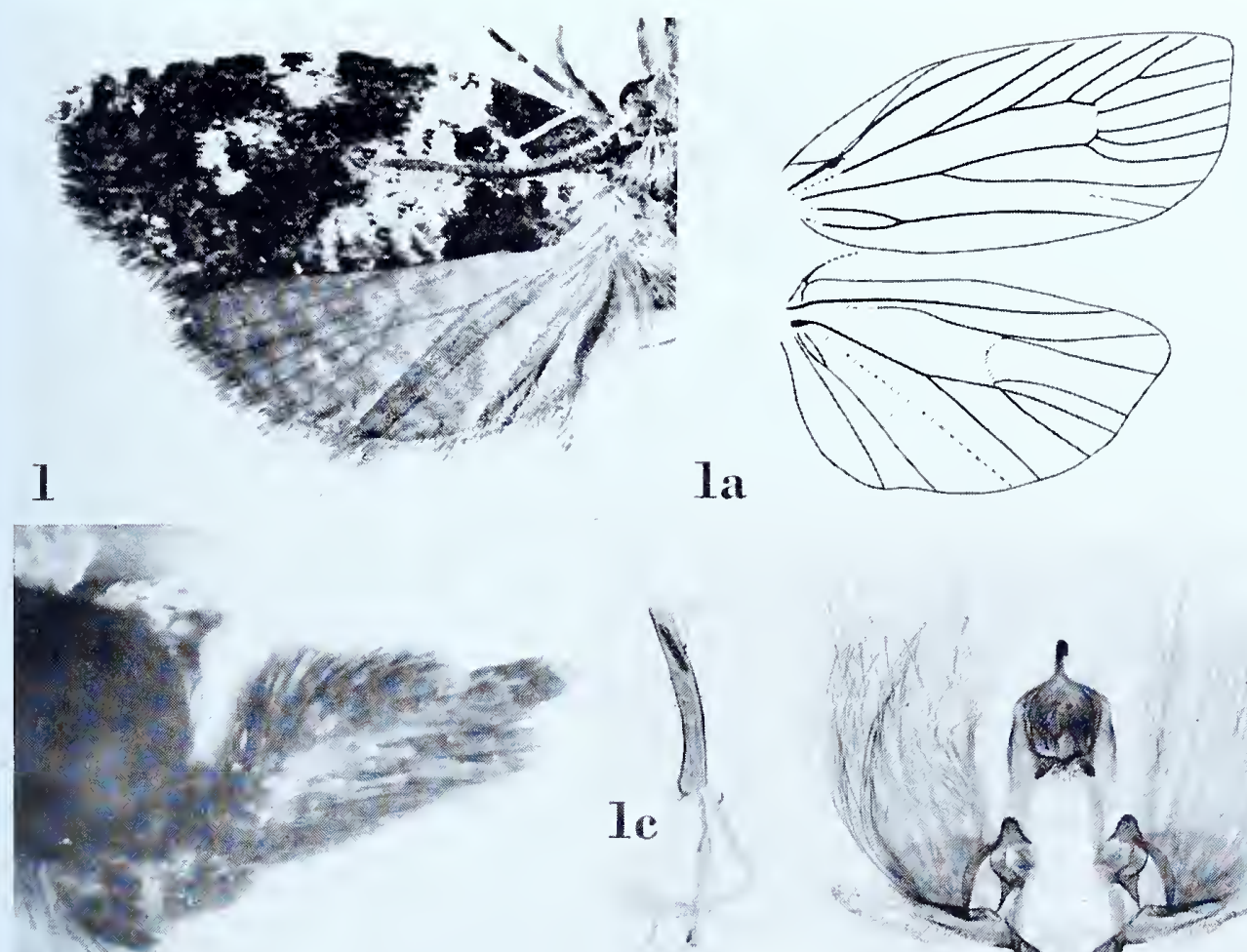

1b
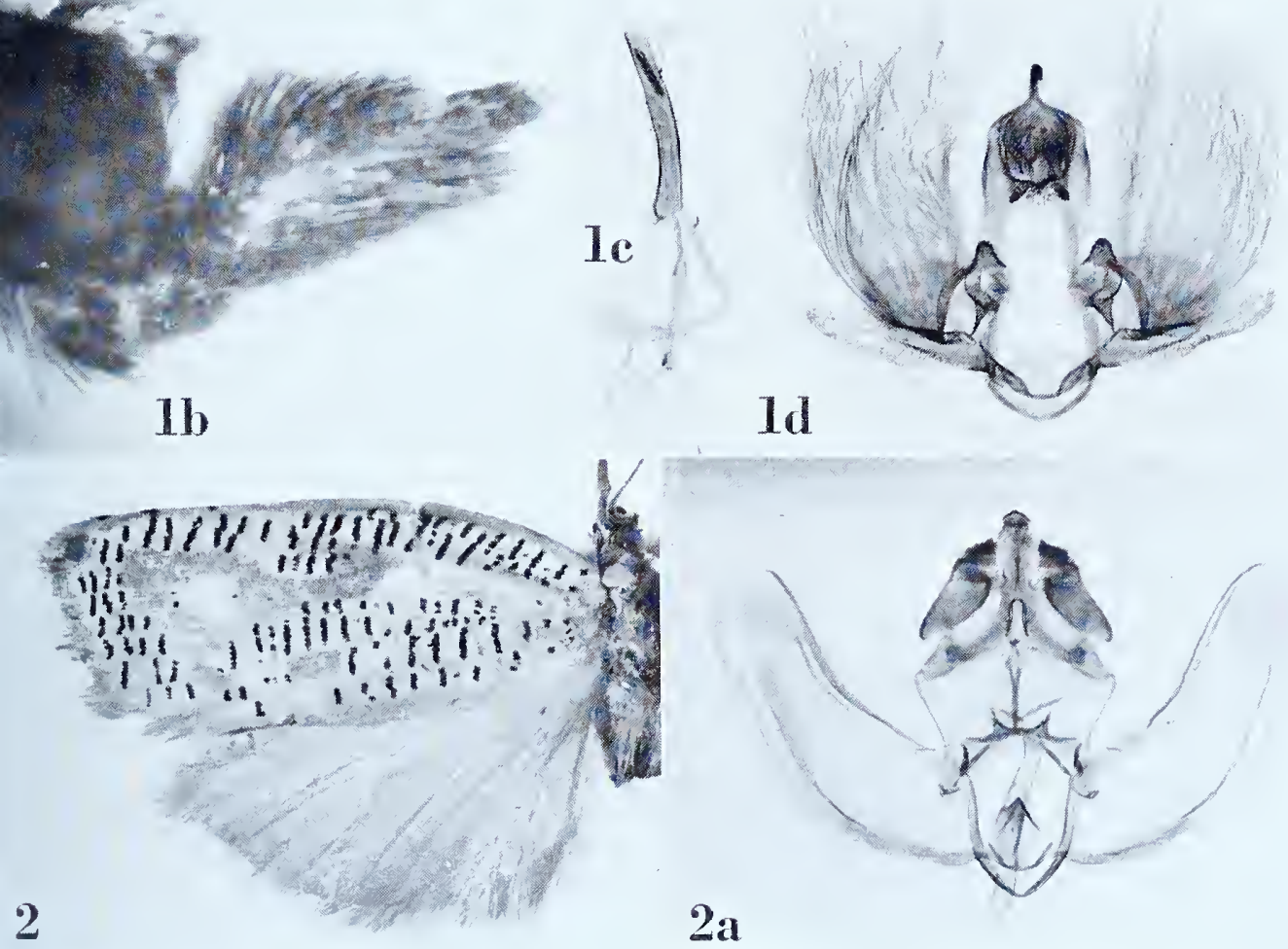

SPHETERISTA and TEMPLEMANIA 

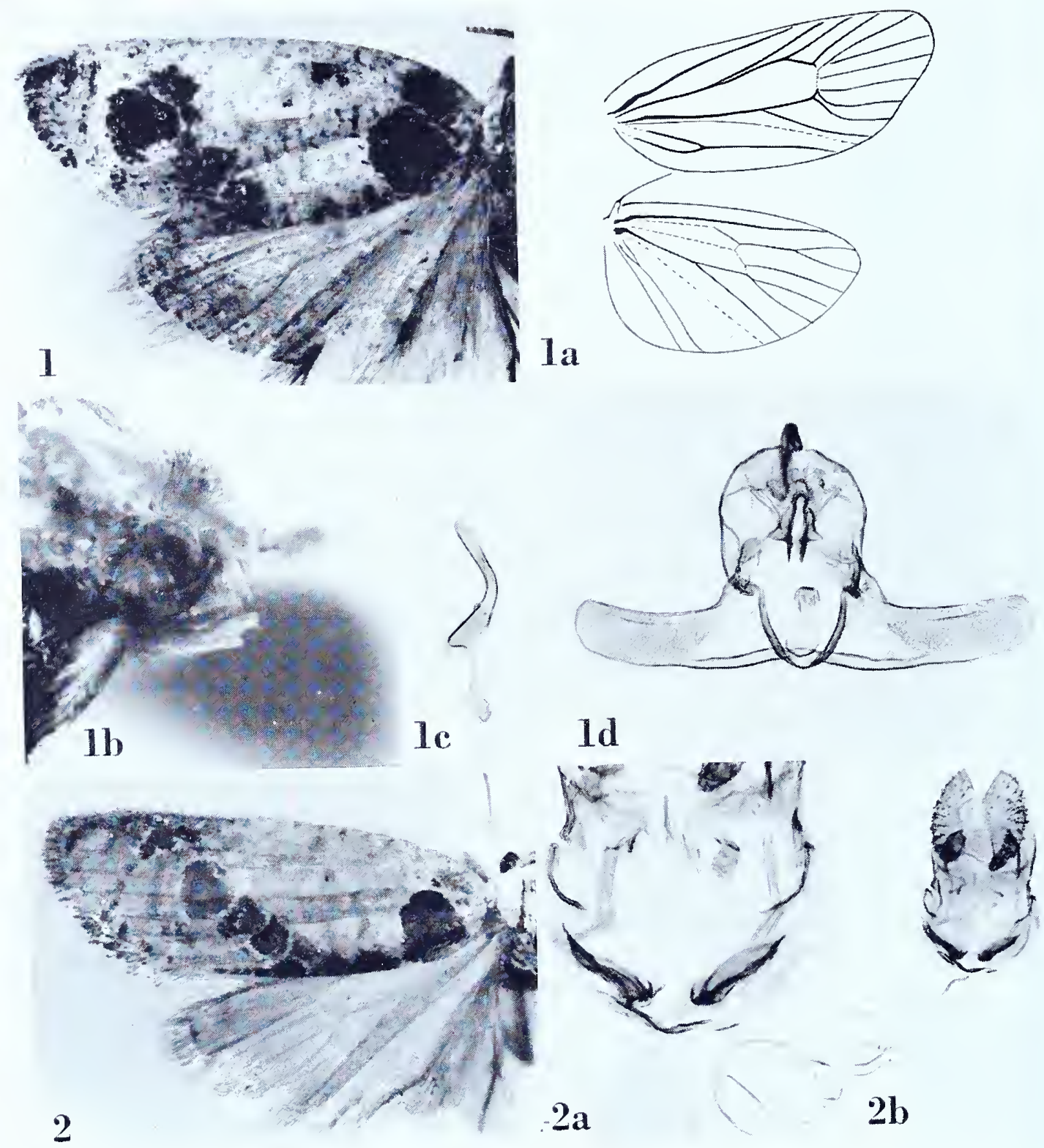

TERTHREUTIS 


\section{TERTHREUTIS Meyrick}

Terthrentis Meyrick, I918, Exotic Microlepidoptera, 2: I70. (Typus generis: Terthrentis sphaerocosma Meyrick, ibid. [monotypy].)

Amniodes Meyrick, 1938, in Caradja and Meyrick, Deuts. Ent. Zeit. Iris, 52: 13 (new synonymy).

\section{Terthreutis sphaerocosma Meyrick}

Plate i I 5, Figures I-Id

Terthreutis sphaerocosma Meyrick, 1918, Exotic Microlepidoptera, 2: 170.

" స̊․ I 6-23 mm. . . Sikkim, Bhotan (Dudgeon); Assam, Khasis; May, July, October, six specimens."

Lectotype: A male measuring $20 \mathrm{~mm}$., "Khasi Hills, Assam. .6.1906." Slide No. 6885. Three specimens are missing.

Figure I, left wings; $\mathrm{I}$ a, venation of right wings; $\mathrm{I} b$, lateral aspect of head to show palpus; rc, lateral aspect of aedeagus; id, ventral view of male genitalia with aedeagus removed.

\section{Terthreutis bulligera Meyrick}

\section{Plate I 15, Figures 2-2b}

Terthreutis bulligera Meyrick, I928, Exotic Microlepidoptera, 3:459.

"ㅇ. 22 mm. ... Bengal, Calcutta (Atkinson); I ex."

Type: The female indicated above, "Calcutta, Bengal. A. .65." Slide No. 6886.

Figure 2, left wings; 2 a, detail of genital plate and ostium; 2 b, ventral view of female genitalia. 
TORTRIX

\section{TORTRIX Linnaeus}

\section{Tortrix agroeca Meyrick}

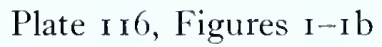

Tortrix agroeca Meyrick, i908, Proc. Zool. Soc. London, i 908 : 723 .

" ô. $20 \mathrm{~mm}$. . . . Transvaal, Pretoria district, in December (Fanse); one specimen."

Type: The male denoted above, "E. Pretoria, Transvaal. Janse. i 2.i 2.o6." Slide No. 9378 .

Figure I, left wings; Ia, lateral aspect of aedeagus; I b, ventral view of male genitalia with aedeagus removed.

\section{Tortrix caementosa (Meyrick)}

Plate i i6, Figures 2-2b

Cacoecia caementosa Meyrick, i 9o8, Journ. Bombay Nat. Hist. Soc., i 8: 6 5 .

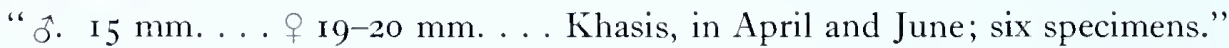

Lectotype: A male dated ".6. I 9o6". Slide No. 6832. One specimen is missing.

Figure 2, left wings; $2 a$, lateral aspect of aedeagus; $2 b$, ventral view of male genitalia with aedeagus removed. Outer surface of harpe with a large, oval concavity densely filled with long, deciouous, hair-like scales.

\section{Tortrix capnosticha Meyrick}

Plate i 6 , Figures 3-3b

Tortrix capnosticha Meyrick, I917, Trans. Ent. Soc. London, I917: 8.

" ${ }^{7}+$ I $^{-1} 5 \mathrm{~mm}$. . . Peru, Lima, in August (Parish); six specimens."

Lectotype: A male measuring I 3 mm. Slide No. 6336. All specimens bear identical data and are dated "8. 4 ".

Figure 3 , left wings; 3 a, lateral aspect of aedeagus; 3 , ventral view of male genitalia with aedeagus removed.

\section{Tortrix cavillata Meyrick \\ Plate i 6 , Figures $4-4 b$}

Tortrix cavillata Meyrick, 1922, Exotic Microlepidoptera, 2: 497.

" $\widehat{o}$. I8-20 mm. . . . Victoria, Melbourne, August, October (Anderson); 2 ex. (Wals. Coll., type 225 I6)."

Type: The above indicated male so marked in the British Museum, "Melbourne, Victoria. x.I892. Anderson. 22516." Slide No. 9353.

Figure 4 , left wings; 4 a, lateral aspect of aedeagus; 4 b, ventral view of male genitalia with aedeagus removed. 

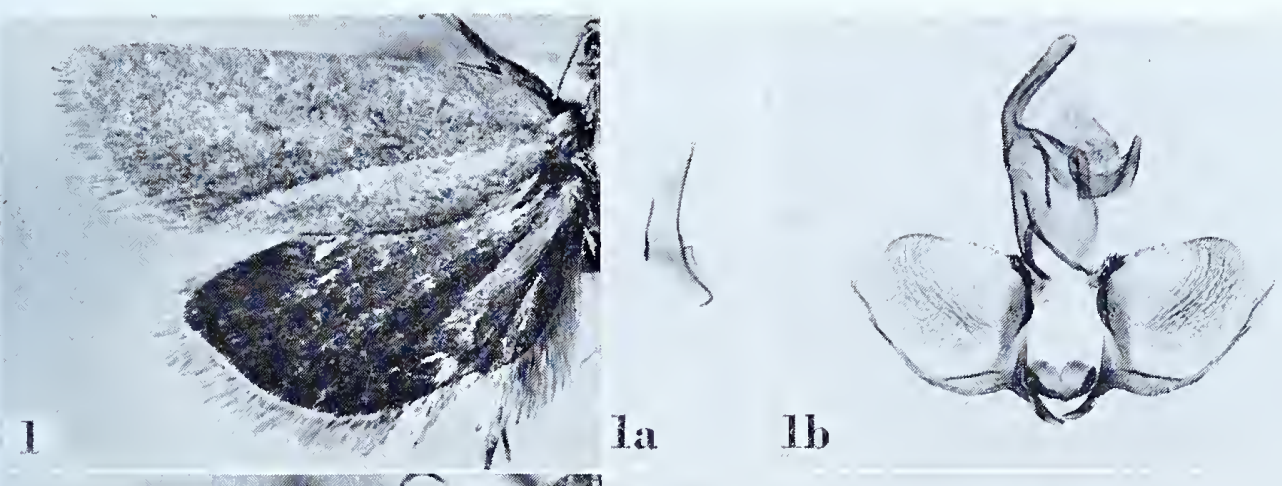

2
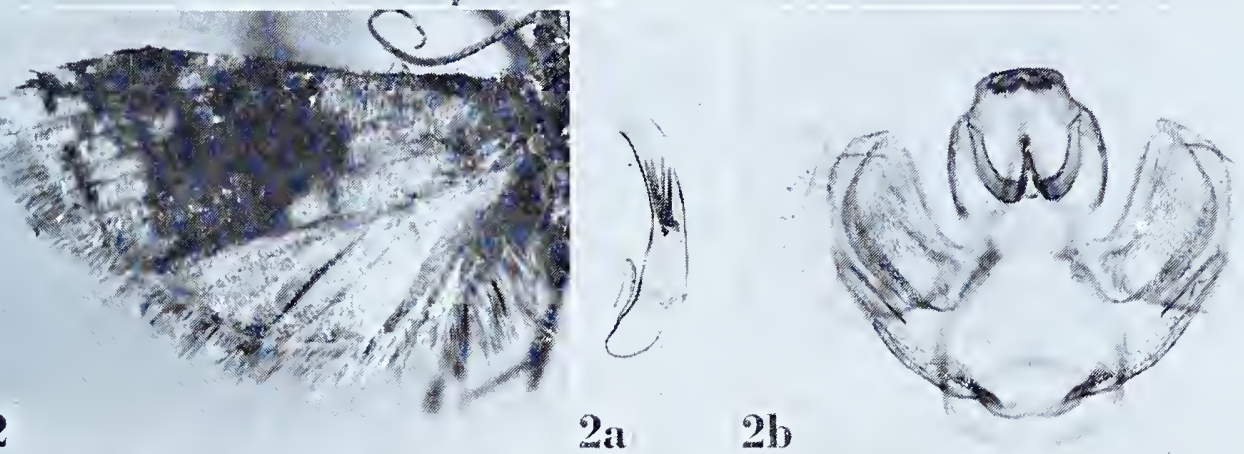

3
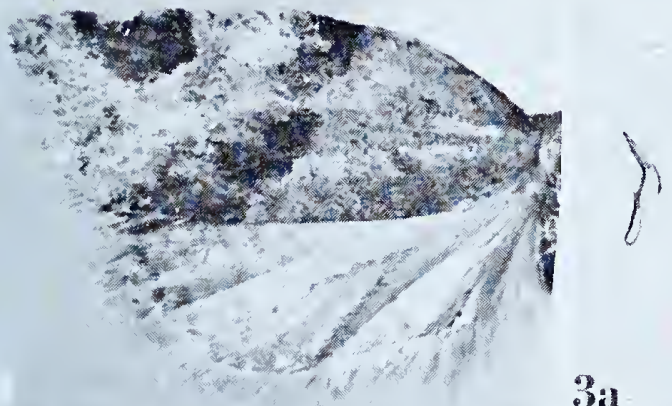

$3 a$
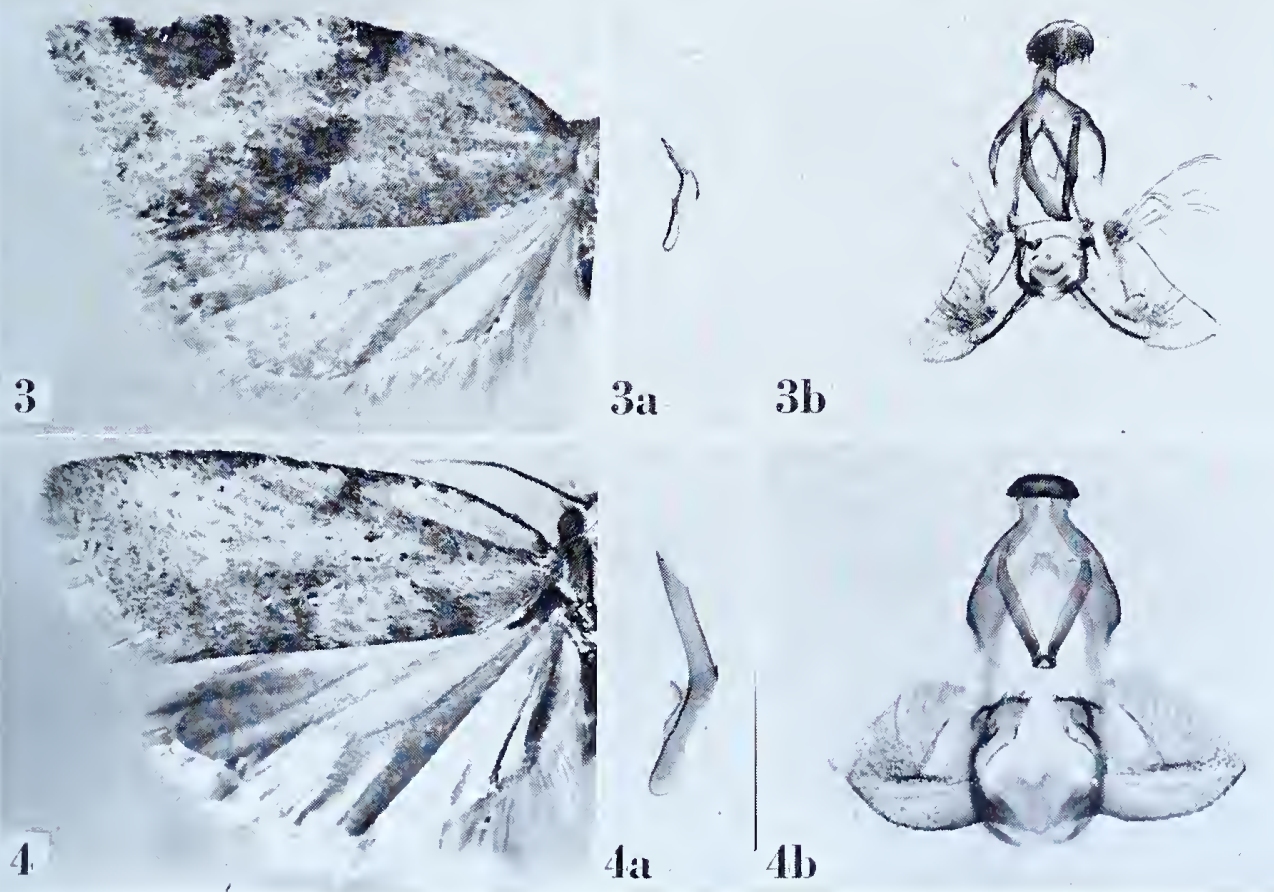

TORTRIX 


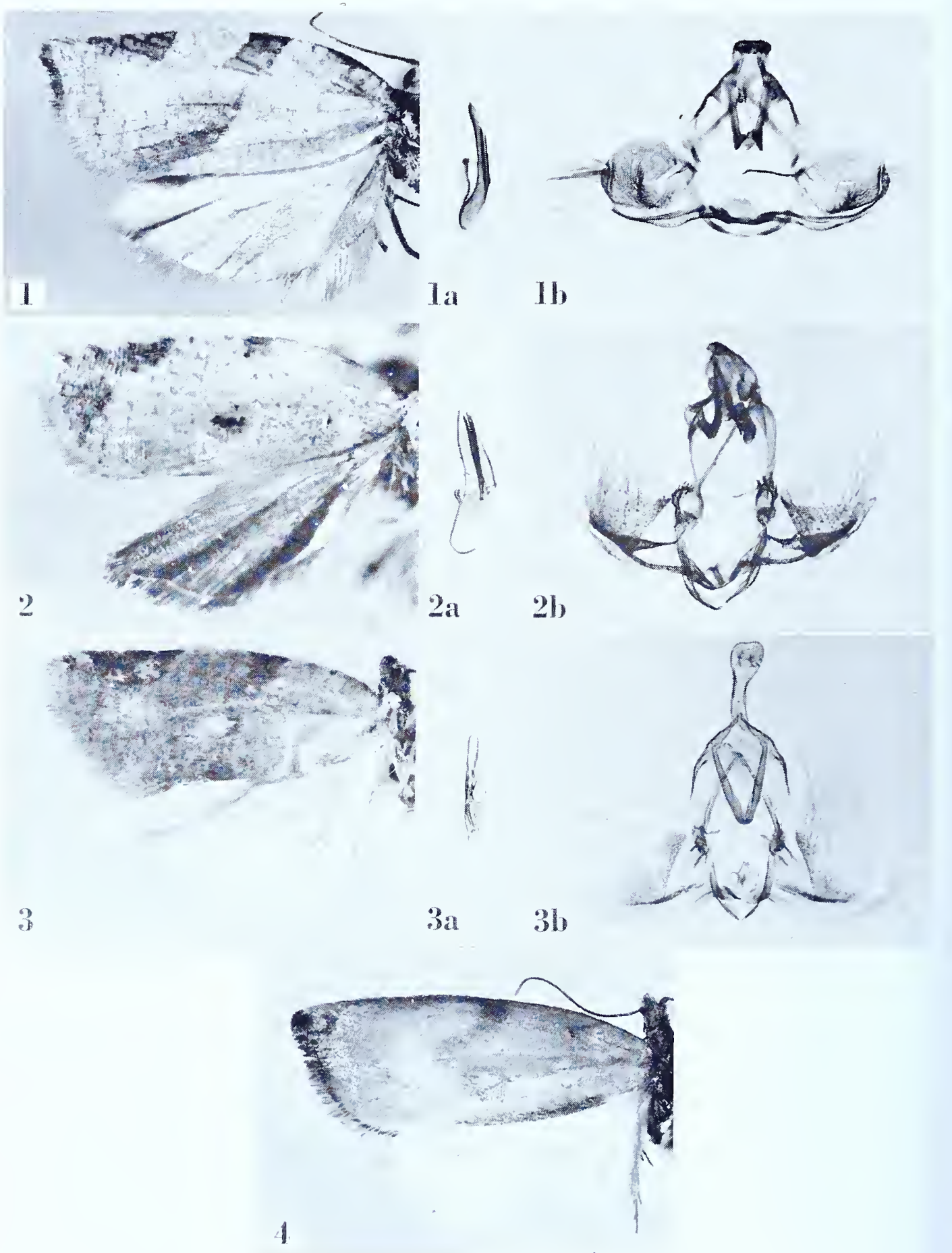




\section{Tortrix chlorodoxa Meyrick}

Plate I 7 , Figures $1-1 b$

Tortrix chlorodoxa Meyrick, 1920, Exotic Microlepidoptera, 2: 34I.

" 훙. 20-23 mm. . . Punjab, Murree, 7,500 feet, June (Dutt); 4 ex."

Lectotype: A male measuring 22 mm., "Murree, Punjab. D' 7,500' .6.IS." Slide No. 6848 . Two specimens are missing.

Figure I, left wings: $\mathbf{a}$, lateral aspect of aedeagus; $\mathrm{s}$, ventral view of male genitalia with aedeagus removed.

\section{Tortrix chrysodetis Meyrick}

Plate I 7 , Figure 4

Tortrix chrysodetis Meyrick, I 926, Exotic Microlepidoptera, 3: 248.

"†. $23 \mathrm{~mm}$. . . Colombia, Central Cordilleras, I I,500 feet, November; i ex."

Type: The female indicated above, without abdomen, dated “.I I.20".

Figure 4, left wings.

\section{Tortrix coenographa Meyrick}

Plate I 7 , Figures 2-2b

Tortrix coenographa Meyrick, I938, Trans. R. Ent. Soc. London, 87: 506.

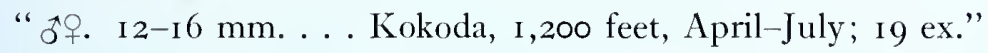

Type: The male so labelled in the British Museum, "Kokoda, Papua, I,200 ft. vii.1933. L. E. Cheesman." Slide No. 7020.

Figure 2, left wings; $2 a$, aedeagus; $2 b$, ventral view of male genitalia with aedeagus removed.

\section{Tortrix devexa Meyrick}

Plate i 7 , Figures $3-3 b$

Tortrix devexa Meyrick, 1926, Exotic Microlepidoptera, 3:248.

" o. I 7 mm. . . Colombia, Mt. Tolima, i 2,500 feet, October; i ex."

Type: The above indicated male dated ".10.20". Slide No. 9376.

Figure 3 , left wings; 3 a, aedeagus; 3 b, ventral view of male genitalia with aedeagus removed. 
TORTRIX

\section{Tortrix diametrica Meyrick}

Plate i 8 , Figures i-ib

Tortrix diametrica Meyrick, 1932, Trans. Ent. Soc. London, 80: i Io.

" స. 20-2 I mm. . . J Jem-Jem Forest, 8,ooo feet, October; 2 ex."

Type: 'The male so marked in the British Museum, "Abyssinia: Djem-Djem Forest. circa 8,000 ft. 9.x. 1926 . H. Scott." A second, small label reads "at light". A third label, in Meyrick's hand, bears the inscription "Tortrix diametrica n. sp." Slide No. 936 I.

Figure I, left wings; Ia, lateral aspect of aedeagus; ib, ventral view of male genitalia with aedeagus removed.

\section{Tortrix dinota Meyrick}

Plate i 8 , Figuies $2-2 \mathrm{c}$

Tortrix dinota Meyrick, i9 I8, Exotic Microlepidoptera, 2: i 68.

"ф. $23 \mathrm{~mm}$. . . Nyasaland, Namiwawa, bred from larva in spun shoots of Gossypium (Mason); one specimen. Type in British Museum."

Type: 'The above indicated specimen so marked in the British Museum. It is dated "Io-iv-i915". Slide No. 6840.

Figure 2 , left wings; $2 \mathrm{a}$, ventral view of female genitalia; $2 \mathrm{~b}$, detail of genital plate and ostium; 2c, signum.

\section{Tortrix dissipata Meyrick}

Plate i i 8 , Figures 3-3b

Tortrix dissipata Meyrick, I922, Exotic Microlepidoptera, 2: 496.

" ^. I 3 mm., o i $9 \mathrm{~mm}$. ... West Australia, C. Naturaliste, December (Turner); 2 ex. (Wals. Coll. type 300287 )."

Type: 'The above indicated male so marked in the British Museum, "Yallingup, C. Naturaliste, S.W. Australia. xii.r 913. 'Turner." Slide No. 9354.

Figure 3 , left wings; 3 a, lateral aspect of aedeagus; $3 \mathrm{~b}$, ventral view of male genitalia with aedeagus removed.

\section{Tortrix districta Meyrick \\ Plate i 8 , Figures $4-4 b$}

Toririx districta Meyrick, I920, Exotic Microlepidoptera, 2: 342.

" $\hat{o}$. I 7 mm. . . Japan, Tokio, July; I ex. Nearest aerosana."

Type: The above indicated male dated "7.19". Slide No. $68_{47}$.

Figure 4 , left wings; $4 \mathrm{a}$, lateral aspect of aedeagus; $4 \mathrm{~b}$, ventral view of male genitalia with aedeagus removed. 

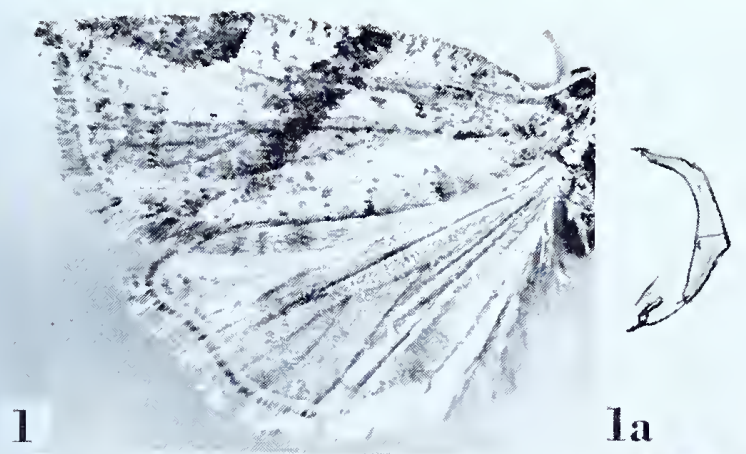

2
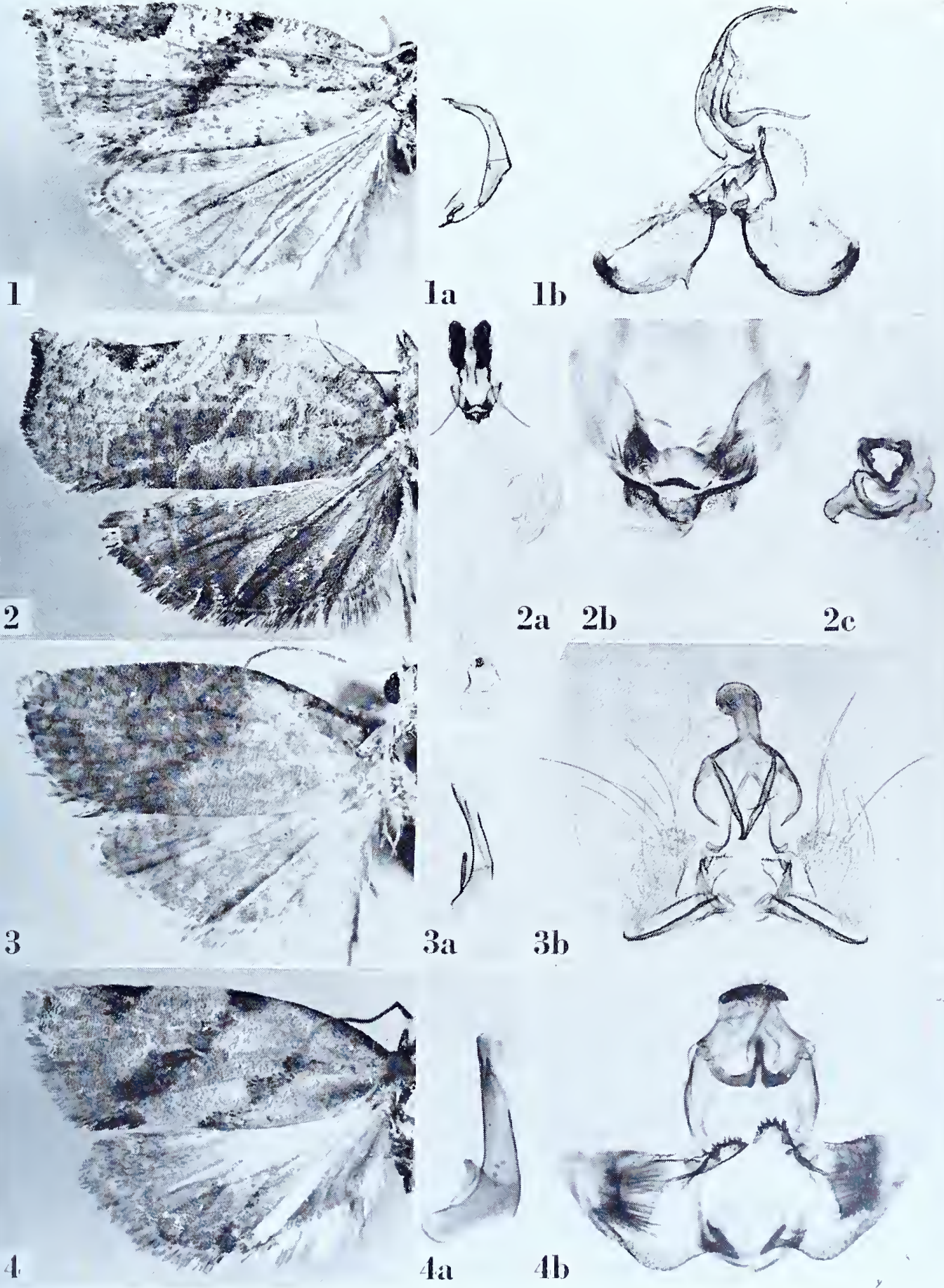

$2 \mathbf{a} \quad 2 b$

$2 \mathrm{c}$
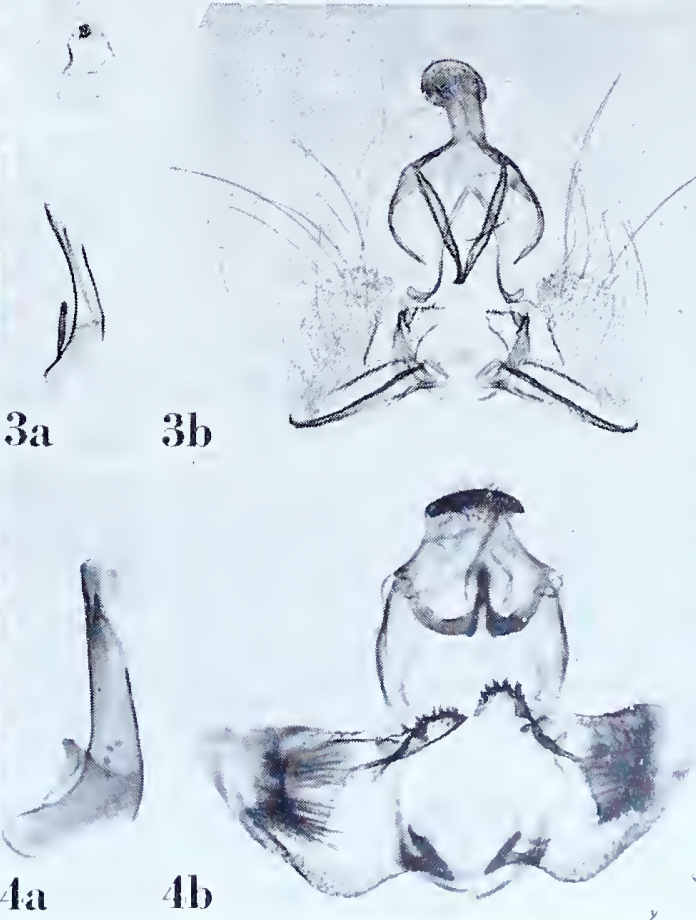

TORTRIX 


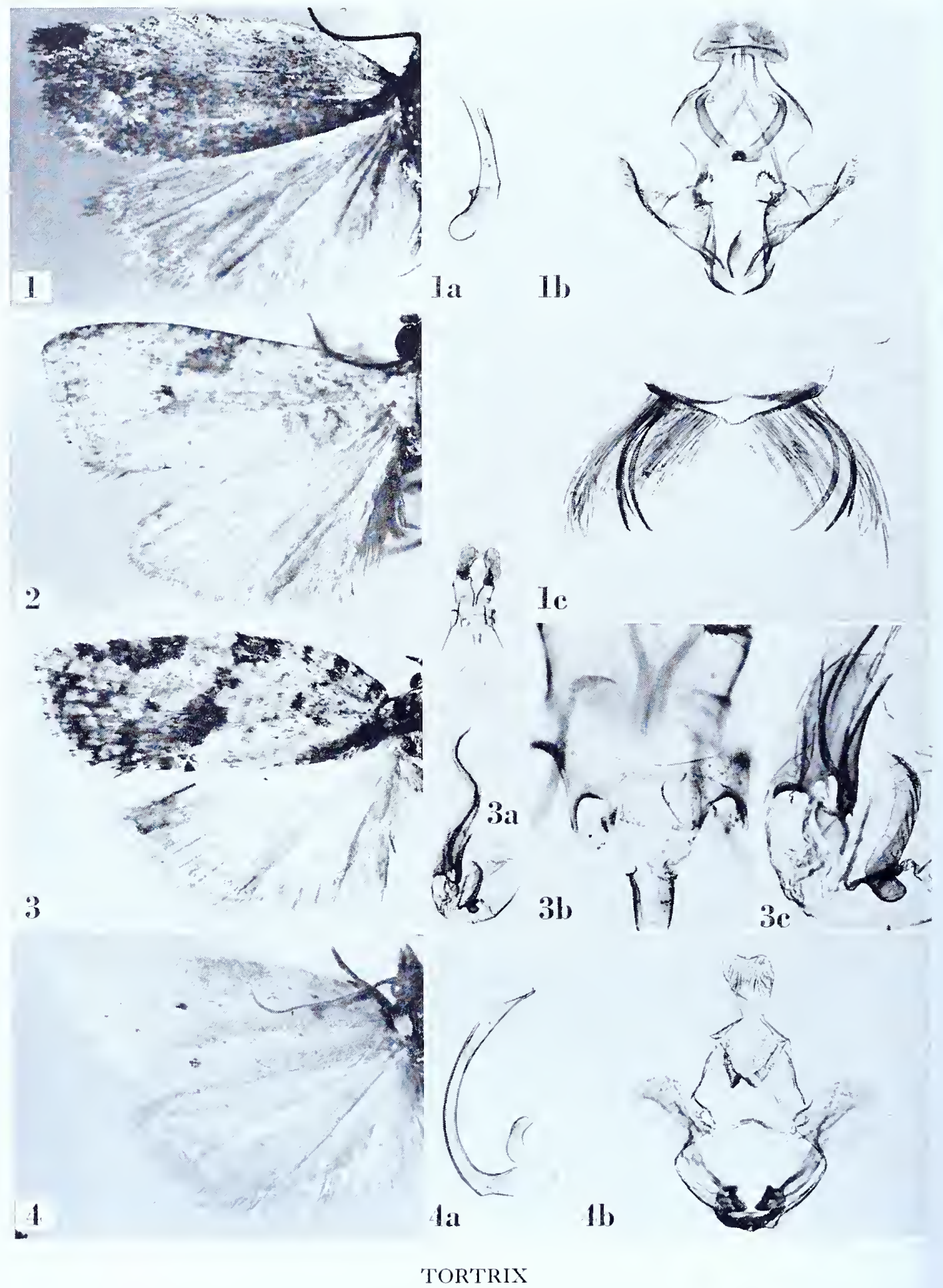


TORTRIX

\section{Tortrix endopyrrha Meyrick}

Plate i i9, Figures I-ic

Tortrix endopyrrha Meyrick, I930, Exotic Microlepidoptera, 3: 609.

“ "o. I 5-I6 mm.... Uganda, Bulambuli, 9,00o feet, July, August (G. L. R. Hancock); 4 ex. (type Brit. Mus.)."

Type: The male so marked in the British Museum, dated "r9-vii-r929". Slide No. 6843 .

Figure I, left wings; $\mathrm{ra}$, lateral aspect of aedeagus; $\mathrm{rb}$, ventral view of male genitalia with aedeagus removed; Ic, 8 th sternite.

\section{Tortrix entherma Meyrick}

Plate i i9, Figure 2

Tortrix entherma Meyrick, I9I4, Exotic Microlepidoptera, I: I95.

"今. $18 \mathrm{~mm}$.... Nyassaland, Mt. Mlanje, in August (Neave); one specimen. Type in British Museum."

Type: The above indicated male, without abdomen, so marked in the British Museum, dated "28.viii.r9r3". A small white label bears the inscription "M96".

Figure 2, left wings.

\section{Tortrix eurymenes Meyrick}

Plate i i9, Figures 3-3c

Tortrix eurymenes Meyrick, I930, Exotic Microlepidoptera, 3:608.

“ㅇ. $28 \mathrm{~mm}$. . . . Dutch New Guinea, Mt. Goliath, 5-7,000 feet (Meek); I ex. (Coll. Paravicini). Perhaps nearest xylodes."

Type: The above indicated female so marked in the British Museum. A small white label bears the inscription "M84". Slide No. 6842.

Figure 3 , left wings; $3^{a}$, ventral view of female genitalia; 3 , detail of genital plate and ostium; 3 c, signum.

\section{Tortrix furtiva Meyrick}

Plate i i 9 , Figures $4-4 b$

Tortrix furtiva Meyrick, I91 I, Ann. Transvaal Mus., 2: 223.

" $\hat{D}^{2}$ I $6-17 \mathrm{~mm} . .$. Haenertsburg, in December (Swierstra); three specimens."

Lectotype: \$, I 7 mm., "Haenertsburg, Transvaal. CIS. 6.12.09." Slide No. 9348.

Figure 4 , left wings; $4 \mathrm{a}$, lateral aspect of aedeagus ; $4 \mathrm{~b}$, ventral view of male genitalia with aedeagus removed. 


\section{Tortrix griseicoma Meyrick \\ Plate I20, Figures I-Ib}

Tortrix griseicoma Meyrick, 1924, Exotic Microlepidoptera, 3: I 15.

" (Fletcher); 8 ex. (3 ô, 5 f)."

Lectotype: A male measuring I 8 mm., dated ".8.23". Slide No. 6837 .

Figure I, left wings; $\mathrm{ia}$, lateral aspect of aedeagus; $\mathrm{ib}$, ventral view of male genitalia with aedeagus removed.

\section{Tortrix homophyla Meyrick}

Plate 120, Figures 2-2b

Tortrix houophyla Meyrick, i917, Trans. Ent. Soc. London, I917: 8.

" ‡. I 2 mm. . . Colombia, La Crumbre, 5,60o feet, in May (Parish); one specimen."

Type: The specimen indicated above dated "5-14". Slide No. 6337.

Figure 2, left wings; $2 \mathrm{a}$, lateral aspect of aedeagus; $2 \mathrm{~b}$, ventral view of male genitalia with aedeagus removed.

\section{Tortrix humana Meyrick}

Plate 120, Figures $3-3 \mathrm{~b}$

Tortrix humana Meyrick, I912, Exotic Microlepidoptera, г : 6.

" స. I 9 mm. . . Sikkim, Darjiling, 7,000 feet, in August; one specimen."

Type: The male indicated above, "Darjiling, Bengal. D. .8.o4." Slide No. 6846.

Figure 3 , left wings; 3 a, lateral aspect of aedeagus; 3 b, ventral view of male genitalia with aedeagus removed.

\section{Tortrix illiberalis Meyrick}

Plate I20, Figures $4-4 \mathrm{c}$

Tortrix illiberalis Meyrick, I918, Exotic Microlepidoptera, 2: I68.

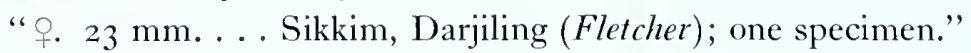

Type: The female indicated above, "Darjiling, India, TBF. .r 7." Slide No. 6839.

Figure 4 , left wings; 4 a, ventral view of female genitalia; 4 b, detail of genital plate and ostium; $4 \mathrm{c}$, signum. 

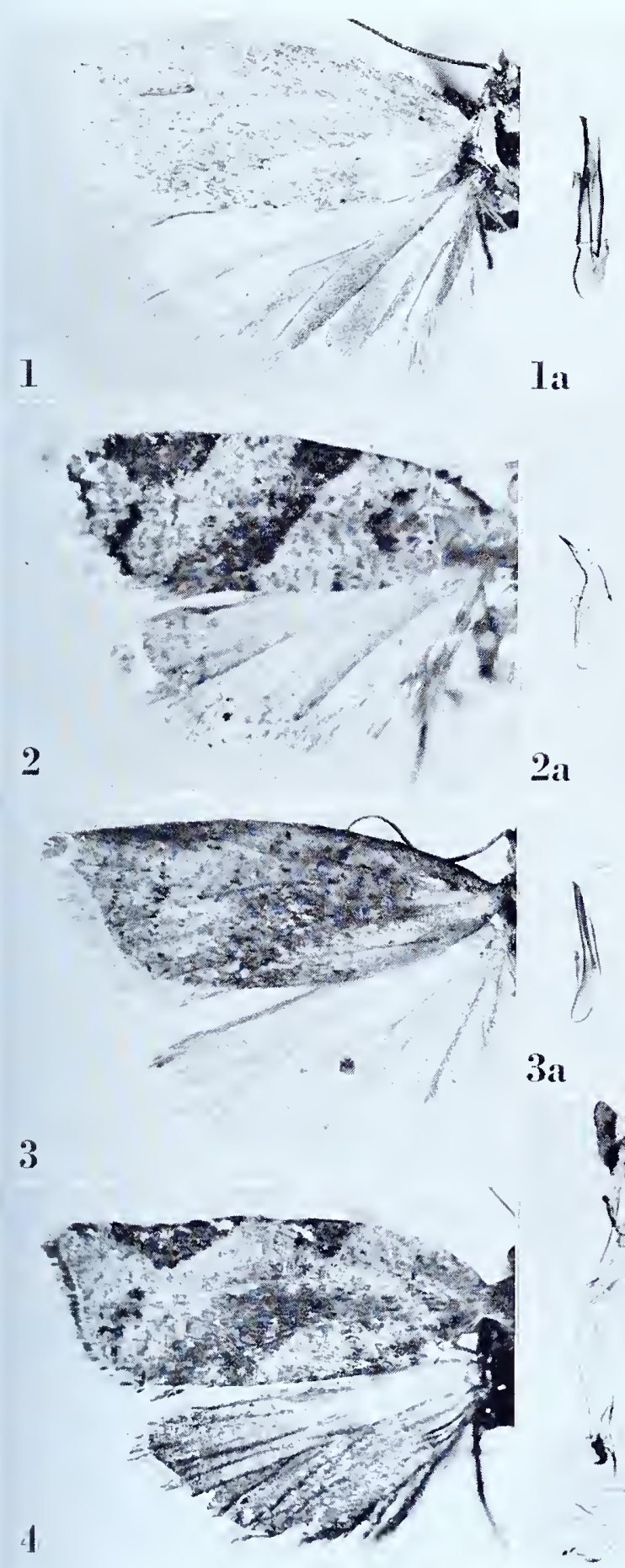

1

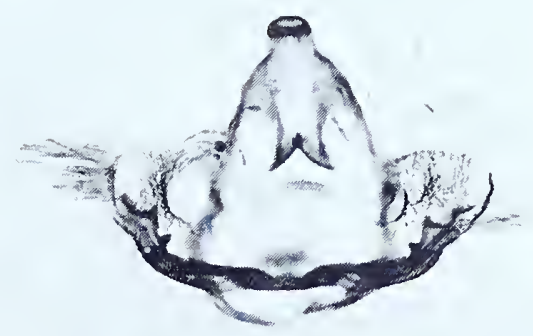

116

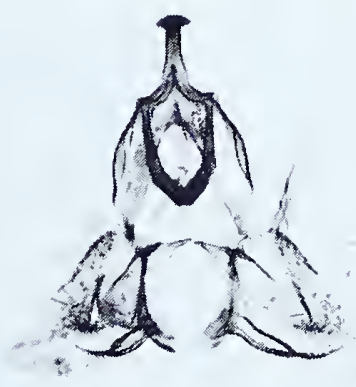

2b)
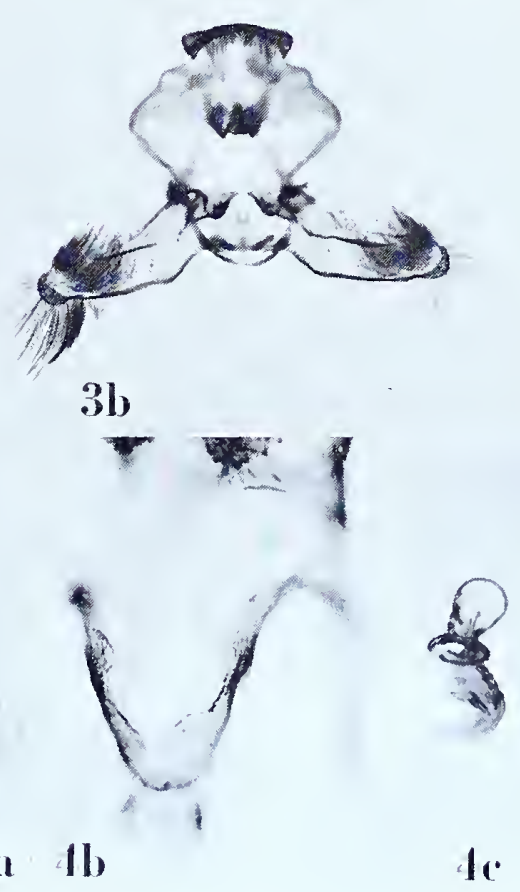

TORTRIX 


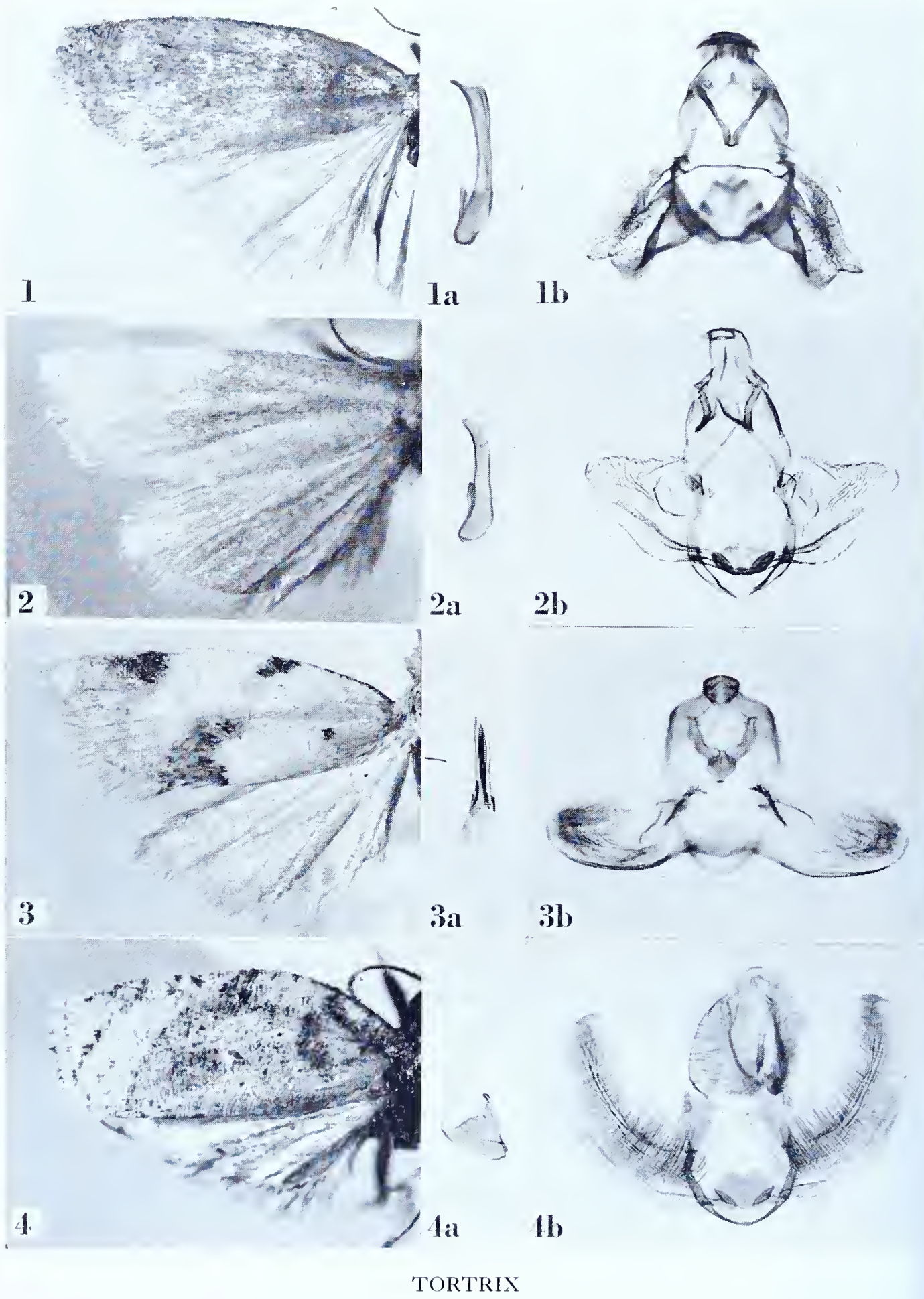




\section{Tortrix imperita Meyrick}

Plate I2I, Figures I-Ib

Tortrix imperita Meyrick, 1937, in Caradja and Meyrick, Deuts. Ent. Zeit. Iris, 51: 174 .

" o. $_{1} 8 \mathrm{~mm}$. . . . Yül., 4,00o-5,00o m., June; I ex. An obscure species allied to the Himalayan humana Meyr."

Type: The above indicated male labelled, "Likiang, China. H. I3,ooo. .6.35." Slide No. 6850 .

Figure $\mathrm{I}$, left wings; $\mathrm{a}$, lateral aspect of aedeagus; $\mathrm{rb}$, ventral view of male genitalia with aedeagus removed.

\section{Tortrix insincera Meyrick}

Plate I2 I, Figures 2-2b

Tortrix insincera Meyrick, I912, Exotic Microlepidoptera, I: 7 .

" స̊ํ. 22-23 mm. . . Asia Minor, Alma Dagh; two specimens."

Type: The male so marked in the British Museum, "Alma Dagh, Asia Minor. J. .o6." Slide No. 9363 .

Figure 2, left wings; $2 \mathrm{a}$, lateral aspect of aedeagus; $2 \mathrm{~b}$, ventral view of male genitalia with aedeagus removed.

\section{Tortrix insulata Meyrick}

Plate 12 I, Figures $3^{-} 3^{b}$

Tortrix insulata Meyrick, I908, Journ. Bombay Nat. Hist. Soc., i 8: 6I 9.

" $\$$. I 4 -16 mm., q i $6-\mathrm{I} 8 \mathrm{~mm}$. . . . Simla, in July; six specimens."

Lectotype: A male measuring i 6 mm., "Simla, India. R. .7.89." Slide No. $68_{35}$.

Figure 3 , left wings; 3 a, lateral aspect of aedeagus; 3 b, ventral view of male genitalia with aedeagus removed.

\section{Tortrix intrepida Meyrick}

Plate 12 I, Figures $4-4 \mathrm{~b}$

Tortrix intrepida Meyrick, 1912, Exotic Microlepidoptera, I: 7 .

" ô. I 4 mm., $q$ I9 mm. ... Natal, Pinetown $($ Leigh); I ô, I $q$; Comoro Is., Anjouan and Grand Comoro, in June and July (Leigh), I to, I . . Much like capensana. . .."

Lectotype: ô, I4 mm., "Anjouan, Comoro Is. L. .6.1 I." Slide No. 9385. The male and female from Pinetown are larger than the lectotype measuring $17 \mathrm{~mm}$. and $23 \mathrm{~mm}$., respectively, and are dated ".г.o9".

Figure 4 , left wings; 4 a, lateral aspect of aedeagus; 4 b, ventral view of male genitalia with aedeagus removed. 
TOR'TRIX

\section{Tortrix isotetras Meyrick}

Plate I22, Figures I-IC

Tortrix isotetras Meyrick, 1934, Ann. Mag. Nat. Hist. (10), 14:403.

"q. 18 mm. . . Fernando Po, Moka, Nov. 2; 1 ex."

Type: The female denoted above so marked in the British Museum, "Fernando Po: Moka. 2.I I.r 933. W. H. T. Tams." Slide No. 9360.

Figure I, left wings; Ia, ventral view of female genitalia; Ib, signum; Ic, detail of genital plate and ostium.

\section{Tortrix isozona Meyrick}

Plate 122, Figures 2-2b

Tortrix isozona Meyrick, I908, Journ. Bombay Nat. Hist. Soc., I8: 615.

" ${ }^{\circ} . \quad 13 \mathrm{~mm}$. . . . Khasis, in June; one specimen. Superficially very like Capua melanatma."

Type: The above indicated male, "Khasi Hills, Assam. .6.1 906." Slide No. 683 I.

Figure 2, left wings; 2a, lateral aspect of aedeagus; $2 \mathrm{~b}$, ventral view of male genitalia with aedeagus removed.

\section{Tortrix leptograpta Meyrick}

Plate 122, Figure 3

Tortrix leptograpta Meyrick, 1924, Exotic Microlepidoptera, 3: I I5; ibid., 1927, 3: 369 .

“ ‘. 2 I mm. ... Kashmir, Gulmarg, 8,500 feet, July (Fletcher); i ex. Probably allied to tricensa."

Type: The above indicated male, without abdomen, dated ".7.23". This species was redescribed on p. 369 as a new species. The same specimen was used.

Figure 3 , left wings.

\section{Tortrix leucocharis Meyrick}

Plate 122, Figures $4-4 \mathrm{~b}$

Tortrix leucocharis Meyrick, I933, Exotic Microlepidoptera, 4:423.

"o. ro mm. . . Fiji, Vunidawa, September (H. Phillips); I ex. (Brit. Mus.)."

Type: The male so marked in the British Museum, "Vunidawa, Fiji. 29.1.1933. H. Phillips. 809." Slide No. 9352. I believe Meyrick's date of "September" is in error due to the fact that the pin pierces the label at the point of the "I".

Figure 4 , left wings; $4 \mathrm{a}$, lateral aspect of aedeagus ; 4 b, ventral view of male genitalia with aedeagus removed. 

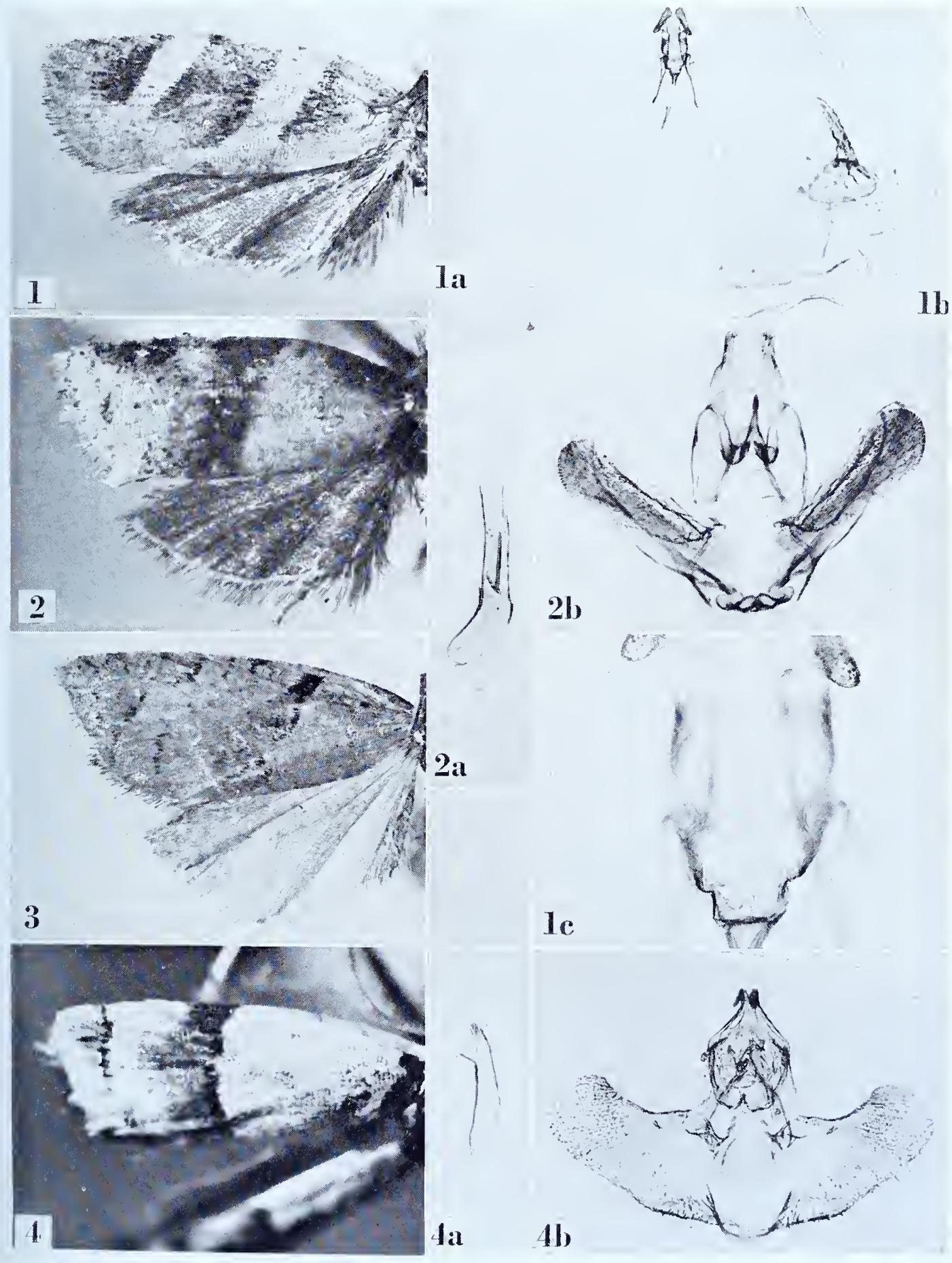

TORTRIX 


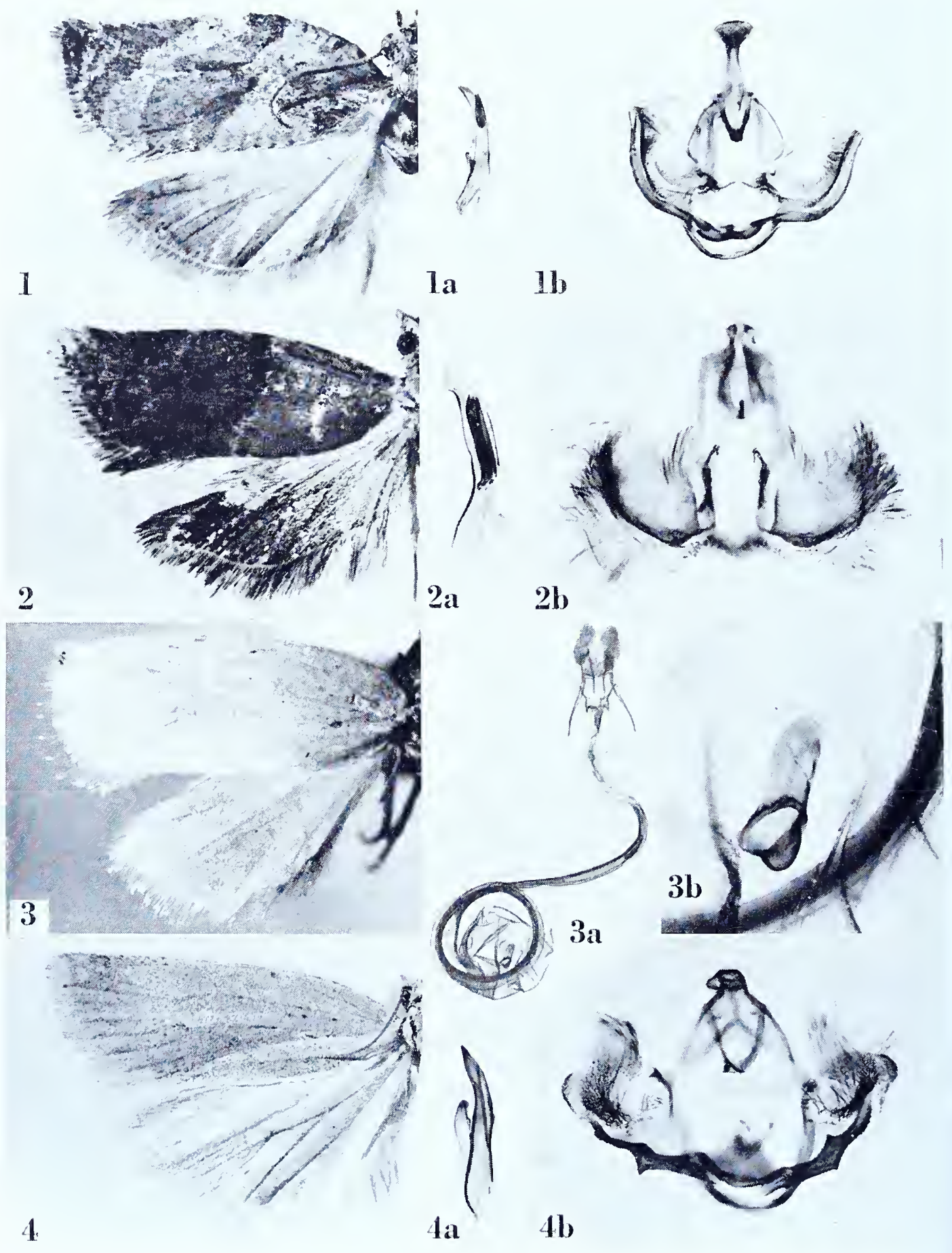

TORTRIX 


\section{'Tortrix lignea Meyrick}

Plate 123 , Figures $x-r b$

Tortrix lignea Meyrick, 1917, Trans. Ent. Soc. London, 1917: I7.

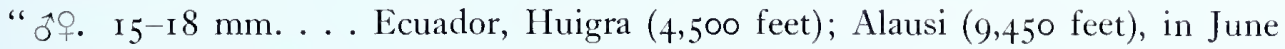
(Parish); six specimens."

Lectotype: A male measuring $15 \mathrm{~mm}$. (barely!), from "Huigra, Ecuador. 4,500 ft., Parish. 6-14." Slide No. 6338 .

Figure I, left wings; $\mathrm{ia}$, lateral aspect of aedeagus; $\mathrm{rb}$, ventral view of male genitalia with aedeagus removed.

\section{Tortrix noctivola Meyrick}

See Eucosma noctivola Meyrick.

\section{Tortrix liobathra Meyrick}

Plate 123, Figures 2-2b

Tortrix liobathra Meyrick, I923, Exotic Microlepidoptera, 3: 55.

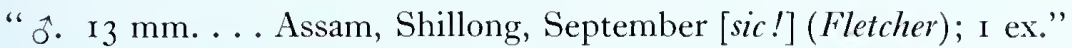

Type: The male indicated above but dated ".10.18”. Slide No. $68_{3} 6$.

Figure 2, left wings; $2 \mathrm{a}$, lateral aspect of aedeagus; $2 \mathrm{~b}$, ventral view of male genitalia with aedeagus removed.

\section{Tortrix martyranthes Meyrick}

Plate I23, Figures $3-3 \mathrm{~b}$

Tortrix martyranthes Meyrick, 1938, Trans. R. Ent. Soc. London, 87: 505 .

" o. $18 \mathrm{~mm}$. ... Mt. Tafa, 8,500 feet, March. I ex."

Type: The specimen referred to above, erroneously recorded as a male. The type, in the British Museum, is labelled, "Mt. 'Tafa, Papua, 8,500 ft., iii-r934, L. E. Cheesman." Slide No. 70I8. The "genital tuft blackish" mentioned by Meyrick is a patch of black scales, a female character.

Figure 3 , left wings; 3 a, ventral view of female genitalia; 3 b, signum.

\section{Tortrix neurophaea Meyrick}

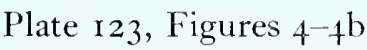

Tortrix neurophaea Meyrick, 1932, Exotic Microlepidoptera, 4:341.

" ऊ. 22-25 mm., ㅇ I $6 \mathrm{~mm}$. . . Kashmir, Killanmarg, I0,500 feet, July, August (T. B. Fletcher); 3 ex."

Lectotype: A male measuring $22 \mathrm{~mm}$., dated “.7.3 I". Slide No. $68_{34}$.

Figure 4 , left wings; 4 a, lateral aspect of aedeagus; 4 b, ventral view of male genitalia with aedeagus removed. 
TORTRIX

\section{'Tortrix noseropis Meyrick \\ Plate I24, Figures I-Ib}

Tortrix noseropis Meyrick, 1928, Exotic Microlepidoptera, 3: 458.

"ㅇ. $25 \mathrm{~mm}$... . Bengal, Calcutta (Atkinson); I ex."

Type: The above indicated female without date. Slide No. $68_{+4}$.

Figure I, left wings; $\mathbf{a}$, ventral view of female genitalia; $\mathrm{I} b$, detail of genital plate and ostium.

\section{Tortrix operosa (Meyrick)}

Plate I24, Figures 2-2b

Cacoecia operosa Meyrick, i 9o8, Journ. Bombay Nat. Hist. Soc., i 8: 6 I 6.

" $\jmath+$. I I-I 4 mm. . . Maskeliya, Madulsima, Diyatalawa, Ceylon (Pole, I'anghn, Fletcher, de Mowbray); Nilgiris (Andrewes); in August, October, and from January to May; twenty-five specimens."

Lectotype: A male measuring 12 mm., "Maskeliya, Ceylon. Pole. .3.o4." Slide No. $68_{33}$. Thirteen specimens are missing.

Figure 2 , left wings; $2 \mathrm{a}$, lateral aspect of aedeagus; $2 \mathrm{~b}$, ventral view of male genitalia with aedeagus removed.

\section{Tortrix ophiograpta Meyrick}

Plate I24, Figures $3-3 \mathrm{~b}$

Tortrix ophiograpta Meyrick, i 932, Trans. Ent. Soc. London, 8o: I 10.

“ J. 2 I-22 mm. . . Jem-Jem Forest and Mt. Chillálo, 9, ooo feet, October, November; 2 ex. Allied to dinota."

Type: The male so marked in the British Museum, "Abyssinia: Djem-Djem Forest. 8,000-9,000 ft. 7-9.x.I926. H. Scott." Slide No. 9358. A second label in Meyrick's hand reads "Tortrix ophiograpta n. sp."

Figure 3, left wings; 3 a, lateral aspect of aedeagus; $3 \mathrm{~b}$, ventral view of male genitalia with aedeagus removed.

\section{Tortrix oriphanes Meyrick}

Plate 124 , Figures $4-4$ b

Tortrix oriphanes Meyrick, I930, Exotic Microlepidoptera, 3: 608.

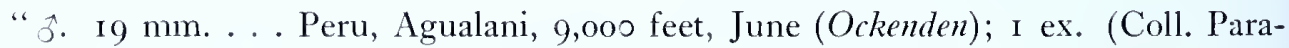
vicini)."

Type: The above indicated specimen so marked in the British Museum. Slide No. 684 I.

Figure 4 , left wings; $4 \mathrm{a}$, lateral aspect of aedeagus; $4 \mathrm{~b}$, ventral view of male genitalia with aedeagus removed. 

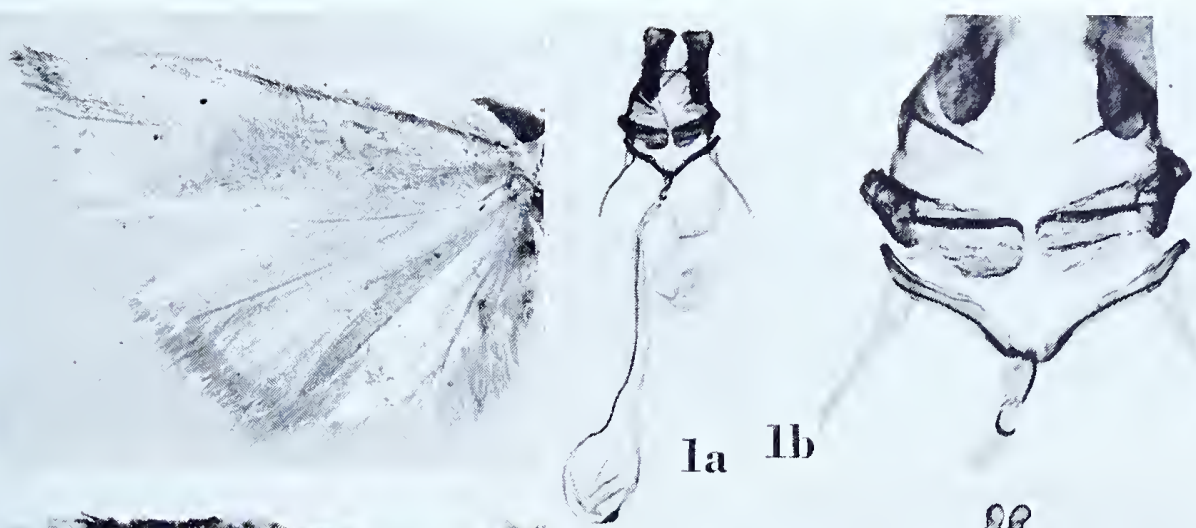

2
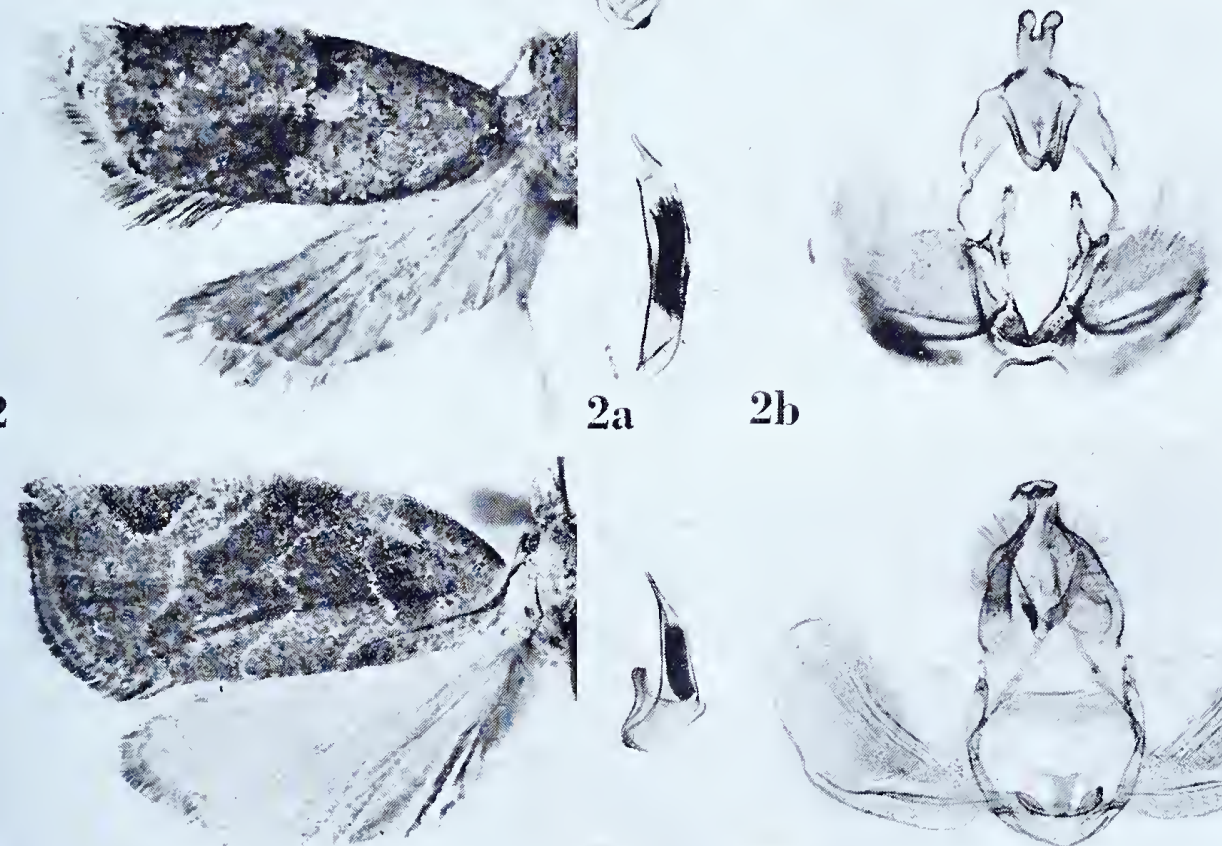

3
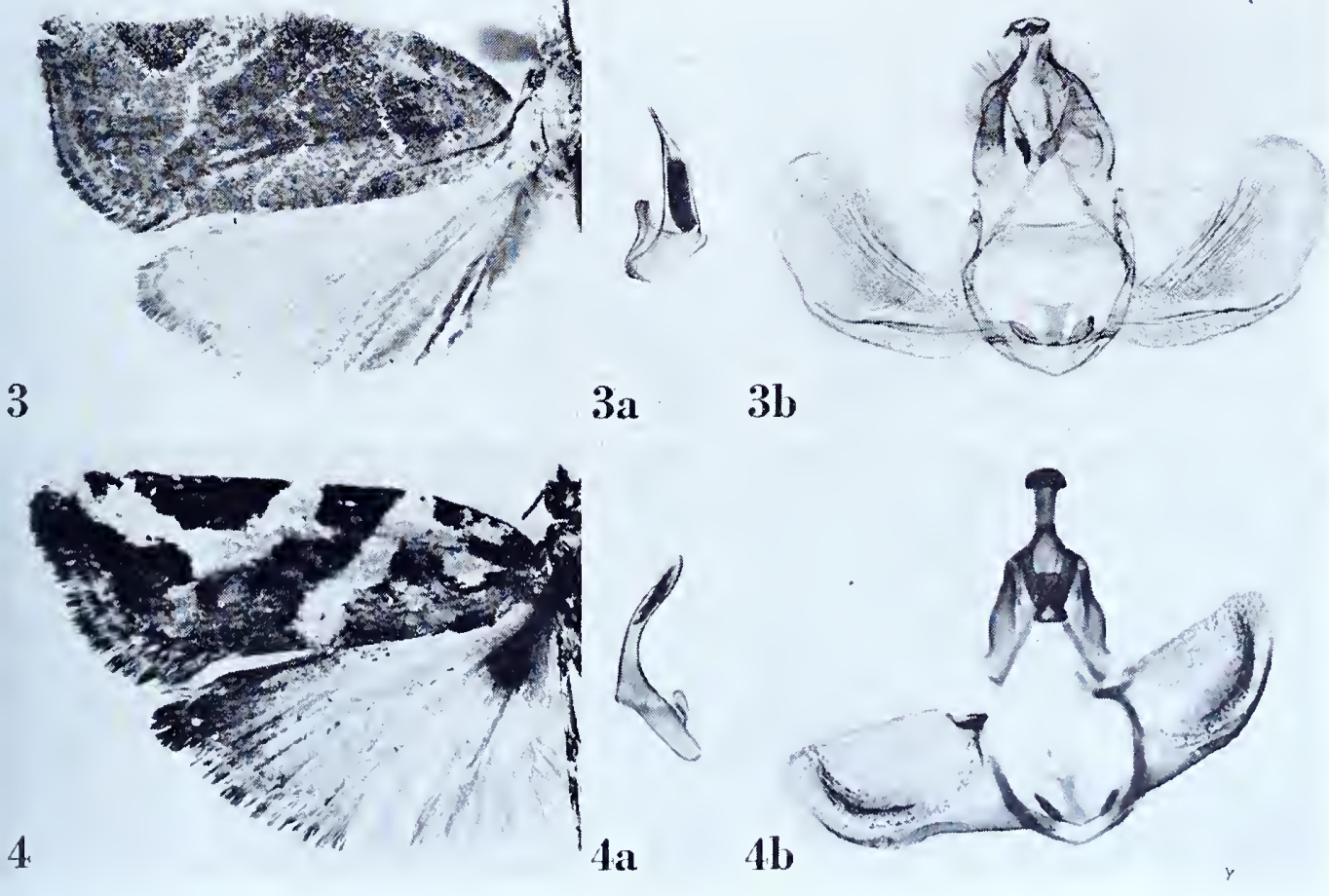

TORTRIX 

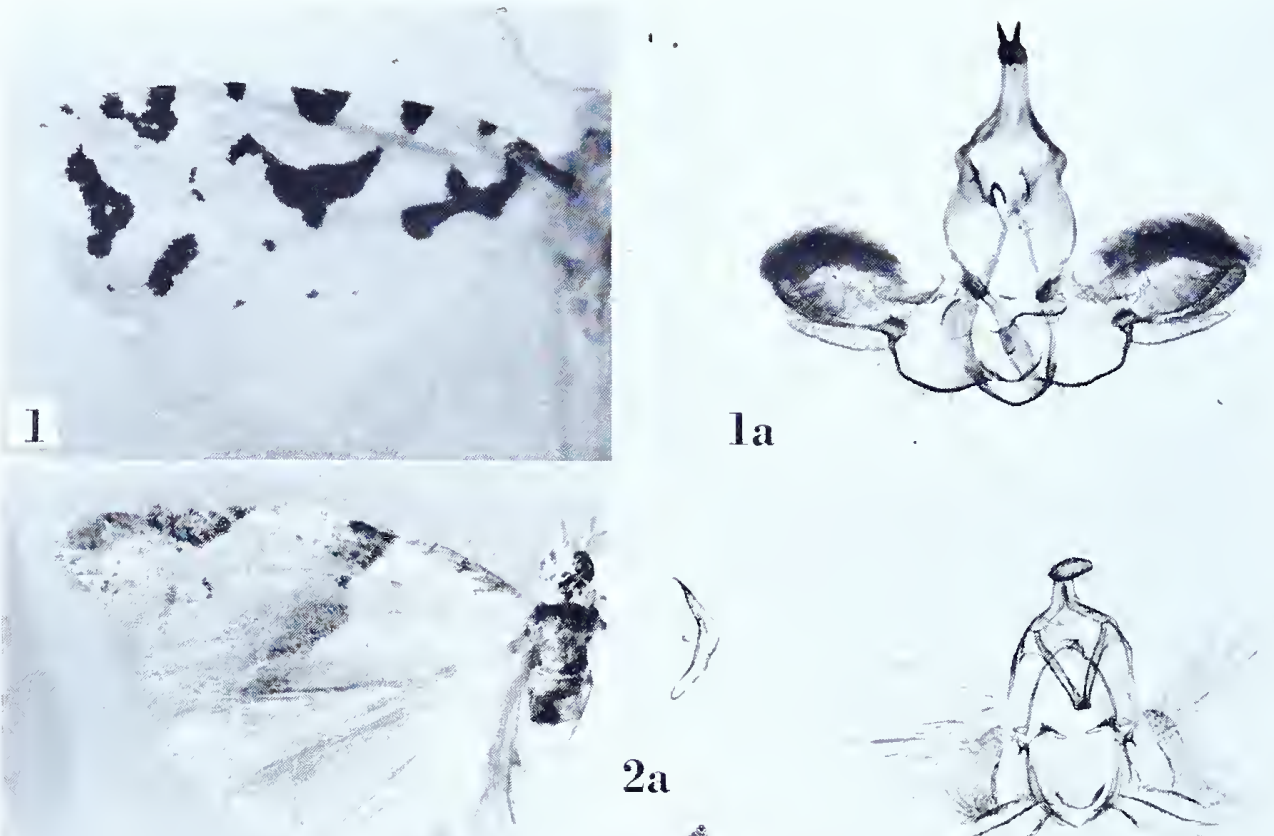

2
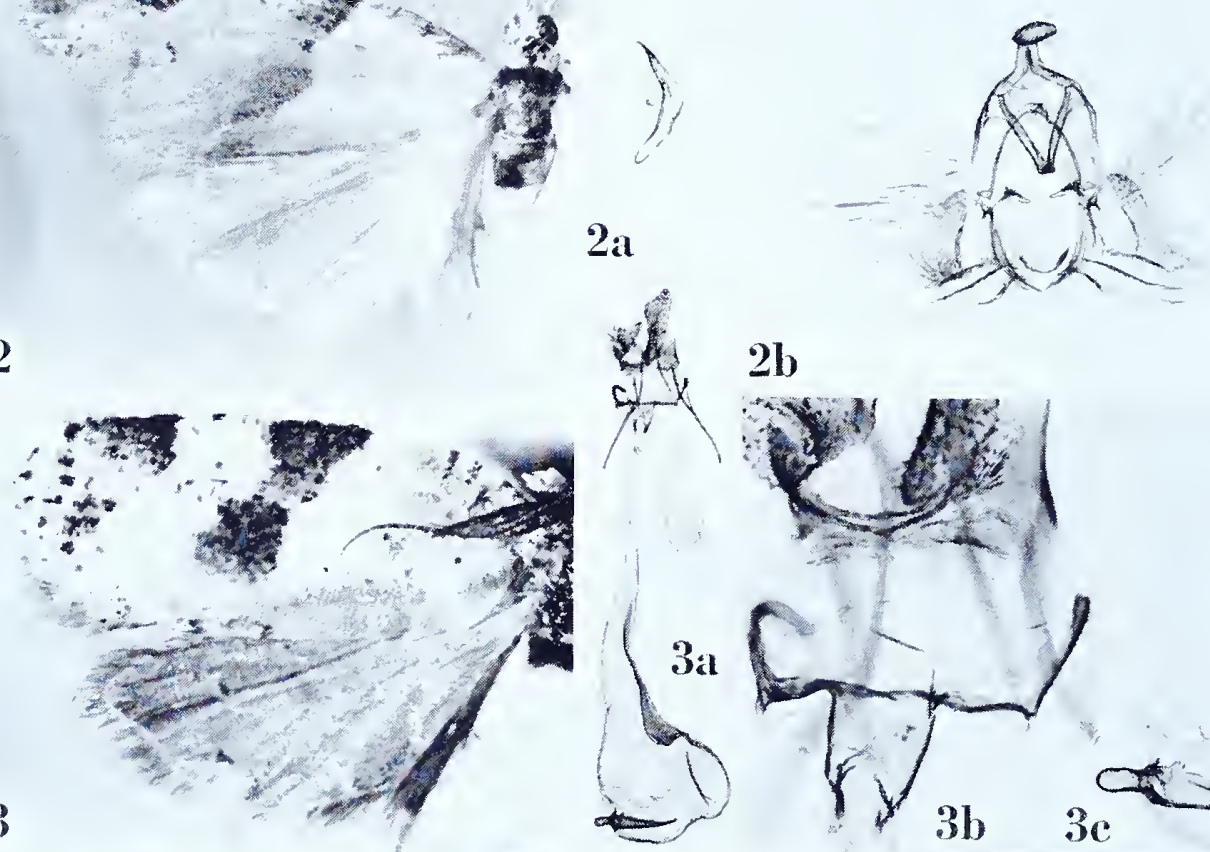

$2 b$

3
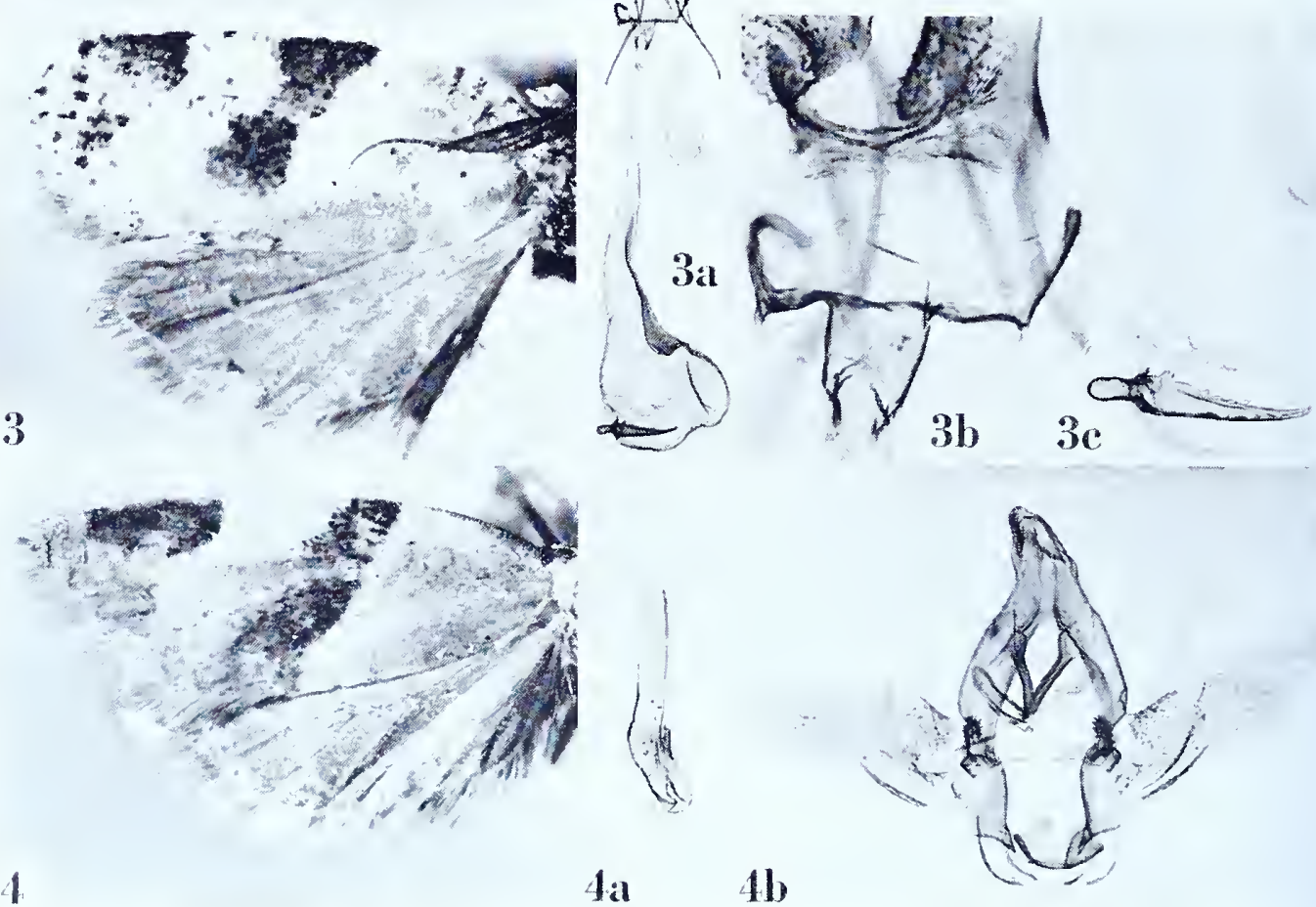


\section{Tortrix ornithotypa (Meyrick), new combination}

Plate I25, Figures I-Ia

Argyroploce ornithotypa Meyrick, I938, Trans. R. Ent. Soc. London, 87: 5 II.

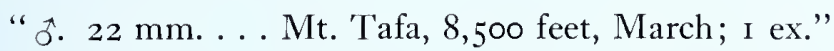

Type: The above indicated male so marked in the British Museum, "Mt. Tafa, Papua, 8,500 ft. iii.r 936. L. E. Cheesman." Slide No. 7022.

Figure I, left wings; ra, ventral view of male genitalia with aedeagus in situ.

\section{Tortrix pelospila Meyrick}

Plate 125, Figures 2-2b

Tortrix pelospila Meyrick, I 932, Exotic Microlepidoptera, 4:255.

" top I8-2 I mm. ... Mexico, Mexico City, June; 3 ex. Also three in Vienna Museum."

Lectotype: A male in the Meyrick collection dated ".6.20". Slide No. 7845 .

Figure 2, left wings; $2 \mathrm{a}$, lateral aspect of aedeagus; $2 \mathrm{~b}$, ventral view of male genitalia with aedeagus removed.

\section{Tortrix petrophracta Meyrick}

Plate 125 , Figures $3-3 \mathrm{c}$

Tortrix petrophracta Meyrick, I938, Trans. R. Ent. Soc. London, 87: 506.

"ㅇ. I 4 mm. . . Kokoda, I,200 feet, April; I ex."

Type: The female indicated above so marked in the British Museum, "Kokoda, Papua. I,200 ft. iv.1933. L. E. Cheesman." Slide No. 7019.

Figure 3 , left wings; $3^{\mathrm{a}}$, ventral view of female genitalia; 3 , detail of genital plate and ostium; 3 c, signum.

\section{Tortrix physetopa Meyrick \\ Plate 125 , Figures $4-4 b$}

Tortrix physetopa Meyrick, I932, Trans. Ent. Soc. London, 80: I I .

“ ‘ำ. I 6-i 8 mm. . . J Jem-Jem Forest and Mt. Chillálo, 8,000-9,000 feet, October, November; 5 ex. Doubtless related to prona."

Type: The male so marked in the British Museum, "Abyssinia: Djem-Djem Forest. ca. 9,000 ft. 4.x.1926. H. Scott." Slide No. 9362. A second label, in Meyrick's hand, reads "Tortrix physetopa n. sp."

Figure 4 , left wings; $4^{\mathrm{a}}$, aedeagus; 4 b, ventral view of male genitalia with aedeagus removed. 
TORTRIX

\section{Tortrix prona Meyrick}

Plate i26, Figures $\mathrm{I}-\mathrm{Ib}$

Tortrix prona Meyrick, I9I I, Ann. Transvaal Mus., 2: 223.

"Male and female, I3-I4 mm. ... Haenertsburg, in December (Swierstra); Pinetown, Natal, in January (Leigh); four specimens."

Lectotype: ơ, I3 mm., "Pinetown, Natal. L. .r.o9." Slide No. 9350.

Figure I, left wings; Ia, lateral aspect of aedeagus; $r b$, ventral view of male genitalia with aedeagus removed.

\section{Tortrix psoricodes Meyrick}

Plate 126, Figures 2-2b

Tortrix psoricodes Meyrick, I9I I, Ann. 'T'ransvaal Mus., 2: 223.

"Male, $19 \mathrm{~mm}$.; female, 20-23 mm. ... Haenertsburg and Woodbush Village, in December (Swierstra); three specimens."

Lectotype: ô, 19 mm., "Haenertsburg, 'Transvaal. CIS. 9.12.09." Slide No. 935 I.

Figure 2, left wings; $2 \mathrm{a}$, lateral aspect of aedeagus; $2 \mathrm{~b}$, ventral view of male genitalia with aedeagus removed.

\section{Tortrix sanidota Meyrick}

Plate 126 , Figures $3-3 \mathrm{~b}$

Tortrix sanidota Meyrick, 1912, Exotic Microlepidoptera, I: 7 .

" 30 . I $7^{-24} \mathrm{~mm}$. ... Comoro Is., Mayotte and Grand Comoro, from May to July (Leigh); nine specimens."

Lectotype: ô, 17 mm., "Grand Comoro, Comoro Is. L. 7.I I." Slide No. 9377.

Figure 3 , left wings; 3 a, lateral aspect of aedeagus; $3 \mathrm{~b}$, ventral view of male genitalia with aedeagus removed.

\section{'Tortrix seclusa Meyrick}

Plate 126, Figures $4-4 \mathrm{c}$

Tortrix seclusa Meyrick, I926, Exotic Microlepidoptera, 3: 247.

" ơor. I6-20 mm. . . Palestine, Mt. Carmel, at light (Bodkin); 6 ex. (type Brit. Mus.)."

Type: The female so marked in the British Museum, "Palestine, Mt. Carmel. 1925, at light. G. E. Bodkin." Slide No. 9357.

Figure 4 , left wings; $4 \mathrm{a}$, ventral view of female genitalia; $4 \mathrm{~b}$, signum; $4 \mathrm{c}$, detail of genital plate and ostium. 

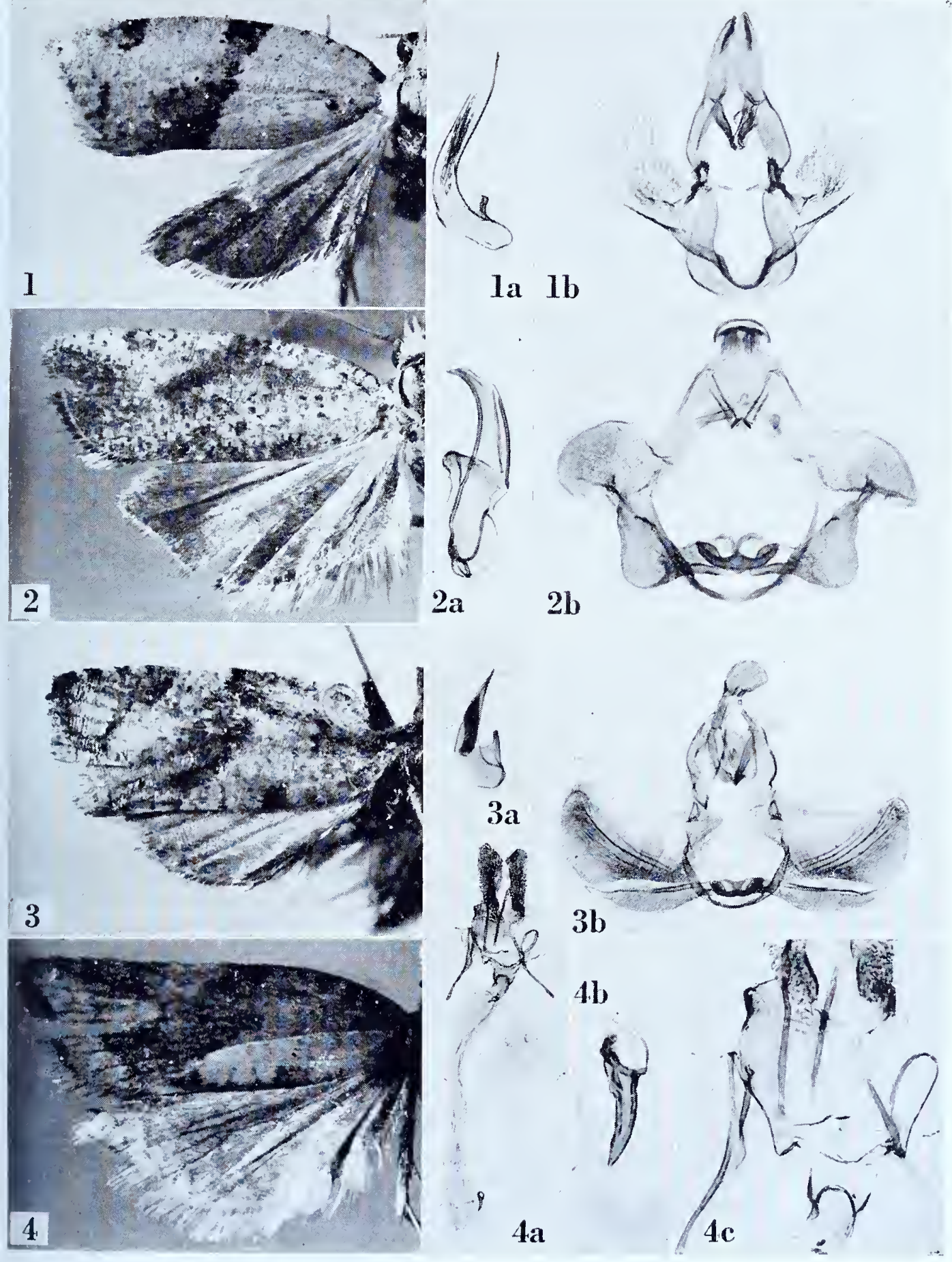

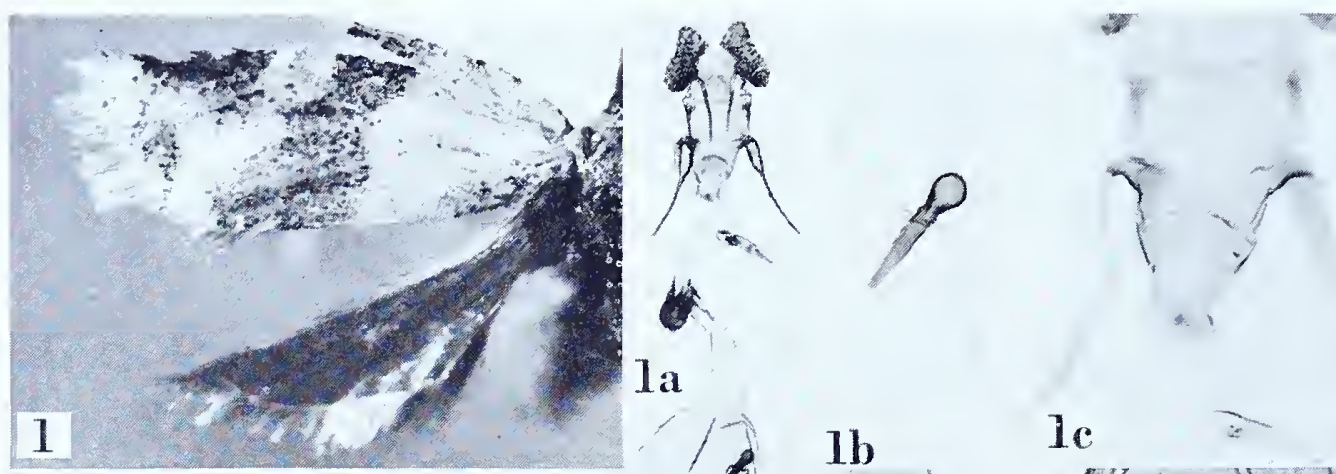

Ia

2

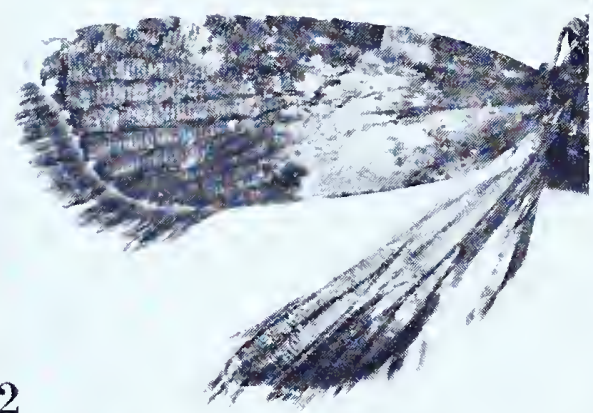

1

Ib
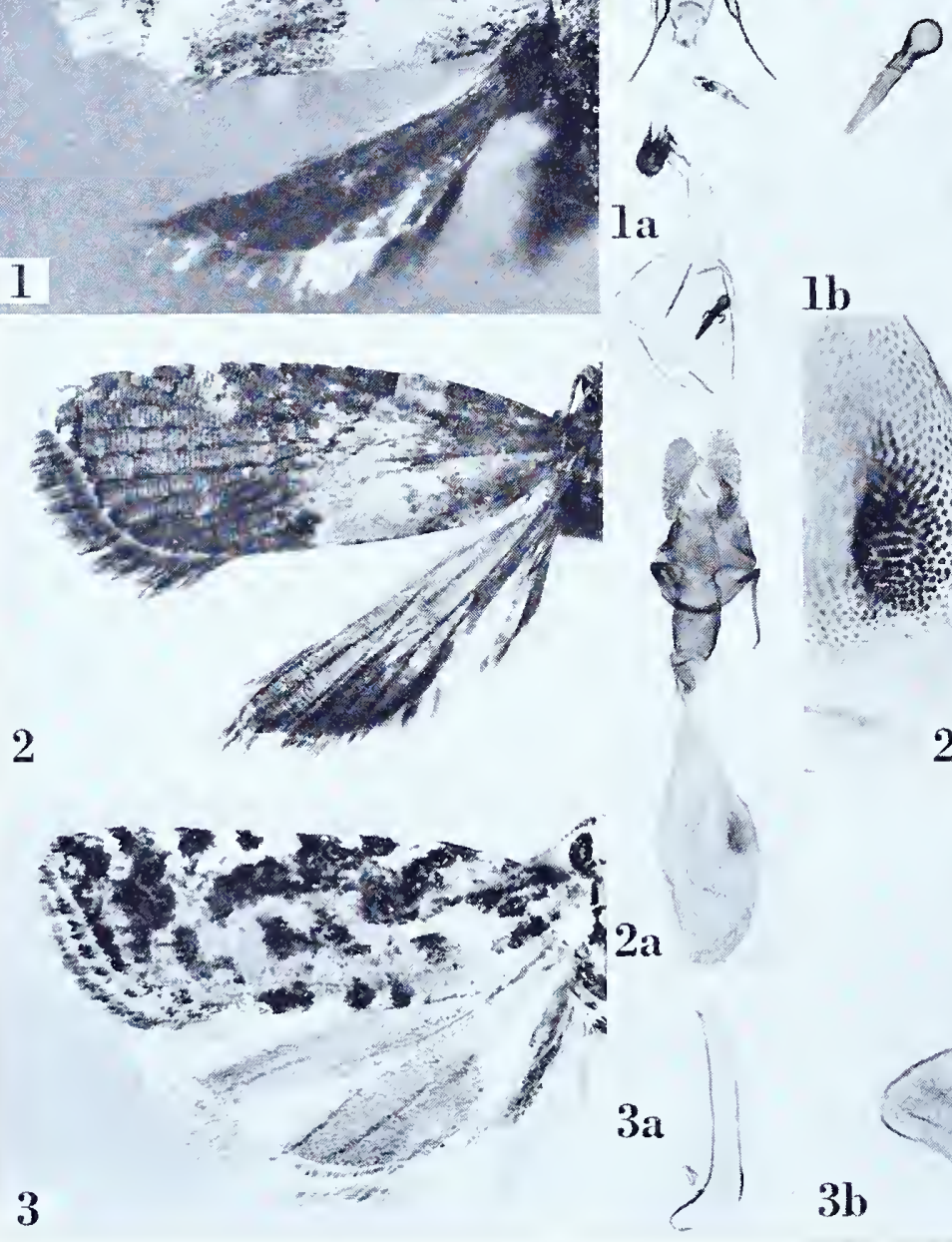

b
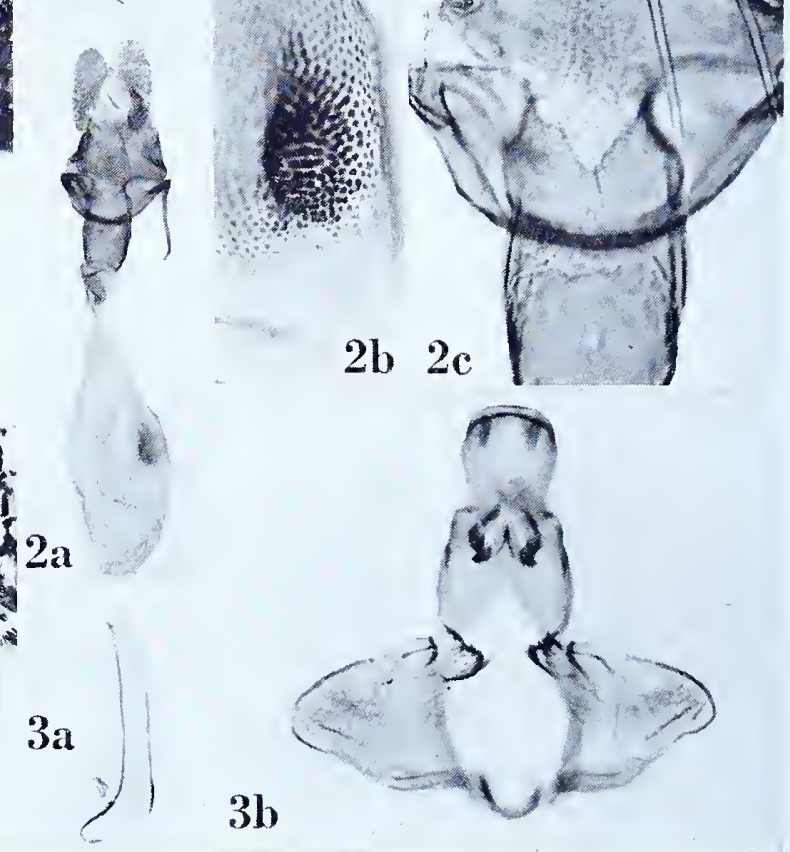

TOR'TRIX 


\section{Tortrix segnis Meyrick}

Plate 127, Figures I-I C

Tortrix segnis Meyrick, 1918, Exotic Microlepidoptera, 2: I68.

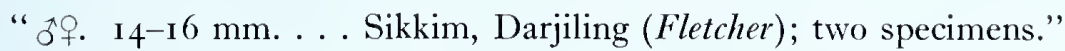

Lectotype: The female. Slide No. 6838. The male lacks the abdomen.

Figure I, left wings; ıa, ventral view of female genitalia; $\mathbf{r b}$, signum; Ic, detail of genital plate and ostium.

\section{Tortrix semifulva (Meyrick)}

Plate 127, Figures 2-2c

Schoenotenes semifulva Meyrick, 1908, Journ. Bombay Nat. Hist. Soc., 18: 620.

"ㅇ. 12-13 mm. ... Khasis, in October; three specimens."

Lectotype: A female measuring I3 mm., "Khasi Hills, Assam. .ı.1906." Slide No. 6849 .

Figure 2, left wings; 2a, ventral view of female genitalia; $2 \mathrm{~b}$, signum; $2 \mathrm{c}$, detail of genital plate and ostium.

\section{Tortrix spilographa Meyrick}

Plate 127 , Figures $3-3 \mathrm{~b}$

Tortrix spilographa Meyrick, 1937, Exotic Microlepidoptera, 5: 127.

“웅. 21-23 mm. . . . Cape Colony, Aberdeen, bred October from larvae feeding on Elytropappus rhinocerotis (Compositae) (C. C. Waterneyer); ro ex. (type Brit. Mus). A remarkable type."

Type: The male so marked in the British Museum labelled as follows: (I) "S. Africa, Cape Province." (2) "Larvae feeding on rhinosterbos (Elytropappus rhinocerotis)." (3) "Aberdeen C. P. Oct. 1930. C. C. Watermeyer." (4) "SN2046; 5, AcP4231."

(5) In Meyrick's hand, "Tortrix spilographa n. sp." Slide No. 9355.

Figure 3 , left wings; 3 a, lateral aspect of aedeagus; 3 b, ventral view of male genitalia with aedeagus removed. 
TORTRIX

\section{Tortrix synastra Meyrick}

Plate I28, Figures I-IC

Tortrix synastra Meyrick, I9I8, Exotic Microlepidoptera, 2: I69.

"q. $20 \mathrm{~mm}$. . . Madagascar, Antananarivo; one specimen."

Type: The female denoted above, "Antananarivo, Madagascar. M. .r3." Slide No. 9342 .

Figure I, left wings; $\mathbf{a}$, ventral view of female genitalia; Ib, signum; ic, detail of genital plate and ostium.

\section{Tortrix translucida (Meyrick)}

Plate 128, Figures 2-2a

Cacoecia translucida Meyrick, 1908, Journ. Bombay Nat. Hist. Soc., 18: 6r6.

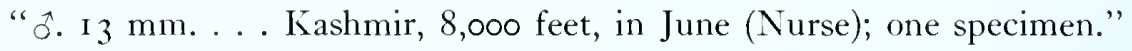

Type: The above indicated male dated ".6.or". Slide No. 6828.

Figure 2, left wings; 2 a, ventral view of male genitalia with aedeagus in situ.

\section{Tortrix tricensa Meyrick}

Plate 128 , Figures $3-3 \mathrm{~b}$

Toririx tricensa Meyrick, 1912, Exotic Microlepidoptera, I : 6.

“우. I $5-18 \mathrm{~mm}$. . . Assam, Khasis, in April, Cctober and November; eight specimens."

Lectotype: A male measuring $15 \mathrm{~mm}$., dated ".10.1906". Slide No. 6845. One specimen is missing.

Figure 3 , left wings; 3 a, lateral aspect of aedeagus; 3 b, ventral view of male genitalia with aedeagus removed.

\section{Tortrix xestochalca Meyrick}

Plate I28, Figure 4

Tortrix xestochalca Meyrick, 19=6, Exotic Microlepidoptera, 3:248.

" . $20 \mathrm{~mm}$. . . Colombia, Cañon del Tolima, 5,600 feet, November; i ex."

Type: The specimen indicated above dated ".I I.20". The abdomen of the type is missing.

Figure 4 , left wings. 


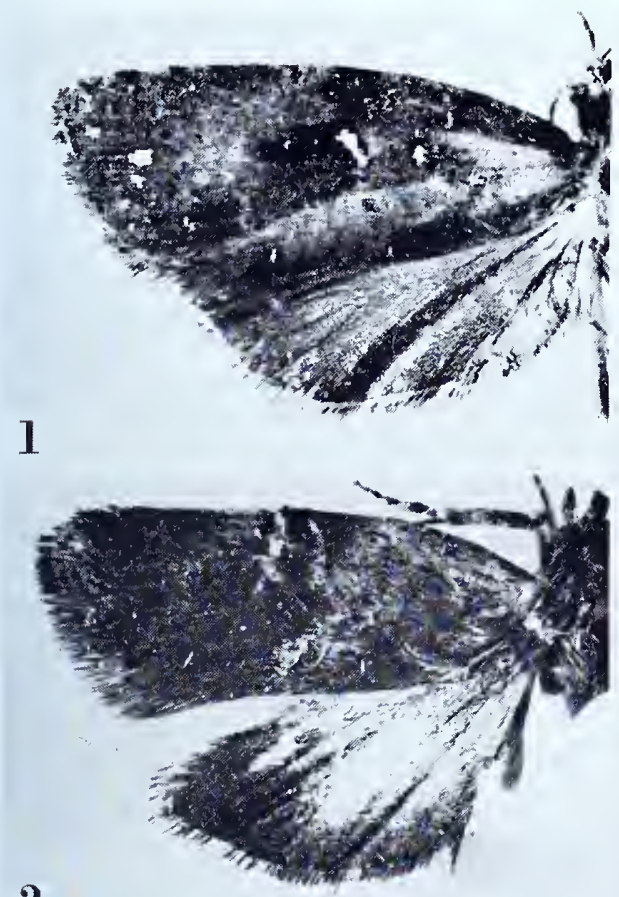

2

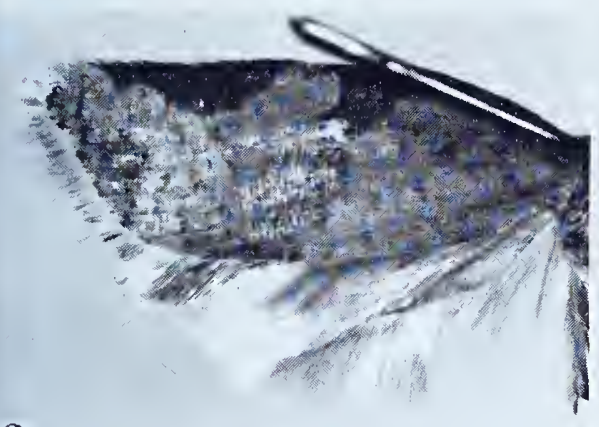

3

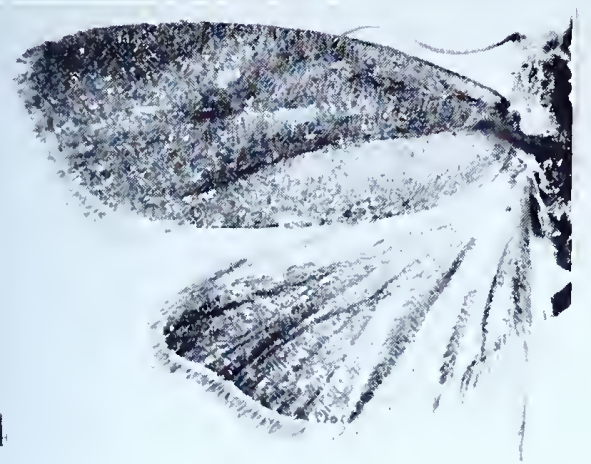

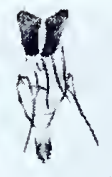

$2 a$

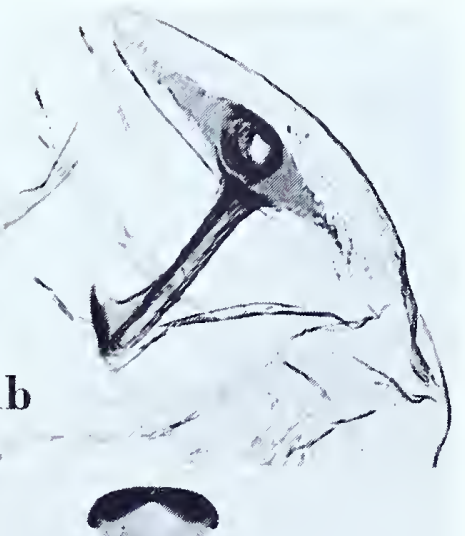

$1 a$

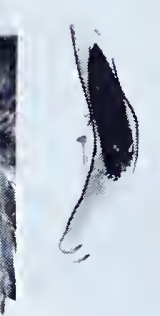

3a

$3 b$

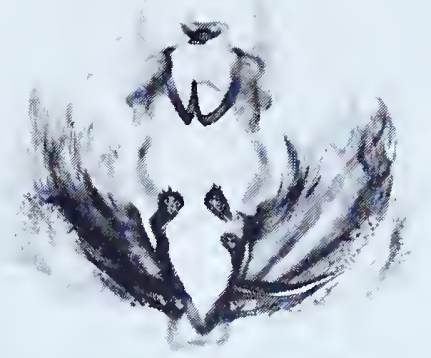

Ic

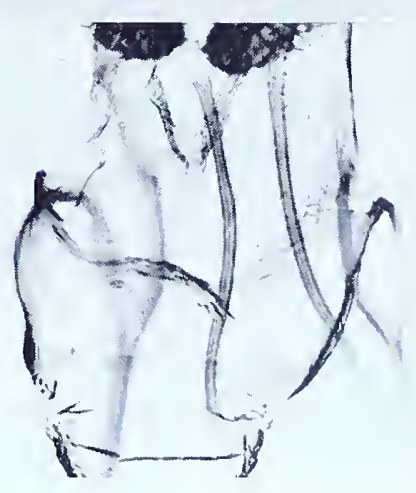

TORTRIX 


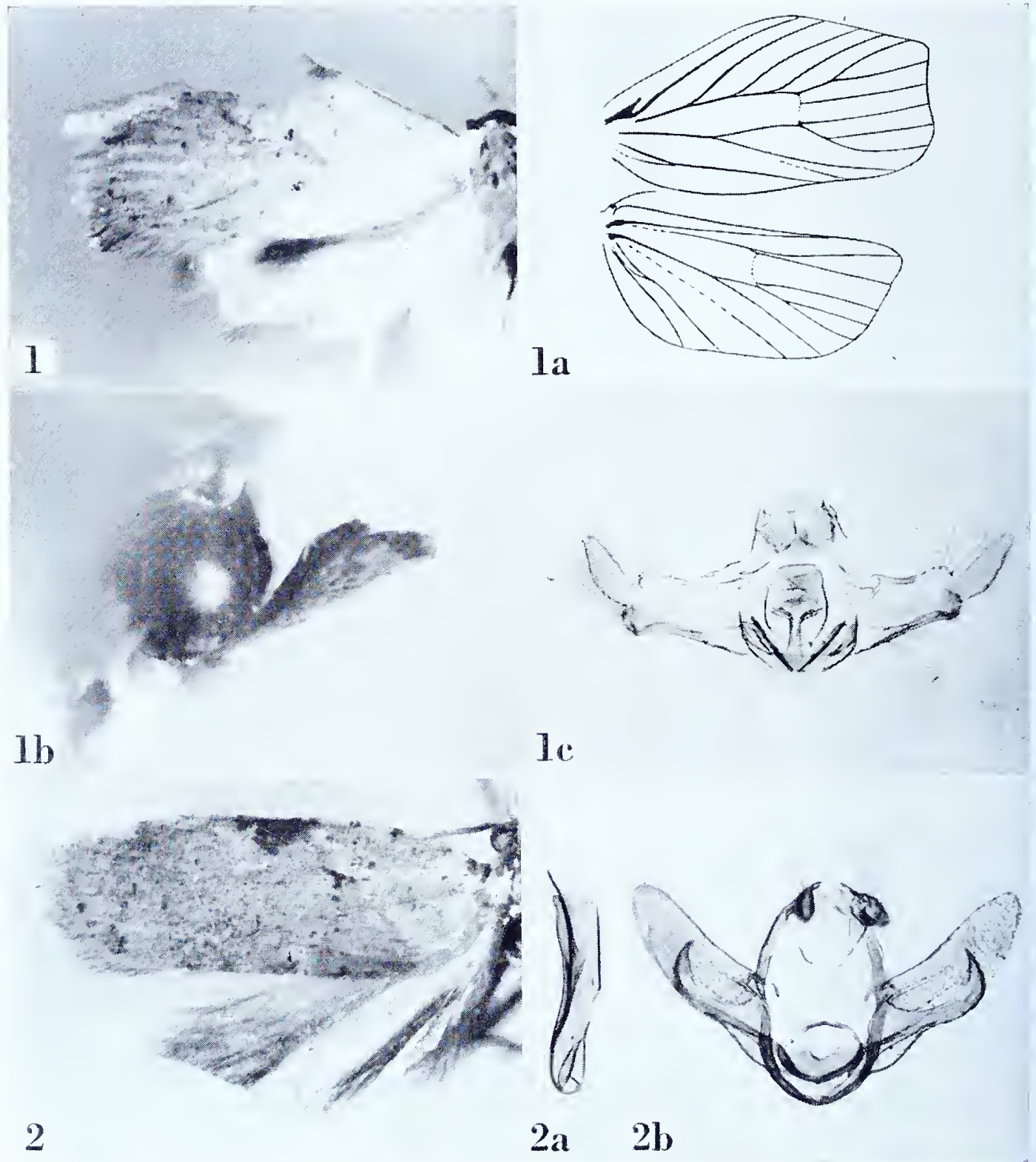




\section{TYMBARCHA Meyrick}

Tymbarcha Meyrick, I908, Journ. Bombay Nat. Hist. Soc., 18: 622. (Typus generis: Tymbarcha cerinopa Meyrick, ibid. [monotypy].)

\section{Tymbarcha cerinopa Meyrick}

Plate I29, Figures I-IC

Tymbarcha cerinopa Meyrick, I908, Journ. Bombay Nat. Hist. Soc., I8: 622.

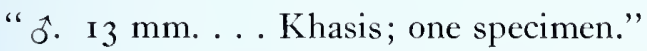

Type: The male indicated above, "Khasi Hills, Assam. D. .I go6." Slide Diakonoff No. I 152.

Figure I, left wings; Ia, venation of right wings; $\mathrm{Ib}$, lateral aspect of head to show palpus; Ic, ventral view of male genitalia with aedeagus in situ.

\section{Tymbarcha astuta Meyrick}

Plate 129, Figures 2-2b

Tymbarcha astuta Meyrick, I9I2, Exotic Microlepidoptera, I : I4.

" $\hat{0}$. $14 \mathrm{~mm}$. ... Assam, Khasis; one specimen."

Type: The above indicated male, "Khasi Hills, Assam. D. . I 9o6." Slide No. 6887.

Figure 2, left wings; 2a, lateral aspect of aedeagus; 2 b, ventral view of male genitalia with aedeagus removed. 


\section{ULODEMIS Meyrick}

Ulodemis Meyrick, I907, Journ. Bombay Nat. Hist. Soc., 17: 736. (Typus generis: Ulodemis trigrapha Meyrick, ibid. [monotypy].)

\section{Ulodemis trigrapha Meyrick}

Plate I30, Figures I-Id

Ulodemis trigrapha Meyrick, 1907, Journ. Bombay Nat. Hist. Soc., 17: 736.

" 1 fo. 20-23 mm.... Bhotan (3,000 feet) in April, May and August; three specimens (Dndgeon)."

Lectotype: A male measuring 21 mm., "Bhotan. GCD. .5.92." Slide No. 6853. 'The lectotype is the only one of the original three remaining in the Meyrick collection.

Figure $\mathrm{I}$, left wings; $\mathrm{ra}$, venation of right wings; $\mathrm{r} b$, lateral view of head to show palpus; ic, lateral aspect of aedeagus; Id, lateral view of male genitalia with aedeagus removed.

\section{Ulodemis falsa Meyrick}

Plate I30, Figures 2-2b

Ulodemis falsa Meyrick, 1914, Journ. Bombay Nat. Hist. Soc., 22: 77 I.

"3․ 22-25 mm. . . Nilgiris, 3,500 feet from August to October (Andrewes), 9 specimens $(5$ ô, 4 f ); also one from Ceylon. ..."

Lectotype: A male measuring 22 mm., "Nilgiri Hills, S. India. HLA. 3,500' .8.o7." Slide No. 6855 .

Figure 2, left wings; 2a, lateral aspect of aedeagus; $2 \mathrm{~b}$, lateral view of male genitalia with aedeagus removed. 

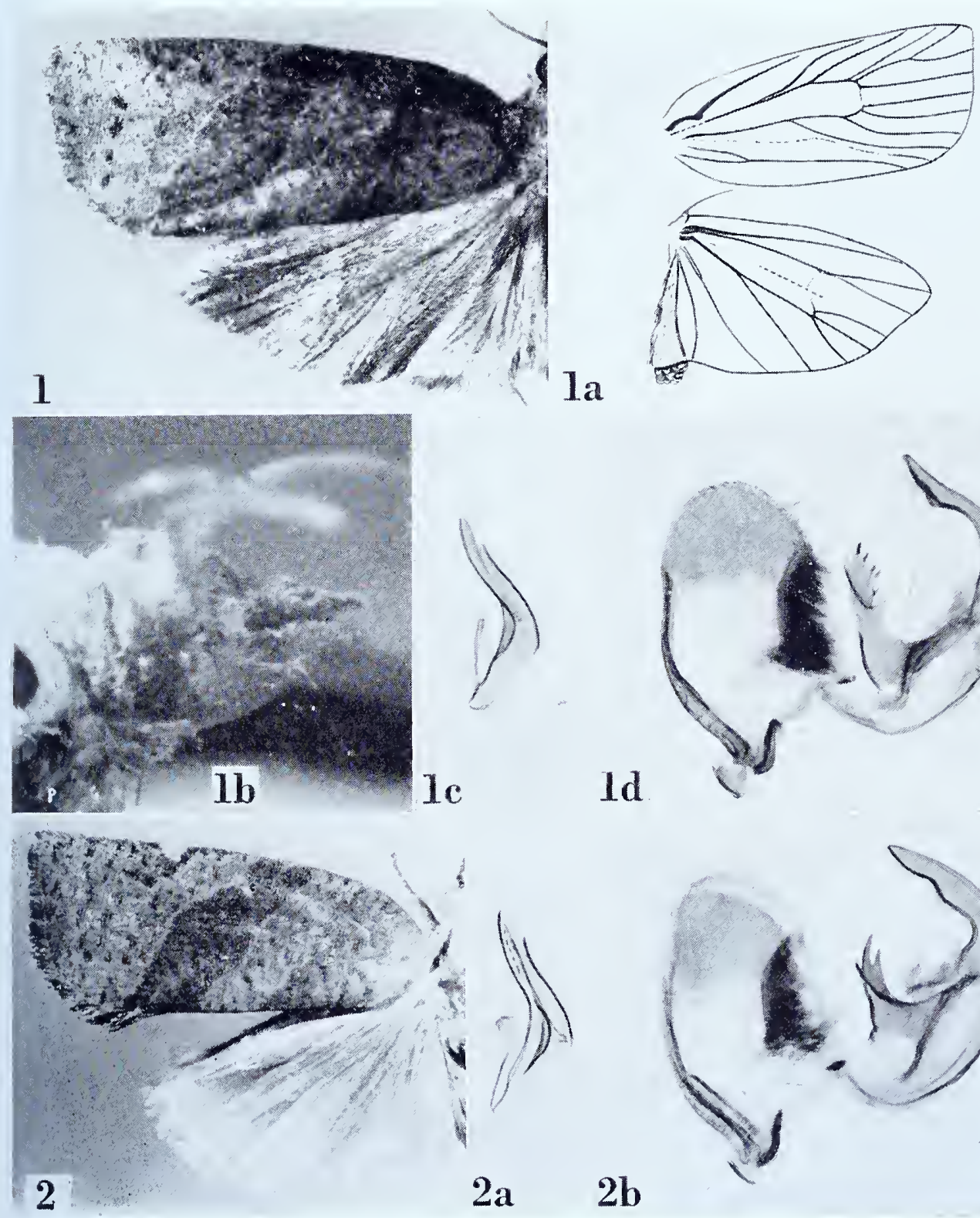

2

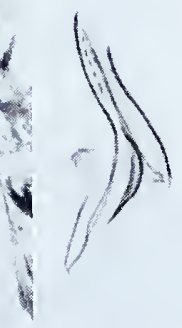

$2 \mathrm{a}$

$2 b$

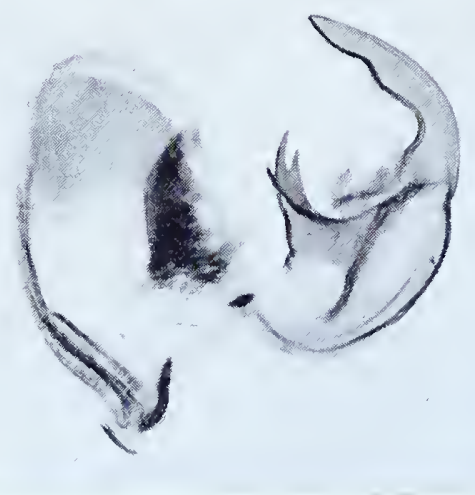

ULODEMIS 

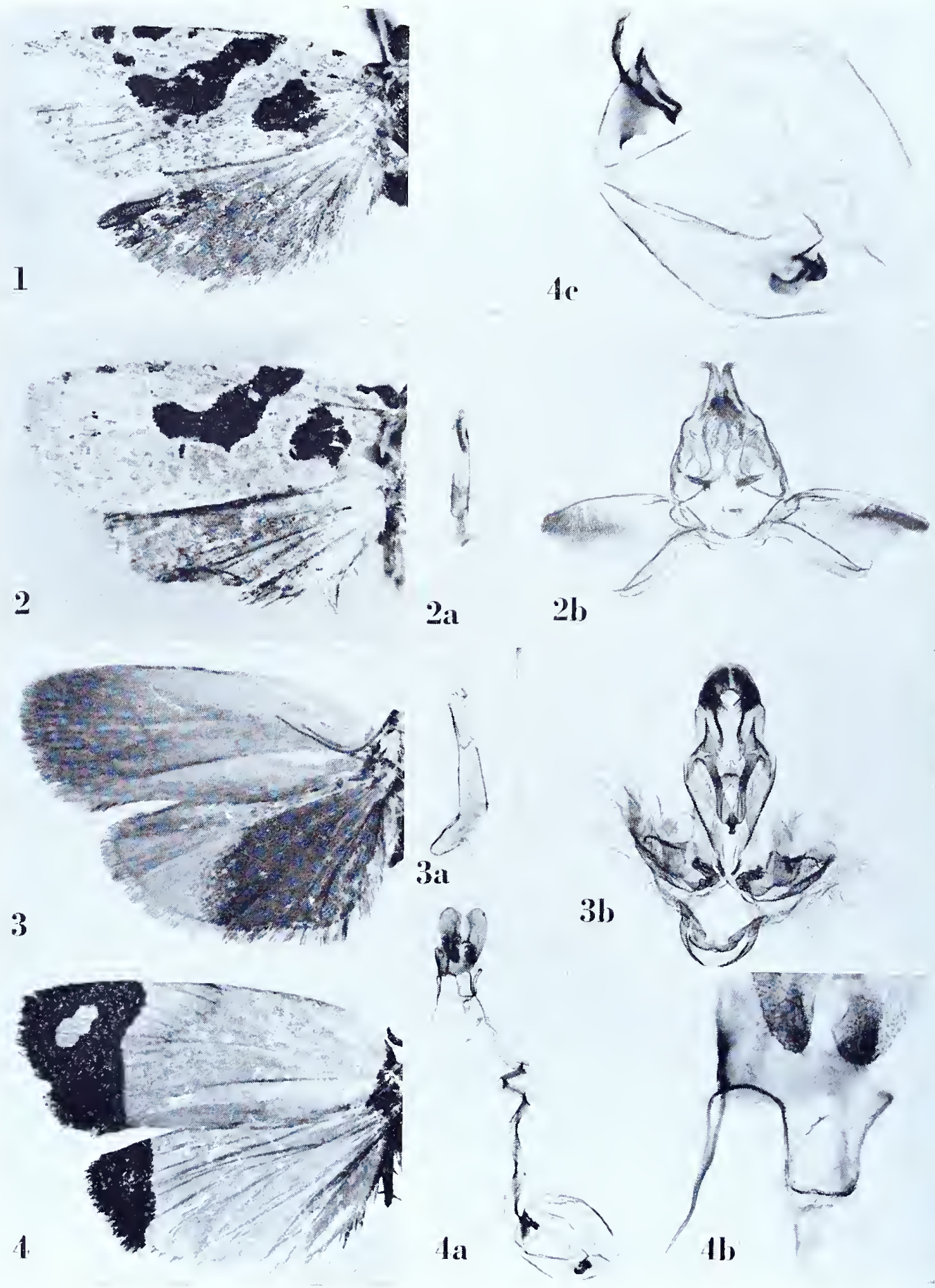

XENOTHICTIS AND ZACORISCA 


\section{XENO'THIC'TIS Meyrick \\ Xenothictis atriflora Meyrick \\ Plate I3 I, Figures I; 2-2b}

Xenothictis atriflora Meyrick, 1930, Exotic Microlepidoptera, 3: 609.

Tortrix melananchis Meyrick, 1933, Exotic Microlepidoptera, 4: 424 (new synonymy).

[atriflora]

“ڤ. I 9 mm. ... Fiji, Vunidawa, December (Phillips); I ex. (Brit. Mus.). In rather imperfect condition but very distinct."

Type: The male, without abdomen, so marked in the British Museum, "Vunidawa, Fiji. C. S. Phillips. 12.12.29." A small white label bears the inscription " $\mathrm{M}_{3006}$ ".

Figure I, left wings.

[melananchis]

“ స. 19 mm. . . Fiji, Vunidawa, September (H. Phillips); r ex. (Brit. Mus.)."

Type: The male so marked in the British Museum, "Vunidawa, Fiji. .26.9.1932. H. Phillips. 73r." Slide No. 9356 .

Figure 2, right wings (image reversed); $2 \mathrm{a}$, aedeagus; $2 \mathrm{~b}$, ventral view of male genitalia with aedeagus removed.

\section{ZACORISCA Meyrick \\ Zacorisca heliaula Meyrick \\ Plate I 3 r, Figures $3-3 \mathrm{~b}$}

Zacorisca heliaula Meyrick, I910, 'Trans. Ent. Soc. London, I910: 433.

" ${ }^{\circ}$. 28-29 mm. . . Philippines, Mindoro, at 5,000 feet, in November; two specimens."

Lectotype: The smaller of the two males both of which are dated ".I I.95". Slide No. 6826.

Figure 3 , left wings; 3 a, lateral aspect of aedeagus; 3 b, ventral view of male genitalia with aedeagus removed.

\section{Zacorisca electrina (Meyrick)}

Plate 13 I, Figures $4-4 \mathrm{c}$

Megalodoris electrina Meyrick, I912, Exotic Microlepidoptera, I: 5 .

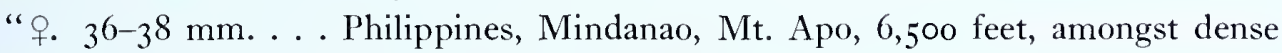
forest, in October (Mounsey). Allied to stephanitis. ..."

Lectotype: A female measuring $3^{8} \mathrm{~mm}$. Slide No. 6824. There are three specimens in the Meyrick collection, with identical data, dated ".I0.10".

Figure 4 , left wings; 4 a, ventral view of female genitalia; 4 b, detail of genital plate and ostium; $4 \mathrm{c}$, bursa copulatrix to show signum. 



\section{OLETHREUTIDAE}

\section{NOTE}

Argyroploce Hübner (I825) is a synonym of, and is superseded by, Olethreutes Hübner (I 822 ). Meyrick assigned a great mass of species, many unrelated to Olethreutes s. str., to Argyroploce. The latter name is abandoned in this work but most of the species placed in Argyroploce by Meyrick are retained together until such time as they are assigned correctly. Cacoecia Hübner (1825), likew ise, falls to Archips (Hübner) r 822, and the same applies to the species now assigned to Archips as indicated under Olethreutes. 

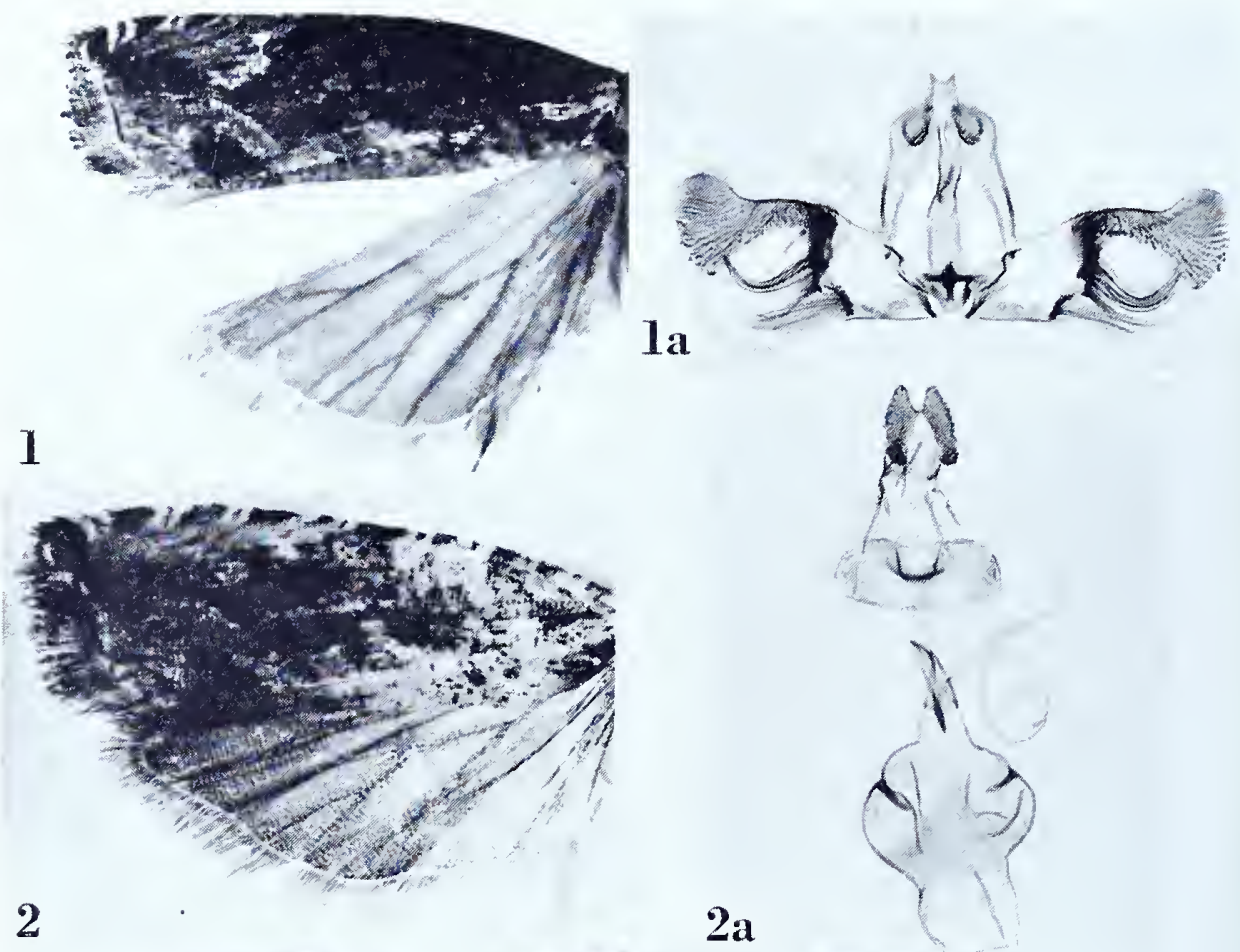

2

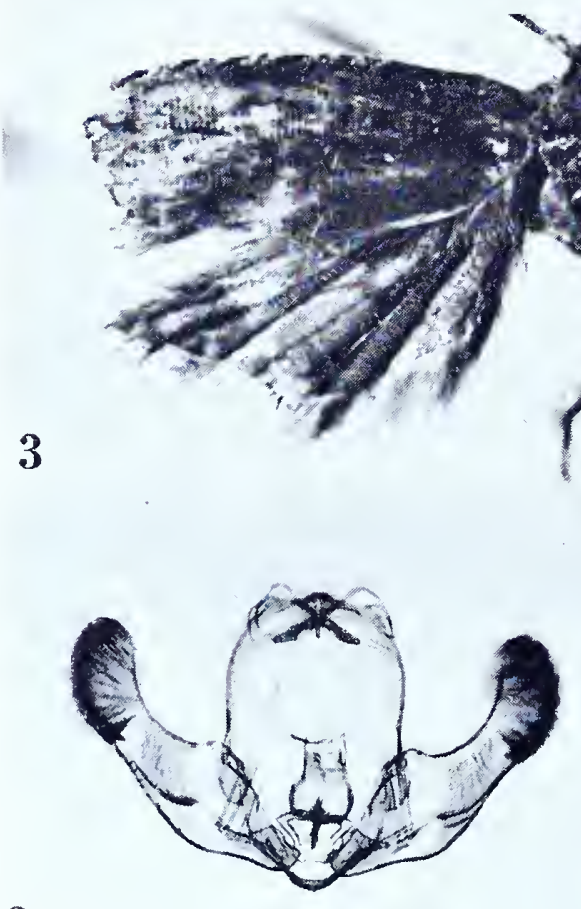

$3 a$

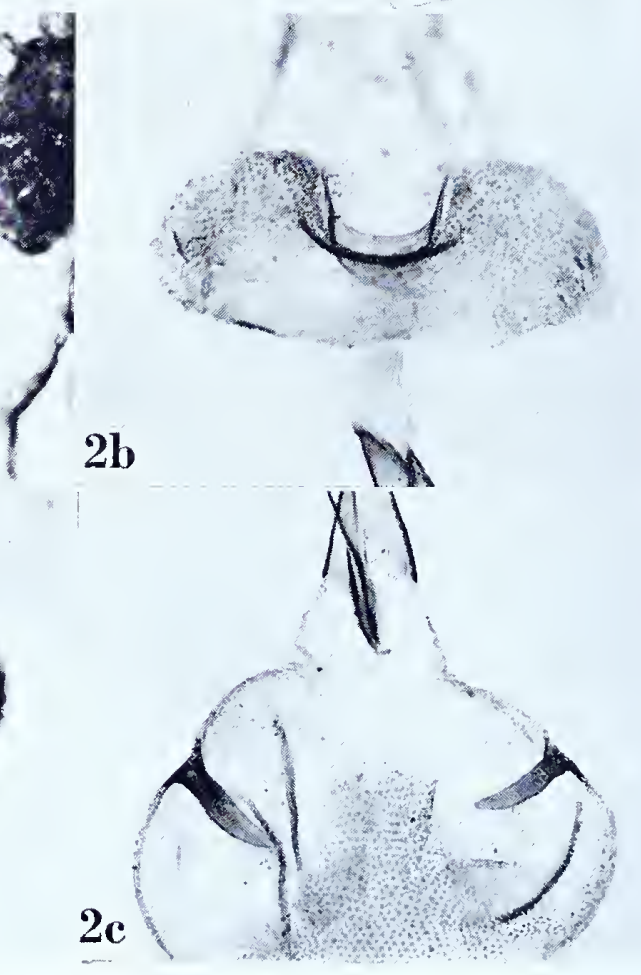




\section{ACROCLITA Lederer}

\section{Acroclita aestuosa (Meyrick), new combination}

Plate I 32, Figures I-Ia; 2-2c

Spilonota aestuosa Meyrick, I912, Journ. Bombay Nat. Hist. Soc., 2 I : 854.

Acroclita ligyropis Meyrick, 1937, in Caradja and Meyrick, Deuts. Ent. Zeit. Iris, 51: 176. Spilonota aestuosa (Meyrick), Diakonoff, I950, Bull. Brit. Mus. (Nat. Hist.) Ent., I (4): 284. [aestuosa]

"§. I $7^{-21} \mathrm{~mm} . .$. Darjiling; Khasis; in May and August, two specimens."

Lectotype: The male, "Darjiling, Bengal. D. .808." Slide No. 6717.

Figure I, left wings; Ia, ventral view of male genitalia with aedeagus in situ.

[ligyropis]

"ô. i 7 mm. . . Y Yül., 3,200 m., VII, I ex."

Type: The specimen referred to above, "Likiang, China. H. .7.34", erroneously recorded as a male. Slide No. 6942.

Figure 2, left wings; $2 a$, ventral view of female genitalia; $2 b$, detail of genital plate and ostium; 2c, bursa copulatrix to show signa.

\section{Acroclita anachastopa Meyrick}

Plate $3^{2}$, Figures $3^{-} 3^{\mathrm{a}}$

Acroclita anachastopa Meyrick, I934, Exotic Microlepidoptera, 4: 483; Diakonoff, I950, Bull. Brit. Mus. (Nat. Hist.) Ent., I (4): 277.

"주. Iо-I I mm. ... Java, Telawa, bred August from fruits of Glochidion and flowers of Mallotus (Euphorbiaceae) (Dr. L. G. E. Kalshoven); 4 ex."

Lectotype: The male selected by Diakonoff. Slide No. 694I.

Figure 3 , left wings; 3 a, ventral view of male genitalia with aedeagus in situ. 
ACROCLITA

\section{Acroclita belinda Meyrick}

Plate I33, Figures I-IC

Acroclita belinda Meyrick, I 112, Journ. Bombay Nat. Hist. Soc., 2 I : 858; Diakonoff, I 950, Bull. Brit. Mus. (Nat. Hist.) Ent., I (4): 277.

" fof $^{\circ}$ I I-I 3 mm. . . Khasis, in July and August; two specimens."

Lectotype: 'The female, "Khasi Hills, Assam. .7.I906", selected by Diakonoff. Slide No. 6935 .

Figure $\mathrm{I}$, left wings; $\mathbf{a}$, ventral view of female genitalia; $\mathrm{ib}$, detail of genital plate and ostium; ic, signa.

\section{Acroclita cameraria Meyrick}

See Acroclita madens Meyrick.

\section{Acroclita canthonias Meyrick}

Plate 133 , Figures 2-2a

Acroclita canthonias Meyrick, 1920, Exotic Microlepidoptera, 2: 343 .

“ㅇ. I I mm. . . . Bengal, Pusa, November, 'on stem of Ficus glomerata' (Fletcher); 1 ex."

Type: The above indicated female, without abdomen, dated "9.ir.I7". Male genitalia figured from a specimen labelled, "Pusa, Bihar. TBF. bred .3 .23 ". Slide No. 6947.

Figure 2, left wings; 2a, ventral view of male genitalia with aedeagus in situ.

\section{Acroclita catharotorna Meyrick}

\section{Plate 133 , Figure 3}

Acroclita catharotorna Meyrick, 1935, in Caradja and Meyrick, Materialien zu einer Microlepidopteren Fauna der Chinesischen Provinzen Kiangsu, Chekiang und Hunan, 53 .

"... o. I 3 mm. . . 2 ex., Tienmushan, IV, V. Shanghai. ..."

Lcctotype: The male, without abdomen, "'Tien-Mu-Shan, China. H. 5,300' .4.32." Figure 3 , left wings.

\section{Acroclita cheradota Meyrick \\ Plate ${ }_{3} 33$, Figures $4-4 \mathrm{a}$}

Acroclita cheradota Meyrick, 1912, Journ. Bombay Nat. Hist. Soc., 21: 856; Diakonoff, I950, Bull. Brit. Mus. (Nat. Hist.) Ent., I (4): 277.

“ two specimens. Larva feeding in rolled leaves of Ficus religiosa (Lefroy)." 

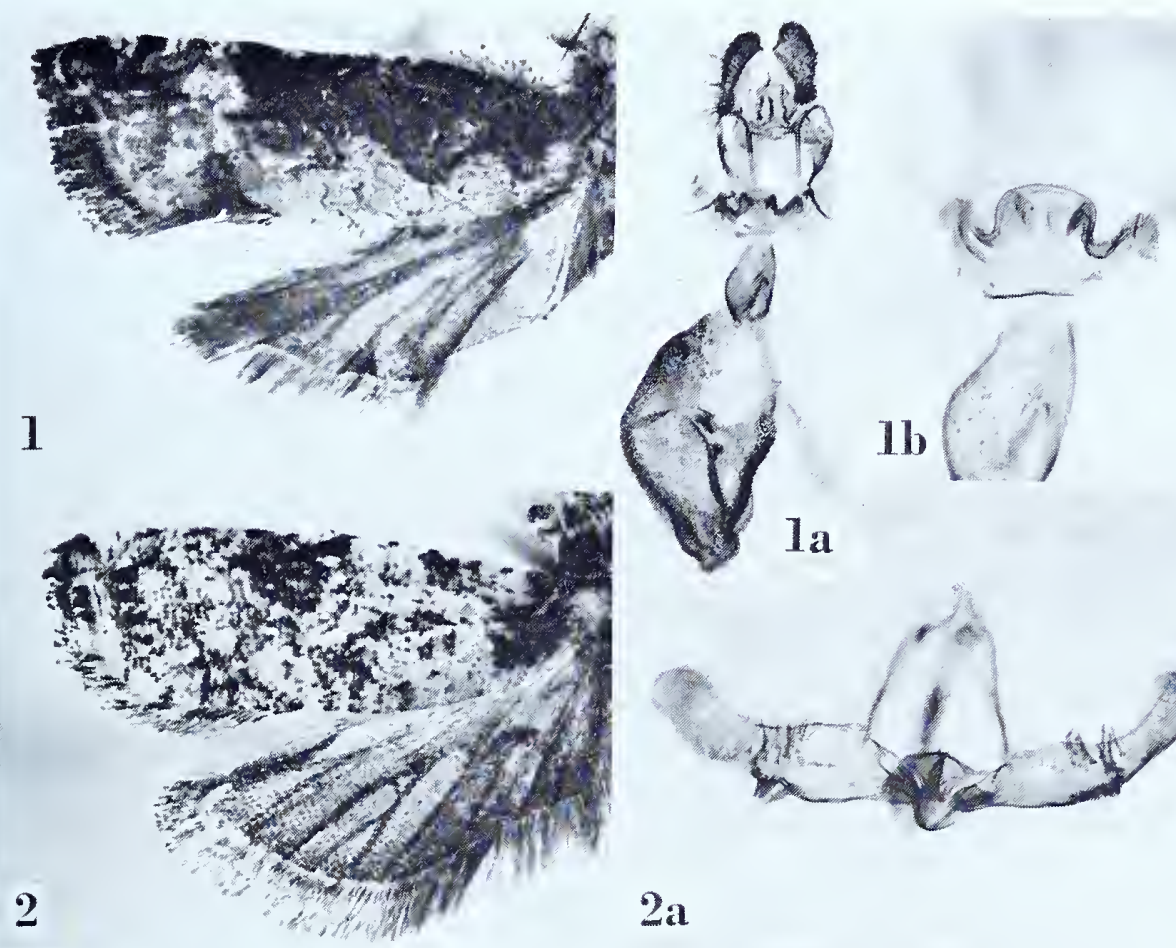

2
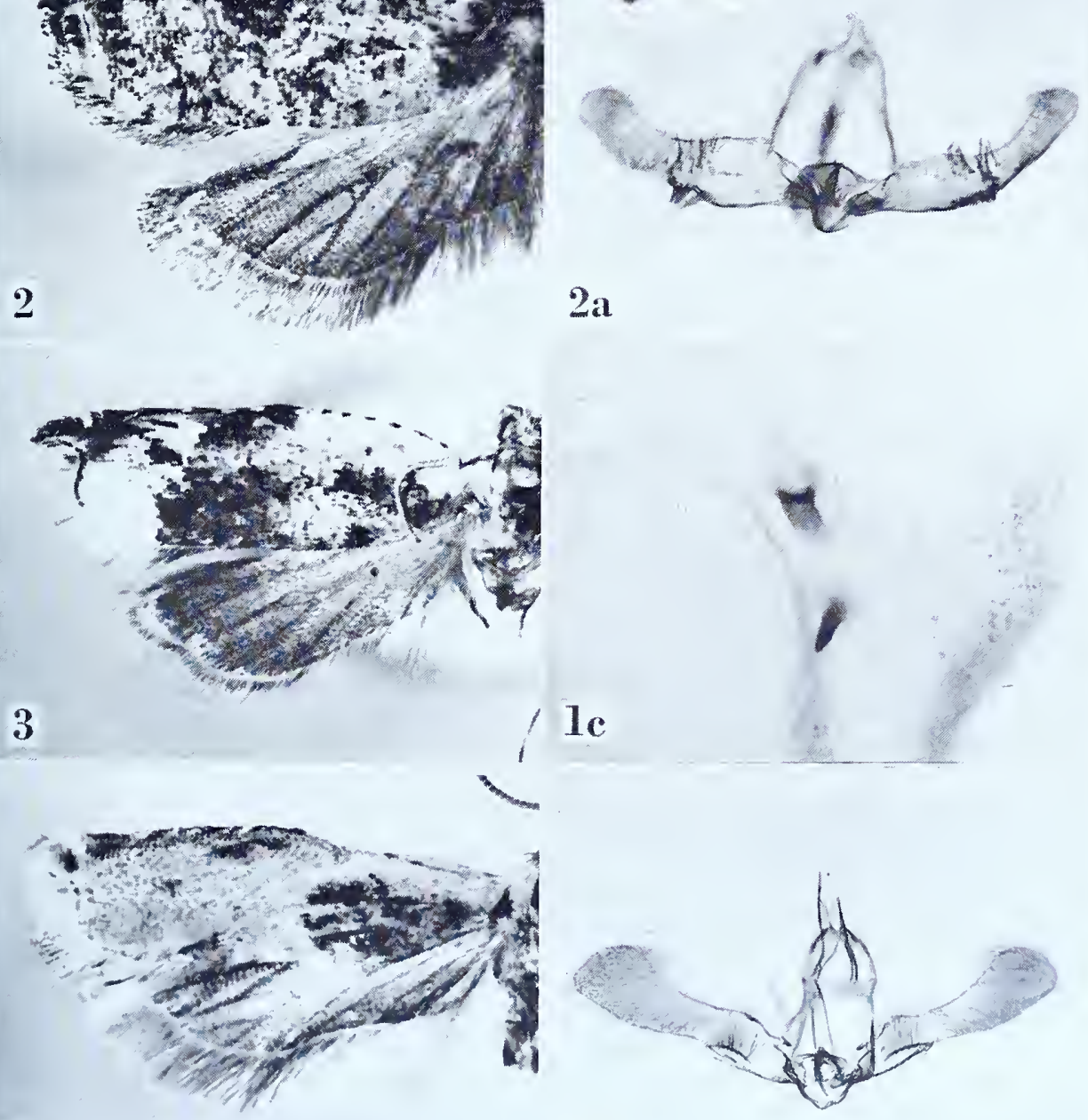

4

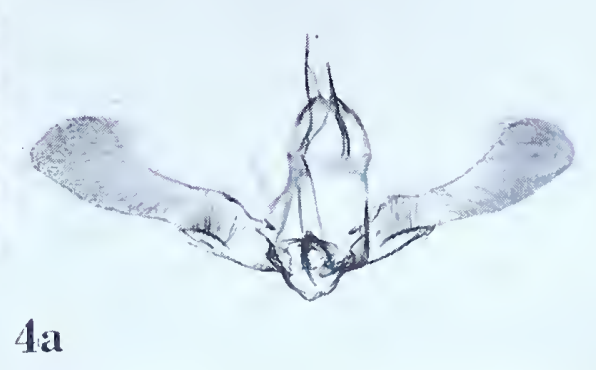

ACROCLITA 

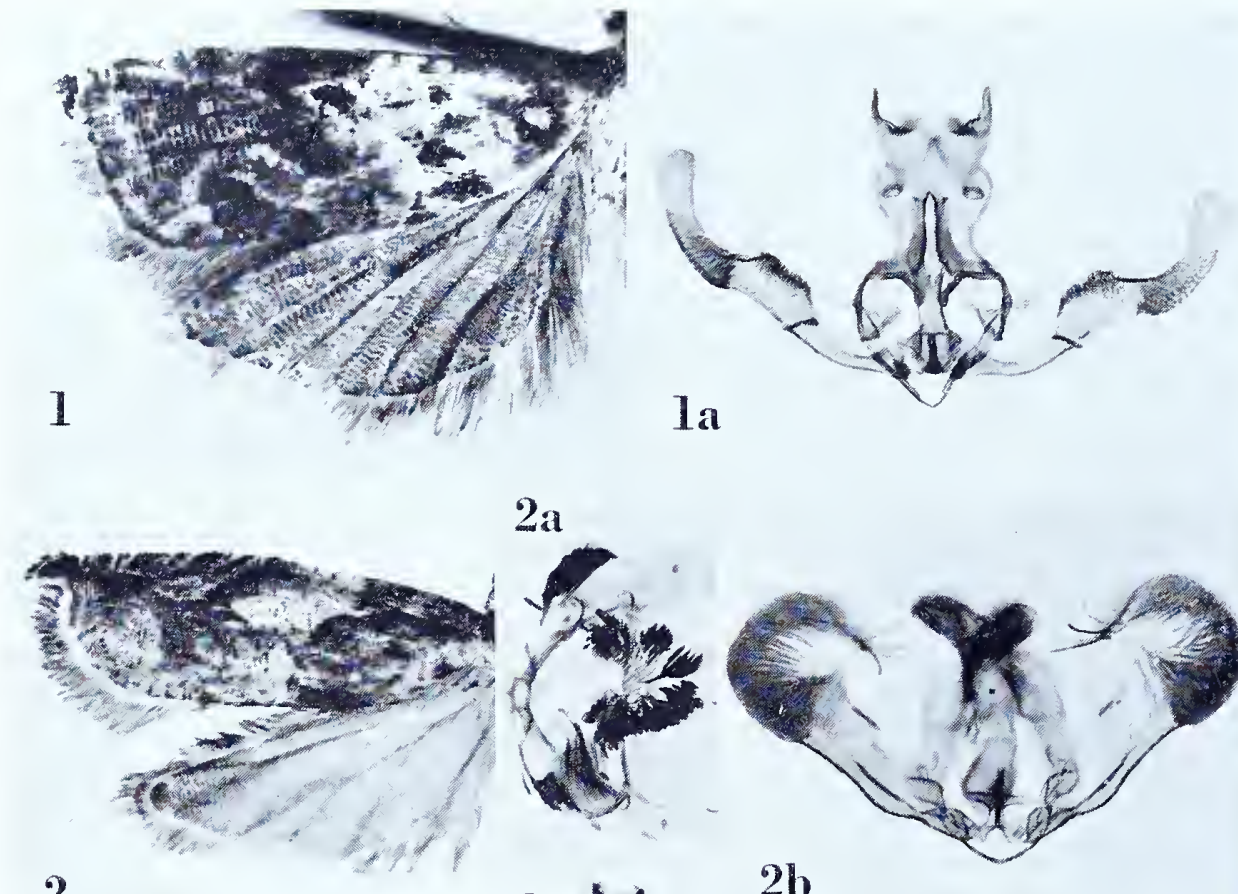

$2 a$

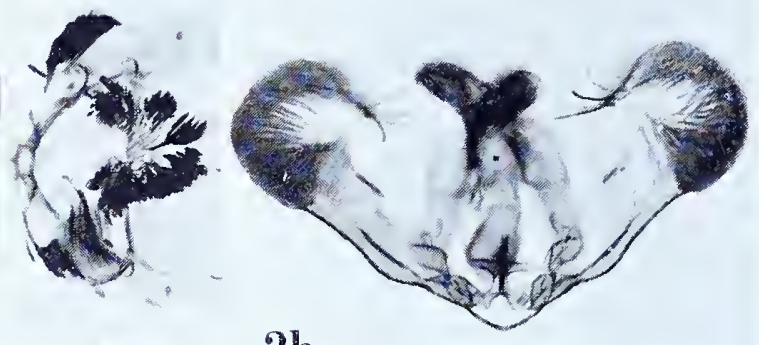

2

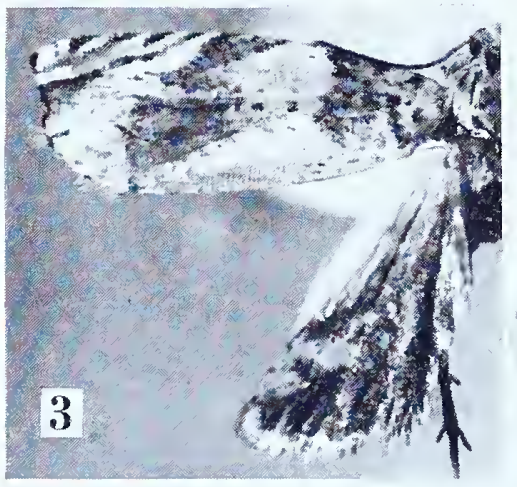

3

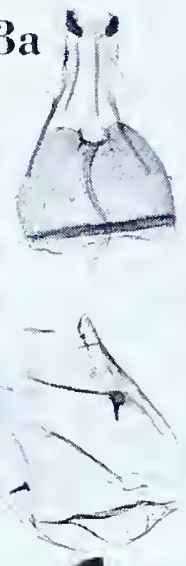

$2 \mathrm{~b}$
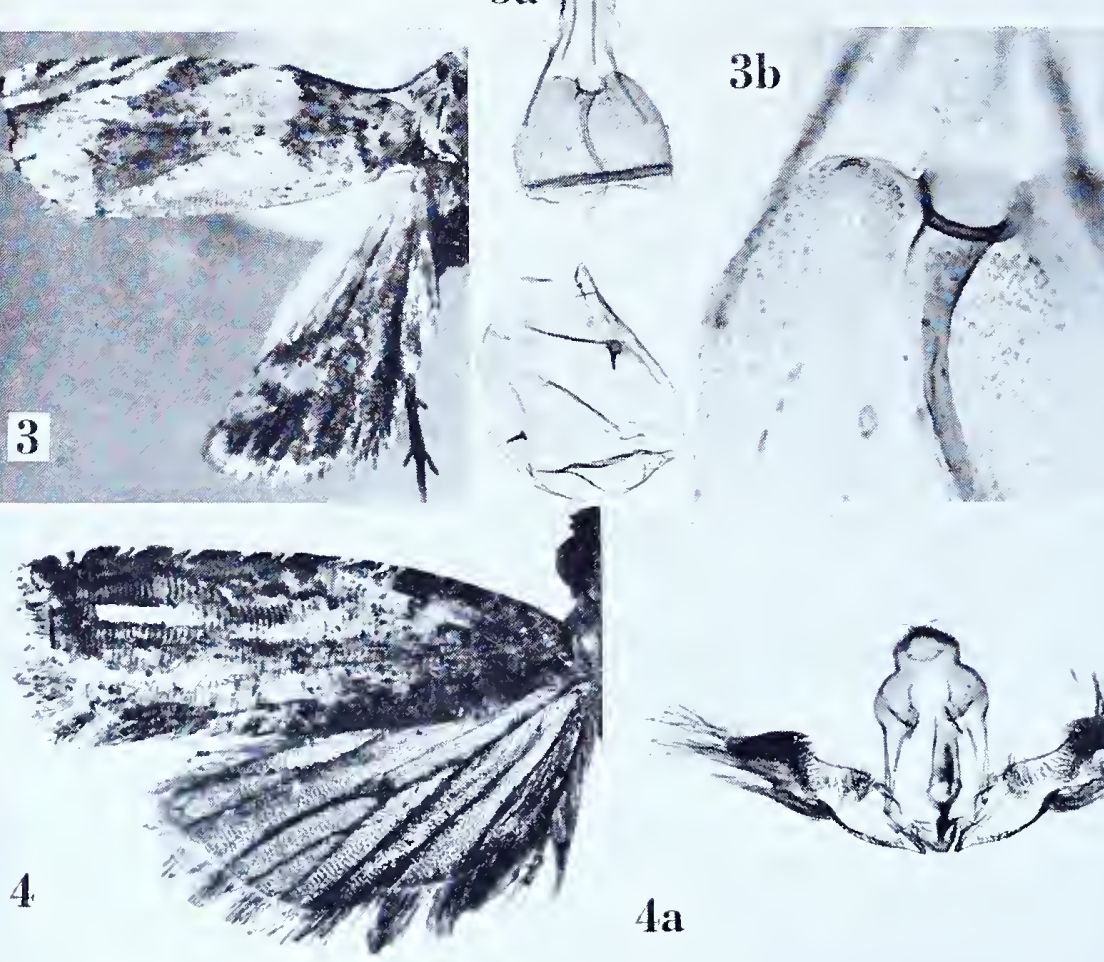


\section{Acroclita chlorissa Meyrick}

Plate I34, Figures I-Ia

Acroclita chlorissa Meyrick, I912, Journ. Bombay Nat. Hist. Soc., 2 I : 859; Diakonoff, I950, Bull. Brit. Mus. (Nat. Hist.) Ent., I (4): 277.

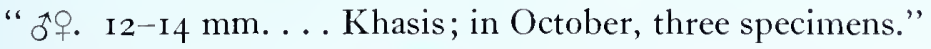

Lectotype: A male measuring I 2 mm., "Khasi Hills, Assam. .10.1906", selected by Diakonoff. Slide No. 6936.

Figure I, left wings; Ia, ventral view of male genitalia with aedeagus $i n$ sitn.

\section{Acroclita clivosa Meyrick}

Plate 134, Figures 2-2b

Acroclita clivosa Meyrick, 1912, Journ. Bombay Nat. Hist. Soc., 21: 855; Diakonoff, 1950, Bull. Brit. Mus. (Nat. Hist.) Ent., I (4): 277.

" J. $^{1}$ I $^{-1} 4 \mathrm{~mm}$. . . . Khasis; in October, two specimens."

Lectotype: The male measuring I3 mm., selected by Diakonoff. Slide No. 6938 . Both specimens are labelled, "Khasi Hills, Assam. .10.1906".

Figure 2, left wings; $2 \mathrm{a}$, anterior abdominal tufts; $2 \mathrm{~b}$, ventral view of male genitalia with aedeagus in sitn.

\section{Acroclita cordelia Meyrick}

Plate 134 , Figures $3^{-} 3 \mathrm{~b}$

Acroclita cordelia Meyrick, I935, in Caradja and Meyrick, Materialien zu einer Microlepidopteren Fauna der Chinesischen Provinzen Kiangsu, Chekiang und Hunan, 52.

“... ô. I $3 \mathrm{~mm}$. ... I ex., Shanghai, VIII. A distinct species, perhaps related to paulina Meyr."

Type: The above indicated specimen, erroneously recorded as a male, "Shanghai, China. C. .8.32." Slide No. 7I I 5 .

Figure 3 , left wings; 3 a, ventral view of female genitalia; 3 b, detail of genital plate and ostium.

\section{Acroclita corinthia Meyrick}

Plate I34, Figures $4^{-4 a}$

Acroclita corinthia Meyrick, I912, Journ. Bombay Nat. Hist. Soc., 21: 858; Diakonoff, 1950, Bull. Brit. Mus. (Nat. Hist.) Ent., I (4): 277.

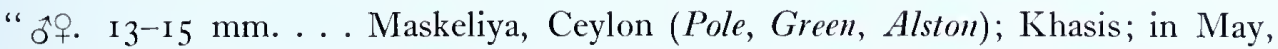
and from October to December, five specimens. 'The characteristic hindwings distinguish this species."

Lectotype: The male, "Maskeliya, Ceylon. Pole, .5.06", selected by Diakonoff. Slide No. $695^{\circ}$.

Figure 4 , left wings; 4 a, ventral view of male genitalia with aedeagus in sitn. 
ACROCLITA

\section{Acrôclita dejiciens Meyrick}

Plate 135 , Figures $\mathrm{I}-\mathrm{I} b$

Acroclita dejiciens Meyrick, I932, Exotic Microlepidoptera, 4:221.

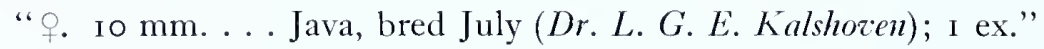

Type: The female indicated above, "Seneng, Java. K. .7.31." Slide No. 6928.

Figure 1, left wings; $\mathbf{a}$, ventral view of female genitalia; $\mathrm{s} b$, detail of genital plate and ostium.

\section{Acroclita dissoplaca Meyrick}

Plate i 35, Figures 2-2a

Acroclita dissoplaca Meyrick, I 936, Exotic Microlepidoptera, 5: 23.

Spilonota dissoplaca (Meyrick), Diakonoff, I950, Bull. Brit. Mus. (Nat. Hist.) Ent., I (4): 295.

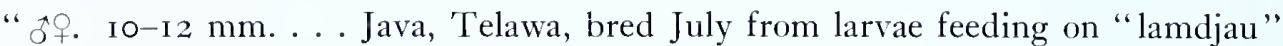
(Dr. L. G. Kalshoven); 3 ex. Probably allied to dejiciens Meyr."

Lectotype: A male measuring io mm., dated “.7.35”, selected by Diakonoff. Slide No. 6923 .

Figure 2, left wings; 2a, ventral view of male genitalia with aedeagus in situ.

\section{Acroclita esmeralda Meyrick}

Plate i 35 , Figures $3-3 \mathrm{~b}$

Acroclita esineralda Meyrick, I912, Journ. Bombay Nat. Hist. Soc., 2 I : 858; Diakonoff, I950, Bull. Brit. Mus. (Nat. Hist.) Ent., 1 (4): 278.

" $\jmath^{\circ}+$. 9-1o mm. . . Khasis, in October, two specimens."

Lectotype: A female, "Khasi Hills, Assam. .ıо.ı 906." Slide No. 695I. Diakonoff cites a "Holotype $\delta$ " and "Allotype ${ }^{\circ}$ ", but both specimens are females. Since Meyrick did not select a type the designation of lectotype above appears valid.

Figure 3 , left wings; $3^{a}$, ventral view of female genitalia; 3 , detail of genital plate and ostium.

\section{Acroclita grypodes Meyrick}

Plate I35, Figures 4-4a; Plate I 36 , Figures I-I b

Acroclita grypodes Meyrick, I91 2, Journ. Bombay Nat. Hist. Soc., 2 I : 856.

Acroclita vulturina Meyrick, I936, Exotic Microlepidoptera, 4: 610; Diakonoff, i 950, Bull. Brit. Mus. (Nat. Hist.) Ent., I (4): 278 .

\section{[grypodes]}

“ ふิ. I 7 mm. ... Maskeliya, Ceylon (Pole); in May, one specimen."

Type: The male indicated above dated ".5.06". Slide No. 6933. 


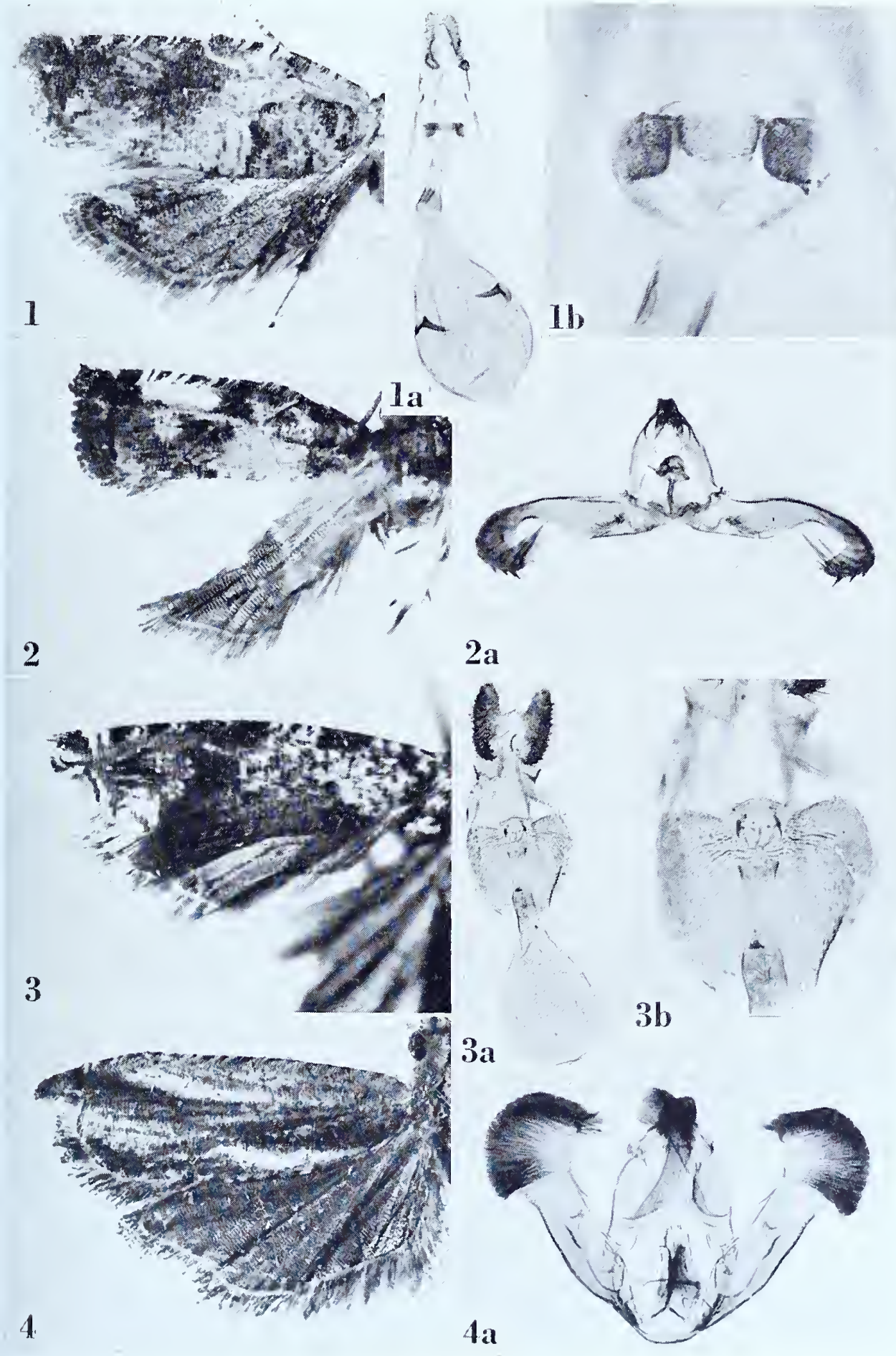

ACROCLITA 


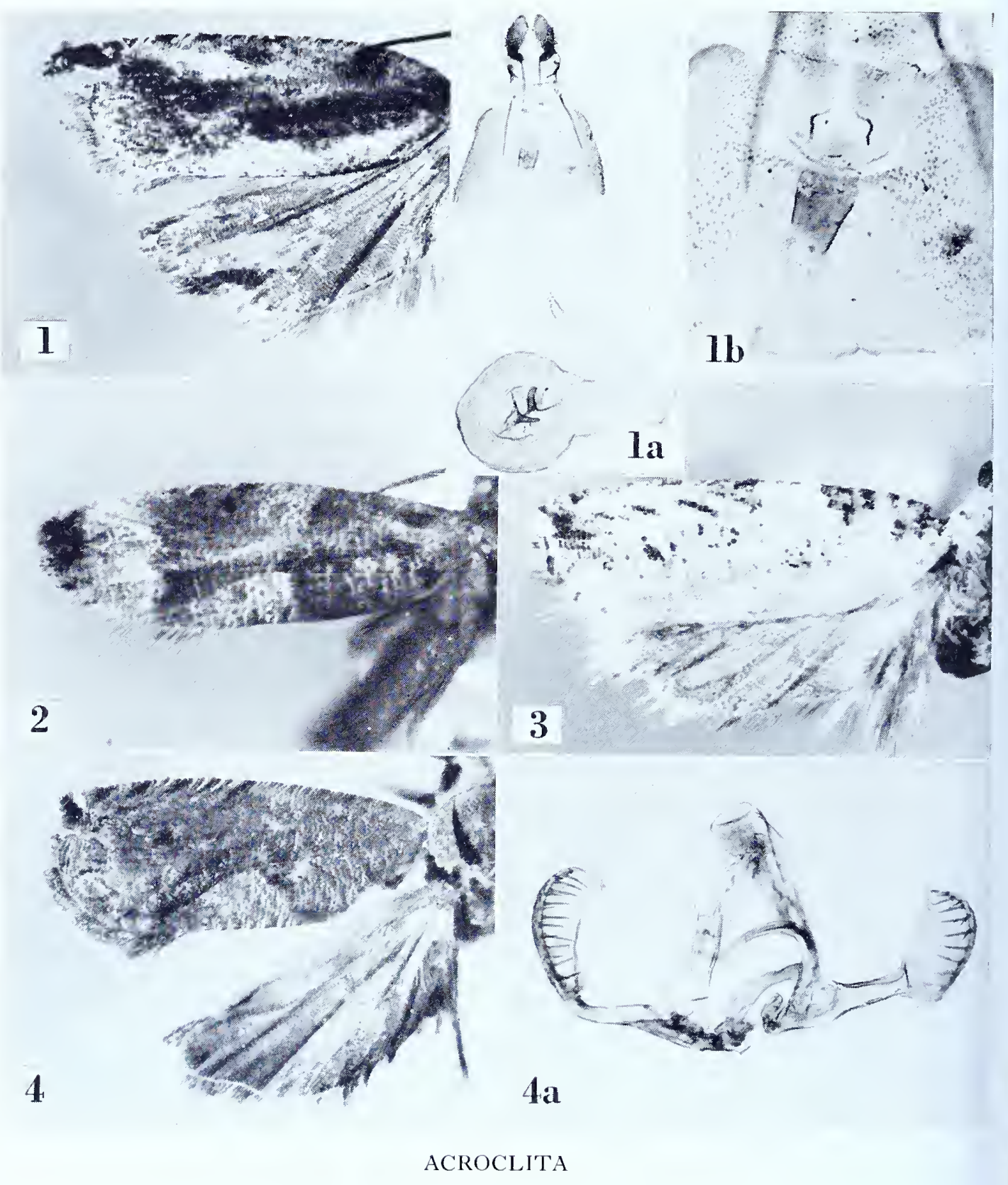




\section{Acroclita hercoptila Meyrick}

Plate 136 , Figure 2

Acroclita hercoptila Meyrick, 1927, Exotic Microlepidoptera, 3: 333 .

“ $7.7 \mathrm{~mm}$... Sumatra, bred in August from larva mining leaf of Salix sp. (Dr. L. Fulmek); i ex."

Type: The above indicated male without abdomen.

Figure 2, left wings.

\section{Acroclita iridorphna Meyrick}

Plate 136 , Figures $4-4$ a

Acroclita iridorphna Meyrick, 1936, Exotic Microlepidoptera, 4: 609; Diakonoff, I950, Bull. Brit. Mus. (Nat. Hist.) Ent., I (4): 278 .

“ ‘ํ. 12-13 mm. . . . Formosa, Taihoku, October, November (Prof. S. Issiki); 2 ex."

Lectotype: The male, dated "I 7-I I-32". Slide No. 6948. For this species Diakonoff selected a "Holotype ơ" and "Allotype $q$ " but, since no type was selected by Meyrick and each specimen is of equal value, the above lectotype designation appears valid.

Figure 4, left wings; 4 a, ventral view of male genitalia with aedeagus in sitll.

\section{Acroclita ligyropis Meyrick}

See Acroclita aestuosa (Meyrick).

\section{Acroclita loxoplecta Meyrick}

Plate 136 , Figure 3

Acroclita loxoplecta Meyrick, 1935, in Caradja and Meyrick, Materialien zu einer Microlepidopteren Fauna der Chinesischen Provinzen Kiangsu, Chekiang und Hunan, 53; Diakonoff, I950, Bull. Brit. Mus. (Nat. Hist.) Ent., I (4): 279.

“... o. 13-14 mm. . . . 2 ex., Tienmushan, IV. Allied to scatebrosa Meyr. ..."

Lectotype: The male, without abdomen, in the Meyrick collection, "'Tien-Mu-Shan, China. C. $5,000^{\prime} \cdot 4 \cdot 32^{\prime \prime}$, selected by Diakonoff.

Figure 3, left wings.

\section{Acroclita macrosaris (Meyrick), new combination \\ Plate 140 , Figures $2-2 \mathrm{~b}$}

Eucosma macrosaris Meyrick, I938, in Caradja and Meyrick, Deuts. Ent. Zeit. Iris, 52: 84 . “... ô. I 7 mm. . . D Djokjakarta; I ex."

Type: The above indicated male so marked in the British Museum, "Djokjakarta, Java. HO. .36." Slide No. $733^{6}$.

Figure 2 , left wings; 2 a, lateral view of denuded abdomen to show densely scaled pockets; $2 \mathrm{~b}$, ventral view of male genitalia with aedeagus in situ. 


\section{Acroclita madens Meyrick}

Plate 137 , Figures I-IC

Acroclita madens Meyrick, I92 I, Zool. Meded., 6: I53.

Acroclita cameraria Meyrick, 1932, Exotic Microlepidoptera, 4: 22I; Diakonoff, 1950, Bull. Brit. Mus. (Nat. Hist.) Ent., I (4): 277.

"q. I2-I 4 mm. . . Java, Scneng, bred August (Dr. L. G. E. Kalshoven); 4 cx."

Lectotyfe: The female measuring $14 \mathrm{~mm}$., dated ".8.3 I", selected by Diakonoff. Slide No. 7113 .

Figure I, left wings; 1 a, ventral view of female genitalia; 1 , detail of genital plate and ostium; Ic, signa.

\section{Acroclita melanomochla Meyrick}

Plate 137 , Figure 2

Acroclita melanomochla Meyrick, I936, Exotic Microlepidoptera, 4: 24; Diakonoff, I950, Bull. Brit. Mus. (Nat. Hist.) Ent., 1 (4): 279.

“ ing in longitudinal fold in apical point of leaf of Mangifera indica (Prof. S. Issiki); 4 ex."

Lectotype: Ĵ, I 2 mm., "Heito, Formosa, S. I. bred . . 4.35", without abdomen, selected by Diakonoff.

Figure 2, left wings.

\section{Acroclita multiplex Meyrick}

Plate 137 , Figures $3^{-3}$ b

Acroclita multiplex Meyrick, 1912, Journ. Bombay Nat. Hist. Soc., 21: 860; Diakonoff, I950, Bull. Brit. Mus. (Nat. Hist.) Ent., I (4): 279.

".+ I $4-16 \mathrm{~mm}$. ... Patipola and Ohiya, Ceylon (Pole, Green); in April and November, two specimens. Superficially extremcly like Eucosma crenmitis. . . ."

Lectotype: The female, "Ohiya, Ceylon. EEG. .r I.o7", selected by Diakonoff. Slide No. 6953 .

Figure 3 , lcft wings; $3 \mathrm{a}$, ventral view of female genitalia; $3 \mathrm{~b}$, detail of genital plate and ostium.

\section{Acroclita neaera Meyrick}

Plate 137 , Figures $4-4 a$

Acroclito neaera Meyrick, I912, Journ. Bombay Nat. Hist. Soc., 21:859; Diakonoff, I950, Bull. Brit. Mus. (Nat. Hist.) Ent., I (4): 280.

" $f_{f}$. I a $^{-1} 3 \mathrm{~mm}$. . . Maskeliya, Ceylon (Pole); in May and June, two specimens."

Lectotype: The male datcd ".6.04". Slide No. 6934. Diakonoff cited a "I Iolotype" male and "Allotype" femalc, but the two original specimens have equal status and the designation of a lectotype is mandatory.

Figure 4, left wings; 4 a, ventral view of male genitalia with aedeagus in situ. 


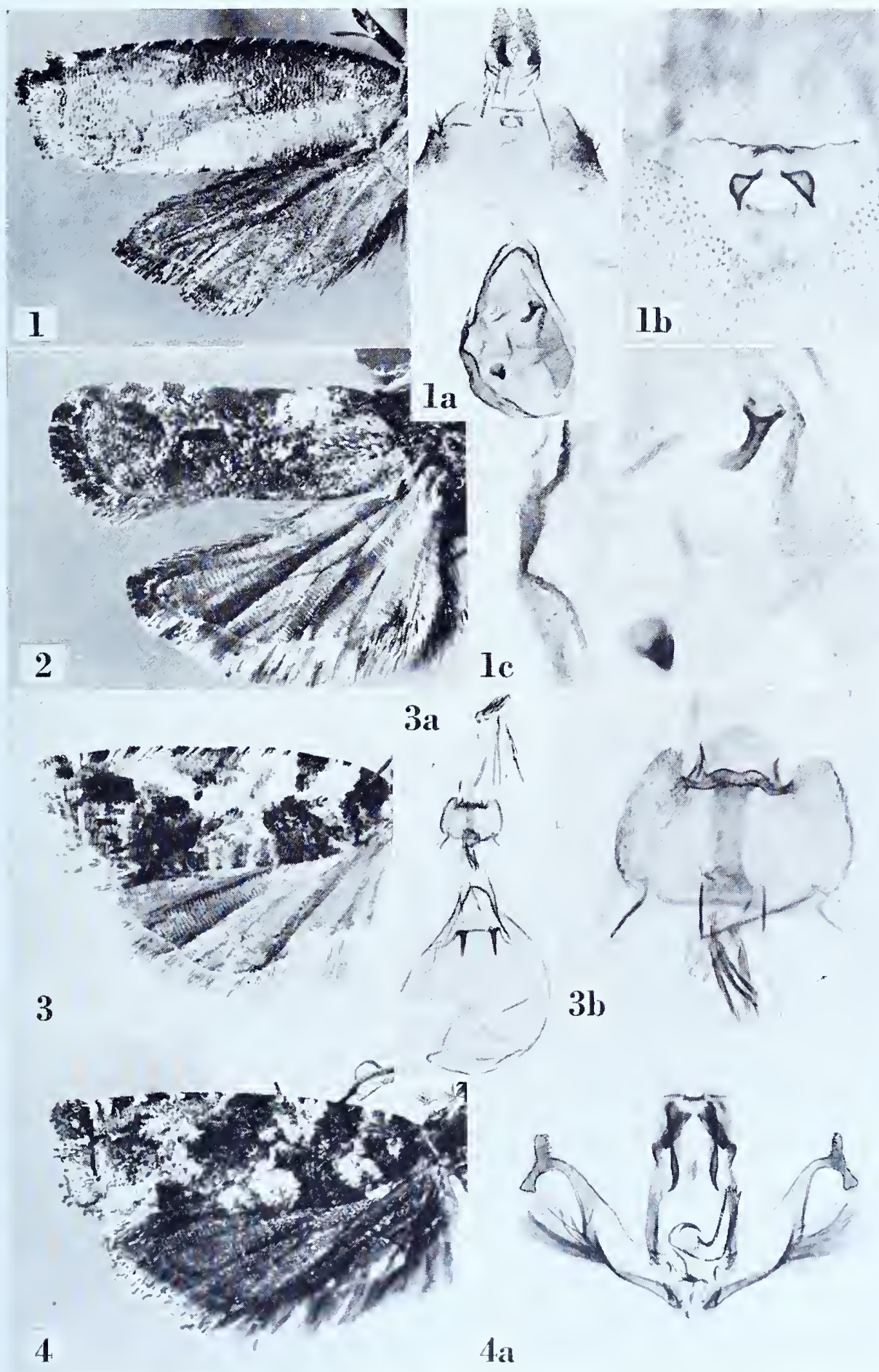




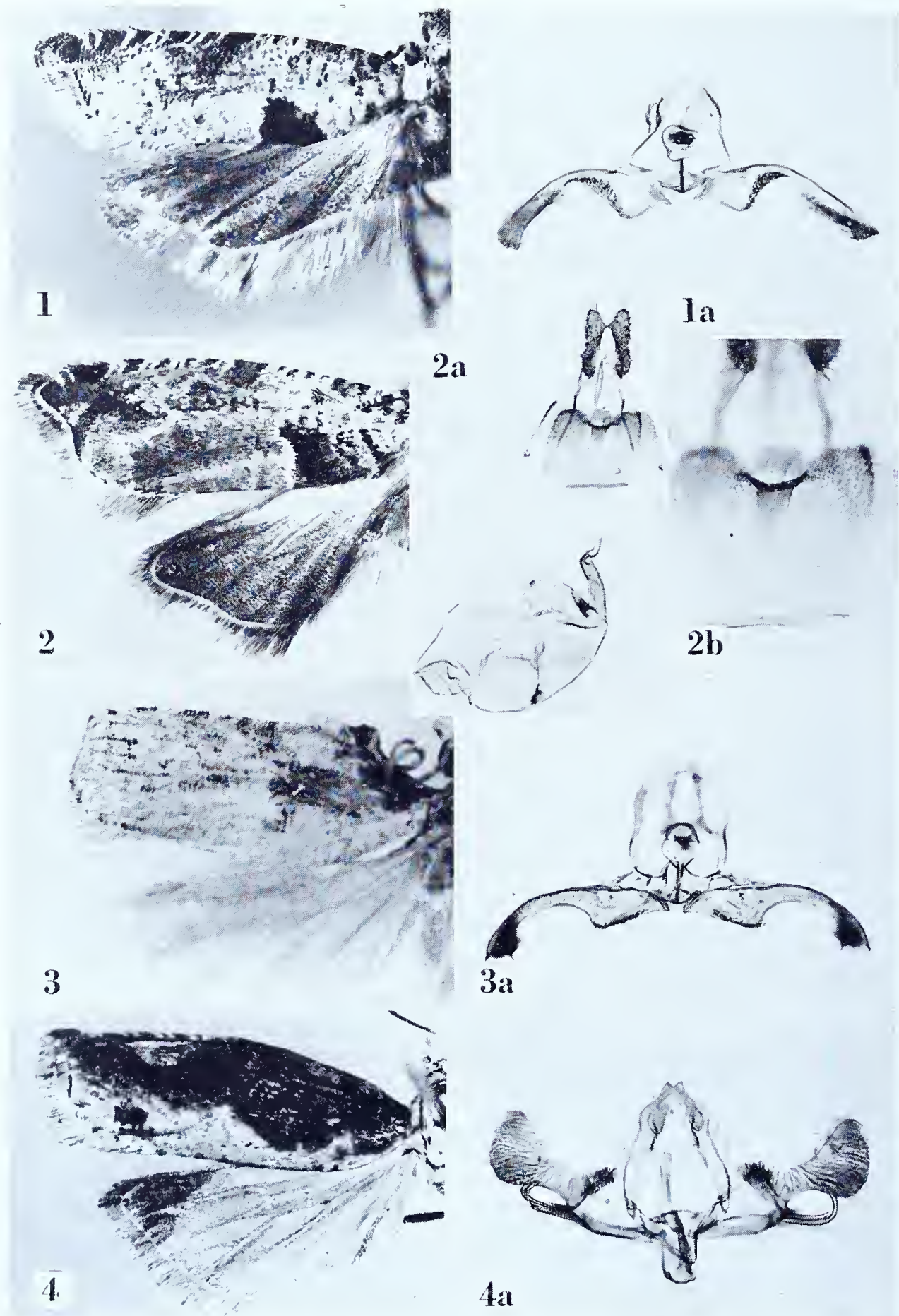




\section{Acroclita notophthalma Meyrick}

Plate I 38 , Figures I-I a

Acroclita notophthalma Meyrick, I933, Exotic Microlepidoptera, 4:417: Diakonoff, I950, Bull. Brit. Mus. (Nat. Hist.) Ent., I (4): 280.

“ "숭. I I-I 2 mm. . . India, U.P., Dehra Dun, bred November from larvae feeding on leaves of Casearia tomentosa (Flacourtiaceae) (Indian Forest Entomologist); 5 ex."

Lectotype: A male measuring I I mm., dated "I I.32". Slide No. 6944. Diakonoff selected a specimen dated "I.36" which cannot be one of the original specimens.

Figure I, left wings; ra, ventral view of male genitalia with aedeagus in sitn. The harpes are turned towards the observer and, therefore, the cucullus appears narrower than is actually the case.

\section{Acroclita paulina Meyrick}

Plate 138 , Figures $2-2 \mathrm{~b}$

Acroclita paulina Meyrick, 1925, Exotic Microlepidoptera, 3: I40.

"ㅇ. I $8 \mathrm{~mm}$. ... Kumaon, Muktesar, 7,000 feet, April (Fletcher); I ex."

Type: The female indicated above dated “.4.23". Slide No. 6955.

Figure 2, left wings; $2 \mathrm{a}$, ventral view of female genitalia; $2 \mathrm{~b}$, detail of genital plate and ostium.

\section{Acroclita physalodes (Meyrick)}

Plate I $_{3} 8$, Figures $3-3$ a

Rhopobota plysalodes Meyrick, I910, Trans. Ent. Soc. London, I910: 368.

Acroclita physalodes (Meyrick), Diakonoff, I950, Bull. Brit. Mus. (Nat. Hist.) Ent., I (4): 280.

" 꿍. I $3^{-14} \mathrm{~mm}$. . . Chagos Islands, I. du Coin, in June, two specimens; also one from Galle, in April (Fletcher)."

Lectotype: A male measuring I 3 mm., "I. du Coin, Chagos Is. TBF. 25.6.05", selected by Diakonoff. Slide No. 7 I I4.

Figure 3 , left wings; $3^{\mathrm{a}}$, ventral view of male genitalia with aedeagus in situ.

\section{Acroclita pythonias (Meyrick)}

\section{Plate 138 , Figures $4-4$ a}

Rhopobota pythonias Meyrick, I910, Trans. Ent. Soc. London, I910: 434.

Acroclita pythonias (Meyrick), Diakonoff, I950, Bull. Brit. Mus. (Nat. Hist.) Ent., I (4): 280.

" $\hat{~}$. I $7 \mathrm{~mm}$. . . Java, Bandong; one specimen."

Type: The male indicated above, "Bandong, Java. R. .o7." Slide No. 6943.

Figure 4 , left wings; 4 a, ventral view of male genitalia with aedeagus in sitn. 


\section{Acroclita scatebrosa (Meyrick)}

Plate I39, Figures I-IC

Ancylis scatebrosa Meyrick, I9 I2, Journ. Bombay Nat. Hist. Soc., 2 I : 86 I.

Acroclita scatebrosa (Meyrick), Diakonoff, I950, Bull. Brit. Mus. (Nat. Hist.) Ent., I (4): 280.

"q. I $3^{-I} 4 \mathrm{~mm}$. . . Khasis; in June, two specimens."

Lectotype: The female measuring I 3 mm., selected by Diakonoff. Slide No. 6956. Both specimens are labelled, "Khasi Hills, Assam. .6. Igo6".

Figure I, left wings; $\mathrm{ra}$, ventral view of female genitalia; $\mathrm{r} b$, detail of genital plate and ostium; ic, signa.

\section{Acroclita scleropa Meyrick}

Plate 139 , Figures 2-2a

Acroclita scleropa Meyrick, i 9 I 2, Journ. Bombay Nat. Hist. Soc., 2 I : 857; Diakonoff, I 950, Bull. Brit. Mus. (Nat. Hist.) Ent., I (4): 280.

" $\hat{o}+$. I 5-i6 mm. . . . Namunakuli, Patipola, and Maskeliya, Ceylon (Green, Pole, Alston); from January to April, five specimens."

Lectotype: A male measuring i 5 mm., "Namunakuli, Ceylon. EEG. .2.ro", selected by Diakonoff. Slide No. 6932. One specimen is nissing.

Figure 2, left wings; 2a, ventral view of male genitalia with aedeagus in sitn.

\section{Acroclita spiladorma Meyrick}

Plate 139 , Figures $3^{-} 3^{\mathrm{c}}$

Acroclita spiladoma Meyrick, I932, Exotic Microlepidoptera, 4:22 I .

“o. I+ mm. . . . Java, teak-forest, bred December (Dr. L. G. E. Kalshozen); I ex. Allied to scleropa."

Type: "The above indicated female, "Java. LGK. bred .r 2.30." Slide No. 8534 .

Figure 3, right wings (image reversed); $3 \mathrm{a}$, ventral view of female genitalia; $3 \mathrm{~b}$, detail of genital plate and ostium; 3 , signa.

\section{Acroclita spilocausta Meyrick}

Plate I 39, Figures 4-4a

Actoclita spilocausta Meyrick, 1934, Exotic Microlepidoptera, 4: 484; Diakonoff, 1950, Bull. Brit. Mus. (Nat. Hist.) Ent., I (4): 280.

" $\hat{o}$. Io $\mathrm{mm}$. . . Java, "Telawa, bred March from larvae feeding on leaves of Buchanania florida (Anacardiaceae) (Dr. L. G. E. Kalshoven). Allied to naevana."

Type: The above indicated male dated ".3.33". Slide No. 67 to.

F'igure 4 , left wings; 4 a, ventral view of male genitalia with aedeagus in sitn. 

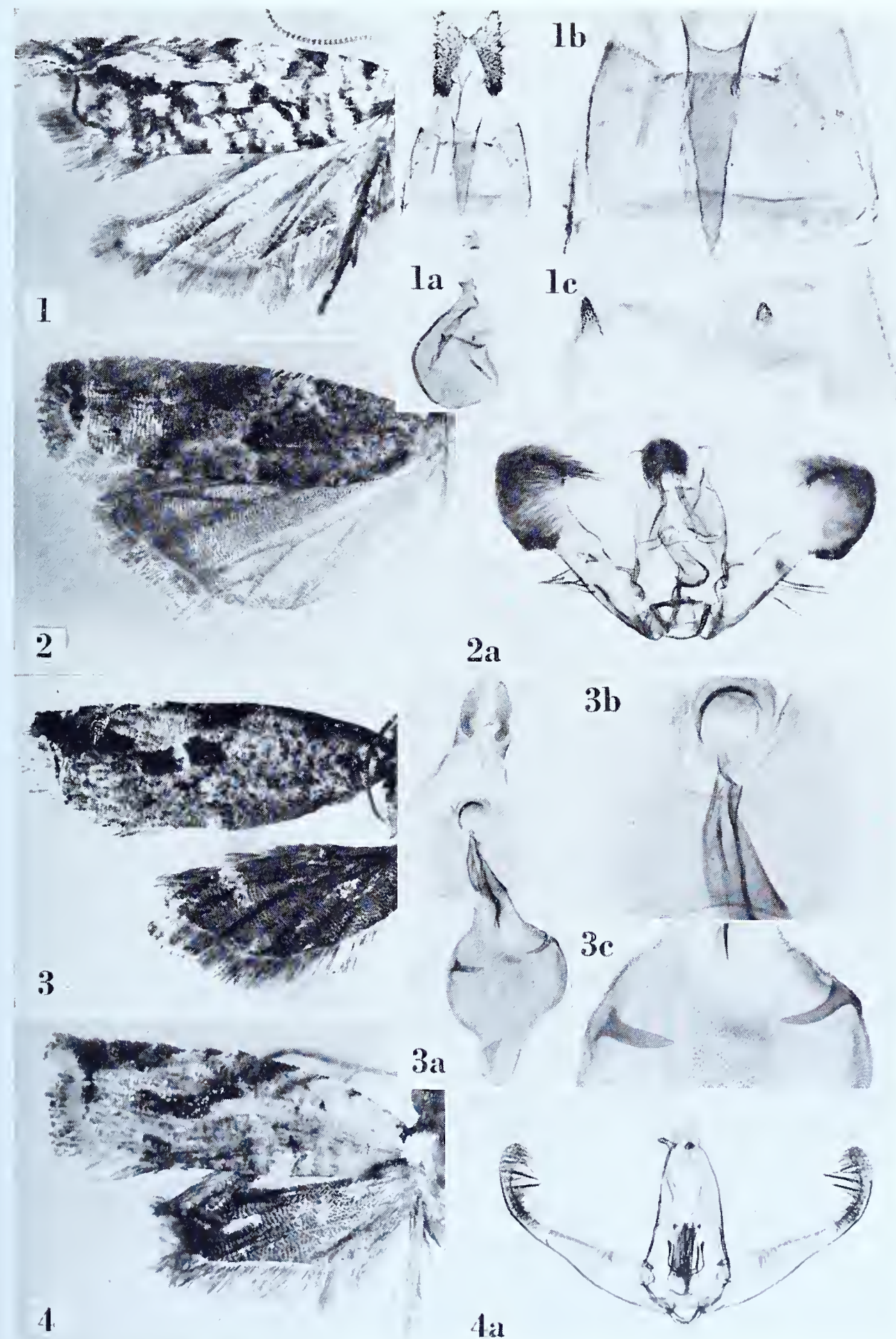


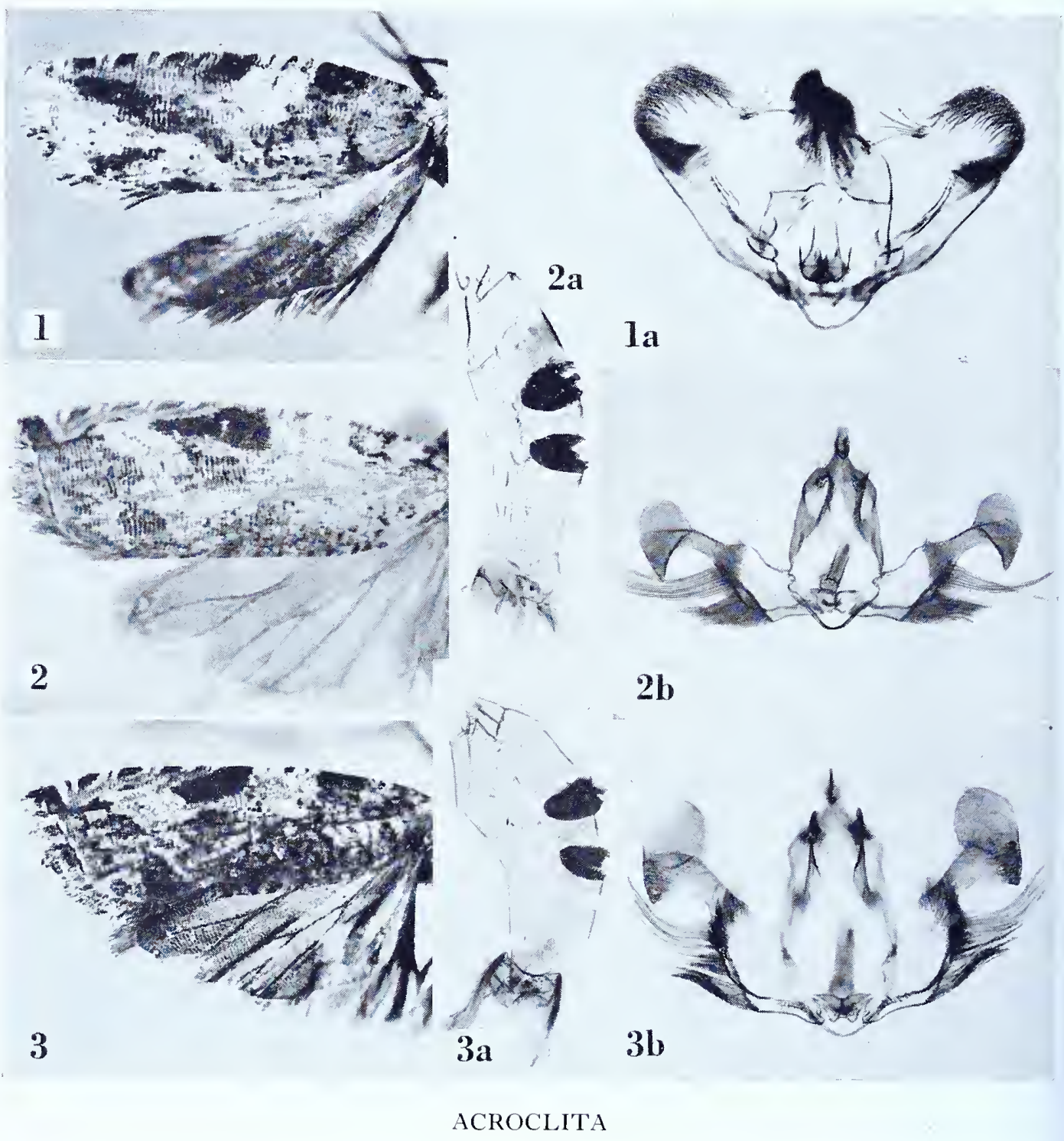




\title{
Acroclita symbolias Meyrick
}

\author{
Plate I40, Figures I-Ia
}

Acroclita symbolias Meyrick, I9ı2, Journ. Bombay Nat. Hist. Soc., 21 : 857; Diakonoff, I 950, Bull. Brit. Mus. (Nat. Hist.) Ent., I (4): 280.

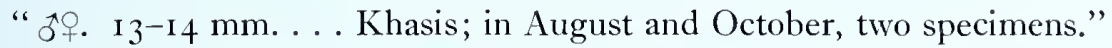

Lectotype: The male, "Khasi Hills, Assam. .ro.1906", selected by Diakonoff. Slide No. 6937 .

Figure I, left wings; Ia, ventral view of male genitalia with aedeagus in sitn.

\section{Acroclita thysanota Meyrick}

Plate 140 , Figures $3-3 \mathrm{~b}$

Acroclita thysanota Meyrick, I912, Journ. Bombay Nat. Hist. Soc., 2 I: 860; Diakonoff, I950, Bull. Brit. Mus. (Nat. Hist.) Ent., I (4):280.

" o. 1 5-16 mm. ... Khasis; in November, two specimens."

Lectotype: The smaller of the two males, "Khasi Hills, Assam. . i I. go6", selected by Diakonoff. Slide No. 6954 .

Figure 3 , left wings; $3^{\text {a }}$, lateral aspect of denuded abdomen to show densely scaled pockets; 3 b, ventral view of male genitalia with aedeagus in situ.

Continued from p. 268.

Lectotype: The male, "Pusa, Bengal. NML. bred .4.07." Both specimens lack the abdomen and the female retains only the left pair of wings. Male genitalia figured from a specimen from "Dehra Dun, India. RNM. bred .4.32." Slide No. 6952. Diakonoff selected the male as "Holotype" and the female as "Allotype", but since no designation was given by Meyrick both specimens have equal value. The male, then, becomes "lectotype" as designated above.

Figure 4, left wings; 4 a, ventral view of male genitalia with aedeagus in sitn. 


\section{Acroclita trachynota Meyrick}

Plate 14I, Figures I-Ib

Acroclita trachynota Meyrick, 1926, Sarawak Mus. Journ., 3: 150; Diakonoff, I950, Bull. Brit. Mus. (Nat. Hist.) Ent., I (4): 280.

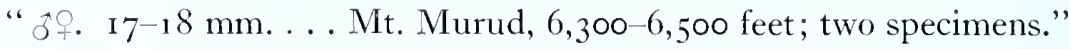

Lectotype:, i 7 mm., "Mt. Murud, Borneo, 6,500', 3.1 I.22." Slide No. 912 г. 'The male is missing. Diakonoff designated a "Holotype", but the original series consisted of two specimens of equal taxonomic value. The lectotype designation, therefore, stands.

Figure I, left wings; ra, ventral view of female genitalia; rb, detail of ostium.

\section{Acroclita trimelaena Meyrick \\ Plate I4I, Figures 2-2a}

Acroclita trimelaena Meyrick, 1922, Exotic Microlepidoptera, 2: $52 \mathrm{I}$.

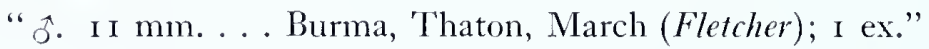

Type: The male indicated above dated ".3.1 8". Slide No. 6949.

Figure 2, left wings; $2 \mathrm{a}$, ventral view of male genitalia with aedeagus in situ.

\section{Acroclita vigescens Meyrick}

Plate 14 I, Figures $3-3 \mathrm{~b}$

Acroclita vigescens Meyrick, 1920, Exotic Microlepidoptera, 2: 343; Diakonoff, I950, Bull. Brit. Mus. (Nat. Hist.) Ent., I (4): 280.

“ fo. 8-I I mm. ... Bengal. Pusa, bred from larvae on Cordia latifolia and C. myxa, March, April (Fletcher); Bombay, Sarat, May (Maxwell); 4 ex."

Lectotype: A female, "Surat, Bardoli. RM. bred. .5.19", selected by Diakonoff. Slide No. 6946.

Figure 3 , left wings; 3 a, ventral view of female genitalia; 3 b, detail of genital plate and ostium. There is a single, small signum.

\section{Acroclita vulturina Meyrick}

See Acroclita grypodes Meyrick. 


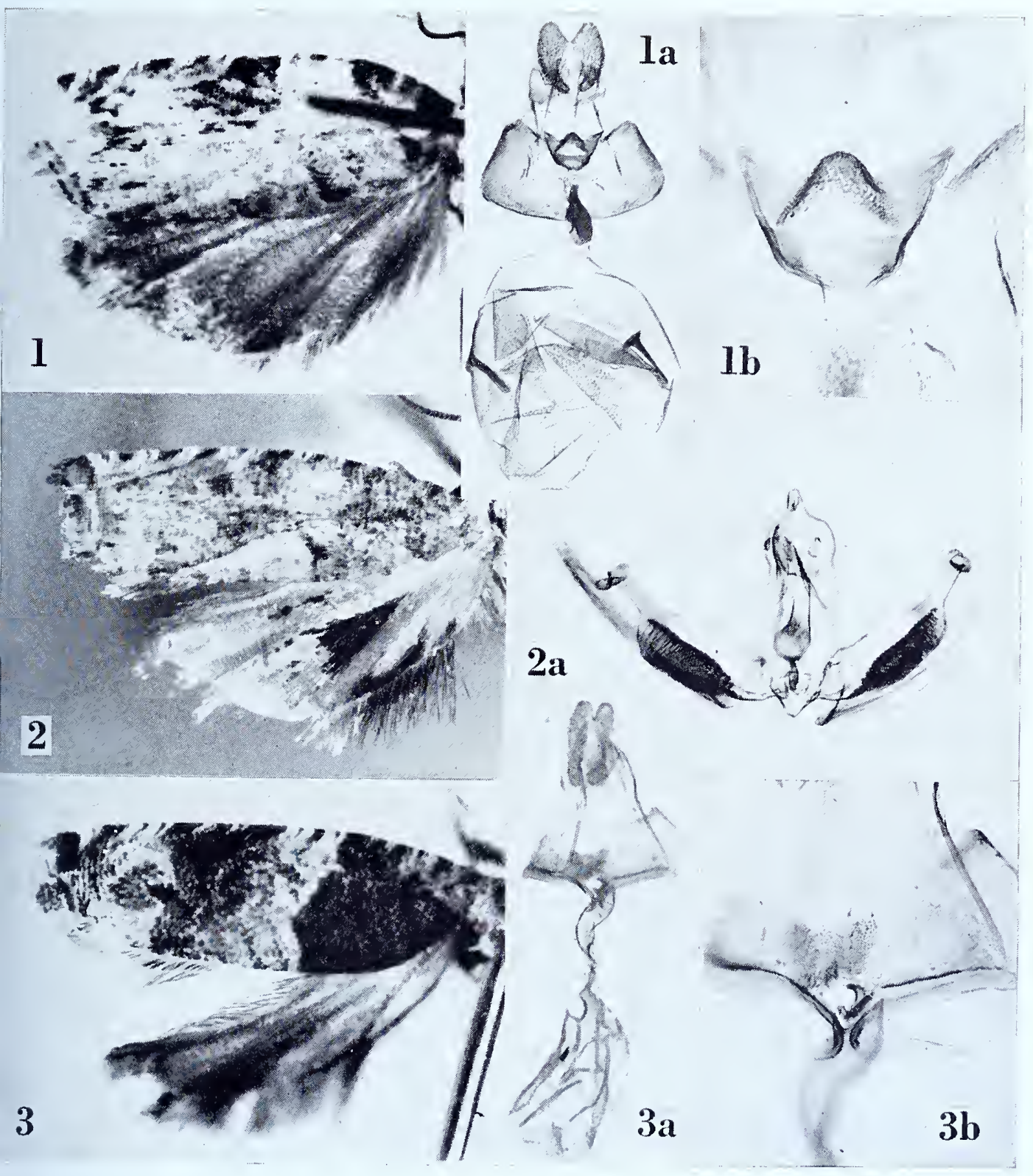

ACROCLITA 

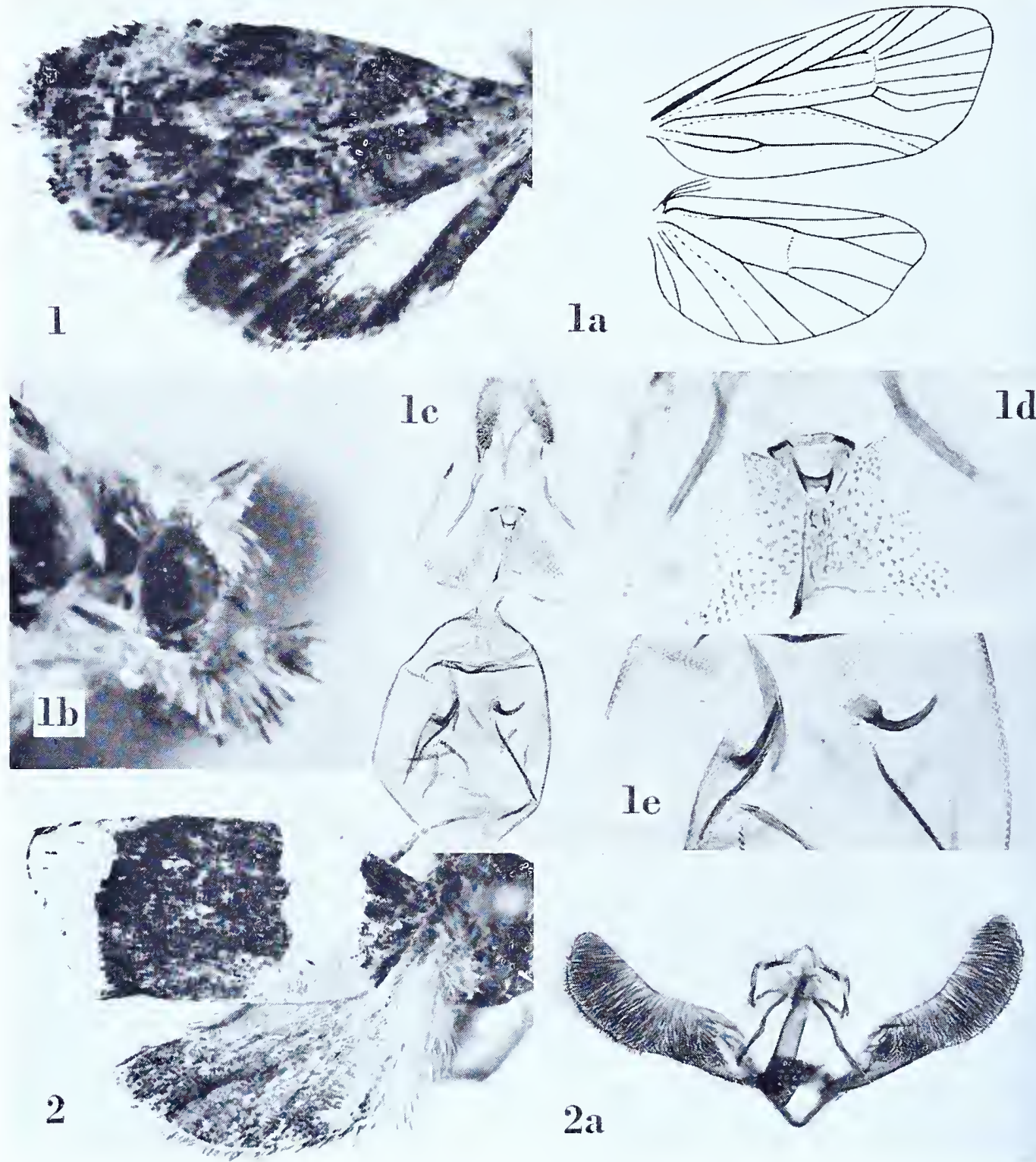

AGRIOPHANES and ANATHAMNA 


\section{AGRIOPHANES Meyrick}

Agriophanes Meyrick, 1930, Exotic Microlepidoptera, 3: 600. (Typus generis: Agriophanes pycnostrota Meyrick, ibid. [monotypy].)

\section{Agriophanes pycnostrota Meyrick \\ Plate I42, Figures I-Ie}

Agriophanes pycnostrota Meyrick, 1930, Exotic Microlepidoptera, 3:600.

"ㅇ․ 10 mm. . . Madras, Kodaikanal, 7,00o feet, September (Fletcher); I ex."

Type: The female indicated above, "Kodaikanal, India. 'TBF. 7,000' .9.29." Slide No. 7290.

Figure $\mathrm{I}$, left wings; Ia, venation of right wings; $\mathrm{ib}$, lateral aspect of head to show palpus; Ic, ventral view of female genitalia; Id, detail of genital plate and ostium; Ie, signa.

\section{ANATHAMNA Meyrick}

\section{Anathamna megalozona Meyrick}

Plate 142 , Figures 2-2a

Anathamna megalozona Meyrick, I916, Exotic Microlepidoptera, I: ${ }_{5}^{62 .}$

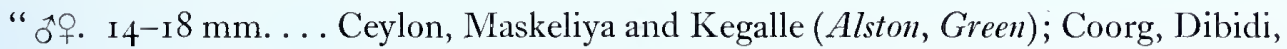
3,500 feet (Newcome), Pallibetta (Fletcher); in February, March, May, August and September, eight specimens."

Lectotype: A male measuring I4 mm., "Maskeliya, Ceylon. Alston. .9.o6.” Slide No. 7167 .

Figure 2, left wings; 2a, ventral view of male genitalia with aedeagus in situ.

Continued from $p .272$.

Figure 4 , left wings; 4 a, ventral view of male genitalia with aedeagus in situ. [vulturina]

“ㅇ. I 5-17 mm. . . J Java, Mt. Gedé, bred December from an unnamed plant (Dr. L. G. Kalshoven); 2 ex. Allied to grypodes from Ceylon."

Lectotype: The female measuring $17 \mathrm{~mm}$., dated "I2.33", selected by Diakonoff. Slide No. 6945. The second specimen is missing.

Figure I, left wings; Ia, ventral view of female genitalia; $r b$, detail of genital plate and ostium. 


\section{ANCYLIS Hübner \\ Ancylis ancorata Meyrick}

Plate I43, Figures I-Ib

Ancylis ancorata Meyrick, I912, Journ. Bombay Nat. Hist. Soc., 21 : 862; Diakonoff, I950, Bull. Brit. Mus. (Nat. Hist.) Ent., I (4): 28I.

"ㅇ. I2-I3 mm. . . Kegalle, Ceylon (Alston), Konkan (Young); three specimens."

Lectotype: A female measuring I 2 mm., "Kegalle, Ceylon. CCA. .o9", selected by Diakonoff. Slide No. $695^{8}$.

Figure I, left wings; Ia, ventral view of female genitalia; $\mathbf{b}$, detail of genital plate and ostium.

\section{Ancylis anthracaspis Meyrick}

Plate 143 , Figures $2-2 \mathrm{a}$

Ancylis anthracaspis Meyrick, I93I, in Caradja, Bull. Sect. sci. Acad. roum., I4: 64; Diakonoff, I950, Bull. Brit. Mus. (Nat. Hist.) Ent., I (4): 28 I.

" o. I $2-13$ mm. ...2 ex. August. Recalls derasana, but probably nearest siculana."

Lectotype: The larger of the two males, "Kwanhsien, China, F. .8.30." Slide No. 7111 . The specimen selected by Diakonoff cannot be one of the original specimens since he cites the date of ".7.28".

Figure 2, left wings; $2 \mathrm{a}$, ventral view of male genitalia with aedeagus in situ.

\section{Ancylis aromatias Meyrick}

Plate 143 , Figures $3^{-} 3^{a} ; 4^{-} 4^{b}$

Ancylis aromatias Meyrick, I9I2, Exotic Microlepidoptera, I: 3I ; Diakonoff, I950, Bull. Brit. Mus. (Nat. Hist.) Ent., I (4):28I.

Aucylis cyanostoma Meyrick, i916, Exotic Microlepidoptera, 2: i6 (new synonymy).

\section{[aromatias]}

“ (Newcome); two specimens."

Lectotype: The male dated ".i I.I 1.06". Slide No. 6975.

Figure 3 , left wings; 3 a, ventral view of male genitalia with aedeagus in situ.

[cyanostoma]

" . $15 \mathrm{~mm}$. . . . Bengal, Pusa, bred in January from larvae feeding in spun leaves of $Z i z y p h u s$ jujuba (Fletcher). The peculiarly coloured palpi are a special characteristic."

Lectotype: One of the above indicated females both of which are dated "3 I.I.I6", selected by Diakonoff.

Figure 4 , left wings; $4 \mathrm{a}$, ventral view of female genitalia; $4 \mathrm{~b}$, detail of genital plate and ostium. 


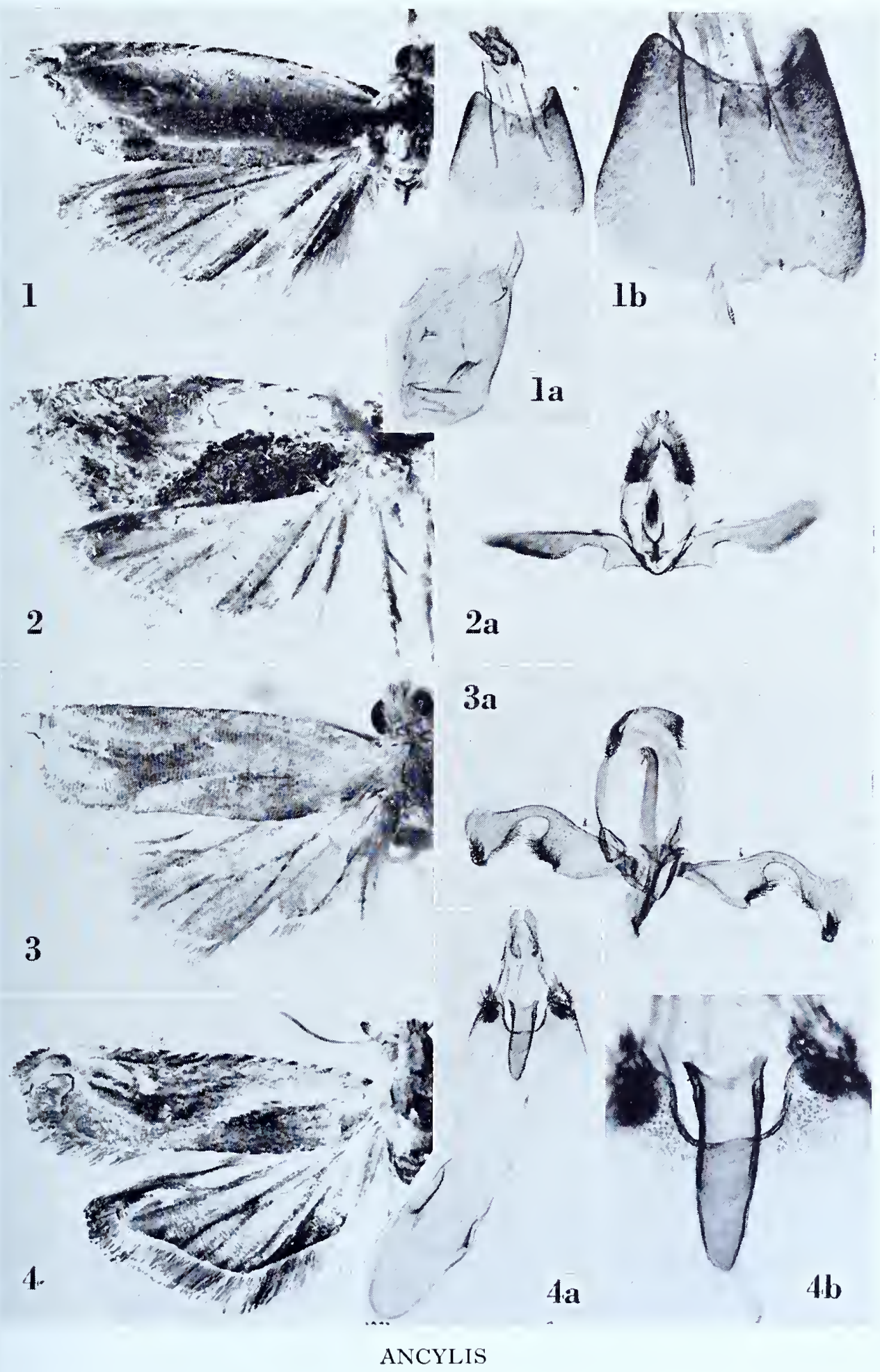



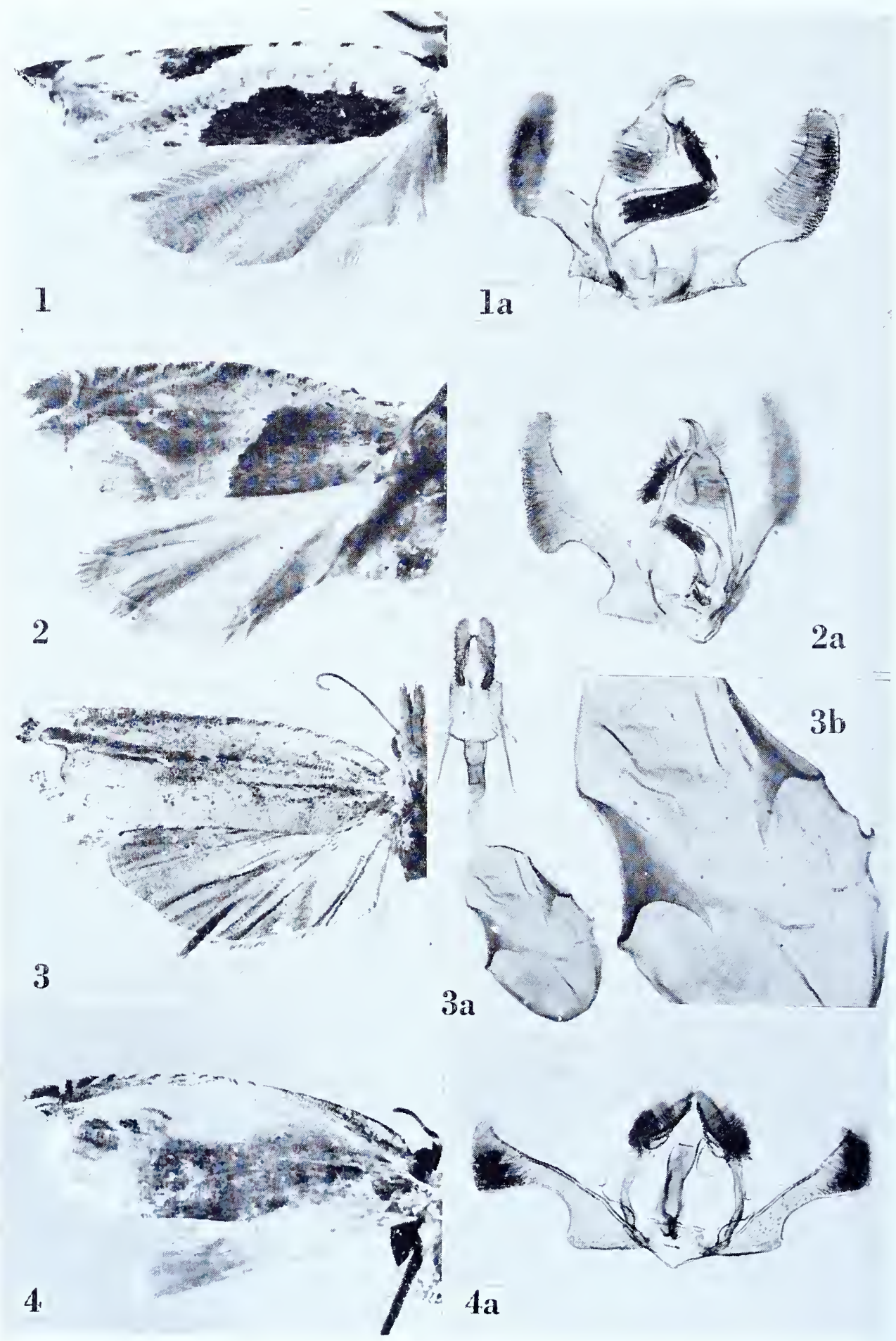

$4 a$ 


\section{Ancylis celerata (Meyrick)}

\section{Plate I44, Figures I-Ia}

Eucosma celerata Meyrick, I9ı2, Journ. Bombay Nat. Hist. Soc., 2 I : 863; Diakonoff, Bulı. Brit. Mus. (Nat. Hist.) Ent., I (4): 28I.

"s. 9-ro mm. ... N. Coorg, 3,500 feet (Newcome); in May and December, three specimens."

Lectotype: A male measuring Io mm., "Dibidi, N. Coorg. Newcome. Io.I2.06", selected by Diakonoff. Slide No. 6983 .

Figure I, left wings; ra, ventral view of male genitalia with aedeagus in situ.

\section{Ancylis comptana (Fröhlich)}

Plate 144, Figures 2-2a

Tortrix comptana Fröhlich, I 828, Enumer. Tort. Wurt., 99.

Ancylis sculpta Meyrick, 1912, Exotic Microlepidoptera, I: 33; Diakonoff, 1950, Bull. Brit. Mus. (Nat. Hist.) Ent., I (4): 282.

\section{[sculpta]}

" ${ }^{*} .12 \mathrm{~mm}$. ... Korea, Port Hamilton, in April (Fletcher); one specimen."

Type: The male indicated above and dated " ${ }_{5}$ 5.4.99". Slide No. 6977.

Figure 2, left wings; 2 a, ventral view of male genitalia with aedeagus in situ.

\section{Ancylis cyanostoma Meyrick}

See Ancylis aromatias Meyrick.

\section{Ancylis glycyphaga Meyrick \\ Plate 144 , Figures $3^{-} 3^{b}$}

Ancylis glycyphaga Meyrick, I9ı2, Exotic Microlepidoptera, I: 32; Diakonoff, Bull. Brit. Mus. (Nat. Hist.) Ent., I (4): $28 \mathrm{r}$.

"ㅇ․ $\quad$ I $5^{-1} 8 \mathrm{~mm} . .$. Bengal, Pusa; Assam, Khasis; in January, four specimens."

Lectotype: The female measuring i 8 mm., "Pusa, Bengal, TBF. .r 3.I.ro", selected by Diakonoff. Slide No. 6976 .

Figure 3 , left wings; $3 \mathrm{a}$, ventral view of female genitalia; $3 \mathrm{~b}$, signa.

\section{Ancylis hemicatharta Meyrick}

Plate 144, Figures 4-4a

Ancylis hemicatharta Meyrick, 1935, in Caradja and Meyrick, Materialien zu einer Microlepidopteren Fauna der Chinesischen Provinzen Kiangsu, Chekiang und Hunan, 54. “... o. $16 \mathrm{~mm}$. ... I ex., Tienmushan, VI. Allied to lactana."

Type: The above indicated male dated ".6.32”. Slide No. 7108.

Figure 4 , left wings; 4 a, ventral view of male genitalia with aedeagus in situ. 


\section{Ancylis hylaea Meyrick}

Plate I 45, Figures I-Ia

Ancylis lyylaea Meyrick, I912, Exotic Microlepidoptera, I : 31 ; Diakonoff, I950, Bull. Brit. Mus. (Nat. Hist.) Ent., I (4): $28 \mathrm{I}$. " 3 ㅇ. I I -14 mm. ... Assam, Khasis, in October and November; five specimens."

Lectotype: A male measuring I3 mm., dated ".ir.I907", selected by Diakonoff. Slide No. 6974 .

Figure I, left forewing; Ia, ventral view of male genitalia with aedeagus in situ.

\section{Ancylis lutescens Meyrick}

Plate I45, Figures 2-2a

Ancylis lutescens Meyrick, I912, Exotic Microlepidoptera, I: 32; Diakonof, Bull. Brit. Mus. (Nat. Hist.) Ent., I (4):28I.

“ fo․ $^{\circ}$ I 4-I 5 mm. . . Bengal, Pusa, in March, April, July, and October (Fletcher); five specimens."

Lectotype: The male dated ".19.10.07", without abdomen, selected by Diakonoff. Genitalia figured from one of the original specimens dated "20.10.07". Slide No. 6973.

Figure 2, left wings; 2a, ventral view of male genitalia with aedeagus in situ.

\section{Ancylis microphthora Meyrick}

Plate 145 , Figures $3-3 \mathrm{c}$

Ancylis microphthora Meyrick, 1936, Exotic Microlepidoptera, 4: 609; Diakonoff, Bull. Brit. Mus. (Nat. Hist.) Ent., I (4): 282.

" 구․ i I-I2 mm. . . Java, Telawa, bred April from larvae feeding on leaves of Schefflera (?) (Araliaceae) (Dr. L. G. Kalshoven); 5 ex."

Lectotype: A female measuring i 2 mm., selected by Diakonoff. Slide No. 7 I 2.

Figure 3 , left wings; 3 a, ventral view of female genitalia; $3^{b}$, detail of ostium; 3c, signunı. 


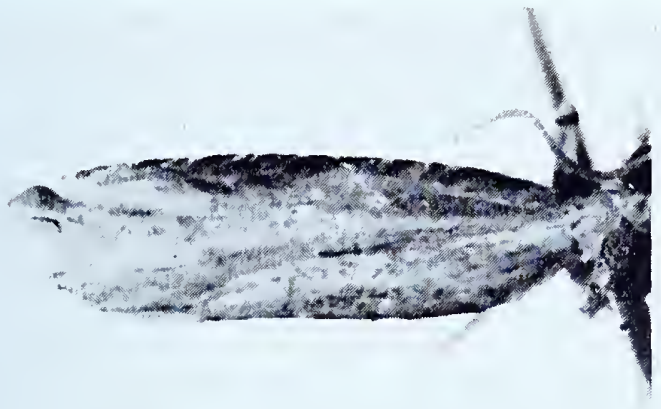

1

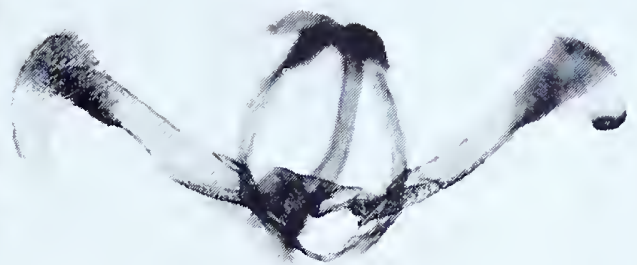

$1 a$
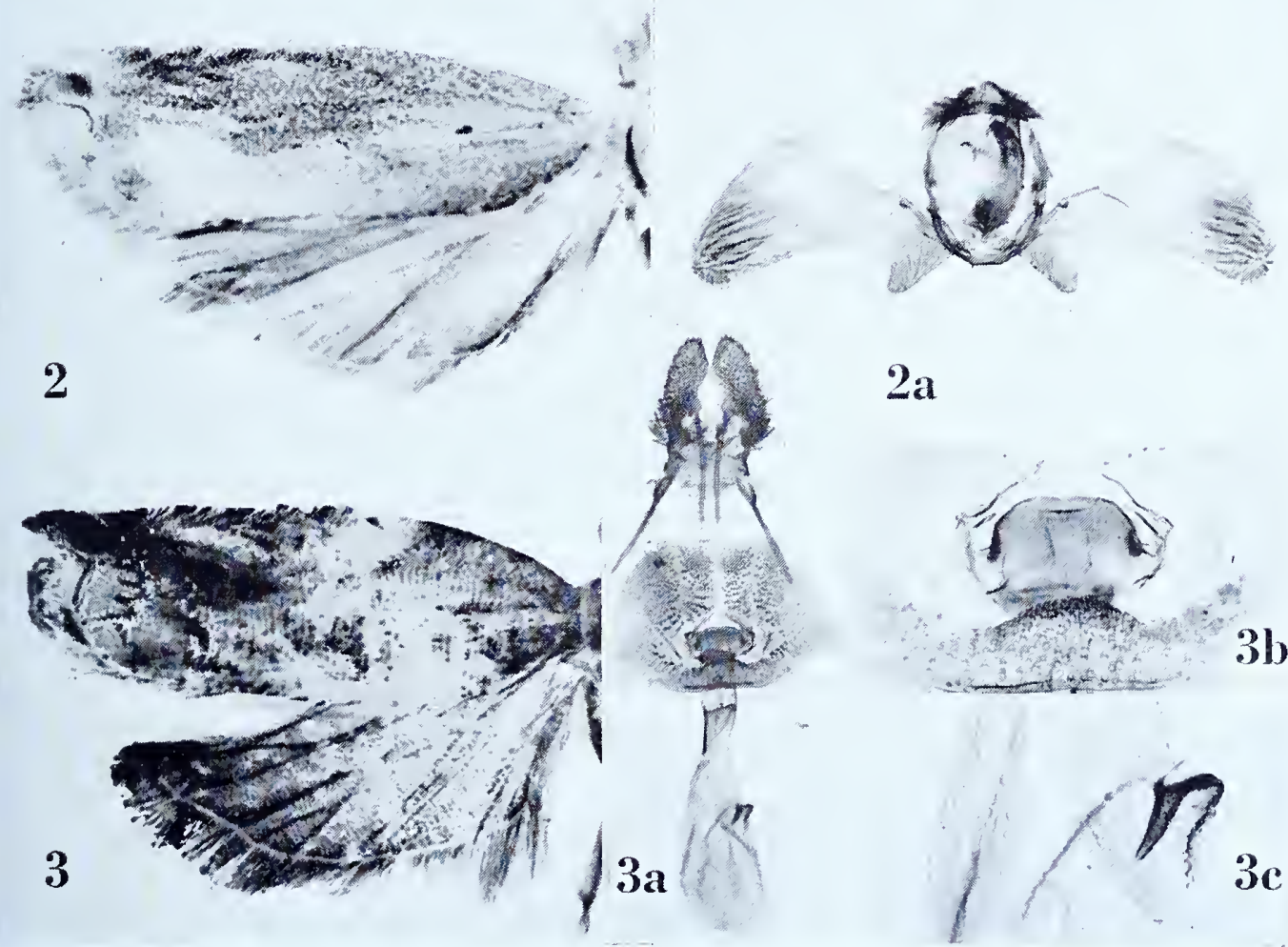

ANCYLIS 

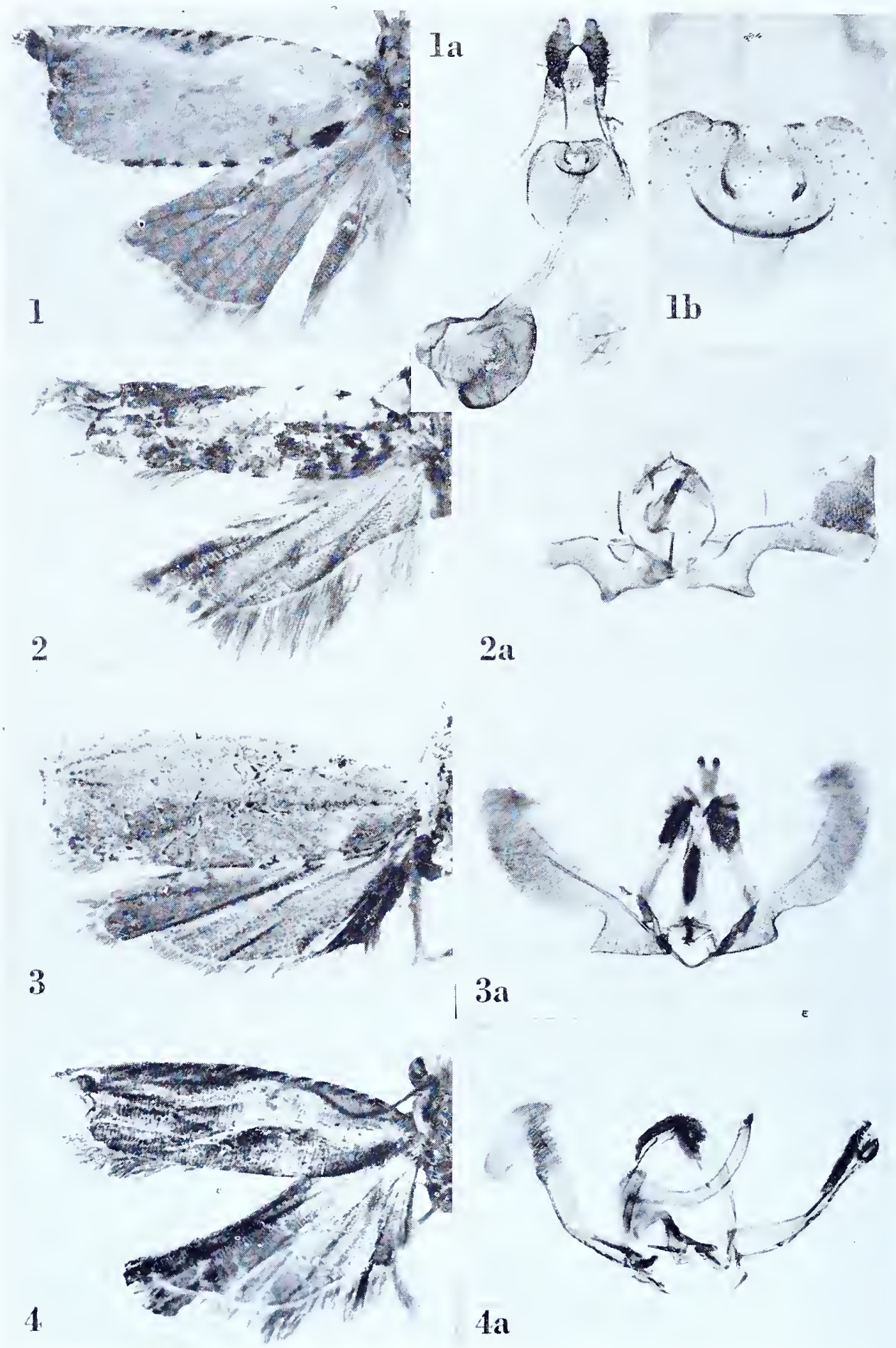

$3 a$

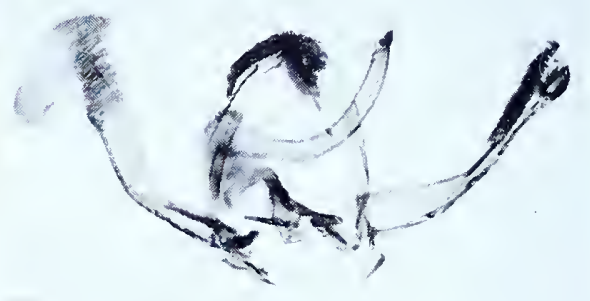

$4 a$ 


\section{Ancylis rhacodyta Meyrick}

Plate 146 , Figures $\mathrm{I}-\mathrm{I} b$

Ancylis rhacodyta Meyrick, 1938, Trans. R. Ent. Soc. London, 87: 5 Io.

"q. I7-19 mm. ... Mt. Tafa, 8, 500 feet, March; 2 ex."

Type: The female so marked in the British Museum, "Mt. Tafa, Papua, 8,500 ft. iii-1934. L. E. Cheesman." Slide No. 7033.

Figure I, left wings; Ia, ventral view of female genitalia; Ib, detail of ostium.

\section{Ancylis rostrifera Meyrick}

Plate i 46, Figures 2-2a

Ancylis rostrifera Meyrick, I912, Journ. Bombay Nat. Hist. Soc., 2 I: 862; Diakonoff, I950, Bull. Brit. Mus. (Nat. Hist.) Ent., I (4): 282.

" 0 . I I-I 2 mm. . . Maskeliya, Ceylon (Pole); in October, two specimens."

Lectotype: The male measuring I 2 mm., selected by Diakonoff. Slide No. 6982. Diakonoff's date of "I.06" is obviously a printing error since both specimens are dated ". 10.06 ".

Figure 2, left wings; 2a, dorsal view of male genitalia with aedeagus in sitn (right harpe damaged).

\section{Ancylis sculpta Meyrick}

See Ancylis comptana (Fröhlich).

\section{Ancylis thalera Meyrick}

Plate 146 , Figures $3-3$ a

Ancylis thalera Meyrick, I907, Journ. Bombay Nat. Hist. Soc., I8: I42; Diakonoff, I950, Bull. Brit. Mus. (Nat. Hist.) Ent., I (4): 282.

" ${ }^{1}+$ I $^{-1} 3^{-1} \mathrm{~mm}$. . . Khasi Hills, from June to August; twenty specimens. . .."

Lectotype: A male measuring I 3 mm., dated “.6.1906”, selected by Diakonoff. Slide No. 6961. Eight of the original specimens are missing.

Figure 3 , left wings; 3 a, ventral view of male genitalia with aedeagus in situ.

\section{Ancylis tumida Meyrick}

Plate 146 , Figures $4^{-4 a}$

Ancylis tımida Meyrick, I912, Exotic Microlepidoptera, I: 30.

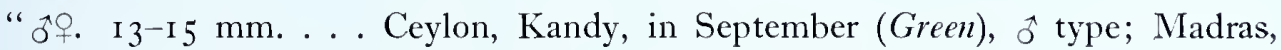
N. Coorg, 3,500 feet, in August (Newcome); two specimens."

Type: The male designated by Meyrick, "Kandy, Ceylon. Green. .9.07." Slide No. 6960.

Figure 4, left wings; $4 \mathrm{a}$, ventral view of male genitalia with aedeagus in situ. 


\section{AN'TICHLIDAS Meyrick}

Antichlidas Meyrick, I931, Bull. Sect. sci. Acad. roum., I4: 65. (Typns generis: Antichlidas holocinista Meyrick, l.c., 66 [monotypy].)

\section{Antichlidas holocnista Meyrick}

Plate I 47, Figures I-Id

Antichlidas holocnista Meyrick, I93 I, Bull. Sect. sci. Acad. roum., I4: 66; Diakonoff, I 95 , Bull. Brit. Mus. (Nat. Hist.) Ent., I (4): 282.

"ㅇ. $17-20 \mathrm{~mm} . . .4$ ex. July, August."

Lectotype: A male, "Kwanhsien, China. F. .7.28", selected by Diakonoff. Slide No. 7 I Iо. Meyrick recorded only females, but one, the lectotype, is a male.

Figure I, left wings; Ia, venation of right wings; $\mathrm{Ib}$, lateral aspect of head to show palpus; Ic, modified terminal abdominal segments; id, lateral aspect of male genitalia with aedeagus in sitn. 

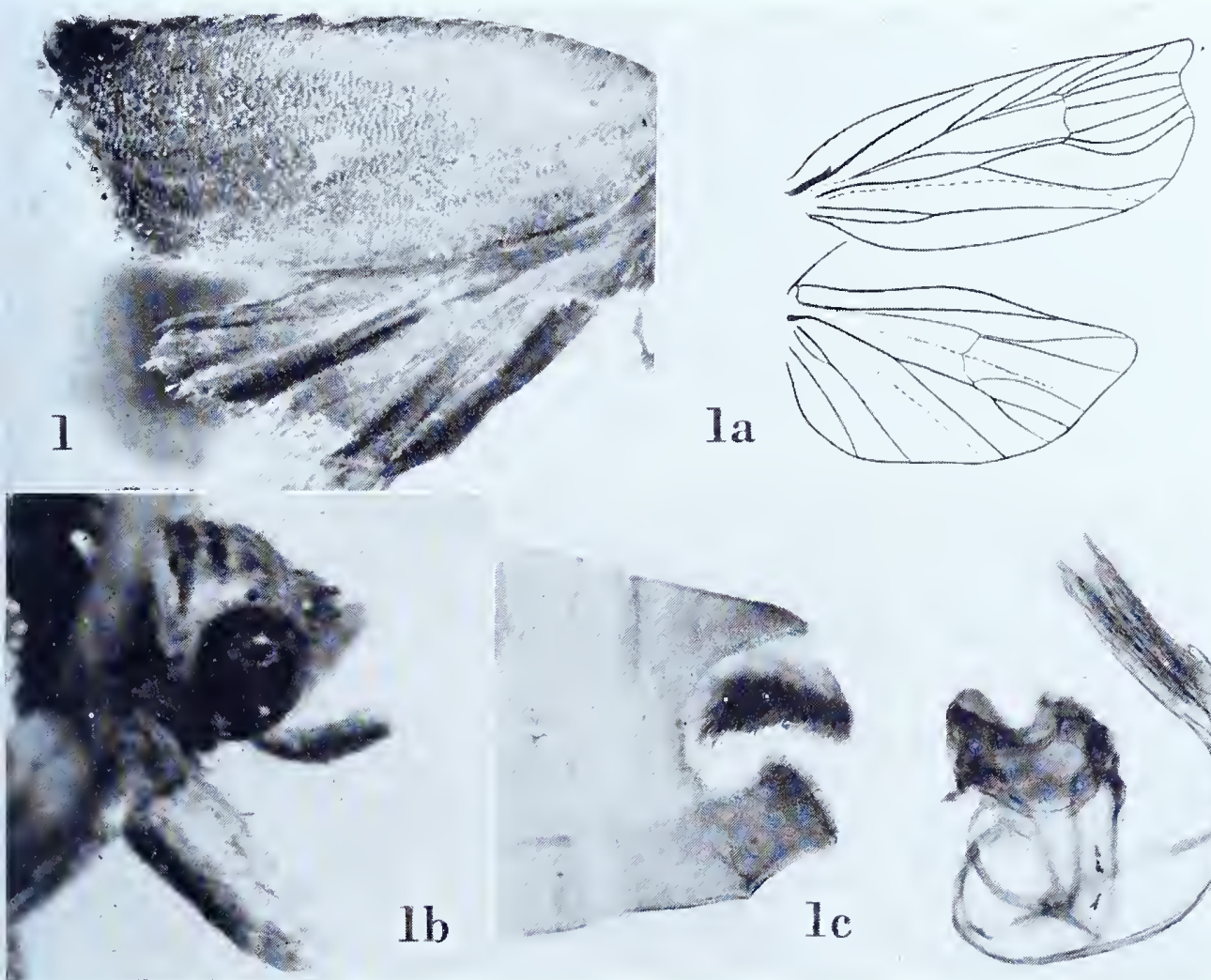

Ib
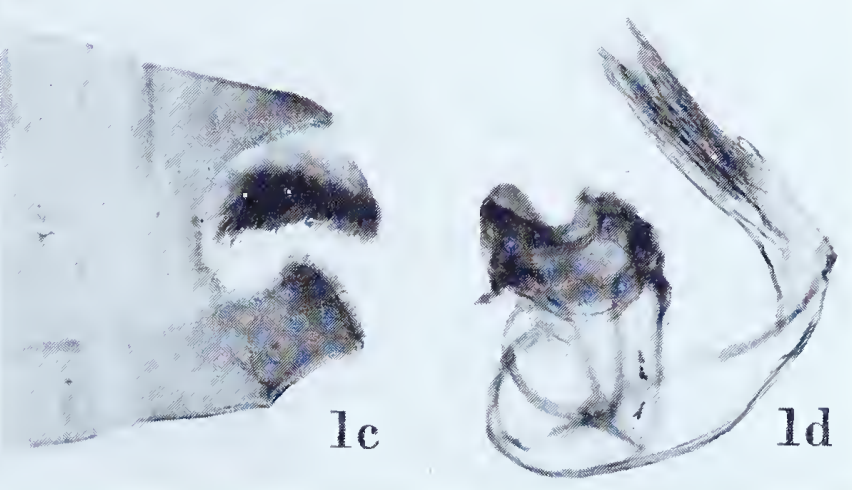

ANTICHLIDAS 

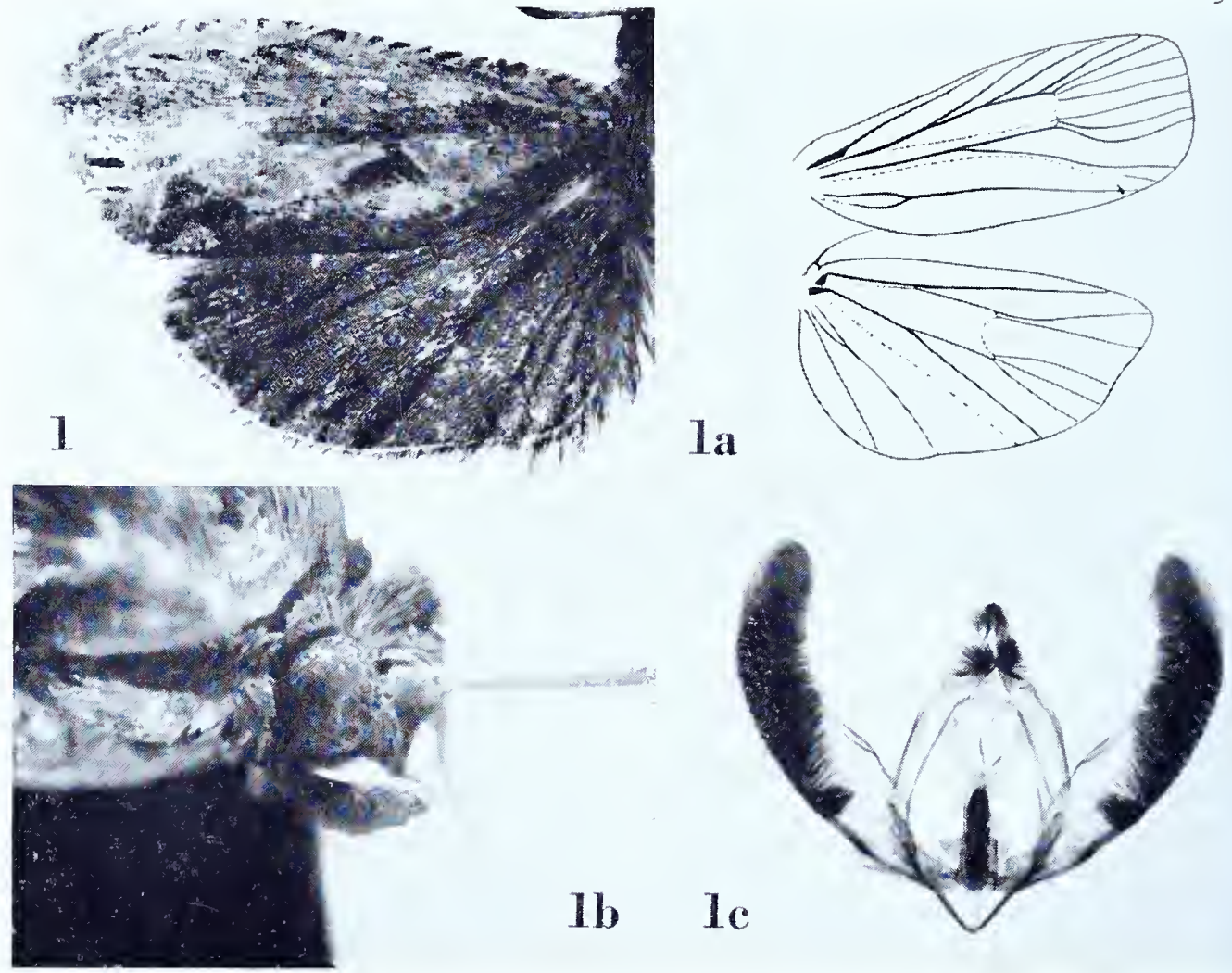

AN'TIC'TENISTA 


\section{ANTIC'TENISTA Meyrick}

Antictenista Meyrick, 1927, Exotic Microlepidoptera, 3:337. (Typus generis: Antictenista mesotricha Meyrick, ibid. [monotypy].)

\section{Antictenista mesotricha Meyrick}

Plate I48, Figures I-IC

Antictenista mesotricha Meyrick, I927, Exotic Microlepidoptera, 3:337.

" đ. 2 I mm. ... Brazil, São Paulo; I ex."

Type: The male indicated above with ".20" in the lower right corner of the pinlabel. Slide No. 6404. This species is very close to Episimns lupata (Meyrick) and is probably conspecific. Antictenista is a synonym of Episimns Walsingham.

Figure I, left wings; Ia, venation of right wings; $\mathrm{Ib}$, lateral aspect of head to show palpus; ic, ventral view of male genitalia with aedeagus in situ. 


\section{APHANIA Hübner}

\section{Aphania funerea (Meyrick)}

Plate I49, Figures I-Ia

Argyroploce funerea Meyrick, 1920, Exotic Microlepidoptera, 2: 350.

Argyroploce youngana McDunnough, I922, Can. Ent., 54:4I (new synonymy).

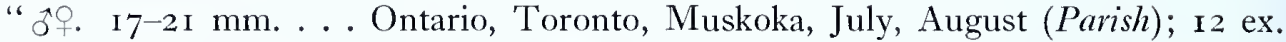

This may be regarded in America as capreana, from which however it is quite distinct."

Lectotype: A male measuring 19 mm., "Toronto, Canada. Parish. .7.I2." Slide No. 7340 .

Figure I, left wings; ra, ventral view of male genitalia with aedeagus in situ.

\section{Aphania generosa (Meyrick), new combination}

Plate 149, Figures 2-2a

Argyroploce generosa Meyrick, I909, Journ. Bombay Nat. Hist. Soc., 19: 594.

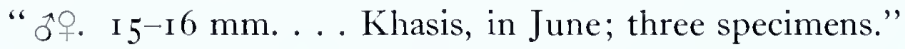

Lectotype: A male measuring 15 mm., "Khasi Hills, Assam. D. igo6." Slide No. $728 \mathrm{I}$.

Figure 2, left wings; $2 \mathrm{a}$, ventral view of male genitalia with aedeagus in situ. 

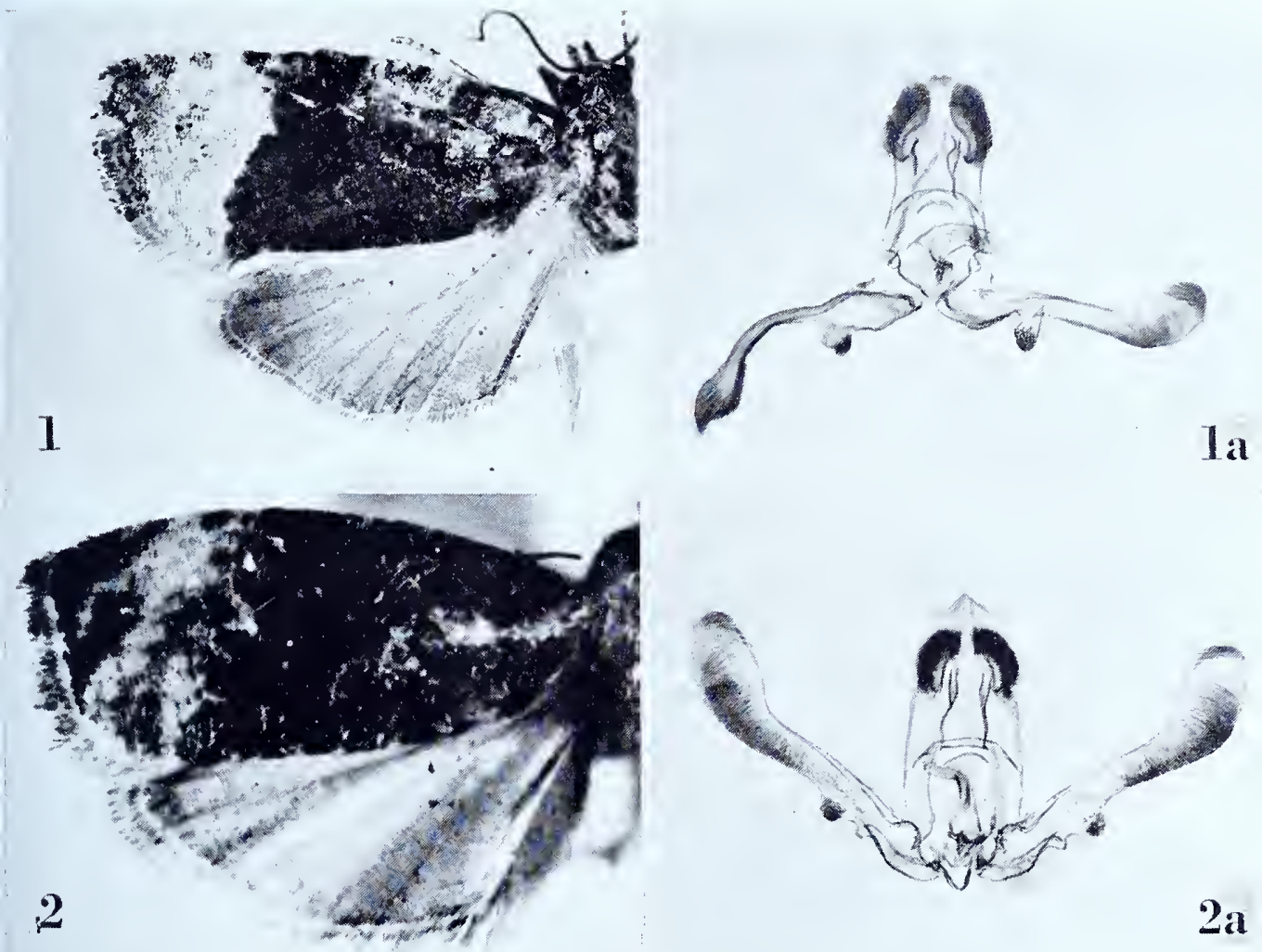

APHANIA 

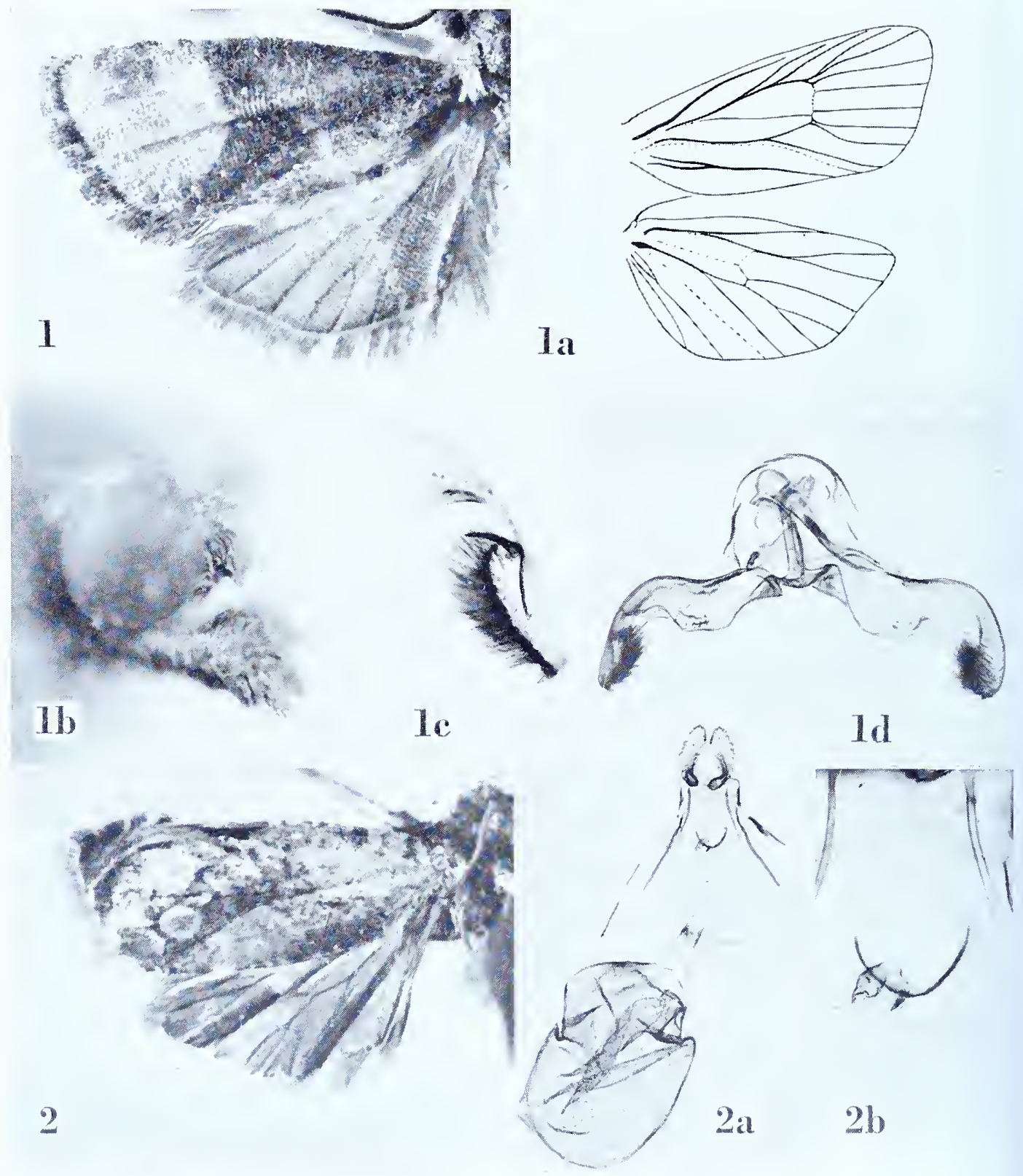

AR'TICOLLA 


\section{ARTICOLLA Meyrick}

Articolla Meyrick, 1907, Journ. Bombay Nat. Hist. Soc., i 7: 976. (Typus generis : Articolla cyclidias Meyrick, ibid. [monotypy].)

\section{Articolla cyclidias Meyrick}

Plate I50, Figures $1-\mathrm{Id}$

Articolla cyclidias Meyrick, 1907, Journ. Bombay Nat. Hist. Soc., I $7: 976$.

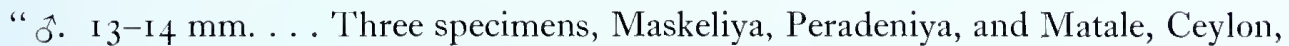
in October, January, and April (Pole, de Mowbray, Green)."

Lectotype: The male, “Matale, Ceylon. JP. .r.04." Slide No. 7ı62.

Figure I, left wings; Ia, venation of right wings; Ib, lateral view of head to show palpus; ic, outer edge of cucullus to show large seta; Id, ventral view of male genitalia with aedeagus in situ.

\section{Articolla prospera Meyrick}

Plate I 50, Figures 2-2b

Articolla prospera Meyrick, I909, Journ. Bombay Nat. Hist. Soc., I9: 59I.

"†. I7 mm. ... Khasis, in June; one specimen."

Type: The female denoted above, "Khasi Hills, Assam. .6.ı go6." Slide No. 7г6г.

Figure 2, left wings; $2 \mathrm{a}$, ventral view of female genitalia; $2 \mathrm{~b}$, detail of ostium. 


\section{ASAPHISTIS Meyrick}

Asaphistis Meyrick, 1909, Journ. Bombay Nat. Hist. Soc., 19: 590. (Typns generis: Asaphistis praeceps Meyrick, ibid. [monotypy].)

\section{Asaphistis praeceps Meyrick \\ Plate I5 I, Figures I-IC}

Asaphistis praeceps Meyrick, Journ. Bombay Nat. Hist. Soc., I9: 590.

" o. I 5-16 mm. ... Khasis, in September; two specimens."

Lectotype: The smaller of the two, "Khasi Hills, Assam. D. I 906." Slide No. 7159.

Figure I, left wings; 1 a, venation of right wings; $\mathrm{ib}$, lateral view of head to show palpus; ic, ventral view of male genitalia with aedeagus in sitn.

\section{ATERPIA Guenée}

\section{Aterpia constructa (Meyrick), new combination}

Plate I 5 I, Figures 2-2a

Argyroploce constructa Meyrick, 1922, Exotic Microlepidoptera, 2: 526.

“ $\hat{0}^{\circ}$. I $5^{-1} 7 \mathrm{~mm}$. . . . Punjab, Murree, 7,500 feet, June (Dutt); 7 ex. Extremely similar to the North American instructana."

Lectotype: A male measuring $17 \mathrm{~mm}$. Slide No. 7300 . All specimens bear identical data and are dated ".6.18".

Figure 2, left wings; $2 \mathrm{a}$, ventral view of male genitalia with aedeagus in situ. 

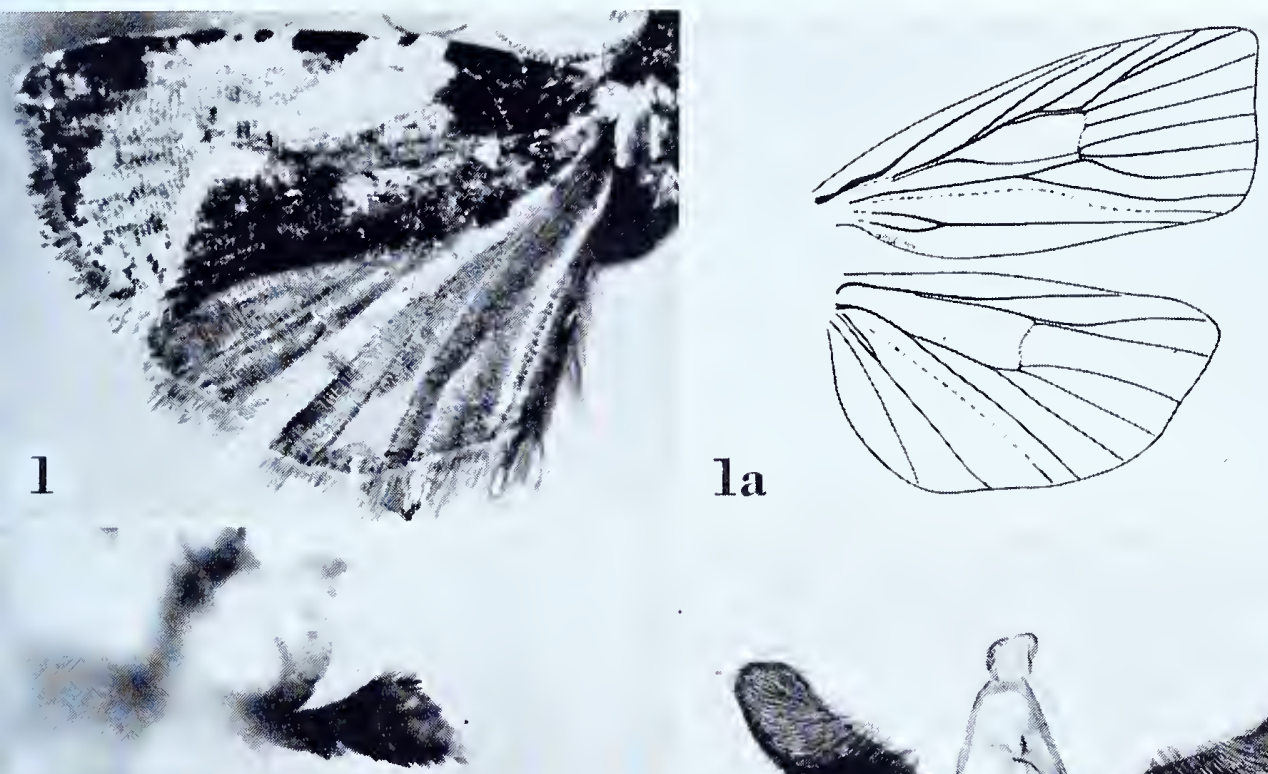

$x^{1}=x^{2}=$

$1 \mathrm{~b}$

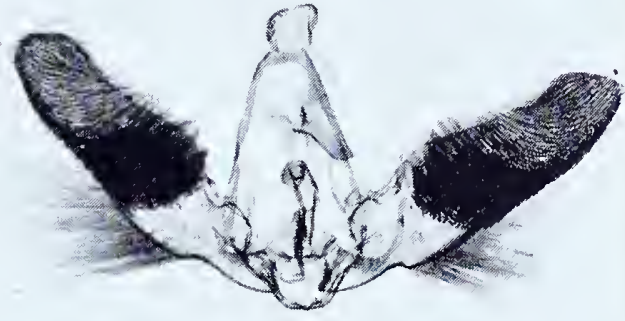

1c

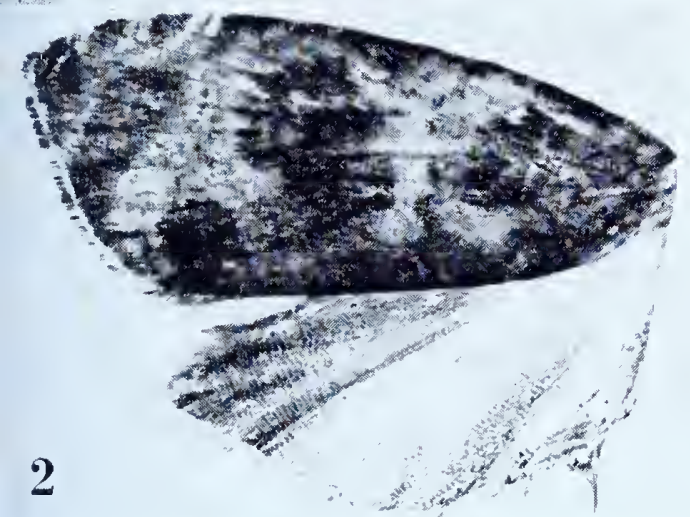

$2 \mathbf{a}$

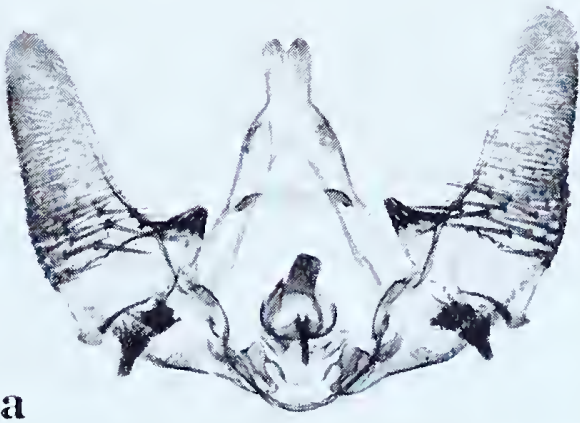

ASAPHISTIS and ATERPIA 

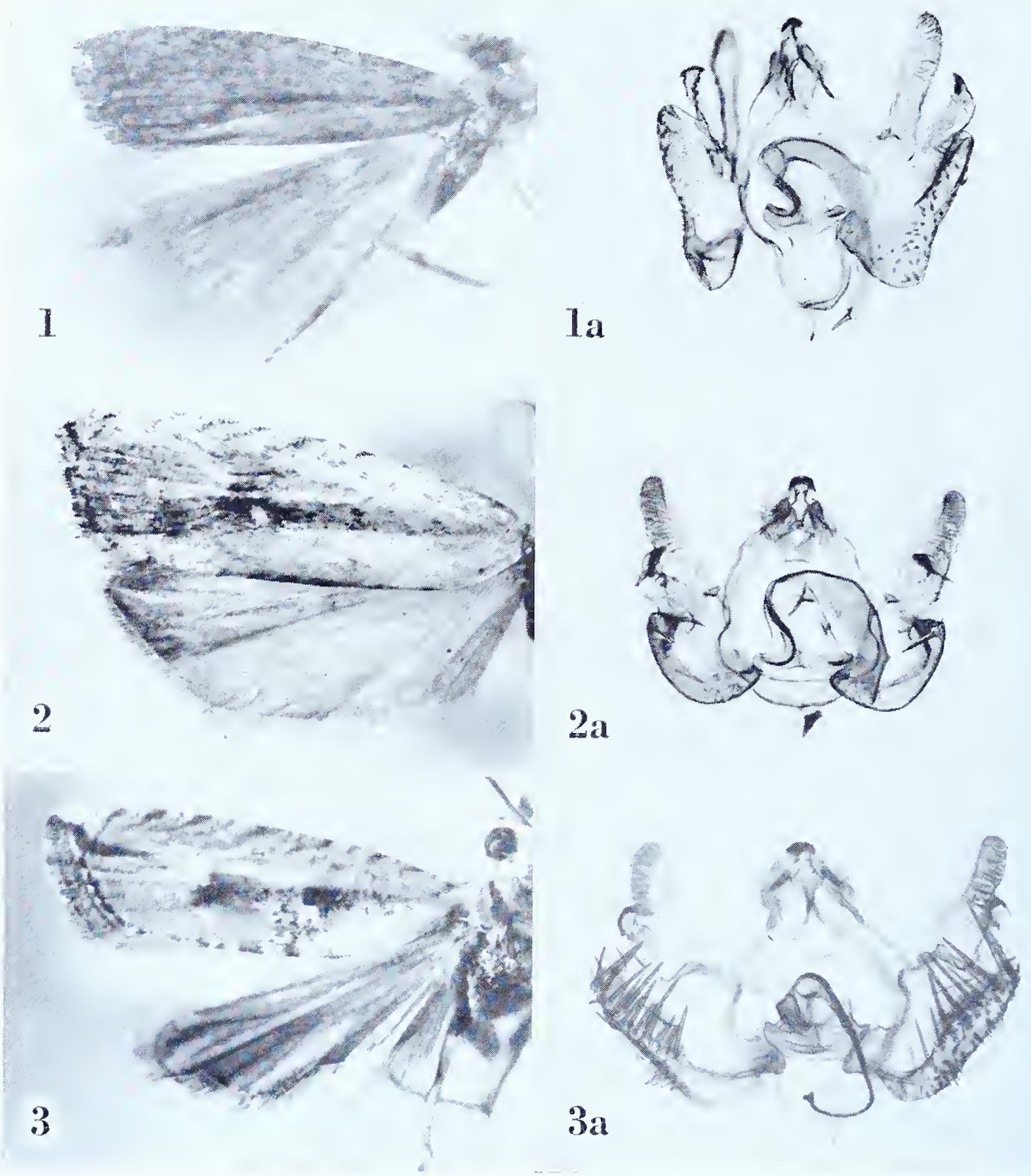

BAC'TRA 


\section{BACTRA Stephens \\ Bactra cerata (Meyrick)}

Plate I 52, Figures I-Ia

Polychrosis cerata Meyrick, I 909, Journ. Bombay Nat. Hist. Soc., 19: 587 ; Diakonoff, I950,

Bull. Brit. Mus. (Nat. Hist.) Ent., I (4): 285 .

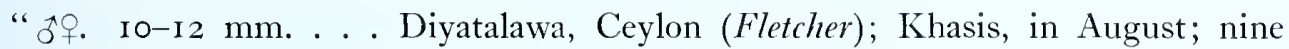
specimens."

Lectotype: A male measuring io mm., dated "I 9.8.07", selected by Diakonoff. Slide No. 7 I 46.

Figure I, left wings; Ia, ventral view of male genitalia with aedeagus in situ.

\section{Bactra clarescens Meyrick}

Plate 152 , Figures 2-2a

Bactra clarescens Meyrick, i912, Trans. Ent. Soc. London, i9 I : 689.

" 국. I 5-17 mm. ... Dutch Guiana, Paramaribo, in August and December; five specimens."

Lectotype: 'The male. Slide No. 6409. One specimen is missing; remainder are dated "I 2.92".

Figure 2, left wings; 2a, ventral view of male genitalia with aedeagus in situ.

\section{Bactra commensalis Meyrick}

Plate I52, Figures $3-3$ a

Bactra commensalis Meyrick, I922, Exotic Microlepidoptera, 2: 522; Diakonoff, I950, Bull. Brit. Mus. (Nat. Hist.) Ent., I (4): 286.

" 50 . I 0-I2 mm. . . Bengal, Pusa, bred April to June from larvae mining stems of Cynodon dactylon (Fletcher); 6 ex. (2 o, ++ +); also Bombay, Surat, July (MaxwellLefroy), I ¿...."

Lectotype: A male measuring $12 \mathrm{~mm}$., "Pusa, Bengal. TBF. bred .6.20", selected by Diakonoff. Slide No. 7I 85 . Three specimens are missing. Diakonoff considers this a synonym of copidotis, but I think it is distinct.

Figure 3 , left wings; 3 a, ventral view of male genitalia with aedeagus in situ. 
BACTRA

\section{Bactra copidotis Meyrick}

Plate ${ }_{153}$, Figures I-1a; 2-2a

Bactra copidotis Meyrick, 1909, Journ. Bombay Nat. Hist. Soc., 19: 584.

Bactra phcnacistis Meyrick, 1909, Journ. Bombay Nat. Hist. Soc., I9: 585 ; Diakonoff, I950, Bull. Brit. Mus. (Nat. Hist.) Ent., I (4): 286.

[copidotis]

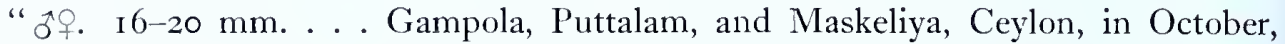
November and February (Pole, Green); Palni Hills, 6,000 feet (Campbell); five specimens."

Lectotype: A male measuring 16 mm., "Gampola, Ceylon. JP. .ro.o I", selected by Diakonoff. Slide No. 7I 43.

Figure I, left wings; ra, ventral view of male genitalia with aedeagus in situ. [phenacistis]

“ 'ơ. I 4-19 min... Maskeliya, Ceylon, from November to May (Pole, de Mowbray, Alston); seven specimens."

Lectotype: A male measuring I4 mm., "Maskeliya, Ceylon. Alston. .4.o6", selected by Diakonoff. Slide No. 7r 36 .

Figure 2, left wings; 2a, ventral view of male genitalia with aedeagus in situ.

\section{Bactra erasa Meyrick}

Plate ${ }_{53}$, Figures $3-3 \mathrm{~b}$

Bactra etasa Meyrick, 1928, Exotic Microlepidoptera, 3:442; Diakonoff, I950, Bull. Brit. Mus. (Nat. Hist.) Ent., I (4): 286.

“․ 12-1 4 mm.... S. Andamans, July (Ferrar); 12 ex. . . . it is nearest tornastis. ..."

Lectotype: A female measuring $14 \mathrm{~mm}$., selected by Diakonoff. Slide No. 7151. All specimens are dated ".7.27".

Figure 3 , left wings; 3 a, ventral view of female genitalia; 3 b, detail of ostium.

\section{Bactra geraropa Meyrick}

Plate 153 , Figures $4-4 \mathrm{~b}$

Bactra geraropa Meyrick, I93 I, Exotic Microlepidoptera, 4: 147; Diakonoff, 1950, Bull. Brit. Mus. (Nat. Hist.) Ent., I (4): 289 .

"․ . 1 5-16 mm. . . Formosa, Taihoku, July, September (S. Issiki); 2 ex."

Lectotype: The larger of the two females, dated ".9.25", selected by Diakonoff. Slide No. 7 I 86.

Figure 4, left wings; $4 \mathrm{a}$, signum; $4 \mathrm{~b}$, ventral view of female genitalia. 

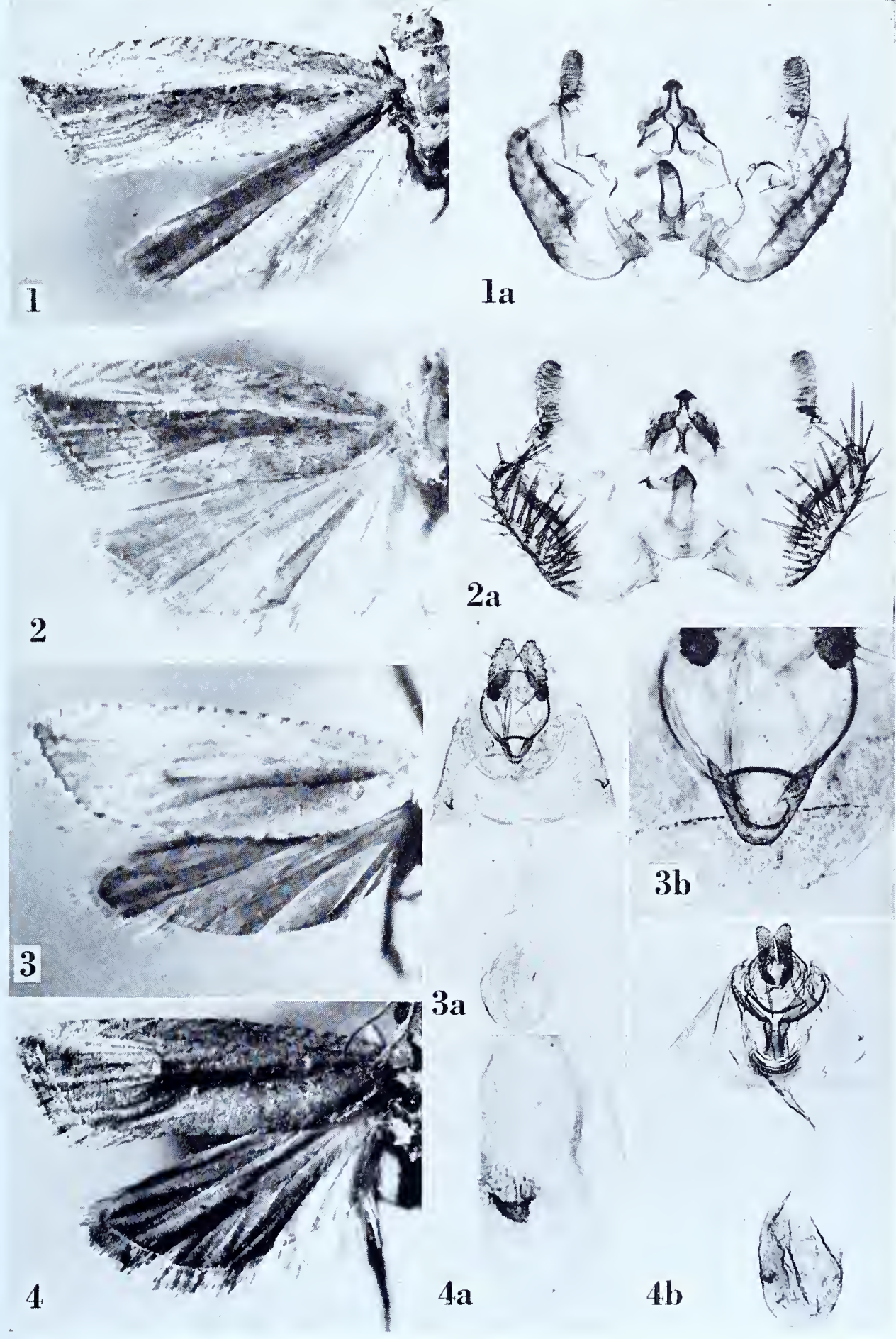

BACTRA 

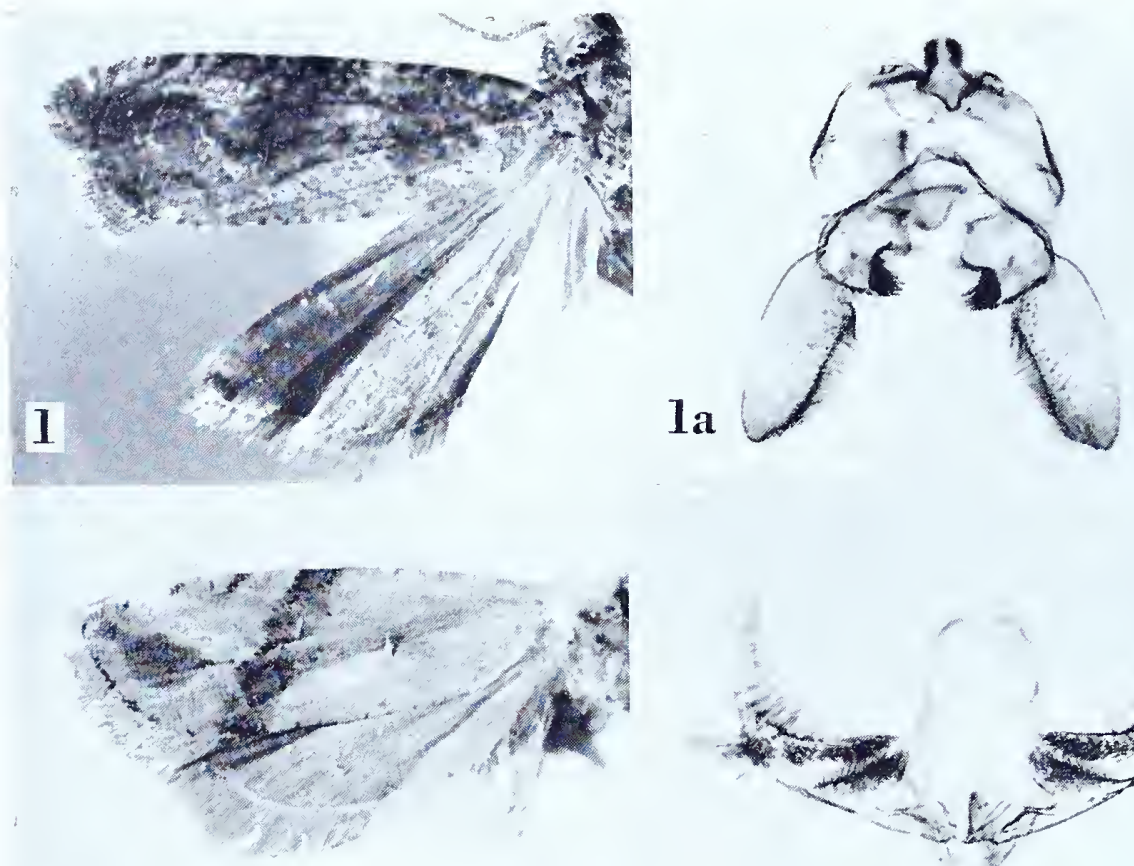

2
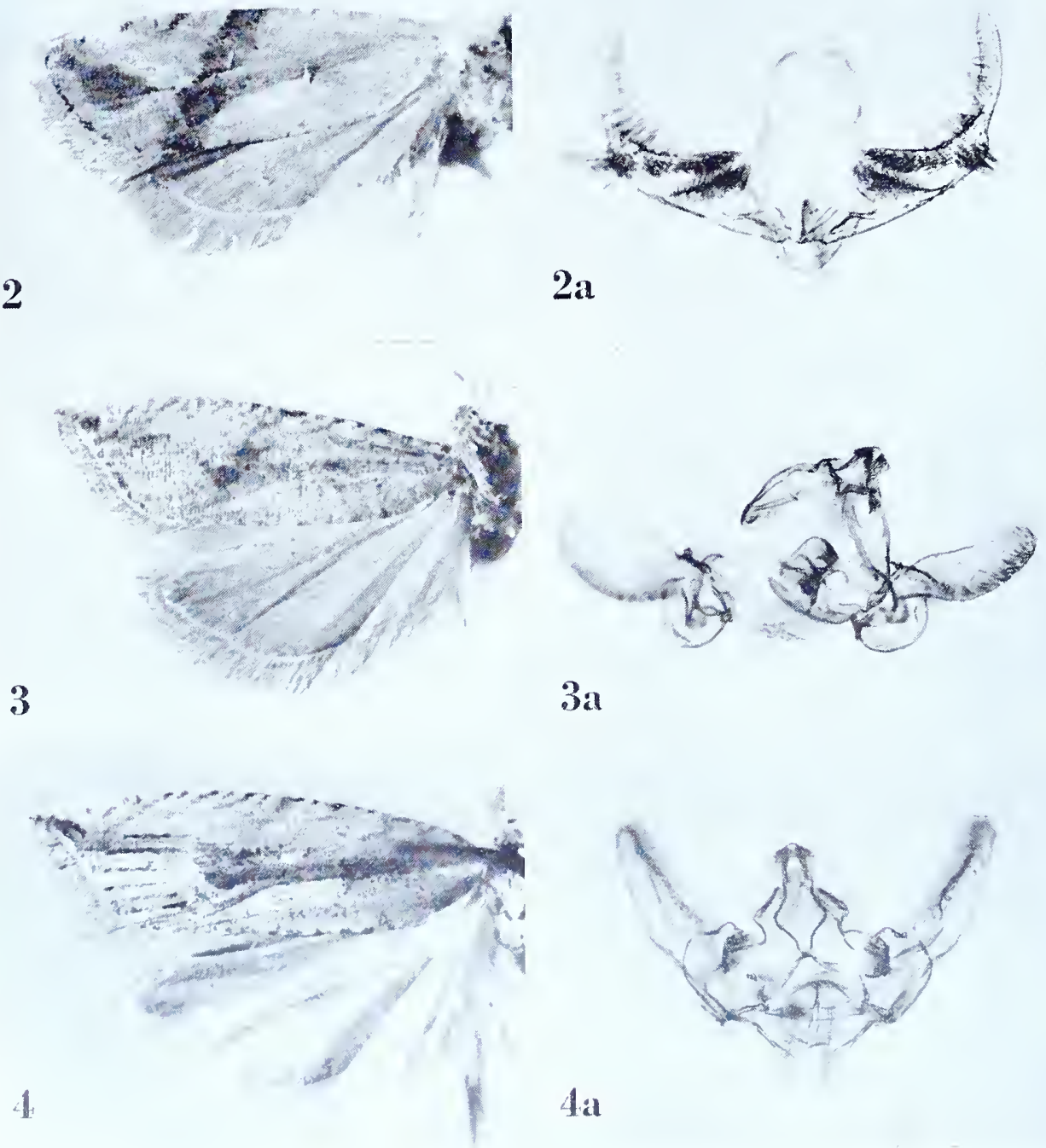

$4 a$

BACTRA 


\section{Bactra graminivora Meyrick}

Plate I 54, Figures I-Ia

Bactra graminivora Meyrick, 1922, Exotic Microlepidoptera, 2: 521 ; Diakonoff, 1950, Bull. Brit. Mus. (Nat. Hist.) Ent., I (4): 287 .

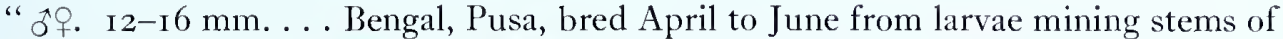
Cynodon dactylon (Gramineae) (Fletcher); 12 ex. (7 $\hat{0}, 5$ †)."

Lectotype: A male measuring I6 mm., dated “.5.20”, selected by Diakonoff. Slide No. $7 \mathrm{I} 84$.

Figure I, left wings; Ia, ventral view of male genitalia with aedeagus in sitn.

\section{Bactra harmonia (Meyrick)}

Plate 154, Figures 2-2a

Polychrosis harmonia Meyrick, 1908, Proc. Zool. Soc. London, I908; 716.

" ơ (Fanse); nine specimens."

Lectotype: วิ, 10 mm., “N.E. Pretoria, Transvaal. Janse. 13.1.07.” Slide No. 9398.

Figure 2, left wings; $2 \mathrm{a}$, ventral view of male genitalia with aedeagus in sitn.

\section{Bactra helophaea Meyrick \\ Plate 154 , Figures $3^{-} 3^{\mathrm{a}}$}

Bactra helophaea Meyrick, I928, Exotic Microlepidoptera, 3:442; Diakonoff, I950, Bull. Brit. Mus. (Nat. Hist.) Ent., I (4): 287 .

" o. I3 mm., o I7 mm. . . Assam, Shillong, August, September (Fletcher); 3 ex. An obscure insect, most like truculenta. ..."

Lectotype: The male, "Shillong, Assam. 'TBF. 5,000' .9.27", selected by Diakonoff. Slide No. 7150. 'This is not a synonym of furfurana as stated by Diakonoff. The strong setae of the sacculus of furfurana are absent in helophaea.

Figure 3 , left wings; $3 \mathrm{a}$, ventral view of male genitalia with aedeagus in sitn.

\section{Bactra honesta Meyrick}

Plate I $_{54}$, Figures $4-4$ a

Bactra honesta Meyrick, I909, Journ. Bombay Nat. Hist. Soc., 19: 585 ; Diakonoff, I950, Bull. Brit. Mus. (Nat. Hist.) Ent., I (4): 287.

" 궁. I $4^{-16} \mathrm{~mm} . .$. Khasis, from June to September; twenty specimens."

Lectotype: A male measuring I 5 mm., "Khasi Hills, Assam. .9.Igo6", selected by Diakonoff. Slide No. 7139.

Figure 4, left wings; $4^{\mathrm{a}}$, ventral view of male genitalia with aedeagus in sitn. 
BAC'TRA

\section{Bactra legitima Meyrick}

\section{Plate 155, Figure I}

Bactra legitima Meyrick, I9I I, Trans. Linnean Soc. London, 14: 269.

“官. I 4-I6 mm. ... Silhouette, Mare aux Cochons plateau, and south side of Mont Pot-à-eau, I,000-I, 500 feet, in August and September; two specimens."

Type: 'The female, without abdomen, so marked in the British Museun, "Seychelles, Silhouette, Mare aux Cochons. I,500 ft. ix-1908. H. Scott."

Figure I, left wings.

\section{Bactra leucogama Meyrick}

Plate $\mathrm{I}_{55}$, Figures 2-2a

Bactra leucogama Meyrick, I909, Journ. Bombay Nat. Hist. Soc., 19: $5^{8} 4$; Diakonoff, $195^{\circ}$, Bull. Brit. Mus. (Nat. Hist.) Ent., I (4): 287 .

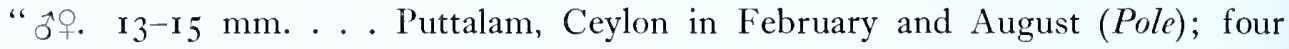
specimens. Recognisable by the pale ochreous colouring. ...."

Lectotype: A male measuring $14 \mathrm{~mm}$., dated ".8.04", selected by Diakonoff. Slide No. 7144 .

Figure 2, left wings; $2 \mathrm{a}$, ventral view of male genitalia with aedeagus in situ.

\section{Bactra litigatrix Meyrick}

Plate 155 , Figures $3-3$ a

Bactra litigatrix Meyrick, I929, 'Trans. Ent. Soc. London, 76: 495.

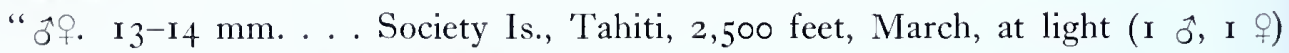
Raiatea, May (I +) (Miss Cheesman); 3 ex."

Type: The female so marked in the British Museum, "Fautaua, Tahiti, at light. 2,500 ft., I3 3.25. C. L. Collenette." Slide No. 7327. Miss Cheesman collected the Raiatea specimen.

Figurc 3, left wings; 3 a, ventral view of male genitalia with aedeagus in situ.

\section{Bactra metriacma Meyrick}

\section{Plate i 55, Figures $4-4$ a}

Bactra metriacma Meyrick, I909, Journ. Bombay Nat. Hist. Soc., 19: 582 ; Diakonoff, Buli. Brit. Mus. (Nat. Hist.) Ent., I (4): 288.

“ $\hat{\text { Oํ. }}$ I 6-19 mm. . . Maskeliya, Ceylon, from August to November (Green, Pole); seven specimens. At first sight much like phenacistis. ...."

Lectotype: A male measuring I9 mm., "Maskeliya, Ceylon, EEG. /8/02", selected by Diakonoff. Slide No. 7142 .

Figure 4, left wings; 4 a, ventral view of male genitalia with aedeagus in situ. 

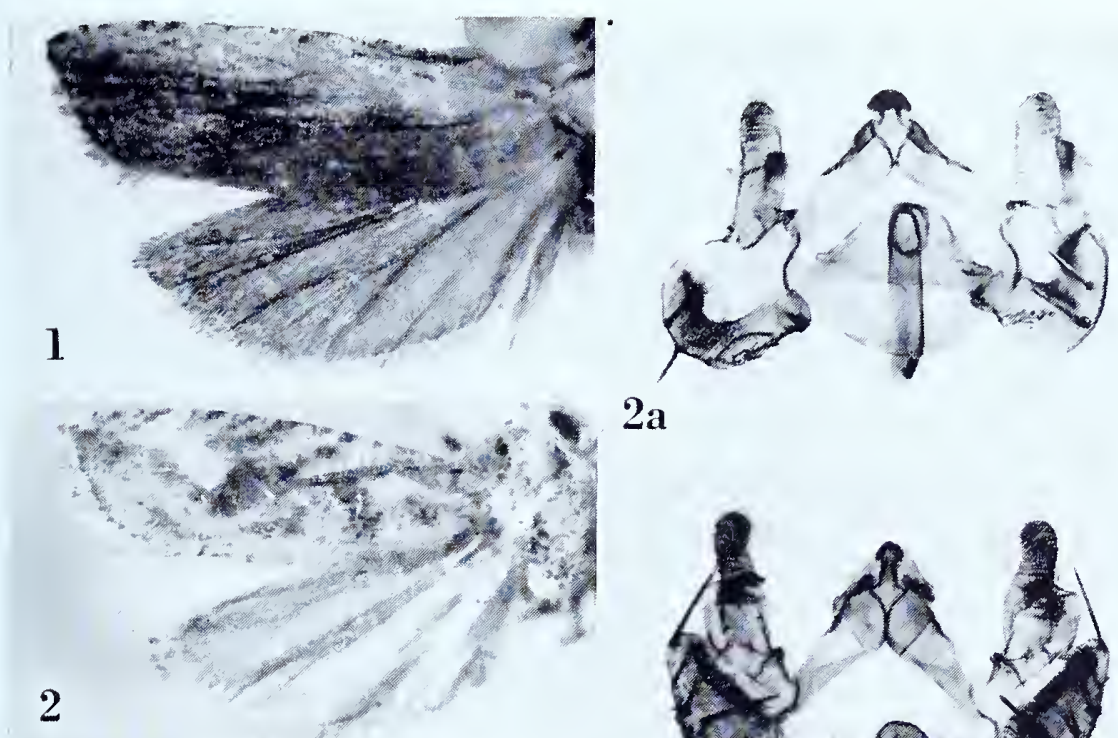

$2 a$
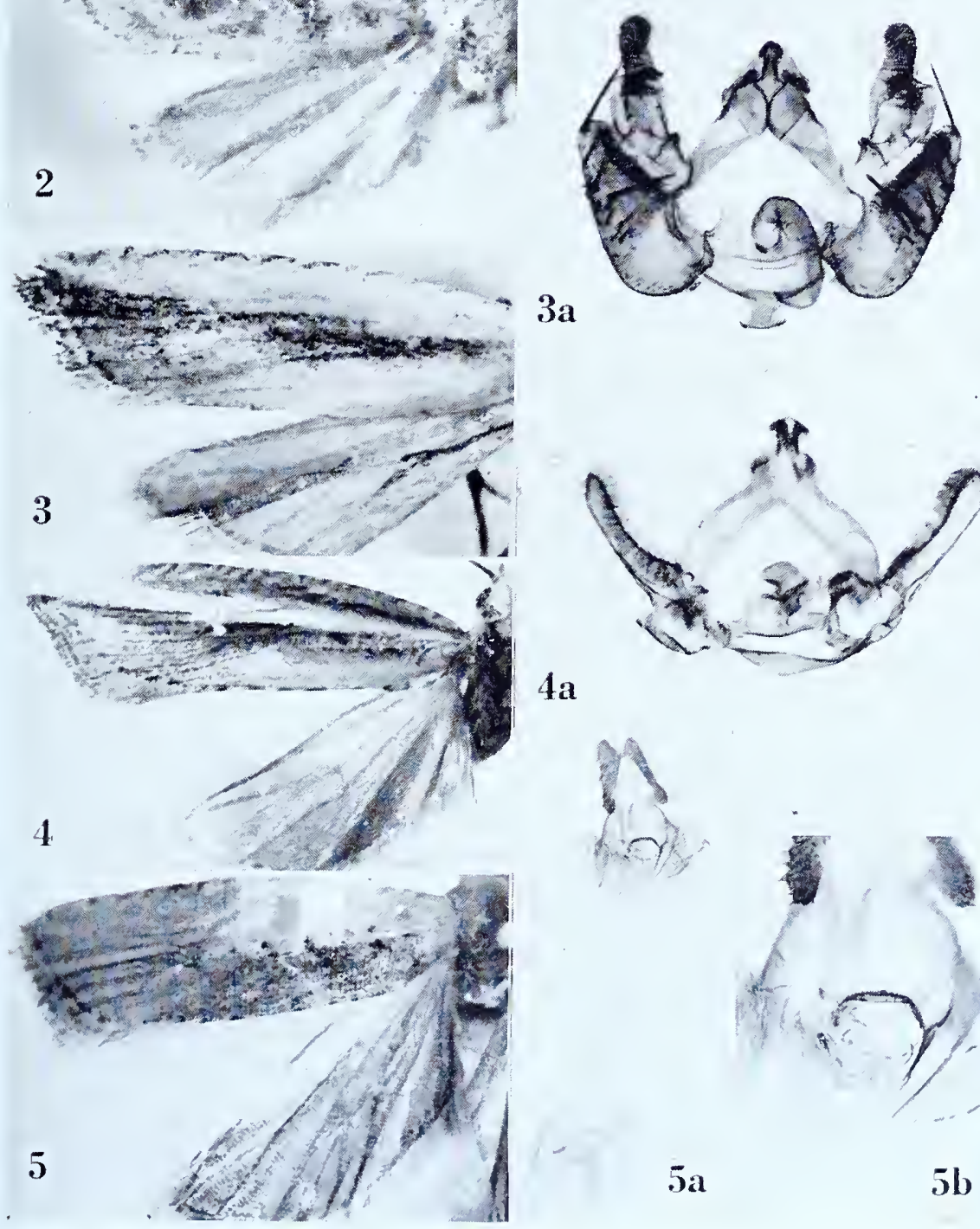

$4 a$

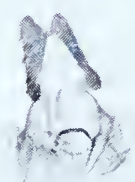

$$
\text { BACTRA }
$$



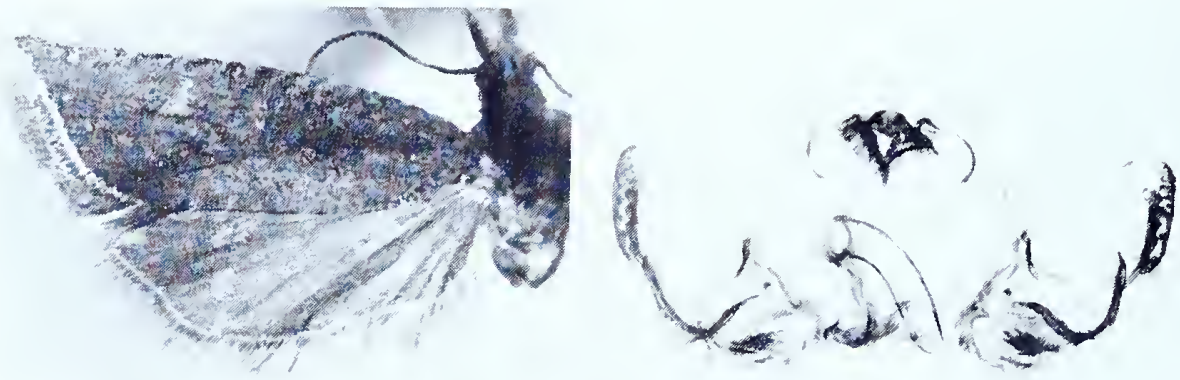

1

Ia

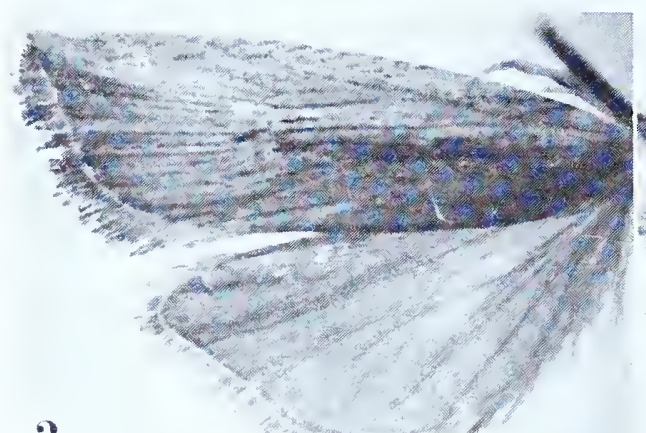

2
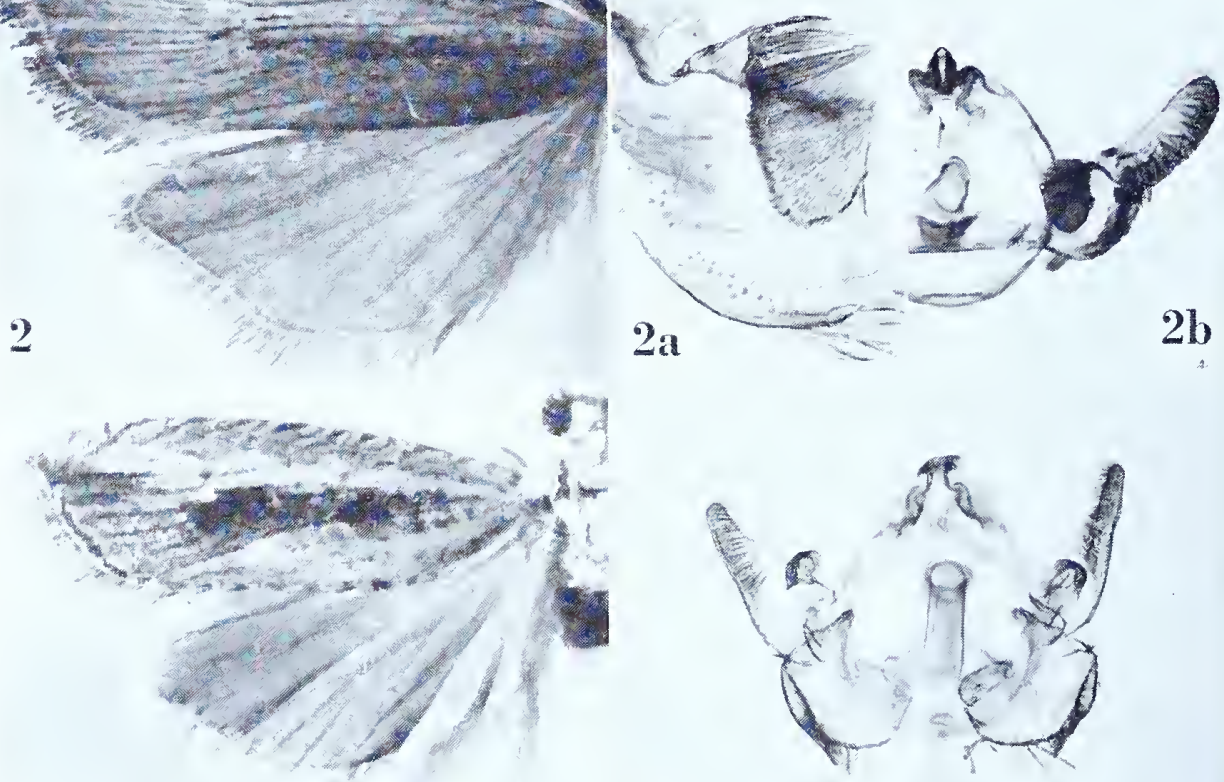

3
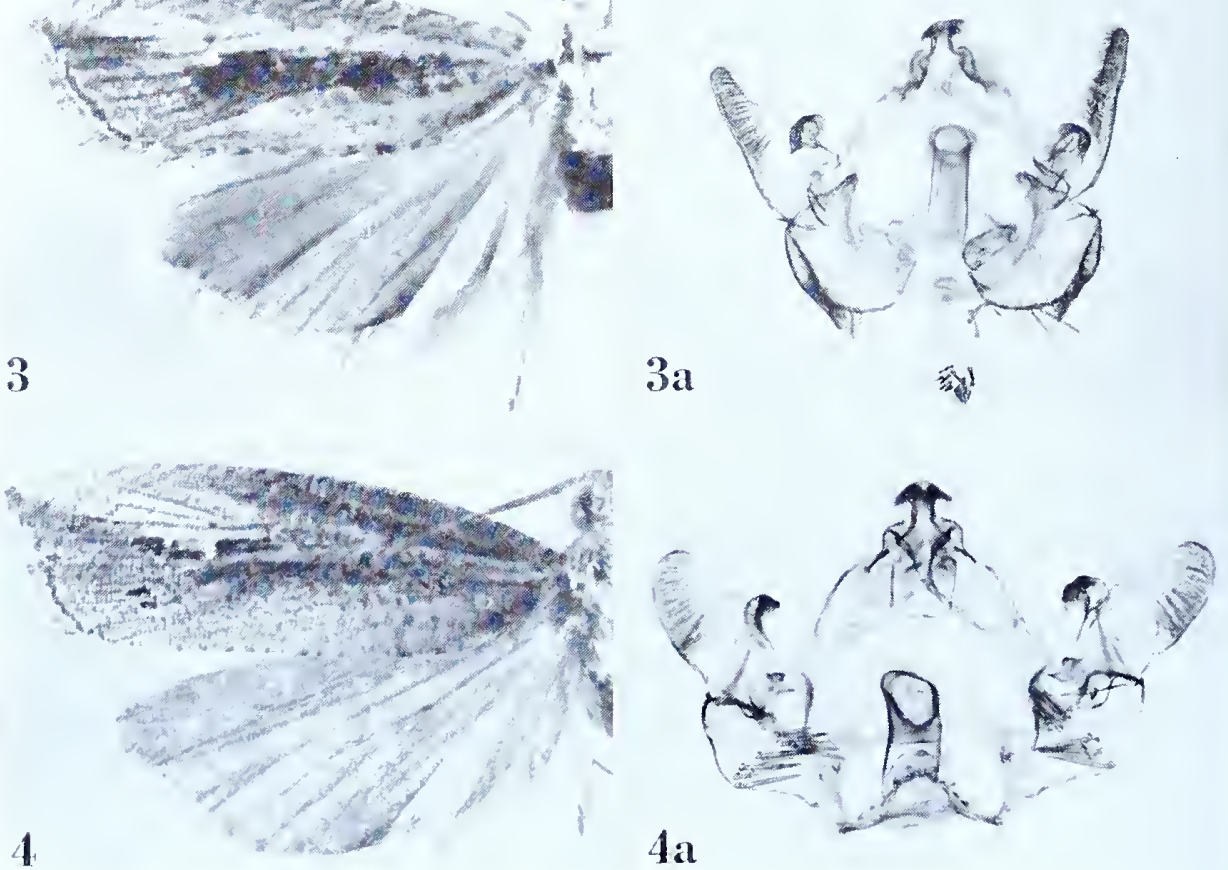


\section{Bactra sardonia (Meyrick)}

Plate ${ }_{5} 6$, Figures $\mathrm{I}-\mathrm{Ia}$

Pamplusia sardonia Meyrick, I 908, Proc. Zool. Soc. London, I908: 718.

" top I $5^{-1} 8 \mathrm{~mm}$. . . T Transvaal, N.E. Pretoria district, in December and January (Fanse); three specimens."

Lectotype: $0^{*},{ }_{5}$ mm., "N.E. Pretoria, Transvaal. Janse. I3.r.07." Slide No. 9400.

Figure I, left wings; Ia, ventral view of male genitalia with aedeagus in situ.

\section{Bactra scythropa Meyrick}

See Bactra truculenta Meyrick.

\section{Bactra seria Meyrick}

Plate ${ }_{5} 6$, Figures $2-2 \mathrm{~b}$

Bactra seria Meyrick, I917, Trans. Ent. Soc. London, I917: 24.

" o. I 8-2 I mm. . . Peru, Aqualani [sic]; three specimens."

Lectotype: The male measuring 2 I mm., dated ".5.05”. Slide No. 6408 .

Figure 2, left wings; $2 \mathrm{a}$, modified setae of sacculus, enlarged; $2 \mathrm{~b}$, ventral view of male genitalia with aedeagus in situ.

\section{Bactra tornastis Meyrick}

Plate ${ }_{5} 6$, Figures $3^{-}-3^{a}$

Bactra tornastis Meyrick, I 909, Journ. Bombay Nat. Hist. Soc., I9: 586; Diakonoff, 1950, Bull. Brit. Mus. (Nat. Hist.) Ent., I (4): 289 .

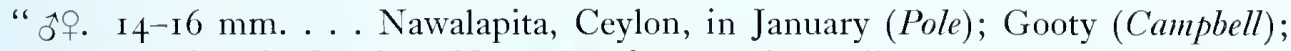
Coorg, 3,500 feet, in October (Newcome); four specimens."

Lectotype: The male, "Dibidi, N. Coorg, Newcome. I2.10.06", selected by Diakonoff. Slide No. 7 r 38 .

Figure 3 , left wings; 3 a, ventral view of male genitalia with aedeagus in situ.

\section{Bactra truculenta Meyrick}

Plate ${ }_{5} 6$, Figures $4^{-4}{ }^{\mathrm{a}}$

Bactra truculenta Meyrick, I909, Journ. Bombay Nat. Hist. Soc., I9: 586; Diakonoff, I950, Bull. Brit. Mus. (Nat. Hist.) Ent., I (4): 289 .

Bactra scythropa Meyrick, I9I I, Proc. Linnean Soc. N. S. Wales, $36: 254$; Diakonoff, 1950 , Bull. Brit. Mus. (Nat. Hist.) Ent., I (4): 289 .

\section{[truculenta]}

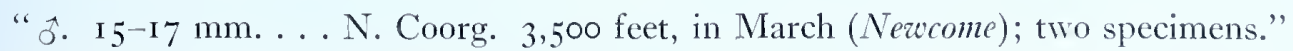

Lectotype: The male measuring $17 \mathrm{~mm}$., "Dibidi, N. Coorg, Newcome. 6.3.07", selected by Diakonoff. Slide No. 7137 .

Figure 4, left wings; 4 a, ventral view of male genitalia with aedeagus in situ. 


\section{CROCIDOSEMA Zeller \\ Crocidosema callida Meyrick \\ Plate I 57, Figures I-Ia}

Crocidosema callida Meyrick, I917, 'Trans. Ent. Soc. London, I917: I8.

" o. I 7 mm. . . Peru, Chosica, 2,80o feet, in July (Parish); one specimen."

Type: The above indicated specimen dated "7-14". Slide No. 626r.

Figure I, left wings; Ia, ventral view of male genitalia with aedeagus in situ.

\section{Crocidosema cosmoptila Meyrick}

Plate $\mathbf{5} 5$, Figures 2-2a

Crocidosema cosmoptila Meyrick, 1917, Trans. Ent. Soc. London, 1917: I7.

" $\hat{0}$. $17 \mathrm{~mm}$. . . A Argentina, R. Parana, in April; one specimen."

Type: The specimen indicated above and dated ".4. I I". Slide No. 6379.

Figure 2, left wings; $2 \mathrm{a}$, ventral view of male genitalia with aedeagus in situ.

\section{Crocidosema impendens Meyrick}

Plate 157 , Figures $3^{-3}$ a

Crocidosema impendens Meyrick, Trans. Ent. Soc. London, I917: I7.

" ${ }^{7}+$. 16-17 mm. ... Ecuador, Alausi, 9,450 feet, in June (Parish); three specimens."

Lectotype: The male measuring $16 \mathrm{~mm}$. (barely!). All are dated ".6.14". Slide No. $6{ }_{3} 80$.

Figure 3 , left wings; 3 a, ventral view of male genitalia with aedeagus in situ.

Continued from p. 312 .

\section{Bactra microtripta Meyrick}

Plate 155 , Figures $5^{-5} \mathrm{~b}$

Bactra microtripta Meyrick, 1927, Insects of Samoa, 3, Lepidoptera, fasc. 2, p. 75.

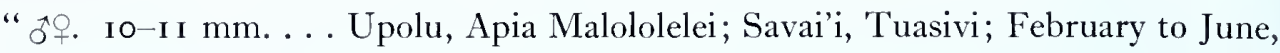
8 ex...."

Type: The female so marked in the British Museum, "Samoa Is., Apia, Upolu. 31.v.24. P. A. Buxton and G. H. Hopkins." Slide No. 7326.

Figure 5 , left wings; 5 a, ventral view of female genitalia; 5 b, detail of genital plate and ostium.

\section{Bactra phenacistis Meyrick}

See Bactra copidotis Meyrick.

$$
\text { [316] }
$$



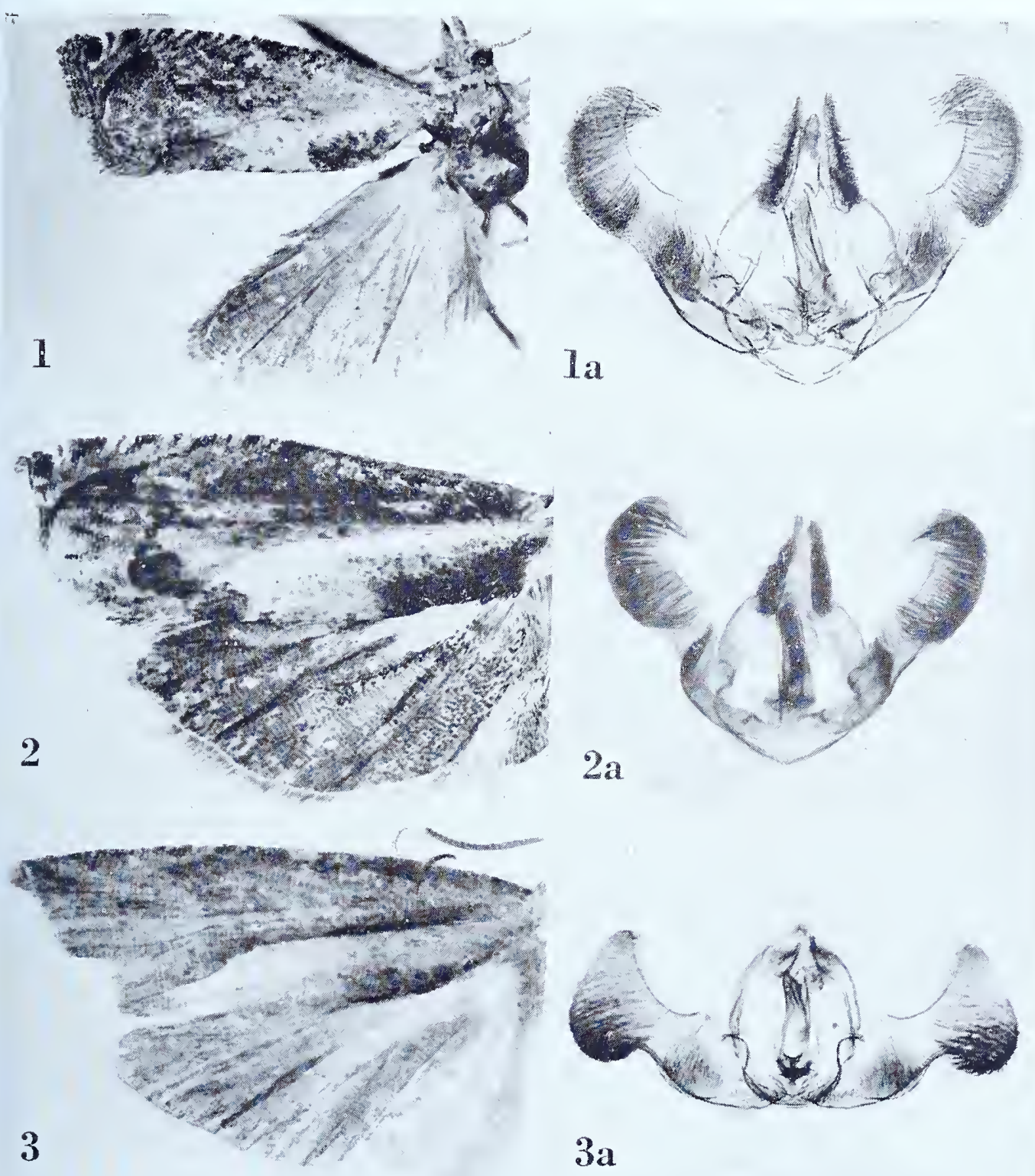

CROCIDOSEMA 


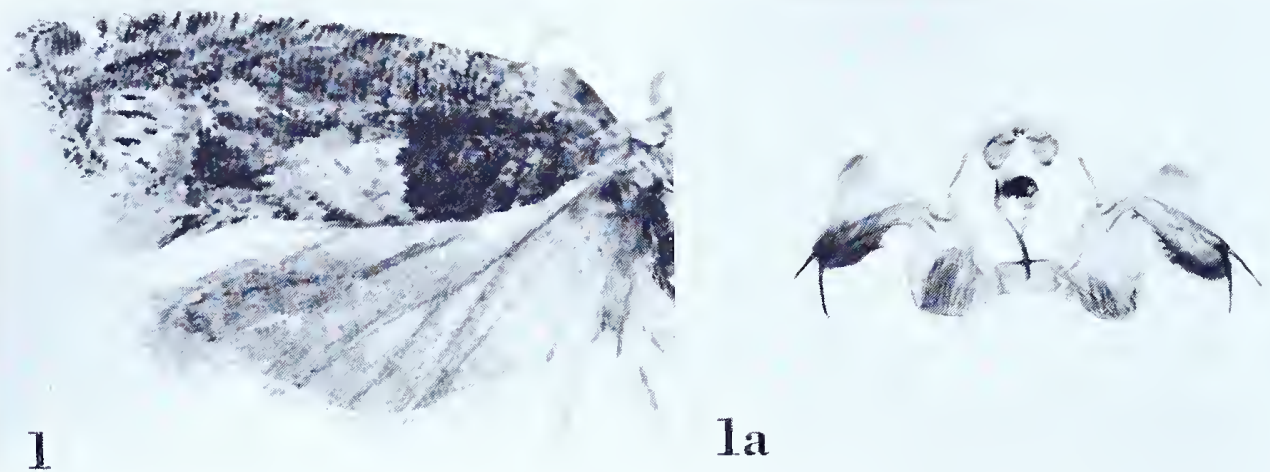

1

2
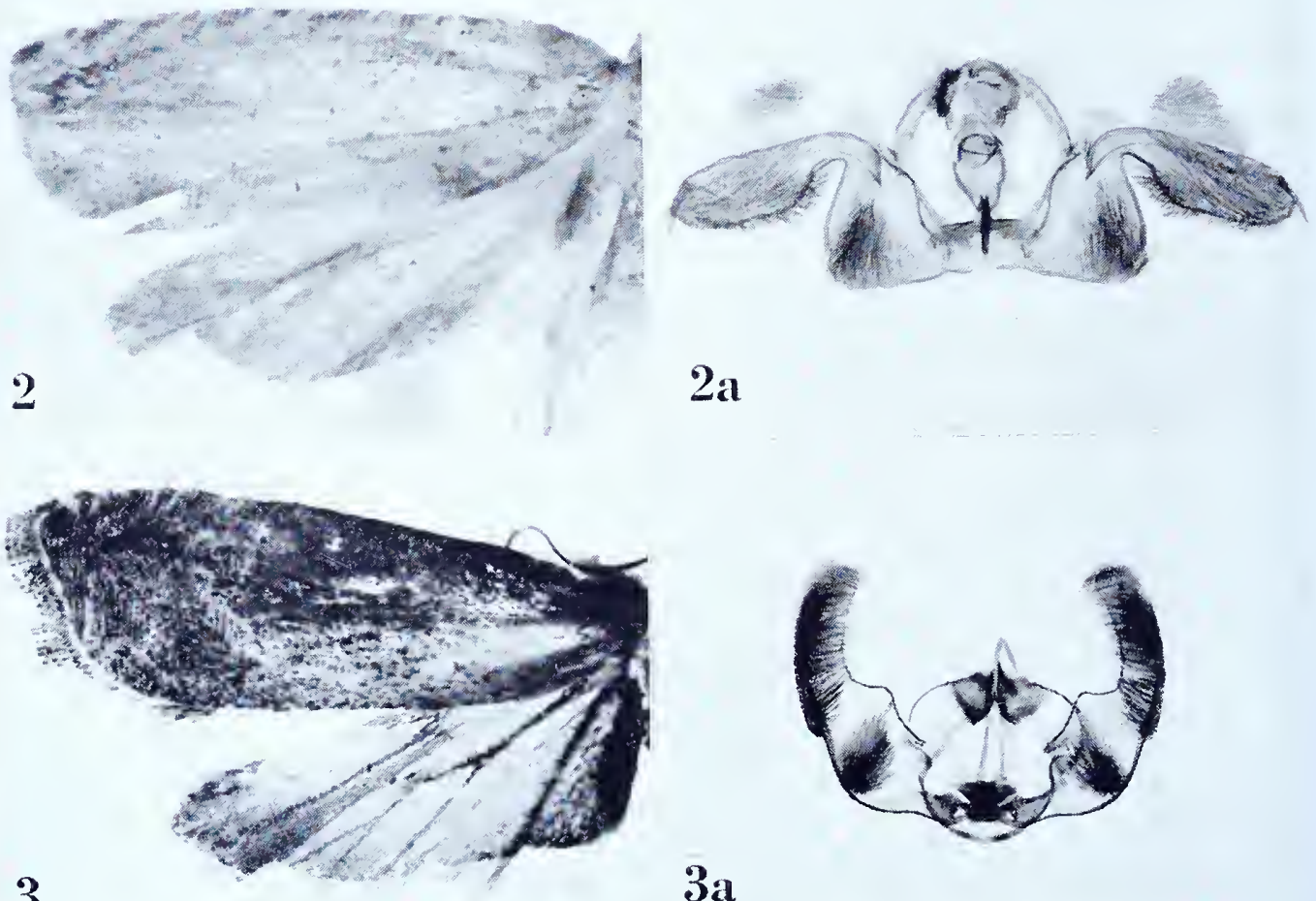

$3 \mathbf{a}$

CROCIDOSEMA

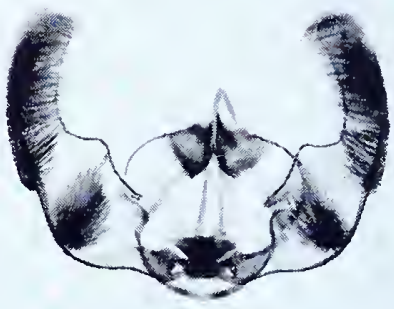




\section{Crocidosema plebeiana Zeller}

Plate 158 , Figures $1-1 \mathrm{a} ; 2-2 \mathrm{a}$

Crociáosema plebeiana Zeller, I847, Isis, $72 \mathrm{I}$.

Crocidosema ptiladelpha Meyrick, I9 17, Trans. Ent. Soc. London, I9 17 : I8 (new synonymy). Crocidosema synneurota Meyrick, I926, Trans. Ent. Soc. London, 74: 276.

[ptiladelpha]

" o. I I-I4 mm.; +. I4-15 mm. . . Ecuador, Huigra, 4,500 feet, in June; Peru, Chosica, 2,800 feet, and Lima, 500 feet, in July and August (Parish); forty-five specimens. The of is easily distinguished from plebeiana by the costal tuft. . .."

Lectotype: A male, "Lima, Peru, 500 ft., Parish. 8-I4." Slide No. 638r. Only ten specimens remain in the Meyrick collection.

Figure I, left wings; Ia, ventral view of male genitalia with aedeagus in situ.

[synneurota]

“ ส우. I I-I $2 \mathrm{~mm}$. . . A Albemarle and Indefatigable Islands, July, August; 3 ex. ( $\mathrm{I} \hat{\jmath}, 2$ ? ). These are all in damaged condition."

Type: 今ૈ, I I mm., marked “TYPE o ” in the British Museum, “Albemarle, Galapagos, at light, $200 \mathrm{ft.}$ 7.8.24. St. George Expedn. C. L. Collenette." A small white label bears the inscription " $\mathrm{M}_{42}$ ". Slide No. 9425 .

Figure 2, left wings; 2a, ventral view of male genitalia with aedeagus in situ.

\section{Crocidosema ptiladelpha Meyrick}

See Crocidosema plebeiana Zeller.

\section{Crocidosema roraria Meyrick}

Plate $5^{8}$, Figures $3^{-} 3^{\text {a }}$

Crocidosema roraria Meyrick, I917, Trans. Ent. Soc. London, I917: I6.

" సึํ. I6-1 $8 \mathrm{~mm}$. . . . Peru, Matucana, 7,780 feet, in July (Parish); six specimens (I 30,5 ㅇ).”

Lectotype: The male. Slide No. 6378. All specimens are dated “.7.14”.

Figure 3 , right wings (image reversed); 3 a, ventral view of male genitalia with aedeagus in situ.

\section{Crocidosema synneurota Meyrick}

See Crocidosema plebeiana Zeller. 


\section{CRUSIMETRA Meyrick}

Crusimetra Meyrick, I912, Journ. Bombay Nat. Hist. Soc., 21: 855. (Typus generis: Crusimetra verecunda Meyrick, ibid. [monotypy].)

\section{Crusimetra verecunda Meyrick}

Plate I 59, Figures I $\rightarrow$ I C

Crusimetra verecunda Meyrick, I912, Journ. Bombay Nat. Hist. Soc., 21 : 855; Diakonoff, 1950, Bull. Brit. Mus. (Nat. Hist.) Ent., I (4): 282.

"

Lectotype: A male measuring 15 mm., selected by Diakonoff. Slide No. 6957. One specimen is missing; the remainder are dated ".2.10".

Figure I, left wings; Ia, venation of right wings; $\mathrm{Ib}$, lateral aspect of head to show palpus; Ic, ventral view of male genitalia with aedeagus in situ. 

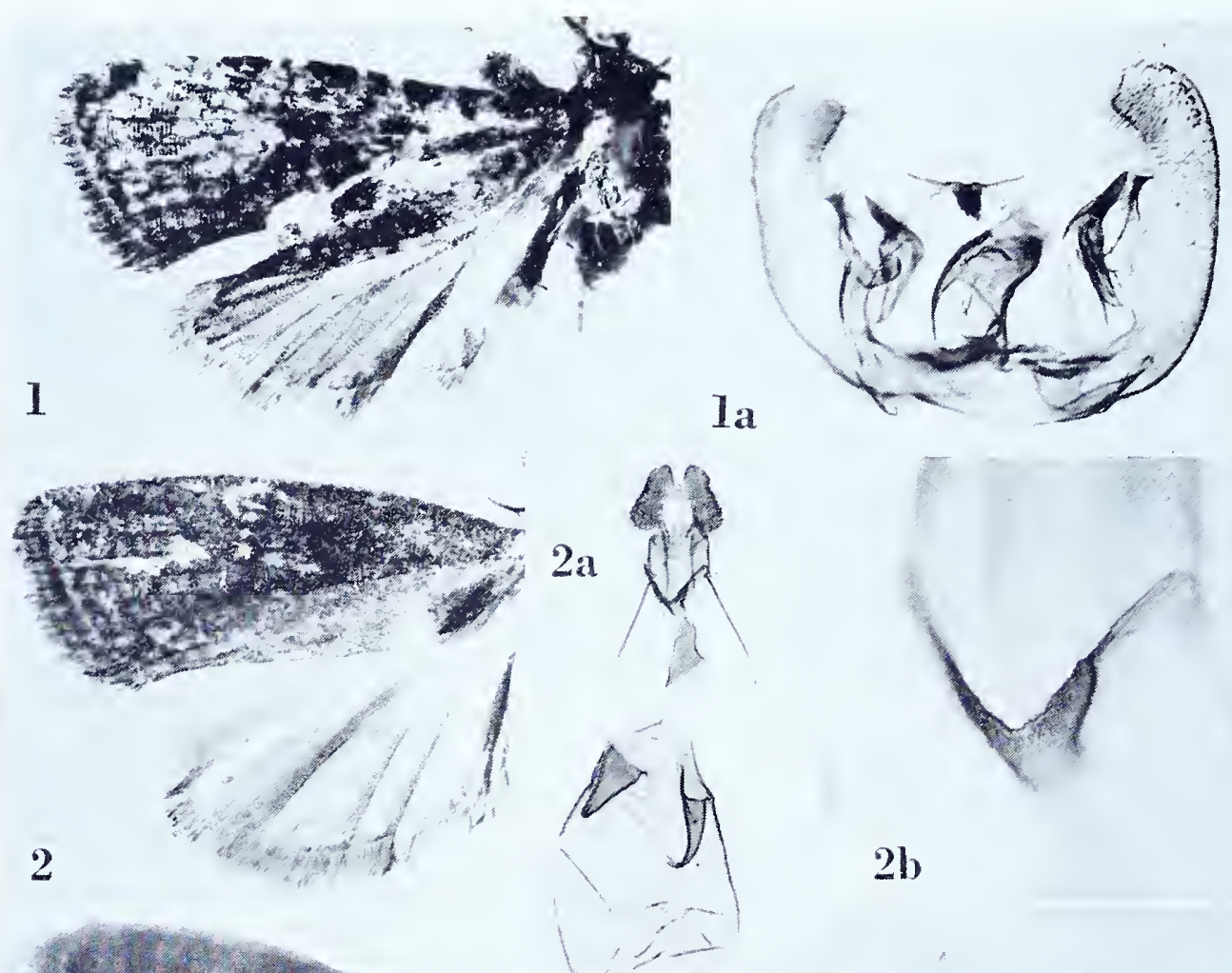

2b

$3 a$
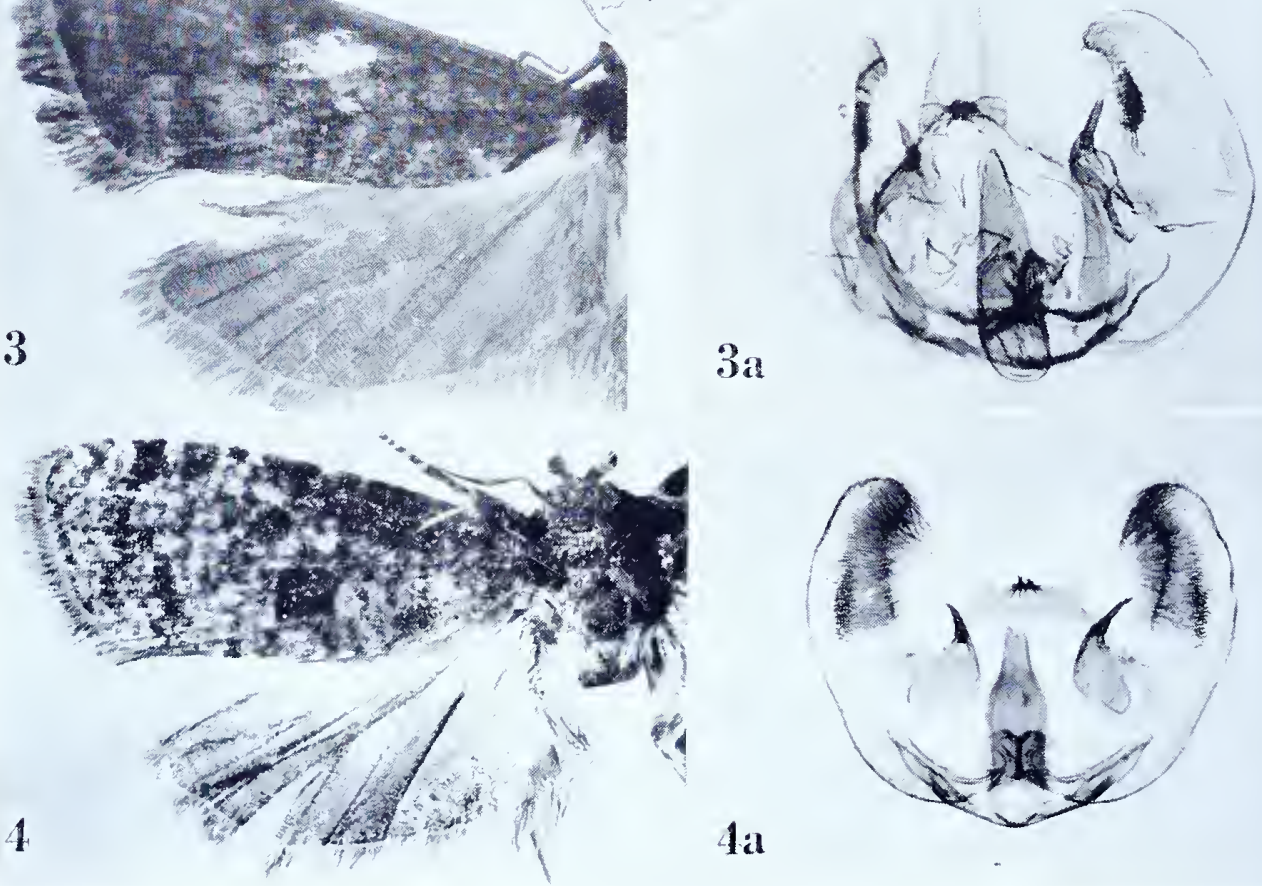


\section{CRYPTASPASMA Walsingham}

\section{Cryptaspasma brachyptycha (Meyrick), new combination}

Plate i6o, Figures I-Ia

Eucosma brachyptycha Meyrick, I9I I, Proc. Linnean Soc. New South Wales, 36: 246.

" o. I $8 \mathrm{~mm}$. . . Q.: Cooktown (Meek) one specimen. Also one from Ceylon, smaller ( $16 \mathrm{~mm}$.$) , but otherwise similar."$

Lectotype: The male, "Kegalla, Ceylon, GCA. .09." Slide No. 7r25. In the absence of the Cooktown specimen I have selected the Ceylon specimen as the lectotype.

Figure I, left wings; Ia, ventral view of male genitalia with aedeagus in sitn.

\section{Cryptaspasma helota (Meyrick)}

Plate 160 , Figures 2-2b; 3-3a

Notocelia helota Meyrick, I905, Journ. Bombay Nat. Hist. Soc., I6: 586.

Hysterosia zophocosma Meyrick, I93I, Exotic Microlepidoptera, 4: I 59 .

Cryptaspasma lngubris (Felder), Diakonoff, 1949, Bijdragen Tot de Dierkunde, 28: 135. [helota]

" ๙. I $5 \mathrm{~mm}$., o $20-26 \mathrm{~mm}$. . . . Four specimens, Maskeliya and Badulla, Ceylon, in July and November (Green, Pole)."

Lectotype: A female, "Badulla, Ceylon, EEG./I1/03." Slide No. 7123. The lectotype is the only one of the original four remaining in the Meyrick collection.

Figure 2, left wings; $2 \mathrm{a}$, ventral view of female genitalia; $2 \mathrm{~b}$, detail of genital plate and ostium.

[zophocosma]

" o. 15 mm. . . Formosa, Ranrun, July (S. Issiki); I ex."

Type: 'The male so marked in the British Museum, dated ".8.7.25". Slide No. 940 I

Figure 3, left wings; 3 a, ventral view of male genitalia with aedeagus in sitn.

\section{Cryptaspasma lasiura (Meyrick), new combination}

Plate i6o, Figures $4-4$ a

Encosma lasiura Meyrick, 1912, Journ. Bombay Nat. Hist. Soc., 2 I : 868.

“o. 2I-22 mm. . . N. Coorg, 3,500 feet (Newcome); in August, two specimens."

Lectotype: The male measuring $22 \mathrm{~mm}$. Slide No. 7124. Both bear identical data and are dated " 14.8 .06 ".

Figure 4, left wings; 4 a, ventral view of male genitalia with aedeagus in situ. 


\section{CRYP'TOPHLEBIA Walsingham}

\section{Cryptophlebia batrachopa (Meyrick), new combination Plate i6 I, Figures I-Ia}

Enarmonia batrachopa Meyrick, 1908, Proc. Zool. Soc. London, 1908: 718 .

“ 30 . I $8-22 \mathrm{~mm}$. . . . Cape Colony, Eastern portion; Natal; Transvaal; Rhodesia; bred in July and August from larvae feeding in citrus fruits, stone-fruits, and guavas, sometimes doing extensive damage (Lomsbrry); four specimens."

Lectotype: ô, $19 \mathrm{~mm}$. . . . "Kongha, Cape Colony. ex guava. CWM. .o6." Slide No. 9403 .

Figure I, left wings; ra, ventral view of male genitalia with aedeagus $i m$ sitm.

\section{Cryptophlebia colivora (Meyrick), new combination}

Plate I6I, Figures 2-2b

Argyroploce colivora Meyrick, 1932, Exotic Microlepidoptera, 4:310.

“ (Sterculiaceae) (E. Hargreaves); I ex. (Brit. Mus.)."

Type: The above indicated male so marked in the British Museum, dated "I I.ii.32". Slide No. 7070.

Figure 2, left wings; 2a, denuded abdomen to show modified terminal segment; $2 \mathrm{~b}$, ventral view of male genitalia with aedeagus in sitn.

\section{Cryptophlebia encarpa (Meyrick)}

Plate 16 I, Figures $3-3$ b

Argyroploce encarpa Meyrick, I920, Exotic Microlepidoptera, 2: 349 .

"q. I6-17 mm. .. Bengal, Calcutta, April, larva in pulp Tangerine orange (Fletcher); Ceylon, off coast, February (Fletcher); 2 ex."

Lectotype: The female, "Calcutta (hotel), Bengal. 'TBF. .4.I 7." Slide No. 7194.

Figure 3 , left wings; 3 , ventral view of female genitalia; 3 b, detail of genital plate and ostium.

\section{Cryptophlebia isomalla (Meyrick), new combination Plate i6 I, Figures $4-4$ a}

Eucosma isomalla Meyrick, 1927, Insects of Samoa, 3, Lepidoptera, fasc. 2, p. 73.

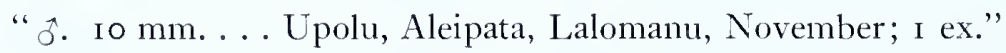

Type: The male indicated above, so marked in the British Museum, dated "xiI924". Slide No. 7007 .

Figure 4 , left wings; 4 a, ventral view of male genitalia with aedeagus in sitn.

\section{Cryptophlebia lasiandra (Meyrick)}

See Cryptopllebia ombrodelta (Lower). 


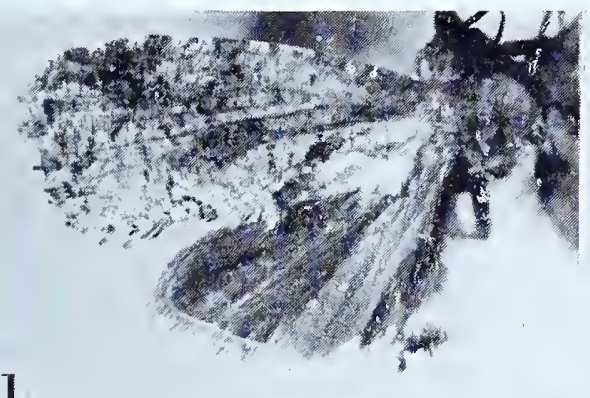

1
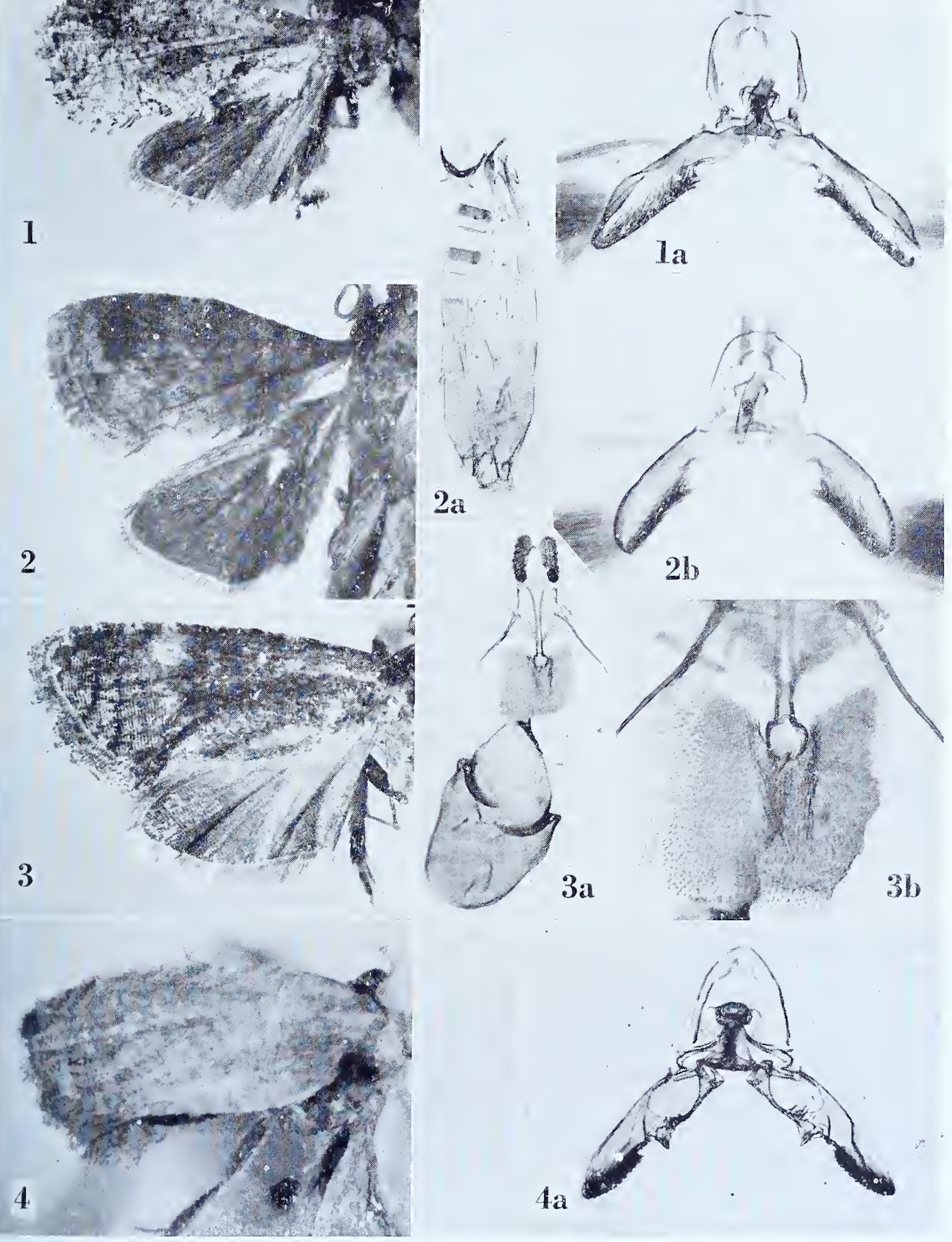


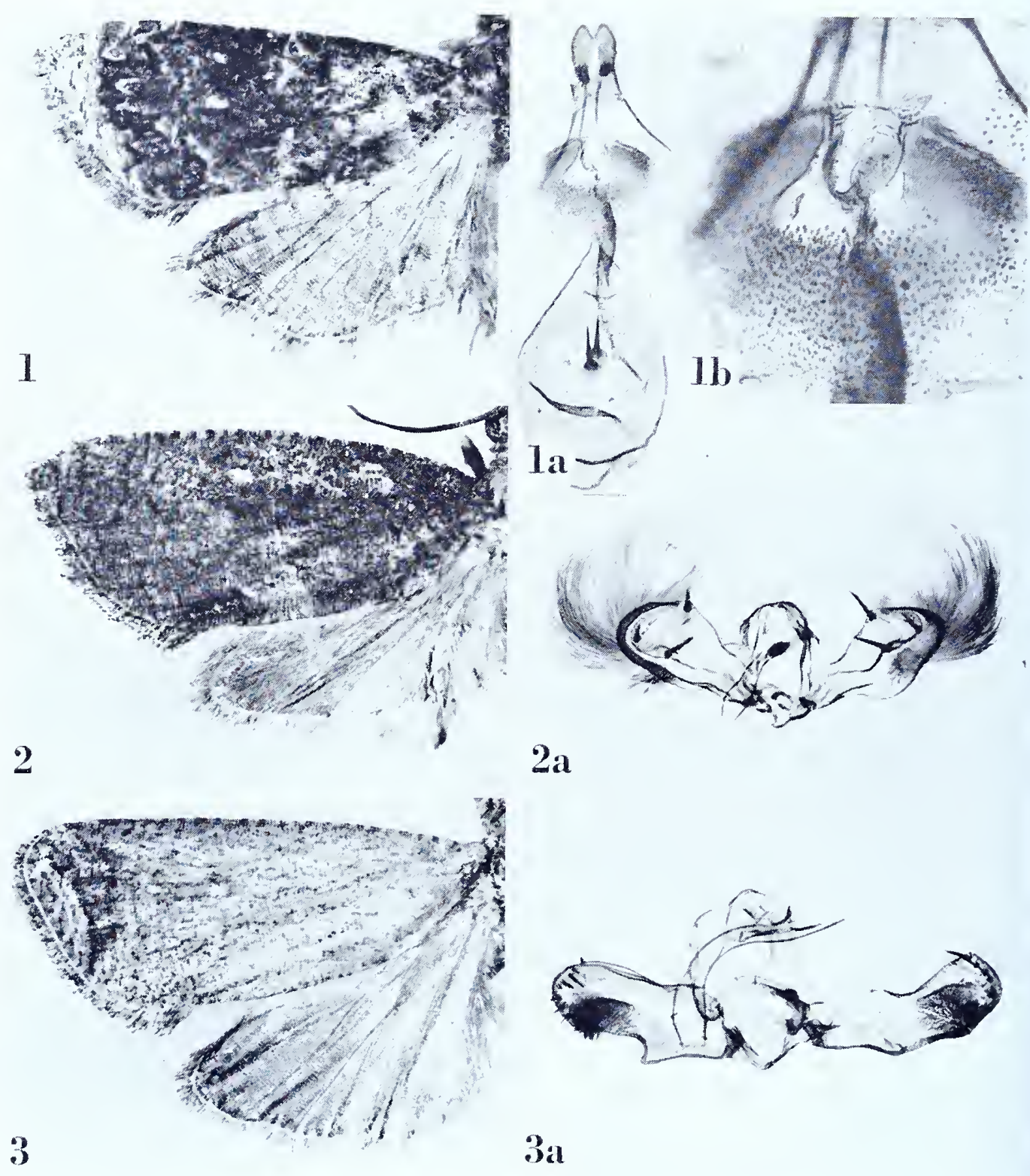

CRYPTOPHLEBIA 


\section{Cryptophlebia leucotreta (Meyrick), new combination}

Plate 162 , Figures $\mathrm{I}-\mathrm{r} b$

Argyroploce leucotreta Meyrick, i913, Ann. Transvaal Mus., 3: 276.

“․ 19-20 mm. ... Pretoria (Swierstra), in May, one specimen; also one in my own collection from Durban, Natal, in October (Leigh)."

Type: The female measuring $20 \mathrm{~mm}$., "Pretoria, Transvaal. CJS. i i.5.1 I." Slide No. 7193. This specimen, undoubtedly the type, is in the Meyrick collection, although Meyrick implied that it was elsewhere.

Figure I, left wings; ıa, ventral view of female genitalia; $\mathrm{rb}$, detail of genital plate and ostium.

\section{Cryptophlebia ombrodelta (Lower)}

Plate 162 , Figures 2-2a

Arotrophora (?) ombrodelta Lower, I 898, Proc. Linnean Soc. New South Wales, $23: 48$.

Argyroploce lasiandra Meyrick, I909, Journ. Bombay Nat. Hist. Soc., I9: 592 (new synonymy).

[lasiandra]

“今. 2 I mm. . . Trincomali, Ceylon, in November (Greeu); one specimen."

Type: The male denoted above dated ".ı I.06". Slide No. 7179.

Figure 2, left wings; 2a, ventral view of male genitalia with aedeagus in situ.

\section{Cryptophlebia rhynchias (Meyrick)}

Plate 162 , Figures $3^{-} 3^{\mathrm{a}}$

Platypeplus rhynchias Meyrick, I905, Journ. Bombay Nat. Hist. Soc., I6: 586.

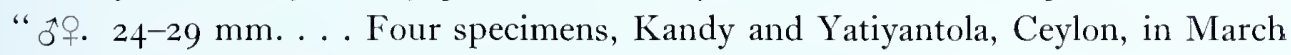
and November (Green)."

Lectotype: A male, "Yatiyantola, Ceylon. EEG ./3/02." Slide No. 7210.

Figure 3 , left wings; 3 a, ventral view of male genitalia with aedeagus in sitn. 


\section{CYPHOPHANES Meyrick}

Cyphophanes Meyrick, I937, Exotic Microlepidoptera, 5: 160. (Typus generis: Cyphophanes dyscheranta Meyrick, ibid. [monotypy].)

\section{Cyphophanes dyscheranta Meyrick}

Plate ${ }_{1} 6_{3}$, Figures $\mathbf{I}-\mathrm{IC}$

Cyphophanes dyscheranta Meyrick, 1937, Exotic Microlepidoptera, 5: I60.

“ $\$$;ㅇ․ I I - I $3 \mathrm{~mm}$. . . . J Java, Telawa, bred January from larvae feeding on leaves of Murraya (Rutaceae) (Dr. L. G. Kalshoven); 4 ex.”

Lectotype: A male measuring I I mm. Slide No. 7I66. Two specimens are missing. Figure I, left wings; Ia, venation of right wings; $\mathrm{Ib}$, lateral aspect of head to show palpus; Ic, ventral view of male genitalia with aedeagus in situ. 

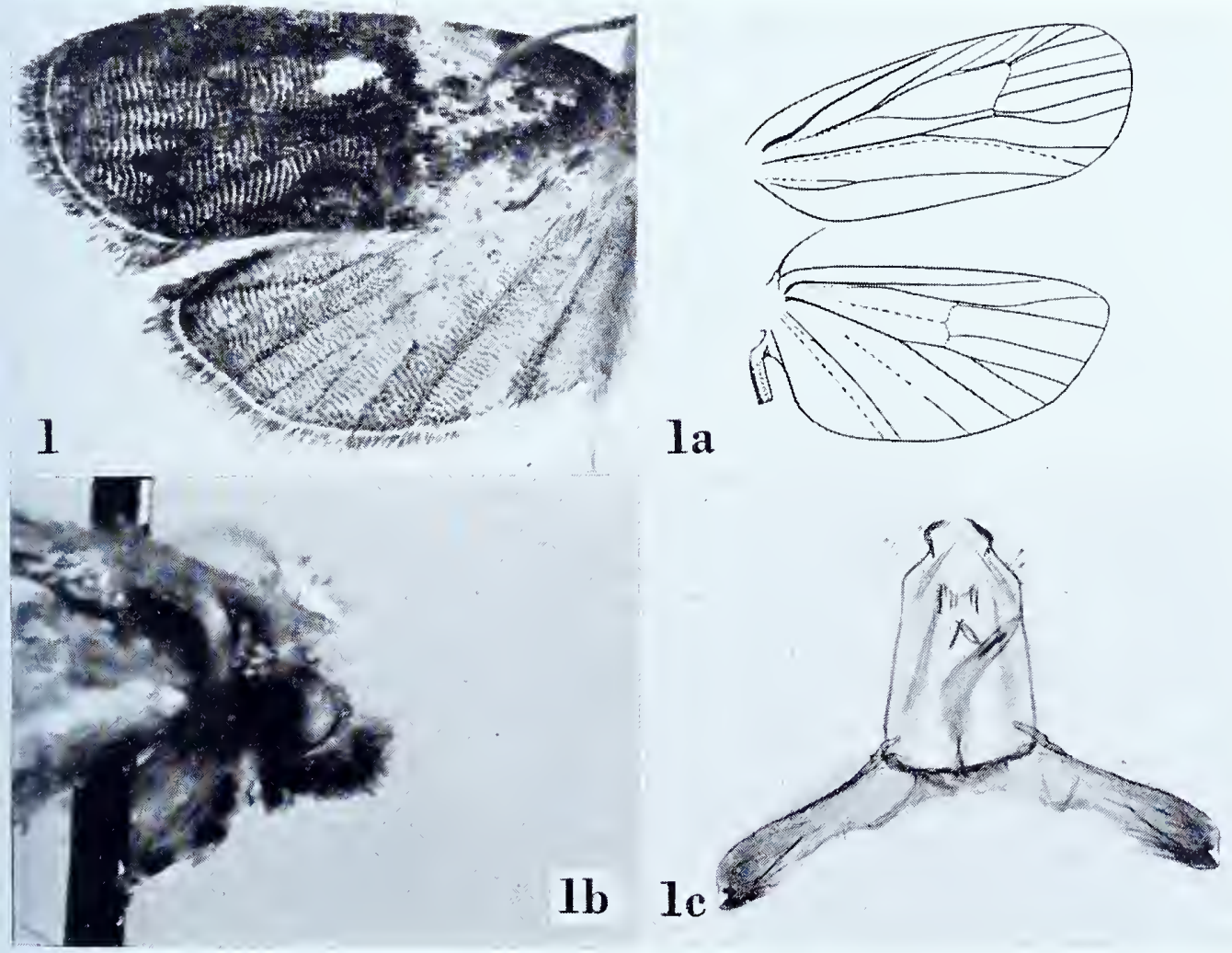

CYPHOPHANES 


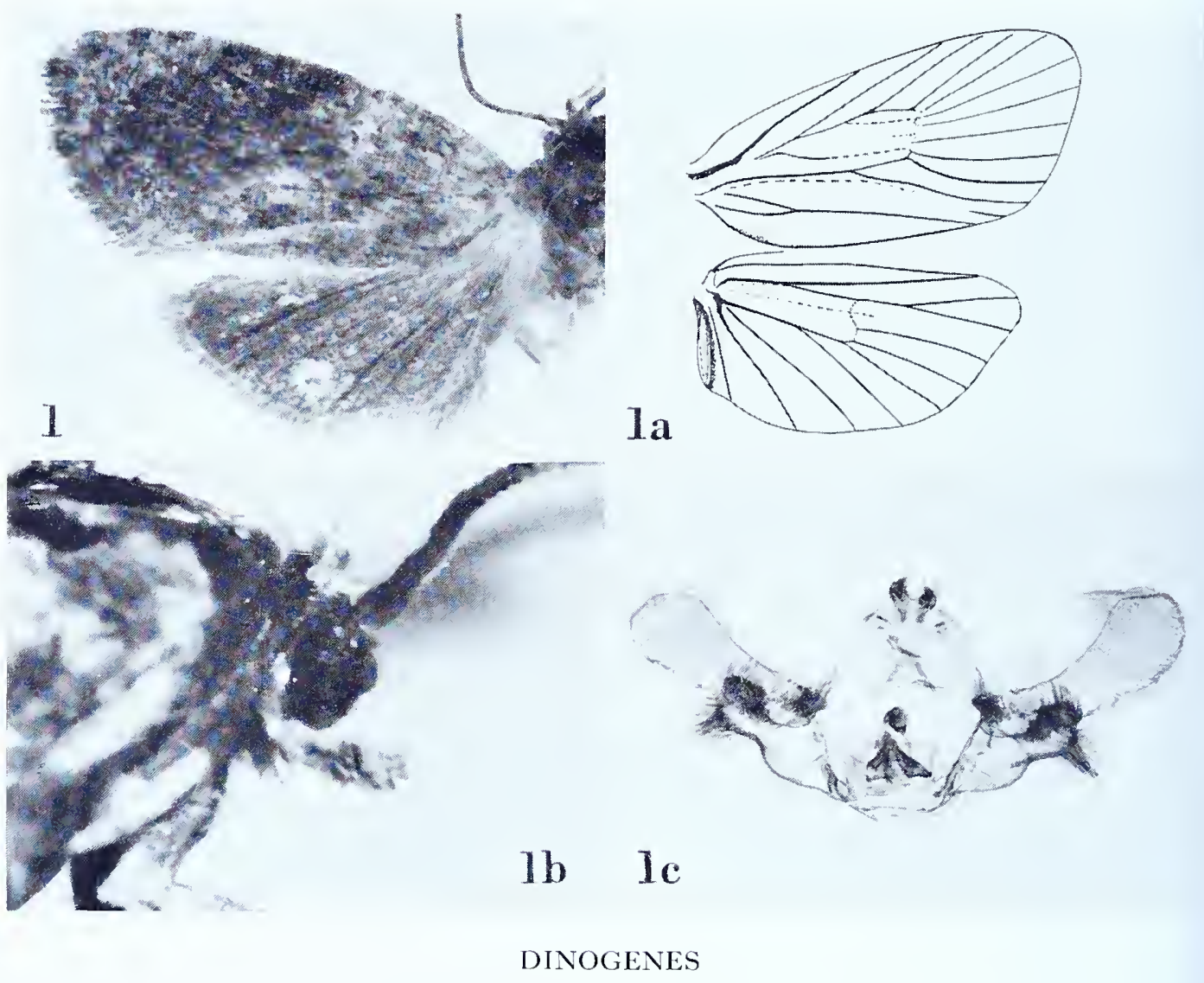




\section{DINOGENES Meyrick}

Dinogenes Meyrick, 1934, Exotic Microlepidoptera, 4: 485. (Typus generis: Dinogenes meteoropa Meyrick, 1.c., 486 [monotypy].)

\section{Dinogenes meteoropa Meyrick}

Plate I64, Figures I-IC

Dinogenes meteoropa Meyrick, 1934, Exotic Microlepidoptera, 4: 486.

" 추․ I2-13 mm. . . U Uganda, Kampala, December (H. Hargreaves); 6 ex. (type Brit. Mus.)."

Type: The male so marked in the British Museum, "Uganda, Kampala. 3.xii.r932. H. Hargreaves." Slide No. 740 . In addition to the locality label there is a narrow blue one with the inscription "Dinogenes (n.g.) meteoropa n. sp.", in Meyrick's hand. Figure I, left wings; Ia, venation of right wings; $\mathrm{Ib}$, lateral aspect of head to show palpus; Ic, ventral view of male genitalia with aedeagus in situ. 


\section{ENDOTHENIA Stephens}

\section{Endothenia banausopis (Meyrick), new combination}

Plate 165 , Figures $1-1$ a

Argyroploce banansopis Meyrick, 1938, in Caradja and Meyrick, Deuts. Ent. Zeit. Iris, 52: 2. “... ô. I 5 mm. . . Y Yül., 3,200 m., VIII, г ex."

Type: 'The male indicated above, "Likiang, China. H. .8.34." Slide No. 730 .

Figure I, left wings; ra, ventral view of male genitalia with aedeagus in situ.

\section{EPIBLEMA Hübner}

\section{Epiblema leucopetra (Meyrick), new combination \\ Plate 165 , Figures $2-2 \mathrm{a}$}

Eucosua leucopetra Meyrick, 1908, Proc. Zool. Soc. London, 1908: 719.

“ $\$$. $12-14 \mathrm{~mm}$. . . Transvaal, Pretoria district, in December, January, and July (Fanse); seven specimens."

Lectotype: ô, 14 mm., "N.E. Pretoria, Transvaal, Janse. 8.x.07." Slide No. 9391.

Figure 2, left wings; 2a, ventral view of male genitalia with aedeagus in situ.

\section{Epiblema porpota (Meyrick), new combination \\ Plate 165 , Figures $4^{-4}$ a}

Cydia porpota Meyrick, 1907, Journ. Bombay Nat. Hist. Soc., 17: 733.

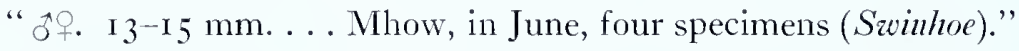

Lectotype: A male measuring I 3 mm., dated ".6.82". Slide No. 6964. Three specimens are missing.

Figure 4, left wings; $4 \mathrm{a}$, ventral view of male genitalia with aedeagus in situ.

\section{Epiblema riciniata (Meyrick), new combination \\ Plate 165 , Figures $3-3$ a}

Encosma riciniata Meyrick, I91, Ann. Transvaal Mus., 2: 226.

"Male, I 5-16 mm. . . Haenertsburg, in December (Swierstra); two specimens."

Lectotype: ô, 5 mm., "Haenertsburg, Transvaal. CJS. 9. I 2.09." Slide No. 9393.

Figure 3 , left wings; 3 a, ventral view of male genitalia with aedeagus in situ. 

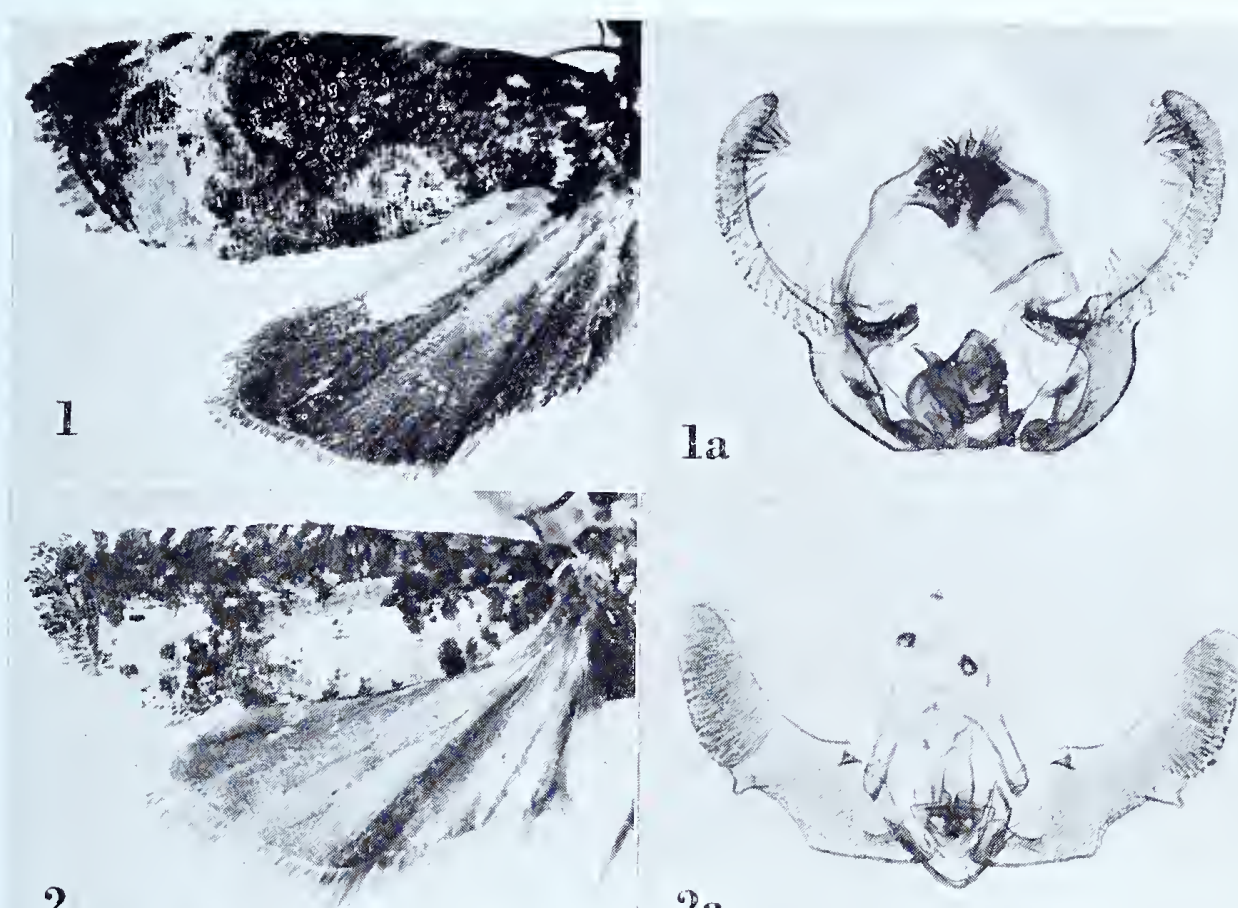

2
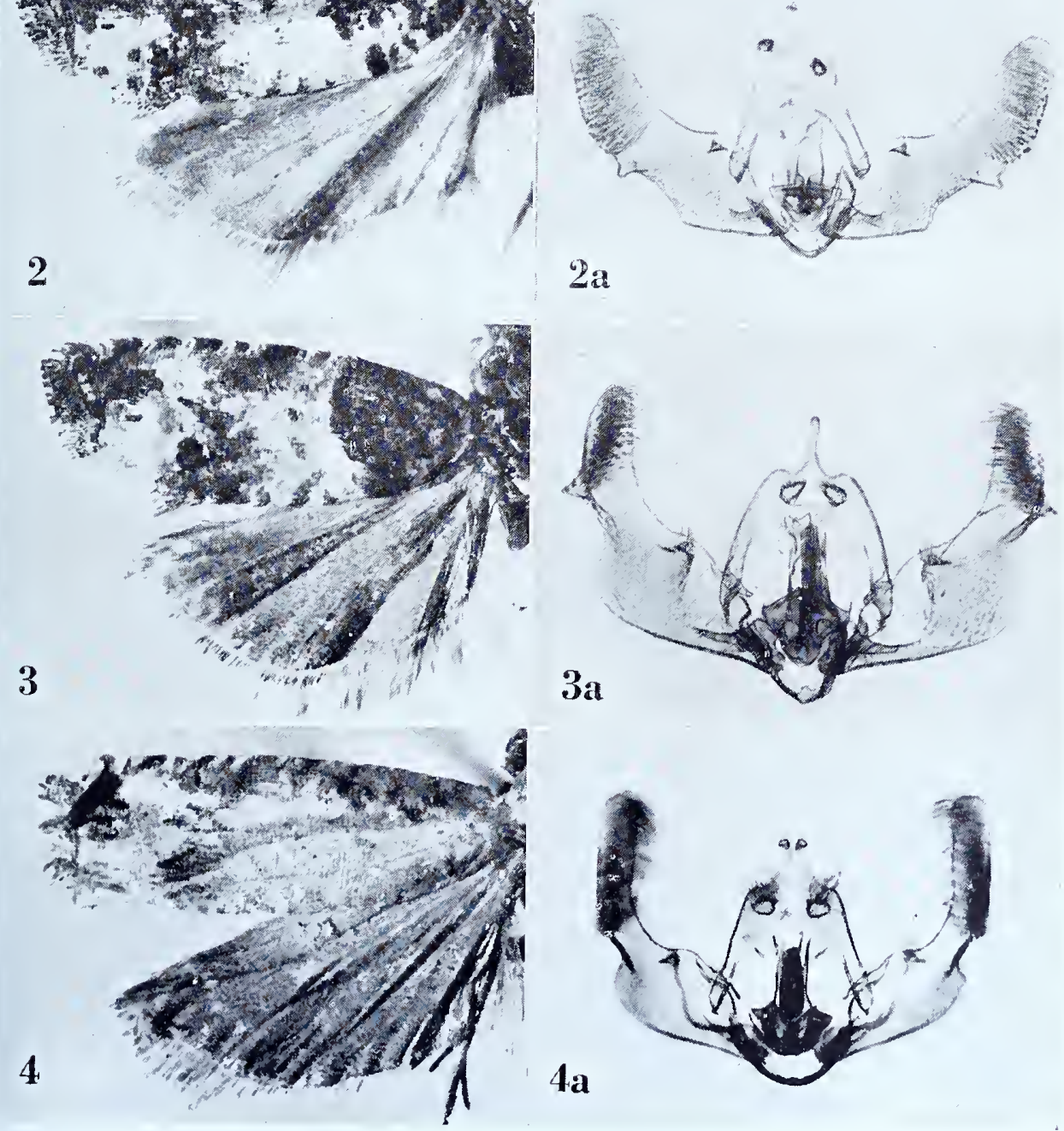

ENDOTHENIA and EPIBLEMA 

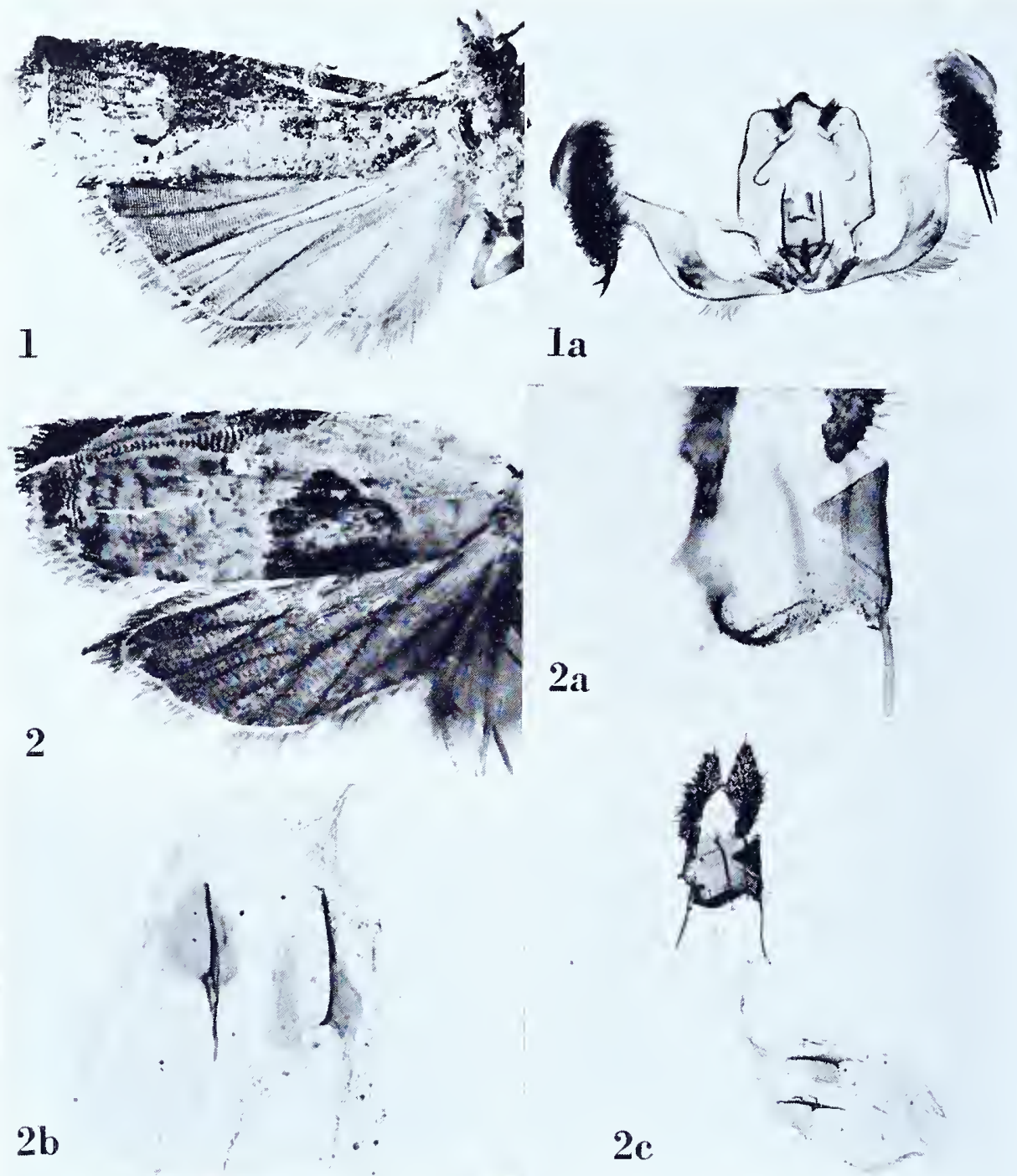

$2 b$
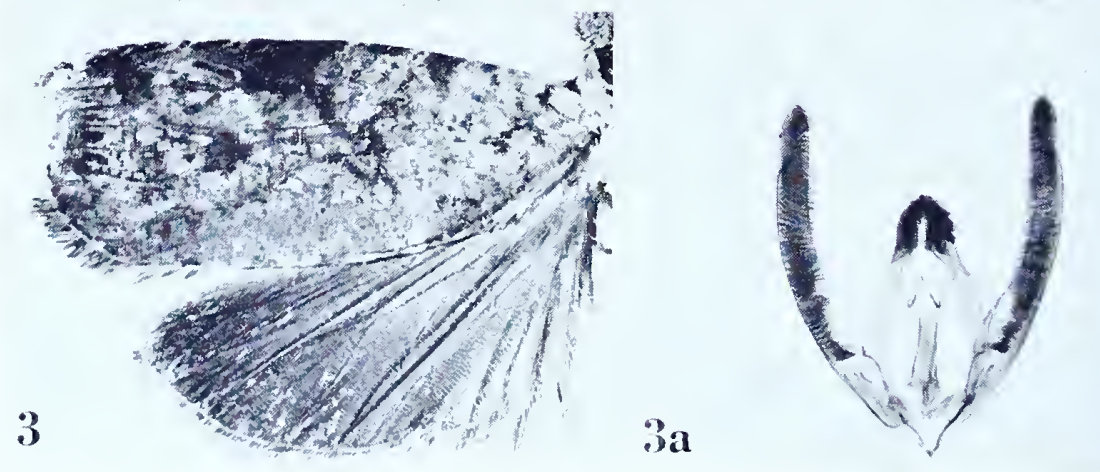

EPINOTIA and EPISIMUS 


\section{EPINOTIA Hübner}

\section{Epinotia ancyrota (Meyrick), new combination}

Plate i66, Figures I-Ia

Epiblema ancyrota Meyrick, 1907, Journ. Bombay Nat. Hist. Soc., I7: 733.

“ $\hat{\circ}$. 22-25 mm. . . Maskeliya, Ceylon; in January, March, June, and August, five specimens (Pole, de Mowbray)."

Lectotype: A male measuring $22 \mathrm{~mm}$., "Maskeliya, Ceylon. Pole. .6.05." Slide No. 7035 .

Figure I, left wings; ra, ventral view of male genitalia with aedeagus in situ.

\section{EPISIMUS Walsingham \\ Episimus atricapilla (Meyrick)}

Plate 166, Figures 2-2c

Eucosma atricapilla Meyrick, I917, Trans. Ent. Soc. London, I917: 2 I.

“․ $12 \mathrm{~mm}$. . . B British Guiana, Bartica, in February (Parish); one specimen."

Type: The female indicated above and dated ".2.13". Slide No. 6396.

Figure 2, left wings; $2 \mathrm{a}$, detail of genital plate and ostium; 2b, signa; 2 , ventral view of female genitalia.

\section{Episimus caveata (Meyrick), new combination \\ Plate 166 , Figures $3-3$ a}

Argyroploce caveata Meyrick, I912, Trans. Ent. Soc. London, I9 Ir: 691.

"ㅇ․ $22 \mathrm{~mm}$. . . Venezuela, Palma Sola; one specimen."

Type: The specimen indicated above, without abdomen, with "D. .o6" at the bottom of the pin-label. Genitalia figured from a male in the Meyrick collection, "R. Maroni, Fr. Guiana. LeM. .I6." Slide No. 6424.

Figure 3 , left wings; 3 a, ventral view of male genitalia with aedeagus in sitn. 
EPISIMUS

\title{
Episimus digna (Meyrick)
}

\author{
Plate 167 , Figures $\mathrm{I}-\mathrm{Ia}$
}

Eucosma digna Meyrick, I917, Trans. Ent. Soc. London, 1917: 22.

“ J. I I-I2 mm. ... British Guiana, Bartica, in December (Parish); two specimens."

Lectotype: The larger of the two males. Slide No. 6402. Both specimens are dated “. 12.12 ".

Figure I, left wings; ra, ventral view of male genitalia with aedeagus in situ.

\section{Episimus encaustica (Meyrick)}

Plate $\mathbf{i} 67$, Figures $2-2 \mathrm{~b}$

Eucosma encaustica Meyrick, 1922, Exotic Microlepidoptera, 2: 5 I 8.

" $\hat{\sigma}^{\circ}+$. I $4^{-16} \mathrm{~mm}$. . . Brazil, Santarem, Obidos, Parintins, Manaôs, August to November (Parish); 6 ex."

Lectotype: The male, “Manaôs, Brazil, Parish. i r.19." Slide No. 6397.

Figure 2, left wings; $2 \mathrm{a}$, posterior tufts of abdomen of male; $2 \mathrm{~b}$, ventral view of male genitalia with aedeagus in sitn.

\section{Episimus lupata (Meyrick)}

Plate 167 , Figures $3-3$ a

Argyroploce lupata Meyrick, I9I2, Trans. Ent. Soc. London, I91 I : 690.

" f. $_{27} \mathrm{~mm}$... . Colombia, San Antonio, 5,80o feet, in November and December; two specimens."

Lectotype: The male dated ". I2.07”. Slide No. 6403.

Figure 3 , left wings; 3 a, ventral view of male genitalia with aedeagus in situ.

\section{Episimus melanaspis Meyrick}

Plate 167 , Figures $4-4 \mathrm{a}$

Episimus melanaspis Meyrick, I927, Exotic Microlepidoptera, 3:337.

" f. 2 I mm. . . . Colombia, San Antonio, 6,600 feet, February; I ex."

Type: The male indicated above dated “.2.20”. Slide No. 6398.

Figure 4, left wings; 4 a, ventral view of male genitalia with aedeagus in sitn.

See Eucosma mollita (Meyrick).

\section{Episimus mollita Meyrick}



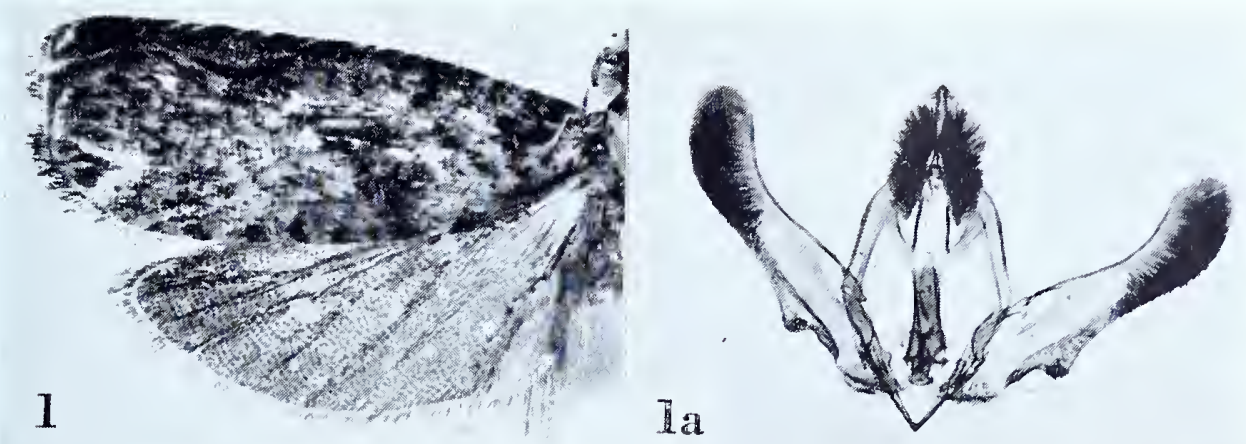

2
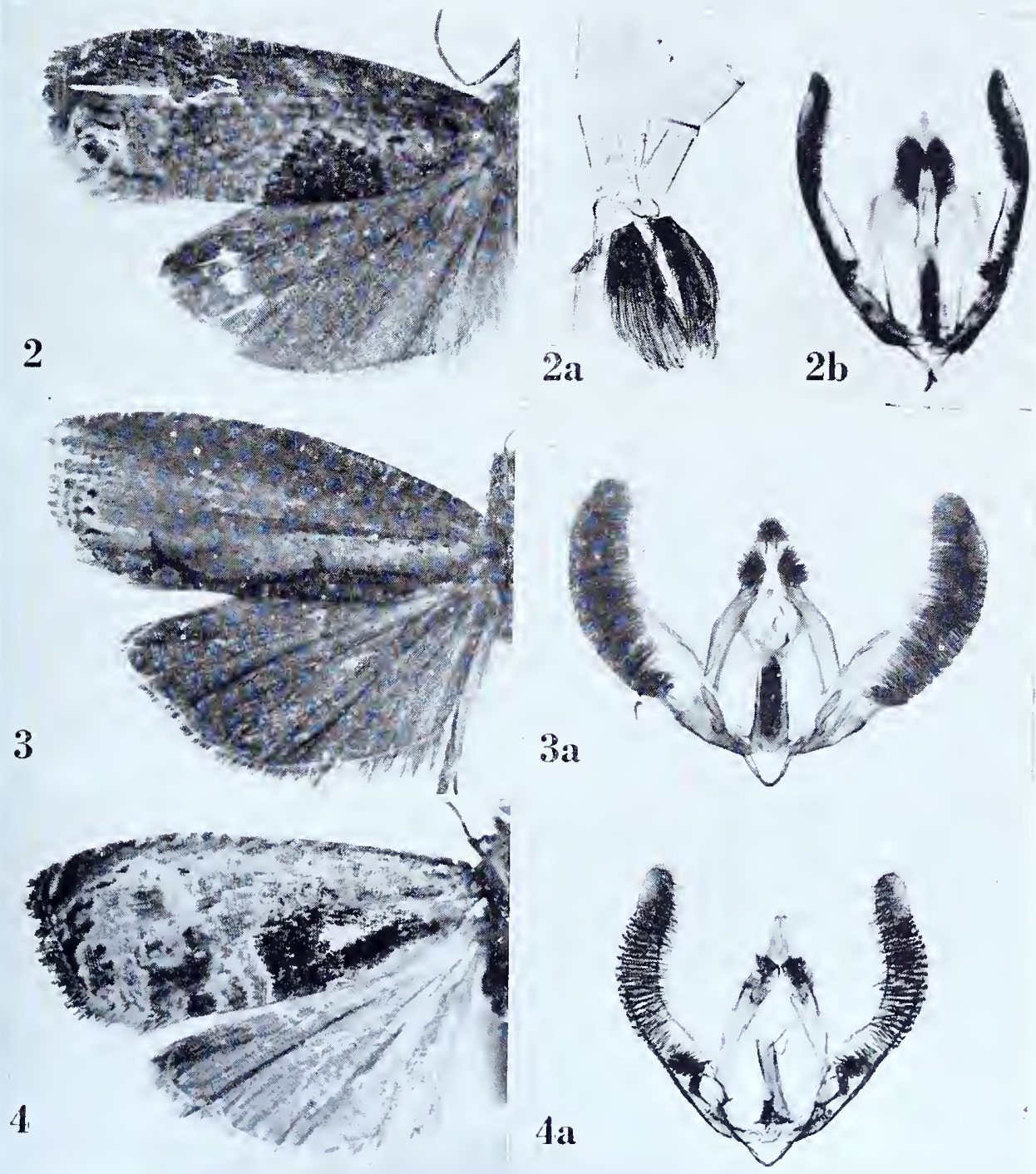


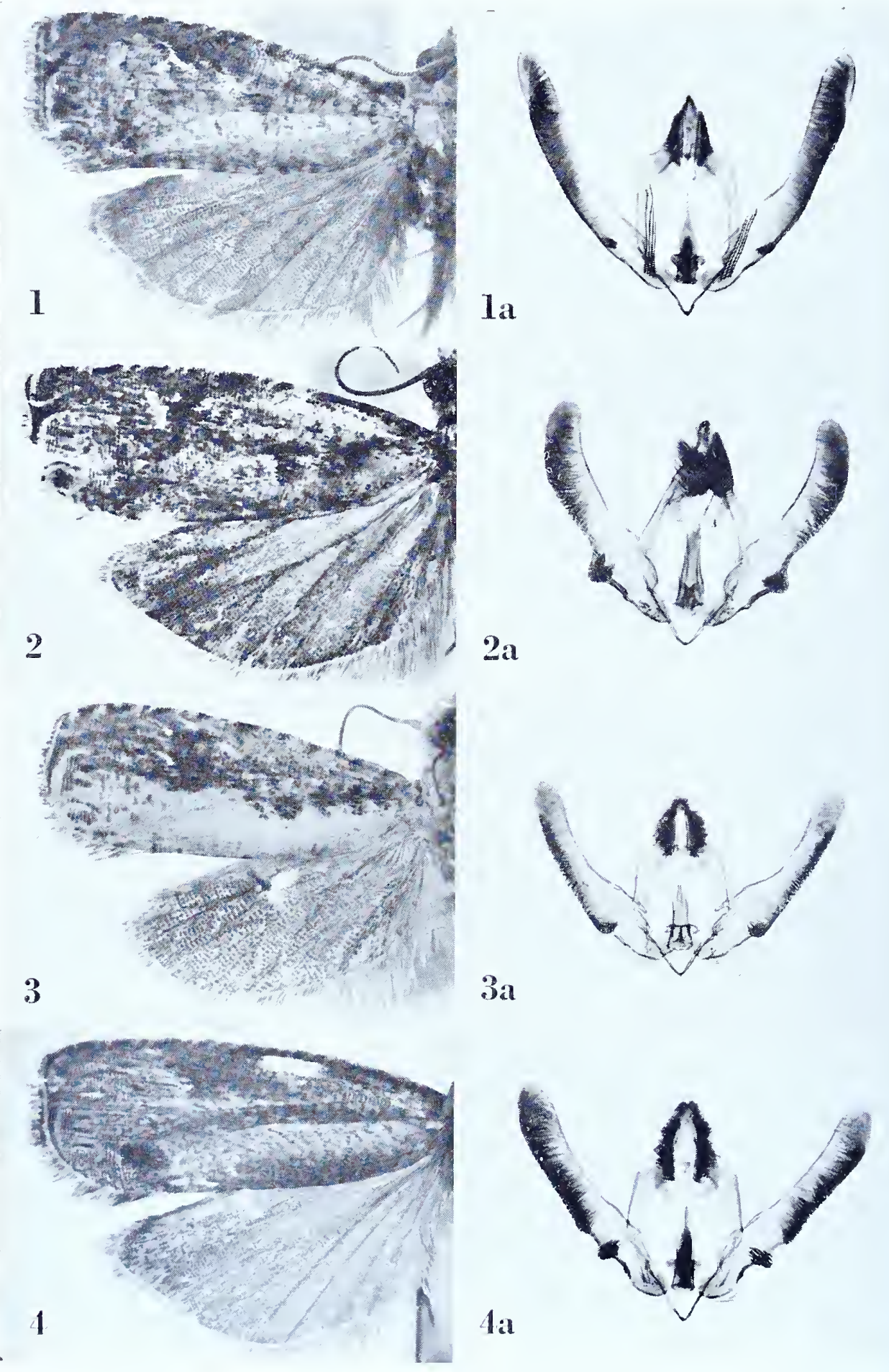


See Eucosma operta (Meyrick).

\section{Episimus operta Meyrick}

\section{Episimus ortygia (Meyrick) \\ Plate $\mathrm{I} 68$, Figures $\mathrm{I}-\mathrm{Ia}$}

Eucosina ortygia Meyrick, I917, Trans. Ent. Soc. London, 1917: 22.

" $\delta^{\circ}$. I $7-18 \mathrm{~mm}$.... British Guiana, Bartica and Mallali, from December to March (Parish); eleven specimens."

Lectotype: A male, "Mallali, Brit. Guiana. Parish. -3.13." Slide No. 6400. Three specimens are missing.

Figure I, left wings; Ia, ventral view of male genitalia with aedeagus in situ.

\section{Episimus prudens (Meyrick)}

Plate i 68, Figures 2-2a

Eucosma prudens Meyrick, I917, Trans. Ent. Soc. London, I917: 22.

" for $^{\circ}$ I $5 \mathrm{~mm}$. . . . Peru, Lima, in August (Parish); three specimens."

Lectotype: The male. Slide No.640I. The three specimens bear the date "8-14".

Figure 2, left wings; 2a, ventral view of male genitalia with aedeagus in situ.

\section{Episimus religiosa (Meyrick)}

Plate 168 , Figures $3-3$ a

Eucosma religiosa Meyrick, I9I7, Trans. Ent. Soc. London, I917:21.

" $\hat{\text {. }}$ I $2 \mathrm{~mm}$. . . . British Guiana, Bartica, in January (Parish); one specimen."

Type: The specimen indicated above dated ".I.I3". Slide No. 6392.

Figure 3 , left wings; $3^{\mathrm{a}}$, ventral view of male genitalia with aedeagus in situ.

\section{Episimus vermiculata (Meyrick)}

Plate I68, Figures $4^{-4 a}$

Argyroploce vermiculata Meyrick, 1912, Trans. Ent. Soc. London, I91 г : 690.

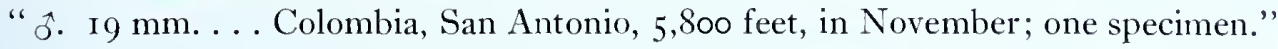
Type: The specimen indicated above and dated “. I1.07”. Slide No. 6399.

Figure 4, left wings; $4 \mathrm{a}$, ventral view of male genitalia with aedeagus in situ. 


\section{ERINAEA Meyrick}

Erinaea Meyrick, I907, Journ. Bombay Nat. Hist. Soc., i 8: I4I. (Typus generis: Erinaea chlorantha Meyrick, ibid. [monotypy].)

\section{Erinaea chlorantha Meyrick}

Plate i69, Figures I-ie

Erinaea chlorantha Meyrick, I907, Journ. Bombay Nat. Hist. Soc., I 8: I 4I.

“ ${ }^{*}+$. I I 7-2 I mm. ... Maskeliya, Ceylon, from December to April; nine specimens (Pole, de Mowbray)."

Lectotype: A female measuring $2 \mathrm{I}$ mm., "Maskeliya, Ceylon. de Mowbray. .I.04." Slide No. 7I 8 I. Four specimens are missing and none of the original males are available for study. The head of the lectotype is missing.

E. verditer Hampson is distinct from chlorantha and is hereby removed from synonymy.

Figure I, left wings; $\mathrm{ra}$, venation of right wings; $\mathrm{ib}$, lateral aspect of head to show palpus (second specimen); Ic, ventral view of female genitalia; Id, signa; I e, detail of ostium. 

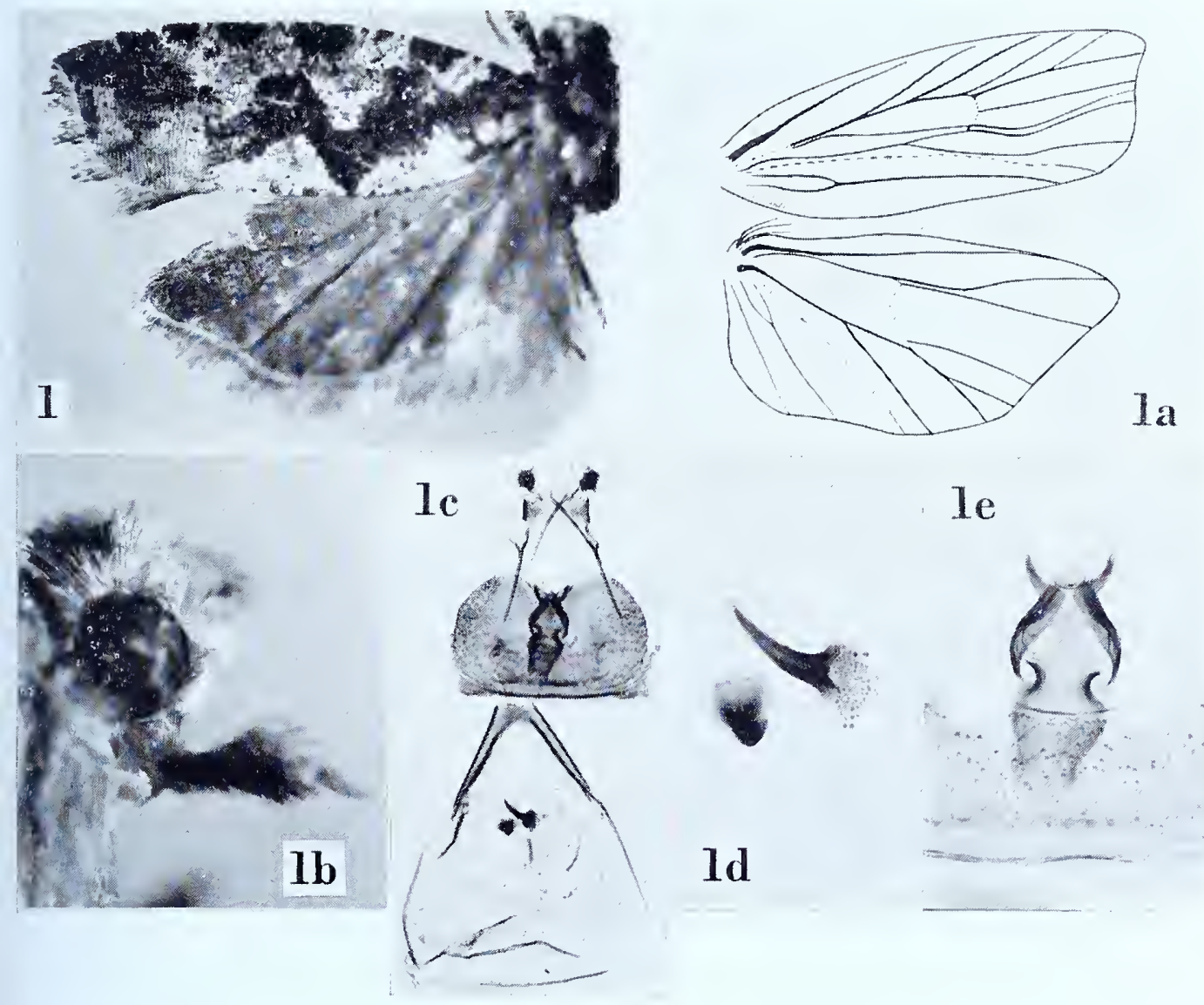

ERINAEA 

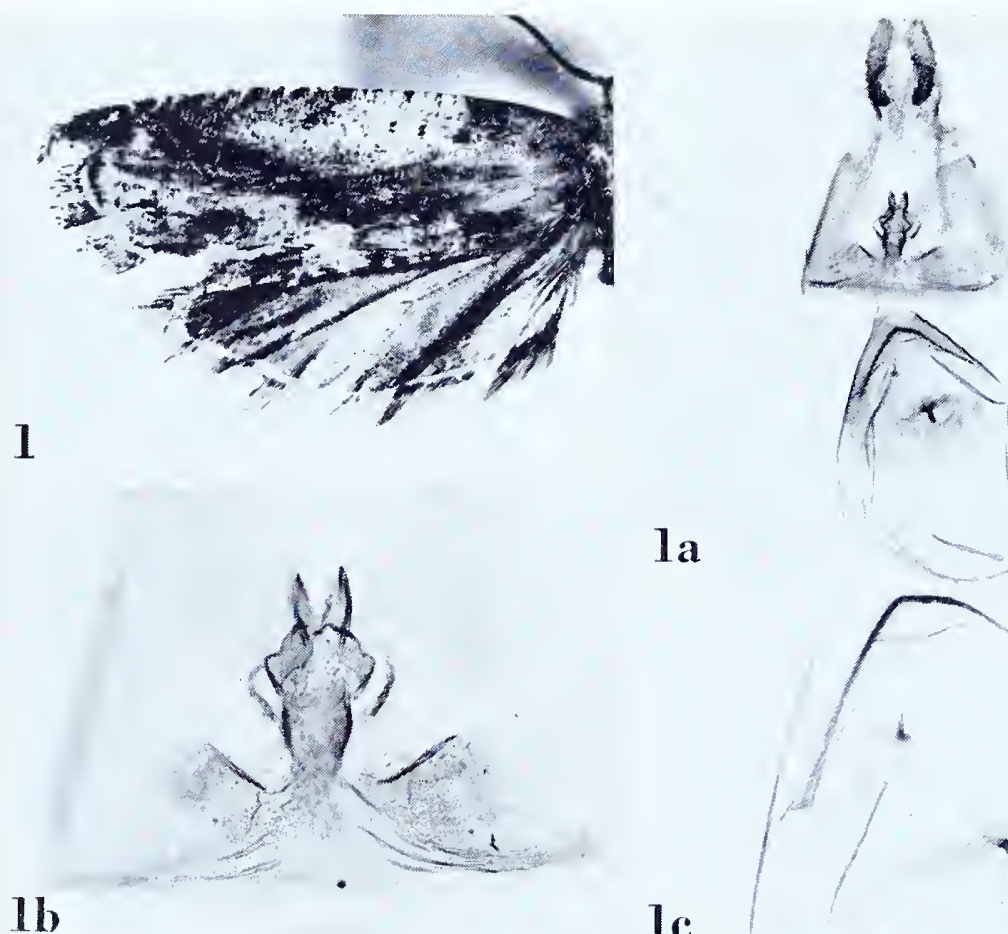

la

lc
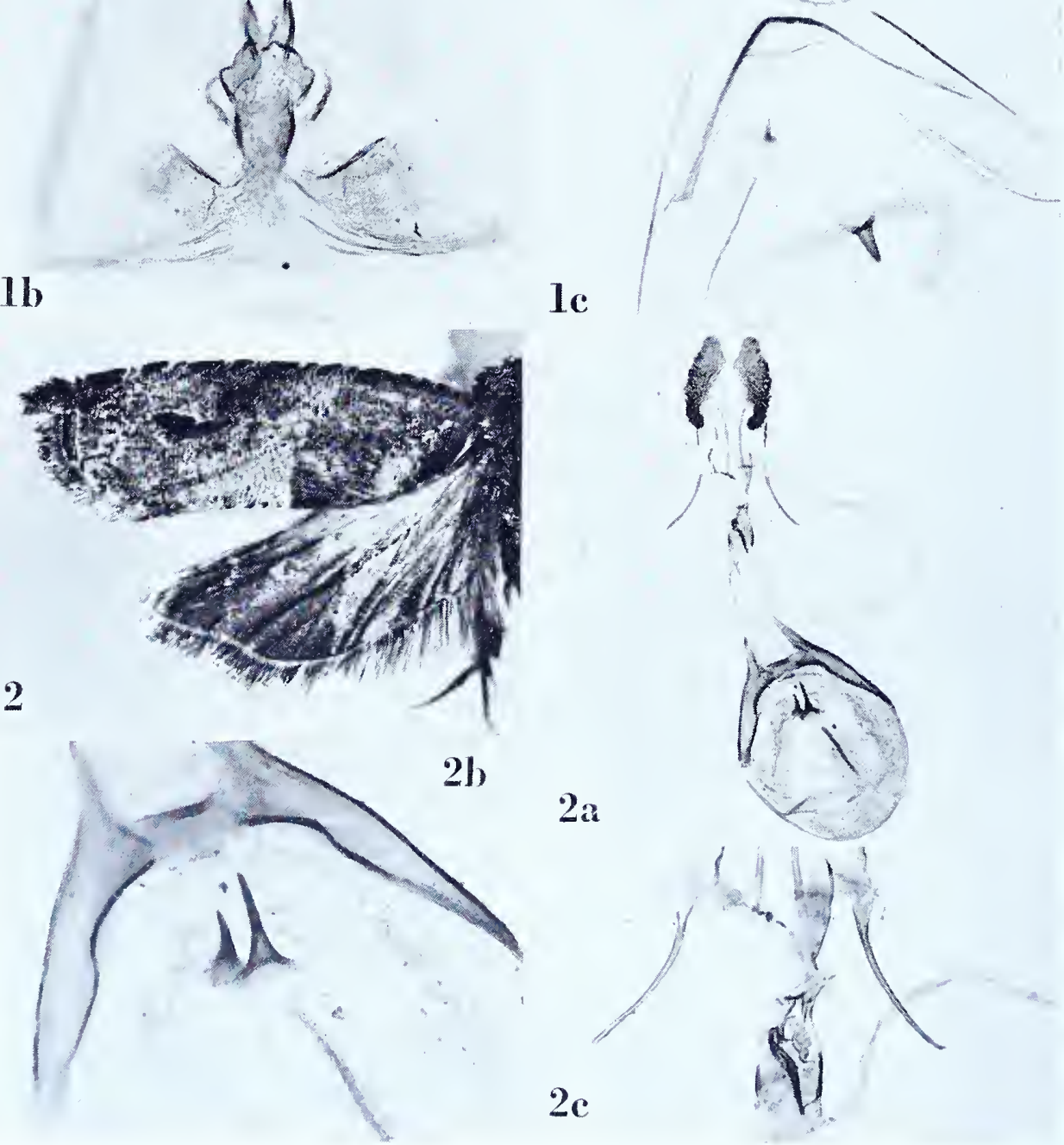

$2 \mathrm{a}$
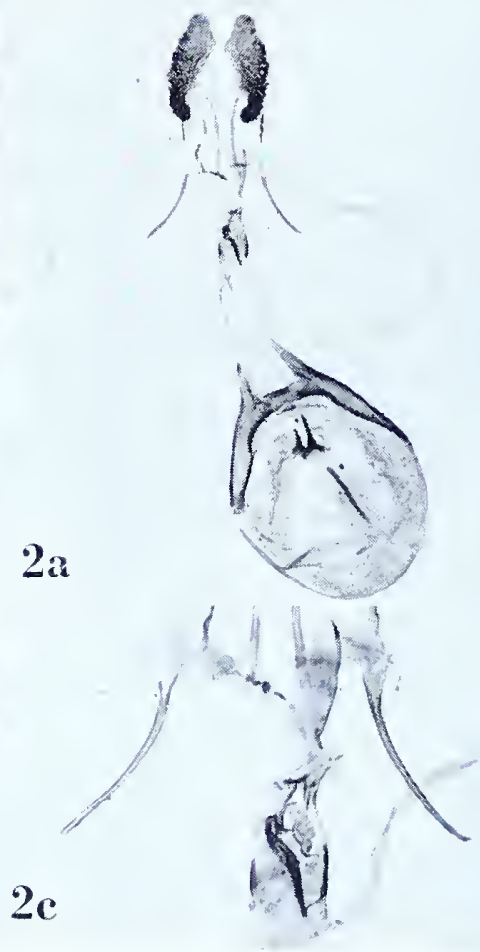

ERINAEA 


\section{Erinaea eclipticodes (Meyrick), new combination}

Plate 170 , Figures I-IC

Acroclita eclipticodes Meyrick, 1935, in Caradja and Meyrick, Materialien zu einer Microlepidopteren Fauna der Chinesischen Provinzen Kiangsu, Chekiang und Hunan, 52. “... . . I4 mm. ... I ex., Tienmushan, IV. Allied to gryphodes Meyr. from Ceylon."

Type: The above indicated female, "Tien-Mu-Shan, China. C. 5,000' .4.32." Slide No. 8539.

Figure I, left wings; 1 a, ventral view of female genitalia; $\mathbf{c} b$, detail of genital plate and ostium; Ic, signa.

\section{Erinaea microrrhyncha (Meyrick), new combination}

Plate 170 , Figures 2-2c

Acroclita microrrhyncha Meyrick, I93 I, Exotic Microlepidoptera, 4: I27.

"q. 15 mm. . . Indian N.W. Frontier, Parachinar, bred October from leaves of apple collected September (Mujtaba); I ex. Allied to naevana, but broader winged."

Type: The female indicated above dated ".9.17". Slide No. 6939. In conversation with Dr. Diakonoff he informed me that microrrhyncha is a synonym of E. naevana (Hübn.) and credit for this synonymy belongs to him.

Figure 2, left wings; $2 a$, ventral view of female genitalia; $2 b$, signa; $2 c$, detail of ostium. 


\section{EUCOENOGENES Meyrick}

Eucoenogenes Meyrick, I938, Trans. R. Ent. Soc. London, 89:49. (New name for Caenogenes Meyrick, 1937 [preoccupied].)

Caenogenes Meyrick, 1937, Exotic Microlepidoptera, 5: 159. (Typus generis: Caenogenes melanancalis Meyrick, 1.c., I60 [monotypy].)

\section{Eucoenogenes melanancalis (Meyrick), new combination}

Plate i 7I, Figures I-I

Caenogenes melanancalis Meyrick, I937, Exotic Microlepidoptera, 5: I60.

“㷏 $\quad$ I $2 \mathrm{~mm}$. ... India, U.P. Dehra Dun, bred May from larvae mining leaves of Eugenia jambolana (R. N. Mather); 2 ex."

Lectotype: The female, "Dehra Dun, India. RNM. bred. .5.36." Slide No. 7II6. The male is missing.

Figure I, left wings; Ia, venation of right wings; $\mathrm{Ib}$, lateral aspect of head to show palpus; Ic, signa; Id, ventral view of female genitalia; I e, detail of genital plate and ostium. 


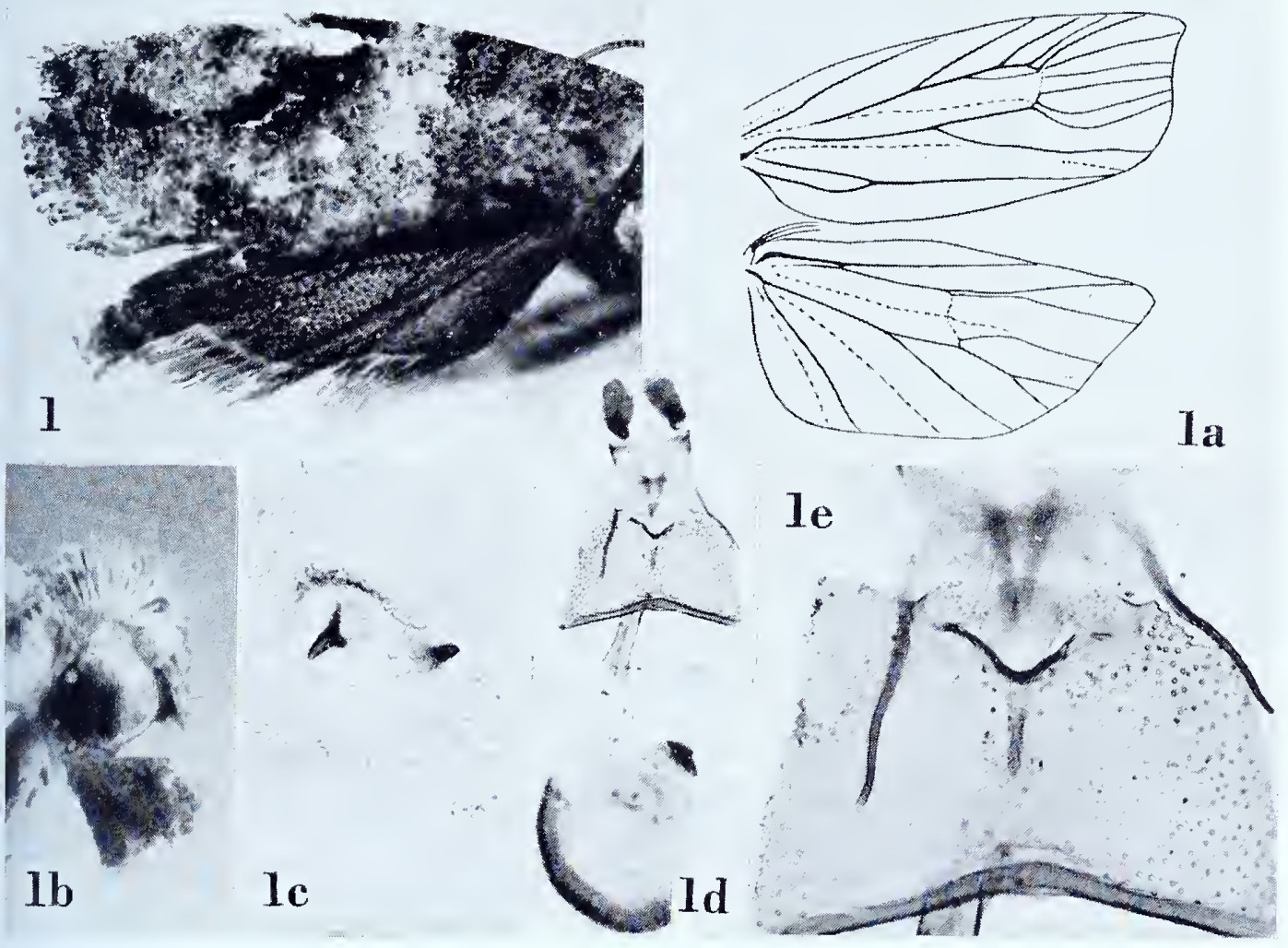

EUCOENOGENES 


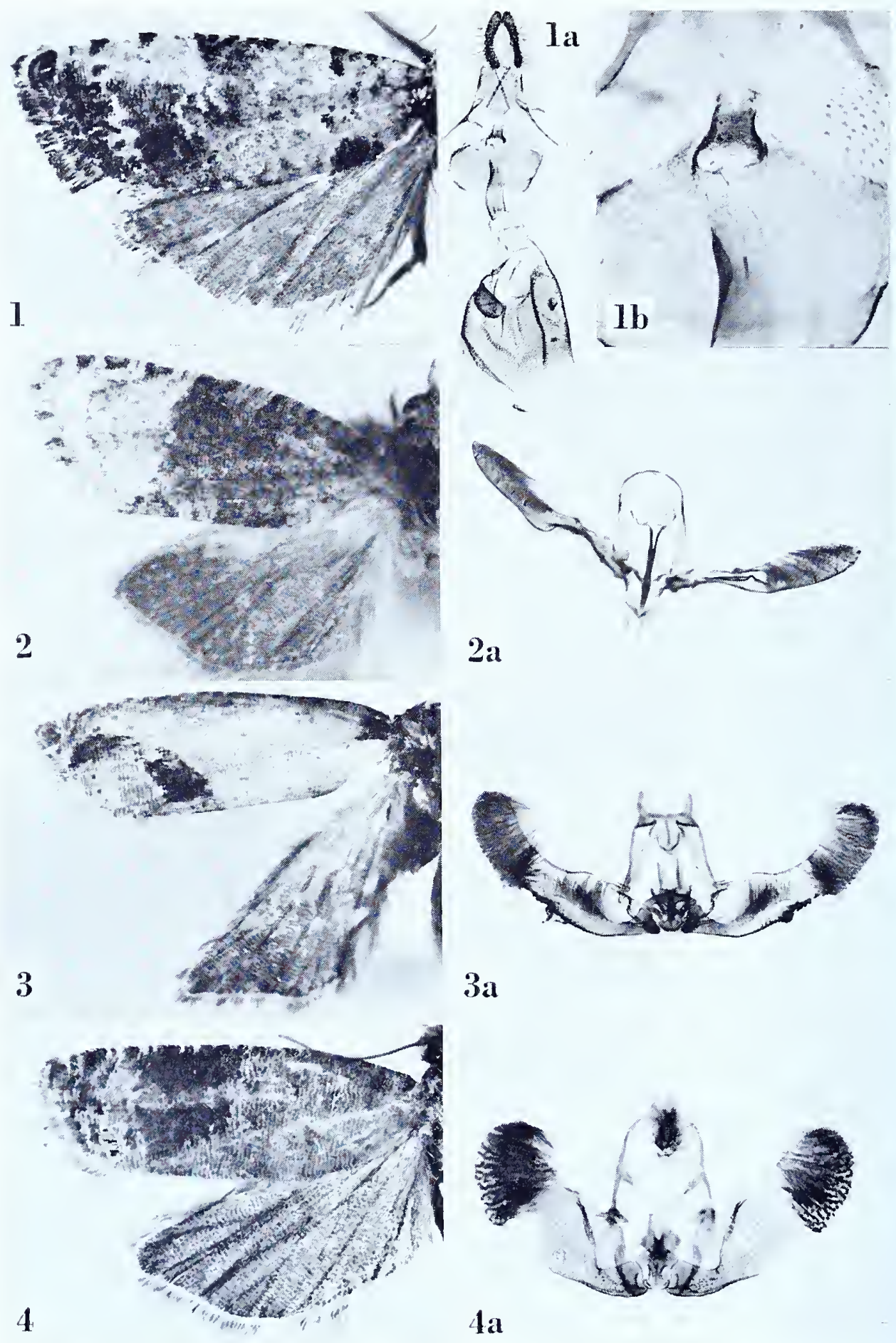




\section{EUCOSMA Hübner \\ Eucosma abathrodes (Meyrick), new combination}

Plate $\mathrm{I} 72$, Figures $\mathrm{I}-\mathrm{Ib}$

Gypsonoma abathrodes Meyrick, I937, in Caradja and Meyrick, Deuts. Ent. Zeit. Iris, 5 I: 177 .

“.. ․ $19 \mathrm{~mm}$. ... Y Yül., 4,000 m. VII, ı ex."

Type: The female denoted above, "Likiang, China. H. .7.34." Slide No. 7 Io3.

Figure I, left wings; ra, ventral view of female genitalia; $\mathrm{rb}$, detail of genital plate and ostium.

\section{Eucosma agriochlora Meyrick}

Plate I72, Figures 2-2a

Encosma agriochlora Meyrick, I929, Trans. Ent. Soc. London, 76: 495 .

" o. $7 \mathrm{~mm}$., Marquesas, Nuka Hiva, January, at light; i ex."

Type: The above indicated specimen so labelled in the British Museum, "Nuka Hiva, Marquesas, at light. I8.I.1925. C. L. Collenette." Slide No. 7009.

Figure 2, left wings; 2a, ventral view of male genitalia with aedeagus in situ.

\section{Eucosma antrifera Meyrick}

Plate I72, Figures $3-3$ a

Encosma antrifera Meyrick, I935, in Caradja and Meyrick, Materialien zu einer Microlepidopteren Fauna der Chinesischen Provinzen Kiangsu, Chekiang und Hunan, $5^{6}$. "§. I 4 mm. . . . 2 ex., Tienmushan, X. ..."

Lectotype: The one remaining specimen in the Meyrick collection, "Tien-Mu-Shan, China. C. 5,000' .10.32." Slide No. 7102.

Figure 3 , right wings (image reversed); 3 a, ventral view of male genitalia with aedeagus in situ.

\section{Eucosma argyrocyma Meyrick}

\section{Plate i 72, Figures $4-4 \mathrm{a}$}

Eucosma argyrocyma Meyrick, I92 I, Exotic Microlepidoptera, 2: 447.

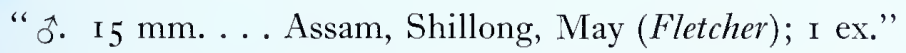

Type: The above indicated specimen, without abdomen, dated ".5.18". Male genitalia figured from a specimen, "Shillong, Assam, 5,000' TBF. .5.28." Slide No. 7094 .

Figure 4 , left wings; $4 \mathrm{a}$, ventral view of male genitalia with aedeagus $i n$ sitn. 
EUCOSMA

\section{Eucosma autolitha Meyrick}

Plate I73, Figures I-Ia

Encosma antolitha Meyrick, I93 I, Exotic Microlepidoptera, 4: I 45.

" ऊ. I 3 mm. . . Japan, Hasimoto, August (S. Issiki); I ex."

Type: The male denoted above dated "i 2.8. I9". Slide No. 7099.

Figure I, left wings; Ia, ventral view of male genitalia with aedeagus in situ.

\section{Eucosma axiotima Meyrick}

Plate 173, Figures 2-2a

Encosma axiotima Meyrick, I937, in Caradja and Meyrick, Deuts. Ent. Zeit. Iris, 5 г : 178. “... o. $28 \mathrm{~mm}$. . . Yül., VIII, 3,200 m., 4 ex. Similar to ocladias Meyr. . .."

Lectotype: A male measuring 28 mm., "Likiang, China. H. .8.34." Slide No. 7I21. Figure 2, left wings; 2 a, ventral view of male genitalia with aedeagus in situ.

\section{Eucosma bactropa Meyrick}

Plate 173, Figure 3

Eucosma bactropa Meyrick, 1927, Exotic Microlepidoptera, 3: 336.

" స. $22 \mathrm{~mm}$. . . Colombia, Alto de las Ances, 7,250 feet, March; I ex."

Type: The specimen indicated above, without abdomen, dated ".3.20".

Figure 3, left wings.

\section{Eucosma baryphragma Meyrick}

Plate 173 , Figures $4-4 b$

Encosma baryphragma Meyrick, I937, Exotic Microlepidoptera, 5: 159.

"૧. I6-I 7 mm. ... Fiji, Vunidawa, October, January (H. Phillips); 2 ex. Allied to the Indian perfectana Walk., but not closely."

Type: The female so marked in the British Museum, "Vunidawa, Fiji. I9.r.r933. H. Phillips 1005." Slide No. 7335.

Figure 4, left wings; 4 a, ventral view of female genitalia; 4 b, detail of genital plate and ostium. 

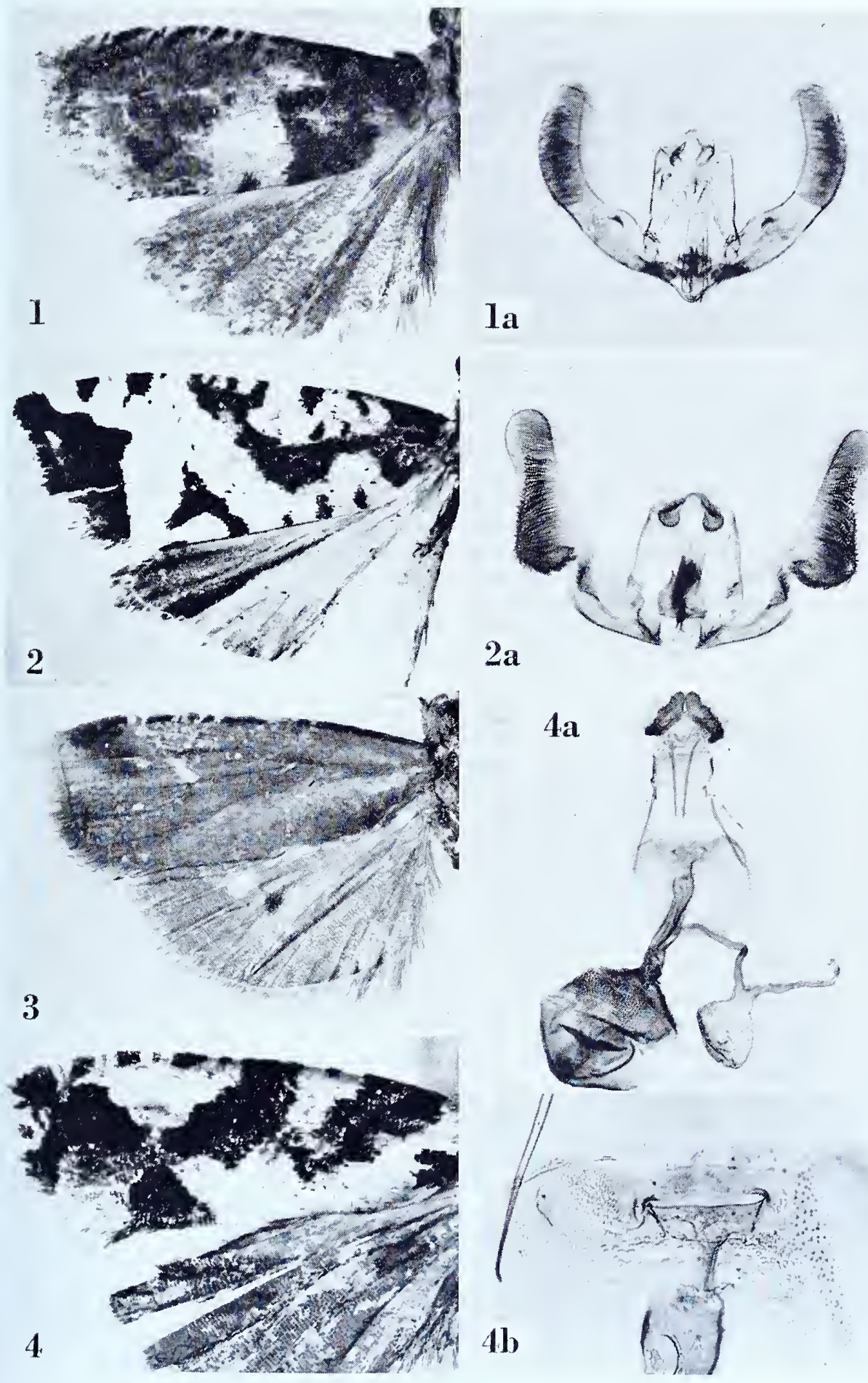

EUCOSMA 


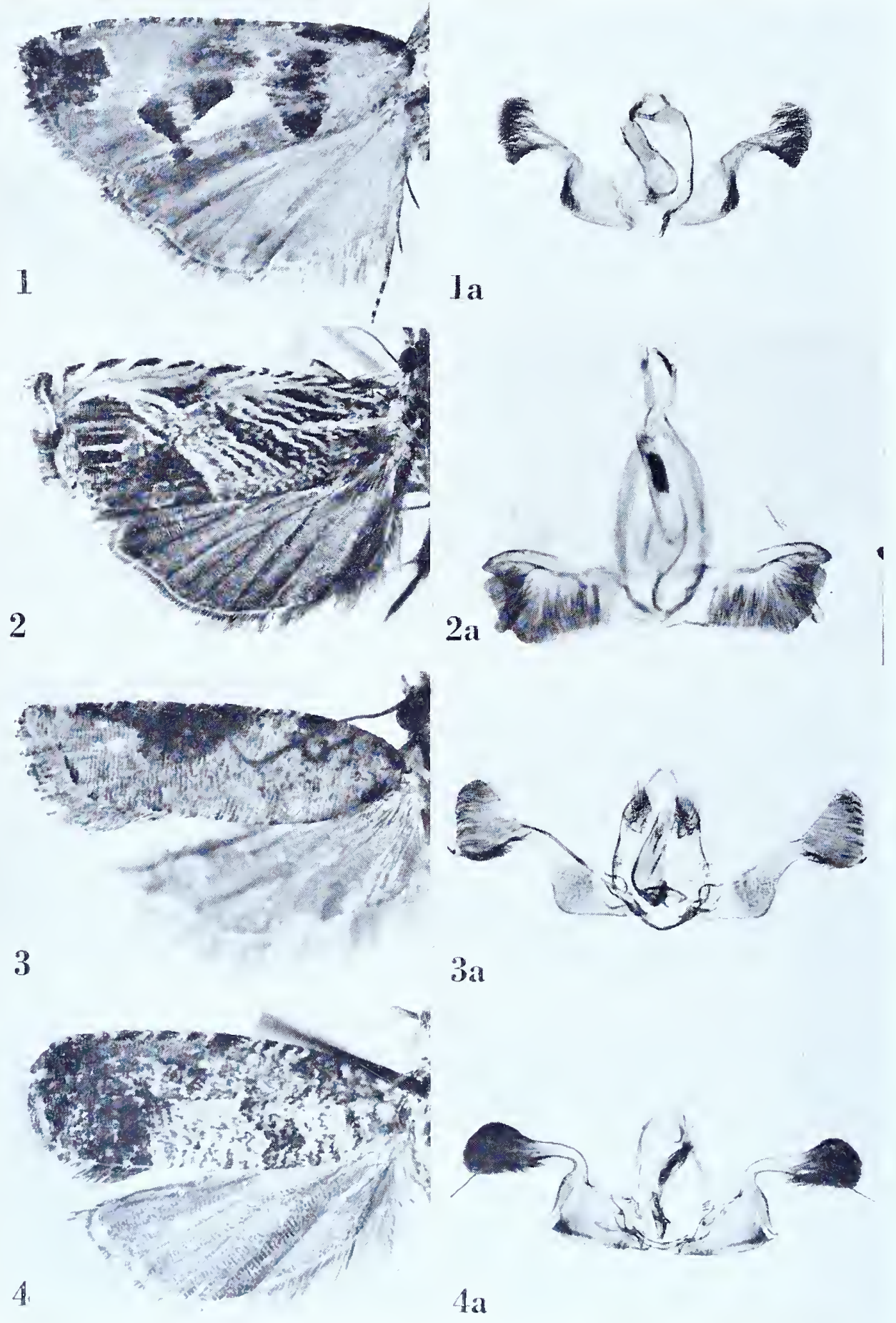




\section{Eucosma beryllina Meyrick}

Plate I74, Figures I-Ia

Eucosma beryllina Meyrick, 1927, Exotic Microlepidoptera, 3: 335 .

" oํ․ 25-27 mm. . . Colombia, Mt. Tolima, I0,500-1 2,500 feet, October, December; 2 ex."

Lectotype: The male, dated "12.20". Slide No. 6384. The female is missing.

Figure I, left wings; Ia, ventral view of male genitalia with aedeagus in sitı. There is a single, moderately large, seta from the cucullus.

\section{Eucosma calligrapha Meyrick}

Plate 174, Figures 2-2a

Eucosma calligrapha Meyrick, I9ı2, Journ. Bombay Nat. Hist. Soc., 21 : 865.

" 추․ I7-19 mm. ... Khasis; Dawna Hills, Burma (Annandale); from August to October, and in March, eight specimens. Allied to isogramma and speculatrix."

Lectotype: A male measuring 19 mm., "Khasi Hills, Assam. .ı.1906." Slide No. 6988.

Figure 2, left wings; $2 \mathrm{a}$, ventral view of male genitalia with aedeagus in situ.

\section{Eucosma capitulata (Meyrick)}

Plate 174, Figures 3-3a

Cydia capitulata Meyrick, I907, Journ. Bombay Nat. Hist. Soc., I8: 142.

" o. I $2-14 \mathrm{~mm}$. . . Maskeliya, Ceylon, in June and November; three specimens (Pole)."

Lectotype: The male dated "..11.05". Slide No. 6963.

Figure 3 , left wings; $3 \mathrm{a}$, ventral view of male genitalia with aedeagus in situ.

Eucosma cataglypta Meyrick

Plate 174 , Figures $4-4$ a

Eucosma cataglypta Meyrick, 1935, in Caradja and Meyrick, Materialien zu einer Microlepidopteren Fauna der Chinesischen Provinzen Kiangsu, Chekiang und Hunan, 55. " o. I $2 \mathrm{~mm}$. ... I ex. Shanghai. V. Perhaps related to trimaculana."

Type: The male indicated above, "Shanghai, China. C. 4.5.32." Slide No. 7097. Figure 4 , left wings; 4 a, ventral view of male genitalia with aedeagus in situ. 
EUCOSMA

\section{Eucosma catamochla Meyrick}

Plate 175 , Figures $I-I b$

Eucosma catamochla Meyrick, 1932, Exotic Microlepidoptera, 4:223.

“ 'ํ. I I-I3 mm. . . Java, teak-forest, bred July, August (Dr. L. G. E. Kalshoven); 5 ex. Obscure-looking but distinct."

Lectotype: A male measuring I3 mm., "Java. K. .7.31." Slide No. 7096. Two specimens are missing.

Figure $\mathrm{I}$, left wings; $\mathrm{I}$ a, posterior abdominal tufts; $\mathrm{rb}$, ventral view of male genitalia with aedeagus in situ.

\section{Eucosma ceriodes Meyrick}

Plate I75, Figures 2-2a

Eucosma ceriodes Meyrick, I909, Journ. Bombay Nat. Hist. Soc., 19: 607.

"๙ึ… . Khasis, from July to September; ten specimens. Allied to ancyrota Meyr...."

Lectotype: A male measuring 16 mm., "Khasi Hills, Assam. .9.1906." Slide No. 7088 .

Figure 2, left wings; 2a, ventral view of male genitalia with aedeagus in situ.

\section{Eucosma chaomorpha Meyrick}

Plate 175 , Figures $3-3$ a

Eucosma chaomorpha Meyrick, 1928, Trans. Ent. Soc. London, 76: 495 .

" o. I 5 mm., ․ $18-22$ mm. . . Marquesas, Nuka Hiva, Hiva Oa, up to 300 feet, December, January, at light; 4 ex."

Type: The male so marked in the British Museum, "Nuka Hiva, Marquesas. At light, roo ft., I5.r.25. C. L. Collenette." Slide No. 70 Io.

Figure 3, left wings; 3 a, ventral view of male genitalia with aedeagus in situ.

\section{Eucosma chlorobathra Meyrick}

Plate 175 , Figures $4-4 \mathrm{~b}$

Eucosma chlorobathra Meyrick, I9 I, Trans. Linnean Soc. London, 14: 268.

"ㅇ. 9-10 mm. ... Aldabra; two specimens."

Type: The female so marked in the British Museum, "Seychelles, Aldabra. Igo8. J. C. F. Fryer." Slide No. 7337.

Figure 4 , left wings; 4 a, ventral view of female genitalia; 4 b, detail of genital plate and ostium. 

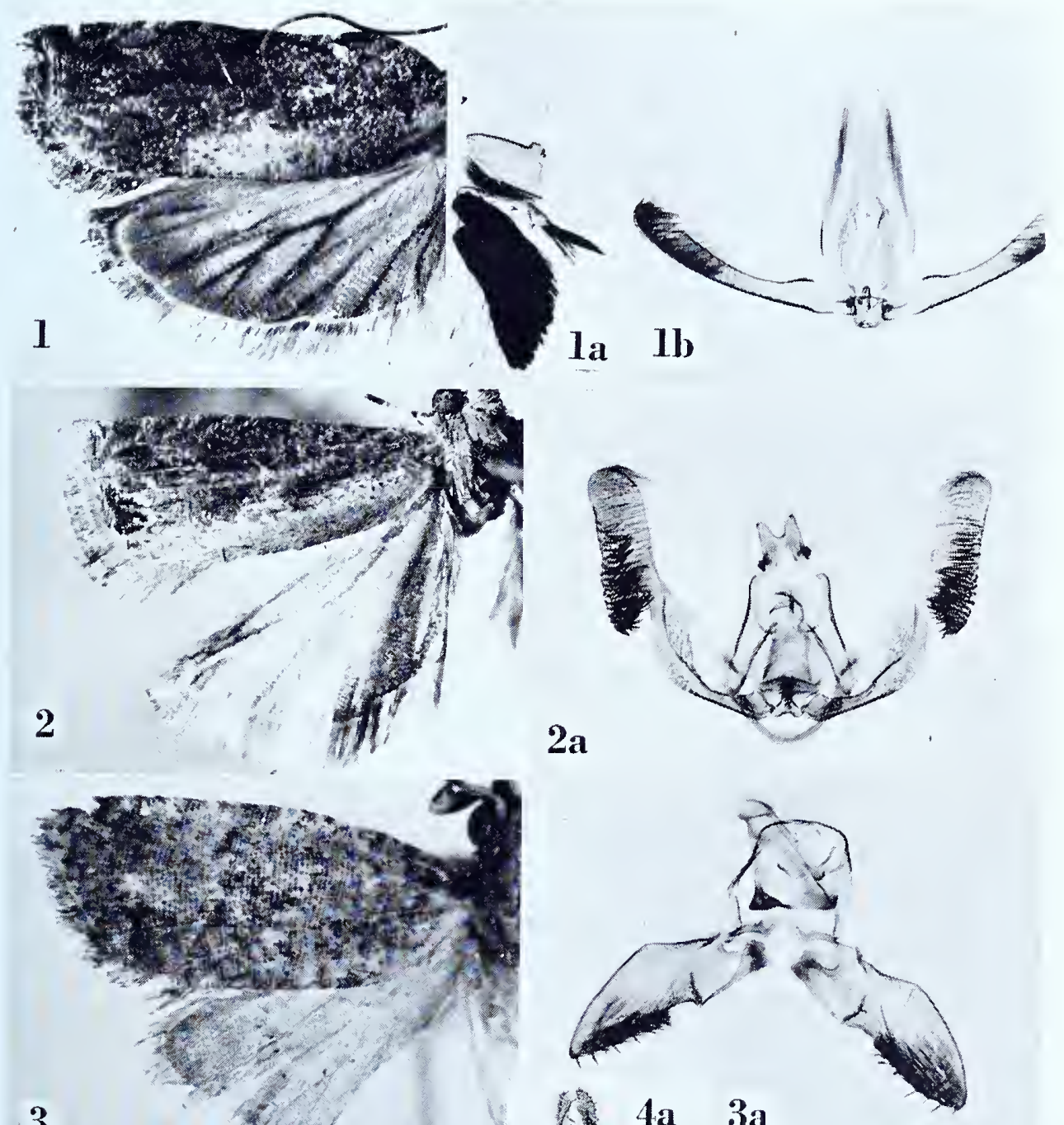

3 1.

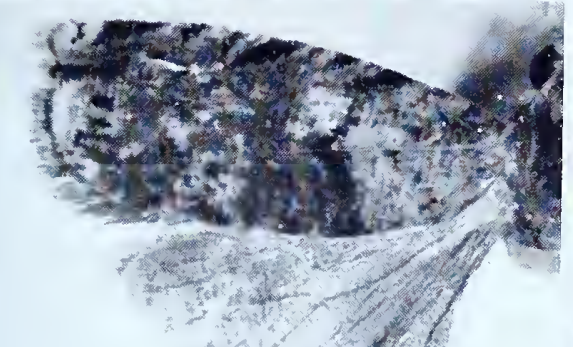

4

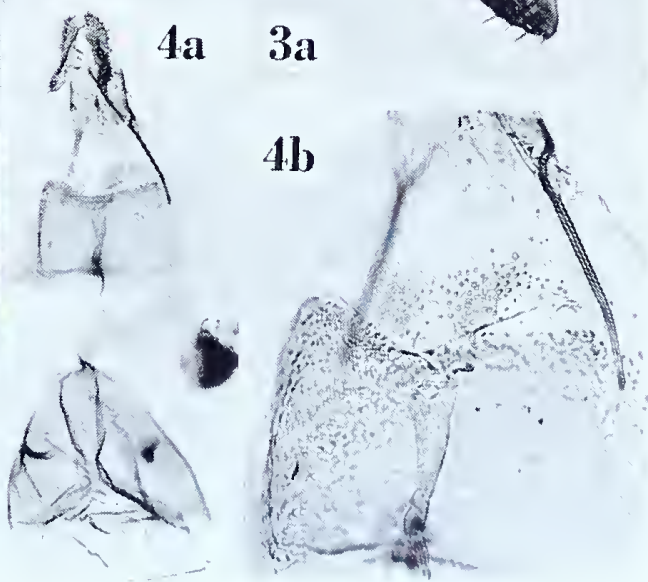

EUCOSMA 
Meyrick Catalogue

Vol. III. Plate i 76
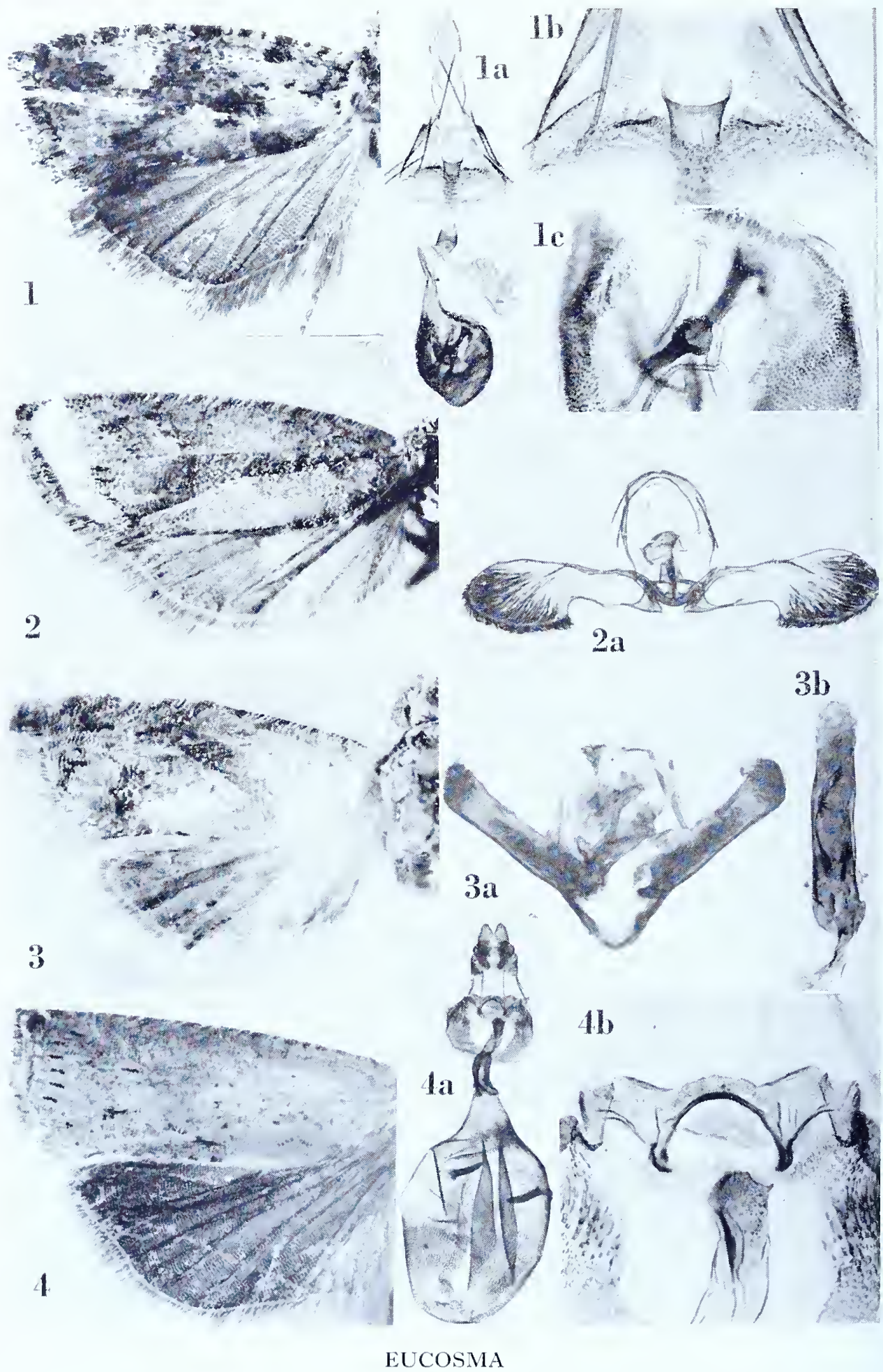


\section{Eucosma chloromima Meyrick}

Plate 176 , Figures I-I C

Eucosma chloromima Meyrick, I93 I, in Caradja, Bull. Sect. sci. Acad. roum., I4: 65.

"․ I 7-2 I mm. ... I ex., July; also I from Sikkim, 4,500 feet, August (Dndgeon), and I from Dalhousie, Kashmir, June. Allied probably to prominens. ..."

Lectotype: 'The female, "Kwanshien, China. F. .7.30." Slide No. 7095.

Figure I, left wings; гa, ventral view of female genitalia; ıb, ostium; гc, signa.

\section{Eucosma chloroterma Meyrick}

Plate i 76, Figures 2-2a

Encosma chloroterma Meyrick, I913, Ann. Transvaal Mus., 3: 272.

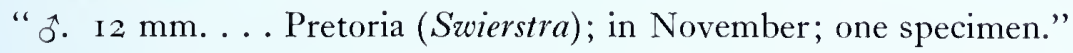

Type: The above indicated male, "Pretoria, Transvaal. CJS. 3.Ir.o6." Slide No. 9394 .

Figure 2, left wings; 2a, ventral view of male genitalia with aedeagus in sitn.

\section{Eucosma clepsidoma Meyrick}

Plate 176 , Figures $3-3 b$

Encosma clepsidoma Meyrick, I916, Exotic Microlepidoptera, 2: I8.

"․ $8 \mathrm{~mm}$. ... S. India, Coimbatore, bred in April from galls on an unidentified plant (Fletcher); one specimen."

Type: The specimen indicated above dated “.I.4.I4", erroneously recorded as a female. Slide No. 7046.

Figure 3 , left wings; 3 a, ventral view of male genitalia; 3 b, aedeagus (the genitalia are badly damaged by fungus).

\section{Eucosma climacosema Meyrick}

Plate 176 , Figures $4-4 \mathrm{~b}$

Encosma climacosema Meyrick, 1938, Trans. R. Ent. Soc. London, 87: 51 I.

"ㅇ. $19 \mathrm{~mm}$. . . S Sabron, 2,000 feet, July; I ex."

Type: The female indicated above, so marked in the British Museum, "Cyclops Mts., Sabron, British New Guinea. 2,00o ft. vii.ı936. L. E. Cheesman." Slide No. $701 \mathrm{I}$.

Figure 4 , left wings; $4 \mathrm{a}$, ventral view of female genitalia; 4 b, detail of genital plate and ostium. 


\section{Eucosma conciliata Meyrick}

Plate 177 , Figures $\mathrm{I}-\mathrm{I} b ; 2-2 \mathrm{a}$

Eucosma conciliata Meyrick, I920, Exotic Microlepidoptera, 2: 245.

Eucosma heteropa Meyrick, I920, Exotic Microlepidoptera, 2: 35 r.

[conciliata]

"ㅇ. I 2 mm. . . . Bengal, Pusa, bred April from larva on flowers of Butea frondosa (Fletcher); i ex."

Type: 'The female indicated above dated ".4.I7". Slide No. 7050.

Figure I, left wings; ra, ventral view of female genitalia; $r b$, detail of ostium.

[heteropa]

“ ${ }^{\circ}$. I mm. . . . Bengal, Pusa, May. Bred from pupa in rolled leaf (Fletcher); C. India, Dehra Dun, bred from shoots of Butea (Legunninosae) (Beeson); 2 ex."

Lectotype: 'The male, "Dehra Dun, U.P. India. CB. bred. .8. I 7." Slide No. 739 .

Figure 2, left wings; 2a, ventral view of male genitalia with aedeagus in sitn.

\section{Eucosma cremastropis Meyrick}

Plate 177 , Figures $3^{-3} \mathrm{~b}$

Encosma cremastropis Meyrick, I930, Exotic Microlepidoptera, 3: 599.

" ^o․ I $4^{-1} 5 \mathrm{~mm}$. . . U Uganda, Kampala, bred August from seeds of Podocarpus (Coniferae) imported from S. Africa (Hancock); 2 ex. Type Brit. Mus."

Type: The female so marked in the British Museum, "Kampala, Uganda. viii.r 928. G. L. R. Hancock." Slide No. 7333. A second label reads "From seeds of Podocarpus imported from S. Africa."

Figure 3 , left wings; 3 , ventral view of female genitalia; 3 b, detail of genital plate and ostium.

\section{Eucosma cremnitis Meyrick}

Plate 177 , Figures $4^{-4 a}$

Encosma cremnitis Meyrick, I912, Journ. Bombay Nat. Hist. Soc., 2 r : 864.

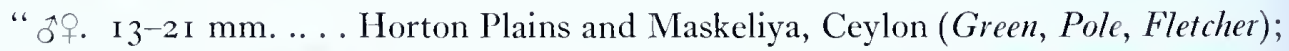
Palnis, 6,000 feet (Campbell); in August, and from March to May, twelve specimens."

Lectotype: The male labelled, "Maskeliya, Ceylon. Pole. 3.06." Slide No. 6984.

Figure 4 , left wings; 4 a, ventral view of male genitalia with aedeagus in sitn. 

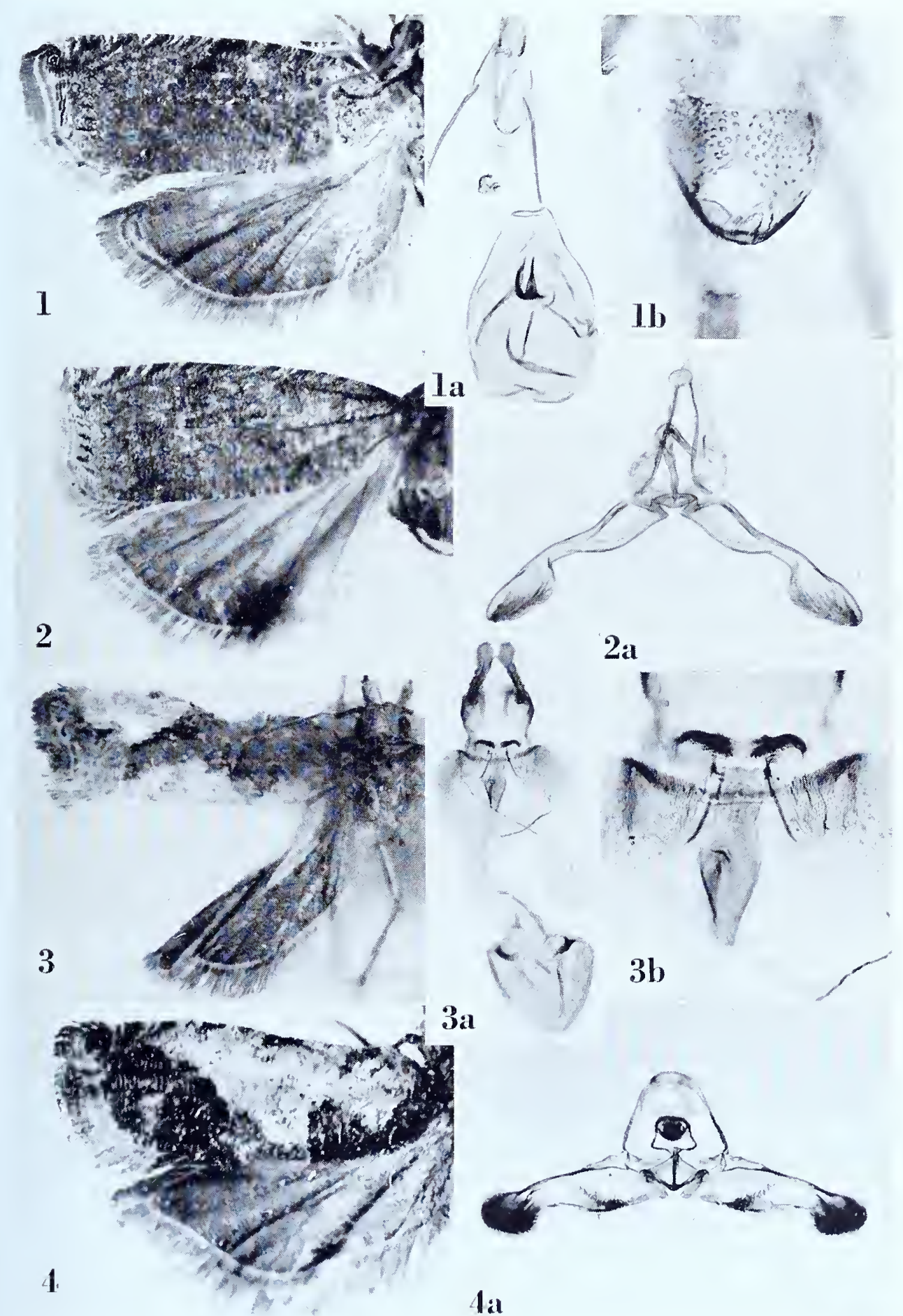

$3 a$

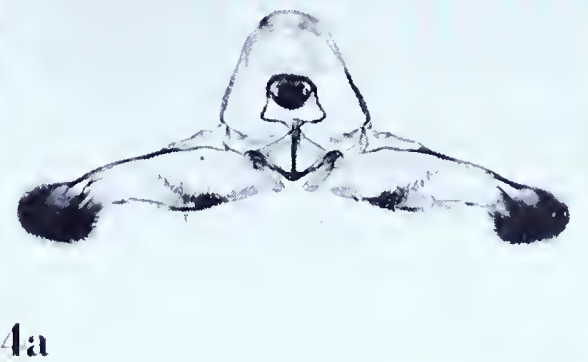



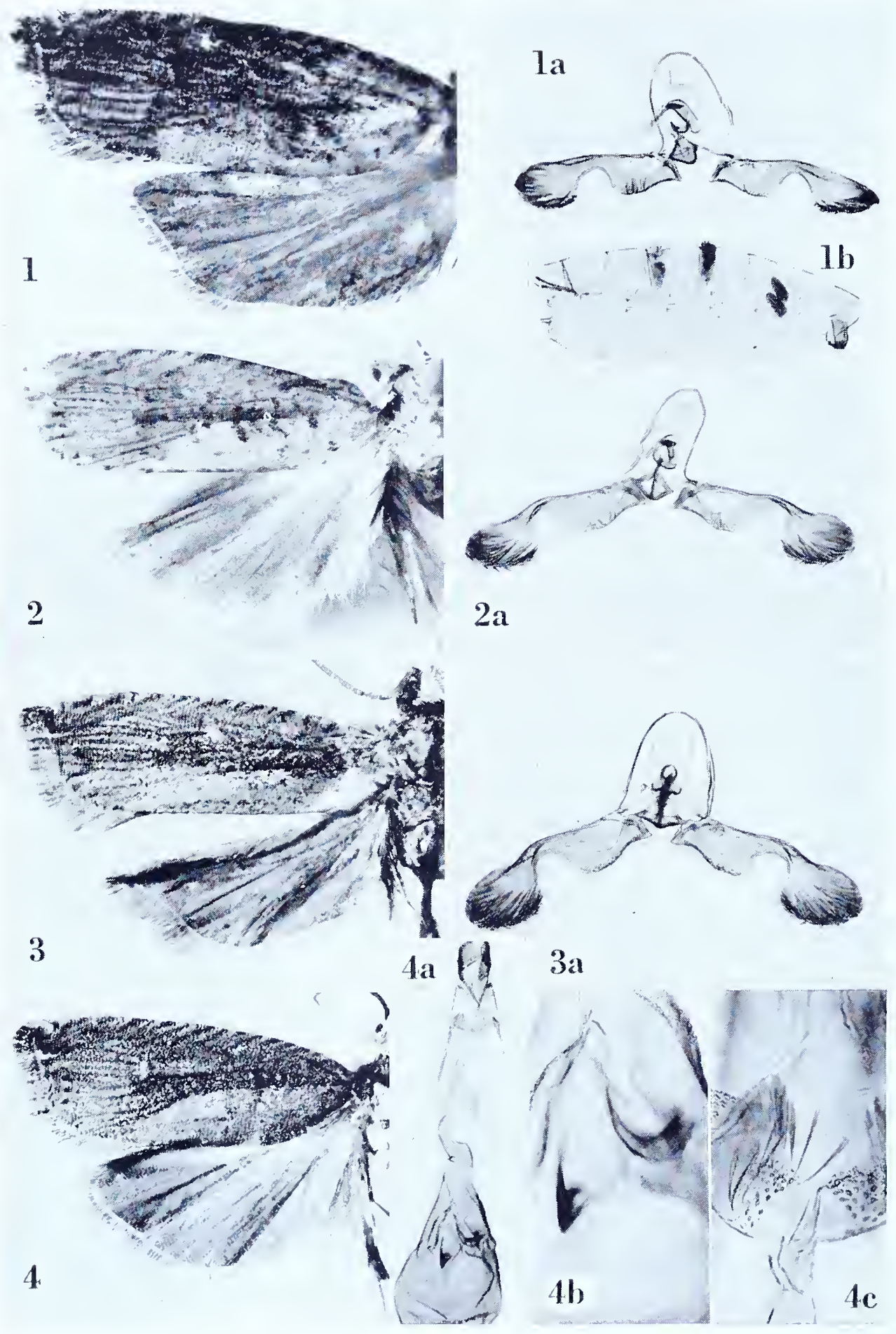

EUCOSMA 


\section{Eucosma critica (Meyrick)}

Plate I 78 , Figures I-I b; $2-2 \mathrm{a} ; 3-3 \mathrm{a} ; 4-4 \mathrm{c}$

Encelis critica Meyrick, 1905, Journ. Bombay Nat. Hist. Soc., I6: $5^{87}$.

Eucosma ludicra Meyrick, I9 2, Journ. Bombay Nat. Hist. Soc., 2 r : 867.

Encosma psendomorpha Meyrick, i9 6, Exotic Microlepidoptera, 2: i9 (new synonymy).

Encosma trichocrossa Meyrick, r9r6, Exotic Microlepidoptera, I : 563.

[critica]

" ô. I 2-I 4 mm. . . . Two specimens, Surat, Bombay, in October (Maxwell-Lefroy). Larva feeds in spun-up shoots of Cajanns indicus (Maxwell-Lefroy)."

Lectotype: The male measuring is mm., "Surat, Bombay. HML. 6/ro/04." Slide No. 7036.

Figure I, left wings; ra, ventral view of male genitalia with aedeagus in situ; rb, denuded abdomen to show tufts and modified $4^{\text {th }}$ and $5^{\text {th }}$ segments.

[ludicra]

" $\jmath^{7}+$. I3-I5 mm. . . . N. Coorg, 3,500 feet (Newcome); in November, four specimens.'

Lectotype: The male measuring I 3 mm., "Dibidi, N. Coorg. Newcome. .4.i i.o6." Slide No. 6994.

Figure 2, left wings; 2a, ventral view of male genitalia with aedeagus in sit $u$.

[pseudomorpha]

"․ $14 \mathrm{~mm}$. . . . Bengal, Pusa, in August (Fletcher); one specimen."

Type: The above indicated female dated "25.8.r 5 ”. Slide No. 7048.

Figure 4 , left wings; 4 , ventral view of female genitalia; 4 b, signa; $4 \mathrm{c}$, ostium.

[trichocrossa]

" $\$$. I 4 mm. . . . Bengal, Pusa, bred in May from larvae feeding in pods of Cajanns indicus (Fletcher); two specimens."

Lectotype: The specimen labelled, "Pusa, Bengal, TBF. bred. 4.5.I4." Slide No. 7037. A second label reads "e. 1. pods Cajanns indicns".

Figure 3, left wings; 3 a, ventral view of male genitalia with aedeagus in sitn. 


\section{Eucosma cyanopsis Meyrick}

Plate 179 , Figures $1-1 b ; 2-2 b$

Eucosma cyanopis Meyrick, I9r2, Journ. Bombay Nat. Hist. Soc., 2 I : 866.

Encosma melamochlaena Meyrick, 1936, Exotic Microlepidoptera, 4: 6I I (new synonymy). [cyanopis]

" $\mathrm{O}^{\mathrm{I}} \mathrm{I}^{-1} 5 \mathrm{~mm}$. ... Khasis; in September and October, two specimens."

Lectotype: The male labelled, "Khasi Hills, Assam. .9.1906." Slide No. 6991.

Figure I, left wings; Ia, denuded abdomen to show densely scaled pockets; $\mathrm{Ib}$, ventral view of male genitalia with aedeagus in sitm.

[melanochlaena]

“ ڤ. I4 mm. ... Java, Mt. Gedé, bred December from an unnamed plant (Dr. L. G. Kalshoz'en); i ex."

Type: The above indicated male dated “.12.33". Slide No. 7 Ior.

Figure 2, left wings; $2 \mathrm{a}$, denuded abdomen to show densely scaled pockets; $2 \mathrm{~b}$, ventral view of male genitalia with aedeagus $i n$ situ.

\section{Eucosma defensa Meyrick}

Plate 179 , Figures $3-3 \mathrm{c}$

Encosma defensa Meyrick, 1922, Exotic Microlepidoptera, 2: 517.

" 5 우. 10-12 mm. . . Fiji, Lautoka, bred in November and December from larvae feeding on leaves of Pongamia glabra (Legmminosae) (Greemwood); 4 ex. Type Brit. Mus."

Type: The female so marked in the British Museum and dated "zo.II [ I I ?]-I 92 I". Slide No. 7040. I suspect that "II" was mistaken for "I I".

Figure 3 , left wings; 3 , ventral view of female genitalia; 3 b, detail of genital plate and ostium; $3 \mathrm{c}$, signum.

\section{Eucosma dianthes Meyrick}

Plate 179, Figures 4-4a

Encosma dianthes Meyrick, 1928, Exotic Microlepidoptera, 3: 439.

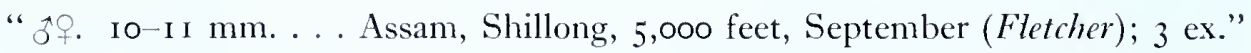

Lectotype: A male measuring I I mm., dated “26.9.27”. Slide No. 7093.

Figure 4 , left wings; 4 a, ventral view of male genitalia with aedeagus in sitı. 


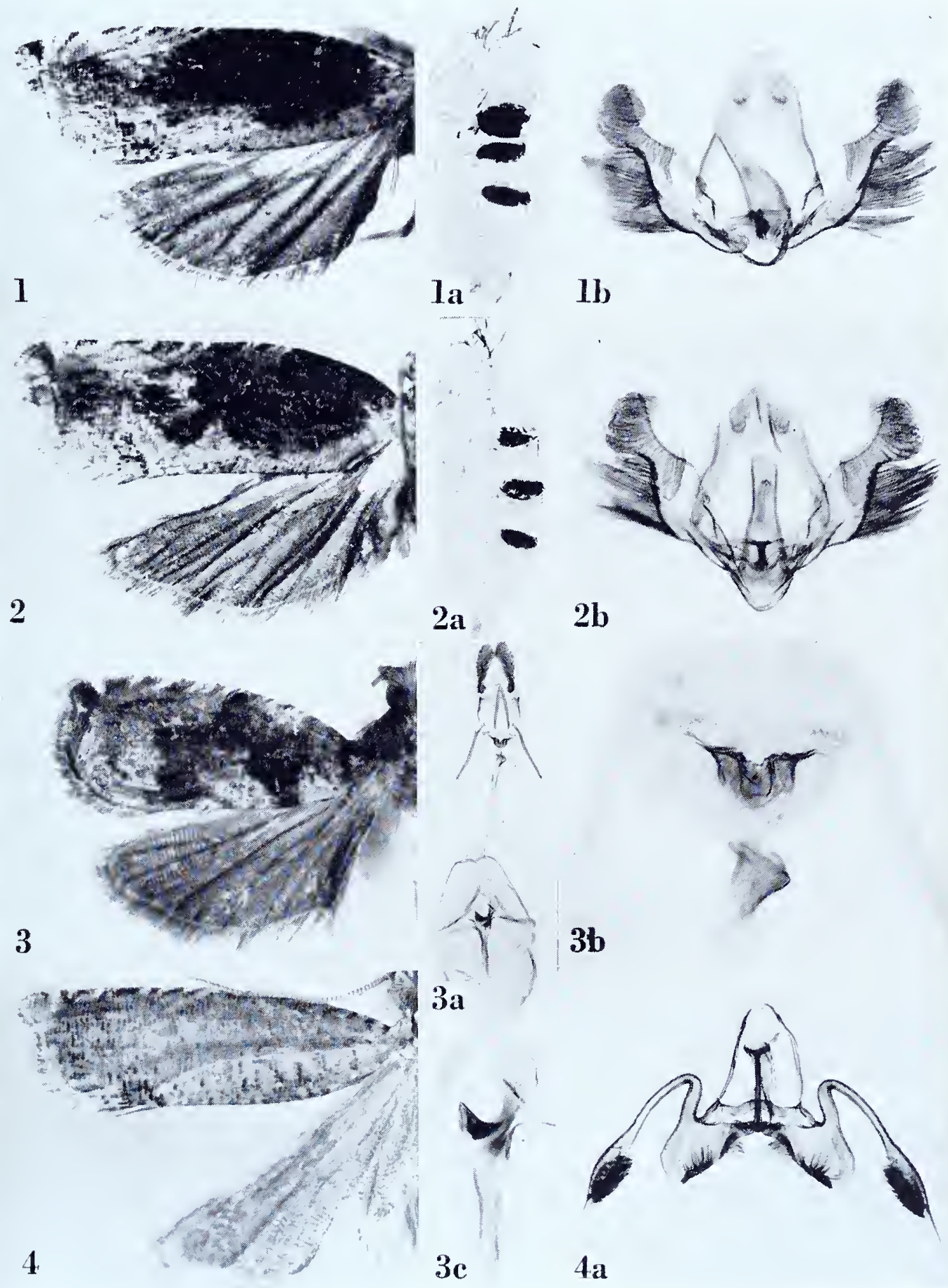




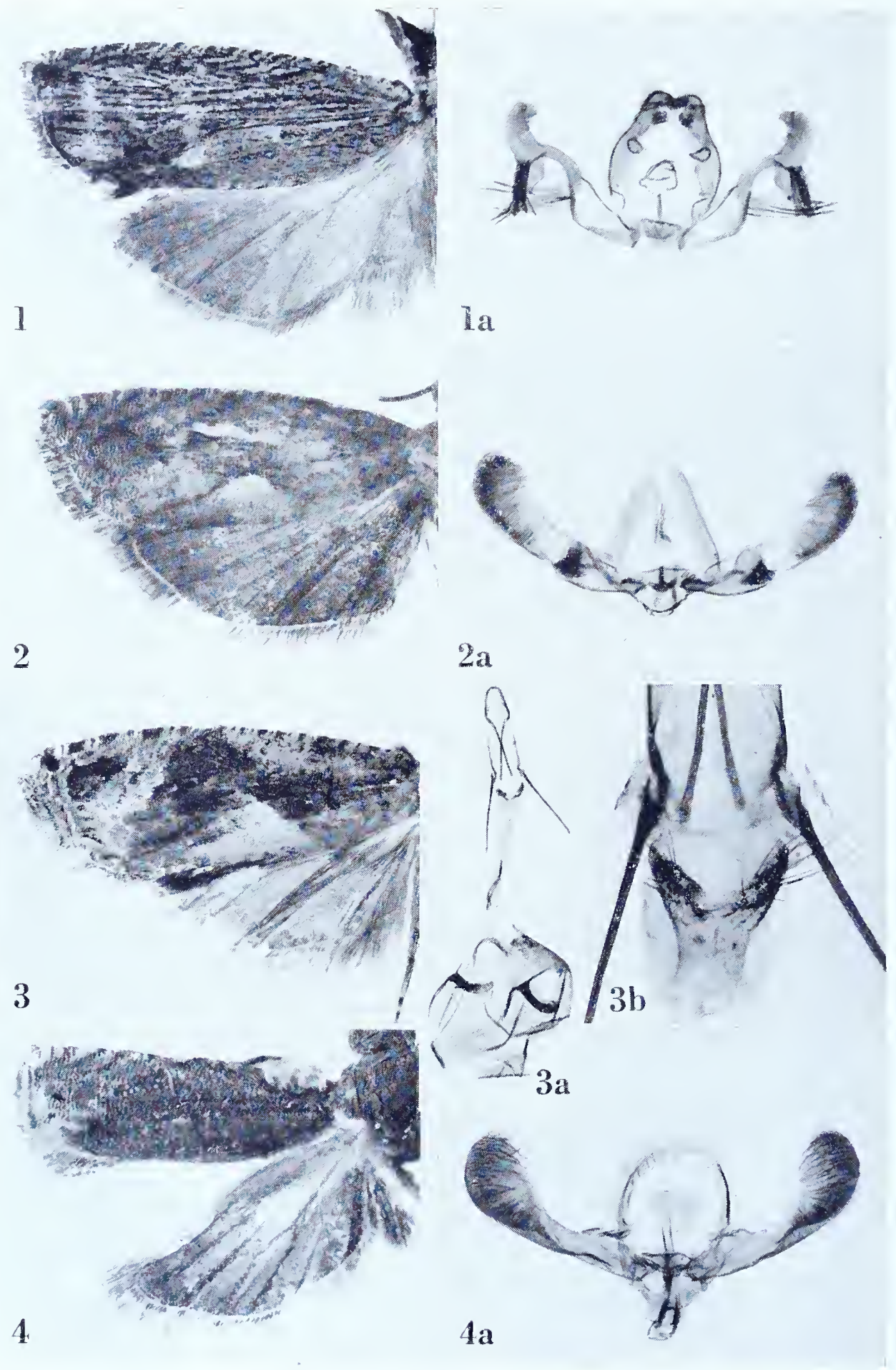


EUCOSMA

\section{Eucosma diogma Meyrick}

Plate i 80 , Figures I-I a

Encosma diogma Meyrick, 1927, Exotic Microlepidoptera, 3: 336.

" ึ. $22 \mathrm{~mm}$. . . . Colombia, Mt. Tolima, r2,500 feet, October; I ex."

Type: The specimen indicated above dated ".ro.20”. Slide No. 6382.

Figure I, left wings; ra, ventral view of male genitalia with aedeagus in sit $u$.

\section{Eucosma dryocarpa Meyrick}

Plate i 8o, Figures 2-2a

Eucosma dryocarpa Meyrick, 1925, Exotic Microlepidoptera, 3: 142.

" o. I 4 mm., q I 9 mm. . . India, U.P., Mussoorie, 6,500 feet, Dehra Dun, bred March from acorns of Quercus dilatata (Forest Zoologist); 2 ex."

Lectotype: The male, "Mussoorie, India. B. bred. 3.22." Slide No. 704I.

Figure 2, left wings; 2a, ventral view of male genitalia with aedeagus in sitn.

\section{Eucosma dryochra Meyrick}

Plate 8o, Figure 3

Encosma dryochra Meyrick, 1937, Exotic Microlepidoptera, 5: 99.

"s. 15-16 mm. . . . Trinidad, bred from larvae feeding on Passiflora lanrifolia; 2 ex. (type Brit. Mus.)."

Type: The male, without abdomen, so marked in the British Museum, dated " $14-7-30 "$ ".

Figure 3 , right wings (image reversed).

See Gypsonoma ephoropa (Meyrick).

\section{Eucosma ephoropa Meyrick}

\section{Eucosma eridarcha Meyrick}

Plate 180 , Figures $3-3 \mathrm{~b}$

Encosma eridarcha Meyrick, 1927, Exotic Microlepidoptera, 3:336.

" o. 20-2r mm., +. 29 mm. . . Colombia, Mt. Tolima, I2,500 feet, December; 3 ex.... although the sexes differ much in detail (probably variable), they are generally similar and I have no doubt correctly united."

Lectotype: The female measuring $29 \mathrm{~mm}$., and dated ".I2.20". Slide No. 6383 . One specimen is missing ( $\sigma^{*}$ ?) but the second specimen, presumably one of the original three, measuring $20 \mathrm{~mm}$., is a female of a different species.

Figure 3 , left wings; 3 a, ventral view of female genitalia; 3 b, detail of genital plate and ostium.

[continued on P. 419 . 
EUCOSMA

\section{Eucosma eutechna Meyrick \\ Plate I 8 I, Figures I-Ia}

Eucosma entechua Meyrick, 1936, Exotic Microlepidoptera, 4:61о.

" 3 ㅇ․ I $5^{-1} 6 \mathrm{~mm}$... . Malaya, Kuala Lumpur, bred November from larvae on Elaterioidea tapos (Euphorbiaceae); 4 ex. (type Brit. Mus.)."

Type: The male so labelled in the British Museum and dated "28.i I.1934". The abdomen of the type is missing; the genitalia are figured from a "cotype" with identical data. Slide No. 7039 .

Figure I, left wings; 1 a, ventral view of male genitalia with aedeagus in sitn.

\section{Eucosma evidens Meyrick}

Plate 18 I, Figures 2-2b

Encosma eridens Meyrick, 1917, 'Trans. Ent. Soc. London, 1917: I9.

" $\delta$. (Parish); Dutch Guiana, Paramaribo; Cuba, Holguin; twenty-two specimens."

Lectotype: A female, "Bartica, Brit. Guiana. Parish. .12.I2." Slide No. 6391. The twelve specimens remaining in the Meyrick collection are females.

Figure 2, left wings; $2 \mathrm{a}$, ventral view of female genitalia; $2 \mathrm{~b}$, detail of genital plate and ostium.

\section{Eucosma favicolor Meyrick \\ Plate 18 , Figures $3-3$ a}

Encosma favicolor Meyrick, 1927, Insects of Samoa, 3, Lepidoptera, fasc. 2: 72.

" o. I I mm. ... Upolu, Malololelei, 2,00o feet, December; i ex. Perhaps most nearly allied to E. pervicax of North Australia."

Type: The above indicated male so marked in the British Museum, "Samoan Is. Upolu, Malololelei. 2,000 ft. xii. 1925. P. A. Buxton and G. H. Hopkins." Slide No. 7006 .

Figure 3, left wings; 3 a, ventral view of male genitalia (damaged) with aedeagus in situ.

\section{Eucosma glaciata (Meyrick)}

Plate $18 \mathrm{I}$, Figures $4-4 \mathrm{a}$

Cydia glaciata Meyrick, I907, Journ. Bombay Nat. Hist. Soc., I 8: 142.

" $\$$ to. I I I-I 4 mm., Khasi Hills, in June and July; four specimens."

Lectotype: A male measuring i I mm., labelled "Khasi Hills, Assam. .6.1906". Slide No. 6962.

Figure 4, left wings; 4 a, ventral view of male genitalia with aedeagus in situ.

$$
[364]
$$



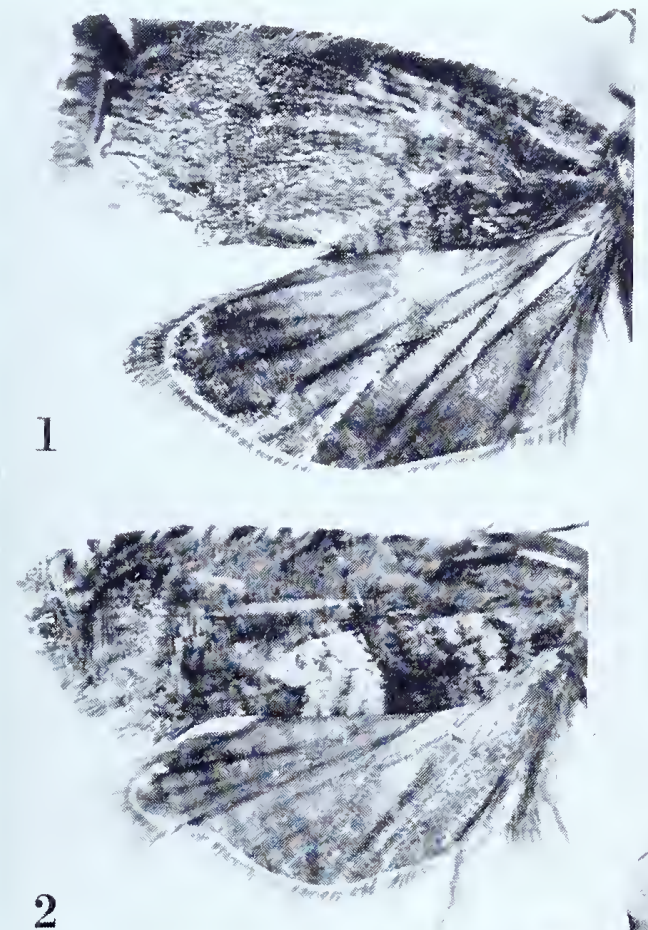

\section{2}

3
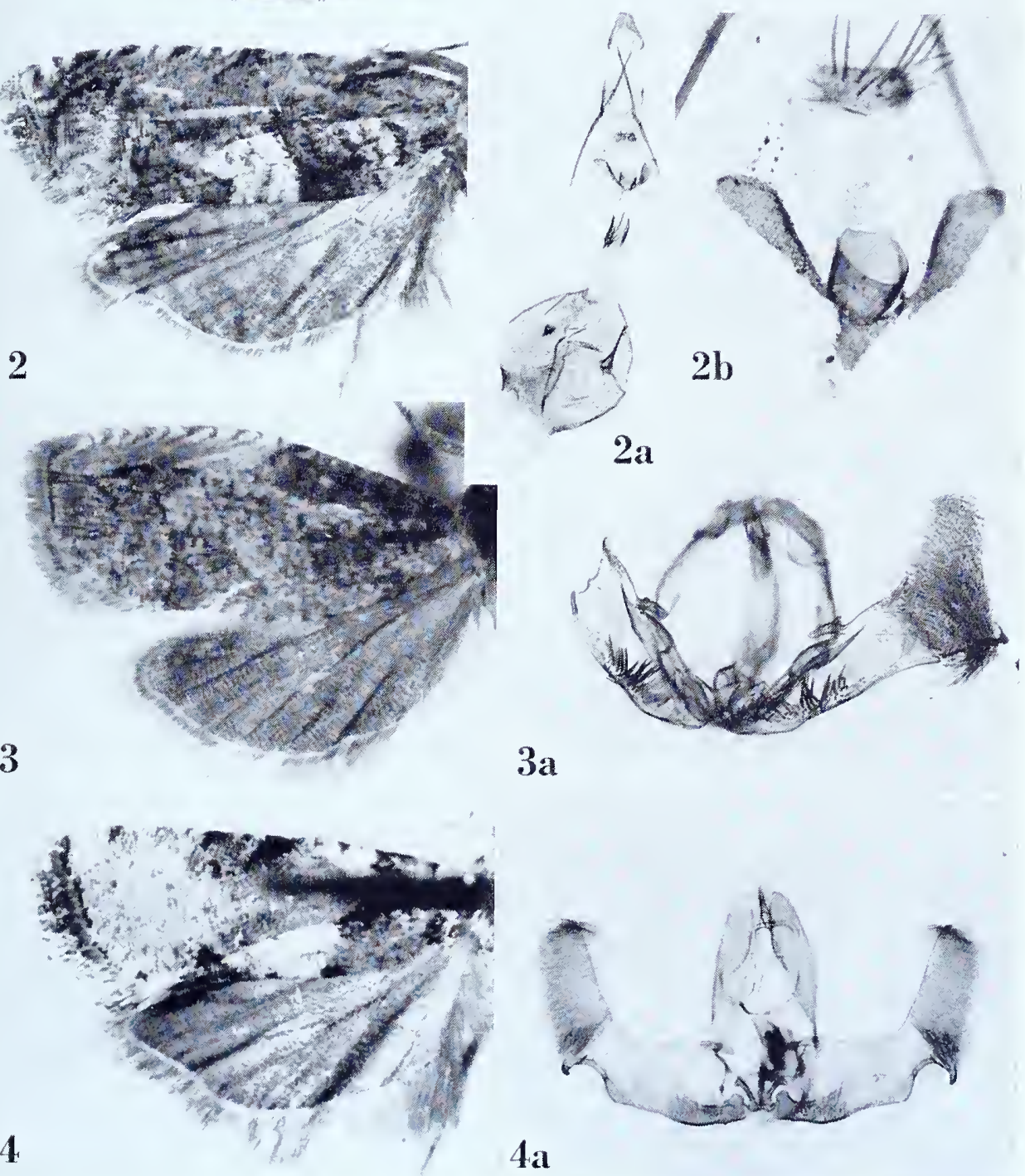

$3 a$

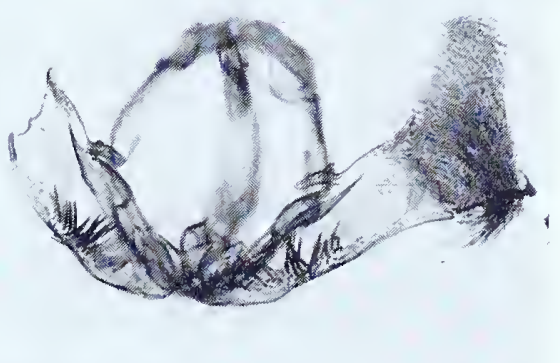

EUCOSMA 

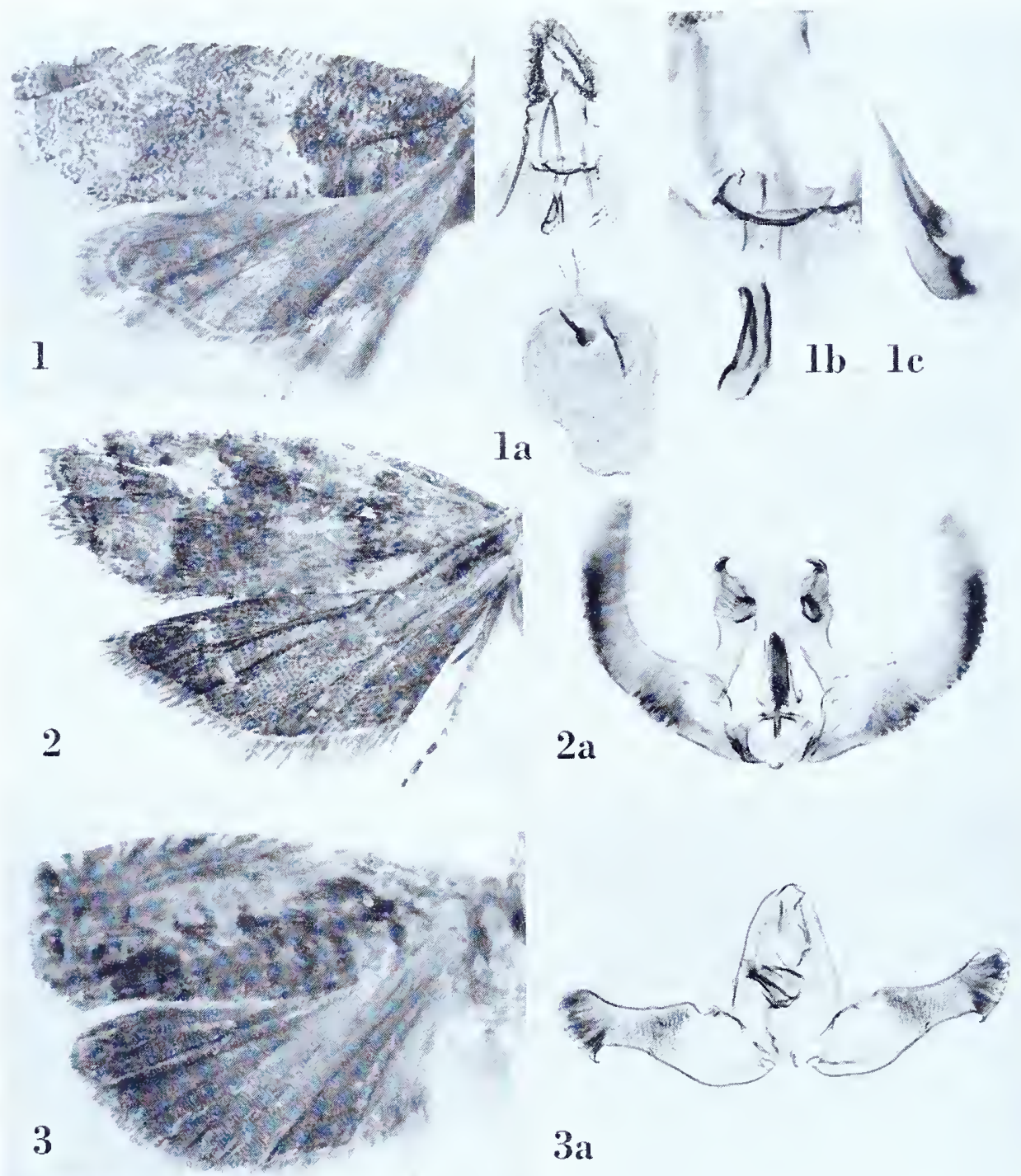

$3 a$
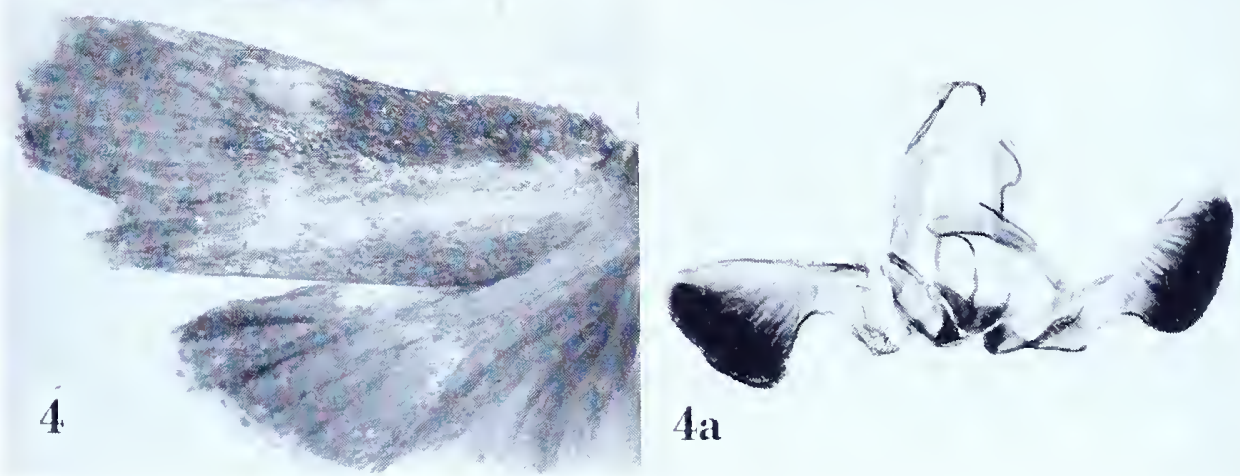


\section{Eucosma hapalosarca Meyrick}

Plate I 82, Figures I-IC

Eucosma hapalosarcha Meyrick, 1924, Exotic Microlepidoptera, 3:67.

" 3ㅇ. I I-12 mm. . . Punjab, Kureshia Forest, Multan, bred April from larvae defoliating Populus euphratica (Beeson); 8 ex."

Lectotype: A female measuring $12 \mathrm{~mm}$. Slide No. 7043. The three remaining specimens in the Meyrick collection bear identical data, "Multan, Punjab. B. bred .4.22."

Figure I, left wings; Ia, ventral view of female genitalia; Ib, detail of ostium; Ic, signa.

Eucosma heteropa Meyrick

See Eucosma conciliata Meyrick.

\section{Eucosma holocrypta Meyrick}

See Gypsonoma holocrypta (Meyrick).

\section{Eucosma hypsidryas Meyrick \\ Plate I 82, Figures 2-2a}

Eucosma hypsidryas Meyrick, 1925, Exotic Microlepidoptera, 3: I 40.

“ ${ }^{\circ}+$. 12 mm. . . India, U.P., Deoban, Chakrata Div., 9,00o feet, bred from larvae in buds of Picea morinda (Forest Zoologist); 4 ex. Group of nisella. . .."

Lectotype: A male, "Deoban, U.P., India. CB. 9,000' bred. 6.23." Slide No. 7044.

Figure 2, left wings; $2 \mathrm{a}$, ventral view of male genitalia with aedeagus in sitn.

\section{Eucosma involucrata Meyrick}

Plate 182 , Figures $3-3$ a

Eucosma involucrata Meyrick, 1927, Insects of Samoa, 3, Lepidoptera, fasc. 2: 73 .

" o. I $6 \mathrm{~mm}$. .. . Samoan Islands, but without specific locality; I ex. Very distinct."

Type: The above indicated specimen so labelled in the British Museum, "Samoan Is. P. A. Buxton and G. H. Hopkins." Slide No. 7008.

Figure 3 , left wings; 3 a, ventral view of male genitalia with aedeagus in situ.

\section{Eucosma ischnobathra (Meyrick), new combination}

Plate 182 , Figures $4-4$ a

Acharneodes ischnobathra Meyrick, I938, Trans. R. Ent. Soc. London, 87: 5 I I.

“ . $19 \mathrm{~mm}$. . . Mafulu, 4,000 feet, December. I ex."

Type: The male so marked in the British Museum, "Mafulu, Papua, 4,000 ft., xii-I 933. L. E. Cheesman." Slide No. 7026.

Figure 4, left wings; 4 a, ventral view of male genitalia with aedeagus in situ. 


\section{Eucosma isogramma (Meyrick) \\ Plate ${ }_{1} 8_{3}$, Figures $\mathrm{I}-\mathrm{I}$ a}

Cydia isogramma Meyrick, i 908, Proc. Zool. Soc. London, I 908: 720.

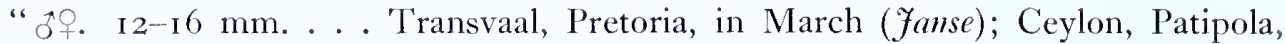
Maskeliya, and Diyatalawa, from March to September (Green, Pole, Alston, Fletcher); eight specimens."

Lectotype: A male measuring I 5 mm., "Patipola, Ceylon. EEG. .3.06." Slide No. 7090 .

Figure I, left wings; ra, ventral view of male genitalia with aedeagus in situ.

See Cryptophlebia isomalla (Meyrick).

\section{Eucosma isomalla Meyrick}

\section{Eucosma legitima Meyrick}

Plate 183 , Figures 2-2a

Eucosma legitima Meyrick, I912, Journ. Bombay Nat. Hist. Soc., 21 : 865.

" $\$$ fo. $14^{-1} 5 \mathrm{~mm} . .$. Khasis; in April, and from August to November, six specimens."

Lectotype: A male measuring 14 mm., "Khasi Hills, Assam. .4.1907." Slide No. 6987 .

Figure 2, left wings; 2a, ventral view of male genitalia with aedeagus in situ.

\section{Eucosma leucantha Meyrick \\ Plate 183 , Figures $3^{-} 3^{b}$}

Eucosma leucantha Meyrick, 193 I, Exotic Microlepidoptera, 4: I 45.

"ㅇ. I $8 \mathrm{~mm}$. . . J Japan, 'Tokio, July (S. Issiki); I ex."

Type: The female indicated above dated "7.7.18". Slide No. 7105.

Figure 3 , left wings; $3 \mathrm{a}$, ventral view of female genitalia; $3 \mathrm{~b}$, detail of genital plate and ostium.

\section{Eucosma macrosaris Meyrick}

See Acroclita macrosaris (Meyrick). 


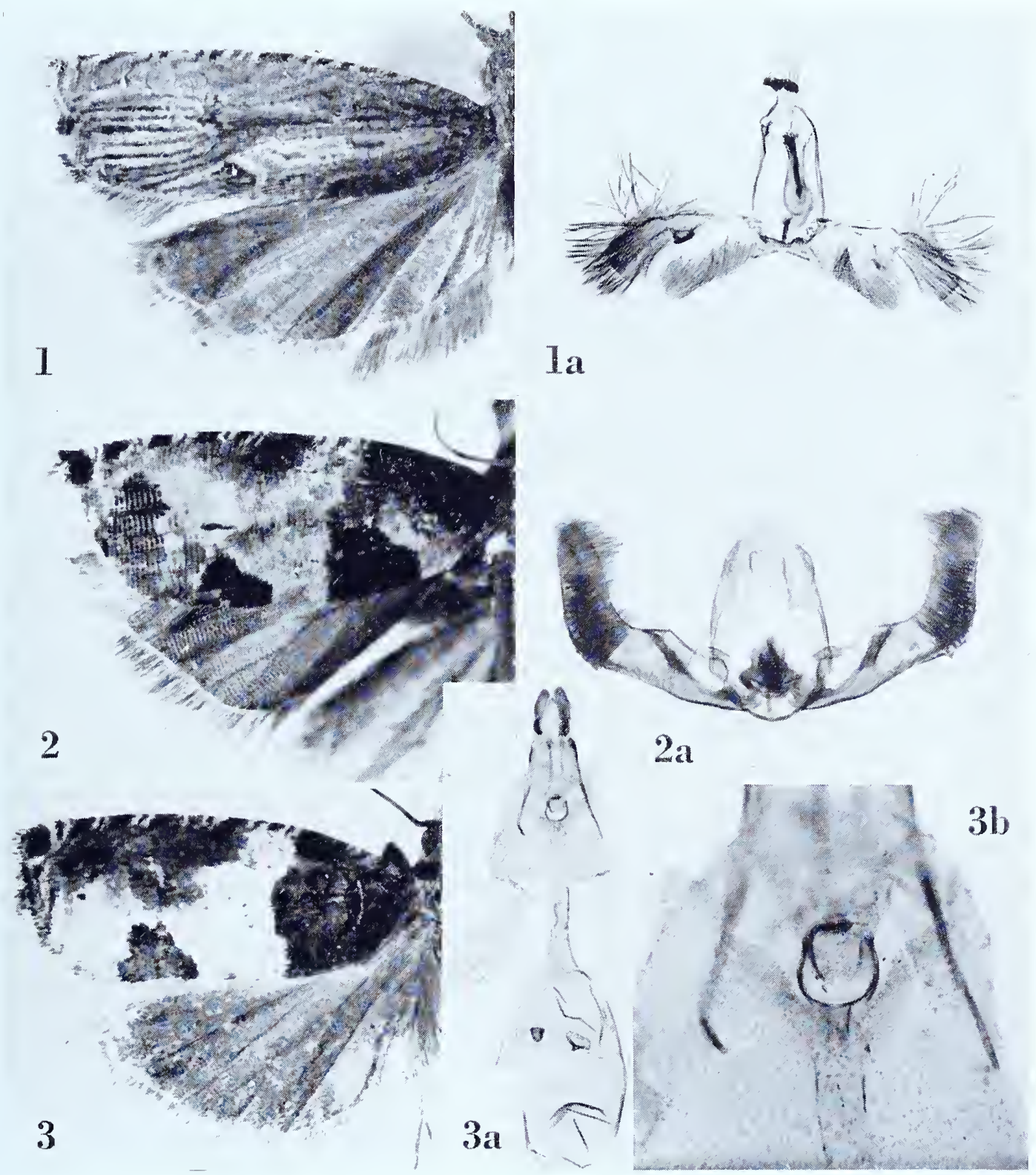

EUCOSMA 


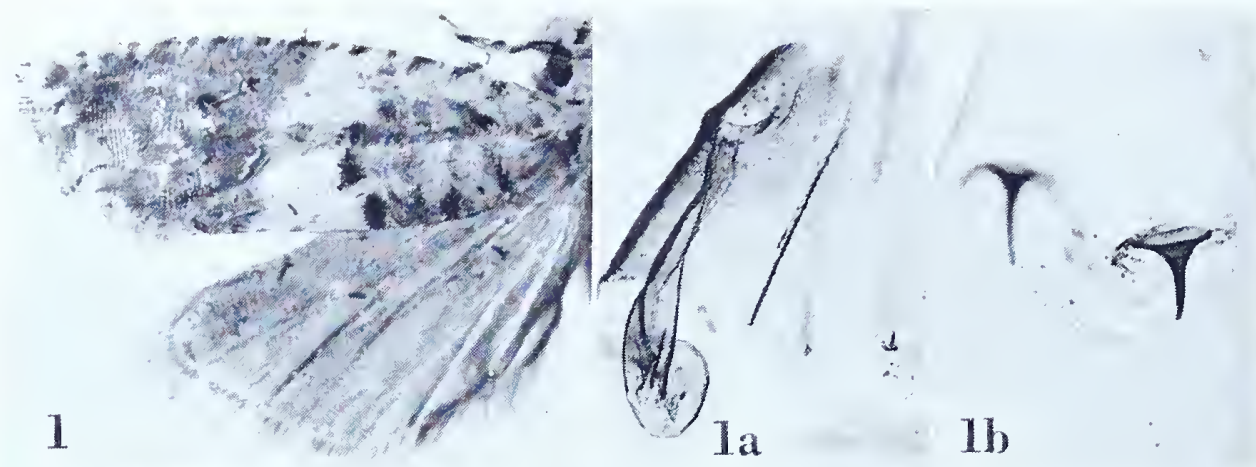

2
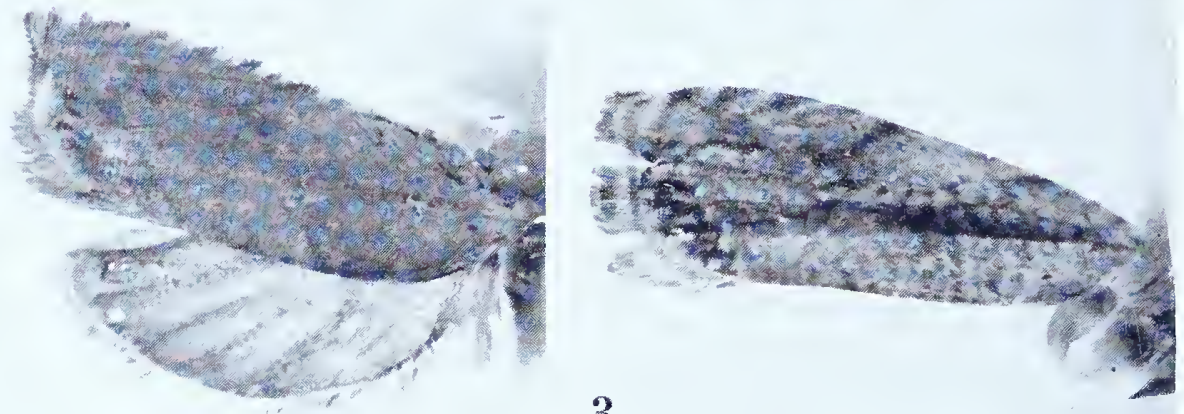

3
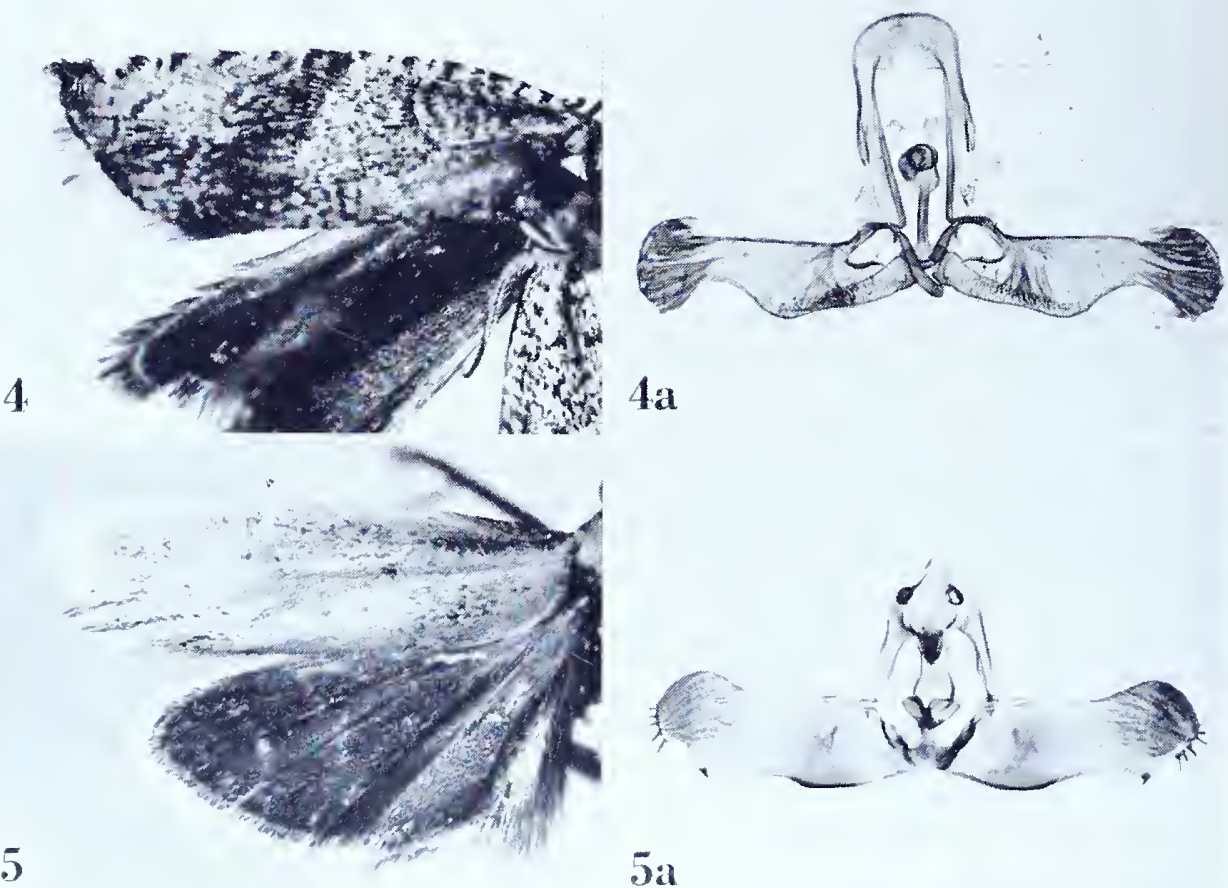

$4 a$

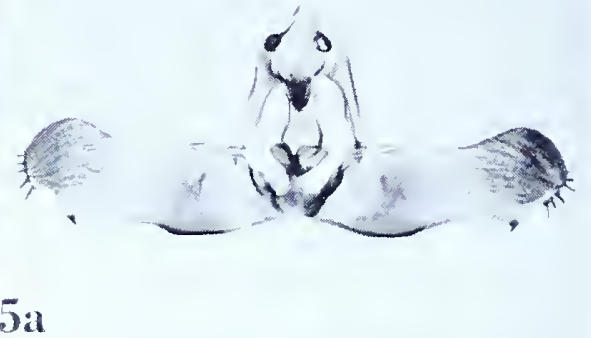

EUCOSMA 


\section{Eucosma leucodesma Meyrick}

Plate I 84 , Figures $I-I b$

Eucosma leucodesma Meyrick, i9ı2, Trans. Ent. Soc. London, I9 I : 688.

"q. I4 mm. ... Argentina, Parana; one specimen."

Type: The specimen indicated above with "R. .o6" at the bottom of the pin-label. Slide No. 6393 .

Figure I, left wings; Ia, ventro-lateral view of genital plate and ostium; ib, signa.

\section{Eucosma lioplintha Meyrick}

Plate I 84 , Figure 2

Eucosma lioplintha Meyrick, I920, Exotic Microlepidoptera, 2: 344.

"亏. $10 \mathrm{~mm}$. .. . Madras, Dindigul, September (Maxwell); I ex."

Type: The above indicated male, without abdomen, dated "28.9.16".

Figure 2, left wings.

\section{Eucosma loxaspis Meyrick}

Plate I 84 , Figure 3

Eucosma loxaspis Meyrick, 1931, Exotic Microlepidoptera, 4: 127.

"․ I $2 \mathrm{~mm}$. . . Java, Buitenzorg, bred from larvae ... on shoots of bamboo . . . (Dr. W. Roepke); 2 ex. (type Brit. Mus.)."

Type: The specimen, without abdomen or hindwings, so marked in the British Museum, "Buitenzorg. e. 1. I919. W. Roepke."

Figure 3, left forewing.

\section{Eucosma ludicra Meyrick}

See Eucosma critica Meyrick.

\section{Eucosma marmaroxantha Meyrick}

Plate 184 , Figures $4^{-} 4^{\mathrm{a}}$

Eucosma marmaroxantha Meyrick, 1937, in Caradja and Meyrick, Deuts. Ent. Zeit. Iris, 5I: I 80.

"... o. I4 mm. ... Yül., 4,000-5,000 m., June; i ex."

Type: 'The male denoted above, "Likiang, China. H. I3,000' .6.35." Slide No.7rog.

Figure 4 , right wings (image reversed); 4 a, ventral view of male genitalia with aedeagus in situ. 
EUCOSMA

\section{Eucosma melanaula Meyrick}

Plate 185 , Figures I-Ia

Encosma melanaula Meyrick, i916, Exotic Microlepidoptera, 2: 17.

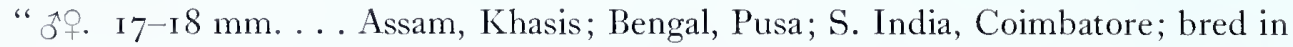
October and from January to March from larvae feeding in flowers or pods of Cajanns indicus and Phaseolus mungo (Leguminosae) (Fletcher); six specimens. ..."

Lectotype: A male measuring $16 \mathrm{~mm}$., "Pusa, Bengal. TBF. 3.r.ı." Slide No. 7045 .

Figure I, left wings; ra, ventral view of malc gcnitalia with aedeagus in situ.

\section{Eucosma melanochlaena Meyrick}

See Eucosma cyanopis Meyrick.

\section{Eucosma melanoneura Meyrick \\ Plate 185 , Figures 2-2a}

Encosma melanoneura Meyrick, I91 2, Journ. Bombay Nat. Hist. Soc., 21: 866.

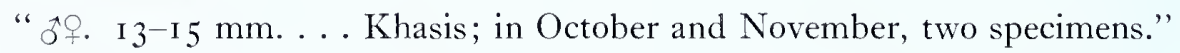

Lectotype: The male, "Khasi Hills, Assam. .Io.rgo6." Slide No. 6992.

Figure 2, left wings; 2a, ventral view of male genitalia with aedeagus in sitn.

\section{Eucosma meridospila Meyrick}

Plate i 85 , Figures $3^{-} 3^{\mathrm{a}}$

Eucosma meridospila Meyrick, I922, Exotic Microlepidoptera, 2: 518. 6 ex."

" สำ. I3-14 mm. . . Brazil, Obidos, Santarem; August, September (Parish);

Lectotype: A male, "Obidos, Brazil, Parish. 9-19." Slide No. 6394. The six specimens are badly damaged by verdigris.

Figure 3, left wings; 3 a, ventral view of malc genitalia with aedeagus in situ.

\section{Eucosma metagrapta Meyrick}

Plate 185 , Figures $4-4$ a

Eucosma metagrapta Meyrick, I932, Exotic Microlepidoptera, 4:224.

" §. Io mm. . . Java, teak-forest, July (Dr. L. G. E. Kalshozen); I ex."

Type: The above indicated specimen, "Java, K. .7.3I." Slide No. 7054.

Figure 4 , left wings; 4 a, ventral view of male genitalia with aedeagus in sitn. 


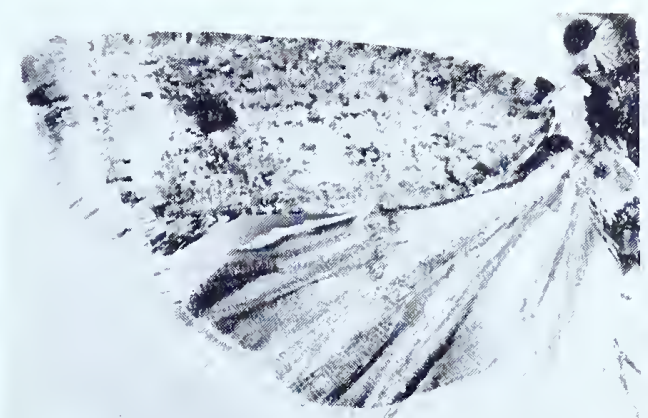

1

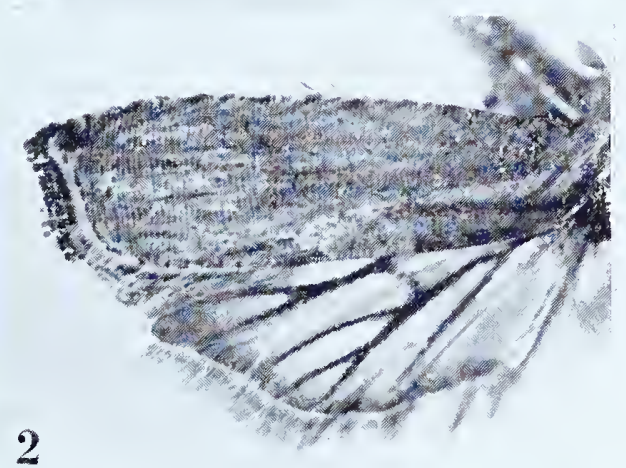

2
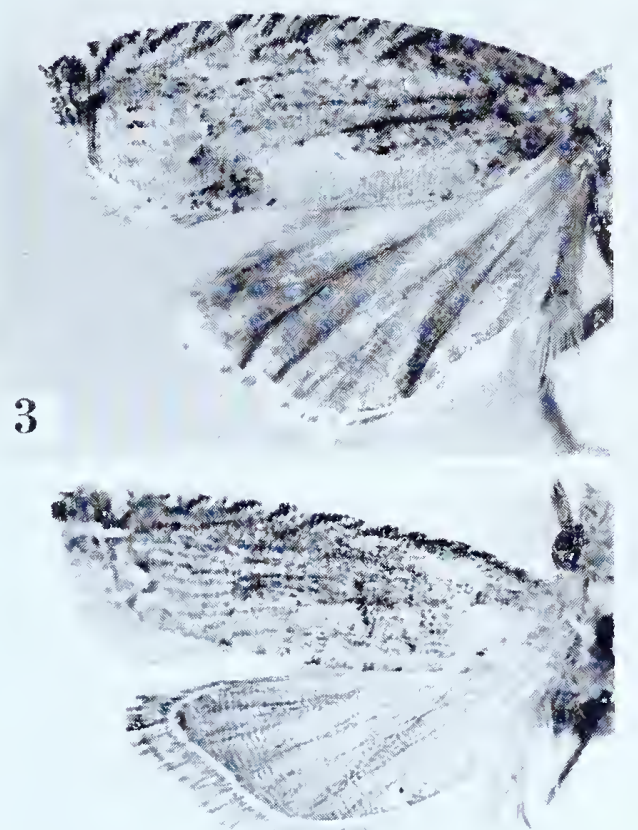

4

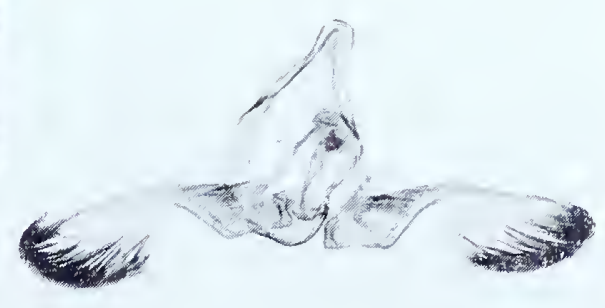

la
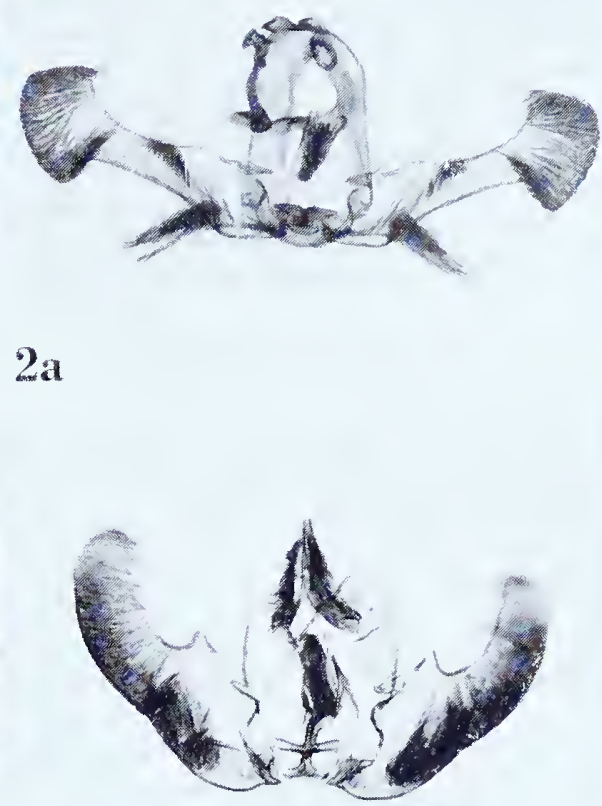

$3 a$

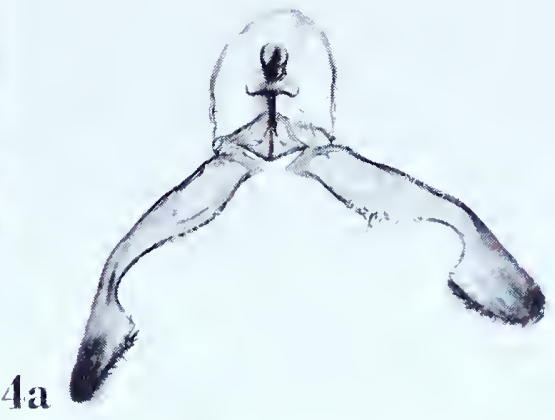




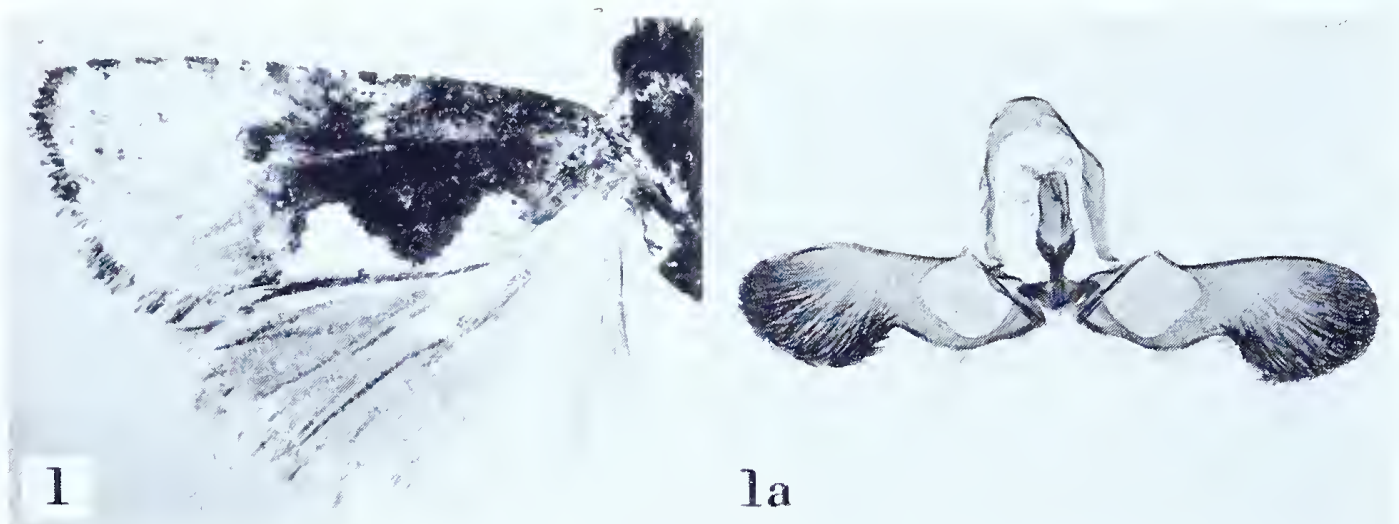

2
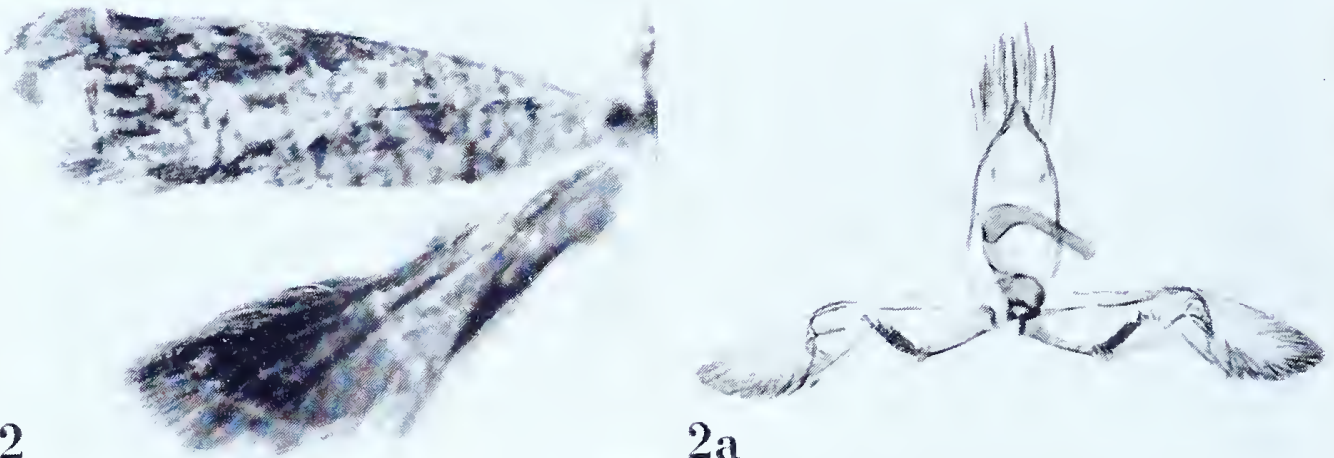

2a
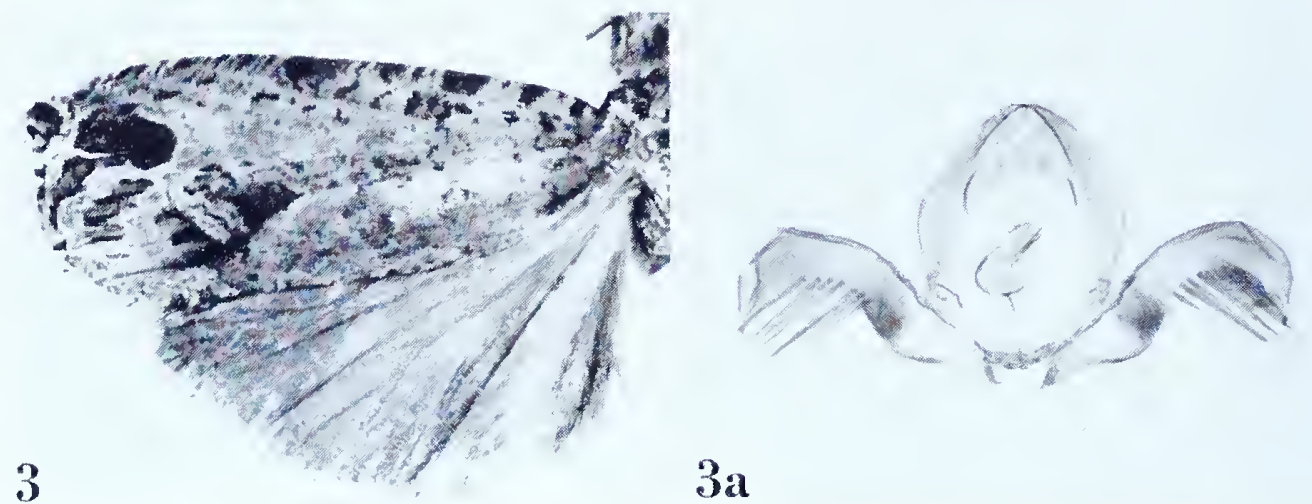

$3 a$

EUCOSMA 


\section{Eucosma metamorphica Meyrick}

Plate I86, Figures I-Ia

Eucosma metamorphica Meyrick, 1928, Exotic Microlepidoptera, 3:439.

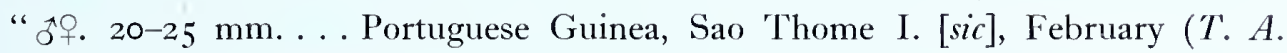
Barns); 5 ex. Very variable."

Lectotype: ơ, $20 \mathrm{~mm}$., dated “.2.26”. Slide No. 9396.

Figure I, left wings; Ia, ventral view of male genitalia with aedeagus in situ.

\section{Eucosma mollita (Meyrick), new combination}

Plate 186 , Figures 2-2a

Episimus mollita Meyrick, I93 I, Exotic Microlepidoptera, 4: I47.

" ๙ోํ. 7-8 mm. . . Java, Semarang, bred December (F. A. T. H. Verbeek); 4 ex."

Lectotype: A male, "Seneng, Java. V. .I2.30." Slide No. 7187. There are only two specimens in the Meyrick collection $(\delta, \rho)$. Despite the apparent discrepancy in locality I have no doubt that the two are from the original series; they are glued on card. Certainly not an Episimus and only tentatively placed in Encosma.

Figure 2, left wings; $2 \mathrm{a}$, ventral view of male genitalia with aedeagus in situ.

\section{Eucosma muscosa Meyrick}

Plate 186 , Figures $3^{-} 3^{a}$

Encosma muscosa Meyrick, 1927, Exotic Microlepidoptera, 3: 335 .

" ${ }^{\circ} .23 \mathrm{~mm}$. . . Colombia, Alto de las Ances, 7,250 feet, April; i ex."

Type: The above indicated specimen dated “.4.20". Slide No. 6385. Tegumen and outer surface of harpes profusely covered with hair-like scales. These were removed to show the structure of the genitalia.

Figure 3, left wings; 3 a, ventral view of male genitalia with aedeagus in situ. 


\section{Eucosma nereidopa Meyrick}

Plate 187 , Figures $1-1 \mathrm{~b} ; 2-2 \mathrm{~b}$

Eucosma nereidopa Meyrick, 1927, Exotic Microlepidoptera, 3: 333 .

Eucosma phylloscia Meyrick, 1937, Exotic Microlepidoptera, 5: 158 (new synonymy). [nereidopa]

" $+16 \mathrm{~mm}$. . . Kenya Colony, Kericho, bred in July from larva boring in berries of Coffea (Wilkinson); i ex. (Brit. Mus.)."

Type: 'The above indicated specimen so marked in the British Museum. Slide No. 7328 .

Figure I, left wings; $\mathbf{a}$, ventral view of female genitalia; $\mathrm{Ib}$, detail of genital plate and ostium.

$$
\text { [phylloscia] }
$$

“항. I $4^{-1} 6 \mathrm{~mm}$. . . Uganda, N. Bugishu, 6,000 feet, bred ... from berries of Coffea (A. Kerr); 6 ex. (type Brit. Mus.)."

Type: The female so marked in the British Museum. Slide No. 7329.

Figure 2, left wings; 2a, detail of genital plate and ostium; 2b, ventral view of female genitalia.

\section{Eucosma noctivola (Meyrick), new combination \\ Plate 187 , Figures $3-3 \mathrm{c}$}

Tortrix noctivola Meyrick, 1932, Exotic Microlepidoptera, 4: 342.

“官. I 7-1 $8 \mathrm{~mm}$. . . . Kashmir, Killanmarg, 10,500 feet, July (T. B. Fletcher); 2 ex. An obscure insect, but distinct."

Lectotype: The female measuring 17 mm., "Killanmarg, Kashmir. 'TBF. 8,800' .7.3 I." Slide No. 6830. The second specimen is missing.

Figure 3 , left wings; $3 \mathrm{a}$, ventral view of female genitalia; $3 \mathrm{~b}$, detail of genital plate and ostium; 3 c, bursa copulatrix to show signa. 


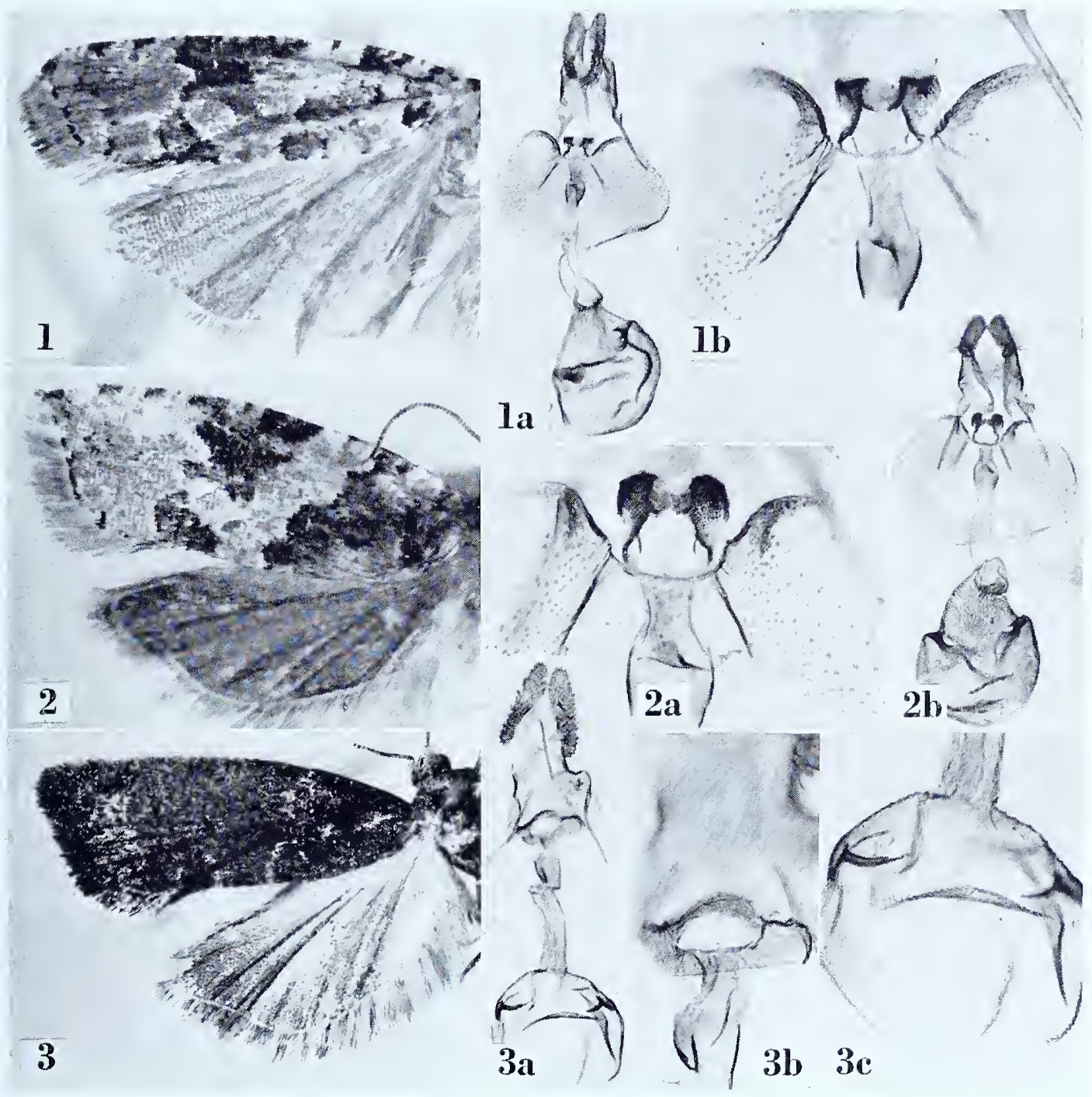

EUCOSMA 

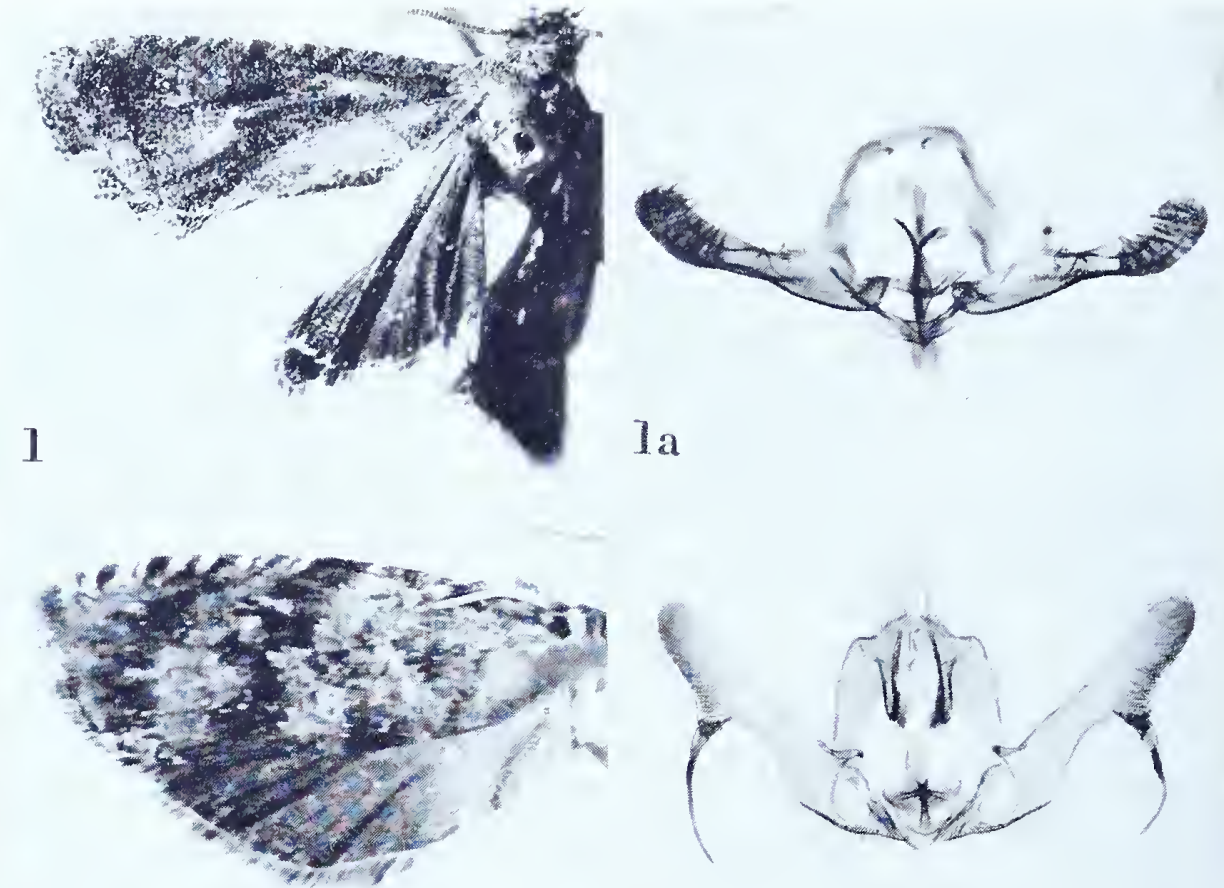

2

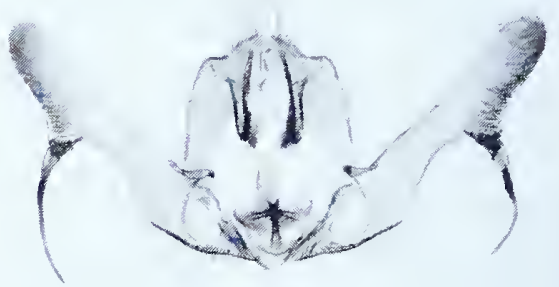

$2 a$
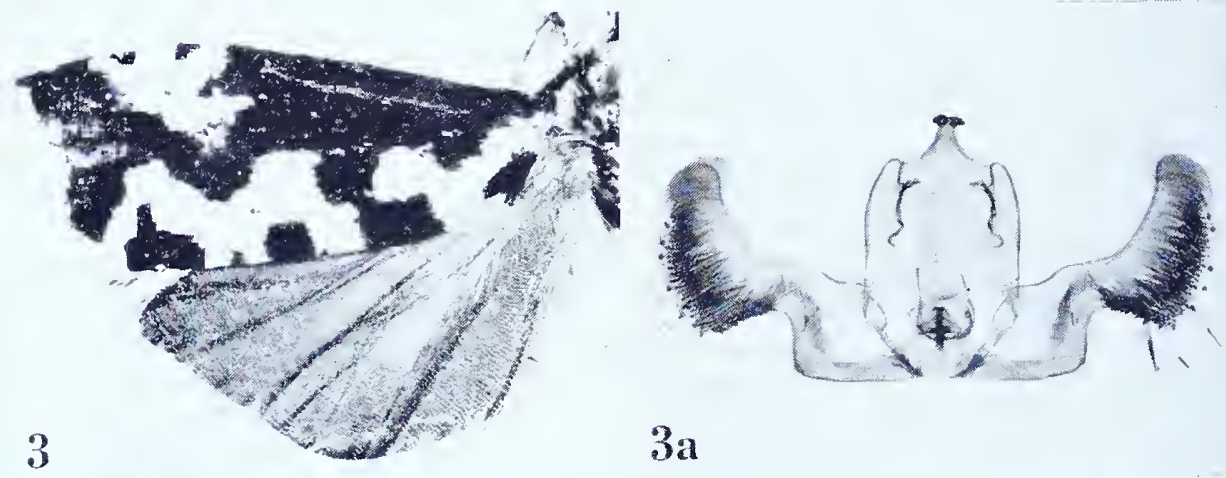

3a
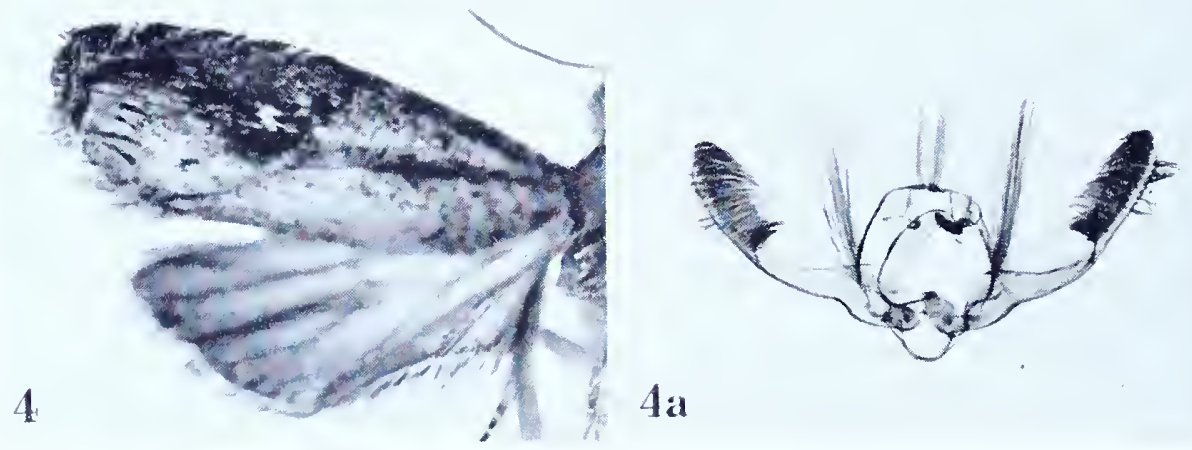

$4 a$

EUCOSMA 


\section{Eucosma notanthes Meyrick \\ Plate I88, Figures I-Ia}

Eucosma notanthes Meyrick, 1936, Exotic Microlepidoptera, 4:610.

"ㅇ․ ㄷ 2 mm. . . Formosa, Kagi, bred from Eleaocarpus serratus (F. Sonan); i ex."

Type: The specimen indicated above, "Kagi, Formosa, JS. bred. .33," erroneously recorded as a female. Slide No. 7057 .

Figure I, left wings; Ia, ventral view of male genitalia with aedeagus in situ.

\section{Eucosma numellata Meyrick}

Plate I 88, Figures 2-2a

Eucosma mumellata Meyrick, I912, Journ. Bombay Nat. Hist. Soc., 2 I : 868.

" $\delta$ ․ I I I-I 3 mm. . . . Khasis, in March and October, three specimens."

Lectotype: đ. Khasi Hills, Assam. Slide No. 72 I 7.

Figure 2, left wings; 2 a, ventral view of male genitalia with aedeagus in sitı.

\section{Eucosma ocladias (Meyrick)}

Plate 188 , Figures $3-3$ a

Epiblema ocladias Meyrick, I9o6, Journ. Bombay Nat. Hist. Soc., I7: 137 .

“ $\hat{o}$ ㅇ. I 8-26 mm. . . . Seven specimens, Maskeliya, Ceylon, in March, May, July, August, October and November (de Mowbray, Pole, Green)."

Lectotype: A male measuring 23 mm., dated ". I 1.05”. Slide No. 71 20.

Figure 3 , left wings; 3 a, ventral view of male genitalia with aedeagus in situ.

\section{Eucosma operta Meyrick}

Plate i 88 , Figures $4^{-4}$ a

Eucosma operta Meyrick, 1917, Trans. Ent. Soc. London, 1917: 20.

"§. I I mm. . . British Guiana, Bartica, in December (Parish); one specimen."

Type: The specimen indicated above dated “.ı 2. I 2." Slide No. 6395.

Figure 4 , left wings; 4 a, ventral view of male genitalia with aedeagus in sit $t$. 
EUCOSMA

\section{Eucosma orthopeda Meyrick \\ Plate I 89, Figure I}

Eucosura orthopeda Meyrick, I 934, Exotic Microlepidoptera, 4: 484 .

“ s. $18 \mathrm{~mm}$. . . U Uganda, Angelo, December (G. L. R. Hancock); I ex. (Brit. Mus.). ..."

Type: 'The above indicated male, without abdomen, so marked in the British Museum, dated "20.xii.1932".

Figure $\mathrm{I}$, left wings.

\section{Eucosma palmodes Meyrick \\ Plate 189 , Figures 2-2b}

Encosma palmodes Meyrick, 1920, Exotic Microlepidoptera, 2: 344.

“ㅇ․ 10-12 mm. ... Ceylon, Maskeliya, January, April, May (Pole); 5 ex."

Lectotype: A female measuring $12 \mathrm{~mm}$., dated “.5.06”. Slide No. 7049.

Figure 2, right wings (image reversed); $2 \mathrm{a}$, ventral view of female genitalia; $2 \mathrm{~b}$, detail of genital plate and ostium.

\section{Eucosma pentagonaspis Meyrick \\ Plate i 89 , Figures $3-3$ a}

Eucosma pentagonaspis Meyrick, 1931, Exotic Microlepidoptera, 4: I 44.

" o. I I mm. . . Formosa, Taihoku, April (S. Issiki); I ex. Perhaps most like the European simploniana. ..."

Type: 'The male indicated above dated “.4.21". Slide No. 7100.

Figure 3 , left wings; 3 a, ventral view of male genitalia with aedeagus in situ.

\section{Eucosma phaeocremna Meyrick}

See Gypsonona phaeocremna (Meyrick).

\section{Eucosma phoenocrossa Meyrick \\ Plate i 89, Figures $4-4$ a}

Eucosma phoenocrossa Meyrick, 1925, Exotic Microlepidoptera, 3: $14 \mathrm{I}$.

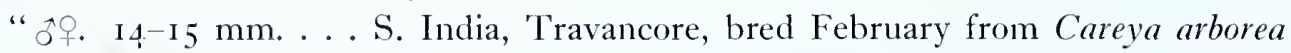
(Lecythidaceae); 2 ex."

Lectotype: The male, "Travancore, S. India. RMP. bred .2.23." Slide No. 7042. 'The female is missing.

Figure 4, right wings (image reversed); 4a, ventral view of male genitalia with aedeagus in sitn.

Eucosma phylloscia Meyrick

See Eucosuna nereidopa Meyrick. 

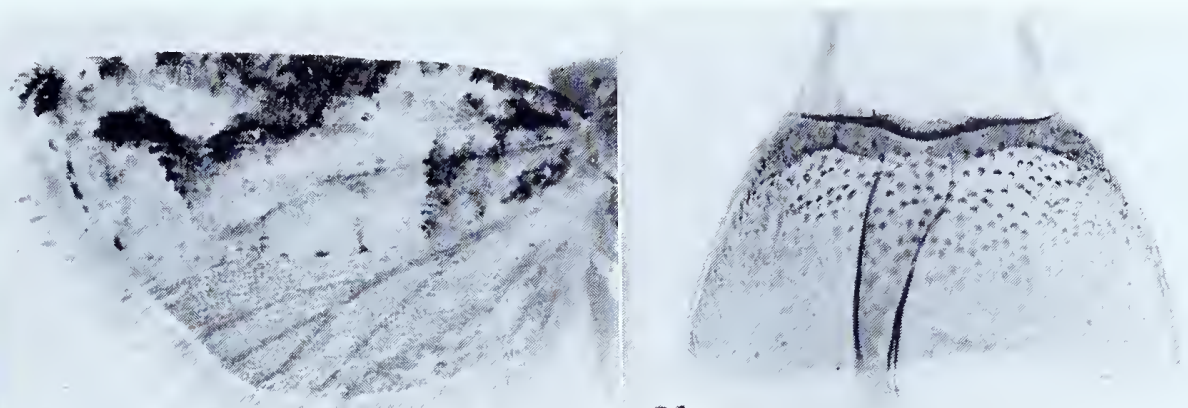

1

2b
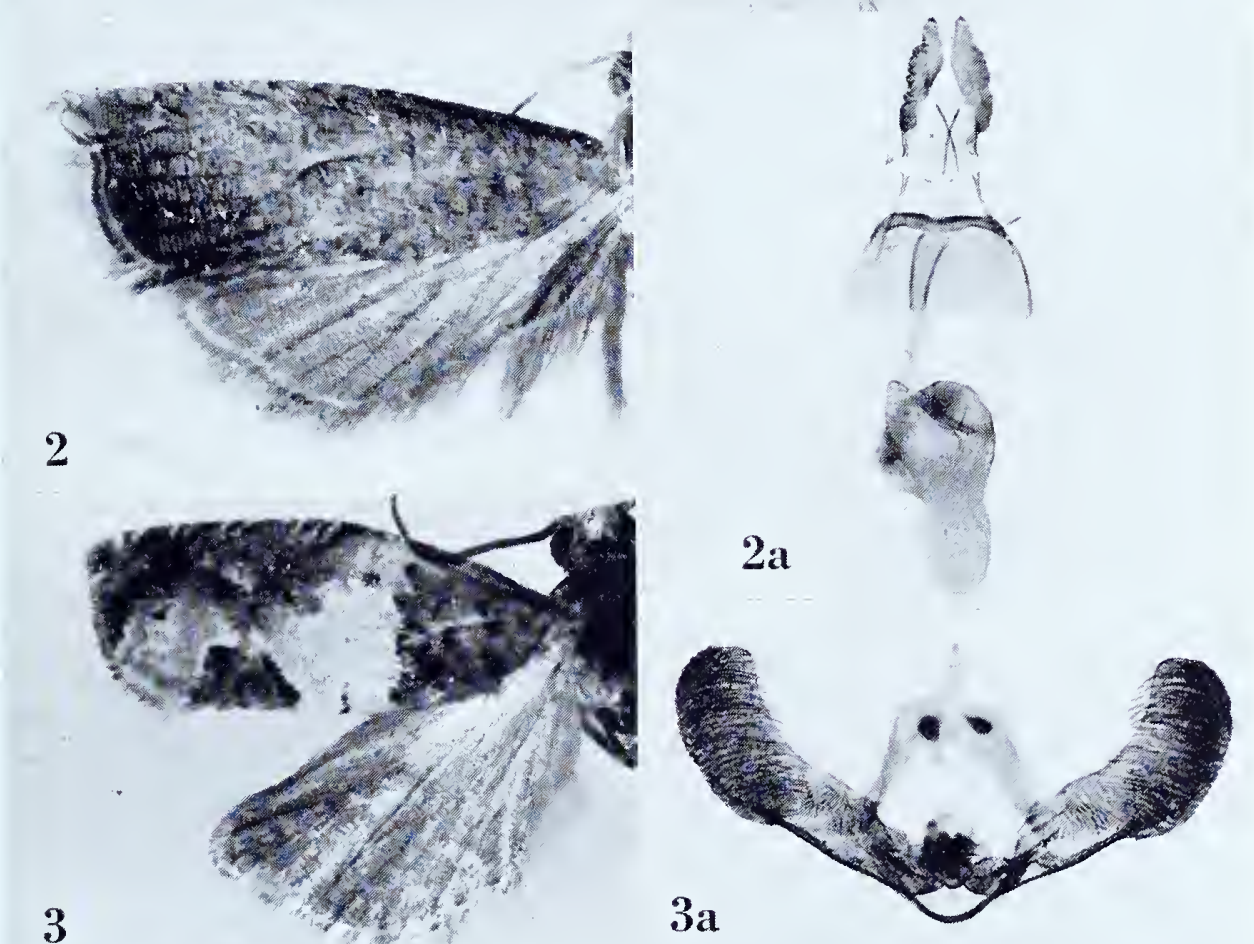

3

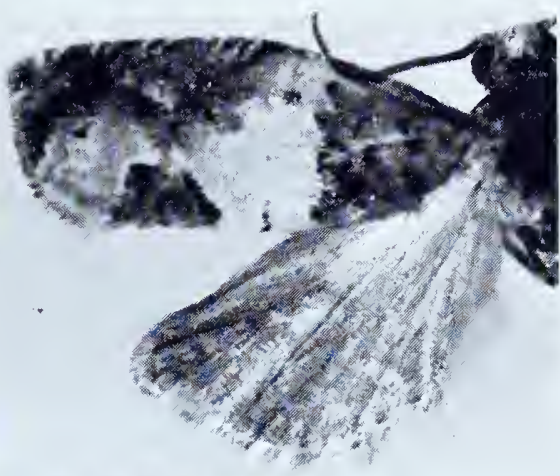

$3 a$

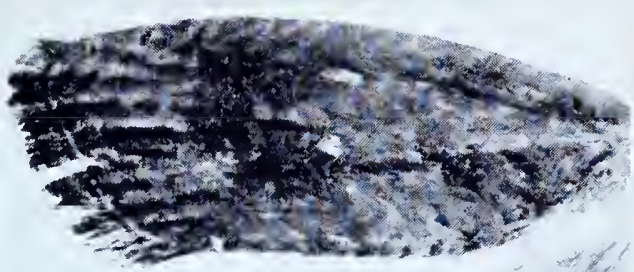

4
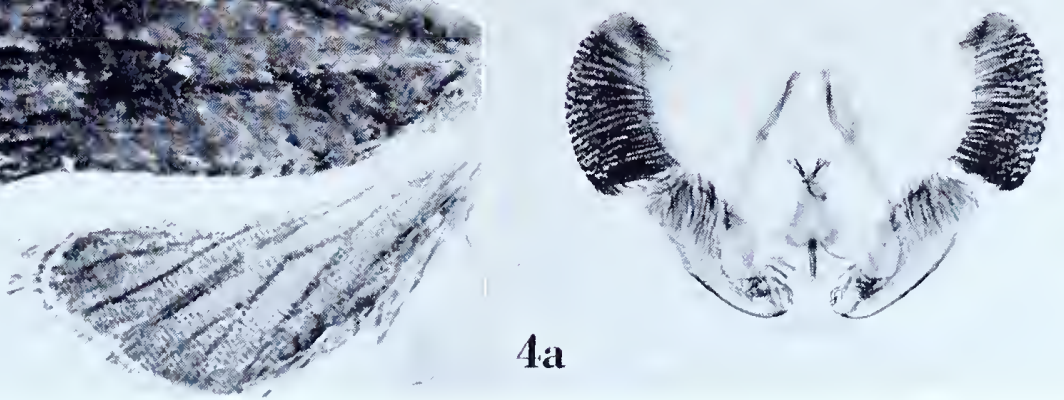

EUCOSMA 


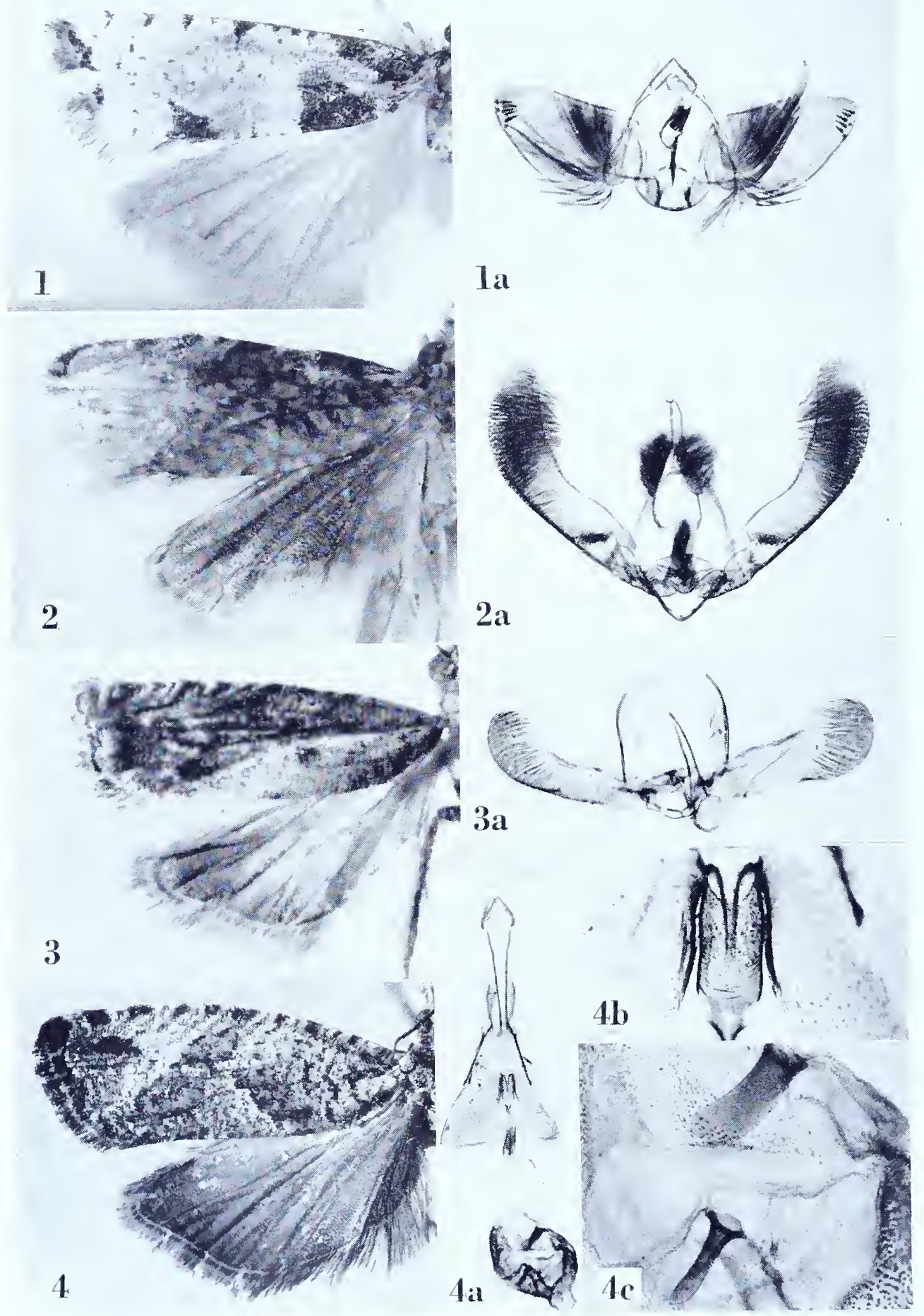




\section{Eucosma picrodelta Meyrick \\ Plate 190, Figures I-Ia}

Encos:a picrodelta Meyrick, I932, Trans. Ent. Soc. London, 80: I I.

" §. 2 I mm. . . J Jem-Jem Forest, over 8,000 feet, October; I ex."

Type: The male so marked in the British Museum, "Djem-Djem Forest, Abyssinia, over 8,000 ft. IO-X-1926. H. Scott." Slide No. 7013 .

Figure I, left wings; ra, ventral view of male genitalia with aedeagus il situ.

\section{Eucosma plumbaginea Meyrick}

Plate 190, Figures 2-2a

Eucosma plumbaginea Meyrick, I931, Exotic Microlepidoptera, 4: I27.

" đ. I 5 mm. . . Uganda, Makindye, September (H. Hargreaves); I ex. (Brit. Mus.)."

Type: The specimen so marked in the British Museum, dated "I9.ix.I929". A small white label bears the inscription "M3050". Slide No. 733I.

Figure 2, left wings; 2a, ventral view of male genitalia with aedeagus in sitn.

\section{Eucosma procellosa Meyrick \\ Plate 190, Figures $3-3$ a}

Eucosma procellosa Meyrick, I917, Trans. Ent. Soc. London, 1917: 19.

" to․ Io-I I mm. . . . Peru, Chosica, 2,800 feet, and Lima, 500 feet, in July and August (Parish); forty-two specimens."

Lectotype: A male, "Lima, Peru, 500 ft., Parish. 8-14." Slide No. 6390. Only thirteen specimens of the original series remain in the Meyrick collection.

Figure 3 , left wings; 3 a, ventral view of male genitalia with aedeagus in sitn.

\section{Eucosma prominens Meyrick}

Plate 190, Figures $4-4 \mathrm{c}$

Eucosma prominens Meyrick, I922, Exotic Microlepidoptera, 2: 517.

"ㅇ. 20-2 I mm. . . . Punjab, Murree, 7,500 feet, June (Dutt); 2 ex."

Lectotype: The female measuring 2 I mm., dated “.6.18”. Slide No. 7038 .

Figure 4 , left wings; 4 a, ventral view of female genitalia; 4 b, detail of ostium; $4 \mathrm{c}$, signa. 


\section{Eucosma psammacta (Meyrick)}

Plate 19I, Figures I-Ia

Cydia psammacta Meyrick, i908, Proc. Zool. Soc. London, I908: $72 \mathrm{I}$.

“ tof $^{\circ}$ I 7-19 mm. ... Transvaal, Pretoria district, in December and January (Fanse); three specimens."

Lectotype: ô, I $8 \mathrm{~mm}$., dated “I2.07”. Slide No. 9397.

Figure I, left wings; ra, ventral view of male genitalia with aedeagus in sitn.

\section{Eucosma pseudomorpha (Meyrick)}

See Encosma critica Meyrick.

\section{Eucosma psychrodora (Meyrick), new combination}

Plate I9I, Figures 2-2a

Phtheochroa psychrodora Meyrick, 1936, Exotic Microlepidoptera, 5:23.

" $70.20 \mathrm{~mm}$. . . Syria, Bludan, June (E. P. Wiltshire); 2 ex. Allied to variosolana Chr."

Type: The male so marked in the British Museum, "Bludan, Syria. EPW. г.6.36." Slide No. 9322.

Figure 2, left wings; 2 a, ventral view of male genitalia with aedeagus in sitn.

\section{Eucosma pylonitis Meyrick \\ Plate I9I, Figures $3^{-} 3^{\mathrm{a}}$}

Encosma pylonitis Meyrick, 1932, Exotic Microlepidoptera, 4:307.

" o. 16-I7 mm. ... Kashmir, Gulmarg, 8,800 feet, June, beaten from Pinus excelsa (T. B. Fletcher); 2 ex. Probably allied to diniana."

Lectotype: The male measuring $17 \mathrm{~mm}$., dated ".6.3 I". Slide No. 7r22. The second specimen is missing.

Figure 3 , left wings; 3 a, ventral view of male genitalia with aedeagus in sitn. 

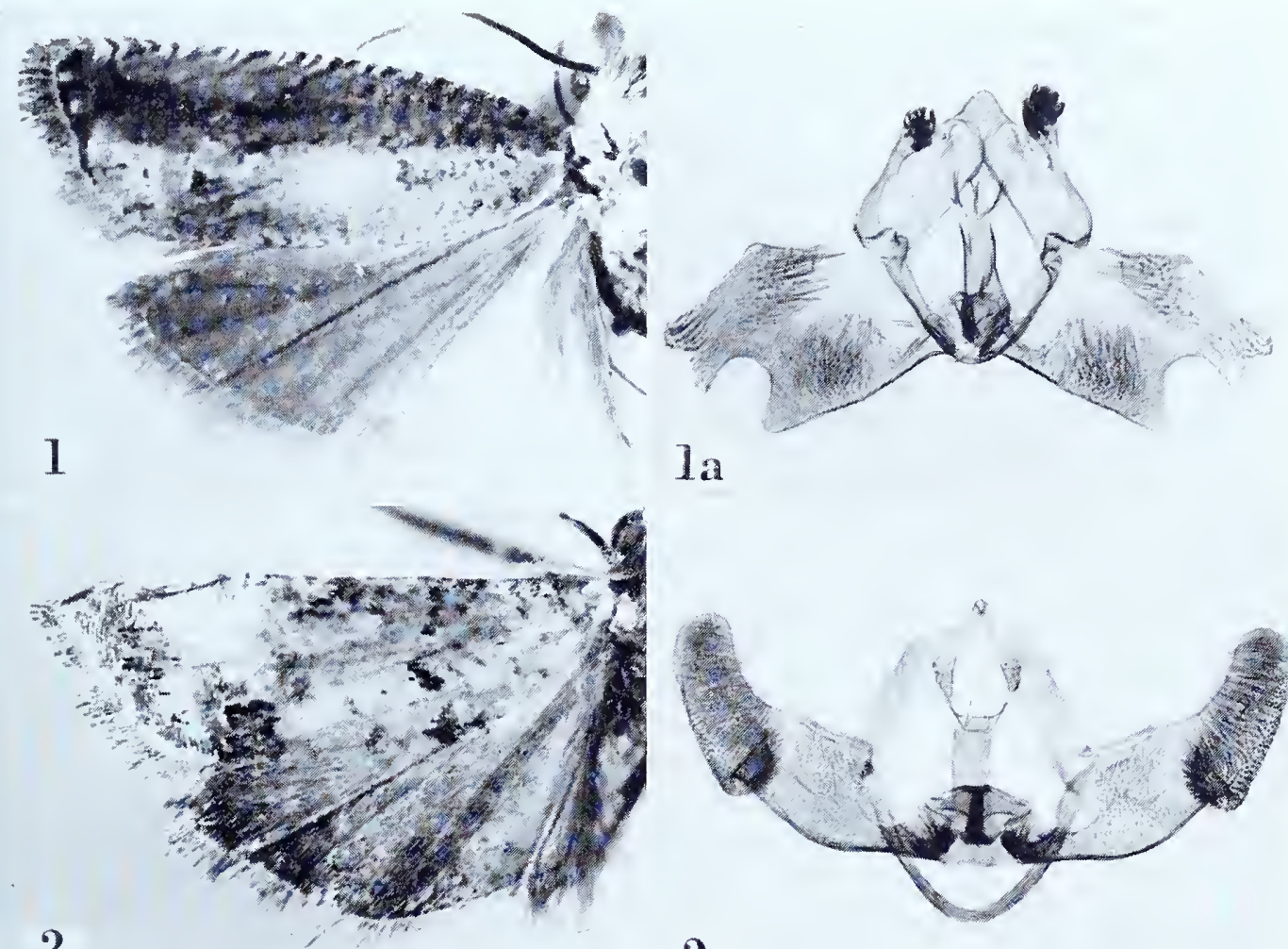

2

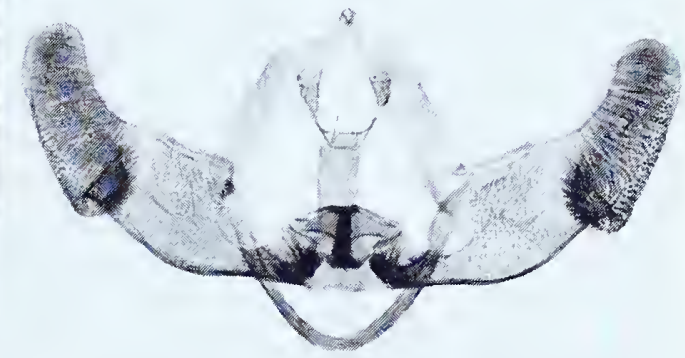

$2 a$

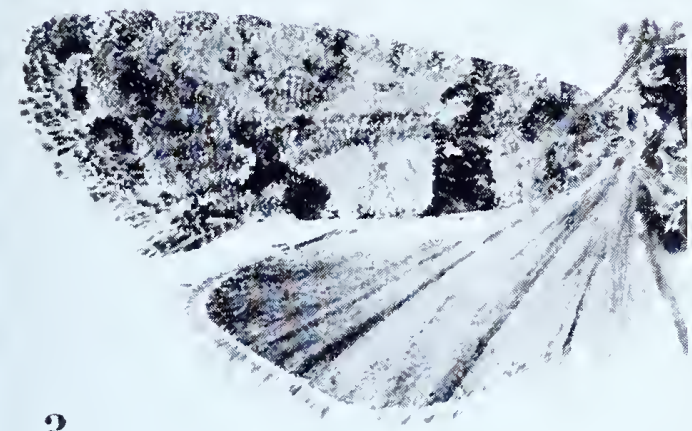

3

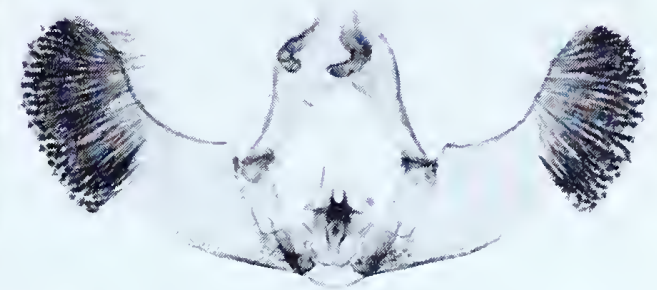

$3 a$

EUCOSMA 

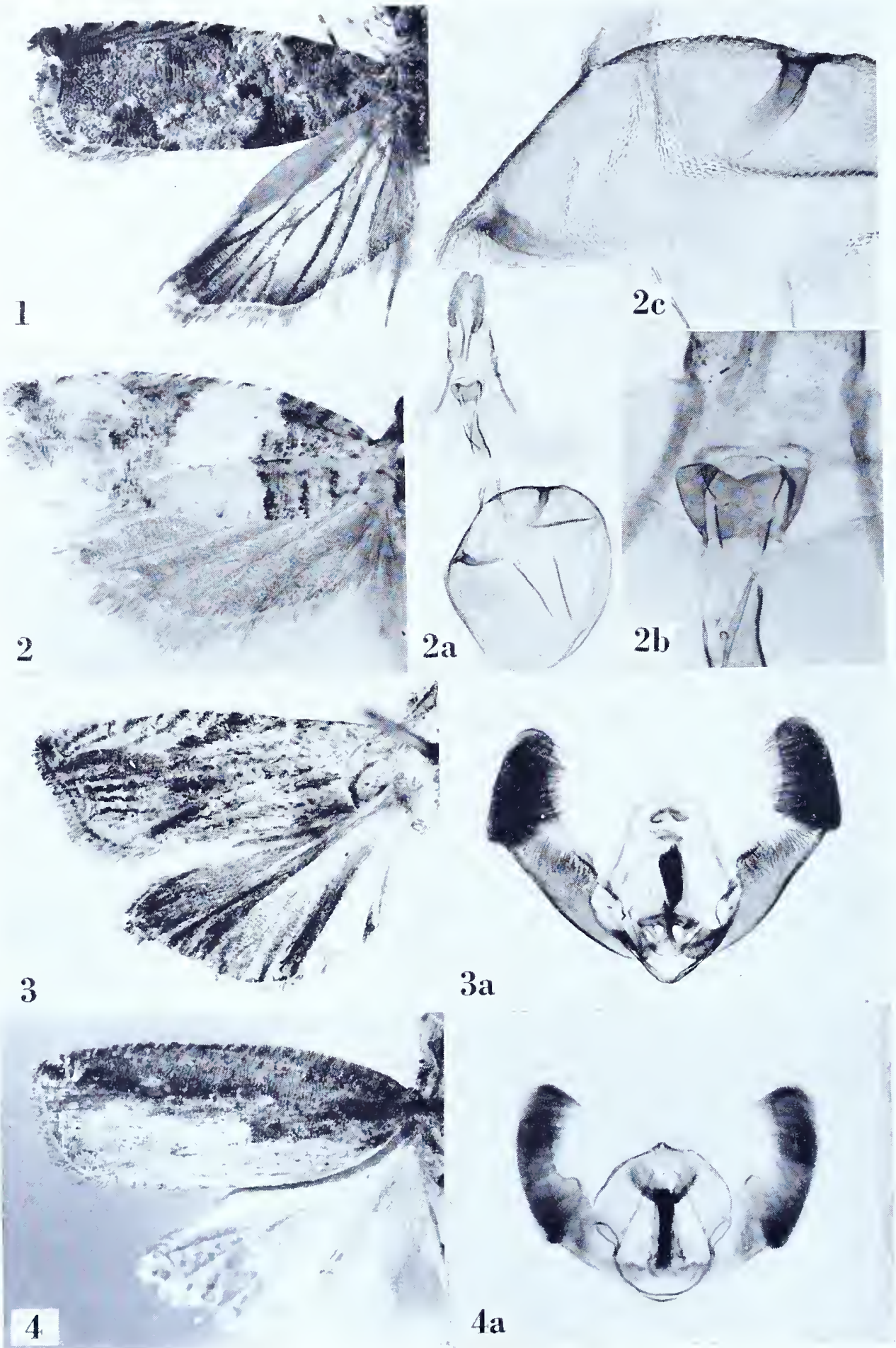


\section{Eucosma rhymogramma Meyrick}

Plate I92, Figure I

Encosma rhymogramma Meyrick, i9i6, Exotic Microlepidoptera, 2: i7.

"ㅇ. 15 mm. . . U Upper Burma, Myitkyina, in August (Fletcher); one specimen."

Type: The above indicated female dated ".8.15". The abdomen of the type is missing.

Figure $\mathrm{I}$, left wings.

\section{Eucosma sandycitis Meyrick}

Plate i 92, Figures 2-2c

Eucosma sandycitis Meyrick, I9 16, Exotic Microlepidoptera, I: $5^{6} \mathrm{I}$.

“ㅇ. $14 \mathrm{~mm}$. . . . Nyassaland, Mt. Mlanje, in December (Neave); one specimen . . . perhaps nearest marmara. Type in British Museum."

Type: The specimen so marked in the British Museum, "Mt. Mlanje, Nyasaland. 7.xii.ı19. S. A. Neave." A small white label bears the inscription "M8 77 ". Slide No. 7332 .

Figure 2, left wings; $2 \mathrm{a}$, ventral view of female genitalia; $2 \mathrm{~b}$, detail of ostium; 2c, signa.

\section{Eucosma scutiformis Meyrick}

Plate 192, Figures $3-3$ a

Eucosma scntiformis Meyrick, I93I, in Caradja, Bull. Sect. sci. Acad. roum., I4: 64.

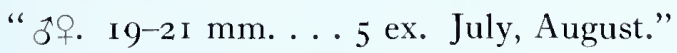

Lectotype: A male measuring 19 mm., "Kwanhsien, China. F. .7.28." Slide No. 7092 .

Figure 3 , left wings; 3 a, ventral view of male genitalia with aedeagus in situ.

\section{Eucosma sediliata (Meyrick)}

Plate 192, Figures $4-4$ a

Argyroploce sediliata Meyrick, igr2, Trans. Ent. Soc. London, I9 I : 689.

"ふै. $23 \mathrm{~mm}$. . . Colombia, San Antonio, 5,80o feet, in November; one specimen." Type: The specimen indicated above dated “.11.07”. Slide No. 6389 .

Figure 4, left wings; 4 a, ventral view of male genitalia with aedeagus in sitn. 
EUCOSMA

\section{Eucosma semicurva Meyrick}

Plate 193, Figures I-I b

Eucosma senicurva Meyrick, I912, Journ. Bombay Nat. Hist. Soc., 2 1 : 864.

"ㅇ. 1 $5^{-1} 6 \mathrm{~mm}$. . . . Khasis; in June, two specimens."

Lectotype: The female measuring $16 \mathrm{~mm}$. Slide No. 6990. Both specimens are labelled, "Khasi Hills, Assam. .6.1906."

Figure I, left wings; 1 a, ventral view of female genitalia; $\mathrm{ib}$, signa.

\section{Eucosma sepulchrana Meyrick}

See Eucosma mediostriata (Walsingham).

\section{Eucosma solidata Meyrick}

See Gypsonoma solidata (Meyrick).

\section{Eucosma sparactis Meyrick}

Plate 193, Figures 2-2a

Eucosma sparactis Meyrick, 1928, Exotic Microlepidoptera, 3:440.

“ ". I 5-16 mm.... Uganda, Kampala, November (Hancock); 2 ex. (type Brit. Mus.). Near riciniata."

Type: Ô, I 5 mm., "Uganda, Kampala. 25.iii.1927. G. L. R. Hancock." Slide No. $733^{\circ}$. The disparity in the dates is due to the fact that the pin has nearly obliterated the third digit of the Roman numeral "III" and Meyrick missed it. The second specimen is clearly marked in Arabic ".3.27".

Figure 2 , left wings; $2 \mathrm{a}$, ventral view of male genitalia with aedeagus in situ.

\section{Eucosma speculatrix (Meyrick)}

Plate 193 , Figures $3-3 \mathrm{~b}$

Cydia speculatrix Meyrick, 1907, Journ. Bombay Nat. Hist. Soc., I 8: 143.

"สํ. I $3^{-1} 5 \mathrm{~mm}$. . . . Khasi Hills, in September; twelve specimens. Also one $\widehat{0}$ from Darjiling, in August, with hindwings greyer, but apparently not otherwise different."

Lectotype: A male measuring 14 mm., "Khasi Hills, Assam. .9.1906." Slide No. 7091 .

Figure 3 , left wings; 3 a, ventral view of male genitalia with aedeagus in situ; 3 b, denuded abdomen to show abdominal pockets which receive a hair-pencil from hindwings.

[continued on page 423 . 


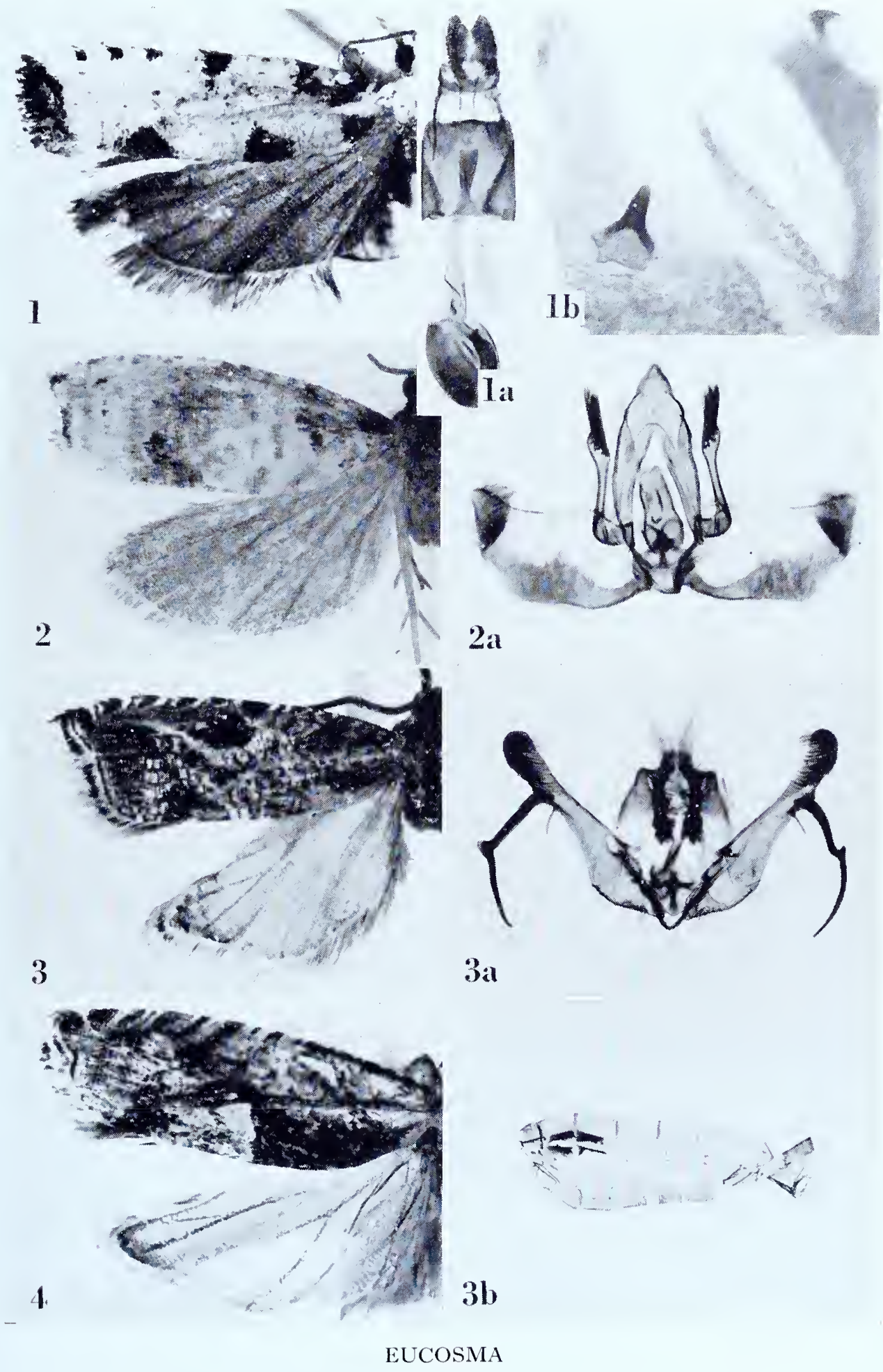



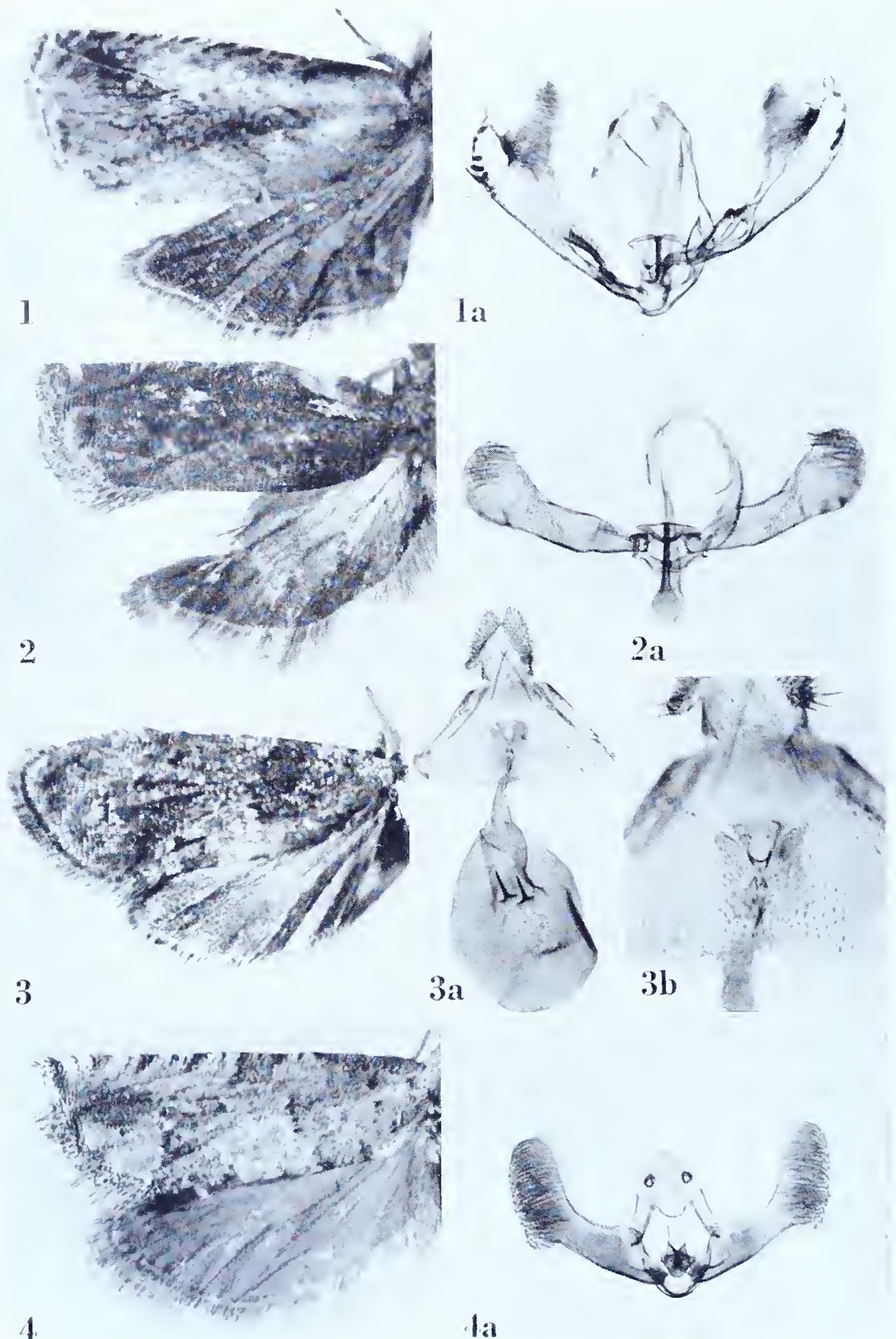

EUCOSMA 


\section{Eucosma spicea Meyrick}

Plate 194, Figures I-ia

Eucosma spicea Meyrick, I912, Journ. Bombay Nat. Hist. Soc., 2 I : 867.

" 0 . I 3 mm. . . Khasis; in June, one specimen."

Type: The above indicated male, "Khasi Hills, Assam. .6.1906." Slide No. 6993.

Figure I, left wings; ra, ventral view of male genitalia with aedeagus in situ.

\section{Eucosma stereoma Meyrick}

Plate 194, Figures 2-2a

Eucosma stereoma Meyrick, I9I2, Exotic Microlepidoptera, I: 33 .

" $\hat{\beta}+$. Io-I I mm. . . Bengal, Pusa, in August (Fletcher); two specimens."

Lectotype: The male, dated ".4.8.I I". Slide No. 6978.

Figure 2, left wings; $2 \mathrm{a}$, ventral view of male genitalia with aedeagus in situ.

\section{Eucosma subdecora Meyrick}

Plate 194, Figures $3-3 \mathrm{~b}$

Eucosma subdecora Meyrick, I922, Exotic Microlepidoptera, 2: 5 I 8.

" $\$$. $9 \mathrm{~mm}$. . . Madras, Palnis, 7,000 feet, August (Fletcher); I ex."

Type: The specimen denoted above, "Palnis, India, 7,000' TBF. .8.2 I", erroneously recorded as a male. Slide No. 7098.

Figure 3 , left wings; $3 \mathrm{a}$, ventral view of female genitalia; $3 \mathrm{~b}$, detail of genital plate and ostium.

\section{Eucosma symbolaspis Meyrick}

Plate 194, Figures $4-4^{\mathrm{a}}$

Eucosma symbolaspis Meyrick, I927, Exotic Microlepidoptera, 3:334.

" สำ. I3-1 8 mm. . . . Texas, Alpine, 7,000-8,000 feet, April, May; i 8 ex. Nearest insidiosana."

Lectotype: A male measuring 15 mm., "Brenster Co. Texas, 7,000 ft. .4.26." Slide No. 6387 .

Figure 4 , left wings; 4 a, ventral view of male genitalia with aedeagus in situ. 
EUCOSMA

\section{Eucosma tolerans Meyrick}

Plate 195, Figures I-Ia

Encosma tolerans Meyrick, I930, Exotic Microlepidoptera, 3: 599.

" o. I $8 \mathrm{~mm}$. . . . Tibet, Gyantse, i3, ooo feet, August (Colonel F. M. Bailey); i ex. Allied to the North American pulveratana."

Type: The above indicated specimen dated ".8.28". Slide No. 7053 .

Figure I, left wings; ra, ventral view of male genitalia with aedeagus in situ.

\section{Eucosma tonitraulis Meyrick}

Plate 195 , Figures 2-2b

Eucosma tonitranlis Meyrick, I934, Ann. Mag. Nat. Hist., I4: 405.

" I. $7 \mathrm{~mm}$. ... Sâo Tomé, Nov. 5; i ex. Possibly related to melananla Meyr...."

Type: The specimen so marked in the British Museum, "São Thomé I. W. Africa. 5-xi-1932. W. H. T. Tams." Slide No. 7012.

Figure 2, left wings; $2 \mathrm{a}$, ventral view of male genitalia with aedeagus in situ; $2 \mathrm{~b}$, part of denuded abdomen to show posterior tufts.

See Enlia torrens (Meyrick).

\section{Eucosma torrens Meyrick}

\section{Eucosma trichocrossa Meyrick}

See Eurosma critica Meyrick.

\section{Eucosma trilithopa Meyrick \\ Plate 195, Figures $3^{-} 3^{\mathrm{a}}$}

Encosma trilithopa Meyrick, 1937, in Caradja and Meyrick, Deuts. Ent. Zeit. Iris, 51 : 178. “... ô. I 4 mm. ... Yül, 2,800 m., VI, I ex."

Type: The male indicated above labelled, "Likiang, China. H. .6.34." Slide No. 7106.

Figure 3 , left wings; 3 a, ventral view of male genitalia with aedeagus in situ.

\section{Eucosma tumulata (Meyrick)}

Plate 195, Figures $4-4 \mathrm{c}$

Cydia tummlata Meyrick, i 908, Proc. Zool. Soc. London, i 908: 720.

"ㅇ․ I $6 \mathrm{~mm}$. . . . Transvaal, Pretoria district, in December and January (Fanse); one specimen." [sic!]

Type: The female in the Meyrick collection labelled, "Pretoria, Transvaal. Janse. 25.i.o7." Slide No. 9395. Meyrick recorded two months but only one specimen!

Figure 4 , left wings; 4 a, ventral view of female genitalia without ovipositor; $4 \mathrm{~b}$, detail of genital plate and ostium; 4c, signa. 


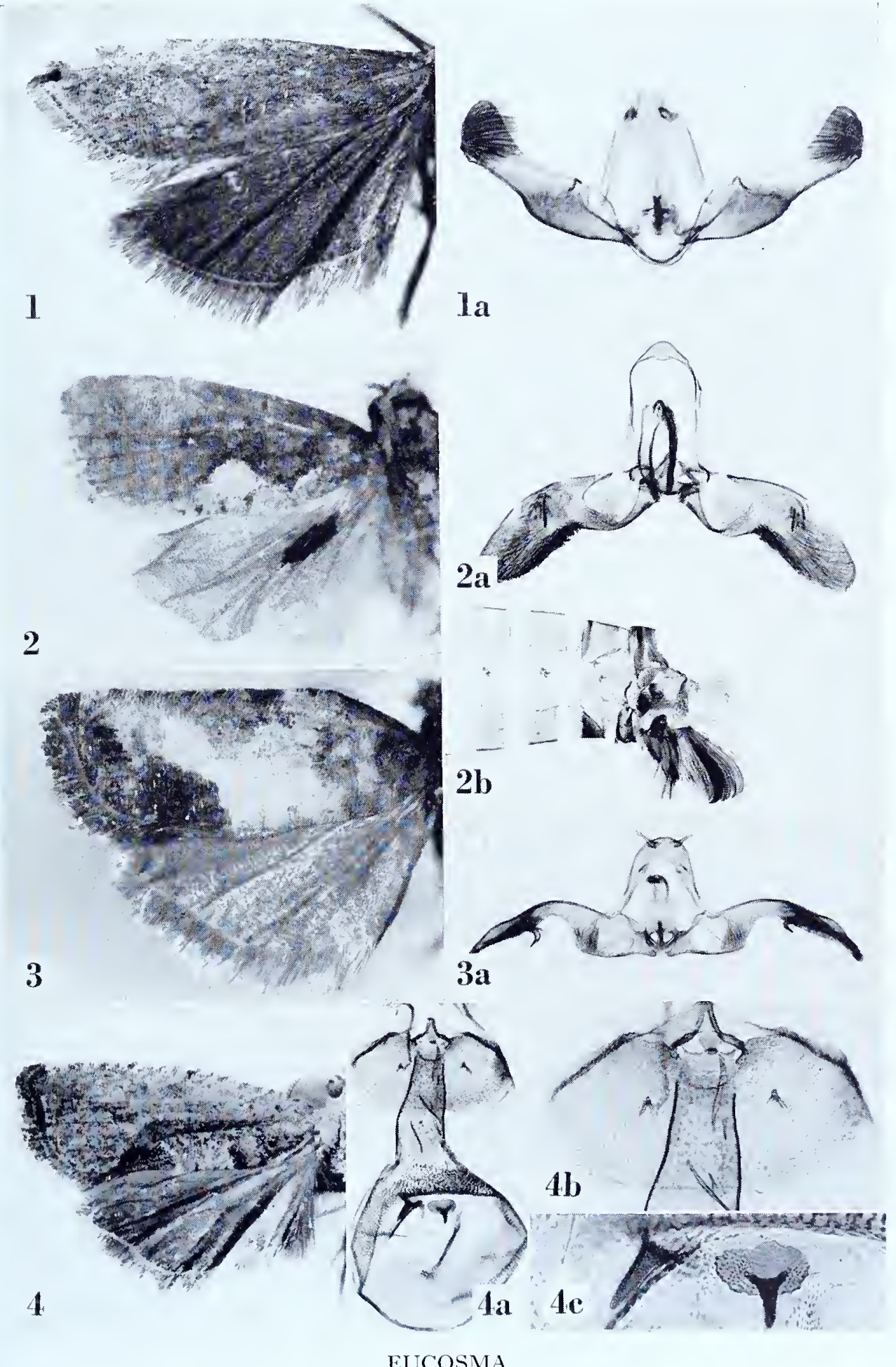



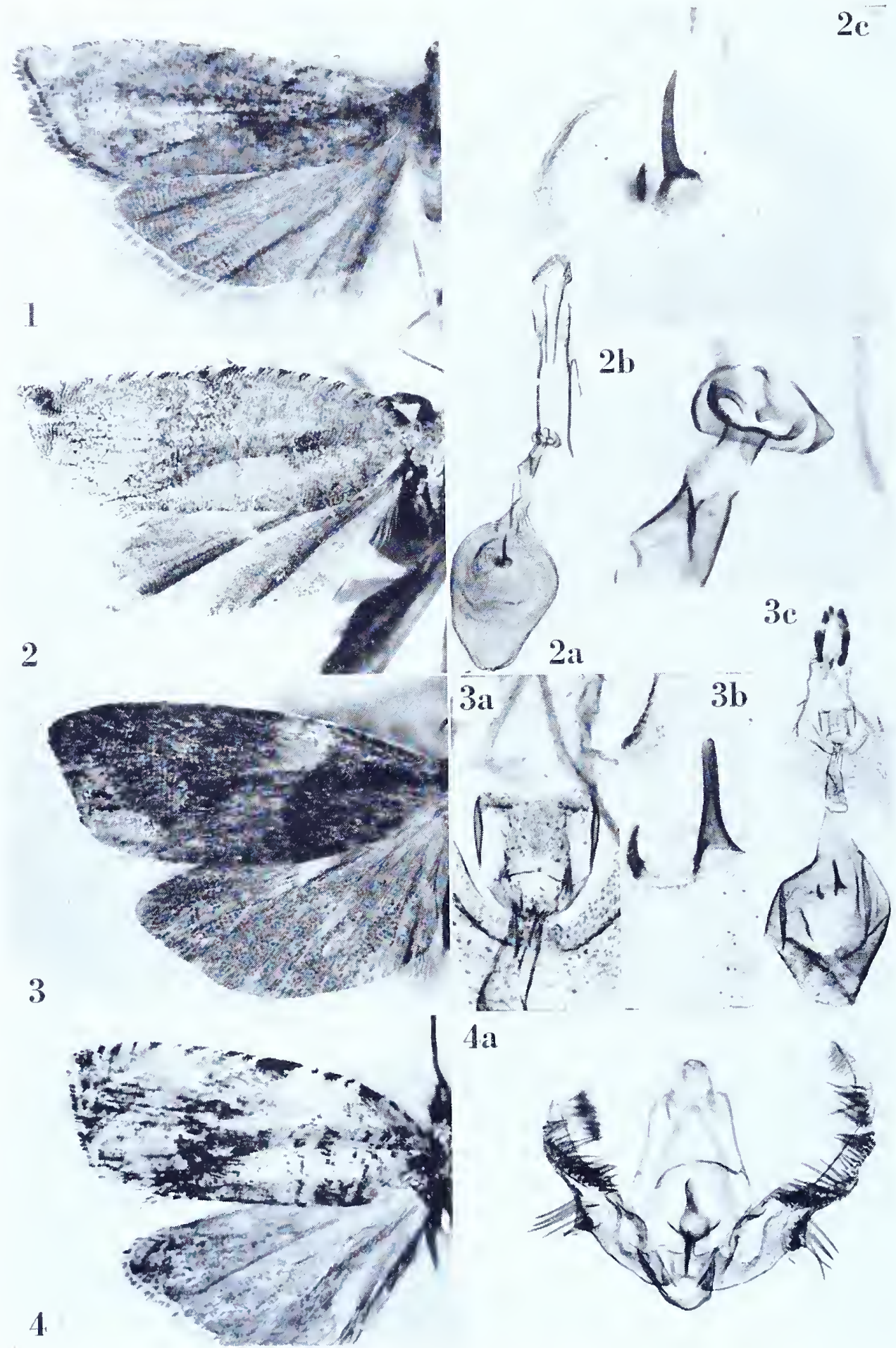


\section{Eucosma vulpecularis Meyrick}

Plate 196, Figure I

Eucosma vulpecularis Meyrick, I932, Trans. Ent. Soc. London, 80: 1 I I.

"

Type: The male so marked in the British Museum, "Djem-Djem Forest, Abyssinia. ca. 8,000 ft., 5-7-x-1926. H. Scott." The abdomen of the type is missing.

Figure I, left wings.

\section{Eucosma xerophloea Meyrick}

Plate 196, Figures 2-2c

Eucosma xerophloea Meyrick, 1933, Exotic Microlepidoptera, 4:418.

“ స์․ I2-16 mm. . . Punjab, Multan, Ghazighat, bred September from larvae feeding on Populus eupliratica (Indian Forest Entomologist); 8 ex."

Lectotype: A female measuring 16 mm., dated “.9.28”. Slide No. 6980. Five specimens are missing.

Figure 2, left wings; $2 \mathrm{a}$, ventral view of female genitalia; $2 \mathrm{~b}$, detail of ostium; 2c, signa.

\section{Eucosma zelota Meyrick}

Plate 196, Figures $3-3 \mathrm{c}$

Eucosma selota Meyrick, I916, Exotic Microlepidoptera, 2: 18.

“‥ $14 \mathrm{~mm}$. . . Punjab, Abbottabad, in May (Fletcher); one specimen."

Type: The female indicated above dated "21.5.15”. Slide No. 7047.

Figure 3 , left wings; $3 \mathrm{a}$, detail of ostium; $3 \mathrm{~b}$, signa; $3 \mathrm{c}$, ventral view of female genitalia.

\section{EXARTEMA Clemens}

\section{Exartema lobocasis (Meyrick), new combination}

Plate 196 , Figures $4^{-} 4^{a}$

Argyroploce lobocasis Meyrick, $193^{6}$, in Caradja and Meyrick, Deuts. Ent. Zeit. Iris, $5^{\circ}:{ }_{1} 6$. “... o. 13 mm. .. . Taishan, 5., 6., 3 ex...."

Type: The specimen in the Meyrick collection "Taishan, China. II. $5,000^{\prime} \cdot 5 \cdot 34$." Slide No. 7295. I designate this type rather than "lectotype" because Meyrick stated (l.c., p. 154 ) that he retained the types.

Figure 4 , left wings; $4 \mathrm{a}$, ventral view of male genitalia with aedeagus in situ (both harpes of the type are damaged). 


\section{GRAPHOLITHA Treitschke \\ Grapholitha bigeminata (Meyrick), new combination}

Plate i97, Figures I-Ia

Laspeyresia bigeminata Meyrick, 1935, in Caradja and Meyrick, Materialien zu einer Microlepidopteren Fauna der Chinesischen Provinzen Kiangsu, Chekiang und Hunan, 63 .

“... o. 9 mm.... Hoengshan, io.III, r.IV. 3 ex."

Type: The male in the Meyrick collection, "Hoeng-Shan, China. H. I0.3.33." Slide No. $735^{8}$.

Figure I, right wings (image reversed); Ia, ventral view of male genitalia with aedeagus in sith.

\section{Grapholitha biserialis (Meyrick), new combination}

Plate 197, Figures 2-2a

Laspeyresia biserialis Meyrick, 1935, in Caradja and Meyrick, Materialien zu einer Microlepidopteren Fauna der Chinesischen Provinzen Kiangsu, Chekiang und Hunan, 64. “... o. I $3 \mathrm{~mm}$. . . . I ex., Tienmushan, IV. Appears genuinely related to perlepidana."

Type: The male referred to above, "Tien-Mu-Shan, China. C. 5,000' 44.32." Slide No. 7359 .

Figure 2, left wings; 2a, ventral view of male genitalia with aedeagus in situ.

\section{Grapholitha callisphena (Meyrick), new combination}

Plate 197 , Figures $3^{-} 3^{\mathrm{c}}$

Laspeyresia callisphena Meyrick, I907, Journ. Bombay Nat. Hist. Soc., i 8: I44.

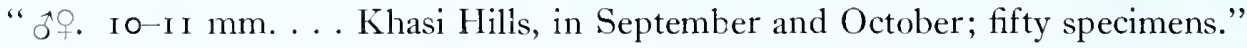

Lectotype: A female measuring i mm., dated ".9. I 9o6". Slide No. 738r. Only nine specimens remain in the Meyrick collection and the six specimens with abdomens are females.

Figure 3 , left wings; $3 \mathrm{a}$, ventral view of female genitalia; $3 \mathrm{~b}$, signa; $3 \mathrm{c}$, detail of ostium.

\section{Grapholitha cyanogona (Meyrick), new combination Plate 197, Figures $4-4 \mathrm{c}$}

Laspeyresia cyanogona Meyrick, I907, Journ. Bombay Nat. Hist. Soc., I8: I46.

"ô. IO-I I mm. ... Khasi Hills, in September; two specimens."

Lectotype: A female dated ".9.1906". Slide No. 7380 . Both specimens appear to be females, but the second lacks hindwings and abdomen.

Figure 4 , left wings; $4 \mathrm{a}$, ventral view of female genitalia; $4 \mathrm{~b}$, detail of ostium; $4^{\mathrm{c}}$, signa. 


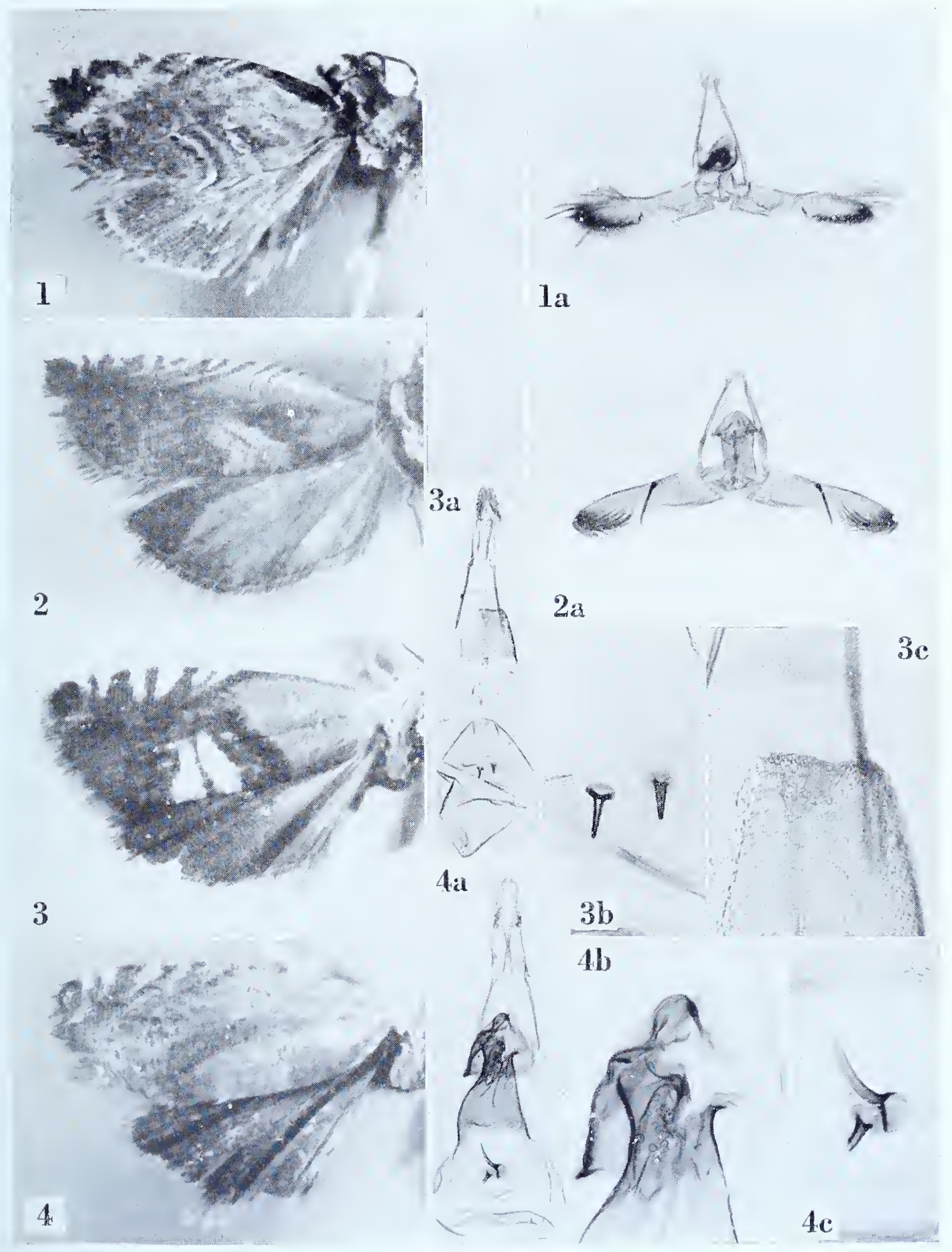



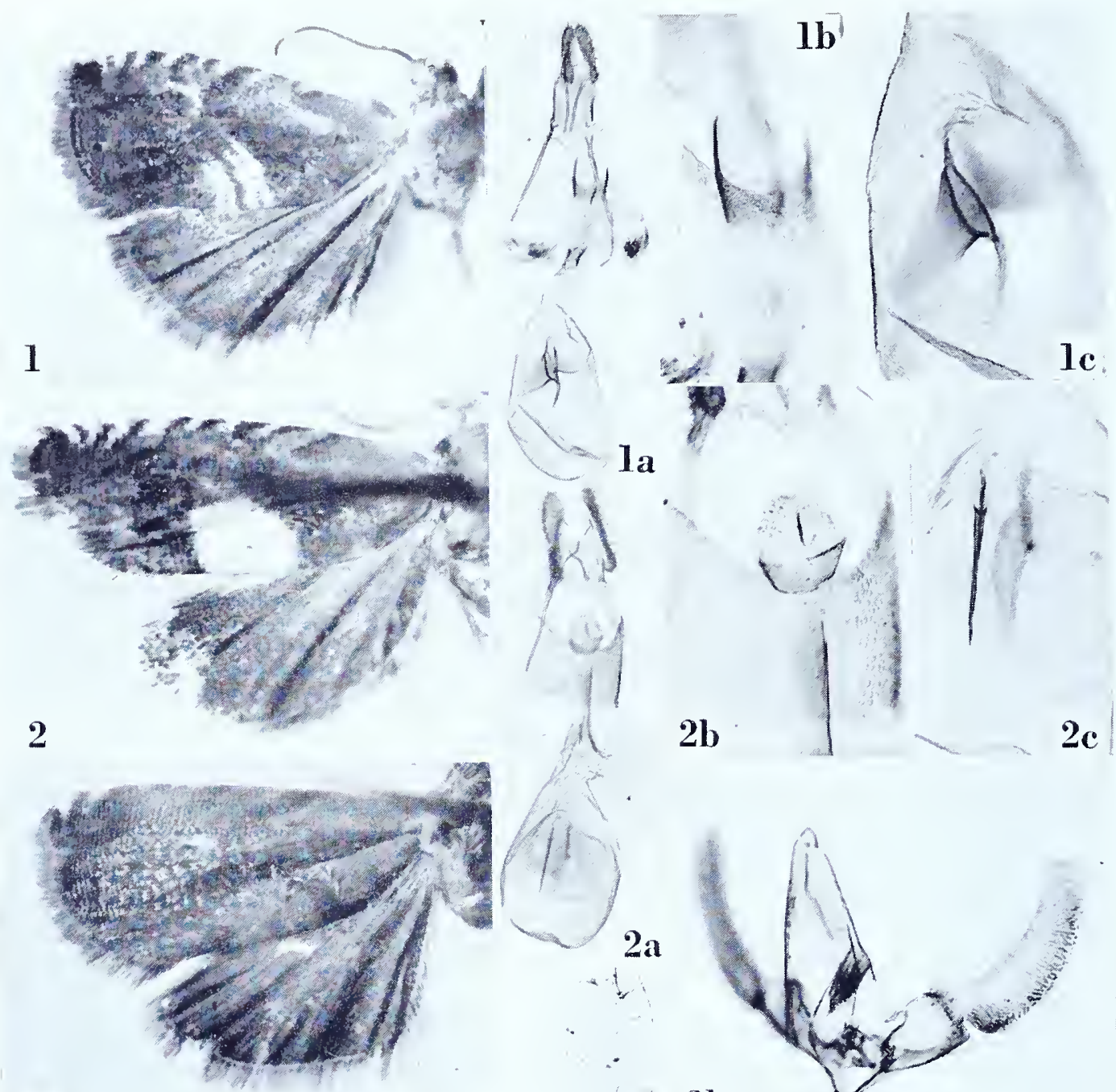

3
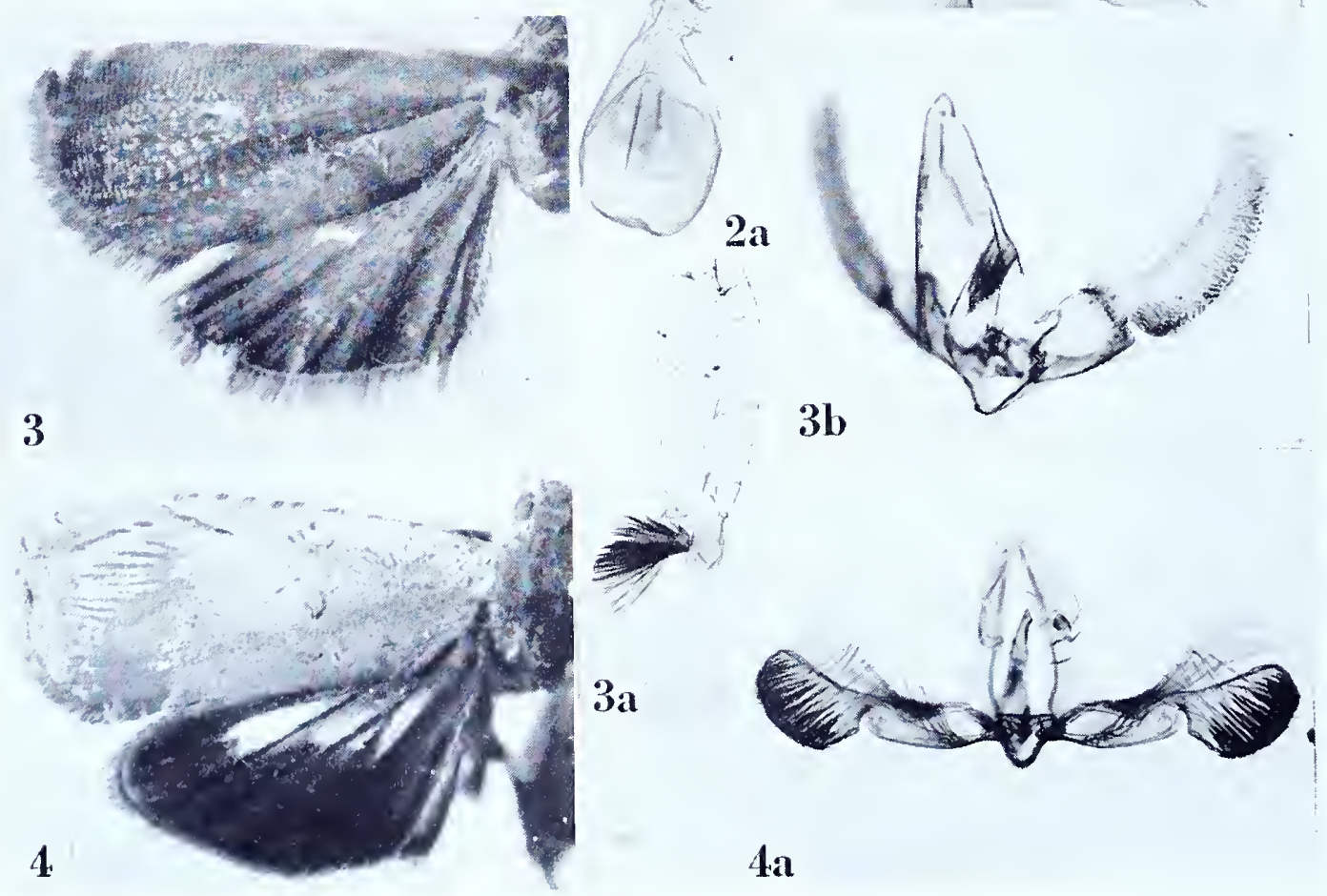


\title{
Grapholitha fistularis (Meyrick), new combination
}

\author{
Plate 198, Figures $1-1 \mathrm{C}$
}

Laspeyresia fistularis Meyrick, 1928, Exotic Microlepidoptera, 3:449.

"ㅇ. 1 I mm.... St. Matthias I., July (Eichhorn); i ex. Nearly allied to delineana...."

Type: The female denoted above dated "July, 1923". Slide No. 7409.

Figure $\mathrm{r}$, left wings; 1 a, ventral view of female genitalia; $\mathbf{b}$, detail of genital plate and ostium; Ic, signa.

\section{Grapholitha hylophanes (Meyrick), new combination}

Plate 198 , Figures $2-2 \mathrm{c}$

Laspeyresia hylophanes Meyrick, 1928, Exotic Microlepidoptera, 3:447.

"ㅇ. $9 \mathrm{~mm}$. . . . Punjab, Simla, 7,500 feet, in jungle, June (Fletcher); x ex. Between callisphena and torodelta. ..."

Type: The female indicated above dated ".6.2 I". Slide No. 7369.

Figure 2, left wings; $2 \mathrm{a}$, ventral view of female genitalia; $2 \mathrm{~b}$, detail of genital plate and ostium; 2 c, signa.

\section{Grapholitha ioxesta (Meyrick), new combination \\ Plate 198 , Figures $3-3 \mathrm{~b}$}

Laspeyresia ioxesta Meyrick, 1922, Exotic Microlepidoptera, 2: 532.

" o. Io mm. . . Brazil, Pará, July (Parish); x ex."

Type: The above indicated specimen dated "7-29". Slide No. 6489.

Figure 3 , left wings; $3 \mathrm{a}$, denuded abdomen to show posterior tufts; $3 \mathrm{~b}$, ventrolateral view of male genitalia with aedeagus in situ.

\section{Grapholitha optica (Meyrick), new combination \\ Plate 198 , Figures $4-4$ a}

Laspeyresia optica Meyrick, 1912, Journ. Bombay Nat. Hist. Soc., 21 : 875 .

" $\jmath$. I $6 \mathrm{~mm}$. . . . Khasis; in June, one specimen."

Type: The above indicated male, "Khasi Hills, Assam. .6.1 906." Slide No. 7366.

Figure 4 , left wings; $4^{\mathrm{a}}$, ventral view of male genitalia with aedeagus $i n$ situ. 


\section{Grapholitha palamedes (Meyrick), new combination}

Plate I 99, Figures $\mathrm{I}-\mathrm{Ib}$

Laspeyresia palamedes Meyrick, 1916, Exotic Microlepidoptera, I : 564.

" ${ }^{3} .8 \mathrm{~mm}$.... S. India, Coimbatore, in June (Fletcher); one specimen."

Type: The above indicated specimen dated "I7.6.13", erroneously recorded as a male. Slide No. 7408 .

Figure I, left wings; $\mathrm{a}$, ventral view of female genitalia; $\mathrm{rb}$, detail of genital plate and ostium.

\section{Grapholitha pycnograpta (Meyrick), new combination}

Plate 199, Figures 2-2b

Laspeyresia pycnograpta Meyrick, I 936, Exotic Microlepidoptera, 4: 616.

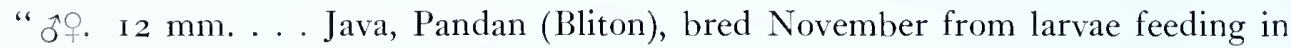
galls of Shorea (Dipterocarpaceae) (Dr. L. G. E. Kalshoven); 2 ex."

Lectotype: The male, "Pandan, Java. K. bred .i2.34." Slide No. 7365. The female is missing. The discrepancy in date is probably due to a lapsus.

Figure 2, left wings; $2 \mathrm{a}$, denuded abdomen to show posterior tufts; $2 b$, ventral view of male genitalia with aedeagus in situ.

\section{Grapholitha sporosema (Meyrick), new combination}

Plate 199, Figures $3-3 \mathrm{~b}$

Laspeyresia sporosema Meyrick, 1922, Exotic Microlepidoptera, 2: 53 I.

“ "م. 12 mm. . . Brazil, Obidos, September (Parish); ı ex."

Type: The above indicated male dated "9.19". Slide No. 6496.

Figure 3 , left wings; 3 a, denuded abdomen to show posterior tufts; 3 b, ventral view of male genitalia with aedeagus in situ. 


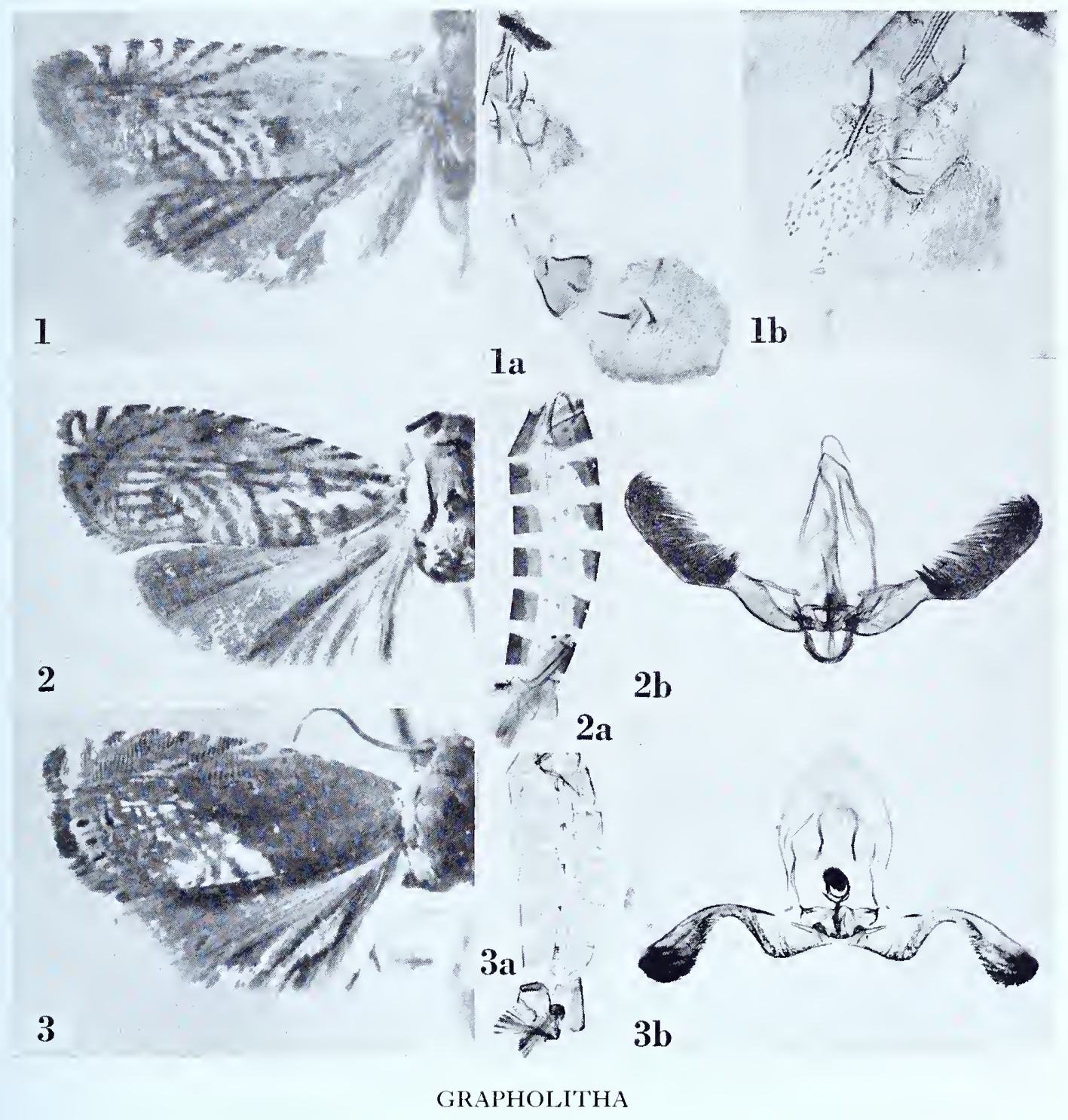



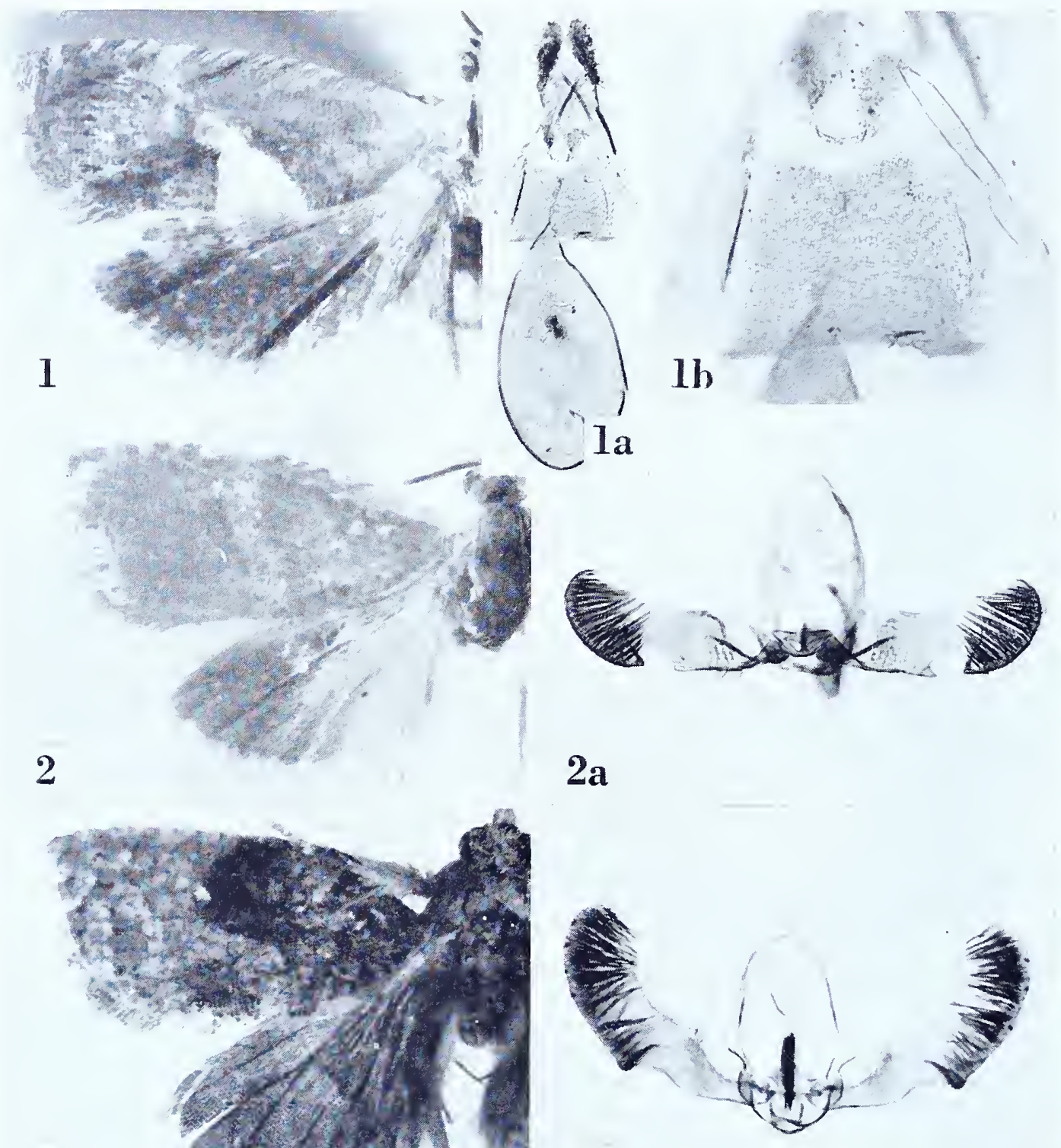

3

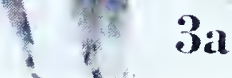

GRAPHOLITHA and GYMNANDROSOMA 


\section{Grapholitha torodelta (Meyrick), new combination}

Plate 200, Figures I-Ib

Laspeyresia torodelta Meyrick, 1914, Journ. Bombay Nat. Hist. Soc., 22: 772.

" $\sigma^{\circ}$. 9-10 mm. . . . Coimbatore, and in Malabar, bred in December and January (Fletcher); eight specimens. ..."

Lectotype: A female measuring ro mm., "Coimbatore, S. India. TBF. 8.I.I3." Slide No. 7396. The male sex was erroneously recorded by Meyrick; all are females.

Figure I, left wings; $r a$, ventral view of female genitalia; $r b$, detail of genital plate and ostium.

\section{Grapholitha uranatma (Meyrick), new combination}

Plate 200, Figures 2-2a

Laspeyresia uranatma Meyrick, 1936, Exotic Microlepidoptera, 4:615.

" 3 + . I I mm. . . Java, Telawa, bred October from larvae feeding in shoots of (?) Millettia sericea (Leguminosae) (Dr. L. G. Kalshoven); allied to cyanogona Meyr."

Lectotype: 'The male, "Telawa, Java. K. bred. . I0.34." Slide No. 7367.

Figure 2, left wings; 2a, ventral view of male genitalia with aedeagus in situ.

\section{GYMNANDROSOMA Dyar}

\section{Gymnandrosoma torticornis (Meyrick), new combination}

Plate 200, Figures $3-3^{\mathrm{a}}$

Argyroploce torticornis Meyrick, I93I, Exotic Microlepidoptera, 4: 137.

"우. $17 \mathrm{~mm}$. . . . Trinidad, bred from larvae on banana (Musa) and cacao plants (Theobroma) (D. Farrell); 3 ex. (type Brit. Mus.)."

Type: The male so marked in the British Museum, "Trinidad, F. W. Urich, Cacao." Slide No. 64I4.

Figure 3 , left wings; 3 a, ventral view of male genitalia with aedeagus in situ. 


\section{GYPSONOMA Meyrick \\ Gypsonoma anthracitis Meyrick}

Plate 20I, Figures 1-Ib

Gypsonoma anthracitis Meyrick, I912, Journ. Bombay Nat. Hist. Soc., 21 : 863; Diakonoff, I 950, Bull. Brit. Mus. (Nat. Hist.) Ent., I (4): 283 .

" $\hat{0}+$ r. Io-I I mm. . . Maskeliya, Ceylon (de Mowbray); in May, two specimens."

Lectotype: The male. Both specimens have identical data and are dated ".5.06". Slide No. 7I 82 . Diakonoff selected a "holotype", but since both specimens have equal value the lectotype designation stands.

Figure 1, left wings; Ia, ventral view of male genitalia with aedeagus in sitn; $\mathrm{Ib}$, lateral view of abdomen to show tufts.

\section{Gypsonoma ephoropa (Meyrick), new combination \\ Plate 20I, Figures 2-2a}

Encosma ephoropa Meyrick, 1931, Exotic Microlepidoptera, 4: 146.

“‡. I 5 mm. . . Japan, Sapporo, June (S. Issiki); I ex. . .."

Type: The male denoted above dated "27.6.17". Slide No. 7104.

Figure 2, left wings; $2 \mathrm{a}$, ventral view of male genitalia with aedeagus in sith.

\section{Gypsonoma holocrypta (Meyrick), new combination}

Plate 20I, Figures $3^{-} 3^{\text {a }}$

Encosma holocrypta Meyrick, I93 I, Exotic Microlepidoptera, 4: 146.

" ${ }^{\prime}+$. $16 \mathrm{~mm}$. . . J Japan, Sapporo, June $(S$. Issiki $) ; 2$ ex. This very featureless insect is not obviously near anything."

Lectotype: The male. Slide No. 7089. Both have identical data and are dated "27.6.17". The right forewing is missing from the lectotype and both forewings are missing from the female.

Figure 3 , left wings; 3 a, ventral view of male genitalia with aedeagus in sit $u$.

\section{Gypsonoma phaeocremna (Meyrick), new combination Plate 20I, Figures $4^{-} 4^{\mathrm{a}}$}

Encosma phaeocremma Meyrick, 1937, im Caradja and Meyrick, Deuts. Ent. Zeit. Iris. 51: I 79 .

“. . . \$ํ. I6-I7 mm. . . Y Yül., VI, 4,000-5,000 m., 3 ex.”

Lectotype: The male, "Likiang, China. I2,800'-15,000' H. 26.6.35." Slide No. 7107. All of the specimens are males.

Figure 4, left wings; 4 a, ventral view of male genitalia with aedeagus in situ. 

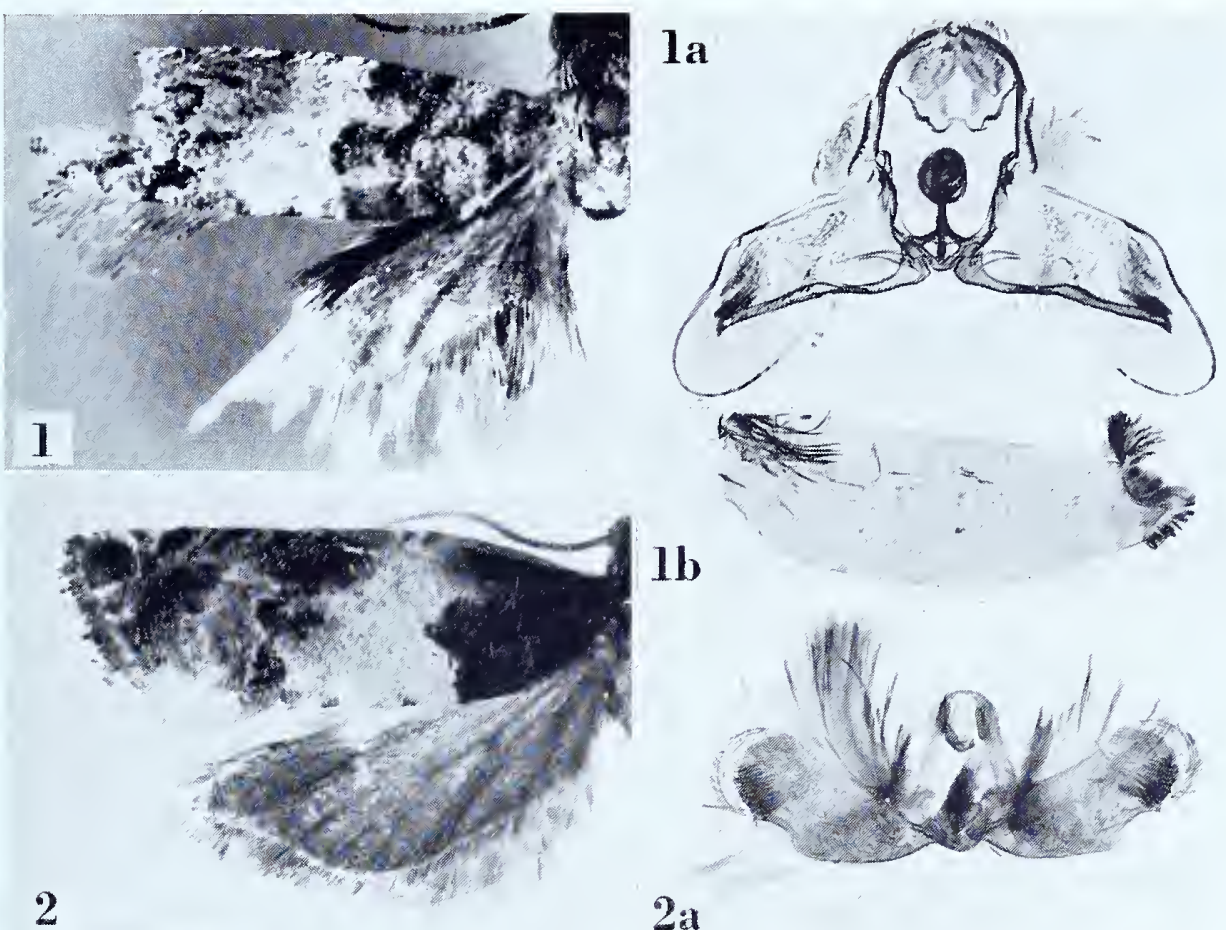

$1 b$

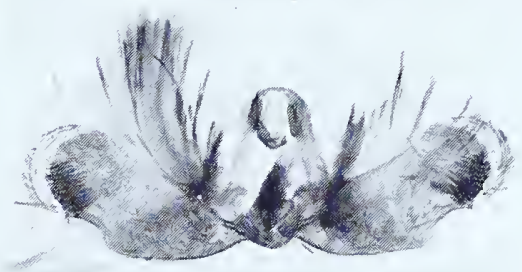

2a
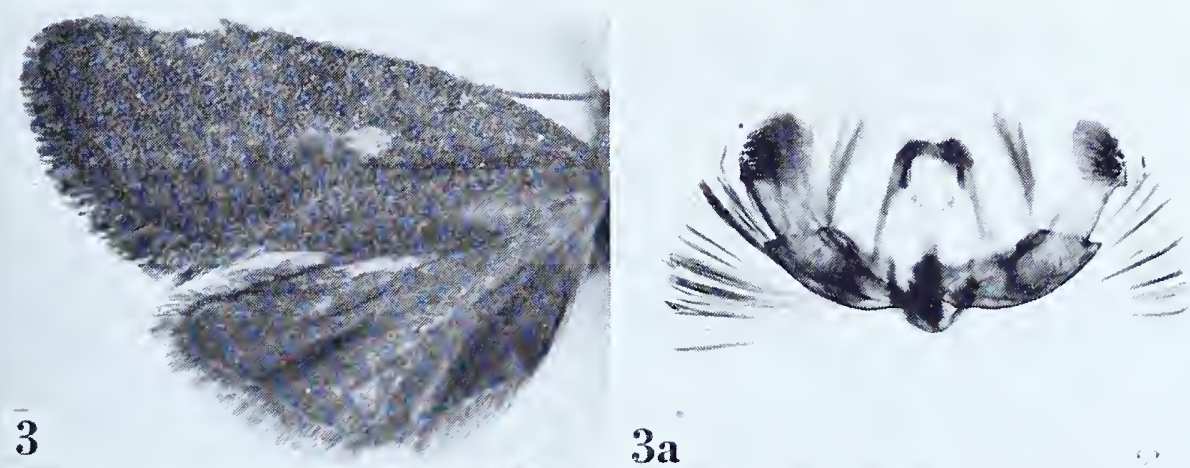

$3 a$
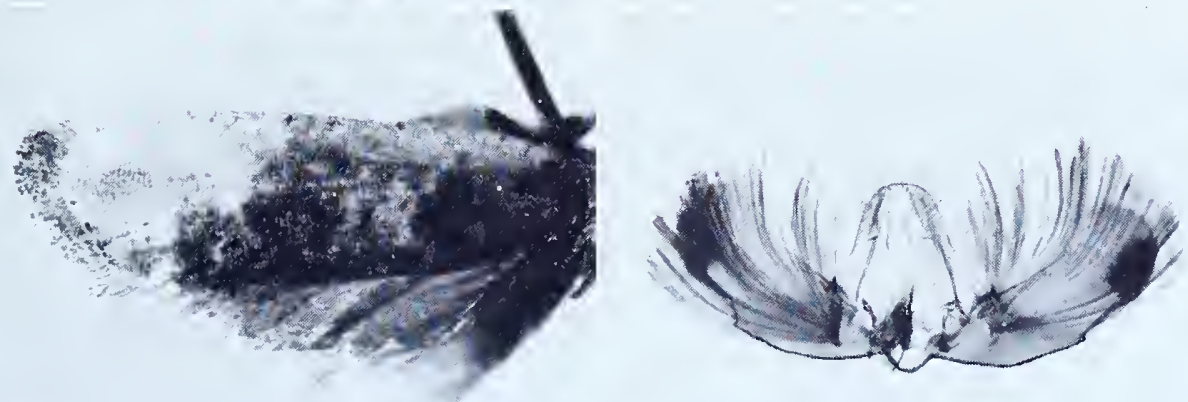

4

$4 a$

GYPSONOMA 

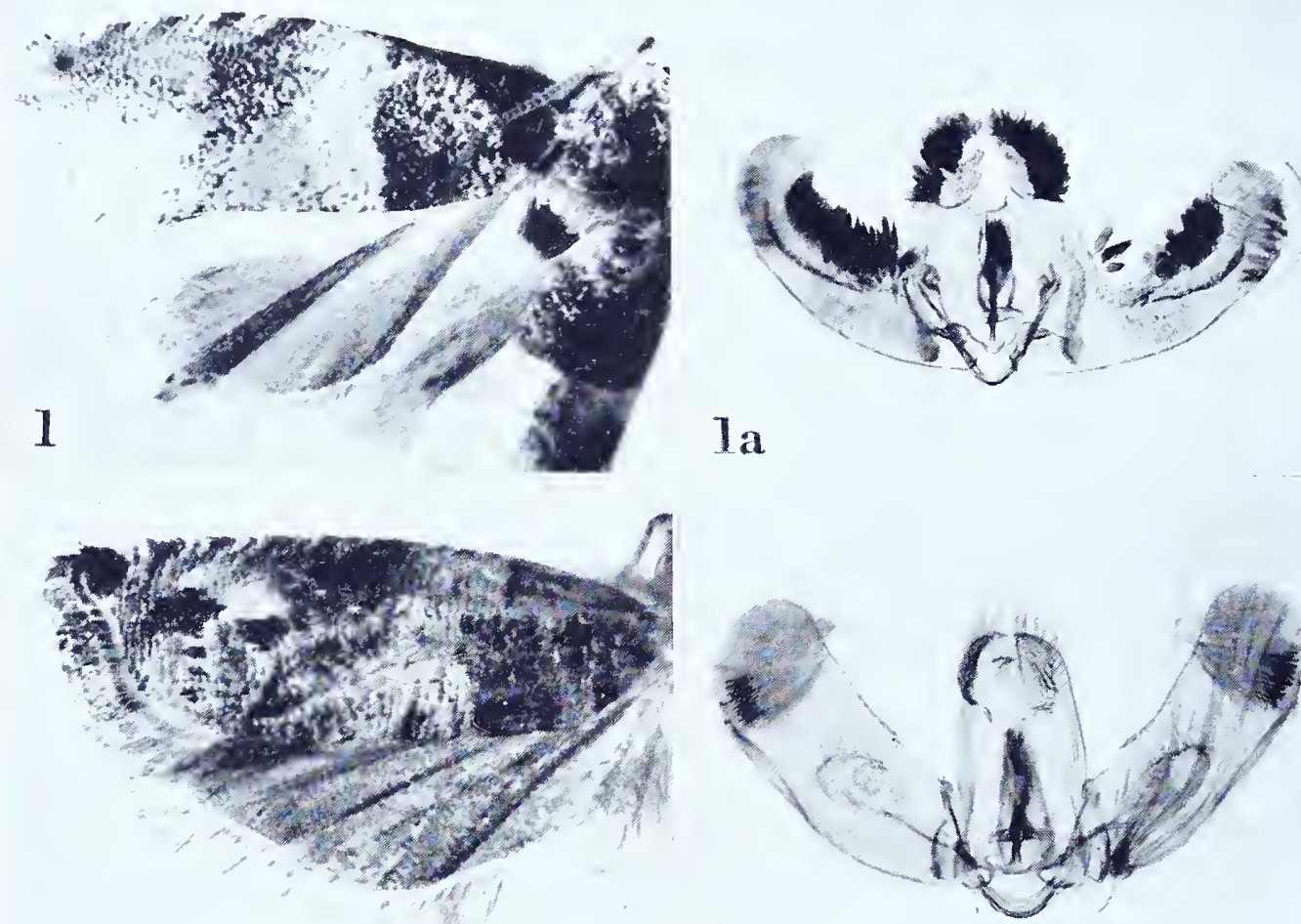

2

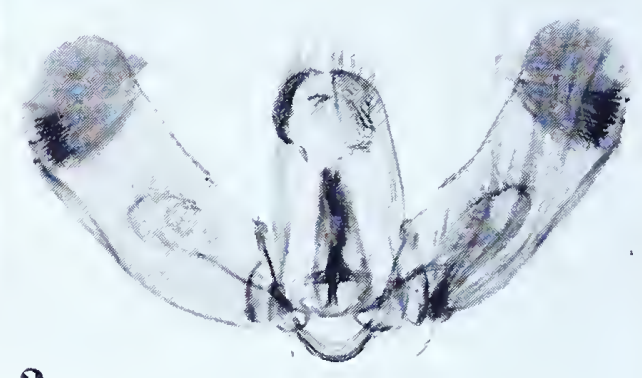

$2 a$
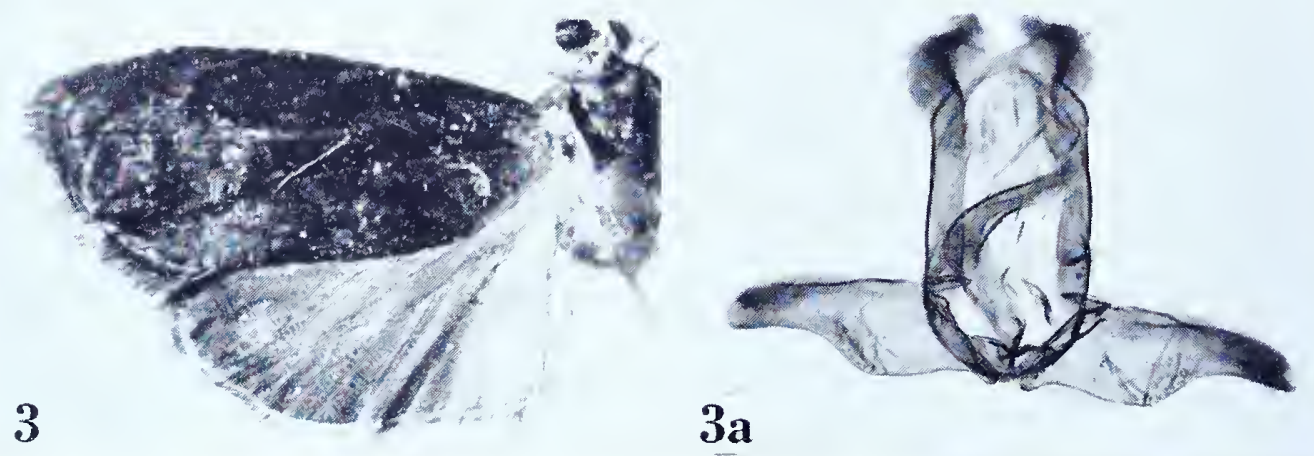

GYPSONOMA and HELICTOPHANES 


\section{Gypsonoma riparia Meyrick \\ Plate 202, Figures I-Ia}

Gypsonoma riparia Meyrick, I933, Exotic Microlepidoptera, 4:418; Diakonoff, 1950, Bull. Brit. Mus. (Nat. Hist.) Ent., I (4): 283 .

" to . 9-I I mm. ... Punjab, Multan, Ghazighat, bred September from larvae feeding on Populus euphratica (Indian Forest Entomologist); 6 ex. Nearly allied to the European aceriana. ..."

Lectotype: A male measuring $10 \mathrm{~mm}$., dated “.9.28”. Slide No. $698 \mathrm{I}$, selected by Diakonoff. Three specimens are missing.

Figure I, left wings; ra, ventral view of male genitalia with aedeagus in sitn.

\section{Gypsonoma solidata (Meyrick), new combination}

Plate 202, Figures 2-2a

Encosma solidata Meyrick, I912, Journ. Bombay Nat Hist. Soc., 2 I : 865.

" fo․ I I $-13 \mathrm{~mm} . .$. Khasis; in April and July, three specimens."

Lectotype: A male measuring 12 mm., "Khasi Hills, Assam. .4.1907." Slide No. 6989 .

Figure 2, left wings; 2a, ventral view of male genitalia with aedeagus in sitn.

\section{HELICTOPHANES Meyrick \\ Helictophanes dryocoma (Meyrick) \\ Plate 202, Figures 3-3a}

Argyroploce dryocoma Meyrick, 1916, Exotic Microlepidoptera, 2: 21.

" ${ }^{\circ}$. I I mm. ... S. India, Shevaroys, 4,500 feet, in December (Fletcher); one specimen."

Type: The male denoted above, "Shevaroys, S. India. 'TBF. 4,500' .12.13." Slide No. 7341 .

Figure 3 , left wings; 3 a, ventral view of male genitalia with aedeagus in sitn. 


\section{HEMIMENE Hübner \\ Hemimene ardescens Meyrick}

Plate 203, Figures 1-IC

Henimene ardescens Meyrick, I916, Exotic Microlepidoptera, 2: 26.

" $\vec{O}$. I 4 mm. . . . Peru, Pacaya, in July (Mounsey); one specimen."

Type: The above indicated specimen dated ".7.12", erroneously recorded as a male. Slide No. 6459.

Figure I, left wings; Ia, ventral view of female genitalia; Ib, signum; Ic, detail of genital plate and ostium.

\section{Hemimene carneola Meyrick}

Plate 203, Figures 2-2c

Hemimene canneola Meyrick, i9i6, Exotic Microlepidoptera, 2: 29.

" ô. $8 \mathrm{~mm}$. . . . Ecuador, Huigra, 4,500 feet, in June (Parish); one specimen."

Type: The above indicated specimen dated "6.14", erroneously recorded as a male. Slide No. 648ז.

Figure 2, left wings; 2a, signum; 2b, detail of genital plate and ostium; $2 \mathrm{c}$, ventral view of female genitalia.

\section{Hemimene citrophricta Meyrick}

Plate 203, Figures $3-3 \mathrm{c}$

Henimene citropliricta Meyrick, I922, Exotic Microlepidoptera, 2: 528.

" o. 7 mm. . . . Brazil, Pará, July (Parish); i ex."

Type: The specimen referred to above dated " 7 - I9", erroneously recorded as a male. Slide No. 6464.

Figure 3 , left wings; $3 a$, ventral view of female genitalia; $3 \mathrm{~b}$, detail of genital plate and ostium; $3 \mathrm{c}$, signum.

\section{Hemimene daedalopis Meyrick}

Plate 203, Figures $4-4 \mathrm{c}$

Hemintene daedalopis Meyrick, I 922, Exotic Microlepidoptera, 2: 530.

" + . I I $\rightarrow$ I 2 mm. . . Peru, Jurimaguas, March $($ Parish); 2 ex."

Lectotype: The larger of the two females both of which are dated " 3.20 ". Slide No. 6472 .

Figure 4 , left wings; 4 , detail of ostium; 4 b, signa; $4 c$, ventral view of female genitalia. 


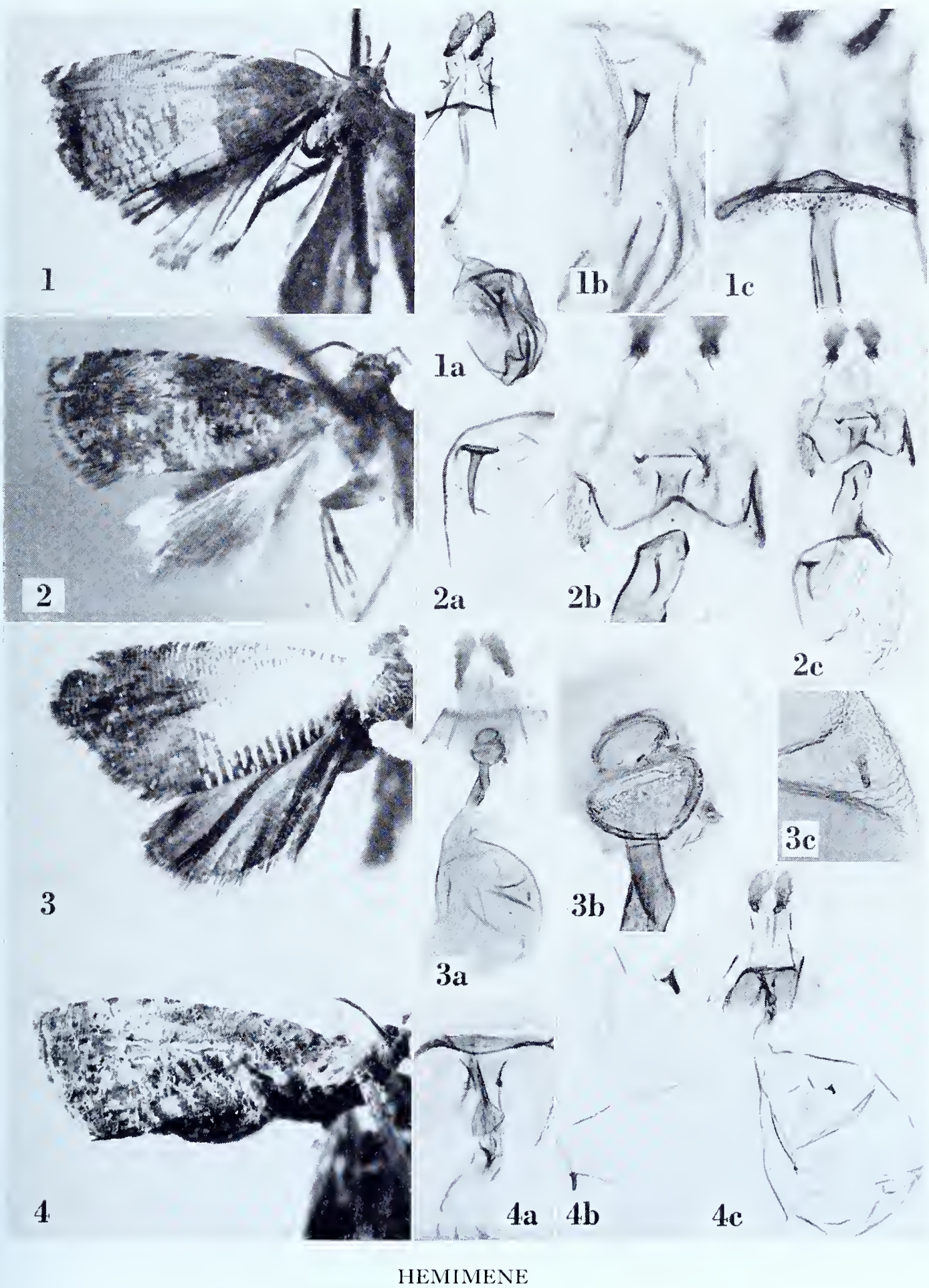




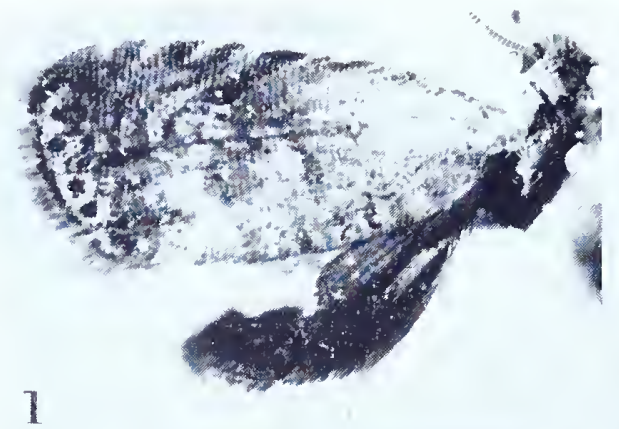

2
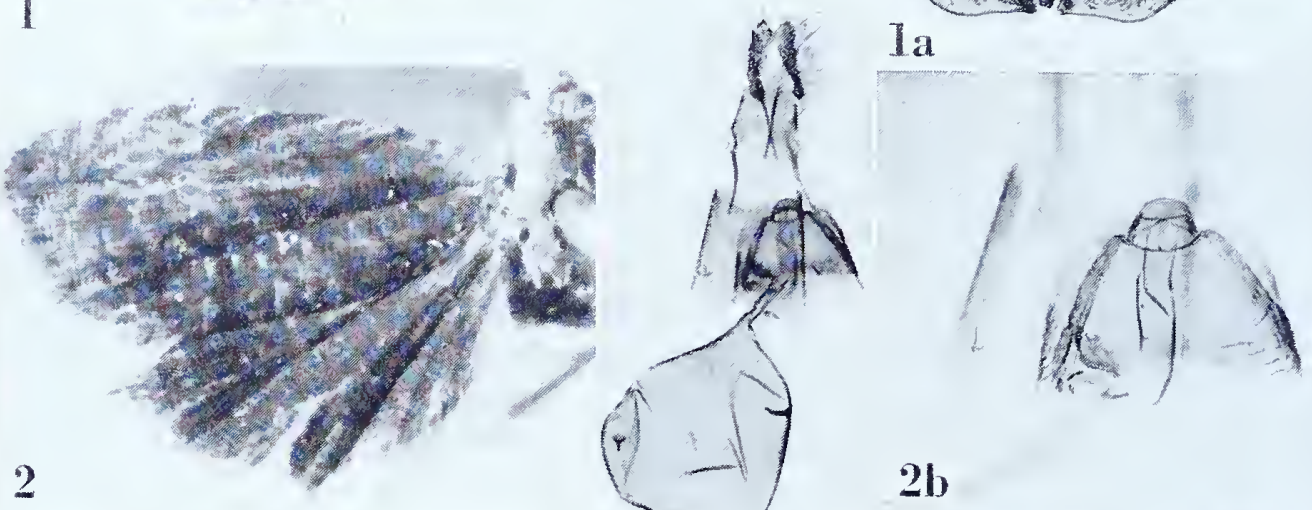

$(4-1)$

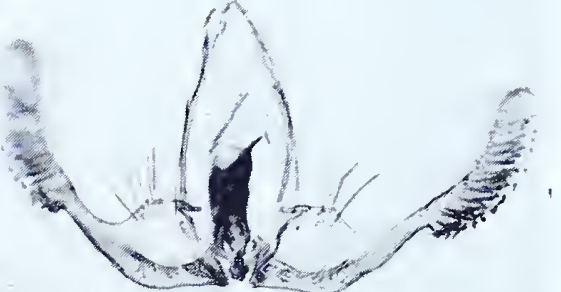

$2 a$
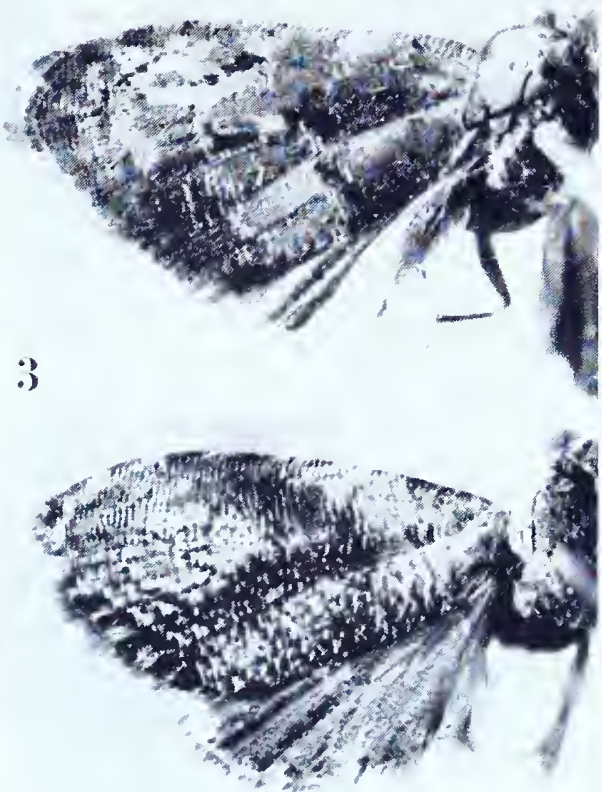

4
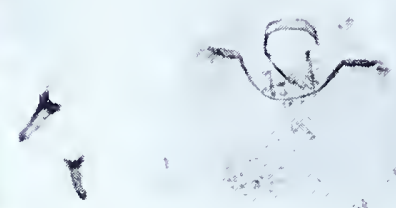

$2 b$
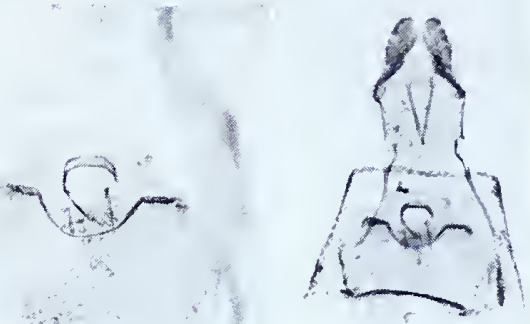

$3 a \quad 3 b$

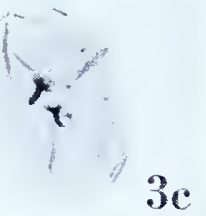

$4 a$

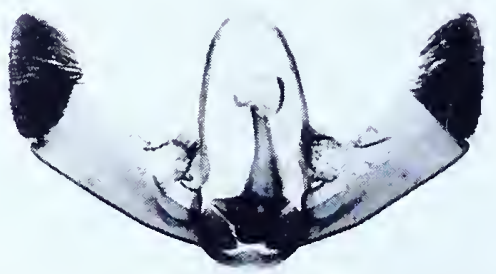




\section{Hemimene diagrapta Meyrick}

Plate 204, Figures I-Ia

Hemimene diagrapta Meyrick, I922, Exotic Microlepidoptera, 2: 27.

" of . I I-I I mm. ... British Guiana, Bartica and Mallali, from January to March (Parish); nine specimens."

Lectotype:'The male labelled, "Bartica, Brit. Guiana, Parish. .2.13." Slide No. 6470. One specimen is missing.

Figure I, left wings; ra, ventral view of male genitalia with aedeagus in sitn.

\section{Hemimene ferrata Meyrick}

Plate 204, Figures 2-2b

Hemimene ferrata Meyrick, i 916, Exotic Microlepidoptera, 2: 28.

"ㅇ. 9-10 mm. . . British Guiana, Bartica, in February (Parish); two specimens."

Lectotype: The larger of the two females both of which are dated ".2.13". Slide No. 6476 .

Figure 2, left wings; 2a, ventral view of female genitalia; $2 \mathrm{~b}$, detail of genital plate and ostium.

\section{Hemimene fulvipalpis Meyrick}

Plate 204 , Figures $3^{-3} \mathrm{c}$

Hemimene fnlvipalpis Meyrick, I922, Exotic Microlepidoptera, 2: 529.

"ㅇ. $9 \mathrm{~mm}$. . . . Brazil, Parintins, October (Parish); г ex."

Type: The female indicated above dated "Io-19". Slide No. 6466.

Figure 3 , left wings; $3 \mathrm{a}$, signa; $3 \mathrm{~b}$, detail of genital plate and ostium; $3 \mathrm{c}$, ventral view of female genitalia.

\section{Hemimene iocrossa Meyrick}

Plate 204, Figures $4^{-4}$ a

Hemimene iocrossa Meyrick, I916, Exotic Microlepidoptera, 2:25.

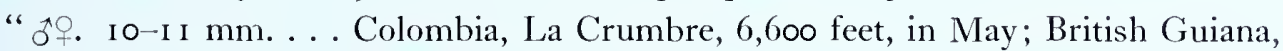
Bartica, in December (Parish); five specimens."

Lectotype: A male, "La Crumbre, Colombia. P. 6,600 ft., 5-I4." Slide No. 646I. Figure 4 , left wings; 4 a, ventral view of male genitalia with aedeagus in situ. 
HEMIMENE

\section{Hemimene latebrata Meyrick}

Plate 205, Figures $\mathrm{I}-\mathrm{I} b$

Hemimene latebrata Meyrick, I916, Exotic Microlepidoptera, 2: 26.

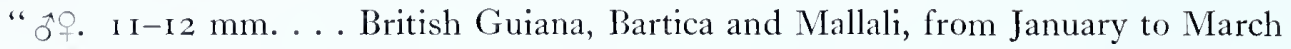
(Parish); twelve specimens."

Lectotype: A male measuring I I mm., labclled, "Bartica, Brit. Guiana, Parish. .2.1 3." Slide No. 6467 .

Figure $\mathrm{I}$, left wings; $\mathrm{ia}$, denuded abdomen to show scale tufts; $\mathrm{rb}$, ventral view of male genitalia with aedeagus in sitn.

\section{Hemimene limenita Meyrick}

Plate 205, Figures 2-20

Hemimene limenita Meyrick, 1922, Exotic Microlepidoptera, 2: 530.

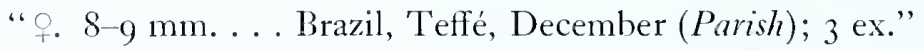

Lectotype:,$+ 8 \mathrm{~mm}$. Slide No. 6479. All specimens bear identical data and arc dated "I2.19".

Figure 2 , left wings; $2 a$, ventral view of female genitalia; $2 b$, detail of genital plate and ostium; 2c, signum.

\section{Hemimene luctifica Meyrick}

Plate 205, Figures $3-3 \mathrm{a}$

Hemimene luctifica Meyrick, 1922, Exotic Microlepidoptera, 2: 27.

" $f \nmid .12-13$ mm. ... British Guiana, Bartica and Mallali, from December to March (Parish); twenty specimens."

Lectotype:A male measuring 12 mm., labelled "Bartica, Brit. Guiana, Parish. .I.I3." Slide No. 6468. Nine specimens are missing.

Figure 3 , left wings; 3 a, ventral view of male genitalia with aedeagus in situ.

\section{Hemimene marmarocyma Meyrick}

Plate 205, Figures $4-4 \mathrm{~b}$

Hermimene [sic!] marmarocyma Meyrick, I93I, in Caradja and Meyrick, Bull. Sect. sci. Acad. roum., if: 66.

"†. $15-16 \mathrm{~mm} . . .2$ ex., July."

Lectotype: The female measuring i 5 mm., "Kwanhsien, China. F. 77.30." Slide No. $734^{2}$.

Figure 4 , lcft wings; 4 a, ventral view of female genitalia; $4 \mathrm{~b}$, detail of genital plate and ostium. 


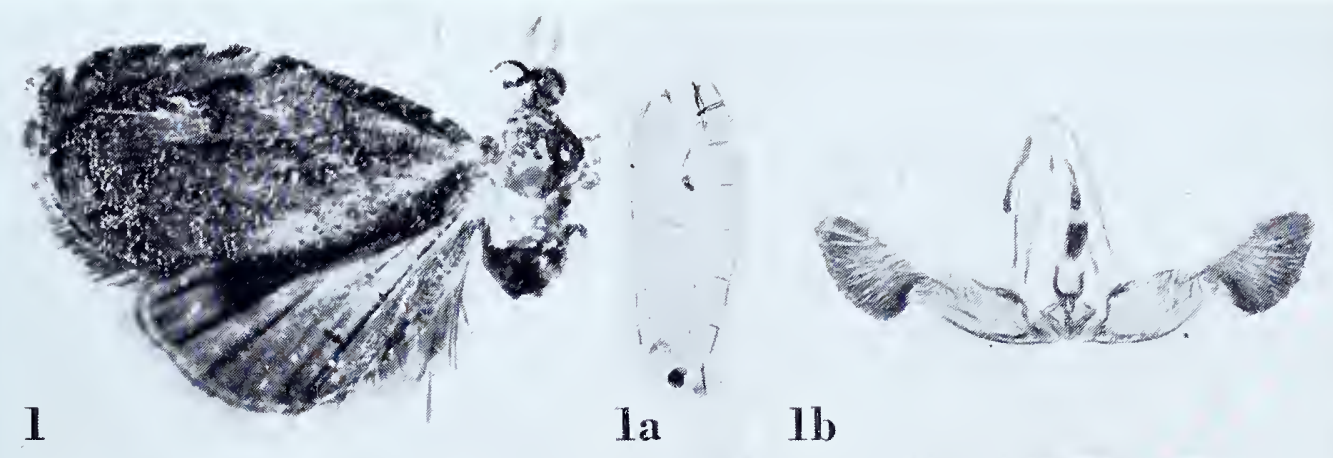

2

3
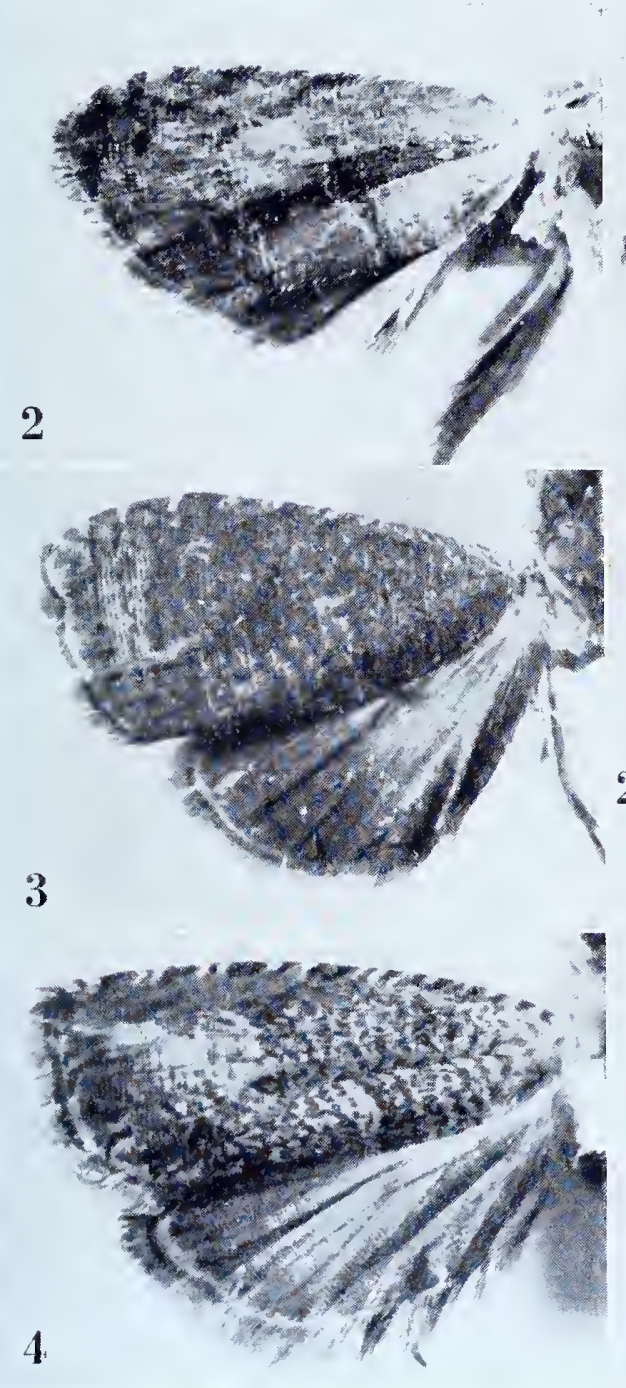

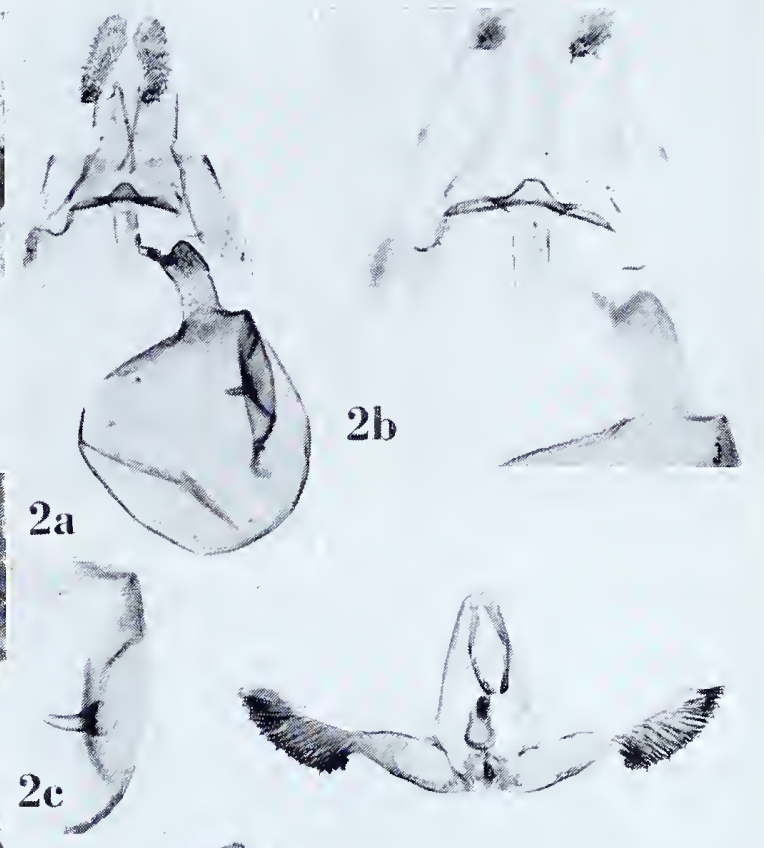

y

4

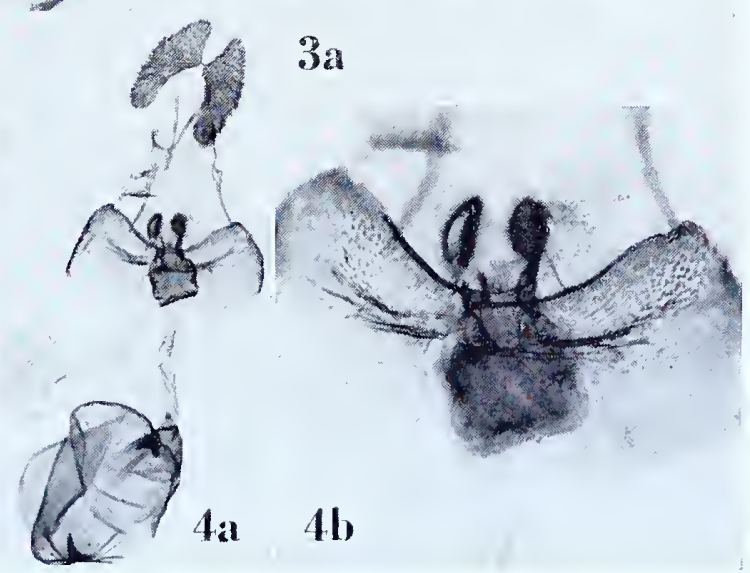



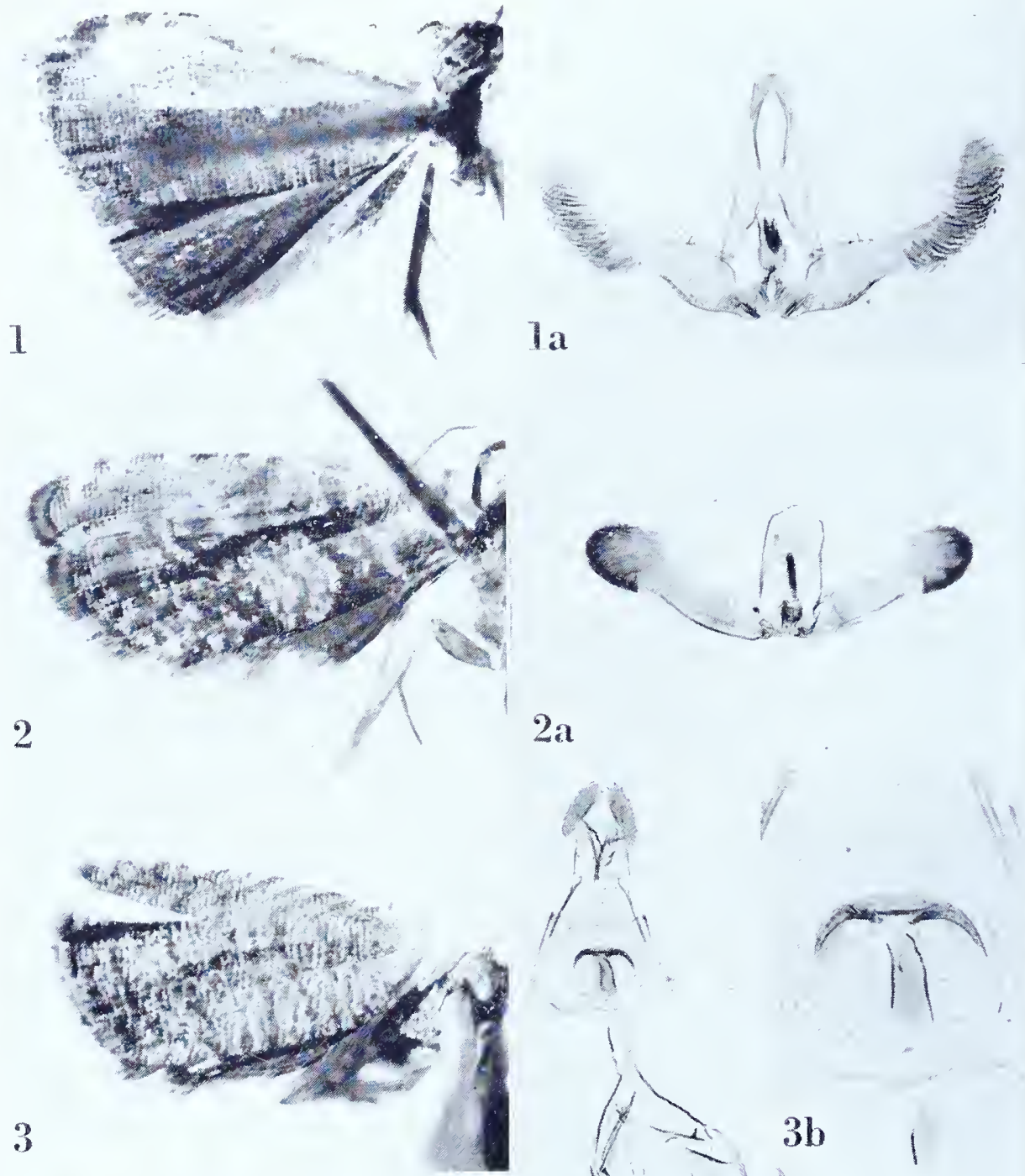

$2 a$
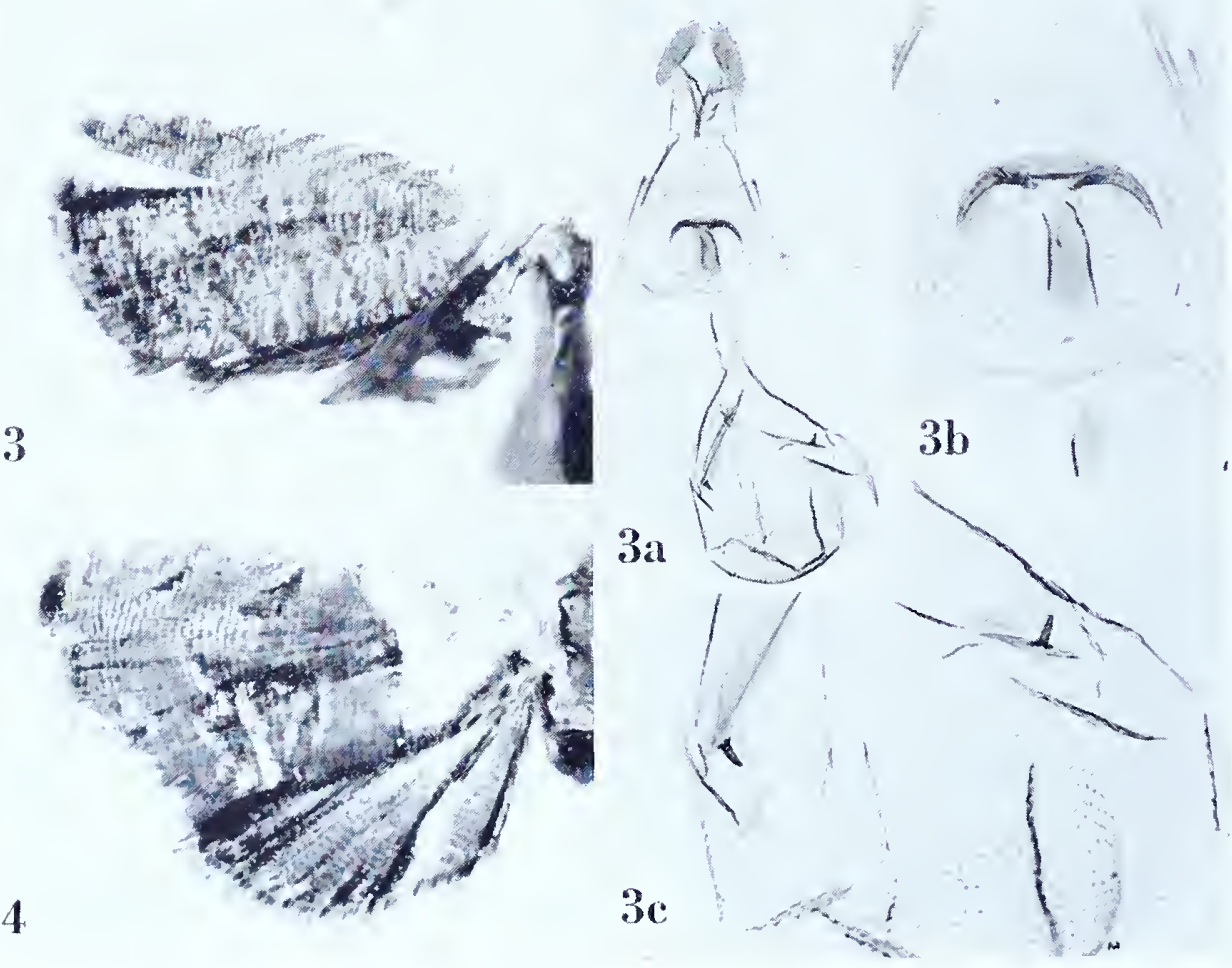

HEMIMENE 


\section{Hemimene militaris Meyrick}

Plate 206, Figures I-Ia

Hemimene militaris Meyrick, I9I6, Exotic Microlepidoptera, 2: 28.

"o. $9 \mathrm{~mm}$. . . . British Guiana, Bartica, in January (Parish); one specimen."

Type: The male indicated above dated “.I.r3”. Slide No. 6463.

Figure I, left wings; ra, ventral view of male genitalia with aedeagus in situ.

\section{Hemimene neotricha Meyrick}

Plate 206, Figures 2-2a

Hemimene neotricha Meyrick, I922, Exotic Microlepidoptera, 2: 527.

"ợ. 8-9 mm. . . . Peru, Iquitos, May (Parish); 3 ex. The only South American species of the genus in which I have observed a costal fold."

Lectotype: The male measuring $9 \mathrm{~mm}$. Slide No. 6475. The three specimens are dated " 5.20 ".

Figure 2, left wings; 2a, ventral view of male genitalia with aedeagus in sitn.

\section{Hemimene octavia Meyrick}

Plate 206, Figures $3^{-} 3^{\mathrm{c}}$

Hemimene octavia Meyrick, 1922, Exotic Microlepidoptera, 2: 528 .

" ふૈ+․ 9-10 mm. . . . Peru, Jurimaguas, March (Parish); 4 ex."

Lectotype: A female measuring $9 \mathrm{~mm}$. Slide No. 6469. The four specimens bear the date "3.20". Only two of the four, both females, have abdomens.

Figure 3 , left wings; 3 a, ventral view of female genitalia; 3 , detail of genital plate and ostium; $3 \mathrm{c}$, bursa copulatrix to show signa.

\section{Hemimene patriocosma Meyrick \\ Plate 206, Figure 4}

Hemimene patriocosma Meyrick, I927, Exotic Microlepidoptera, 3: 341.

" o. $8 \mathrm{~mm}$. . . . Peru, Cocapata, i 2,000 feet; i ex."

Type: The specimen indicated above, lacking abdomen and right hindwing. In the lower right corner of the pin-label is the figure " 20 ".

Figure 4, left wings. 
HEMIMENE

\section{Hemimene penetralis Meyrick}

Plate 207 , Figures $\mathrm{I}-\mathrm{I} b$

Hemimene penetralis Meyrick, 1916, Exotic Microlepidoptera, 2: 24.

" $\tilde{o}^{+}+9^{-10} \mathrm{~mm}$. . . British Guiana, Mallali, in March (Parish); three specimens."

Lectotype: The male. Slide No. 6462. All of the specimens arc dated ".3.13".

Figure I, left wings; Ia, denuded abdomen to show modifications; $\mathrm{ib}$, ventral view of male genitalia with aedeagus in situ.

\section{Hemimene polyplecta Meyrick}

Plate 207, Figures 2-2b

Hemimene polyplecta Meyrick, 1922, Exotic Microlepidoptera, 2: 529.

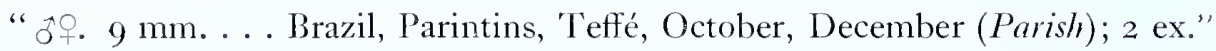

Lectotype: The male, "Parintins, Brazil, Parish. Io-19." Slide No. 6477. There is a median, dorsal furrow on segments 3,4 and 5 of the abdomen which receives a hair-pencil from the hindwing. On each side of the furrow are enlarged scales.

Figure 2, left wings; $2 \mathrm{a}$, denuded abdomen to show modifications; $2 \mathrm{~b}$, ventral view of male genitalia with aedeagus in sitn.

\section{Hemimene praecisa Meyrick}

Plate 207 , Figures $3-3 \mathrm{~b}$

Hemimene praecisa Meyrick, 1022, Exotic Microlepidoptera, 2: 28.

" ${ }^{\circ}+$. 9-10 mm. . . B British Guiana. Bartica, in January (Parish); the male example has lost abdomen and hindwings; the latter may probably have a dorsal blotch beneath as in the allied species."

Lectotype: + , dated “.I.I3”. Slide No. 6473.

Figure 3 , left wings; 3 a, ventral view of female genitalia; 3 b, detail of genital plate and ostium.

\section{Hemimene psacastis Meyrick}

Plate 207 , Figures $4-4 \mathrm{~b}$

Hemimene psacastis Meyrick, 1922, Exotic Microlepidoptera, 2: 527.

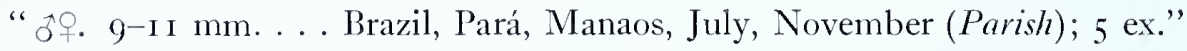

Lectotype: The male labelled, "Manaos, Brazil, Parish. i I.I9." Slide No. 6474.

Figure 4 , left wings; 4 a, denuded abdomen to show modifications; 4 b, ventral view of male genitalia with aedeagus in sit $H$. 


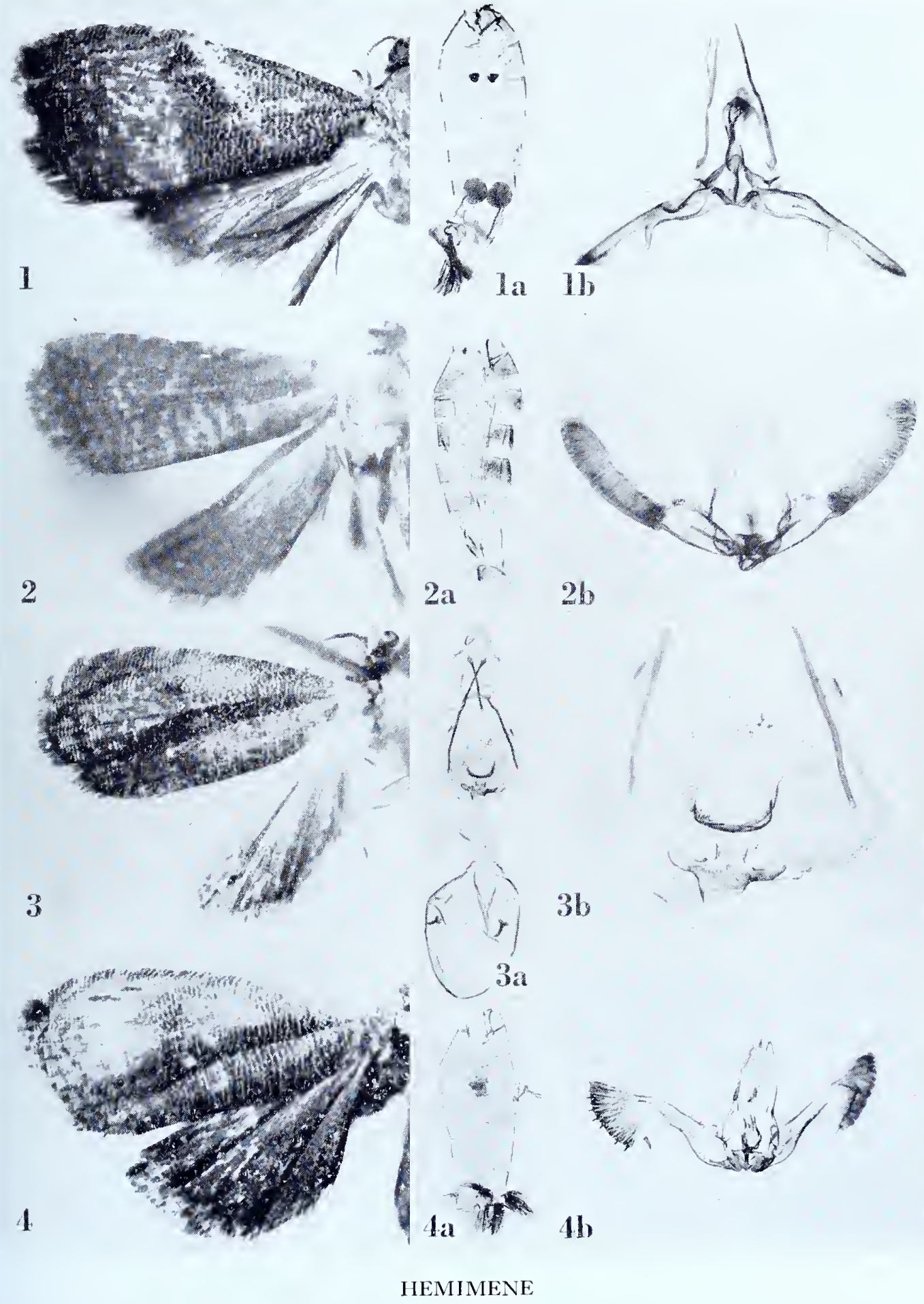




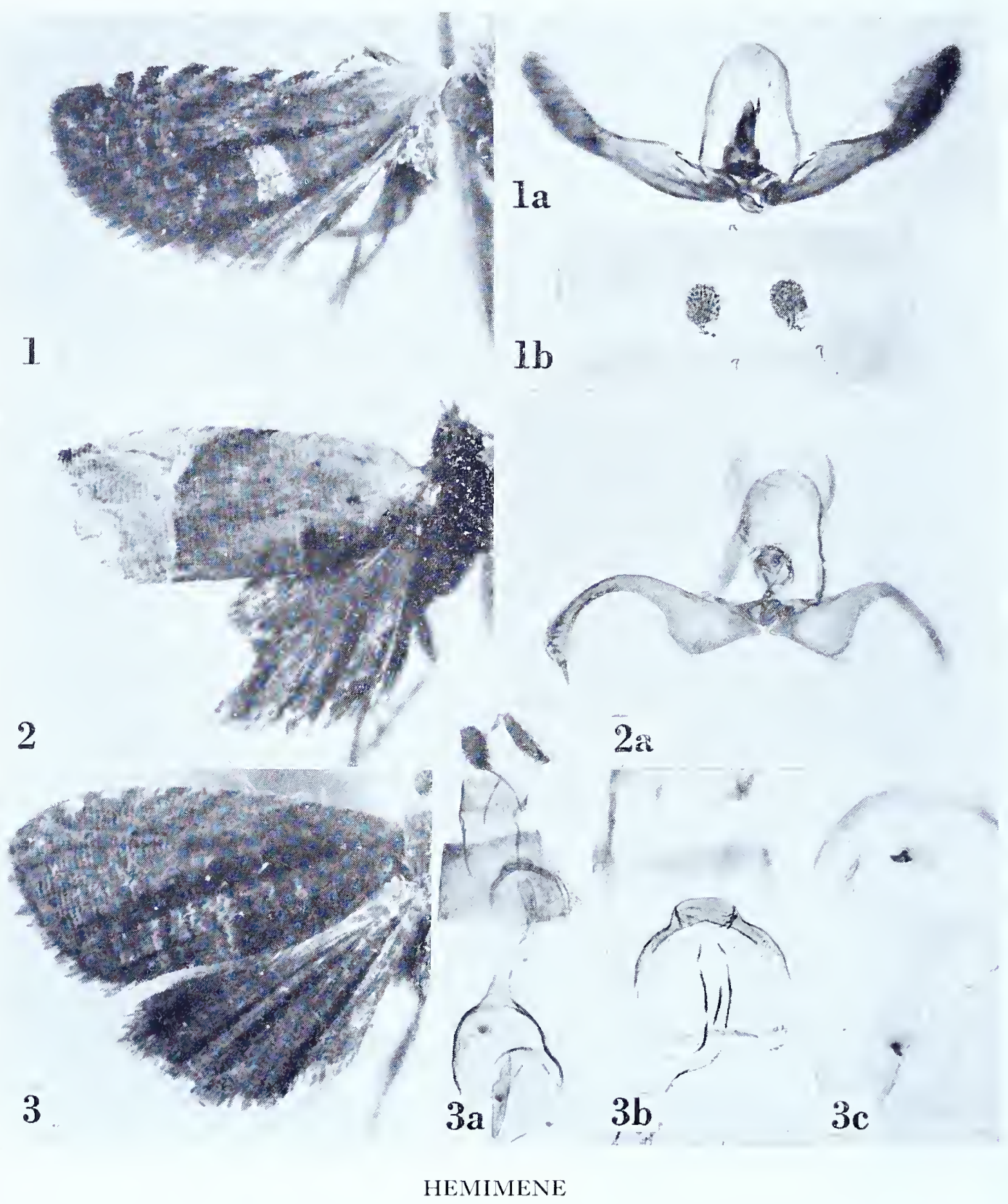




\section{Hemimene semiarcha Meyrick}

Plate 208, Figures $\mathbf{I}-\mathbf{I} b$

Hemimene semiarcha Meyrick, 1922, Exotic Microlepidoptera, 2: 528.

" đ. $8 \mathrm{~mm}$. . . Brazil, Pará, July (Parish); I ex."

Type: The above indicated specimen dated "7-19". Slide No. 6465.

Figure I, left wings; ıа, ventral view of male genitalia with aedeagus in sitı; $\mathbf{\imath b}$, glandular area between abdominal segments 2 and 3 .

\section{Hemimene sevocata Meyrick}

Plate 208, Figures 2-2a

Hemimene sevocata Meyrick, 1916, Exotic Microlepidoptera, 2: 29.

" $0.8 \mathrm{~mm}$. . . British Guiana, Bartica, in February (Parish); one specimen."

Type: The specimen indicated above dated “.2.13”. Slide No. 6480.

Figure 2, left wings; 2 , ventral view of male genitalia with aedeagus in sitn.

\section{Hemimene siderophanes Meyrick}

Plate 208, Figures $3^{-3} \mathrm{c}$

Hemimene siderophanes Meyrick, 1922, Exotic Microlepidoptera, 2: 529.

“․ 9-10 mm. . . . Brazil, Teffé, December; Peru, Jurimaguas, March (Parish); 2 ex."

Lectotype: The female, "Jurimaguas, Peru, Parish. 3.20." Slide No. 6478 .

Figure 3 , left wings; 3 a, ventral view of female genitalia; 3 , detail of genital plate and ostium; $3 \mathrm{c}$, signa.

Continued from p. 363 .

\section{Eucosma eriomis Meyrick}

Plate 180 , Figures $4-4 \mathrm{a}$

Encosma eriomis Meyrick, 1933, Exotic Microlepidoptera, 4: 419.

“ సิํ. 9-Iо mm. . . J Java, Seneng, bred November, December from larvae feeding on leaves of Acacia pennata and Dichrostachys cinerea (Leguminosae) (Dr. L. G. E. Kalshoven); 3 ex."

Lectotype: A male dated “.12.31”. Slide No. 6979. Two specimens are missing.

Figure 4, left wings; 4 a, ventral view of male genitalia with aedeagus in sitn.

\section{Eucosma eumarodes Meyrick}

See Spilonota holotephras (Meyrick). 
HEMIMENE

\section{Hemimene stabulata Meyrick}

Plate 209, Figures I-IC

Hemimene stabnlata Meyrick, I916, Exotic Microlepidoptera, 2:25.

“今. 9 mm. . . . Colombia, La Crumbre, 6,60o feet, in May (Parish); one specimen...."

Type: The specimen indicated above, erroneously recorded as a male, dated ".5.14". Slide No. 6460.

Figure I, left wings; ra, ventral view of female genitalia; Ib, signum; Ic, detail of genital plate and ostium.

\section{Hemimene thylacura Meyrick}

Plate 209, Figures 2-2b

Hemimene thylacura Meyrick, I922, Exotic Microlepidoptera, 2: 527.

"亏. 9 mm. . . Brazil, Parintins, October (Parish); I ex."

Type: The male indicated above dated "ro-r9". Slide No. $647 \mathrm{r}$.

Figure 2, left wings; $2 \mathrm{a}$, ventral view of male genitalia with aedeagus in sitn; $2 \mathrm{~b}$, denuded abdomen to show modifications.

\section{Hemimene tornograpta Meyrick \\ Plate 209, Figure 3}

Hemimene tomograpta Meyrick, I927, Exotic Microlepidoptera, 3: 34r.

"ㅇ. 10 mm. . . . Peru, Cocapata, I2,000 feet; I ex."

Type: The above indicated female without abdomen. In the lower right corner of the pin-label is the figure " 20 ".

Figure 3 , left wings.

Contimusd from $p .37 I$.

\section{Eucosma mediostriata (Walsingham)}

Plate 184 , Figures $5-5$ a

Paedisca mediostriata Walsingham, i895, Trans. Ent. Soc. London, I 895: 508.

Ercosma sepulchrana Meyrick, I927, Exotic Microlepidoptera, 3: 334 (new synonymy).

[sepulchrana]

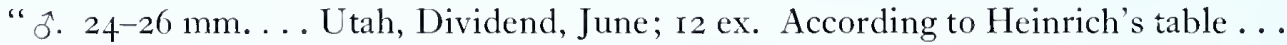
this would be the species regarded by him as ceramitis Meyr. (handama Kearf.), ..."

Lectotype: A male measuring $26 \mathrm{~mm}$. Slide No. 6386. All specimens bear identical data and are dated ".6.26".

Figure 5, left wings; 5 a, ventral view of male genitalia with aedeagus in sitn. 


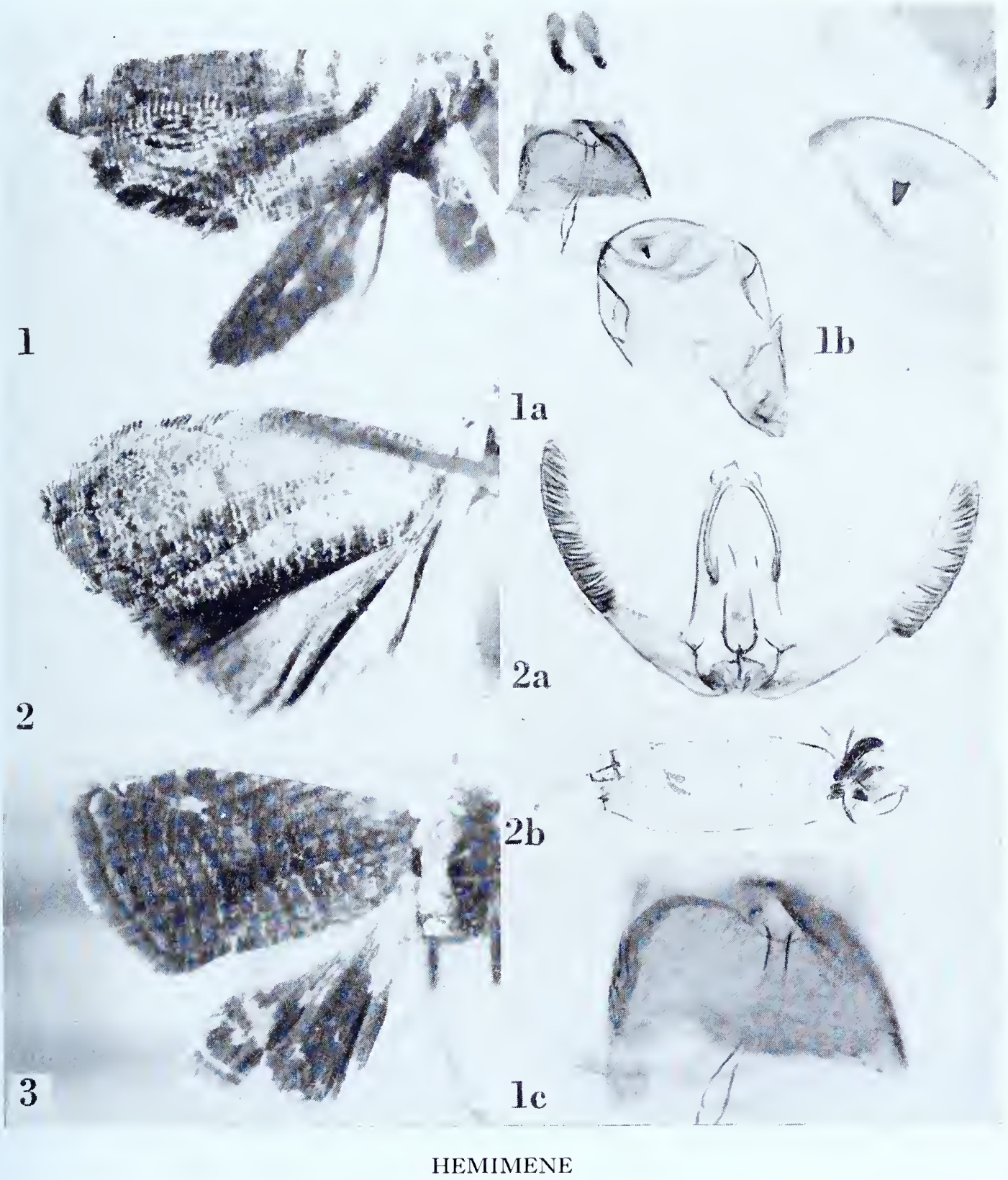




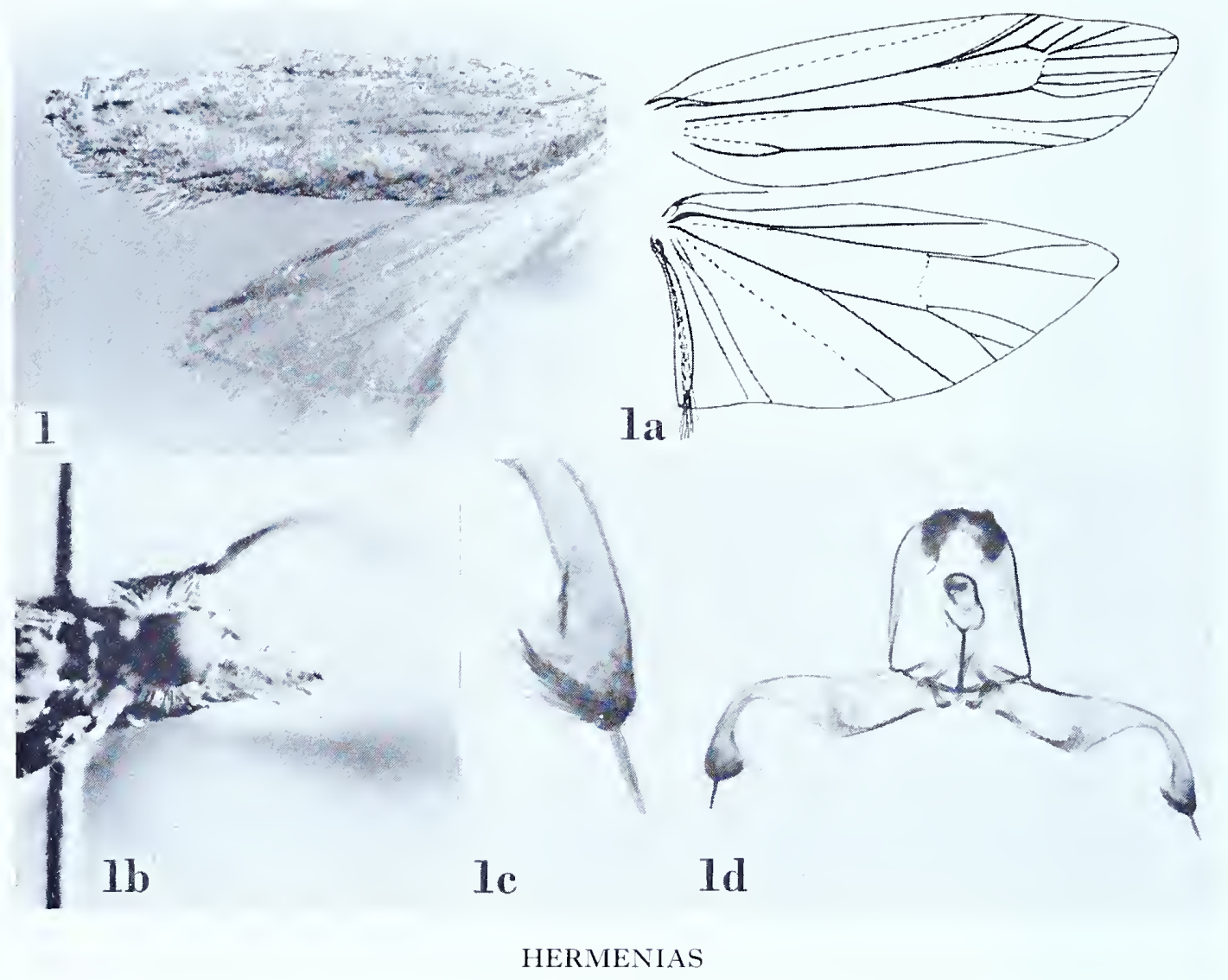




\section{HERMENIAS Meyrick}

Hermenias Meyrick, I9 I I, Proc. Linnean Soc. New South Wales, 36: 225. (Typus generis: Hermenias epidola Meyrick, ibid. [by original designation].)

\section{Hermenias epidola Meyrick}

Plate 210, Figures $\mathrm{I}-\mathrm{Id}$

Hermenias epidola Meyrick, Proc. Linnean Soc. New South Wales, 36: 225 .

Illustrated from a male specimen in the Meyrick collection. Slide No. 9563.

Figure $\mathrm{I}$, left wings; Ia, venation of right wings; $\mathrm{rb}$, lateral aspect of head to show palpus; ic, enlarged cucullus to show terminal seta; id, ventral view of male genitalia with aedeagus in situ.

Continued from $p .39 I$.

\section{Eucosma sphalerodes Meyrick}

Plate 193 , Figure 4

Eucosma sphalerodes Meyrick, I934, Ann. Mag. Nat. Hist., (ser. 10) 14:404.

"o. I 2 mm., ㅇ I3-14 mm. . . Principe I., Dec. 22; 6 ex."

Type: The male so labelled in the British Museum, "Principe I. W. Africa. 22-xii-1932. W. H. T. Tams." The abdomen of the type is missing.

Figure 4, left wings. 


\section{Hermenias implexa Meyrick}

Plate 2 I , Figures I-Ia

Hermenias implexa Meyrick, i912, Journ. Bombay Nat. Hist. Soc., 21: 852; Diakonoff, I950, Bull. Brit. Mus. (Nat. Hist.) Ent., I (4): 283 .

“今ㅇ. I4-I6 mm. ... Namunakuli and Patipola, Ceylon (Gresn); from February to May, eight specimens."

Lectotype: A male measuring 15 mm., dated ".2.10", selected by Diakonof. Slide No. 69 I 6.

Figure I, left wings; гa, ventral view of male genitalia with aedeagus in sitn.

\section{Hermenias pachnitis Meyrick}

Plate 2 I I, Figures 2-2a

Hermenias pachnitis Meyrick, I912, Journ. Bombay Nat. Hist. Soc., 21: 852; Diakonoff, I 950, Bull. Brit. Mus. (Nat. Hist.) Ent., I (4):283.

"s+o. I 4-15 mm. ... Maskeliya and Patipola, Ceylon (Pole, Green, Alston); in November, December, April and May, four specimens."

Lectotype: The male, "Maskeliya, Ceylon. Pole. .5.06", selected by Diakonof. Slide No.6915. One specimen is missing.

Figure 2, left wings; 2a, ventral view of male genitalia with aedeagus in sitn.

\section{Hermenias palmicola Meyrick}

Plate 2 I , Figures $3^{-} 3^{a}$

Hermenias palmicola Meyrick, ı1 2, Journ. Bombay Nat. Hist. Soc., 21: 853; Diakonoff, I $95^{\circ}$, Bull. Brit. Mus. (Nat. Hist) Ent., I (4): 283 .

" 3 jo. x I-12 mm. . . Trincomali, Puttalam, and Batticaloa, Ceylon (Green, Fletcher, Pole); in May, June and October, three specimens. Very like implexa, but smaller...."

Lectotype: The male, "Batticaloa, Ceylon. EEG. .5.06", selected by Diakonoff. Slide No. 69I4.

Figure 3 , left wings; 3 a, ventral view of male genitalia with aedeagus $i n$ sitn.

\section{Hermenias zygodelta Meyrick}

Plate 2I I, Figure 4

Hermenias zygodelta Meyrick, I938, Trans. R. Ent. Soc. London, 87: 509.

" o. I $6 \mathrm{~mm}$. ... Mafulu, 4,000 feet, January; i ex."

Type: The specimen so marked in the British Museum, "Papua, Mafulu, 4,000 ft., I.1934. L. E. Cheesman." The abdomen of the type is missing.

Figure 4 , left wings. 

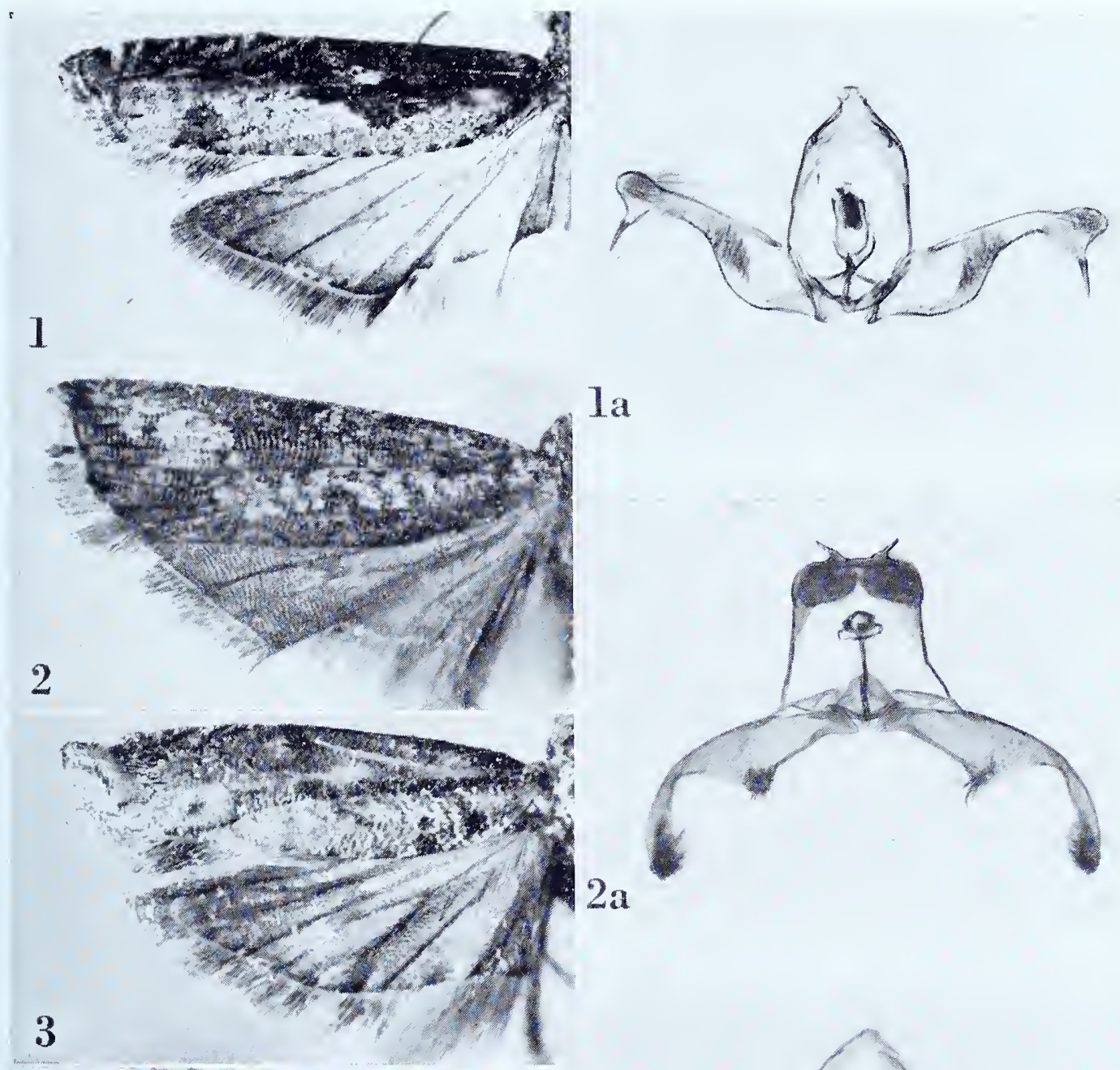

la
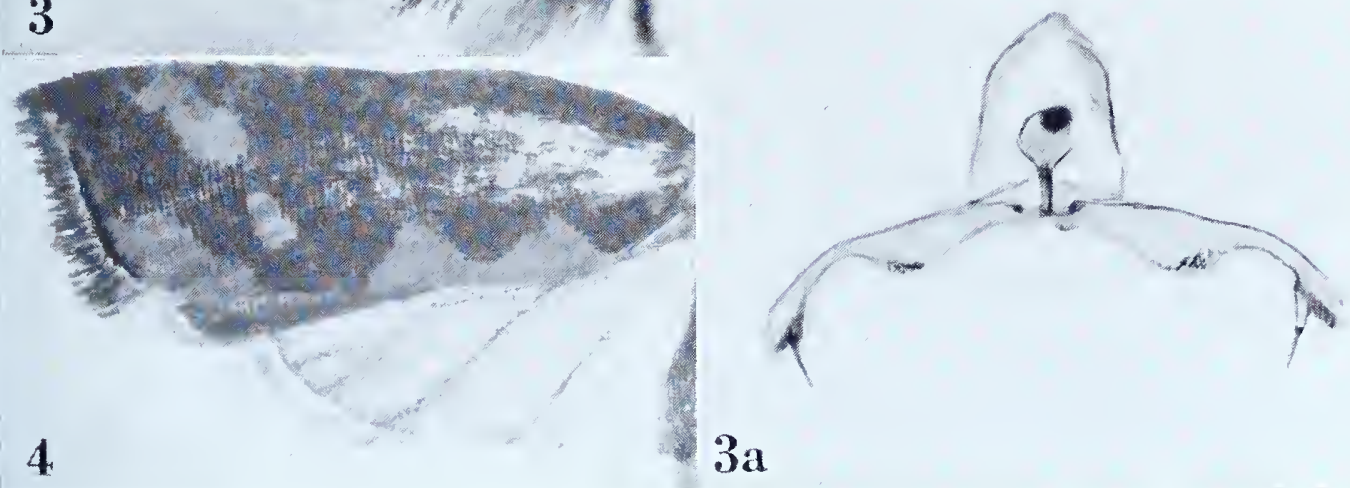

HERMENIAS 


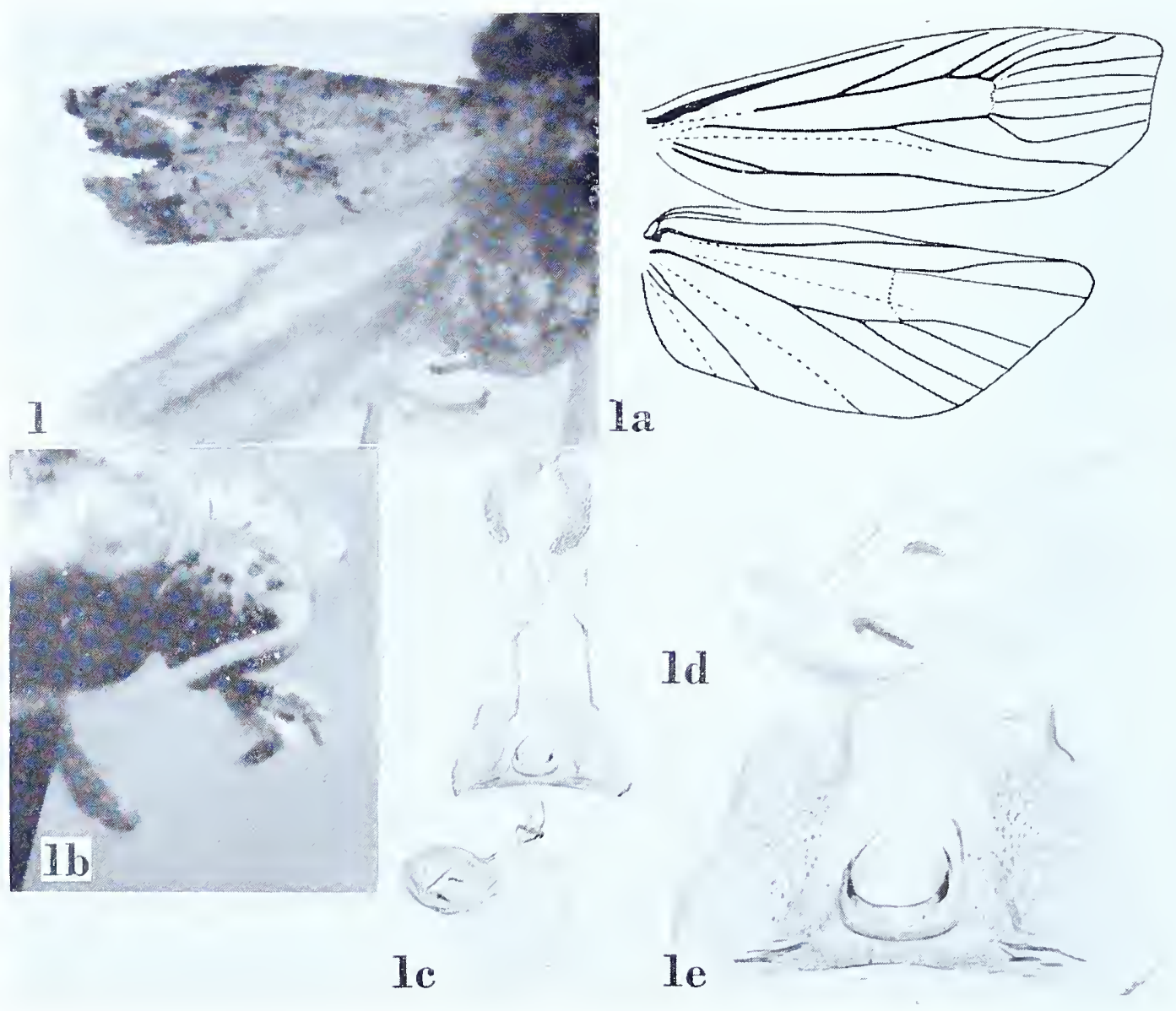

HERPYSTIS 
HERPYSTIS

\section{HERPYSTIS Meyrick}

Herpystis Meyrick, I91 I, Trans. Linnean Soc. London, I4:268. (Typus generis: Herpystis rusticula Meyrick, ibid. [monotypy].)

\section{Herpystis rusticula Meyrick}

Plate 2 I2, Figures I-Ie

Herpystis rusticula Meyrick, I9I I, Trans. Linnean Soc. London, I4: 268.

" . $9 \mathrm{~mm}$. . . . Silhouette, Mare aux Cochons plateau, I, 000 feet, in September; one specimen, not in good condition."

Type: The above indicated specimen, erroneously recorded as a male and so marked in the British Museum, "Seychelles; Silhouette, Mare-aux-Cochons. ix.Igo8. H. Scott." Slide No. 9445 .

Figure I, left wings; $\mathrm{Ia}$, venation of right wings; $\mathrm{Ib}$, lateral aspect of head to show palpus; Ic, ventral view of female genitalia; Id, part of bursa copulatrix showing signa; I e, detail of genital plate and ostium. 


\section{Herpystis iodryas Meyrick}

Plate 2 I3, Figures I-Ib

Herpystis iodryas Meyrick, I937, in Caradja and Meyrick, Deuts. Ent. Zeit. Iris, 5 I : 176.

"ㅇ. I 5 mm. . . Y Yül., 3,200 m., VI, I ex."

Type: The female denoted above, "Likiang, China. H. .6.34." Slide No. 7119.

Figure $\mathrm{I}$, right wings (image reversed); $\mathrm{ra}$, ventral view of female genitalia; $\mathrm{Ib}$, detail of genital plate and ostium.

\section{Herpystis jejuna Meyrick}

Plate 2 I3, Figures 2-2a

Herpystis jejma Meyrick, I9 16, Exotic Microlepidoptera, 2: i6; Diakonoff, I950, Bull. Brit. Mus. (Nat. Hist.) Ent., I (4): 284 .

" ơ. 8-9 mm. ... N. Coorg, Dibidi, 3,500 feet, in February and September (Newcome); Bengal, Pusa, in October (Fletcher); three specimens."

Lectotype: A male, "Dibidi, N. Coorg. LN. .2.I3", selected by Diakonoff. Slide No. 7II 8 .

Figure 2, left wings; $2 \mathrm{a}$, ventral view of male genitalia with aedeagus in situ.

\section{Herpystis tinctoria Meyrick}

\section{Plate 213, Figures 3-3a}

Herpystis tinctoria Meyrick, I916, Exotic Microlepidoptera, 2: I6.

" స. Io mm. . . . Coorg, Pollibetta, in October (Fletcher); one specimen." Type: The male denoted above dated ". Io.15". Slide No. 7 I 7 .

Figure 3 , left wings; 3 a, ventral view of male genitalia with aedeagus in sitn. 


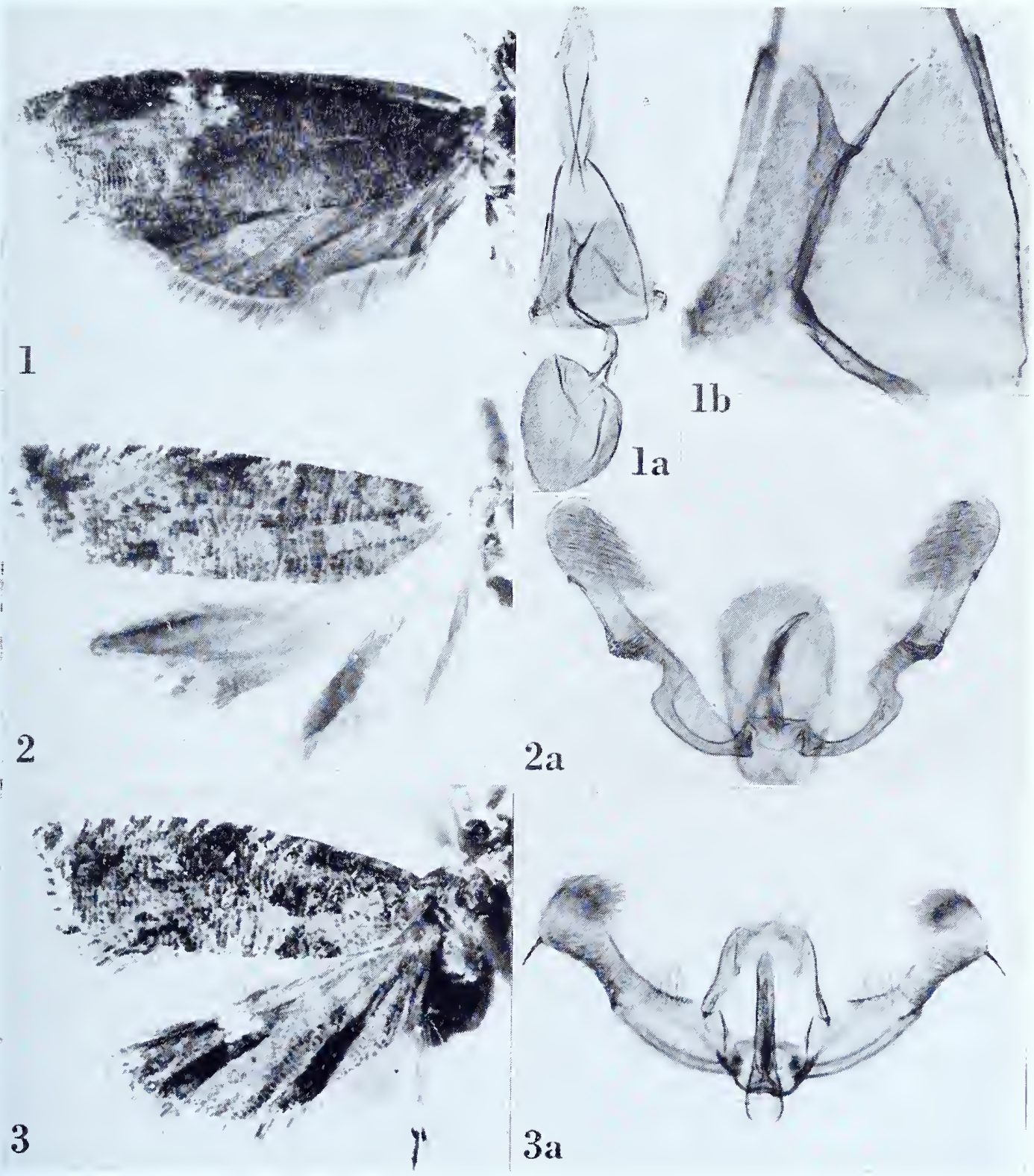

HERPYSTIS 

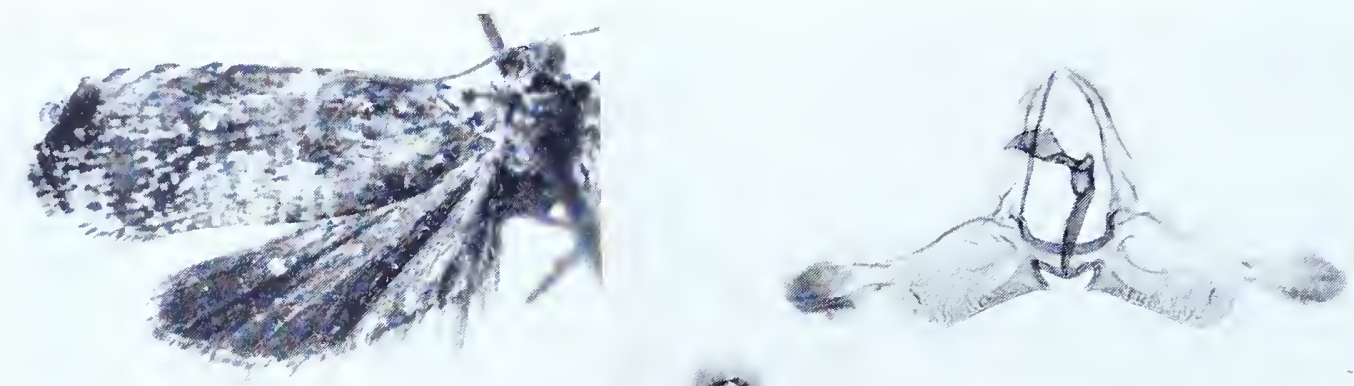

1

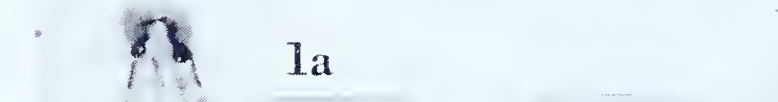

2

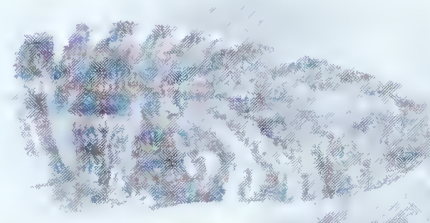

3
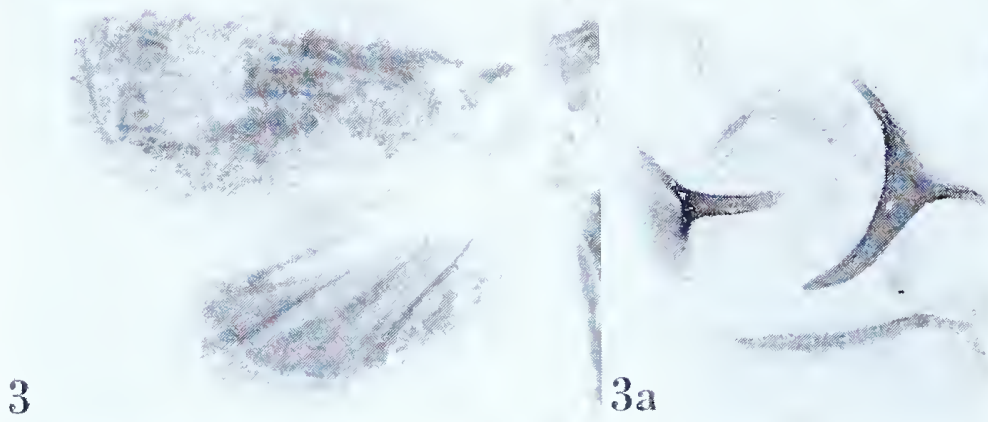

$3 \mathrm{~b}$
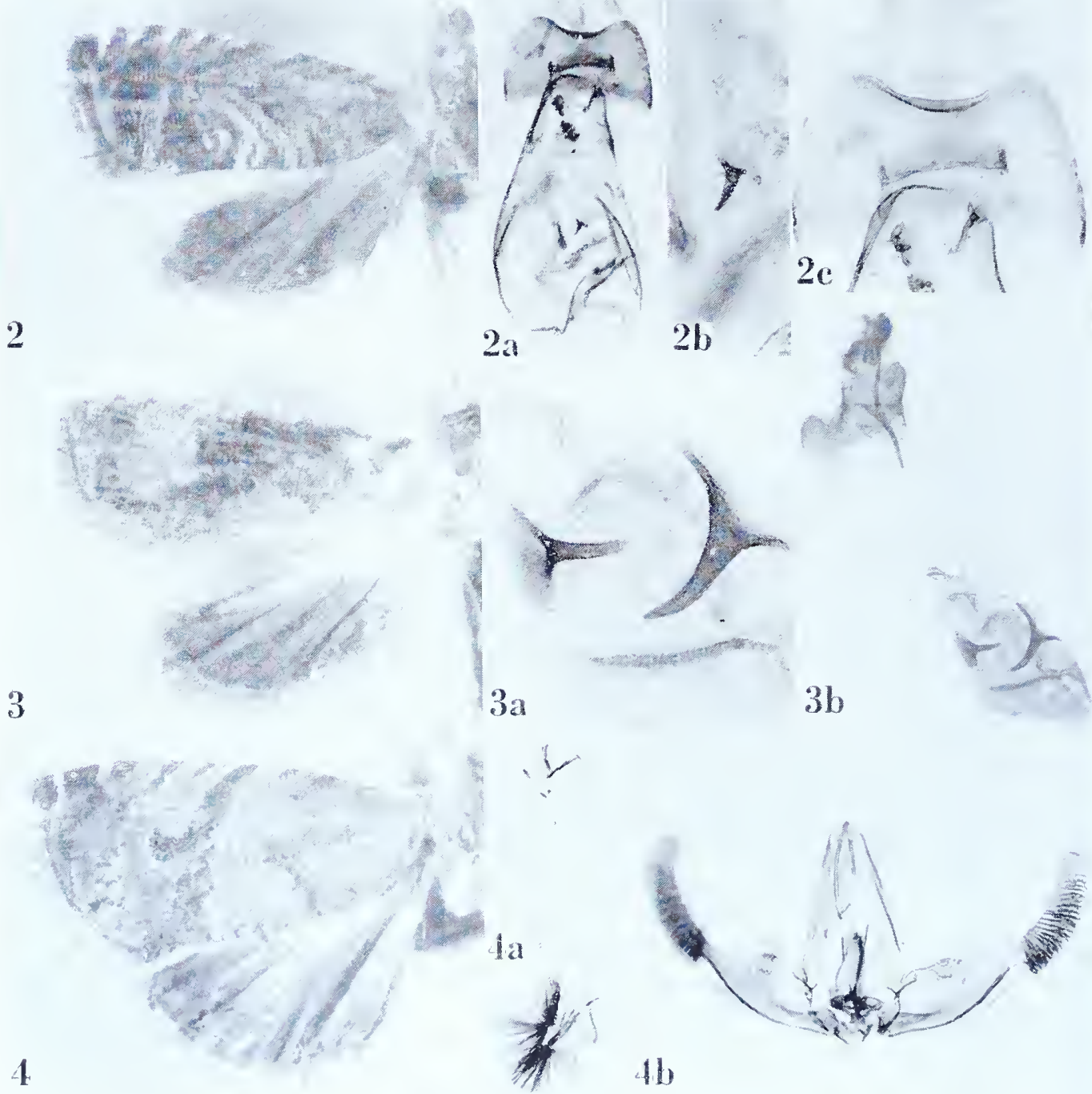

(b) 


\section{LASPEYRESIA Hübner}

\section{Laspeyresia aeologlypta Meyrick}

Plate 2 I 4, Figures I-Ia

Laspeyresia aeologlypta Meyrick, i936, Exotic Microlepidoptera, 4: 61 5.

“ స. I 2 mm. ... Japan, Honsyû, Yumoto, August (Prof. S. Issiki); I ex. A distinct form."

Type: The male indicated above, "Yumoto, Japan, SI. 6.8.34." Slide No. 7368.

Figure I, left wings; ra, ventral view of male genitalia with aedeagus in situ.

\section{Laspeyresia aeologramma Meyrick}

Plate 214, Figures 2-2c

Laspeyresia aeologramuıa Meyrick, 1916, Exotic Microlepidoptera, 2: 21.

"․ $8 \mathrm{~mm}$. . . L Lower Burma, Minbu, in August (Fletcher); one specimen."

Type: "The above indicated specimen dated ".8. 5 ". Slide No. 7393.

Figure 2 , left wings; $2 \mathrm{a}$, ventral view of female genitalia; $2 \mathrm{~b}$, signum; $2 \mathrm{c}$, detail of genital plate and ostium.

\section{Laspeyresia amphilecta Meyrick}

Plate 2 I 4 , Figures $3-3$ b

Laspeyresia amplilecta Meyrick, 1925, Exotic Microlepidoptera, 3: I 45 .

"․ I I mm. . . Bengal, Pusa, bred July from larva boring shoots of Cordia myxa (Fletcher); i ex."

Type: The female denoted above dated ".7.20". Slide No. 7398 .

Figure 3 , left wings; $3 \mathrm{a}$, signa; $3 \mathrm{~b}$, ventral view of female genitalia (badly damaged by museum pests).

\section{Laspeyresia ancoloba Meyrick}

Plate 21 4, Figures 4-4b

Laspeyresia ancoloba Meyrick, 1922, Exotic Microlepidoptera, 2: 533.

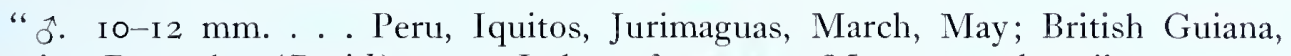
Bartica, December (Patish); 3 ex. I also refer nomaea Meyr., near here."

Lectotype: Ô, "Jurimaguas, Peru. Parish. 3.20." Slide No. 6482. This species probably should be referred to Grapholitlac.

Figure 4, left wings; 4 a, denuded abdomen showing posterior tufts; $4 \mathrm{~b}$, ventral view of male genitalia with aedeagus in situ. 
LASPEYRESIA

\section{Laspeyresia anticipans Meyrick}

Plate 2I 5, Figures I-IC

Laspeyresia anticipans Meyrick, 1927, Exotic Microlepidoptera, 3:342.

“․ $13 \mathrm{~mm}$. . . . S. India, Pollachi, Coimbatore district, bred in August from larva webbing flowers of mango (Mangifera) (Menon); I ex. (Brit. Mus.). . .."

Type: 'The above indicated female, so labelled in the British Museum. There is no date on the locality label, but a small white label beneath bears the date " $30 . I V .23$ ". Slide No. 7404 .

Figure I, left wings; ia, ventral view of female genitalia; $\mathbf{b}$, signa; ic, detail of ostium.

\section{Laspeyresia calliglypta Meyrick}

Plate 2 I5, Figures 2-2b

Laspeyresia calliglypta Meyrick, I932, Trans. Ent. Soc. London, 80: I I3.

"․ Io mm. .. . Jem-Jem Forest, edge of forest, 9,000 feet, October; i ex. A very distinct form."

Type: The female so marked in the British Museum and labelled, "Abyssinia: Djem-Djem Forest. Edge of forest ca. 9,000 ft. 4.x.26. H. Scott." Slide No. 7406.

Figure 2, left wings; $2 \mathrm{a}$, signa; $2 \mathrm{~b}$, lateral view of female genitalia.

\section{Laspeyresia chalybdica Meyrick \\ Plate $2 \mathrm{I}_{5}$, Figures $3-3 \mathrm{~b}$}

Laspeyresia chalybdica Meyrick, I922, Exotic Microlepidoptera, 2: 533.

"o. $9 \mathrm{~mm}$. . . Peru, Iquitos, May (Parish); i ex."

Type: The specimen indicated above dated "5.20". Slide No. 6486 .

Figure 3 , left wings; $3 \mathrm{a}$, ventral view of female genitalia; $3^{\mathrm{b}}$, detail of genital plate and ostium.

\section{Laspeyresia chelias Meyrick}

Plate 215, Figures $4-4 \mathrm{c}$

Laspeyresia chelias Meyrick, I907, Journ. Bombay Nat. Hist. Soc., I8: I45.

" ${ }^{\circ}$. I I mm. . . Maskeliya, Ceylon, in October; one specimen (Pole)."

Type: The specimen referred to above, erroneously recorded as a male, dated “.10.04". Slide No. 7378 .

Figure 4, left wings; $4^{\mathrm{a}}$, ventral view of female genitalia; 4 b, detail of ostium; 4 c, signa.

\section{Laspeyresia crocopa Meyrick}

See Laspeyresia tricentra Meyrick. 


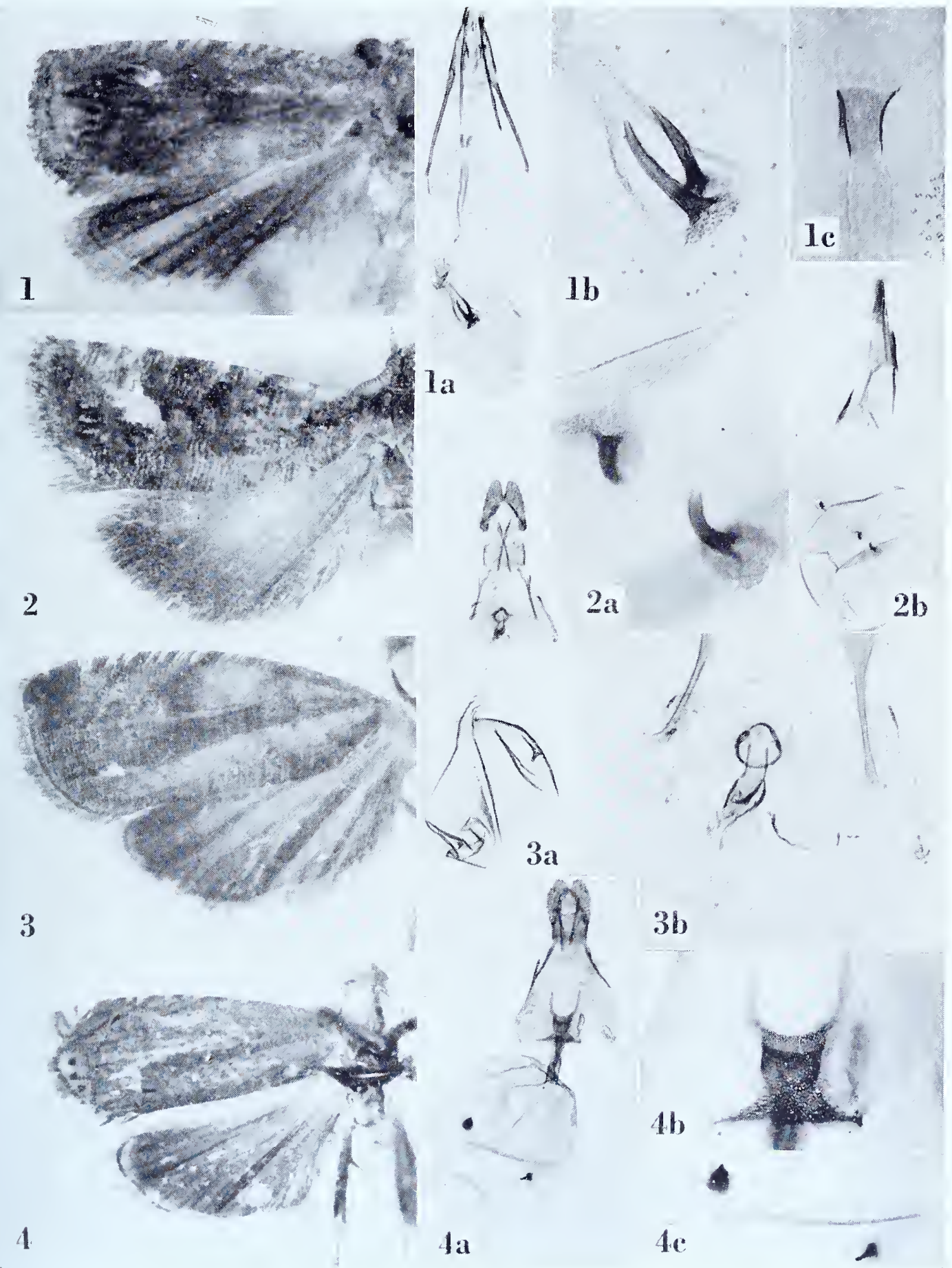



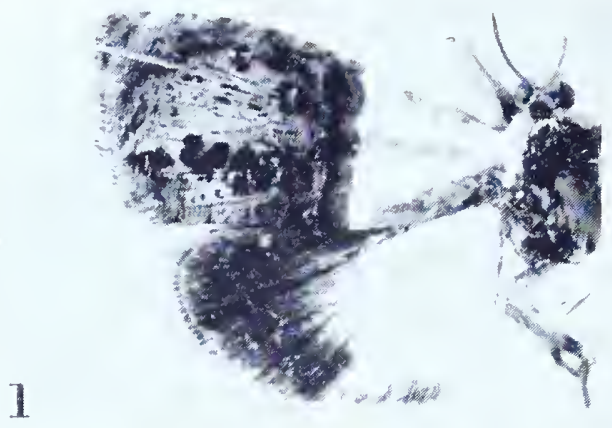

la
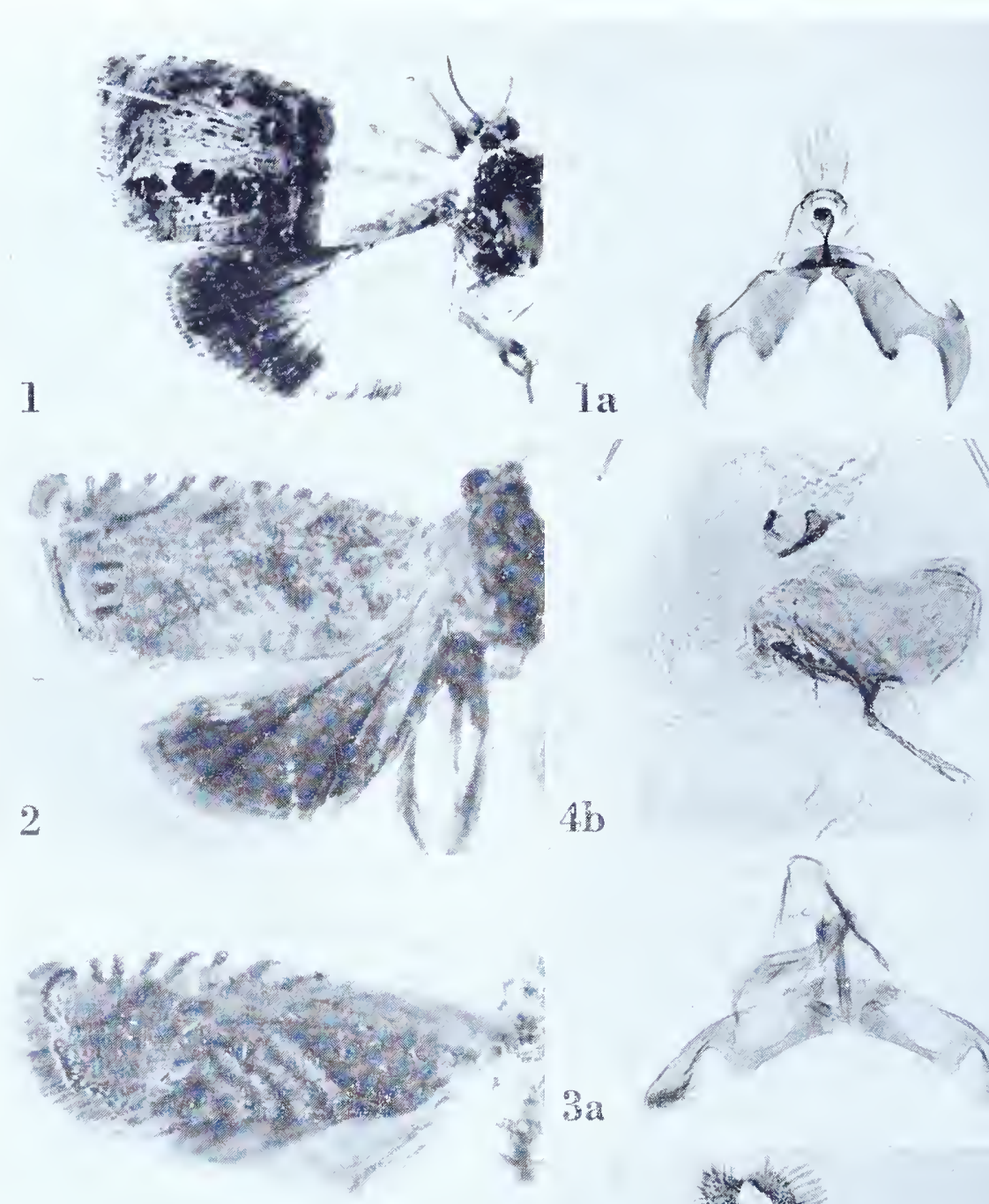

3
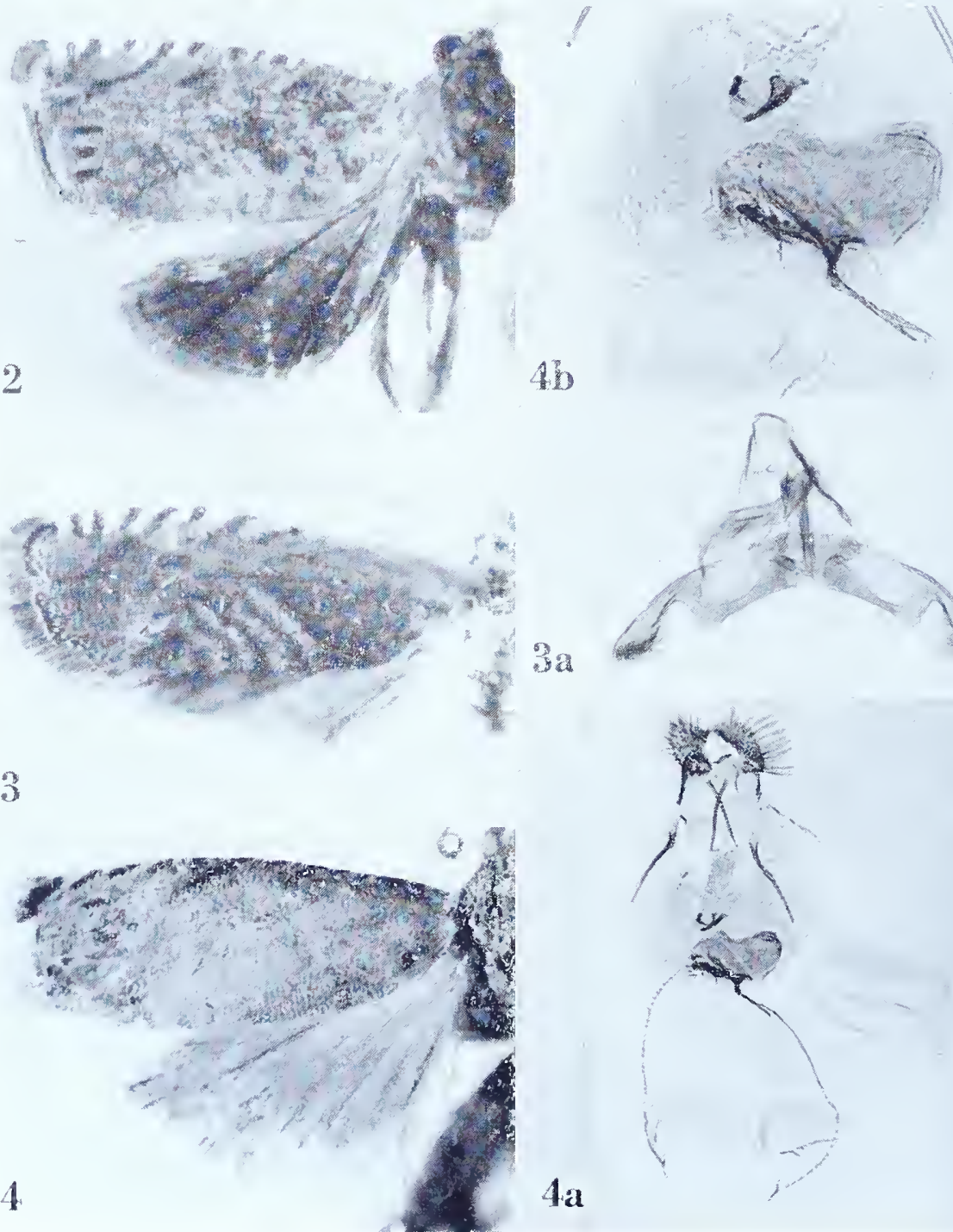

$$
\text { LASPEYRESIA }
$$




\section{Laspeyresia cymbalora (Meyrick) \\ Plate 216, Figures I-Ia}

Copromorpha cymbalora Meyrick, 1907, Journ. Bombay Nat. Hist. Soc., I 8: I 52.

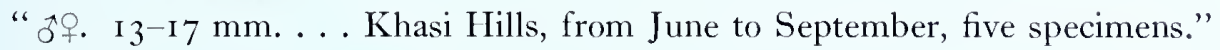

Lectotype: A male measuring $16 \mathrm{~mm}$. "Khasi Hills, Assam. 7.1906." Slide No. $7+16$.

Figure I, left wings; Ia, ventral view of male genitalia with aedeagus in situ.

\section{Laspeyresia daedalota Meyrick}

Plate 216 , Figure 2

Laspeyresia daedalota Meyrick, i 91 6, Exotic Microlepidoptera, 2: 23.

"‥ I I mm. . . . Bengal, Pusa, bred in July from flowers of Cassia fistula (Leguminosae) (Fletcher); one specimen."

Type: The female denoted above dated "I 5.7.I 5", without abdomen.

Figure 2, left wings.

\section{Laspeyresia delineana Walker}

Plate 216 , Figures $3-3$ a

Grapholita delineana Walker, I 863, List Lep. Ins. B.M. 28: 389 .

Laspeyresia isacna Meyrick, I907, Journ. Bombay Nat. Hist. Soc., i 8: I 44.

" 1 ㅇ․ 9-1о mm. . . Khasi Hills, in May and September; fifteen specimens."

Lectotype: A male measuring 9 mm., dated ".9.1 906 ". Slide No. $738_{4}$.

Figure 3 , left wings; 3 a, ventral view of male genitalia with aedeagus in situ.

\section{Laspeyresia detrita Meyrick}

Plate 216, Figure 4-4b

Laspeyresia detrita Meyrick, I928, Exotic Microlepidoptera, 3:450.

" $\hat{0}$ ㅇ. I I-I 3 mm. . . Sudan Medani, May, September (H. B. Yohnston); 2 ex. Allied to planifrontana Reb. ..."

Lectotype: ㅇ, I 3 mm., dated “.9.27”. Slide No. 9406. Both examples are females.

Figure 4 , right wings (image reversed); 4 a, ventral view of female genitalia; 4 b, detail of genital plate and ostium. 


\section{Laspeyresia dissias Meyrick \\ Plate 2 7 , Figures I-Ia}

Lasteyresia dissias Meyrick, 1907, Journ. Bombay Nat. Hist. Soc., 18: 144.

" o. $8 \mathrm{~mm}$. . . Barberyn Island, Ceylon; in February; one specimen (Fletcher)."

Type: The male denoted above dated "23.2.07". Slide No. 7364 .

Figure I, left wings; ra, ventral view of male genitalia with aedeagus in situ.

\section{Laspeyresia elevata Meyrick}

Plate 217, Figures 2-2b

Lasfeyresia elevata Meyrick, I916, Exotic Microlepidoptera, 2: 24.

"q. I I mm. . . Ecuador, Huigra, 4,500 feet, in June (Parish); one specimen."

Type: The specimen indicated above dated "6-1 4 ". Slide No. 6492.

Figure 2 , left wings; $2 \mathrm{a}$, ventral view of female genitalia; $2 \mathrm{~b}$, detail of genital plate and ostium.

\section{Laspeyresia endrosias Meyrick}

Plate 2i 7 , Figures $3^{-3 a}$

Laspeyresia endrosias Meyrick, I907, Journ. Bombay Nat. Hist. Soc., I 8: 145.

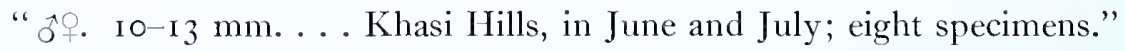

Lectotype: A male measuring I I mm., dated ".6.1 906". Slide No. 7382.

Figure 3 , left wings; 3 a, ventral view of male genitalia with aedeagus in situ.

\section{Laspeyresia ethelinda Meyrick}

Plate 217 , Figures $4-4 a$

Lasfeyresia ethelinda Meyrick, 1934, Exotic Microlepidoptera, 4: 486.

" for. $^{1}$ I $6-\mathrm{I} 7 \mathrm{~mm}$. ... India, U.P. Mundali, 8,500 feet, bred April, May, from cones of Picea morinda (Coniferae) (F. C. M. Gardner); 5 ex. ..."

Lectotype: A male, "Mundali, India, U.P. JCG. bred. 5.33." Slide No. 7407. One specimen is represented by the pin and label only; two others are missing.

Figure 4, left wings; 4 a, ventral view of male genitalia with aedeagus in situ. 


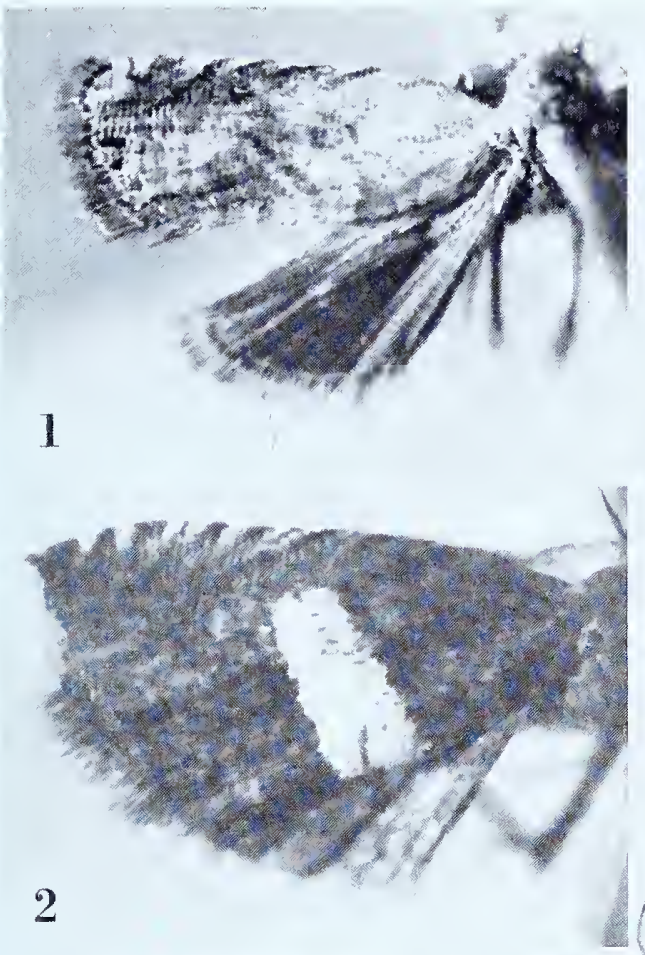

Ia

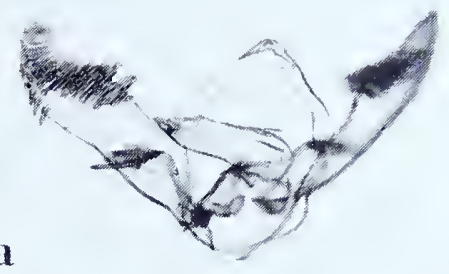

2
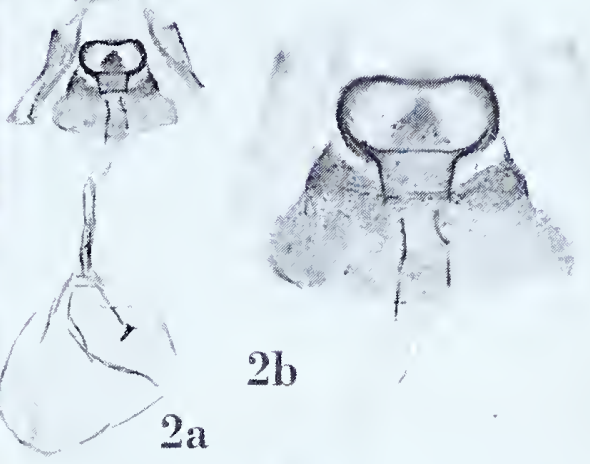

$2 b$
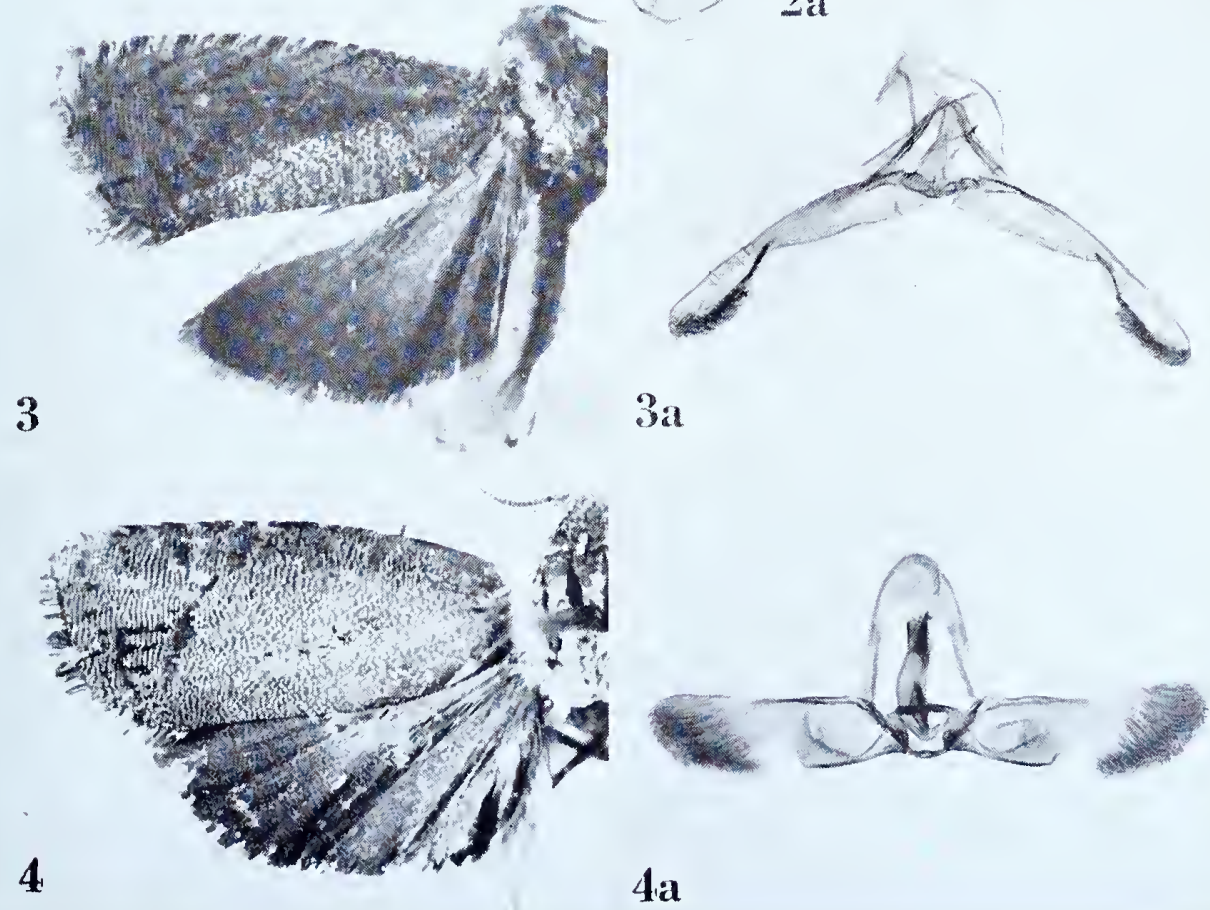

$4 a$ 

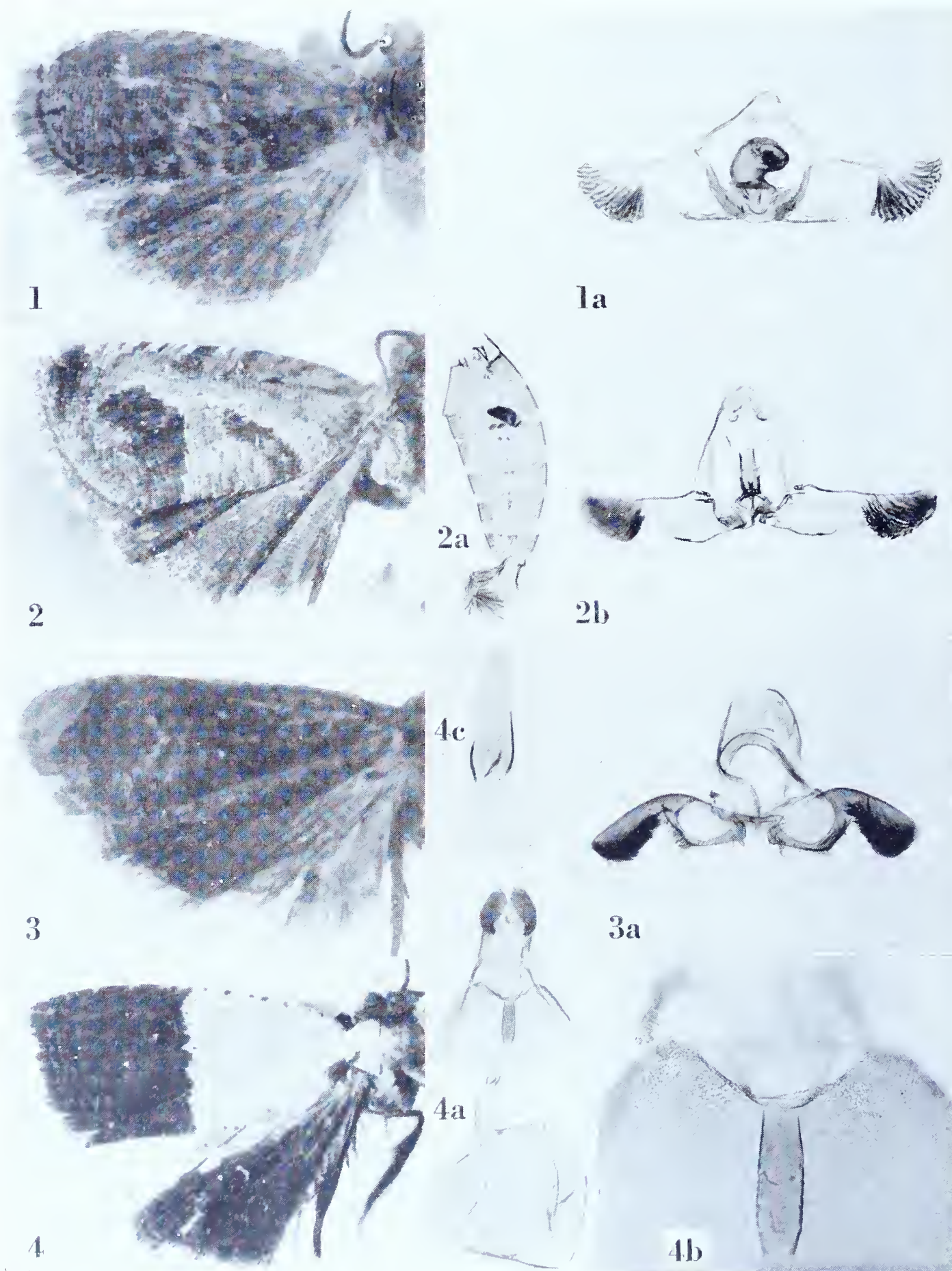

$3 a$ 


\section{Laspeyresia exocentra Meyrick}

Plate 2I 8 , Figures I-Ia

Laspeyresia exocentra Meyrick, I939, Trans. R. Ent. Soc. London, 89: 52.

" o. 8-9 mm. . . Java: Buitenzorg, 2 ex., bred March, June, from larvae on Desmodium ovalifolinm Guill. \& Perr. (Tjoa Tjien Mo)."

Type: The male so marked in the British Museum and labelled, "On Desmodinm ovalifolinm. Bzg. 20.III.37. Coll. Tjoa Tjien Mo. No. 236.” Slide No. 7402.

Figure I, left wings; Ia, ventral view of male genitalia with aedeagus in situ.

\section{Laspeyresia exsurgens Meyrick}

Plate 2i 8 , Figures $2-2 \mathrm{~b}$

Laspeyresia exsurgens Meyrick, I922, Exotic Microlepidoptera, 2: 534.

" o. 9-10 mm. . . Brazil, Para, July (Parish); 2 ex."

Lectotype: The male measuring $9 \mathrm{~mm}$. Slide No. 6485. Both bear identical data and are dated " $7-19$ ".

Figure 2, left wings; $2 \mathrm{a}$, denuded abdomen to show scale tufts; $2 \mathrm{~b}$, ventral view of male genitalia with aedeagus in sitn.

\section{Laspeyresia fabivora Meyrick}

Plate 21 8 , Figures $3-3 a$

Laspeyresia fabivora Meyrick, I928, Exotic Microlepidoptera, 3:449.

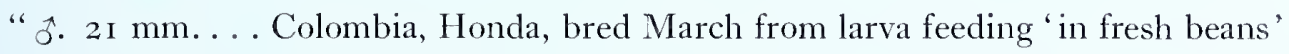
(Dr. F. Zacher); i ex. (Brit. Mus.). A peculiar type."

Type: The specimen indicated above and so marked in the British Museum, dated "5.III.1927". Slide No. 6499.

Figure 3 , left wings; 3 a, ventral view of male genitalia with aedeagus in situ.

\section{Laspeyresia gratulata Meyrick}

Plate $2 \mathrm{I} 8$, Figures $4-4 \mathrm{c}$

Laspeyresia gratulata Meyrick, 1916, Exotic Microlepidoptera, 2: 23 .

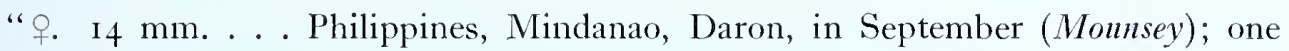
specimen."

Type: The above indicated female dated ".9.10". Slide No. 7413.

Figure 4, left wings; 4 a, ventral view of female genitalia; 4 b, detail of genital plate and ostium; 4 c, inception of ductus seminalis. 


\section{Laspeyresia guttifera Meyrick \\ Plate 219, Figures I-Ia}

Laspeyresia guttifera Meyrick, I9I3, Trans. Ent. Soc. London, I9I3: I73.

"今. $15 \mathrm{~mm}$. . . Paraguay; one specimen."

Type: The above indicated specimen labelled "Paraguay, B. .o6". Slide No. 6488.

Figure I, left wings; ra, ventral view of male genitalia with aedeagus in sitn.

\section{Laspeyresia haemograpta Meyrick}

\section{Plate 2 I9, Figure 2}

Laspeyresia haenograpta Meyrick, I928, Exotic Microlepidoptera, 3:45I.

" $\hat{0}$. Io mm. . . Andamans, Mt. Harriet, I,200 feet, February (Ferrar); i ex."

Type: The male indicated above but dated ".4.27". The abdomen is missing.

Figure 2, left wings.

\section{Laspeyresia hemidoxa Meyrick \\ Plate 2 I9, Figures 3-3a}

Lasteyresia hemidoxa Meyrick, I907, Journ. Bombay Nat. Hist. Soc., I8: I45.

" 우. I I-I2 mm. . . Khasi Hills, in September; four specimens."

Lectotype: A male measuring I I mm. Slide No. 7375. All specimens bear identical data and are dated ".9. I906".

Figure 3, left wings; 3 a, ventral view of male genitalia with aedeagus in sitn.

\section{Laspeyresia inflata Meyrick \\ Plate 2 I9, Figure 5}

Laspeyresia inflaia Meyrick, i916, Exotic Microlepidoptera, 2: 23.

"․ ${ }_{5} 5$ mm. ... Philippines, Mindoro, Butas R., in February (Monısey); one specimen."

Type: The female indicated above, "Butas R. Mindoro. M. .2.10", without abdomen or right forewing.

Figure 5, left wings.

\section{Laspeyresia isacma Meyrick}

See Laspeyresia delineana (Walker).

\section{Laspeyresia lathraeopa Meyrick \\ Plate 2 I9, Figures $4-4$ a}

Laspeyresia lathraeopa Meyrick, I922, Exotic Microlepidoptera, 2: 532.

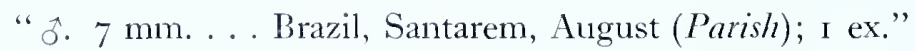

Type: The specimen indicated above dated "8-I9". Slide No. 6487.

Figure 4 , left wings; 4 a, ventral view of male genitalia with aedeagus $i n$ situ. 

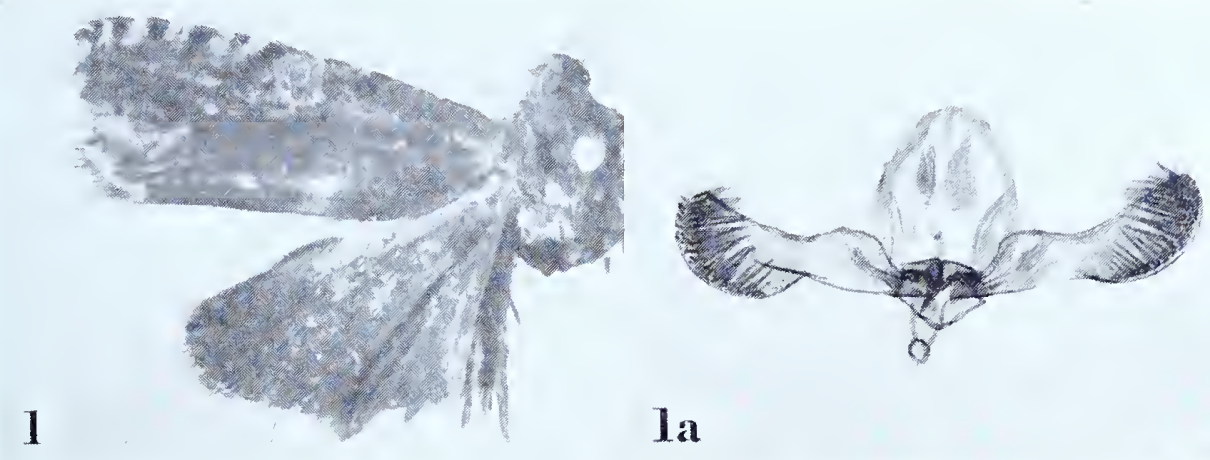

Ia

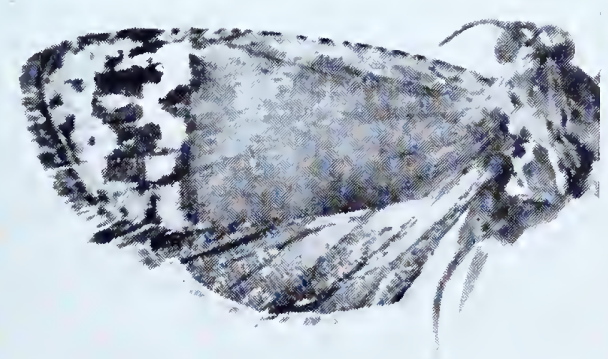

2
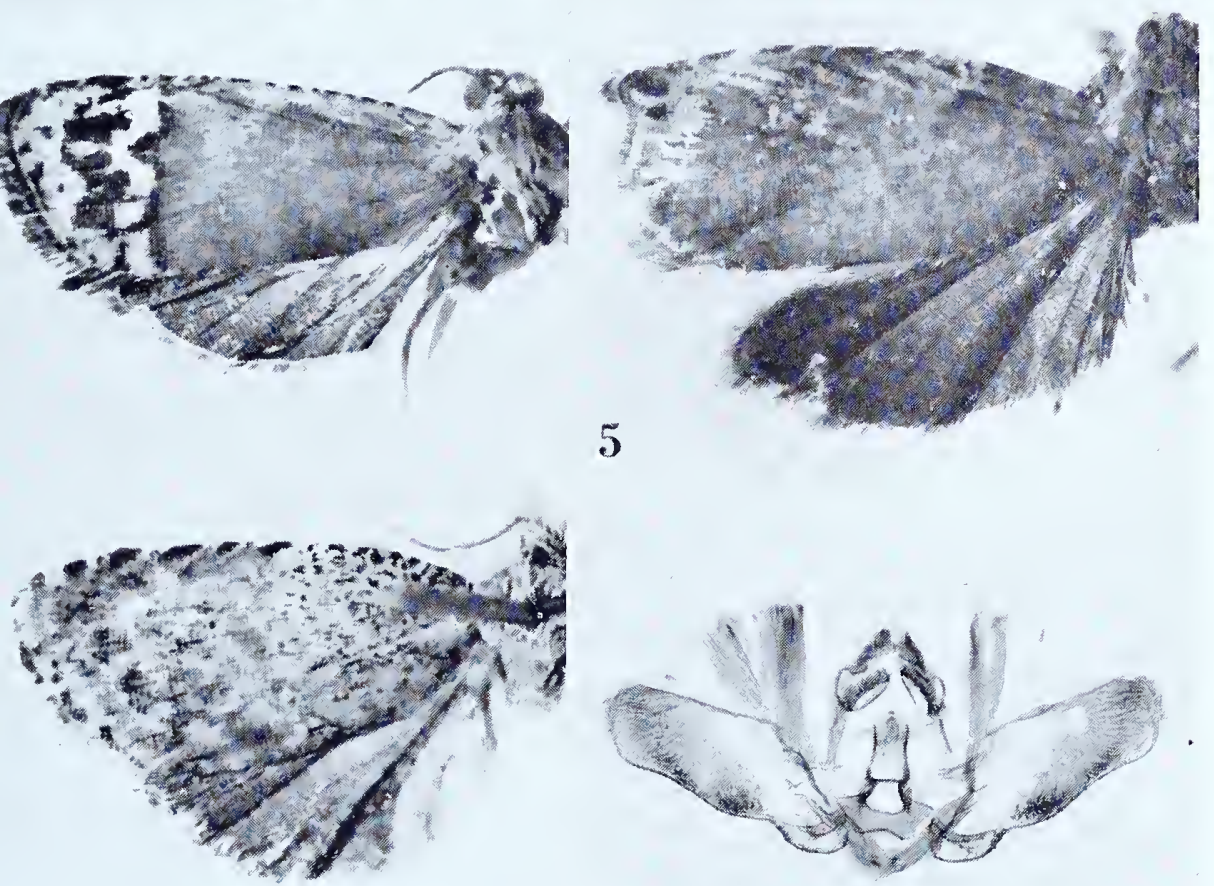

3

$3 a$
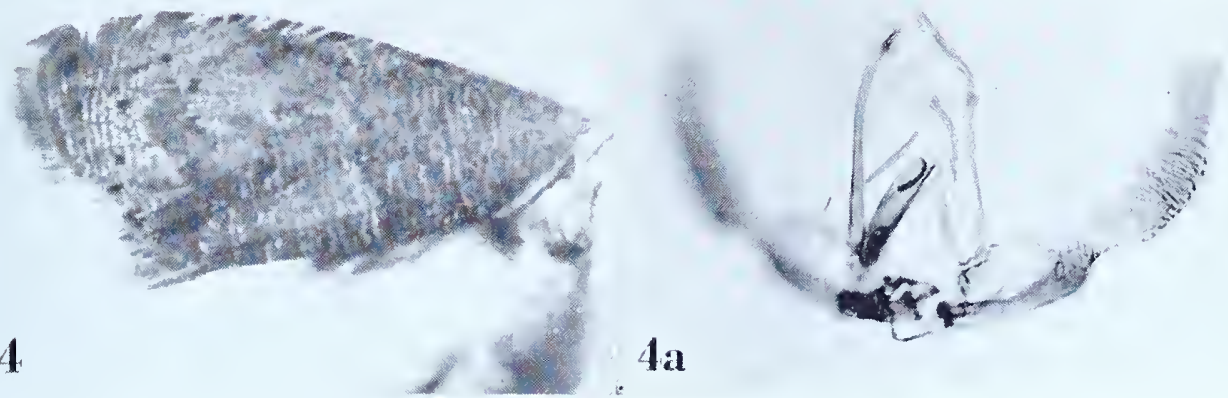

LASPEYRESIA 

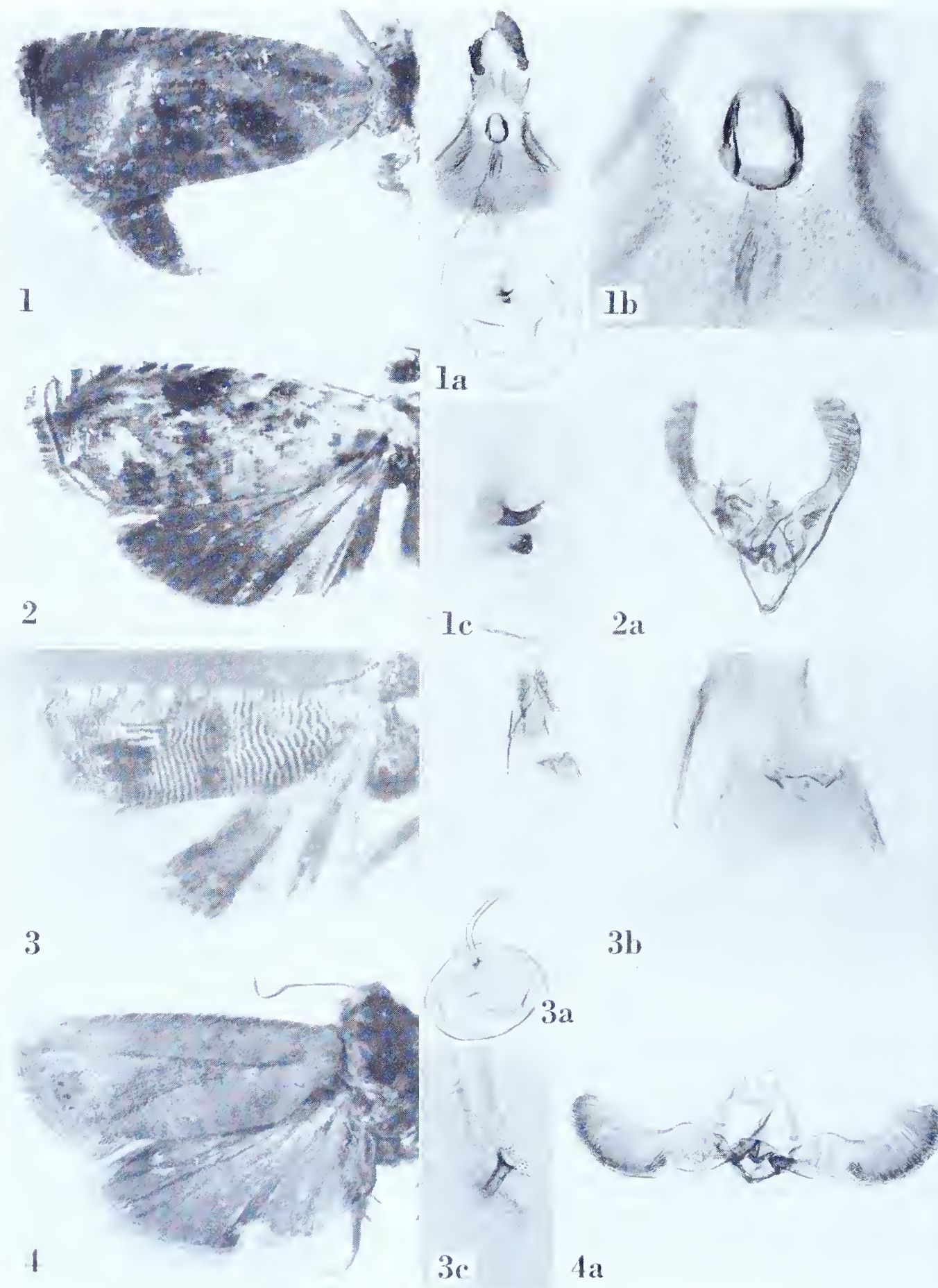
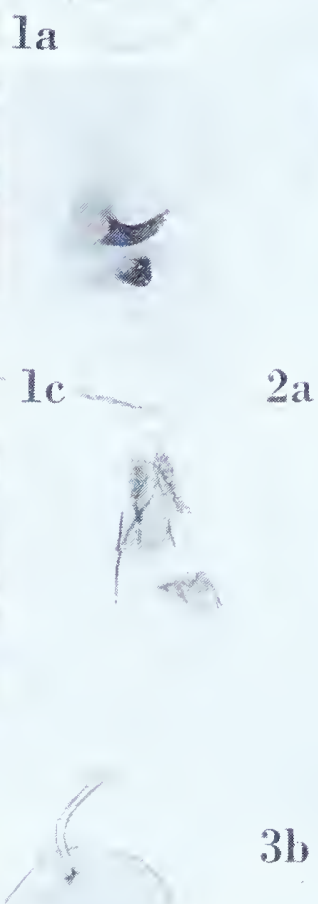

31
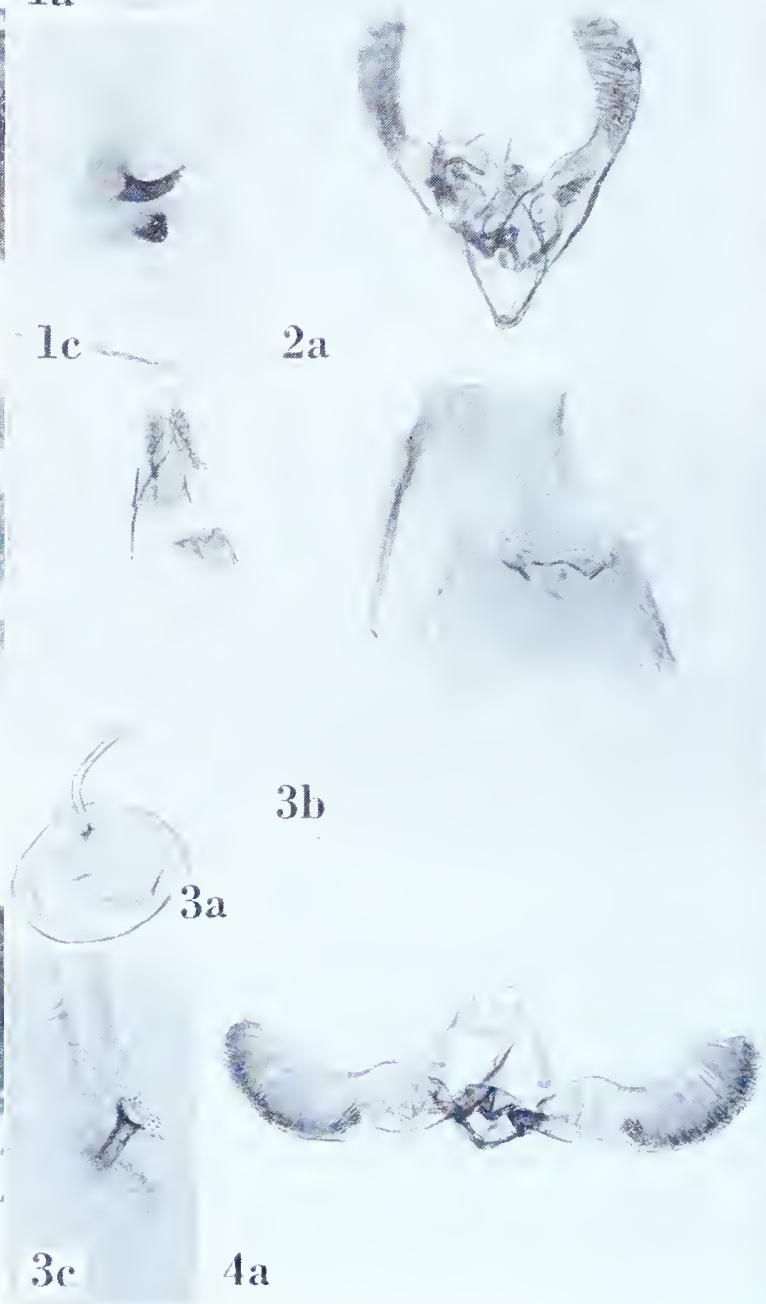

$4 a$ 


\section{Laspeyresia leucitis Meyrick}

Plate 220, Figures I-IC

Laspeyresia leucitis Meyrick, I907, Journ. Bombay Nat. Hist. Soc., I8: 143.

"o. I9 mm. . . . Khasi Hills; one specimen."

Type: The above indicated female, "Khasi Hills, Assam. D. 1906." Slide No. 7363.

Figure $\mathbf{~}$, left wings; $\mathbf{a}$, ventral view of female genitalia; $\mathbf{b}$, detail of genital plate and ostium; ic, signa.

\section{Laspeyresia leucostoma Meyrick}

Plate 220, Figures 2-2a

Laspeyresia lencostoma Meyrick, I9ı2, Journ. Bombay Nat. Hist. Soc., 2 г : 876 .

“ ‘ㅇ․ I I-I 5 mm. . . . Maskeliya, Ceylon (Alston); Palnis (Campbell); Khasis; from May to October, eight specimens."

Lectotype: A male measuring I2 mm., "Khasi Hills, Assam. .7.I907." Slide No. 7372 .

Figure 2, left wings; 2a, ventral view of male genitalia with aedeagus in situ.

\section{Laspeyresia lucida Meyrick}

Plate 220, Figures $3-3 \mathrm{c}$

Laspeyresia lncida Meyrick, I916, Exotic Microlepidoptera, 2: 22.

" $\hat{\text { ôp. }}$ 8-9 $\mathrm{mm}$. . . . S. India, Coimbatore, in November and January, attached to Cassia (Fletcher)."

Lectotype: A female measuring 8 mm., dated “23.1.13”. Slide No. 7388 . Meyrick does not state how many specimens he had before him when he described the species. There are two specimens in his collection, the second dated " 24 .I I.I 3 ", both females.

Figure 3 , left wings; 3 a, ventral view of female genitalia; 3 b, detail of genital plate and ostium; 3 c, signa.

\section{Laspeyresia malesana Meyrick}

Plate 220, Figures $4-4$ a

Laspeyresia malesana Meyrick, I920, Exotic Microlepidoptera, 2: 352 .

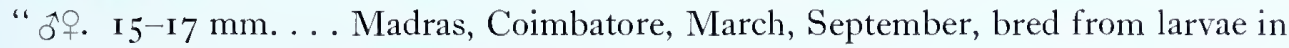
pods Parkinsonia (Leguminosae) (Fletcher); 3 ex. ..."

Lectotype: A male measuring $16 \mathrm{~mm}$., "Coimbatore, S. India. TBF. bred .3.16." Slide No. 7386. The other two specimens are missing.

Figure 4, left wings; $4^{\mathrm{a}}$, ventral view of male genitalia with aedeagus in situ. 


\section{Laspeyresia magnetica Meyrick}

Plate 22 I, Figures I-Ia

Laspeyresia magnetica Meyrick, 1928, Exotic Microlepidoptera, 3: $45 \mathrm{I}$.

“ carpaceae) (Corbett); I ex. Near pulverula."

Type: The male so labelled in the British Museum and dated "2.vii.I928". A second, small white label bears the number " 48 I 7 ". Slide No. 7405.

Figure I, left wings; ra, ventral view of male genitalia with aedeagus in sitn.

\section{Laspeyresia mamertina Meyrick}

Plate 22I, Figures 2-2b

Laspeyresia mamertina Meyrick, 1920, Exotic Microlepidoptera, 2: 353 .

"†. Io mm. . . Bengal, Pusa, March, bred from larvae on leaf of Loranthus (Loranthaceae) (Fletcher); i ex."

Type: The female denoted above dated ".3.17". Slide No. 7390.

Figure 2, left wings; $2 \mathrm{a}$, ventral view of female genitalia; $2 \mathrm{~b}$, detail of genital plate and ostium.

\section{Laspeyresia melicrossis Meyrick}

Plate 22 I, Figures $3-3 \mathrm{~b}$

Laspeyresia melicrossis Meyrick, I932, Exotic Microlepidoptera, 4: 3 I I.

" ơ

Lectotype: The male dated ".7.3I". Slide No. 7385 . The female is missing.

Figure 3 , left wings; 3 a, ventral view of male genitalia with aedeagus in situ; 3 b, denuded abdomen to show modifications.

\section{Laspeyresia miranda Meyrick}

Plate 22I, Figures $4^{-4} 4^{\mathrm{c}}$

Laspeyresia miranda Meyrick, I9I I, 'Trans. Ent. Soc. London, I4:27I.

"สำ. $13 \mathrm{~mm}$. ... Aldabra; two specimens."

Type: The female so marked in the British Museum, "Seychelles: Aldabra. Igo8. J. C. F. Fryer." Slide No. 7427 .

Figure 4 , left wings; $4 \mathrm{a}$, ventral view of female genitalia; $4 \mathrm{~b}$, detail of genital plate and ostium; $4 \mathrm{c}$, signa. 
$3 b$
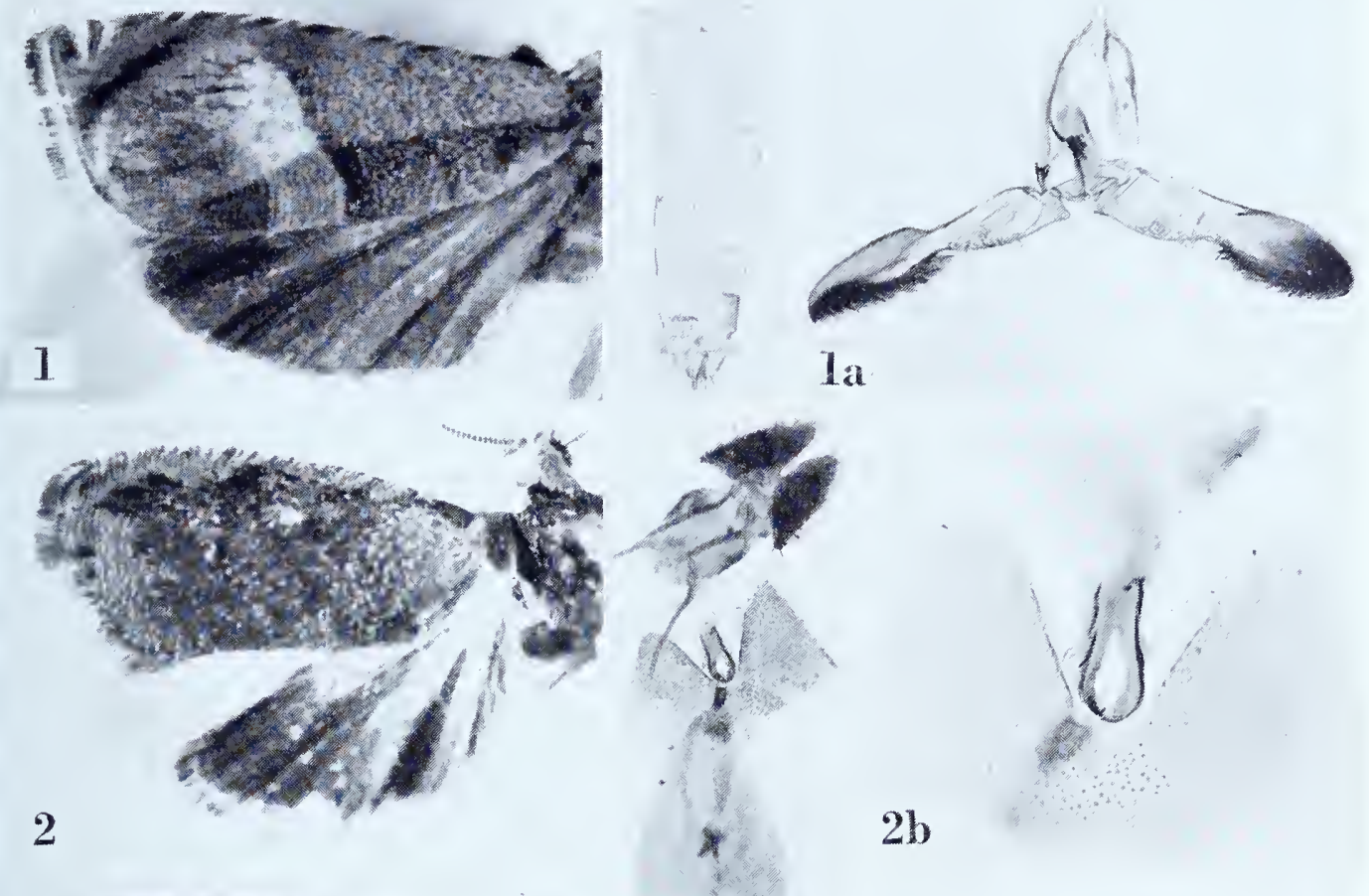

$2 b$

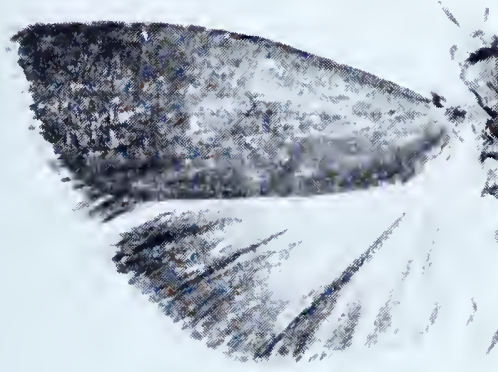

3

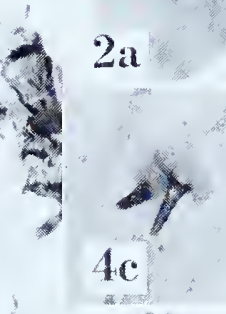

6
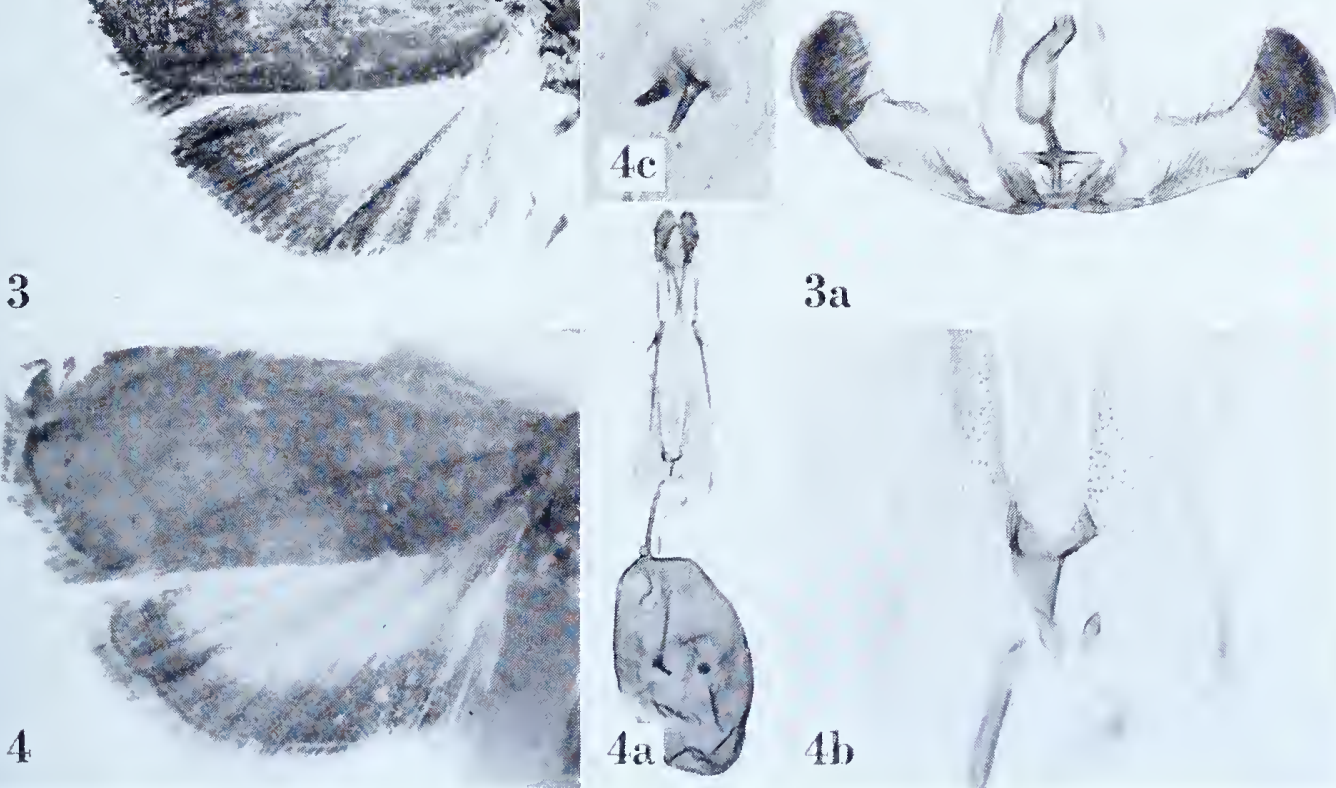

3a

LASPEYRESIA 

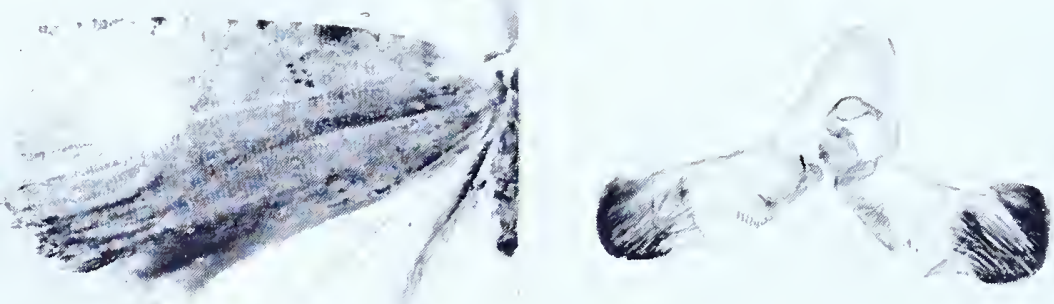

1

$1 a$

2
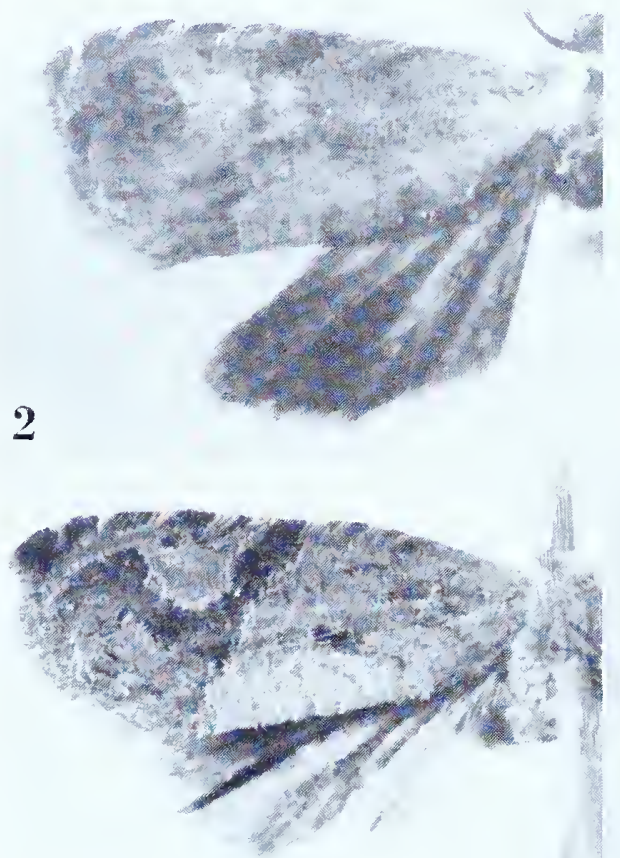

3

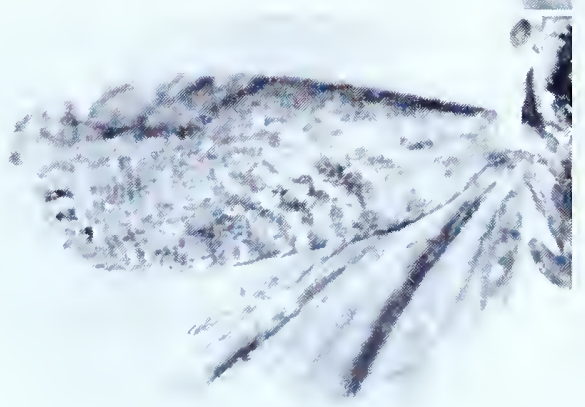

4.

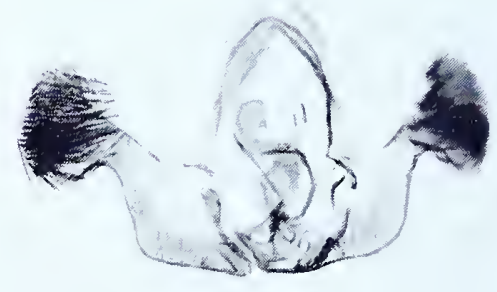

$2 a$

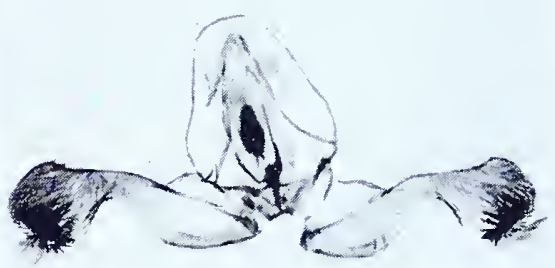

$3 a$

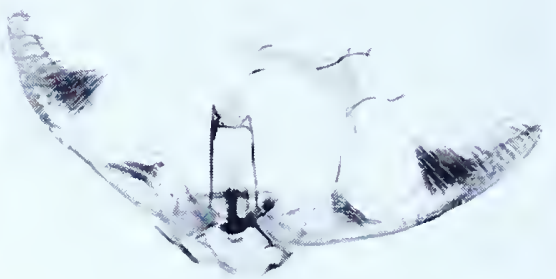

$4 a$ 


\section{Laspeyresia neolopha (Meyrick), new combination}

Plate 222, Figures I-Ia

Eulia neolopha Meyrick, 1926, Exotic Microlepidoptera, 3: 259.

" of. I 7 mm. . . . Colombia, Mt. Tolima, i 2,500 feet, November; i ex."

Type: The specimen indicated above dated ". I r.20". Slide No. $635^{8}$.

Figure I, left wings; ra, ventral view of male genitalia with aedeagus in situ.

\section{Laspeyresia nomaea (Meyrick)}

Plate 222, Figures 2-2a

Argyroploce nomaea Meyrick, I9I7, 'Trans. Ent. Soc. London, I917: 27.

" ffo $^{\circ}$ 9-1o mm. ... British Guiana, Bartica, from December to February (Parish); six specimens."

Lectotype: The male dated “.I2.I2". Slide No.6484. One specimen is missing.

Figure 2, left wings; $2 \mathrm{a}$, ventral view of male genitalia with aedeagus in situ.

\section{Laspeyresia obtecta Meyrick}

Plate 222, Figures 3-3a

Laspeyresia obtecta Meyrick, I922, Exotic Microlepidoptera, 2: 534.

" "A. I I mm. . . . Brazil, Teffé, January (Parish); i ex."

Type: The above indicated male dated "I.20". Slide No. 6483 .

Figure 3 , left wings; 3 a, ventral view of male genitalia with aedeagus in sitn.

\section{Laspeyresia ochropa (Meyrick)}

Plate 222, Figures $4^{-} 4^{\mathrm{a}}$

Lipoptycha ochropa Meyrick, I905, Journ. Bombay Nat. Hist. Soc., i6: 587 .

" o. 8-9 mm. ... Three specimens taken by myself at Kandy, Ceylon, in December."

Lectotype: The male measuring $9 \mathrm{~mm}$. Slide No. 74I 4 . The three specimens bear identical data, "Kandy, Ceylon. I 8/12/86."

Figure 4 , right wings (image reversed); $4 \mathrm{a}$, ventral view of male genitalia with aedeagus in situ. 


\section{Laspeyresia orthopyrga Meyrick}

Plate 223, Figures I-Ia

Laspeyresia orthopyrga Meyrick, I922, Exotic Microlepidoptera, 2: 532.

" J. Io mm. ... Peru, Jurimaguas, March (Parish); I ex."

Type: The above indicated male dated "3.20". Slide No. 6497.

Figure I, left wings; Ia, ventral view of male genitalia with aedeagus in situ.

\section{Laspeyresia parastrepta Meyrick}

Plate 223, Figures 2-2a

Laspeyresia parastrepta Meyrick, I907, Journ. Bombay Nat. Hist. Soc., i 8: I 47.

" $\hat{0}+$. I2-I3 mm. ... Khasi Hills, in September; twenty-five specimens. Very similar to L. tricentra."

Lectotype: A male measuring $12 \mathrm{~mm}$. Slide No. 7379. The twelve remaining specimens of the original series bear identical data and are dated ".9.1906".

Figure 2, left wings; 2a, lateral view of male genitalia with aedeagus in situ.

\section{Laspeyresia pentasticta Meyrick}

Plate 223, Figures $3^{-} 3^{\mathrm{c}}$

Laspeyresia pentasticta Meyrick, I916, Exotic Microlepidoptera, 2: 22.

"†. 9 mm. . . Coorg, Pallibetta, in October (Fletcher); one specimen."

Type: The above indicated female dated “.10.15”. Slide No. 7392.

Figure 3 , left wings; 3 a, ventral view of female genitalia; 3 b, detail of genital plate and ostium; $3 \mathrm{c}$, signa.

\section{Laspeyresia perfricta Meyrick}

Plate 223, Figures $4-4 \mathrm{c}$

Laspeyresia perfricta Meyrick, 1920, Exotic Microlepidoptera, 2: 352.

"․ I I $3^{-1} 4 \mathrm{~mm}$. . . Bengal, Pusa, August, September, bred from larvae boring top shoots Pongamia glabra (Legmminosae) (Fletcher); 4 ex."

Lectotype: A female measuring 14 mm., dated ".S. I9". Slide No. 7387 . Two specimens are missing.

Figure 4 , left wings; $4^{a}$, ventral view of female genitalia; 4 b, detail of genital plate and ostium; $f \mathrm{c}$, signa. 


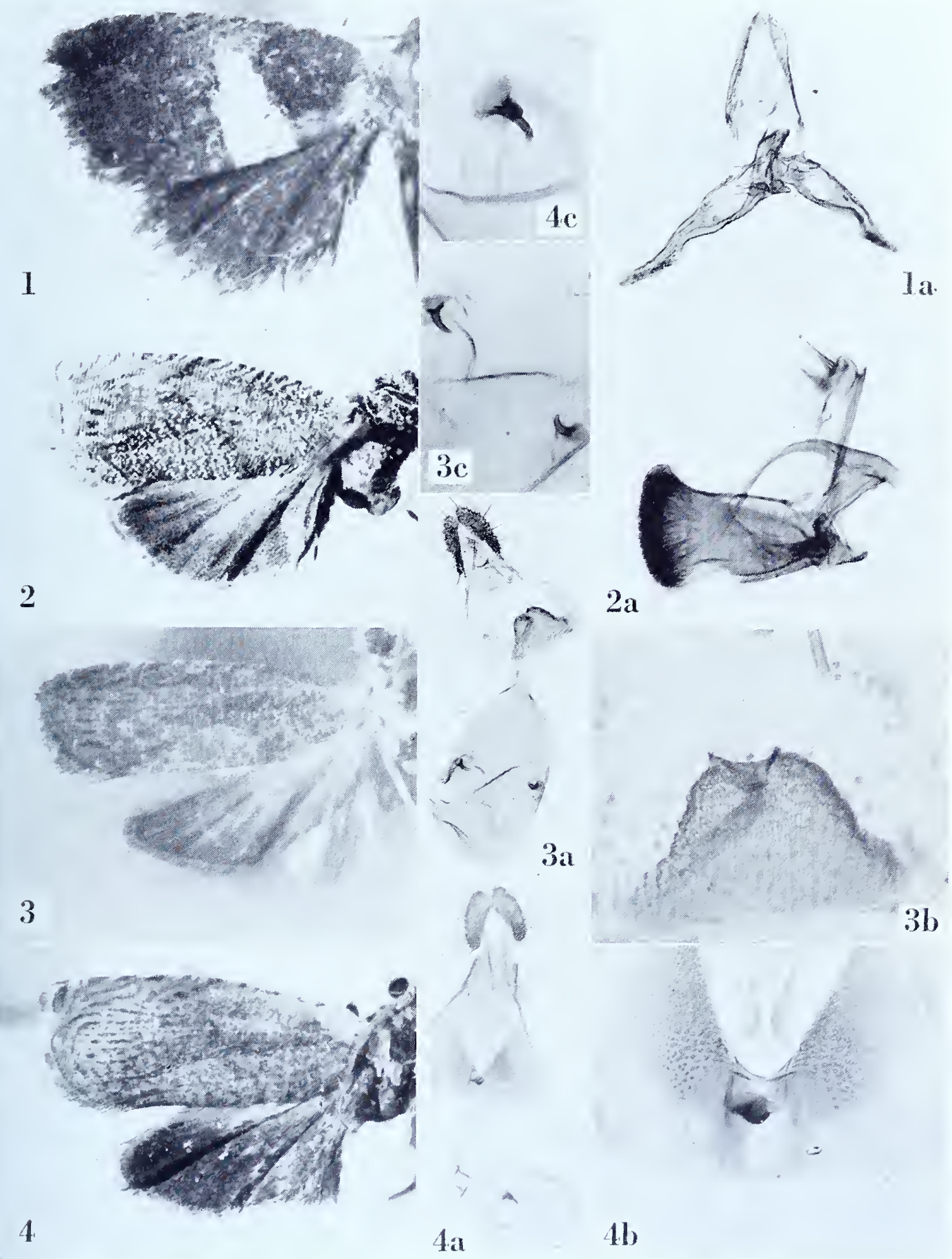

LASPEYRESIA 

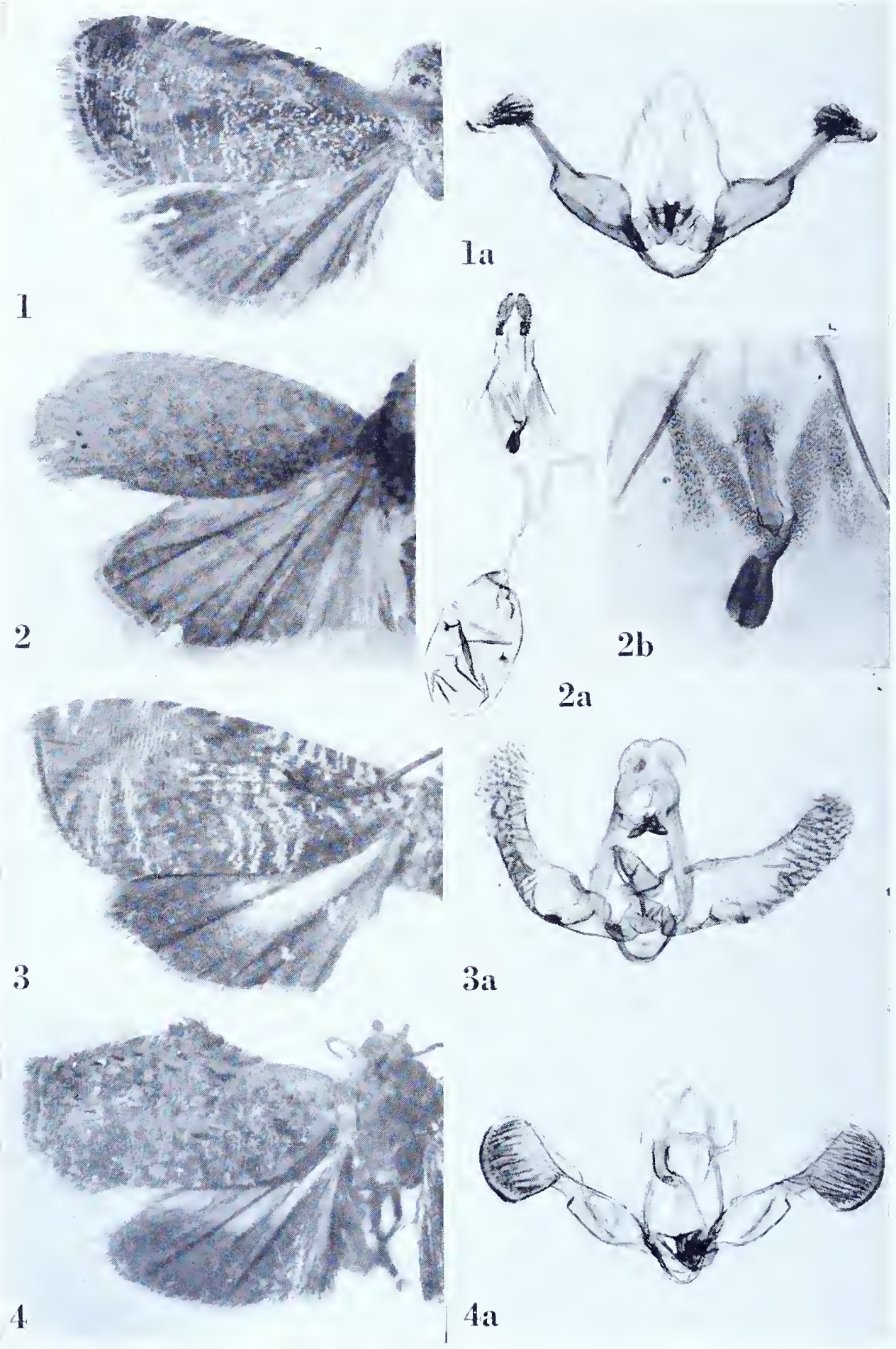


\section{Laspeyresia perrupta Meyrick}

Plate 224, Figures I-Ia

Laspeyresia perrupta Meyrick, I922, Exotic Microlepidoptera, 2: $53 \mathrm{I}$.

" ơơ. 9 mm. . . B Brazil, Teffé, December (Parish); 6 ex."

Lectotype: A male. Slide No. 6490. All bear identical data and are dated "12.19".

Figure I, left wings; ra, ventral view of male genitalia with aedeagus in situ.

\section{Laspeyresia platydryas Meyrick}

Plate 224, Figures 2-2b

Laspeyresia platydryas Meyrick, 1932, Exotic Microlepidoptera, 4: 226.

“ㅇ․ $17 \mathrm{~mm}$.... S. Rhodesia, Salisbury, bred June from seeds of Acacia sp. (M. C. Mossop); I ex. (Brit. Mus.). Similar in colouring to campestris. ..."

Type: The female so marked in the British Museum, "Salisbury, S. Rhodesia Dept. Agric. June 193I." A second label reads "Ex Acacia sp. seeds. M. C. Mossop Collector." Slide No. 9399.

Figure 2, left wings; $2 \mathrm{a}$, ventral view of female genitalia; $2 \mathrm{~b}$, detail of genital plate and ostium.

\section{Laspeyresia primigena Meyrick}

Plate 224, Figures $3^{-} 3^{a}$

Laspeyresia primigena Meyrick, 1912, Journ. Bombay Nat. Hist. Soc., 21 : 877.

" 0 . I I-I $3 \mathrm{~mm}$. ... Khasis; in October and November, two specimens."

Lectotype: The male, "Khasi Hills, Assam. .r r.19o6." Slide No. 7374.

Figure 3 , left wings; 3 a, ventral view of male genitalia with aedeagus in situ.

\section{Laspeyresia prolopha Meyrick}

Plate 224, Figures $4^{-4} 4^{a}$

Laspeyresia prolopha Meyrick, 1912, Journ. Bombay Nat. Hist. Soc., 2 I : 875 .

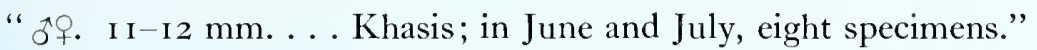

Lectotype: A male measuring I I mm., "Khasi Hills, Assam. .6.19o6." Slide No. 7370 .

Figure 4, left wings; 4 a, ventral view of male genitalia with aedeagus in situ.

\section{Laspeyresia pseudonectis Meyrick}

Sce Laspeyresia tricentra Meyrick. 


\section{Laspeyresia ptychora Meyrick}

Plate 225, Figures I-1a

Laspeyresia ptychora Meyrick, I907, Journ. Bombay Nat. Hist. Soc., I8: I47.

" 3 fo. 12-15 mm. . . N. Coorg (3,000 feet), in August (Newcome); Madulsima, Ceylon, in November (I'anghu); six specimens."

Lectotype: A male measuring $13 \mathrm{~mm}$., "Dibidi, N. Coorg. Newcome. Io.8.o6." Slide No. 7377 .

Figure I, left wings; Ia, lateral aspect of male genitalia with aedeagus in sitn.

\section{Laspeyresia pulverula Meyrick}

Plate 225, Figures 2-2c

Laspeytesia pulvernla Meyrick, I912, Journ. Bombay Nat. Hist. Soc., 21 : 876.

" o. I 4 mm. . . Khasis; in June, one specimen."

Type: The specimen referred to above, erroneously recorded as a male, "Khasi Hills, Assam. .6.1906." Slide No. 7371.

Figure 2 , left wings; $2 \mathrm{a}$, ventral view of female genitalia; $2 \mathrm{~b}$, detail of genital plate and ostium; $2 \mathrm{c}$, signa.

\section{Laspeyresia pycnochra Meyrick}

Plate 225, Figures $3^{-} 3^{\mathrm{c}}$

Laspeyresia pycnochra Meyrick, I920, Exotic Microlepidoptera, 2: 353.

" $q .13 \mathrm{~mm}$. . . Madras, Coimbatore, March, bred from larva in pod Sesbania grandiflora (Legunininosae) (Fletcher); I ex."

Type: The female indicated above, "Coimbatore, S. India. TBF. bred. .3.16." A second label reads "e. L. pods Sesbania grandiflora”. Slide No. 7389.

Figure 3 , left wings; $3 \mathrm{a}$, ventral view of female genitalia; $3 \mathrm{~b}$, signa; $3 \mathrm{c}$, detail of ostium.

\section{Laspeyresia pycnota Meyrick}

Plate 225, Figures $4-4 \mathrm{~b}$

Laspeyresia pycnota Meyrick, I914, Journ. Bombay Nat. Hist. Soc., 22: 772.

"ㅇ. $10 \mathrm{~mm}$. .. . Yellapur, Kanara, in October (Maxzell); two specimens."

Lectotype: One of the above indicated females both of which bear identical data and are dated "I3.IO.I I". Slide No. 7395.

Figure 4 , left wings; 4 a, ventral view of female genitalia; 4 b, detail of ostium. 


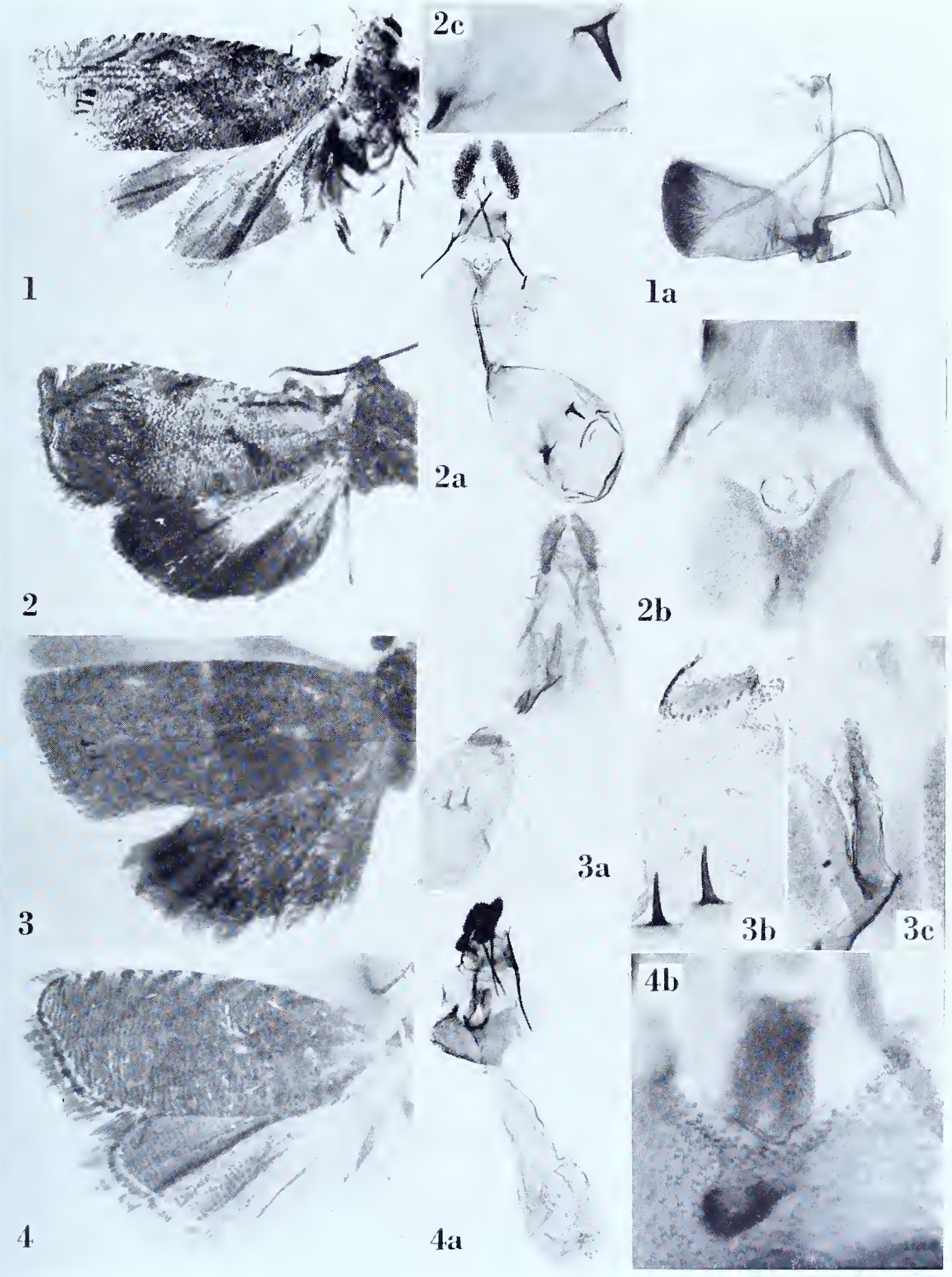



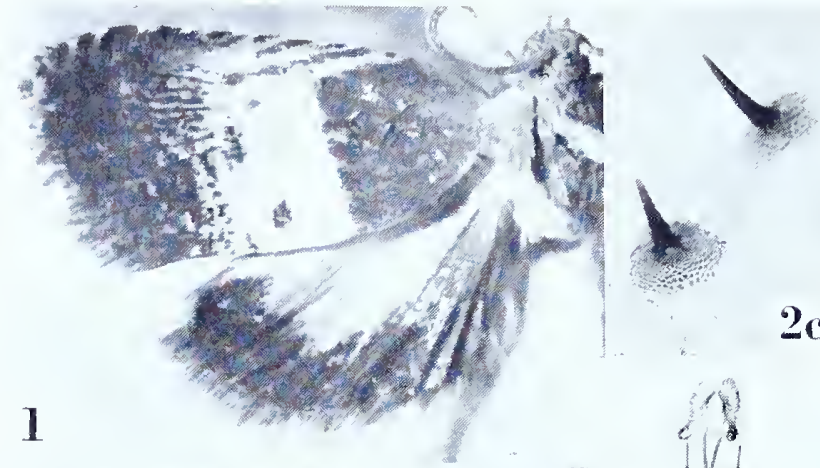

2
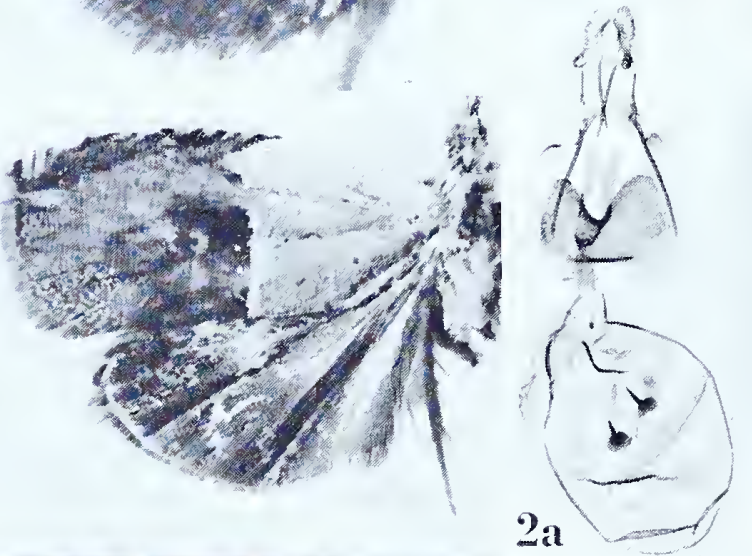

Ia

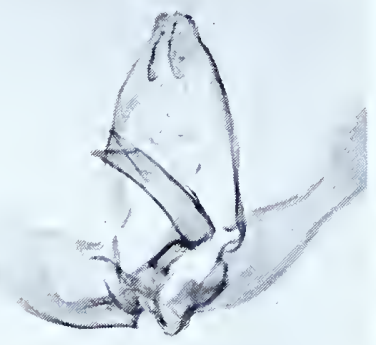

$2 b$

3
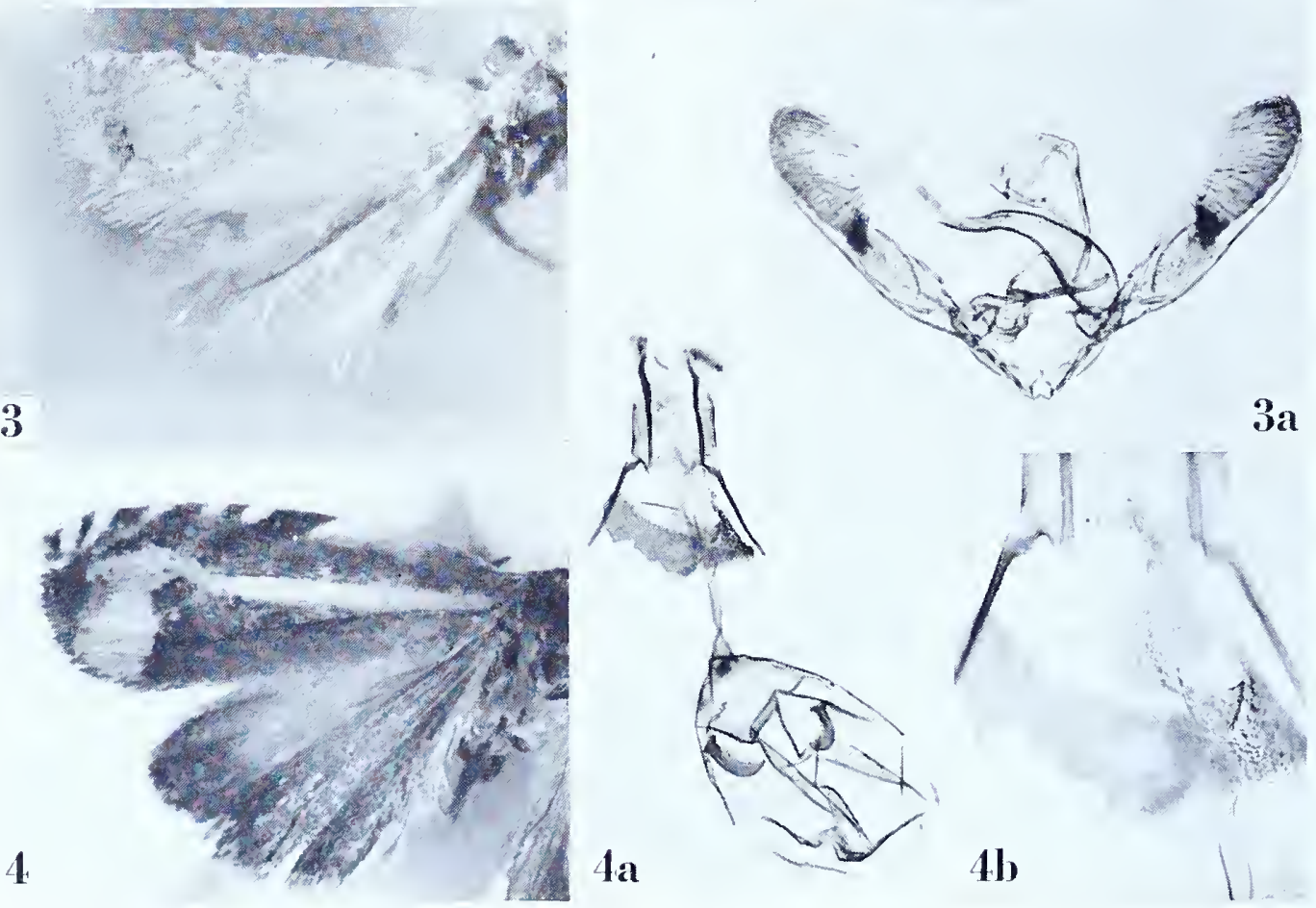


\section{Laspeyresia pyrozona Meyrick}

Plate 226, Figures I-Ia

Laspeyresia pyrozoua Meyrick, I9I6, Exotic Microlepidoptera, 2:24.

"§. 12 mm. . . British Guiana, Bartica, in February (Parish); one specimen."

Type: The specimen indicated above dated ".2.I3". Slide No. 6493.

Figure I, left wings; ra, ventral view of male genitalia with aedeagus in situ.

\section{Laspeyresia reflectrix Meyrick}

Plate 226, Figures 2-2c

Laspeyresia reflectrix Meyrick, I928, Exotic Microlepidoptera, 3: 448 .

"o. $15 \mathrm{~mm}$.... Nyasaland, Zomba (Barlow); I ex. Allied to excisa Wals."

Type: The above indicated female, "Zomba, Nyasaland. H. Barlow." Slide No. 9407 .

Figure 2, left wings; $2 \mathrm{a}$, ventral view of female genitalia; $2 \mathrm{~b}$, detail of genital plate and ostium; $2 \mathrm{c}$, signa.

\section{Laspeyresia refrigescens Meyrick}

Plate 226, Figures $3^{-3}$ a

Laspeyresia refrigesceus Meyrick, 1924, Exotic Microlepidoptera, 3: 68.

" ㄱำ. 9-I I mm. ... Egypt, Aswan (Hayward); 7 ex. Near lotana."

Lectotype: ô, I I mm., “Aswan, Egypt. KJH. .20.” Slide No. 9408.

Figure 3 , left wings; 3 a, ventral view of male genitalia with aedeagus in situ.

\section{Laspeyresia rhodaspis Meyrick}

Plate 226, Figures $4-4 \mathrm{~b}$

Laspeyresia rhodaspis Meyrick, 1928, The Entomologist, 6I : 23I.

"ㅇ. I $3 \mathrm{~mm}$. . . . Peru; I ex. (British Museum)."

Type: The specimen indicated above labelled, "Peru, Stgr. I903," marked type in the British Museum.

Figure 4 , left wings; $4 \mathrm{a}$, ventral view of female genitalia; 4 b, detail of genital plate and ostium. 


\section{Laspeyresia staphiditis Meyrick}

Plate 227 , Figures $\mathbf{I}-\mathbf{I}$ a

Laspeyresia staphiditis Meyrick, I930, Exotic Microlepidoptera, 3: 604.

“ ‘ิ+. I I-I 2 mm. . . . Bihar, Pusa, bred December, January, March from larvae boring twigs of Bauhinia purpurea (Leguminosae) (Fletcher); 4 ex. Allied to stirpicola and amplilecta."

Lectotype: The male measuring I I mm. [barely], "Pusa, India. TBF. bred .3.29." One specimen is missing.

Figure I, left wings; Ia, ventral view of male genitalia with aedeagus in sitı.

\section{Laspeyresia stelosema Meyrick}

Plate 227 , Figures $2-2 \mathrm{c}$

Laspeyresia stelosema Meyrick, I93 I, Exotic Microlepidoptera, 4: I 43.

" + . I 3-I 4 mm. ... Uganda, Kampala, bred from fruit of "nautoki" (H. Hargreaves); 2 ex. (type Brit. Mus.)."

Type: The female in the British Museum designated by Meyrick, dated " i o.x.ı 903 ". Slide No. 7428 .

Figure 2 , left wings; $2 \mathrm{a}$, ventral view of female genitalia; $2 \mathrm{~b}$, detail of genital plate and ostium; 2c, signa.

\section{Laspeyresia stictobathra Meyrick}

\section{Plate 227, Figure 3}

Laspeyresia stictobatlıra Meyrick, I9I 6, Exotic Microlepidoptera, 2: 22.

" o. $9 \mathrm{~mm}$. ... S. India, Coimbatore, in October (Fletcher); one specimen."

Type: The above indicated specimen dated ".3.10.13", without abdomen.

Figure 3 , left wings.

\section{Laspeyresia stirpicola Meyrick}

Plate 227 , Figures $4^{-4 a}$

Laspeyresia stirpicola Meyrick, 1926, Mem. Dept. Agric. India, 9: 259.

Laspeytesia stirpicola Meyrick, 1927, Exotic Microlepidoptera, 3:342 [preoccupied].

“ $\delta$. I $12-15 \mathrm{~mm} . . .4$ examples ... Daltonganj."

" 3 ㅇ. I $2-15 \mathrm{~mm}$. . . . Bihar and Orissa, Choto Nagpur plateau, bred in May from larvae boring in tender pollarded stems of Butea froudosa (Leguninosae) (Office of Indian Iuperial Eutomologist); 4 ex."

Lectotype: A male measuring 14 mm., "Daltonganj, Bihar and Orissa. M. bred .5.25." Slide No. 7394 .

[continued on $p \cdot .60$. 


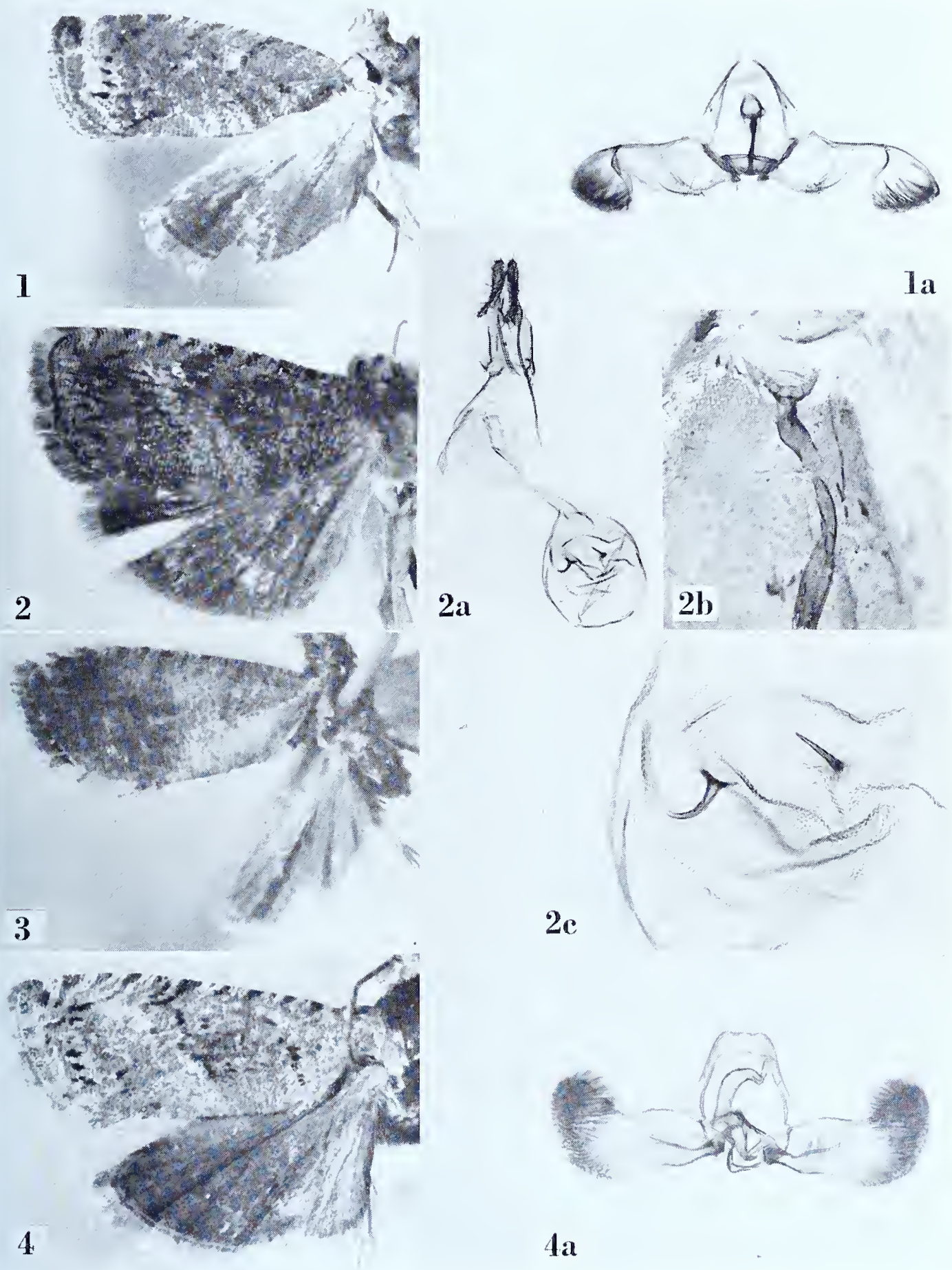




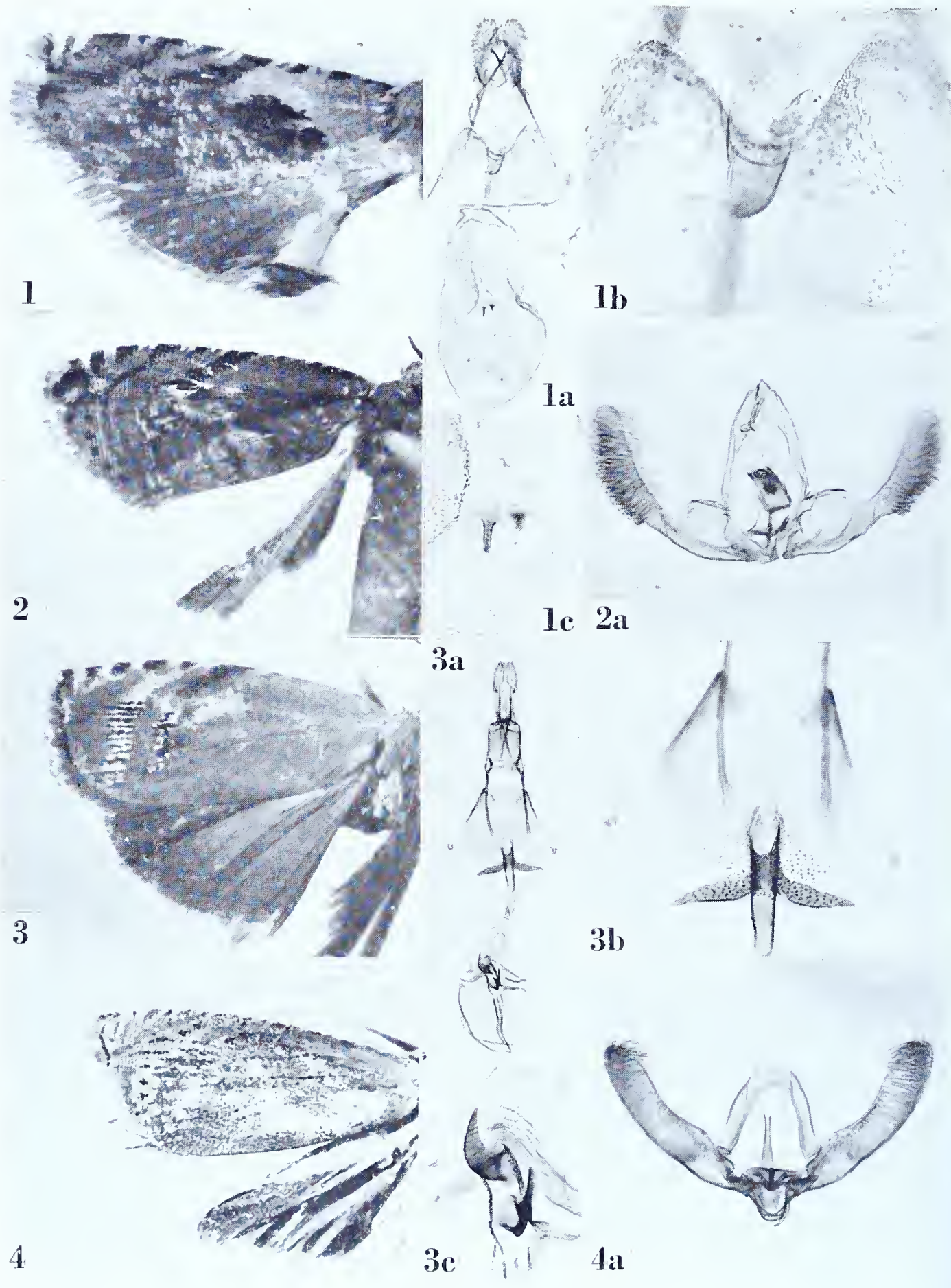




\section{Laspeyresia taocosma Meyrick}

Plate 228, Figures I-IC

Laspeyresia taocosma Meyrick, 1914, Exotic Microlepidoptera, I : 197.

" . $12 \mathrm{~mm}$. . . Gold Coast, Aburi (Patterson); one specimen. Type in British Museum."

Type: The female, erroneously recorded as a male, so marked in the British Museum, "Aburi, Gold Coast, 1912. Patterson. 1914-556." Slide No. 7403. A small label in Meyrick's hand bears the name of the insect and the word "type".

Figure I, left wings; $x a$, ventral view of female genitalia; $x b$, detail of genital plate and ostium; Ic, signa.

\section{Laspeyresia tetrasticta Meyrick}

Plate 228, Figures 2-2a

Laspeyresia tetrasticta Meyrick, 1909, Trans. Ent. Soc. London, 1909: I4.

" ${ }^{\circ}$. I I-I 2 mm. . . B Bolivia, Songa; two specimens."

Lectotype: The male, with "S. .07" at the bottom of the pin-label. Slide No. 649r. The second specimen is female.

Figure 2, right wings (image reversed); $2 \mathrm{a}$, ventral view of male genitalia with aedeagus in situ.

\section{Laspeyresia tonosticha Meyrick}

Plate 228, Figures $3-3 \mathrm{c}$

Laspeyresia tonosticha Meyrick, 1922, Exotic Microlepidoptera, 2: 531 .

" 축. 16 mm. . . . Brazil, Parintins, Teffé, October, December (Parish); 2 ex."

Lectotype: The female, "Teffé, Brazil, Parish. 12-19." Slide No. 6494. Both specimens are females, the opposite sex having been recorded in error.

Figure 3 , left wings; $3 \mathrm{a}$, ventral view of female genitalia; $3 \mathrm{~b}$, detail of genital plate and ostium; $3 \mathrm{c}$, signa.

\section{Laspeyresia trasias Meyrick \\ Plate 228, Figures $4-4 \mathrm{a}$}

Laspeyresia trasias Meyrick, 1928, Exotic Microlepidoptera, 3:448.

" for $^{\circ}$ I $3^{-14}$ mm. . . China, Peking, bred (Dr. F. G. Needham), details not sent but will be published by captor; 3 ex. Allied to chelias."

Lectotype: A male measuring 14 mm., "Peking, China. JGN. bred. .28." Slide No. 7410.

Figure 4, left wings; 4 a, ventral view of male genitalia with aedeagus in situ. 


\section{Laspeyresia tricentra Meyrick}

Plate 229, Figures I-Ia; 2-2a; 3-3a

Laspeyresia tricentra Meyrick, I907, Journ. Bombay Nat. Hist. Soc., I 7: 734.

Laspeyresia crocopa Meyrick, I 9o7, Journ. Bombay Nat. Hist. Soc., i 8: I 46 (new synonymy). Laspeyresia psendonectis Meyrick, 1907, Journ. Bombay Nat. Hist. Soc., i8: I46 (new synonymy).

\section{[tricentra]}

" $\sigma^{\text {fo }}$. I I-I 3 mm. . . . Maskeliya, Peradeniya, and Puttalam, Ceylon; Travancore, Moaw, Bombay, Poona (Pole, Greell, Swinhoe); ten specimens. Larva feeds in stems of Crotalaria ("Dekkan hemp") (Green)....."

Lectotype: A male measuring I I mm., "Maskeliya, Ceylon. Pole. 4.o6." Slide No. 7415. Four specimens are missing.

Figure I, left wings; Ia, lateral aspect of male genitalia with aedeagus in situ. [crocopa]

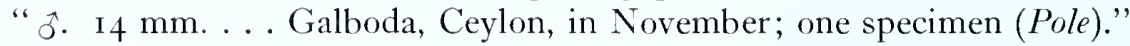

Type: 'The above indicated male, "Galboda, Ceylon. JP. .r i .о . " Slide No. 7376.

Figure 2, left wings; $2 \mathrm{a}$, lateral aspect of male genitalia with aedeagus in sitn. [pseudonectis]

“ $\hat{\jmath}$. Io mm... Surat, in October; one specimen (Maxwell-Lefroy). Larva tunnels stems of Crotalaria juncea (Maxwell-Lefroy). Very similar to L. tricentra but distinct by the sexual characters of posterior legs and hindwings."

Type: The above indicated specimen, "Surat, Bombay. HML. 27.10.04", without abdomen. Male genitalia figured from a male from Pusa. Slide No. $738_{3}$.

Figure 3, left wings; $3 \mathrm{a}$, lateral aspect of male genitalia with aedeagus in situ.

Contimued from p. 456 .

Meyrick described this species twice under the same name, using the four specimens both times. In the first description only the first part of the locality was given and in the second "Bihar and Orissa". For the lectotype I have given the data as it appears on the pin-label and it is the same for the four specimens.

Figure 4, left wings; fa, ventral view of male genitalia with aedeagus in situ. 

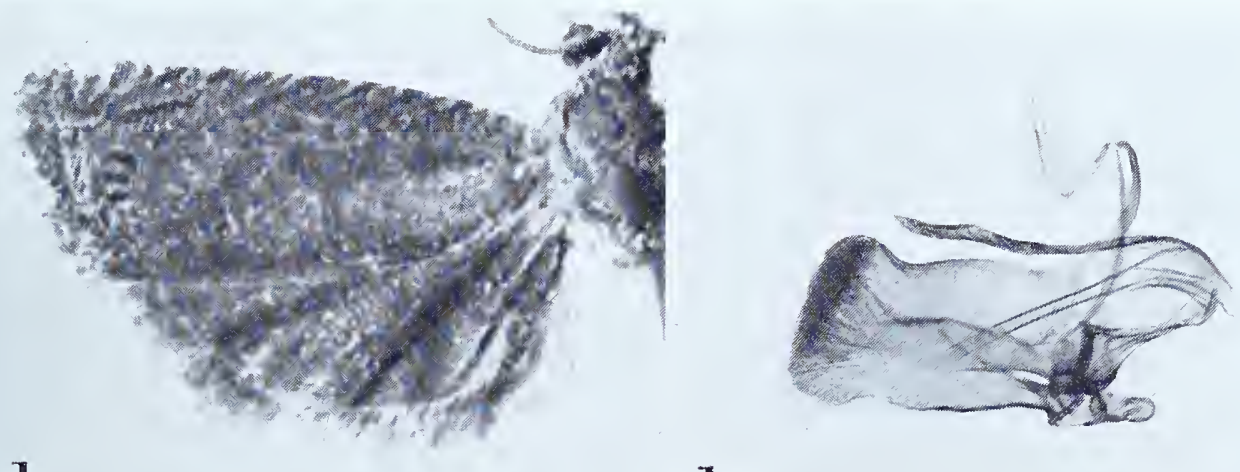

1

Ia

2

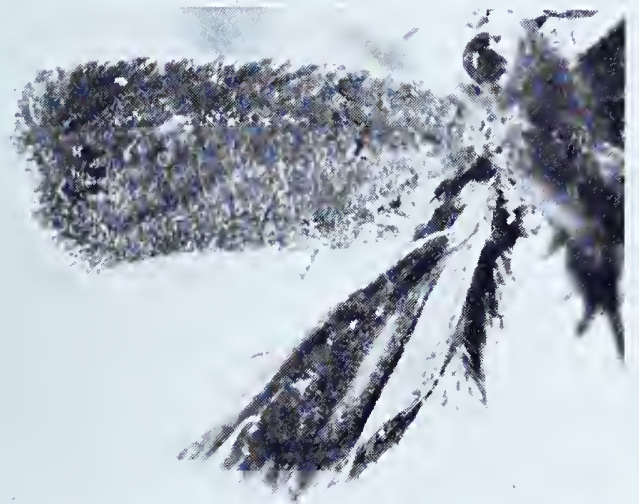

$2 a$
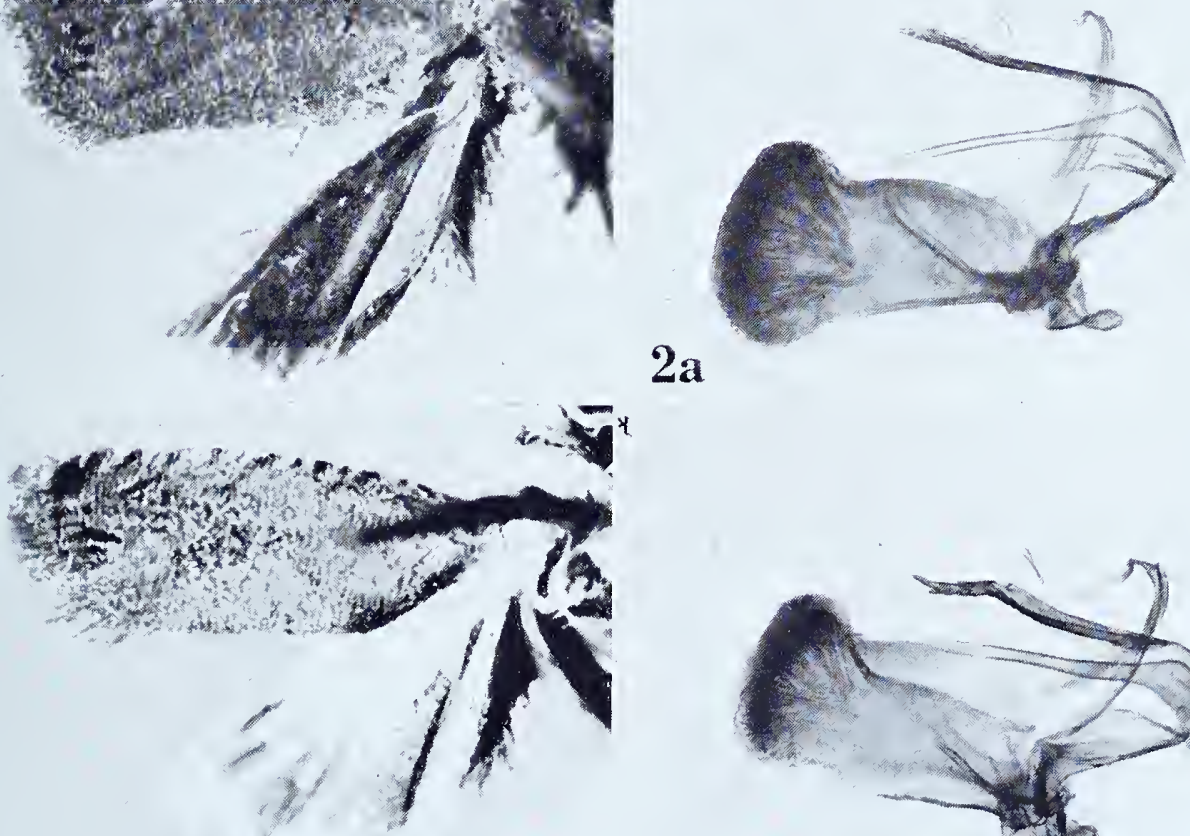

3

3a

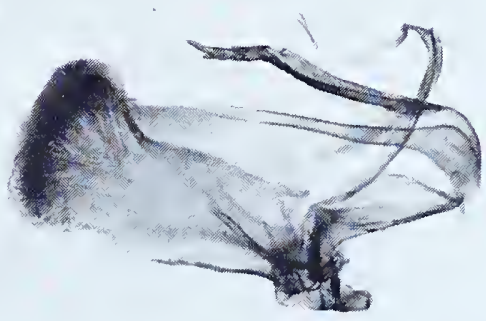

LASPEYRESIA 

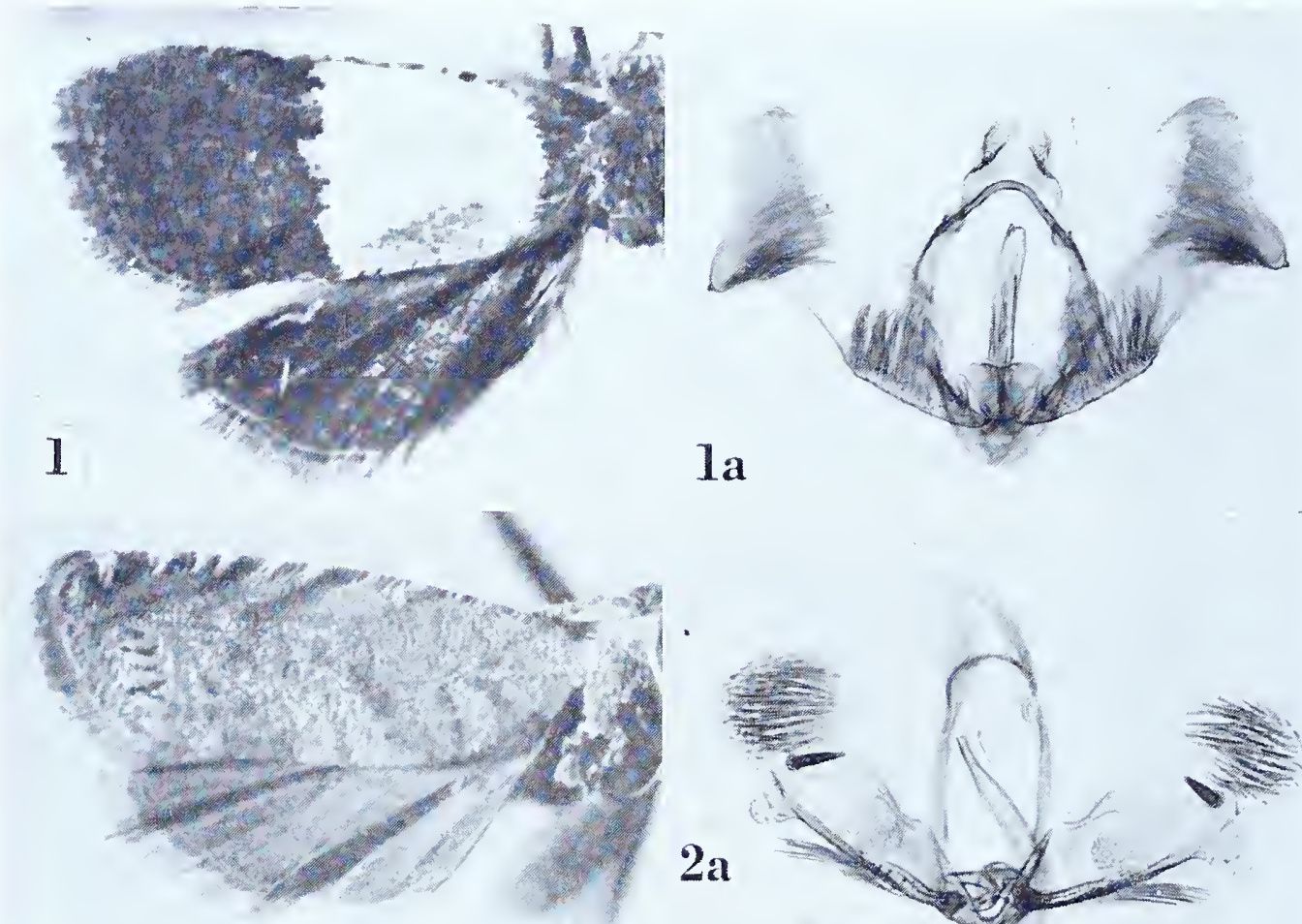

2
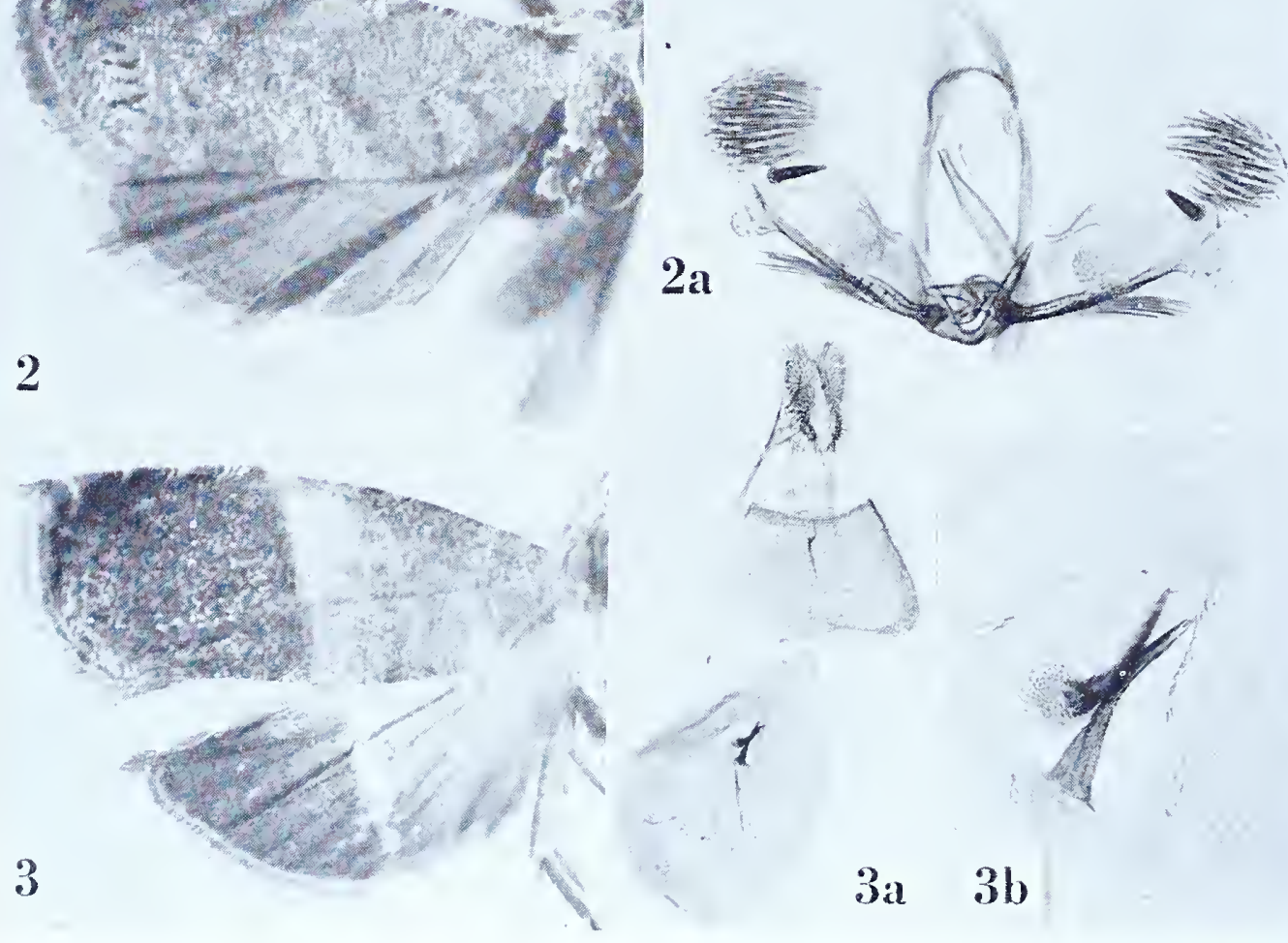

$3 a \quad 3 b$

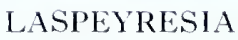




\section{Laspeyresia turifera Meyrick}

Plate 230, Figures I-Ia

Laspeyresia turifera Meyrick, 1912, Journ. Bombay Nat. Hist. Soc., 21 : 876.

" $\hat{\text { o. }}$ I $3 \mathrm{~mm}$. . . . Khasis; in March, one specimen."

Type: The male denoted above, "Khasi Hills, Assam. 3.1907." Slide No. 7373.

Figure I, left wings; Ia, ventral view of male genitalia with aedeagus il situ.

\section{Laspeyresia xerophila Meyrick}

Plate 230, Figures 2-2a

Laspeyresia xerophila Meyrick, I939, Trans. R. Ent. Soc. London, 89: 5 I.

"Male, Io mm. ... India: Bihar, Pusa, bred May from larvae in dry branches of Trewia nudiflora L. (Euphorbiaceae) (M. Bose); 2 ex. . .."

Lectotype: The male in the Meyrick collection, "Pusa, Bihar. MB. bred. .5.36." Slide No. $74 \mathrm{I}$ I. The second specimen is missing.

Figure 2, left wings; 2 a, ventral view of male genitalia with aedeagus $i$ in situ.

\section{Laspeyresia xylocrossa Meyrick}

Plate 230 , Figures $3-3 \mathrm{~b}$

Laspeyresia xylocrossa Meyrick, i939, 'Trans. R. Ent. Soc. London, 89: 52.

"Male, female, го-г I mm. . . Java, Telawa, bred August from larvae feeding in shoots of an unidentified plant (Dr. L. G. Kalshoveu ); 4 ex."

Lectotype: A female measuring i m mm., dated ".8.35". Slide No. 7412. Two specimens are missing and both specimens in the Meyrick collection are females.

Figure 3, left wings; $3 \mathrm{a}$, ventral view of female genitalia; $3 \mathrm{~b}$, signa. 


\section{LOBESIA Stainton \\ Lobesia acanthis (Meyrick), new combination \\ Plate 23I, Figures I-Ia}

Polychrosis acantliis Meyrick, 1920, Exotic Microlepidoptera, 2: 348 .

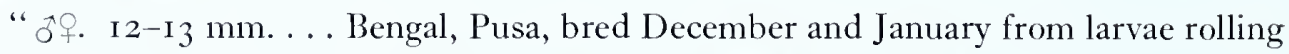
leaves and boring stems of Gusticia gendarussa (Acanthaceae) (Fletcler); Coorg, Dibidi, 3,500 feet, November (Newcome); 3 ex."

Lectotype: The male, "Dibidi, N. Coorg. LN. .ri.12." Slide No. 7153. All specimens are males.

Figure I, left wings; Ia, ventral view of male genitalia with aedeagus in situ.

\section{Lobesia aeolopa Meyrick}

Plate 23 I, Figures 2-2a

Lobesia aeolopa Meyrick, 1907, Journ. Bombay Nat. Hist. Soc., I7: 976; Diakonoff, 1950, Bull. Brit. Mus. (Nat. Hist.) Ent., I (4): 29I.

“ ‘ㅇ․ IO-I 2 mm. ... Ten specimens, Maskeliya and Peradeniya, Ceylon; Bombay; from November to May (Pole, Green, Young). ..."

Lectotype: A male measuring 12 mm., "Maskeliya, Ceylon. Pole. .5.06", selected by Diakonoff. Slide No. $7 \mathrm{I} 98$.

Figure 2, left wings; 2 a, ventral view of male genitalia with aedeagus in situ.

\section{Lobesia anceps (Meyrick), new combination}

Plate 23 , Figures $3-3$ a

Polychrosis anceps Meyrick, I909, Journ. Bombay Nat. Hist. Soc., I 9: 588.

“ํㅜ. 1 2-1 4 mm. . . Puttalam, Ceylon, in April (Pole); two specimens."

Lectotype: The male. Slide No. 7 I 48 . Both specimens have identical data and are dated ".4.04".

Figure 3, left wings; 3 a, ventral view of male genitalia with aedeagus in situ.

\section{Lobesia arenacea (Meyrick), new combination}

Plate 231 , Figures $4^{-4} 4^{\mathrm{a}}$

Polychrosis arenacea Meyrick, 1917, Trans. Ent. Soc. London, I917: 23.

“ $\hat{\jmath}+$. I I-I2 mm. . . Ecuador, Duran, low swampy country, in June (Parish); twenty-three specimens. Varies remarkably, but easy of recognition."

Lectotype: A male measuring i m m. Slide No. 6410. Ten specimens are missing, the remainder are dated "6.14".

Figure 4 , left wings; 4 a, ventral view of male genitalia with aedeagus in situ. 

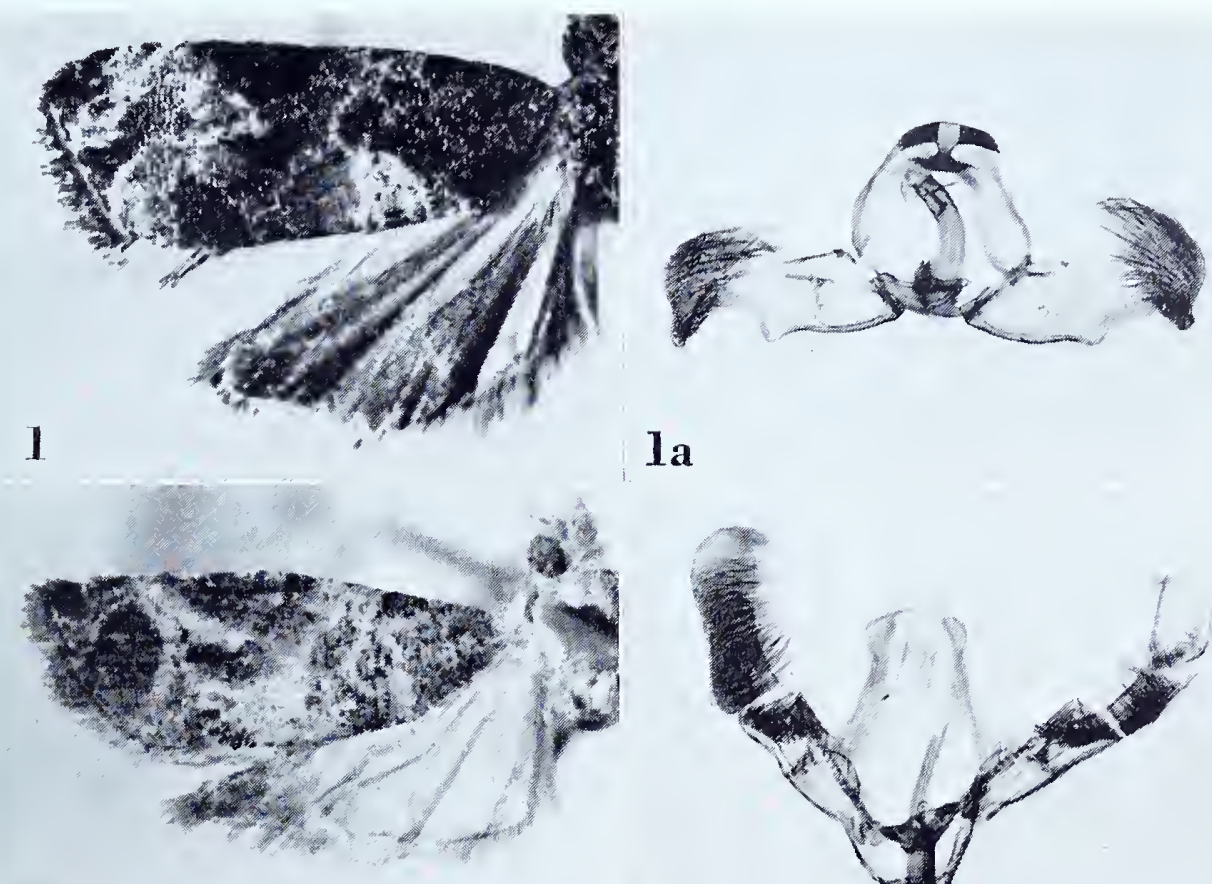

2
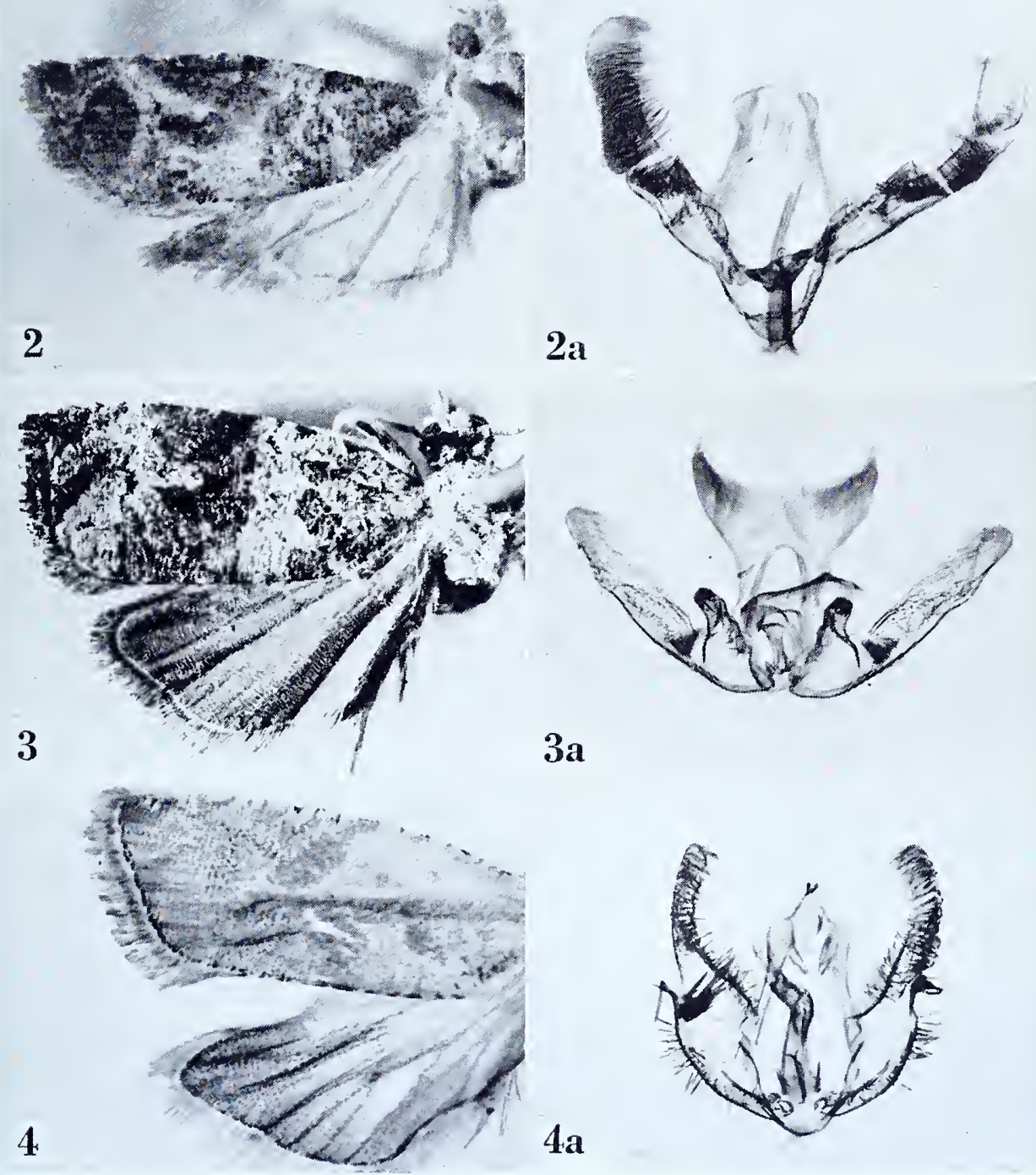

LOBESIA 


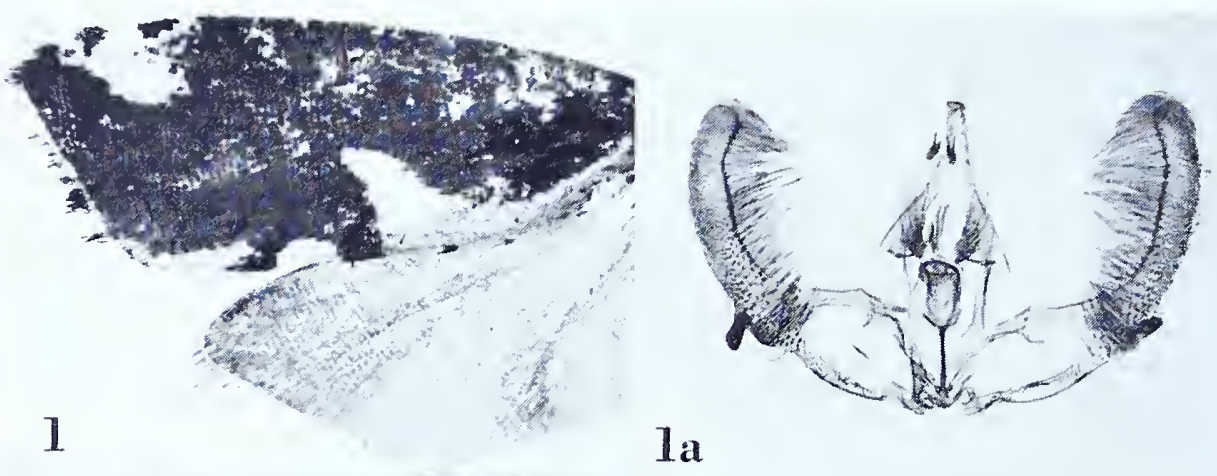

2
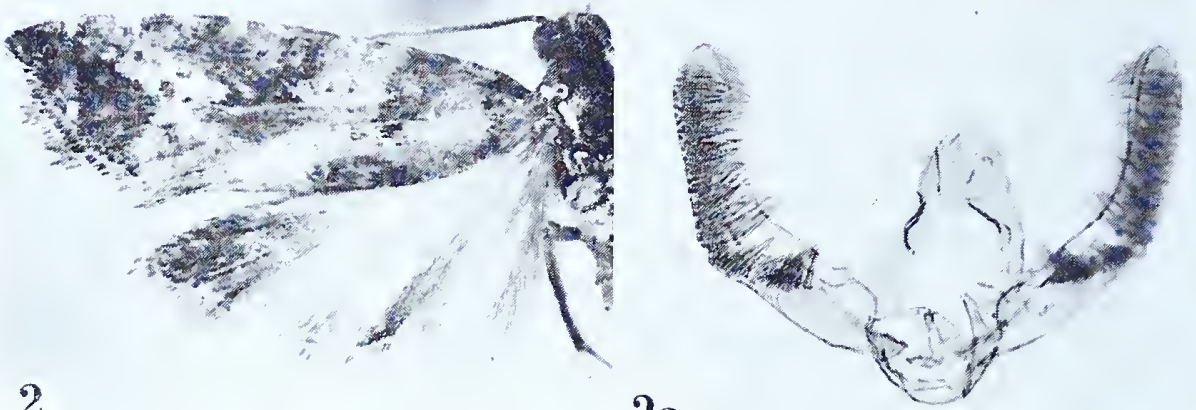

$2 a$
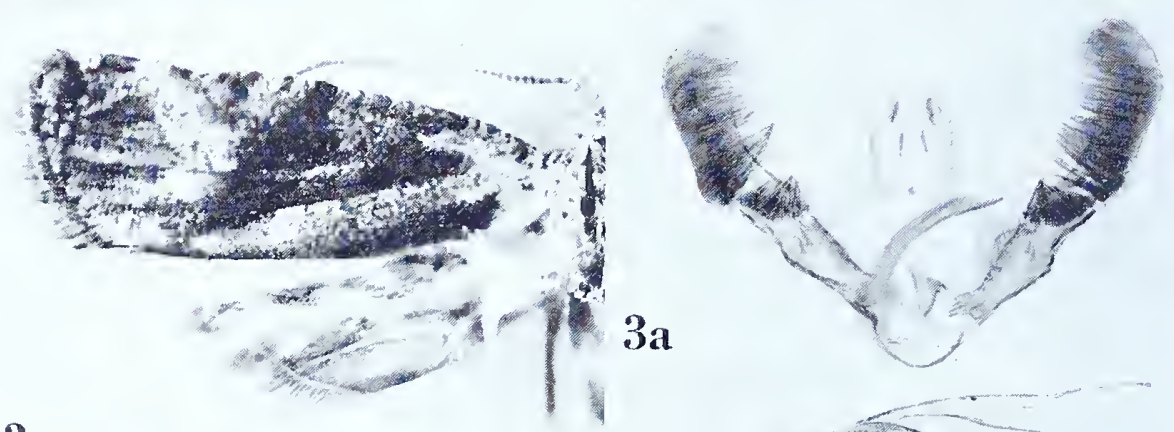

3

$C^{-1}+3$

$\frac{3}{3 b}$

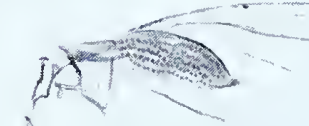

y 30

b r

4
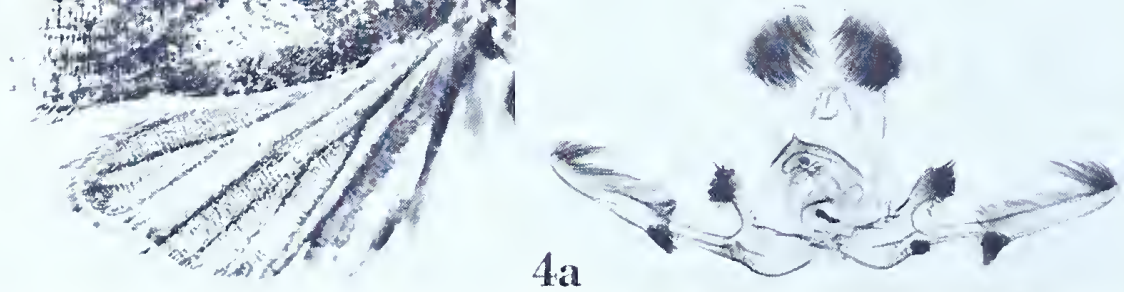


\section{Lobesia chionolitha (Meyrick), new combination}

Plate 232, Figures I-I a

Polychrosis chionolitha Meyrick, i 938, Trans. R. Ent. Soc. London, 87: 5 I I.

"o. i 7-20 mm. ... Mt. Tafa, 8,500 feet, March; 3 ex."

Type: The male so marked in the British Museum, "Mt. Tafa, Papua, 8,500 ft. iii-r 934. L. E. Cheesman." Slide No. 702 I.

Figure I, left wings; Ia, ventral view of male genitalia with aedeagus in sitn.

\section{Lobesia clarisecta Meyrick}

Plate 232, Figures 2-2a

Lobesia clarisecta Meyrick, I932, Exotic Microlepidoptera, 4: 308; Diakonoff, i950, Bull. Brit. Mus. (Nat. Hist.) Ent., I (4): 29I.

" ํำ. I4 mm. ... Kashmir, Gulmarg, 8,800 feet, June (T. B. Fletcher); 3 ex."

Lectotype: A male dated "6.3I". Slide No. 7I 33. Diakonoff cited a "Holotype", but this should be lectotype. One specimen is missing.

Figure 2, left wings; 2a, ventral view of male genitalia with aedeagus in sitn.

\section{Lobesia dryopelta Meyrick}

Plate 232, Figures $3-3 \mathrm{~b}$

Lobesia dryopelta Meyrick, I932, Exotic Microlepidoptera, 4: 225; Diakonoff, I950, Bull. Brit. Mus. (Nat. Hist.) Ent., I (4): 292.

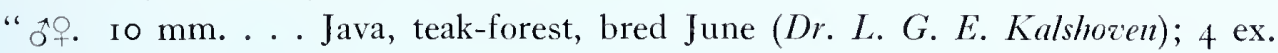
( I $0 \hat{0}, 3$ ㅇ)."

Lectotype: The male, "Java. K. .6.3I", selected by Diakonoff. Slide No. 7I 3 I.

Figure 3 , left wings; 3 a, ventral view of male genitalia with aedeagus in sitn; 3 b, part of denuded abdomen to show ventral modifications of anterior segments.

\section{Lobesia fallax (Meyrick), new combination}

Plate 232, Figures $4-4 \mathrm{a}$

Polychrosis fallax Meyrick, I909, Journ. Bombay Nat. Hist. Soc., i 9: $5^{87}$.

"수․ I $5^{-17} \mathrm{~mm}$. . . Khasis, from July to September; twelve specimens."

Lectotype: A male measuring 16 mm., "Khasi Hills, Assam. 9.1906." Slide No. 7147 .

Figure 4 , left wings; 4 a, ventral view of male genitalia with aedeagus in sitm. 


\section{Lobesia fetialis (Meyrick)}

Plate 233, Figures I-Ia

Polychrosis fetialis Meyrick, I920, Exotic Microlepidoptera, 2: 346.

" + . I $\mathrm{mm}$. . . Bengal, Pusa, bred in January from larva on flowers of Leucas (Labiatae) (Fletcher); I ex."

Type: The male denoted above dated ".ı.16". Slide No. 7r29.

Figure I, left wings; Ia, ventral view of male genitalia with aedeagus in sitn.

\section{Lobesia formalis (Meyrick), new combination}

Plate 233, Figures 2-2a

Polychrosis formalis Meyrick, I935, in Caradja and Meyrick, Materialien zu einer Microlepidopteren Fauna der Chinesischen Provinzen Kiangsu, Chekiang und Hunan, 57. “... o. I 5 mm. ... 7 ex., Tienmushan, IV, Linping, III, VIII, Hoengshan, I4.IV. Allied to fallax and acanthis."

Lectotype: A male, "Tien-Mu-Shan, China, H. 5,300' .4.32." Slide No. 7152. Five specimens are missing and are, presumably, in the Caradja collection.

Figure 2, left wings; 2a, ventral view of male genitalia with aedeagus $i n$ situ.

\section{Lobesia gabina (Meyrick), new combination}

Plate 233, Figures 3-3a

Polychrosis gabina Meyrick, I909, Journ. Bombay Nat. Hist. Soc., I9: 588.

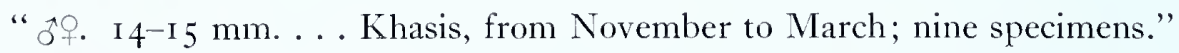

Lectotype: A male measuring I4 mm., "Khasi Hills, Assam. .3.1907." Slide No. 7 I 49 .

Figure 3 , left wings; 3 a, ventral view of male genitalia with aedeagus in situ.

\section{Lobesia genialis Meyrick}

Plate 233, Figures $4-4$ a

Lobesia genialis Meyrick, I912, Journ. Bombay Nat. Hist. Soc., 2 I : 869.

" ऊ. $12 \mathrm{~mm}$. . . Peradeniya, Ceylon (Green); in January, one specimen."

Type: The male indicated above dated ".r.o8". Slide No. 719 I.

Figure 4 , left wings; 4 a, ventral view of male genitalia with aedeagus in situ. 


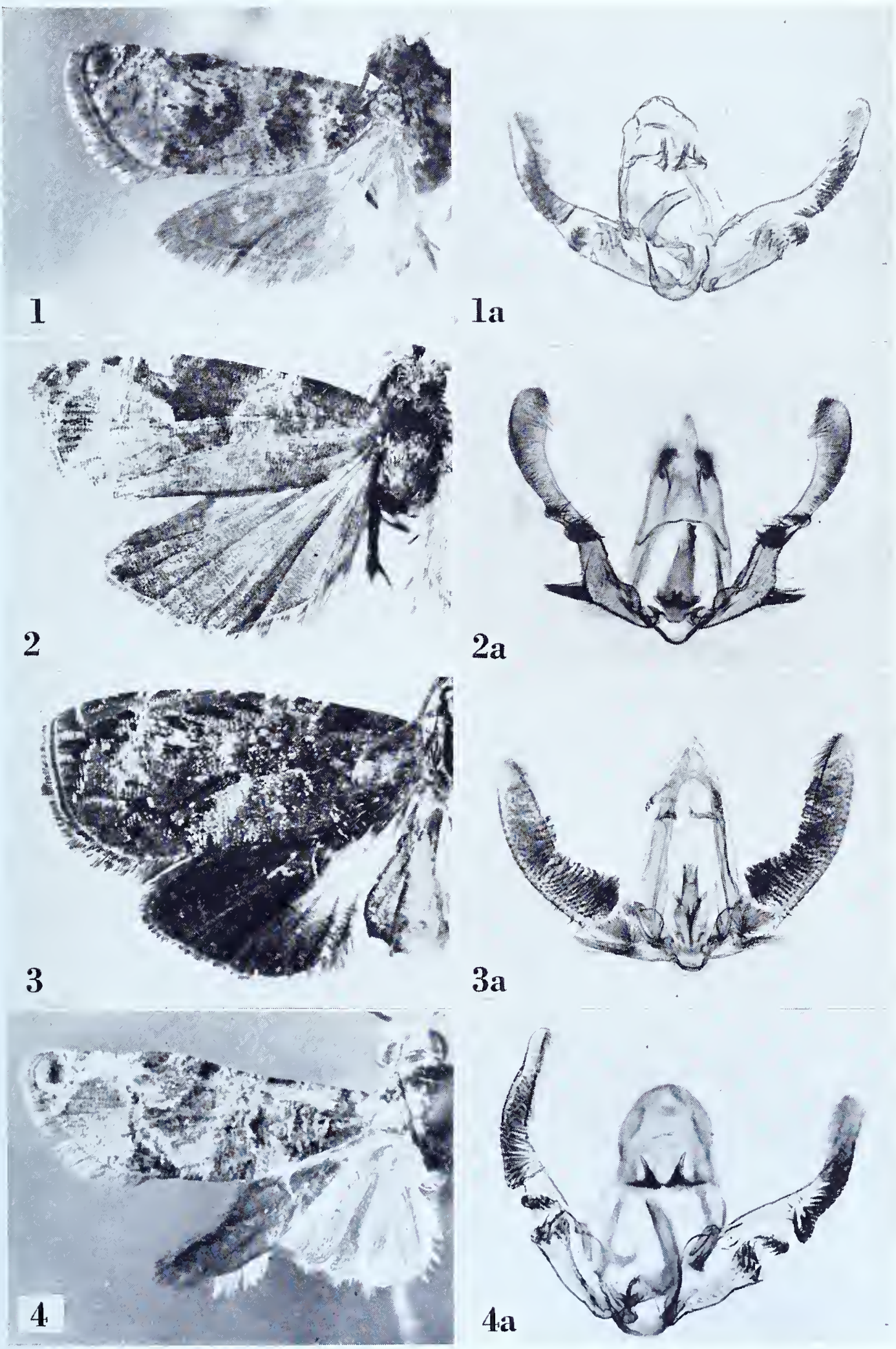



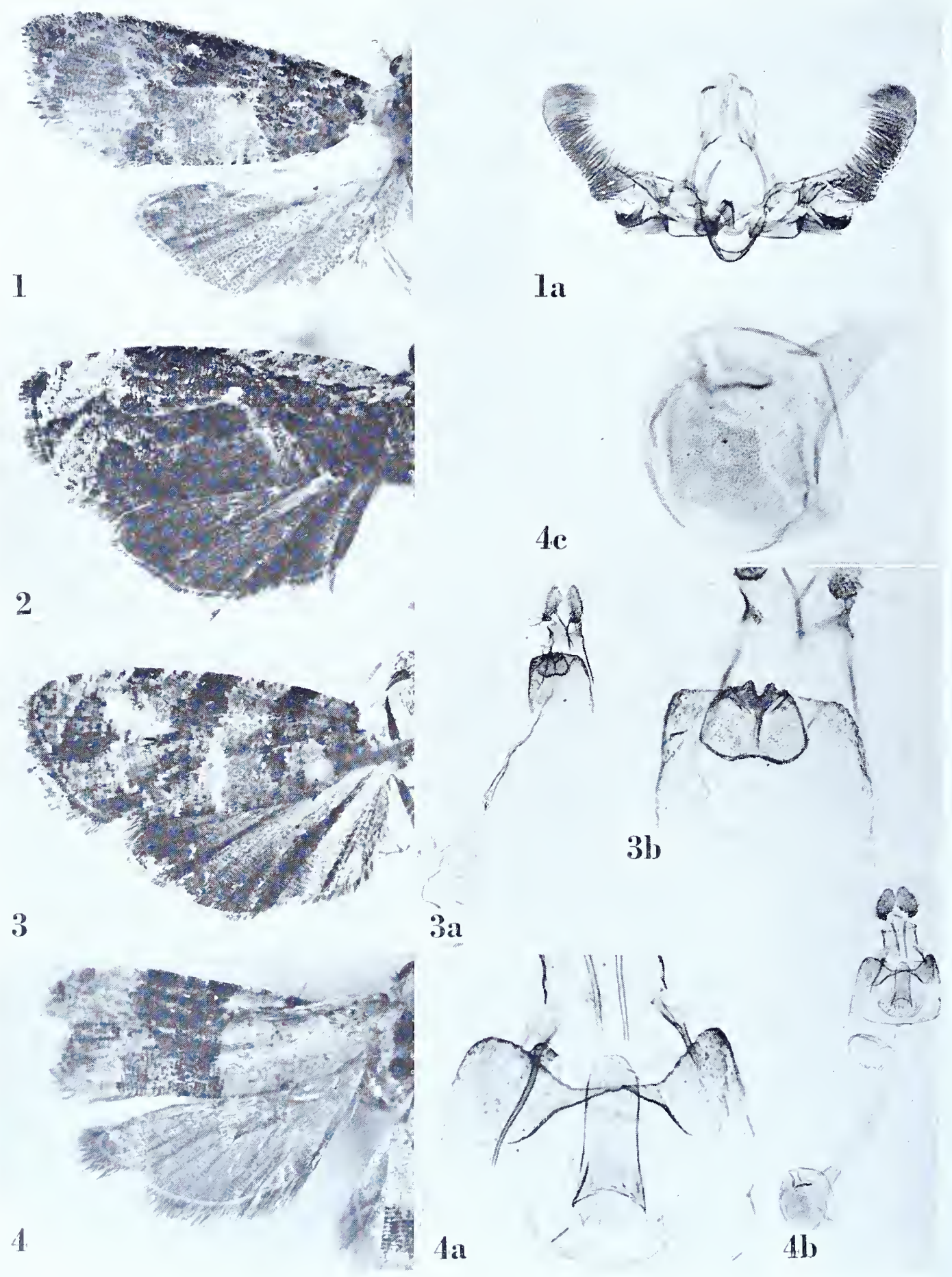


\section{Lobesia glebifera (Meyrick)}

Plate 234, Figures I-Ia

Polychrosis glebifera Meyrick, I912, Exotic Microlepidoptera, I: 34 .

“o. I $3^{-1} 4 \mathrm{~mm}$. . . Asia Minor, Alma Dagh; two specimens. Near bicinctana. ..."

Type: The male so marked in the British Museum, "Alma Dagh, Asia Minor. J. .06." Slide No. 7325 .

Figure $\mathrm{r}$, left wings; $\mathrm{xa}$, ventral view of male genitalia with aedeagus in sitn.

\section{Lobesia organica (Meyrick), new combination}

Plate 234, Figure 2

Polychrosis organica Meyrick, I920, Exotic Microlepidoptera, 2: 348.

" o. I 4 mm. . . Ceylon, Kandy, March (Mackwood); i ex."

Type: The above indicated male, without abdomen, dated ".3.09".

Figure 2, left wings.

\section{Lobesia orphica (Meyrick), new combination}

Plate 234, Figures $3-3 \mathrm{~b}$

Polychrosis orphica Meyrick, 1920, Exotic Microlepidoptera, 2: 347 .

"․ I I mm. . . . Assam, Khasis, June, August; 2 ex."

Lectotype: The female dated ".8.1906”. Slide No. 7154.

Figure 3 , left wings; 3 , ventral view of female genitalia; 3 b, detail of genital plate and ostium.

\section{Lobesia orthomorpha (Meyrick)}

Plate 234, Figures $4-4 \mathrm{c}$

Polychrosis orthomorpha Meyrick, 1928, Exotic Microlepidoptera, 3: 443.

"ㅇ. I I mm. . . . New Hebrides, Efate, Espiritu Santo, July, August (Buxton); 2 ex. (type Brit. Mus.)."

Type: The specimen so labelled in the British Museum, dated "I.viii.I925". Slide No. 705 $\mathrm{x}$.

Figure 4 , left wings; 4 a, detail of genital plate and ostium; 4 b, ventral view of female genitalia; $4 \mathrm{c}$, bursa copulatrix. 


\section{Lobesia oxymochla (Meyrick), new combination}

Plate 235 , Figures $1-1$ a

Polychrosis oxymochla Meyrick, I917, Trans. Ent. Soc. London, 1917: 24.

" ${ }^{\dagger}$ ‥ $\mathrm{I}_{2}-\mathrm{I}_{4} \mathrm{~mm}$. . . . Peru, Lima, in August (Parish); twenty-eight specimens. Varies considerably in distinctness of markings."

Lectotype: A male measuring $12 \mathrm{~mm}$. Slide No. 64I I. There are twelve specimens remaining in the Meyrick collection all dated "8-14".

Figure I, left wings; Ia, ventral view of male genitalia with aedeagus in situ.

\section{Lobesia pedias (Meyrick), new combination}

Plate 235, Figures 2-2b

Polychrosis pedias Meyrick, 1920, Exotic Microlepidoptera, 2: 347 .

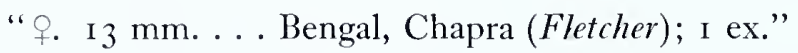

Type: The female denoted above, "Chapra, Bengal. TBF. .i6." Slide No. 7127.

Figure 2, left wings; $2 \mathrm{a}$, ventral view of female genitalia; $2 \mathrm{~b}$, detail of ostium.

\section{Lobesia peplotoma Meyrick}

Plate 235 , Figures $3^{-3}$ a

Lobesia peplotoma Meyrick, 1928, Exotic Microlepidoptera, 3:442.

“ ‘우. IO-I I mm. ... New Hebrides, Efate, July (Buxton); 3 ex. (type Brit. Mus.). Resembles the Australian physophora...."

Type: The male so marked in the British Museum, "New Hebrides, Efate Is. Vila. vii.1925. P. A. Buxton." Slide No. 7322.

Figure 3 , left wings; 3 a, ventral view of male genitalia with aedeagus in situ. 

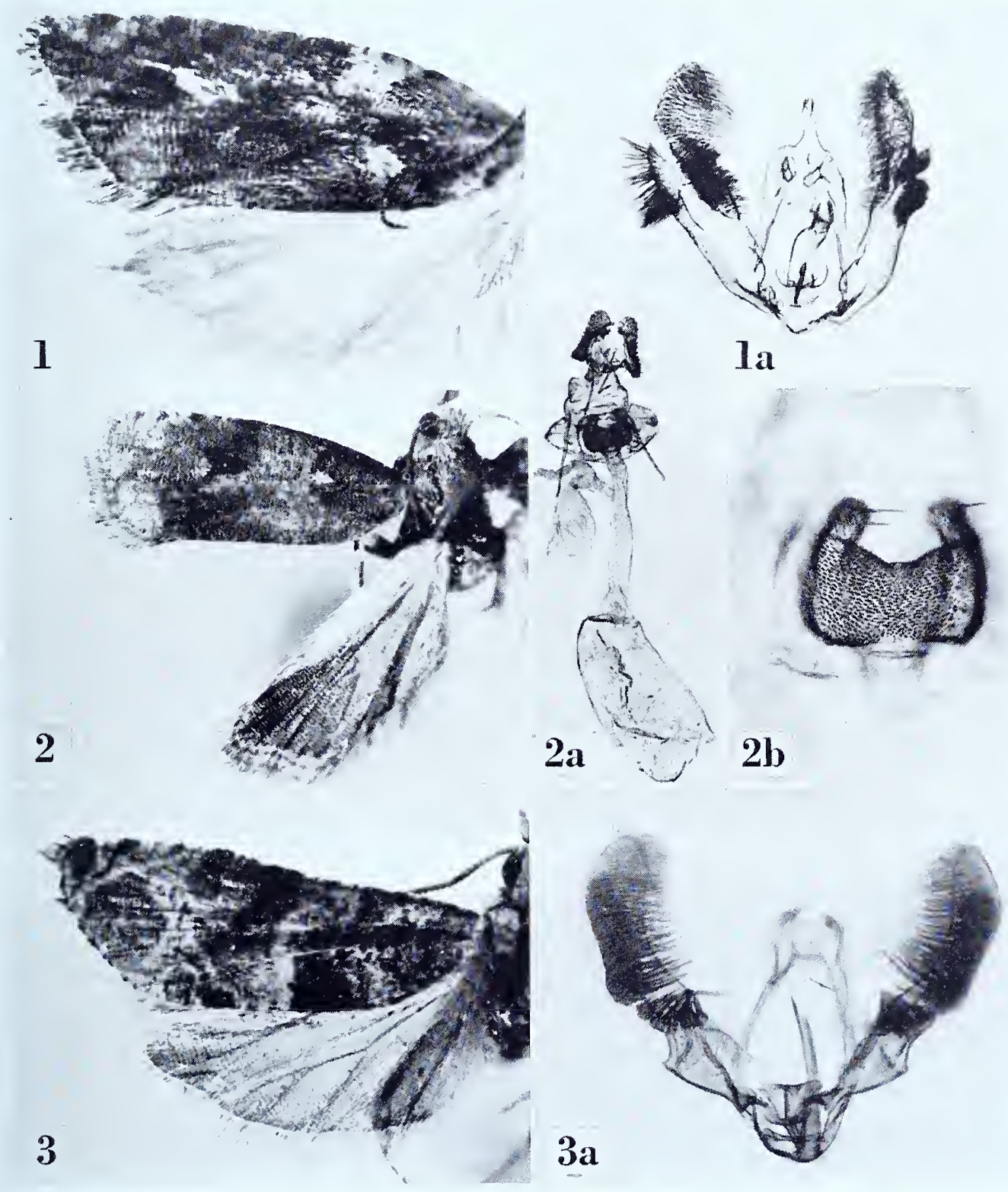

LOBESIA 

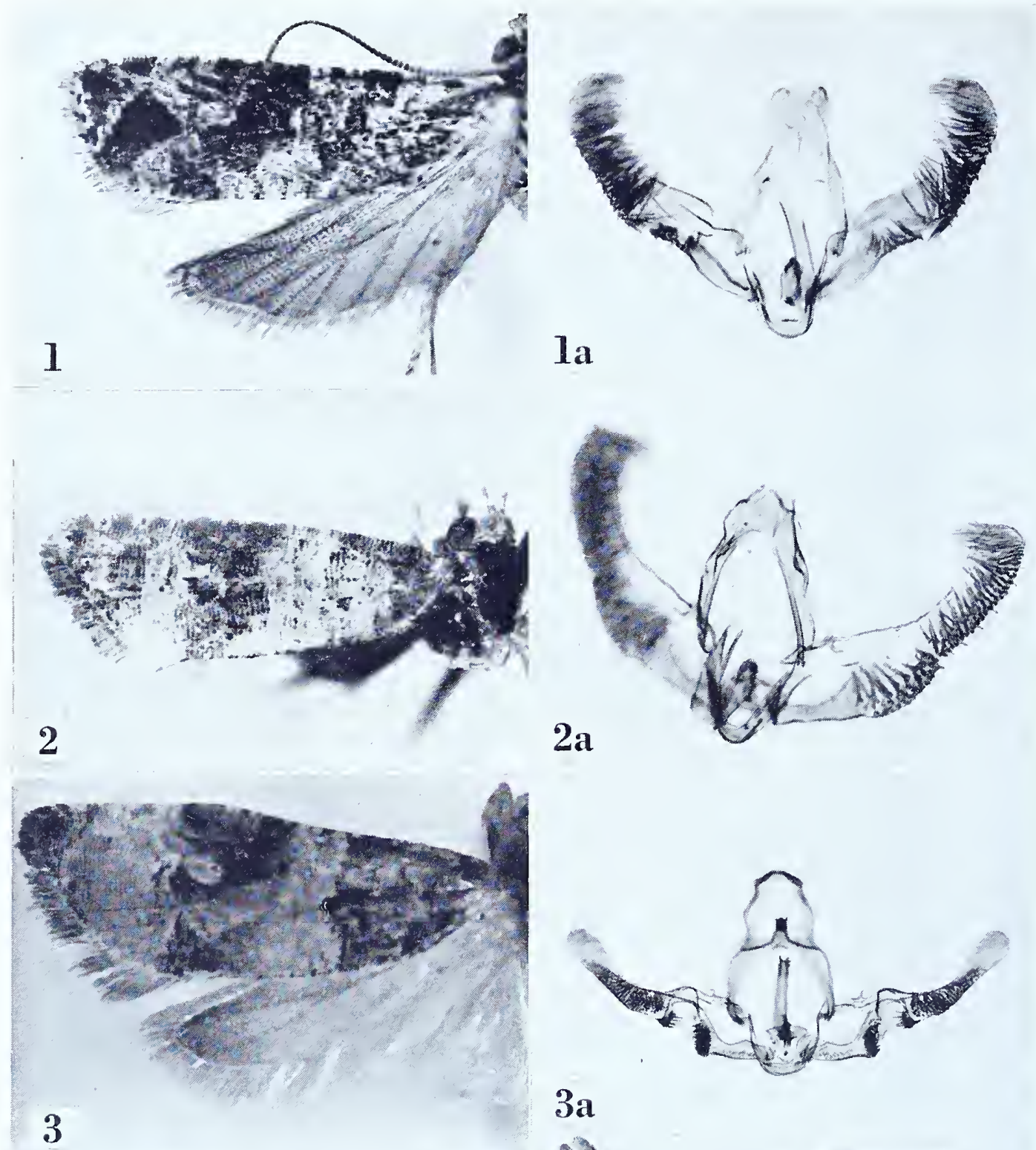

$3 a$
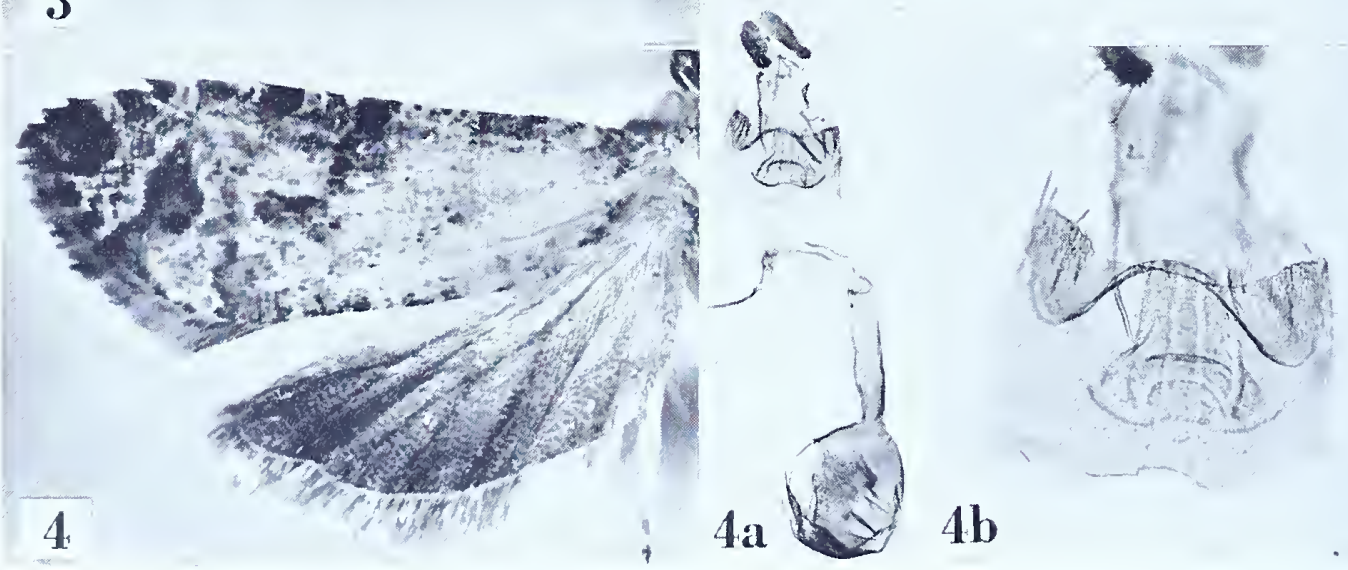

$4 \mathrm{~b}$ 


\section{Lobesia rhipidoma (Meyrick)}

Plate 236, Figures $1-$ Ia

Polychrosis rhipidoma Meyrick, 1925, Exotic Microlepidoptera, 3: I 42.

" . $_{\text {. I }} \mathrm{mm}$. . . . Fiji, Labasa, bred August from larva feeding on flowers of Clerodendron amicornm (Greenwood); i ex. (Brit. Mus.)."

Type: The above indicated specimen in the British Museum dated "Aug. r923". Slide No. $705^{2}$.

Figure I, left wings; Ia, ventral view of male genitalia with aedeagus in sitn.

\section{Lobesia serangodes (Meyrick)}

Plate 236, Figures 2-2a

Polychrosis serangodes Meyrick, 1920, Exotic Microlepidoptera, 2: 346.

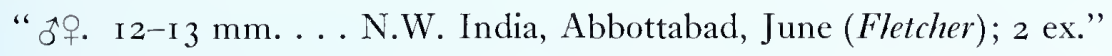

Lectotype: The male dated ".6.16". Slide No. 7189. The female is missing.

Figure 2, left forewing; 2a, ventral view of male genitalia with aedeagus in sitn.

\section{Lobesia sitophaga Meyrick}

Plate $23^{6}$, Figures $3^{-} 3^{\mathrm{a}}$

Lobesia sitophaga Meyrick, 1922, Exotic Microlepidoptera, 2: 534 .

“ ${ }^{3} .14 \mathrm{~mm}$. ... Uganda, Kampala, February, bred from larva feeding in ripening seed of white millet (Panicum?); I ex. (Brit. Mus.)."

Type: The male denoted above so labelled in the British Museum, dated "28.ii. I 922 ". Slide No. 7323 .

Figure 3 , left wings; 3 a, ventral view of male genitalia with aedeagus in sitn.

\section{Lobesia transtrifera (Meyrick)}

Plate 236 , Figures $4-4 b$

Polychrosis transtrifera Meyrick, I920, Exotic Microlepidoptera, 2: 346.

"ㅇ. I I mm. ... Queensland, Brisbane, February (Dodd); г ex. Wals. Coll. (19473)."

Type: The female referred to above so marked in the British Museum. The data are "Toowong, Queensland, I7.ii.r897. Dodd. I9473." Slide No. 7324.

Figure 4 , left wings; 4 a, ventral view of female genitalia; 4 b, detail of genital plate and ostium. 


\section{MACRAESTHETICA Meyrick}

Macraesthetica Meyrick, 1932, Exotic Microlepidoptera, 4:256. (Typus generis: Tortrix rubiginis Walsingham, 1907, Fauna Hawaiiensis, I (́) : 702, p. II, fig. 24 [by original designation].)

\section{Macraesthetica rubiginis (Walsingham) \\ Plate 237, Figures I-IC}

Figured from a specimen from Hawaii in the British Museum.

Figure I, left wings; гa, venation of right wings; Ib, lateral view of head to show palpus; Ic, ventral view of male genitalia with aedeagus in situ.

This genus is hereby transferred from the Tortricidae to the Olethreutidae. 

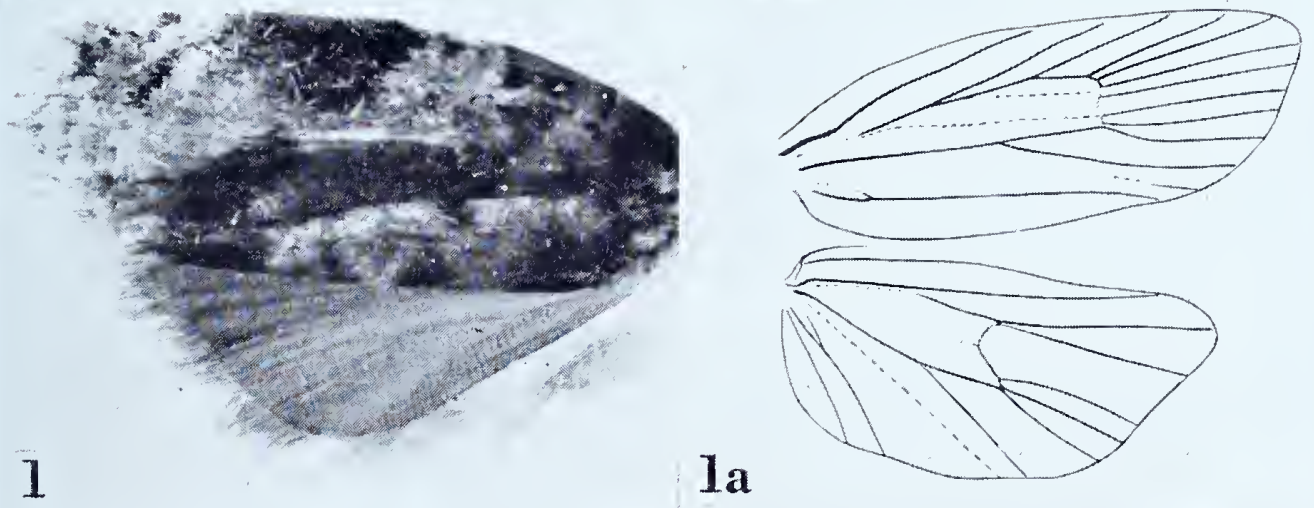

$1 b$

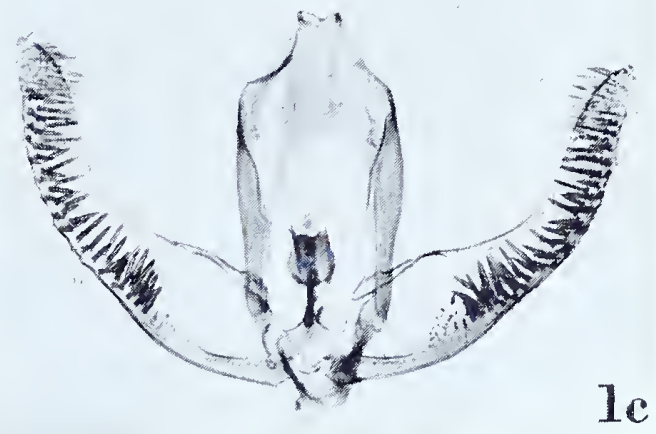

MACRAESTHETICA 


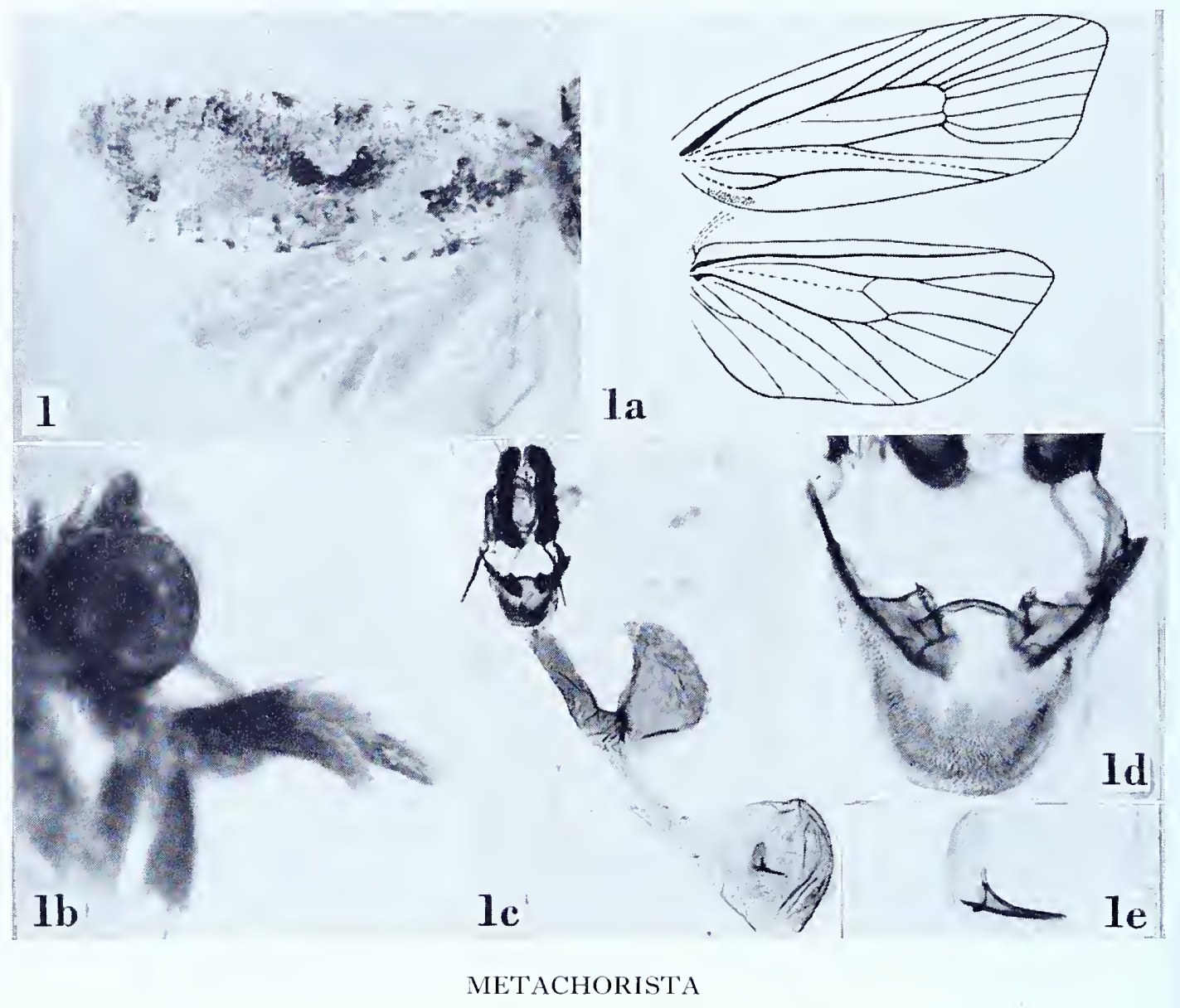




\section{METACHORISTA Meyrick}

Metachorista Meyrick, I938, Trans. R. Ent. Soc. London, 87: 5Io. (Typus generis: Metachorista ursula Meyrick, ibid. [monotypy].)

\section{Metachorista ursula Meyrick \\ Plate 238 , Figures I-Ie}

Metachorista ursula Meyrick, I938, Trans. R. Ent. Soc. London, 87: 5 Io.

“o. $18 \mathrm{~mm}$. . . Kokoda, I, 200 feet, July; I ex."

Type: The above indicated female so marked in the British Museum, "Kokoda, Papua, I,200 ft. vii-1933. L. E. Cheesman." Slide No. 7025.

Figure I, left wings; Ia, venation of right wings; $\mathrm{Ib}$, lateral aspect of head to show palpus; Ic, ventral view of female genitalia; rd, detail of genital plate and ostium; Ie, signum. 
OLETHREUTES

\section{OLE'THREUTES Hübner \\ Olethreutes acrosema (Meyrick), new combination \\ Plate 239, Figures I-Ia}

Argyroploce acrosema Meyrick, I909, Journ. Bombay Nat. Hist. Soc., i9: 60 I.

" $\hat{o}$. $23^{-24} \mathrm{~mm}$. . . Khasis, in June; two specimens. Allied to group of orophias."

Lectotype: The male measuring 24 mm., "Khasi Hills, Assam. .6.I 9o6." Slide No. 7 r69.

Figure I, left wings; Ia, ventral view of male genitalia with aedeagus in situ.

\section{Olethreutes aegidia (Meyrick), new combination}

Plate 239, Figures 2-2a

Argyroploce aegidia Meyrick, i 932, 'I'rans. Ent. Soc. London, 80: i i 2.

" o. $20 \mathrm{~mm}$. . . . Jem-Jem Forest, 9,00o feet, October; I ex."

Type: The male so marked in the British Museum, "Abyssinia: Djem-Djem Forest. ca. 9,000 ft. 4.x.I926. H. Scott." Slide No. 7308.

Figure 2, left wings; 2 a, ventral view of male genitalia with aedeagus in situ.

\section{Olethreutes aeolantha (Meyrick), new combination}

Plate 239, Figures $3-3 b$

Argyroploce aeolantha Meyrick, I914, Journ. Bombay Nat. Hist. Soc., 22: 77I.

" $\hat{f}$. I $4^{-17}$ mm. . . Khasis, in October; Baco River, Mindoro, Philippines, in February; two specimens. Allied to solaris and eximiana."

Lectotype: The female measuring i 4 mm., "Khasi Hills, Assam. .ıo. igo6." Slide No. 7236. The Philippine specimen is also a female and is not conspecific with the lectotype.

Figure 3 , left wings; $3^{a}$, ventral view of female genitalia; $3^{b}$, detail of genital plate and ostium.

\section{Olethreutes aeolochlora (Meyrick), new combination}

Plate 239 , Figures $4-4$ b

Argyroploce aeolochlora Meyrick, I9I6, Exotic Microlepidoptera, i : 562.

" o. I $8 \mathrm{~mm}$. . . . Assam, Khasis, in May; one specimen."

Type: The above indicated male, "Khasi Hills, Assam. .5.I907." Slide No. 7265.

Figure 4 , left wings; $4 \mathrm{a}$, ventral view of male genitalia with aedeagus in situ; $4 \mathrm{~b}$, partly denuded abdomen showing conspicuous segmental tufts. 

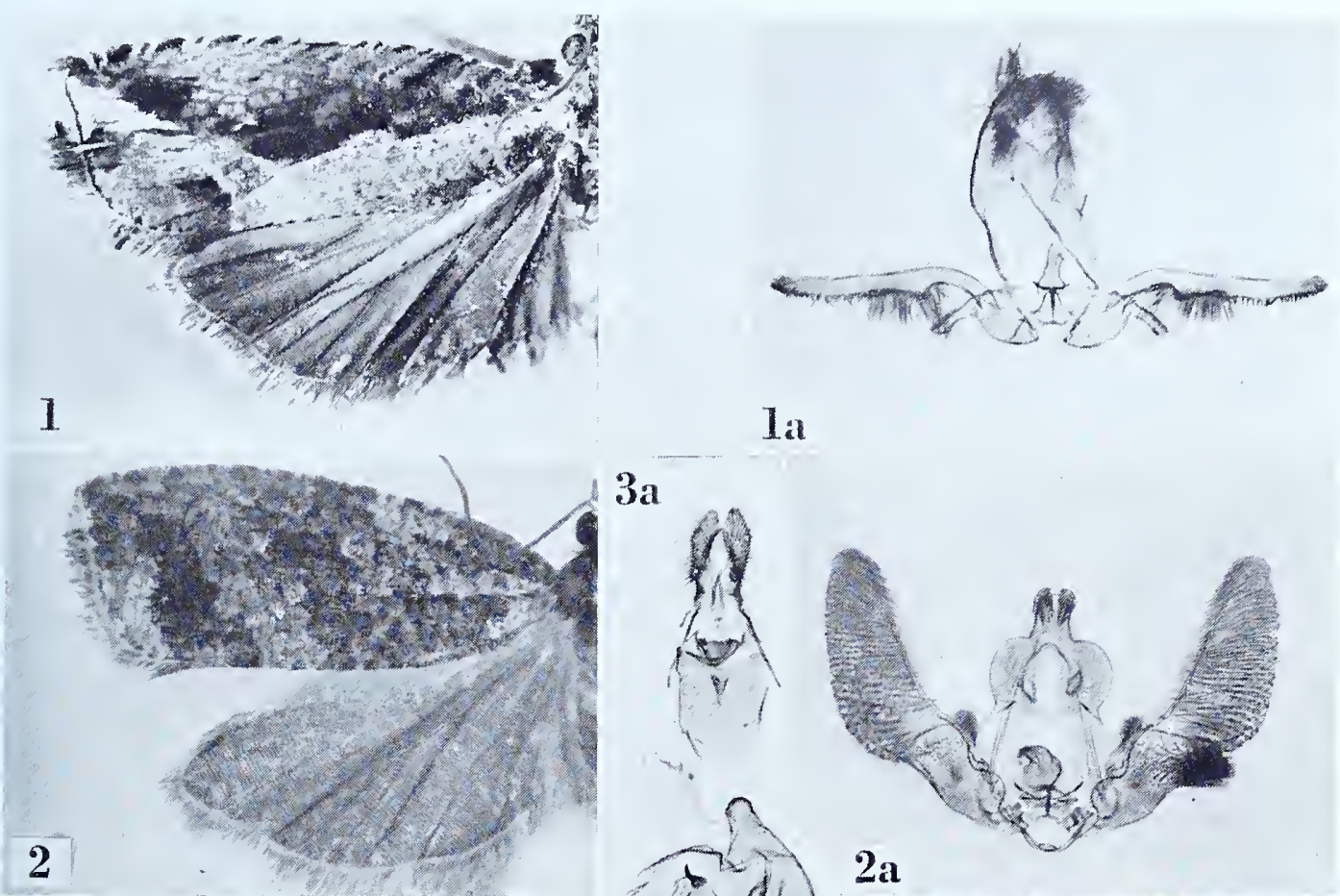

3a

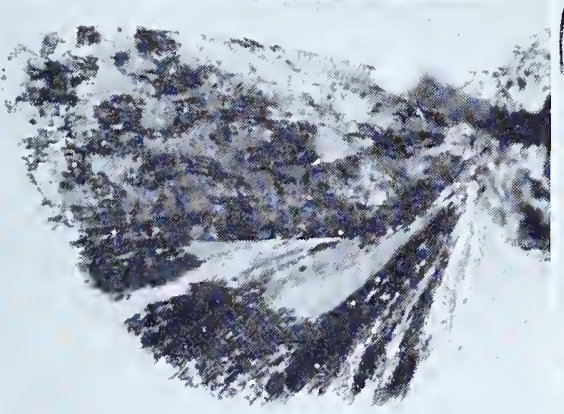

3
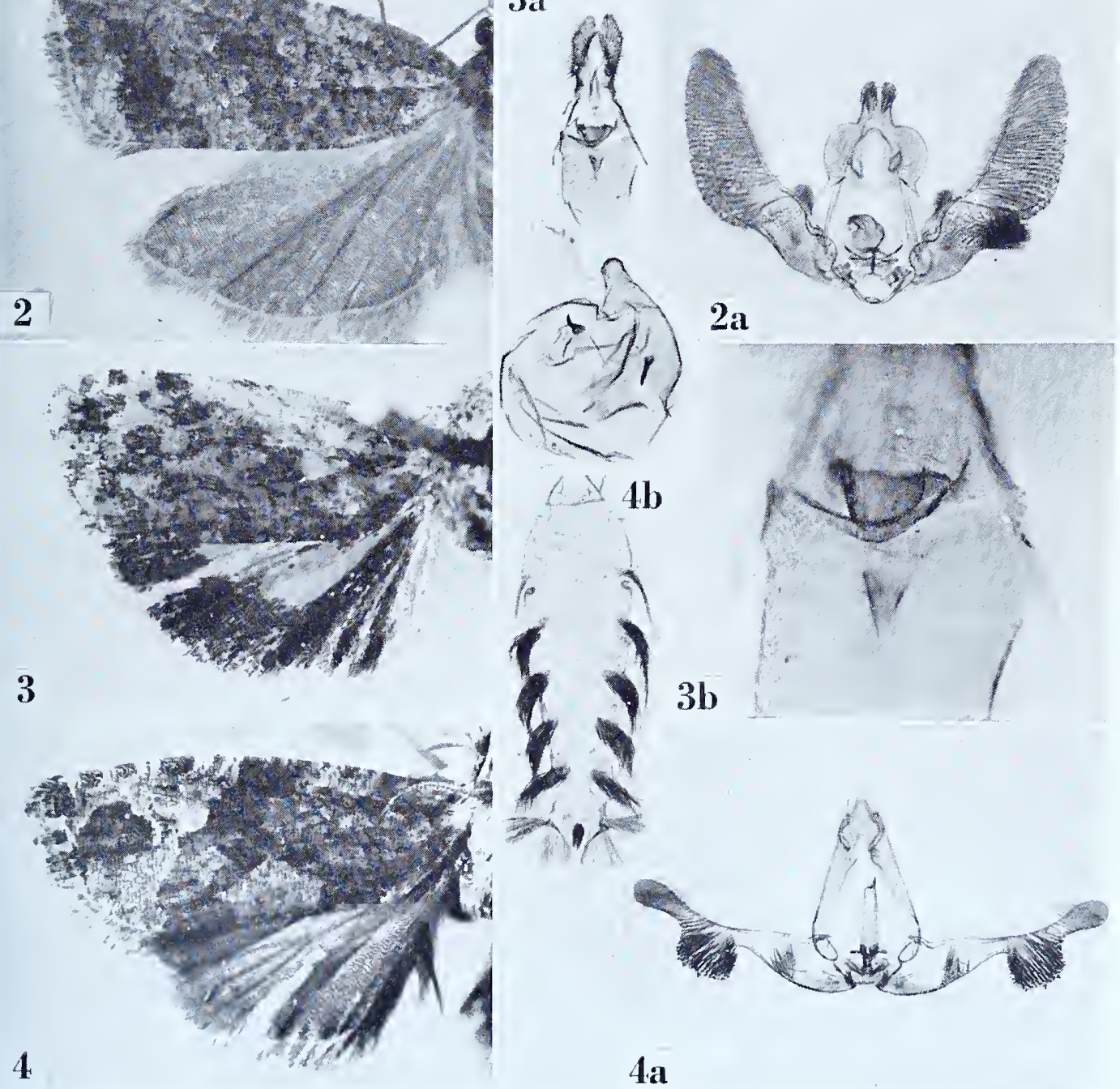

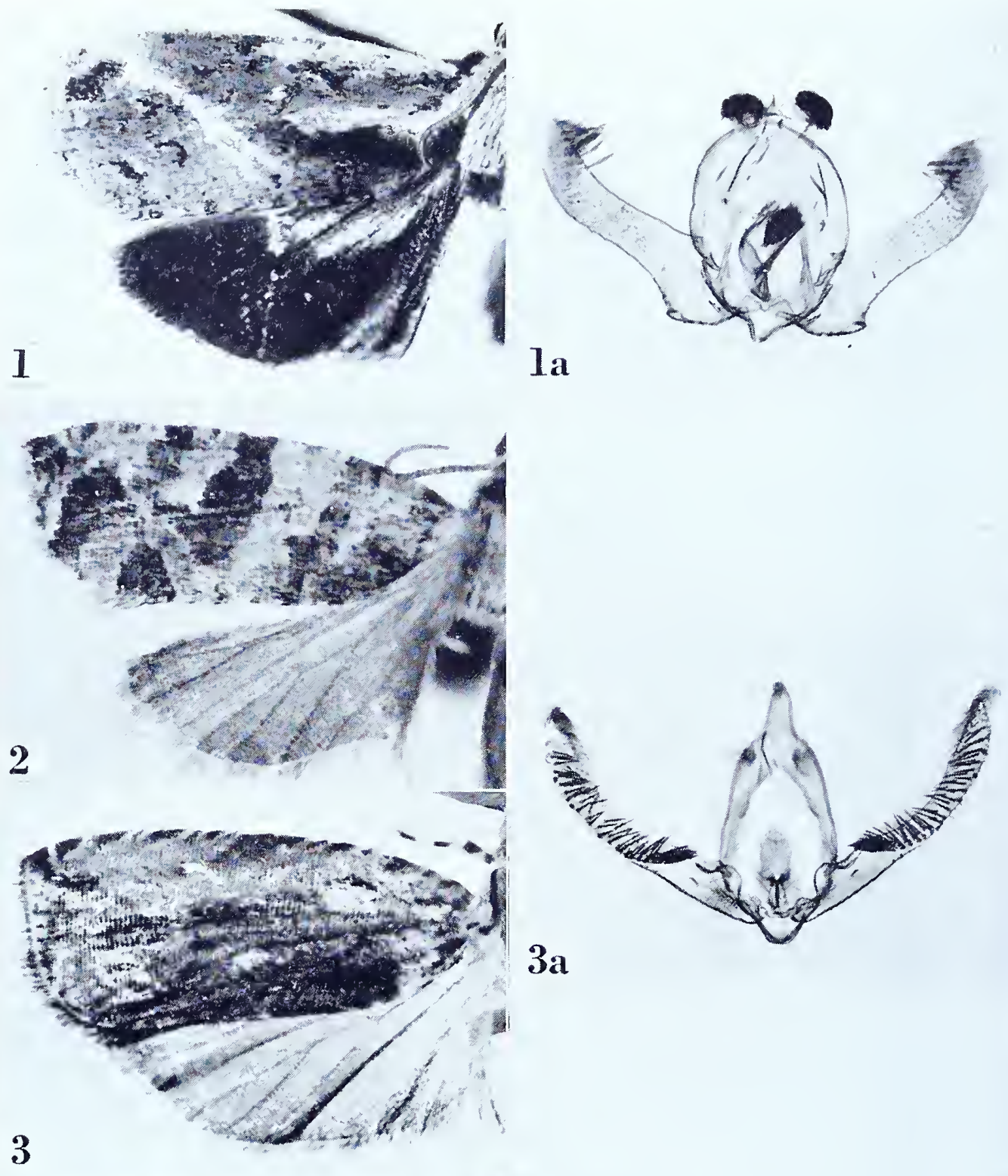

3a
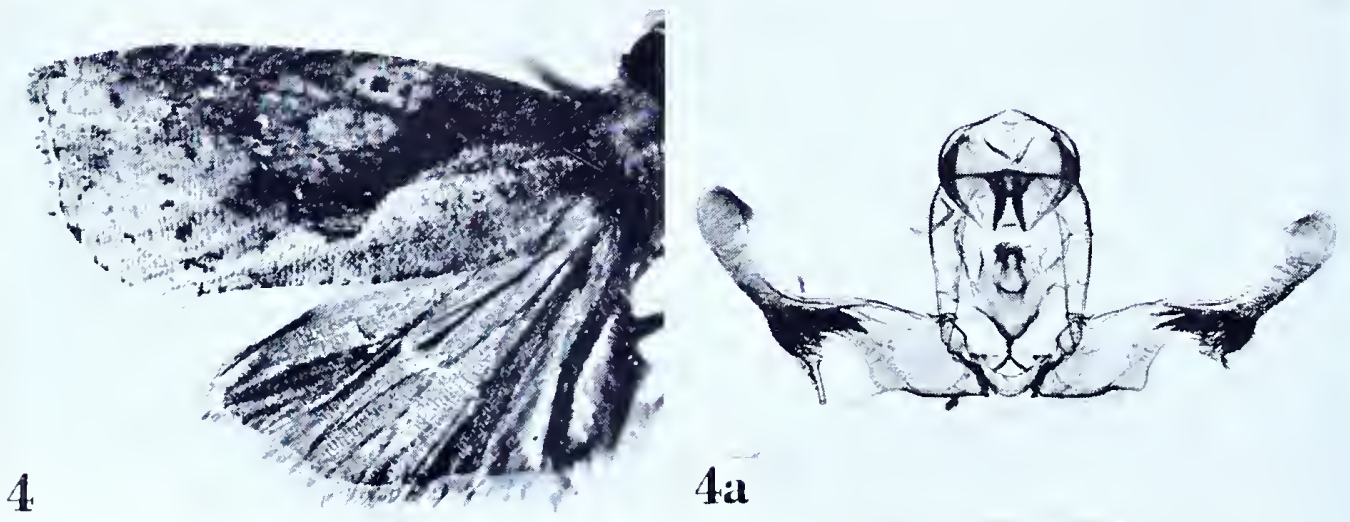

$4 a$ 


\section{Olethreutes aeraria (Meyrick), new combination}

Plate 240, Figures I-Ia

Argyroploce aeraria Meyrick, I909, Journ. Bombay Nat. Hist. Soc., 19: 605.

" ${ }^{\prime}+{ }^{\circ}$. I $3^{-1} 5 \mathrm{~mm} . .$. Khasis, from December to March; fourteen specimens."

Lectotype: A male measuring I4 mm., "Khasi Hills, Assam. .i 2.I go6." Slide No. 7232 .

Figure I, left wings; I a, ventral view of male genitalia with aedeagus in situ.

\section{Olethreutes agathopis (Meyrick), new combination}

Plate 240, Figure 2

Argyroploce agathopis Meyrick, I 927, Insects of Samoa, 3, Lepidoptera, fasc., 2: 76.

“․ I2-I3 mm. . . U Upolu, Malololelei, 2,000 feet, April, June; 2 ex. Allied to the green miniochlora group."

Type: The specimen so marked in the British Museum dated "25.vi.r924". The abdomen of the type is missing.

Figure 2, left wings.

\section{Olethreutes albipalpis (Meyrick)}

See Olethreutes hemiplaca (Meyrick).

\section{Olethreutes anaplecta (Meyrick), new combination}

Plate 240 , Figures $3^{-} 3^{a}$

Argyroploce anaplecta Meyrick, 1909, Journ. Bombay Nat. Hist. Soc., I9: 598.

“ 3 ㅇ. I 5-16 mm. . . . Maskeliya, Ceylon, in February, May and June (Pole, de Mowbray); three specimens."

Lectotype: The male, "Maskeliya, Ceylon. de Mowbray. .6.06." Slide No. 7254.

Figure 3 , left wings; 3 a, ventral view of male genitalia with aedeagus in situ.

\section{Olethreutes ancalota (Meyrick), new combination}

Plate 240 , Figures $4^{-} 4^{\mathrm{a}}$

Enarmonia ancalota Meyrick, I907, Journ. Bombay Nat. Hist. Soc., I 8: i 40.

" November; six specimens (Green, Pole)."

Lectotype: A male measuring i 8 mm., "Kandy, Ceylon. Pole. .5.98." Slide No. 7170.

Figure 4, left wings; 4 a, ventral view of male genitalia with aedeagus in situ. 
OLE'THREU'TES

\section{Olethreutes ancosema (Meyrick), new combination}

Plate 24I, Figures I-Ia

Argyroploce ancosena Meyrick, I 932, Exotic Microlepidoptera, 4:3 3 o.

" ๙̃. I 3 mm. . . . Fiji, Lautoka, June (H. Phillips); I ex. (Brit. Mus.)."

Type: The above indicated male so marked in the British Museum, dated "I r.6. I930". Slide No. 7076.

Figure I, left wings; ıa, ventral view of male genitalia with aedeagus in sitn.

\section{Olethreutes anemodes (Meyrick), new combination}

Plate 24I, Figures 2-2c

Argyroploce anemlnodes Meyrick, 1912, Journ. Bombay Nat. Hist. Soc., 21: 873 .

"

Lectotype: The female dated ".6.07". Slide No. 7222.

Figure 2, left wings; $2 \mathrm{a}$, ventral view of female genitalia; $2 \mathrm{~b}$, signa; $2 \mathrm{c}$, detail of genital plate and ostium.

\section{Olethreutes antaea (Meyrick), new combination}

\section{Plate 24I, Figures 3-3a}

Argyroploce antaea Meyrick, 1912, Journ. Bombay Nat. Hist. Soc., 2 1: 872.

" July to November; five specimens."

Lectotype: A male measuring 15 mm., "Kandy, Ceylon. FMMI. .7.09." Slide No. 7223 .

Figure 3 , left wings; 3 a, ventral view of male genitalia with aedeagus in sitn.

See Olethreutes purpurissatana (Kennel).

\section{Olethreutes archimedias (Meyrick)}

\section{Olethreutes aristomorpha (Meyrick), new combination}

Plate 24I, Figure +

Argyroploce aristomorpha Meyrick, 193 I, Exotic Microlepidoptera, 4: I38.

"ㅇ. $19 \mathrm{~mm}$. ... Sierra Leone, Njala, October (E. Hargreaves); г ex. (Brit. Mus.)."

Type: The female denoted above, so marked in the British Museum, dated " 5 -x-30".

The abdomen of the type is missing.

Figure 4, left wings. 


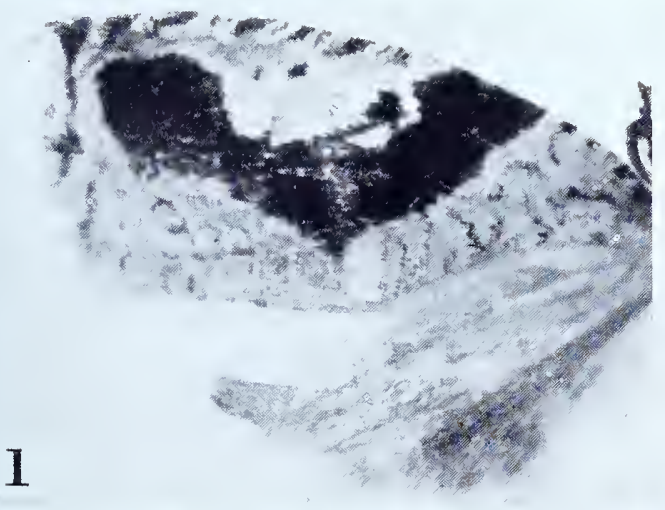

la
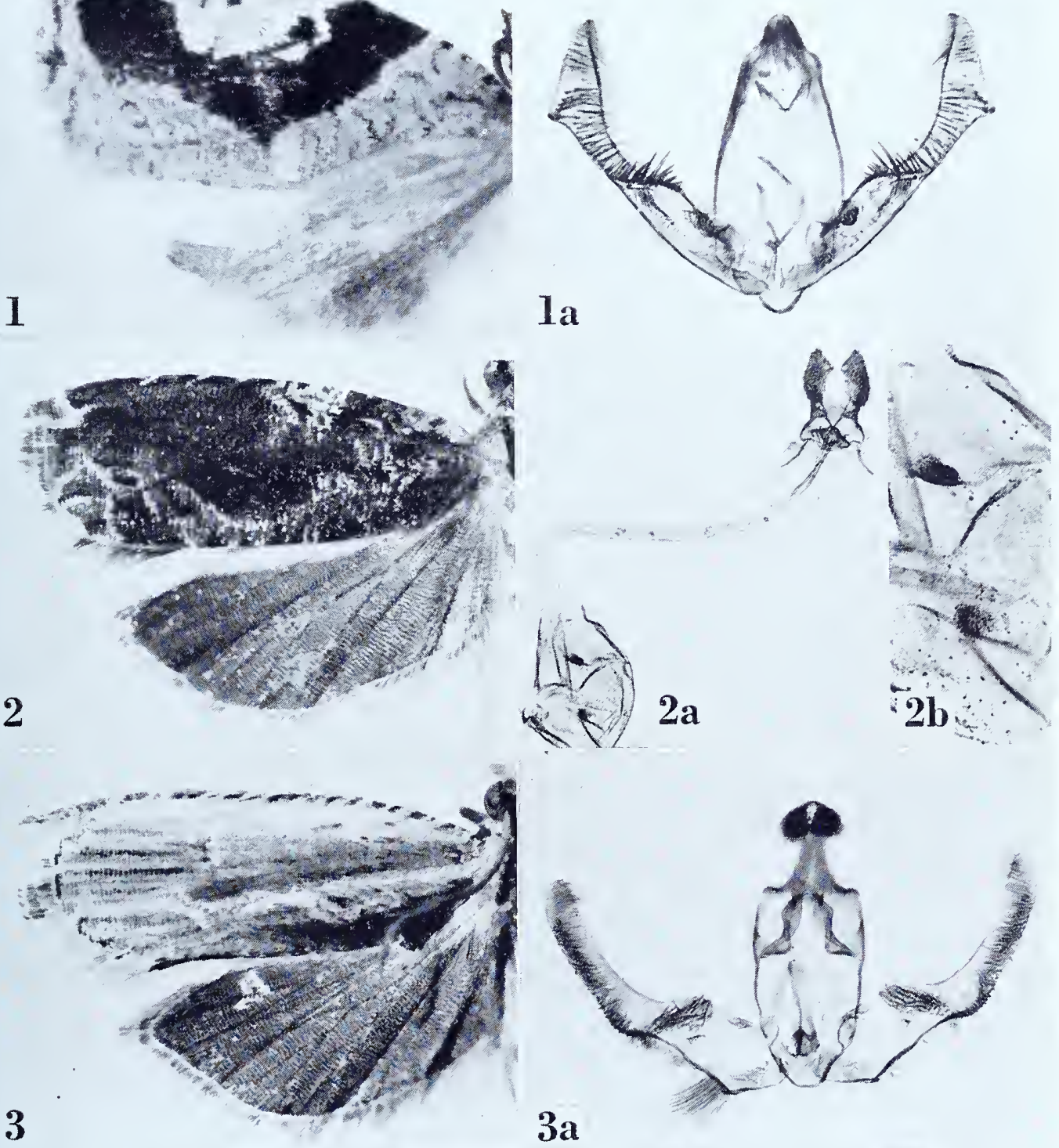

4
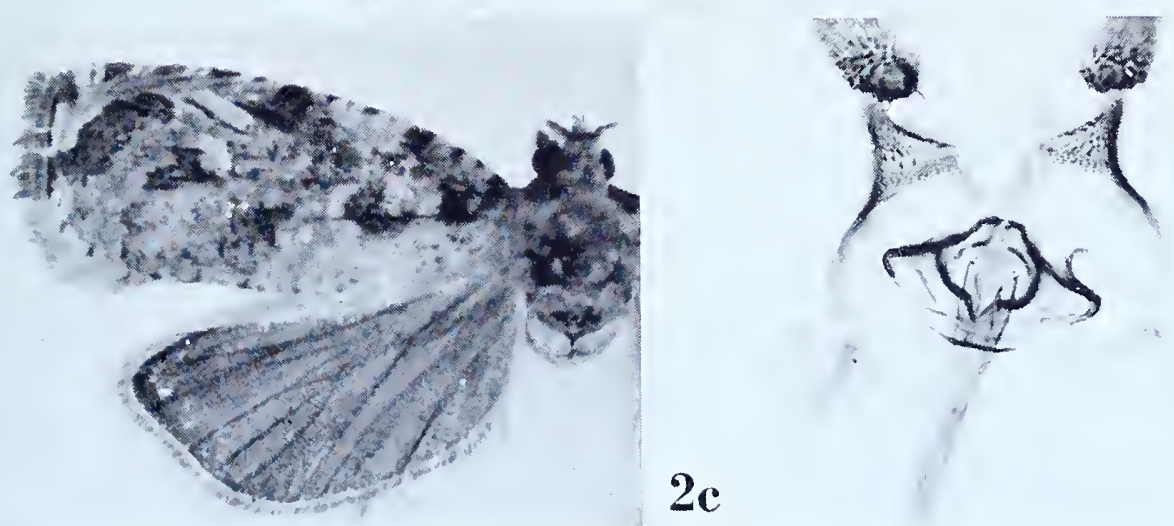

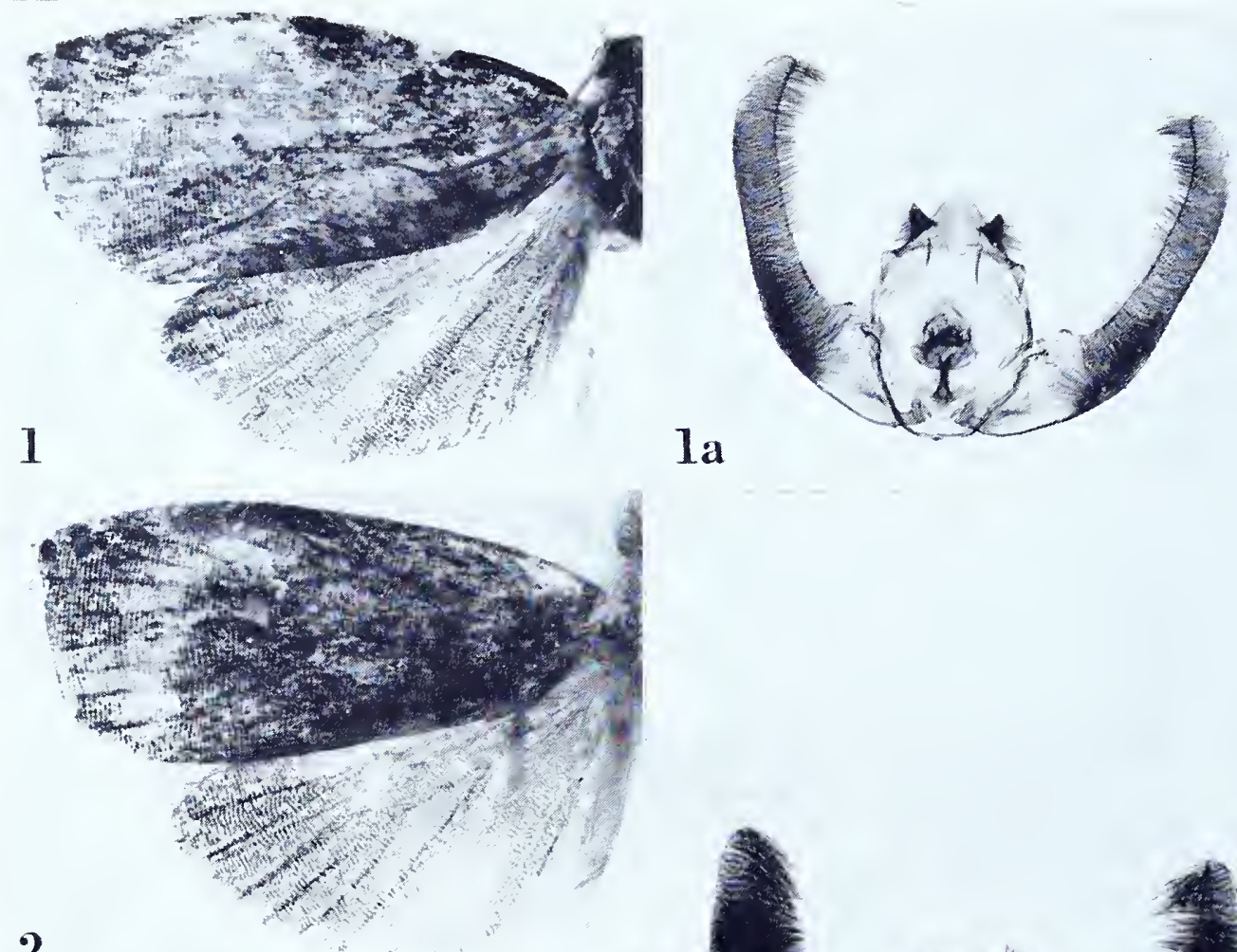

2
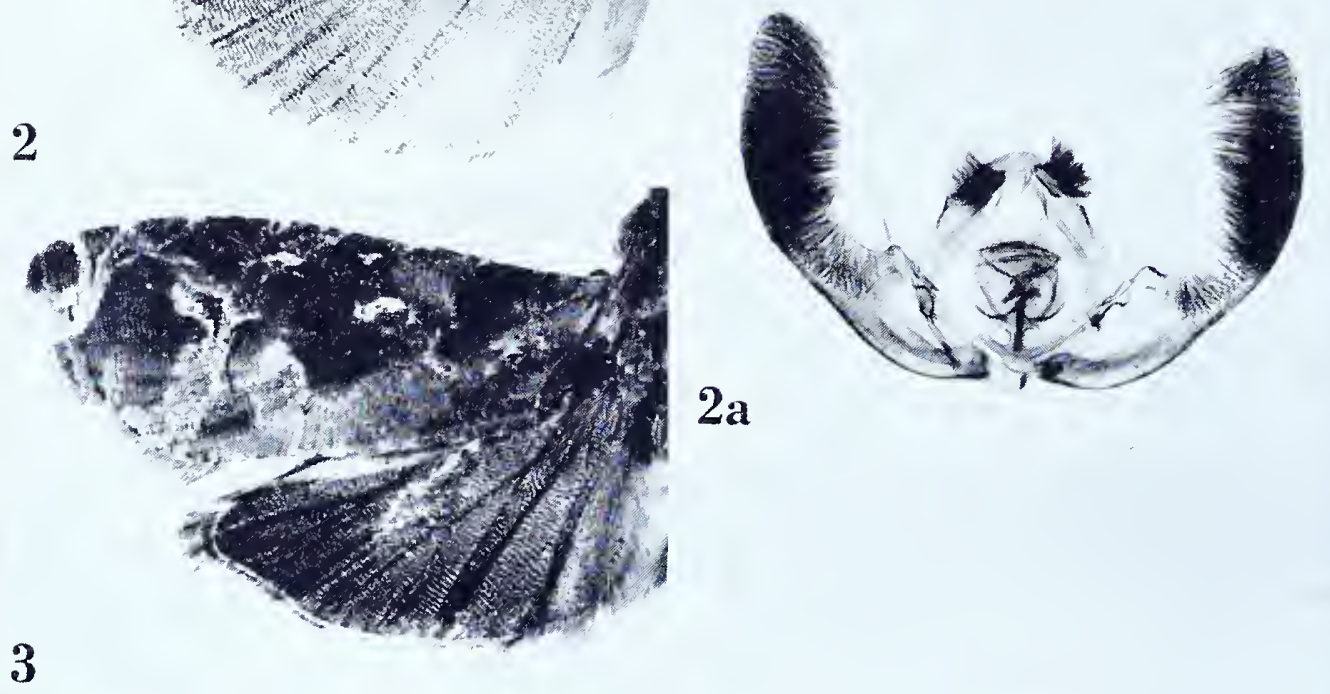

$2 a$
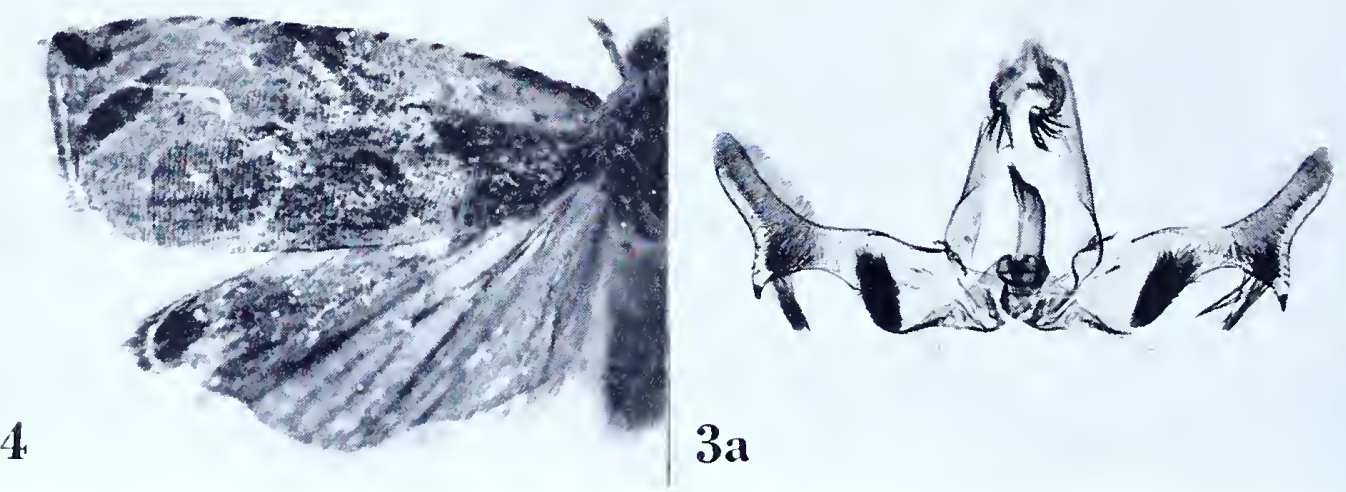

OLE'THREU'TES 


\section{Olethreutes astrosema (Meyrick), new combination}

Plate 242, Figures I-Ia

Argyroploce astrosema Meyrick, I909, Journ. Bombay Nat. Hist. Soc., I 9: 594.

" $\hat{\jmath}+$. 20-2 I mm. . . Khasis, in June; two specimens."

Lectotype: The male, "Khasi Hills, Assam. .6.1906." Slide No. 7282.

Figure I, left wings; Ia, ventral view of male genitalia with aedeagus in situ.

\section{Olethreutes attica (Meyrick), new combination}

Plate 242, Figures 2-2a

Eucosma attica Meyrick, 1907, Journ. Bombay Nat. Hist. Soc., 18: 137.

" 후․ I 8-23 mm. . . . Khasi Hills, from June to September; seven specimens."

Lectotype: A male measuring 2 I mm., "Khasi Hills, Assam. .9.1906." Slide No. 7292.

Figure 2, left wings; 2 a, ventral view of male genitalia with aedeagus in situ.

\section{Olethreutes autoberylla (Meyrick), new combination}

Plate $24^{2}$, Figures $3^{-} 3^{\mathrm{a}}$

Argyroploce autoberylla Meyrick, I932, Exotic Microlepidoptera, 4: 226.

“Ј. I 4 mm. . . Java, bred (F. A. T. H. Verbeek); I ex. Allied to callichlora."

Type: The male denoted above, "Java. V. .31." Slide No. 7267.

Figure 3 , left wings; 3 a, ventral view of male genitalia with aedeagus in situ.

\section{Olethreutes balanacma (Meyrick), new combination}

\section{Plate 242, Figure 4}

Argyroploce balanacma Meyrick, 1914, Exotic Microlepidoptera, I : 275.

“․ $17 \mathrm{~mm}$. . . Portuguese East Africa, E. of Mt. Chiperone, in April (Neave); one specimen. Type in British Museum."

Type: The female referred to above, so marked in the British Museum, but labelled "Ruo Valley, 2,000 ft. Port. E. Africa, E. of Mt. Mlanje. 4.iii.rgr3, S. A. Neave." The abdomen of the type is missing. Despite the discrepancy in the data there is no doubt the specimen indicated is the type.

Figure 4, left wings. 


\section{OLETHREUTES}

\section{Olethreutes branchiodes (Meyrick), new combination}

Plate 243, Figures $1-1$ a

Argyroploce branchiodes Meyrick, I9I0, 'Trans. Ent. Soc. London, I910: 435.

" $\hat{o}$. $20 \mathrm{~mm}$. . . Borneo, Pulo Laut; one specimen."

Type: The male indicated above dated ".6.9I". Slide No. 7275 .

Figure I, left wings; Ia, ventral view of male genitalia with aedeagus in sitn.

\section{Olethreutes brevisecta (Meyrick), new combination}

Plate 243, Figures 2-2a

Argyroploce brevisecta Meyrick, i930, Exotic Microlepidoptera, 3: 60 I.

“ô. I 3 mm. ... Benin, Agouë (Abbé Menager); i ex. (Coll. Paravicini). Probably related to fluctuatana Wals."

Type: The male indicated above, so marked in the British Museum, dated " 884 ". Slide No. 706I.

Figure 2, left wings; 2a, ventral view of male genitalia with aedeagus in sitn.

\section{Olethreutes bryoscopa (Meyrick), new combination}

Plate 243, Figures $3-3$ a

Argyroploce bryoscopa Meyrick, 1928, Exotic Microlepidoptera, 3: 445.

“ 2 ex.'

Lectotype: ô, 27 mm., "Bitje, Ja River, Cameroons, 2,000 ft. Dry season. G. L. Bates." Slide No. 9402.

Figure 3 , left wings; 3 a, ventral view of male genitalia with aedeagus in sitn.

\section{Olethreutes calchantis (Meyrick), new combination}

Plate 243 , Figures $4-4 b$

Argyroploce calchantis Meyrick, I9I4, Exotic Microlepidoptera, I: 196.

“o. I 2-I3 mm. . . Nyassaland, Mt. Mlanje, in October (Neave); two specimens. Type in British Museum. Allied to priniana group."

Type: The female so marked in the British Museum, "Mt. Mlanje, Nyasaland. ir.x.I9I3. S. A. Neave." Slide No. 7311. A small white label bears the inscription "MI40". A third label, in Meyrick's hand, reads "Argyroploce calchantis Meyr. type."

Figure 4 , left wings; $4^{\mathrm{a}}$, ventral view of female genitalia; $4^{\mathrm{b}}$, detail of genital plate and ostium. 


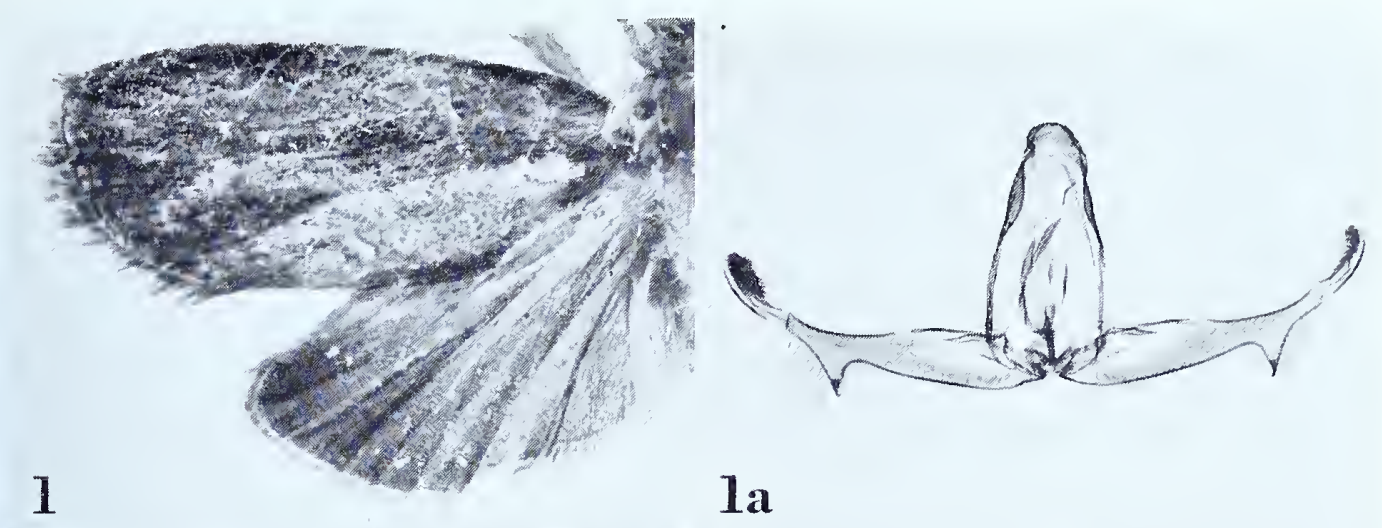

2
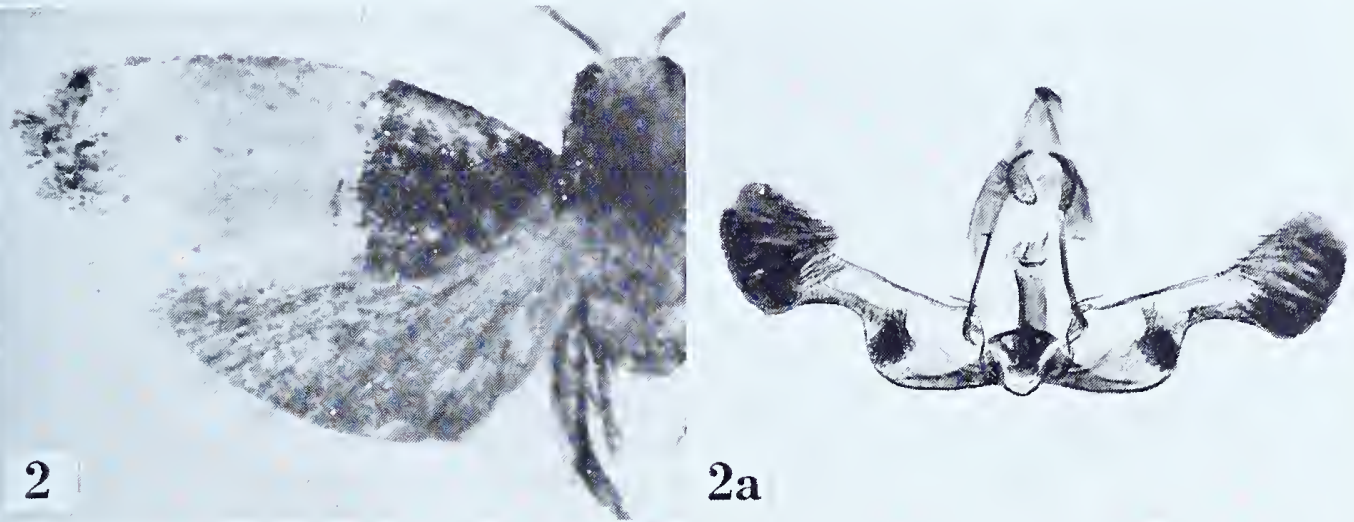

$2 \mathbf{a}$
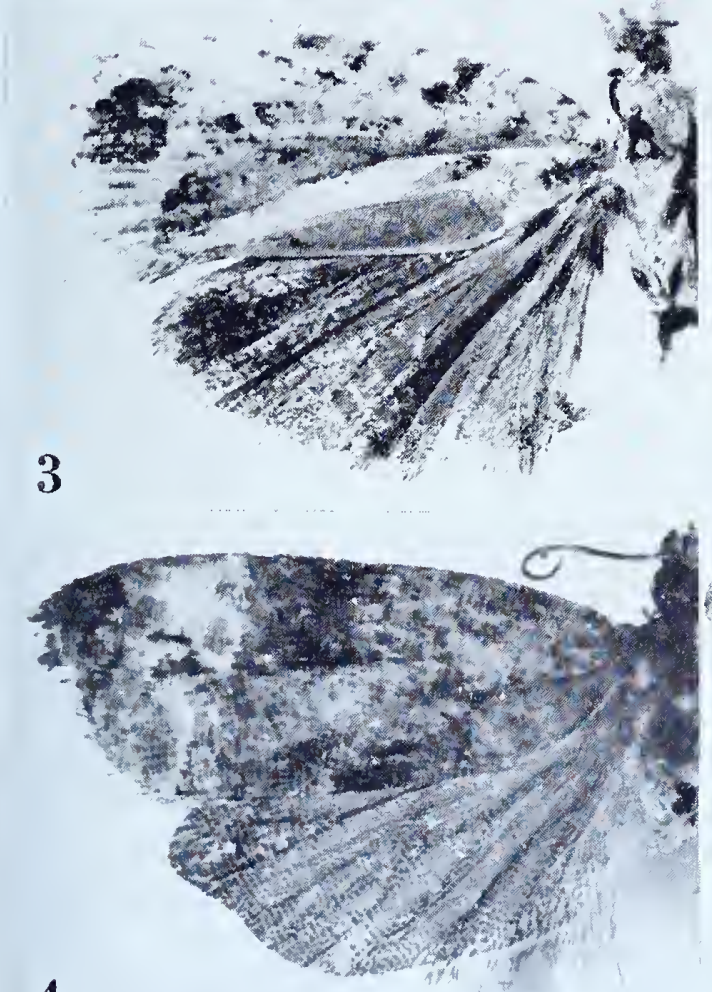

4

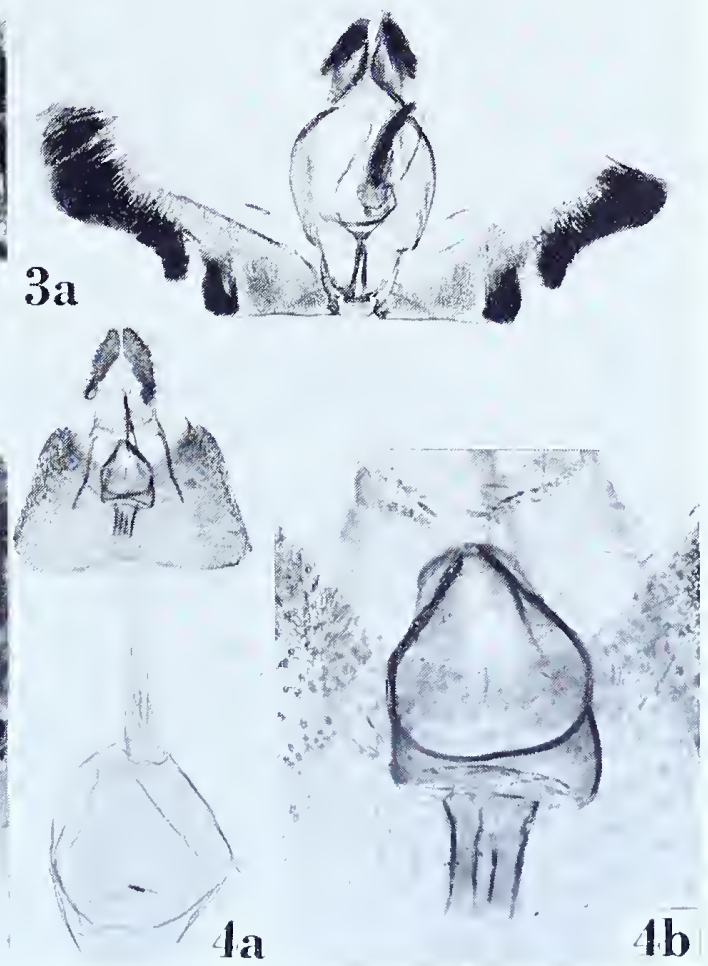



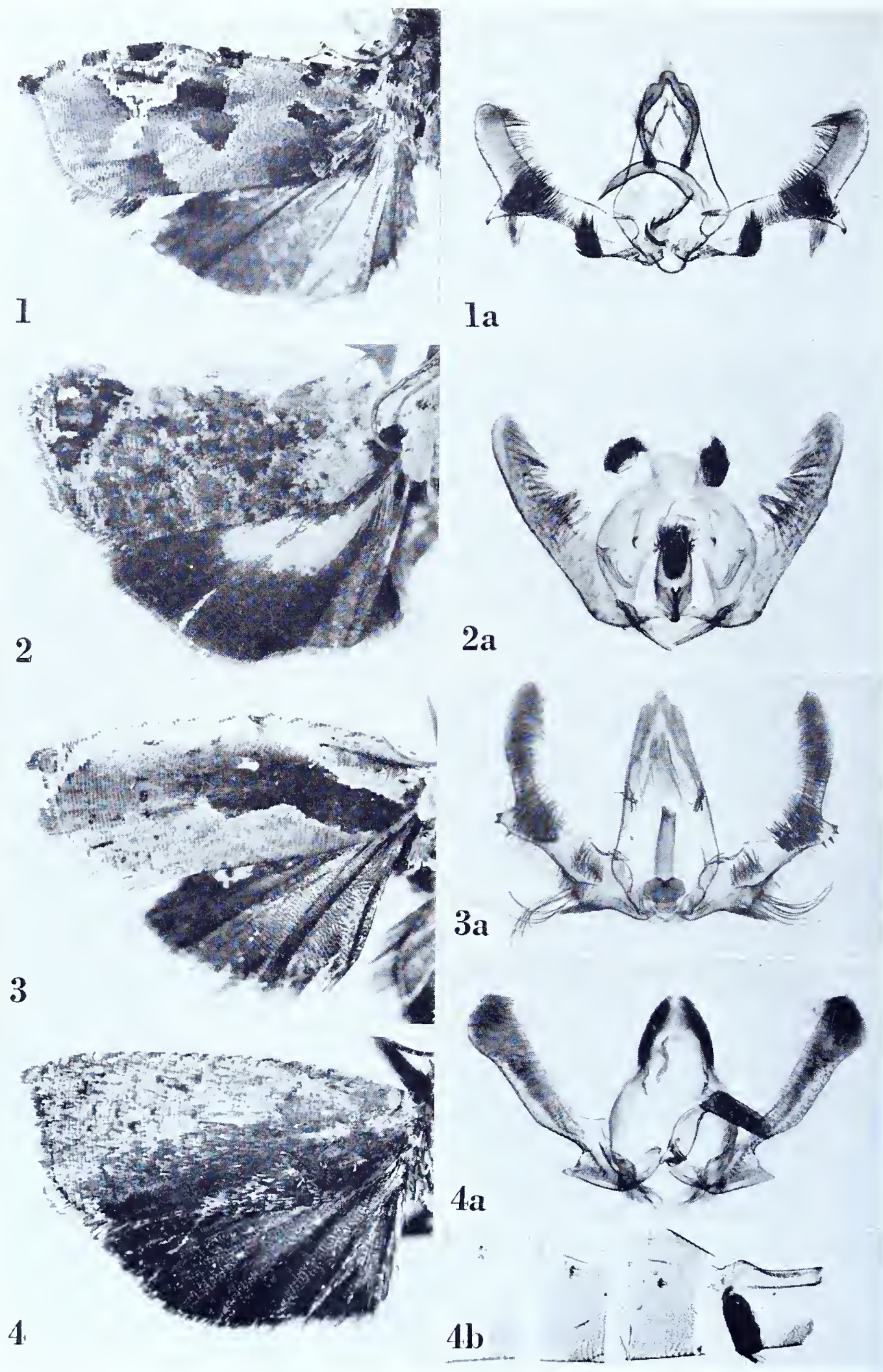


\title{
Olethreutes callichlora (Meyrick), new combination
}

\author{
Plate 244, Figures I-ra
}

Argyroploce callichlora Meyrick, I909, Journ. Bombay Nat. Hist. Soc., 19: 603.

" 0 . $18 \mathrm{~mm}$. ... Khasis, in December; one specimen."

Type: The male indicated above, "Khasi Hills, Assam. .12.1906." Slide No. 725 I.

Figure I, left wings; Ia, ventral view of male genitalia with aedeagus in sitı.

\section{Olethreutes callicratis (Meyrick), new combination}

Plate 244, Figures 2-2a

Argyroploce callicratis Meyrick, 1909, Journ. Bombay Nat. Hist. Soc., 19: 605.

" $\delta$. $15 \mathrm{~mm}$. . . Khasis, in October; one specimen."

Type: The male indicated above, "Khasi Hills, Assam. .10.1906." Slide No. 7230.

Figure 2, left wings; 2 a, ventral view of male genitalia with aedeagus in sitn.

\section{Olethreutes camarotis (Meyrick), new combination}

\author{
Plate 244 , Figures $3-3$ a
}

Argyroploce camarotis Meyrick, 1936, Exotic Microlepidoptera, 4:6 6 2.

“구. I 6-20 mm. . . Bengal, Kalimpong, bred November from larva rolling leaves of Michelia campaca (Magnoliaceae) (Indian Forest Service); Assam, Khasis, November, February, June; 12 ex. (var. a from both localities). . .."

Lectotype: A male measuring I6 mm., "Kalimpong, Bengal. IFS. bred .I I.33." Slide No. 7244 .

Figure 3, left wings; 3 a, ventral view of male genitalia with aedeagus in situ.

\section{Olethreutes caryactis (Meyrick), new combination}

Plate 244, Figures $4-4 b$

Argyroploce caryactis Meyrick, 1909, Journ. Bombay Nat. Hist. Soc., 19: 596.

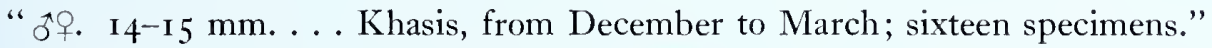

Lectotype: ô, 14 mm., "Khasi Hills, Assam. .12.1906." Slide No. 7175. Two specimens are missing.

Figure 4 , left wings; $4^{\mathrm{a}}$, ventral view of male genitalia with aedeagus in situ; 4 b, part of denuded abdomen to show posterior tufts. 
OLETHREUTES

Olethreutes caryocryptis (Meyrick), new combination

Plate 245, Figures I-Ia

Tortrix caryocryptis Meyrick, I932, Exotic Microlepidoptera, 4:342.

" ふิ. I 5 mm. . . . Kashmir, Gulmarg, 8,800 feet, June [sic! ] (T. B. Fletcher); I ex."

Type: The male indicated above dated ".7.3I". Slide No. 6829.

Figure I, left wings; Ia, ventral view of male genitalia with aedeagus in sitn.

Transferred from Tortrix ('Tortricidae) to Olethrentes.

\section{Olethreutes caryosema (Meyrick), new combination}

Plate 245, Figures 2-2a

Argyroploce caryosema Meyrick, I93 I, Exotic Microlepidoptera, 4: i3 8.

" $\hat{\jmath}+$. 2 I-22 mm. . . . Formosa, Kyuhabon, October (S. Issiki); Assam, Khasis;

2 ex. This distinct form is allied to pachmodes."

Lectotype: The male, "Kyuhabon, Formosa. SI. .ı o.26." Slide No. 7270.

Figure 2 , left wings; $2 \mathrm{a}$, ventral view of male genitalia with aedeagus in sit $n$.

\section{Olethreutes cassiterastra (Meyrick)}

See Olethreutes stellans (Meyrick).

\section{Olethreutes cataphracta (Meyrick), new combination}

Plate 245 , Figures $3-3$ a

Argyroploce cataphracta Meyrick, I917, Trans. Ent. Soc. London, I917: 25.

“ $\tilde{o}^{\circ}$. I $4^{-1} 5 \mathrm{~mm}$. . . . British Guiana, Bartica, from December to February (Parish); seventeen specimens."

Lectotype: A male measuring I4 mm., dated "...I3". Slide No. 6418. Four specimens are missing.

Figure 3 , left wings; 3 a, ventral view of male genitalia with aedeagus in sitn.

\section{Olethreutes catarrhactopa (Meyrick), new combination}

Plate 245 , Figures $4-4$ a

Argyroploce catarrhactopa Meyrick, I938, Trans. R. Ent. Soc. London, 87: 5 I2.

"3․ 2 2 -24 mm. . . Mt. Tafa, 8,500 feet, February, March; 2 ex."

Type: The male so marked in the British Museum, "Mt. 'Tafa, Papua, 8,500 ft. iii-I934. L. E. Cheesman." Slide No. 7024.

Figure 4 , left wings; 4a, ventral view of male genitalia with aedeagus in sitn (left harpe missing). 

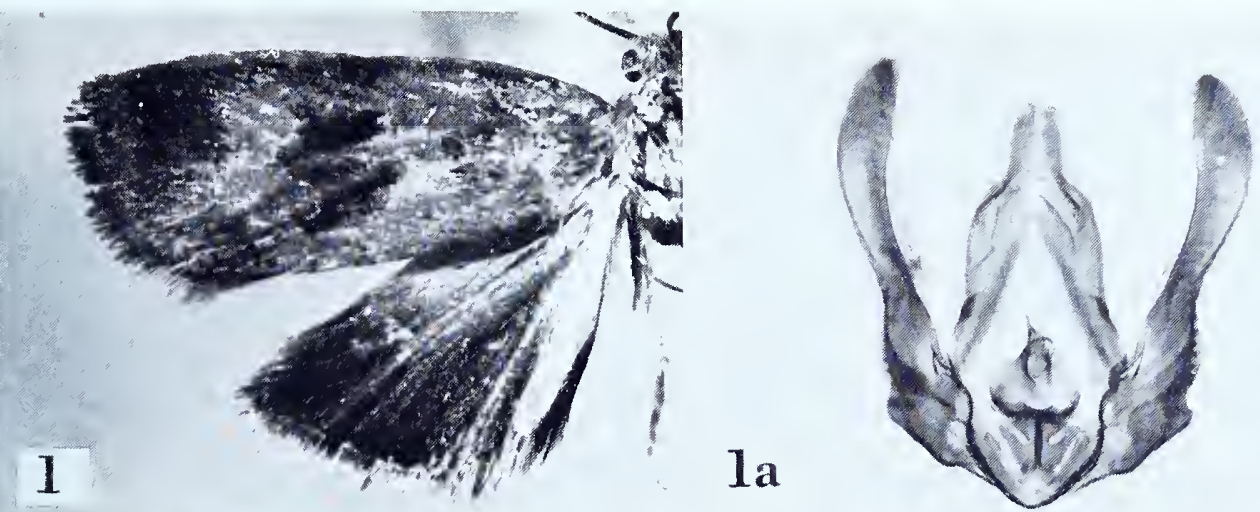

2
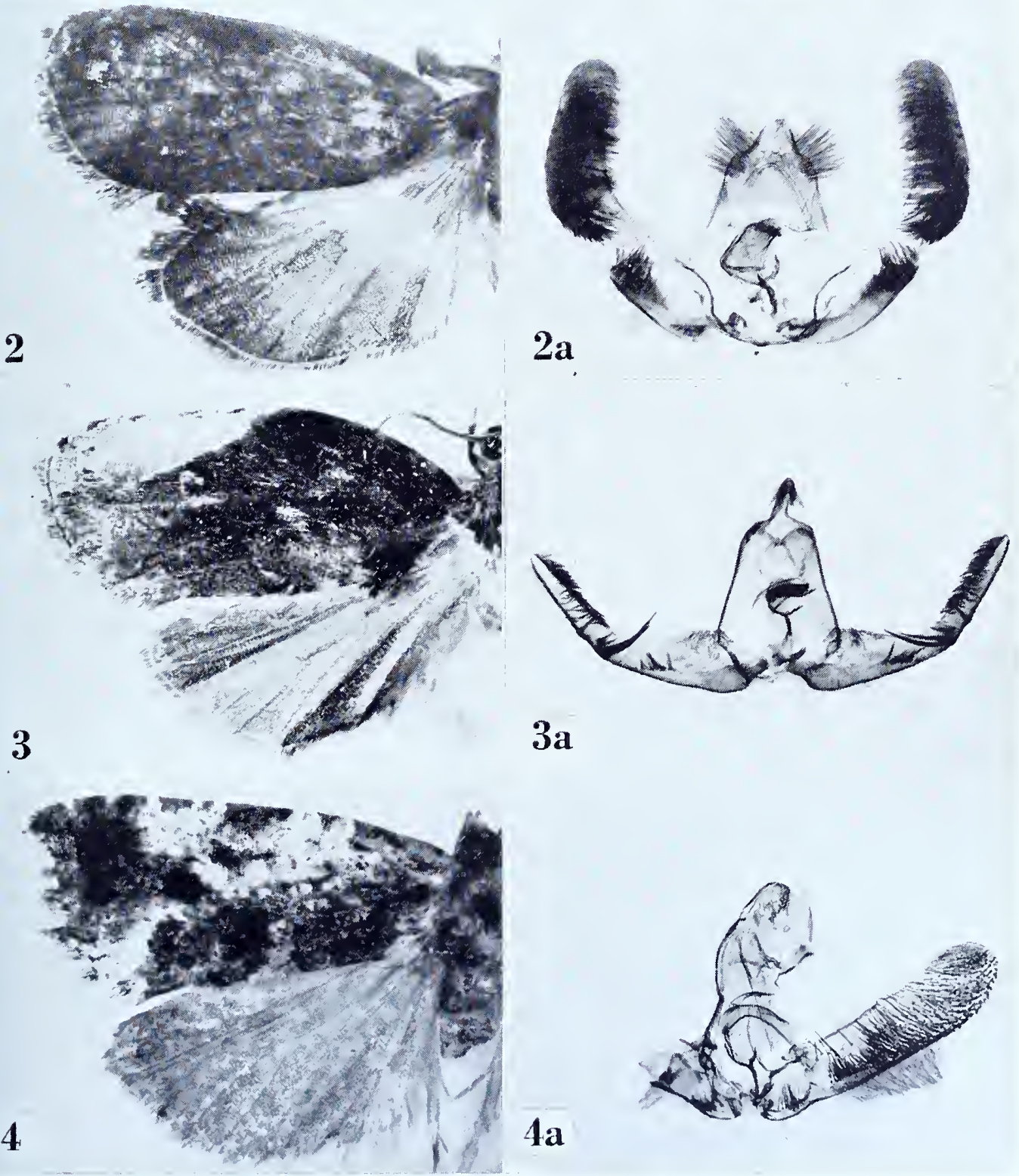


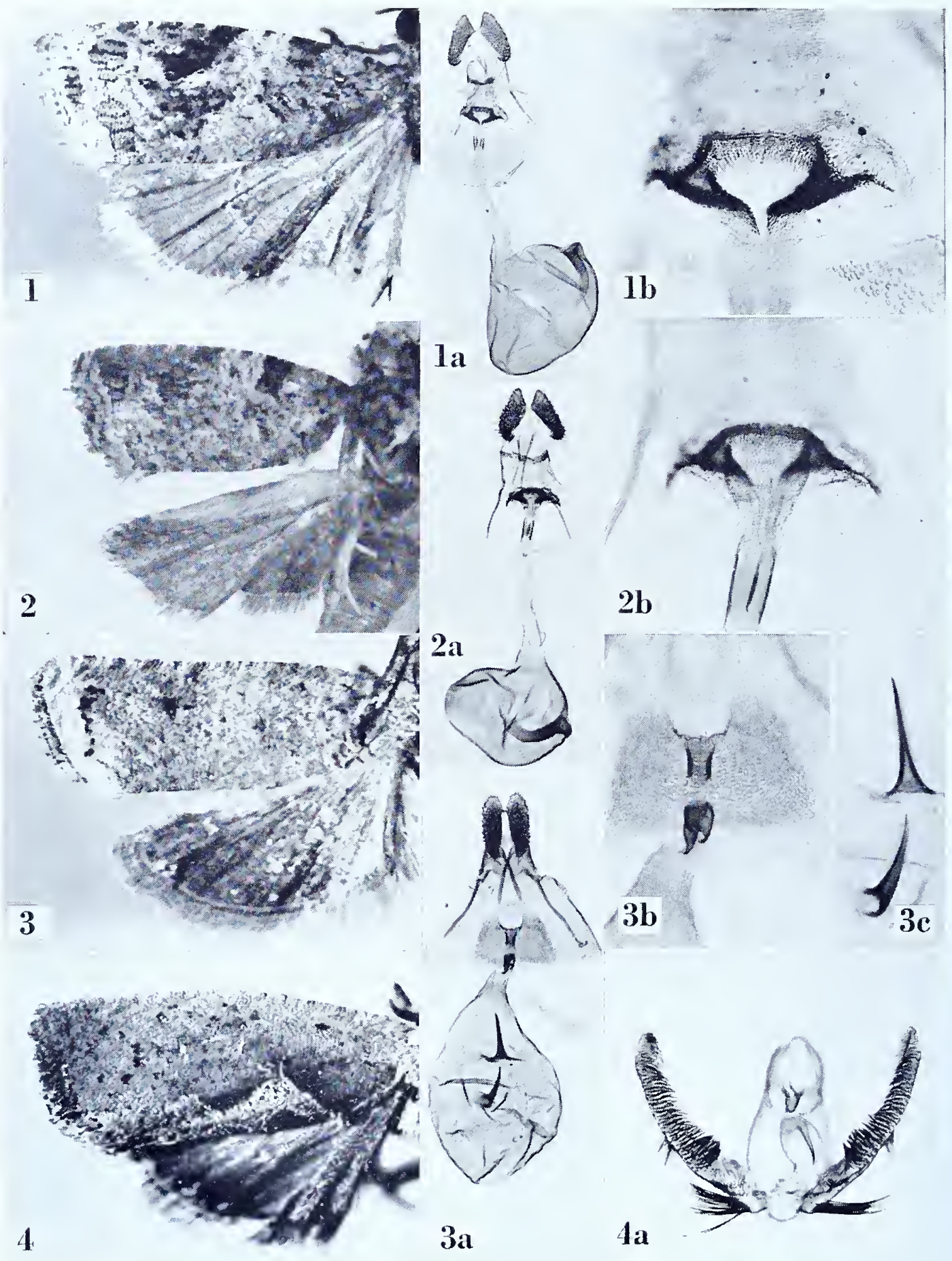




\section{Olethreutes cellifera (Meyrick), new combination}

Plate 246, Figures $I-I b ; 2-2 b$

Polychrosis cellifera Meyrick, I912, Journ. Bombay Nat. Hist. Soc., 21 : 860.

Argyroploce codonectis Meyrick, 1927, Exotic Microlepidoptera, 3:339; 1931, 4: 129.

[cellifera]

“ *ํ. I I $^{-1} 5$ mm. . . . Colombo, Ceylon (Mackwood); Pusa (Fletcher); in July, two specimens."

Lectotype: The female dated ".7.08". Slide No. 7203 .

Figure I, left wings; ra, ventral view of female genitalia; $r$, detail of ostium.

[codonectis]

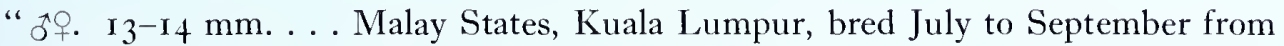
larvae feeding on shoots and leaves of Eugenia malaccensis and E. aquea (Myrtaceae) (Corbett, Gater); 14 ex. (type Brit. Mus.). Also an example from Coorg, Dibidi, November (Newcome).

Type: The female so marked in the British Museum, "Malay Pen., Kuala Lumpur. 3o.vii.r924. G. H. Corbett and B. A. Gater." Slide No. 7072.

Figure 2, left wings; 2a, ventral view of female genitalia; $2 \mathrm{~b}$, detail of ostium.

\section{Olethreutes cenchropis (Meyrick), new combination}

Plate 246, Figures $3^{-} 3^{\mathrm{c}}$

Argyroploce cenchropis Meyrick, 1920, Exotic Microlepidoptera, 2: 349.

"․ I 3 mm. . . Bengal, Pusa, June, larva in fruits of Cordia myxa (Fletcher); I ex."

Type: The female indicated above dated “6.I7”. Slide No. 7 I92.

Figure 3 , left wings; $3^{\mathrm{a}}$, ventral view of female genitalia; $3^{\mathrm{b}}$, detail of genital plate and ostium; 3 c, signa.

\section{Olethreutes centritis (Meyrick), new combination}

\section{Plate 246, Figures $4^{-} 4^{\mathrm{a}}$}

Argyroploce centritis Meyrick, I912, Journ. Bombay Nat. Hist. Soc., 21 : 872. " ${ }^{*}$. $16 \mathrm{~mm}$. . . Khasis, in November, one specimen. Allied to caryactis." Type: 'The male indicated above, "Khasi Hills, Assam. .I 1.1906." Slide No. 7177. Figure 4 , left wings; 4 a, ventral view of male genitalia with aedeagus in situ. 


\title{
Olethreutes cerographa (Meyrick), new combination
}

\author{
Plate 247 , Figures I-1 a
}

Eucosma cerographa Meyrick, 1907, Journ. Bombay Nat. Hist. Soc., 17: 977.

" 今. 10-12 mm. ... Eight specimens, Maskeliya, Ceylon, in March and April (Pole)."

Lectotype: A male measuring $12 \mathrm{~mm}$., dated “.3.06”. Slide No. 7271 .

Figure I, left wings; Ia, ventral view of male genitalia with aedeagus in situ.

\section{Olethreutes circumplexa (Meyrick), new combination}

$$
\text { Plate 247, Figures 2-2a }
$$

Argyroploce circumplexa Meyrick, 1922, Exotic Microlepidoptera, 2: 523.

"ว. $15 \mathrm{~mm}$. . . B Brazil, Parintins, October (Parish); I ex."

Type: The above indicated male dated ". I0-19". Slide No. 7348.

Figure 2, left wings; $2 \mathrm{a}$, ventral view of male genitalia with aedeagus in sitn.

\section{Olethreutes clydonias (Meyrick)}

See Temnolopha mosaica Lower.

\section{Olethreutes clytocarpa (Meyrick), new combination}

Plate 247 , Figures $3-3 \mathrm{~b}$

Argyroploce clytocarpa Meyrick, 1920, Exotic Microlepidoptera, 2: 349.

" $ڤ .14 \mathrm{~mm}$. . . . Philippines; I ex."

Type: The male denoted above labelled, "Philippines. M. .ı.." Slide No. $733^{8}$.

Figure 3 , left wings; $3 \mathrm{a}$, denuded abdomen to show lateral grooves; $3 \mathrm{~b}$, ventral view of male genitalia with aedeagus in situ.

\section{Olethreutes codonectis (Meyrick)}

See Olethreutes cellifera (Meyrick).

\section{Olethreutes compsitis (Meyrick), new combination}

Plate 247 , Figures $4-4 \mathrm{~b}$

Argyroploce compsitis Meyrick, 1912, Journ. Bombay Nat. Hist. Soc., 21: 870.

“․ $13 \mathrm{~mm}$. . . Maskeliya, Ceylon (Alston); in November, one specimen."

Type: The above indicated female dated ".11.06". Slide No. 7227.

Figure 4 , left wings; 4 a, ventral view of female genitalia; $4 \mathrm{~b}$, detail of genital plate and ostium. 

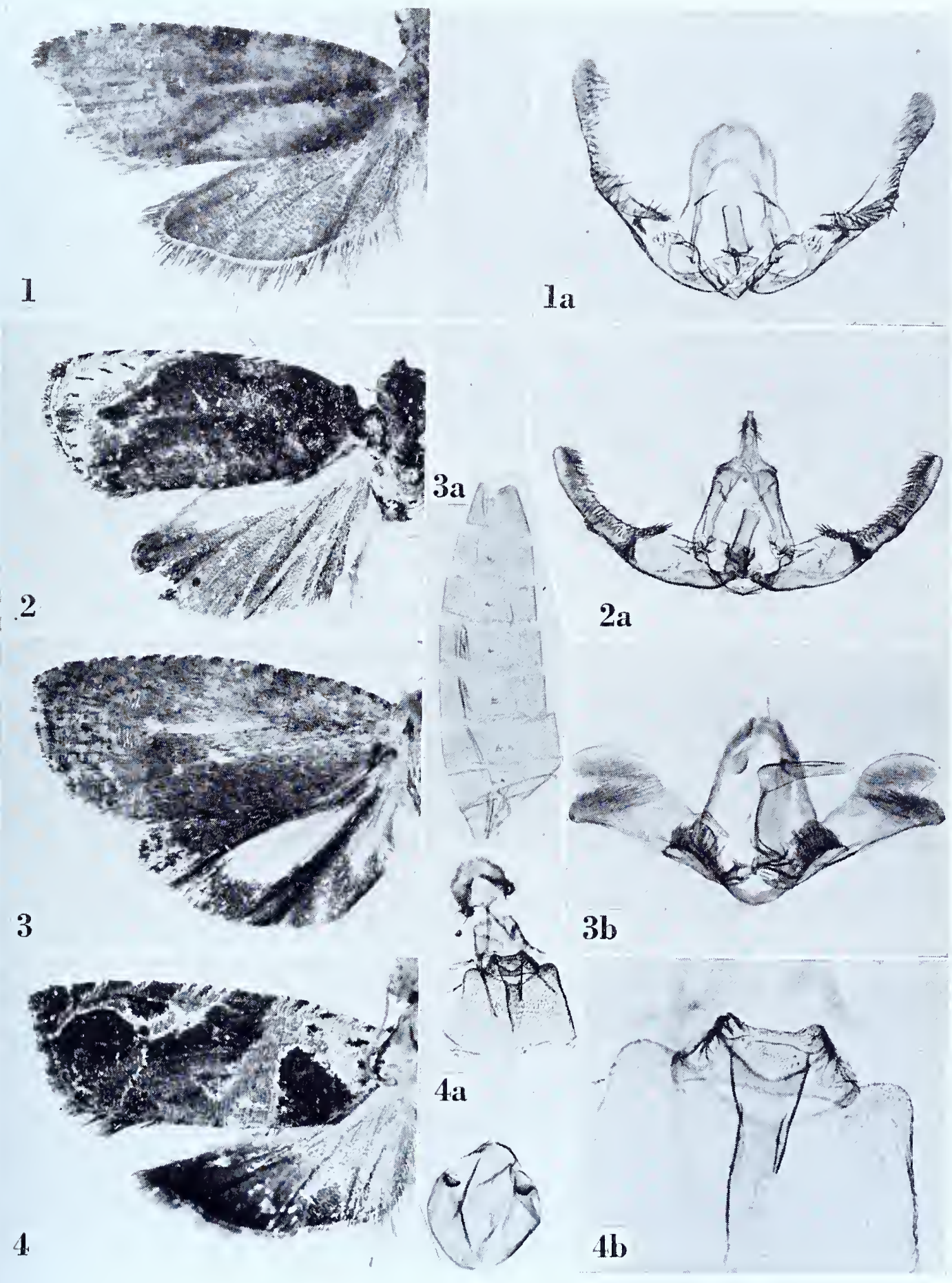


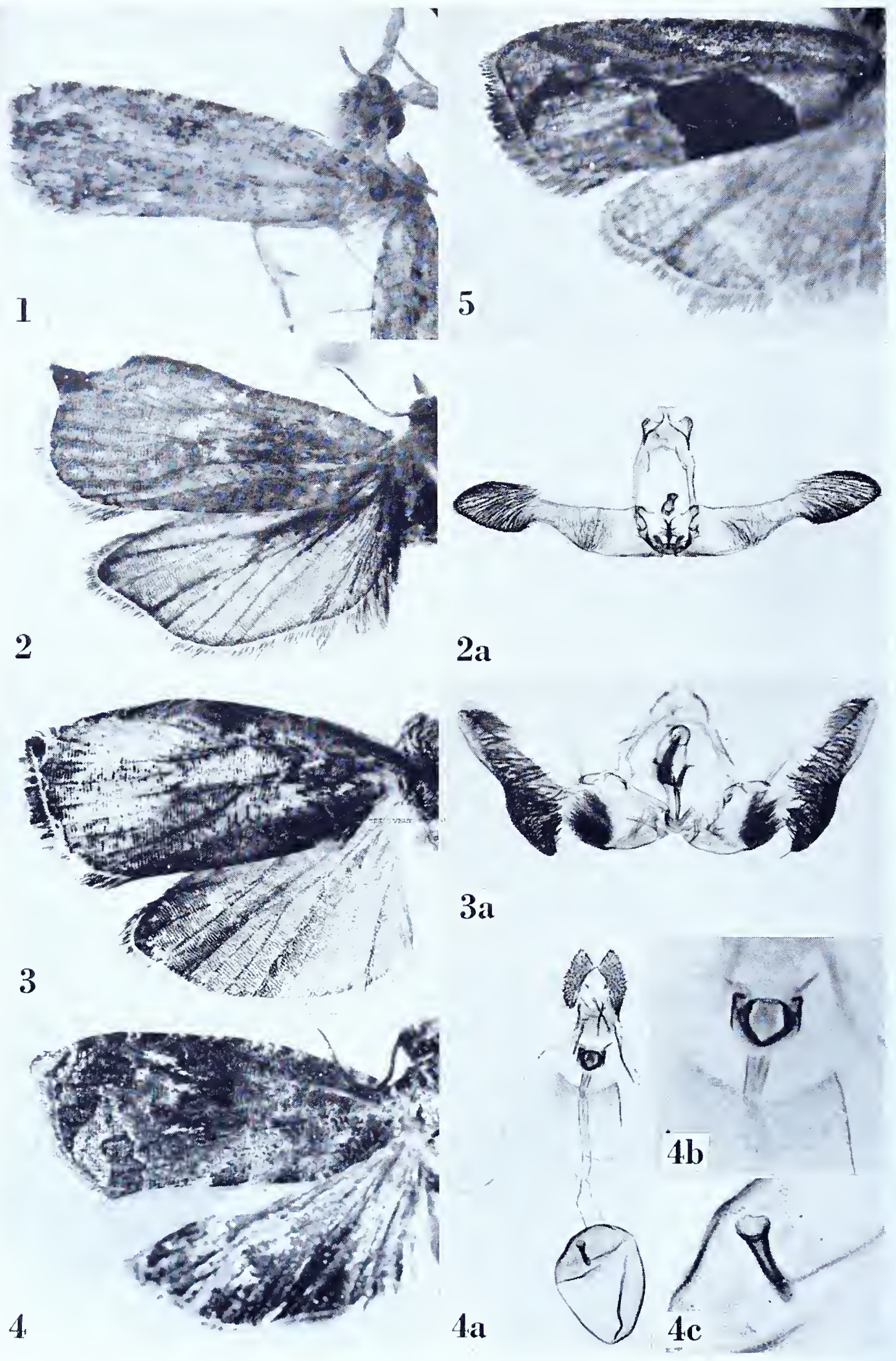




\title{
Olethreutes conchopleura (Meyrick), new combination
}

\author{
Plate 248 , Figure I
}

Argyroploce conchopleura Meyrick, I9I I, Trans. Linnean Soc. London, I4: 27 I.

“ o. $12 \mathrm{~mm}$. . . . Silhouette, Mare aux Cochons plateau, I,ooo feet, in September; one specimen. Allied to the Indian dimorpha Meyr."

Type: The above indicated specimen so marked in the British Museum. The head, forewings and three legs are all that remain of the type.

Figure $\mathrm{I}$, left forewing.

\section{Olethreutes constructa (Meyrick)}

See Aterpia coustructa (Meyrick).

\section{Olethreutes corthyntis (Meyrick), new combination}

Plate 248 , Figures 2-2a

Argyroploce corthyutis Meyrick, I909, Journ. Bombay Nat. Hist. Soc., 19: 596.

" $\hat{o}^{\circ}$. 19-21 mm. ... Patipola and Hakgala, Ceylon, in April and May (Green, Alston, Pole); six specimens. Nearly allied to lichenoides Wals."

Lectotype: A male measuring 20 mm., "Patipola, Ceylon. A. .4.06." Slide No. 7284. Meyrick's corthyutis was sunk as a synonym of lichenoides, but is a distinct species and is hereby removed from synonymy.

Figure 2, left wings; $2 \mathrm{a}$, ventral view of male genitalia with aedeagus in sitn.

\section{Olethreutes cremnocrates (Meyrick), new combination}

\section{Plate 248 , Figure 5}

Argyroploce cremnocrates Meyrick, 1932, Exotic Microlepidoptera, 4: 225.

" o. I 6 mm. ... British New Guinea, Biagi, Mambare R., 5,000 feet (Meek); i ex. (Coll. Paravicini)."

Type: The above indicated male so marked in the British Museum, dated "г.iv.o6". The abdomen of the type is missing.

Figure 5, left wings.

\section{Olethreutes creserias (Meyrick), new combination \\ Plate 248 , Figures $3^{-} 3^{\text {a }}$}

Platypeplus creserias Meyrick, I905, Journ. Bombay Nat. Hist. Soc., I6: 585.

" $\$$. $17 \mathrm{~mm}$. ... One specimen, Haragam, Ceylon, in July (Green)."

Type:'The above indicated male, "Haragam, Ceylon. EEG./7/02." Slide No. 7297. Meyrick suppressed creserias as a synonym of albitibiana Snellen (I901), but I am not 
OLE'THREUTES

\section{Olethreutes crossoleuca (Meyrick), new combination}

Plate 249, Figures $1-\mathrm{Ib}$

Argyroploce crossoleuca Meyrick, 1933, Exotic Microlepidoptera, 4:420.

"ㅇ. I $4^{-1} 5 \mathrm{~mm}$. . . J Java, bred October from larvae feeding on leaves of Glochidion (?) (Dr. L. G. E. Kalshoven); 2 ex. A peculiar form."

Lectotype: The female measuring I 4 mm., "Java, LGK, .Iо.3I." One specimen is missing. Slide No. 7272 .

Figure $\mathrm{I}$, right wings (image reversed); $\mathrm{ra}$, ventral view of female genitalia; $\mathrm{I} b$, detail of genital plate and ostium.

\section{Olethreutes cyanophaea (Meyrick), new combination}

Plate 249, Figures 2-2c

Argyroploce cyanophaea Meyrick, I927, Exotic Microlepidoptera, 3:339.

" 5 ㅇ. I6-1 $8 \mathrm{~mm}$. . . Tanganyika Territory, bred from the fruit of Allanblackia, February (Ritchie); 6 ex. Type British Museum."

Type: 'The female so labelled in the British Museum, dated "2-26”. Slide No. 7312.

Figure 2, left wings; $2 \mathrm{a}$, ventral view of female genitalia; $2 \mathrm{~b}$, detail of genital plate and ostium; 2c, signum.

\section{Olethreutes cyanura (Meyrick), new combination}

Plate 249 , Figures $3-3$ a

Argyroploce cyantita Meyrick, I9o9, Journ. Bombay Nat. Hist. Soc., I 9: 598.

" $\widehat{0}+$. $18-20 \mathrm{~mm}$.... Khasis; Gunong Ijan, Malay Peninsula; in June and September; five specimens."

Lectotype: 'The male, "Gunong Ijan, Malay Peninsula. R. .o7." Slide No. 7255.

Figure 3 , left wings; $3 \mathrm{a}$, ventral view of male genitalia with aedeagus iu situ.

\section{Olethreutes cybicopa (Meyrick), new combination}

Plate 249 , Figures $4-4 \mathrm{a}$

Argyroploce cybicopa Meyrick, 1933, Exotic Microlepidoptera, 4:42 I.

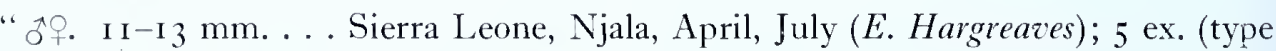
Brit. Mus.). Nearly allied to orthocosma Meyr."

Type: The male, so marked in the British Museum, "Sierra Leone, Njala. 4.IV.32. E. Hargreaves." Slide No. 73 1 7 .

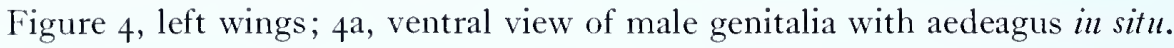



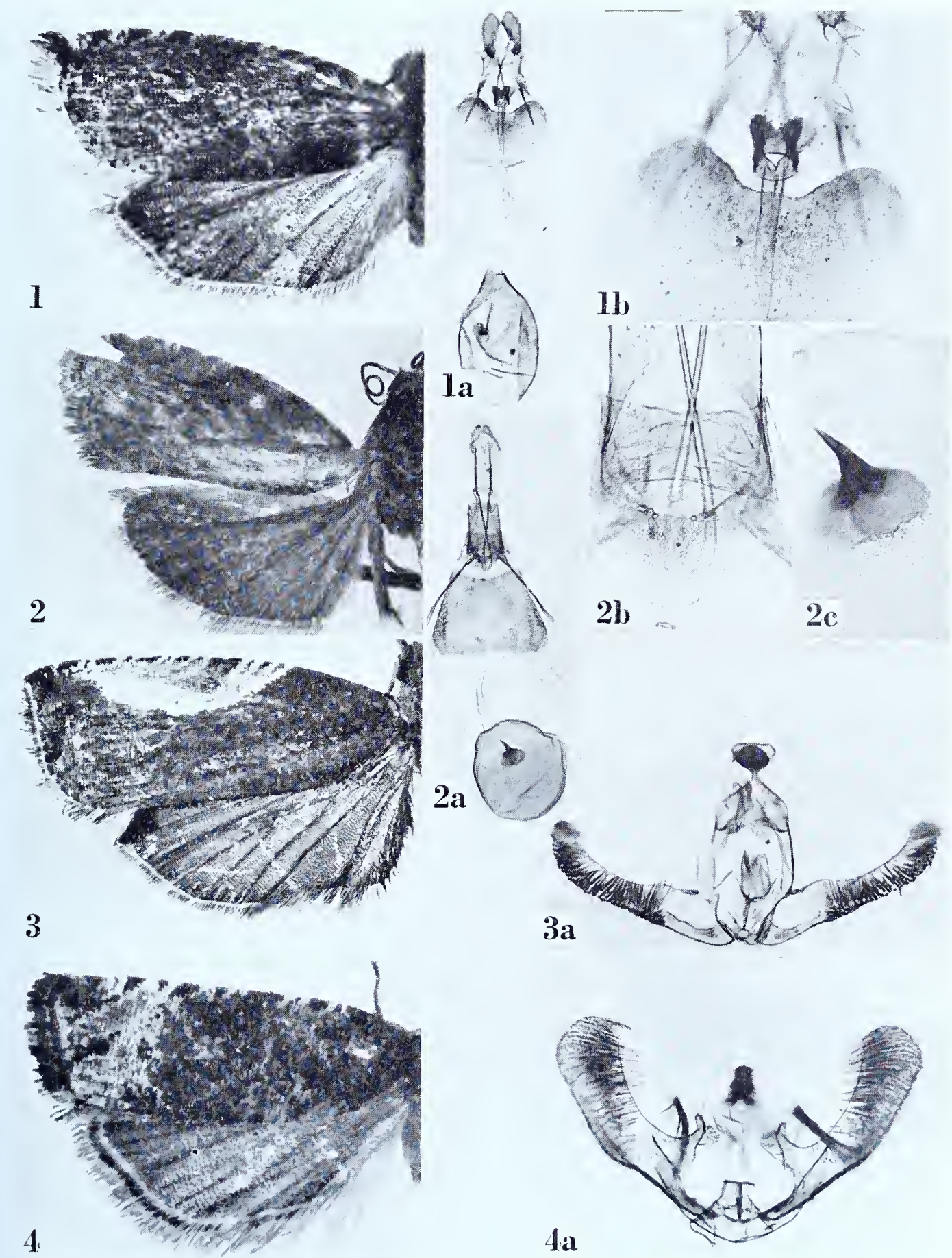


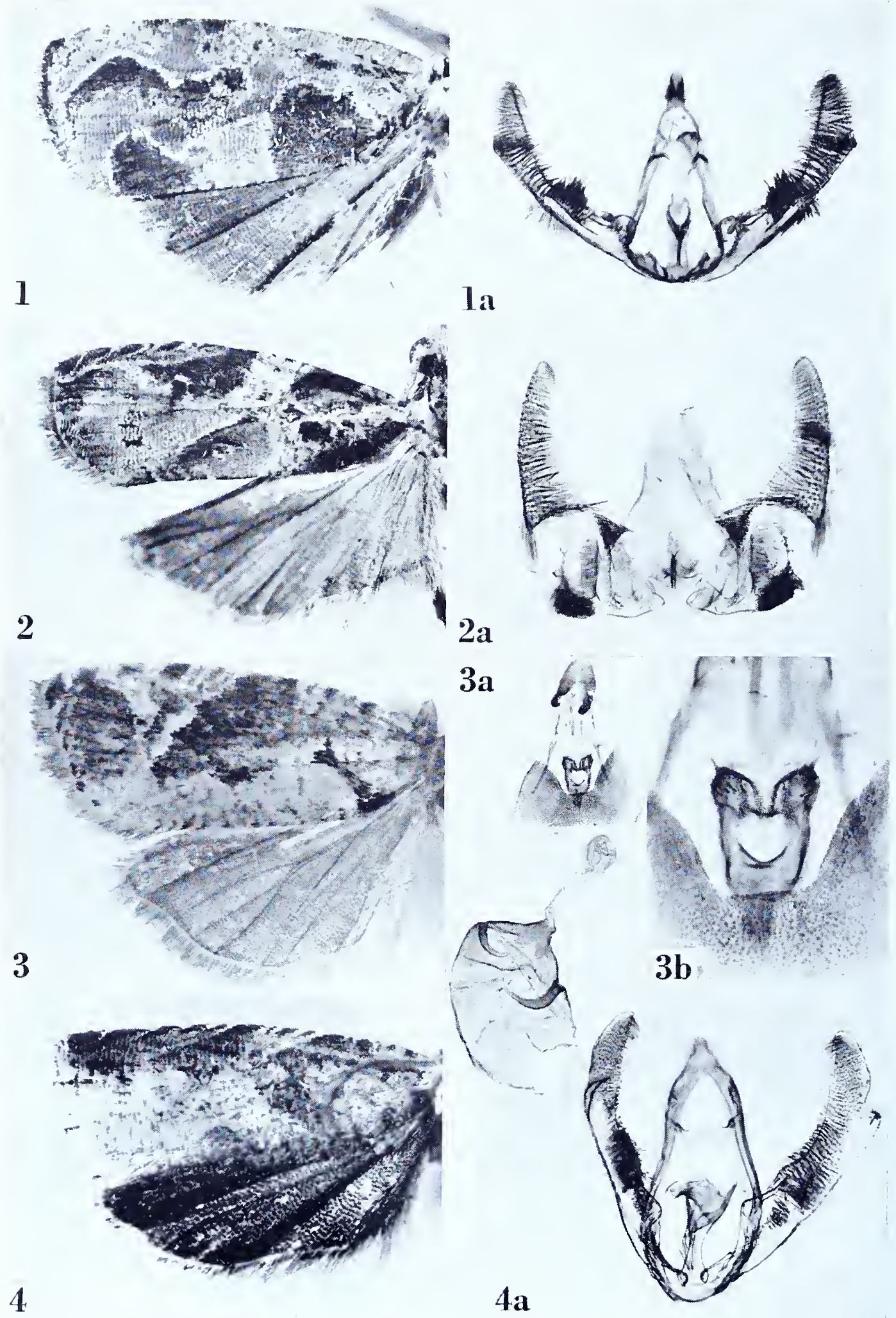




\section{Olethreutes cycladica (Meyrick), new combination}

Plate 250, Figures 1-Ia

Argyroploce cycladica Meyrick, 1917, Trans. Ent. Soc. London, 1917: 27.

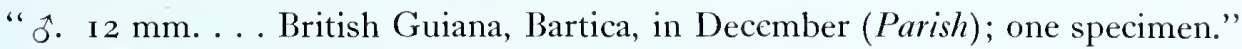

Type: The male indicated above and dated ".12.12". Slide No. 6419.

Figure I, left wings; Ia, ventral view of male genitalia with aedeagus in situ.

\section{Olethreutes cymotoma (Meyrick), new combination}

Plate 250, Figures 2-2a

Argyroploce cymotoma Meyrick, 1917, Trans. Ent. Soc. London, 1917: 26.

" $0^{*}+$. I $3^{-1} 4 \mathrm{~mm} . .$. British Guiana, Bartica, in January and February (Parish);

five specimens. Allied to albimacula Wals."

Lectotype: A male measuring 14 mm., dated “.ı.13". Slide No. Sor3.

Figure 2, left wings; 2 a, ventral view of male genitalia with aedeagus in situ.

\section{Olethreutes decidua (Meyrick), new combination}

Plate 250 , Figures $3-3 \mathrm{~b}$

Argyroploce decidıa Meyrick, 1934, Ann. Mag. Nat. Hist. (Ser. 10), 14: 406.

“ส์․ I 8-19 mm. . . São Tomé, Nov. 2-30; 2 ex. Allied to purpurissatana."

Type: The female so marked in the British Museum, and dated "20.XI.ı932".

Slide No. 7073 .

Figure 3 , left wings; 3 , ventral view of female genitalia; 3 b, detail of ostium.

\section{Olethreutes dimorpha (Meyrick), new combination}

\section{Plate 250 , Figures $4-4 \mathrm{a}$}

Argyroploce dimorpha Meyrick, 1909, Journ. Bombay Nat. Hist. Soc., 19: 606.

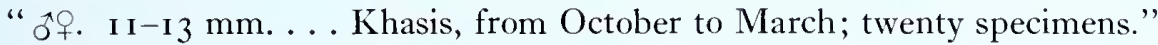

Lectotype: A male measuring 12 mm., "Khasi Hills, Assam. .3.1907." Two specimens are missing. Slide No. 7228.

Figure 4, left wings; 4 a, ventral view of male genitalia with aedeagus $i n$ situ. 


\title{
Olethreutes diserta (Meyrick), new combination
}

\author{
Plate 25I, Figures $\mathrm{I}-\mathrm{Ib}$
}

Argyroploce diserta Meyrick, I909, Journ. Bombay Nat. Hist. Soc., I9: 593.

" 70 . 24-25 mm. . . . Khasis, in September; two specimens."

Lectotype: The male, "Khasi Hills, Assam. D. i go6." Slide No. 7279.

Figure I, left wings; Ia, denuded anterior segments of abdomen showing lateral hair-pencils; $\mathrm{Ib}$, ventral view of male genitalia with aedeagus in situ.

\section{Olethreutes doctrinalis (Meyrick), new combination}

Plate 25I, Figures 2-2b

Argyroploce doctrinalis Meyrick, I934, Ann. Mag. Nat. Hist. (Ser. 10), 14: 407.

" Aㅇ. I $8-20$ mm. . . . São Tomé, Oct. 28-Nov. 2; 2 ex."

Type: The female so designated in the British Museum and dated "28.X.1932". Slide No. 7074 .

Figure 2, left wings; $2 \mathrm{a}$, ventral view of female genitalia; $2 \mathrm{~b}$, detail of genital plate and ostium.

\section{Olethreutes eaolotechna (Meyrick)}

See Phaecalophora eaolotechna (Meyrick).

\section{Olethreutes ebenina (Meyrick), new combination}

Plate 25 1 , Figures $4-4 \mathrm{a}$

Argyroploce ebenina Meyrick, i9i6, Exotic Microlepidoptera, 2: 20.

" 궁. I I-I2 mm. . . Kanara, Karwar, bred in July from larvae feeding gregariously between spun leaves of Diospyros (Ebenaceae); . . f five specimens."

Lectotype: o, I I mm., "Karwar, Kanara, RM. bred. 6.7.13." Slide No. 7306.

Figure 4 , right wings (image reversed); 4 a, ventral view of male genitalia with aedeagus in situ. 

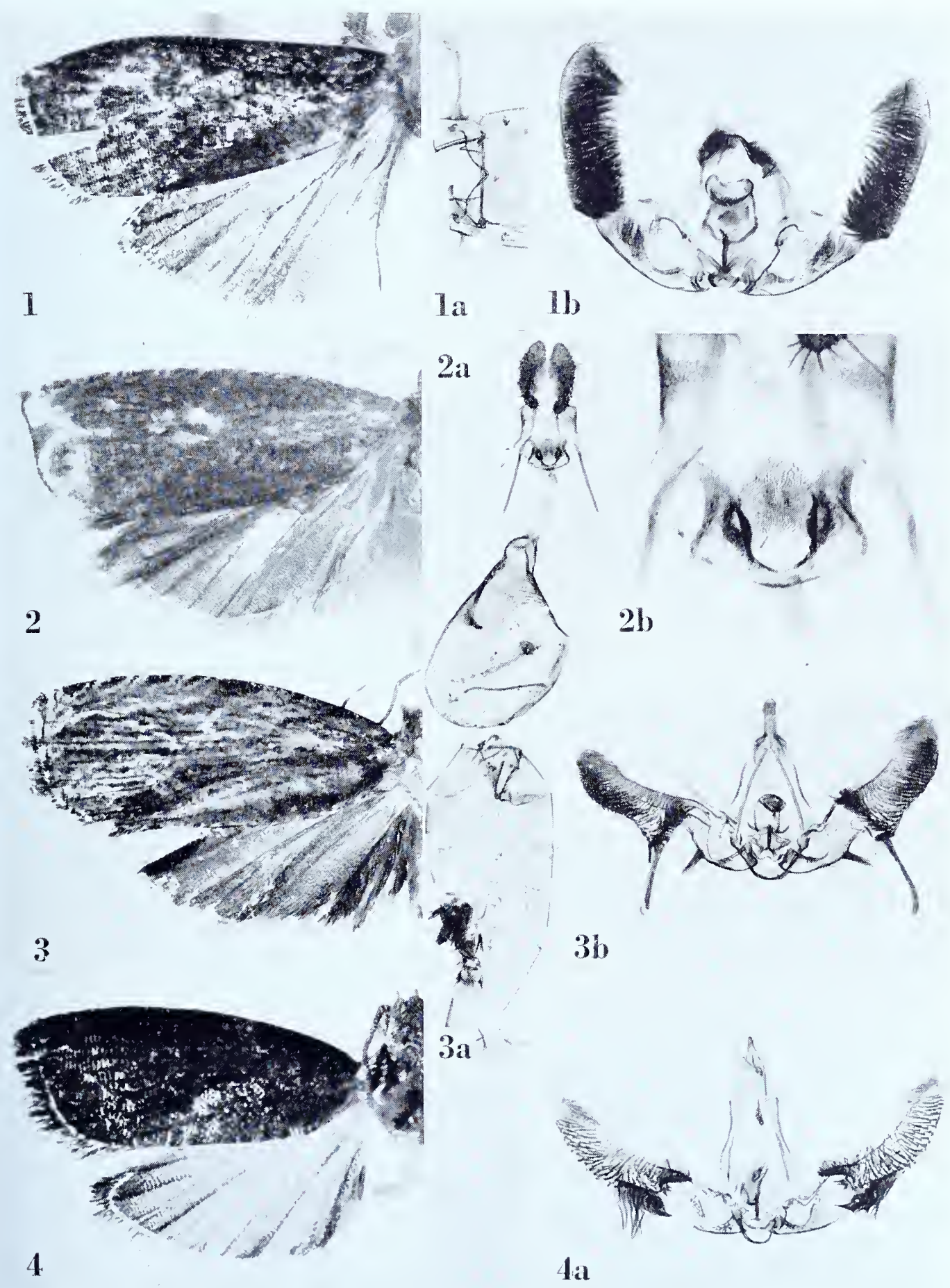

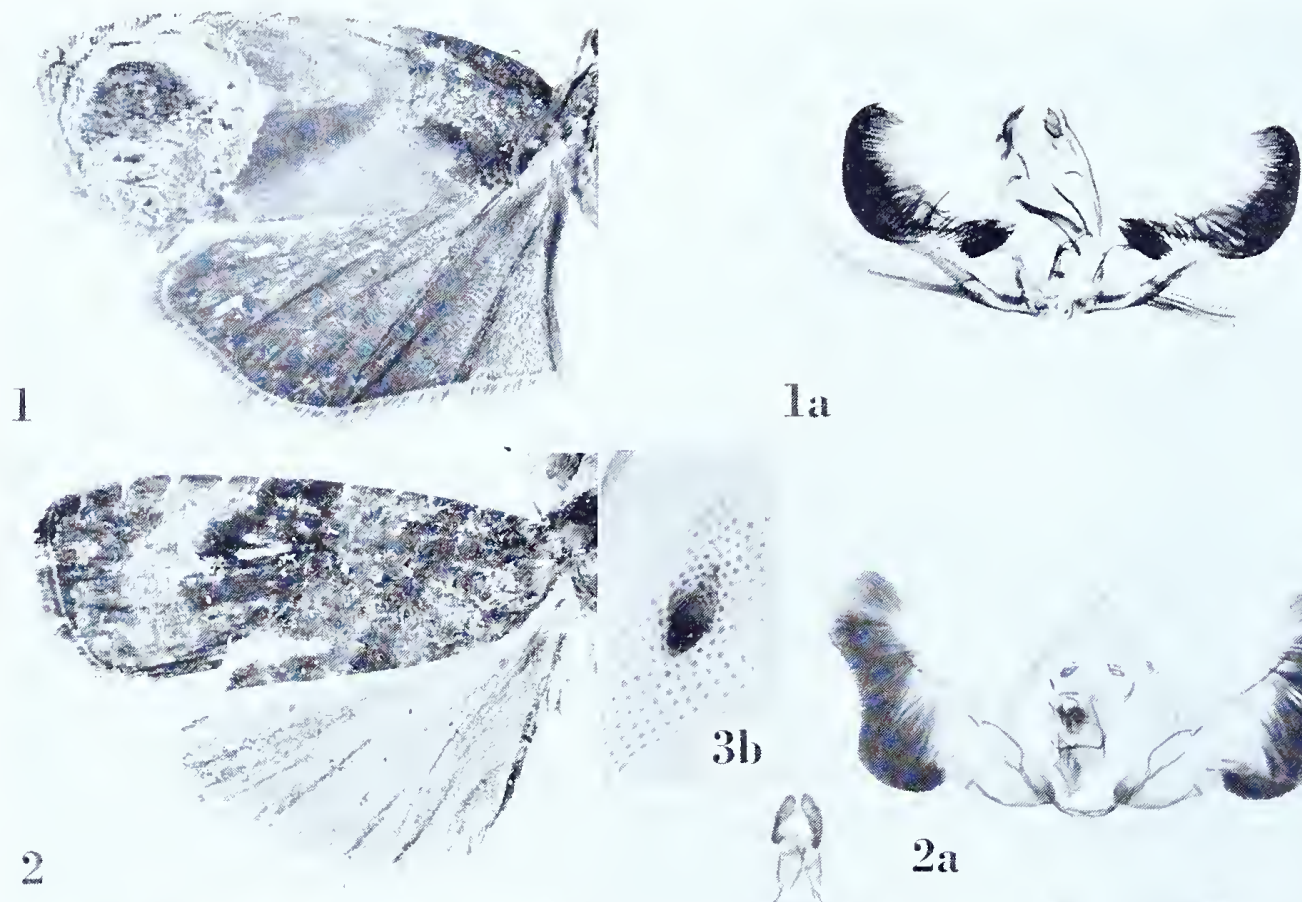

la
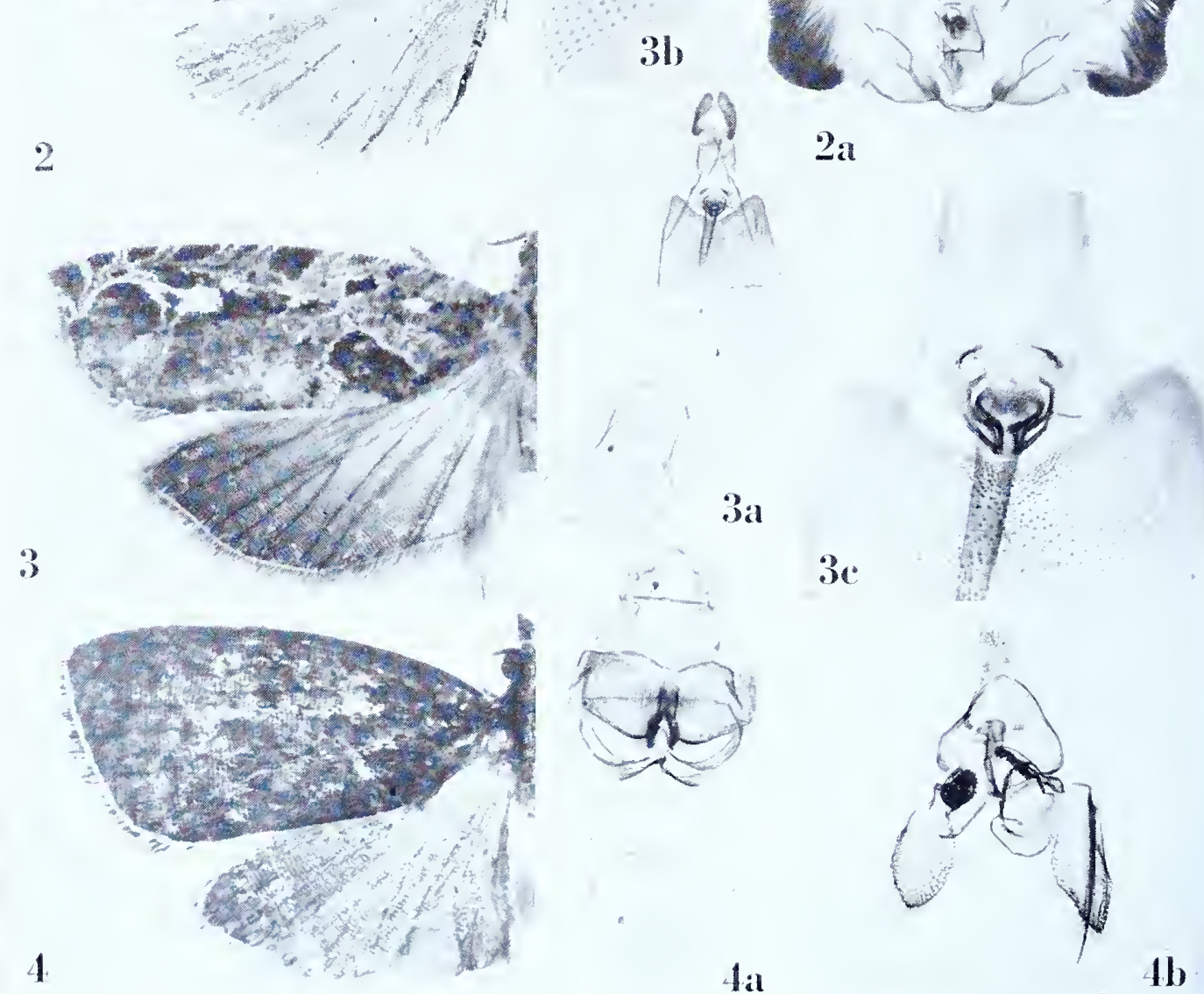

4at

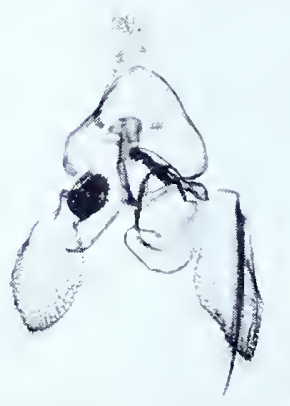

4b 


\title{
Olethreutes elaeanthes (Meyrick), new combination
}

\author{
Plate 252, Figures I-ra
}

Argyroploce elaeanthes Meyrick, 1927, Exotic Microlepidoptera, 3: 340 .

“ ${ }^{\text {. }}$ I $8 \mathrm{~mm}$. . . Bolivia, Andes, ro,ooo feet; i ex. Near malachitana."

Type: The male indicated above and with ".20" in the lower right corner of the pin-label. Slide No. 6422.

Figure r, left wings; ra, ventral view of male genitalia with aedeagus in sitn.

\section{Olethreutes electrias (Meyrick), new combination}

Plate 252, Figure 2-2a

Argyroploce electrias Meyrick, i912, Trans. Ent. Soc. London, i91 г : 691.

" స. $25 \mathrm{~mm}$. . . Colombia, San Antonio, 5,80o feet, in November; one specimen."

Type: The male indicated above dated ".I I.07". Slide No. 6413.

Figure 2, left wings; 2a, ventral view of male genitalia with aedeagus in sitn.

\section{Olethreutes englytopa (Meyrick), new combination}

Plate 252, Figures $3^{-} 3^{\mathrm{C}}$

Argyroploce englytopa Meyrick, 1938 , $i$ Caradja and Meyrick, Deuts. Ent. Zeit. Iris, 52: 85 . "o. 24 mm. . . . Mt. Guntur; r ex."

Type: The female so marked in the British Museum, "Mt. Guntur, Garoet, Westjava, I $35^{\circ} \mathrm{m}$. Overbeck leg." Slide No. 7068.

Figure 3 , left wings; $3^{\mathrm{a}}$, ventral view of female genitalia; $3 \mathrm{~b}$, signum; $3^{\mathrm{c}}$, detail of genital plate and ostium.

\section{Olethreutes erotias (Meyrick), new combination}

Plate 252, Figures $4-4 \mathrm{~b}$

Platypeplns erotias Meyrick, 1905, Journ. Bombay Nat. Hist. Soc., r6: 584 .

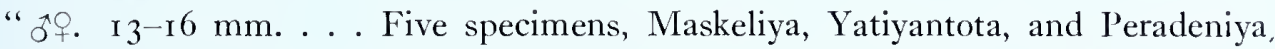
Ceylon, in February, March, July, September and November (Green, Pole)."

Lectotype: The male, measuring 14 mm., "Peradeniya, Ceylon. Green. r r.or." Slide No. 729r. 'The Yatiyantota specimen is missing.

Figure 4, left wings; 4 a, denuded abdomen showing modifications of segments; $4 \mathrm{~b}$, ventral view of male genitalia with aedeagus in sitn. 


\section{Olethreutes escharota (Meyrick), new combination}

Plate 253, Figures I-I a

Argyroploce escharota Meyrick, I9 10, 'Trans. Ent. Soc. London, I9 10: 436.

" $\hat{o} .2$ I mm. . . . Celebes, in September; one specimen."

Type: The male denoted above, "S. Celebes. D. .9.91." Slide No. 7274.

Figure I, left wings; Ia, ventral view of male genitalia with aedeagus in sitn.

\section{Olethreutes euedra (Meyrick), new combination}

Plate 253, Figures 2-2b

Argyroploce euedra Meyrick, I936, in Caradja and Meyrick, Deuts. Ent. Zeit. Iris, 50: 156.

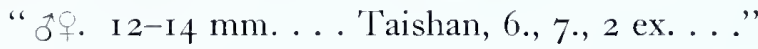

Type: 'The female, "Taishan, China. H. 5,000' .6.34." Slide No. 7304.

Figure 2, left wings; 2a, ventral view of female genitalia; 2b, detail of ostium.

\section{Olethreutes euryopis (Meyrick), new combination}

\section{Plate 253, Figures $3-3$ a}

Argyroploce euryopis Meyrick, I937, in Caradja and Meyrick, Deuts. Ent. Zeit. Iris, 5 I : I 82. “... ơ. I9 mm. . . . Yül., 4,000 m., VI, r ex. Most like cancasica Kenn."

Type: The male denoted above, "Likiang, China. H. .6.34." Slide No. 7287.

Figure 3 , left wings; 3 a, ventral view of male genitalia with aedeagus in sitn.

\section{Olethreutes exsignata (Meyrick), new combination}

Plate 253, Figures 4-4a

Argyroploce exsiguata Meyrick, i916, Exotic Microlepidoptera, 2: i9.

" o. $20 \mathrm{~mm}$. ... S. India, Palnis, 6,000 feet, in May (Fletcher, Campbell); two specimens. Remarkably similar to Eucosma helota, but without the structural peculiarities of $\jmath^{t} . "$

Lectotype: ", "Palni Hills, S. India, Campbell. .o6." Slide No. 7206.

Figure 4 , left wings; 4 a, ventral view of male genitalia with aedeagus in sit $u$. 

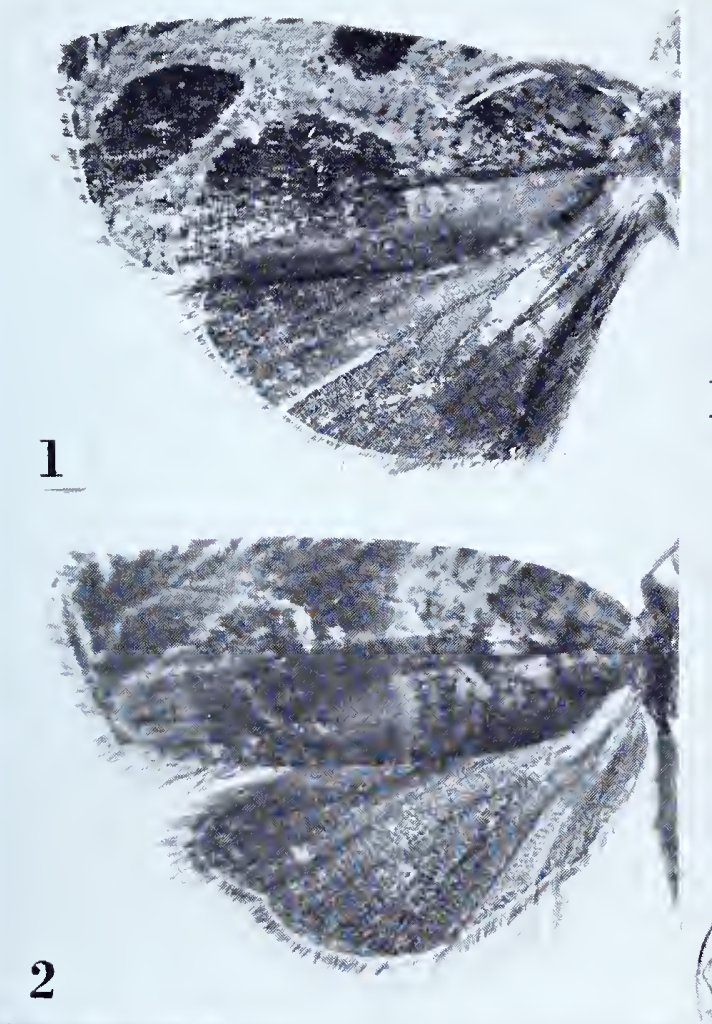

la
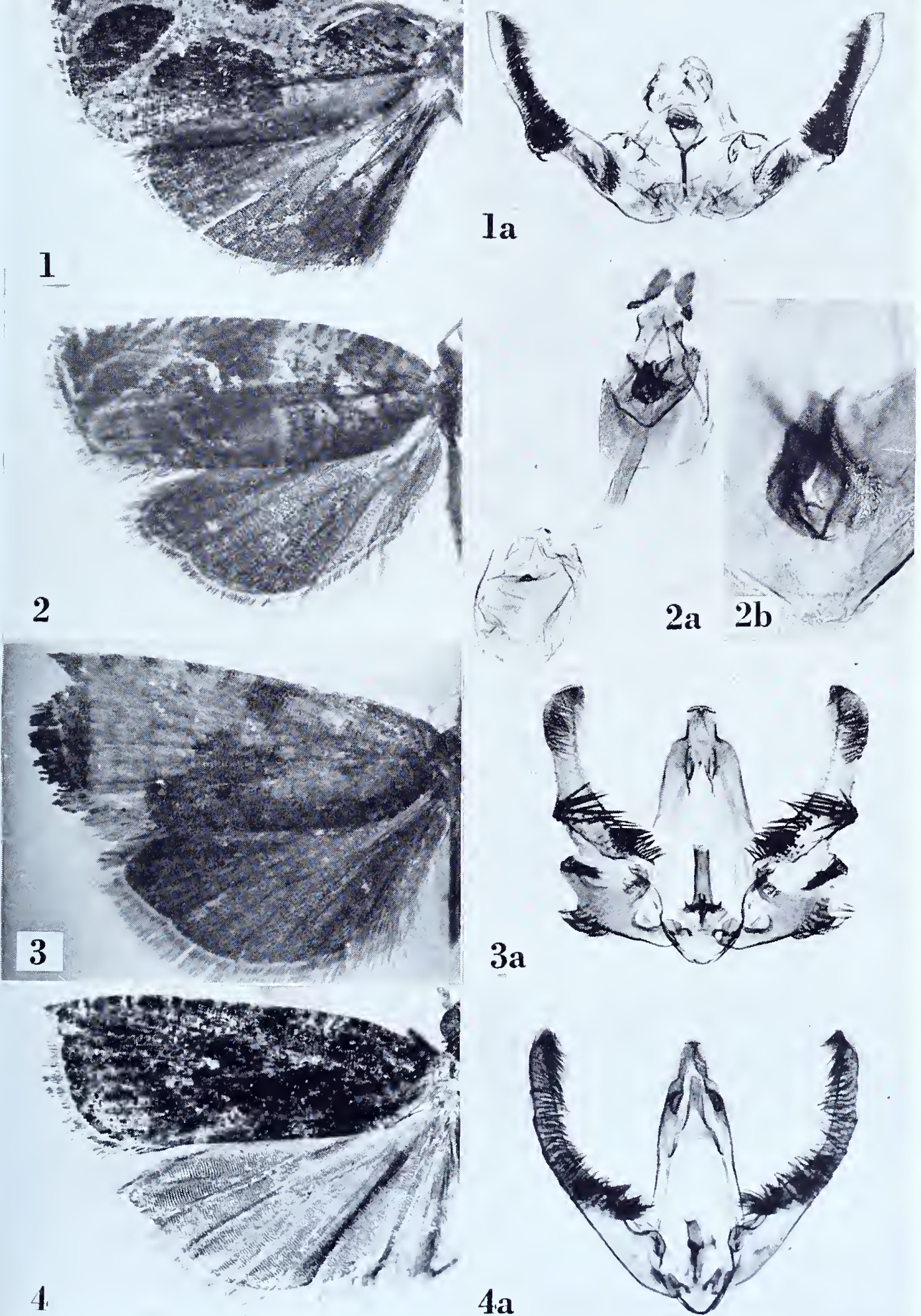

$3 a$

$4 a$

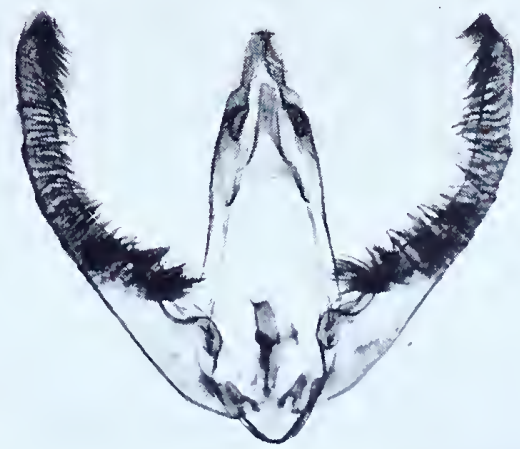



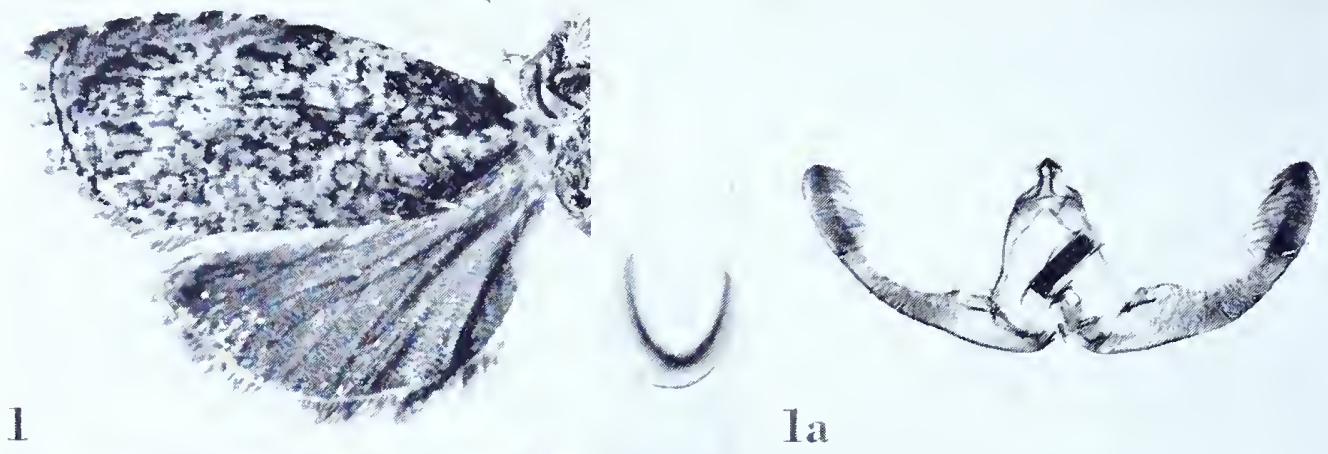

2
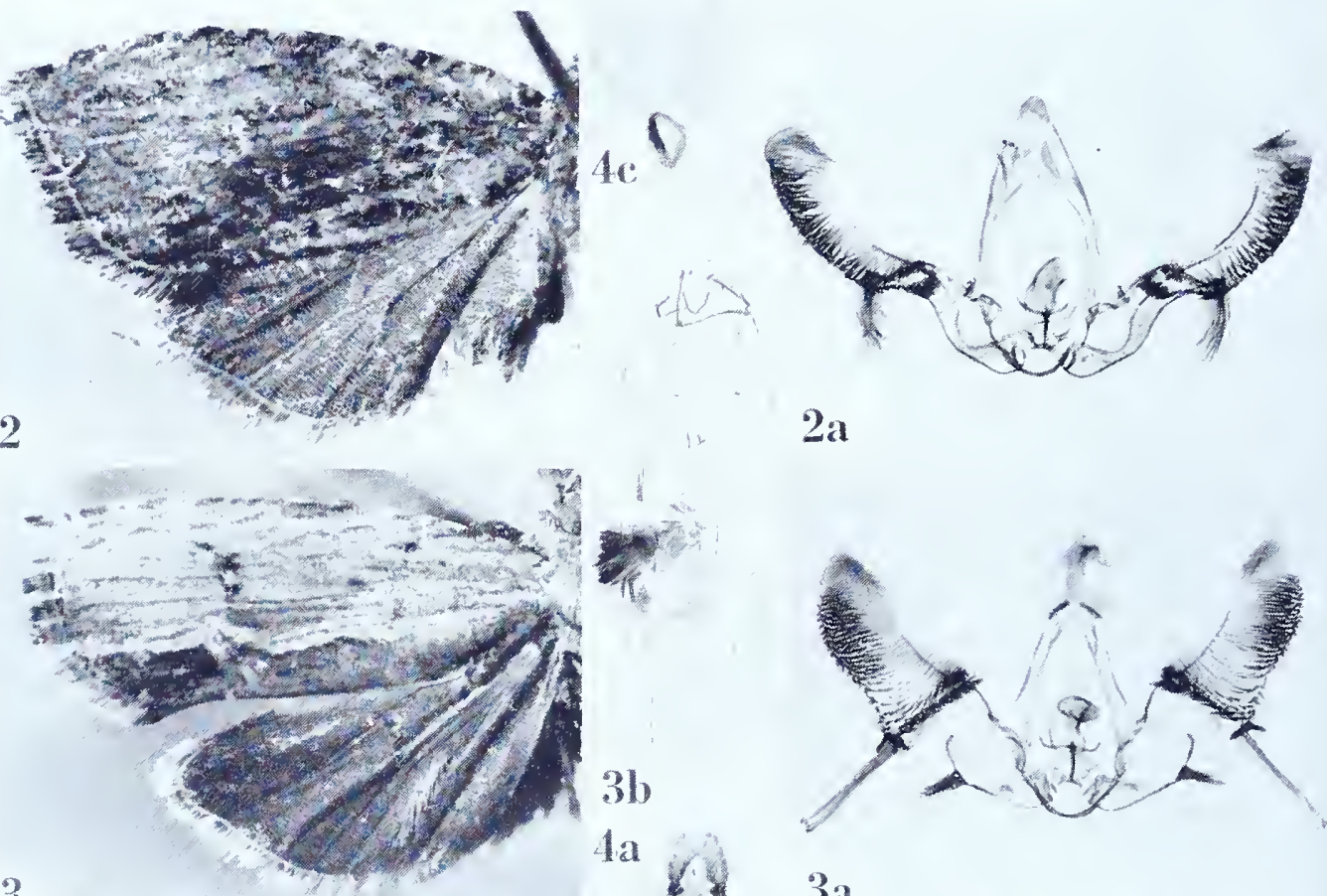

3
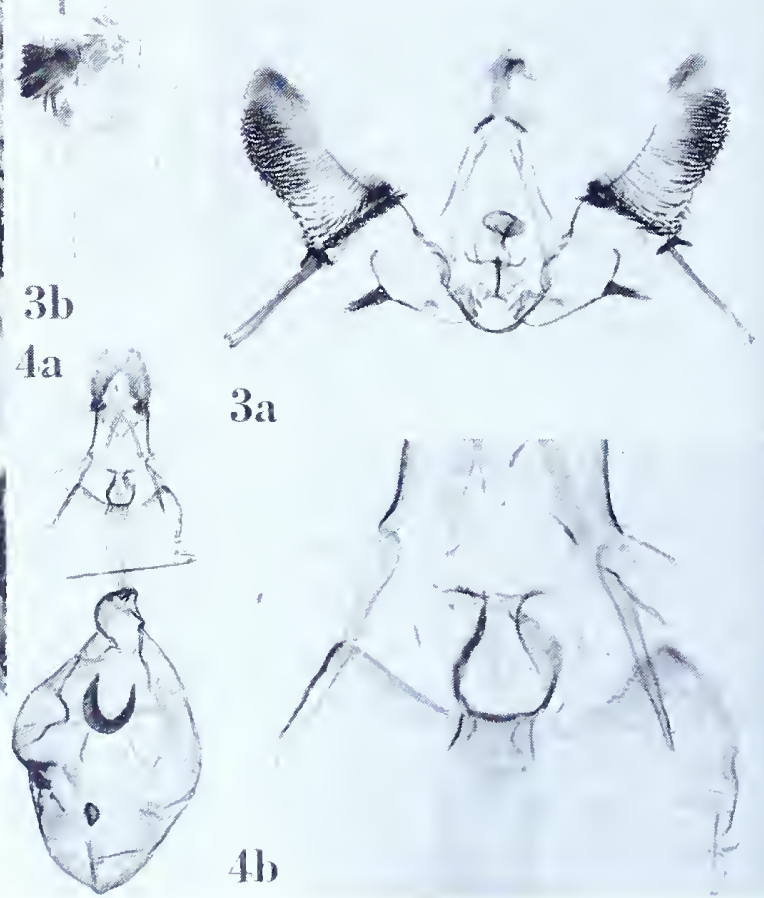

OLETHREUTES and PHAECADOPHOR 1 


\section{Olethreutes faceta (Meyrick), new combination}

Plate 254, Figures I-Ia

Argyroploce faceta Meyrick, I917, Trans. Ent. Soc. London, 1917: 25.

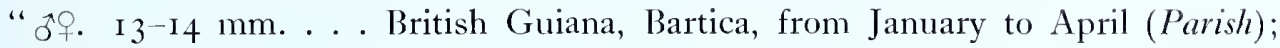
five specimens."

Lectotype: A male measuring $14 \mathrm{~mm}$., and dated “.2.13”. Slide No. 64I7. One specimen is missing.

Figure I, left wings; Ia, ventral view of male genitalia with aedeagus in situ.

\section{Olethreutes fibrata (Meyrick), new combination}

Plate 254, Figures 2-2a

Argyroploce fibrata Meyrick, I909, Journ. Bombay Nat. Hist. Soc., 19: 597.

" 70 . 16-1 $8 \mathrm{~mm}$. . . Khasis, in September and October; four specimens."

Lectotype: A male measuring i6 mm., "Khasi Hills, Assam. .ı. igo6." Slide No. 7257 .

Figure 2, left wings; $2 \mathrm{a}$, ventral view of male genitalia with aedeagus in situ.

\section{Olethreutes glyceranthes (Meyrick), new combination}

Plate 254, Figures $4-4 \mathrm{C}$

Argyroploce glyceranthes Meyrick, I928, Exotic Microlepidoptera, 3:445.

"申. I4 mm. . . A Andamans, I,200 feet, June (Ferrar); i ex. . .."

Type: The above indicated specimen, “Mid-Andamans, I,200' .6.27." Slidc No. 9298.

Figure 4 , left wings; $4 \mathrm{a}$, ventral view of female genitalia; $4 \mathrm{~b}$, detail of genital platc and ostium; $4 \mathrm{c}$, signa. 


\title{
Olethreutes gutturalis (Meyrick), new combination
}

\author{
Plate 255, Figures $\mathrm{I}-\mathrm{I} \mathrm{b}$
}

Argyroploce gutturalis Meyrick, 1934, Ann. Mag. Nat. Hist. (Ser. 10), 14: 407.

" o. $12 \mathrm{~mm}$. . . São Tomé, Oct. 29; 3 ex. . .."

Type: The male so marked in the British Museum, dated "29.X.r932". Slide No. 7075 .

Figure 1, left wings; 1a, lateral aspect of aedeagus; $\mathrm{I} b$, ventral view of male genitalia with aedeagus removed.

\section{Olethreutes gyrotis (Meyrick), new combination}

Plate 255, Figures 2-2b

Argyroploce gyrotis Meyrick, I 909, Journ. Bombay Nat. Hist. Soc., 19: 604.

"․ I $5^{-1} 7 \mathrm{~mm}$. . . Khasis, in June and July; nine specimens."

Lectotype: A female measuring 17 mm., "Khasi Hills, Assam. 7.1906." Slide No. 7233. The original nine specimens are in the Meyrick collection and the series contains both sexes.

Figure 2, left wings; 2a, ventral view of female genitalia; 2b, detail of genital plate and ostium.

\section{Olethreutes halantha (Meyrick), new combination}

\section{Plate 255 , Figures $3-3$ a}

Argyroploce halantha Meyrick, I909, Journ. Bombay Nat. Hist. Soc., I9: 601.

“ eight specimens."

Lectotype: วิ, I 8 mm., "Palni Hills, S. India. Campbell. .o6." Slide No. 7199.

Figure 3 , left wings; 3 a, ventral view of male genitalia with aedeagus in sitn.

\section{Olethreutes halixanta (Meyrick), new combination}

Plate 255 , Figures $4^{-4} 4^{a}$

Argyroploce halixamta Meyrick, I910, Trans. Ent. Soc. London, 1910: 435.

" ${ }^{\circ}$. $18 \mathrm{~mm}$. . . Borneo, Pulo Laut, in June; one specimen."

Type: The above indicated male dated ".6.9I". Slide No. 7200.

Figure 4 , left wings; 4 a, ventral view of male genitalia with aedeagus $i n$ sitn. 

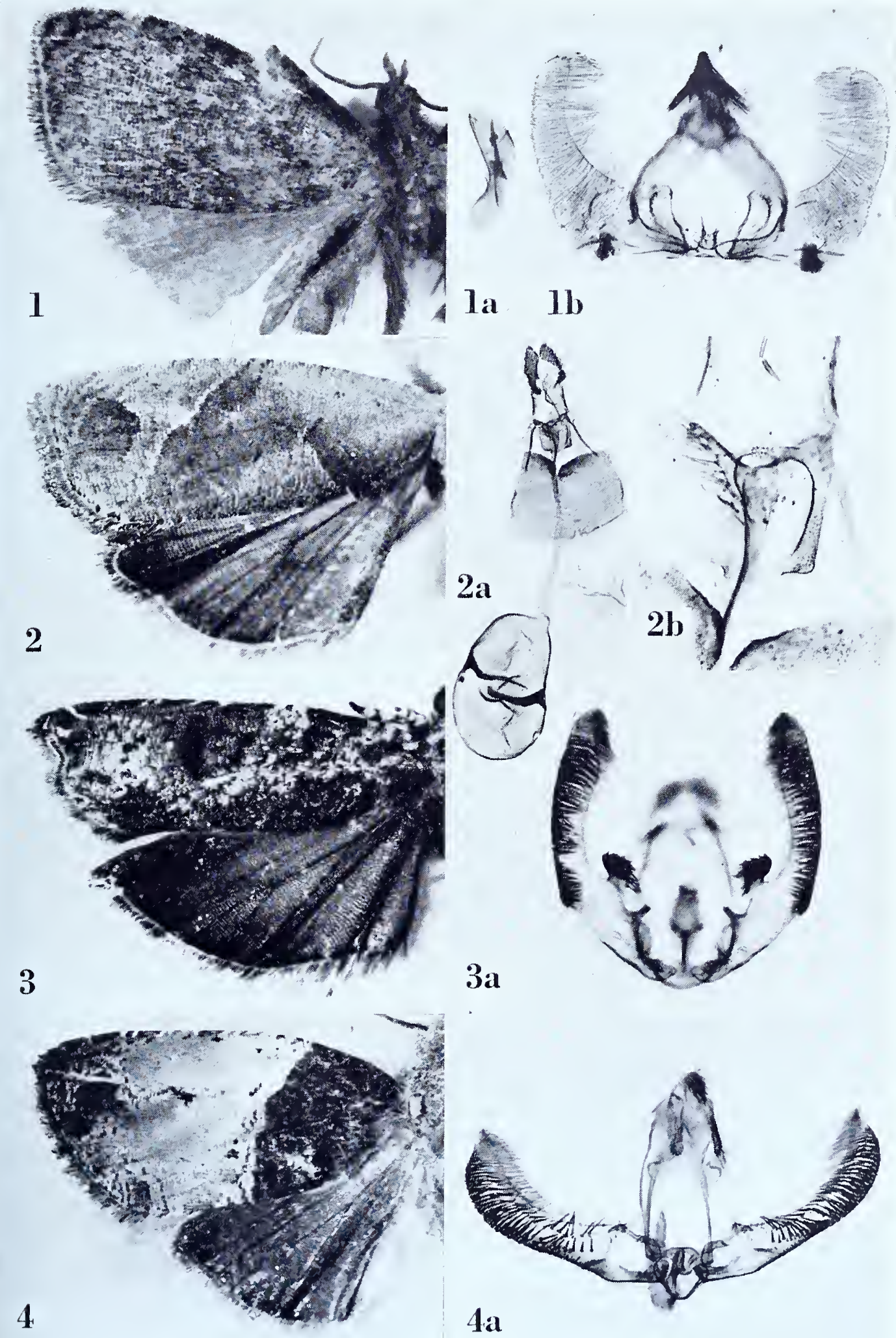


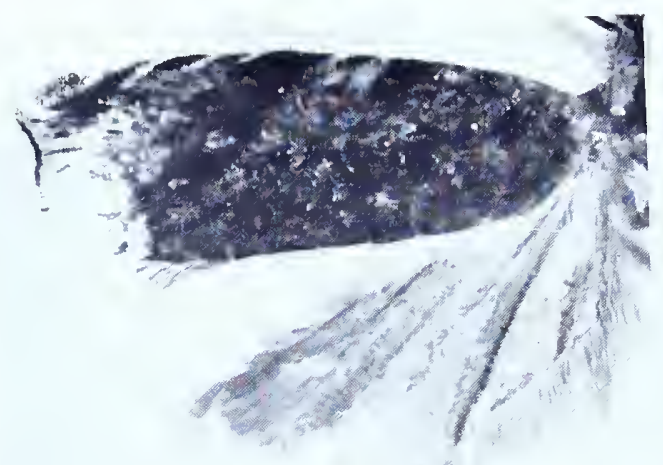

1

$3 \mathrm{~b}$
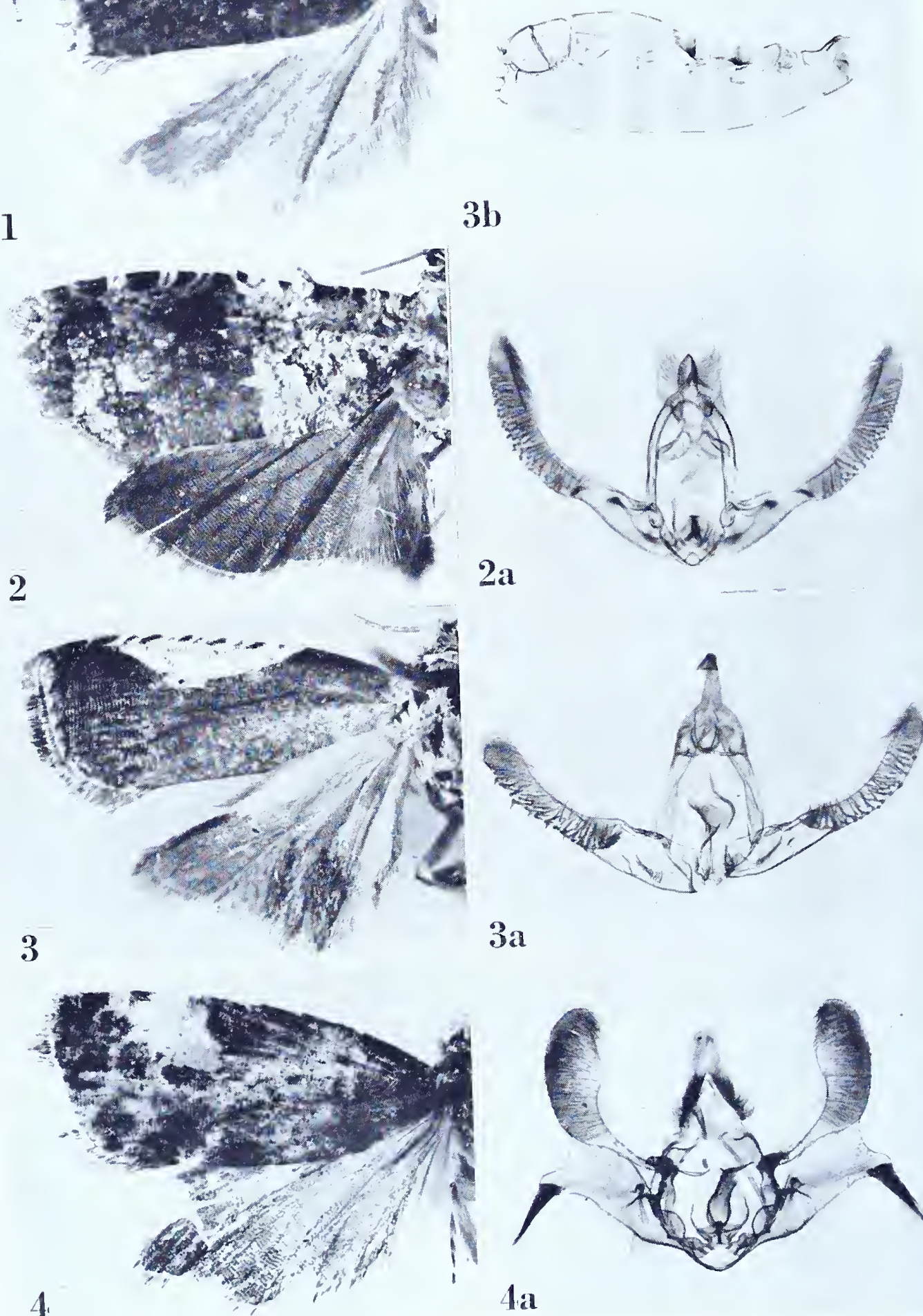

$3 a$ 


\section{Olethreutes hapalaspis (Meyrick), new combination}

Plate 256 , Figure 1

Acroclita hapalaspis Meyrick, I93 I, Exotic Microlepidoptera, 4: I 44.

" o. I I mm. ... Japan, Hasimoto, June (S. Issiki); I ex."

Type: The specimen indicated above without abdomen, dated "20.6.20".

Figure I, left wings.

\section{Olethreutes harmonica (Meyrick), new combination}

Plate 256 , Figures 2-2a

Platypeplns harmonica Meyrick, I905, Journ. Bombay Nat. Hist. Soc., i6: 584.

" o. I $8 \mathrm{~mm}$. ... One specimen, Peradeniya, in August (Green)."

Type: The male denoted above dated ".8.02". Slide No. 7207.

Figure 2, left wings; 2a, ventral view of male genitalia with aedeagus in situ.

\section{Olethreutes hedraea (Meyrick), new combination \\ Plate 256 , Figures $3-3 b$}

Platypeplus hedraea Meyrick, ig05, Journ. Bombay Nat. Hist. Soc., i6: $5^{8} 4$.

" $\delta$. I $4^{-1} 5 \mathrm{~mm}$. . . . Two specimens, Kandy, Ceylon, in August and September (Green). Easily known by the white costal patch."

Lectotype: The male measuring $15 \mathrm{~mm}$., dated ".9.02". Slide No. 7258.

Figure 3 , left wings; 3 a, ventral view of male genitalia with aedeagus in sitn; $3 \mathrm{~b}$, latcral aspect of denuded abdomen to show dorsal pits of $5^{\text {th }}$ and 6 th tergites.

\section{Olethreutes hedrotoma (Meyrick), new combination}

Plate $25^{6}$, Figures $4-4$ a

Argyroploce hedrotoma Meyrick, 1938, in Caradja and Meyrick, Deuts. Ent. Zeit. Iris, $5^{2}$ : I.

"§. I9 mm. . . Y Yül., 3,200-4,000 m., V. VI; 2 ex."

Lectotype: The male measuring 19 mm., "Likiang, China. II. .7·34." Slide No. 7296. Despite the discrepancy in date I think there is no doubt that the lectotype is one of the original specimens and that the difference is due to a printing error.

Figure 4, left wings; 4 a, ventral view of male genitalia with aedeagus in sitn. 
Olethreutes heliophanes (Meyrick), new combination

Plate 257, Figures I-Ia

Argyroploce heliophanes Meyrick, 1922, Exotic Microlepidoptera, 2: 523.

“

Lectotype: The male dated "5.20". Slide No. 64I 5.

Figure I, left wings; Ia, ventral view of male genitalia with aedeagus in situ.

\section{Olethreutes hemigrapta (Meyrick), new combination}

\section{Plate 257 , Figures $2-2 \mathrm{c}$}

Argyroploce henigrapta Meyrick, I93 I, Exotic Microlepidoptera 4: I 33 .

"q. I $5 \mathrm{~mm}$. . . Formosa, Taihoku, May (S. Issiki); I ex. Allied to aprobola."

Type: The female indicated above dated ".5.21". Slide No. 7219.

Figure 2, left wings; $2 a$, ventral view of female genitalia; $2 b$, detail of ostium; $2 \mathrm{c}$, signa.

\section{Olethreutes hemiopta (Meyrick)}

See Olethrentes threnodes (Meyrick).

\section{Olethreutes hemiplaca (Meyrick), new combination}

\section{Plate 257 , Figures $3-3^{a}$}

Argyroploce hemiplaca Meyrick, I922, Exotic Microlepidoptera, 2: 525. (Type: Paris.) Argyroploce albipalpis Meyrick, I93 I, Exotic Microlepidoptera, 4: I 40.

\section{[albipalpis]}

" $\sigma^{7}+$. I 5-17 mm. . . . China, 'Tientsin; 4 ex."

Lectotype: The male measuring is mm., "Tientsin, China. FWT. .28." Slide No. 7302 .

Figure 3 , left wings; 3 a, ventral view of male genitalia with aedeagus in sit $n$.

\section{Olethreutes herbifera (Meyrick), new combination}

\section{Plate 257 , Figures $4-4$ a}

Argyroploce herbifera Meyrick, i909, Journ. Bombay Nat. Hist. Soc., i 9: 603. " $\hat{\jmath}$ ㅇ․ 2 I-22 mm. . . Khasis, in October; Maskeliya, Ceylon, in May (de Mowbray); four specimens."

Lectotype: A male measuring 2 I mm., "Khasi Hills, Assam. .ıo.ı 9o6." Slide No. $725^{2}$.

Figure 4, left wings; 4 a, ventral view of male genitalia with aedeagus in situ. 

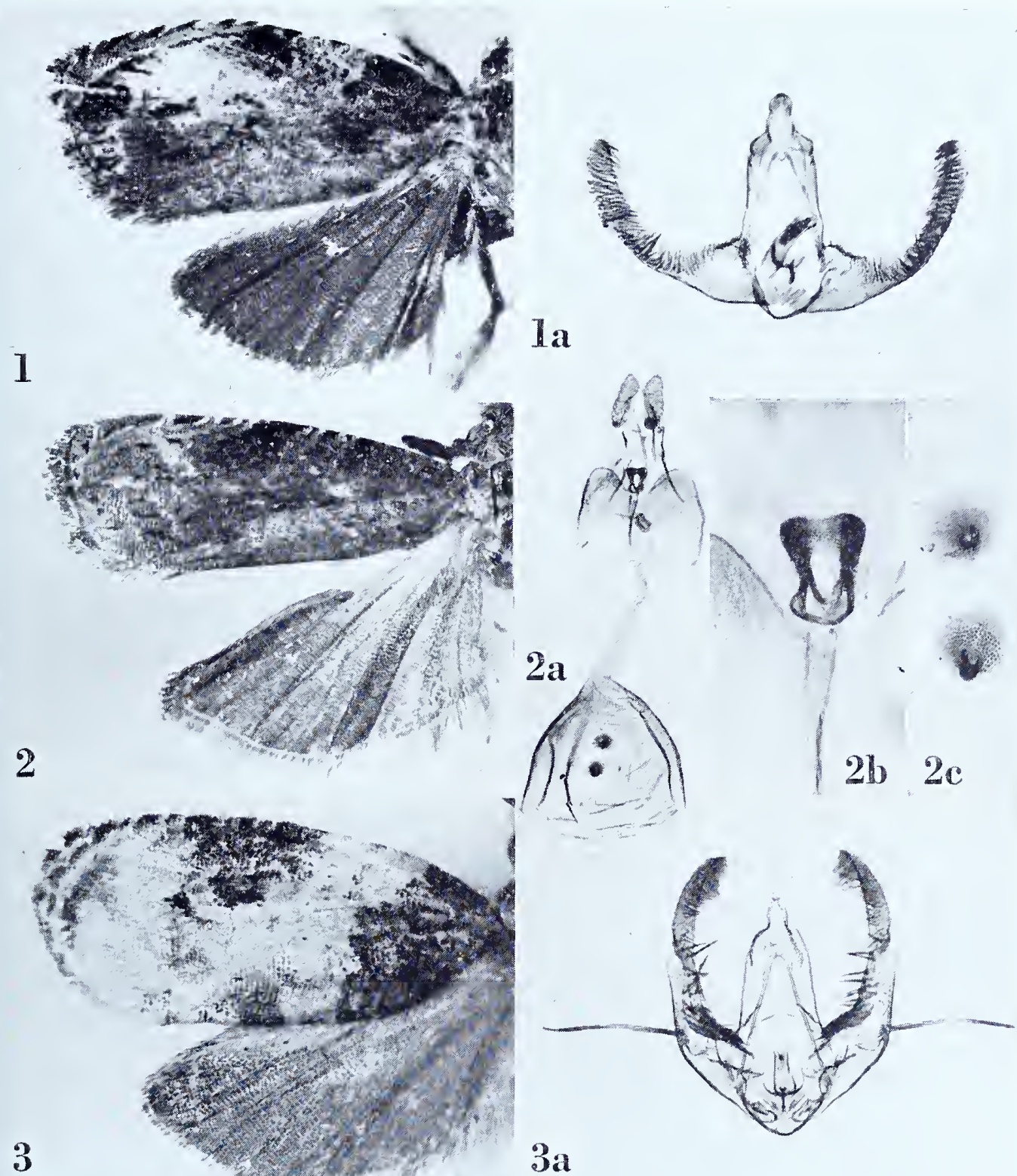

3
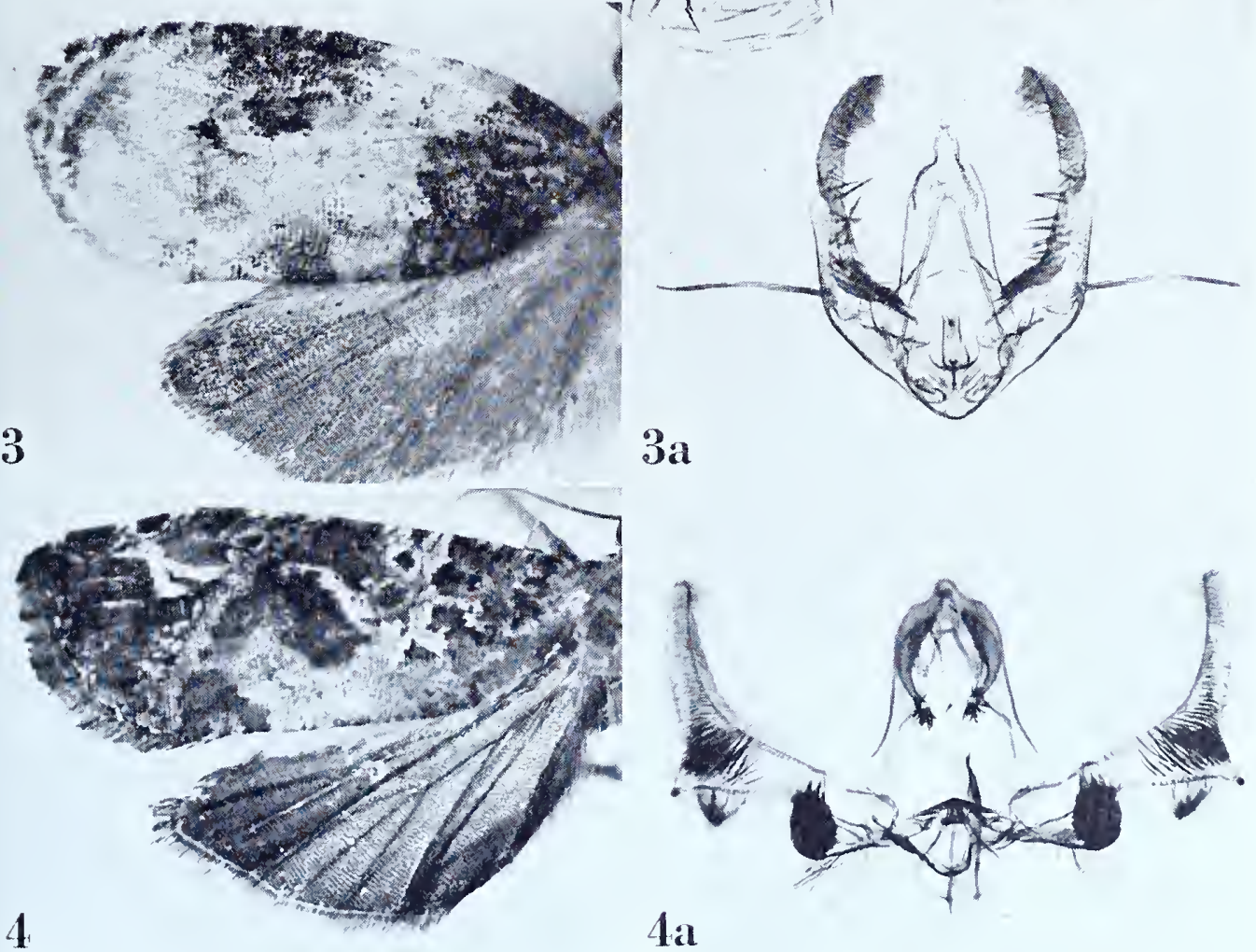

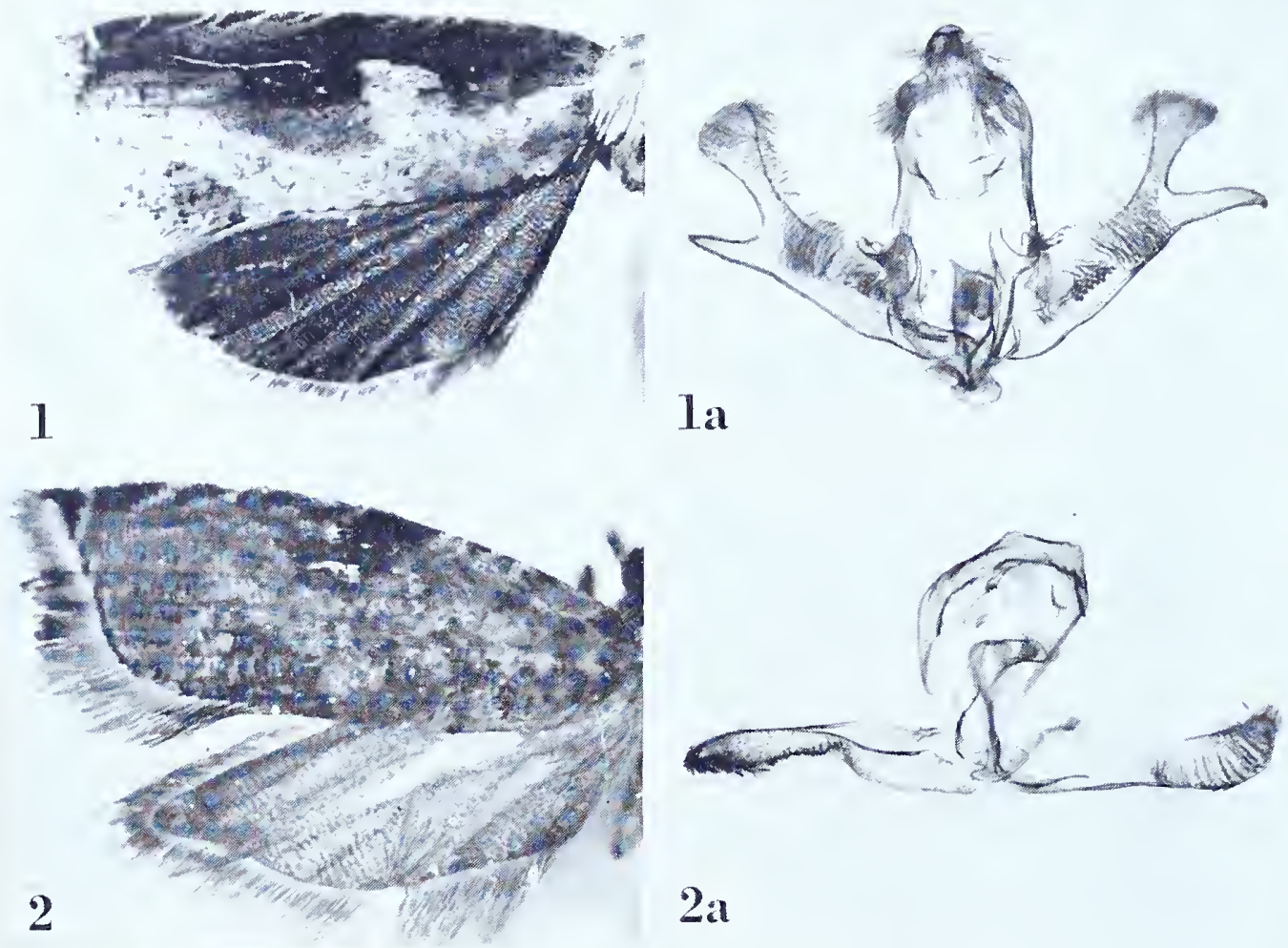

$2 a$
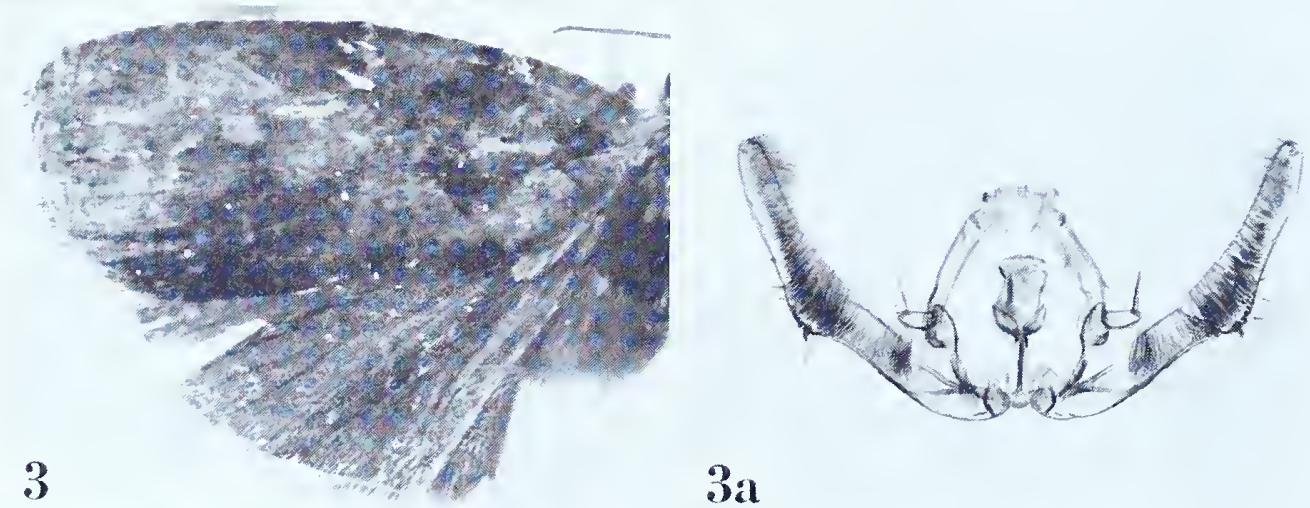

$3 a$
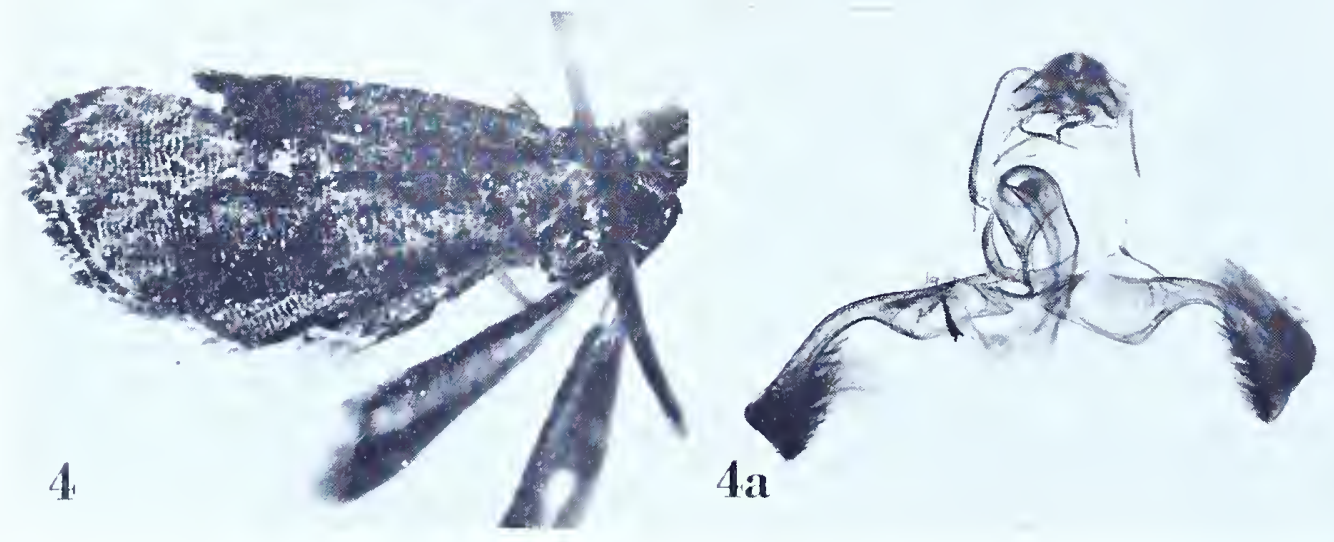


\title{
Olethreutes herbosa (Meyrick), new combination
}

Plate 258 , Figures I-Ia

Argyroploce herbosa Meyrick, 1909, Journ. Bombay Nat. Hist. Soc., I9: 600.

" ${ }^{\text {fop. }}$ I $^{-1} 5 \mathrm{~mm}$. . . . Khasis, in June, October, and November; four specimens."

Lectotype: A male measuring 14 mm., "Khasi Hills, Assam. .I I.I906." Slide No. $722 \mathrm{I}$.

Figure I, left wings; ra, ventral view of male genitalia with aedeagus in situ.

\section{Olethreutes heteraspis (Meyrick)}

See Olethrentes semiculta (Meyrick).

\section{Olethreutes hilaraspis (Meyrick), new combination}

\author{
Plate 258, Figures 2-2a
}

Argyroploce hilaraspis Meyrick, I93 I, Exotic Microlepidoptera, 4: І 39.

" fo. I I I-I 2 mm. . . Assam, Khasis, July, September; 2 ex. Perhaps allied to cerographa."

Lectotype: The male, "Khasi Hills, Assam. 7.1906." Slide No. 7269.

Figure 2, left wings; 2 a, ventral view of male genitalia with aedeagus $i$ in situ.

\section{Olethreutes hilarograpta (Meyrick), new combination}

Plate 258 , Figures $3^{-} 3^{a}$

Argyroploce litarograpta Meyrick, I 93 I, Exotic Microlepidoptera, 4: 42I.

“ ${ }^{\text {* }}$..$~ I 3^{-1} 7 \mathrm{~mm}$. .. J Java, Seneng, bred from larvae feeding on leaves of a species of Anonaceae (Dr. L. G. E. Kalshoveu); Assam, Khasis, December; 4 ex."

Lectotype: The male, "Khasi Hills, Assam. .r2.1906." Slide No. 7273. Two specimens are missing.

Figure 3 , left wings; 3 a, ventral view of male genitalia with aedeagus in sitn.

\section{Olethreutes hoplista (Meyrick), new combination}

\section{Plate $25^{8}$, Figures $4^{-4} 4^{a}$}

Argyroploce hoplista Meyrick, 1927, Exotic Microlepidoptera, 3: 340.

" 추. I 1-I 4 mm. . . Sumatra, Sinabaeng, 3,300 feet, bred July from Barleria sp. (Fulmek); 2 ex.; India, Bombay (Maxwell), Belgaum (Fletcher), October, 2 ex."

Lectotype: ô, I 3 mm., "Sinabaeng, Sumatra. F. bred. .7.25." Slide No. 7307.

Figure 4 , left wings; 4 a, ventral view of male genitalia with aedeagus in situ (one strong cornutus present). 


\title{
Olethreutes hyalitis (Meyrick), new combination
}

\author{
Plate 259, Figures I-Ia
}

Argyroploce hyalitis Meyrick, I 909, Journ. Bombay Nat. Hist. Soc., I9: 599.

" 3 f 9 . I $5^{-1} 8 \mathrm{~mm}$. . . . Khasis, in June and July; sixteen specimens."

Lectotype: A male measuring I5 mm., "Khasi Hills, Assam. .6.19o6." Slide No. 7286. Five specimens are missing.

Figure I, left wings; ra, ventral view of male genitalia with aedeagus in situ.

\section{Olethreutes hygrantis (Meyrick), new combination}

\section{Plate 259, Figures 2-2b}

Argyroploce hygrantis Meyrick, I9I I, Trans. Linnean Soc., I4:270.

" $\hat{O}$. $17 \mathrm{~mm}$... . Silhouette, south side of Mont Pot-à-eau, at I, 500 feet, in August; one specimen."

Type: The specimen so labelled in the British Museum, "Seychelles, Silhouette, I, 500 ft., Mont Pot-à-eau. VIII.rgo8. H. Scott." Slide No. 7077.

Figure 2 , left wings; $2 \mathrm{a}$, ventral view of male genitalia with aedeagus in situ; $2 \mathrm{~b}$, part of denuded abdomen showing posterior tufts.

\section{Olethreutes impolita (Meyrick), new combination}

Plate 259 , Figures $3^{-3}$ a

Argyroploce impolita Meyrick, 1917, 'Trans. Ent. Soc. London, 1917: 28.

“ ${ }^{\circ}$. $24 \mathrm{~mm}$. . . Colombia, San Antonio, 5,80o feet, in November; one specimen."

Type: The male indicated above dated ". I 1.07". Slide No. 6420.

Figure 3 , left wings; 3 a, ventral view of male genitalia with aedeagus in sitn ( 3 or 4 strong setae at base of cucullus on inner margin).

\section{Olethreutes informalis (Meyrick), new combination}

Plate 259, Figures $4-4$ a

Argyroploce informalis Meyrick, I935, in Caradja and Meyrick, Materialien zu einer Microlepidopteren Fauna der Chinesischen Provinzen Kiangsu, Chekiang und Hunan, 59.

“ $\hat{~}$. I 2 mm. . . L Lungtan, I6.IX. I ex."

Type: The male referred to above labelled, "Nanking, China. H. I6.9.33". Slide No. 7294 .

Figure 4 , right wings (image reversed); 4 a, ventral view of male genitalia with aedeagus removed. 

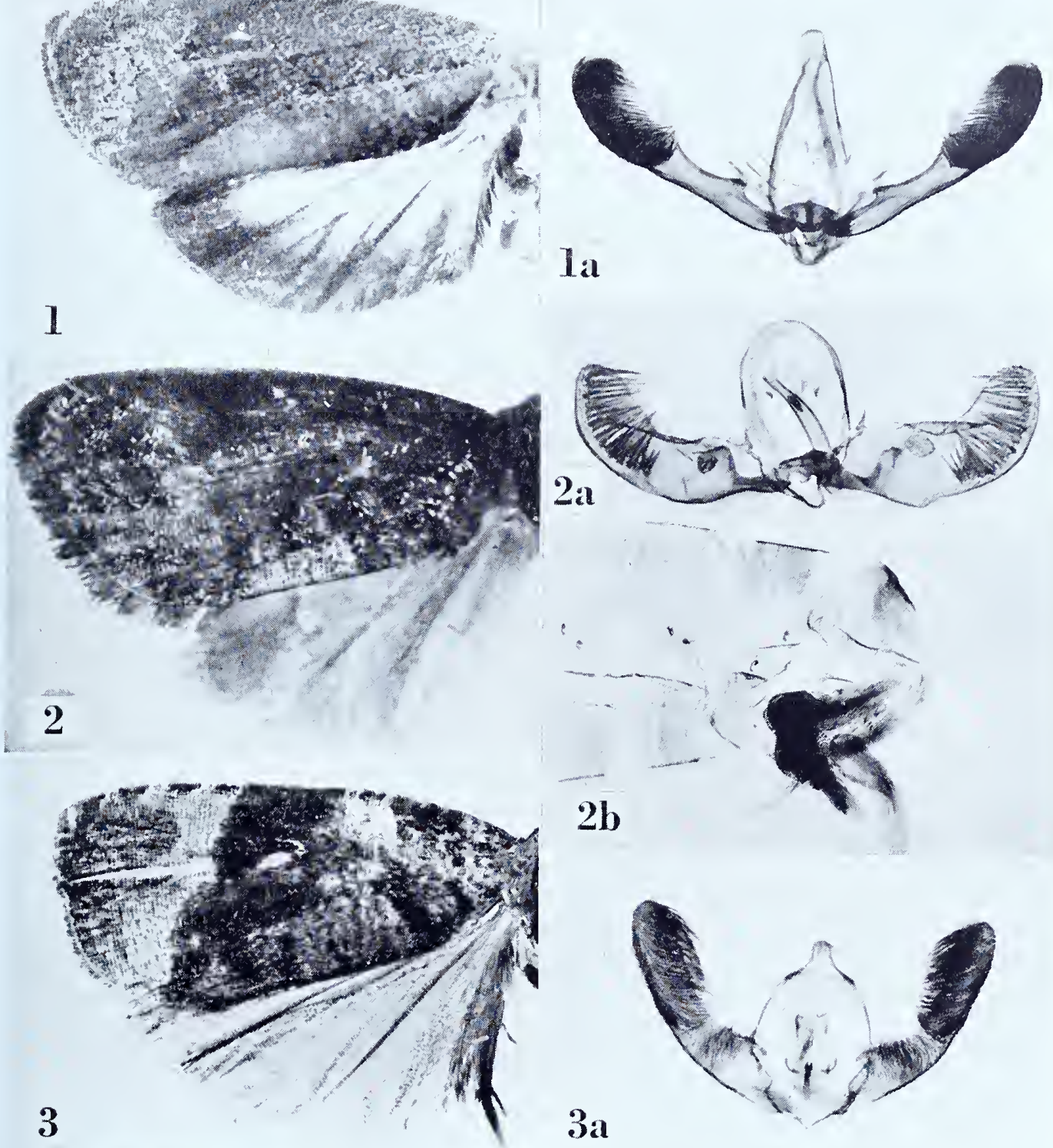

3a
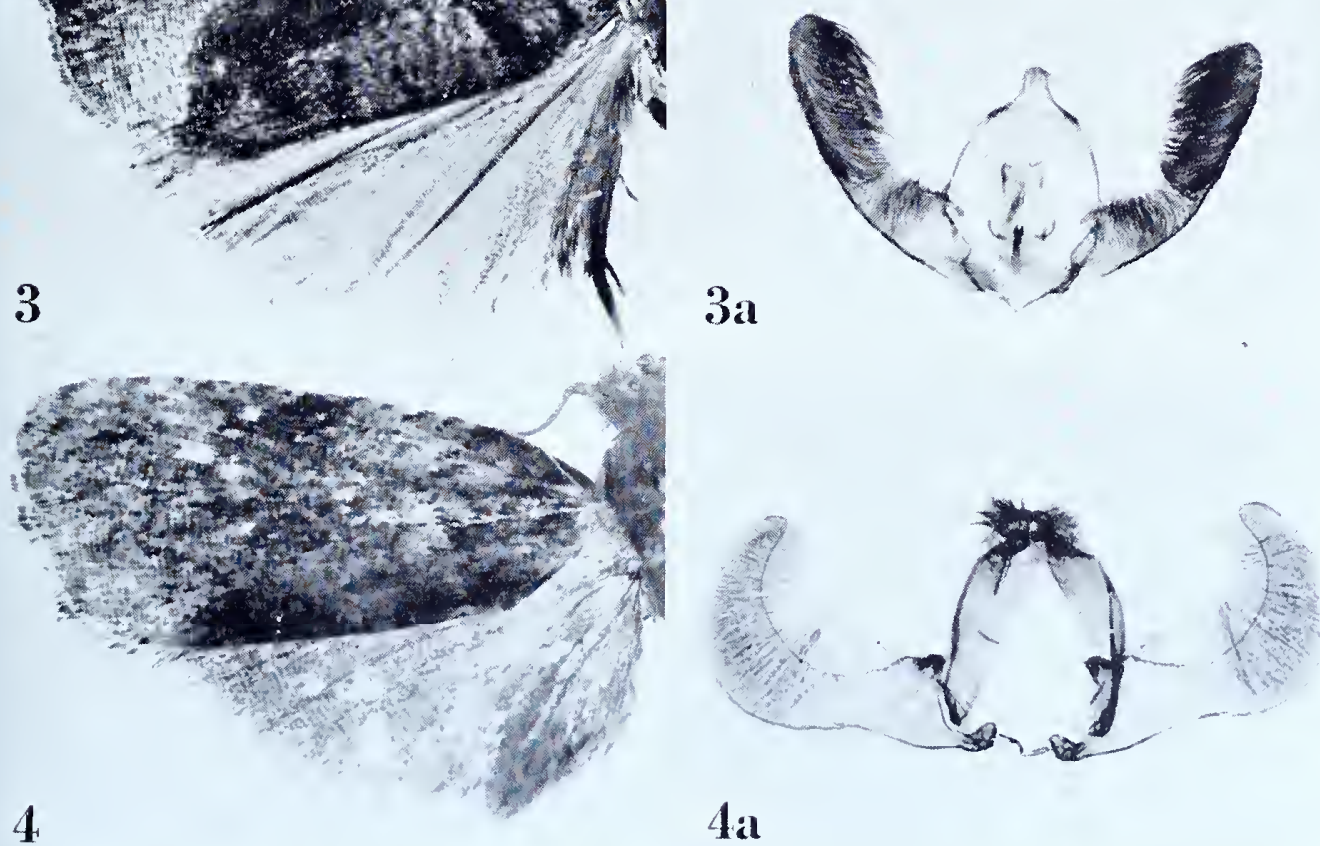


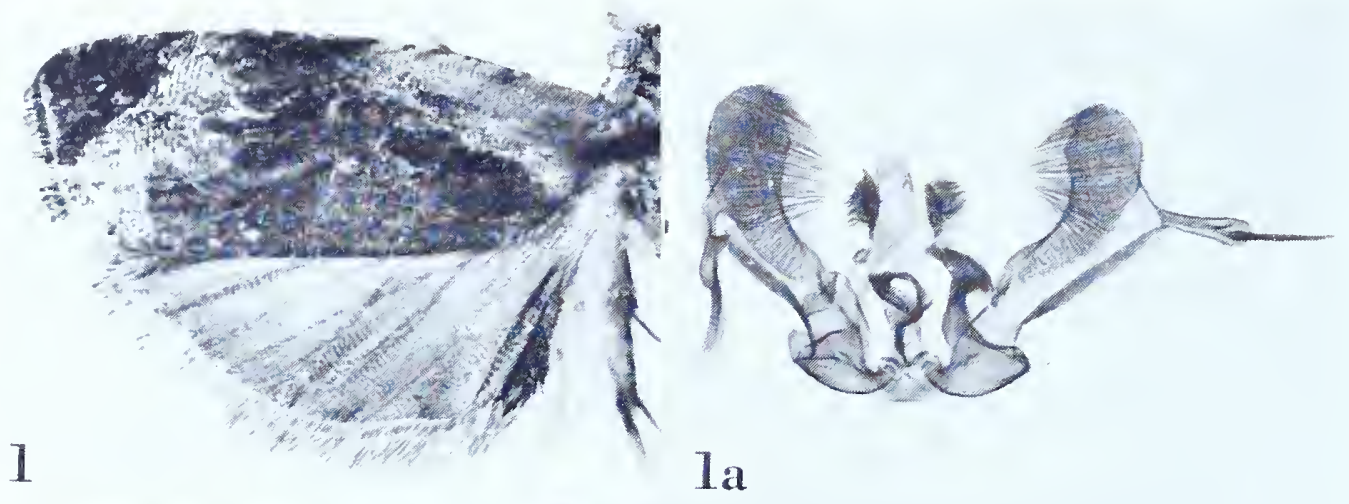

2
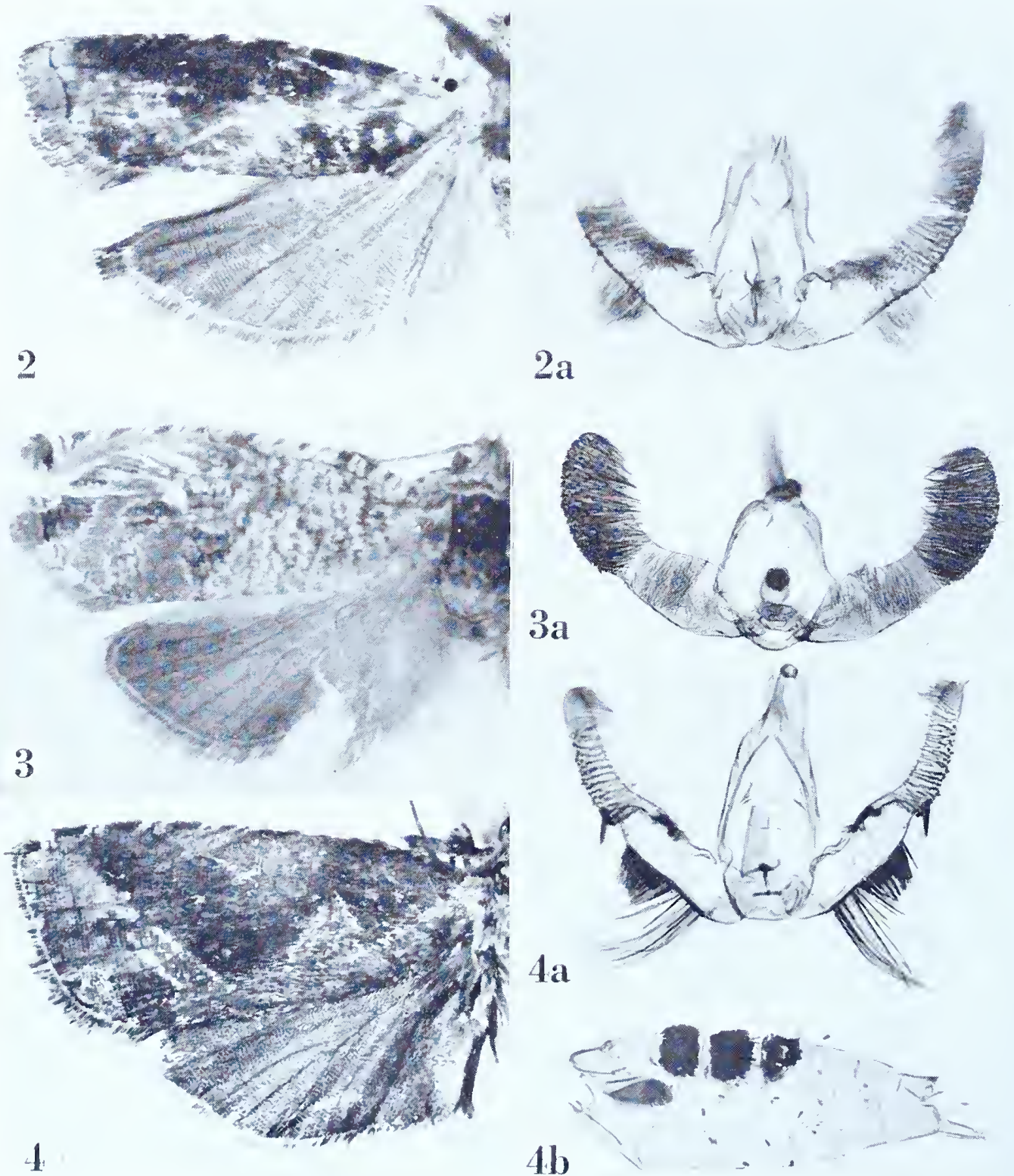

$4 a$

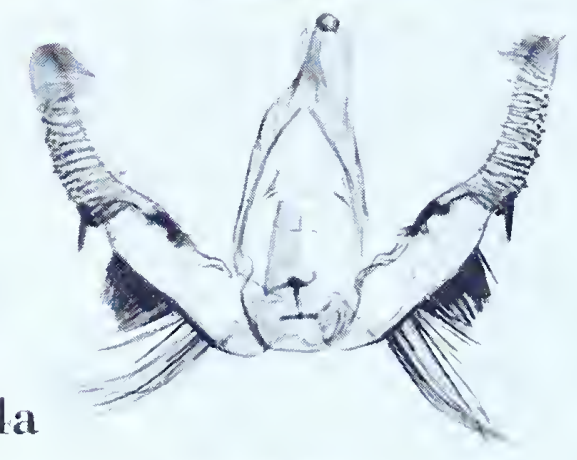

$4 b$

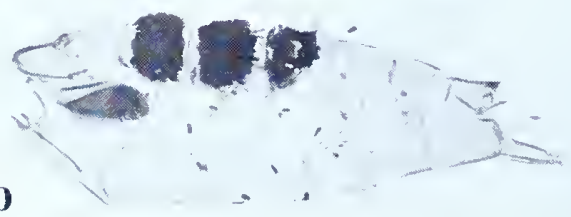




\section{Olethreutes iograpta (Meyrick), new combination}

Plate 260, Figures I-ra

Eucosma iograpta Meyrick, I907, Journ. Bombay Nat. Hist. Soc., I 8: I 37.

" $\delta^{*}+$ I $^{-1} 5 \mathrm{~mm}$. . . Khasi Hills, in June and July; twelve specimens."

Lectotype: A male measuring I4 mm., "Khasi Hills, Assam. .7.igo6." Slide No. 7240 . One specimen is missing.

Figure I, left wings; ra, ventral view of male genitalia with aedeagus in situ.

\section{Olethreutes iophaea (Meyrick), new combination}

Plate 260, Figures 2-2a

Argyroploce iophaea Meyrick, i912, Journ. Bombay Nat. Hist. Soc., 21 : 873 .

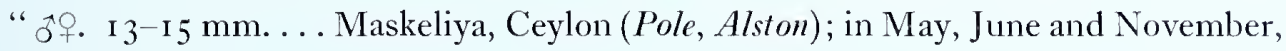
four specimens."

Lectotype: The male dated “.5.04". Slide No. 7218.

Figure 2, left wings; 2 a, ventral view of male genitalia with aedeagus in situ.

\section{Olethreutes iorrhoa (Meyrick), new combination}

Plate 260, Figures $3^{-} 3^{a}$

Argytoploce iorrhoa Meyrick, 1914, Exotic Microlepidoptera, I : 196.

“ ô. I $8 \mathrm{~mm}$. ... Nyassaland, Mt. Mlanje, in December (Neave); one specimen. 'Type in British Museum."

Type: The male so marked in the British Museum, "Mt. Mlanje, Nyasaland. Ir.XII.r9r3. S. A. Neave." A small white label bears the inscription, "M40". Slide No. 7309 .

Figure 3 , left wings; 3 a, ventral view of male genitalia with aedeagus in sitn.

\section{Olethreutes ioxantha (Meyrick), new combination}

\section{Plate 260, Figures $4-4 \mathrm{~b}$}

Enarmonia ioxantha Meyrick, I907, Journ. Bombay Nat. Hist. Soc., I8: I39.

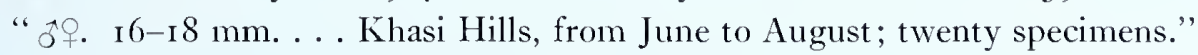

Lectotype: ô, I6 mm., dated "7.1906”. Slide No. 7172. Ten specimens are missing.

Figure 4 , left wings; $4 \mathrm{a}$, ventral view of male genitalia with aedeagus in situ; $4 \mathrm{~b}$, denuded abdomen showing dorsal tuft and antero-lateral fold which receives a hairpencil. 


\section{Olethreutes isodoxa (Meyrick), new combination}

Plate 26I, Figure I

Argyroploce isodoxa Meyrick, I928, Exotic Microlepidoptera, 3: 444.

" I. I6 mm. ... New Hebrides, Tanna, September (Buxton); I ex. (Brit. Mus.). Devoid of character but the example is in very good condition."

Type: The above indicated female so marked in the British Museum, "S. New Hebrides, Tanna. -ix. I925. P. A. Buxton and G. H. Hopkins." The abdomen of the type is missing.

Figure $\mathrm{I}$, left wings.

\section{Olethreutes isopercna (Meyrick), new combination}

Plate 26I, Figures 2-2a

Argyroploce isopercna Meyrick, I927, Exotic Microlepidoptera, 3: 340.

" ふ. 2 I mm. . . Colombia, San Antonio, 6,600 feet, February; i ex."

Type: The above indicated male dated ".2.20". Slide No. 6423.

Figure 2, left wings; 2a, ventral view of male genitalia with aedeagus in sitn.

\section{Olethreutes lecythocera (Meyrick), new combination}

Plate 26I, Figures $3-3 \mathrm{a}$

Argyroploce lecythocera Meyrick, I937, Exotic Microlepidoptera, 5: i 60.

Argyroploce lecythophora Meyrick, I 939, Trans. R. Ent. Soc. London, 89: 49.

“... ofo. I6-i $8 \mathrm{~mm}$. . . ."

Lectotype: A male measuring I6 mm., "Telawa, Java. K. bred .i2.35." Slide No. 7215. 'The species was partially described in the first reference, validating the name. The original series consisted of four specimens.

Figure 3 , left wings; 3 a, ventral view of male genitalia with aedeagus in sitn.

\section{Olethreutes leucaspis (Meyrick), new combination}

Plate 26I, Figures $4-4 \mathrm{a}$

Eucosma leucaspis Meyrick, I902, in Gardiner, The Fauna and Geography of the Maldive and Laccadive Archipelagoes, I : 126.

" ô. I4-1 5 mm. ... Minikoi; 3 specimens."

Type: At Cambridge. The species is figured from a specimen in the British Museum from Assam. Slide No. BM. 82.

Figure 4 , left wings; 4 a, ventral view of male genitalia with aedeagus in sit $n$. 

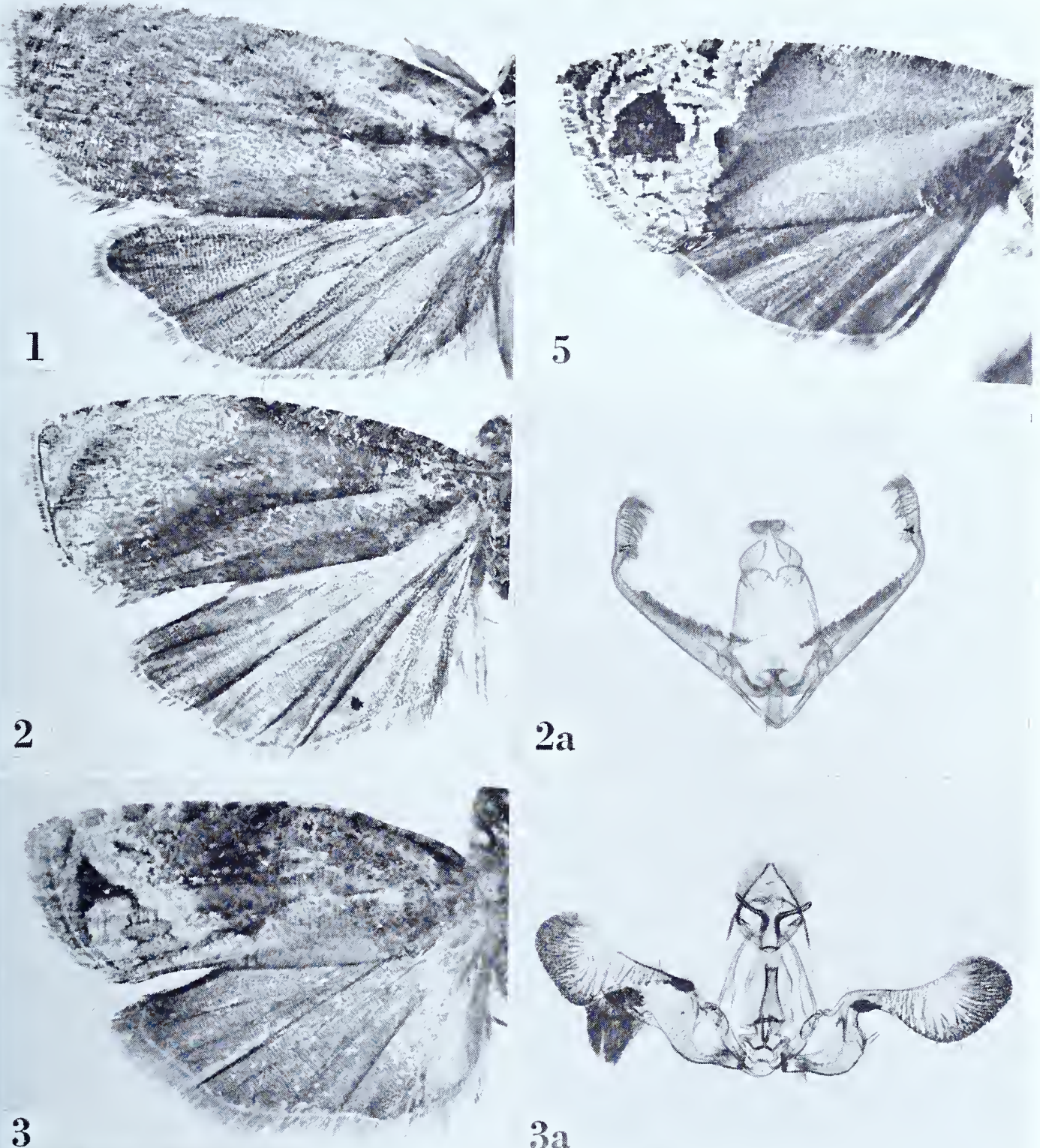

$3 \mathrm{a}$
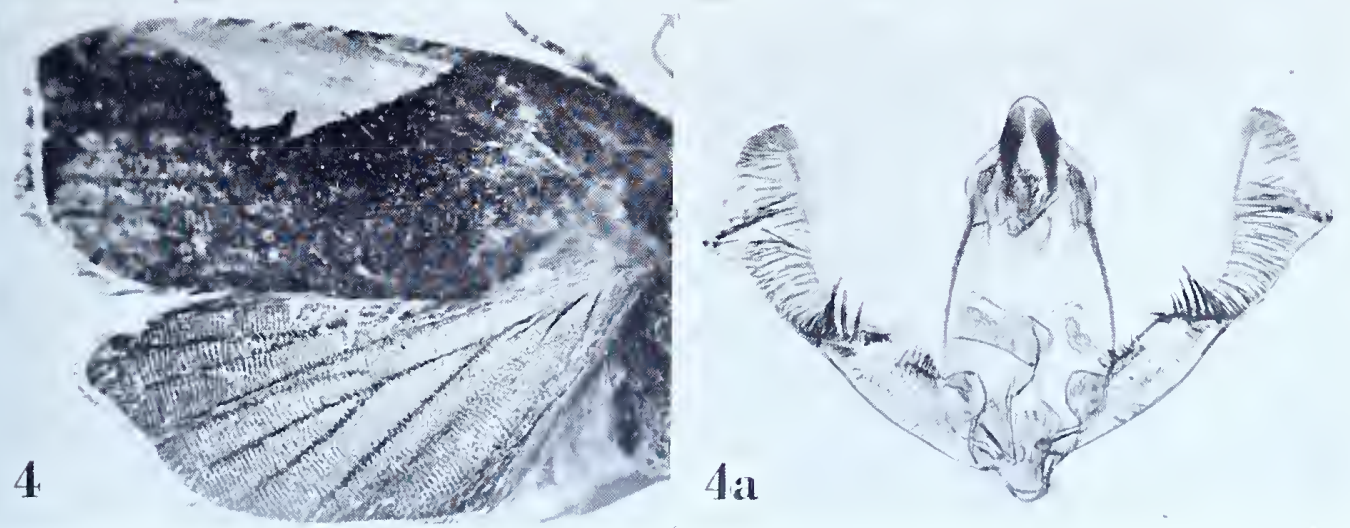


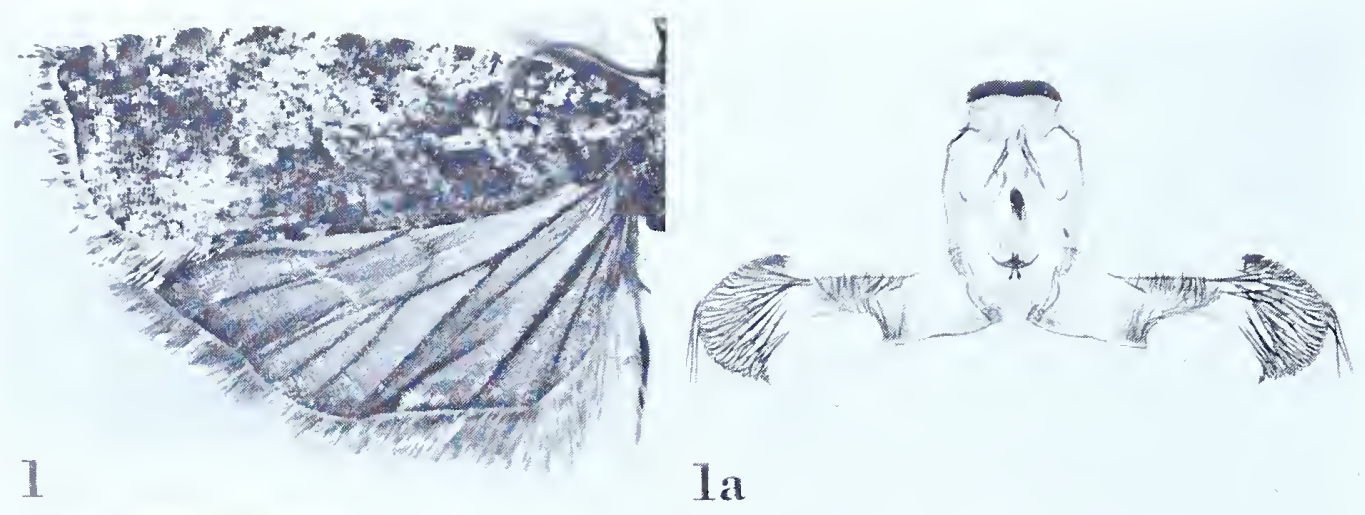

2
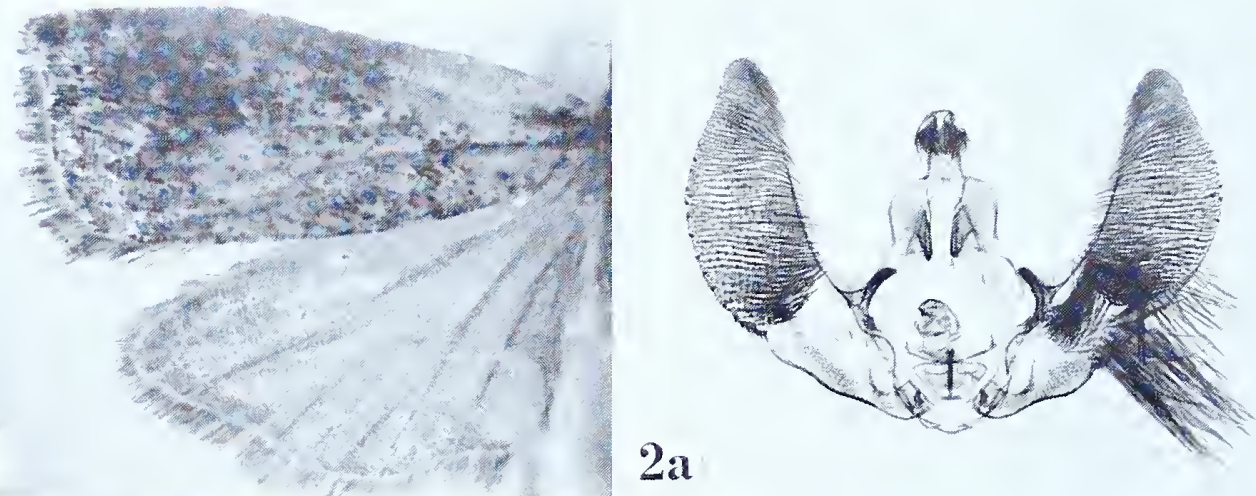

3
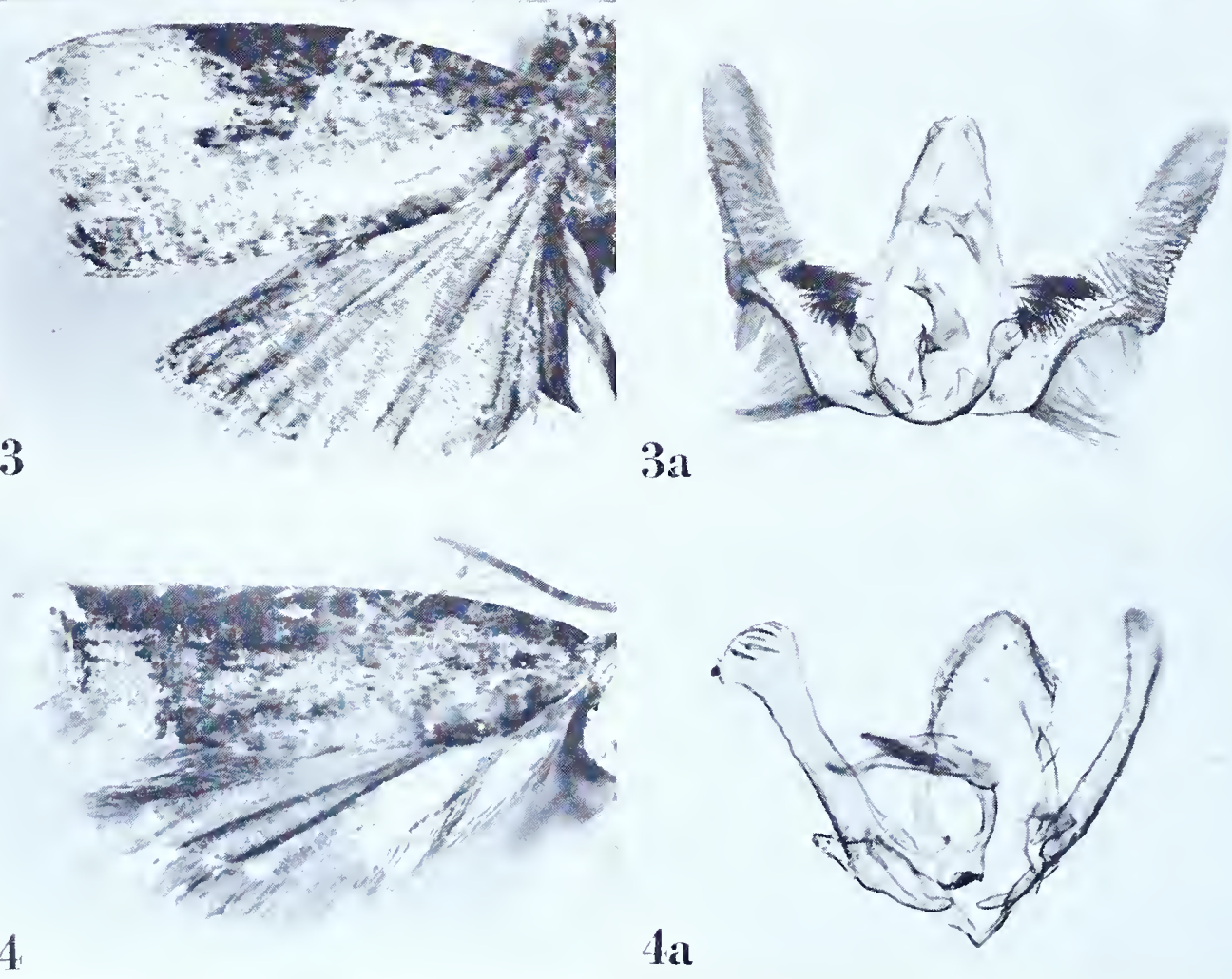


\section{Olethreutes litigiosa (Meyrick), new combination}

Plate 262, Figures I-Ia

Eucosma litigiosa Meyrick, i912, Journ. Bombay Nat. Hist. Soc., 21 : 867.

" $\mathcal{O}^{\prime}$. 20-22 mm. . . Khasis, in June, September and October; five specimens."

Lectotype: f, 20 mm., "Khasi Hills, Assam. .9.1906." Slide No. 7174.

Figure I, left wings; ra, ventral view of male genitalia with aedeagus in sitn.

\section{Olethreutes maschalista (Meyrick), new combination}

Plate 262, Figures 2-2a

Argyroploce maschalista Meyrick, 1932, Trans. Ent. Soc. London, 80: 112.

“숭. I 8-2 I mm. . . . Jem-Jem Forest, 8,000-9,000 feet, October; 5 ex."

Type: 'The male so marked in the British Museum, "Abyssinia, Djem-Djem Forest, nearly 9,000 ft. I-X-1926. H. Scott." Slide No. 7320.

Figure 2, left wings; 2a, ventral view of male genitalia with aedeagus in situ.

\section{Olethreutes mensifera (Meyrick), new combination}

Plate 262, Figures $3-3$ a

Argyroploce mensifera Meyrick, 1916, Exotic Microlepidoptera, 2: 19.

" $\hat{0}$. $16 \mathrm{~mm}$.... Sikkim, Darjiling, 5,000 feet, in October (Fletcher); one specimen."

Type: 'The above indicated male labelled, "Phoobsering, Darjiling. 'TBF. 5, $00 \mathrm{O}^{\prime}$ . I0.10". Slide No. 7205 .

Figure 3, left wings; 3 a, ventral view of male genitalia with aedeagus in situ.

\section{Olethreutes metactenis (Meyrick)}

See Phaecadophora fimbriata Walsingham.

\section{Olethreutes microplaca (Meyrick), new combination}

Plate 262, Figures $4-4$ a

Argyroploce microplaca Meyrick, 1912, Journ. Bombay Nat. Hist. Soc., 2 I : 873. " $\sigma^{\text {to}}+$. 8-9 mm. ... Khasis, in October and November, three specimens."

Lectotype: ô, 9 mm., "Khasi Hills, Assam. .ro.ı go6." Slide No. 7216.

Figure 4 , left wings; $4^{\mathrm{a}}$, ventral view of male genitalia with aedeagus in situ. 


\section{Olethreutes milichopis (Meyrick), new combination Plate $26_{3}$, Figure I}

Argyroploce milichopis Meyrick, I93 I, Exotic Microlepidoptera, 4: I32.

"ㅇ. Io mm. . . Japan, Hasimoto, September (S. Issiki); i ex. Allied to numellata."

Type: 'The specimen referred to above, without abdomen, erroneously recorded as a female. The type is dated ".9.20".

Figure I, left wings.

\section{Olethreutes miltographa (Meyrick), new combination}

\section{Plate 263, Figures 2-2b}

Eıcosma miltograplia Meyrick, i907, Journ. Bombay Nat. Hist. Soc., i8: I38.

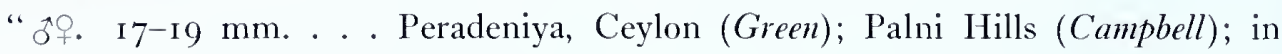
November, four specimens."

Lectotype: O, I 9 mm., "Palni Hills, S. India. Campbell” (no date). Slide No. 7 I 76.

Figure 2, left wings; $2 \mathrm{a}$, ventral view of male genitalia with aedeagus in situ; $2 \mathrm{~b}$, part of denuded abdomen to show posterior tufts.

\section{Olethreutes mixanthes (Meyrick), new combination}

Plate $26_{3}$, Figures $3-3$ a

Argyroploce mixanthes Meyrick, 1932, Exotic Microlepidoptera, 4: 309.

“․ $16 \mathrm{~mm}$. ... Kashmir, Gulmarg, 8,800 feet, July (T. B. Fletcher); I ex. Allied to halantha...."

Type: The specimen referred to above dated ".7.3I", erroneously recorded as a female. Slide No. 72 I 3 .

Figure 3 , left wings; 3 a, ventral view of male genitalia with aedeagus in situ.

\section{Olethreutes mniochlora (Meyrick), new combination}

Plate $26_{3}$, Figures $4-4$ a

Eucosma mniochlora Meyrick, I907, Journ. Bombay Nat. Hist. Soc., I8: I38.

“ ‡९. 22-23 mm. . . Palni Hills (6,000 feet); six specimens (Campbell)."

Lectotype: A male measuring 23 mm., "Palni Hills, S. India. Campbell. 6,00o' .06." Slide No. 7242 .

Figure 4 , left wings; 4 a, ventral view of male genitalia with aedeagus in situ. 

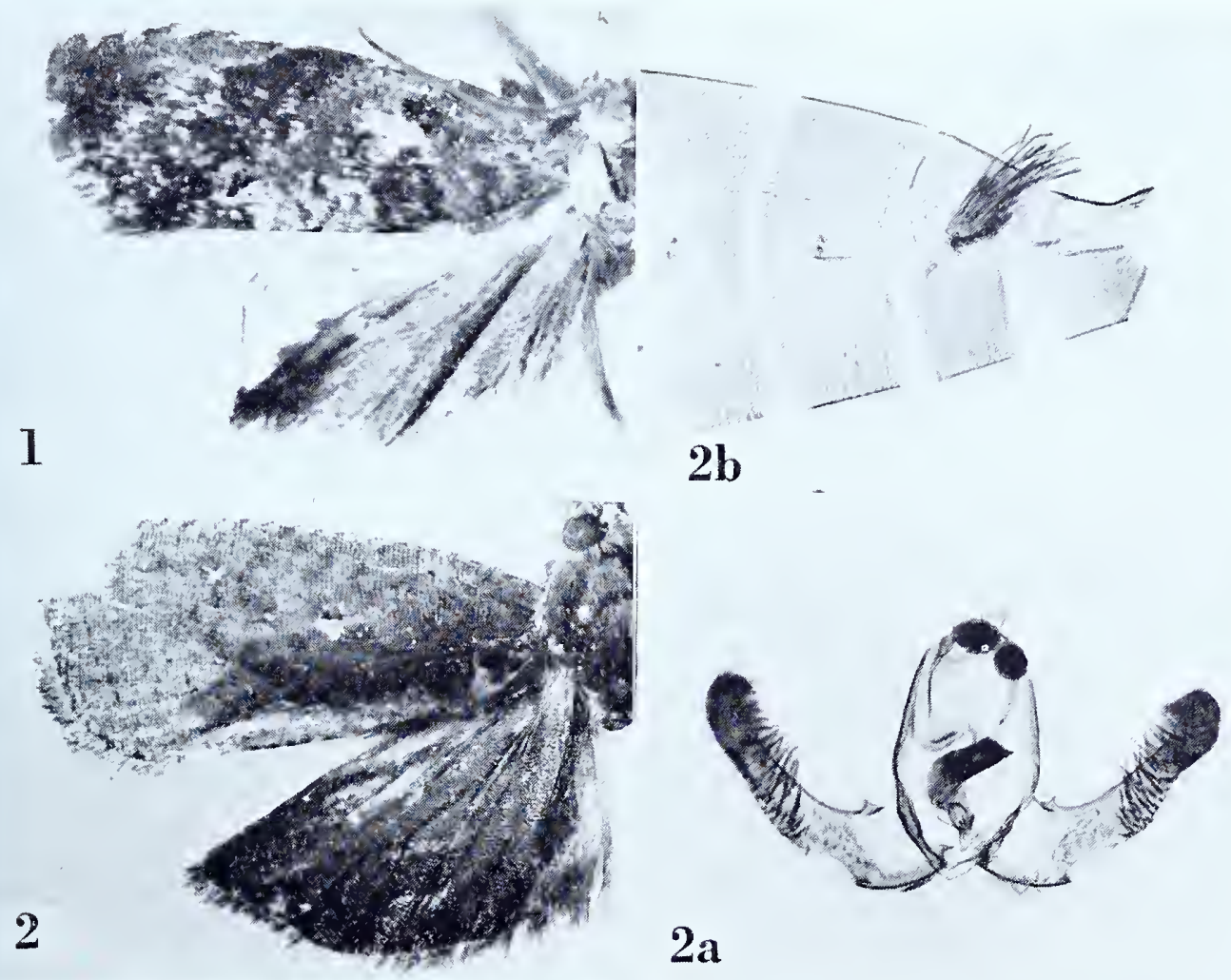

$2 \mathbf{a}$

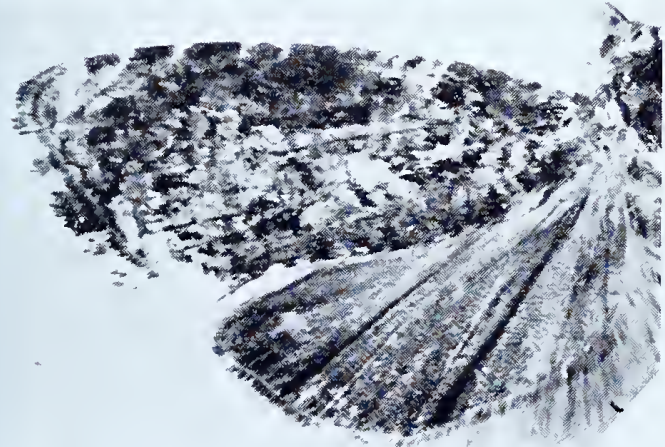

3
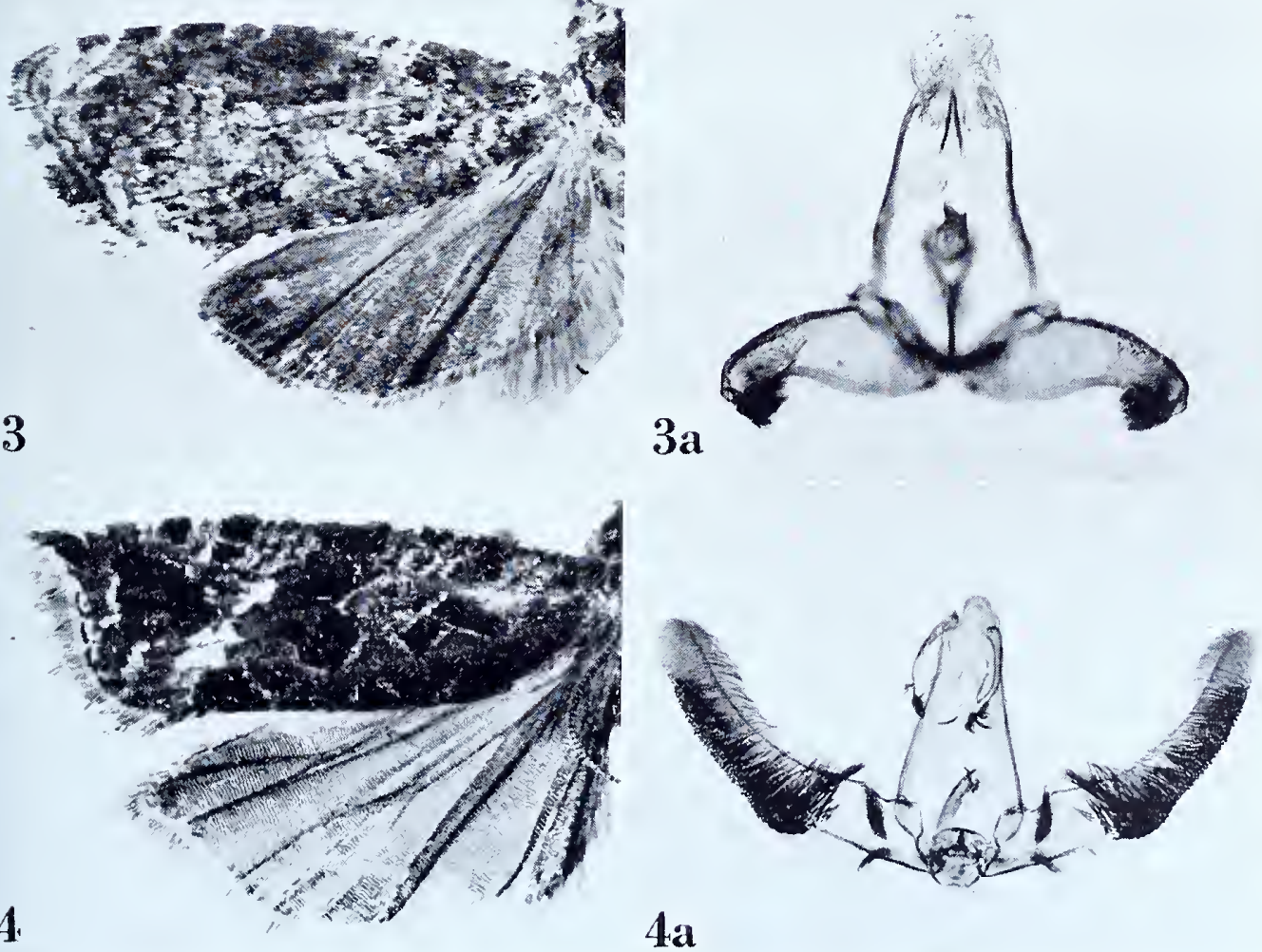


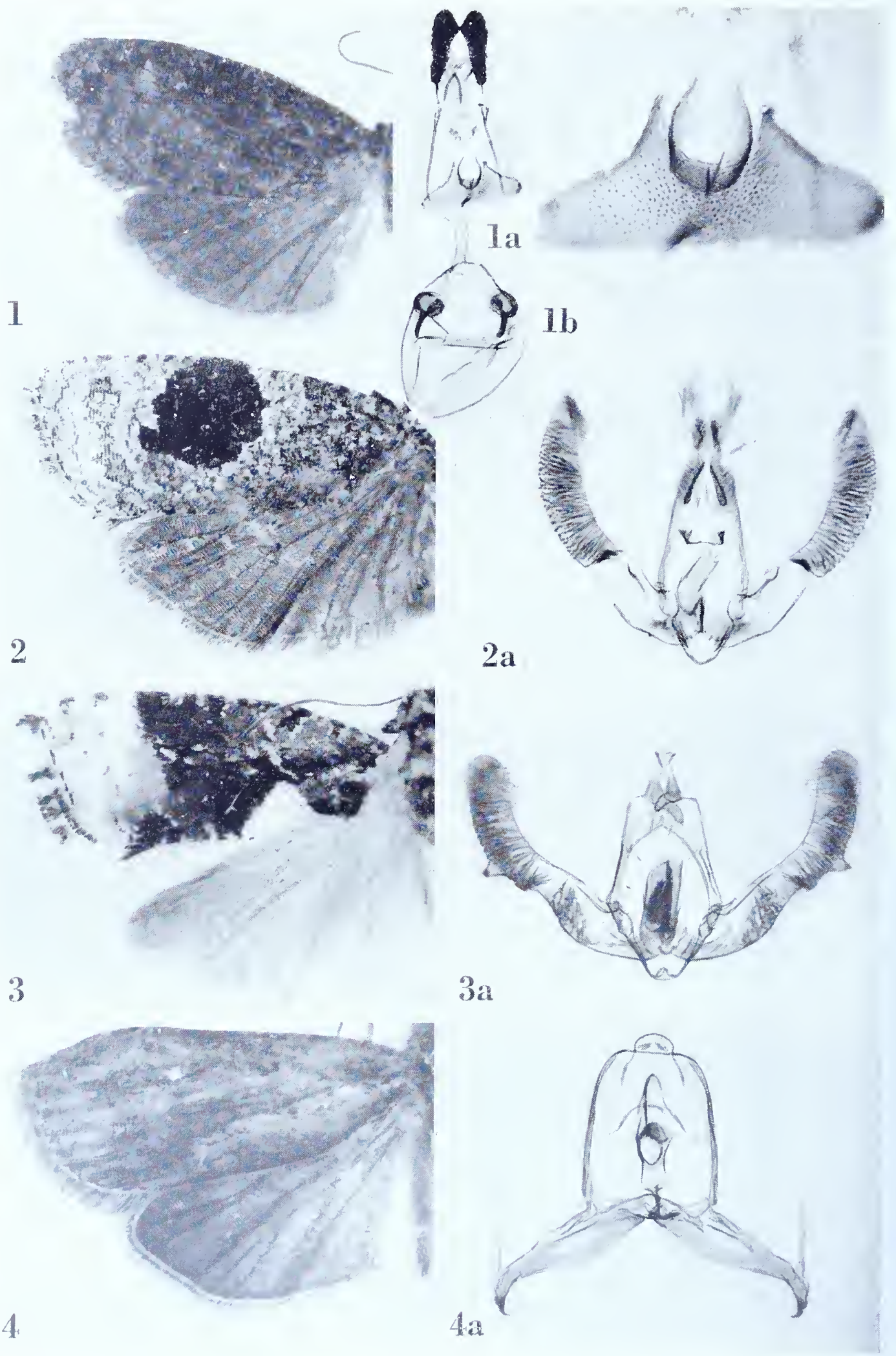




\section{Olethreutes molybdachtha (Meyrick), new combination}

Plate 264, Figures $\mathrm{I}-1 \mathrm{~b}$

Argyroploce molybdachtha Meyrick, I93o, Exotic Microlepidoptera, 3:603.

“․ I9 mm. . . Ivory Coast, Bingerville, November (Gaston Melou); i ex. (Coll. Paravicini)."

Type: The above indicated female so labelled in the British Museum, "Afrique Occidentale, Côte d'Ivoire, Bingerville. Gaston Melou. November, I913." Slide No. 7060 .

Figure 1 , left wings; $1 \mathrm{a}$, ventral view of female genitalia; $1 \mathrm{~b}$, detail of genital plate and ostium.

\section{Olethreutes mormopa (Meyrick), new combination}

Plate 264, Figures 2-2a

Platypeplns mormopa Meyrick, i9o6, Journ. Bombay Nat. Hist. Soc., I7: I36.

" ๙ิ. I9 mm. .. . Two specimens, Maskeliya, Ceylon, in February (de Mowbray, Alston)."

Lectotype: The male, "Maskeliya, Ceylon. de Mowbray. .2.04." Slide No. 7204.

Figure 2, left wings; za, ventral view of male genitalia with aedeagus in sit?.

\section{Olethreutes niphodelta (Meyrick), new combination}

Plate 264, Figures $3-3$ a

Argyroploce niphodelta Meyrick, I925, Exotic Microlepidoptera, $3:$ I 43.

" o. I $6 \mathrm{~mm}$. . . Assam, Shillong, 5,000 feet (Fletcher); r ex. Conspicuously distinct."

Type: 'The specimen referred to above labelled, "Khasi Hills, Assam. TBF. .4.1924." Slide No. 7268. Despite the apparent discrepancy in locality there is no doubt the specimen illustrated is the type. Shillong is in the Khasi Hills and Meyrick used one of his regular labels without adding "Shillong".

Figure 3 , left wings; $3 \mathrm{a}$, ventral view of male genitalia with aedeagus in situ.

\section{Olethreutes oedalea (Meyrick), new combination}

Plate 264, Figures $4^{-4 a}$

Argyroploce oedalea Meyrick, I909, Journ. Bombay Nat. Hist. Soc., I9: 593 .

" fop $^{\circ}$ 19-20 mm. . . Kandy and Peradeniya, Ceylon, from July to September (Greell); three specimens. Specially characterised by the discal tuft of scales."

Lectotype: The male, "Kandy, Ceylon. Green. 9.02." Slide No. 7280.

Figure 4, left wings; 4 a, ventral view of male genitalia with aedeagus in situ. 
Olethreutes olenarcha (Meyrick), new combination

Plate 265 , Figure I

Argyroploce olenarcha Meyrick, I931, Exotic Microlepidoptera, 4: I36.

" . $16 \mathrm{~mm}$. . . . Formosa, Kyuhabon, October (S. Issiki); I ex. Probably allied to aspiclias. ..."

Type: 'The female denoted above, without abdomen, dated ". 10.26".

Figure $\mathrm{I}$, left wings.

\section{Olethreutes ornithotypa (Meyrick)}

See Tortrix ornithotypa (Meyrick).

\section{Olethreutes orophias (Meyrick), new combination}

Plate 265 , Figures 2-2a

Eucosma orophias Meyrick, i 907, Journ. Bombay Nat. Hist. Soc., I 7: 732.

" ơ. 2 I -24 mm. . . Simla (Nurse), Khasi Hills, in August and September; seven specimens."

Lectotype: วิ, 22 mm., "Simla, Punjab. CGN. 8.97." Slide No. 7I7I.

Figure 2 , left xvings; 2a, ventral view of male genitalia with aedeagus in situ.

\section{Olethreutes pachypleura (Meyrick), new combination Plate 265 , Figure 5}

Argyroploce pachypleura Meyrick, I 92 I, Exotic Microlepidoptera, 2: 448.

" o. I 2 mm. . . . Fiji, Lautoka, March (Greenwood); I ex. (Brit. Mus.)."

Type: The above indicated specimen so marked in the British Museum, "Lautoka, Fiji Is., 21.iii. I9I9. W. Greenwood." 'The type lacks the abdomen and one hindwing.

Figure 5, left forewing.

\section{Olethreutes palliata (Meyrick), new combination \\ Plate 265 , Figures $3-3 a$}

Argyroploce palliata Meyrick, I909, Journ. Bombay Nat. Hist. Soc., I9: 595 .

" ${ }^{\circ}$. $17^{-1} 8 \mathrm{~mm}$. . . Khasis, in June, September, and October ; four specimens."

Lectotype: ô, 17 mm., "Khasi Hills, Assam. .9. 1906." Slide No. 7 I97.

Figure 3 , left wings; 3 a, ventral view of male genitalia with aedeagus in situ.

[continued on p. 560 . 

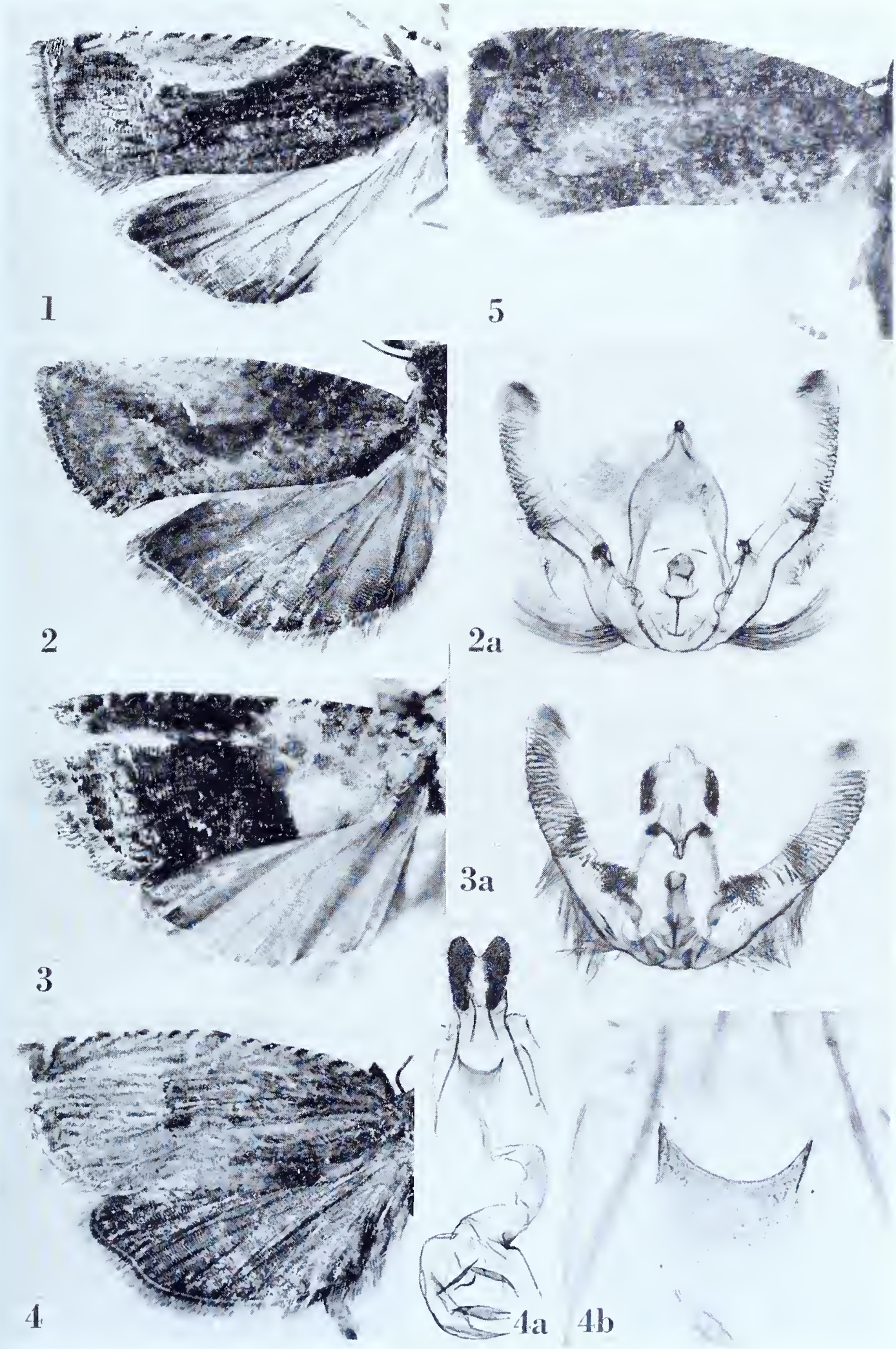

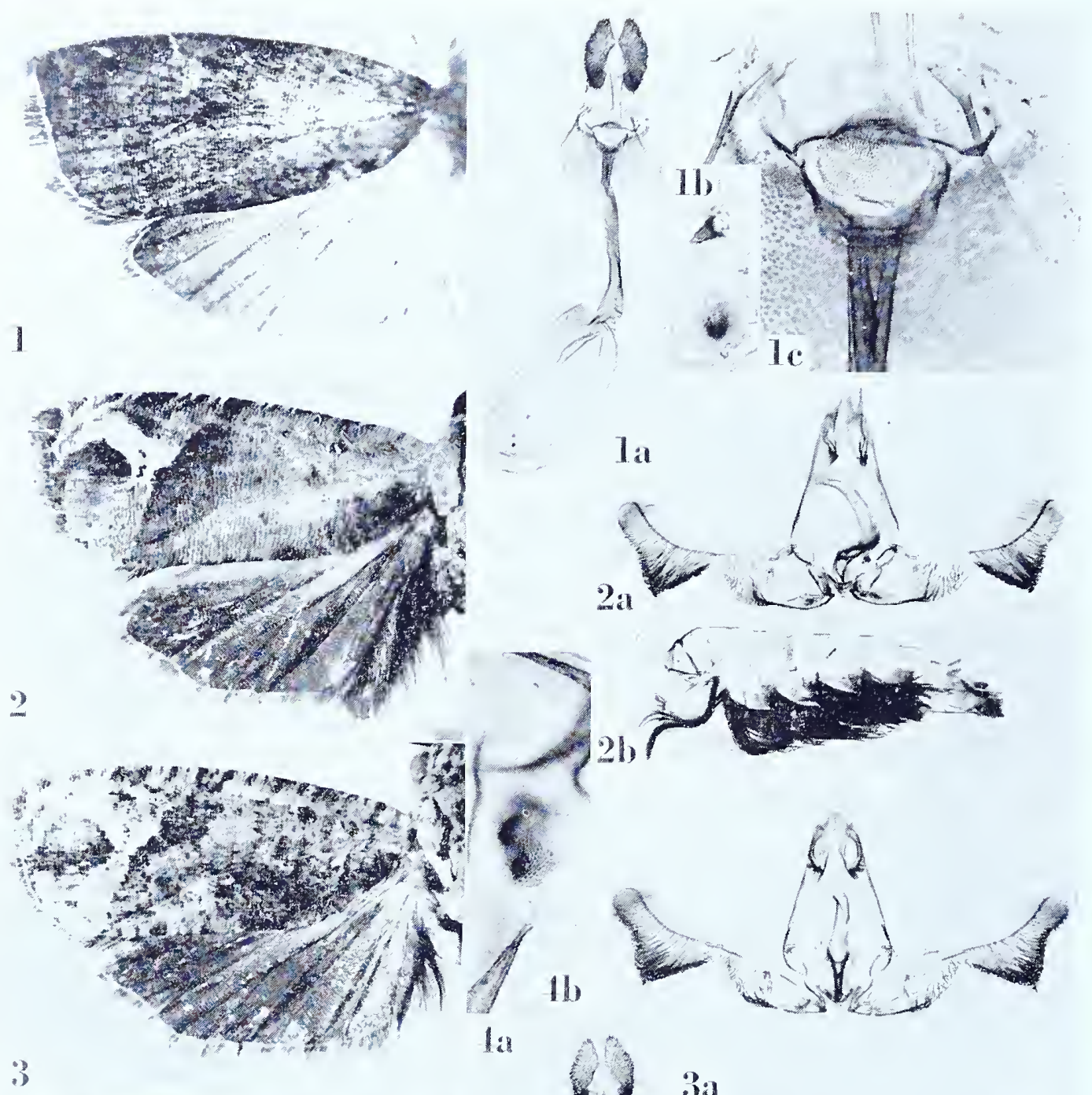

If
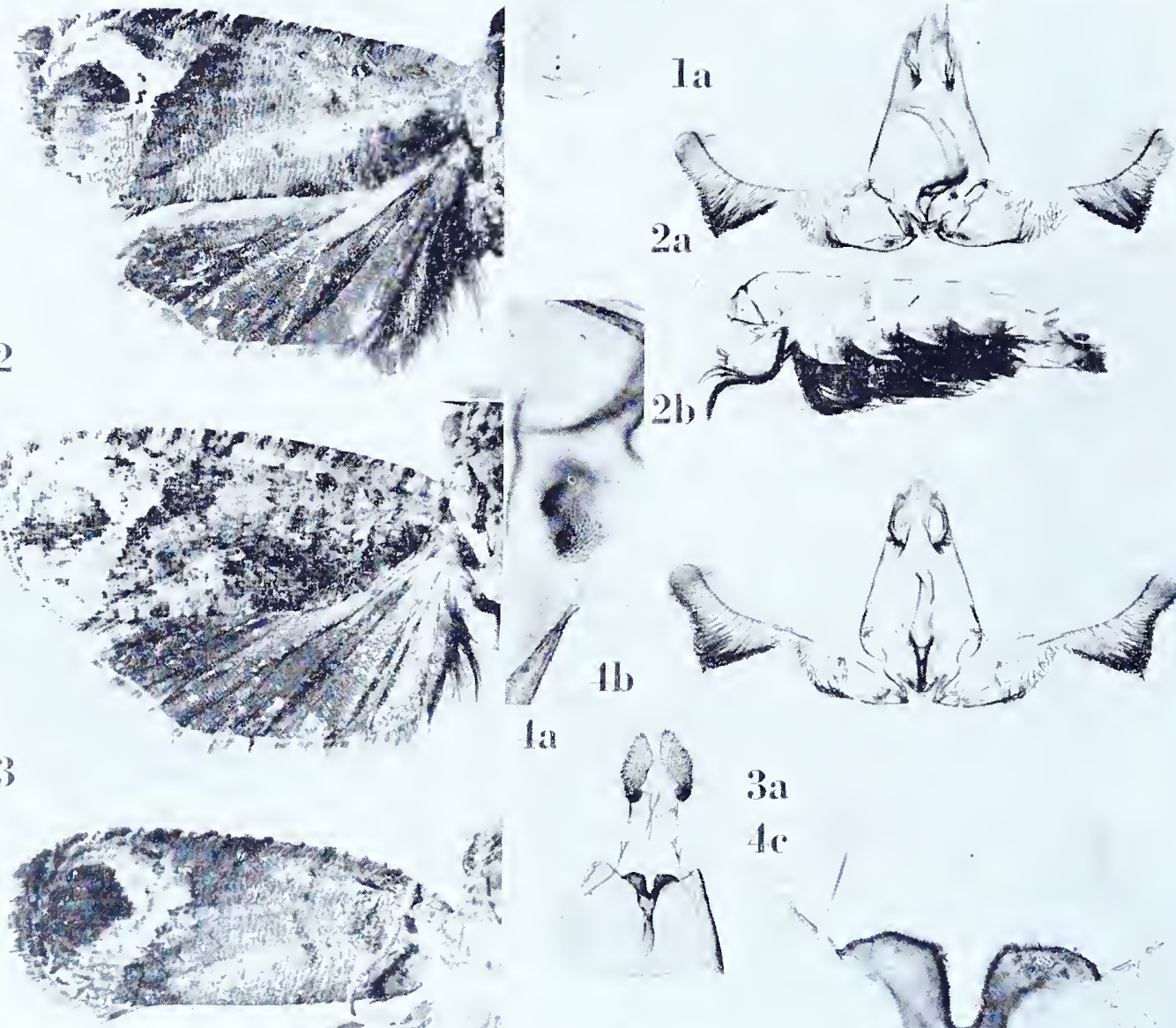

b

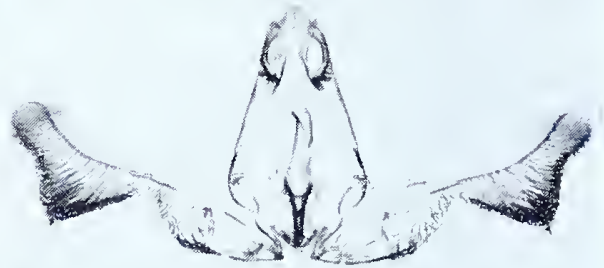

las

$4 y^{3} \quad 3 a$

I
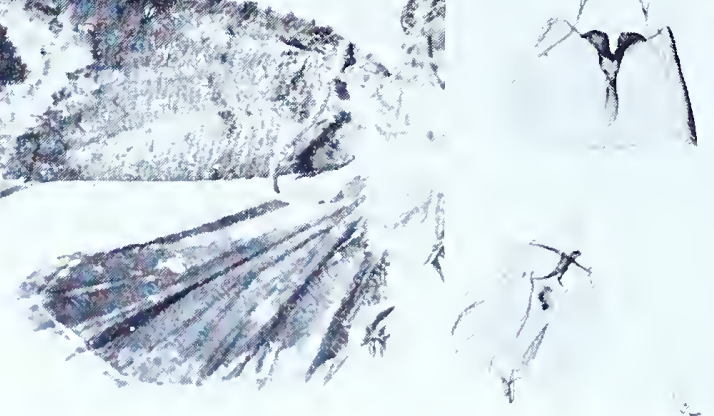

4c. 


\section{Olethreutes pertexta (Meyrick), new combination}

Plate 266, Figures I-IC

Argyroploce pertexta Meyrick, 1920, Exotic Microlepidoptera, 2: $35 \mathrm{I}$.

"궁. I 8-22 mm. ... Sikkim, Darjiling (Fletclier); 2 ex."

Lectotype: 9, 22 mm., "Darjiling, India. 'TBF. . 7 ." Slide No. 7305.

Figure I, left wings; ıa, ventral view of female genitalia; rb, signa; Ic, detail of genital plate and ostium.

\section{Olethreutes phyllochlora (Meyrick), new combination}

Plate 266, Figures 2-2b;3-3a; $4-4 c$

Platypeplus phylloclilora Meyrick, i905, Journ. Bombay Nat. Hist. Soc., i6: 585 .

Argyroploce ptilosoma Meyrick, i916, Exotic Microlepidoptera, i : 563 (new synonymy).

Argyroploce temenopis Meyrick, 1936, Exotic Microlepidoptera, 4: 614 (new synonymy).

[phyllochlora]

" $\sigma^{2}$ I $5^{-1} 7$ mm. . . Three specimens, Peradeniya, Kandy and Haragam, Ceylon, in July and August (Green)."

Lectotype: The male, "Haragam, Ceylon. EEG. /7/02." Slide No. 7262. The "Peradeniya" specimen is missing.

Figure 2, left wings; 2a, ventral view of male genitalia with aedeagus in sitn; 2b, partly denuded abdomen to show segmental tufts.

[ptilosoma]

“ o. I7 mm. ... S. India, Shevaroys, 4,500 feet, in December (Fletclier); one specimen."

Type: The male denoted above dated ".12.13”. Slide No. 7266.

Figure 3, left wings; 3 a, ventral view of male genitalia with aedeagus in sit $\%$.

[temenopis]

"q. $16 \mathrm{~mm}$. . . . Formosa, Kagi, bred from larva feeding in rolled leaf of Persea americana (K. Fulknda); 1 ex. Allied to phyllochlora Meyr."

Type: The above indicated female dated ".9.34". Slide No. $726 \mathrm{I}$.

Figure 4 , left wings; 4 a, ventral view of female genitalia; 4 b, signa; $4^{c}$, detail of ostium. 


\section{Olethreutes phyllodoxa (Meyrick), new combination}

Plate 267 , Figures I-IC

Argyroploce phyllodoxa Meyrick, I932, Exotic Microlepidoptera, 4: 3 Io.

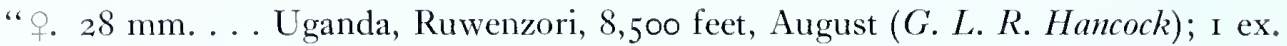
(Brit. Mus.)."

Type: The above indicated specimen so designated in the British Museum, dated “21.viii.r931". Slide No. $707 \mathrm{I}$.

Figure I, left wings; $\mathrm{a}$, ventral view of female genitalia; $\mathrm{rb}$, detail of genital plate and ostium; ic, signa.

\section{Olethreutes platycremna (Meyrick), new combination}

Plate 267, Figures 2-2a

Argyroploce platycremna Meyrick, 1935, in Caradja and Meyrick, Materialien zu einer Microlepidopteren Fauna der Chinesischen Provinzen Kiangsu, Chekiang und Hunan, 6r.

“... oै I 3 mm., . . . 2 ex., Tienmushan, IV, V. Allied to albipalpis."

Type: The male in the Meyrick collection, "Tien-Mu-Shan, China, H. 5,300' -4.32." Slide No. 7303 .

Figure 2, left wings; 2 a, ventral view of male genitalia with aedeagus in situ.

\section{Olethreutes platymolybdis (Meyrick), new combination}

Plate 267 , Figures $3-3 \mathrm{c}$

Argyroploce platymolybdis Meyrick, 1930, Exotic Microlepidoptera, 3: 603.

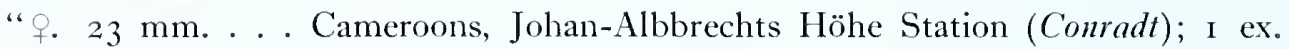
(Coll. Paravicini). Recognisable by the unusually broad wings."

Type: 'The female indicated above, so marked in the British Museum, dated "I 896 ". Slide No. 7063 .

Figure 3 , left wings; $3 \mathrm{a}$, ventral view of female genitalia; $3 \mathrm{~b}$, signa; $3 \mathrm{c}$, detail of genital plate and ostium.

\section{Olethreutes platyzona (Meyrick), new combination}

Plate 267 , Figures $4-4$ a

Argyroploce platyzona Meyrick, I917, 'Trans. Ent. Soc. London, 1917: 28.

"o. I6 mm. ... French Guiana, R. Maroni; one specimen."

Type: The male indicated above with "LeM. . 5 " at the bottom of the pin-label. Slide No. 642 I.

Figure 4, left wings; 4a, ventral view of male genitalia with aedeagus in situ. 


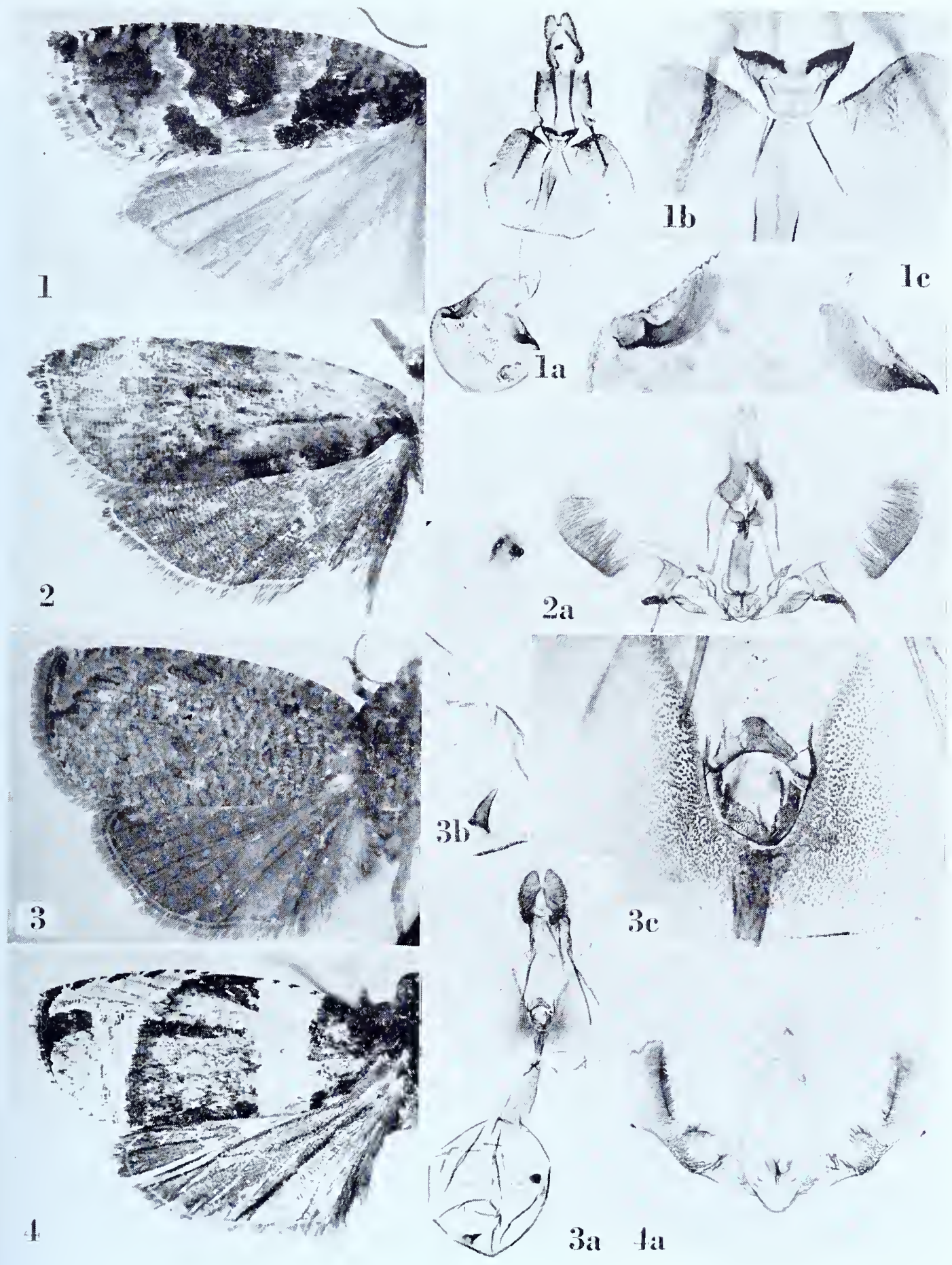

OLETHREUTES 


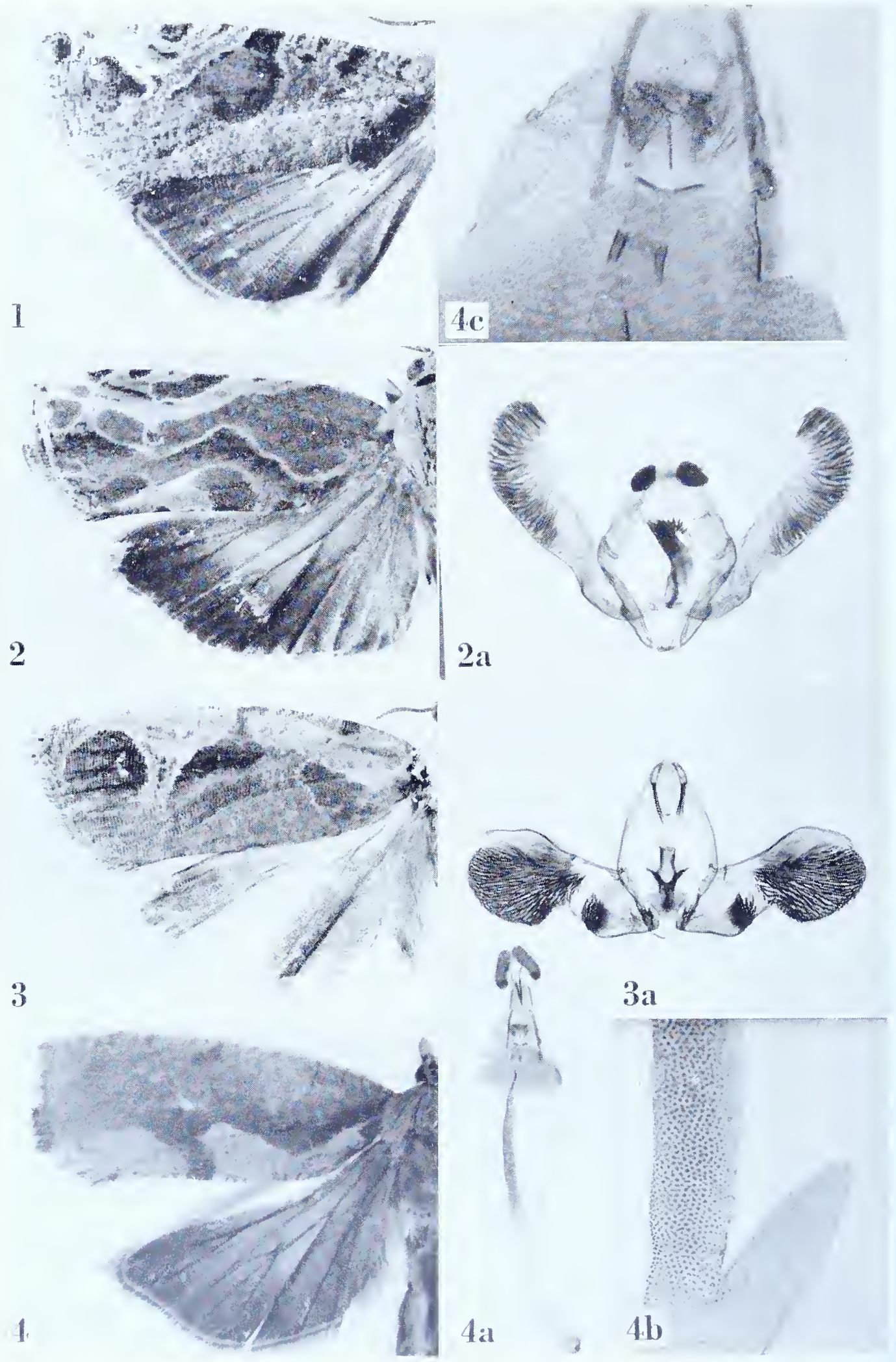




\section{Olethreutes plinthograpta (Meyrick), new combination}

Plate 268, Figure 1

Argyroploce plinthograpta Meyrick, I93 I, Exotic Microlepidoptera, 4: I 35.

" స. I $6 \mathrm{~mm}$. . . Formosa, Taihoku, November (S. Issiki); I ex. Allied to gyrotis."

Type: The male denoted above, without abdomen, dated "6.in.23".

Figure I, left wings.

\section{Olethreutes poetica (Meyrick), new combination}

Plate 268, Figures 2-2a

Argyroploce poetica Meyrick, I909, Journ. Bombay Nat. Hist. Soc., I9: 437.

Encosna mosaica Meyrick, I907, Journ. Bombay Nat. Hist. Soc., 18: I 38 (preoccupied).

" of. 19-20 mm. . . Maskeliya, Ceylon (Alston); Palni Hills (Campbell); three specimens."

Lectotype: A male measuring 19 mm., "Palni Hills, S. India. Campbell." Slide No. 7238 . The three original specimens are males.

Figure 2, left wings; 2a, ventral view of male genitalia with aedeagus in situ.

\section{Olethreutes pompholycias (Meyrick), new combination}

Plate 268, Figures $3^{-} 3^{\mathrm{a}}$

Argyroploce pompholycias Meyrick, 1935, in Caradja and Meyrick, Materialien zu einer Microlepidopteren Fauna der Chinesischen Provinzen Kiangsu, Chekiang und Hunan, 58 .

“. . . \. 22-23 mm. . . 7 ex., Tienmushan, VI, VII. Allied to purpurissatana Kenn."

Lectotype: A male measuring 23 mm., "Tien-Mu-Shan, China. H. 5,000' .6.32." Slide No. 7246 .

Figure 3 , left wings; 3 a, ventral view of male genitalia with aedeagus in sitn.

\section{Olethreutes pontifraga (Meyrick), new combination}

Plate 268, Figures $4^{-4} \mathrm{c}$

Argyroploce pontifraga Meyrick, 1928, Exotic Microlepidoptera, 3: 444.

“q. $22 \mathrm{~mm}$. . . Uganda, Nambalzidza, January (Hancock); i ex. (Brit. Mus.)."

Type: The female denoted above dated "24-I-I927". Slide No. 73 I9.

Figure 4 , left wings; $4 \mathrm{a}$, ventral view of female genitalia; $4 \mathrm{~b}$, posterior evagination of bursa copulatrix; 4 c, detail of genital plate and ostium. 


\title{
Olethreutes praesiliens (Meyrick), new combination
}

\author{
Plate 269, Figures I-IC
}

Argyroploce praesiliens Meyrick, 1924, Exotic Microlepidoptera, 3: 68.

"․ 22 mm. .. U Uganda, Kampala, August (Hargreaces); I ex. (Brit. Mus.)."

Type: The above indicated female so marked in the British Museum, "Uganda, Kampala. Io.viii.ı 922. H. Hargreaves." Slide No. 7315. Though somewhat darker this is probably the female of xylodelta.

Figure I, left wings; Ia, ventral view of female genitalia; $\mathrm{Ib}$, detail of ostium; Ic, signa.

\section{Olethreutes prasinias (Meyrick), new combination}

Plate 269 , Figures $2-2 b$

Argyroploce prasinias Meyrick, i916, Exotic Microlepidoptera, I : 562.

" స. I 5-16 mm. ... Kanara, Kur, in October (Maxzuell); Ceylon, Haputale, in February (Pole); two specimens."

Lectotype: The male, "Kur, Kanara. RM. I2.10.14." Slide No. 7264.

Figure 2, left wings; $2 \mathrm{a}$, partly denuded abdomen to show segmental tufts; $2 \mathrm{~b}$, ventral view of male genitalia (except left harpe) with aedeagus in sitn.

\section{Olethreutes protocyma (Meyrick), new combination}

Plate 269 , Figures $3-3 \mathrm{~b}$

Argyroploce protocyma Meyrick, 1936, Exotic Microlepidoptera, 4:613.

"q. 20 mm. . . Formosa, Pinansyusan, Hinode, August (Prof. S. Issiki); I ex."

Type: The above indicated female dated "I 6.8.33". Slide No. 7277.

Figure 3 , left wings; $3^{\mathrm{a}}$, ventral view of female genitalia; $3 \mathrm{~b}$, detail of genital plate and ostium.

\section{Olethreutes ptilosoma (Meyrick)}

See Oletlureutes phyllochlora (Meyrick).

\section{Olethreutes purpurissatana (Kennel), new combination}

Plate 269, Figures $4^{-4 a}$

Pentlina purpurissatana Kennel, I 901, Iris, 13:252

Argyroploce archimedias Meyrick, 1912, Exotic Microlepidoptera, I: 63.

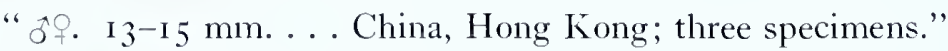

Lectotype: A male measuring 15 mm., "Hong Kong, China. R. .07." Slide No. 7245.

Figure 4, left wings; 4 a, ventral view of male genitalia with aedeagus in sitn. 


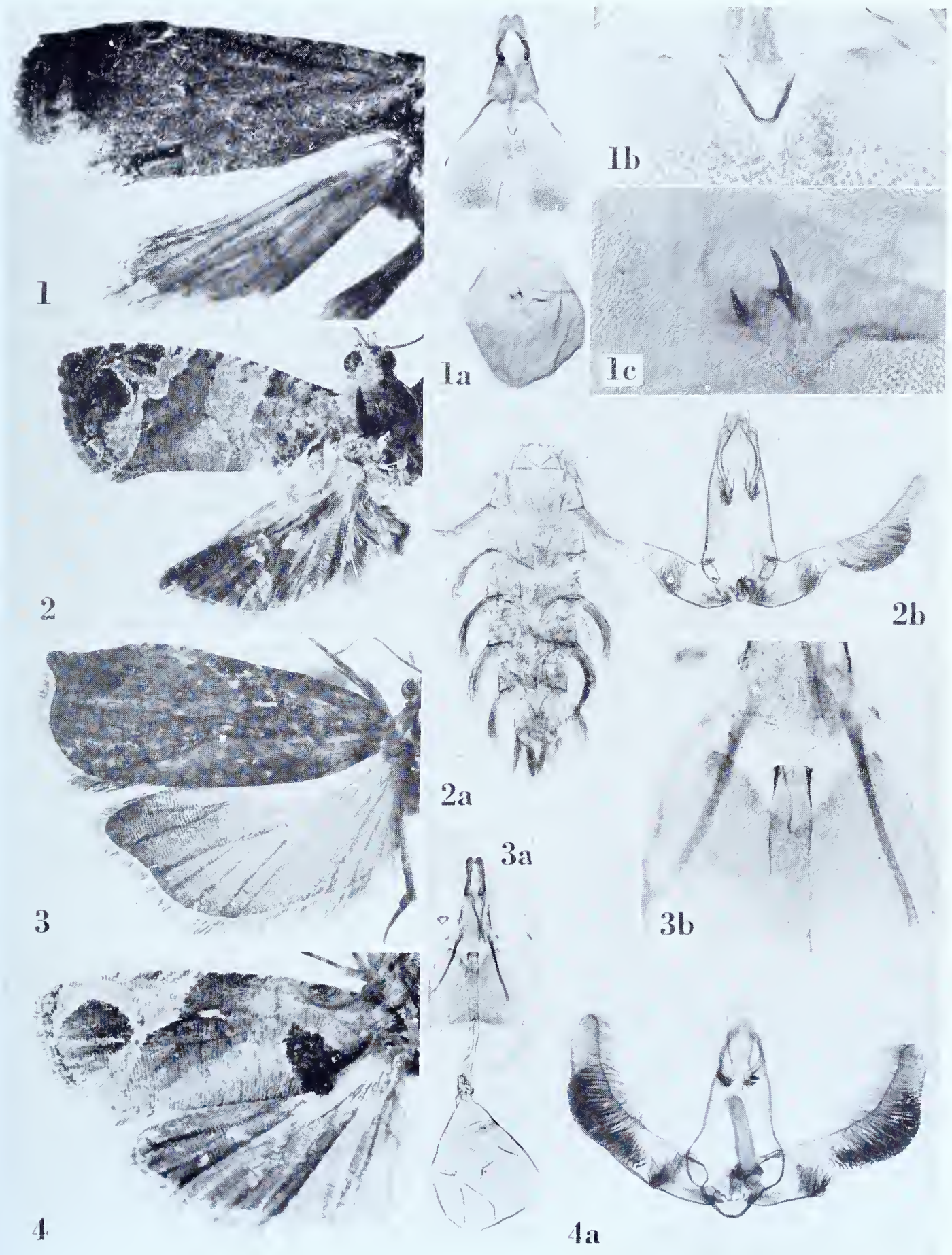




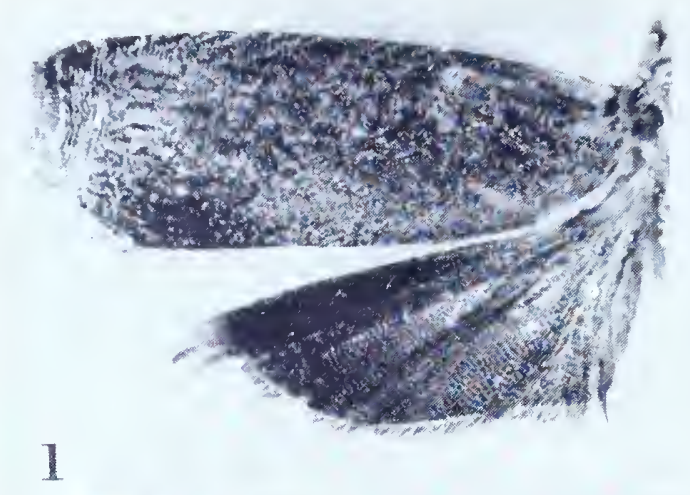

$1 \mathbf{a}$
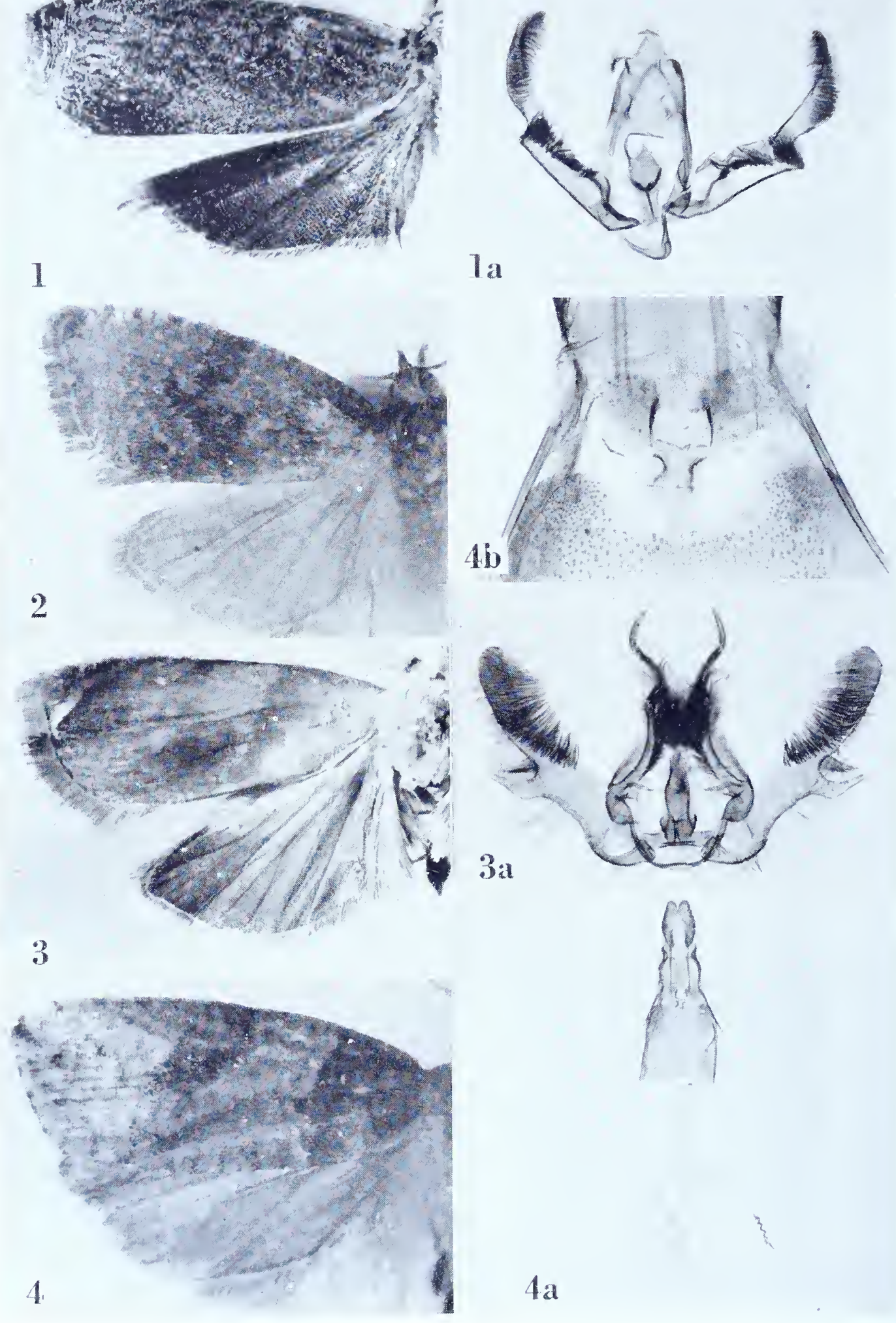


\title{
Olethreutes pyrrhocrossa (Meyrick), new combination
}

\author{
Plate 270, Figures I-Ia
}

Argyroploce pyrrhocrossa Meyrick, I912, Journ. Bombay Nat. Hist. Soc., $21: 874$.

" s. $^{+}$. I 5-I $6 \mathrm{~mm}$. . . Khasis; in March and November, three specimens. Specially characterised by the contrasted reddish cilia of forewings."

Lectotype: A male measuring I 5 mm., "Khasi Hills, Assam. .3.1906." Slide No. 7224 .

Figure I, left wings; гa, ventral view of male genitalia with aedeagus $i n$ sitn.

\section{Olethreutes rhetorica (Meyrick), new combination}

Plate 270, Figure 2

Argyroploce rhetorica Meyrick, I920, Exotic Microlepidoptera, 2:350.

" o. I 8 mm. .. . N.W. Persia, Enzeli, May (Capt. P. A. Bnxton); i ex., Brit. Mus."

Type: The above indicated male so marked in the British Museum, dated "I-v-I9I9". The abdomen of the type is missing.

Figure 2, left wings.

\section{Olethreutes rhodantha (Meyrick), new combination}

\section{Plate 270 , Figures $3^{-} 3^{\text {a }}$}

Encosma rhodantha Meyrick, I907, Journ. Bombay Nat. Hist. Soc., I8: 138 .

" స. $20 \mathrm{~mm}$. . . Khasi Hills, in September; one specimen."

Type: The male indicated above, "Khasi Hills, Assam. .9.1906." Slide No. 724I.

Figure 3 , left wings; 3 a, ventral view of male genitalia with aedeagus $i n$ sitn.

\section{Olethreutes rhodochranta (Meyrick), new combination}

\section{Plate 270, Figures $4-4 \mathrm{~b}$}

Argyroploce rhodochranta Meyrick, I933, Exotic Microlepidoptera, 4: 4I9.

“․ 22 mm. . . Uganda, Sanga, October (G. L. R. Hancock); I ex. (Brit. Mus.)."

Type: The female denoted above, so marked in the British Museum, dated “I 7-X-1932”. Slide No. 7318.

Figure 4 , left wings; 4 a, ventral view of female genitalia; 4 b, detail of genital plate and ostium. 


\title{
Olethreutes rupifera (Meyrick), new combination
}

\author{
Plate 271, Figures I-1a
}

Argyroploce rupifera Meyrick, r9o9, Journ. Bombay Nat. Hist. Soc., I9: 602.

"

Lectotype: A male measuring 16 mm., "Khhasi Hills, Assam. .I2.Igo6." Slide No. $725^{\circ}$. One specimen is missing.

Figure I, left wings; ra, ventral view of male genitalia with aedeagus in situ.

\section{Olethreutes sandycota (Meyrick), new combination}

Plate 27I, Figures 2-2a

Argyroploce sandycota Meyrick, I912, Journ. Bombay Nat. Hist. Soc., 21 : 872.

" o. $12 \mathrm{~mm}$. . . . Hakgala, Ceylon (Greenl); in April, one specimen."

Type: The male indicated above dated “.4.07”. Slide No. 7 I 78 .

Figure 2, left wings; 2 a, ventral view of male genitalia with aedeagus in situ.

\section{Olethreutes sardiodes (Meyrick), new combination}

Plate 27x, Figures $3-3 \mathrm{~b}$

Argyroploce sardiodes Meyrick, 1922, Exotic Microlepidoptera, 2: 523 .

"ô. $16 \mathrm{~mm}$. . . Peru, Iquitos, March (Parish); ı ex."

Type: The male indicated above dated "3.20". Slide No. 6416.

Figure 3 , left wings; 3 a, denuded abdomen to show abdominal pit; 3 b, ventral view of male genitalia with aedeagus in situ.

\section{Olethreutes scolecitis (Meyrick), new combination}

Plate 27 I, Figures $4-4 \mathrm{C}$

Argytoploce scolecitis Meyrick, I916, Exotic Microlepidoptera, 2: 20.

“․ $20 \mathrm{~mm}$. . . Bengal, Chapra (Mackensie); one specimen."

Type: 'I'he female denoted above but labelled "Chapra, Bengal. TBF. . i 4." Slide No. 7237. All data agree except the "TBF".

Figure 4, left wings; $4^{a}$, ventral view of female genitalia; $4 \mathrm{~b}$, detail of ostium; $4 \mathrm{c}$, signum. 


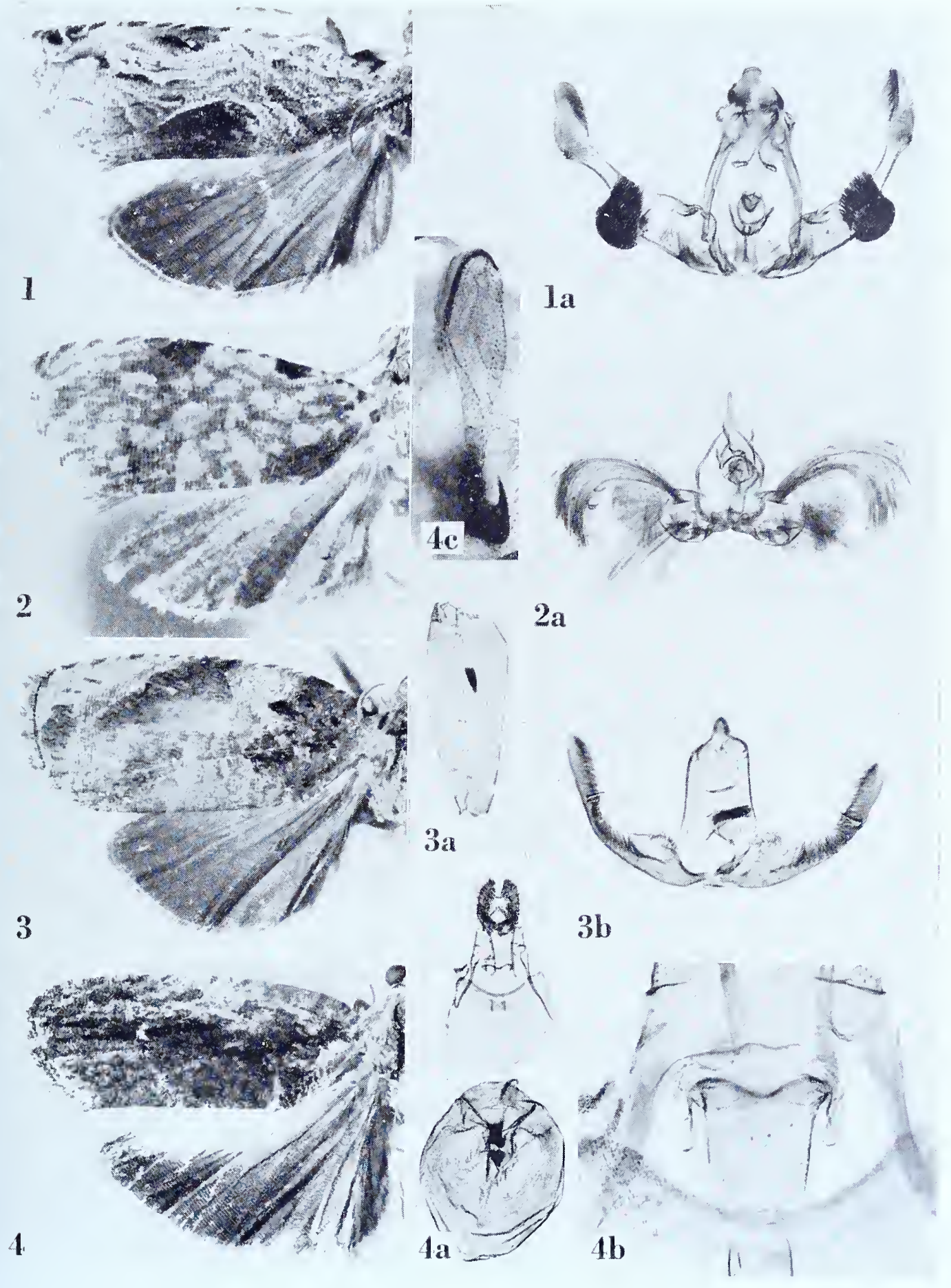



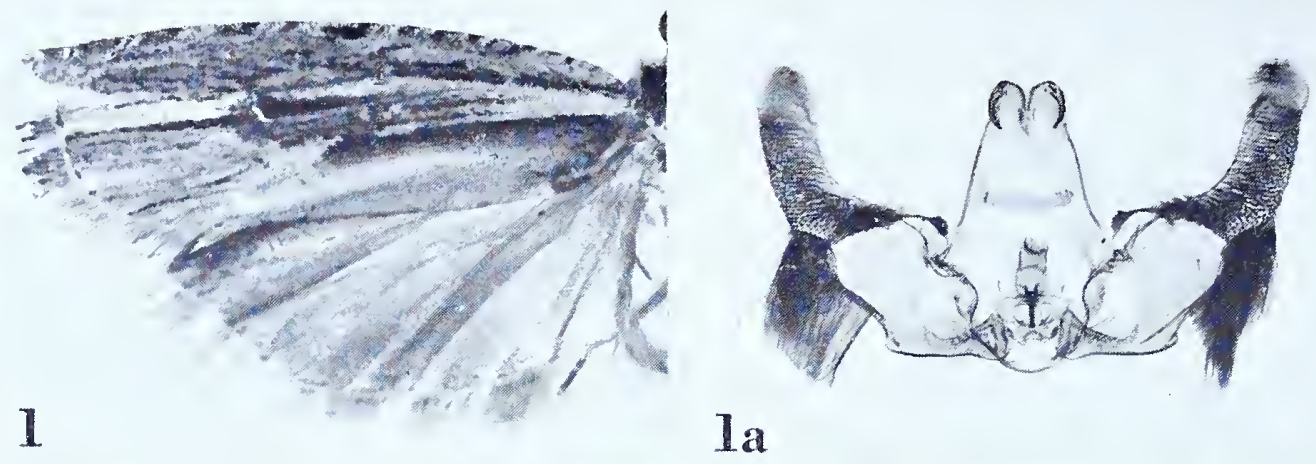

2
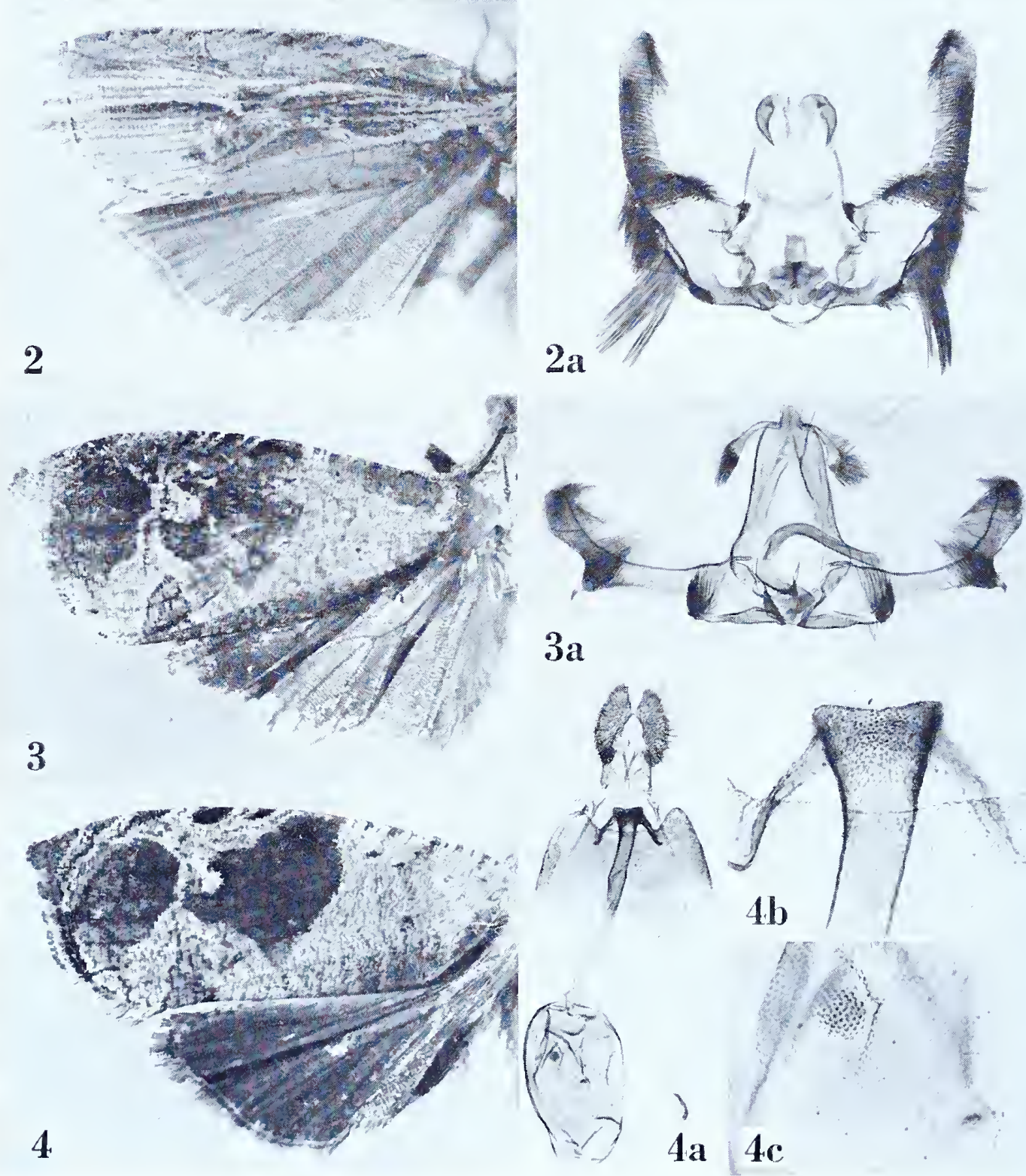


\section{Olethreutes scolopendrias (Meyrick), new combination}

Plate 272, Figures I-Ia

Argyroploce scolopendrias Meyrick, 1912, Journ. Bombay Nat. Hist. Soc., 2 I : 87 I.

" ${ }^{3} .19 \mathrm{~mm}$. ... Nilgiris, 6,000 feet (Andrewes); in May, one specimen. Very similar to scorpiastis. ..."

Type: The male denoted above, "Nilgiri Hills, S. India. HLA. 6,000' .5.07." Slide No. 7225 .

Figure I, left wings; Ia, ventral view of male genitalia with aedeagus in situ.

\section{Olethreutes scorpiastis (Meyrick), new combination}

Plate 272, Figures 2-2a

Argyroploce scorpiastis Meyrick, I912, Journ. Bombay Nat. Hist. Soc., 21 : 871 .

“ 3 우. I $6-18 \mathrm{~mm} . .$. Khasis; in October and November, four specimens."

Lectotype: ô, 18 mm., "Khasi Hills, Assam. .ı.1906." Slide No. 7226.

Figure 2, left wings; $2 \mathrm{a}$, ventral view of male genitalia with aedeagus in situ.

\section{Olethreutes semiculta (Meyrick), new combination}

Plate 272 , Figures $3-3 \mathrm{a}, 4-4 \mathrm{c}$

Argyroploce semiculta Meyrick, I909, Journ. Bombay Nat. Hist. Soc., I9: 604.

Argyroploce heteraspis Meyrick, 1936, Exotic Microlepidoptera, 4:614 (new synonymy).

[semiculta]

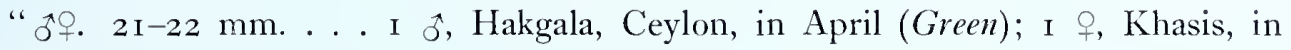
November."

Lectotype: The male, "Hakgala, Ceylon. EEG. .4.07." Slide No. 7202.

Figure 3 , left wings; 3 a, ventral view of male genitalia with aedeagus in situ.

[heteraspis]

"․ $18 \mathrm{~mm}$. . . . Formosa, Kagi, bred from larva feeding in rolled leaf of Persea americana (Lauraceae) (K. Fukuda); I ex."

Type: The female denoted above, "Kagi, Formosa. KF. bred .34." Slide No. 7260.

Figure 4 , left wings; $4 \mathrm{a}$, ventral view of female genitalia; $4^{\mathrm{b}}$, detail of ostium; $4 \mathrm{c}$, signa. 


\section{Olethreutes semnodryas (Meyrick), new combination}

Plate 273, Figures I-Ia

Argyroploce semnodryas Meyrick, 1936, Exotic Microlepidoptera, 4:613. "ô. 13 mm. ... Formosa, Taihoku, April (Prof. S. Issiki); r ex."

Type: The male denoted above dated ". $14 \cdot 4 \cdot 33$ ”. Slide No. 7278.

Figure 1 , left wings; ra, ventral view of male genitalia with aedeagus in situ.

\section{Olethreutes sistrata (Meyrick), new combination}

Plate 273, Figures 2-2a

Argyroploce sistrata Meyrick, I9I I, Ann. Transvaal Mus., 2: 228.

"Male and female, I 7-20 mm... Woodbush Village (Swierstra); Pinetown, Natal (Leigh); in December and January; nine specimens."

Lectotype: J, I 7 mm., "Pinetown, Natal. L. I.o9." Slide No. 9404.

Figure 2 , left wings; $2 \mathrm{a}$, ventral view of male genitalia with aedeagus in sitn.

\section{Olethreutes solaris (Meyrick), new combination}

\section{Plate 273, Figures 3-3c}

Argyroploce solaris Meyrick, I909, Journ. Bombay Nat. Hist. Soc., 19: 605.

"․ I $4^{-1} 5 \mathrm{~mm}$. . . Khasis, in October and November; three specimens. ..."

Lectotype: A female measuring 14 mm., "Khasi Hills, Assam. .ro.igo6." Slide No. $723 \mathrm{I}$.

Figure 3 , left wings; 3 , ventral view of female genitalia; 3 , detail of ostium; $3^{c}$, signa.

\section{Continucd from p. 499.}

able to verify the synonymy, in the absence of Snellen's species, so am treating Meyrick's creserias as valid.

Figure 3 , left wings; 3 a, ventral view of male genitalia with aedeagus in situ.

\section{Olethreutes crocospila (Meyrick), new combination}

Plate 248 , Figures $4-4 \mathrm{c}$

Argyroploce crocospila Meyrick, i939, Trans. R. Ent. Soc. London, 89: 50.

"Female, I $4 \mathrm{~mm}$. . . Java, Buitenzorg, bred June from larva feeding on leaf of Engenia (Dr. L. G. Kalshoven); I ex."

Type: The female denoted above dated ".6.35". Slide No. 7195 .

Figure 4 , left wings; $4^{\mathrm{a}}$, ventral view of female genitalia; 4 b, detail of ostium; $4 \mathrm{c}$, signum. 

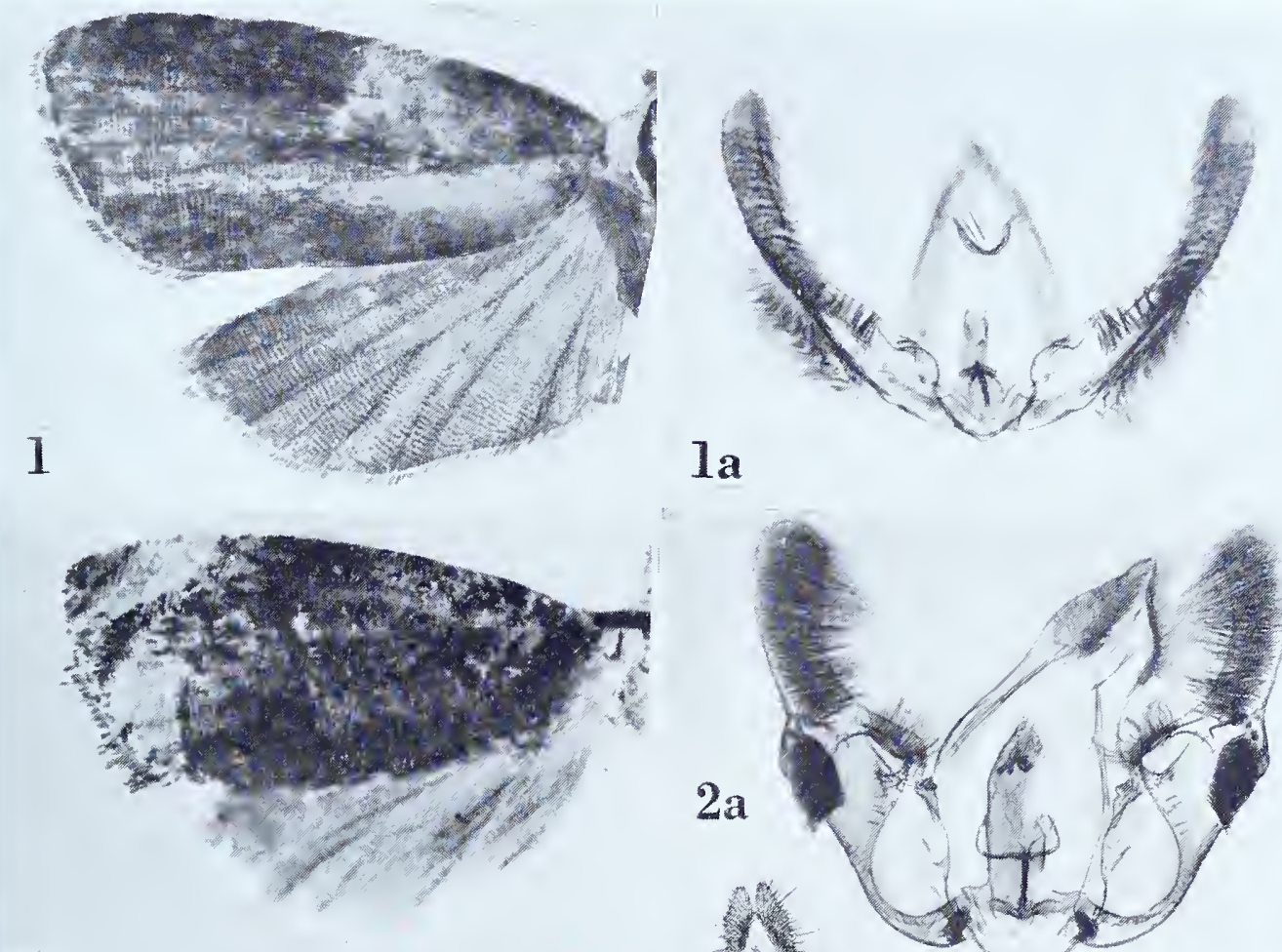

2

3

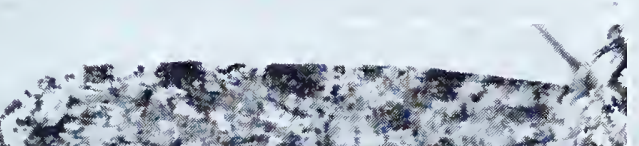

$2 a$
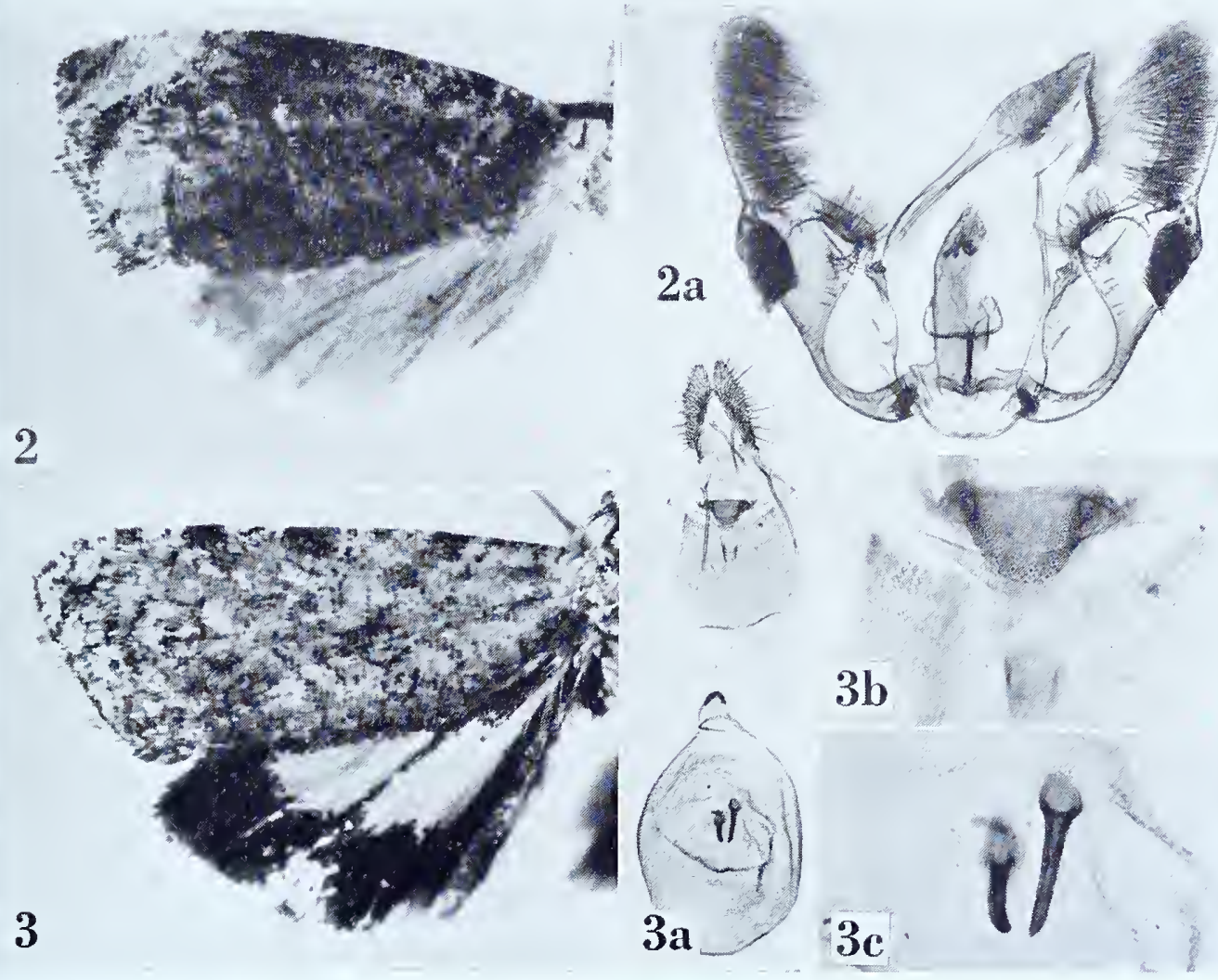

OLETHREUTES 

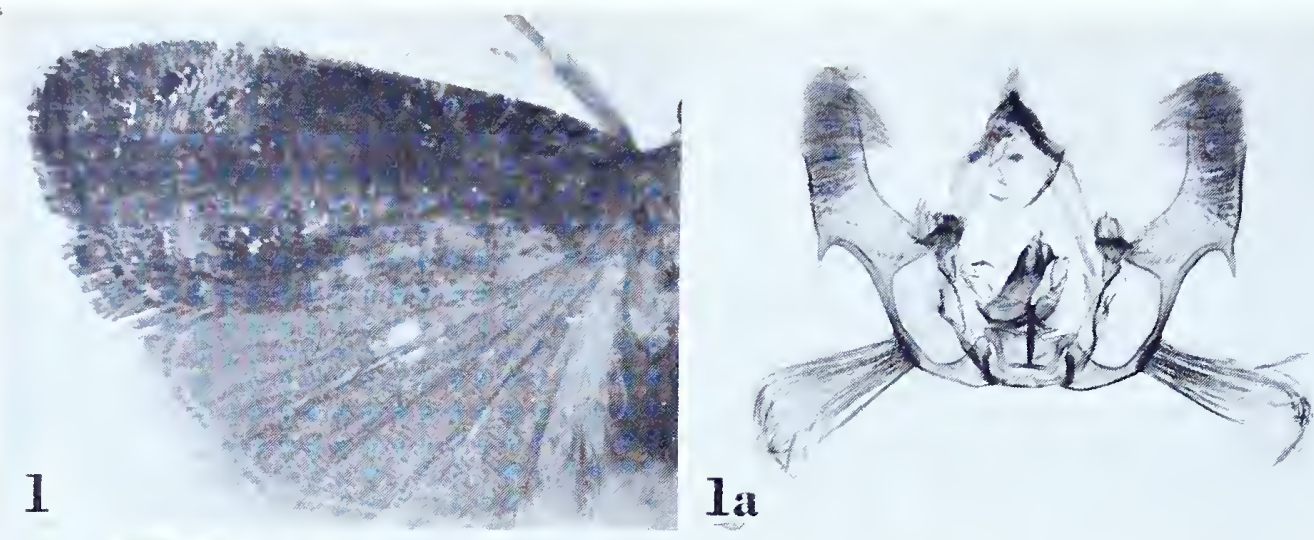

2
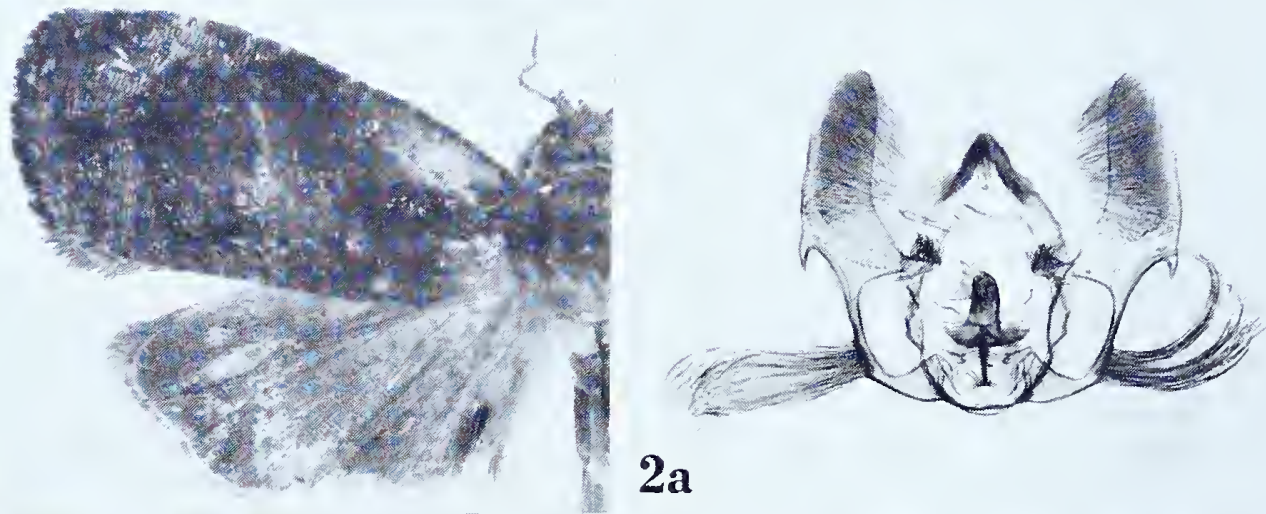

$2 a$
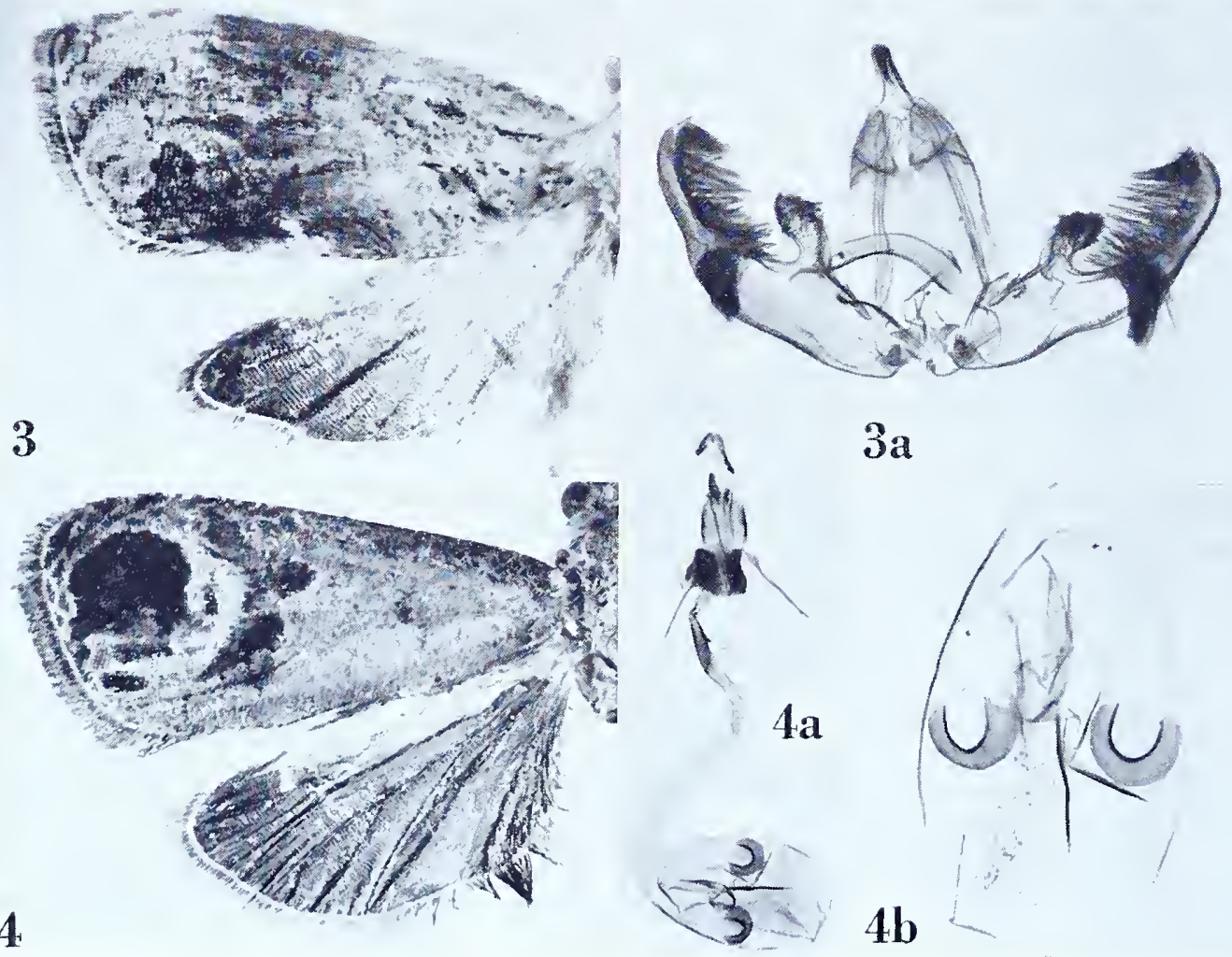


\section{Olethreutes stellans (Meyrick), new combination}

Plate 274, Figures $1-1 \mathrm{a} ; 2-2 \mathrm{a}$

Argyroploce stellans Meyrick, 1922, Exotic Microlepidoptera, 2: 525.

Argyroploce cassiterastra Meyrick, I93 I, Exotic Microlepidoptera, 4: I 30 (new synonymy).

[stellans]

“ స. I 3 mm. . . Uganda (Hargreaves); I ex. (Brit. Mus.). Near hygrantis."

Type: 'The specimen referred to above, so marked in the British Museum, "Kampala, Uganda. 6.r.ı2I. H. Hargreaves." Slide No. 73 I0.

Figure I, left wings; Ia, ventral view of male genitalia with aedeagus in sitn.

[cassiterastra]

" o. $15 \mathrm{~mm}$. . . Uganda, Kampala, bred October from flowers of a bean $(H$. Hargreaves); I ex. (Brit. Mus.). Perhaps allied to sistrata which has similar spots."

Type: The above indicated specimen so marked in the British Museum, dated "20-x-1930". Slide No. 7313.

Figure 2, left wings; 2a, ventral view of male genitalia with aedeagus in situ.

\section{Olethreutes stibaropa (Meyrick), new combination}

\section{Plate 274, Figures $3-3^{a}$}

Argyroploce stibaropa Meyrick, 1933, Exotic Microlepidoptera, 4:420.

" ${ }^{3}$. $14 \mathrm{~mm}$. . . Java, Seneng, bred March from larva feeding on leaves of Mischocarpus sondaicus (Dr. L. G. E. Kalshoven); I ex. ..."

Type: The male denoted above dated ".3.32". Slide No. 7299.

Figure 3 , left wings; 3 a, ventral view of male genitalia with aedeagus in situ.

\section{Olethreutes streblopa (Meyrick), new combination}

\section{Plate 274, Figures $4-4 \mathrm{~b}$}

Argyroploce streblopa Meyrick, I936, Exotic Microlepidoptera, 4:614.

"․ $20 \mathrm{~mm}$. . . Panama, Trinidad R., September (A. Busck); Guatemala, Chejel (Schals); 2 ex. Mr. A. Busck, to whom I am indebted for these specimens, states that the species has recently been reared from fruits of Protinn panamense (Burseracerae) (Zetek)."

Lectotype: The female "Chejel, Guatemala, S. .8.35." Slide No. 6425.

Figure 4 , left wings; 4 a, ventral view of female genitalia; 4 b, signa. 
Olethreutes stygiaula (Meyrick), new combination

Plate 275, Figures I-Ia

Argyroploce stygianla Meyrick, I933, Exotic Microlepidoptera, 4:419.

" 5 . I I6-I7 mm. . . Java, Seneng, bred May, June from larvae feeding on leaves of Pandanus (Dr. L. G. E. Kalshoven)."

Lectotype: The male dated ".6.32". Slide No. 7243. Meyrick did not state the number of specimens he had before him when he described the species but there were at least two. The male is the only specimen remaining in the Meyrick collection.

Figure I, left wings; $\mathrm{Ia}$, ventral view of male genitalia with aedeagus in sit $\%$.

\section{Olethreutes temenopis (Meyrick)}

See Olethreutes phyllochlora (Meyrick).

\section{Olethreutes tetanota (Meyrick), new combination}

Plate 275, Figures $2-2 b$

Argyroploce tetanota Meyrick, I909, Journ. Bombay Nat. Hist. Soc., I9: 602.

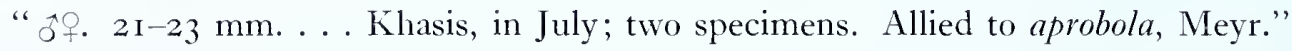

Lectotype: The male, "Khasi Hills, Assam. .7.1906." Slide No. 7198. The abdomen of the second specimen is missing.

Figure 2, left wings; $2 \mathrm{a}$, ventral view of male genitalia with aedeagus ill situ (the tip of the uncus is broken off); 2 b, partly denuded abdomen to show modified scales.

\section{Olethreutes tetracona (Meyrick)}

See Olethreutes threnodes (Meyrick).

\section{Olethreutes tetrarcha (Meyrick), new combination \\ Plate 275, Figure 3}

Argyroploce tetrarcha Meyrick, I920, Exotic Microlepidoptera, 2: 349 .

"o. It mm. ... Queensland, Brisbane, February (Dodd); I ex. Wals. Coil. (19223)."

Type: The specimen, without abdomen, labelled "Type" in the British Museum. The abdomen is missing. The pin-label reads "Toowong, Queensland. I6.ii.r897. Dodd. I9223."

Figure 3, left wings. 

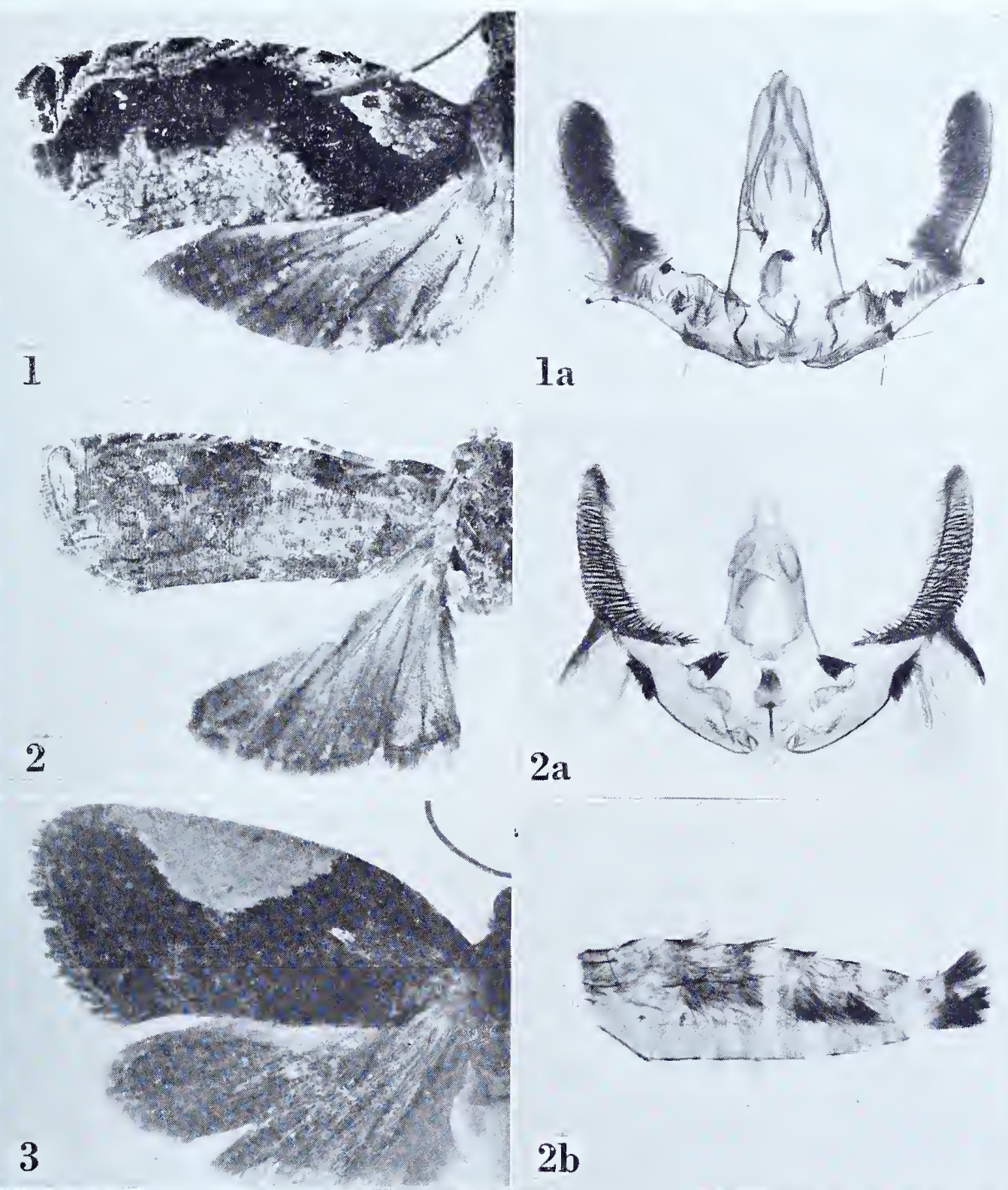

$2 b$
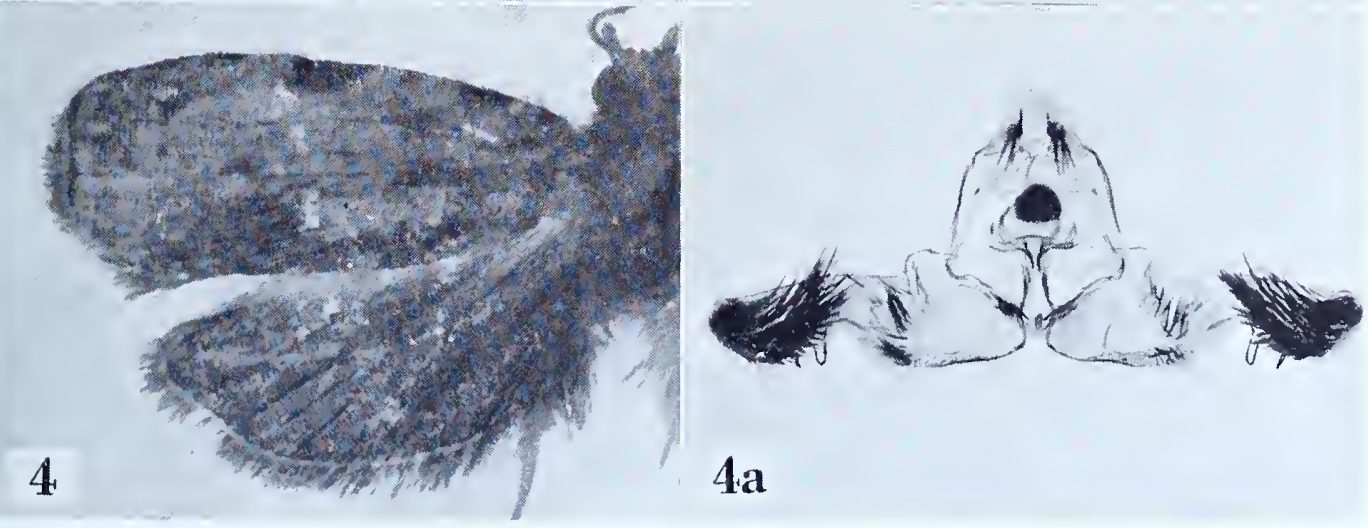

$4 a$ 

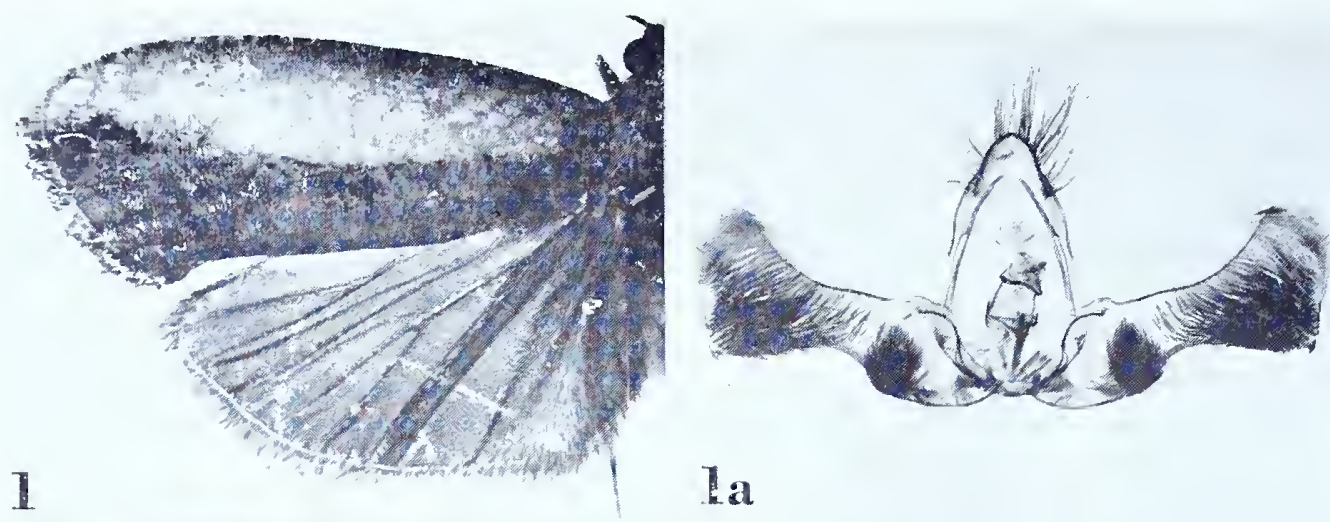

Ia

2
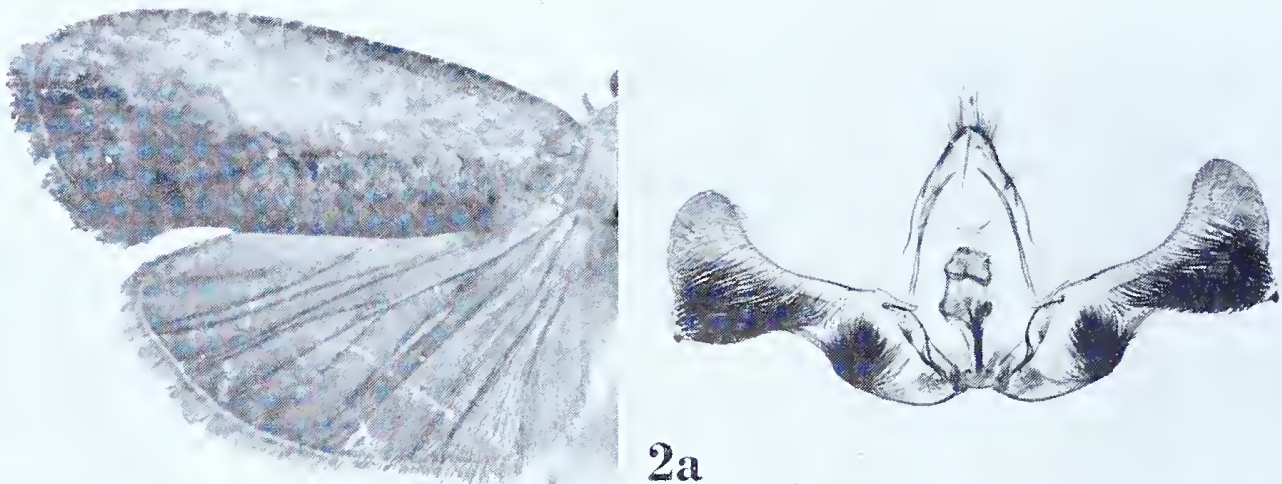

$2 a$
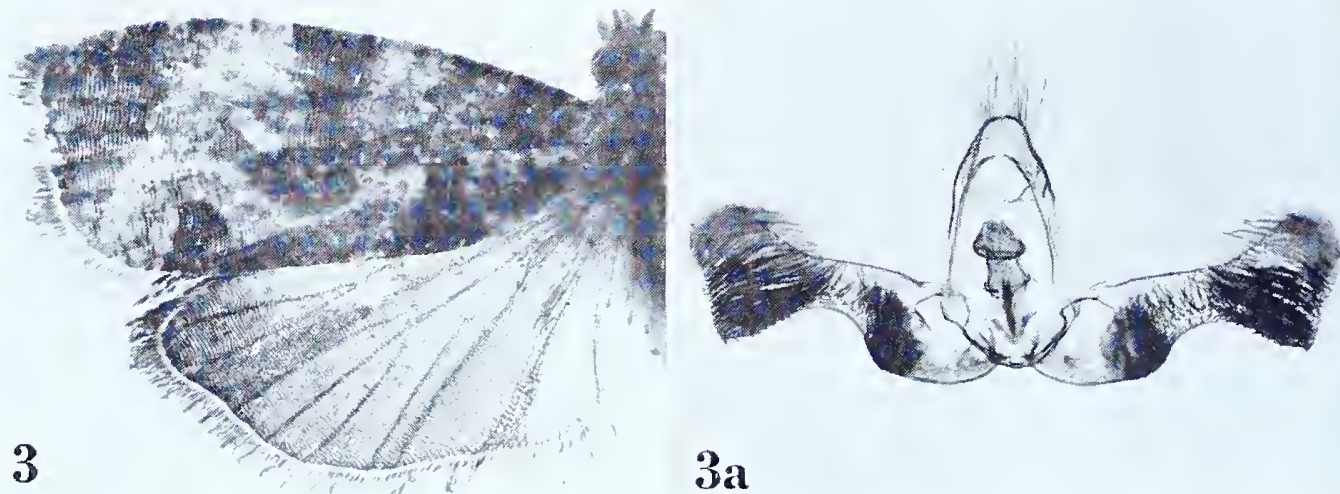

$3 a$
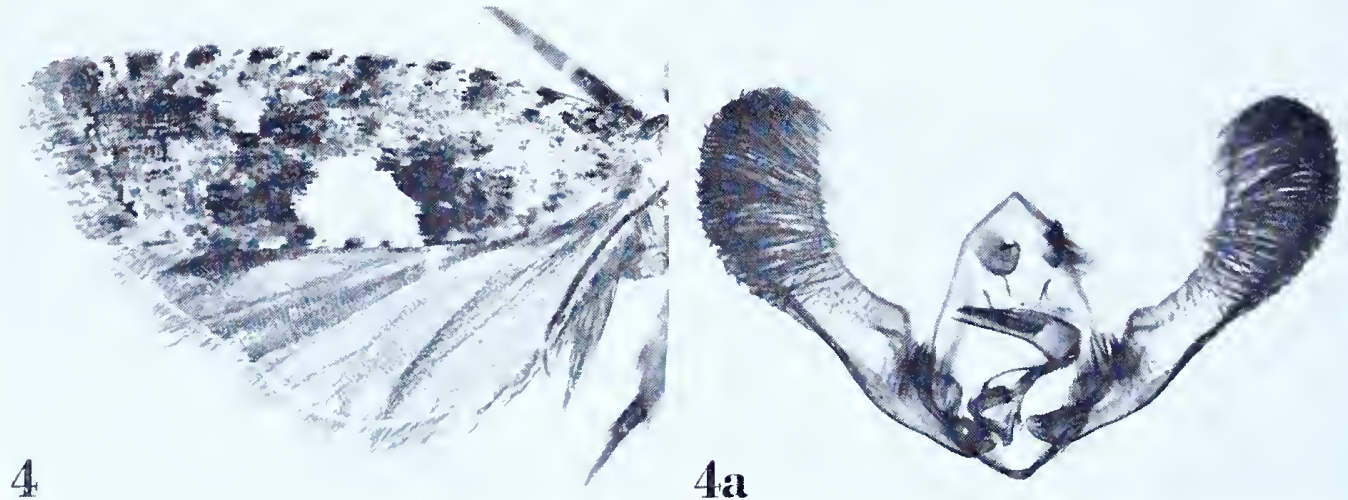


\section{Olethreutes threnodes (Meyrick), new combination}

Plate 276 , Figures $1-1 \mathrm{a} ; 2-2 \mathrm{a} ; 3^{-3}$ a

Platypeplus threnodes Meyrick, 1905, Journ. Bombay Nat. Hist. Soc., r6: $5^{8} 5$.

Platypeplus hemiopta Meyrick, 1905, 1.c., 586.

Platypeplns tetracona Meyrick, 1907, Journ. Bombay Nat. Hist. Soc., I7: 73I (new synonymy).

[threnodes]

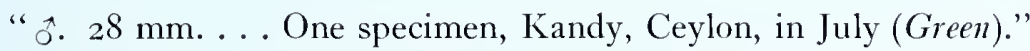

Type: Lost. There is no specimen in the Meyrick collection dated July; but there are two specimens dated ".4.96" and ".6.07", the former most nearly fitting the description and used for illustration. Slide No. 7208.

Figure I, left wings; ra, ventral view of male genitalia with aedeagus in sitn.

[hemiopta]

" o. $28 \mathrm{~mm}$. . . One specimen, Peradeniya, Ceylon, in September (Green)."

Type: The male indicated above dated ".9.00". Slide No. 7209.

Figure 2, left wings; 2 a, ventral view of male genitalia with aedeagus in situ.

[tetracona]

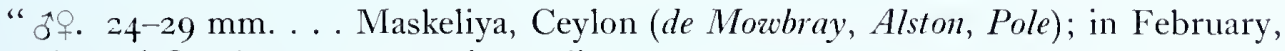
March, and October, seven specimens."

Lectotype: A male measuring 26 mm., "Maskeliya, Ceylon. de Mowbray. . I0.04." Slide No. 7276 .

Figure 3 , left wings; 3 a, ventral view of male genitalia with aedeagus in sitn.

\section{Olethreutes thymelopa (Meyrick), new combination}

Plate 276 , Figures $4-4 \mathrm{a}$

Argyroploce thymelopa Meyrick, 1938, in Caradja and Meyrick, Deuts. Ent. Zeit. Iris, 52 : I. “. . . 17-18 mm. ... Yül., 2,800-3,200 m., VI, VII; 5 ex."

Lectotype: A male, "Likiang, China. H. .7.34." Slide No. 7214. Two specimens are missing and are, presumably, in the Caradja collection. Meyrick did not indicate the sexes, but there are one male and two females in his collection.

Figure 4, left wings; $\{$ a, ventral view of male genitalia with aedeagus in situ. 


\section{Olethreutes tonica (Meyrick), new combination}

Plate 277, Figures I-ia

Argyroploce tonica Meyrick, I909, Journ. Bombay Nat. Hist. Soc., I9: 606.

" for $_{+}$I $2-14$ mm. . . Maskeliya, Kandy and Haldamulla, Ceylon (Green, Pole); Khasis; in May, and from August to September; eight specimens."

Lectotype: A male measuring it mm., "Kandy, Ceylon, Green. .8.o6." Slide No. 7229 .

Figure I, left wings; Ia, ventral view of male genitalia with aedeagus in sit $u$.

\section{Olethreutes tonsoria (Meyrick), new combination}

Plate 277, Figures 2-2a

Argyroploce tonsoria Meyrick, I909, Journ. Bombay Nat. Hist. Soc., 19: 592.

" $\hat{0} .16 \mathrm{~mm}$. . . Bentota, Ceylon; one specimen, bred in January from larva feeding in fruit of Barringtonia racemosa (Green)."

Type: The male denoted above dated “. I.02". Slide No. 7196.

Figure 2 , left wings; $2 \mathrm{a}$, ventral view of male genitalia with aedeagus $i n$ situ.

\section{Olethreutes tornophanes (Meyrick), new combination}

\section{Flate 277 , Figure 3}

Argyroploce tomophanes Meyrick, 1930, Exotic Microlepidoptera, 3: 603 .

"․ $20 \mathrm{~mm}$. . . Solomon Is., Guadalcanar (Meek); I ex. (Coll. Paravicini). Most like the Australian evedra."

Type: The specimen so marked in the British Museum, without head or abdomen, dated "I 90 I".

Figure 3 , right wings (image reversed).

\section{Olethreutes torquata (Meyrick), new combination}

Plate 277 , Figures $4-4 \mathrm{c}$

Argyroploce torquata Meyrick, 1927, Exotic Microlepidoptera, 3:339.

" $\tilde{f}+$. I2-15 mm. . . Bermuda, June to September (Ogilvie); I5 ex. (type Brit. Mus.)."

Type: The female so marked in the British Museum, with left forewing missing. The specimen is labelled, "Bermuda Exp. Sta. . . ." but the rest of the data are indecipherable. Slide No. 7069 .

Figure 4 , right wings (image reversed); $4 \mathrm{a}$, signum; $4 \mathrm{~b}$, ventral view of female genitalia; 4 c, detail of genital plate and ostium. 

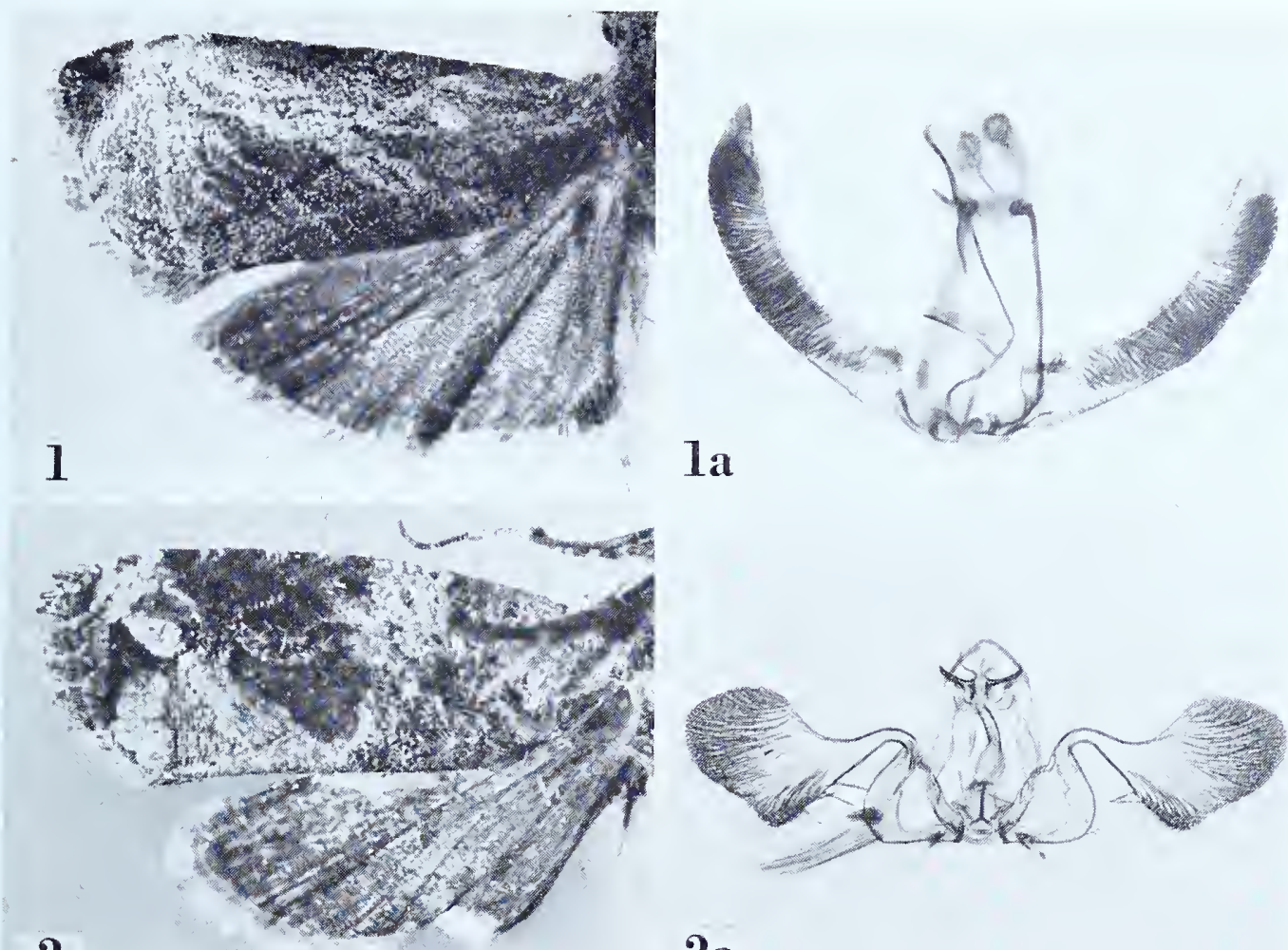

2

$2 a$
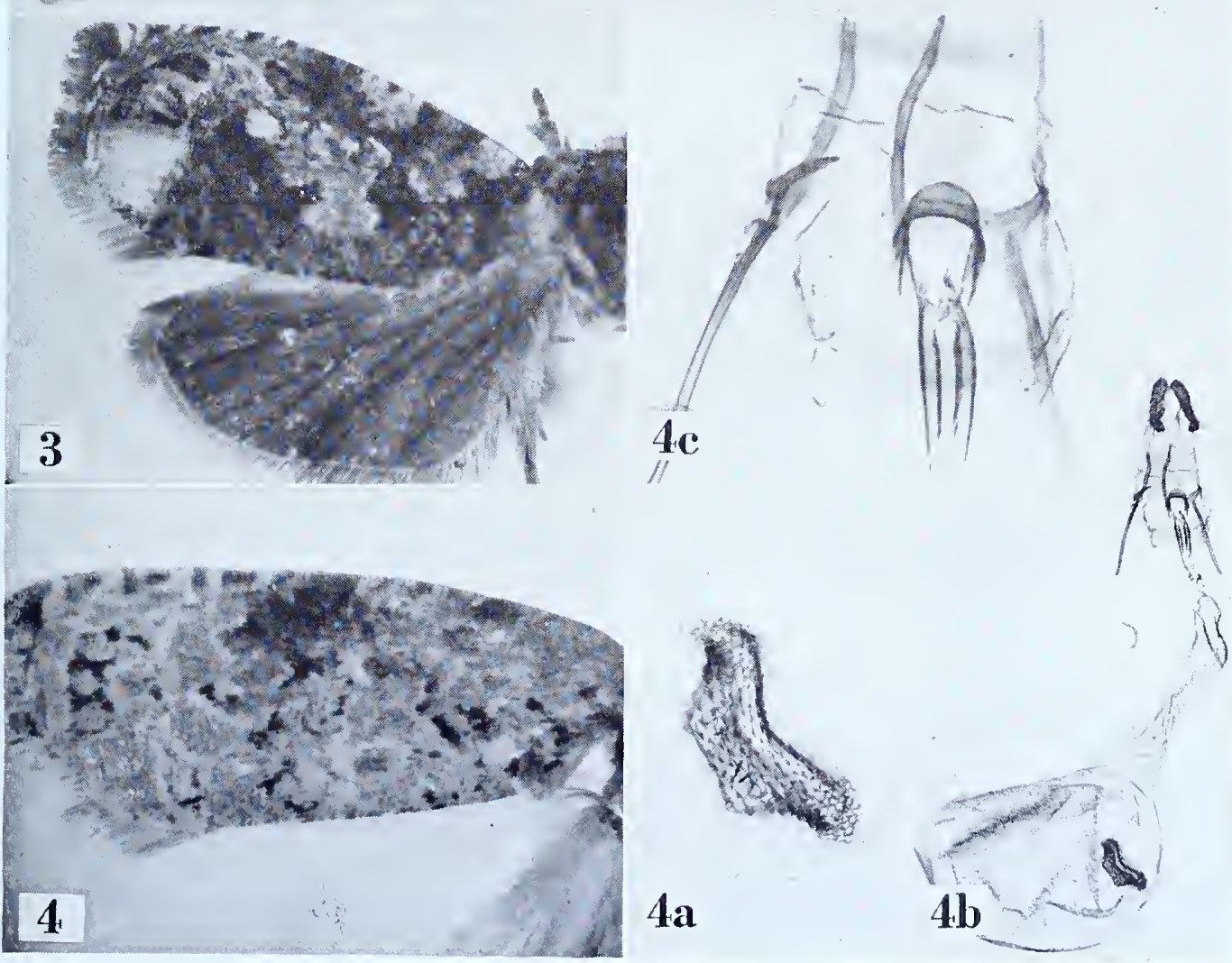


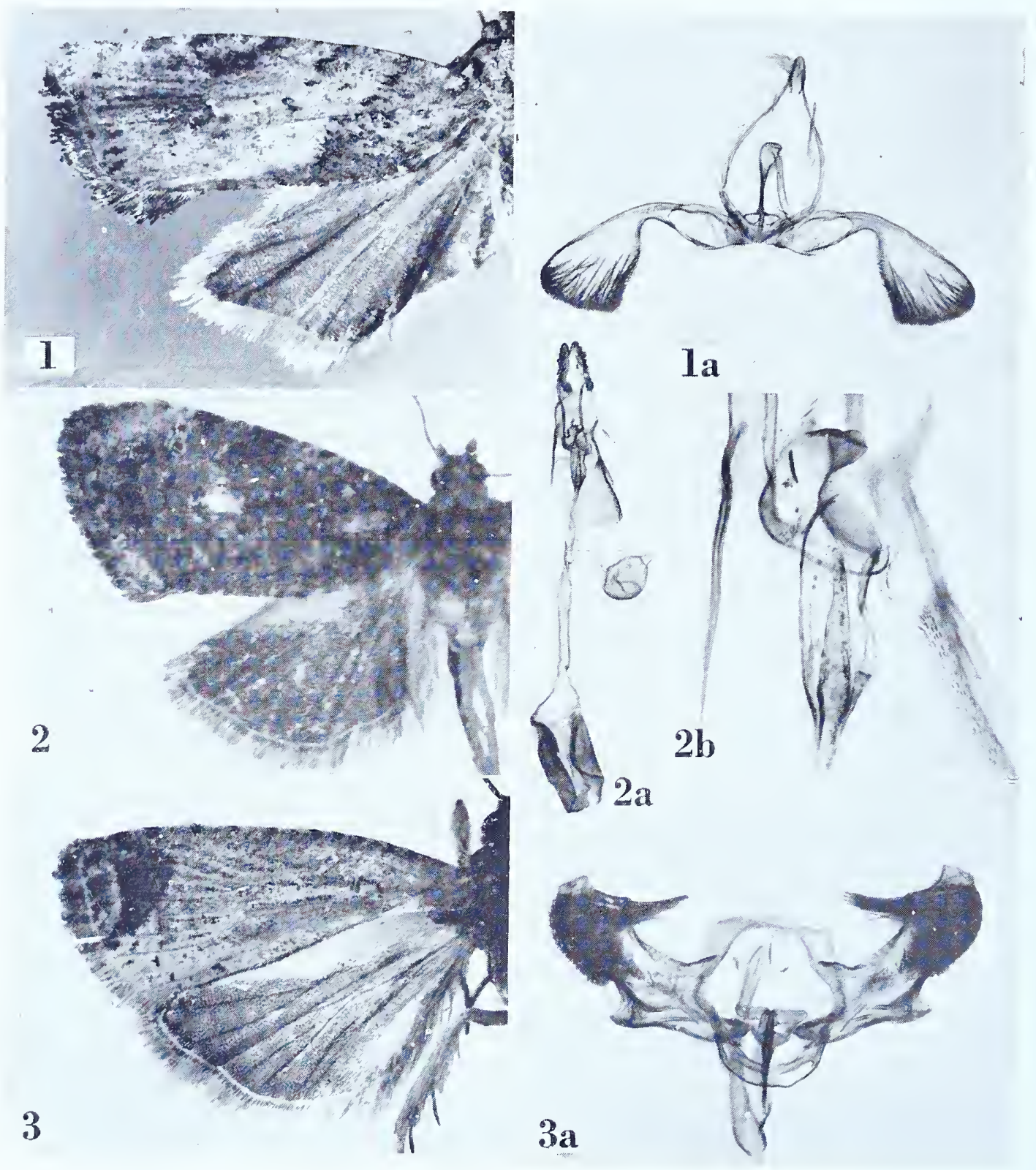

OLETHREUTES 


\section{Olethreutes trophiodes (Meyrick), new combination}

Plate 278, Figures I-Ia

Eucosma trophiodes Meyrick, I908, Journ. Bombay Nat. Hist. Soc., i8: 6гз.

" of 7 . i $6-23 \mathrm{~mm}$. . . Maskeliya, Madulsima, Diyatalawa, Hakgala, Patipola, Newera Eliya, Ceylon (Pole, Green, Fletcler); Nilgiris (Andrewes); Coorg (Newcome); Khasis; from March to May, and August to November; twenty-five specimens."

Lectotype: ô, 20 mm., "Hakgala, Ceylon. EEG. .4.07." Siide No. 7173. Nine specimens are missing.

Figure I, left wings; Ia, ventral view of male genitalia with aedeagus in sill.

\section{Olethreutes vinculigera (Meyrick), new combination}

Plate 278 , Figures $2-2 \mathrm{~b}$

Argyroploce vinculigera Meyrick, 1939, Trans. R. Ent. Soc. London, 89: 50.

"․ I2-I 4 mm. . . U Uganda, Kampala, bred March, November, from Acantlus (T. H. C. Taylor); 2 ex. Type in British Museum."

Type: The female so marked in the British Museum, "Uganda, Kampala iii-1936. T. II. C. Taylor. ex Acanthus." An additional label, in Meyrick's hand, reads "Argyroploce vinculigera n. sp." Slide No. 73i6.

Figure 2, left wings; $2 \mathrm{a}$, ventral view of female genitalia; $2 \mathrm{~b}$, detail of ostium.

\section{Olethreutes xylodelta (Meyrick), new combination}

Plate 278 , Figures $3^{-} 3^{\mathrm{a}}$

“ '. 2 I mm. . . U Uganda, Kampala, bred August, 'raintree borer' (Hargreazes); I ex. (Brit. Mus.)."

Type: The above indicated male, so marked in the British Museum, "Uganda, Kampala. Io.8.22. H. Hargreaves." Also on the label, "No. A. 39" and "Coll. H. H.". Slide No. 73I4.

Figure 3 , left wings; 3 a, ventral view of male genitalia with aedeagus in situ.

Continued from p. 524 .

\section{Olethreutes liochlora (Meyrick), new combination}

Plate 26I, Figure 5

Argyroploce liochlora Meyrick, I914, Journ. Bombay Nat. Hist. Soc., 22: 771.

"O. I $5 \mathrm{~mm}$. . . Ganesh Gudi, Kanara, in May (Maxwell); one specimes."

Type: The above indicated male dated "I I.5.12", without abdomen.

Figure 5, left wings. 
OMIOSTOLA

\section{OMIOSTOLA Meyrick}

Oniostola Meyrick, 1922, Exotic Microlepidoptera, 2: 519. (Typus generis: Omiostola alplitopa Meyrick, ibid. [by original designation].)

\section{Omiostola alphitopa Meyrick}

Plate 279, Figures I-IC

Oniostola alphitopa Meyrick, I922, Exotic Microlepidoptera, 2: 519.

“3. I 5-1 8 mm. ... Brazil, Obidos, Manaos, September, November (Parish); 2 ex."

Lectotype: The male, "Manaos, Brazil, Parish. i I.I9." Slide No. 6405.

Figure I, left wings; Ia, venation of right wings; $\mathrm{Ib}$, lateral aspect of head to show palpus; Ic, ventral view of male genitalia with aedeagus in situ.

\section{Omiostola adamantea Meyrick}

Plate 279, Figures 2-2a

Omiostola adamantea Meyrick, I922, Exotic Microlepidoptera, 2: 520.

“ స̊ํ. I 8-20 mm. . . Brazil, Manaos, November (Parish); 5 ex."

Lectotype: The male measuring $18 \mathrm{~mm}$. Slide No. 6407. All specimens bear the date "i i.ig".

Figure 2, left wings; $2 \mathrm{a}$, ventral view of male genitalia with aedeagus $i$ situ.

\section{Omiostola macrotrachela Meyrick}

Plate 279, Figures 3-3a

Omiostola macrotrachela Meyrick, 1922, Exotic Microlepidoptera, 2: 519.

" $\hat{0}$. 30-35 mm. . . Colombia, San Antonio, 5,80o feet, November ; 2 ex."

Lectotype: The male measuring $30 \mathrm{~mm}$., dated "i 1.07". Slide No. 6406.

Figure 3 , left wings; 3 a, ventral view of male genitalia with aedeagus in situ.

Continued from $p .532$.

\section{Olethreutes paragramma (Meyrick), new combination}

Plate $26_{5}$, Figures $4-4 b$

Argyroploce paragramma Meyrick, I909, Journ. Bombay Nat. Hist. Soc., i 9: 598.

"ㅇ. $19 \mathrm{~mm}$. . . . Pusa, Bengal, bred in September from stem of bamboo (Lefroy); one specimen."

Type: The above indicated female dated "20.9.06”. Slide No. 7253.

Figure 4 , left wings; 4 a, ventral view of female genitalia; 4 b, detail of genital plate and ostium.

$$
[560]
$$



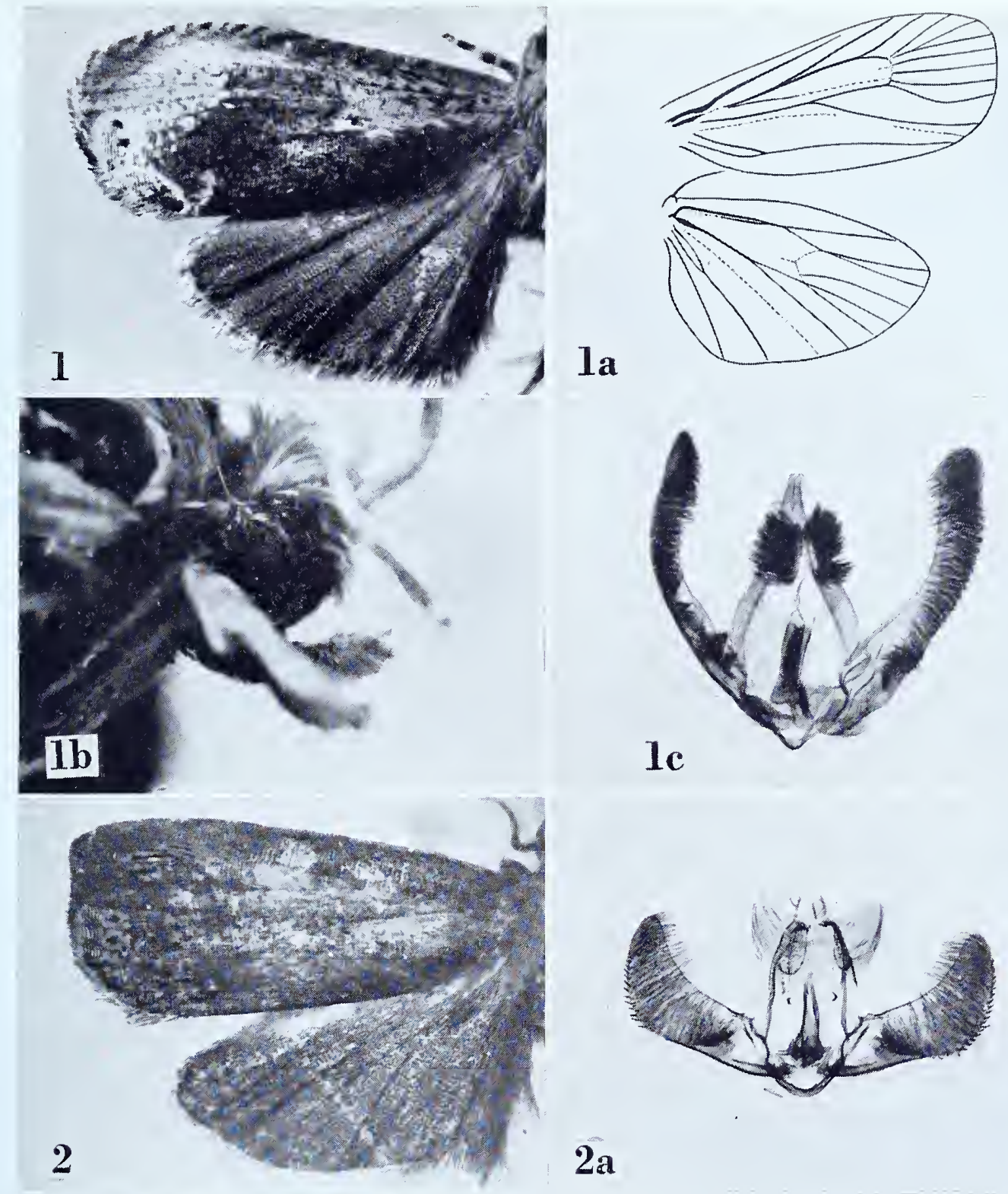

2a
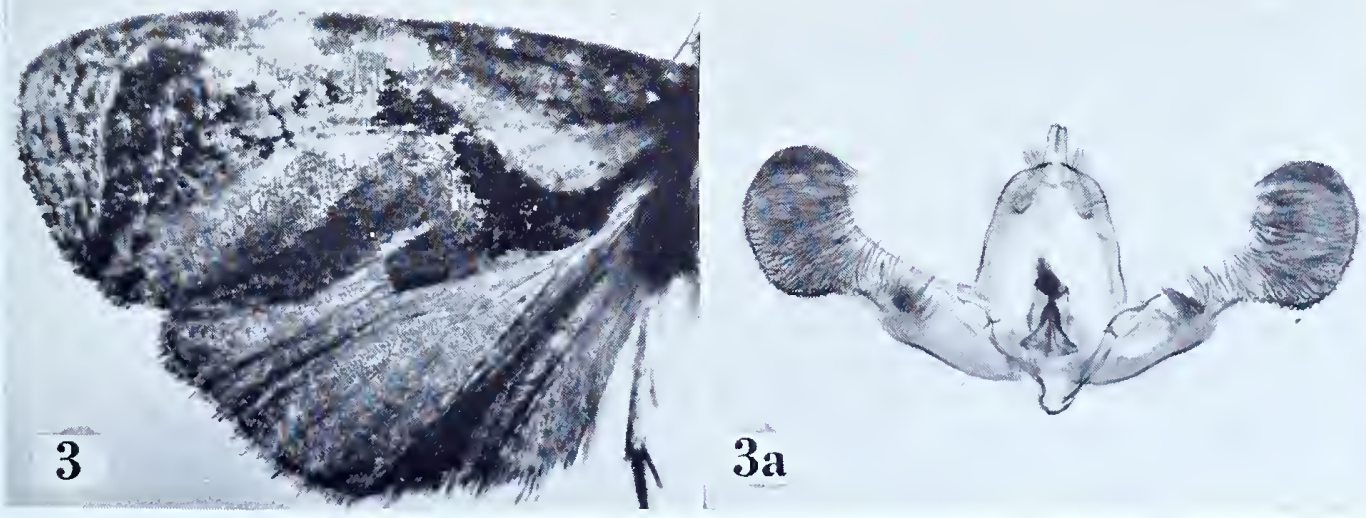

$3 a$ 

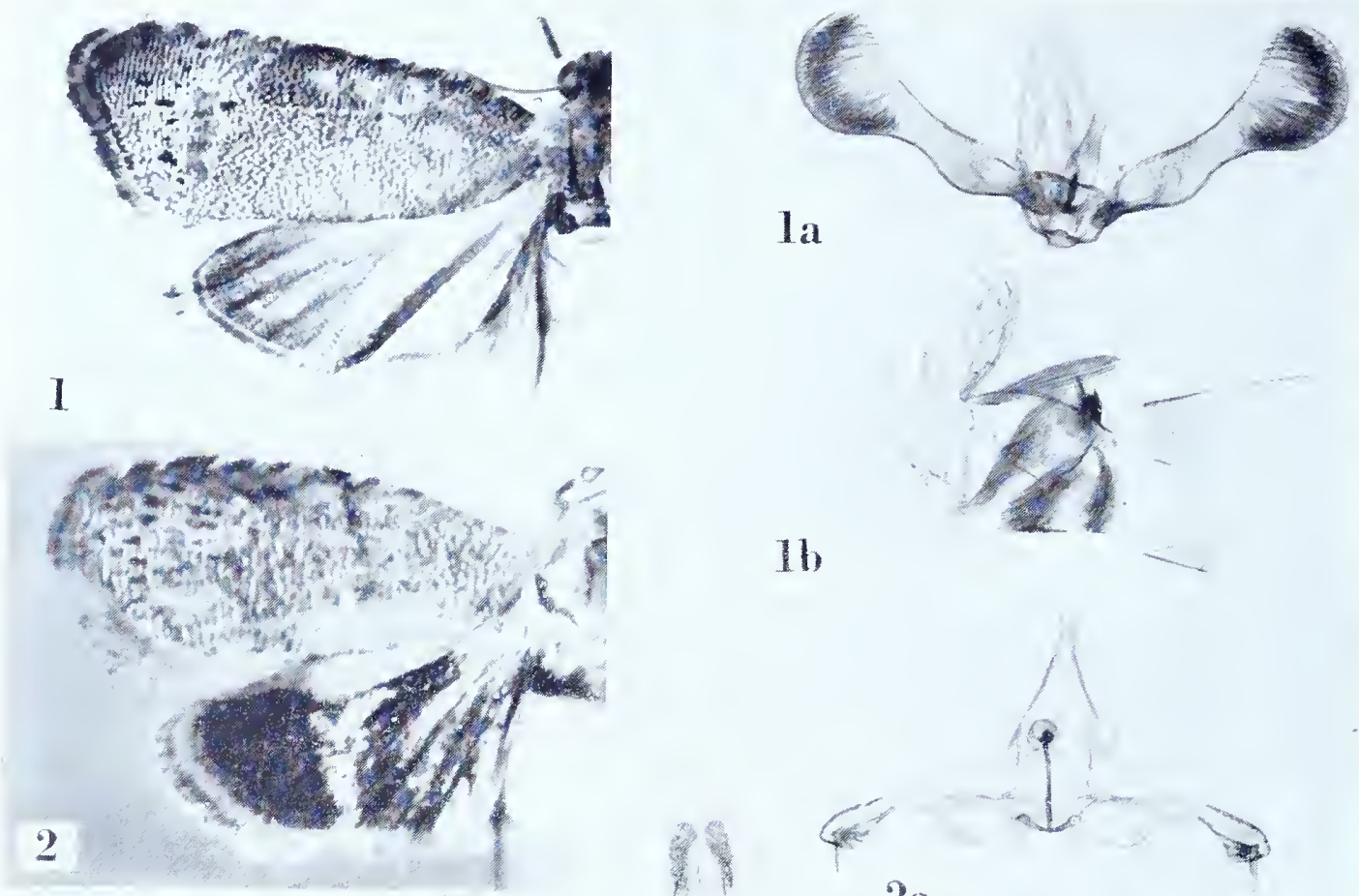

1b
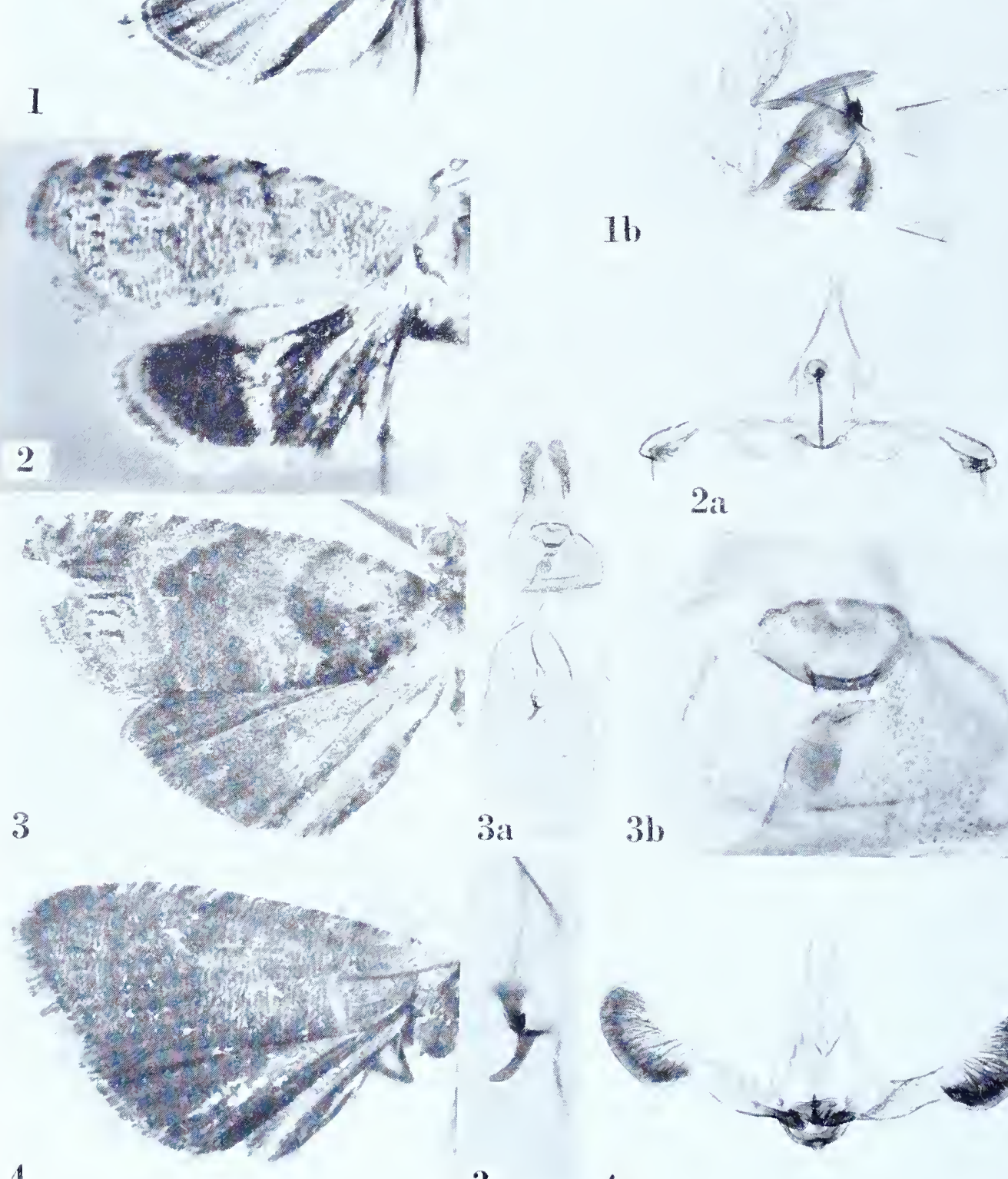

$3 a$
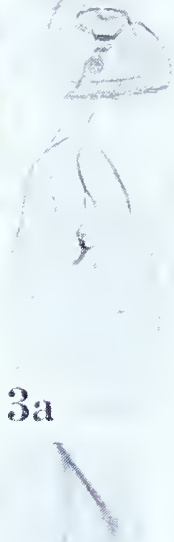

$3 \mathrm{~b}$
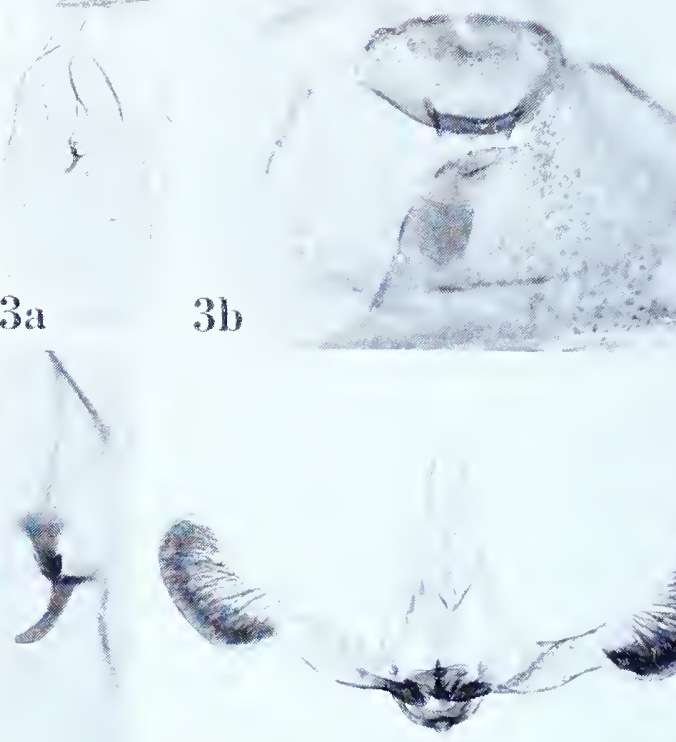

$3 c$
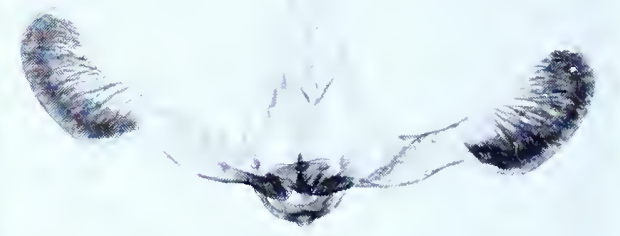

4

PAMMENE 


\section{PAMMENE Hübner \\ Pammene dicastica Meyrick}

Plate 280, Figures $\mathrm{I}-\mathrm{I}$ b

Pammene dicastica Meyrick, 1922, Exotic Microlepidoptera, 2: 526.

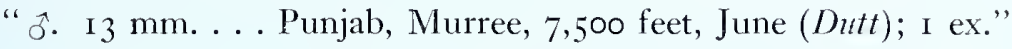

Type: The above indicated male dated ".6.18". Slide No. 7353.

Figure 1, left wings; 1 a, ventral view of male genitalia with aedeagus in situ; $\mathrm{Ib}$, part of denuded abdomen to show posterior tufts.

\section{Pammene ellipticopa Meyrick}

Plate 280, Figures 2-2a

Pammene ellipticopa Meyrick, I934, Exotic Microlepidoptera, 4:486.

" $0.8 \mathrm{~mm}$. . . Java, Telawa, bred October from larvae feeding in shoots of an undetermined plant (Dr. L. G. E. Kalshoven ); 2 ex. Allied to peristictis Meyr. . ."

Lectotype: The male dated “.10.33”. Slide No. 7362.

Figure 2, left wings; 2a, ventral view of male genitalia with aedeagus in situ.

\section{Pammene hexaphora Meyrick}

Plate 280, Figures $3^{-} 3^{\mathrm{c}}$

Pammene hexaphora Meyrick, 1935, in Caradja and Meyrick, Materialien zu einer Microlepidopteren Fauna der Chinesischen Provinzen Kiangsu, Chekiang und Hunan, 62.

"... o. I4 mm. ... I ex., Shanghai, VI. Allied to salvana Stgr."

Type: The female indicated above dated "10.6.32". Slide No. 7344.

Figure 3 , left wings; 3 a, ventral view of female genitalia; 3 , detail of genital plate and ostium; 3 c, signum.

\section{Pammene homotorna Meyrick}

Plate 280 , Figures $4-4 \mathrm{a}$

Pammene homotoma Meyrick, 1912, Journ. Bombay Nat. Hist. Soc., $21: 874$. " 구. I I-I3 mm. . . Khasis; in June and September, six specimens." Lectotype: The male, "Khasi Hills, Assam. .6.1906." Slide No. 7360.

Figure 4, left wings; 4 a, ventral view of male genitalia with aedeagus in sitn. 
PAMMENE

\section{Pammene isocampta Meyrick \\ Plate 28 I, Figures $I-I$ a}

Pammene isocampta Meyrick, 1914, Exotic Microlepidoptera, I: 196.

" o. I I-I $2 \mathrm{~mm}$. . . Ceylon, Peradeniya, bred in February (Rutherford); two specimens. 'Associated with Lecaninm sp.,' presumably feeding on these Coccids. Type in British Museum."

Type: The male so marked in the British Museum, "Peradeniya, Ceylon. 1913, A. Rutherford." Slide No. 7347.

Figure I, left wings; Ia, ventral view of male genitalia with aedeagus in sitn.

\section{Pammene leucodora Meyrick}

Plate 28I, Figures 2-2b

Pammena [sic!] lencodora Meyrick, I 928, Exotic Microlepidoptera, 3: 447.

" ${ }^{*}$. I I $3^{-I} 4 \mathrm{~mm} . .$. Philippines, Los Baños (Baker); 2 ex. Very near rescissa from Java. ..."

Lectotype: The male, "Los Baños, Philippines. B. .27." Slide No. 7354.

Figure 2, left wings; $2 \mathrm{a}$, ventral view of male genitalia with aedeagus in sitn; 2b, part of denuded abdomen to illustrate posterior tufts.

\section{Pammene marmaranthes Meyrick}

Plate 28 I, Figures $3^{-} 3^{a}$

Pammene marmaranthes Meyrick, 1933, Exotic Microlepidoptera, 4: 422.

". . 8-ro mm. . . Java, bred January from Murraya exotica (Rutaceae) (Dr. L. G. E. Kalshoren); 2 ex. The specimens are damaged but sufficiently distinguishable."

Lectotype: The female measuring ro mm., dated ".r.32". Slide No. 7346 . The second specimen is missing.

Figure 3, left wings; 3 a, ventral view of female genitalia.

\section{Pammene oxystaura Meyrick \\ Plate $28 \mathrm{I}$, Figures $4-4 \mathrm{~b}$}

Pammene oxystanra Meyrick, 1935, in Caradja and Meyrick, Materialien zu einer Microlepidopteren Fauna der Chinesischen Provinzen Kiangsu, Chekiang und Hunan, 62.

"... 3ㅇ․ I I-I 2 mm., 7 ex., Tienmushan, Shanghai, IX. Nanking 15. VI. Allied to rescissa Meyr. from Java."

Lectotype: A male measuring i 2 mm., "Tien-Mu-Shan, China. C. 5,300' .9.32." Slide No. 7345 .

Figure 4 , left wings; 4 a, ventral view of male genitalia with aedeagus in sitn; 4 b, part of denuded abdomen to show posterior tufts.

$$
[564]
$$



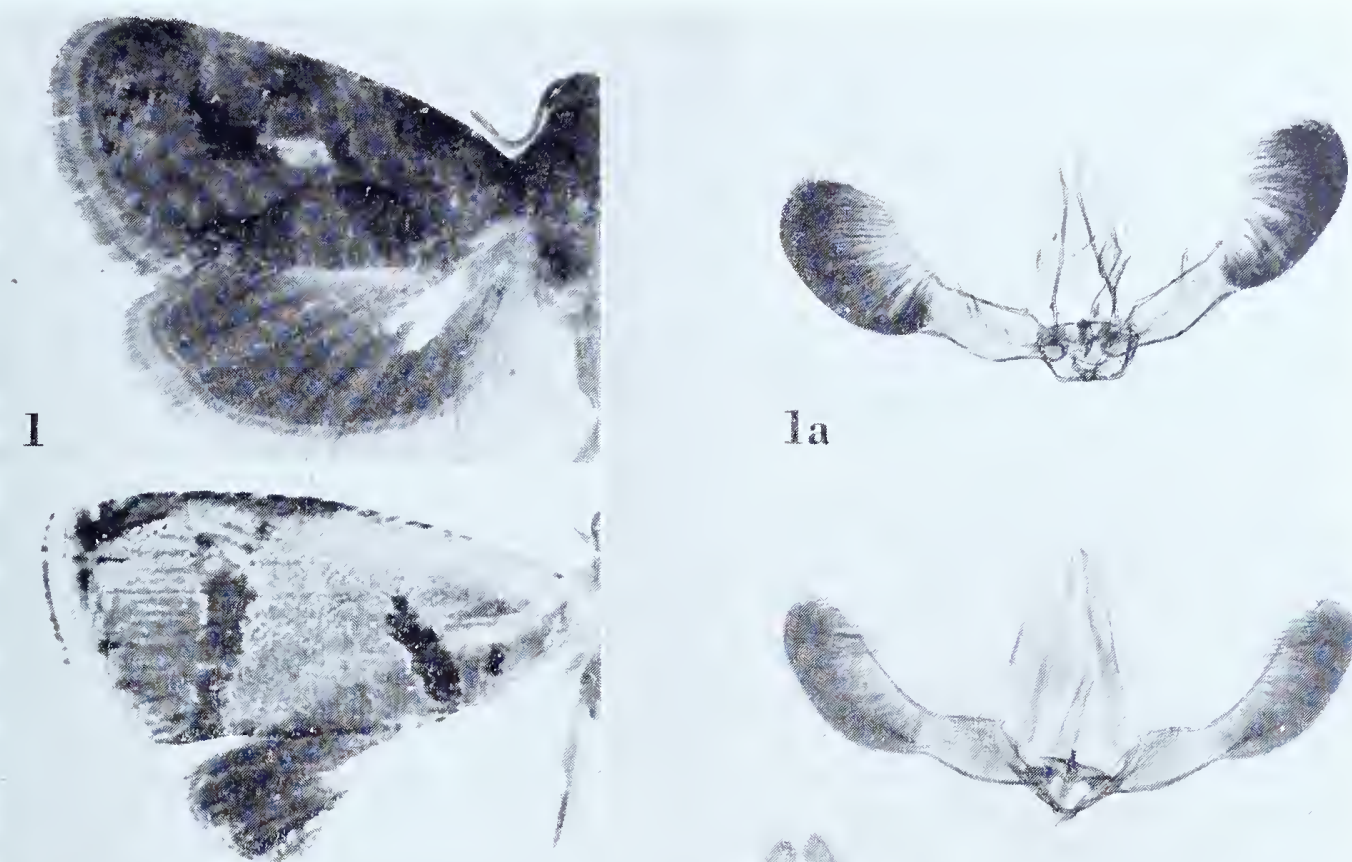

2

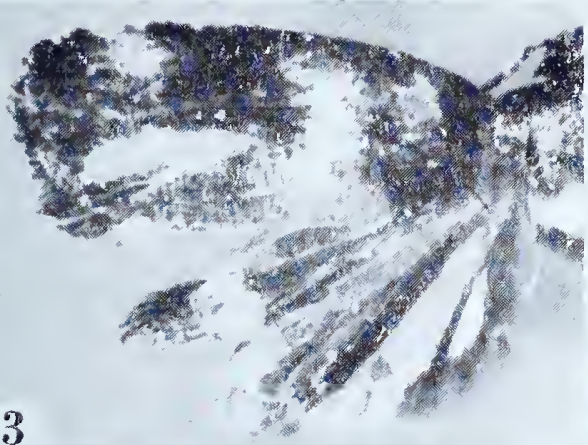

3

4
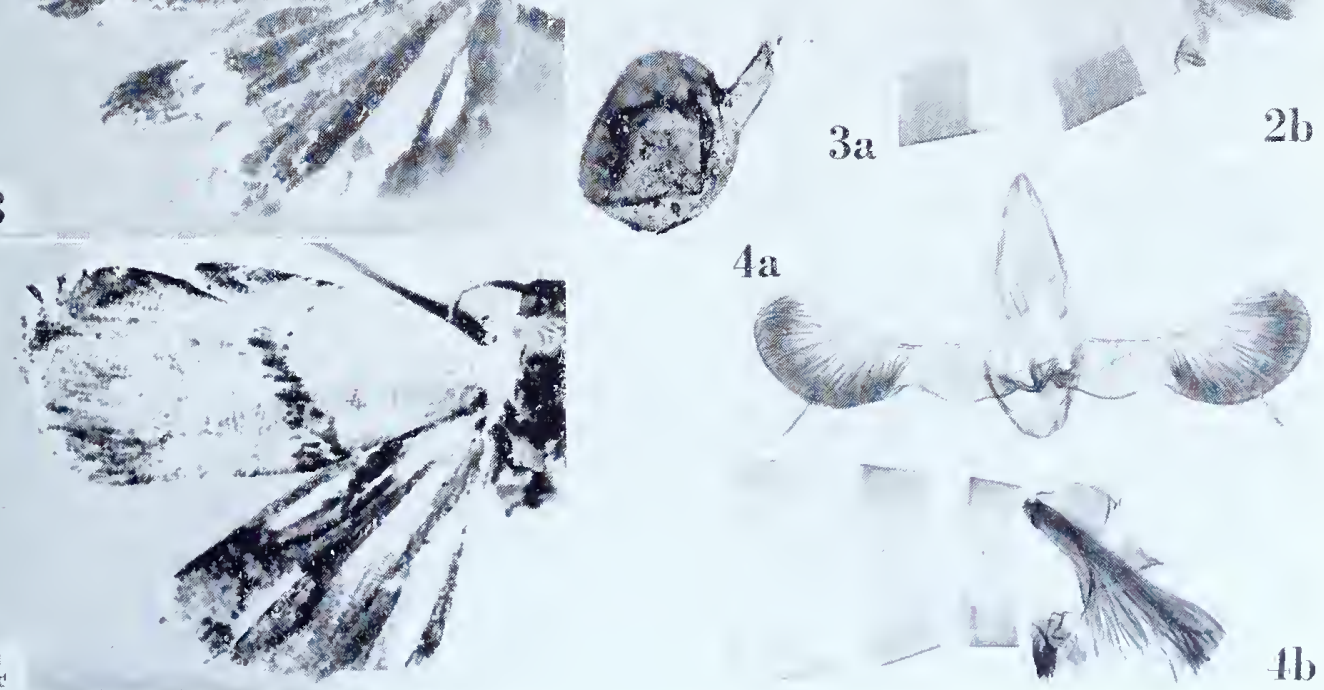

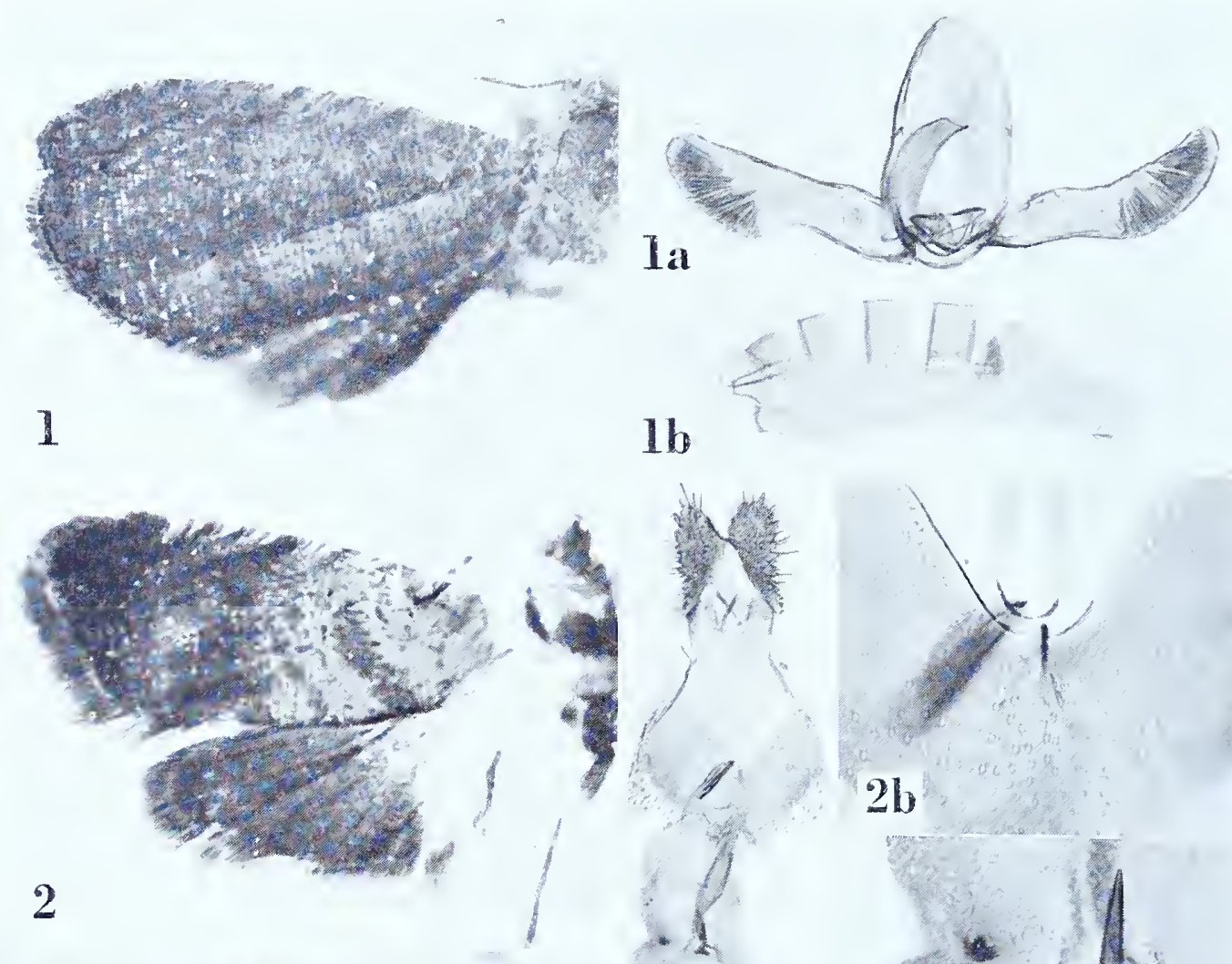

Ib
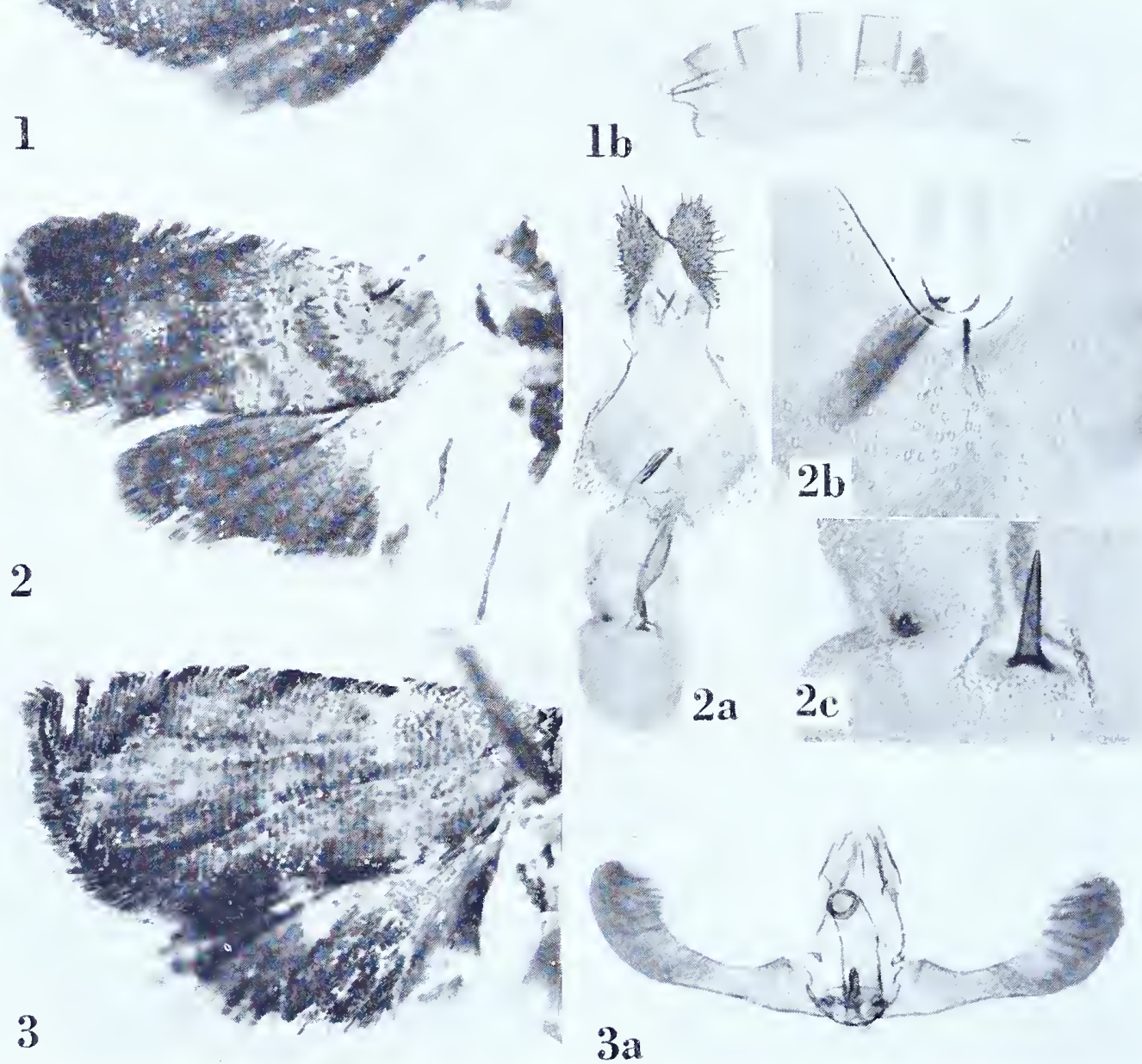

\section{$2 a \quad 2 c$}

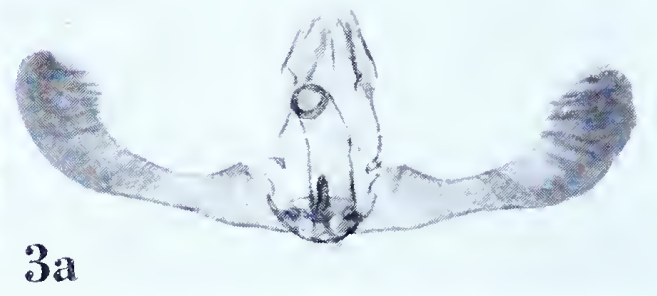

PAMMENE 


\section{Pammene peristictis Meyrick}

Plate 282, Figures I-Ib

Pammene peristictis Meyrick, I912, Journ. Bombay Nat. Hist. Soc., 21 : 874.

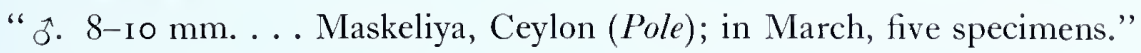

Lectotype: A male measuring ı mm., "Maskeliya, Ceylon. Pole. -3.o6." Slide No. $736 \mathrm{I}$.

Figure г, left wings; гa, ventral view of male genitalia with aedeagus in sitn; гb, denuded abdomen to show small, internal tuft from anterior edge of 6th segment.

\section{Pammene quercivora Meyrick}

Plate 282, Figures 2-2c

Pammene quercivora Meyrick, I920, Exotic Microlepidoptera, 2: $35 \mathrm{I}$.

"․ 8-9 mm. . . Assam, Shillong, 5,00o feet, July, bred from larvae on leaves of Quercus Griffithi (Fletcher); 2 ex."

Lectotype: The female measuring 9 mm., dated "7.I 8". Slide No. $73+3$.

Figure 2, left wings; 2a, ventral view of female genitalia; $2 \mathrm{~b}$, detail of ostium; $2 \mathrm{c}$, signa.

\section{Pammene theristis Meyrick}

Plate 282, Figures $3-3$ a

Pammene theristis Meyrick, I912, Journ. Bombay Nat. Hist. Soc., 21 : 874 .

“ for $^{\circ}$ I I-I 4 mm. ... Maskeliya, Ceylon (Pole, de Mowbray); Kumaon; in May, June and October, four specimens. Bred from seedlings of Shorea robusta (Indian Forest Service)."

Lectotype: 'The male, "Maskeliya, Ceylon. de Mowbray. .5.o6." Slide No. 7355. One specimen is missing.

Figure 3, left wings; 3 a, ventral view of male genitalia with aedeagus in sit $ı$.

Continued from p. 552 .

\section{Olethreutes thermopetra (Meyrick), new combination}

Plate 275 , Figures $4-4^{\mathrm{a}}$

Argyroploce thermopetra Meyrick, 1930, Exotic Microlepidoptera, 3: 602.

“ . $18 \mathrm{~mm}$.... Cameroons, Lolodorf, February (Conradt); i ex. (Coll. Paravicini). Allied to iorrhoa."

Type: The above indicated male so marked in the British Museum. A small white label bears the inscription " $21 /$ ii.95". Slide No. 7064.

Figure 4 , left wings; 4 a, ventral view of male genitalia with aedeagus in situ.

$$
\left[5^{67}\right]
$$




\section{PARABACTRA Meyrick}

Parabactra Meyrick, 1910, Ent. Mon. Mag., 46: 72.

Epibactra Meyrick, 1909, Journ. Bombay Nat. Hist. Soc., 19: 582. (Typus generis: Epibactra arenosa Meyrick, ibid. [monotypy] (preoccupied).)

\section{Parabactra arenosa (Meyrick)}

Plate $28_{3}$, Figures I-IC

Epibactra arenosa Meyrick, I909, Journ. Bombay Nat. Hist. Soc., 19: 582. mens."

“ o. I $7^{-22} \mathrm{~mm}$. . . Maskeliya, Ceylon, in June and October (Pole); three speci-

Lectotype: The male measuring $20 \mathrm{~mm}$., dated ".6.04". Slide No. 7126.

Figure $\mathrm{x}$, left wings; $\mathrm{ia}$, venation of right wings; $\mathrm{x} b$, lateral aspect of head to show palpus; Ic, ventral view of male genitalia with aedeagus in sitn.

\section{Parabactra foederata (Meyrick)}

Plate $28_{3}$, Figures 2-2a

Bactra foederata Meyrick, I909, Journ. Bombay Nat. Hist. Soc., 19: 582; Diakonoff, 1950, Bull. Brit. Mus. (Nat. Hist.) Ent., I (4): 293.

" $\hat{o}$. 20-22 mm. . . Maskeliya, Ceylon, in April and August (de Mowbray, Pole); two specimens."

Lectotype: The male, selected by Diakonoff, dated ".8.04", from which the abdomen is missing. Genitalia figured from a male, "Namunukuli, Ceylon. EEG. 2.10." Slide No. 7r 34 .

Figure 2, left wings; 2 a, ventral view of male genitalia with aedeagus in sitn.

\section{Parabactra sociata (Meyrick)}

Plate $28_{3}$, Figures $3^{-}-3^{a}$

Bactra sociata Meyrick, 1909, Journ. Bombay Nat. Hist. Soc., 19: 583; Diakonoff, 1950, Bull. Brit. Mus. (Nat. Hist.) Ent., I (4): 293 .

“ 今. I7-1 8 mm., ㅇ 2I-23 mm. . . Maskeliya and Kelewewa, Ceylon, in May, July, September, and January (Pole, Alston); four specimens."

Lectotype: The male, "Maskeliya, Ceylon, Pole. .7.05", selected by Diakonoff. Slide No. 7 I 35 .

Figure 3, left wings; 3 a, ventral view of male genitalia with aedeagus in sit $u$. 

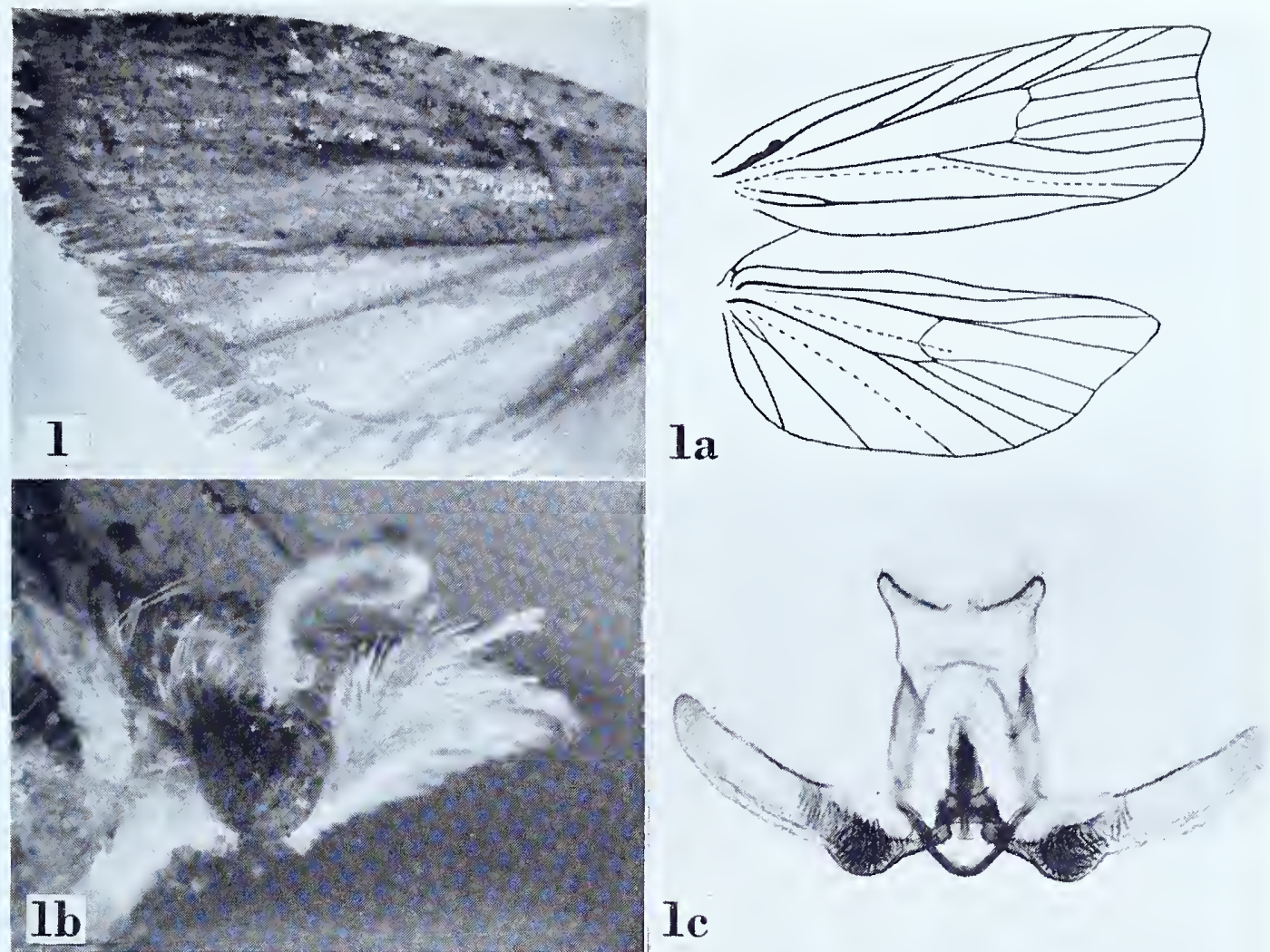

Ic
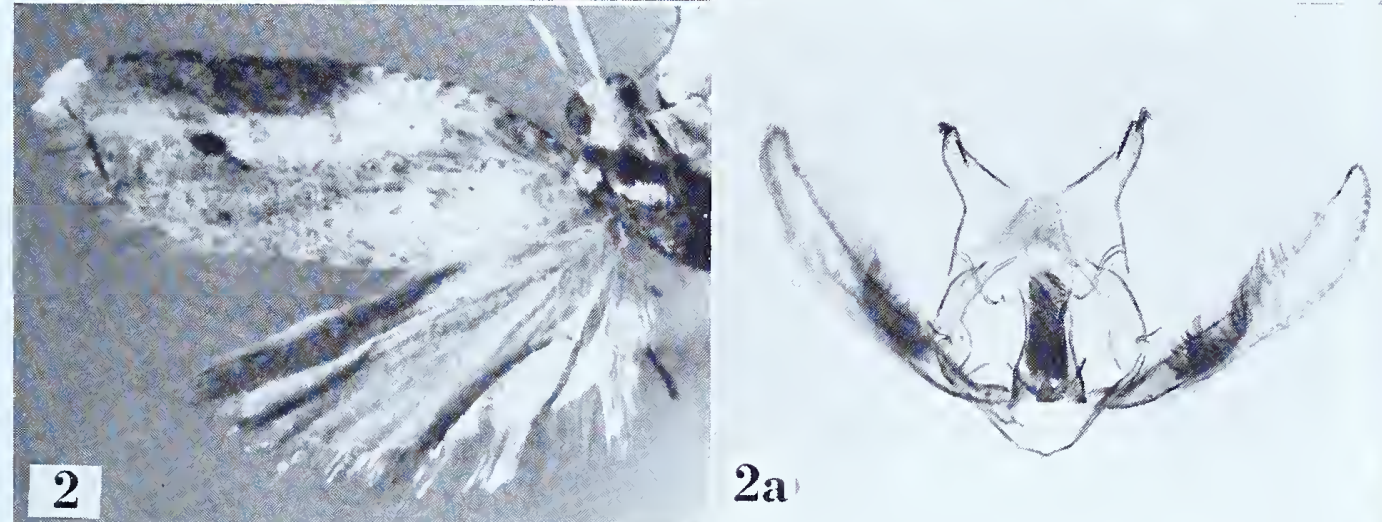

$\mathbf{2 a}$

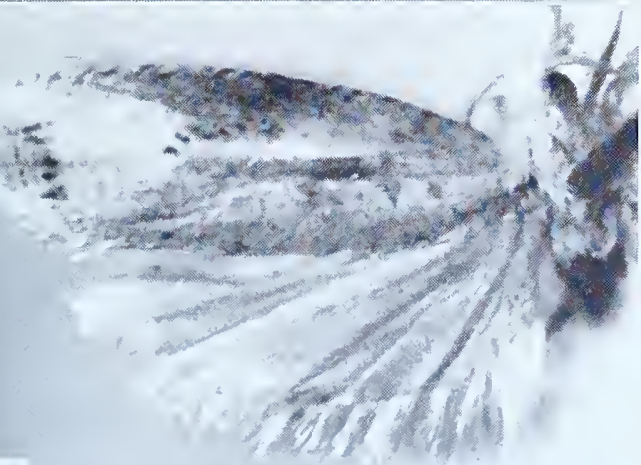

3

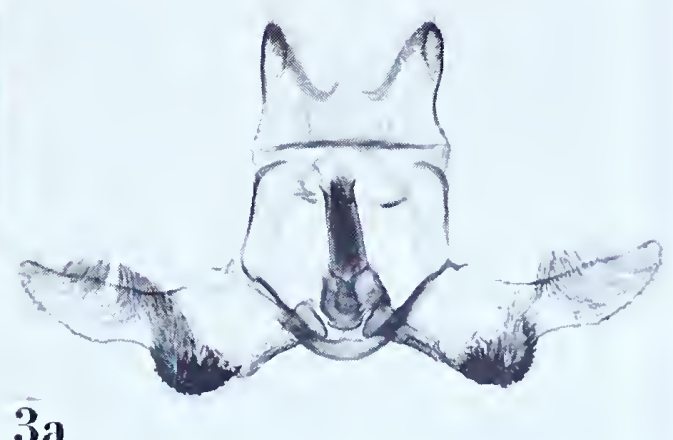




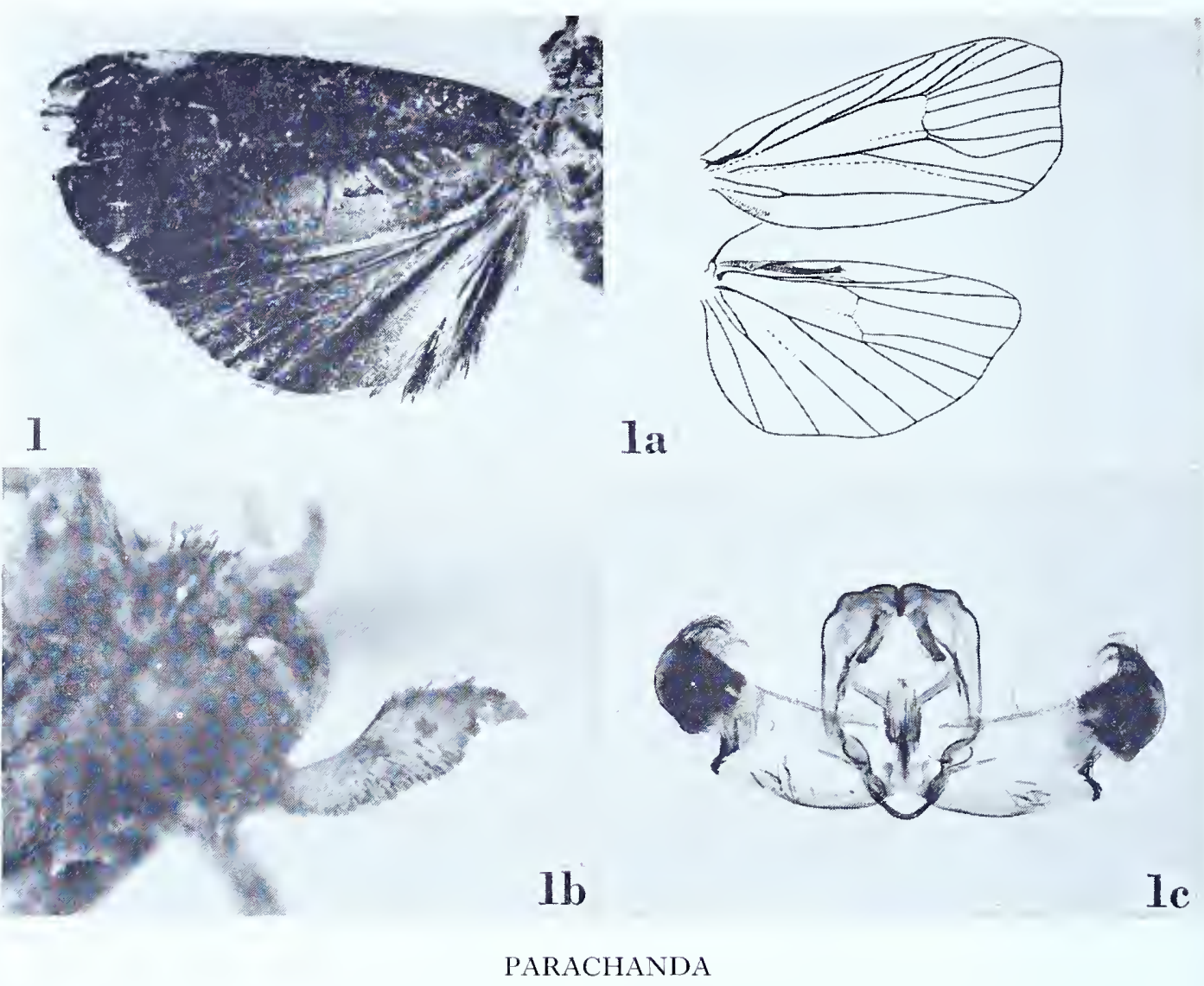




\section{PARACHANDA Meyrick}

Parachanda Meyrick, I927, Exotic Microlepidoptera, 3: 338. (Typns generis: Parachanda phantastis Meyrick, ibid. [monotypy].)

\section{Parachanda phantastis Meyrick \\ Plate 28 , Figures $\mathrm{I}-\mathrm{IC}$}

Parachanda phantastis Meyrick, i927, Exotic Microlepidoptera, 3: $33^{8}$.

" o. 29 mm. . . Bolivia, Andes, i o,ooo feet; i ex."

Type: The specimen indicated above with ".20" in the lower right corner of the pin-label. Slide No. 6412.

Figure I, left wings; $\mathrm{I} a$, venation of right wings; $\mathrm{Ib}$, lateral aspect of head to show palpus; Ic, ventral view of male genitalia with aedeagus in situ.

\section{PHAECADOPHORA Walsingham}

\section{Phaecadophora eaolotechna (Meyrick), new combination}

Plate 25 , Figures $3^{-} 3^{b}$

Argyroploce eaolotechna Meyrick, in Caradja and Meyrick, Materialien zu einer Microlepidopteren Fauna der Chinesischen Provinzen Kiangsu, Chekiang und Hunan, 60. " 37. I7-I 8 mm. . . . Lungtan. 29-VII. I6-IX. Io ex."

Lectotype: A male measuring 18 mm., "Nanking, China. H. I9.8.33." Slide No. 7247 .

Figure 3 , left wings; 3 a, denuded abdomen to illustrate ventral abdominal tufts; $3^{\mathrm{b}}$, ventral view of male genitalia with aedeagus in sit $l$.

\section{Phaecadophora fimbriata Walsingham}

$$
\text { Plate 254, Figures } 3^{-3} \mathrm{~b}
$$

Phaecadophora fimbriata Walsingham, i900, Ann. Mag. Nat. Hist., 6: Izo.

Argyroploce metactenis Meyrick, I909, Journ. Bombay Nat. Hist. Soc., I9: 597.

$$
\text { [metactenis] }
$$

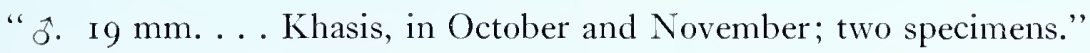

Lectotype: The male, "Khasi Hills, Assam. .ro.rgo6." Slide No. 7285.

Figure 3 , left wings; 3 a, ventral view of male genitalia with aedeagus in sit $u$ : $3 \mathrm{~b}$, lateral aspect of denuded abdomen showing ventral abdominal tufts. 
PLATYPEPLUS

\section{PLATYPEPLUS Walsingham}

Platypeplus aprobola (Meyrick), new combination

Plate 285 , Figures I-Ia

Eccopsis aprobola Meyrick, i 886, 'Trans. Ent. Soc. London, i 886: 275.

"今. $20 \mathrm{~mm}$., f. $19 \mathrm{~mm}$. . . Tonga (Mathew); two specimens."

Type: The male so marked in the British Museum, "Tonga, Mathew Ioro. No. 1512." Slide No. 7065.

Figure I, left wings; Ia, ventral view of male genitalia with aedeagus in situ.

\section{Platypeplus charadraea (Meyrick), new combination}

Plate 285 , Figures 2-2a

Argyroploce charadraea Meyrick, I909, Journ. Bombay Nat. Hist. Soc., 19: 594.

" fo. 18-21 mm.... Maskeliya and Patipola, Ceylon, in April and May (Alston, Pole); three specimens."

Lectotype: The male, "Maskeliya, Ceylon. Alston. .05." Slide No. 7283.

Figure 2, left wings; 2 a, ventral view of male genitalia with aedeagus in situ.

\section{Platypeplus eumenica (Meyrick), new combination}

Plate 285 , Figures $3-3$ a

Argyroploce enmenica Meyrick, 1929, Trans. Ent. Soc. London, $76: 496$.

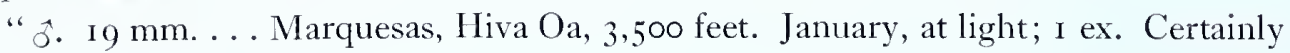
allied to aprobola."

Type: The male so labelled in the British Museum, "Hiva Oa, Marquesas, at light, 3,500 ft., 28.1.25. St. George Expedn. C. L. Collenette." Slide No. 732 I.

Figure 3 , left wings; 3 a, ventral view of male genitalia with aedeagus in situ.

\section{Platypeplus piratodes (Meyrick), new combination}

Plate 285, Figures 4-4a; Plate 286, Figures I-Ia

Articolla piratodes Meyrick, 1930, Exotic Microlepidoptera, 3:601.

Argyroploce syudeltias Meyrick, 1938, Trans. R. Ent. Soc. London, 87: 512 (new synonymy). [piratodes]

"§. 21 mm. . . British New Guinea, Owgarra (Meek); i ex. (Coll. Paravicini). This conspicuous species is probably allied to cyclidias."

Type: The above indicated male, "Owgarra, B. N. Guinea. A. S. Meek." Slide No. $705^{8}$.

[contimued on P. 575 . 

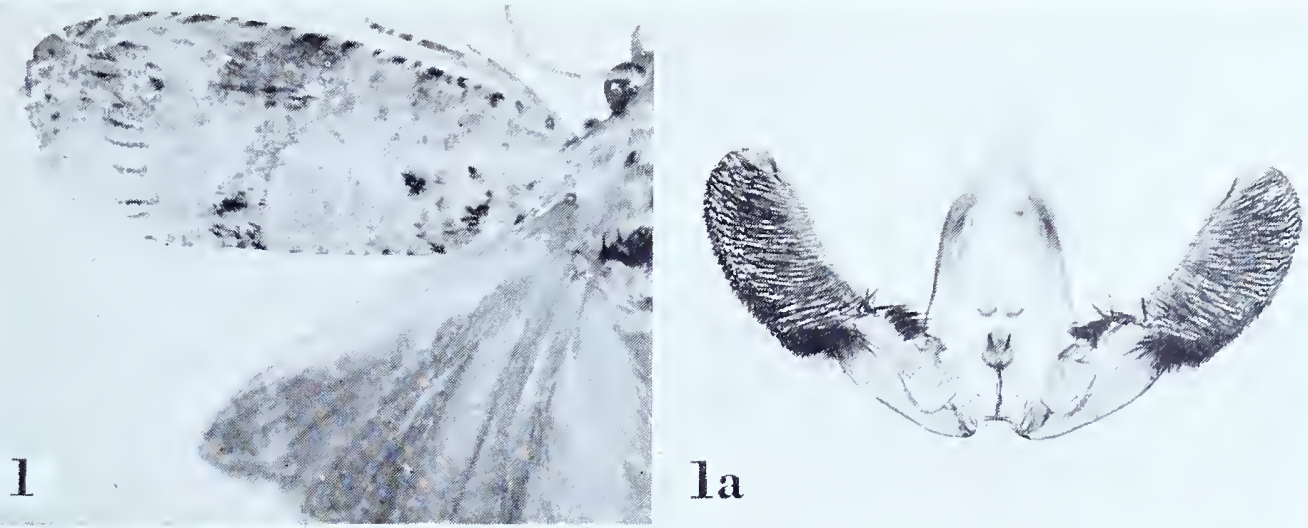

Ia
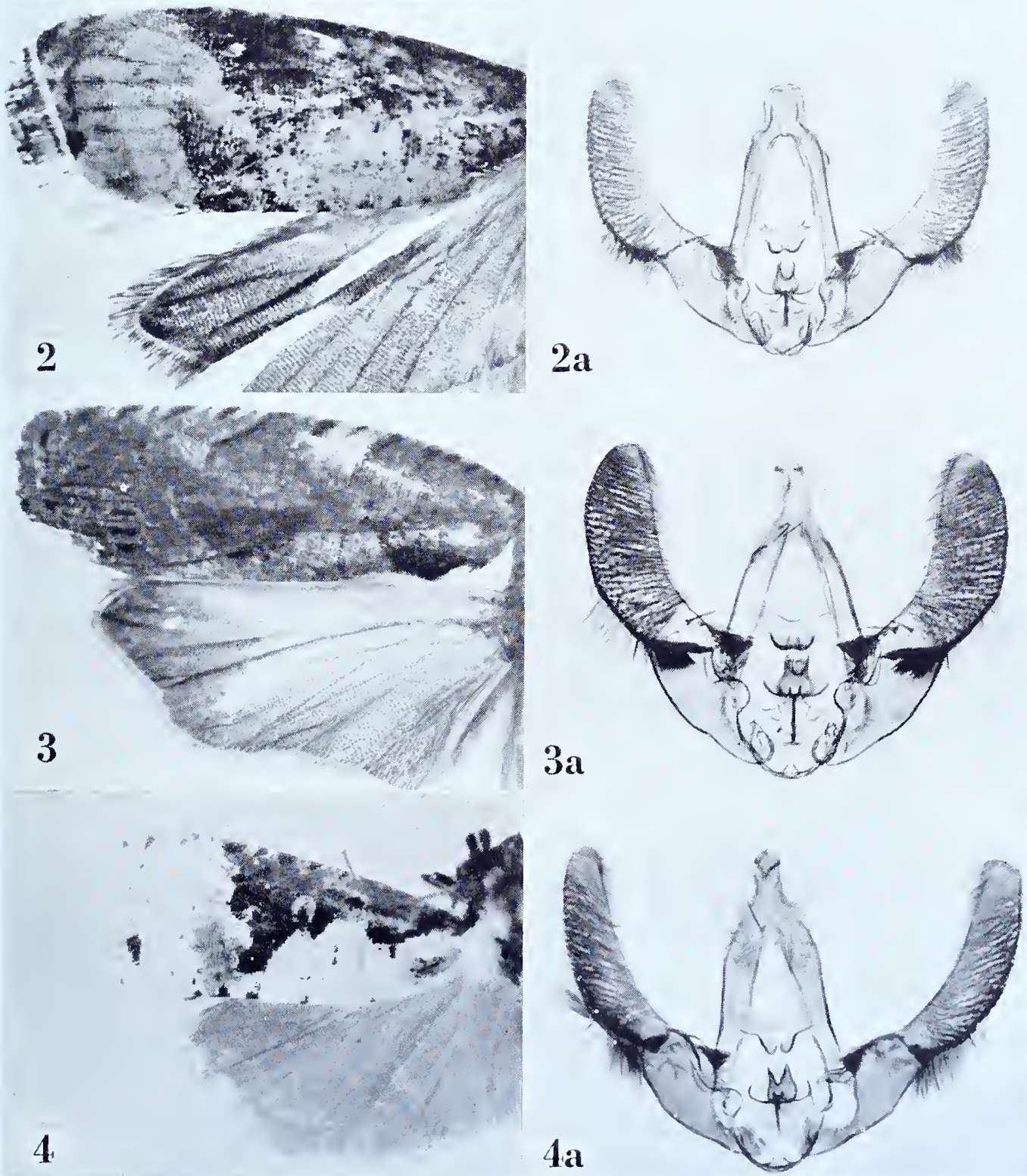


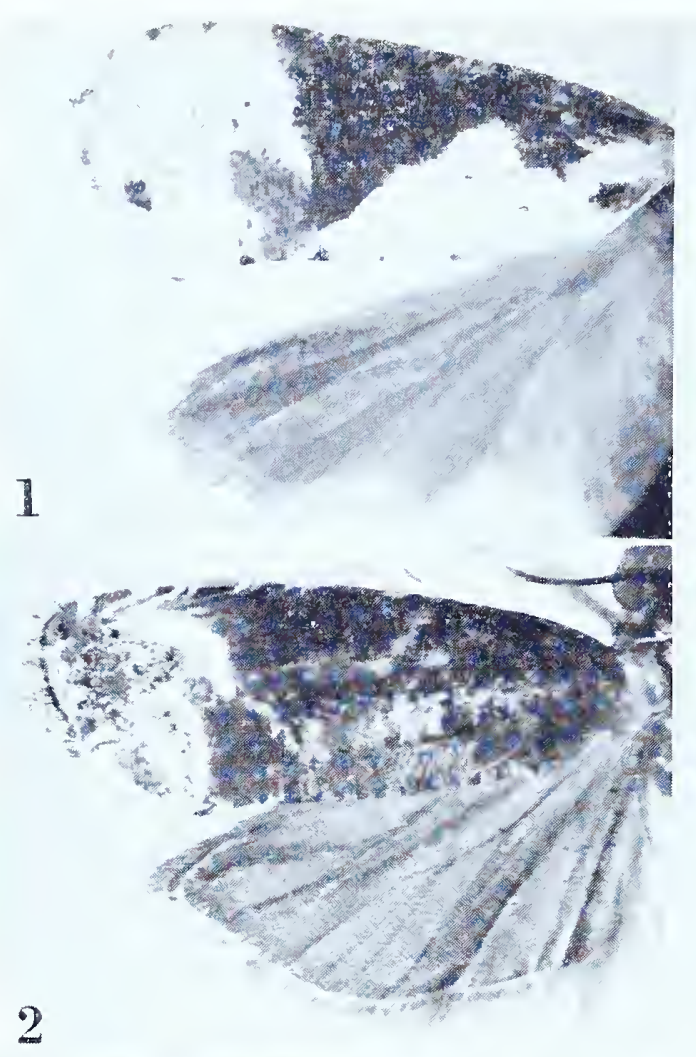

la

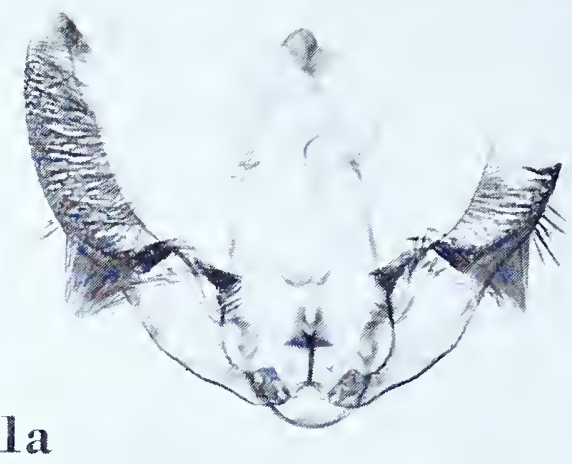

$2 a$
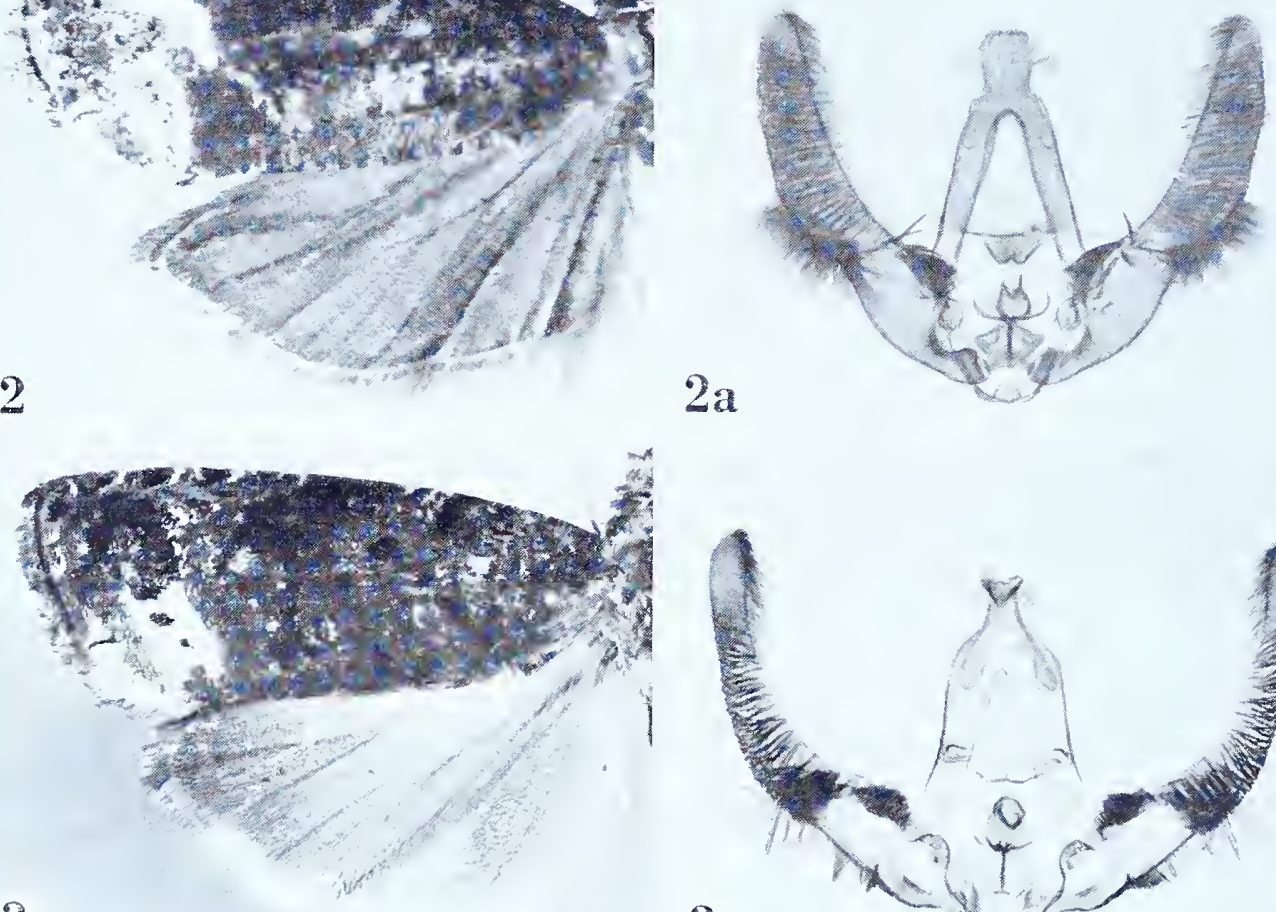

3
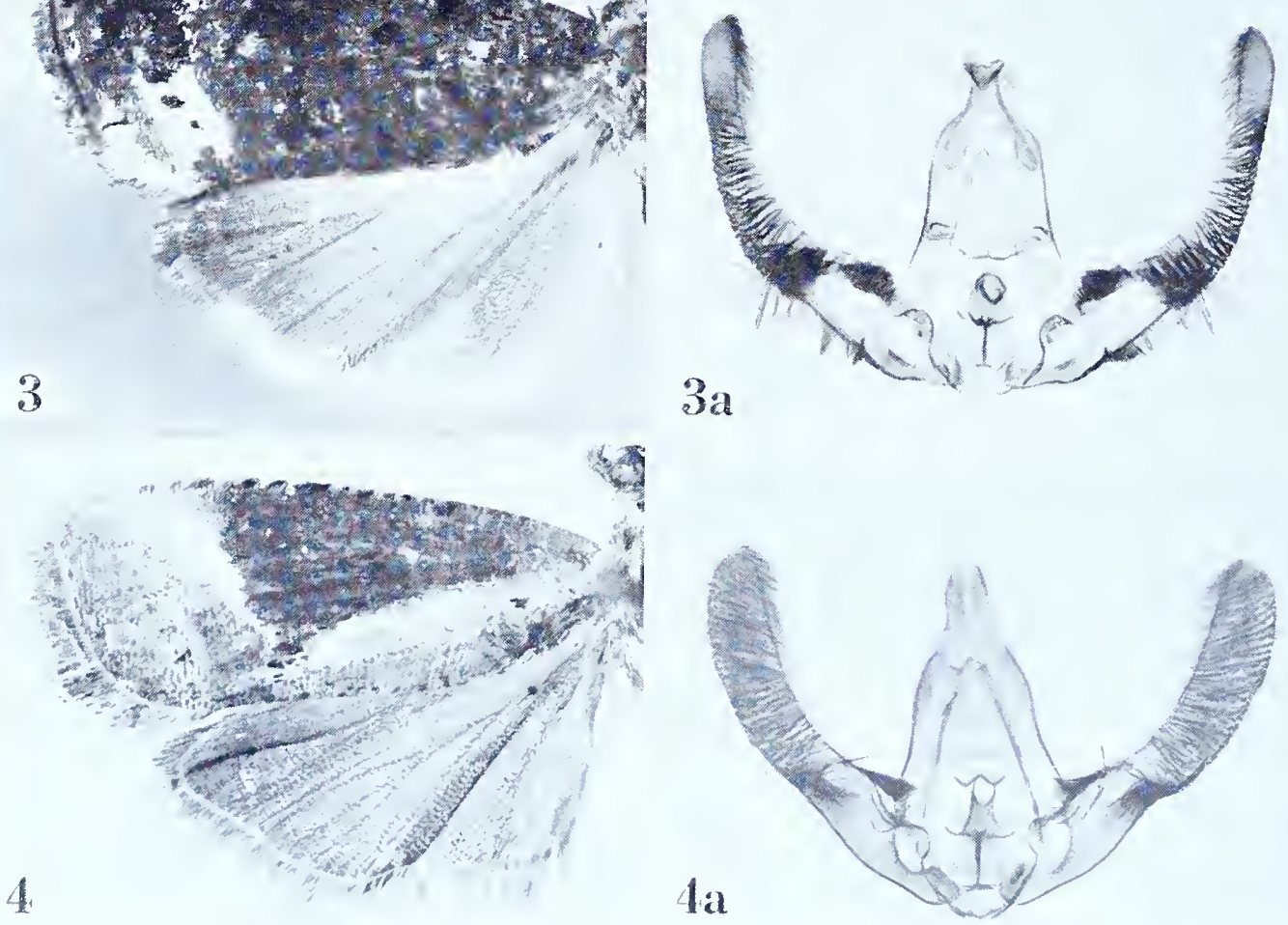


\section{Platypeplus ptarmicopa (Meyrick), new combination}

Plate 286, Figures 2-2a

Argyroploce ptarmicopa Meyrick, i 936, Exotic Microlepidoptera, 4: 6r 2.

" fo. I6-I7 mm. . . . Formosa, Taihoku and Sozan, July, September (Prof. S. Issiki); China, Mt. Omei, 4,00o feet (Franck); 3 ex. Allied to aprobola Meyr. . .."

Lectotype: 'The male, "Taihoku, Formosa, SI. 20.7.33." Slide No. 72 I 2.

Figure 2, left wings; 2a, ventral view of male genitalia with aedeagus in situ.

\section{Platypeplus scaeaspis (Meyrick), new combination}

Plate 286, Figures $3-3^{a}$

Argyroploce scaeaspis Meyrick, I 937, in Caradja and Meyrick, Deuts. Ent. Zeit. Iris, 5 I : I 82.

". . . o. 2 I mm. . . . Yül., 2,800 m., VII; I ex."

Type: The male indicated above, "Likiang, China. H. .7.34." Slide No. 72 I I.

Figure 3 , left wings; 3 a, ventral view of male genitalia with aedeagus in sitn.

\section{Platypeplus tectigera (Meyrick), new combination}

Plate 286. Figures $4-4$ a

Argyroploce tectigera Meyrick, I9 10, Trans. Ent. Soc. London, i 9 Io: 436.

" o. I 6 mm. . . J Java, Bandong; one specimen."

Type: The above indicated specimen, "Bandong, Java. R. .o7." Slide No. 720 r.

Figure 4 , left wings; 4 a, ventral view of male genitalia with aedeagus in situ.

Continued from p. 572.

Figure 4, right wings (image reversed); 4a, ventral view of male genitalia with aedeagus in situ.

[syndeltias]

"ふે. $24 \mathrm{~mm}$. . . . Mt. Tafa, 8,500 feet, March; I ex. Allied to ornithotypa. . . ."

Type: 'The above indicated male so marked in the British Museum, "Mt. 'Tafa, Papua, 8,500 ft. iii-i 934. L. E. Cheesman.” Slide No. 7023.

Figure I, left wings; Ia, ventral view of male genitalia with aedeagus in situ. 


\section{PROSCHISTIS Meyrick}

Proschistis Meyrick, 1907, Journ. Bombay Nat. Hist. Soc., I7: 73I. (Typus generis: Proschistis zaleuta Meyrick, ibid. [monotypy].)

\section{Proschistis zaleuta Meyrick \\ Plate 287 , Figures I-IC}

Proschistis zaleuta Meyrick, I907, Journ. Bombay Nat. Hist. Soc., I7: 73I.

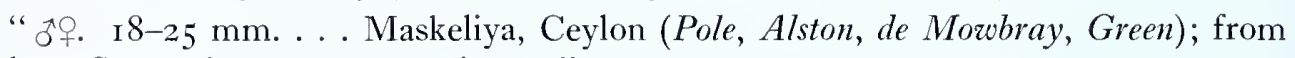
July to September, twenty specimens."

Lectotype: A male measuring $23 \mathrm{~mm}$., "Maskeliya, Ceylon. Alston. .7.05." Slide No. 7155. Only two of the original twenty specimens remain in the Meyrick collection.

Figure I, left wings; Ia, venation of right wings; $\mathrm{rb}$, lateral aspect of head to show palpus; Ic, ventral view of male genitalia with aedeagus in situ. There is a paired, posterior abdominal tuft present in the male. 

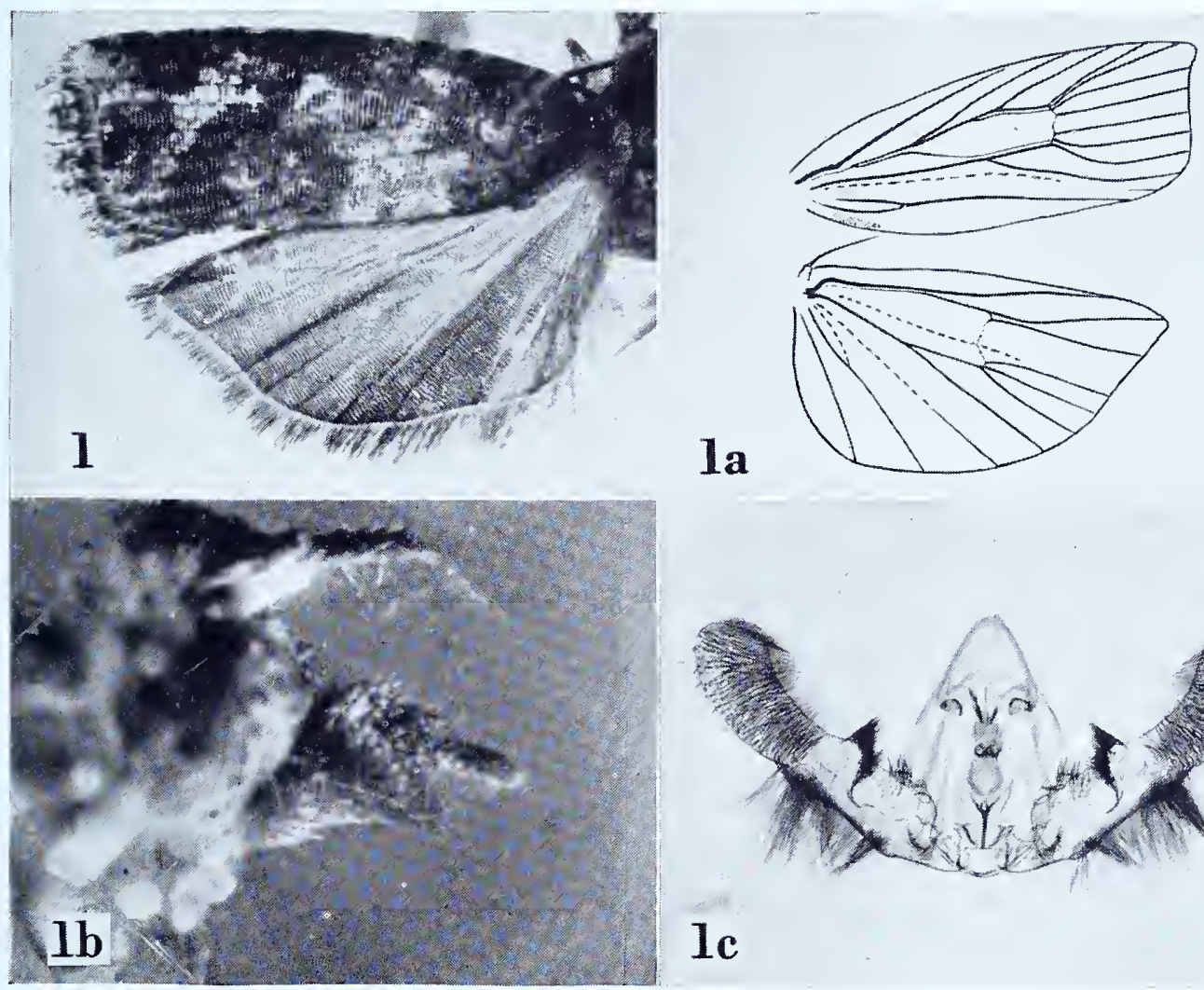

PROSCHISTIS 


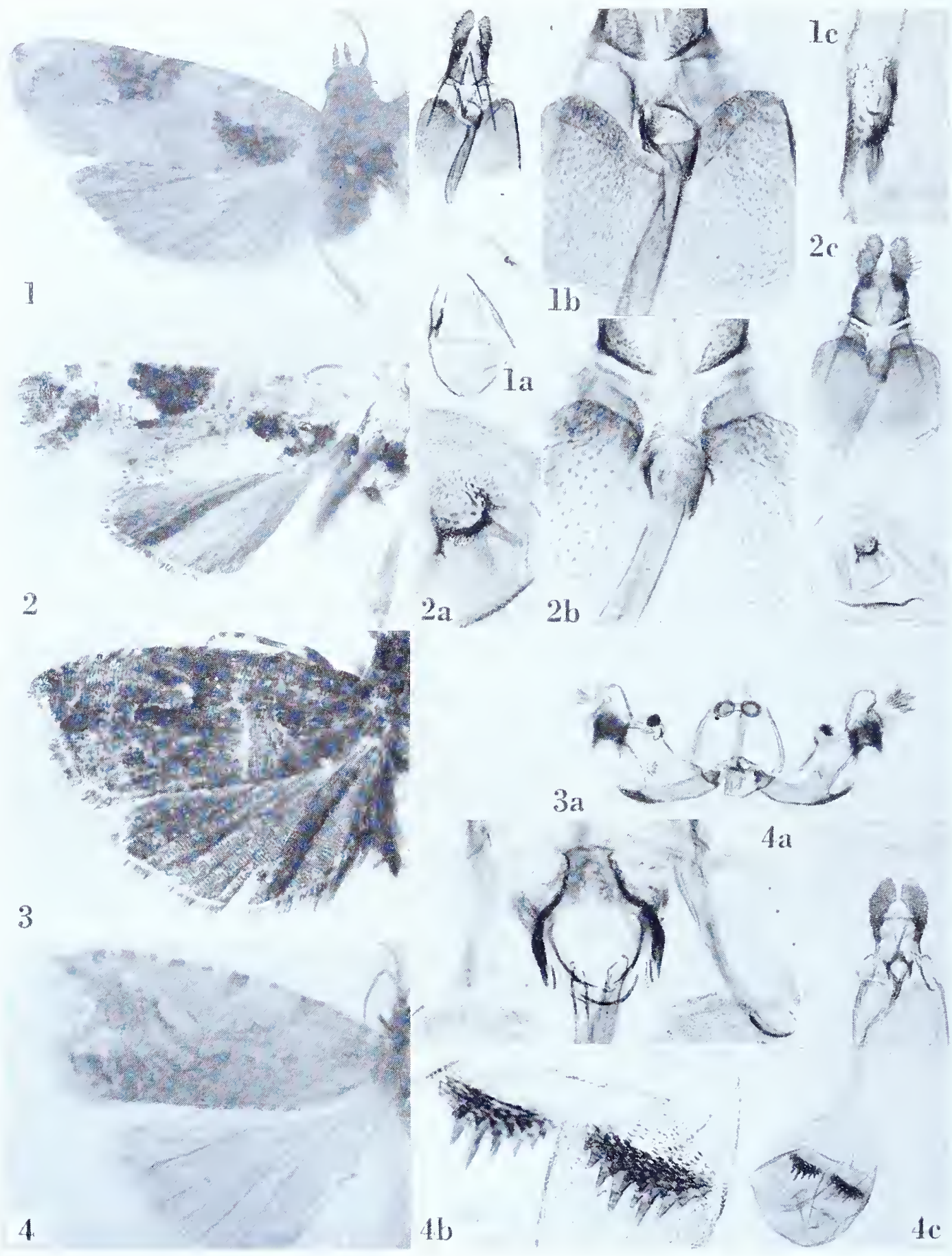




\section{Proschistis atricapsis (Meyrick), new combination}

Plate 288, Figures I-IC

Argyroploce atricapsis Meyrick, 1930, Exotic Microlepidoptera, 3: 602.

“․ $13 \mathrm{~mm}$. . . Nigeria, Ogrugu [sic]; I ex. (Coll. Paravicini)."

Type: The female so labelled in the British Museum, "Ogruga, Niger. ex PercyLathy, I903." Slide No. 7062.

Figure I, left wings; $\mathbf{a}$, ventral view of female genitalia; $\mathrm{ib}$, detail of genital plate and ostium; Ic, signum.

\section{Proschistis inflicta (Meyrick), new combination}

Plate 288, Figures 2-2c

Polychrosis inflicta Meyrick, I920, Exotic Microlepidoptera, 2:347.

“ㅇ. I $2-13$ mm. . . Bombay, Dharwar, January (Maxwell); 2 ex."

Lectotype: The female measuring 13 mm., "Dharwar, Kanara. RM. 4.I.I6." Slide No. 7 I 90.

Figure 2, left wings; $2 \mathrm{a}$, signum; $2 \mathrm{~b}$, detail of genital plate and ostium; 2 , ventral view of female genitalia.

\section{Proschistis invida Meyrick}

Plate 288, Figures $3^{-} 3^{a}$

Proschistis invida Meyrick, 1909, Journ. Bombay Nat. Hist. Soc., 19: 590.

" సㅇ․ $14^{-16} \mathrm{~mm} . .$. Khasis, in September; four specimens."

Lectotype: A male measuring I4 mm., "Khasi Hills, Assam. .9.1906." Slide No. 7158 .

Figure 3, left wings; 3 a, ventral view of male genitalia with aedeagus $i n$ sitn.

\section{Proschistis iricolor Meyrick}

Plate 288, Figures $4-4 \mathrm{c}$

Proschistis iricolor Meyrick, 1930, Exotic Microlepidoptera, 3: 60 I.

"ㅇ. $22 \mathrm{~mm}$. . . . Dutch New Guinea, Mt. Goliath, 5-7,000 feet (Meek); I ex. (Coll. Paravicini). Nearest to actaea from Solomon Is., but very distinct."

Type: The above indicated female so marked in the British Museum. It is without date. Slide No. 7059 .

Figure 4 , left wings; $4^{\mathrm{a}}$, detail of ostium; $4_{4}^{\mathrm{b}}$, signa; $4^{\mathrm{c}}$, ventral view of female genitalia. 


\section{Proschistis lucifera Meyrick}

Plate 289, Figures I-Ib

Proschistis Incifera Meyrick, I909, Journ. Bombay Nat. Hist. Soc., I 9: 589 .

"․ $23 \mathrm{~mm}$. . . Palni Hills (Campbell); one specimen."

Type: The female denoted above, "Palni Hills, S. India. Campbell. .o6." Slide No. 7 I 56 .

Figure I, left wings; $\mathbf{a}$, ventral view of female genitalia; $\mathrm{rb}$, signa.

Proschistis mniopyrrha (Meyrick), new combination

Plate 289 , Figures $2-2 \mathrm{c}$

Argyroploce mniopyrrha Meyrick, I93 I, Exotic Microlepidoptera, 4: I34.

"q. I 2 mm....Java, Buitenzorg (Dr.W.Roepke); I ex.(Brit. Mus.). Next pyrrhocrossa."

Type: The female so marked in the British Museum, dated "1919". Slide No. 7066.

Figure 2, left wings; 2a, signa; 2b, detail of genital plate and ostium; 2c, ventral view of female genitalia.

\section{Proschistis petromacha (Meyrick), new combination}

Plate 289 , Figures $3^{-3} \mathrm{c}$

Argyroploce petromacha Meyrick, I93 I, Exotic Microlepidoptera, 4: I28.

“早. I $3^{-1} 5 \mathrm{~mm}$. . . . Sierra Leone, Njala, October (E. Hargreaves); 2 ex. (type Brit. Mus.). ..."

Type:'The female so marked in the British Museum, dated "I I-x-30". Slide No. 7067.

Figure 3 , left wings; $3 \mathrm{a}$, ventral view of female genitalia; $3 \mathrm{~b}$, detail of genital plate and ostium; $3 \mathrm{c}$, signum.

\section{Proschistis sideroxyla (Meyrick), new combination}

Plate 289 , Figures $4-4 \mathrm{c}$

Argyroploce sideroxyla Meyrick, I93 I, Exotic Microlepidoptera, 4: I33.

“․ I7 mm. . . Formosa, Kyuhabon, October (S. Issiki); I ex. Related to herbosa."

Type: The female indicated above, dated ".I0.26”. Slide No. 7220.

Figure 4 , left wings; 4 a, signum; 4 b, detail of ostium ; 4 c, ventral view of female genitalia.

\section{Proschistis stygnopa Meyrick}

Plate 290, Figure 5

Proschistis stygnopa Meyrick, I935, in Caradja and Meyrick, Materialien zu einer Microlepidopteren Fauna der Chinesischen Provinzen Kiangsu, Chekiang und Hunan, 57. “... o. $23 \mathrm{~mm}$. . . 4 ex., Tienmushan, VI. Perhaps most allied to agitata. ..."

Lectotype: The one remaining specimen in the Meyrick collection, "Tien-Mu-Shan, China. H. 5,000' .6.32." The abdomen of the lectotype is missing.

Figure 5, left wings. 


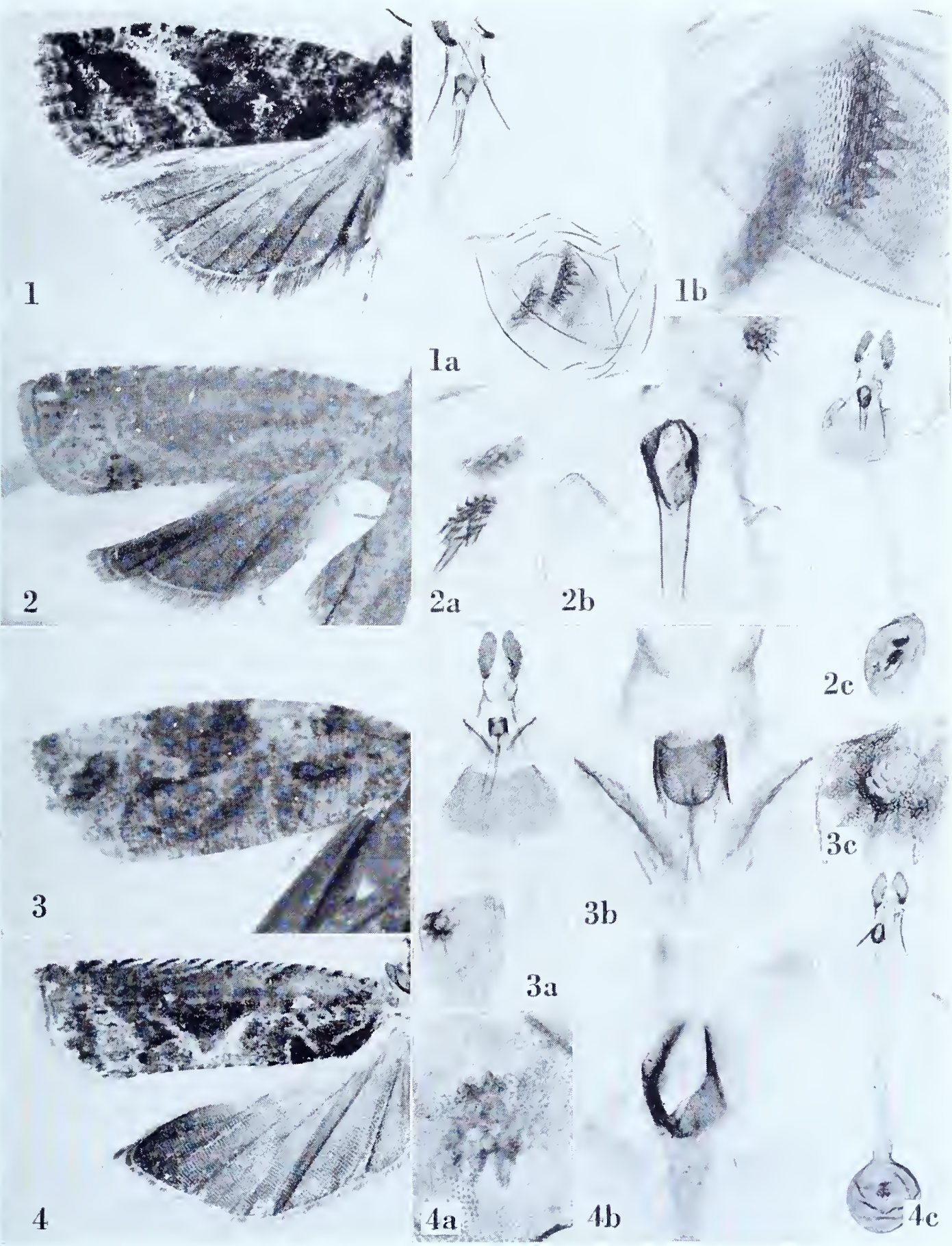




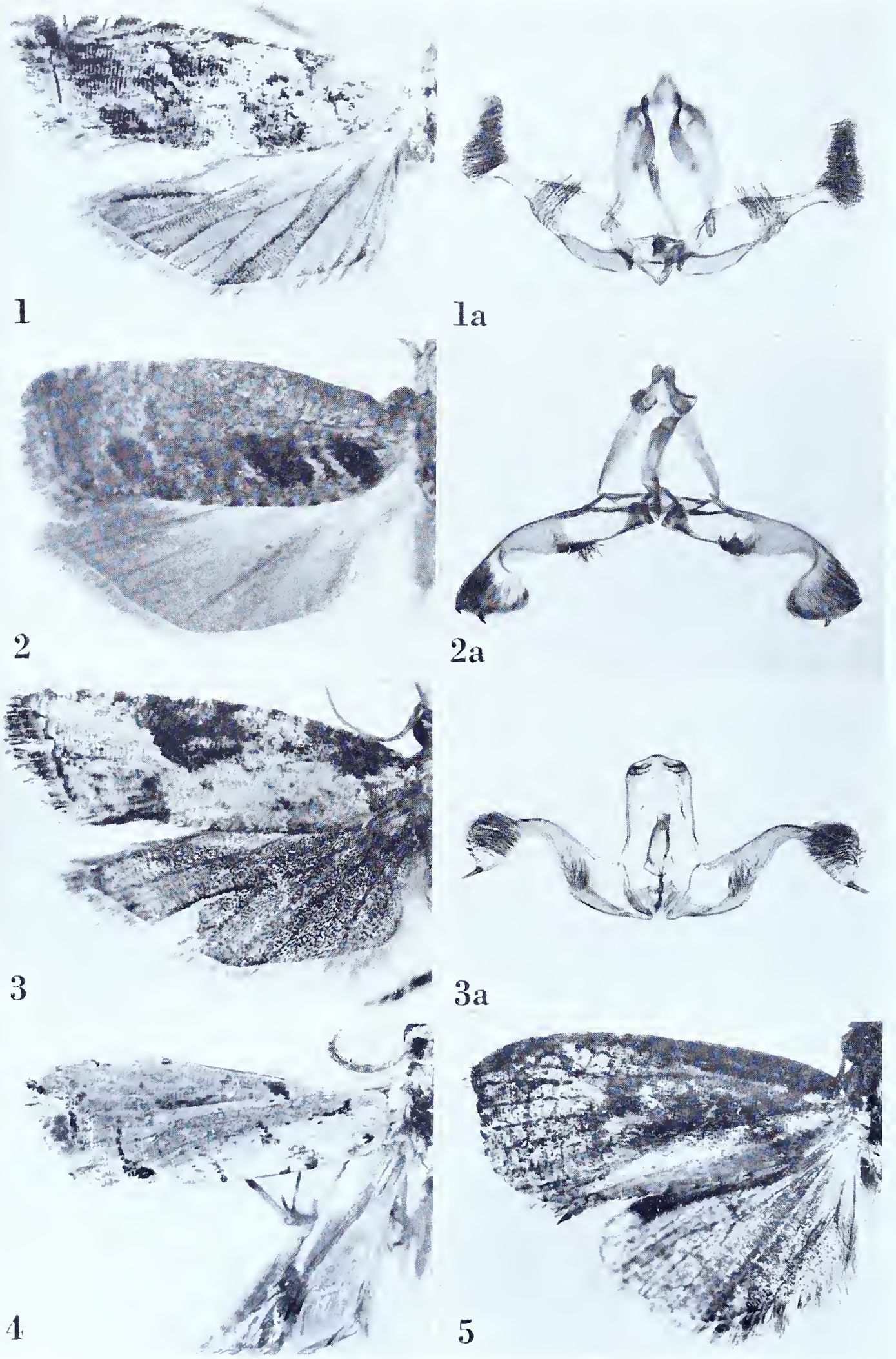




\section{SPILONOTA Stephens}

\section{Spilonota algosa Meyrick}

Plate 290, Figures I-Ia

Spilonota algosa Meyrick, I912, Journ. Bombay Nat. Hist. Soc., 2 I : 854; Diakonoff, I 950 , Bull. Brit. Mus. (Nat. Hist.) Ent., I (4): 284 .

" fo․ $^{\circ}$ I 2-I 5 mm. ... Khasis; in August and September, fourteen specimens."

Lectotype: A male measuring I 5 mm., "Khasi Hills, Assam. .9.I906", selected by Diakonoff. Slide No. 69 I 8.

Figure I, left wings; ra, ventral view of male genitalia with aedeagus in situ.

\section{Spilonota asbolandra Meyrick}

Plate 290, Figures 2-2a

Spilonota asbolandra Meyrick, I938, Trans. R. Ent. Soc. London, 87: 509.

“수. I 5-20 mm. . . . Mt. Tafa, 8,500 feet, March; 22 ex. Kokoda, I, 200 feet, July, 4 ex., but these not differing from dark forms taken at higher elevations. The variability is excessive. ..."

Type: The male so marked in the British Museum, "Papua, Mt. Tafa. 8,500 ft. iii.r 934. L. E. Cheesman." Slide No. 6996.

Figure 2, left wings; 2a, ventral view of male genitalia with aedeagus in situ.

\section{Spilonota babylonica Meyrick}

Plate 290, Figures $3^{-} 3^{\text {a }}$

Spilonota babylonica Meyrick, I912, Journ. Bombay Nat. Hist. Soc., 21 : 854 .

“ ${ }^{*}$. I $5 \mathrm{~mm}$. . . Nilgiris, 6,000 feet (Andrewes); in May, one specimen."

Type: The male indicated above, "Nilgiri Hills, S. India. HLA. 6,000' .5.07." Slide No. 6922.

Figure 3 , left wings; 3 a, ventral view of male genitalia with aedeagus in situ.

\section{Spilonota beryllina Meyrick}

Plate 290, Figure 4

Spilonota beryllina Meyrick, I925, Treubia, 6: 428 .

" f. $^{2} 20 \mathrm{~mm}$. . . J Java, Tjibodas, I, $500 \mathrm{~m}$., in August; one specimen."

Type: The above indicated male labelled, "Tybodas, Java. B. 5,000' .8.2 I", without abdomen. On the original label the locality is spelt "Tybodas", which is incorrect.

Figure 4 , left wings. 


\section{Spilonota calceata (Meyrick)}

Plate 29I, Figures I-Ia

Timetocera calceata Meyrick, I908, Journ. Bombay Nat. Hist. Soc., I8: I4I ; Diakonoff, 1950, Bull. Brit. Mus. (Nat. Hist.) Ent., I (4): 284.

"숭. I $4_{-1} 8 \mathrm{~mm}$. ... Khasi Hills, in June; eleven specimens. Very close to the European ocellana...."

Lectotype: A male measuring $15 \mathrm{~mm}$., selected by Diakonoff. Slide No. 6927.

Figure I, left wings; Ia, ventral view of male genitalia with aedeagus in situ.

\section{Spilonota glaucothoe Meyrick}

Plate 29I, Figures 2--2b

Spilonota glaucothoe Meyrick, 1927, Insects of Samoa, 3, Lepidoptera, fasc. 2: 70.

“ㅇ. $17 \mathrm{~mm}$. ... U Upolu, Malololelei, 2,000 feet, April; I ex. Allied to A. melanacta...."

Type: The above indicated specimen, so marked in the British Museum, dated “2 I.iv.i925”. Slide No. 6998.

Figure 2 , left wings; $2 \mathrm{a}$, ventral view of female genitalia; $2 \mathrm{~b}$, detail of genital plate and ostium.

\section{Spilonota hexametra Meyrick}

Plate 29I, Figures 3-3c

Spilonota hexametra Meyrick, 1920, Exotic Microlepidoptera, 2: 342.

"ㅇ. 14 mm. . . N.W. India, Peshawar, June (Fletcher); I ex."

Type: The above indicated female dated ".6.16". Slide No. 6920.

Figure 3 , left wings; $3^{\mathrm{a}}$, ventral view of female genitalia; 3 , detail of ostium; $3^{c}$, signa. 


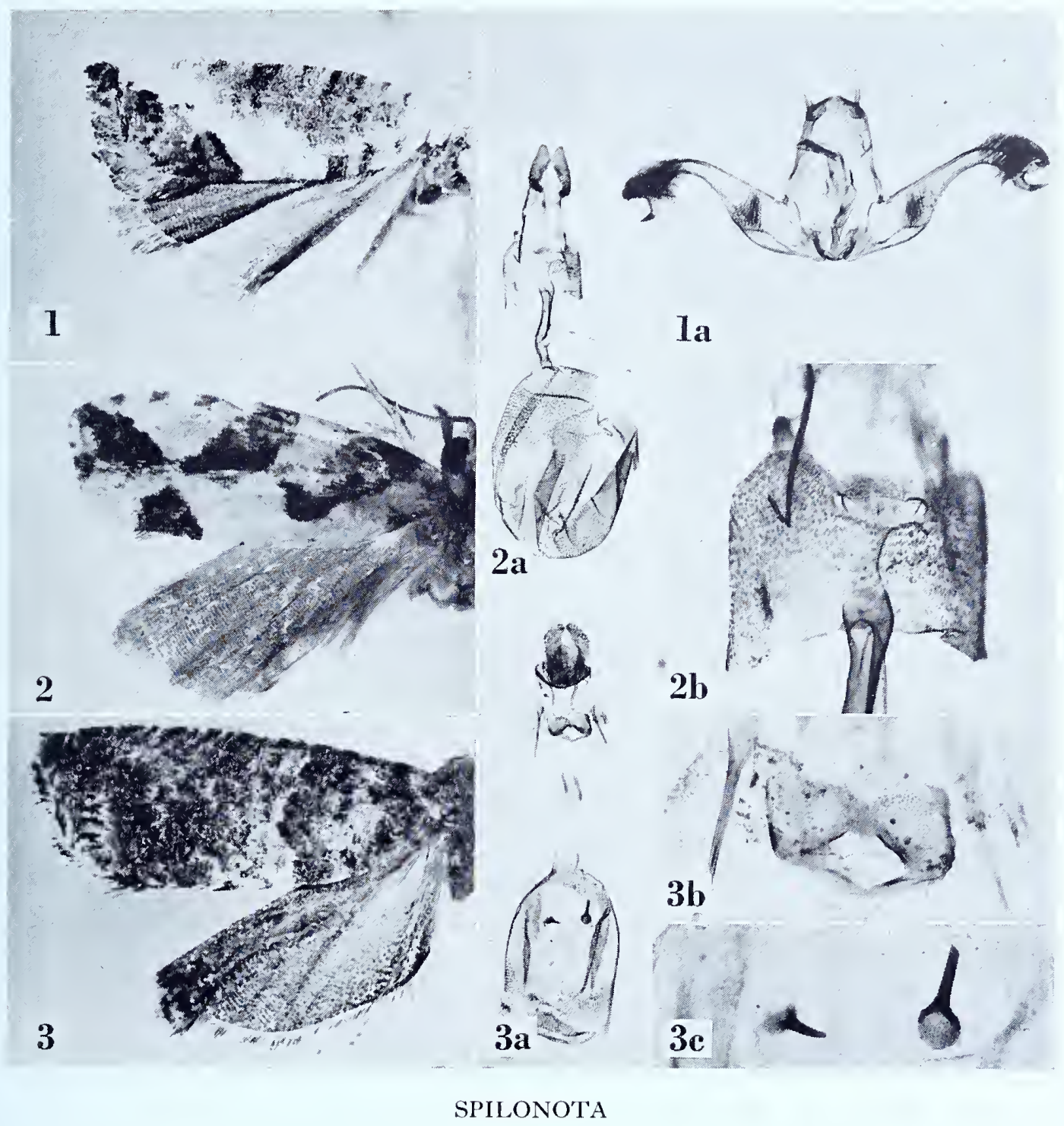




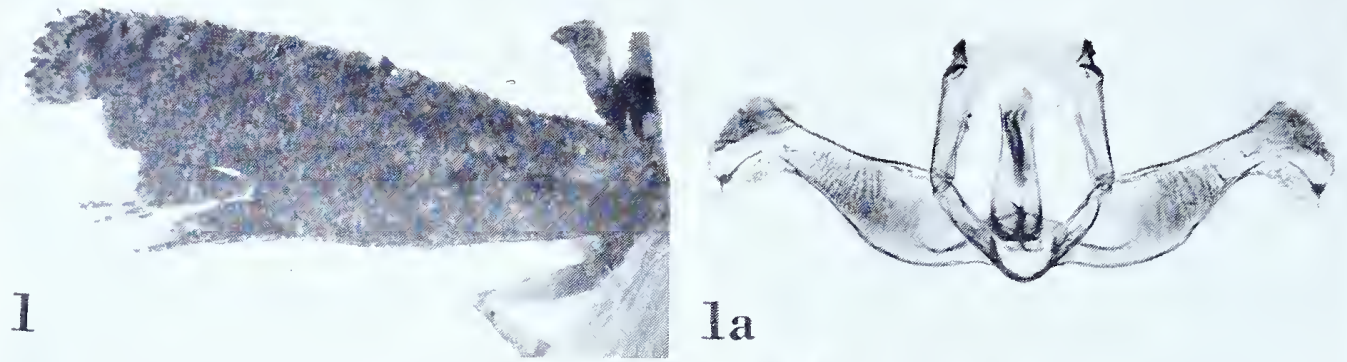

2
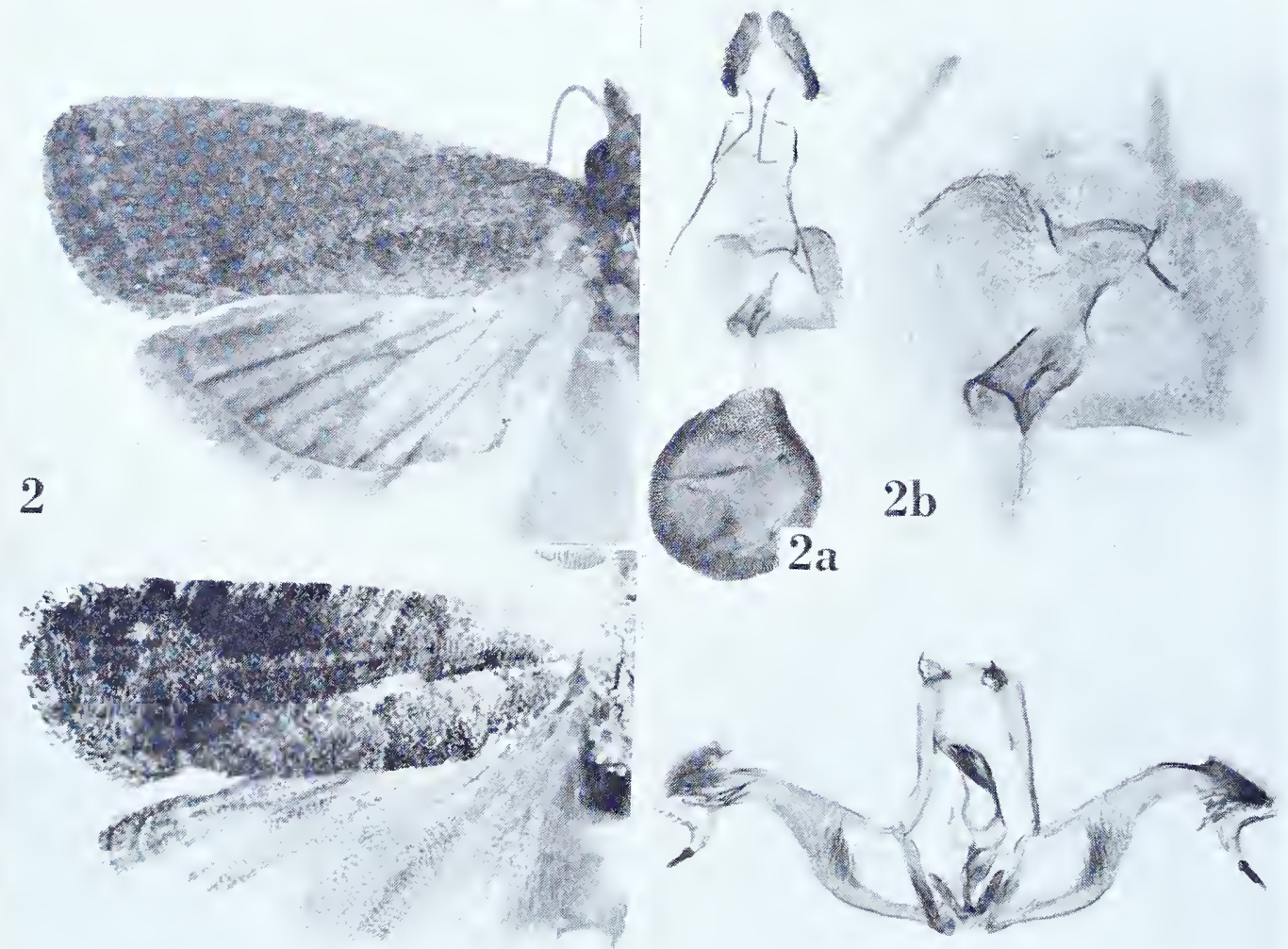

3

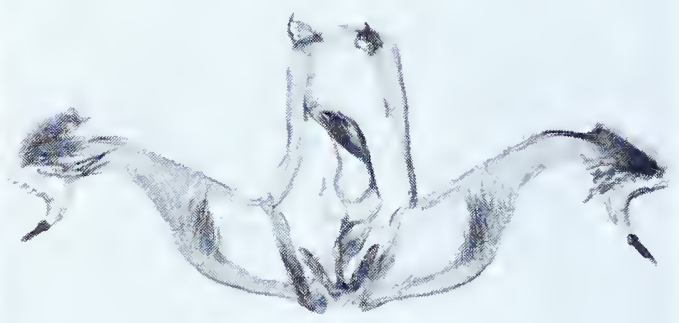

$3 a$
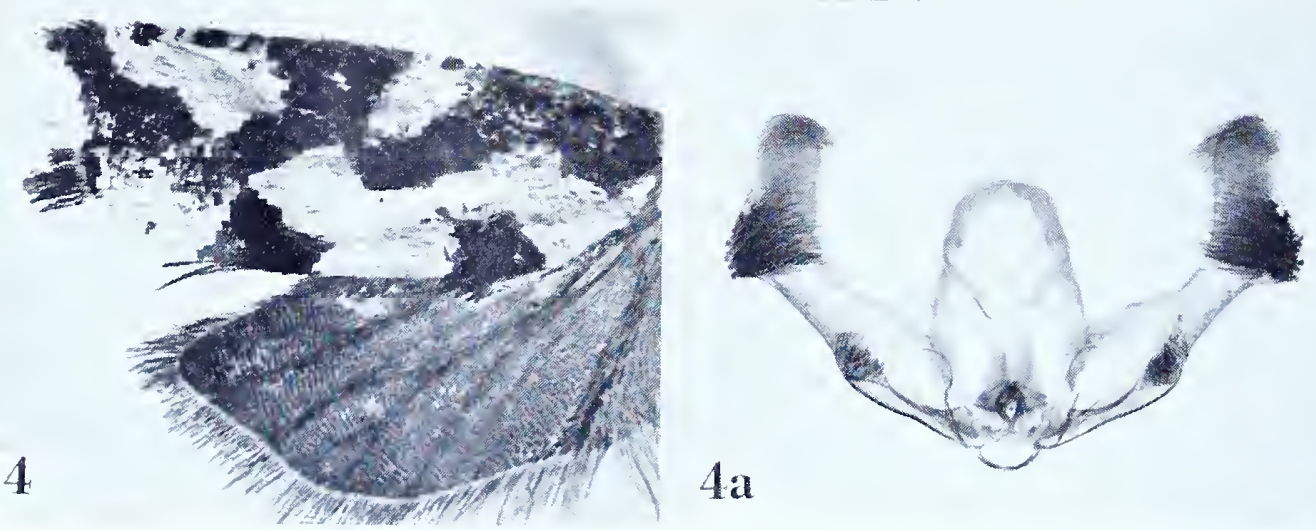
For the first two species on Plate 292, see page opposite Plate 297.

\section{Spilonota lechriaspis Meyrick}

Plate 292, Figures $3^{-} 3^{\mathrm{a}}$

Spilonota lecliriaspis Meyrick, 1932, Exotic Microlepidoptera, 4: 306; Diakonoff, 1950, Bull. Brit. Mus. (Nat. Hist.) Ent., I (4): 285 .

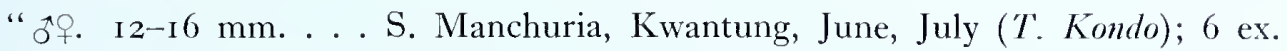
Larva . . very injurious to apple. ..."

Lectotype: A male measuring I 5 mm., dated ".6.30", selected by Diakonoff. Slide No. 6925 .

Figure 3 , left wings; 3 a, ventral view of male genitalia with aedeagus in situ.

\section{Spilonota melanacta (Meyrick)}

Plate 292, Figures $4-4$ a

Enarmonia melanacta Meyrick, ı9o8, Journ. Bombay Nat. Hist. Soc., I8: I40; Diakonoff, 1950, Bull. Brit. Mus. (Nat. Hist.) Ent., I (4): 285 .

" ${ }^{\circ}$ I $4^{-1} 6 \mathrm{~mm} . .$. Khasi Hills, in June; three specimens. The palpi are peculiar. ..."

Lectotype: A male measuring $15 \mathrm{~mm}$., dated ".6.1906", selected by Diakonoff. Slide No. 6926. Diakonoff gives the date "I 903 ", which I think is a misprint.

Figure 4 , left wings; $4 \mathrm{a}$, ventral view of male genitalia with aedeagus in situ. 


\section{Spilonota melanocopa Meyrick \\ Plate 293, Figures I-Ia}

Spilonota melanocopa Meyrick, i912, Journ. Bombay Nat. Hist. Soc., 21: 853; Diakonoff, I950, Bull. Brit. Mus. (Nat. Hist.) Ent., I (4): 285.

" 우. 1 $5^{-17} \mathrm{~mm} . .$. Khasis, in June; six specimens."

Lectotype: A male measuring 16 mm., "Khasi Hills, Assam. D. .i go6," selected by Diakonoff. Slide No. $692 \mathrm{I}$.

Figure I, left wings; Ia, ventral view of male genitalia with aedeagus in situ.

\section{Spilonota stichoceros Meyrick}

Plate 293, Figures 2-2a

Spilonota stichoceros Meyrick, 1938, Trans. R. Ent. Soc. London, 87: 510.

" o. I 4 mm. . . . Mafulu, 4,000 feet, January; i ex."

Type: 'The above indicated specimen, "Papua, Mafulu. 4,000 ft., I.I934. L. E. Cheesman." Slide No. 6997.

Figure 2, left wings; $2 \mathrm{a}$, ventral view of male genitalia with aedeagus in situ.

\section{Spilonota thalassitis Meyrick \\ Plate 293, Figures $3-3$ a}

Spilonota thalassitis Meyrick, 1910, Trans. Ent. Soc. London, I910: 434; Diakonoff, 1950, Bull. Brit. Mus. (Nat. Hist.) Ent., I (4): 285 .

"ふ. I 5-16 mm. . . J Java, Bandong; two specimens."

Lectotype: The male measuring I $6 \mathrm{~mm}$., selected by Diakonoff. Slide No. 6924.

Figure 3 , left wings; 3 a, ventral view of male genitalia with aedeagus in sitn.

\section{Spilonota thyellopis Meyrick}

Plate 293, Figure 4

Spilonota thyellopis Meyrick, 1926, Trans. Ent. Soc. London, 74: 273.

" o. $20 \mathrm{~mm}$. ... At 800 feet; I ex. This is doubtless attached to a Myrtaceous shrub, as customary."

Type: The specimen so marked in the British Museum, "Rapa Island, at light. $800 \mathrm{ft}$., I 7.4.25. C. L. Collenette." The abdomen of the type is missing.

Figure 4 , left wings. 


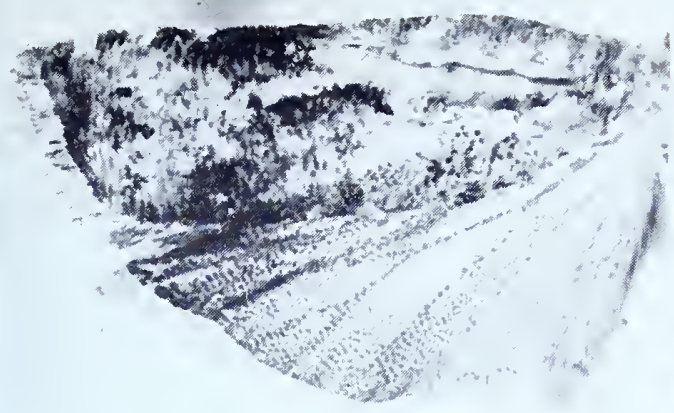

1
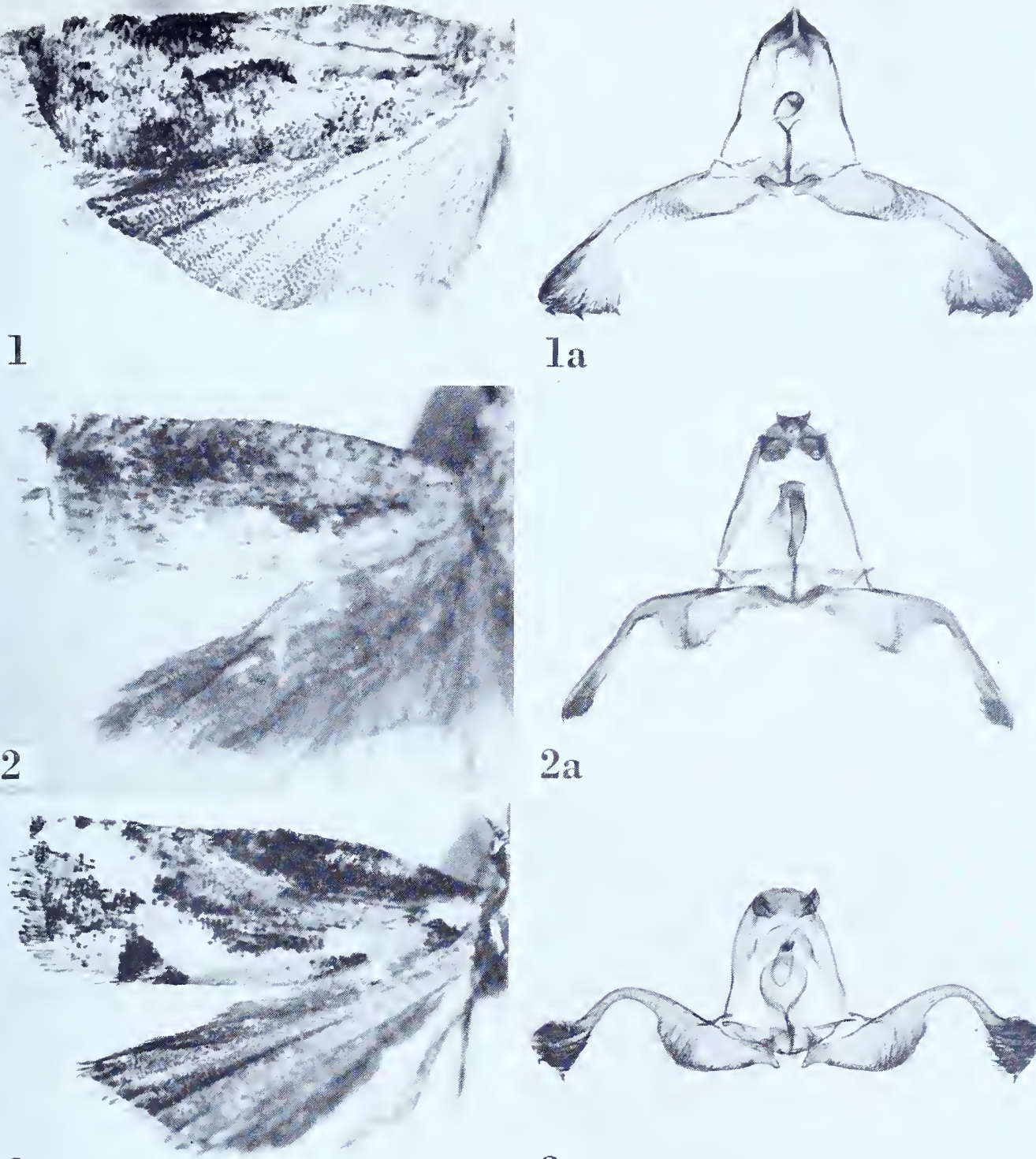

2a
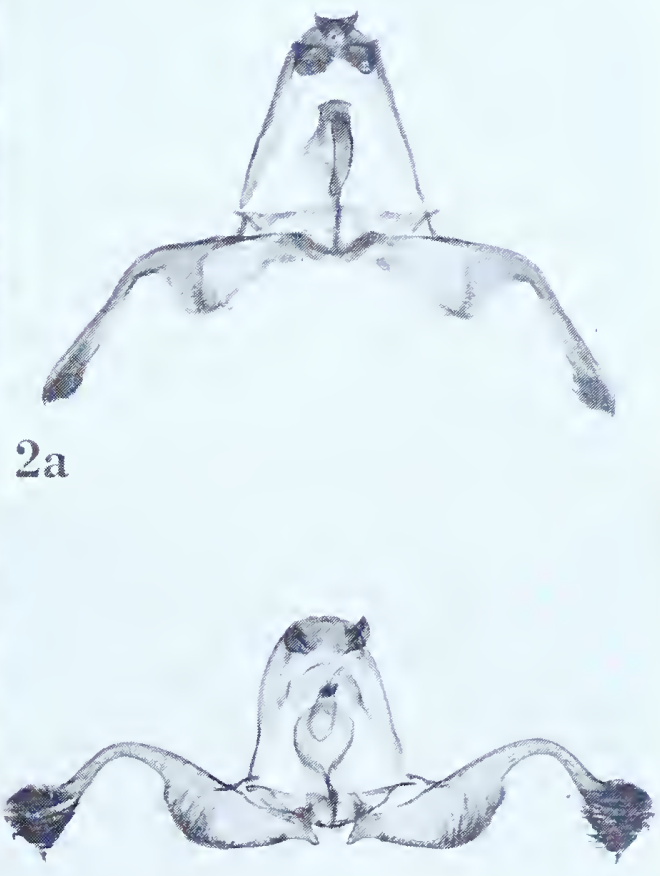

3

$3 a$

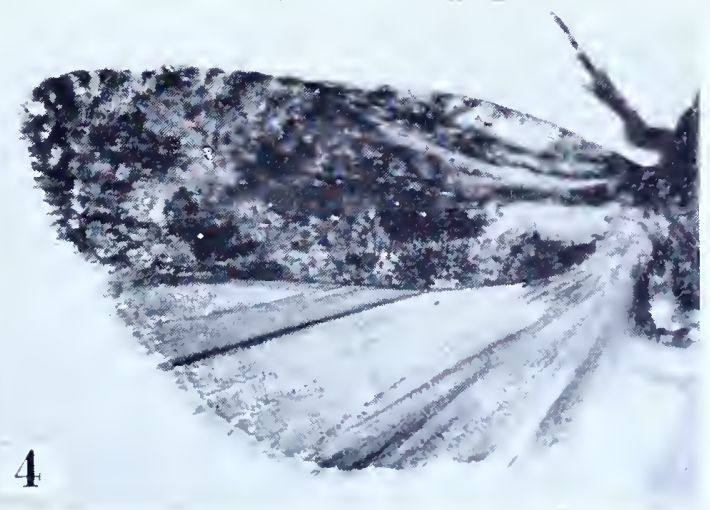



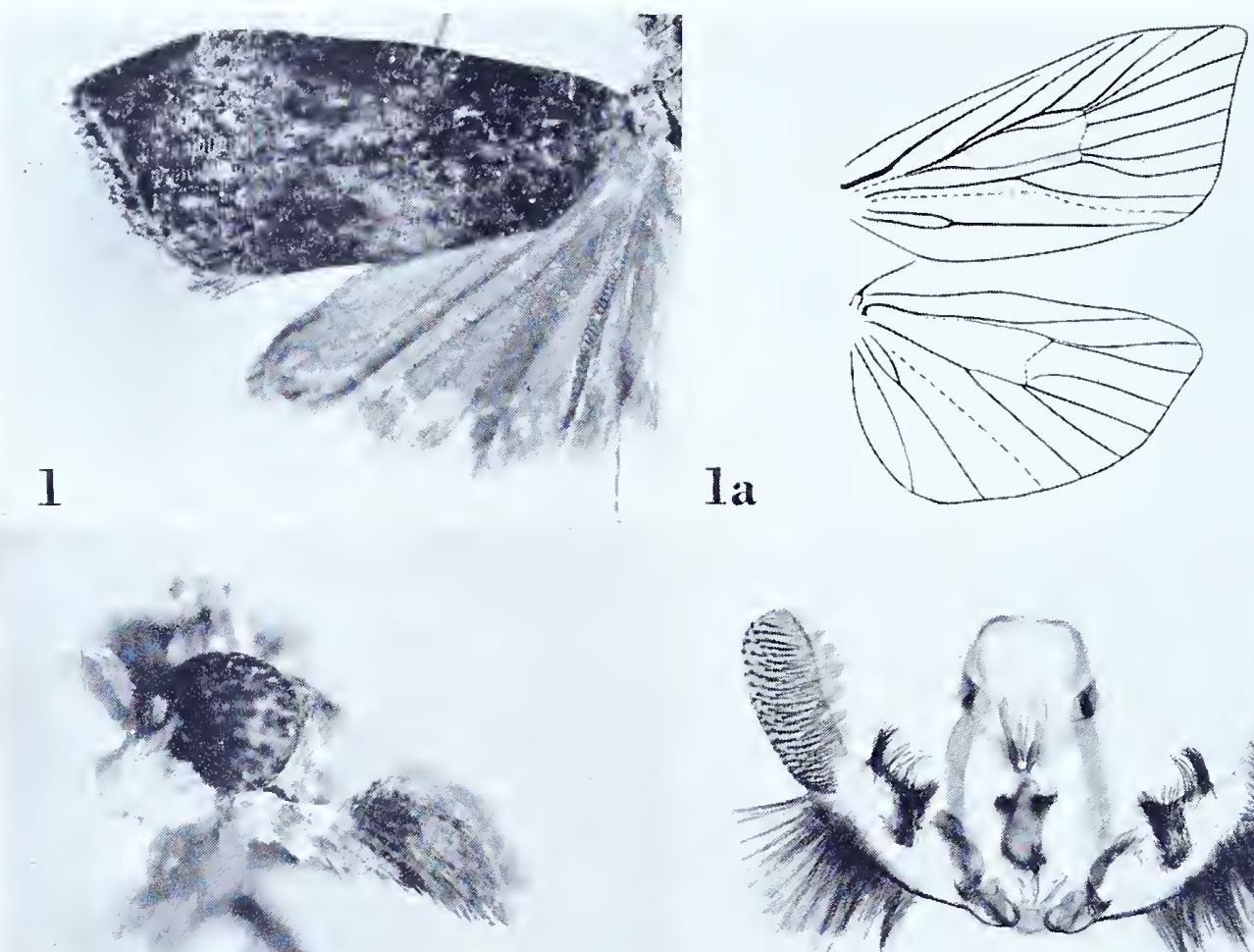

Ib

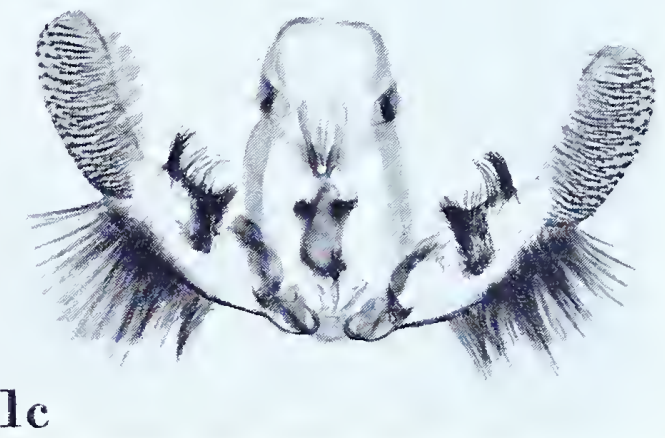

SPOROCELIS 


\section{SPOROCELIS Meyrick}

Sporocelis Meyrick, 1907, Journ. Bombay Nat. Hist. Soc., I7: 732. (Typus generis: Sporocelis marmaropa Meyrick, ibid. [monotypy].)

\section{Sporocelis marmaropa Meyrick}

Plate 294, Figures I-I C

Sporocelis marmaropa Meyrick, 1907, Journ. Bombay Nat. Hist. Soc., I7: 732.

" ơ․ I6-I $8 \mathrm{~mm}$.... Maskeliya, Ceylon; in May and August, three specimens (de Mowbray, Pole)."

Lectotype: A male measuring I 8 mm., dated ".5.04" (Pole). Slide No. 7 I 68.

Figure $\mathrm{I}$, left wings; $\mathrm{ra}$, venation of right wings; $\mathrm{rb}$, lateral aspect of head to show palpus; Ic, ventral view of male genitalia with aedeagus in situ. 


\section{STATHERO'TIS Meyrick}

Statherotis Meyrick, 1909, Journ. Bombay Nat. Hist. Soc., 19: 591. (Typus generis: Statherotis decorata Meyrick, ibid. [monotypy].)

\section{Statherotis decorata Meyrick}

Plate 295, Figures I-IC

Statherotis decorata Meyrick, I900, Journ. Bombay Nat. Hist. Soc., 19: 59 I.

“ $\delta$. IS $1 \mathrm{~nm}$. . . Maskeliya, Ceylon, in April (Pole); one specimen. The special colouring and structures of the hindwings will doubtless prove to be confined to the $\hat{\jmath} . "$

Type: The male denoted above, dated ".4.06". Slide No. 7 I60.

Figure I, left wings; ra, venation of right wings; modified scales also illustrated; Ib, lateral aspect of head to show palpus; Ic, ventral view of male genitalia with aedeagus in situ. 


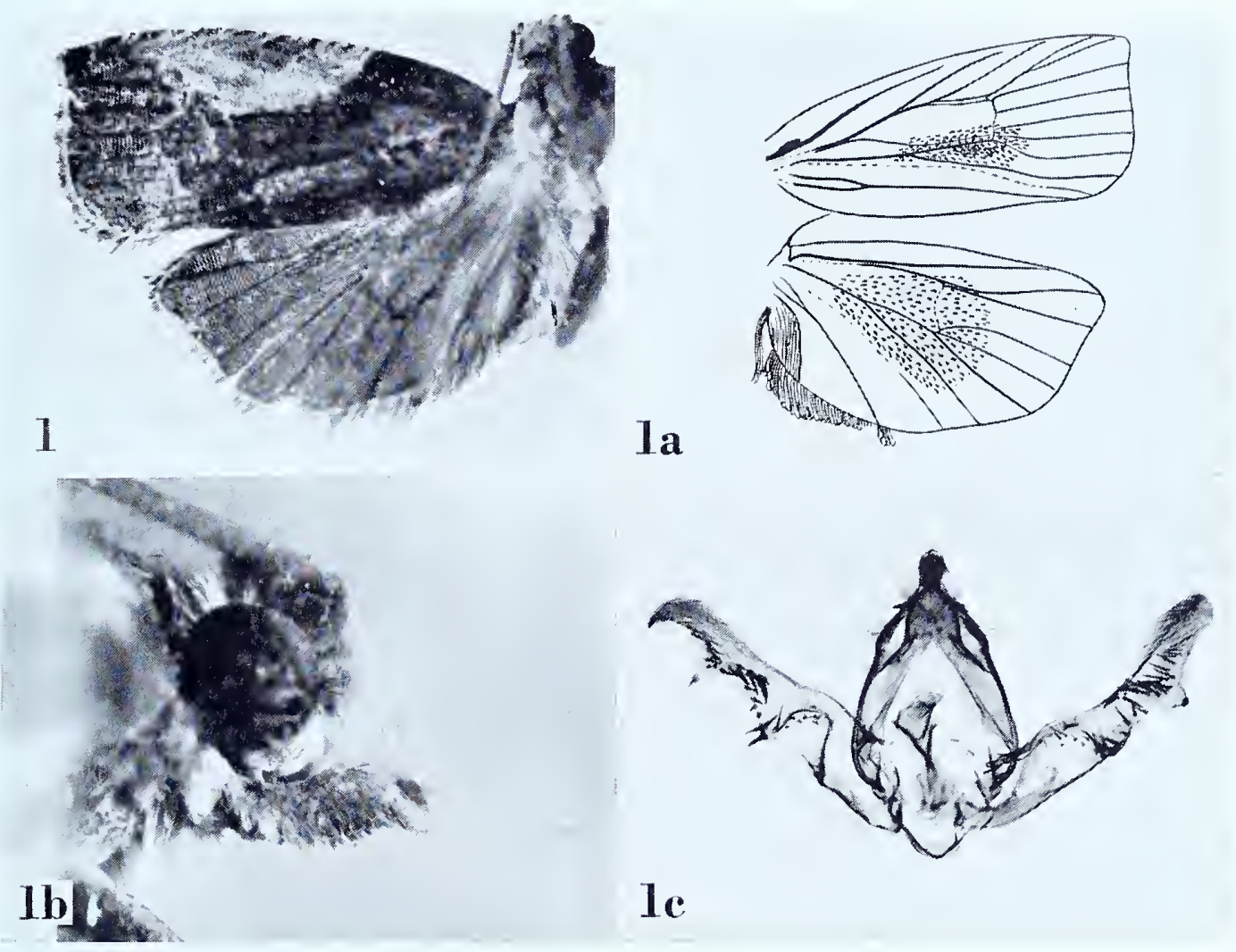

STATHEROTIS 

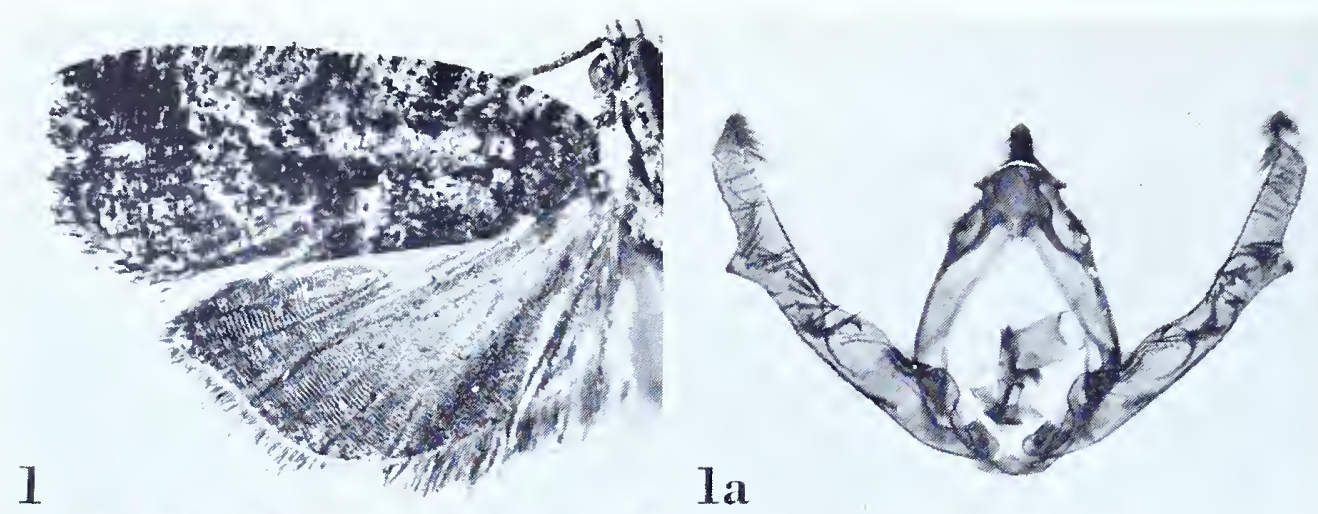

2
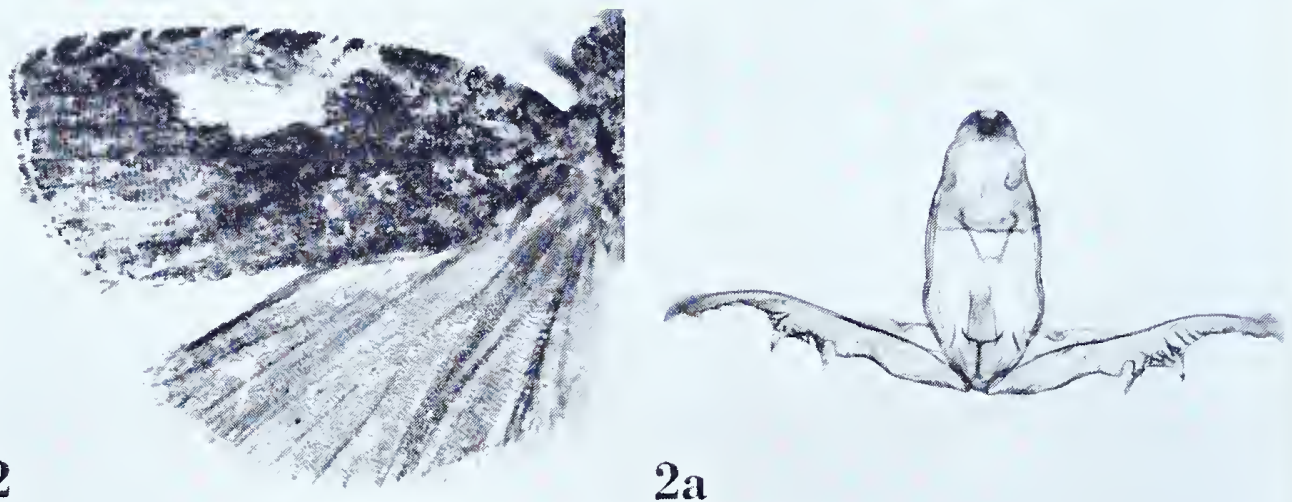

$2 a$
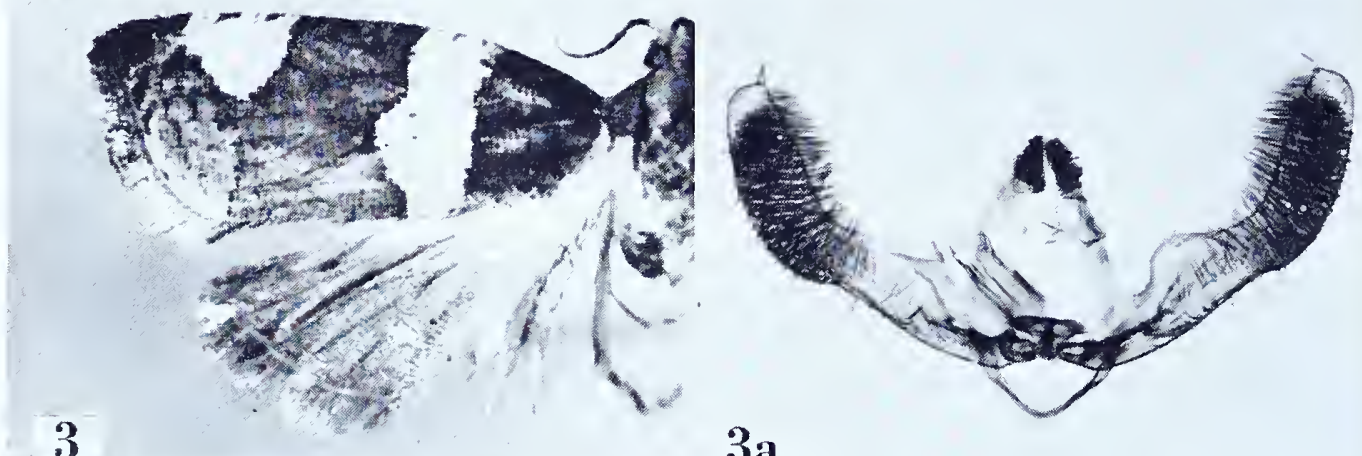

$3 a$
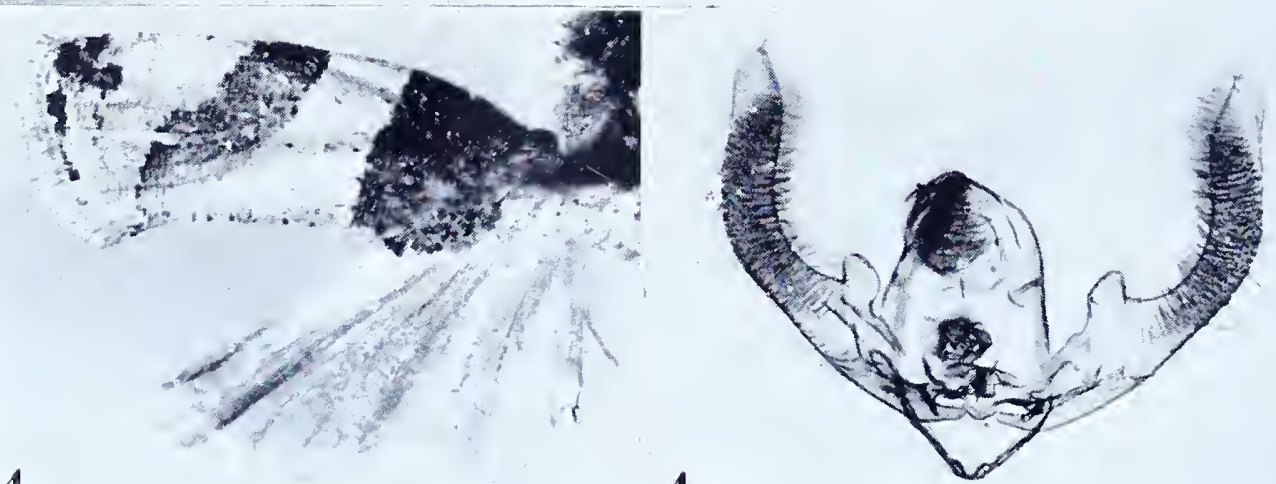


\section{Statherotis agitata (Meyrick), new combination}

Plate 296, Figures $1-1$ a

Proschistis agitata Meyrick, Journ. Bombay Nat. Hist. Soc., 19: 589 .

" 3 3우. I9-2 I mm. . . Maskeliya and Patipola, Ceylon, in February and October (Alston, de Mowbray); four specimens...."

Lectotype: A male measuring 19 mm., "Maskeliya, Ceylon. de Mowbray. .2.04." Slide No. 71 57.

Figure I, left wings; $\mathbf{a}$, ventral view of male genitalia with aedeagus in situ.

\section{Statherotis aspidias (Meyrick), new combination}

Plate 296, Figures 2-2a

Argyroploce aspidias Meyrick, I909, Journ. Bombay Nat. Hist. Soc., 19: 599.

" $\$$ 우. $17-18 \mathrm{~mm}$. . . . Khasis, in August and September; four specimens."

Lectotype: The male, "Khasi Hills, Assam. .9.1906." Slide No. 7256.

Figure 2, left wings; 2a, ventral view of male genitalia with aedeagus in situ.

Obviously the two species below do not belong in the genus Statherotis but are retained temporarily in this genus, where they were described, until they can be properly placed.

\section{Statherotis catharota Meyrick}

Plate 296 , Figures $3^{-3}$ a

Statherotis catharota Meyrick, 1928, Exotic Microlepidoptera, 3: 443.

" o. I0-I 2 mm. . . Andamans, Port Blair, July, October (Ferrar); 2 ex."

Lectotype: The male dated “.7.27”. Slide No. 7163 .

Figure 3 , left wings; 3 a, ventral view of male genitalia with aedeagus in situ.

\section{Statherotis relapsa Meyrick}

Plate 296, Figures $4-4$ a

Statherotis relapsa Meyrick, 1928, Exotic Microlepidoptera, 3: 444.

" o. I I mm. . . . Ceylon, Puttalam, April (Pole); i ex."

Type: The above indicated male dated ".4.04". Slide No. 7165.

Figure 4, left wings; 4 a, ventral view of male genitalia with aedeagus in situ. 


\section{STREPSICRATES Meyrick \\ Strepsicrates dilacerata (Meyrick), new combination \\ Plate 297, Figures I-Ia}

Spilonota dilacerata Meyrick, i 928, Trans. Ent. Soc. London, 76: 494.

" 30 . I6-I $8 \mathrm{~mm}$. . . . Austral Is., Rurutu, 400-650 feet, March, at light; 9 ex. A distinct species related to Indian forms."

Type: 'The specimen so marked in the British Museum, "Rurutu, Austral Islands, at light, 650 ft. $23 \cdot 3 \cdot 25$. C. L. Collenette.” Slide No. 6995 .

Figure I, left wings; Ia, ventral view of male genitalia with aedeagus in situ.

\section{Strepsicrates holotephras (Meyrick), new combination}

Plate 292, Figures I-Ia; 2-2b

Spilonota holotephras Meyrick, I 924, Exotic Microlepidoptera, 3:67.

Encosma enmarodes Meyrick, 1924, Exotic Microlepidoptera, 3: 68 (new synonymy).

[holotephras]

“3․ I $5 \mathrm{~mm}$. . . Fiji, Lautoka, June, July, bred from larvae on leaves of guava (Psidinm) (Veitch); + ex. (type Brit. Mus.)."

Type: The male so marked in the British Museum, dated "26-vi-1922". Slide No. 7235 .

Figure I, left wings; ra, ventral view of male genitalia with aedeagus in situ. [eumarodes]

" o. $16 \mathrm{~mm}$... Fiji, mountains near Lautoka, bred from larva on leaf of unidentified plant, January (Greenwood); i ex. (Brit. Mus.)."

Type: The female so marked in the British Museum, Lautoka Mts., Fiji. 24.I.I92 I. W. Greenwood." Slide No. 7334.

Figure 2, left wings; $2 \mathrm{a}$, ventral view of female genitalia; $2 \mathrm{~b}$, detail of genital plate and ostium.

\section{Strepsicrates rhothia (Meyrick), new combination \\ Plate 297, Figures 2-2a}

Spilonota rhothia Meyrick, I910, Trans. Ent. Soc. London, I910: 368 ; Diakonoff, 1950, Bull. Brit. Mus. (Nat. Hist.) Ent., I (4): 285 .

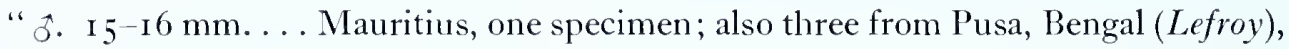
and Maskeliya, Ceylon (Pole), in February and March; bred from larvae feeding on leaves of Psidimm grava...."

Lectotype: A male measuring 15 mm., "Maskeliya, Ceylon, Pole. .3.04”, selected by Diakonoff. Slide No. 6919 .

Figure 2, left wings; 2a, ventral view of male genitalia with aedeagus in situ. [continued on p. 600 . 

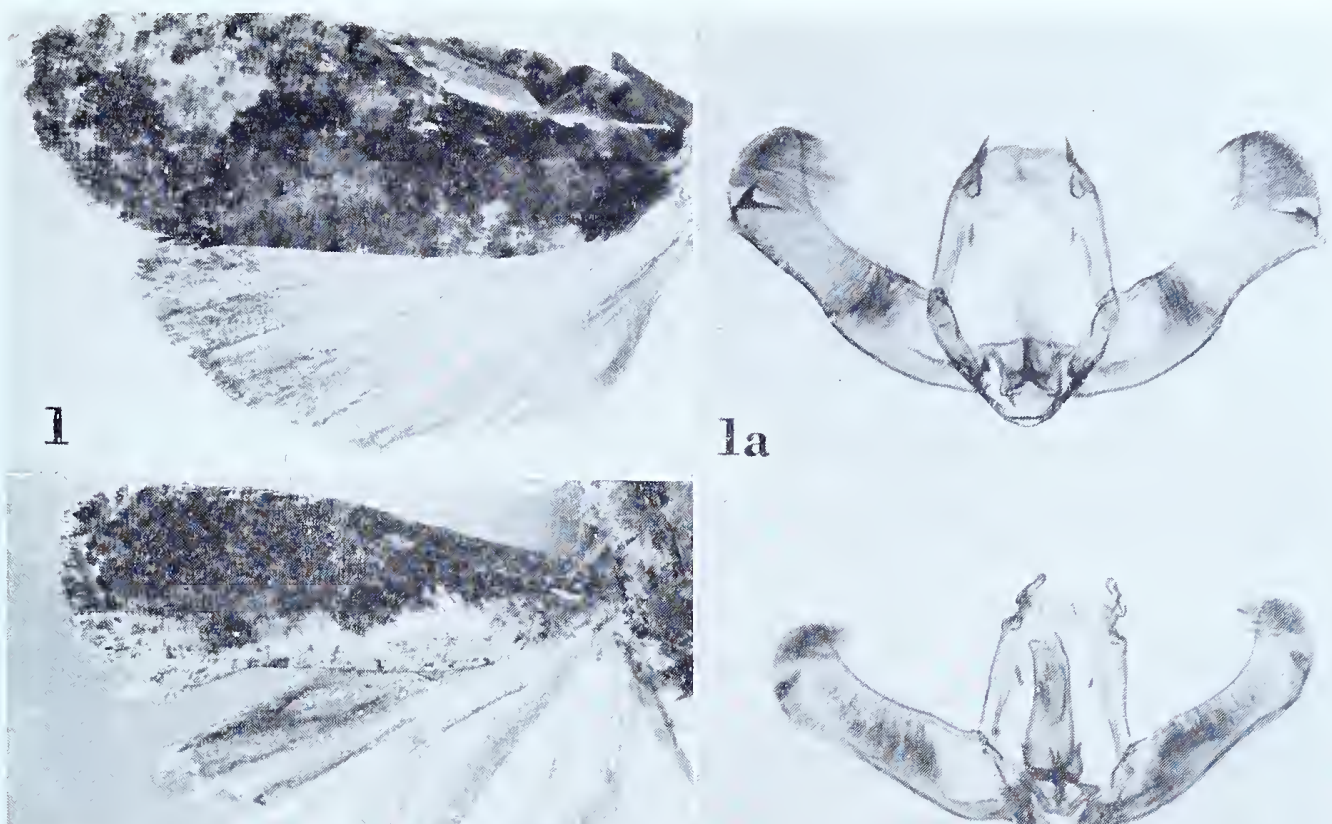

2

$2 \mathrm{a}$
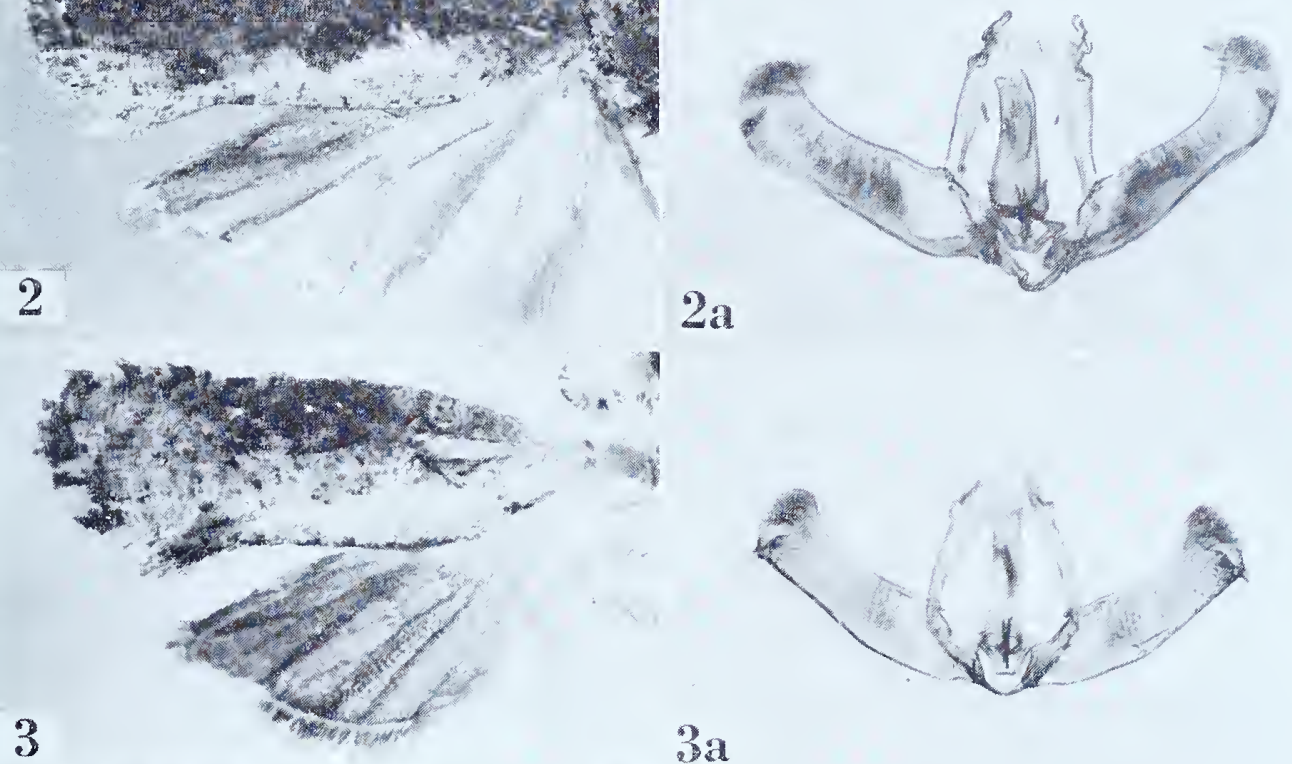

1
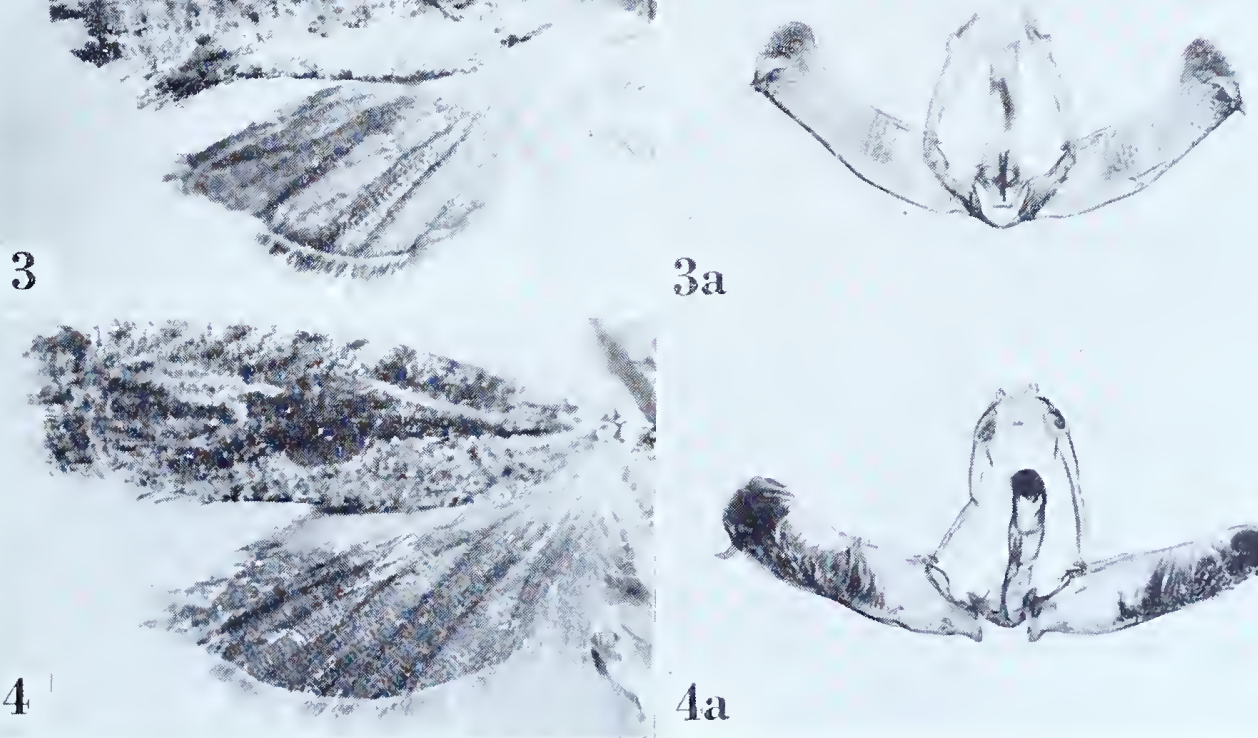

32

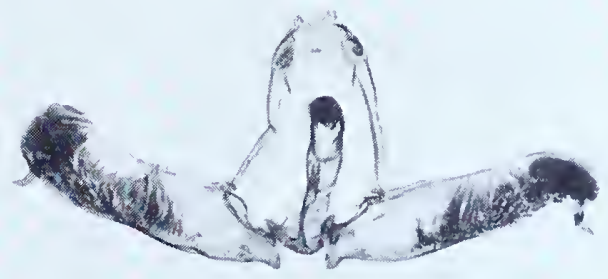

lat 


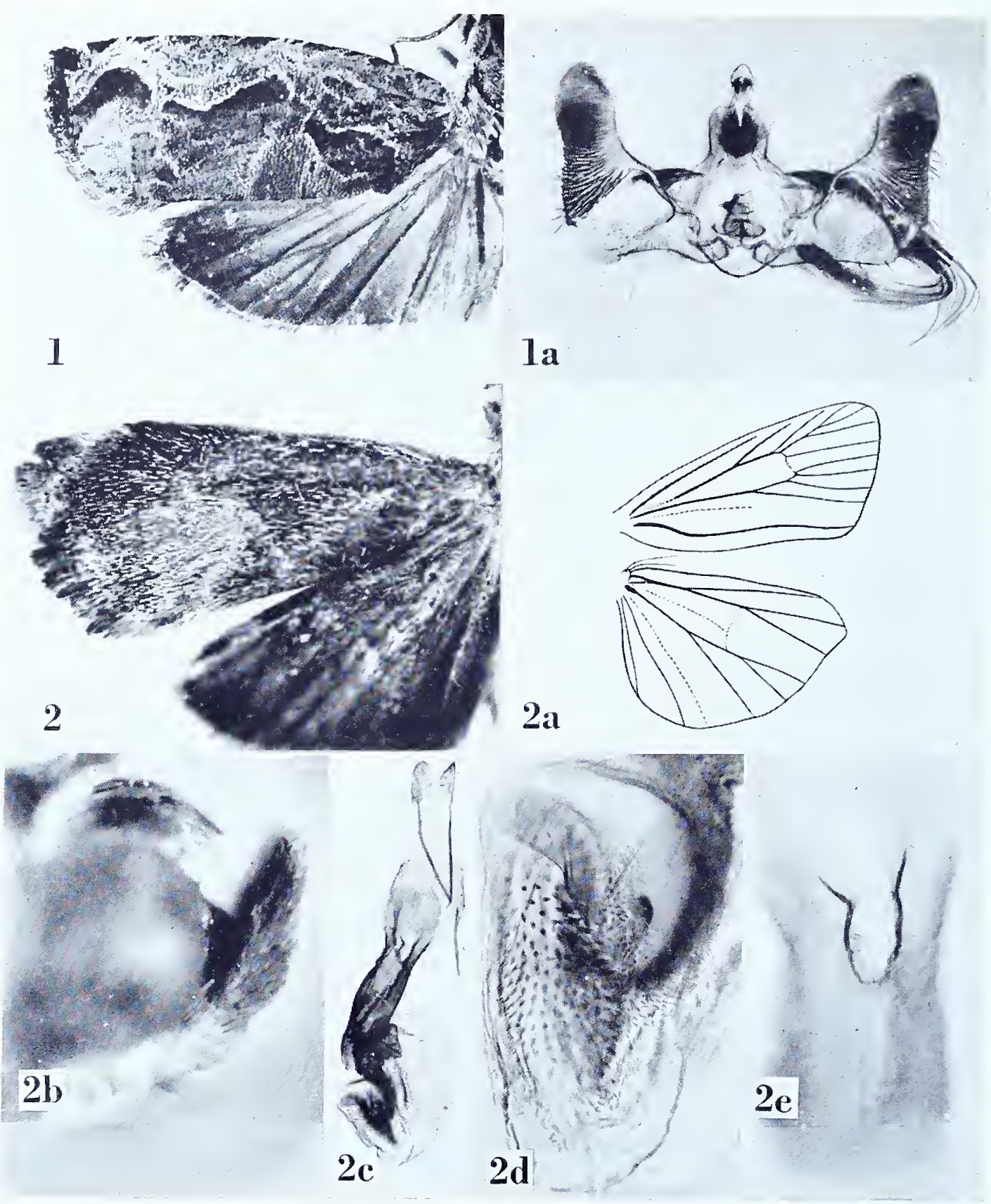

TEMNOLOPHA and MNESIPYRGA 


\section{TEMNOLOPHA Lower \\ Temnolopha mosaica Lower \\ Plate 298 , Figures I-Ia}

Temnolopha mosaica Lower, I901, Trans. and Proc. R. Soc. of South Australia, 25: 72. Cydia clydonias Meyrick, I907, Journ. Bombay Nat. Hist. Soc., I 7: 734; 1909, I9: 437 .

[clydonias]

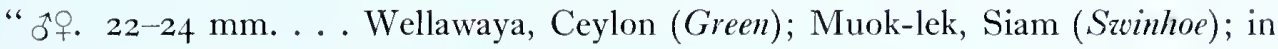
November and January, seven specimens."

Lectotype: A male measuring i 8 mm., "Wellawaya, Ceylon. EEG. .i r.05." Slide No. 7239. Four of the original specimens are missing and none, including nine specimens subsequently added, attained more than $20 \mathrm{~mm}$. Lower gives the dimensions of his species as " $15-20 \mathrm{~mm}$.", indicating an apparent error of Meyrick's.

Figure I, left wings; Ia, ventral view of male genitalia with aedeagus in situ. 


\section{NOCTUIDAE}

\section{MNESIPYRGA Meyrick}

Mnesipyrga Meyrick, I9I3, Trans. Ent. Soc. London, 1913: I70. (Typus generis: Mnesipyrga trichostrota Meyrick, ibid., I7I [monotypy].)

\section{Mnesipyrga trichostrota Meyrick}

Plate 298, Figures 2-2e

Mnesipyrga trichostrota Meyrick, I913, 'Trans. Ent. Soc. London, I913: I7г.

"†. I $8 \mathrm{~mm}$... . Peru, Chanchamayo; one specimen."

Type: The above indicated specimen with "R. .I I" at the bottom of the pin-label. Slide No. 6285. (See volume I, p. 25, of this work.)

Figure 2, left wings; 2a, venation of right wings; $2 \mathrm{~b}$, lateral aspect of head to show palpus; 2c, ventral view of female genitalia; $2 \mathrm{~d}$, detail of bursa copulatrix; $2 \mathrm{e}$, ostium.

Continued from p. 596.

\section{Strepsicrates smithiana Walsingham}

Plate 297, Figures $3-3$ a

Strepsicrates smithiana Walsingham, 1892, Proc. Zool. Soc. London, I891: 506.

Spilonota imminens Meyrick, I9I7, Trans. Ent. Soc. London, I9I7: I5 (new synonymy). “ $\hat{\jmath}+$. I I-I $3 \mathrm{~mm}$. . . British Guiana, Mallali, in March (Parish); nine specimens." Lectotype: OA, I I mm., dated “.3.13”. Slide No. 6260.

Figure 3 , left wings; 3 a, ventral view of male genitalia with aedeagus in situ.

\section{Strepsicrates tetropsis (Busck), new combination}

Plate 297, Figures $4-4 \mathrm{a}$

Eucosma tetropsis Busck, I9I3, Insecutor Inscitiae Menstruus, I : 9I.

Spilonota viridans Meyrick, I917, Trans. Ent. Soc. London, I917: I5 (new synonymy).

" $3+$. I $2-13 \mathrm{~mm}$. . . B British Guiana, Bartica, December to February (Parish); twenty-seven specimens."

Lectotype: A male dated “.2.13”. Slide No. 6259. Fifteen specimens are missing. Figure 4 , left wings; 4 a, ventral view of male genitalia with aedeagus $i n$ situ.

[600]

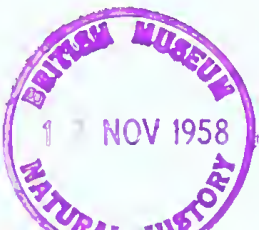




$$
\frac{1}{62=}
$$






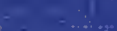

Bf $: \because 3$

$\therefore$.

$\therefore$

.

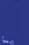

$\therefore$

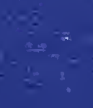

i

7?

$(2,15$

$\therefore i$

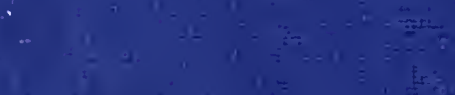

$=$

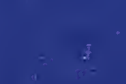

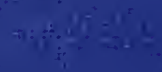

$\therefore$
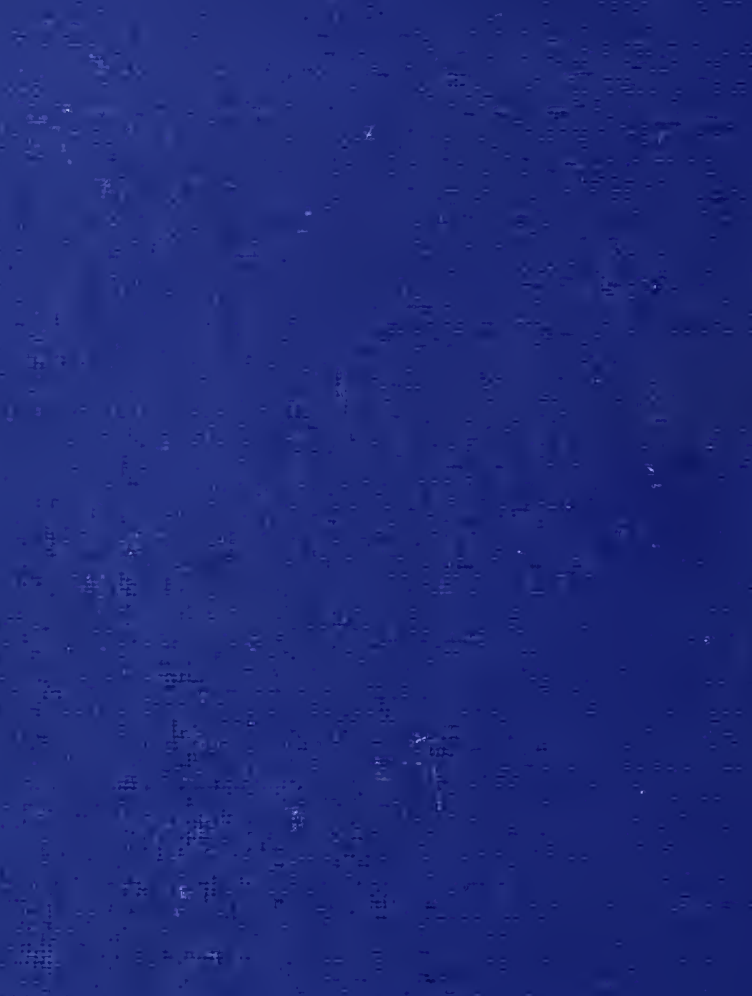

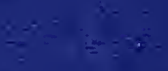

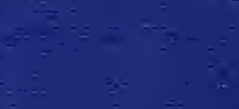

